
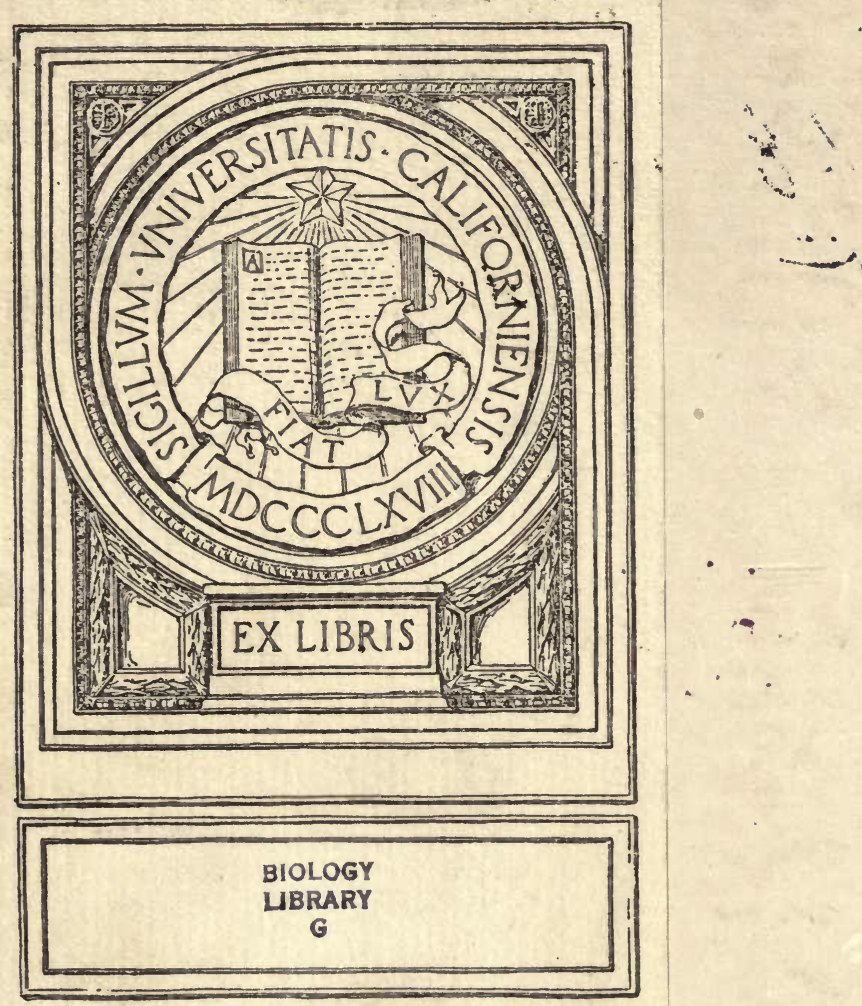

2 




\title{
THE \\ BAHAMA \\ FLORA
}

BY

NATHANIEL LORD BRITTON, Ph.D., Sc.D., LL.D. DIRECTOR-IN-CHIEF OF THE NEW YORK BOTANICAL GARDEN, PROFESSOR IN COLUMBIA UNIVERSITY

AND

CHARLES FREDERICK MILLSPAUGH, M.D.

CURATOR OF BOTANY, FIELD MUSEUM OF NATURAL HISTORY

\author{
NEW YORK \\ PUBLISHED BY THE AUTHORS \\ JUNE 26, 1920
}


Copyright, 1920

By Nathaniel Lord Britton

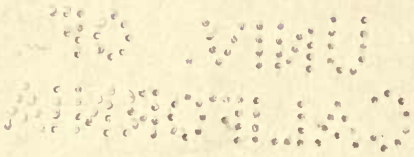




\section{CONTENTS}

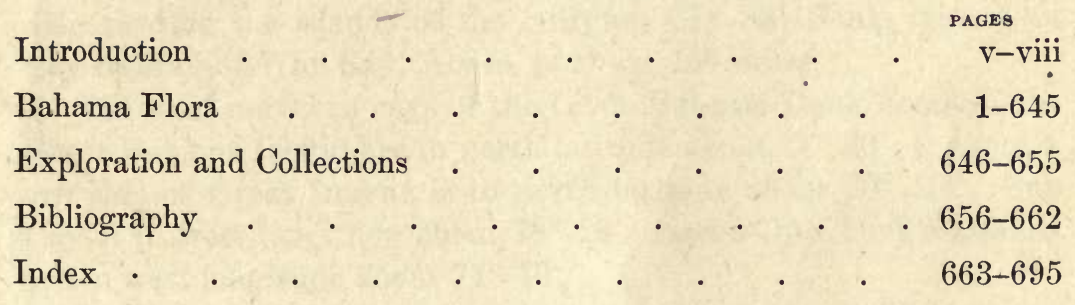





\section{INTRODUCTION.}

The numerous Bahama Islands form an archipelago situated east of Florida and north of Cuba and Hispaniola, comprising 29 islands, 661 cays and 2387 rocks with a total land area of about 4424 square miles; the nearest island to the Florida coast is Gun Cay, distant about 40 miles nearly east from Cape Florida; the island nearest Cuba is the little Cay Sal, about 35 miles north, across the Nicholas Channel, while the nearest to Hispaniola is Great Inagua, lying about 60 miles north of Cape St. Nicholas.

The axis of the archipelago is in a general way northwest and southeast, with a total length of over 600 miles; the greatest width, disregarding the islands of the outlying Cay Sal Bank, from Gun Cay to Man-of-War Cay, Abaco, is about 150 miles.

The most northern cays of the Little Bahama Bank north of the Great Bahama Island are in north latitude about $27^{\circ} 30^{\prime}$; the southern side of Great Inagua is in north latitude about $20^{\circ} 55^{\prime}$. Gun Cay is in west longitude about $79^{\circ} 20^{\prime}$; cays of the Turk's Islands are in west longitude about $71^{\circ} 10^{\prime}$.

The many islands and eays stand on banks, in shallow water, with oceanic depths among and between them. The region has, doubtless, been subjected to alternate periods of uplift and depression in past geologic time, but the vertical movements have probably been relatively small; during times of uplift, some of the present islands may have been connected, but there is no evidence that there ever was land connection with either Florida, Cuba or Hispaniola.

Most of the islands are low, but hilly and rocky, the ranges of hills usually running lengthwise of the island; on New Providence, the hills rise to about 100 feet elevation; on Cat Island, aneroid barometer readings indicated altitudes up to 205 feet (published records of greater elevations on Cat Island were not substantiated by our observations); on Watling's Island, hills rise to about 140 feet. Most of Andros, the Great Bahama and Abaco are low and nearly level. At points where the hills come to the sea there are bold rocky headlands, such as Columbus Bluff, at the scuthern end 
of Cat Island. On the western side of Andros and on the southern side of New Providence are large areas known as "swash," subject to overflow by the sea in storms. Beaches of white limestone sand are occasional, and the interior of parts of some of the islands is quite sandy (white-lands), notably Eleuthera, Little San Salvador and some of the Berry Islands. Large salt-water lakes at sea level, but without connection with the ocean, unless underground, are striking features on New Providence (Lake Cunningham) and on Watling's Island. Mangrove swamps are local along the coastal lines. There are no fresh-water streams, but fresh-water marshes exist on some of the larger islands.

The rocks of the Bahama Islands are wholly aeolian limestone; their surface is often greatly eroded into sharp "dog-tooth" projections, and there are many "sink-holes," these sometimes 10 feet deep or deeper. Small caves are occasional. Where composed mainly of sand, the soil is often of considerable depth, but it is usually thin and meagre, often colored red or reddish (red-lands) by iron oxide leached from the limestone.

There are extensive forests of the Caribbean Pine (Pinus caribaea), much reduced in recent years by lumbering, on the Great Bahama, Abaco, Andros and New Providence, and this tree occurs again on the Caicos Islands, but does not exist on any other islands of the Archipelago. On the larger islands, notably Andros, New Providence and Great Bahama, and on some of the smaller ones, hardwood forests (coppices) occur, sometimes wholly enclosed by pinelands, like the similar "hammocks" of southern Florida. These coppices are made up of a considerable variety of tall tree species. On most of the smaller islands, however, and in parts of the larger ones, the woody vegetation is wholly of shrubs and low trees, often of great density of growth, forming the "scrub-lands." Portions of these areas may have had larger trees upon them in the past, cut out for lumber and firewood, but over great areas there is no evidence of large trees ever having existed. Locally some of these areas are known as "low coppices."

The relationships of the native Bahamian flora are, as would be expected, with those of Florida, Cuba and Hispaniola, and it may be assumed that the species which are in common have been transported from one or another of the land masses by natural agencies of winds, migratory birds or oceanic currents. 
The flora as here recorded is composed of species as follows:

\begin{tabular}{|c|c|c|}
\hline & Bahama Flora & Endemic \\
\hline Spermatophyta & .. 995 & 133 \\
\hline Pteridophyta .... & 33 & 0 \\
\hline Bryophyta ......... & 69 & 1 \\
\hline \multicolumn{3}{|l|}{ Thallophyta: } \\
\hline Fungi . & 150 & 18 \\
\hline Lichens & 197 & 19 \\
\hline Algae (incl. Diatomeae) & 519 & 14 \\
\hline Myxomycetes ..... & 11 & 0 \\
\hline & $\overline{1982}$ & $\overline{185}$ \\
\hline
\end{tabular}

The Fungi, except the Basidiomycetes, are as yet very incompletely known, many more lichens probably exist in the Bahamas, and the fresh-water and aerial algae have been little collected or studied. Practically nothing is known about the Bacteria.

In addition to the numerous collections made by the authors, or under their supervision, the herbaria of the New York Botanical Garden and the Field Museum of Natural History contain the personal herbarium of Mr. Lewis J. K. Brace and the prime set of the collections of Mrs. Northrop, Dr. W. C. Coker, Mr. Wm. Cooper, Mr. A. H. Curtiss, Mr. Alex. E. Wight, Dr. J. T. Rothrock and Prof. F. S. Earle. In addition the Missouri Botanical Garden kindly loaned to the authors the complete original collection of Prof. A. S. Hitcheock. These collections enabled them to substantiate the species published in Dolley's "Provisional List of the Bahamas, etc."; Mrs. Northrop's "Flora of New Providence and Andros," and Coker's "Vegetation of the Bahama Islands." The authors have also, at various intervals, been able to consult the collections of Catesby, Eggers, Hjalmarson, Daniell, Herrick, Allen, Barbour and Bryant, and others deposited in European and American herbaria. This has rendered possible the critical notes and observations recorded in the text concerning a large number of species heretofore erroneously accredited to the Bahamas.

In addition to the exsiccatae mentioned above a complete series of living orchids, cacti and bromeliads, together with many other plants of special interest were brought into the Garden conservatories and there observed through several flowering seasons.

The authors have not included cultivated species except such as have shown a strong tendency to become spontaneous. 
Grateful acknowledgment for assistance in the preparation of this volume is tendered to Dr. John K. Small, for eritical comparative work as regards plants of Florida and for proof-reading; to Mr. Percy Wilson for bibliographical work, proof-reading and indexing; to Mr. W. R. Maxon for information relative to the Ferns; to Mrs. N. L. Britton for her contribution of the treatment of the Musci; to Professor Alexander W. Evans for his contribution of the Hepaticae; to Professor Lincoln W. Riddle for the chapter on Lichens; to Dr. Marshall A. Howe and Mr. Frank S. Collins for the chapters on Algae; to Mr. Charles S. Boyer for the list of Diatoms; to Dr. Fred J. Seaver and Dr. William A. Murrill for their work on the Fungi; and to Mr. L. J. K. Brace for many notes and for lists of common names of plants. Much information regarding species was also obtained from the Royal Gardens, Kew, England, and from the British Museum of Natural History, and is highly appreciated. 


\section{THE BAHAMA FLORA}

All plants may be grouped in four main categories, known as Phyla or Subkingdoms, as follows:

Phylum 1. Spermatophyta, those which bear seeds, a seed being different from all other vegetable structures by containing an embryonic plantlet. All spermatophytes bear flowers of one kind or another, and this phylum is also called Anthophyta, or flowering plants and, to distinguish it from the three other phyla collectively, Phanerogamia. Phyla 2, 3 and 4 taken together are called Cryptogamia; all these are seedless.

Phylum 2. Pteridophyta, comprises ferns and fern allies; all are flowerless and have two separate and distinct alternating generations, the one represented by the fully developed plant having root, stem and leaves, with vascular tissue and bearing spores, a spore being a single vegetable cell capable of growing into a new plant; the other, called the prothallium stage, is small, inconspicuous, grows from the spores, has no vascular tissue, is not differentiated into root, stem and leaves, and bears the sexual organs; from the female organ of the prothallium (archegonium) the fully developed spore-bearing plant again arises; the male organ, borne either on the same prothallium or on a different one, is called an antheridium.

Phylum 3. Bryophyta, consists of mosses and their allies; all are small flowerless plants with alternating sexual and nonsexual (spore-bearing) generations, but the spore-bearing generation never becomes separated and independent; the sexual generation is commonly the more conspicuous and is, in most cases, differentiated into stem and leaves, while the spore-bearing generation is never thus differentiated; their spores are borne in conceptacles termed capsules, and from the spores the plant again develops. Bryophytes consist almost wholly of cellular or nonvascular tissue.

Phylum 4. Thallophyta, includes the algae, fungi and lichens; 
all are flowerless and their methods of reproducing and propagation are varied. They contain no vascular tissue (except a few large algae) and the plant body is not differentiated into stem and leaves. Many of them are of microscopic size.

\section{Phylum 1. SPERMATÓPHYTA.}

\section{Seed-bearing Plants.}

Plants producing seeds which contain an embryo formed of one or more rudimentary leaves (cotyledons), a stem (hypocotyl, radicle), and a terminal bud (plumule), or these parts sometimes undifferentiated before germination. Microspores (pollen-grains) are borne in microsporanges (anther-sacs) on the apex or side of a modified leaf (filament). The macrosporanges (ovules) are borne on the face of a flat or inrolled much modified leaf (carpel) and contain one macrospore (embryo-sac); this develops the minute female prothallium, an archegone of which is fertilized by means of a tube (pollen-tube), a portion of the male prothallium sprouting from the pollen-grain.

There are two classes which differ from each other as follows:

Ovules and seeds contained in a closed cavity (ovary); stigmas 1 or more.

Class 1. ANgrospermat.

Ovules and seeds borne on the face of a scale; stigmas none.

Class 2. Gymnospermae.

\section{Class 1. ANGIOSPÉRIMAE.}

Ovules (macrosporanges) enclosed in a cavity (the ovary) formed by the infolding and uniting of the margins of a modified rudimentary leaf (carpel), or of several such leaves joined together, in which the seeds are ripened. The pollen-grains (microspores) on alighting upon the summit of the carpel (stigma) germinate, sending out a pollen-tube which penetrates its tissues and reaching an ovule enters the orifice of the latter (micropyle), and its tip coming in contact with a germ-cell in the embryo-sac, fertilization is effected. In a few cases the pollen-tube enters the ovule at the chalaza, not at the micropyle.

There are two sub-classes, distinguished as follows: 


\section{Sub-class 1. MONOCOTYLÉDONES.}

Embryo with a single cotyledon and the first leaves of the germinating plantlet alternate. Stem composed of a ground-mass of soft tissue (parenchyma) in which bundles of wood-cells are irregularly imbedded; no distinction into wood, pith and bark. Leaves usually parallel-veined, mostly alternate and entire, commonly sheathing the stem at the base and often with no distinction of blade and petiole. Flowers mostly 3-merous or 6-merous.

$\dagger$ CARPELS 1 OR MORE, DISTINCT (united, at least partially, in Vallisnerlaceae and others of the Naiadales, whlch are aquatic herbs, in Hydrocharitales and in some palms and Pandanales); parts of the usually Imperfect flowers mostly unequal in number.

Inflorescence varlous, not a true spadix.

Leaves neither compound nor flabellate.

Flowers not in the axils of dry chaffy scales. Endosperm mealy or fleshy; perfanth of bristles or chaffy scales, or wanting; flowers monoecious, spicate or capltate.

Endosperm none, or very little.

Perianth rudimentary, of 4 small sepals in Potamogeton, or none. Perianth present. Carpels distinct. Carpels united.

Flowers in the axils of dry chaffy scales, arranged in spikes or spikelets.

Leaves pinnately or palmately compound, or flabellate; trees or shrubs.

Inflorescence a fleshy spadix, with or without a Order 1. Pandanales.

Order 2. Naiadales.

Order 3. Alismales.

Order 4. HYDROCHARITALES.

Order 5. Poales.

Order 6. ARECALES. spathe; or plants minute, floating free, the flowers few or solitary on the margin or back of the thallus.

†† CARPELS UNITED INTO A COMPOUND OVARI; parts of the usually complete flowers mostly in 3 's or 6's.

Seeds with endosperm.

Endosperm mealy; ovary mostly superior.

Endosperm fleshy or horny.

Seeds without endosperm, very numerous and minute;

ovary Inferlor; flowers very Irregular.

Order 8. XYRIDALFis.

Order 9. Lrurates.

Order 10. ORCHIDALES.

\section{Order 1. PANDANÀLES.}

Our species aquatic or marsh plants, with narrow elongated leaves and very small, imperfect and incomplete flowers in spikes or heads. Perianth of bristles, or of chaffy scales. Ovary 1, 1-2-celled. Endosperm mealy or fleshy.

The order takes its name from the tropical genus Pandanus, the socalled Screw-Pine.

\section{Family 1. TYPHÀCEAE J. St. Hil.}

\section{Cat-tail Famiry.}

Marsh or aquatic plants with creeping rootstocks, fibrous roots and glabrous erect, terete stems. Leaves linear, flat, ensiform, striate, sheathing at the base. Flowers monoecious, densely erowded in terminal spikes, which are subtended by spathaceous, usually fugacious bracts, and divided at intervals by smaller bracts, which are caducous, the staminate spikes uppermost. Perianth of bristles. Stamens 2-7, the filaments connate. 
Ovary 1, stipitate, 1-2-celled. Ovules anatropous. Styles as many as the cells of the ovary. Mingled among the stamens and pistils are bristly hairs, and among the pistillate flowers many sterile flowers with elavate tips. Fruit nut-like. Endosperm copious. The family comprises only the following genus :

\section{TỲPHA. L. Sp. Pl. 971.1753.}

Characters of the family. [Name ancient.] About 10 species, widely distributed in temperate and tropical regions. Type species: Typha latifolia L.

\section{Typha angustifòlia L. Sp. Pl. 971. 1753.}

Typha domingensis Pers. Syn. Pl. 2: 532. 1807.

Typha angustifolia domingensis Griseb. Fl. Br. W. I. 512. 1864.

Stems slender, 1.5-3.5 m. high. Leaves narrowly linear, 3-20 mm. wide, erect, often as long as the stem; spikes light brown, the staminate and pistillate portions usually separated, the two together sometimes $0.5 \mathrm{~m}$. long, the pistillate, when mature, $6-16 \mathrm{~mm}$. in diameter, and provided with bractlets; stigmas linear or linear-oblong; pollen-grains simple; fruit not furrowed, not bursting in water; outer coat of the seed not separable.

In fresh water or slightly brackish marshes, Great Bahama, Abaco, New Providence, Andros, Eleuthera, Watling's Island :-Bermuda; Jamalca; Cuba to Tortola and Trinidad; southern United States to Patagonia; Europe; Asia. Referred by Dolley to Typha latifolia L. CAT-TaIL. Slag.

\section{Order 2. NAIADÀLES.}

Aquatic or marsh herbs, the leaves various. Flowers perfect, monoecious or dioecious. Perianth rudimentary, or wanting. Parts of the flower mostly unequal in number. Carpels 1 or more, distinct and separate or united; endosperm none, or very little.

Carpels distinct.

Carpels 2, united, or 1 only.

Fam. 1. ZaNnichelliaceat. Fam. 2. CYMODOCEACEAE.

\section{Family 1. ZANNICHELLIÀCEAE Dumort.}

\section{Pondweed Family.}

Perennial plants, the foliage mostly submerged. Leaves very narrow or broad. Flowers monoecious or perfect, small, and inconspicuous. Perianth present or none. Stamens 1-4, with extrorse anthers. Carpels 1-seeded. Fruit drupe-like. Endosperm none. Four genera and sixty or more species, mostly inhabiting fresh water.

Perianth of 4 segments.

Perianth wanting.
1. Potamogeton.

2. Ruppia.

1. POTAMOGÉTON L. Sp. Pl. 126. 1753.

Leaves alternate or the uppermost opposite, often of 2 kinds, submerged and floating, the submerged mostly linear, the floating coriaceous, lanceolate, ovate or oval. Spathes stipular, often ligulate, free or connate with the base of the leaf or petiole, enclosing the young buds and usually soon perishing after expanding. Peduncles axillary, usually emersed. Flowers small, spicate, green or red. Perianth-segments 4, short-clawed, concave, valvate. Stamens 4, 
inserted on the claws of the perianth-segments. Anthers sessile. Ovaries 4, sessile, distinct, 1-celled, 1-ovuled, attenuated into a short style, or with a sessile stigma. Fruit of 4 drupelets, the pericarp usually thin and hard or spongy. Seeds crustaceous, campylotropous, with an uncinate embryo thickened at the radicular end. [Greek, in allusion to the aquatic habitat.] About 65 species, mostly natives of temperate regions. Type species: Potamogeton natans $\mathrm{L}$.

\section{Potamogeton heterophýllus Schreb. Spic. Fl. Lips. 21.1771.}

Stems slender, compressed, much branched, sometimes $4 \mathrm{~m}$. long. Floating leaves pointed at the apex, mostly rounded or subcordate at the base, 1.5$10 \mathrm{~cm}$. long, 8-30 mm. wide, 10-18-nerved, on petioles $2-10 \mathrm{~cm}$. long; submerged leaves pellucid, sessile, linear-lanceolate, acuminate, cuspidate, rather stiff, 2-15 $\mathrm{cm}$. long, 2-16 mm. wide, 3-9-nerved, the uppermost often petioled; peduncles often thickened upward, sometimes clustered; stipules spreading, obtuse, 1.5-2.5 $\mathrm{cm}$. long; spikes $1.8-4 \mathrm{~cm}$. iong; fruit roundish or obliquely obovoid, $2-3 \mathrm{~mm}$. long, 1-2 mm. thick, indistinctly 3-keeled; style short, obtuse, apical; apex of the embryo nearly touching the base, pointing slightly inside of it.

In fresh water pools and ditches, Great Bahama, Andros, Nesw Providence, Great Exuma :- North America and Europe. PONDwEed.

\section{RÚPPIA L. Sp. Pl. 127. 1753.}

Slender, widely branched aquatics with capillary stems, slender alternate 1-nerved leaves tapering to an acuminate apex, and with membranous sheaths. Flowers on a capillary spadix-like peduncle, naked, consisting of 2 sessile anthers, each with 2 large separate sacs attached by their backs to the peduncle, having between them several pistillate flowers in 2 sets on opposite sides of the rachis, the whole cluster at first enclosed in the sheathing base of the leaf. Stigmas sessile, peltate. Fruit a small obliquely-pointed drupe, several in each cluster and pedicelled; embryo oval, the cotyledonary end inflexed, and both that and the hypocotyl immersed. [Name in honor of Heinrich Bernhard Rupp, a German botanist.] In the development of the plants the staminate flowers drop off and the peduncle elongates, bearing the pistillate flowers in 2 clusters at the end, but after fertilization it coils up and the fruit is drawn below the surface of the water. Three or four species, widely distributed, the following typical.

\section{Ruppia marítima L. Sp. Pl. 127. 1753.}

Stems usually whitish, often $1 \mathrm{~m}$. long, the internodes irregular, naked. Leaves $2-8 \mathrm{~cm}$. long, $1.5 \mathrm{~mm}$. or less wide; sheaths with a short free tip; peduncles in fruit sometimes $0.3 \mathrm{~m}$. long; pedicels $4-6$ in a cluster, 1-3.5 cm. Jong; drupes with a dark hard shell, ovoid, about $2 \mathrm{~mm}$. long, of ten oblique or gibbous at the base, pointed with the long style, but varying much in shape; forms with very short peduncles and pedicels, and with broad, strongly marked sheaths occur.

In shallow salt and brackish water throughout the archipelago:-Coast of Eastern North America; Bermuda; Cuba to Trinidad; temperate and tropical regions of the Nid World. Ditch-Grass. 


\section{Family 2. CYMODOCEACEAE Kerner.}

\section{Manatee-grass Family.}

Submerged marine perennial herbs, with long rootstocks. Leaves linear, sheathing. Flowers monoecious or dioecious, solitary or cymose. Staminate flowers of 2 long-pedicelled anthers, the anthers 2-celled, longitudinally dehiscent. Pistillate flowers of 1 or 2 earpels, the 1 or 2 stigmas filiform. Fruit nut-like, 1-seeded. Two known genera, the following.

1. Cymodocea. 2. Halodule.

1. CYMOdÒCEA Konig; Konig \& Sims, Ann. Bot. 2: 96.1805.

Leaves terete in our species, acute. Flowers dioecious. Pistillate flowers of 2 earpels; stigmas 2. Seed pendulous. [Named for Cymodoce, one of the Nereids.] Type species: Cymodocea aequorea Konig.

1. Cymodocea manatòrum Aschers. Sitzb. Ges. Naturf. Freunde, 1868: 19. 1868.

Rootstock branched, rooting at the nodes. Leaves 0.4-3.2 dm. long, terete or nearly so, about $2 \mathrm{~mm}$. thick, their bases enclosed by membranous stipular sheaths $1-5 \mathrm{~cm}$. long.

Shallow salt water, Great Bahama, Abaco, Mariguana:-Bermuda; Florida; West Indies. MANATEE-GRASS.

\section{HALODÙLE Endl. Gen. 1368. 1841.}

Marine perennials with jointed rootstocks and linear, flat sheathing leaves, the small flowers dioecious. Perianth wanting. Staminate flower of 2 anthers unequally attached to a pedicel. Pistillate flower a solitary naked carpel; style short; stigma one, slender. Fruit globular, small. [Greek, referring to the saline habitat.] A few species of tropical and subtropical waters. Type species: Diplanthera tridentata Steinh.

1. Halodule Wrìghtii Aschers. Sitzb. Ges. Naturf. Freunde, 1868: 19. 1868.

Diplanthera Wrightii Aschers. in E. \& P. Nat. Pfl. Nachtr. 37. 1897.

Rootstock slender, nearly white, $3 \mathrm{dm}$. long or longer, copiously rooting at the nodes. Leaves narrowly linear, $1 \mathrm{~mm}$. wide or less, acute, sheathing at the base, the scarious sheath 1-3 cm. long; anthers about $6 \mathrm{~mm}$. long; fruit nearly black.

Shallow salt water, Rose Island, Eleuthera, Mariguana:-Florida ; Cuba ; Porto Rico; St. Thomas; St. Crolx; Jamaica; Martinique; Panama.

\section{Order 3. ALISMÀLES.}

Aquatic or uliginous herbs, mostly acaulescent and with rootstocks. Leaves alternate, mostly basal, broad or narrow. Flowers perfect, monoecious or dioecious, clustered. Calyx of 3 sepals. Corolla of 3 thin petals, or sometimes wanting. Stamens several or many; filaments slender or short; anthers with inconspicuous connectives. Pistils few to many, distinct; ovary superior; style stout or slender; stigma small. Fruit a head of achenes in the following family. 


\section{Family 1. ALISMÀCEAE DC.}

\section{Water-Plantain Family.}

Aquatic or marsh herbs, mostly glabrous, with fibrous roots, scapose stems and basal long-petioled sheathing leaves. Inflorescence racemose or paniculate. Flowers pedicelled, the pedicels verticillate and subtended by bracts. Receptacle flat or convex. Sepals 3, persistent. Petals 3, larger, deciduous, imbricated in the bud. Stamens 6 or more; anthers 2-celled, extrorse or dehiscing by lateral slits. Ovaries 1-celled, usually with a single ovule in each cell. Carpels becoming achenes in fruit in our species. Seeds uncinate-eurved. Embryo horseshoe-shaped. Endosperm none. Latextubes are found in all the species, according to Micheli. About 13 genera and 70 species, of wide distribution in fresh water swamps and streams.

Flowers perfect.

Flowers monoeclous or dioeclous.
1. Echinodorus.

2. Sagittaria.

\section{ECHINóDORUS Richard; Engelm. in A. Gray, Man. 460. 1848.}

Perennial or annual herbs with long-petioled elliptic, ovate or lanceolate, often cordate or sagittate leaves, 3-9-ribbed and mostly punctate with dots or lines. Seapes often longer than the leaves; inflorescence racemose or paniculate, the flowers verticillate, each verticil with 3 outer bracts and numerous inner bracteoles. Flowers perfect; sepals 3 , distinct, persistent; petals white, deciduous; receptacle large, convex or globose; stamens 12-30; ovaries numerous; style obliquely apical, persistent; stigma simple. Fruit achenes, more or less compressed, coriaceous, ribbed and beaked, forming spinose heads. [Greek, in allusion to the spinose heads of fruit.] About 14 species, mostly natives of America. Type species: Echinodorus rostratus Engelm.

\section{Echinodorus cordifòlius (L.) Griseb. Kar. 109. 1857.}

Alisma cordifolia L. Sp. Pl. 343. 1753.

Echinodorus rostratus Engelm. in A. Gray, Man. 460. 1848.

Leaves variable in form, often broadly ovate, obtuse, cordate at the base, $15-20 \mathrm{~cm}$. long and wide, but in smaller plants sometimes nearly lanceolate, acute at each end and but $2-5 \mathrm{~cm}$. long; petioles angular, striate; scapes 1 or more, erect, $12-40 \mathrm{~cm}$. tall; flowers $3-6$ in the verticils; pedicels erect after flowering; sepals shorter than the heads; petals 4-6 mm. long; stamens often 12; styles longer than the ovary; fruiting heads bur-like, 4-6 $\mathrm{mm}$. in diameter; achenes about $3 \mathrm{~mm}$. long, narrowly obovate or falcate, 6-8-ribbed; beak apical, oblique, about one-half the length of the achene.

In sink-holes and fresh water swamps, Andros, Cat Island, Watling's Island, Crooked Island, Acklin's Island, Fortune Island, Great Exuma, Grand Turk:-Southeastern United States; Jamalca; Cuba to St. Thomas and Barbadoes. BUR-HEAD.

\section{SAGITTÀRIA L. Sp. Pl. 993. 1753.}

Perennials, mostly with tuber-bearing or nodose rootstocks, basal longpetioled nerved leaves, the nerves connected by numerous veinlets, and erect, decumbent or floating scapes, or the leaves reduced to bladeless phyllodes. Flowers monoecious or dioecious, borne near the summits of the scapes in verticils of 3 's, pedicelled, the staminate usually uppermost. Verticils 3-bracted. Sepals 
persistent, those of the pistillate flowers reflexed or spreading in our species. Petals 3, white, deciduous. Stamens inserted on the convex receptacle; staminate flowers sometimes with imperfect ovaries. Pistillate flowers with numerous distinct ovaries, sometimes with imperfect stamens; ovule solitary; stigmas small, persistent. Achenes numerous, densely aggregated in globose or subglobose heads, compressed. Seed erect, curved. [Latin, referring to the arrow-shaped leaves of some species.] About 40 species, natives of temperate and tropical regions. Type species: Sagittaria sagittifolia L.

1. Sagittaria lancifòlia L. Pl. Jam. Pug. 27. 1759.

Monoecious, glabrous; scape rigid, erect, stout or rather slender, striate, branched or simple, longer than the leaves. Leaves lanceolate or oblonglanceolate, acute or acuminate at both ends, firm, entire, the blades 5-9-nerved, 0.2-0.4 m. long, gradually narrowed into the long petioles, apparently pinnately veined; flowers numerous, $1-2.5 \mathrm{~cm}$. broad; bracts ovate or ovate-lanceolate, usually not united at the base, glabrous or nearly so, equalling or shorter than the fruiting pedicels; stamens numerous; filaments cobwebby-pubescent, equalling or longer than the anthers; achene narrowly obovate-cuneate, 2-3 $\mathrm{mm}$. long, winged on both margins, its sides smooth, its beak tapering, oblique.

In fresh water or slightly brackish swamps and savannas, New Providence. Andros, Great Bahama :- Southern United States to Argentina; Jamaica; Cuba to Barbadoes. LANCE-LEAVEd SAGITTARIA.

\section{Order 4. HYDROCHARITÀLES.}

Floating or more or less emersed herbs, perennial by rootstocks or stolons. Flowers monoecious or dioecious, arising from spathes. Perianth of 2 dissimilar series of parts or the corolla wanting. Stamens 3-12. Carpels 3-15, united. Ovary inferior, with several parietal placentae or several-celled. Endosperm none.

Ovary 1-celled, with 2-5 parietal placentae; stigmas 3-5. Fam. 1. ElodeaceaE. Ovary 6-9-celled; stigmas 6-9.

Fam. 2. HYDROCharitaceaE.

\section{Family 1. ELODEÀCEAE Dumort.}

\section{TAPE-GRASS FAMILY.}

Stoloniferous or rhizomatous aquaties, fresh-water or marine, submerged or the leaves sometimes floating. Leaves various, opposite, verticillate or faseicled. Flowers small, regular or nearly so, monoecious, dioecious or polygamous, enclosed in a spathe composed of 1-3 bracts. Calyx of the pistillate flowers with a tube and 3 lobes or sepals, that of staminate flowers often small or obsolete. Petals 3 or wanting. Stamens 3-12; filaments short or the anthers sessile. Pistil 1; ovary 1-celled with 2-5 parietal placentae; ovules usually numerous. Fruit small, indehiscent. Seeds without endosperm.

1. HALÓPHILA Thouars; Gaud. in Freyc. Voy. 429. 1829.

Submerged or floating marine herbs, with slender rootstocks, branched stems and opposite or whorled, petioled leaves, the dioecious flowers solitary in spathes. Staminate flower peduncled, with 3 sepals, and 3 stamens with nearly 
sessile, extrorse anthers. Pistillate flower sessile, with 3 very small sepals, a 1-celled, beaked ovary and a 3-parted style. Fruit enclosed in the spathe. Seeds numerous, the embryo with spirally bent cotyledons. [Greek, salt-loving.] About 7 species of tropical distribution. Type species: Caulinia ovalis R. Br.

1. Halophila Engelmànni Aschers. in Neumayer, Anleit. Wiss. Beob. 368. 1875.

Rootstocks buried in sand or mud in water up to $4 \mathrm{~m}$. deep or deeper, branched, the slender stems 3-6 dm. long. Leaves linear-oblong to oblanceolate, mostly whorled at the ends of the branches, short-petioled, 1-3 cm. long, 3-6 $\mathrm{mm}$. wide, obtuse or acutish at the apex, narrowed at the base, 3-nerved, finely and sharply serrulate; pistillate flowers axillary, enclosed by 2 lanceolate bracts, the hypanthium flask-shaped, about $8 \mathrm{~mm}$. long, the sepals minute, the 3 stigmas filiform, about $3 \mathrm{~cm}$. long; staminate flowers unknown.

In sait water, often washed ashore, Abaco, North Bimini, Rose Island, Great Exuma :-Florida; Cuba. HaLOPHILA.

\section{Family 2. HYDROCHARITÀCEAE Aschers.}

Frog's-bit FAmily.

Submerged or floating aquatic herbs, the leaves various. Flowers regular, mostly dioecious, appearing from an involucre or spathe of 1-3 bracts or leaves. Perianth 3-6-parted, the segments either all petaloid or the 3 outer ones small and herbaceous, the tube adherent to the ovary at its base in the pistillate flowers. Stamens 3-12, distinet or monadelphous. Anthers 2-celled. Ovary 6-9-celled. Styles 6-9, with entire or 2-cleft stigmas. Ovules anatropous or orthotropous. Fruit ripening under water, indehiscent. Seeds numerous, without endosperm. About 14 genera and 40 species of wide distribution in warm and temperate regions.

\section{THALiAssta Banks; Konig \& Sims, Ann. Bot. 2: 96.1805.}

Marine herbs, with elongated rootstocks. Leaves several at a joint, sheathing at the base, linear, elongated, the scape arising from the cluster of leaves. Flowers dioecious, solitary in narrow spathes of two bracts, these united into a tube at the base. Staminate flowers long-pedicelled; perianth of 3 petaloid sepals; stamens 6 ; filaments very short; anthers opening laterally. Pistillate flower nearly sessile in the spathe, caducous; ovary 6-9-celled, beaked. Fruit stalked, rugose or nearly echinate, opening by many valves. Seeds numerous. [Greek, referring to its growth in the ocean.] Two known species, the following typical.

\section{Thalassia testùdinum Konig; Konig \& Sims, Ann. Bot. 2: 96. 1805.}

Submersed, glabrous. Rootstocks creeping, elongated; stems short, arising from the nodes of the rootstock; leaves $2-5$, sheathing the stem; blades linear, strap-like, 0.5-3 dm. long, obtuse, withering-persistent; scapes solitary, central; fruit globose or oval, echinate-pubescent, pointed.

In shallow salt water, Andros and New Providence to Watling's Island and Inagua :-Bermuda; Florida; throughout the West Indies. Turtue-grass. Catesby, 2: pl. 38 . 


\section{Order 5. POÀLES.}

Grasses and sedges. Monocotyledonous plants, mostly herbaceous, with leafy or leafless, usually simple, stems (culms), the leaves usually narrow and elongated, entire or minutely serrulate. Flowers mostly perfect, small, incomplete, in the axils of dry, chaffy scales (glumes) arranged in spikes or spikelets.

Fruit a caryopsis (grain) ; culm mostly hollow. Fruit an achene; culm solid.

Fam. 1. PoAceat.

Fam. 2. CYPERACEAE.

\section{Family 1. POÀCEAE R. Br.}

\section{Grass FAMily.}

Annual or perennial herbs, of various habit, rarely shrubs or trees. Culms (stems) generally hollow, but occasionally solid, the nodes closed. Leaves sheathing, the sheaths usually split to the base on the side opposite the blade; a scarious or cartilaginous ring, naked or hairy, rarely wanting, called the ligule, is borne at the orifice of the sheath. Inflorescence spicate, racemose or paniculate, consisting of spikelets composed of two to many 2-ranked imbricated bracts, called scales (glumes), the two lowest in the complete spikelet always empty, one or both of these sometimes wanting. One or more of the upper scales, except sometimes the terminal ones, contains in the axil a flower, which is usually enclosed by a bract-like awnless organ called the palet, placed opposite the scale and with its back toward the axis (rachilla) of the spikelet, generally 2keeled; sometimes the palet is present without the flower, and vice versa. Flowers perfect or staminate, sometimes monoecious or dioecious, sub. tended by 1-3 minute hyaline scales called the lodicules. Stamens 1-6, usually 3. Anthers 2-celled, versatile. Ovary 1-celled, 1-ovuled. Styles 1-3, commonly 2 and lateral. Stigmas hairy or plumose. Fruit a seedlike grain (caryopsis). Endosperm starchy. About 3500 species widely distributed throughout the world, growing in water and on all kinds of soil. Those yielding food-grains are called cereals. The species are more numerous in tropical countries, while the number of individuals is much greater in temperate regions, often forming extended areas of turf.

A. Spikelets articulated below the empty scales or below a subtending involucre, or attached to and deciduous with the internodes of a readily disarticulating rachis, 1-flowered, or if 2-flowered the lower flower imperfect.

1. Fruiting scale and palet hyaline, thin, more delicate than the empty scales.

* Spikelets unisexual, the pistillate borne in the lower, the staminate in the upper, part of the same spike.

** Spikelets in pairs, one sessile and perfect, the other pedicellate and sometimes perfect, more commonly staminate or empty, or sometimes reduced to a single scale, or wanting.

Axis of the racemes continuous.

Axis of the racemes articulated.

Raceme single: pedicels and internodes of the rachis club-shaped.

Racemes in pairs or more; pedicels and rachis-

2. Fruiting scale and palet never hyaline and thin, as firm as the emptr scales, or firmer.

1. Spikelets prickly.

2. Spikelets not prickly, but sometimes enclosed in a spiny involucre.

1. Tripsacum.

\section{Imperata.}

3. Schizachyrium.

4. Andropogon.

5. Nazia. 
Spikelets in clusters of 3 or 4 , the empty scales forming a false involucre.

** Splkelets otherwise arranged.

$f$ Splkelets not sunken in the rachis.

\$ Spikelets without a subtending involucre of bristles or valves.

$\$$ Scales awnless.

Fruiting scale chartaceous, the margins hyaline and flat.

Racemes in whorls, or approximate at the summit of the stem; outer scales of the splkelet with short hairs or glabrous.

Racemes on an elongated axis ; outer scales of the spikelet clothed with long hairs exceeding the splkelet.

Fruiting scale indurated, rigid, the margins inrolled and not hyaline.

Opening in the fruiting scale turned toward the rachis.

opening in the fruiting scale turned away from the rachis.

Spikelets plano-convex, arranged in secund racemes, of 3 scales. Splkelets unequally bi-convex, in panicles, or rarely in secund racemes, of 4 scales.

Culms herbaceous.

Culms woody.

$\$ \&$ Scales, or some of them, awned or awnpointed.

Third scale awned or awn-pointed, the second and first scales awnless or with awns successively shorter.

Third scales awnless or awn-pointed, the second and first scales with awns successively longer.

¥ Spikelets with an involucre.

Involucre of bristles.

Bristles persistent; spikelets deciduous.

Bristles deciduous with the splkelets. Involucre of 2 spine-bearing valves.

†† Splkelets sunken in one side of a flat thick rachis.

B. Spikelets articulated above the empty persistent scales, 1-many-flowered.

1. Stems herbaceous, hence annual; leaves scattered.

* Spikelets of 3 scales, 1 -flowered.

Flowering scale awned, closely embracing the grain. Awns 3.

Awn 1.

Flowering scales awnless, the grain dropping from it when mature.

** Spikelets of 4 or more scales, usually with 2 or more flowers.

† Spikelets in 2 rows, forming 1-sided splkes or racemes.

Spikelets wholly deciduous.

Spikelets not wholly declduous.

1 perfect flower in each spikelet.

No empty scales above the flowers.

1-several empty scales above the flower.

Spikes in whorls or closely approximate.

Second empty scale acute; awn of the flowering scales usually long.

Second empty scale truncate or 2 toothed; flowering scales awnless or awn-pointed.

Spikes remote.

2-several perfect flowers in each spikelet.

Splkelets densely crowded; splkes digitate. Spikes with terminal spikelets.

Splkes with the rachis extending beyond the spikelets in a naked point.

6. Anthephora.

7. Syntherisma

8. Valota.

9. Axonopus.

10. Paspalum.

11. Panicum

12. Lasiacis.

13. Echinochloa.

14. Oplismenus.

15. Chaetochloa.

16. Cenchropsis.

17. Cenchrus.

18. Stenotaphrum.

19. Aristida.

20. Muhlenbergia.

21. Sporobolus.

22. Spartina.

23. Capriola.

24. Chloris.

25. Eustachys.

26. Bouteloua.

27. Eleusine.

28. Dactyloctenium. 
Spikelets alternate; spikes remote.

29. Leptochloa.

†† Splkelets in open or spike-like panicles or racemes.

Rachilla with hairs longer than the flowering scales and enveloping them; tall reed-like grasses.

Rachilla and flowering scales glabrous.

Flowering scales 3-nerved; first 2 scales of the spikelets empty.

Inflorescence of long branches, along which the appressed spikelets are arranged on short pediceis; lateral nerves of the flowering scales pubescent.

Inflorescence an open or contracted panicle, rarely racemose; lateral nerves of the flowering scale glabrous.

Flowering scales 5-many-nerved ; first 2-6 scales of the splkelets empty.

Plants not dioecious; splkelets flat, 2-edged. Plants dioecious ; spikelets compressed.

2. Stems woody, perennial; leaves on short branches which form dense whorls at the nodes.

30. Phragmites.

31. Diplachne.

32. Eragrostis.

33. Uniola.

34. Distichlis.

35. Arthrostylidium.

1. TRÍPSACUM L. Syst. Nat. ed. 10, 1261. 1759.

Tall perennial grasses with thick rootstocks, rather broad, flat leaves and monoecious flowers. Spikelets 1-2-flowered, in terminal or axillary, solitary or clustered, elongated spikes. Staminate spikelets in 2 's at each node of the upper part of the axis, 2-flowered, consisting of four scales, the two outer coriaceous, the two inner thinner, the palet hyaline; stamens 3. Pistillate spikelets in excavations at the lower joints of the spike, 1-flowered; stigmas exserted; style slender. Grain partly enclosed in the excavations of the spikes, covered in front by the horny exterior lower scale. [Name from the Greek, in allusion to the polished outer scales.] About 7 species, natives of America, the following typical.

1. Tripsacum dactyloìdes L. Syst. Nat. ed. 10, 1261.1759.

Rootstock 1.25-2.5 cm. thick; culms stout, erect, 1-2 m. tall. Leaves smooth and glabrous, $3 \mathrm{dm}$. or more long, 1.25-3.75 $\mathrm{cm}$. wide; spikes terminal, and in the upper axils, solitary or 2-3 together, 1-1.25 dm. long; outer scales of the staminate spikelets linear and obtuse, $8 \mathrm{~mm}$. long, about $2 \mathrm{~mm}$. wide, faintly many-nerved; exterior scale of the pistillate spikelets horny, shining.

Scrub-lands, Inagua :-Rhode Island to Nebraska, Florida and Texas ; Hispaniola ; Trinidad; Mexico; South America. GAMA-Grass.

\section{IMPERÀTA Cirillo, Pl. Rar. Neap. 2: 26. 1792.}

Perennial grasses with elongated leaves, the spikelets in dense terminal spike-like, silvery-hairy panicles. Spikelets 1-flowered, rarely 2-flowered, unequally pedicellate in pairs; scales 4 , thin, hyaline, awnless, the 2 outer ones empty, pilose, the third glabrous, usually empty, the fourth glabrous, subtending a perfect flower and its 2 -nerved palet. Stamens 1 or 2. Styles distinct, stigmas plumose. [Commemorates Ferrante Imperate, Italian naturalist of the sixteenth century.] About 5 species of tropical distribution. Type species: Lagurus cylindricus $\mathrm{L}$.

1. Imperata brasiliénsis Trin. Mem. Acad. St. Petersb. VI. 2: 331.1832.

Culms $8 \mathrm{dm}$. high, or less; sheaths glabrous; leaf-blades erect, 1-4 dm. long, less than $1 \mathrm{~cm}$. wide, the upper surface densely hirsute near the base, the 
apex long-acuminate, the base narrowed; panicle 1-2 dm. long, 2-3 cm. thick, obtuse, its branches erect or nearly so; spikelets $3-4.5 \mathrm{~mm}$. long, the subtending hairs about twice as long, nearly white.

Borders of savannas, Andros, New Providence and Eleuthera:-Florida; Cuba ; continental tropical America. Silver-plume Grass.

\section{SCHIZACHỲRIUM Nees, Agrost. Bras. 331. 1829.}

Annual or perennial grasses, the spikelets in spike-like racemes, terminating the culm or its branches. Rachis articulated, the internodes cup-shaped or appendaged, the basal callus barbed. Spikelets in pairs at each node of the rachis, one sessile, the other stalked, the sessile one dorsally compressed, 1-flowered, the flower perfect; first scale 2-keeled with infolded margins, the second awnless or bristle-tipped, the third 2-nerved or nerveless, the fourth usually 2-cleft, usually bearing a bent awn. Stalked spikelet usually flowerless. Stamens mostly 3. Styles distinct; stigmas plumose. [Greek, cleft-chaff.] Some 40 species, or more, of tropical and subtropical America. Type species: Andropogon brevifolius $\mathbf{S w}$.

Leaf-blades flat, or sometimes conduplicate when dry, never terete; racemes glabrous or nearly so.

Leaf-blades terete; racemes long-hairy.

1. S. semiberbe.

2. S. gracile.

1. Schizachyrium semibèrbe Nees, Agros. Bras. 336. 1829.

Andropogon semiberbis Kunth, Enum. 1: 489. 1833.

Perennial; culms glabrous, branched, erect, 6-12 dm. high; leaves glabrous; sheaths compressed, keeled; blades 1-3 dm. long, 2-5 mm. wide; racemes narrow, 5-8 $\mathrm{cm}$. long, the internodes of the rachis as long as the sessile spikelets or shorter, glabrous or nearly so; sessile spikelets $5-7 \mathrm{~mm}$. long, the first scale glabrous or with a few short hairs, its infolded margins touching, the third and fourth scales ciliate, the fourth 2-cleft nearly to the base, its awn 12-15 mm. long; stalked spikelet of one hispidulous scale about $3 \mathrm{~mm}$. long, with an awn about as long.

Pine-lands, New Provldence:-Florida; Cuba: Hispaniola; Porto Rico; Trinldad; South America. Recorded by Coker as Andropogon tener Kunth. STIFF BEARD-GRASS.

2. Schizachyrium grácile (Spreng.) Nash, in Small, Fl. SE. U. S. 60. 1903.

Andropogon gracilis Spreng. Syst. 1: 284. 1825.

Perennial, tufted, glabrous, except the inflorescence; culms slender, branched, $2-6 \mathrm{dm}$. high. Sheaths striate; leaf-blades $2 \mathrm{dm}$. long or less, terete, less than $1 \mathrm{~mm}$. in diameter; racemes long-stalked, 3-5 $\mathrm{cm}$. long, the rachis clothed with long silky hairs; sessile spikelet 5-6 mm. long, the first scale chartaceous with hispidulous keels, the second scale acute, the fourth 2-cleft, bearing an awn 13-20 mm. long; stalked spikelet of one short-awned scale 1-2.5 mm. long.

Pine-lands and scrub-lands, Abaco, Great Bahama, Andros. New Providence, Eleuthera, Cat Island, North Calcos :- Florida; Jamalca ; Hispaniola ; Porto Rico; Cuba; Guadaloupe. SLENDER BEARD-Grass.

\section{ANDROPÒGON L. Sp. Pl. 1045. 1753.}

Perennial grasses with usually long narrow leaves, and terminal and axillary racemes. Spikelets in pairs at each node of the jointed hairy rachis, one sessile, and perfect, the other with a pedicel and either staminate, empty or 
reduced to a scale, or none. Perfect spikelet consisting of 4 scales, the outer 2 coriaceous, the second keeled and acute, the two inner hyaline, the fourth more or less awned and subtending a palet and perfect flower. Stamens 1-3. Grain free. [Greek, in allusion to the bearded rachis.] About 150 species, widely distributed in tropical and temperate regions. Type species: Andropogon hirtum L.

Branches of the inflorescence crowded at the summit of the stem in 1 or more dense corymbiform clusters.

Branches of the inflorescence scattered along the stem in a long narrow panicle.

1. A. glomeratus.

2. A. virginicus.

1. Andropogon glomeràtus (Walt.) B. S. P. Prel. Cat. N. Y. 67. 1888.

Cinna glomerata Walt. F1. Car. 59. 1788.

Andropogon tenuispatheus Nash, N. A. Fl. 17: 113. 1912.

Culms $1.5 \mathrm{dm}$. high or less, much branched, the ultimate flowering branches forming oblong corymbiform clusters, the nodes of the secondary branches densely barbed. Sheaths keeled; leaf-blades $4 \mathrm{dm}$. long or less, $3-7 \mathrm{~mm}$. wide; spathes $2.5-3 \mathrm{~cm}$. long, glabrous; racemes in pairs, 1-2 cm. long; sessile spikelet 3-4 mm. long, the awn 10-15 $\mathrm{mm}$. long; pedicellate spikelet a rudimentary scale, or wanting.

Pine-lands, scrub-lands, and savannas, Abaco, Andros, New Providence, Eleuthera, Acklin's Island, Fortune Island, Crooked Island, Mariguana, Inagua :- southeastern United States: Mexico; West Indies ; troplcal continental America. Re. ferred by Dolley to Anatherum macrurum, following Grisebach. BUSHY BEARDGRASS. BED-GRASS.

\section{Andropogon virgínicus L. Sp. Pl. 1046. 1753.}

Culms tufted, 5-10 dm. tall, many times longer than the basal leaves; sheaths, at least the lower ones, more or less tuberculate-hirsute on the margins; leaves $4 \mathrm{dm}$. long or less, more or less hirsute on the upper surface near the base; spathes $3-5 \mathrm{~cm}$. long, racemes generally in pairs, $2-3 \mathrm{~cm}$. long; sessile spikelet $3-4 \mathrm{~mm}$. long, the awn $10-15 \mathrm{~mm}$. long; pedicellate spikelet wanting or rarely present as a minute scale.

Pine-lands and white-lands, Abaco, Elbow Cay, Great Bahamas, Great Sturrup Cay, New Providence, and Watling's Island:-Bermuda; Massachusetts to Missouri and southward to Mexico; Cuba; Hispaniola; Jamaica. Virginia BEARD-Grass.

\section{NÀZIA Adans. Fam. Pl. 2: 31, 581. 1763.}

Annual grasses, diffusely branched, with flat leavea and 1-flowered deciduous spikelets, either solitary or in clusters of $3-5$ in a terminal spike. Scales of spikelet 2 or 3 , the outermost small or wanting, the second rigid and covered with hooked prickles, the third membranous, subtending a palet and perfect flower. [Name unexplained.] Two species, of tropical and temperate regions. Type species: Cenchrus racemosus L.

1. Nazia alièna (Spreng.) Scribn. Bull. U. S. Dep. Agr. Agrost. 17: 28.1899.

Lappago aliena Spreng. Neue Entdeck. 3: 15. 1822.

Tufted, 1-3 dm. high, the culms often rooting at the lower nodes, slender, glabrous. Sheaths glabrous; leaf-blades $2-8 \mathrm{~cm}$. long, $4 \mathrm{~mm}$. wide or less, their margins ciliate. Inflorescence 4-10 cm. long; spikelets $2-3 \mathrm{~mm}$. long; the second scale bearing prickles $0.5 \mathrm{~mm}$. long or less, the prickles with swollen opaque bases.

Sandy fields, Grand Turk Island and Ambergris Cay :-southwestern United States to the Argentine; Cuba to St. Thomas and Antigua. Prickle-grass. 
6. ANTHÈPHORA Schreb. Beschr. Gras. 2: 105. pl. 44. 1810.

Tufted grasses, the culms often branched, erect or prostrate, the leares mostly flat, the 1-flowered spikelets in deciduous clusters of 3 or 4 , forming elongated terminal, slender spikes. Empty scales of the spikelets rigid, the first one indurated, large, involucre-like, the others acute or short-awned; upper and inner scales thin, the innermost enclosing a thin palet and a perfect flower, the stamens 3 , the styles united at the base, the stigmas plumose. [Greek, flower-bearing.] Five known species, of tropical distribution, the following typical.

1. Anthephora hermaphrodita (L.) Kuntze, Rev. Gen. Pl. 759. 1891.

Tripsacum hermaphroditum L. Syst. ed. 10, 1261. 1759.

Annual; culms 3-10 dm. long, rooting and branching at the lower nodes. Leaves flat, $7-20 \mathrm{~cm}$. long, 4-10 $\mathrm{mm}$. wide, glabrous or hirsute, acuminate; spikes 2-12 cm. long, continuous and dense, or interrupted below, about $4 \mathrm{~mm}$. thick, the slender rachis flexuous; clusters of spikelets about $7 \mathrm{~mm}$. long; lower scales ovate to elliptic, acute to acuminate, glabrous or hispidulous.

South Caicos:- West Indies and continental tropical America, commoniy in waste and cultivated grounds. ANTHEPHORA.

\section{SYNTHERÍSMA Walt. Fl. Car. 76. 1788.}

Annual grasses, with flat leaves and spikelets borne in pairs or sometimes in 3 's, in secund spikes which are digitate or approximate at the summit of the culm. Spikes often purplish. Scales of the spikelet 4 , sometimes 3 by the suppression of the lowest one; the fourth or innermost scale chartaceous, subtending a palet of similar texture and a perfect flower. Stamens 3. Stigmas plumose. [Greek, crop-making, in allusion to its abundance.] Species about 20, widely distributed in temperate and tropical regions. Type species: Syntherisma praecox Walt.

Rachis of the racemes with the angles naked, not winged; first scale of the spikelet usually wanting.

Rachis of the racemes with the lateral angles broadly winged, thus making it appear flat; first scale of the spikelet usually present.

Splkelets about $2.5 \mathrm{~mm}$. long, one fifth as wide as long, a cuminate.

Spikelets 3-3.5 mm. long, one fourth as wide as long or more. acute.

1. S. fliformis.

2. S. digitata.

3. S. sanguinalis.

1. Syntherisma filiförmis (L.) Nash, Bull. Torrey Club 22: 420. 1895.

Panicum filiforme L. Sp. Pl. 57. 1753.

Milium paniceum Sw. Prod. 24. 1788.

Syntherisma paniceum Nash, N. A. Fl. 17: 152. 1912.

Culms 1.5-7 dm. tall. Sheaths at least the lower ones hirsute; leaves 3-20 cm. long, 1-4 mm. wide; racemes $2-5,2-10 \mathrm{~cm}$. long, erect or ascending; spikelets about $1.8 \mathrm{~mm}$. long, $0.75 \mathrm{~mm}$. wide, elliptic, acute, in pairs, the first scale wanting, the second 3 -nerved, the third 7 -nerved, the fourth scale deep chestnutbrown at maturity.

White-lands, sea-beaches, and roadsides, Andros, New Providence, and Cat Isiand :-New Hampshire to Michigan, Florida and Mexico; Cuba; Hispaniola ; Jamaica; Porto Rico. Slender Finger-grass. 
2. Syntherisma digitàta (Sw.) Hitchc. Contr. U. S. Nat. Herb. 12: 142.1908.

Milium digitatum Sw. Prodr. 24. 1788.

Digitaria horizontalis Willd. Enum. 92. 1809.

Panicum horizontale Meyer, Prim. Fl. Esseq. 54. 1818.

Syntherisma setosa Nash, Bull. Torrey Club 25: 300. 1898.

Culms 4-10 dm. long, branched, tufted, at length decumbent below and rooting at the lower nodes. Leaves more or less densely hirsute, $2-12 \mathrm{~cm}$. long, 2-7 mm. wide; racemes several, 3-14 cm. long, whorled or alternate or approximate in pairs, widely spreading; rachis very narrow; spikelets in pairs, about $2.5 \mathrm{~mm}$. long, lanceolate, acuminate; first scale minute, glabrous; second scale 3-nerved, appressed-pubescent; third scale 7-nerved, also appressedpubescent; fruiting scale nearly $2 \mathrm{~mm}$. long, shorter than the third, elliptic, greenish when mature.

Sandy places and cultivated ground, Berry Islands, Andros, New Providence, Great Exuma, Eleuthera, Watling's Island, Long Island:-Florida ; throughout tropical America. Socthern CraB-Grass.

3. Syntherisma sanguinàlis (L.) Dulac, Fl. Haut. Pyr. 77. 1867.

Panicum sanguinale L. Sp. P1. 57. 1753.

Digitaria sanguinalis Scop. Fl. Carn. ed. 2, 1: 52. 1772.

Digitaria marginata Link, Enum. Hort. Berol. 1: 102. 1821.

Digitaria fimbriata Link, Hort. Berol. 1: 226. 1827.

Panicum fimbriatum Kunth, Rev. 33. 1829.

Syntherisma marginatum Nash, N. A. Fl. 17: 154. 1912.

Culms $8 \mathrm{dm}$. long or less, finally branched, prostrate at the base and rooting at the lower nodes. Lower leaf-sheaths densely papillose-hirsute; blades $2-8$. cm. long, 5-10 mm. wide, erect or ascending, glabrous or more or less pubescent; racemes $2-9,2-12 \mathrm{~cm}$. long, erect or ascending, alternate, in pairs or whorls; spikelets $3-3.5 \mathrm{~mm}$. long, about $0.8 \mathrm{~mm}$. wide, lanceolate, very acute, in pairs; first scale small, glabrous, the second and third appressed-pubescent with long hairs, the second one 3-nerved, the third slightly exceeding the flowering scale, 7-nerved, the pubescence usually becoming widely spreading, the fourth one lanceolate, very acute, yellowish white at maturity.

Sandy places, roadsides and waste places, Great Bahama, Abaco, New Providence, Eleuthera, Long Island, Elbow Cay, Fortune Island, Acklin's Island, Inagua:temperate and tropical America. Native of the Old World. Referred by Hitchcock to Panicum Linkianum Kth. LARGER CraB-GrasS.

\section{VAนòTA Adans. Fam. Pl. 2: 495. 1763.}

Tall perennial grasses, with fląt leaves and large terminal pubescent panicles. Spikelets lanceolate, acute or acuminate; scales 4 , the 3 outer ones membranous, empty, the first minute or rudimentary, the second silky-pilose and ciliate, the fourth one shorter, glabrous, shining, chartaceous. [Perhaps in honor of P. Vallot.] Several species, of warm temperate and tropical America, the following typical.

1. Valota insulàris (L.) Chase, Proc. Biol. Soc. Wash. 19: 188. 1906.

Andropogon insulare L. Syst. Nat. ed. 10, 1304. 1759.

Panicum leucophaeum H.B.K. Nov. Gen. \& Sp. 1: 97.1815.

Panicum insulare Meyer, Prim. Fl. Esseq. 60. 1818.

Trichachne insularis Nees, Agrost. Bras. 86. 1829.

Culms erect, slender, 1-1.6 m. high, clustered. Leaves $3 \mathrm{dm}$. long or less, 1-2 cm. wide, acuminate, glabrous or their sheaths pubescent; panicle narrow, often $3 \mathrm{dm}$. long, little, if any more than $3 \mathrm{~cm}$. thick; spikelets 4-6 mm. long, 
acuminate; second and third scale 3-nerved, long-hairy; fruiting scale chestnutbrown.

Sandy soll and cultivated ground, Abaco, Andros, New Providence. Eleuthera, Great Exuma, Cat Island, Long Cay, Acklin's Island, Inagua, and Anguilla Isles :Florida; Bermuda; West Indles and continental troplcal America. Referred by Dolley to Tricholaena leucophaea. SILKY-GRAss.

\section{AxONÒPUS Beauv. Agrost. 12. 1812.}

Perennial grasses, with the culms usually rooting at the lower nodes, with flat leaves and 1-flowered spikelets, borne singly in 2 rows in one-sided spikes which (in our species) are disposed in a single pair at the summit of the culm, or sometimes with an additional one a short distance below. Spikelets oblong to lanceolate, convex on the outer surface, flat on the inner. Scales 3 , the outer 2 membranous, the inner one firm and with its opening turned toward the rachis, substending a perfect flower. Stamens 3. Styles separate.. Stigmas plumose. Grain free. [Greek, foot-axis.] About 12 species, of warm temperate and tropical regions, the following typical.

\section{Axonopus compréssus (Sw.) Beauv. Agrost. 12, 154. 1812.}

Mitium compressum Sw. Prodr. 24. 1788.

Paspalum tristachyon Lam. Tab. Encycl. 1: 176. 1791.

Anastrophus compressus Schlecht.; Nash, in Small, Fl. SE. U. S. 79. 1903.

Stolons numerous, leafy, sometimes $6 \mathrm{dm}$. long. Culms 1.5-6 dm. tall, slender, compressed, glabrous; sheaths loose; leaves glabrous, sometimes sparsely ciliate, obtuse, those of the culm 5-10 $\mathrm{cm}$. long, 4-6 mm. wide, those of the stolons about $2.5 \mathrm{~cm}$. long, $2-4 \mathrm{~mm}$. wide; spikes $2-5,2.5-5 \mathrm{~cm}$. long, approximate at the summit of the long and slender stalk; spikelets not crowded nor secund, about $2 \mathrm{~mm}$. long, acute.

Grassy places, New Providence :-Virginla to Florida and Texas; the West Indies and continental troplcal America. FLAT Jornt-Grass.

\section{PÁSPALUM L. Syst. Nat. ed. 10, 855. 1759.}

Perennial grasses, various in habit, with generally flat leaves and 1-flowered spikelets, borne singly or in pairs in 2 rows on 1 -sided spikes, which are single, in pairs or panicled. Spikelets oblong to orbicular, flat on the outer surface, convex on the inner. Scales 3 , the outer ones membranous, the inner one indurated and subtending a palet and perfect flower. Stamens 3. Styles separate. Stigmas plumose. Grain ovoid or oblong, free. [An ancient Greek name for some grass, used by Hippocrates.] About 160 species, of wide distribution in tropical and temperate regions, most abundant in America. Type species: Panicum dissectum. L.

\section{Racemes single, or, if more than 1, distant, never in palrs.}

Spikelets wingless.

Spikelets $1.5 \mathrm{~mm}$. long or less; racemes usually short, rarely exceeding $4 \mathrm{~cm}$. long.

Spikelets singly disposed.

Spikelets normally in pairs.

1. P. Poiretii.

Splkelets appressed-pubescent or glabrous.

Primary pedicel much shorter than its splkelet.

Primary pedicel nearly as long as its spikelet. Spikelets glandular-pubescent.

Spikelets exceeding $1.5 \mathrm{~mm}$. long; racemes long, rarely under $6 \mathrm{~cm}$.

2. P. caespitosum.

3. P. portoricense.

4. P. Simpsoni. 
Racemes 6 or fewer; blades usually $4-8 \mathrm{~mm}$. wide or less; stems slender.

Racemes numerous, usually 10 or more; blades up to $1 \mathrm{~cm}$. wide or more; stems stout.

Rachis of the splkelet glabrous; sheaths not nodulose.

Rachis sparingly pllose; lower sheaths nodulose. Splkelets with a fimbriate wing.

Racemes in pairs at the summit of the stem; spikelets singly disposed.

Racemes long and slender; spikelets less than $2 \mathrm{~mm}$. long, nearly orbicular.

Racemes short and stout; splkelets over $2 \mathrm{~mm}$. long, ovate. Spikelets pubescent, ovate, 2.5-3 mm. long.

Splkelets glabrous, ovate-lanceolate, $3-4 \mathrm{~mm}$. Iong.

5. P. glabrum.

6. $P$. secans.

7. $P$. millegrana.

8. P. fimbriatum.

9. P. conjugatum.

10. P. distichum.

11. P. vaginatum.

1. Paspalum Poirètii R. \& S. Syst. 2: 878. 1817.

Perennial; culms densely tufted, $5 \mathrm{dm}$. high or less, slender, glabrous, simple, or sometimes branched at the base. Leaves $5-10 \mathrm{~cm}$. long, 3-6 mm. wide, glabrous or sparingly hirsute, or ciliate; racemes 1-3, erect or ascending, $2-4 \mathrm{~cm}$. long, the rachis about $0.5 \mathrm{~mm}$. wide; spikelets $1.5 \mathrm{~mm}$. long, $0.9 \mathrm{~mm}$. wide, elliptic, appressed-pubescent, singly disposed, the scales 3-nerved, the fruiting one oval. PALUM.

Savanna, Andros:-Cuba; Hispaniola; Porto Rico; Jamalca. PoIret's PAS-

2. Paspalum caespitòsum Fluege, Gram. Monog. 161. 1810.

Paspalum Blodgettii Chapm. Fl. S. U. S. 571.1860.

Tufted; culms slender, 3-6 dm. high. Leaves glabrous, narrowly linear, flat, 5-20 cm. long, 3-7 mm. wide, erect or nearly so, with glabrous sheaths; racemes $2-6$, erect, $1-5 \mathrm{~cm}$. long, the rachis very narrow; spikelets in pairs, a little less than $2 \mathrm{~mm}$. long and nearly $1 \mathrm{~mm}$. wide, elliptic, the first scale wanting, the second and third sparingly papillose-pubescent with appressed hairs, 3-nerved, the fruiting scale yellowish white.

Pine-lands, scrub-lands, and clearings, Abaco, Great Bahama, Berry Islands, South Biminl, Andros, New Providence, Eleuthera, Cat Island, Great Exuma, Inagua, and the Anguilla Isles:- Florida; Cuba to Porto Rico; Jamaica. Slender PASPALUM.

\section{Paspalum portoricénse Nash, Bull. Torr. Club 30:377. 1903.}

Culms tufted, glabrous, very slender, spreading, $6 \mathrm{dm}$. long or less, simple or rarely branched. Leaves flat, 5-12 $\mathrm{cm}$. long, 3-5 mm. wide, with a few long hairs at the base; racemes $1-3$, very slender, $2-6 \mathrm{~cm}$. long, ascending; spikelets geminate, ablong-elliptic, acute, about $1.8 \mathrm{~mm}$. long, $0.8 \mathrm{~mm}$. wide, glabrous, about as long as the primary pedicel, the first and second scales 3 -nerved.

Crooked Island (according to Hitchcock) ; Porto Rico.

4. Paspalum Simpsoni Nash, Bull. Torr. Club 24: 39. 1897.

Paspalum gracillimum Nash, in Small, Fl. SE. U. S. 73. 1903.

Tufted, similar to $P$. caespitosum; culms slender, 4-8 dm. high. Basal sheaths hirsute, the upper glabrous; leaves flat, linear-lanceolate, 4-10 cm. long, 3-10 mm. wide, glabrous on both sides, the margins ciliate; racemes 3-כ, spreading, 2-7 cm. long, the rachis narrow; spikelets in pairs, obovoid, about $1.5 \mathrm{~mm}$. long, and $0.8 \mathrm{~mm}$. thick, the first scale wanting, the second and third 3-nerved, densely pubescent with short glandular hairs.

Scrub-lands, white-lands, and clearings, Great Bahama, Abaco, Berry Islands, Andros, New Providence, Cave Cay, Watling's Island, Little Sań Salvador, Acklin's Island, Fortune Island, Mariguana, and Inagua :-Fiorida ; Cuba; Jamaica; Porto Rico. Simpson's Paspalum. 
5. Paspalum glàbrum Poir. in Lam. Encycl. 5: 30.1804.

Paspalum Helleri Nash, Bull. Torr. Club 30: 376. 1903.

Culms tufted, slender, glabrous, erect or ascending, simple, 3-10 dm. high. Leaves 5-20 $\mathrm{cm}$. long, 3-8 $\mathrm{mm}$. wide, roughish-margined, with a few hairs at the base of the blade; racemes 2-6, narrow, $10 \mathrm{~cm}$. long or less, erect or spreading; spikelets many, oval, glabrous or pubescent, 1.7-2 $\mathrm{mm}$. long, obtuse.

Moist grounds, Abaco and Great Sturrup Cay to Andros, North Calcos, Grand Turk and Inagua:- Cuba to Tortola and Barbadoes; Jamaica. Referred by Hitchcock to $P$. nanum C. Wright.

6. Paspalum sécans Hitch. \& Chase, Contr. U. S. Nat. Herb. 18: 319.1917.

Perennial, forming clumps; culms simple, erect glabrous, 1-2 m. tall. Leafsheaths with a row of white hairs at the mouth, the blades much elongated, sometimes $1 \mathrm{~m}$. long, 5-10 mm. wide, flat, but in drying more or less involute, their margins serrulate; racemes 5-20, slender, spreading, 5-15 cm. long; rachis glabrous; spikelets glabrous, about $2.5 \mathrm{~mm}$. long, $1.5 \mathrm{~mm}$. wide.

Moist soll, New Providence, Acklin's Island, and Inagua :-Cuba; Porto Rico; Barbadoes; Jamaica; St. Crolx; Antigua. Referred by Nash to $P$. Schreberianum, Tall paspalum.

7. Paspalum millegràna Schrad. in Schultes, Mant. 2: 175. 1824.

Paspalum Underwoodii Nash, Bull. Torrey Club 30: 375. 1903.

Culms stout, 1-1.5 m. high, often clustered, smooth. Lower sheaths nodulose, overlapping; leaves elongated, roughish, 5-10 $\mathrm{mm}$. wide, commonly pubescent above; racemes many, close toegther, ascending or nearly erect, 4-10 $\mathrm{cm}$. long; spikelets glabrous, suborbicular or obovate-orbicular, about $2 \mathrm{~mm}$. long, usually purplish; rachis sparingly pilose.

New Providence (according to Hitchcock and Chase) :-Jamalca; Cuba; Porto Rico; Tobago; Trinidad to southern Brazil. UNDERWOOD'S PASPALUM.

\section{Paspalum fimbriàtum H.B.K. Nov. Gen. \& Sp. 1: 93.1815.}

Annual; culms tufted, glabrous, often branched below, 3-8 dm. high, the sheaths hirsute or glabrous. Leaves $1-2.5 \mathrm{dm}$. long, $1.5 \mathrm{~cm}$. wide or less, ciliate; racemes $2-6$, erect or ascending, $2.5-7 \mathrm{~cm}$. long; spikelets mostly in pairs, suborbicular, 2.5-3.5 mm. long, the scales papillose, 3-nerved, the lower one with a broad cleft wing, with ciliate segments, the next with a similar partial wing, the fruiting scale 7-ridged.

Waste and cultivated grounds, Andros, New Providence, Eleuthera, Cat Island : -Cuba, Hispaniola and Porto Rico to Trinidad; Jamaica; South America. FringeD Paspalum.

9. Paspalum conjugàtum Berg. Acta Helv. 7: 129. 1762.

Smooth and glabrous. Culms compressed, 2-9 dm. tall, finally decumbent at the base and rooting at the lower nodes; leaves 4-16 cm. long, 4-12 $\mathrm{mm}$. wide; racemes in pairs, slender, often curved, spreading or ascending, 5-12 $\mathrm{cm}$. long, the rachis straight, or flexuous toward the apex, $0.6-0.8 \mathrm{~mm}$. broad; spikelets crowded, much compressed dorsally, singly disposed, $1.5 \mathrm{~mm}$. long, 1-1.2 $\mathrm{mm}$. broad, apiculate, the 2 outer scales 2-nerved, the nerves marginal, the first scale ciliate on the margins with very long lax hairs, the third scale smooth, white.

Grassy places along roads, apparently introduced, New Providence :-Bermuda ; Southern United States; Cuba to St. Thomas and Barbadoes; Jamaica; continentai tropical America; Old World tropies. Two-spiked Paspalui. 


\section{Paspalum dístichum L. Pugil. Pl. Jam. 5. 1759.}

Culms 1-6 dm. tall, from a long stout rootstock; sheaths compressed, keeled, usually crowded and overlapping, especially at the base and on the innovations, glabrous, or more or less hairy on the margins; leaves commonly less than $1 \mathrm{dm}$. long, 3-6 $\mathrm{mm}$. wide, usually glabrous; racemes terminal, in pairs, ascending, $2-5 \mathrm{~cm}$. long; spikelets singly disposed, ovate, $2.5-3 \mathrm{~mm}$. long, acute, the 2 oufer scales firm, 5 -nerved, rarely 7 -nerved, the first scale glabrous, the second appressed-pubescent, the third apiculate, pubescent at the apex.

Fresh water marsh, New Providence:-Bermuda; Virginia to Florida, Texas and California, and north on the coast to Oregon; the West Indies and tropical America. Hitchcock's plant from Fortune Island, referred to this species, proves to be $P$. vaginatum Sw. JoINT-GRASS.

\section{Paspalum vaginàtum Sw. Prodr. 21. 1788.}

Culms 2-6 dm. tall, from a long stout rootstock; sheaths compressed, keeled, usually crowded and overlapping, at least at the base and on the innovations, glabrous; leaves folded, or involute when dry, $1.5 \mathrm{dm}$. long or less, 2-4 $\mathrm{mm}$. wide, glabrous, or sparingly hairy; racemes terminal, usually in pairs, rarely more or but a single one, erect or ascending, 3-7 $\mathrm{cm}$. long; spikelets singly disposed, ovate-lanceolate, acute, 3-4 $\mathrm{mm}$. long, the 2 outer scales glabrous, thin, the first scale 4-nerved, the lateral nerves approximate at the margin, the midnerve suppressed, the second scale 5-nerved, the lateral nerves rather near together, the third scale glabrous at the apex or with 2 or 3 hairs.

Borders of marshes, New Providence, Watling's Island, Fortune Island, and Inagua :-Bermuda; southern United States; West Indies; tropical continental America. Sheathed Paspalum.

Paspalum sp. Hitcheock and Chase (Contr. U. S. Nat. Herb. 18: 316) record a plant of this genus from Inagua, not certainly referable to any known species.

\section{PANICUM L. Sp. Pl. 55. 1753.}

Annuals or perennials, various in habit, with open or contracted panicles. Spikelets 1-2-flowered, when 2-flowered the lower one staminate only. Scales 4, the 3 lower membranous, empty, or the third with a staminate flower, varying in the same species; the inner or fourth scale chartaceous, shining, enclosing a palet of similar texture and a perfect flower. Awns none. Stamens 3. Styles distinct. Stigmas plumose. Grain free, enclosed in the hardened fruiting scale and palet. [Old Latin name for some grass, probably the cultivated sorghum, referring to its panicle, taken from Pliny.] About 500 species, in temperate and tropical regions. Type species: Panicum miliaceum L.

A. Palet little or not at all enlarged when mature.

1. Inflorescence consisting of spike-like often 1-sided branches or racemes.

Spikelets singly disposed, in 2 distinct rows, on very short equal pedicels ; first scale truncate.

Spikelets otherwise arranged, on unequal pedicels ; first scale acute or obtuse, never truncate.

Fourth scale of the spikelet transversely rugose.

Panicle branches terminating with a spikelet, no prolongation.

Pedicels shorter than the spikelets.

Stems all fertile, the nodes naked, or occasionally sparsely pubescent.

Outer scales of the spikelet with no cross-veinlets; stems often rooting at the lower nodes.

Outer scales of the spikelet with manifest cross-veinlets ; stems rarely rooting at the lower nodes.

1. P. geminatum.

2. P. adspersum.

3. P. fasciculatum. 
Fertile stems tall and stout, the sterile long and creeping, the nodes densely barbed.

Some of the pedicels equaling or longer than the spikelets.

Panicle branches extending beyond the spikelet in a sterile rudiment.

Splkelets less than $2 \mathrm{~mm}$. 1ong.

Spikelets $2 \mathrm{~mm}$. long or more.

Fourth scale of the spikelet smooth.

2. Inflorescence usually a diffuse, rarely narrow panicle, its branches not spike-like.

Fourth scale of the splkelet transversely rugose.

Fourth scale smooth.

Annuals, or if perennials, not with tufts of leaves at the base of the stem.

Splkelets lanceolate to ovate, acute to acuminate, glabrous; leaf-blades elongated, linear.

Plants tufted, no long creeplng rootstocks; spikelets $3 \mathrm{~mm}$. long or less.

Panicle narrow, dense, its branches appressed.

Stems slender, $6 \mathrm{dm}$. tall or less; basal sheaths round.

Stems stout, usually $1 \mathrm{~m}$. tall or more: basal sheaths compressed, keeled, equitant.

Panicle broad at maturity, loose and open, its branches spreading or ascending.

First scale one half as long as the spikelet or more, broadly ovate, acute.

Sheaths glabrous; stems slender. 11. P. diffusum.

Sheaths densely papillose-hispld; stems stout.

First scale rarely exceeding one fourth the length of the spikelet, orbicular, truncate or rounded at the apex.

4. P. barbinode.

5. P. maximum.

6. P. distantiflorum.

7. $P$. Chapmani.

8. P. laxum.

5. P. maximum.

9. P. tenerum.

10. P. condensum.

12. P. Ghiesbreghtii.

13. P. dichotomiflorum.

Plants with long stout rootstocks; leaf-

blades very thick and firm; spikelets 4-5

$\mathrm{mm}$. long; seacoast grass.

Splkelets elliptic, pubescent; leaf-blades broad, ovate-lanceolate.

Perennials, with basal tufts of leaves.

Spikelets $1.5 \mathrm{~mm}$. long, glabrous.

Spikelets $2 \mathrm{~mm}$. long, pubescent.

Primary leaf-blades $5 \mathrm{~mm}$. wide or less, strongly striate; spikelets broadly obovold.

Primary leaf-blades up to $12 \mathrm{~mm}$. Wide; spikelets elliptic.

B. Palet much enlarged when mature.

14. P. amarulum.

15. $P$. trichoides.

16. $P$. coerulescens.

18. P. nitidum.

19. P. exiguiflorum.

1. Panicum geminàtum Forsk. Fl. Aegypt.-Arab. 18. 1775.

Aquatic. Culms 6-12 dm. long, usually clothed with sheaths below; leaves glabrous, $2.5 \mathrm{dm}$. long or less, $6-10 \mathrm{~mm}$. wide; racemes $10-20$, one-sided, the rachis broadly winged, appressed, 2-4 cm. long; spikelets about $2.5 \mathrm{~mm}$. long, ovate, acute, glabrous, singly disposed in 2 rows, the first scale broader than long and clasping the spikelet at its base, truncate at the apex, the fourth scale transversely wrinkled.

Wet or molst places, Great Bahama, Abaco, Berry Islands, New Providence, Eleuthera, Cat Island, Great Exuma, Long Island, Fortune Island, Crooked Island, and Inagua :-Bermuda; southern Florida and Texas; in tropical regions generally. Erroneously referred, by authors, to $P$. paspaloides Pers. WATER-GRASS.

2. Panicum adspérsum Trin. Gram. Pan. 146. 1826.

Culms ascending or spreading, rooting at the lower nodes, branched, compressed, glabrous, 3-10 dm. long. Sheaths ciliate above; leaf-blades 5-20 cm. 
long, 8-20 mm. wide, glabrous, or sometimes ciliate at the base, abruptly actrminate, rough-margined; panicles 6-15 $\mathrm{cm}$. long, composed of many spikelike racemes; spikelets short-stalked, 3-4 mm. long, 1.5-1.8 $\mathrm{mm}$. wide, fusiform; first scale acute, glabrous, 5-nerved, about one-third as long as the whole spikelet; second and third scales 5-7-nerved, hispid at least above, rarely glabrous.

New Providence and Anguilla Isles:-Florida; Cuba to Porto Rico, Tortola and Martinique; Jamaica. LoOSE PANIC-Grass.

\section{Panicum fasciculàtum Sw. Prodr. 22. 1788.}

Panicum fuscum Sw. Prodr. 23. 1788.

Panicum flavescens Sw. Prodr. 23. 1788.

Panicum paniculatum Nash, Bull. Torr. Club 30: 381. 1903.

Perennial; culms glabrous or somewhat pubescent above, slender or rather stout, erect, spreading or ascending, $0.3-1 \mathrm{~m}$. long. Leaves flat, $3 \mathrm{dm}$. long or less, $0.6-2 \mathrm{~cm}$. wide, glabrous or more or less pubescent, the sheaths sometimes pilose or hispid; panicles $\overline{5}-15 \mathrm{~cm}$. long, the branches raceme-like, ascending; spikelets commonly approximate, short-stalked, brown, $2-2.5 \mathrm{~mm}$. long, glabrous, the outer scales reticulate-veined, the fourth scale rugose.

Waste places, Grand Turk Island :- -southern Florida and Texas; the West Indies and tropical continental America. BRown PANIC-Grass.

4. Panicum barbinòde Trin. Mém. Acad. St. Petersb. VI. Sci. Nat. 1: 256. 1834.

Sterile culms 1-2 m. long, rooting at the nodes, the fertile ones erect, 6-10 dm. tall or more, the nodes densely barbed; leaf-sheaths often overlapping, papillose-hirsute; blades 1-3 dm. long, glabrous or pubescent, $6-16 \mathrm{~mm}$. wide; panicle 1.5-2 dm. long, its branches spreading or ascending; spikelets about $3 \mathrm{~mm}$. long, glabrous.

New Providence and Acklin's Island:-Bermuda; Florida to Texas; the West Indies and tropical America and Old Worid tropics. Has been confused with $P$. molle Sw. PARA Grass.

\section{Panicum máximum Jacq. Ic. Pl. Rar. 1: 2, pl. 13. 1781-6.}

Culm 1-2 m. tall or more, leafy; leaf-sheaths overlapping, glabrous, or tuberculate-pubescent; blades elongated, $1-4 \mathrm{~cm}$. wide, glabrous; panicle $3-6$ $\mathrm{dm}$. long, its branches erect or nearly so, very long; spikelets glabrous, $3-4 \mathrm{~mm}$. long, the fourth scale transversely rugose.

In swales and along swamps, New Providence, Eleuthera, Fortune Island, Turks Islands, and Inagua :- Bermuda; Georgia and Florida to Texas; ; the West Indies and continental America. Referred by Coker to $P$. elephantipes Nees. GuineA Grass.

6. Panicum distantiflòrum A. Rich. in Sagra, Hist. Cuba 11: 304. 1850.

Culms glabrous, tufted, slender, wiry, branched, 6-8 dm. high. Sheaths compressed; leaf-blades 1-3 dm. long, only 1 or $2 \mathrm{~mm}$. wide, involute in drying; panicles narrow, 2-7 cm. long, their branches nearly erect; spikelets elliptic, glabrous, acute, about $1.5 \mathrm{~mm}$. long; first scale about one-half as long as the whole spikelet, 5-nerved, acute; second scale obtuse, about two-thirds as long as the fruit.

Srrub-lands, Long Island and Inagua:-Cuba; Hispaniola; Curaçao. NARRow PANIC-GRASS.

\section{Panicum Chàpmani Vasey, Bull. Torrey Club 11: 61. 1884.}

Culms glabrous or nearly so, tufted, slender, 3-10 dm. high, simple, or sometimes branched below. Leaves 2-4 dm. long, 4-6 mm. wide, acuminate, the sheaths sparingly ciliate; panicles $3 \mathrm{dm}$. long or less, composed of sessile 1-sided spike-like racemes of 3-12 spikelets, the flexuous rachis terminated by a 
short bristle; spikelets nearly sessile, about $2 \mathrm{~mm}$. long, in 2 rows, obovoid, glabrous, the first seale obtuse, about one-half as long as the whole spikelet, the second scale 7-nerved, the fourth scale transversely wrinkled.

Scrub-lands and along marshes, New Provldence, Rose Island, Great Exuma :southern Florida. CHAPMAN's PANIC-GRASS.

8. Panicum láxum Sw. Prodr. 23. 1788.

Panicum agrostidiforme Lam. Tabl. Encycl. 1: 172. 1791.

Panicum tenuiculmum Meyer, Prim. Fl. Esseq. 58. 1818.

Culms simple or little branched, often decumbent and rooting at the lower nodes, 4-12 dm. high. Sheaths hirsute above, otherwise glabrous; leaves 1-2.5 dm. long, 4-15 $\mathrm{mm}$. wide, glabrous, or sparingly pubescent on the upper side; panicles $0.5-3 \mathrm{dm}$. long, with many, slender spike-like branches, the lower branches spreading, the ultimate branchlets mostly secund; spikelets 1-1.5 $\mathrm{mm}$. long, about $0.7 \mathrm{~mm}$. wide, short-stalked; first scale 1-3-nerved, about onethird the length of the whole spikelet, the second somewhat shorter than the third.

Turks Islands:- nearly throughout tropical America. RED-TOP PANIC-GRASS.

9. Panicum ténerum Beyr.; Trin. Mem. Acad. St. Petersb. VI 1: 341. 1834.

Culms slender, stiff, tufted, glabrous, 4-9 dm. high. Sheaths glabrous, or the lower softly pubescent; leaf blades $4-15 \mathrm{~cm}$. long, 2-4 $\mathrm{mm}$. wide, or the upper much smaller, erect, somewhat involute in drying, somewhat pubescent, at least toward the base; panicles solitary and terminal, $3-8 \mathrm{~cm}$. long, or also a few smaller ones lateral; spikelets $2-2.8 \mathrm{~mm}$. long, about $1 \mathrm{~mm}$. wide, shortstalked, rather erowded; first scale about one-half the length of the whole spikelet, 1-nerved, the second and third 5-7-nerved.

Open places in pine and scrub-lands, Andros and New Providence:-Georgia and Florida to Texas; Cuba ; Porto Rico. SLENDER PANiC-Grass.

10. Panicum condènsum Nash, in Small, Fl. SE. U. S. 93. 1903.

Culms tufted, branched, $0.6-1 \mathrm{~m}$. tall, the basal sheaths compressed and keeled. Leaves $2-4 \mathrm{dm}$. long, 6-8 mm. wide, erect or nearly so; panicles large, dense, oblong, 1-2.5 dm. long, their branches erect; spikelets numerous, about $2.3 \mathrm{~mm}$. long, acute, glabrous; first scale acuminate, about one-half the length of the whole spikelet; second and third scales acuminate.

Fresh water swamps and wet places, Andros, New Providence, Acklin's Island and Cat Island:- New Jersey to Florlda and Texas; Cuba; Porto Rico; Guadaloupe; Jamaica; Mexico. Dense Panic-grass.

\section{Panicum diffùsum Sw. Prodr. 23. 1788.}

Perennial; culms tufted, spreading or ascending, simple or little branched, glabrous with pubescent nodes, 2-5 dm. high. Sheaths striate, glabrous or pubescent; leaf-blades $2 \mathrm{dm}$. long or less, 1-3 mm. wide, sparingly pubescent; panicles 5-10 cm. long, open, the branches filiform; spikelets few, near the ends of the panicle-branches, short-stalked, about $2 \mathrm{~mm}$. long and $1 \mathrm{~mm}$. wide; first scale acute, about one-half as long as the spikelet; second and third scales 7-9-nerved.

Coppice, New Providence:-Jamaica; Cuba to St. Thomas, Tortola and Martinique, Diffuse Panic-grass.

12. Panicum Ghiesbreghtii Fourn. Mex. Pl. 2: 29. 1886.

Panicum hirtivaginum Hitche. Contr. U. S. Nat. Herb. 12: 223. 1909.

Perennial; culms erect, tufted, rather stout, 6-8 $\mathrm{dm}$. high, the nodes hirsute. Sheaths hirsute; leaf-blades flat, up to $6 \mathrm{dm}$. long and $12 \mathrm{~mm}$. wide, hirsute or glabrate; panicle 2-3 dm. long, its branches ascending; spikelets numerous, short-stalked, about $3 \mathrm{~mm}$. long and $1 \mathrm{~mm}$. wide; first scale acute, 
one-half to two-thirds as long as the whole spikelet; second and third scales 7-9-nerved.

A weed, Crooked Island:-Cuba; Porto Rico; Guadeloupe; Antigua; continental troplcal America.

13. Panicum dichotomiflòrum Michx. Fl. Bor. Am. 1: 48. 1803.

Panicum bartowense Scribn. \& Merr. Cire. U. S. Dept. Agric. Agrost. 35: 3. 1901.

Culms at first erect, 3-6 dm. tall, simple, later decumbent and geniculate, 1-1.5 m. long, branched at all the upper nodes. Sheaths loose, glabrous, or papillose-hispid, somewhat flattened; leaves $1.5-6 \mathrm{dm}$. long, 4-20 mm. wide, longacuminate, scabrous on the margins and occasionaly on the nerves; panicles pyramidal, 1-4 dm. long; spikelets 2-3 mm. long, crowded, lanceolate, acute, glabrous, sometimes purplish; first scale about one-fourth as long as the spikelet; second and third scales about equal, acute, 5-7-nerved; fourth scale elliptic, shining.

Swamps and water holes, Great Bahama, North Bimini, Andros, New Providence, Cat Cay, Watling's Island, Crooked Island, and Great Exuma :-Maine to Nebraska, Florida and Texas: Bermuda; Cuba. Recorded by Coker as $P$. elephantipes Nees; has been confused with $P$. proliferum Lam. SPREAding WitchGRASS.

14. Panicum amàrulum Hitchc. \& Chase. Contr. U. S. Nat. Herb. 15: 96.1910.

Culms rather stout, tufted, glabrous, glaucous, 4-15 dm. high, the sheaths overlapping. Leaves $1.5-3 \mathrm{dm}$. long, 6-12 $\mathrm{mm}$. wide, leathery, the margins involute; panicle narrow, sometimes $7 \mathrm{dm}$. long, its branches erect; spikelets about $5 \mathrm{~mm}$. long; first scale about one-half as long as the whole spikelet, the third somewhat longer than the second.

Sea-beaches and sand dunes. Great Bahama and New Providence :-Virginia to Florida and Mississippi; Cuba; Jamalca. SEA-BEACH Grass.

15. Panicum trichoìdes Sw. Prodr. 24. 1788.

Panicum brevifolium of authors. Not L. 1753.

Panicum capillaceum Lam. Tabl. Encycl. 1: 173. 1791.

Culms slender, ascending or erect, $6 \mathrm{dm}$. high or less, pubescent. Sheaths pubescent and ciliate; leaf-blades membranous, 2-7 $\mathrm{cm}$. long, 1-2 $\mathrm{cm}$. wide, ovate-lanceolate, acuminate at the apex, cordate-clasping at the base, glabrous or sparingly pubescent; panicles $2 \mathrm{dm}$. long or less, their branches filiform, spreading and ascending; spikelets nearly ellipsoid, about $1.2 \mathrm{~mm}$. long, sparingly hirsute; first scale acute, 1-nerved, about one-half as long as the whole spikelet; second and third scales 3 -nerved.

Turks Islands:-Jamaica; Cuba to Tortola and Trinidad; tropical continental America. HaIr-Like PaNiC-grass.

16. Panicum coeruléscens Hack.; Hitchc. Contr. Nat. Herb. 12: 219.1909.

Culms slender, tufted, glabrous, at first erect and simple, later reclining and with short, fascicled branches at the nodes, $8 \mathrm{dm}$. long or less. Sheaths glabrous, or the lower cometimes pubescent; leaves of the vernal stage $5-8 \mathrm{~cm}$. long, 3-7 mm. wide, glabrous or very nearly so; panicles of the vernal stage 3-7 cm. long, those of the autumnal stage usually reduced to a few spikelets; spikelets about $1.5 \mathrm{~mm}$. long, obovoid, glabrous; first scale about one-third the length of the whole spikelet.

Moist places and in swamps, Great Bahama, Andros, New Providence, Cat Island (?) Crooked Island:- New Jersey to Florida and Texas; Cuba. Referred by Dolley to $P$. dichotomum L. BLUISH PANIC-GRAss.

17. Panicum neurànthum Griseb. Cat. Pl. Cuba 232. 1866.

Culms tufted, slender, at length much branched, 3-7.5 dm. tall. Sheaths glabrous, or the lower pubescent; leaves smooth and glabrous, the primary 
erect, acuminate, $2.5-10 \mathrm{~cm}$. long, 2-5 $\mathrm{mm}$. wide, those on the branches shorter, erect or ascending, usually involute when dry, concealing the small secondary panicles; primary panicle $2.5-10 \mathrm{~cm}$. long, its branches at first erect, at length spreading; spikelets numerous, about $2 \mathrm{~mm}$. long, densely pubescent with short, spreading hairs, the second and third scales 7-nerved.

Swamps and savannas, Andros and New Providence :-Florlda; Cuba. NERved PANIC-GRASS.

18. Panicum nítidum Lam. Tabl. Encycl. 1: 172. 1791.

Culms slender, tufted, $3-10 \mathrm{dm}$. long, erect or reclining, often becoming much-branched, the nodes bearded. Sheaths glabrous, ciliate, or the lower pubescent; leaves of the vernal stage $5-12 \mathrm{~cm}$. long, 3-10 $\mathrm{mm}$. wide, the basal ones tufted, those of the autumnal stage much smaller, 1-3 cm. long, 1-3 $\mathrm{mm}$. wide; panicles of the vernal stage $5-8 \mathrm{~cm}$. long, often nearly as wide, those of. the autumnal stage smaller, sometimes reduced to a few spikelets; spikelets $2 \mathrm{~mm}$. long, $1 \mathrm{~mm}$. wide, pubescent, the first scale about one-third as long as the whole spikelet.

Pine and palmetto lands, Great Bahama:-Virginia to Missouri, Florida and Texas; Cuba. SHINING PANIC-GRASS.

19. Panicum exiguifiòrum Griseb. Cat. Pl. Cub. 234. 1866.

Panicum tricolor Hack. Oest. Bot. Zeitsch. 51: 370. 1901.

Perennial; culms tufted, glabrous, slender, simple or somewhat branched, erect or ascending, 1-5 dm. high. Leaves 1-6 $\mathrm{cm}$. long, 0.5-1.5 mm. wide, flat, glabrous or their sheaths ciliate; panicles $2-10 \mathrm{~cm}$. long, their few slender branches spreading or finally reflexed, bearing several, short-stalked spikelets about $1.5 \mathrm{~mm}$. long; first scale 3-nerved, about one-third as long as the spikelet; second scale nearly as long as the first; palet large, subcoriaceous, forcing the spikelet open at maturity.

Moist grounds, Acklin's Island, Fortune Island and Inagua :-Cuba.

An imperfect specimen of a Panicum, perhaps representing $P$. lucidum Ashe, was collected on Cat Island (Britton \& Millspaugh 57\%6).

\section{IASIACIS (Griseb.) Hitchc. Contr. U. S. Nat. Herb. 15: 16. 1910.}

Perennial, woody, often elongated and vine-like grasses, with flat leaves, the inflorescence of terminal panicles of large subglobose somewhat oblique 1-flowered spikelets. Scales 4, somewhat coriaceous or chartaceous, not awned, bearing an apical tuft of short hairs. Grain enclosed in the hard fruiting scale and palet. [Greek, hairy-tip.] Ten species or more, of tropical and subtropical America. Type species: Panicum divaricatum L.

1. Lasiacis divaricàta (L.) Hitchc. Contr. U. S. Nat. Herb. 15: 16. 1910.

Panicum divaricatum L. Syst. Nat. ed. 10, 871. 1759.

Culm glabrous, smooth, much branched, erect or arching, 2-3 m. long, the branches sometimes pendent. Sheaths ciliate; leaves glabrous, acuminate, those of the main culm 8-12 $\mathrm{cm}$. long, 1-2 cm. wide, those of the branches smaller; panicle 5-10 em. long, its slender branches spreading; spikelets swollen, $45 \mathrm{~mm}$. long, the scales tipped with woolly hairs, the broad lower scale clasping.

Copplces and scrub-lands, Great Bahama, Abaco, Andros, New Providence, Rose Island, Eleuthera, Cat Island, Little San Salvador, Watling's Island, Rum Cay, Conception Island, Crooked Island, Acklin's Island, Fortune Island, North Caicos, Little Inagua, Inagua, and Angulla Isles :-southern Florida ; West Indies and continental troplcal America. CANE-GRASS. WILD CANE. 
13. ЕСHINóCHLOA Beauv. Agrost. 53. pl. 11, f. 2. 1812.

Usually tall grasses, commonly annuals, with broad leaves and a terminal inflorescence consisting of one-sided racemes racemosely or paniculately arranged. Spikelets 1-flowered, singly disposed, or in smaller racemes or clusters on the ultimate divisions of the inflorescence. Scales 4 , the outer $3 \mathrm{mem}$ branous, hispid on the nerves, the third and usually also the second scale awned, or sometimes merely awn-pointed, the awn often very long; fourth scale indurated, shining, frequently pointed, enclosing a palet of similar texture and a perfect flower. Stamens 3. Styles distinct. Stigmas plumose. Grain free. [Greek, in reference to the stout hispid hairs of the spikelets.] Species about 12, mostly in warm and tropical countries. Type species: Panicum Crus-galli L.

Outer scales of the spikelet not awned; spikelets $2.5-3 \mathrm{~mm}$. long. 1. E. colonum.

רuter scales of the spikelet, at least one of them, awned; spikelets

3.5-4 mm. long, exclusive of the awns.

2. E. Crus-galli.

1. Echinochloa colònum (L.) Link, Hort. Berol. 2: 209. 1833.

Panrcum colonum L. Syst. Nat. ed. 10, 870. 1759.

Culms tufted, smooth and glabrous, $1.5-7.5 \mathrm{dm}$. tall, often decumbent and rooting at the lower nodes. Sheaths compressed, usually crowded; leaves flat, $2.5-17 \mathrm{~cm}$. long, 2-8 $\mathrm{mm}$. wide; inflorescence composed of 3-18, 1-sided, more or less spreading dense racemes $6-50 \mathrm{~mm}$. long, disposed along a 3-angled rachis and generally somewhat exceeding the length of the internodes; spikelets single, in pairs, or in 3 's in 2 rows on one side of the hispidulous, triangular rachis, obovate, pointed, the first scale about one-half as long as the spikelet, 3 -nerved, the second and third scales a little more than $2 \mathrm{~mm}$. long, awnless, 5 -nerved, hispid on the nerves, the fourth scale cuspidate.

Waste places, Turks Islands :-Virginia to Florida and Texas; tropical regions. JUNGLE RICE.

2. Echinochloa Crús-galli (L.) Beauv. Agrost. 53, 161.1812.

Panicum Crus-galli L. Sp. Pl. 56. 1753.

Culms 6-12 dm. tall, often branching at base. Sheaths smooth and glabrous; leaves $1.5-6 \mathrm{dm}$. long, 6-25 mm. wide, glabrous, smooth or scabrous; panicle composed of 5-15 sessile, erect or ascending branches, or the lower branches spreading or reflexed; spikelets ovate, green or purple, densely crowded in 2-4 rows on one side of the rachis; second and third scales about 3 $\mathrm{mm}$. long, scabrous or hispid, the third scale more or less awned, empty, the fourth ovate, abruptly pointed. Widely distributed as a weed in all cultivated regions. Naturalized from Europe.

Waste places, Turks Islands:- widely distributed in temperate and subtropical regions. Native of the Old World. BARNYARD-GrASS.

\section{OPIÍSMENUS Beauv. Fl. Owar. 2: 14, pl. 68. 1807.}

Perennial grasses, often decumbent and branched at the base, with broad flat leaf-blades and inflorescence composed of spikes, bearing on the lower side scattered clusters of a few spikelets. Spikelets 1-flowered. Scales 4 , the 3 outer membranous, the first and second empty, awned, the first equalling or somewhat shorter than the spikelet, the third scale usually awned, empty, or enclosing a small palet, the fourth one shorter than the others, obtuse, awnless, chartaceous, finally indurated, enclosing a shorter palet of similar texture and a perfect flower. Stamens 3. Styles distinct to the base. Stigmas plu- 
mose. [Greek, armed, presumably referring to the awns.] About 4 species, natives of warm regions. Type species: Oplismenus africanus Beauv.

1. Oplismenus hirtéllus (L.) R. \& S. Syst. 2: 481. 1817.

Panicum hirtellum L. Syst. Nat. ed. 10, 870. 1759.

Oplismenus setarius R. \& S. Syst. 2: 481. 1817.

Culms prostrate or nearly so, rooting at the nodes, very slender, $6 \mathrm{dm}$. long or less. Leaves ovate to ovate-lanceolate, acuminate, $1-6 \mathrm{~cm}$. long, $1 \mathrm{~cm}$. wide or less, their sheaths often pubescent; panicle $8 \mathrm{~cm}$. long or less, its filiform short branches erect or spreading; spikelets $3 \mathrm{~mm}$. long, the awns up to $8 \mathrm{~mm}$. long.

Cultivated ground, New Providence:-Bermuda; South Carolina to Florida and Texas; the West Indies and tropical continental America. WooD-Grass.

\section{ChamtochloA Scribn. Bull. U. S. Dep. Agr. Agrost. 4: 38. 1897}

Mostly annual grasses with erect culms and flat leaves, the inflorescence in spike-like clusters. Spikelets 1-flowered, or rarely with a second staminate flower, the basal bristles single or in clusters below the articulation of the rachilla, and therefore persistent. Scales of the spikelet 4 , the three outer membranous, the third often subtending a palet and rarely a staminate flower; the inner or fourth scale chartaceous, subtending a palet of similar texture and a perfect flower. Stamens 3. Styles distinct, elongated. Stigmas plumose. Grain free, enclosed in the scales. [Greek, in reference to the bristles of the inflorescence.] Species about 35, in temperate and tropical regions. Type species: Setaria longiseta Beauv.

Inflorescence with the spikelets racemosely arranged; bristles $5-16$ at the base of each spikelet, involucrate.

Inflorescence with the spikelets in clusters or on manifest branches; bristles 1-3 at the base of each spikelet, not involucrate.

Splkelets $2 \mathrm{~mm}$. long; leaves pubescent.

Spikelets $3 \mathrm{~mm}$. long; leaves glabrous.

1. C. geniculata.

2. C. setosa.

3. C. macrosperma.

1. Chaetochloa geniculàta (Lam.) Millsp. \& Chase, Field. Mus. Bot. 3: 37. 1903.

Panicum geniculatum Lam. Encycl. 4: 727. 1798.

Panicum imberbe Poir. Encycl. Suppl. 4: 272. 1816.

Chaetochloa imberbis Scribn. Bull. U. S. Dep. Agr. Agrost. 4: 39.1897.

Perennial; culms 6-12 dm. long, ascending. Sheaths smooth and glabrous, compressed and keeled; leaves 1-3.5 dm. long, 2-6 mm. wide, pale green or glaucous, smooth or nearly so; spike-like panicle long-exserted, rather slender, 2.5-7 cm. long, about $1.5 \mathrm{~cm}$. thick; spikelets usually single, about $2.5 \mathrm{~mm}$. long and $1.25 \mathrm{~mm}$. wide, the first scale ovate, 3-nerved, about one-half as long as the spikelet, the second scale acute, 3-nerved, the third scale 5-nerved; bristles in two nearly equal clusters of 5 each, very slender, 6-10 $\mathrm{mm}$. long.

Waste places, sink-holes, and in the scrub. Abaco, Great Bahama, Berry Islands, Andros, New Providence, Exuma Chain, Acklin's Island, Fortune Island, Caicos Islands, Grand Turk, Inagua, and Angulla Isles :-Bermuda; Massachusetts to Kansas, Florida and Texas; West Indies; tropical continental America. Referred by Hitchcock and by Coker to Setaria glauca Beauv.; and by Mrs. Northrop to Chaetochloa glauca. Fox-TAIL Grass. 
2. Chaetochloa setòsa (Sw.) Scribn. Bull. U. S. Dep. Agr. Agrost. 4: 39. 1897.

Panicum setosum Sw. Prodr. 22. 1788.

Setaria setosa Beauv. Agrost. 51, 178. 1812.

Panicum paractaenoides Trin. Mem. Acad. St. Petersb. VI. $3^{2}: 219.1834$.

Perennial, tufted; culms wiry, slender, 3-9 dm. high, somewhat flattened. Leaves $2 \mathrm{dm}$. long or less, pubescent or scabrous, 5-15 mm. wide; inflorescence more or less branched, the branches erect, or ascending, the lower sometimes $3 \mathrm{~cm}$. long; bristles 1-3 at the base of all the spikelets or of some of them, 6-12 $\mathrm{mm}$. long; spikelets ovoid, about $2 \mathrm{~mm}$. long.

Sandy or rocky soil, Berry Islands, Water Cay, Acklin's Island, Eleuthera, Crooked Island, Inagua, Little Inagua and Anguilla Isles :-Western Texas and New Mexico; tropical America. Referred by Hitchcock to Setaria caudato (Lam.) R. \& S., and by Coker to Setaria macrostachya H.B.K. BRISTLY Fox-TAIL GRASS.

3. Chaetochloa macrospérma Scribn. \& Merr. Bull. U. S. Dep. Agr. Agrost. 21: 33.1900.

Perennial; culms rather stout, glabrous, up to $1.2 \mathrm{~m}$. high. Leaf-sheaths compressed, the margins ciliate, the blades 1-3 dm. long, 1-2 cm. wide, glabrous; spike-like panicle $2.5 \mathrm{dm}$. long or less, $2-4 \mathrm{~cm}$. thick; bristles $1.5-3 \mathrm{~cm}$. long; spikelets acute, $3 \mathrm{~mm}$. long, the narrowly ovoid flowering scale transversely wrinkled, acute.

Coastal thicket, Frozen Cay, Berry Islands:- southern Florida and Texas. LARGe Fox-TAIL Grass.

[Setaria filiformis of Coker is a misprint for Scleria filiformis.]

\section{CENCHRÒPSIS Nash, in Small, Fl. SE. U. S. 109. 1903.}

Perrenial grasses, with long rootstocks and flat leaves, the spikelets in terminal spikes, each spikelet subtended by an involuere of 1 or 2 outer rows of barbed, thick-based bristles, and 1 or 2 inner rows of barbed spines longer than the bristles, the involucre jointed to the rachis and deciduous. Spikelets of 4 scales, the first and second ones empty, the third enclosing a palet onehalf its length or less, the fourth enfolding a similar palet and a perfect flower. Stamens 3. [Greek, resembling Cenchrus.] A few species, of tropical America. Type species: Cenchrus myosuroides H.B.K.

1. Cenchropsis myosuroìdes (H.B.K.) Nash, in Small, Fl. SE. U. S. 109.1903. Cenchrus myosuroides H.B.K. Nov. Gen. 1: 115. 1815.

Culms erect, slender, 0.6-1.5 m. tall, simple or branched above, glabrous. Leaves 1-3 dm. long, 3-8 mm. wide, glabrous; spikes 5-20 cm. long; involucres numerous, the barbed spines about $5 \mathrm{~mm}$. long, and about as long as the spikelet.

In sandy places, Grand Turk, Inagua, and Angullla Isles :- southern Florida: Mexico; Cuba ; Hispaniola; Porto Rico; tropical South America. SPIKED Fox-TAIL GraSS.

\section{CÉNCHRUS L. Sp. P1. 1049. 1753.}

Annual or perennial grasses, with usually flat leaves. Inflorescence spikelike. Spikelets subtended by a spiny involucre which is deciduous with them at maturity. Scales 4; the first hyaline; the second and third membranous, the latter sometimes having a palet and staminate flower in its axil; the fourth chartaceous, subtending a palet of similar structure which encloses a perfect 
flower. Stamens 3. Styles united below. Stigmas plumose. Grain free, enclosed in the seales. [Ancient Greek name for some grass, probably Millet.] About 12 species, in tropical and temperate regions. Type species: Cenchrus echinatus L.

Involucre 2-spikeleted, armed at the base with commonly shorter often reflexed splnes, usually glabrous, or merely puberulent at the base.

Involucre, over all, 8-12 $\mathrm{mm}$. In diameter.

Body of the involucre 5-6 mm, thick, finely pubescent. 1. C. carolinianus.

Body of the involucre 8-10 mm. thick, densely woolly. Involucre, over all, $5 \mathrm{~mm}$. in diameter or less.

Involucre more than 2-spikeleted, armed at the base with barbed bristles.

Spines on the usually 3-spikeleted involucre basal and slender, rarely any above, erect; bristles very slender.

Splnes on the usually 4-6-spikeleted involucre not basal but occurring on various parts, spreading or often reflexed; bristles stouter and almost spine-like.

2. C. tribuloides.

3. c. microcephalus.

4. c. viridis.

5. c. echinatus.

1. Cenchrus caroliniànus Walt. Fl. Car. 79. 1788.

Culms erect or decumbent from an annual root, 2-9 dm. long. Sheaths usually loose, compressed, smooth; leaves 6-12.5 cm. long; spikes 2.5-6.25 em. long, sometimes partially included in the upper sheath; involucres crowded on the scabrous rachis, '2-spikeleted, globose, pubescent exeept at the base, the spines stout; spikelets about $6 \mathrm{~mm}$. long.

Sand dunes, cultivated grounds, and waste places from South Bimini and Andros to Mariguana, Turks Islands, Inagua, Anguilla Isles and Salt Cay Bank :Maine to Nebraska, Arizona, Texas and Florida; West Indies and tropical contito $C$. tribuloides L. SMALL BUR-GRASS. DEVIL-GRASS.

\section{Cenchrus tribuloìdes L. Sp. Pl. 1050. 1753.}

Culms at first erect, later prostrate and forming mats, 4-6 dm. long, branching; leaf-sheaths compressed; blades 6-12 $\mathrm{cm}$. long, 4-8 mm. wide, smooth or rough, usually flat; spikes $2-6 \mathrm{~cm}$. long; involucres $6-20,1.5-2 \mathrm{~cm}$. broad, enclosing 2 spikelets, pubescent, the spines $3-4 \mathrm{~mm}$. long; spikelets $6-7$ long, usually not exserted beyond the involucre.

Sandy sea-beaches, New Provldence (according to Hitchcock):-New York to Florida and Mississippi; Brazil. LARGE BUR-GRASs.

3. Cenchrus microcéphalus Nash; Hitchc. \& Chase, Contr. U. S. Nat. Herb. 18: 356. 1917.

Culms at length prostrate and branching, up to $1 \mathrm{~m}$. long, smooth and glabrous; leaf-sheaths glabrous, or often ciliate on the margins; blades up to $1 \mathrm{dm}$. long, or those on the innovations longer, 2-3 $\mathrm{mm}$. wide, rough, commonly pubescent on the upper surface, ascending; spike 3-4 cm. long, exserted; involucres $8-12,5-6 \mathrm{~mm}$. long, $5 \mathrm{~mm}$. in diameter or less, the larger spines broad and flat, long-ciliate, the basal spines much shorter, not ciliate; spikelets 2, much exserted beyond the body of the involucre.

Moist soll, Little Harbor Cay and Frozen Cay, Berry Islands. Endemic. BAHAMA BUR-graSS.

\section{Cenchrus víridis Spreng. Syst. 1: 301. 1825.}

C. echinatus viridis Griseb. Fl. Br. W. I. 556. 1864.

Culms erect or ascending, usually $6-8 \mathrm{dm}$. high, branched or simple, the leaf-blades flat, $4 \mathrm{dm}$. long or less. Spike usually dense and cylindric, 8-12 $\mathrm{cm}$. long and often much exserted; involucres usually 3 -spikeleted, armed below with slender spines, the body about $4 \mathrm{~mm}$. in diameter, the barbed bristles slender.

Cultivated land, Andros. New Providence, Eleuthera, Long Island and Mariguana :-Florida; West Indies and tropical continental America. GREeN BuR-GrASs. 
5. Cenchrus echinàtus L. Sp. Pl. 1050. 1753.

Culms finally prostrate and rooting at the nodes, branched; leaf-sheaths loose; blades 1-4 dm. long, 5-16 mm. wide, smooth or rough, flat; spikes 3-12 $\mathrm{cm}$. long, finally more or less exserted; involucres 20-50, containing 4-6 spikelets, green to purplish, villous at the base, the spines $34 \mathrm{~mm}$. long, the bristles at the base numerous, slender, distinctly barbed for their whole length; spikelets 6-7 $\mathrm{mm}$. long.

Sandy soll, waste places and roadsides, Frozen Cay, New Providence, Eleuthera, Watling's Island, Fortune Island, Grand Turk and Inagua :-Bermuda ; North Carolina to Florida and Texas; West Indies; tropical continental America. SOUTHERN BUR-GRASS.

[Cenchrus hirsutus. Dolley's reference to this name is an error for Corchorus hirsutus into which he was led by Herrick's misprint of Cenchorus hirsutus for the same species.]

\section{STENOTÀPHRUM Trin. Fund. Agrost. 175. 1820.}

Perennial ereeping branched grass, with rather stout flattened culms and short linear leaves. Spikelets spicate or panicled, acute, mostly 2 -flowered, imbedded in depressions on one side of the flattened rachis. Scales 4; first scale small or minute, second about as long as the spikelet, third similar to the second, subtending a staminate flower, fourth rigid, enclosing a perfect flower. Stigmas plumose. [Greek, a narrow depression.] A few species of tropical and subtropical distribution, the following typical.

\section{Stenotaphrum secundàtum (Walt.) Kuntze, Rev. Gen. 794. 1891.}

Ischaemum secundatum Walt. Fl. Car. 249. 1788.

Stenotaphrum americanum Schrank, Pl. Rar. Monac. pl. 98. 1819.

Widely creeping, sometimes $5 \mathrm{~m}$. long, glabrous, rooting at the lower nodes. Leaf-sheaths keeled, flattened, the blade linear, 3-15 cm. long, 4-10 mm. wide, blunt and rounded at the apex; spikelets about $6 \mathrm{~mm}$. long in spikes 4-13 $\mathrm{cm}$. long.

Waste places and roadsides, North Bimini, Great Babama, Abaco, Andros, New Providence, and Fortune Island:-Bermuda ; South Carolina to Florida and Texas; West Indies and tropical continental America. RUNNING CraB-Grass.

\section{ARÍSTIDA L. Sp. Pl. 82. 1753.}

Grasses varying greatly in habit and inflorescence. Leaves narrow, often involute-setaceous. Spikelets narrow, 1-flowered. Scales 3, narrow, the two outer carinate; the third rigid and convolute, bearing three awns occasionally united at the base, the lateral awns rarely wanting or reduced to rudiments. Palet 2-nerved. Stamens 3. Styles distinct. Stigmas plumose. Grain free, tightly enclosed in the scale. [Latin, from arista, an awn.] About 100 species, in the warmer regions of both hemispheres. Type species: Aristida adscensionis $\mathrm{L}$.

Awns about equal in length.

First scale shorter than the second.

Annual; blades thin, flat or involute.

Perennial; blades thick, folded or involute.

First scale about as long as the second; perennial. Lateral awns minute.

1. A. adscensionis.

2. A. cognata.

3. A. gyrans.

4. A. scabra. 
1. Aristida adscensiònis L. Sp. Pl. 82. 1753.

Aristida stricta Griseb. Fl. Brit. W. I. 534. 1864. Not Michx. 1803.

Annual, tufted, glabrous; culms slender, erect, or ascending, 3-7 dm. long, branching from the lower nodes. Leaf-blades thin, flat or involute; panicles narrow, $1.5 \mathrm{dm}$. long or less, with short appressed branches or the lower branches spreading; awns about equal in length, 12-20 $\mathrm{mm}$. long.

In sandy places and in the scrub, Great Exuma, Long Island, Fortune Island, Crooked Island, Grand Turk, Caicos Islands, and Inagua :-West Indles; Ascension Island; continental troplcal America. ANNUal Triple-AWNed Grass.

2. Aristida cognàta Trin. \& Rupr. Mem. Acad. St. Petersb. VI. Sci. Nat. 51 : 127.1842.

Perennial; culms slender, tufted, spreading, 3-6 dm. tall. Leaves involute-filiform, the upper shorter; panicle spike-like, strict, or the top sometimes nodding, its short branches ascending; awns 1-2 cm. long, horizontal when old, nearly equal in length.

Roadside, Long Cay :-Jamalca ; Porto Rico ; St. Thomas ; St. Croix. Perexniat. TRIPLE-AW NED GRASS.

\section{Aristida gýrans Chapm. Bot. Gaz. 3: 18. 1878.}

Perennial; culms tufted, wiry, erect, 3-7.5 dm. tall, usually simple, or little branched. Leaves $3-5 \mathrm{~cm}$. long, about $1 \mathrm{~mm}$. wide, flat, or becoming involute in drying; spike-like panicles $0.5-1.5 \mathrm{dm}$. long, strict, or sometimes nodding, the few short branches appressed; outer scales of spikelet awn-pointed, the third scale from two-thirds to three-quarters as long as the first, middle awn 1-1.5 cm. long, horizontal, the lateral awns somewhat shorter, erect or divergent.

White-lands and palmetto-lands, New Providence:-Florida; Cuba; Hispaniola. Recorded by Small in Miami Flora as $A$. purpurascens Poir., which it resembles. FLORIDA TRIPLE-AWNED Grass.

\section{Aristida scàbra (H.B.K.) Kunth, Rev. Gram. 1: 62.1829.}

Streptachne scabra H.B.K. Nov. Gen. 1: 124. 1815.

Streptachne cubensis A. Rich. in Sagra, Hist. Cub. 11: 311.1850.

Perennial; culms $1 \mathrm{~m}$. high or less, erect, simple. Leaves involute, at least when dry, 2-3 dm. long, about $1 \mathrm{~mm}$. thick; panicle 2-3 dm. long, its branches ascending, the longer ones up to $14 \mathrm{~cm}$. long; spikelets short-stalked; terminal awn about $2 \mathrm{~cm}$. long, the lateral ones minute.

Pine and scrub-lands, Great Sturrup Cay, Andros, New Providence, Eleuther', Cat Island, Cave Cay, Rum Cay, Watling's Island, Acklin's Island, Crooked Island, Fortune Island, Mariguana and Inagua:-Cuba; Mexico. Referred by Dolley to Stipa sp. Ortachne floridana (Chapm.) Nash may not be distinct from this. TaLL TRIPLE-A WNED GRASS.

\section{MUHLENBÉRGIA Schreb.; Gmel. Syst. Nat. 2: 171.1791.}

Mostly perennial grasses, with flat or convolute leaves and paniculate inflorescence. Rootstocks often scaly. Spikelets 1-flowered, very rarely 2 -flowered. Scales 3, very rarely 4 ; the outer ones empty, membranous or hyaline, acute and sometimes awned; third scale 3-5-nerved, subtending a palet and perfect flower, obtuse, acute, or very often produced into a capillary awn; palet 2-keeled. Stamens often 3. Styles distinct. Stigmas plumose. Callus minute. Grain narrow, free, tightly enclosed in the scale. [In honor of Henry Muhlen. berg, 1756-1817, North American botanist.] About 60 species, chiefly natives of America, a few Asiatic. Type species: Muhlenbergia Schreberi Gmel. 
1. Muhlenbergia capillàris (Lam.) Trin. Gram. Unifl. 191. 1824.

Stipa capillaris Lam. Tabl. Encycl. 1: 158. 1791.

Culms 4.5-12 dm. tall, erect, simple, smooth or nearly so. Sheaths smooth, the lower short and overlapping, the upper ones much longer; leaves $1.5-3 \mathrm{dm}$. long, 2-4 mm. wide, scabrous; panicle 1.75-3 dm. in length or more, diffuse, the capillary branches 1-2 dm. long, at length widely spreading; spikelets on long hair-like pedicels which are clavate-thickened at the apex; outer scales unequal, acute or short-awned, slightly scabrous; third scale, exclusive of the awn, $4 \mathrm{~mm}$. long, about twice as long as the first one, the awn 6-18 mm. long.

Palmetto-lands, Andros and New Providence :-Massachusetts to Missouri, Florida and Texas; Cuba; Porto Rico. LoNg-a WNed HaIr-grass. PURple-grass,

\section{SPORóboLUs R. Br. Prodr. 169. 1810.}

Perennial or rarely annual grasses, with flat or convolute leaves and open or contracted panicles. Spikelets generally small, 1-flowered, occasionally 2-3flowered. Scales in the 1-flowered spikelets 3 , membranous; the 2 outer empty, the first somewhat shorter; the third scale equalling or longer than the empty ones; palet 2-nerved. Stamens 2-3. Styles very short, distinct. Stigmas plumose. Grain free, and often early deciduous. [Greek, referring to the deciduous grain.] About 100 species, in tropical and temperate regions, very numerous in America. Type species: Agrostis indica L.

Plants with no rootstocks; cuims tufted.

Second scale one half as long as the spikelet or less.

Panicle usually long and narrow, its branches spikelet-bearing to the base; spikelets numerous.

Second scale orbicular, rounded and erose-denticulate at the apex, one fourth to one third as long as the spikelet; spikelets loosely arranged on long slender branches.

Second scale ovate or oblong, acute or obtuse, about one half as long as the spikelet; spikelets densely arranged on the short and appressed branches.

Panicle loose and open, its branches naked at the base, spreading; splkelets few.

Second scale as long as the spikelet or nearly so.

Splkelets about $1.5 \mathrm{~mm}$. long; first scale about one fourth as long as the second; panicle branches rarely over $1.5 \mathrm{~cm}$. long.

Spikelets about $2 \mathrm{~mm}$. long; first scale about one half as long as the second; panicle branches longer.

Plants with long stout rootstocks; grass of sea beaches or saline situations.

1. S. indicus.

2. S. Berteroanus.

3. S. atrovirens.

4. S. argutus.

5. S. domingensis.

6. S. virginicus.

1. Sporobolus índicus (L.) R. Br. Prodr. 170. 1810.

Agrostis indica L. Sp. Pl. 63. 1753.

Agrostis tenacissima L. f. Suppl. 107. 1781.

Sporobolus Jacquemontii Kunth, Rev. Gram. 2: 427, pl. 12\%. 1831.

Glabrous. Culms 3-12 dm. tall, erect, tufted; leaves 2-6 mm. wide, attenuate into a long slender tip, the lower $2-3 \mathrm{dm}$. long, the uper shorter; panicle 1-4 dm. in length, usually elongated, narrow, spike-like; spikelets 1.5-2 $\mathrm{mm}$. long, the outer scales unequal, the second about one-third as long as the third, obtuse, smooth and glabrous, the lower one shorter, and often erosetruncate.

Waste and cuitivated grounds, New Providence and Eleuthera:-West Indies ; continental tropical America. Referred by Dolley to S. tenacissimus Beauv. IVEST INDIAN RUSH-GRASS. 
2. Sporobolus Berteroànus (Trin.) Hitchc. \& Chase, Contr. U. S. Nat. Herb. 18: 370.1917.

Vilfa Berteroana Trin. Mem. Acad. St. Petersb. VI. Sci. Nat. $4^{1}: 100$. 1840.

Sporobolus angustus Buckley, Proc. Phila. Acad. 1862: 88. 1863.

Slender, wiry, $1 \mathrm{~m}$. tall or less. Leaves smooth, nearly erect, 1-3 mm. wide, long-attenuate, the lower ones 1.5-2.5 dm. long, the upper shorter; panicle narrow, often $3 \mathrm{dm}$. long; spikelets about $3 \mathrm{~mm}$. long, crowded on the short appressed branches of the panicle; second scale ovate-oblong, about one half as long as the spikelet.

Sandy places, Andros, New Providence and Turks Islands :-Bermuda; Virginia and Tennessee to Florida and Texas; West Indies. BULL-Grass.

3. Sporobolus atrovirens (H.B.K.) Kunth, Rev. Gram. 1: 68. 1829.

Vilfa atrovirens H.B.K. Nov. Gen. 1: 1381815.

Sporobolus bahamensis Hack. Oest. Bot. Zeitsch. 52: 56. 1902.

Perennial, the roots of long filiform filures. Culms very slender, tufted, erect, glabrous, $3 \mathrm{dm}$. high or less. Leaves glabrous, mostly clustered at the base, narrowly linear, 2-8 cm. long; panicle loose, open, much-branched, 6-15 $\mathrm{cm}$. long, its filiform branches spreading, scattered, $2-4 \mathrm{~cm}$. long; the branchlets bearing a few spikelets about $1.5 \mathrm{~mm}$. long.

Acklin's Island:-Mexico. Filiform Rush-Grass.

4. Sporobolus argùtus (Nees) Kunth, Enum. 1:215. 1833.

Vilfa arguta Nees, Agrost. Bras. 395. 1829.

Perennial; culms $3 \mathrm{dm}$. tall or less, erect, or somewhat decumbent at the base. Sheaths shorter than the internodes, their margins sometimes hirsute at the top; leaves $2.5-5 \mathrm{~cm}$. long, 2-4 mm. wide at the base, acuminate, smooth and glabrous beneath, scabrous, and often sparingly hairy at the base above; panicle 3.75-7.5 $\mathrm{cm}$. in length, the branches $1.25-2.5 \mathrm{~cm}$. long, verticillate, at first appressed, finally widely spreading; spikelets $1.5 \mathrm{~mm}$. long; outer scales smooth and glabrous, the first rounded or obtuse, one-quarter the length of the acute second one; third scale about equalling the second, acute.

Sandy soll and in the scrub, Eleuthera, Long Island, Fortune Island, Mariguana, Grand Turk, and Inagua :-Kansas and Colorado to Loulsiana and Texas; Jamaica; Cuba to St. Croix; Antigua; Trinidad; tropical continental America. PoINTED DROPSEED-GRASS.

5. Sporobolus domingénsis (Trin.) Kunth, Enum. 1: 214. 1833.

Vilfa domingensis Trin.; Spreng. Neue Entdeck. 2: 59. 1821.

Perennial, similar to $S$. argutus, but usually larger, the culms up to $4 \mathrm{dm}$. long, the panicle densely many-flowered, narrow, $9 \mathrm{~cm}$. long or less, its branches $2-4 \mathrm{~cm}$. long. Spikelets $2 \mathrm{~mm}$. long; first scale about one-half as long as the second.

Sandy places, scrub, and roadsides, Abaco, New Providence, Elenthera, Little San Salvador, South Cat Bay, Watling's Island, Long Island, Acklln's Island, Fortune Island, Ambergris Cay, Caicos Islands, Grand Turk, Little Inagua, Inagua, and Anguilla Isles :- Southern Florida and Texas'; Cuba; Hispaniola ; Porto Rico; Jamaica. DOMINGAN DROPSEED-GRASS.

6. Sporobolus virginicus (L.) Kunth, Rev. Gram. 1:67. 1829.

Agrostis virginica L. Sp. Pl. 63. 1753.

Culms 1.5-6 dm. tall, erect or decumbent, from a stout creeping rootstock. Sheaths numerous, short, overlapping and crowded at the lower part of the culm, smooth, glabrous or sometimes pilose on the margins and at the throat; leaves $2.5-20 \mathrm{~cm}$. long, $4 \mathrm{~mm}$. wide or less at the base, distichous, acuminate into a long point, involute on the margins and at the apex, smooth beneath, 
scabrous above or sometimes sparingly hairy; panicle $2.5-7.5 \mathrm{~cm}$. long, 4-10 $\mathrm{mm}$. thick, dense and spike-like, usually exserted; spikelets $2-2.5 \mathrm{~mm}$. long, the outer scales about equal, acute, smooth and glabrous; third scale smooth and glabrous, acute, slightly shorter than the second and about equalling the obtuse palet.

Moist situations, especially in brackish swamps, Great Bahama, Gun Cay Andros, New Providence, Eleuthera, Rum Cay, Long Island, Fortune Island, Crooked Isiand, Grand Turk, Little Inagua, Inagua, Water Cay, and Angulla Isles:-Bermuda; Virginia to Florida and Texas; West Indles and tropical continental America. SEA-SHORE RUSH-GRASS.

\section{SPARTINNA Schreb.; Gmel. Syst. 123. 1791.}

Perennial glabrous grasses, with long horizontal rootstocks, flat or involute leaves, and an inflorescence of one-sided spreading or erect alternate spikes. Spikelets 1-flowered, narrow, deciduous, borne in two rows on the rachis, articulated with the very short pedicels below the scales. Scales 3 ; the two outer empty, keeled, very unequal; the third subtending a perfect flower, keeled, equalling or shorter than the second; palet often longer than its scale, 2-nerved. Stamens 3. Styles filiform, elongated. Stigmas filiform, papillose or shortly plumose. Grain free. [Greek, referring to the cord-like leaves of some species.] About 7 species, widely distributed in saline soil, a few in fresh-water marshes. Type species: Spartina Schreberi Gmel.

1. Spartina pàtens (Ait.) Muhl. Gram. 55. 1817.

Dactylis patens Ait. Hort. Kew. 1: 104. 1789.

Spartina juncea Willd. Enum. 81. 1809.

Culms 3-9 dm. tall, erect, or decumbent at base, smooth. Leaves $1.5-3$ $\mathrm{dm}$. long, 2-4 mm. broad, involute, attenuate into a long tip, smooth and glabrous beneath; spikes $2-10,2.5-5 \mathrm{~cm}$. long, usually ascending, more or less peduncled, the rachis slightly scabrous; spikelets $6-8 \mathrm{~mm}$. long; outer scales acute, scabrous-hispid on the keel, the first usually rather less than one-half as long as the second; third scale somewhat scabrous on the upper part of the keel, emarginate or 2-toothed at the apex, longer than the first and exceeded by the palet.

Sea-beaches, Eleuthera; Fortune Island:-eastern United States; Bermuda; Jamaica ; Porto Rico; Guadaloupe; Martinique. SALT GraSS.

\section{CAPRİola Adans. Fam. Pl. 2: 31. 1763.}

\section{[Cynodon Rich.; Pers. Syn. 1: 85. 1805.]}

Perennial grasses with short flat leaves and spicate inflorescence, the spikes digitate. Spikelets 1-flowered, secund. Scales 3; the 2 lower empty, keeled; flowering scale broader, membranous, compressed; palet a little shorter than the scale, hyaline, 2-keeled. Stamens 3. Styles distinct. Stigmas short, plumose. Grain free. [Name mediæval Latin for the wild goat; that feeds on this grass in waste rocky places.] Four known species, of which three are Australian, the following typical one widely distributed.

1. Capriola Dáctylon (L.) Kuntze, Rev. Gen. 764. 1891.

Panicum Dactylon L. Sp. Pl. 58. 1753.

Cynodon Dactylon Pers. Syn. 1: 85. 1805.

Culms 1-3 dm. tall, erect, from long creeping and branching stolons, smooth and glabrous. Sheaths glabrous or somewhat hairy, crowded at the 
bases of the culms and along the stolons; leaves $2.5-5 \mathrm{~cm}$. long, $2-4 \mathrm{~mm}$. wide, flat, scabrous above; spikes 4 or 5 , digitate, $1-5 \mathrm{~cm}$. long, the rachis flat; spikelets $2 \mathrm{~mm}$. long; outer scales hispid on the keel, narrow, the first shorter than the second.

Waste and cultivated lands, New Providence, Eleuthera and Inagua :-Bermuda; southern New York to Kansas, Florlda and Texas; warm and tropical regions of both the OId World and the New. BERMUDA-GRASS.

\section{CHLòrIS Sw. Prod. 25. 1788.}

Mostly perennial grasses with flat leaves and spicate inflorescence, the spikes few or numerous, verticillate or approximate. Spikelets 1-flowered, arranged in two rows on one side of the rachis. Scales 4 ; the 2 lower empty, unequal, keeled, acute; third and fourth usually awned, the former subtending a perfect flower; palet folded and 2-keeled. Stamens 3. Styles distinct. Stigmas plumose. Grain free, enclosed in the scale. [Greek, greenish-yellow, referring to the color of the herbage.] About fifty species, mostly natives of warm and tropical regions. Type species: Agrostis cruciata $\mathrm{L}$.

Hairs on the margins or nerves of the third scale short, not manifest, appressed to and not extending beyond the apex.

Fourth scale of the splkelet at least one third as long as the second scale and bearing a long awn $4 \mathrm{~mm}$. long or more; spikes 4-6, widely spreading at maturity.

Fourth scale of the spikelet rudimentary, bearing an awn less than $4 \mathrm{~mm}$. long; spikes usually numerous, erect or

Hairs on the margins or nerves of the third scale long,

1. C. Sagraeana. manifest, widely spreading or extending much beyond the apex.

Third and fourth scales only awned, the former densely long-hairy on the midnerve, its awn less than twice the length of the scale.

Marginal hairs less than one half the length of the body of the scale, barely extending beyond its apex; spikes 3-5.

Marginal hairs equaling in length the body of the scale and extending much beyond its apex; spikes usually 6 or more.

Third, fourth and fifth scales awned, the first glabrous on the midnerve, its awn about three times the length of the scale.

2. C. radiata.

3. C. ciliata.

4. C. polydactyla.

5. C.,paraguiensis.

1. Chloris Sagraeàna A. Rich. in Sagra, Hist. Cub. 11: 315.1850 ,

Chloris eleusinoides Griseb. Fl. Brit. W. I. 539. 1864.

Perennial; culms ascending, $6 \mathrm{dm}$. long or less, usually branched below. Leaf-sheaths keeled, the blades narrow, involute; spikes 4-6, slender, 4-8 cm. long, horizontally spreading when old, not pectinate; spikelets imbricated, the fourth scale bearing a filiform awn 4-12 $\mathrm{mm}$. long.

Waste grounds and roadsides, New Providence, Fortune Island and Inagua :Cuba ; Hispaniola ; St. Crolx; Antigua ; Guadeloupe; Jamaica. Referred by Hitchcock to Chloris cruciata Sw. SAGRA's CHLORIS.

2. Chloris radiàta (L.) Sw. Prodr. 26. 1788.

Agrostis radiata L. Pl. Jam. Pugil. 7. 1759.

Annual; culms decumbent, ascending or erect, 2-4 $\mathrm{dm}$. long, usually branched, smooth and slender. Leaf-sheaths compressed, the blades flat, blunt or short-pointed, 2-15 cm. long; spikes several or many, radiating, slender, 4-8 cm. long, not pectinate; spikelets densely imbricated, the fourth scale rudimentary, bearing a filiform awn about $3 \mathrm{~mm}$. long.

Waste places and roadsides, New Providence:-West Indies and tropical continental America. Radiate ChLoRis. 
3. Chloris ciliàta Sw. Prodr. '25. 1788.

Annual; culms decumbent, ascending or nearly erect, rather stiff, $8 \mathrm{dm}$. long or less, smooth, mostly simple. Leaf-sheaths somewhat compressed, the blades flat, long-acuminate, $7-20 \mathrm{~cm}$. long; spikes few, stout, radiate, pectinate, 4-7 cm. long, commonly curved; spikelets pale, approximate, the third and fourth scales short-awned.

Waste places and roadsides, New Providence :-Cuba to St. Thomas, St. Croix, Martinique and Grenada; Jamalca; South America. FrINGEd CHLORIs.

4. Chloris polydáctyla (L.) Sw. Prodr. 26. 1788.

Andropogon barbatum L. Pl. Jam. Pugil. 30. 1759. Not Chloris barbata Sw. 1797.

Andropogon polydactylon L. Sp. Pl. ed. 2, 1483. 1763.

Chloris barbata Nash, Bull. Torrey Club 25: 443. 1898.

Perennial; culms 7-12 dm. high. Leaves smooth, up to $6 \mathrm{dm}$. long, 5-10 $\mathrm{mm}$. wide, long-attenuate. Spikes 6-25, spreading, 5-15 cm. long; spikelets, exclusive of the awns, about $3 \mathrm{~mm}$. long; scales 6 , the 2 empty ones acuminate; third scale pilose on the nerves, bearing an awn 3-4 $\mathrm{mm}$. long; fourth seale bearing an awn 2.5-3 mm. long; fifth and sixth scales awnless.

Cultivated ground, New Providence, Hog Island, Eleuthera, Cat Island, Rum Cay, Long Island:-Florida; Jamaica; Antigua; South America. MANY-SPIKED CHLORIS.

5. Chloris paraguaiénsis Steud. Syn. Pl. Gram. 204. 1854.

Chloris barbata Sw. Fl. Ind. Oce. 1: 200. 1797. Not Andropogon barbatum L. 1759.

Annual; culms decumbent, ascending or erect, 3-6 dm. long, slender, smooth. Leaf-sheaths compressed, the blades flat or folded, long-acuminate, 4-12 cm. long. Spikes few or numerous, radiate, pectinate, 4-8 cm. long; spikelets usually purple, the third, fourth and fifth scales filiform-awned.

Waste places, New Providence, Grand Turk, and Inagua:-tropical and warm temperato regions. PARAguar ChLoris.

\section{EUSTÁCHYS Desv. Nouv. Bull. Soc. Philom. 2: 188.1810.}

Perennial grasses, with flat or folded, usually obtuse leaf-blades, and spicate inflorescence, the spikes single, in pairs or 3-many and digitate. Spikelets usually 1-flowered, rarely 2 -flowered, sessile, crowded in 2 rows. Scales 4 , rarely 5 , the 2 lower empty, persistent, unequal, keeled, the first generally acute, the second oblong, truncate or 2-lobed at the apex, short-awned, the others awnless, mucronate, or short-awned, firmer than the empty scales, the third scale enclosing a perfect flower and a palet, the fourth scale empty, or rarely enclosing a staminate flower. [Greek, beautiful spikes.] About 6 species, natives of tropical America, the following typical.

1. Eustachys petraèa (Sw.) Desv. Nouv. Bull. Soc. Philom. 2: 189. 1810.

Chloris petraea $\mathrm{Sw}$. Prodr. 25. 1788.

Chloris Swartziana Doell. in Mart. Fl. Bras. 23 : 68. 1878.

Culms 3-11 dm. tall; leaves $3 \mathrm{dm}$. long or less, $10 \mathrm{~mm}$. wide or less, smooth; spikes 3-11, usually 4-6, erect, 4-11 $\mathrm{cm}$. long; spikelets about $2 \mathrm{~mm}$. long; scales 4 , the second, exclusive of the awn, 1.5-1.75 $\mathrm{mm}$. long, 2-toothed at the apex, the teeth triangular, acute or obtusish, the awn about $0.5 \mathrm{~mm}$. long; third scale about $2 \mathrm{~mm}$. long, in side view elliptic and about $1 \mathrm{~mm}$. wide, the 
awn short or wanting; fourth scale, in side view, obovate-elliptic, rounded at the apex, awnless.

Waste and cultivated lands, Great Bahama, Abaco, North Bimini, Andros, New Providence, Hog Island, Eleuthera, Cat Island, Watling's Island, Acklin's Island, Crooked Isiand, Long Cay, Mariguana, Grand Caicos, Little Ambergris Cay, Grand Turk, Inagua, Salt Key, and Angulla Isles :-Bermuda; North Carolina to Florlda and Texas; Cuba; Hispaniola; Horto Rico; Jamalca; tropical continental America. WEST INDIAN GRASS. FINGER-GRASS.

\section{BOUTELOÙA Lag. Varied. Cienc. $2^{4}$ : 134. 1805.}

Annual or perennial grasses with flat or convolute leaves and numerous spikelets in few one-sided spikes. Spikelets 1-2-flowered, arranged in two rows on one side of a flat rachis, the rachilla extended beyond the base of the flowers, bearing 1-3 awns and 1-3 rudimentary scales. Two lower scales empty, acute, keeled; flowering scale broader, 3-toothed, the teeth awn-pointed or awned; palet hyaline, entire or 2-toothed. Stamens 3. Styles distinct. Stigmas plumose. Grain oblong, free. [In honor of Claudius Boutelou, a Spanish botanist.] About 30 species, particularly numerous in Mexico and in the southwestern United States. Type species: Bouteloua racemosa Lag.

1. Bouteloua americàna (L.) Scribn. Proc. Phila. Acad. 1891: 306. 1892.

Aristida americana L. Syst. Nat. ed. 10, 879. 1759.

Bouteloua litigiosa Lag. Gen. \& Sp. Nov. 5. 1816.

Perennial, tufted. Culms.wiry, compressed, decumbent or ascending, $7 \mathrm{dm}$ : long or less, often much branched, glabrous. Leaves involute-margined, hairy near the base, 6-10 $\mathrm{cm}$. long, $2 \mathrm{~mm}$. wide or less; raceme open, composed of several spike-like branches $2-3 \mathrm{~cm}$. long; spikelets about 7 on each spike, appressed; second flower rudimentary, with 3 awns of about equal length.

Inagua :-Cuba to Tortola and Barbados; Jamaica; northern South America to Panama. MeSQuite-GR.ASS.

\section{ELEUSINNE Gaertn. Fruct. \& Sem. 1: 7. 1788.}

Tufted annual or perennial grasses, with flat leaves and spicate inflorescence, the spikes digitate or close together at the summit of the culm. Spikelets several-flowered, sessile, closely imbricated in two rows on one side of the rachis, which is not extended beyond them; flowers perfect or the upper staminate. Scales compressed, keeled; the 2 lower empty; the others subtending flowers, or the upper empty. Stamens 3. Styles distinct. Stigmas plumose. Grain loosely enclosed in the scale and palet. [From the Greek name of the town where Ceres was worshipped.] Species 6, natives of the Old World. Type species: Cynosurus coracana $\mathrm{L}$.

1. Eleusine Índica (L.) Gaertn. Fruct. \& Sem. 1: 8. 1788.

Cynosurus indicus L. Sp. Pl. 72. 1753.

Andropogon repens Schoepf, Reise 2: 493. 1788.

Culms 1.5-6 dm. tall, tufted, erect, or decumbent at the base. Sheaths loose, overlapping and often short and crowded at the base of the culm, glabrous or sometimes sparingly villous; leaves $7.5-30 \mathrm{~cm}$. long, 2-6 mm. wide, smooth or scabrous; spikes $2-10,2.5-7.5 \mathrm{~cm}$. long, whorled or approximate at the summit of the culm or one or two sometimes distant; spikelets 3-6-flowered, 3-4 mm. long; acales acute, minutely scabrous on the keel, the first 1-nerved, the second 3-7-nerved, the others 3-5-nerved.

Waste places, Abaco, New Providence, Eleuthera, Fortune Island, Grand Turk, Rum Cay, and Inagua:-Bermuda; common as a weed in all warm temperate and tropical reglons. WIRE-GRASS. 
28. DACTYLOCTÈNIUM. Willd. Enum. Hort. Berol. 1029. 1809.

An annual grass, with flat leaves and spicate inflorescence, the spikes in pairs or digitate. Spikelets several-flowered, sessile, closely imbricated in two rows on one side of the rachis, which is extended beyond them into a sharp point. Scales compressed, keeled, the 2 lower and the uppermost ones empty, the others subtending flowers. Stamens 3. Styles distinct, short. Stigmas plumose. Grain free, rugose, loosely enclosed in the scale. [Greek, referring to the digitately spreading spikes.] A monotypic genus of the warmer parts of the Old World.

1. Dactyloctenium aegýptium (L.) Willd. Enum. Hort. Berol. 1029.1809.

Cynosurus aegyptius L. Sp. P1. 72. 1753.

Culms 1.5-6 dm. long, usually decumbent and extensively creeping at the base. Sheaths loose, overlapping and often crowded, smooth and glabrous; leaves $1.5 \mathrm{dm}$. in length or less, 2-6 mm. wide, smooth or rough, sometimes pubescent, eiliate toward the base; spikes in pairs, or 3-5 and digitate, 1.25-5 cm. long; spikelets 3-5-flowered; scales compressed, scabrous on the keel, the second awned, the flowering ones broader and pointed.

Waste places, New Providence, Eleuthera, Great Bahama, Fortune Island, Caicos Islands, and Inagua :-New York to Californla, Florida and Texas; common as a weed in the West Indies, in tropical America, and in the tropics of the Old World. Egyptian Grass.

29. LEPTÓCHLOA Beauv. Agrost. 71, pl. 15, f. 1. 1812.

Usually tall annual or perennial grasses, with flat leaves and numerous spikes forming a simple panicle. Spikelets usually several-flowered, flattened, alternating in two rows on one side of the rachis. Scales 4 to many; the 2 lower empty, keeled, shorter than the spikelet; the flowering scales keeled, 3-nerved. Palet 2-nerved. Stamens 3. Styles distinct. Stigmas plumose. Grain free, enclosed in the scale and palet. [Greek, in allusion to the slender spikes.] About 12 species, natives of the warmer regions of both hemispheres. Type species: Cynosurus virgatus $\mathrm{L}$.

Spikelets with 7 or 8 scales, the flowering scales awnless, or sometimes the first and rarely the second short-awned; leaves glabrous.

Spikelets with 5 or 6 scales, the flowering scales all awned, the awn of the first scale more than one-half as long as the body; leaves sparingly pilose.

1. L. virgata.

2. L. domingensis.

1. Leptochloa virgàta (L.) Beauv. Agrost. 71, 166.1812.

Cynosurus virgatus L. Syst. Nat. ed. 10, 876. 1759.

Perennial; culms rather slender, smooth, erect or decumbent, somewhat tufted, 2-10 dm. high, little branched or simple. Leaves glabrous, the blades 6-18 cm. long, 4-15 mm. wide; spikes slender, weak, 3-12 cm. long, racemose near the top of the culm; spikelets about $4 \mathrm{~mm}$. long; flowering seales awnless or very short-awned.

Leptochloa. 
2. Leptochloa domingénsis (Jacq.) Trin. Fund. Agrost. 133. 1820.

Cynosurus domingensis Jacq. Misc. Austr. 2: 363. 1781.

Leptochloa virgata gracilis Griseb. Fl. Brit. W. I. 538. 1864.

Perennial, similar to the preceding species, but the leaf-sheaths often mor 6 or less hispid and the blades somewhat villous on the upper surface; flowering scales tipped by filiform awns 1-3 $\mathrm{mm}$. long.

Cultivated grounds and scrub lands, New Providence, Eleuthera, and Great Exuma :-Florida; Mexico; and the West Indies. SLENDER LePTochloA.

\section{PHRAGMìtes Trin. Fund. Agrost. 134. 1820.}

Tall perennial reed-like grasses, with broad flat leaves and ample panicles. Spikelets 3-several-flowered, the first flower often staminate, the others perfect; rachilla articulated between the flowering scales, long-pilose. Two lower scales empty, unequal, membranous, lanceolate, acute, shorter than the spikelet; the third scale empty or subtending a staminate flower; flowering scales glabrous, narrow, long-acuminate, much exceeding the short palets. Stamens 3. Styles distinct, short. Stigmas plumose. Grain free, loosely enclosed in the scale and palet. [Greek, referring to its hedge-like growth along ditches.] Three known species, the following typical one widely distributed, one in Asia, the third in South America.

\section{Phragmites Phragmites (L.) Karst. Deutsch. Fl. 379. 1881.}

Arundo Phragmites L. Sp. Pl. 81. 1753.

Phragmites communis Trin. Fund. Agrost. 134. 1820.

Culms 1.5-5 m. tall, erect, stout, from long horizontal rootstocks, smooth and glabrous. Sheaths overlapping, loose; blades $1.5-3 \mathrm{dm}$. long or more, 8-50 $\mathrm{mm}$. wide, flat, smooth, glabrous; panicle 1.5-3 dm. long or more, ample; spikelets crowded on the ascending branches; first scale 1-nerved, half to two-thirds as long as the 3-nerved second one; flowering scales 1-1.2 cm. long, 3-nerved, long-acuminate, equalling the hairs of the rachilla.

Marshes, Andros, New Providence, and Watling's Island:-Widely distributed in tropical and temperate regions. REED-GRASS.

\section{DIPLÁCHNE Beauv. Agrost. 80, pl. 16, f. 9. 1812.}

Tufted grasses, with narrow flat leaves and long slender spikes arranged in an open panicle, or rarely only one terminal spike. Spikelets several-flowered, narrow, sessile or shortly pedicelled, erect. Two lower scales empty, membranous, keeled, acute, unequal ; flowering scales 1-3-nerved, 2-toothed and mucronate or short-awned between the teeth. Palet hyaline, 2-nerved. Stamens 3. Styles distinct. Stigmas plumose. Grain free, loosely enclosed in the scale and palet. [Greek, referring to the 2-toothed flowering scales.] About 15 species, natives of the warmer regions of both hemispheres, the following typical.

1. Diplachne fasciculàris (Lam.) Beauv. Agrost. 160. 1812.

Festuca fascicularis Lam. Tabl. Encycl. 1: 189. 1791.

Leptochloa fascicularis A. Gray, Man. 588. 1848.

Culms tufted, finally branching, 3-8 dm. tall. Leaves erect, 1-2 dm. long, $3 \mathrm{~mm}$. or less wide, involute when dry, rough; racemes 8 or more, erect or 
ascending, the larger ones 4-8 $\mathrm{cm}$. long; spikelets 4-8 $\mathrm{mm}$. long; scales 10-12, the flowering scales, exclusive of the awn, 3-4 $\mathrm{mm}$. long, the midnerve extending into an awn $1 \mathrm{~mm}$. long or less.

Swamps, Andros, New Providence, Great Exuma, Cat Island, Long Cay, and Inagua :-Florida to Texas, and northward in the Mississippi valley to Illinois; Cuba ; St. Croix; Jamaica ; Mexico. SPIKE-Grass.

32. ERAGRÓSTIS Host, Ic. Gram. Austr. 4: 14, pl. 24. 1809.

Annual or perennial grasses, rarely dioecious, from a few inches to several feet in height, the spikelets in contracted or open panicles. Spikelets 2-manyflowered, more or less flattened. Two lower scales empty, unequal, shorter than the flowering ones, keeled, 1-nerved, or the second 3-nerved; flowering scales membranous, keeled, 3-nerved; palets shorter than the scales, prominently 2-nerved or 2-keeled, usually persisting on the rachilla after the fruiting scale has fallen. Stamens 2 or 3 . Styles distinct, short. Stigmas plumose. Grain free, loosely enclosed in the scale and palet. [Greek, etymology doubtful, perhaps signifying a low grass, or Love-grass, an occasional English name.] A genus of about 100 species, widely distributed throughout all warm and temperate countries. Type species: Briza Eragrostis L.

Palets glabrous on the keels, or merely hispidulous.

Annual; roots fibrous; spikelets not over $1.5 \mathrm{~mm}$. wide.

Perennials.

Pedicels several times longer than the spikelets.

Pedicels shorter than the spikelets.

Stems low, $3 \mathrm{dm}$. tall or less; inflorescence racemose or nearly so.

Stems tall, usually over $1 \mathrm{~m}$.; inflorescence profusely paniculate.

Palets with keels conspicuously ciliate; annuals.

Panicle contracted, spike-like, the branches short and appressed; palets with very long halrs; spikelets $3-4 \mathrm{~mm}$. long.

Panicle open, 1ts branches spreading; palets with shorter hairs; splkelets about $2 \mathrm{~mm}$. long.

1. E. tephrosanthos.

2. E. Elliottii.

3. E. bahamensis.

4. E. prolifera.

5. E. ciliaris.

6. E. amabilis.

1. Eragrostis tephrosánthos Schult. Mant. 2: 316. 1824.

Annual ; culms tufted, slender, erect or ascending, 1-3 dm. high, glabrous. Leaves $4-8 \mathrm{~cm}$. long, $1.5-3 \mathrm{~mm}$. wide, glabrous or nearly so, the sheath ciliate at the top; panicle open, 4-8 cm. long, its filiform branches spreading or ascending; spikelets filiform-peduncled, ovate to ovate-lanceolate, 4-7 $\mathrm{mm}$. long, about $2 \mathrm{~mm}$. wide; scales and palets glabrous.

Waste places and cultivated grounds, New Providence:-Cuba to St. Thomas and Trinldad; Jamaica ; continental troplcal America. ANNUAI LOVE-GRASS.

2. Eragrostis Flliòttii S. Wats. Proc. Am. Acad. 25: 140. 1890.

Poa nitida Ell. Bot. S. C. \& Ga. 1: 162. 1817. Not Lam. 1791.

Eragrostis macropoda Pilger, in Urb. Symb. Ant. 4: 106. 1903.

Perennial; culms tufted, glabrous, rather slender, erect, 4-10 dm. high. Sheaths glabrous; leaf-blades 1-4 dm. Iong, 3-5 mm. wide, scabrous above, smooth beneath; panicle 2-5 dm. long, open, its nearly filiform branches spreading or ascending; pedicels filiform, much longer than the spikelets; spikelets 6-13-flowered, 5-10 $\mathrm{mm}$. long, the flowering scales about $2 \mathrm{~mm}$. long.

Moist places in pine and palmetto-lands and open scrub-lands, Great Bahama, Abaco, Andros, New Providence, Eleuthera, Little San Salvador:-South Carolina to Florida and Louisiana: Cuba: Porto Rico; St. Thomas; Jamaica. Referred by Dolley to E. pectinacea Gray. ELLIOTT'S LOVE-GRASS. 
3. Eragrostis bahaménsis Hitche. Rep. Mo. Bot. Gard. 4: 149.1893.

Perennial, somewhat glaucous; culms slender, wiry, glabrous, 1-3 dm. high. Leaves setaceous, $8 \mathrm{~cm}$. long or less; spikelets sessile, distant, loosely spicate, oblong, many-flowered, 6-10 mm. long, about $2 \mathrm{~mm}$. wide; flowering scales 3-nerved, glaucous, compressed.

Wet or moist rocky places, Rum Cay, Acklin's Island. Ambergris Cay, Little Inagua, Inagua and Grand Turk. Endemic. BAHAMA LovE-GRASS.

4. Eragrostis prolifera (Sw.) Steud. Syn. Pl. Gram. 278. 1855.

Poa prolifera Sw. Prodr. 27. 1788.

Poa domingensis Pers. Syn. 1: 88. 1805.

Eragrostis gigantea Trin. Mem. Acad. St. Petersb. VI. 1: 403. 1831.

Perennial, tall; culms slender, up to $2 \mathrm{~m}$. high, often forming large clumps. Leaves elongated, $1.5-6 \mathrm{~mm}$. wide; panicle large, sometimes 6-7 dm. Iong, broad or narrow, the axils of its branches usually without hairs; spikelets several on the branchlets of the panicle, pale green, short-stalked, linear, about $10 \mathrm{~mm}$. long; palets glabrous.

In sand, Whale Cay:-Cuba; Hispaniola; Guadeloupe; Martinique; Jamaica ; Cayman Islands. TALL LOVE-GRASS.

5. Eragrostis ciliàris (L.) Link, Hort. Berol. 1: 192. 1827.

Poa ciliaris L. Syst. Nat. ed. 10, 875. 1759.

Annual; culms densely tufted, slender, erect or ascending, $3 \mathrm{dm}$. high or less; leaf-sheaths with a tuft of hairs at the top and usually ciliate, the blades flat, 2-7 cm. long, 2-5 mm. wide; panicle narrow, dense, 2-10 cm. long, its branches appressed; spikelets 3-4 mm. long, 6-16-flowered; palet-nerves longciliate.

Waste places and roadsides, Great Bahama, Abaco, Little Harbor Cay, New Providence, Eleuthera, Cat Island, Acklln's Island, Long Cay, Sand Cay, Grand Turk, Inagua, and Angullia Isles :-Georgia and Florida to Mississippi; West Indies and troplcal America.

6. Fragrostis amábilis (L.) W. \& A.; H. \& A. Bot. Beechey Voy. 251. 1841.

Poa amabilis L. Sp. Pl. 68. 1753.

Poa plumosa Retz. Obs. 4:20. 1786.

Eragrostis plumosa Link, Hort. Berol. 1: 192. 1827.

Annual; culms slender, densely tufted, erect or ascending, 1-4 dm. high. Sheaths commonly with a tuft of hairs at the top, their margins usually cilate; leaf-blades $2-10 \mathrm{~cm}$. long, $4 \mathrm{~mm}$. wide or less; panicle-branches spreading or ascending; spikelets about $2 \mathrm{~mm}$. long, $4-8$-flowered, the palets ciliate with very short hairs.

Waste piaces and cuitivated grounds, New Providence and Inagua :-Georgia and Florida; West Indies ; tropical continental America ; Old World Tropics. Recorded by Hitchcock as $E$. major Retz, but written up by him on the label of his Inagua specimen as $E$. minor. PLUMED LOVE-GRASS.

\section{UNİOLA L. Sp. Pl. 71. 1753.}

Erect and often tall grasses with flat or convolute leaves and paniculate inflorescence. Spikelets 3-many-flowered, flat, 2-edged, the flowers perfect, or the upper staminate. Scales flattened, keeled, sometimes winged, rigid, usually acute; the lower 3-6 empty, unequal; the flowering scales many-nerved, the uppermost scales often smaller and empty; palets rigid, 2-keeled. Stamens 1-3. Styles distinct. Stigmas plumose. Grain compressed, free, loosely enclosed 
in the scale and palet. [Name diminutive of unus, one, of no obvious application.] About 8 species, natives of America. Type species: Uniola paniculata L.

Spikelets $12 \mathrm{~mm}$, long or more; inflorescence an open loose panicle.1. U. paniculata. Spikelets 3-4 mm. long; inflorescence of numerous short secund racemes.

2. U. virgata.

1. Uniola paniculàta L. Sp. Pl. 71. 1753.

Culms 1-2.5 m. tall. Leaves $3 \mathrm{dm}$. long or more, about $6 \mathrm{~mm}$. wide, involute when dry, attenuate into a long slender tip; panicle open, loose, 2.25-3 $\mathrm{dm}$. in length or more, the branches erect or ascending, strict, rigid, the lower 6-12.5 cm. long; spikelets many-flowered, short-pedicelled, ovate to oval when mature, $1.25-2.5 \mathrm{~cm}$. long; flowering scales $8-10 \mathrm{~mm}$. long and scabrous on the keels.

Sand dunes and beaches, Abaco, New Providence, Eleuthera, Cat Island, Great Ragged Island, Atwood Cay, Crooked Island, Fortune Island, Mariguana, Turk's Islands, Inagua, and Salt Key :-Virginia to Florida and Texas; Cuba. Sea OATs. Catesby 1: $p l$. 32 .

2. Uniola virgàta (Poir.) Griseb. Fl. Brit. W. I. 531. 1864.

Poa virgata Poir. in Lam. Encycl. 5: 78. 1804.

Uniola racemiflora Trin. Bull. Acad. St. Petersb. 1: 68. 1836.

Culms tufted, 1-2 m. tall, rigid. Leaves $3-5 \mathrm{dm}$. long, rigid, involute, usually curved, $2-3 \mathrm{~mm}$. wide; panicle narrow, virgate, $2-5 \mathrm{dm}$. long, about $2 \mathrm{~cm}$. thick, its many short branches erect, appressed, the spikelets racemosespicate, secund, 3-4 mm. long, oval, few-flowered; flowering scales about 2 mm. long.

Sandy sea-beaches, Abaco, Andros, New Providence, Eleuthera, Cat Island:Cuba ; Hispaniola ; Porto Rico; Vieques; St. Thomas; St. Jan; Saba. SPIKE-Grass.

\section{DISTICHuIs Raf. Journ. de Phys. 89: 104. 1819.}

Dioecious grasses, with rigid culms creeping or decumbent at the base, flat or convolute leaves and spike-like paniculate inflorescence. Spikelets flattened, more numerous on the staminate plants than on the pistillate, $6-16$-flowered; rachilla continuous in the staminate spikelets, articulated in the pistillate. Two lower scales empty, narrow, keeled, acute, shorter than the flowering ones; flowering scales broader, many-nerved, acute, rigid; palets 2-keeled. Stamens 3. Styles thickened at the base, rather long, distinct. Stigmas longplumose. Grain free, enclosed in the scale and palet. [Greek, signifying tworanked, probably in reference to the spikelets.] Four known species, natives of America, inhabiting the seacoast or alkaline soil; one of them is also found in Australia. Type species: Uniola spicata L.

1. Distichlis spicàta (L.) Greene, Bull. Cal. Acad. 2: 415. 1887.

Uniola spicata L. Sp. Pl. 71. 1753.

Culms $7.5-60 \mathrm{~cm}$. tall, erect from a horizontal rootstock, or often decumbent at the base. Sheaths overlapping and often crowded; leaves 1.25-15 $\mathrm{cm}$. long, 2-4 mm. wide, flat or involute; panicle dense and spike-like, $1.8-6 \mathrm{~cm}$. in length, the branches $2.5 \mathrm{~cm}$. long or less, erect; spikelets 6-16-flowered, 8-18 $\mathrm{mm}$. long, pale green; empty scales acute, the first 1-3-nerved, two-thirds as long as the 3-5-nerved second one; flowering scales $3-5 \mathrm{~mm}$. long, acute or acuminate.

Brackish soll, Andros, New Providence, Eleuthera, Watling's Island, Inagua :Nova Scotia to Washington, California, Texas, and Florida; Mexico; Cuba; South America. Erroneously called Bulrosh. Marsh Spike-grass. Rabbit-grass. 
35. ARTHROSTYIIDIUM Rupr. in Mem. Acad. St. Petersb. VI. 5²: 117. 1839.

Woody, mostly vine-like grasses, the leaves usually borne on short branches whorled at the nodes, the leaf-blades linear or lanceolate, jointed with the sheaths. Spikelets racemose, usually appearing only after long intervals, sometimes only after many years. Spikelets linear, few-several-flowered, stalked or nearly sessile, more or less secund, articulated above the lower 3 or 4 empty scales; lowest scale-small, the others similar to earh other, acute or acuminate, many-nerved, not awned; palets narrow, 2-carinate, scarcely shorter than the scales. Flowers perfect. Stamens 3. Ovary glabrous; styles 2. Grain oblong. [Greek, referring to the jointed spikelets.] About 20 species, nativez of tropical America. Type species: Arthrostylidium Haenkei Rupr.

\section{Arthrostylidium capillifòlium Griseb. Mem. Am. Acad. II. 8: 531. 1862.}

Glabrous; stem slender, wiry, woody, elimbing over shrubs and small trees, sometimes $5 \mathrm{~m}$. long, often forming large colonies. Branches numerous, fascicled at the nodes, short; leaves capillary, flexible, 5-15 cm. long; spikelets few; at the ends of the branches, lanceolate, $8-12 \mathrm{~mm}$. long, 2-3 $\mathrm{mm}$. wide, several-flowered.

In low dense copplces and pinelands, Andros, New Providence, Cat Island, Great Exuma :-Cuba ; Porto Rico. OLD MAN's BEARD.

\section{Family 2. CYPERÀCEAE J. St. Hil.}

SEDGE FAMily.

Grass-like or rush-like herbs. Stems (culms) slender, solid (rarely hollow), triangular, quadrangular, terete or flattened. Roots fibrous (many species perennial by long rootstocks). Leaves narrow, with closed sheaths. Flowers perfect or imperfect, arranged in spikelets, one (rarely 2) in the axil of each scale (glume, bract), the spikelets solitary or clustered, 1many-flowered. Scales 2-ranked or spirally imbricated, persistent or deciduous. Perianth hypogynous, composed of bristles, or interior scales, rarely calyx-like, or entirely wanting. Stamens $1-3$, rarely more. Filaments slender or filiform. Anthers 2-celled. Ovary 1-celled. Ovule 1, anatropous, erect. Style 2-3-cleft or rarely simple or minutely 2-toothed. Fruit a lenticular, plano-convex, or trigonous achene. Endosperm mealy. Embryo minute. About 65 genera and 3000 speices, of very wide geographic distribution.

Fertlle flowers perfect.

Basal empty scales of the splkelet none, or not more than two. Scales of the spikelets distichous; bristles none.

Scales of the splkelets spirally imbricated (apparently distlchous in Abildgaardia).

Base of the style persistent as a tubercle on the achene. Splkelet 1; perlanth-bristles usually present; culms leafless.

Splkelets usually several or numerous ; bristles none ; culms leafy below.

Style wholly declduous; no tubercle on the achene.

Base of the style swollen; bristles none. Spikelets nearly terete, not flattened. Spikelets distinctly flattened.

Base of the style not swollen; bristles usually present.

Basal empty scales of the spikelets 3 or more.

Style 2 -cleft, its base persistent as a tubercle on the achene.

Bristles none; culm monocephalous.

Bristles usualiy present; culm usually polycephalous.

1. Cyperus.

2. Eleocharis.

3. Stenophyllus.

4. Fimbristylis.

5. Abildgaardia.

6. Scirpus.

7. Dichromena. 8. Rynchospora. 
Style 3-cleft, its base fused with the top of the achene; tubercle none.

Bristles none.

Bristles present.

Flowers all imperfect; achene bony or crustaceous.

9. Mariscus.

10. Schoenus.

11. Scleria.

\section{CYPÈRUS L. Sp. PI. 44. 1753.}

Annual or perennial sedges. Culms in our species simple, triangular, leafy near the base, and with 1 or more leaves at the summit forming an involucre to the simple or compound, umbellate or capitate inflorescence. Rays of the umbel sheathed at the base, usually very unequal, one or more of the heads or spikes commonly sessile. Spikelets flat or subterete, the scales falling away from the rachis as they mature (nos. 1-7), or persistent and the spikelets falling away from the axis of the head or spike with the scales attached (nos. 8-14). Scales concave, conduplicate or keeled, 2-ranked, all flower-bearing or the lower ones empty. Flowers perfect. Perianth none. Stamens 1-3. Style 2-3-cleft, deciduous from the summit of the achene. [Ancient Greek name for these sedges.] About 600 species, of wide distribution in tropical and temperate regions. Type species: Cyperus esculentus L.

Style-branches 2 ; achene lenticular.

Style-branches 3 ; achene trigonous.

1. C. paniculatus.

Splkelets not breaking up into one-fruited joints.

Scales deciduous from the persistent rachis of the spikelets.

Rachis-wings none, or very narrow.

Annuals.

Scales tipped with recurved awns.

Scales acuminate, not awned. Perennials.

Leaves flat; plants not viscid.

Spikelets yellow, oblong-lanceolate.

Splkelets green-brown, ovate.

Leaves involute; plant viscid.

Rachis-wings manlfest; perennial.

Spikelets falling away above the two persistent lower scales.

Leaves and culms filiform, reclining.

Leaves flat; culms stout or slender, erect. Spikelets with 1-4 achenes.

Spikelets in a single capitate cluster.

Umbel compound; spikes cylindric.

Spikelets with 5-20 achenes.

Scales acute or cuspidate, not awned.

Scales awned.

Spikelets breaking up into one-fruited joints.

Umbel compound; annual with flat leaves.

Spikelets in a single cluster or two; perennial with fillform leaves.

2. C. cuspidatus.

3. C. compressus.

4. C. ochraceus.

5. C. pseudovegetus.

6. C. elegans.

7. C. rotundus.

8. C. floridanus.

9. C. fuligineus.

10. C. ligularis.

11. C. brunneus.

12. C. confertus.

13. C. ferax.

14. C. filiformis.

1. Cyperus paniculàtus Rottb. Descr. \& Icon. 40. 1773.

Cyperus Gatesii Torr. Ann. Lyc. N. Y. 3: 255. 1836.

Annual, bright green. Leaves 1-4 mm. wide; culms slender, tufted, 1-4 dm. tall, often surpassing the leaves; bracts of the involucre $3-5$, surpassing the umbel, the longer ones up to $2 \mathrm{dm}$. long; umbel with 3-8 rays, or rarely nearly capitate: spikelets few, linear or linear-lanceolate, 6-15 $\mathrm{mm}$. long, acute; scales light chestnut-brown, oblong-lanceolate, acute, shining, striate, deciduous at maturity; style 2-cleft; achene lenticular, oblong, grayish, abruptly apiculate, fully half as long as the scale.

Molst ground, New Providence:-southeastern United States; West Indies ; tropical continental America. Referred by Clarke to Pycraeus ferrugineus; recorded by Dolley as $C$. polystachyus Rottb. Panicled CyPerus. 
2. Cyperus cuspidàtus H.B.K. Nov. Gen. 1: 204. 1816.

Annual, glabrous; culms tufted, 2-14 cm. tall, as long as the leaves, or longer. Leaves 1-2 mm. wide, those of the umbel usually 3 or 4 , sometimes 1 $\mathrm{dm}$. long; umbel 2-5-rayed, rarely capitate; rays $0.5-5 \mathrm{~cm}$. long; spikelets linear, 5-12 mm. long, about $1.5 \mathrm{~mm}$. wide, digitate, many-flowered; scales chestnut-brown, nearly $2 \mathrm{~mm}$. long, strongly 3-5-nerved, keeled, the recurvedspreading awn-like tip nearly as long as the body; stamens 1-3; achene broadly obovoid, $0.5 \mathrm{~mm}$. long, trigonous, brown, apiculate; style very short.

Wet soil, New Providence, Cat Isiand, Fortune Island, Acklin's Island, South Caicos, Inagua :- southern United States; Cuba; Anegada; Yucatan ; South Amerlca. Recorded by Hitchcock as C. aristatus Rottb. Cuspidate Cyperds.

3. Cyperus compréssus L. Sp. Pl. 46. 1753.

Annual; culms slender, erect or reclining, smooth, 7-25 cm. long. Leaves light green, about $2 \mathrm{~mm}$. wide, those of the involucre $2-3$, the longer exceeding the spikelets; umbel capitate or with $2-3$ short rays; spikelets narrowly lanceolate, acute, 8-20 mm. long, 3-4 mm. wide, very flat, many-flowered; scales light green with a yellow band on each side, ovate, acuminate, firm, keeled, several-nerved, falling away from the narrowly-winged rachis at maturity; stamens 3 ; style 3 -cleft; achene sharply 3-angled, obovoid, obtuse, dull, brown, about one-third as long as the scale.

Waste grounds, New Providence:-United States; Cuba to Virgin Gorda and Trinidad; Jamaica; tropical continental America and Old World tropics. Flat CY PERUS.

\section{Cyperus ochràceus Vahl, Enum. 2: 325. 1806.}

Perennial; culms rather stout, 2-7 dm. tall. Leaves $6 \mathrm{~mm}$. wide or less, the basal ones mostly shorter than the culm, those of the involucre several, spreading, 2 or more of them much longer than the compound or simple umbel; umbel-rays $15 \mathrm{~cm}$. long or less; spikelets numerous, capitate, flattish, blunt, many-flowered, 5-12 mm. long, about $2 \mathrm{~mm}$. wide; scales yellow, ovate to ovatelanceolate, obtusish; stamen 1; achene ovoid, 3-angled, narrowed at both ends.

Swamps, New Providence:- -southern United States; Cuba to Guadaloupe; Jamaica ; tropical continental America. Erroneously referred by Clarke to $C$. Luzulae Rottb., citing Brace no. 408; referred also here by Dolley. Yellow CrPerus.

\section{Cyperus pseudovégetus Steud. Syn. Pl. Cyp. 24. 1855.}

Perennial by thickened tuber-like joints of the rootstocks; culm rather stout, $0.3-1.3 \mathrm{~m}$. high, often equalled by the leaves. Leaves $3-4 \mathrm{~mm}$. wide, smooth, nodulose, the midvein prominent; leaves of the involucre 4-6, spreading; umbel several-rayed, compound; spikelets ovate, flat, many-flowered, light green, densely capitate, 4-6 mm. long; scales keeled, conduplicate, 1-nerved, curved, acute, longer than the linear 3 -angled slightly stalked achene; stamen 1 ; style 3 -cleft.

Swamps, New Providence at Southwest Bay:-southeastern United States. MARSE CYPERUS.

\section{Cyperus élegans L. Sp. Pl. 45. 1753.}

Cyperus viscosus Sw. Prodr. 20. 1788.

Perennial by short rootstocks; culms viscid-pubescent, $8 \mathrm{dm}$. tall or less. Leaves convolute in drying, the basal ones about as long as the culm, those of the involucre about 3 , the longer ones much surpassing the inflorescence; umbel usually compound, the rays up to $15 \mathrm{~cm}$. long; spikelets 2-12 in the clusters, digitate, oblong-lanceolate, 6-15 $\mathrm{mm}$. long, 3-5 mm. wide, compressed; scalez green-brown, ovate, strongly mucronate, about $3 \mathrm{~mm}$. long; stamens and stylebranches 3 ; achene obovoid, 3-angled, nearly black, about half as long as the scale.

Marshes and sink-holes, Great Bahama, New Providence, Eleuthera, Cat Isiand, Watling's Island, Acklin's Isand, Great Exuma, Inagua:-Florida ; Cuba to St. Jan and Trinidad; Jamaica; Yucatan; South America. Viscid CyPerus. 
7. Cyperus rotúndus L. Sp. Pl. 45. 1753.

Perennial by scaly tuber-bearing rootstocks; culm rather stout, $0.1-0.5 \mathrm{~m}$. high, usually longer than the leaves. Leaves 3-6 mm. wide, those of the involuere $3-5$; umbel 3-8-rayed, the longer rays $5-11 \mathrm{~cm}$. long; spikelets linear, clustered, few in each cluster, acute, 8-20 mm. long, 2-3 mm. wide; scales dark purple-brown or with green margins and centre, ovate, acute, appressed when mature, about 3-nerved on the keel; stamens 3 ; style 3 -cleft, its branches exserted; achene 3-angled, about one-half as long as the scale.

Waste and cultivated grounds, New Providence:-United States; Bermuda; West Indies: tropical continental America; warm-temperate and tropical parts of the old Worid. NUT-GRASS.

\section{Cyperus floridànus Britton; Small, Fl. S. E. U. S. 170. 1903.}

Perennial by tuber-like bases of the culms. Culms filiform, wiry, densely clustered, erect or reclining, $0.5-2.5 \mathrm{dm}$. long; leaves filiform, or the lowest reduced to scales, some of them usually as long as the eulm or longer, about $0.5 \mathrm{~mm}$. wide, those of the involucre 2 or 3 , similar to the lower ones, the longer much exceeding the head of spikelets, sometimes $10 \mathrm{~cm}$. long; head composed of few to several spikelets; spikelets digitate, flattened, linearsubulate, $6-15 \mathrm{~mm}$. long, $1 \mathrm{~mm}$. wide, several-flowered, acuminate; scales oblong, $2 \mathrm{~mm}$. long, chestnut-brown, blunt, strongly several-nerved, firm in texture; stamens 3 ; achene linear-oblong, about $1.5 \mathrm{~mm}$. long and $0.5 \mathrm{~mm}$. thick, dull, dark brown. Plant with the habit of $C$. filiformis.

Molst sandy soll, Abaco, Berry Islands, Andros, New Providence:-Florida ; Cuba ; Santo Domingo. Florida Cyperus.

\section{Cyperus fuligíneus Chapm. Fl. S. States 511. 1860.}

Mariscus fuligineus Clarke, Kew Bull. Add. Ser. 8: 16. 1908.

Perennial; culms very slender, smooth, tufted, 1-4 dm. high, rather rigid. Leaves revolute-margined, shorter than the culm, those of the involuere usually 2, unequal; spikelets linear, 6-10 $\mathrm{mm}$. long, 1-1.5 $\mathrm{mm}$. wide, densely crowded in a single terminal head; scales ovate to oval, about $2 \mathrm{~mm}$. long, dark brown, striate, mucronulate; style 3-cleft; achenes oblong-obovoid, trigonous, about $1.5 \mathrm{~mm}$. long, dull, brown.

Sandy and rocky soll, Berry Islands, New Provldence and Eleuthera to Ambergris Cay, Grand Turk, Inagua and the Angullia Isles:-Florlda; Cuban Cays; Anegada ; Bonalre; Curaçao. Recorded by Coker and presumably by Dolley as $C$. Vahlii Steud.; by Hitchcock as C. brunneus $\mathrm{Sw}$.

\section{Cyperus ligulàris L. Amoen. Acad. 5: 391. 1759.}

Perennial; roots fibrous, thick; rootstock short or none; culms stout, 1.2 $\mathrm{m}$. high or less. Leaves 8-20 mm. wide, pale green, rough-margined, the basal ones often overtopping the culm, those of the involucre sometimes $7 \mathrm{dm}$. long; umbel 4-12-rayed, large, compound; spikes oblong or subglobose, 8-10 $\mathrm{mm}$. thick, very dense; spikelets gray to brown, 4-6 mm. long, about $1.5 \mathrm{~mm}$. wide, bearing 2-4 achenes; fruiting scales oval or ovate, striate, blunt, 2.5-3 $\mathrm{mm}$. long; achene narrowly obovoid to ellipsoid, dark brown, dull, 3-angled, about $1.5 \mathrm{~mm}$. long, half as long as the scale.

Swamps, Great Bahama to Andros, New Providence, Fortune Island, North Caicos and Inagua :- southern United States: West Indies and troplcal continental America; tropical Africa. LARGe CyPerus. SAW-grass.

11. Cyperus brúnneus Sw. Fl. Ind. Oce. 1: 116. 1797.

Mariscus brizaeus Clarke in Urban, Symb. Ant. 2: 52.1900.

Perennial by stout rootstocks; culms stout, $7 \mathrm{dm}$. high or less. Leaves 4-10 mm. wide, pale green, the basal often overtopping the culm, those of the involucre 3-5, the longer much surpassing the inflorescence; umbel few-rayed, 
or glomerate, simple or little compound, the rays up to $3 \mathrm{~cm}$. long; spikelets short-spicate, 1-2 cm. long, about $3 \mathrm{~mm}$. wide, with 5-10 achenes; scales brown, ovate, apiculate, strongly striate-nerved; achene obovoid, 3-angled.

Sand dunes and white-lands, throughout the archipelago from Abaco and Great Bahama to the Caicos Islands, Little Inagua and Cay Sal :-Bermuda; Florida; West Indies; Mexico. Consists of several races differing in stalked or sessile spikes, width of leaves, the scales ovate to elliptic-oblong. Recorded by Herrick as C. Vahlii Steud. SAND or COAST CYPERUS.

\section{Cyperus confèrtus Sw. Prodr. 20. 1788.}

Perennial by short rootstocks; culms rather slender, 1-4 dm. high, clustered. Leaves 3-5 mm. wide, the basal ones as long as the culms or shorter, those of the involucre $2 \mathrm{dm}$. long or less, the longer much surpassing the inflorescence; umbel simple, 1-7-rayed; heads subglobose, about $1 \mathrm{~cm}$. thick; spikelets greenish-yellow, $5-7 \mathrm{~mm}$. long, about $2 \mathrm{~mm}$. wide, flat, bearing $5-9$ achenes; fertile scales ovate, keeled, strongly striate, tipped with short, somewhat curved awns; stamens 3 or sometimes 2 ; achene oblong-obovoid, 3 -angled, 1-1.5 $\mathrm{mm}$. long, about half as long as the scale.

Inagua :-Hispaniola to St. Thomas and to Martinique; Jamaica. Curaçao; northern South America; Galapagos. CAPITATE CYPERUS.

\section{Cyperus fèrax L. C. Rich. Act. Soc. Hist. Nat. Paris 1: 106. 1792.}

Annual; smooth; culms rather stout; $3-8 \mathrm{dm}$. tall, usually tufted. Leaves 5-10 $\mathrm{mm}$. wide, the lower ones as long as the culm or shorter, those of the involucre 3 or more, the longer equalling or exceeding the umbel; umbel simple or compound, several-rayed; spikelets linear, subterete, 10-20-flowered, $1.5-2.5 \mathrm{~cm}$. long, $1.5-2.5 \mathrm{~mm}$. thick, the ovate-oblong, appressed, yellow-green, 7-9-nerved scales scarcely imbricated; stamens 3 ; style 3-cleft; achene trigonous, narrowly obovoid, obtuse.

Swamps, Abaco, Cat Cay, New Providence, Exuma Chain, Eleuthera :-Unlted States; West Indies; Central and South America. COARSE CxPERUS.

\section{Cyperus filifòrmis Sw. Prodr. 20. 1788.}

Mariscus filiformis H.B.K. Nov. Gen. 1: 213. 1816.

Perennial; glabrous; culms very slender or filiform, tufted, rather weak, 2-7 dm. long. Leaves usually much shorter than the eulm, about $2 \mathrm{~mm}$. wide, those of the involucre 1 or 2 , mostly longer than the 1 or 2 loose spikes; spikelets $3-10$, nearly digitate, 1-2.5 $\mathrm{cm}$. long, about $1 \mathrm{~mm}$. thick, terete, erect or ascending, several-flowered; scales yellowish with a green keel, acutish, shining, faintly striate, ovate, inrolled, not overlapping; achene shorter than the scale, trigonous, ellipsoid, blackish, pointed at both ends.

Grassy places, New Providence:-Cuba to St. Thomas and St. Croix; Jamaica. The Crooked Island reference of Hitchcock proves to be an error, his plant being Schoenus nigricans L. SLENDER CYPERUS.

Schoepf records Kyllinga monocephala Rottb. as observed by him on New Providence in 1784, but no species of that genus has been collected in the Bahamas by subsequent botanists.

\section{ELEÓCHARIS R. Br. Prodr. 1:224. 1810.}

Annual or perennial sedges. Culms simple, triangular, quadrangular, terete, flattened or grooved, the leaves reduced to sheaths or the lowest very rarely blade-bearing. Spikelets solitary, terminal, erect, several-many-flowered, not subtended by an involucre. Scales concave, spirally imbricated all around. Perianth of 1-12 bristles, usually retrorsely barbed, or wanting in some species. 
Stamens 2-3. Style 2-cleft and achene lenticular or biconvex, or 3-cleft and achene 3 -angled, but sometimes with very obtuse angles and appearing turgid. Base of the style persistent on the summit of the achene, forming a terminal tubercle. [Greek, referring to the growth of most of the species in marshy ground.] About 140 species, widely distributed. Type species: Scirpus palustris $\mathrm{L}$.

Spikeiets littie, if at ail, thicker than the cuims; scales rigid; tail sedges.

Achenes transversely ridged; culms nodose-septate.

Achenes copiously pitted; culms continuous. $\quad 2$. $E$. cellulosa.

Spikelet thicker than the cuim; scales membranous; low sedges.

Upper sheath hyaline, scarious.

Perianth-bristles nearly white; achene $0.5 \mathrm{~mm}$. Iong cuims neariy filiform.

Perianth-bristies brown; achene $1 \mathrm{~mm}$. long; cuims slen-
der.

3. E. flaccida.

4. E. atropurpurea.

1. Eleocharis interstíncta (Vahl) R. \& S. Syst. 2: 149.1817.

Scirpus interstinctus Vahl, Enum. 2: 251. 1806.

Perennial by stout rootstocks; culms stout, terete, 4-10 dm. tall, nodose, hollow. Sheaths oblique, the lower sometimes bearing short blades; spikelet cylindric, terete, 2-4 cm. long, 4-5 mm. thick; scales coriaceous, obtuse, faintly many-nerved, scarious-margined; bristles about 6 , retrorsely barbed, as long as the achene or shorter; style 3-cleft rarely 2-cleft; achene obovold, shining, brown, minutely many-striate and transversely ridged; tubercle conic, acute.

Marshes, Great Bahama, New Providence, Ackiin's Isiand :-eastern United States; Bermuda; Cuba to St. Thomas and Trinidad; Jamaica; tropical continental America. KNOTTED SPIKE-RUSH.

\section{Fleocharis cellulòsa Torr. Ann. Lyc. N. Y. 3: 298. 1836.}

Perennial by long rootstocks; culms obscurely. 3 -angled below, terete above, $7 \mathrm{dm}$. tall or less, not nodose. Sheaths membranous, oblique; spikelet 1.5-3 cm. long, $2.5-4 \mathrm{~mm}$. thick, cylindric, somewhat thicker than the culm; scales coriaceous, obtuse, membranous-margined, many-striate; bristles 6 or 7 , nearly or quite smooth, about as long as the achene; style 3-cleft; achene broadly obovoid, trigonous, striate, copiously pitted; tubercle deltoid, about one-half as wide as the achene.

Marshes, Abaco, Great Bahama, Andros, New Providence, Rose Isiand, Eleuthera, Crooked Isiand, Fortune Island, Great Exuma, Inagua :- southern United States; Bermuda; Cuba; Porto Rico; Jamaica; Yucatan. Round-STEMmed SPIKERUSH.

3. Eleocharis fláccida (Rchb.) Urban, Symb. Ant. 2: 165.1900.

Scirpus flaccidus Rchb.; Spreng. Tent. Suppl. 3. 1828.

Eleocharis ochreata Nees, Linnaea 9: 294. 1834.

Scirpus ochreatus Griseb. Fl. Br. W. I. 570. 1864.

Heleocharis bahamensis Boeckl. Cyp. Nov. 2: 11 in part. 1890.

Perennial by slender rootstocks; culms slender or filiform, 3-angled, 0.5-3 dm. long. Upper sheath white, hyaline, membranous; spikelet oblong or ovoid, 3-6 mm. long, 2-2.5 mm. thick, much thicker than the culm; scales elliptic to oblong-lanceolate, obtuse or the upper acute, thin, pale green with a faint midvein; style '2-cleft; achene lenticular, obovate, smooth, $0.5 \mathrm{~mm}$. long, 2-4 times as long as the conic, acute tubercle; bristles 6 or 7 , retrorsely barbed, as long as the achene, or shorter, or none.

Wet grounds, New Providence, Eieuthera :-Southeastern United States: Cuba ro St. Thomas and Trinidad; Jamaica; tropicai continentai America; Philippine Islands. PAIE SPIKE-RUSH. 
4. Eleocharis atropurpùrea (Retz.) Kunth, Enum. 2: 151. 1837.

Scirpus atropurpureus Retz. Obs. 5: 14. 1789.

Heleocharis Sintenisii Boeckl. Cyp. Nov. 1: 16. 1888.

Heleocharis bahamensis Boeckl. Cyp. Nov. 2: 11. 1890.

Annual; roots fibrous; culms tufted, very slender, 2-9 cm, high. Upper sheath 1-toothed; spikelet ovoid, many-flowered, subacute, 3-4 mm. long, $2 \mathrm{~mm}$. in diameter or less; scales minute, ovate-ollong, persistent, purple-brown with green midvein and very narrow scarious margins; stamens 2 or 3 ; style 2-3cleft; bristles 2-4, fragile, white, minutely downwardly hispid, about as long as the achene; achene jet black, shining, $0.5 \mathrm{~mm}$. long, smooth, lenticular; tubercle conic, minute, depressed but rather acute, constricted at the base.

Hog Island, New Providence, Andros, Acklin's Island:-Florida; Cuba ; Porto Rico; Central and western United States to Central America; Europe; Asia. Referred by Clarke to $E$. camptotricha Schweinitzii Clarke, citing Northrop 524 b, from Conch Sound, Andros, but that has trigonous achenes, proliferous spikelets and is the same as $E$. prolifera Torr., its older name. Our specimen of this number has lenticular achenes; it is possible that two species were distributed under the same number. Mrs. Northrop's no. 745, indicated on her label as the same as 524 b, was determined by Mr. Clarke as E. atropurpurea. PURPLE SPIKE-RUSH.

\section{Eleocharis capitàta (L.) R. Br. Prodr. 225. 1810.}

Scirpus capitatus L. Sp. Pl. 48. 1753.

Annual; roots fibrous; culms densely tufted, nearly terete, almost filiform, 5-25 cm. tall. Upper sheath 1-toothed; spikelet ovoid, obtuse, much thicker than the culm, 3-5 mm. long, 2-3 mm. thick, many-flowered; scales broadly ovate, obtuse, firm, pale or dark brown with a greenish midvein, narrowly scarious-margined, persistent; stamens mostly 2; style 2-cleft; bristles 5-8, slender, downwardly hispid, as long as the achene; achene obovate, jet black, smooth, shining, nearly $1 \mathrm{~mm}$. long; tubercle depressed, apiculate, constricted at the base, very much shorter than the achene.

Moist and wet grounds, Great Bahama, and Andros to Crooked Island, North Caicos and Inagua :-United States; Bermuda; West Indies; tropical continental America; Old World tropics. Capitate SpIKe-RUSH.

\section{STENOPHÝYLUUS Raf. Neog. 4. 1825.}

Mostly annual sedges, with slender erect culms, leafy below, the leaves narrowly linear or filiform, with ciliate or pubescent sheaths. Spikelets umbellate, capitate or solitary, usually subtended by a 1-several-leaved involucre, their scales spirally imbricated all around, mostly deciduous. Flowers perfect. Perianth none. Stamens 2 or 3 . Style 2-3-cleft, glabrous, its base much swollen and persistent as a tubercle on the achene as in Eleocharis. Achene 3angled, turgid or lenticular. [Greek, referring to the narrow leaves.] A genus of some 90 species, natives of temperate and warm regions. Type species: Scirpus stenophyllus Ell.

\section{Stenophyllus Wilsoni Britton, Torreya 13:215. 1913.}

Perennial by short stout rootstocks; culms clustered, somewhat flattened, smooth, stiff, but rather slender, erect, 2-3 dm. tall. Basal sheaths 3 or 4, kladeless, acute, many-nerved, floccose-pubescent, the upper with a scarious margin; spikelets $2-5$ together, in a terminal capitate cluster subtended by a subulate bract $0.5-2 \mathrm{~cm}$. long, or sometimes by 2 bracts, linear-oblong, much compressed, 1-2 cm. long, $4 \mathrm{~mm}$. wide; scales narrowly oblong to oblonglanceolate, loosely pubescent, ciliate, light brown, membranous, obtusish, 5 $\mathrm{mm}$. long, $1.5 \mathrm{~mm}$. wide, the midvein prominent; stamens 3 ; style 3 -cleft, the 
pubescent branches about as long as the glabrous lower part; achene obovoid, dull black, bluntly trigonous, nearly $1 \mathrm{~mm}$. long, capped by a minute depressed tubercle.

Castle Island and Little Inagua. Endemic. Wilson's StenophrluUs.

4. FIMBRÍstyLIS Vahl, Enum. 2: 285. 1806.

Annual or perennial sedges. Culms leafy below. Spikelets umbellate or capitate, terete, several to many-flowered, subtended by a 1-many-leaved involucre, their scales spirally imbricated all around, mostly deciduous, all fertile. Perianth none. Stamens 1-3. Style 2-3-cleft, pubescent or glabrous, its base much enlarged, falling away from the summit of the achene at maturity. Achene lenticular, biconvex, or 3-angled, reticulated, cancellate, or longitudinally ribbed or striate in our species. [Greek, in allusion to the fringed style of some species.] A large genus, the species widely distributed in temperate and tropical regions. Type species: Fimbristylis acuminata Vahl.

Style branches 2 ; achene lenticular.

Achene longitudinally ribbed.

Achene cancellate, reticulate or granular, not ribbed.

Scales pilose-puberulent; leaves short.

Scales glabrous.

Leaves elongated: inflorescence loose.

Leaves involute or plano-convex.

Leaves flat.

Leaves short: inflorescence compact.

Style branches 3 ; achene trigonous.

1. F. diphylla.

2. F. ferruginea.

3. F. castanea.

4. $F$. inaguensis.

5. F. spathacea.

6. F. hirta.

1. Fimbristylis diphýlla (Retz.) Vahl, Enum. 2: 289. 1806.

Scirpus diphyllus Retz. Obs. 5: 15. 1789.

Perennial by short rootstocks, glabrous or pubescent; culms tufted, 1-6 $\mathrm{dm}$. high, slender. Leaves 1-3 $\mathrm{mm}$. wide, shorter than the culm; involucrebracts 3 or 4 , shorter than or surpassing the simple or compound umbel; spikelets oblong or ovoid, 5-10 mm. long, $2.5-4 \mathrm{~mm}$. thick; seales ovate, acure, glabrous; style 2-cleft; achenes scarcely $1 \mathrm{~mm}$. long, obovoid, biconvex, white or yellowish, longitudinally ribbed, reticulated, the ribs smooth.

Moist soll, New Providence and Fortune Island:- southern United States : West Indies; tropical continental America; Old World tropics. Slender FIMBRISTYLIS.

2. Fimbristylis ferrugínea (L.) Vahl, Enum. 2: 291. 1806.

Scirpus ferrugineus L. Sp. Pl. 50. 1753.

Culms tufted, erect, $2-8 \mathrm{dm}$. tall, rather slender. Leaves much shorter than the culm, often very short; involucre-bracts $2-4$, rarely exceeding the simple or slightly compound umbel; spikelets few or several, ovoid-obiong, 8-20 mm. long, 3-4 mm. thick; scales ovate, acutish or mucronulate, brown, pilose-puberulent toward the apex; style 2-cleft; achene obovoid, biconvex, smooth, brownish, half as long as the scale.

Moist saline soll, Berry Islands, Cat Cay, Andros, New Providence and Eleuthera to Mariguana and Inagua:- West Indies; continental tropical America. SALT MARSH Fimbristylis.

3. Fimbristylis castànea (Michx.) Vahl, Enum. 2: 292.1806.

Scirpus castaneus Michx. Fl. Bor. Am. 1: 31. 1803.

Perennial; glabrous; eulms stiff, slender, wiry, trigonous, 3-10 dm. high. Leaves rigid, involute, usually somewhat shorter than the culm, about $2 \mathrm{~mm}$. wide when unrolled, their sheaths often brown, those of the involucre $3-6$, the 
longer sometimes exceeding the simple or compound umbel; umbel-rays several, nearly erect; spikelets ovoid or ovoid-cylindric, acute, 5-12 $\mathrm{mm}$. long, the central ones sessile, the others stalked; scales obtuse, coriaceous, glabrous, brown with a green midvein; stamens 2 ; style 2-cleft; achene lenticular, obovate, brown, reticulate.

Moist saline soll, Andros, New Providence, Rose Island, Eleuthera, Cat Island, Little San Salvador, Watling's Island; Anguilla Isles :-Bermuda ; eastern United States; Cuba. Recorded by Hitchcock, by Dolley and by Mrs. Northrop as Fimbristylis spadicea (L.) Vahl. MARSH Fimbristylis.

\section{Fimbristylis inaguénsis Britton, Torreya 13:216. 1913.}

Perennial by short stout rootstocks; culms rather stout, stiff, smooth, compressed, 3-5 dm. tall. Basal leaves one-third to two-thirds as long as the culm, flat, rather stiff, smooth, 1-2.5 mm. wide, obtuse; leaves of the involucre $2-4$, the longer one usually a little exceeding the inflorescence; umbel compound, 5-7 $\mathrm{cm}$. broad, the rays $2-4 \mathrm{~cm}$. long, ascending, the raylets slender, 0.5-2 cm. long; spikelets narrowly oblong, 8-12 $\mathrm{mm}$. long, about $2.5 \mathrm{~mm}$. thick, acute, many-flowered, solitary at the ends of the rays and raylets; scales brown, glabrous, dull, ovate, carinate, mucronate or the lower short-awned; achene elliptic or obovate-elliptic, flat, blunt, finely reticulated, nearly $1.5 \mathrm{~mm}$. long; style-branches 2.

White-lands and rocky soll. Cat Island. Little San Salvador. Watling's Island, Fortune Island, Crooked Island, Exuma Chaln, Little Ambergris Cay, Inagua :Cuban Cays; Anegada. West INDian Fimbristylis.

\section{Fimbristylis spathácea Roth, Nov. Sp. 24. 1821.}

Scirpus glomeratus Retz. Obs. 4: 11. 1786.

Fimbristylis glomerata Urban, Symb. Ant. 2: 166. 1900. Not Nees. 1834.

Culms tufted, stiff, erect, rather slender, 1-4 dm. high. Basal leaves flat, stiff, much shorter than the culm, $1.5-3 \mathrm{~mm}$. wide, spreading or ascending, the apex bluntish and mucronate; involucral leaves mostly shorter than the compound small dense umbel; spikelets ellipsoid to short-cylindric, 3-6 $\mathrm{mm}$. long, about $2 \mathrm{~mm}$. thick; scales ovate, brownish, glabrous, emarginate, scarious-margined; style 2-cleft; achene about one-half as long as the scale, biconvex, obovate, brown, granular or subtuberculate.

Coppices, waste and cultivated grounds, Great Bahama, Andros, Rum Cay, Fortune Island, Cay Sal :-West Indies and tropical continental America; Old World tropics.

Justice Joseph E. Adderley, at Eight Mile Rocks. Great Bahama, informed us at the time of our visit there in February, 1905, that soon after the hurricane of August 13, 1899, this sedge appeared in clearings, and had soon spread as a troublesome weed through cultivated lands. killing out pasture grasses in places; it had therefore come to be called there "Hurricane Grass."

6. Fimbristylis hírta (Thunb.) R. \& S. Syst. 2: 99.1817.

Cyperus hirtus Thunb. Phyt. Blaett. 1: 6. 1803.

Scirpus exilis Poir. Encycl. Suppl. 5: 105. 1817.

Fimbristylis exilis R. \& S. Syst. 2:98. 1817.

Annual; culms 1-4 dm. long, slender, pilose at least above. Leaves nearly filiform, pubescent, half as long as the culm or less, $0.2-0.5 \mathrm{~mm}$. wide; involucral bracts $3-5$, longer or shorter than the umbel; spikelets $3-14$, on filiform pilose umbel-rays, ovoid, 6-12 $\mathrm{mm}$. long; scales few, ovate, mucronate, chestnut-brown, pilose-puberulent, the midvein green; style glabrous, its 3 branches linear; achene pyriform, pale brown, $1 \mathrm{~mm}$. long, irregularly rugose, sometimes tuberculate.

Bahamas, collected by Dale, according to Clarke:-Cuba; northern South America ; Africa. Hairy Fimbristris. 
5. ABILDGAÀrdiA Vahl, Enum. 2: 296. 1806.

Low, perennial or annual sedges, with slender culms, narrow or setaceous basal leaves, the involucre usually of 1 small bract, the flattened spikelets solitary or few together, several-many-flowered. Scaly imbricated in 2 rows, keeled, deciduous. Bristles none. Stamens 1-3. Style pubescent, deciduous, its base swollen. Stigmas 3. Achene trigonous. [Commemorates P. S. Abildgaard, Danish botanist.] About 15. species of tropical and subtropical distribution, the following typical.

1. Abildgaardia monostàchya (L.) Vahl, Enum. 2: 296. 1806.

Cyperus monostachyos L. Mant. 180. 1771.

Fimbristylis monostachya Hassk. Pl. Jav. Rar. 61. 1848.

Perennial, glabrous; culms tufted, very slender, smooth, thickened at the base, 1-4 dm. high. Leaves setaceous, $0.5 \mathrm{~mm}$. wide, about half as long as the culm; involucral bract short, rarely as long as the spikelet; spikelet ovate or ovate-lanceolate, flat, $1-1.5 \mathrm{~cm}$. long, about $5 \mathrm{~mm}$. wide; scales ovate, keeled, mucronate, pale greenish-brown with white margins; style villous, with 3 short branches; achene obovoid, 2-2.5 mm. long, 3-angled, yellowish, tuberculate.

Grassy places and scrub-lands, Great Bahama, Andros, New Providence, Cat Island, Fortune Island, Inagua :-Florida; Cuba to Porto Rico; St. Jan to Tobago; Anegada; continental tropical America and Old World tropics. FLAT-SPIKED RUSH.

\section{SCÍRPUS L. Sp. Pl. 47. 1753.}

Annual or perennial very small or very large sedges, with leafy culms or the leaves reduced to basal sheaths. Spikelets terete or somewhat flattened, solitary, capitate, spicate or umbellate, subtended by a 1-several-leaved involucre or the involucre wanting in some species. Scales spirally imbricated all around, usually all fertile, the 1-3 lower sometimes empty. Flowers perfect. Perianth of 1-6, slender or rigid, short or elongated, barbed, pubescent or smooth bristles, or none in some species. Stamens 2-3. Style 2-3-cleft, not swollen at the base, wholly deciduous from the achene, or its base persistent as a subulate tip. Achene triangular, lenticular or plano-convex. [Latin name of the Bulrush, said to be from sirs, the Celtic word for rushes.] About 200 species of very wide geographic distribution. Type species: Scirpus lacustris $\mathrm{L}$.

Bracts of the involucre several; scales long-awned; culm trigonous. 1. S. robustus. Bract of the involucre only 1 ; scales short-tipped; culm terete.

2. S. validus.

\section{Scirpus robústus Pursh, Fl. Am. Sept. 56. 1814.}

Perennial by rootstocks; culm stout, stiff, 3-angled with flat sides, smooth, 0.5-1.4 m. tall. Leaves dark green, smooth, 5-10 mm. wide; involucral leaves $2-4$, elongated, similar to the lower ones; spikelets ovoid-oblong, stout, 1.5-2.5 cm. long, 8-10 $\mathrm{mm}$. in diameter, 6-20 together in a dense terminal cluster; scales ovate, brown, puberulent, thin, the midvein excurrent into an, at length, reflexed awn 3-5 mm. long; bristles 1-6, fragile, shorter than the achene, or none; style 3-cleft; achene compressed, flat on the face, convex or with a low ridge on the back, obovate-orbicular, dark brown, shining, $3 \mathrm{~mm}$. long.

Marshes, Little Inagua :-Atlantic and Gulf coasts of the United States. SALT MARSH BULRUSH. 
2. Scirpus válidus Vahl, Enum. 2: 268. 1806.

Perennial by stout rootstocks; culms stout, smooth, terete, erect, 1-3 m. tall, sheathed at the base. Involucre-bract 1, erect, shorter than the umbel, appearing as if continuing the culm; umbel compound, its primary rays slender, 1-6 cm. long; spikelets several or many, oblong-conic, 1 to 5 together, 5-12 $\mathrm{mm}$. long, 3-4 mm. thick; scales ovate, short-tipped; bristles 4-6, downwardly barbed, as long as the achene or longer; stamens 3 ; style 2-cleft; achene obovate, plano-convex, mucronate.

Ponds, Fortune Island:-Continental North America; Bermuda; Cuba; Haiti ; Porto Rico; Jamaica. AMERICAN GREAT BULRUSH.•

\section{DICHRÓMENA Michx. Fl. Bor. Am. 1: 37. 1803.}

Leafy-stemmed sedges, perennial by rootstocks, the spikelets crowded in a terminal head involucrate by the upper leaves, which are often white at the base. Spikelets compressed, several-many-flowered. Scales spirally imbricated all around, several of them with imperfect flowers, or empty. Perianth none. Stamens 3. Style 2-cleft, its branches subulate. Achene lenticular, transversely rugose, crowned with the broad persistent base of the style (tubercle). [Greek, alluding to the two-colored involucral leaves.] About 8 species, natives of America. Type species: Dichromena leucocephala Michx.

Spikelets capltate: involucral bracts reflexed.

Splkelets subspicate; bracts erect or the lower one spreading
1. D. colorata.

2. D. inaguensis.

1. Dichromena coloràta (L.) Hitchc. Rep. Mo. Bot. Gard. 4: 141. 1893.

Schoenus coloratus L. Sp. Pl. 43. 1753.

Dichromena leucocephala Michx. Fl. Bor. Am. 1: 37. 1803.

Glabrous; culm slender, erect, rather sharply triangular, 0.3-0.6 m. tall. Leaves distant, narrowly linear, about $2 \mathrm{~mm}$. wide, much shorter than the culm, those of the involucre 4-6, reflexed when mature, yellowish white at the base; head globose, 1-2 cm. in diameter; spikelets narrowly oblong, acute; scales membranous, lanceolate, nearly white, 1-nerved, subacute at the apex; achene obovate, brown, nearly truncate at the summit, compressed, covered by the tubercle which is not decurrent on its edges.

Scrub-lands and borders of marshes, Abaco, Great Bahama, Andros and New Providence to Calcos Islands and Inagua:- southeastern United States; Bermuda; Cuba to Porto Rico and Martinique; Texas to Yucatan. NARRow-LEAVED DichroMENA. WHITE-HEADED RUSH.

\section{Dichromena inaguénsis Britton, spec. nov.}

Densely tufted; culm very slender, erect, about $3 \mathrm{dm}$. tall. Leaves 1-1.5 $\mathrm{mm}$. wide, two-thirds as long as the culm; involucral bracts 3-5, glabrous, erect, green or whitened only at the base, or the lower one spreading and sometimes $14 \mathrm{~cm}$. long; bractlets ciliolate; spikelets few, subspicate, nearly erect, about $7 \mathrm{~mm}$. long; scales white, obtusish; achene yellowish brown, a little more than $1 \mathrm{~mm}$. long, copiously transversely rugose, capped by a low flatconic tubercle of about one-fourth its length.

Scrub-iands between Northwest Polnt and Southwest Point, Little Inagua (Nash and Taylor 1254). Endemic. INAGUA DICHROMENA.

\section{RYNCHÓSPORA Vahl, Enum. 2:229. 1806.}

Leafy sedges, mostly perennial by rootstocks, with erect 3 -angled or terete culms, narrow flat or involute leaves, and ovoid oblong or fusiform, variously 
clustered spikelets. Scales thin, 1-nerred, imbricated all around, usually mucronate by the excurrent.midvein, the lower empty. Upper flowers imperfect, the lower perfect. Perianth of 1-20 (mostly 6) upwardly or downwardly barbed or scabrous bristles, wanting in some species (no. 2). Stamens commonly 3. Style 2-cleft, 2-toothed or rarely entire. Achene lenticular or swollen, not 3-angled, smooth or transversely wrinkled, capped by the persistent base of the style (tubercle), or in some species by the whole style. [Greek, referring to the beak-like tubercle.] About 200 species, of wide geographic distribution, most abundant in warm regions. Type species: Rynchospora aurea Vahl. Style long, stout, its branches much shorter than the undivided part; spikelets

Heads several or numerous, panicled; achene $1 \mathrm{~mm}$. long. $\quad 1 . K$. cyperoides.

Heads only 1-6; achene $2.5 \mathrm{~mm}$. long. $2 . \quad$. Trucyi.

Style short, its branches mostly as long as the undivided part: splkelets loosely clustered, not capitate.

Perianth-bristles none.

Achene transversely wrinkled.

Achene retlculated.

Perianth-bristles present, upwardly barbed; achene transversely wrinkled.

Achene not stipitate; splkelets about $2 \mathrm{~mm}$. long.

Perianth-bristles much shorter than the achene or obsolete.

Perlanth-bristles as long as the achene or longer. Leaves 2-4 mm. wide. Leaves less than $1 \mathrm{~mm}$. wide.

Achene stipitate; splkelets 5-7 mm. long.

3. R. tenuis.

4. $R$. divergens.
5. R. perplexa.

6. R. microcarpa.

7. K. bahamensis.

8. R. marisculus.

1. Rynchospora cyperoìdes (Sw.) Mart. Denkschr. Akad. Wiss. Muench. 6: 149. 1816-17.

Schoenus cyperoides Sw. Prodr. 19. 1788.

Culms $8 \mathrm{dm}$. high or less, clustered, rather stout, trigonous, leaf-bearing up to or beyond the middle. Leaves $3-5 \mathrm{~mm}$. wide, the upper ones sometimes overtopping the culm; heads subglobose, dense, usually several or numerous, corymbose-paniculate, $8-12 \mathrm{~mm}$. in diameter; bracts similar to the leaves, but shorter; spikelets numerous, their scales 7 , the 4 lower ones empty, 1 of the others subtending an achene; bristles 6, upwardly hispid, longer than the achene; style long, 2-cleft at the apex; achene obovoid, about $1 \mathrm{~mm}$. long, faintly transversely undulate; tubercle subulate, ciliate, about as long as the achene.

Swampy grounds, Great Bahama, New Provldence, Eleuthera, Cat Island. Great Exuma, Ackiln's Island, Crooked Island, Inagua :-West Indies ; tropical continental Amerlca. CAPitate BEAKED-RUSH.

2. Rynchospora Tràcyi Britton, Trans. N. Y. Acad. Sci. 11: 84. 1892.

Ceratoschoenus capitatus Chapm. FI. S. U. S. 529. 1860. Not Rynchospora capitata R. \& S. 1817.

Perennial; culms tufted, slender, glabrous, nearly terete, erect, 5-12 dm. high. Leaves elongated, channelled, 4-8 mm. wide; spikelets lanceolate, 5-7 $\mathrm{mm}$. long, densely clustered in 1-6 globose heads which are 1-2 cm. in diameter; scales yellowish-brown, ovate, acute; bristles 6 , longer than the achene, upwardly barbed; achene flat, obovate, about $2.5 \mathrm{~mm}$. long, ciliate, finely wrinkled; style 2-cleft at the apex; tubercle subulate, setose, at least as long as the achene.

Wet soll, Great Bahama at West End; Andros, in savanna near Stanlard Creek :Florida ; Cuba. TRACY'S BEAKED-RUSH. 
3. Rynchospora ténuis Link, Jahrb. 13:76. 1820.

Rootstocks short, slender; culms very slender, tufted, $1.5-4 \mathrm{dm}$. long, glabrous and smooth, erect or reclining. Leaves $0.5-2 \mathrm{~mm}$. wide, as long as the culm or shorter; corymbs of spikelets 1-3, filiform-stalked; spikelets usually rather loosely clustered, about $4 \mathrm{~mm}$. long, narrowly lanceolate, acute, pale, bearing a single achene; scales acute, the lower ovate, the upper lanceolate; bristles none; style deeply 2-cleft; achene obovate or nearly orbicular, sessile, transversely rugose, about $1 \mathrm{~mm}$. broad; tubercle acute, onefourth to one-half as long as the achene and decurrent on its margins.

Moist ground, Andros, New Providence:-Cuba; Dominica to Grenada; tropical continental America. SLENDEI BEAKED-RUSH.

4. Rynchospora divèrgens Chapm.; M. A. Curtis, Am. Journ. Sci. II. 7: 409. 1849.

Perennial; culms nearly filiform, densely tufted, 1-4 dm. high. Leaves similar to the culms, usually somewhat shorter; spikelets loosely corymbose, ellipsoid, acute, about $3 \mathrm{~mm}$. long; scales ovate to elliptic; kristles none; style 2-cleft, the branches about as long as the undivided part; achene orbicularobovate, $0.5-0.8 \mathrm{~mm}$. long, pale, reticulated, contracted at the base, the short tubercle depressed.

Moist soil, Great Bahama, Andros, New Providence:-southeastern United States; Cuba. LOW BEAKED-RUSH.

\section{Rynchospora perpléxa Britton; Small, Fl. SE. U. S. 197. 1903.}

Perennial by rootstocks; culms slender, usually clustered, 3-12 dm. high. Leaves flat, grass-like, elongated, smooth, 1.5-3 $\mathrm{mm}$. wide; corymbs usually several, rather loose, slender stalked; spikelets numerous, ovoid, about $2 \mathrm{~mm}$. long; scales brown, obtuse or acutish; bristles 6, upwardly barked, shorter than the achene; style 2-cleft at the summit; achene biconvex, transversely wrinkled, about $1 \mathrm{~mm}$. long, the depressed tubercle broader than high.

Wet grounds, Great Bahama, Abaco, Andros, New Providence, Eleuthera, Cat Island:- southeastern United States. SHORT-BRISTLED BEAKED-RUSH.

6. Rynchospora microcàrpa Baldw.; A. Gray, Ann. Lyc. N. Y. 3: 202. 1836.

Perennial by rootstocks; culms rather slender, clustered, $11 \mathrm{dm}$. high or less. Leaves flat or slightly channeled, 1-5 mm. wide; corymbs $3-6$, slenderstalked, with few or many ovoid spikelets about $2.5 \mathrm{~mm}$. long; scales brown; bristles 5 or 6 , upwardly barbed, about as long as the achene or a little longer; style 2-cleft at the summit; achene lenticular, transversely wrinkled, scarcely $1 \mathrm{~mm}$. long, the depressed tubercle blunt.

Wet grounds, Andros, New Providence, Crooked Island:- -southeastern United States. SMALL-FRUITEd BEaKed-RUSH.

\section{Rynchospora bahaménsis Britton, Torreya 13: 217.1913.}

Densely tufted; rootstocks short. Culms nearly filiform, roughish, spreading or reclining, $2-3.5 \mathrm{dm}$. long; leaves setaceous-flattened, less than $1 \mathrm{~mm}$. wide, roughish-margined, the basal ones about one-fourth as long as the culm, the upper $3-5 \mathrm{~cm}$. long; spikelets oblong, $1.5-2 \mathrm{~mm}$. long in $2-4$ distant slender-peduncled clusters, each with a single achene; scales dark brown, ovate-oblong, mucronulate; achene elliptic-obovate, faintly transversely wrinkled, $1.5 \mathrm{~mm}$. long; tubercle flattened, conic, one-third to one-half as long as the achene; bristles upwardly barbed, as long as the achene.

Coppices and borders of swamps, New Providence, Andros:-Cuba ; Porto Rico. BAHAMA BEAKED-RUSH. 
8. Rynchospora marísculus Lindl. \& Nees; Mart. Fl. Bras. $2^{1}$ : 142.1842.

Rynchospora jubata Liebm. Vidensk. Selsk. Skr. V. 2: 254. 1851.

Perennial by rootstocks, glabrous. Culm rather slender, 0.5-1 m. long. Leaves $2-5 \mathrm{dm}$. long, $7 \mathrm{~mm}$. wide or less; corymbs usually several, distant, or the upper ones approximate, dense, the lower slender-stalked, nodding; spikelets numerous, clustered, narrowly ellipsoid, acute, $5-7 \mathrm{~mm}$. long; scales brown, lanceolate or ovate-lanceolate, acute, from 1 to 3 of them subtending achenes; bristles 6 or 7 , longer than the achene, scabrous above, pilose at the base; style 2-cleft at the apex; achene short-stipitate, obovate, transversely undulate, 1.5-2 mm. long; tubercle flat-conic, acute, about one-half as long as the achene.

Moist grounds, New Providence :-Cuba; Haiti; Jamaica ; tropical continental America. LoNa BEAKED-RUSH.

\section{MARÍscus (Hall.) Zinn, Cat. Hort. Goett. 79. 1757.}

Perennial leafy sedges, similar to large Rynchosporas, the spikelets oblong or fusiform, few-flowered, variously elustered. Scales imbricated all around, the lower empty, the middle ones mostly subtending imperfect flowers, the upper usually fertile. Perianth none. Stamens 2 or sometimes 3. Style 2-3cleft, deciduous from the summit of the achene, its branches sometimes 2-3parted. Achene ovoid to globose, smooth or longitudinally striate. Tubercle none. [Greek, referring to the branched inflorescence of some species.] About 40 species, natives of tropical and temperate regions. Type species: Schoenus Mariscus L.

1. Mariscus jamaicénsis (Crantz) Britton in Britton \& Brown, Ill. Fl. ed. 2, 1: 348.1913.

Cladium jamaicense Crantz, Inst. 1: 362. 1766.

Cladium occidentale Schrad. Fl. Germ. 1: 76. 1806.

Culm stout, $1.5-3 \mathrm{~m}$. high, obtusely 3 -angled. Leaves very long, glabrous, 6-20 $\mathrm{mm}$. wide, the margins spinulose-serrulate; umbels several or numerous, decompound, forming a large panicle; spikelets mostly 2-5 together at the ends of the raylets, narrowly ovoid, acute, 4-5 mm. long; uppermost scale subtending $a^{\circ}$ perfect flower; stamens 2 ; achene ovoid, abruptly sharp-pointed, wrinkled, narrowed to the base, $2 \mathrm{~mm}$. long.

Marshes, Abaco, South Bimini, Andros and New Providence to Crooked Island and Inagua :- southern United States; Bermuda; Jamaica; Cuba to Porto Kico; Guadaloupe to Grenada; Mexico. Erroneously recorded by C. B. Clarke as Lagenocarpus guiancnsis Nees, and by Hitchcock as Cladium mariscus (L.) R. Br. SAW GRASS.

\section{SCHOÈNUS L. Sp. Pl. 42. 1753.}

Perennial sedges, with stiff, tufted culms, basal, narrow or semiterete leaves, the 1-few-flowered spikelets clustered, capitate or paniculate, the clusters subtended by 1 bract or few. Scales imbricated in 2 series, the lower ones empty the upper subtending flowers. Perianth of 3-6, scabrous or plumose bristles. Stamens 3. Style slender, scarcely enlarged at the base, 3cleft, deciduous. Achene trigonous; tubercle none. [Greek, a rush.] Sixty species or more, mostly natives of the Old World, the following typical. 
1. Schoenus nígricans L. Sp. Pl. 43. 1753.

Glabrous; culms 2-7 dm. tall, mostly longer than the leaves. Leaves similar to the culm, stiff, sharp-pointed, semiterete, $0.5-1.5 \mathrm{~mm}$. thick, their bases dark brown or nearly black, shining; involucre of 2 bracts, one of them elongated, sometimes $8 \mathrm{~cm}$. long; spikelets about $1 \mathrm{~cm}$. long in a dense, terminal, capitate cluster, 5-8-flowered, compressed, their scales dark chestnutbrown, or nearly black, lanceolate, carinate, acuminate, somewhat shining; perianth-bristles 6 , plumose; achene ellipsoid, white, shining, about $2 \mathrm{~mm}$. long; shorter than the bristles.

Swamps, Andros, New Providence, Eleuthera, Crooked Island, Caicos:-FlorIda; Cuba ; southern California; Europe. Black-Headed Sedge.

\section{SCLÈrIA Berg. Vet. Acad. Handl. 26: 142. 1765.}

Leafy sedges, mostly perennial, the spikelets small, clustered in terminal, or terminal and axillary fascicles, or sometimes interruptedly spicate. Flowers monoecious. Fertile spikelets 1-flowered. Staminate spikelets many-flowered. Scales imbricated, the 1-3 lower and sometimes also the upper ones of the fertile spikelets empty. Perianth none. Style 3-cleft, slender or sometimes swollen at the base, deciduous. Ovary supported on a disk (hypogynium), or this wanting. Stamens 1-3. Achene globose or ovoid, obtuse, crustaceous or bony, white in our species. [Greek, in allusion to the hard fruit.] About 200 species, natives of tropical and temperate regions. Type species: Scleria Flagellum-nigrorum Berg.

Annual; achene with sharp transverse ridges. Perennial; achene smooth.

1. S. verticillata.

2. S. lithosperma.

1. Scleria verticillàta Willd. Sp. Pl. 4:317. 1805.

Roots fibrous; culms very slender or filiform, 3-angled, smooth or nearly so, erect, 1-5 dm. tall. Leaves very narrowly linear, 0.5-1 mm. wide, ereet, shorter than the culm; spikelets in several separated clusters; bracts bristlelike; scales glabrous; achene globose, $1 \mathrm{~mm}$. in diameter, crustaceous, marked by sharp distinct tranverse ridges, or somewhat reticulated; hypogynium none.

Borders of marshes, New Providence:- eastern United States; Cuba. Low NUT-RUSti.

2. Scleria lithospérma (L.) Sw. Prodr. 18. 1788.

Scirpus lithospermus L. Sp. Pl. 51. 1753.

Scleria filiformis Sw. Prodr. 19. 1788.

Perennial by rather short rootstocks, the culms often clustered, slender, weak, glabrous, 2-6 dm. long. Leaves $0.5-3 \mathrm{~mm}$. wide, the upper elongated, the lowest reduced to pubescent or puberulent sheaths; panicles 1-3, distant, glabrous, small, stalked or the upper sessile; bracts filiform, glabrous; achene obovoid-ellipsoid, white, smooth, shining, about $2 \mathrm{~mm}$. long, its base trigonous; hypogynium none.

Coppices and scrub-lands, Abaco, Great Bahama, Berry Islands and Andros to Mariguana and Inagua :-Forida; West Indles; continental tropical America; old World troples. SLENDER NuT-RUsh. 


\section{Order 6. ARECALES.}

Mostly trees with unbranched, erect trunks and a terminal bud, the large leaves pinnately or palmately divided, forming a terminal crown, the small, perfect or imperfect flowers usually panicled, sessile or pedicelled, the panicle subtended by a spathe and usually bracted. Sepals and petals each 3 , distinct or connate. Stamens commonly 6, sometimes $9-12$; filaments distinct or connate below; anthers introrse; pistillate flowers sometimes with staminodia. Ovary various, 1-celled, 3-celled or of 3 distinet carpels; style usually short or wanting; ovules 1 in each carpel, anatropous. Fruit drupaceous, 1-seeded. Seed with horny or cartilaginous endosperm, the small embryo near the surface.

\section{Family 1. ARECÀCEAE Rchb.}

Palm Family. tropical.

Characters of the order. About 150 genera and 1200 species, mostly

Leaves palmately cieft.

Petioles smooth.

Style terminal in fruit. Endosperm smooth. Endosperm grooved.

Style basal in fruit.

Petioles spine-toothed.

Leaves pinnately divided.

Fruit normally 2-3-lobed, not watery within.

Fruit trigonous, large, watery within.
1. Thrinax.
2. Coccothrinax.
3. Sabal.
4. Paurotis.
5. Pseudophoenix.
6. Cocos.

\section{THRINAX Sw. Prodr. 57. 1788.}

Unarmed, mostly tall and slender palms with nearly orbicular, palmately cleft, long-petioled leaves, the narrow segments mostly 2 -cleft at the apex, the petioles flat, the inflorescence sheathed, paniculately branched, the small, perfect flowers white. Calyx and corolla more or less united into a lobed or truncate cup. Stamens mostly 6, the filaments connate at the base. Ovary 1-celled; style terminal, slender; stigma flat or concave. Drupes small, globose. Seed erect; endosperm horny, not grooved; embryo lateral. [Greek, fan.] About 12 species of Florida, the West Indies and Central America. Type species: Thrinax parviflora $\mathrm{Sw}$.

Fruit essentially sessile.

Fruiting pedicels about as long as the fruit.

1. T. microcarpa.

2. T. parviflora.

1. Thrinax microcárpa Sargent, Gard. \& For. 9: 162.1896.

Thrinax keyensis Sargent, Bot. Gaz. 27: 86. 1899.

Thrinax bahamensis O. F. Cook, Mem. Torr. Club 12: 20. 1902.

A tree, up to $12 \mathrm{~m}$. high, with a trunk 2-2.5 dm. in diameter, usually much smaller. Leaves $1.5 \mathrm{~m}$. in diameter or less, deeply cleft into many narrow segments, green and shining above, bluish or silvery-white beneath, the ligule blunt or acute, $1.5-2.5 \mathrm{~cm}$. wide; inflorescence ' $2 \mathrm{~m}$. long or less, as long as the leaves or shorter; pedicels very short, disk-like; perianth about $3 \mathrm{~mm}$. long; 
filaments nearly triangular; drupes 4-6 $\mathrm{mm}$. in diameter, white, very nearly sessile.

Sandy and rocky soll, throughout the archipelago from Great Bahama and Abaco to Mariguana, Caicos Islands and Inagua:-Florida; Cuba. SMaLl-Froited THATCH-PALM. BUFFALO-TOP.

2. Thrinax parviflòra Sw. Prodr. 57. 1788.

Thrinax floridana Sargent, Bot. Gaz. 27: 84. 1899.

A tree up to $9 \mathrm{~m}$. high or more, with a trunk about $1.5 \mathrm{~cm}$. in diameter. Leaves up to $1.5 \mathrm{~m}$. in diameter, deeply cleft into numerous narrow segments, green and shining above, silvery-white beneath, at least when young, the acute ligule 1-2 cm. long; inflorescence up to $1 \mathrm{~m}$. long; pedicels slender, about $3 \mathrm{~mm}$. long; drupes 6-9 mm. in diameter, white, distinctly stalked. PALAI.

Sandy soil, North Cat Cay:-Florida; Cuba ; Jamaica. LARGe-Fruited Thatch-

\section{COCCOTHRÌNAX Sargent, Bot. Gaz. 27: 87. 1899.}

Unarmed, tall or low palms, with nearly orbicular, palmately cleft, petioled leaves, the petioles flat, the segments usually 2-cleft at the apex, the sheathed inflorescence paniculately branched, the small perfect pedicelled flowers white. Calyx and corolla united into a 6-lobed perianth. Stamens 9-12; filaments sukulate. Ovary 1-celled; style terminal; stigma funnelform. Drupes small, globose. Seed erect; endosperm grooved; embryo lateral. [Greek, berryThrinax.] About 10 species, of Florida and the West Indies. Type species: Coccothrinax jucunda Sargent.

1. Coccothrinax argéntea (Lodd.) Sargent, Silva N. A. 14: 85. 1902.

Thrinax argentea Lodd.; R. \& S. Syst. 7: 1300. 1830.

Coccothrinax jucunda Sargent, Bot. Gaz. 27: 89. 1899.

Trunk sometimes $10 \mathrm{~m}$. high, usually not more than $6 \mathrm{~m}$., sometimes very short, $1.5-2 \mathrm{dm}$. in diameter. Leaves nearly orbicular, $7 \mathrm{dm}$. broad or less, cleft to beyond the middle into narrowly lanceolate, acuminate segments, bright green and shining above, silvery-white beneath, at least when young, the slender petioles about as long as the blades, their bases expanded into persistent fibrous sheaths; panicles short-stalked, mostly shorter than the petioles; pedicels $1-3 \mathrm{~mm}$. long, thickened in fruit; flowers about $3 \mathrm{~mm}$. broad; stamens usually 9 ; fruit globose, black, 8-12 mm. in diameter.

Throughout the archipelago from Abaco, Berry Islands and Andros to the Caicos, Inagua and Anguilla Isles and Cay Sal (not observed on Great Bahama) :Florida: Cuba; Hispaniola; Porto Rizo: St. Thomas: St. Jan: St. Crolx: Jamaica. Recorded by Dolley and by Hitcheock as Thrinax parviflora Sw. Silver THATch. SILVER-TOP. BAY-TOP.

3. SABÁL Adans; Guersent, Bull. Soc. Philom. 3: 206.1803.

Unarmed palms, the stems erect, creeping or subterranean, the leaves palmately cleft, with a long petiole and a short rachis, the narrow segments bearing marginal fibres, 1 -cleft or 2 -cleft, the petiole concave above. Panicles spreading or drooping. Flowers perfect, white or greenish. Calyx-lobes 3, unequal. Petals 3 , imbricated. Stamens 6 ; filaments subulate or lanceolate, united at the base. Ovary 3-celled; style 3 -angled; stigma truncate. Drupes solitary, with a thin epicarp and a fleshy pericarp. Seed depressed-globose, 
hard, the endosperm bony. [Name not explained.] About 18 species, of the southern United States, Bermuda, West Indies, Mexico, and northern South America. Type species: Sabal Adansoni Guersent (S. glabra (Mill.) Sargent).

1. Sabal Palmétto (Walt.) Lodd.; R. \& S. Syst. 7: 1487. 1830.

Corypha Palmetto Walt. Fl. Car. 119. 1788.

Sabal umbraculifera Mart. Hist. Nat. Palm. 3: 245. 1839.

Inodes Palmetto O. F. Cook, Bull. Torr. Club 28: 532. 1901.

Sabal Palmetto bahamensis Becc. Palm. Amer. 38. 1907.

Trunk 10-20 m. high, 3-7 dm. in diameter, often clothed, when young, with persistent leaf-bases. Leaves $1-2.5 \mathrm{~m}$. broad, their many linear-lanceolate segments 2-cleft and somewhat drooping at the apex, the stout petioles concave above, often as long as the blades; panicles as long as the leaves or shorter; flowers white, sessile; ealyx cup-shaped, 3-lobed, its lobes obtuse, about $1 \mathrm{~mm}$. long; petals oblong-lanceolate 5-6 $\mathrm{mm}$. long; stamens about as long as the petals; drupes globose, black, 6-12 $\mathrm{mm}$. in diameter, the pulp thir.

Borders of marshes, and in rocky soil, throughout the archipelago from Great Bahama to Watlings, Caicos Islands, Inagua, Anguilla Isles and Cay Sal :-North Carolina to Florida; ?Cuba. Pond-top. Pond Thatch. Hat Palmetio.

4. PAURÒTIS O. F. Cook, Mem. Torr. Club 12: '21. 1902.

[ACOelorraphe Wendl. Bot. Zeit. 37: 147. Hyponym. 1879.]

A slender, clustered palm, the trunks united underground, forming colonies, the leaves palmately cleft with spiny-toothed petioles, the large panicles of greenish-white flowers erect or ascending, the petiole-bases long-persistent. Flowers very small and numerous, sessile and glomerate. Sepals 3, nearly orbicular; petals 3 , valvate. Stamens 6 ; filaments short, their bases dilated and united into a short cup; anthers ovate. Ovary 3 -carpellary. Fruit small, globose. Seed globose, separable from the pericarp, the raphe not intruded into the endosperm. [Greek, referring to the few spathes of the inflorescence.] A monotypic genus. Type species: Paurotis androsana O. F. Cook.

\section{Paurotis Wrìghtii (Griseb. \& Wendl.) Britton, N. A. Trees 141.1908.}

Copernicia Wrightii Griseb. \& Wendl.; Griseb. Cat. Pl. Cub. 220. 1866.

Serenoa arborescens Sargent, Bot. Gaz. 27: 90. 1899.

Paurotis androsana O. F. Cook, Mem. Torr. Club 12: 22. 1902.

Gregarious; trunks 5-8 m. high or exceptionally 10-15 m., 1-1.5 dm. thick. Leaves 6-10 dm. in diameter, deeply cleft into linear-lanceolate, acuminate segments 1-2 $\mathrm{cm}$. broad, light green above, pale green or whitish beneath, 2-cleft above the middle, the slender, compressed petiole about as long as the blade, its margins armed with many rigid, triangular, spine-like teeth 4-7 mm. long; panicles longer than the leaves; flowers about $1.5 \mathrm{~mm}$. broad; fruit $6-8 \mathrm{~mm}$. in diameter.

Borders of swales and sandy ridges, Andros:-Florida; Cuba. Saw Palmetto. SPANISH-TOP.

5. PSEUDOPHOÈNIX Wendl. Bot. Gaz. 11: 314. 1886.

Unarmed palms, with a cylindric or somewhat spindle-shaped trunk enlarged at the base, and large, pinnate leaves of many, narrow segments, the rachis concave above, the petiole short. Inflorescence drooping, usually much 
shorter than the leaves. Flowers pedicellate, monoecious, the pistillate with a short, 3-lobed calyx, 3 valvate petals and 6 stamens or staminodia, the staminate similar, a little larger. [Greek, false date.] Only one species, native of Florida, the Bahamas, Cuba and Hispaniola. Type species: Pseudophoenix Sargentii Wendl.

1. Pseudophoenix vinifera (Mart.) Becc. Pomona College Journ. Econ. Bot. 2: 268. 1912.

Euterpe vinifera Mart. Hist. Nat. Palm. 3: LXXXV. 1845.

Pseudophoenix Sargentii Wendl. Bot. Gaz. 11: 314. 1886.

Cyclospathe Northropi O. F. Cook, Mem. Torr. Club 12: 25. 1902.

A tree up to $8 \mathrm{~m}$. high, usually lower, the trunk 2-3 dm. in diameter. Leaves spreading, 1-2 m. long; petiole concave, thin-margined, 1-2 dm. long; segments linear-lanceolate, acuminate, those at the middle of the leaf 4-5 $\mathrm{dm}$. long, those toward the base and apex shorter; panicle about half as long as the leaves, its branches rather widely spreading, flattened and angled; petals ovate or ovate-oblong, 5-6 mm. long, obtuse, yellowish-green; staminodia less than half as long as the petals; fruiting pedicels 4-6 $\mathrm{mm}$. long; drupe orangered, fleshy, normally 2-3-lobed, 1-2 cm. broad, the calyx persistent at its base.

Sandy and rocky soil, Frozen Cay, Berry Islands; South Bimini; Andros; New Providence; Ship Channel Cay to Great Exuma ; Little San Salvador; Mariguana; Inagua :-Long Key and Elliott's Key, Florida ; Cuban Cays ; Santo Domingo. Recorded by Dolley as Euterpe oleracea Mart. Hog CabBage-Palm. Hog Palmetto.

\section{6. còcos L. Sp. Pl. 1188. 1753.}

Unarmed palms, with pinnate leaves, their numerous segments narrow, their petioles concave above, the monoecious, bracted flowers mostly densely clustered among the petioles, the staminate uppermost in the clusters, smaller than the pistillate. Staminate flowers with 3 small valvate sepals, 3 oblong valvate petals, and 6 stamens with subulate filaments, the anthers linear. Pistillate flowers ovoid, the 3 thick sepals imbricated, the 3 coriaceous petals valvate, the ovary 3 -celled, with 2 of the cells usually empty, the ovule ascending. Fruit 1-seeded, often large, the pericarp fibrous, the bony endocarp 3 porose near the base. Seed with a hollow or solid endosperm, the embryo opposite one of the pores of the endocarp. [The coco-nut.] Perhaps 30 species, of tropical America and subtropical South America, the following typical one widely distributed also in the Old World tropies, its original home unknown.

\section{Cocos nucífera L. Sp. Pl. 1188. 1753.}

Trunk up to $30 \mathrm{~m}$. high, usually $10-20 \mathrm{~m}$. Leaves $3-6 \mathrm{~m}$. long, somewhat drooping, short-petioled, the numerous linear-lanceolate, acuminate segments shining above, 5-7 dm. long, about $5 \mathrm{~cm}$. wide; staminate flowers $10-12$ $\mathrm{mm}$. long; pistillate flowers about $2.5 \mathrm{~cm}$. long; fruit ovoid or ellipsoid, bluntly 3-angled, 2-3 dm. long, the fibrous husk 2-4 cm. thick, the bony endocarp 3-5 mm. thick, the hollow endosperm about $1 \mathrm{~cm}$. thick, filled with a clear saccharine liquid, which ultimately disappears.

Locally spontaneous after cultivation, nearly throughout the archipelago:-all tropical insular and coastal regions. Coco-NUT.

Roystonea regia (H.B.K.) O. F. Cook, RoYaL PALM, recorded from the Bahamas, is known to us in the archipelago only as a planted tree. 


\section{Order 7. ARÀLES.}

Monocotyledonous herbs, mostly fleshy. Inflorescence in the Araceae (which are not now known to be represented by any wild plants in the Bahama flora although Schoepf records observing Arum sagittifolium and Orontium aquaticum on New Providence in 1784) a fleshy spadix, subtended by a spathe, or naked. The Lemnaceae are minute floating thalloid plants, with flowers on the margin or back of the thallus.

\section{Family 1. LEMNÀCEAE Dumort.}

\section{DuckWeed Family.}

Minute perennial floating aquatic plants, without leaves or with only very rudimentary ones. The plant-body consists of a disk-shaped, gated or irregular thallus, which is loosely cellular, densely chlorophyllous and sometimes bears one or more roots. The vegetative growth is by lateral branching, the branches being but slightly connected by slender stalks and soon separating. The inflorescence consists of one or more naked monoecious flowers borne on a slight lateral prominence on the edge or upper surface of the plant. Each flower eommonly consists of but a single stamen or a single flask-shaped pistil. The anther is provided with two to four pollen-sacs, containing spherical minutely barbellate grains. The pistil is narrowed to the funnel-shaped scar-like stigmatic apex, and produces 1-6 erect or inverted ovules. The fruit is a 1-6 seeded utricle. The family comprises the smallest of the flowering plants and contains 4 genera and about 30 species of wide distribution.

\section{LÉMNA L. Sp. Pl. 970. 1753.}

Thallus disk-shaped, usually provided with a central nerve and with or without two or four lateral nerves. Each thallus produces a single root, which is devoid of vascular tissue and is commonly provided with a thin blunt or pointed rootcap. The ovary contains from one to six ovules. Fruit ovoid, more or less ribbed. Endosperm in one or three layers. [Greek, in allusion to the growth of these small plants in swamps.] About 10 species, in temperate and tropical regions. Type species: Lemna trisulca L.

\section{Lemna minor L. Sp. Pl. 970. 1753.}

Thallus obovate or subeircular, $1.5-5 \mathrm{~mm}$. long, thickish, rarely reddish or purplish tinged, short-stalked when young, provided throughout with stomata, nearly symmetrical, obscurely 3-nerved, very rarely 4-5-nerved. Rootcap obtuse or subtruncate; fruit symmetrical, subturbinate; seed with a prominent protruding hilum, deeply and unequally 12-15-ribbed; ovule 1.

Water-holes and sink-holes, near The Bight, Cat Island:-North temperate and subtroplcal zones, but not known to us elsewhere in the West Indies. DuCK-WEED. 


\section{Order 8. XYRIDÀLES.}

Monocotyledonous herbs, mostly with narrow leaves. Flowers usually complete, their parts mostly in 3 's or 6's. Corolla regular or nearly so (except in Commelina). Ovary compound, superior. Endosperm of the seed mealy.

Epiphytic plants with scurfy leaves.

Terrestrial plants, their leaves not scurfy.
Fam. 1. Bromeltaceat.

Fam. 2. Commelinaceae.

\section{Family 1. BROMELIÀCEAE J. St. Hil.}

\section{Pine-Apple Family.}

Epiphytic herbs (some tropical species terrestrial), mostly scurfy, with elongated, entire or spinulose-serrate leaves. Flowers spiked, panicled, or solitary, regular and perfect, usually conspicuously bracted. Perianth of 3 thin distinct or somewhat united sepals, and 3 clawed distinct or united petals. Stamens 6, usually inserted on the base of the corolla. Ovary inferior or superior, 3-celled; ovules numerous in each cavity, anatropous; style short or elongated; stigmas 3. Capsule 3-valved in our species. Seeds numerous, the testa membranous. Embryo small, situated at the base of the copious endosperm. About 45 genera and 900 species, all natives of tropical and subtropical America.

Style filiform.

Stems thread-like, pendent; flowers solitary, rarely 2.

Stems not thread-Iike, rigid ; flowers spicate. Style short or none.

1. Dendropogon.

2. Tillandsia.

3. Catopsis.

\section{DENDROPÒGON Raf. Neog. 3. 1825.}

Pendulous, much-branched plants, with thread-like stems and branches, very narrow, entire leaves and yellow or greenish flowers. Sepals distinct or very nearly so. Petals distinct. Stamens long, the 3 inner ones borne on the bases of the petals; filaments filiform; anthers linear. Ovary superior; style columnar; stigmas short. Capsule septicidally 3-valved. Seeds erect, narrow, supported on a long funiculus which splits into fine threads. [Greek, tree-beard.] About 3 species, the following typical.

1. Dendropogon usneoìdes (L.) Raf. Fl. Tell 4: 25. 1838.

Renealmia usneoides L. Sp. Pl. 287. 1753.

Tillandsia usneoides L. Sp. Pl. ed. 2, 411. 1762.

Stems flexuous, hanging clustered in festoons from the branches of trees, 1-8 m. long, gray and, like the filiform leaves, densely silvery-scurfy all over. Leaves scattered, $2-8 \mathrm{~cm}$. long, scarcely $1 \mathrm{~mm}$. thick, their bases somewhat dilated; flowers sessile and solitary or rarely 2 together in the axils of the leaves; sepals about $6 \mathrm{~mm}$. long, pale green; petals yellow; stamens about as long as the calyx; capsule linear, $2-3 \mathrm{~cm}$. long, at length splitting into 3 linear valves.

Hanging from shrubs and trees, New Providence, Cat Island, Inagua :-Virginia to Florida and Texas; West Indies and continental America south to Paraguay. SPANISH MOSS. OLD MAN'S BEARD. 


\section{TILI.ÁNDSIA L. Sp. Pl. 286. 1753.}

Epiphytic plants with narrow entire leaves and white, yellow or purple flowers. Sepals distinct and separate or very nearly so. Petals distinct. Stamens hypogynous or the three inner ones inserted on the bases of the petals; filaments filiform; anthers linear or linear-oblong. Ovary superior; style subulate; stigmas short. Capsule septicidally 3-valved. Seeds erect, narrow, supported on a long funiculus which splits up into fine threads. [Dedicated to Elias Tillands, Swedish (?) botanist of the seventeenth century.] About 350 species, natives of warm and tropical America. Type species: Tillandsia utriculata L.

Flowering stems scape-like; leaves setaceous-filiform.

Flowering stems leafy, their letves smaller than the basal ones.

Basal leaves about as long as the flowering stems, or longer.

Leaf-bases strongly convex.

Leaf-bases flat or nearly so.

Leaves soft in texture; bracts ribbed.

Leaves firm and stiff; bracts not ribbed.

Basal leaves shorter than the flowering stems.

Bracts and flowers erect or appressed.

Stem-ieaves with long tips.

Stem-leaves reduced to clasping scales.

Bracts and flowers spreading.

\section{T. recurvata.}

2. T. Balbisiana.

3. T. Valenzuelana.

4. T. fasciculata.

5. T. circinata.

6. T. utriculata.

7. T. aloifolia.

1. Tillandsia recurvàta L. Sp. PI. ed. 2, 410. 1762.

Stems clustered on the branches of trees or shrubs, sometimes on other objects, even on telegraph wires, often forming large masses, the leaf-bearing part 3-8 cm. long, terminated by a scape-like, 1-5-flowered (mostly 2-flowered), very slender peduncle 5-12 cm. long. Leaves filiform-setaceous, about as long as the peduncle or shorter, densely covered with soft, spreading scales, their bases a little dilated; bracts lanceolate, $1-1.5 \mathrm{~cm}$. long; sepals lanceolate, acute, shorter than the bracts; petals blue, narrow, about as long as the bracts; capsule linear, prismatic, $2-2.5 \mathrm{~cm}$. long.

On trees and shrubs, Andros, Eleuthera, Cat Island, Watling's Island, Great Exuma, Acklin's Island, Inagua:- Florida; West Indies and continental tropical America. Thread-Leaved Wild Pine.

\section{Tillandsia Balbisiàna Schultes; R. \& S. Syst. 7: 1212. 1830.}

Plants usually solitary on trees or shrubs, sometimes clustered. Leaves densely appressed-scurfy, linear-attenuate from much dilated bases which form a swollen cluster 2-6 dm. long, the lower ones often as long as the rather slender flowering stems, sometimes longer; inflorescence narrow; spikes 3-8, compressed, 5-10 $\mathrm{cm}$. long, the flowers rather close together; bracts oblonglanceolate, acute, 1.5-2 cm. long; sepals narrowly lanceolate, acute, about as long as the bracts; petals blue, 4-5 $\mathrm{cm}$. Iong; capsule subcylindric, about twice as long as the bracts.

On shrubs and low trees, in coppices and scrub-lands, Great Bahama, Abaco, Andros, New Providence, Crooked Island, Inagua, Caicos:-Fiorida; Cuba; Hispaniola; Jamaica ; Central America. BALBIS' WILD PINE. CUTTLEFISH.

Referred to $T$. polystachya L.; in Bull. N. Y. Bot. Gard. $3: 441$, as determined by Prof. Wittmack, but that species is not definitely known to us from the archipelago, although also recorded by Schoepf as observed by him in 1784 .

\section{Tillandsia Valenzuelàna A. Rich. in Sagra, Hist. Cub. 11: 267.1850.}

Plants usually clustered on trees or shrubs, densely appressed-scurfy. Leaves narrowly lanceolate, gradually attenuate from near the base, soft in 
texture, $4 \mathrm{dm}$. long or less, the lower often as long as the flowering stems, their bases 2-4 cm. wide, the upper similar, much smaller; spikes few or several, rather loosely flowered, 7-12 cm. long; bracts pink, numerous, 1.5-2 $\mathrm{cm}$. long, oblong-lanceolate, acute; sepals lanceolate, rather shorter than the bracts; petals blue, $2-3 \mathrm{~cm}$. long; capsules linear-prismatic, about twice as long as the bracts.

On trees in coppices, Marsh Harbor, Abaco:-Florida; Cuba, Jamaica; Mexico to Colombla. VALENzUELA's Wild PiNe.

\section{Tillandsia fasciculàta Sw. Prodr. 56. 1788.}

Plants usually clustered on trees, the flowering stems stout, 2-6 dm. long. Leaves densely appressed-scurfy, lanceolate-attenuate, their bases $5 \mathrm{~cm}$. wide or less, the lower ones often as long as the flowering stems, the upper smaller; spikes subdigitate, compressed, 5-15 $\mathrm{cm}$. long, 1-3 cm. wide, acute, manyflowered; bracts oblong, acute, appressed, rigid, 2-3 cm. long, red or reddish; sepals lanceolate, about as long as the bracts; petals blue, nearly twice as long as the sepals; capsules as lorg as the bracts or somewhat longer.

On trees and shrubs, Great Bahama, Abaco, Andros, New Providence, Eleuthera, Cat Island, Crooked Island, Fortune Island, Inagua:-Florida; IVest Indies and continental tropical America. CLUSTERed WILd PINE. Dog-Drink-Water. Catesby, 2: pl. 89 .

\section{Tillandsia circinàta Schl. Linnaea 18: 430. 1844.}

Tillandsia bulbosa Chapm. Fl. S. States 471. 1860. Not Hook. 1827.

Plants usually clustered on trees or shrubs, 1-3 dm. high, densely silvery scaly. Lowest leaves ovate, acute, 1.5-3 cm. long, the next with broadly expanded bases $2-4 \mathrm{~cm}$. wide, abruptly narrowed above into linear-attenuate, usually recurved tips $2-8 \mathrm{~cm}$. long; the upper ones similar, smaller; spikes $1-3$, compressed, 1-2 dm. long, rather dense; bracts oblong to lanceolate, little spreading, 2-3 cm. long; sepals narrowly lanceolate, about $2 \mathrm{~cm}$. long; petals blue, 2.5-3 cm. long; capsules 2-3 times as long as the bracts.

On trees and shrubs, Great Bahama, New Providence, Andros, Cat Island, Watling's, Fortune, Inagua, Mariguana, Caicos:-Florida ; Cuba ; Hispaniola ; Mexico. Erroneously called IVild Onion. Silvedry WiLd PINe.

\section{Tillandsia utriculàta L. Sp. Pl. 286. 1753.}

Plants solitary or clustered on trees or shrubs, large, sometimes $4 \mathrm{~m}$. high. Basal leaves numerous, densely appressed-scaly, 3-7 dm. long, lanceolate-attenuate with bases gradually expanded and 5-10 $\mathrm{cm}$. wide, the lower ones of the flowering stem similar, but smaller, the upper reduced to acute sheathing scales 2-4 cm. long; inflorescence usually much branched, the branches long, ascending or nearly erect; spikes few-flowered; bracts oblong, appressed, $1.5-3 \mathrm{~cm}$. long; sepals oblong, $2-2.5 \mathrm{~cm}$. long; petals white or nearly white, shorter than the stamens; capsules subcylindric, 4-5 cm. long.

On trees and shrubs, Great Bahama, Berry Islands, Andros, New Providence, Exuma Chain, Cat Island, Crooked Island, Acklin's Island, Little Inagua, Inagua :Florida; Cuba to Anegada and Trinidad; Jamaica; continental tropical America. SWOLlen WILd PINE.

\section{Tillandsia aloifỏlia Hook. Exot. Fl. pl. 205, 1826.}

Tillandsia flexuosa Lindl. Bot. Reg. pl. 749. 1823. Not Sw. 1788.

Plants usually solitary on trees or shrubs, 3-10 dm. long, the flowering stem much longer than the densely appressed-scurfy leaves. Lowest leaves ovate, acute, $8 \mathrm{~cm}$. long or less, the next lanceolate, attenuate-acuminate, $10-20$ cm. long, 3-5 cm. wide near the base, those of the stem sheathing, acute, 2-5 
cm. long; inflorescence paniculate; bracts linear-lanceolate, concave, spreading, 2-3 cm. long; sepals oblong, $2-2.5 \mathrm{~cm}$. long; petals white to purple, about 2 $\mathrm{cm}$. long; stamens longer than the petals; capsules cylindric, pointed, about twice as long as the bracts.

On trees and rocks, Great Bahama, Abaco, Andros, New Providence, Eleuthera, Great Exuma, Crooked Island. Acklin's Island, Fortune Island, Inagua, Mariguana and Calcos Islands :-Florlda ; Cuba ; Hispaniola ; Porto Rico ; Grenada ; Curaçao ; Trinidad; Jamaica ; continental tropical America. FLexuous Wild PINe.

As to the Tillandsia canescens Sw., doubtfully recorded from Abaco by Eaton and Setchell, collected by Herrick, the determination was based on a very young plant without flowers or fruit; an examination of the specimen shows that it can not be certainly named, but it may be $T$. fasciculata $\mathrm{Sw}$.

3. CATÓPSIS Griseb. F1. Br. W. I. 599. 1864.

Epiphytic herbs, the basal leaves tufted, lepidote, entire, the flowering stem scapose, usually longer than the leaves, the inflorescence spicate or paniculate, the white or yellow flowers sessile. Flowers perfect or sometimes dioecious. Sepals distinct or nearly so. Petals distinct. Stamens shorter. than the petals, those of pistillate flowers very short, with sterile anthers, those of staminate or perfect flowers with slender filaments and ovate or elliptic anthers. Ovary of pistillate or perfect flowers ovoid or ellipsoid; style shorter than the ovary or none. Capsule septicidally dehiscent above the middle. Seeds thick, comose. [Greek, a view, the significance not evident.] About 16 species, of tropical and subtropical America. Type species: Catopsis nutans (Sw.) Griseb.

1. Catopsis Berteroniàna (Schultes) Mez. in DC. Mon. Pham. 9: 621. 1896.

Tillandsia Berteroniana Schultes; R. \& S. Syst. 7: 1221. 1830.

Plants solitary or clustered on trees or shrubs. Basal leaves numerous, tufted, lanceolate or oblong-lanceolate, thin, 1-4 dm. long, acute or acuminate, pale green and whitish-pruinose; flowering stem rather slender, 3-9 dm. high, clothed with small, appressed narrowly lanceolate leaves; inflorescence paniculate; flowers close together or the lower distant; bracts subcoriaceous, ovate to oval, obtuse, 6-8 $\mathrm{mm}$. long; sepals oval, a little longer than the bracts; petals white, oblong, about as long as the sepals; capsule ovoid, 6-10 mm. long. On trees and shrubs in coppices, Abaco, Andros, New Providence:-Florida :
Cuba; Jamaica; northern South America. Recorded by Eaton and Setchell and by Dolley as $C$. nutans Griseb., by Hitchcock as C. vitellina (L. K. \& O.) Baker. MEALY WILD PINE. Catesby,'2: pl. $7 \%$.

Bromelia Pinguin $\mathrm{L}$. is recorded as a Bahamian plant by Dolley, but we have not found it wild on any island visited. It is widely distributed in the southern West Indies, and has been planted in the Bahamas.

Guzmania lingulata (L.) Mez. [Tillandsia lingulata L.] recorded by Schoepf as seen by him in New Providence in 1784, is not known to inhabit the Bahamas at the present time.

\section{Family 2. COMMELINÀCEAE Rehb.}

\section{SPIDERWORT FAMILY.}

Perennial or annual leafy herbs with regular or irregular perfect and often showy flowers in cymes, commonly subtended by spathe-like or leafy bracts. Perianth of 2 series; a calyx of mostly 3 persistent sepals and a 
corolla of mostly 3 membranous and deciduous or fugacious petals. Stamens mostly 6 , hypogynous, rarely fewer, all similar and perfect or 2 or 3 of them different from the others and sterile; filaments filiform or somewhat flattened; anthers 2-celled, mostly longitudinally dehiscent. Ovary superior, sessile or very nearly so, 2-3-celled; ovules 1 or several in each cell, anatropous or half anatıopous; style simple; stigmas terminal, entire or obscurely 2-3-lobed. Seeds solitary or several in each cell of the capsule. Capsule 2-3-celled, loculicidally 2-3-valved. Embryo small. Endosperm copious. About 25 genera and 350 species, mostly natives of tropical regions, a few in the temperate zones.

Fertile stamens 1-3.

Fertile stamens 5 or 6 .
1 Commelina.

2. Rhoeo.

1. COMMELINNA L. Sp. Pl. 40. 1753.

Somewhat succulent, branching herbs, with short-petioled or sessile leaves, and irregular mostly blue flowers in sessile cymes subtended by spathe-like bracts. Sepals unequal, the larger ones sometimes slightly united. Petals unequal, 2 of them larger than the third. Perfect stamens 3, rarely 2, one of them incurved and its anther commonly larger. Sterile stamens usually 3, smaller, their anthers various. Filaments all glabrous. Capsule 3-celled. Seeds 1 or 2 in each cavity, the testa roughened, smooth or reticulated. [Dedicated to Kaspar Commelin, 1667-1731, Dutch botanist.] About 95 species of wide distribution in warm and temperate regions. Type species: Commelina communis $\mathrm{L}$.

Spathes not united at the base.

Spathes united at the base.

1. C. longicaulis.

2. C. elegans.

\section{Commelina longicaùlis Jacq. Coll. 3: 234. 1789.}

Glabrous or very nearly so ; stems procumbent or creeping, 3-8 dm. long. Leaves lanceolate or ovate-lanceolate, $2.5-7.5 \mathrm{~cm}$. long, acute or acuminate at the apex, their sheaths someltimes ciliate; spathe acuminate, 1-2.5 cm. long, peduncled, the 2 bracts not united by their margins; flowers few in each spathe, 6-12 mm. broad; ventral cavities of the ovary 2 -ovuled, the dorsal 1 ovuled; capsule commonly 5 -seeded ( 2 seeds in each of the ventral cells, 1 in the dorsal); seeds oblong, reticulated, about $2 \mathrm{~mm}$. long.

Moist waste places, New Providence :-all tropical and warm temperate regions. Referred by previous authors to C. nudifiora L. CREEPING DAY-FLOWER.

\section{Commelina élegans H.B.K. Nov. Gen. 1: 259. 1816.}

Stems branching at the base, the branches decumbent, rooting at the nodes, with puberulent internodes; leaves lanceolate to elliptic or oblonglanceolate, 4-10 $\mathrm{cm}$. long, acute or acuminate at the apex, often rounded at the base, the sheaths $1-1.5 \mathrm{~cm}$. long, naked or sparingly ciliate on the margin; spathes short-peduncled, glabrous or puberulent, 1.5-2 cm. long, acute; petals blue or white; capsules obovoid, $4 \mathrm{~mm}$. long, reticulated especially on the dorsal lobe; seeds 3 , smooth.

Moist shaded situations, New Providence:-Bermuda; Florida; West Indies and continental tropical America. 20 . communis of Schoepf. LARGER DAY-FLown. 


\section{RHOĖo Hance; Walp. Ann. 3: 659. 1852-3.}

A somewhat fleshy, short-stemmed, low herb, glabrous throughout or the mouth of the leaf-sheaths pilose, the leaves much longer than the large-bracted inflorescence, the axillary peduncles simple or forked, the umbelled flowers almost concealed within the bracts. Sepals 3, petal-like, ovate-lanceolate, distinct. Petals 3, ovate. Stamens 6, nearly equal; filaments pilose; anthers oblong. Ovary 3-celled, sessile; ovules solitary in each cavity. Fruit a 3 -valved capsule. Seeds rugose. [Name unexplained.] A monotypic genus.

1. Rhoeo discolor (L'Her.) Hance; Walp. Ann. 3: 660. 1852-3.

Tradescantia discolor L'Her. Sert. Angl. 5. 1788.

Stems stout, 2-15 cm. high, about $1.5 \mathrm{~cm}$. thick, often clustered and sometimes forming large colonies. Leaves few, nearly erect, oblong-lanceolate, 2-4 dm. long, 3-6 cm. wide, acuminate, dark green above, purple beneath, rather fleshy; peduncles 2-4 cm. long; bracts compressed-conduplicate, broader than high, 1.5-3 cm. high, acute; umbel many-flowered; pedicels about $1 \mathrm{~cm}$. long; petals white, 5-8 mm. long; capsule ovoid, obtuse, 3 -angled, about $4 \mathrm{~mm}$. long; seeds about $3 \mathrm{~mm}$. long.

Shaded walls and other rocky places, Andros, New Providence:-Cuba to St. Thomas and Barbadoes; Jamaica; Mexico. Oyster Plant. BoAt Lily.

Schoepf records Tradescantia virginica $\mathrm{L}$. as seen by him in New Providence in 1781, but this United States species is not now known to grow in the Bahamas.

\section{Order 9. LILIÀLES.}

Monocotyledonous plants, mostly with well-developed perianth, the flowers usually regular and complete, and their parts in 3's or 6's. Ovary superior or inferior, compound. Endosperm of the seed fleshy or horny.

Ovary superior (partly inferlor in Aletris).

Herbaceous plants or vines.

Fruit a capsule.

Fruit a fleshy berry; dioecious vines.

Large tall woody plants.

Ovary inferior.

Stamens 6 in our specles.

Erect perennial herbs; flowers perfect.

Twining vines; flowers dioecious.

Stamens 3 , opposite the outer corolla-segments.

Fam. 1. Liliaceae.

Fam. 2. SMILACACEAE.

Fam. 3. DRACAenaceat.

Fam. 4. Amaryllidaceat.

Fam. 5. Dioscoreacear.

Fam. 6. Iridaceat.

\section{Family 1. LILIÀCEAE Adans.}

\section{LiLy Family.}

Scapose or leafy-stemmed herbs from bulbs or corms, or rarely with rootstocks or a woody caudex ( $Y$ ucca), the leaves various. Flowers solitary or clustered, regular, mostly perfect. Perianth parted into 6 distinct or nearly distinct segments, or these more or less united into a tube inferior or partly superior (Aletris). Stamens 6, hypogynous or borne on the perianth or at the bases of its segments; anthers 2-celled, mostly introrse, sometimes extrorse. Ovary 3-celled; ovules few or numerous in each cavity, anatropous or amphitropous; styles united; stigma 3-lobed or capitate. Fruit a usually loculicidal capsule, or in Yucca sometimes fleshy 
and indehiscent. Seeds various, winged or wingless. Embryo in copious endosperm. About 125 genera and 1300 species, widely distributed.

Cavities of the fruit each 1 -seeded.

1. Aloe.

Cavities of the fruit many-seeded.

Fruit with a thin rupturing pericarp.

Fruit a loculicidal capsule.

2. Cordyline.

3. Aletris.

1. ALÒE L. Sp. Pl. 319. 1753.

Succulent plants with a short or elongated caudex, the thick tufted leaves with spiny-toothed margins, the racemose flowers nodding. Perianth subcylindric, the segments connivent or coherent, their tips somewhat spreading. Stamens 6, with slender filaments and oblong anthers. Ovary sessile, 3-angled and 3-celled; style filiform, tipped by the small stigma; ovules many in each cavity of the ovary. Capsule leathery, loculicidally dehiscent. Seeds numerous, black. [Name ancient.] Over 75 species, mostly African. Type species: Aloe perfoliata L.

\section{Aloe vèra L. Sp. Pl. 320. 1753.}

Aloe vulgàris Lam. Encycl. 1: 86. 1783.

Aloe perfoliata vera L. Sp. Pl. 320. 1753.

Aloe barbadensis Mill. Gard. Dict. ed. 8, no. 2. 1768.

Acaulescent, or nearly so, stoloniferous. Leaves 3-6 dm. long, narrowly lanceolate, long-acuminate, turgid, very watery within, pale glaucous-green, the marginal spiny teeth $1 \mathrm{~cm}$. apart or less; scape stout, 6-12 dm. high, bearing distant, broad, acute scales; raceme dense, 1-3 dm. long; bracts lanceolate, acute, longer than the short pedicels: flowers yellow, about $2.5 \mathrm{~cm}$. long; stamens about as long as the perianth, the style longer.

Coastal rocks. sand plains and dunes, spontaneous after cultivation, Great Exuma, Cat Island, North, East and South Caicos and Salt Cay. Native of the Mediterranean Region, escaped in Bermuda, the West Indies and Central America. ALOES.

2. CORDYLINE Adans. Fam. Pl. 2: 54, 543. 1763.

[SANsevieria Thunb. Prodr. Fl. Cap. 65. 1794.]

Fleshy perennial herbs, the leaves tufted, basal, flat or terete, elongated, containing a strong fibre, the rather large flowers in a raceme at the end of a simple scape. Perianth-tube slender, its lobes narrow, spreading. Stamens 6, borne near the top of the perianth-tube, the filaments filiform, the anthers oblong or linear. Ovary 3-celled; ovules 1 in each cavity, erect. Fruit with a thin pericarp. Seeds 1-3, subglobose, fleshy. [Greek, a club.] About 25 species, natives of Asia and Africa. Type species: Aloe hyacinthoides L.

1. Cordyline guineénsis (L.) Britton, Mem. Brooklyn Bot. Gard. 1: 35. 1918.

Aletris hyacinthoides guianensis L. Sp. Pl. ed. 2, 456. 1762.

Aletris guineensis Jaca. Hort. Vind. 1: 36. 1770.

Sansevieria guineensis Willd. Sp. Pl. 2: 159.1799.

Leaves linear, $1 \mathrm{~m}$. long or less, nearly flat, 5-8 cm. wide, dark green an mottled, narrowed at both ends. Scape about as long as the leaves; raceme many-flowered; pedicels $5-8 \mathrm{~mm}$. long; perianth nearly white, its lobes about 
$1.5 \mathrm{~cm}$. long, linear or linear-spatulate, recurved, somewhat shorter than the tube.

Waste grounds, spontaneous after cultivation, New Providence:-Florida; Porto Rico; Cuba; St. Thomas; St. Croix; Jamaica. Native of tropical Africa. AFrICAN BOWSTRING-HEMP.

\section{3. ÁLETRIS L. Sp. Pl. 319. 1753.}

Scapose perennial bitter fibrous-rooted herbs, with basal lanceolate leaves, and small, white or yellow, bracted perfect flowers in a terminal spike-like raceme. Perianth oblong or campanulate, roughened without, 6-lobed, its lower part adnate to the ovary. Stamens 6, inserted on the perianth at the bases of the lobes, included; anthers introrse. Ovary 3-celled; ovules numerous, anatropous; style 3 -cleft above; stigmas minutely 2-lobed. Capsule ovoid, enclosed by the persistent perianth, 3-celled, many-seeded, loculicidal. Seeds oblong, ribbed. Embryo small. Endosperm fleshy. [Greek, signifying to grind corn, apparently in allusion to the rough, mealy flowers.] About 8 species, natives of eastern N. Am. and Asia. Type species: Aletris farinosa L.

\section{Aletris bracteàta Northrop, Mem. Torr. Club 12: 27.1902.}

Basal leaves tufted, grayish green, spreading, narrowly lanceolate, $10 \mathrm{~cm}$. long or less, 6-10 mm. wide, acuminate at the apex, narrowed at the base, those of the scape few, distant and very small. Scape about $6 \mathrm{dm}$. high, erect; raceme erect, many-flowered; pedicels about $1 \mathrm{~mm}$. long; bracts subulate, 4-6 $\mathrm{mm}$. long; perianth white, 6-8 $\mathrm{mm}$. long, tubular-oblong, about $3 \mathrm{~mm}$. thick, its oblong-lanceolate lobes about one-fourth as long as the tube; anthers longer than the filaments; fruit oval, about $5 \mathrm{~mm}$. long.

Wet grounds in savannas and pine-barrens, Abaco and Andros:-Fiorida. SOUTHERN COLIC-ROOT.

\section{Family 2. SMILÀCACEAE Vent.}

\section{Smilax Family.}

Mostly vines with woody or herbaceous, often prickly stems. Leaves alternate, netted-veined, several-nerved, petioled. Petiole sheathing, bearing a pair of slender tendril-like appendages, persistent, the blade falling away. Flowers small, mostly green, dioecious, in axillary umbels. Perianth-segments 6. Stamens mostly 6, distinct; filaments ligulate; anthers basifixed, 2-celled, introrse. Ovary 3-celled, the cavities opposite the inner perianth-segments; ovules 1 or 2 in each cavity, orthotropous; style very short or none; stigmas 1-3. Fruit a globose berry containing 1-6 brownish seeds. Endosperm horny, copious; embryo small, oblong, remote from the hilum. Genera 3, only the following in North America; species about 230 , in warm and temperate regions.

\section{SMIIAX L. Sp. Pl. 1028. 1753.}

Rootstocks usually large and tuberous, stems usually twining, and climbing by means of the coiling appendages of the petiole. Lower leaves reduced to scales. Flowers regular. Perianth-segments distinct, deciduous. Pedicels borne on a globose or conic receptacle, inserted in small pits, generally among 
minute bractlets. Filaments inserted on the bases of the perianth-segments. Staminate flowers without an ovary. Pistillate flowers usually smaller than the staminate, usually with 1-6 abortive stamens. Berry black, red or purple (rarely white), with 3 strengthening bands of tissue running through the outer part of the pulp, connected at the base and apex. Embryo lying under a tubercle at the upper end of the seed. [Ancient Greek name, perhaps not originally applied to these plants.] About 225 species of wide distribution, most abundant in tropical America and Asia. Type species: Smilax aspera L.

Leaves normaliy armed with prickeis; leaves coriaceous.

1. S. havanensis. Leaves unarmed.

Leaves chartaceous, ovate, mostiy 2-lobed near the base.

Leaves coriaceous, elliptic or obiong-lanceolate.

2. S. auriculata.

3. S. laurifolia.

\section{Smilax havanénsis Jacq. Enum. 33. 1760.}

Smilax havanensis dentata O. E. Schulz, in Urban, Symb. Ant. 5: 40, as to Bahama plant, 1904.

Smilax havanensis ovata laevis O. E. Schulz, loc. cit. 41. 1904.

Smilax oblongata O. E. Schulz, loc. cit. 42, as to Bahama plant. 1904.

Smilax oblongata viscifolia O. E. Schulz, loc. cit. 43 , at least as to Bahama plant. 1904.

Smilax populnea O. E. Schulz, loc. cit. 43, as to Bahama plant. 1904.

Woody, climbing or trailing, armed with short hooked prickles or nearly unarmed, 1-4 m. long, the branches angled, often zigzag. Leaves coriaceous, oblong to ovate or suborbicular, spinulose-dentate or entire, 2-12 cm. long, reticulate-veined, 3-7-nerved, obtuse, mucronate or emarginate at the apex, rounded, narrowed or subcordate at the base, the petioles 10-18 $\mathrm{mm}$. long, the stipular sheaths about half as long as the petioles; peduncles about as long as the petioles, 4-30-flowered; pedicels about $4 \mathrm{~mm}$. long; flowers $2-3 \mathrm{~mm}$. broad, the staminate somewhat larger than the pistillate; sepals and petals oblong; berries black, subglobose or ovoid, 4-6 mm. in diameter.

Rocky and sandy soll, throughout the archipelago from Abaco and Great Bahama south to the Caicos and Inagua:-Florida; Cuba; Hispaniola. Our field observations, and specimens, show that the synonyms cited above are of no value in differentiating the large number of races which constitute this specles; there being a wide range in leaf-form and venation and in the relative number of prickles; also in the relative leafiness of the upper parts of the piants; individuai specimens may be unarmed. Hitchcock referred a part of his specimens of this species to $S$. domingen sis Willd. Prickly Green-Brier. SAW-Brier. ChINA-Brier. Chaney-Vine.

\section{Smilax auriculàta Walt. Fl. Car. 245. 1788.}

\section{Smilax Beyrichii Kunth, Enum, Pl. 5: 207. 1850.}

A glabrous vine, often $5 \mathrm{~m}$. long or longer, trailing or climbing, the branches angular, zigzag, bearing a few prickles or unarmed. Leaves oblong to ovate, chartaceous, 2-10 cm. long, abruptly short-pointed, narrow or obtuse at the base, often dilated or auricled below, shining, coarsely reticulate-veined, the stout petioles 6-10 $\mathrm{mm}$. long; peduncle 3-12 $\mathrm{mm}$. long; pedicels several or many, slender, 4-10 mm. long; flowers yellowish-green, fragrant; sepals and petals of staminate flowers nearly linear, $4-5 \mathrm{~mm}$. long, those of pistillate flowers oblong, about $2.5 \mathrm{~mm}$. long; berries black, globose, about $5 \mathrm{~mm}$. in diameter.

Coppices, scrub-lands, savannas and pine-barrens, Abaco, Great Bahama, Andros, South Cat Cay, New Providence and Eleuthera :-Georgla to Fiorida and Louisiana. A URICled Giennirier. Chixa-Brier. 
3. Smilax laurifòlia L. Sp. Pl. 1030. 1753.

Rootstocks bearing tubers sometimes $1.5 \mathrm{dm}$. thick; stem high-climbing, terete; armed with strong straight prickles, the branches angled, mostly unarmed. Petioles stout, 6-16 mm. long; leaves leathery, evergreen, elliptic or oblong-lanceolate, acute or abruptly cuspidate at the apex, narrowed at the base, entire, 3-nerved, or sometimes with an additional pair of nerves near the margins, 5-11 cm. long; peduncles stout, angled, 4-20 mm. long; umbels 6-30flowered; pedicels 4-6 $\mathrm{mm}$. long; staminate flowers 4-6 $\mathrm{mm}$. long; anthers usually about one-third shorter than the filaments; stigma 1, sometimes 2; berries black, ovoid, 4-6 mm. thick.

Border of swamp, Delaport, New Providence; coppices at Staniard Creek, Andros:- Southeastern United States; Cuba. LAUREL-Leaved Greenbrier. Catesby $1: p l$. 15.

Smilax Walteri Pursh, attributed to the Bahamas by O. E. Schulz, from a specimen supposed to have been collected by Maerter, preserved in the Munich herbarium, has not been found on any of the islands in the course of our explorations; we presume the specimen was collected in the United States.

\section{Family 3. DRACAENĀCEAE Link.}

\section{Dracaena Familt.}

Perennial, often large, woody plants, mostly with erect and leafy stems, the leaves alternate, the flowers in terminal panicles or racemes. Sepals and petals each 3 , nearly alike. Stamens 6; filaments distinct; anthers 2-celled. Ovary superior, 1-3-celled; ovules 2 to numerous in each cavity; styles united. Fruit capsular or baccate, dry or fleshy, loculicidally dehiscent or rarely indehiscent. About 10 genera and 100 species, natives of warm and tropical regions.

\section{YÚCCA L. Sp. P1. 319. 1753.}

Large plants, with a short sometimes subterranean caudex, or tall woody and leafy stem, or bracted scape, the leaves linear or lanceolate, usually rigid and sharp-pointed, bearing long marginal thread-like fibres in our species. Flowers large, nodding in a terminal raceme or panicle. Perianth campanulate, or nearly globular, white in our species, of 6 ovate, or ovate-lanceolate connivent segments. Stamens hypogynous, shorter than the perianth; filaments thickened above; anthers small, versatile. Ovary sessile, 3-celled, or imperfectly 6-celled; ovules numerous; style columnar, short, with 3 stigmatic lobes. Fruit a capsule, or fleshy, or spongy and indehiscent. Seeds numerous, flattened, horizontal. [The Haitien name.] About 30 species, natives of North and Central America. Type species: Yucca aloifolia L.

1. Yucca aloifòlia L. Sp. Pl. 319. 1753.

Caudex stout, up to $3.3 \mathrm{~m}$. high, often branched; plant usually growing in colonies, forming large masses. Leaves $1 \mathrm{~m}$. long or less, stiff, sharp-pointed, the upper spreading, the older lower ones deflexed, the base expanded; panicle ample, often $6 \mathrm{dm}$. long, showy; perianth white or purplish-tinged, about $5 \mathrm{~cm}$. long, its segments oblong; capsule pulpy, indehiscent, oblong, 6-8 cm. long; seeds thin.

Sand dunes, New Providence :-Bermuda; Florida to Louisiana ; Cuba ; Jamaica ; Mexico. Spanish Bayonet. 


\section{Family 4. AMARYLLIdÀCEAE Lindl.}

\section{AMaryllis FaMILY.}

Perennial herbs (some tropical species woody or even arboreous), with bulbs or rootstocks, scapose or sometimes leafy stems and usually narrow and entire leaves. Flowers perfect, regular or nearly so. Perianth 6parted or 6-lobed, the segments or lobes distinct, or united below into a tube which is adnate to the surface of the ovary (adnate only to the lower part of the ovary in Lophiola). Stamens 6 in our genera, inserted on the bases of the perianth-segments or in the throat of the perianth opposite the lobes. Anthers versatile or basifixed, 2-celled, the saes usually longitudinally dehiscent. Ovary wholly or partly inferior, usually 3-celled. Style filiform, entire, lobed, or cleft into 3 stigmas at the summit. Ovules usually numerous, rarely only 1 or 2 in each cavity of the ovary, anatropous. Fruit capsular, rarely fleshy. Seeds mostly black, the embryo small, enclosed in fleshy endosperm. About 70 genera and 800 species, principally natives of tropical and warm regions, some in the temperate zones.

Plants with rootstocks or corms.

Inflorescence umbellate; capsule circumscissile; low herbs.

Inflorescence paniculate; capsule 3 -valved; large plants with flowers on tall scapes.

Perianth funnelform.

Perianth rotate-campanulate.

1. Hypoxis.

2. Agave. Bulbous plants.

Filaments distinct.

Filaments united below into a cup.

3. Furcraea.

4. Atamosco.

5. Hymenocallis.

1. HYPÓXIS L. Syst. ed. 10, 986. 1759.

Low, mostly villous herbs, with a corm or short rootstock, grass-like leaves and slender few-flowered scapes, the flowers rather small. Perianth 6-parted, its segments equal or nearly so, separate to the summit of the ovary, witheringpersistent. Stamens inserted on the bases of the perianth-segments; filaments short; anthers erect, sagittate or entire. Ovary 3-celled; style short; stigmas 3 , erect; ovules numerous, in 2 rows in each cavity. Capsule thin-walled, not dehiscent by valves. Seeds globular, black, laterally short-beaked by their stalks. [Greek, originally given to some plant with sour leaves.] About 50 species, widely distributed. Type species: Hypoxis decumbens L.

\section{Hypoxis júncea J. E. Smith, Spic. 15. 1792.}

Leaves linear-filiform, curved, $\cdot 3 \mathrm{dm}$. long or less, 1-2 mm. wide, glabrous above, sheathing at the base. "Scapes 2 or 3 together or solitary, filiform, mostly shorter than the leaves, 1-flowered or 2-flowered at the summit, weak, reclining or prostrate when old; bracts linear-subulate; perianth about $2 \mathrm{~cm}$. broad, its acute segments oblong-lanceolate, pubescent outside, yellow within; capsule 4-6 mm. long; seeds about $0.8 \mathrm{~mm}$. in diameter.

Grassy places and in pine-barrens, Andros, New Providence and Eleuthera :Georgia to Florida, west to Texas; Cuba. Southern Yellow-eyed Grass.

\section{AGÀVE L. Sp. Pl. 323. 1753.}

Fleshy herbs, some species very tall, with a short crown-like or erect caudex and a tall bracted scape, the leaves large, thick, sometimes spiny-toothed, 
basal, or clustered at the top of the caudex, the large bracted flowers in terminal spikes or compound clusters. Perianth tubular or funnelform, withering-persistent, with 6 equal or nearly equal lobes. Stamens inserted on the perianth at the bases of the lobes, exserted. Ovary 3-celled; style slender, exserted, 3-lobed; ovules numerous, in 2 rows in each eavity of the ovary. Capsule 3-lobed, thick-walled, many-seeded. Seeds compressed, somewhat cuneate, black. [Greek, signifying noble.] Perhaps 150 species. All these plants, except the Sisal, are called "Bamboo" in the Bahamas. We have copied here the original descriptions of the Bahama species by Professor Trelease, who had all our specimens for his investigation, and we have nothing to add to them.

Plants not suckering; leaves broad, fleshy, curved.

Leaves broad and stout, about 3 times as long as wide.

Leaves elongated-lanceolate, much longer than wlde.

Prickles of the leaf-margins 10-25 $\mathrm{mm}$. apart, 2-5 $\mathrm{mm}$. long.

Capsules broadly oblong.

Leaves dull, gray; spine rather short.

Leaves somewhat glossy, greenish; spine elongated.

Capsules narrowly oblong.

Prickles 5-10 $\mathrm{mm}$. apart, about $1 \mathrm{~mm}$. long.

Splne stout; prickles often with lenticular bases.

Spine slender; prickles not lenticular.

Plants freely suckering; leaves narrow, hard, stralght.

Leaves erect; flowers $3.5-5 \mathrm{~cm}$. long, yellow.

Leaves gradually tapering, deeply concave; prickles deltold.

Leaves abruptly acute, nearly flat; prickles slender.

Leaves ascending ; flowers $4.5-6.5 \mathrm{~cm}$. long, yellow-green.

\section{A. Braceana.} $-5$

\section{A. bahamana.}

3. A. Millspaughii.

4. A. cacozela.

5. A. acklinicola.

6. A. indagatorum.

\section{A. Nashii.}

8. A. inaguensis.

9. A. sisalana.

\section{Agave Braceàna Trelease, Mem. Nat. Acad. Sci. 11: 40. 1913}

Acaulescent, not cespitose. Leaves gray, broadly oblanceolate. nearly flat, 19 by $65 \mathrm{~cm}$. (or larger \&); spine from brownish becoming gray, smooth, dull, straight or gently curved, conical, flat or round-grooved to about the middle or becoming involute, 3 by $10-15 \mathrm{~mm}$., slightly decurrent; prickles usually 5-10 mm. apart, $2-3 \mathrm{~mm}$. long, straight or the lower gently recurved, triangular, scarcely lenticular at base, the intervening margin straight, or concave when they are raised on low green bases; inflorescence about $7 \mathrm{~m}$. high, paniculate; pedicels about $10 \mathrm{~mm}$. long; flowers golden-yellow, 40-45 $\mathrm{mm}$. long; ovary $20 \mathrm{~mm}$. long, nearly half as long again as the perianth, oblongfusiform; tube conical, about $7 \mathrm{~mm}$. deep; segments $3-4$ by $15-17 \mathrm{~mm}$., threefourths as long as the ovary; filaments inserted nearly in the throat, $35 \mathrm{~mm}$. long, about twice as long as the segments; capsules broadly oblong, 20 by 35 mm., shortly stipitate and beaked; seeds 6 by $8 \mathrm{~mm}$.; bulbils unknown.

Rocky and sandy soll, Abaco; Great Bahama; Andros (?). Endemic. Brace's Century-Plant.

\section{Agave bahamàna Trelease, Mem. Nat. Acad. Sci. 11: 40. 1913.}

Acaulescent, not cespitose. Leaves dull grayish, rather narrowly lanceolate, concave, occasionally somewhat plicate, 15 by $200-300 \mathrm{~cm}$.; spine from brownish becoming gray, smooth, dull, slightly recurved, stoutly conical, usually becoming involutely grooved below the middle, 4-5 by 10-15 mm., decurrent; prickles usually 5-10 $\mathrm{mm}$. apart, 3-5 $\mathrm{mm}$. long, reduced above and below, straight or the longer ones appressed-recurved, triangular, scarcely lenticular at base, sometimes on small green prominences, the intervening margin nearly straight; inflorescence about $10 \mathrm{~m}$. high, the upper third or so 
ovoid-paniculate with slightly ascending branches; bracts deltoid, not imbricated; pedicels about $10 \mathrm{~mm}$. long; flowers golden, $50-60 \mathrm{~mm}$. long; ovary 30-35 mm. long, half as long again as the perianth, oblong-fusiform; tube conical, about $7 \mathrm{~mm}$. deep; segments 4 by $15 \mathrm{~mm}$., about half as long as the ovary, filaments inserted nearly in the throat, $30-35 \mathrm{~mm}$. long, more than twice as long as the segments; capsules oblong, 25 by $50 \mathrm{~mm}$., shortly stipitate and béaked; seeds 6 by $8 \mathrm{~mm}$.

Rocky plains and ridges, Berry Islands, Andros, Eleuthera, Cat Isiand, Cave Cay and Great Exuma. Endemic. Erroneously referred by Dolley and by Urban to Agave americana L.; by Hitchcock to Agave sobolifera Salm-Dyck.; and by Mrs. Northrop and Coker to Agave rigida Mill. BaHAMa CENTCRY-PLANT.

The four following species described by Professor Trelease, may be but races of $A$. bahamana.

3. Agave Millspaùghii Trelease, Mem. Nat. Acad. Sci. 11: 41. 1913.

Acaulescent, not cespitose. Leaves somewhat glossy, green, narrowly oblanceolate, concave, 15 by $125 \mathrm{~cm}$. or more; spine red-brown, smooth, rather dull, straight, conical, triquetrous or V-grooved below the middle, $3-4$ by $15-20$ $\mathrm{mm}$., decurrent for its length or more; prickles usually $15-25 \mathrm{~mm}$. apart, 3-5 $\mathrm{mm}$. long, straight and spreading or occasionally reflexed sometimes with upcurved tips, narrowly triangular, scarcely lenticular at base, the intervening margin nearly straight; inflorescence large, paniculate; bracts broadly triangular; pedicels about $10 \mathrm{~mm}$. long; flowers (yellow?) $50 \mathrm{~mm}$. long; ovary $25 \mathrm{~mm}$. long, little longer than the perianth, fusiform; tube conical, about 7 $\mathrm{mm}$. deep; segments 4 by $15-20 \mathrm{~mm}$, three-fourths as long as the ovary; filaments inserted nearly in the throat, scarcely $30 \mathrm{~mm}$. long, about one-half longer than the segments; capsules short-oblong, 20 by $35 \mathrm{~mm}$., shortly stipitate and beaked; seeds 5 by $7 \mathrm{~mm}$.

Low coppices and scrub-lands, Great Exuma. Endemic. Millspadgh's CenTURY-PLANT.

\section{Agave cacozèla Trelease, Mem. Nat. Acad. Sci. 11: 41. 1913.}

Acaulescent, not cespitose. Leaves yellowish green, somewhat overcast with gray, typically roughish, lanceolate, deeply concave, 20 by $150-200 \mathrm{~cm}$; spine from brownish becoming gray, smooth; dull, straight or the tip slightly refracted, triquetrously conical, openly grooved below the middle, $3-5$ by $15-20$ $\mathrm{mm}$., decurrent; prickles usually 10-15 mm. apart, 2-5 mm. long in the middle, nearly straight or the larger ones appressed-recurved, narrowly triangular, rarely lenticular at base, the intervening margin straight or somewhat concave; inflorescence 6-7 m. high, the upper third densely ovoid-paniculate with horizontal or slightly ascending branches; bracts broadly triangular, not imbricated; pedicels about $10 \mathrm{~mm}$. long; flowers golden, 50-60 mm. long; ovary $35-40 \mathrm{~mm}$. long, about half as long again as the perianth, oblong-fusi: form; tube rather open, about $7 \mathrm{~mm}$. deep; segments $4-5$ by $20 \mathrm{~mm}$., about half as long as the ovary; filaments inserted nearly in the throat, $40-45 \mathrm{~mm}$. long, rather more than twice as long as the segments; capsules narrowly. oblong, 15 by $35-45 \mathrm{~mm}$., shortly conical-stipitate, beaked; seeds 4 by $6-7 \mathrm{~mm}$. Said to be bulbiferous sometimes.

Rocky margins of sait marshes, New Providence. Endemic. New Providence Century-plant.

\section{Agave acklinícola Trelease, Mem. Nat. Acad. Sci. 11: 41. 1913.}

Aspect of $A$. bahamana. Spine from red-brown becoming gray, smooth, glossy, somewhat flexuously recurved, conical, involutely grooved to or beyond the middle, 4-6 by 20-25 mm., decurrent; prickles 5-10 mm. apart, 1-1.5 mm. 
long, straight or gently curved, rather acuminately deltoid often from oblique green prominences, or with lenticular bases, the intervening margin nearly straight; inflorescence, flowers, fruit, and bulbils unknown.

Acklin's Island. Endemic. Acklin's Island Ceñtury-Plant.

6. Agave indagatòrum Trelease, Mem. Nat. Acád. Sci. 11: 42. 1913.

Acaulescent, not cespitose. Leaves somewhat grayish and at first very glaucous beneath, lanceolate, somewhat concave, gradually acute, 20-25 by 150-250 cm.; spine chestnut, smooth, rather glossy, nearly straight, conical, involutely grooved to the middle, 3 by $12 \mathrm{~mm}$., decurrent for about its own length; prickles 5-12 $\mathrm{mm}$. apart, about $1 \mathrm{~mm}$. long, straight or slightly reeurved, narrowly triangular, not lenticular at base, the somewhat membranous at first slightly pink intervening margin straight; inflorescence $9 \mathrm{~m}$. high, paniculate; pedicels 15-20 mm. long; flowers unknown; capsules narrowly oblong, ' 20 by $55-60 \mathrm{~mm}$., thick-stipitate, acuminately pointed; seeds 5 by $7-8$ $\mathrm{mm}$. Said by Dr. Britton to be bulbiferous.

Rocky soil, Watling's Island. Endemic. Watling's Island Century-plant.

7. Agave Náshii Trelease, Mem. Nat. Acad. Sci. 11: 45. 1913.

Acaulescent, cespitose. Leaves gray-green, sometimes purple-tinged, graygreen, somewhat glaucous and transversely banded, attenuate-oblong, concave, 4-5 by $30-50 \mathrm{~cm}$; ; spine purplish brown, smooth, somewhat polished and recurved or upcurved toward the end, conical tapered, narrowly slit-grooved to beyond the middle, 3 by $15 \mathrm{~mm}$., decurrent; prickles usually $3-5 \mathrm{~mm}$. apart, scarcely $2 \mathrm{~mm}$. long, straight or somewhat curved, acuminately triangular, sometimes nearly or quite confluent, the intervening margin nearly straight; inflorescence $3.5-4 \mathrm{~m}$. high, the upper third or more very loosely paniculate with slender outcurved branches; pedicels 5-10 mm. long; flowers light yellow, $35 \mathrm{~mm}$. long; ovary $20 \mathrm{~mm}$. long, exceeding the perianth, subfusiform or obovoid in development; tube openly conical, $3 \mathrm{~mm}$. deep; segments 3 by 10 $\mathrm{mm}$., half as long as the ovary; filaments inserted nearly in the throat, $25 \mathrm{~mm}$. long, more than twice as long as the segments; capsules oblong or oblongpyriform, 20 by $35 \mathrm{~mm}$., or less, slightly stipitate and beaked; seeds 4 by 4-5 $\mathrm{mm}$.

Sandy soll, Inagua. Endemic. Nash's Century-plant.

8. Agave inaguénsis Trelease, Mem. Nat. Acad. Sci. 11: 47. 1913.

Habit of A. Nashii. Leaves typically white-glaucous, oblong or oblanceolate, more quickly acute, flatter, sometimes plicate, $6-9$ by $40-60 \mathrm{~cm}$.; spine often shorter and stouter; prickles closer, 2-3 mm. apart, more recurved and less uniform, very narrowly triangular, almost continuously joined by a narrow blackish border; inflorescence and fruit unknown; pedicels 5-10 mm. long; flowers yellow, $50 \mathrm{~mm}$. long; ovary $25-30 \mathrm{~mm}$. long, exceeding the perianth, subfusiform; tube open, $5 \mathrm{~mm}$. deep; segments 5 by $15-17 \mathrm{~mm}$., half as long as the ovary; filaments inserted nearly in the throat, $35 \mathrm{~mm}$. long, fully twice as long as the segments.

Little Inagua; South Caicos.' Endemic. INAGUa Century-PLANT.

9. Agave sisalàna (Engelm.) Perrine, House Rep. Document 564: 8. 1838.

Agave rigida sisalana Engelm. Trans. Acad. St. Louis, 3: 316. 1876. Agave sisalana armata Trelease, Mem. Nat. Acad. Sci. 11: 49. 1913.

Subacaulescent. Leaves finally green and somewhat glossy, at first lightly glaucous and transversely banded on the back, linear-lanceolate, nearly flat, about 10 by $150 \mathrm{~cm}$; spine dark brown, somewhat pitted and glossy, tumidly 
conical or triquetrous, slightly recurved, shallowly round-grooved near the base, 4-5 by 20-25 mm., not decurrent; prickles exceptionally numerous and $2-4 \mathrm{~mm}$. long, but typically.minute or almost entirely suppressed; inflorescence about $6 \mathrm{~m}$. high, the upper half loosely oblong-paniculate; pedicels $5-10 \mathrm{~mm}$. long; flowers yellowish green, $45-60 \mathrm{~mm}$. long; ovary $20-25 \mathrm{~mm}$. long, shorter than the perianth, soon broadly fusiform; tube urceolate, 15-20 mm. deep; segments 6-8 by $15-20 \mathrm{~mm}$., a little shorter than the ovary; filaments inserted about the upper third of the tube, 40-70 or even $80 \mathrm{~mm}$. long, twice or thrice as long as the segments; capsules, when produced, which is rare, oblong, 20-25 by $60 \mathrm{~mm}$., stipitate and beaked; seeds 7 by $10 \mathrm{~mm}$. Freely bulbiferous.

Rocky plains, spontaneous after cultivation, Andros, New Providence, Cat Isiand. Native of Yucatan. Cultivated throughout the archipelago.

In fields of the cultivated plant many individuals were found with spineless leaf margins, others with very spiny margins, and still others both spiny and spineless margins on the same plant. SisaL.

\section{FURCRAEA Vent. Bull. Soc. Philom. 1: 65. 1793.}

Large succulent plants with tufted basal leaves and tall scapes, the in. florescence terminal, paniculate. Perianth of 6 spreading segments, slightly united at the base. Stamens borne on the bases of the segments; filaments thickened below the middle; anthers linear-oblong. Ovary 3-celled, with many ovules in 2 rows in each eavity; style rather stout, 3-angled and thickened below, tipped by a small stigma. Capsule oblong, 3-sided, 3-valved. Seeds numerous, flat. [Dedicated to Antoine Francois de Fourcray.] About 20 species, natives of tropical America. Type species: Furcraea cubensis Vent.

\section{Furcraea macrophýlla Baker in Hook. Ic. pl. 2501. 1899.}

Leaves many, the larger about $2.3 \mathrm{~m}$. long by $18 \mathrm{~cm}$. wide, nearly equally bright green on both sides, shallowly channeled above, rather firm, gradually narrowed to $5 \mathrm{~cm}$. or $7 \mathrm{~cm}$. wide above the expanded base, the lower prickles 2-3 $\mathrm{mm}$. long, the upper strongly hooked forward, 2-7 cm. apart, borne on triangular, distant teeth 4-6 mm. high; scape up to $10 \mathrm{~m}$. tall, about $1.5 \mathrm{dm}$. thick toward the base, its lanceolate bracts broad-based, the lower 3-6 dm. long, ascending, the upper, shorter, widely spreading; panicle branches curved and tortuous when young; flowers white, fading yellowish green; ovoid bulbils 2-4 cm. long are freely developed on the panicle in place of flowers.

Roadsides and waste grounds, New Providence, Cat Island, Acklin's Island, North and South Caicos:-Bermuda (naturallzed), Cuba, Jamalca. Originally described from garden specimens, of New Providence, grown at Kew. Mr. Percy Wilson says that the North Caicos plants grow in a forest far from habitations and have all the appearances of being native. Referred by Mrs. Northrop to $F$. cubensis and, doubtfully by Drummond to $F$. undulata Jacobi. Drummond (Rep. Mo. Bot. Gard. 18: 43) doubtfully records $F$. cubensis (Jacq.) Vent. from East Caicos. Wild Sisal.

\section{ATAMósco Adans. Fam. Pl. 2: 57, 522. 1763.}

Acaulescent herbs, with coated bulbs and glabrous foliage. Leaves sasal, narrowly linear, flat or channeled. Scape 1-flowered. Perianth white, red, pink. purple or yellow, its tube funnelform, its 6 lobes equal. Stamens 6 , equal or nearly so; filaments adnate to the throat of the perianth-tube; anthers versatile. Ovary 3-celled; style filiform, 3-lobed at top, or stigma nearly capitate. Ovules numerous, in two rows in each cavity. Capsule 3-celled, subglobose or depressed, more or less 3-lobed, loculicidally 3-valved. Seeds black or nearly 
so, usually flattened. [Aboriginal name.] Abcut 35 species, natives of America. Type species: Amaryllis Atamasco L.

Flower rose-pink, $2-3 \mathrm{~cm}$. wide.

1. A. rosea.

Flower bright red, 7-8 $\mathrm{cm}$. wide.

2. A. cardinalis.

1. Atamosco ròsea (Lindl.) Greene, Pittonia 3: 188. 1897.

Zephyranthes rosea Lindl. Bot. Reg. 10: pl. 821. 1824.

Bulbs subglobose, usually less than $2 \mathrm{~cm}$. in diameter, short-necked. Scape rather slender, $2 \mathrm{dm}$. high or less, as long as the leaves or longer; leaves 3-4 $\mathrm{mm}$. wide; spathe about half as long as the peduncle, 2-cleft at the top; perianth 2-3 cm. long, rose-pink, with a short tube and obovate bluntish segments; style 3 -cleft; capsule about $8 \mathrm{~mm}$. thick.

Roadsides, spontaneous after cultivation. New Providence and on Grand Turk where it was observed carpeting a pasture of over five acres in extent. Native of cuba. Erroneously called Croces and SNowdrop. SMall PiNk Atamasco-lilly.

\section{Atamosco cardinàlis (C. H. Wright) Britton.}

Zephyranthes cardinalis C. H. Wright, Bot. Mag. pl. 8553. 1914.

Bulbs up to $6 \mathrm{~cm}$. in diameter. Scape rather stout, 10-12 cm. high, pink at the base, green above, about as long as the leaves; leaves $6-8 \mathrm{~mm}$. wide; spathe somewhat longer than the peduncle, acute, pink, 2-3 cm. long; perianth bright red, its funnelform tube $2-3 \mathrm{~cm}$. long, its oblong-oblanceolate segments 4-5 cm. long. RED ATAMASCO-LILY.

Grown in Bahama gardens; perhaps native somewhere in the archipelago.

\section{HYMENOCÁLLIS Salisb. Trans. Hort. Soc. 1: 338. 1812.}

Mostly tall bulbous herbs with usually lanceolate or linear-oblong leaves, and large white eapitate or umbelled flowers on solid scapes, each flower subtended by 2 membranous bracts. Perianth of 6 spreading or recurved, narrow equal elongated lobes, united below into a long cylindric tube. Stamens inserted in the top of the perianth-tube, the lower parts of the long filaments connected by a membranous erown; anthers linear, versatile. Ovary 3-celled; ovules only 1 or 2 in each cavity; style filiform, long-exserted; stigma small, entire or nearly so. Capsule rather fleshy. Seeds usually only 1 or 2, large, green, fleshy. [Greek, beautiful membrane, referring to the crown.] About 30 species, all American. Type species: Hymenocallis littoralis Salisb.

Perianth-segments as long as the tube or longer.

Perianth-segments shorter than the tube.
1. H. declinata.

2. H. caymanensis.

1. Hymenocallis declinàta (Jacq.) M. J. Roem. Fam. Nat. 4: 171. 1847.

Pancratium declinatum Jacq. Select. Am. 99. 1763.

Hymenocallis arenicola Northrop, Mem. Torr. Club. 12: 28. 1902.

Bulb subglobose, often $8 \mathrm{~cm}$. in diameter. Leaves fleshy, sessile, nearly linear or linear-oblong, $6 \mathrm{dm}$. long or less, 4-6 $\mathrm{cm}$. wide, rounded or acute at the apex, gradually narrowed to the broadened base, many-nerved, dark green; scape stout, as long as the leaves or shorter; flowers 5-13, sessile, fragrant; bracts ovate to lanceolate, acute or acuminate, 3-6 $\mathrm{cm}$. long; ovary oblong, 1-1.5 cm. long; perianth-tube slender, 5-10 cm. long; perianth-segments 
linear, 8-12 cm. long, longer than the tube; crown 3-4 cm. long, about one-third as long as the stamens; style about as long as the perianth.

Sandy coastal ridges and dunes, Great Bahama to Andros, New Providence, Eleuthera, Cat Island and Great Exuma:-Hispaniola to St. Jan, St. Kitts and Montserrat. SPIDER-LILY. DAY-LILY.

2. Hymenocallis caymanénsis Herb. Amaryl. 214. 1837.

Bulb subglobose. Leaves fleshy, sessile, 3-8 dm. long, 3-8 cm. wide, linear or linear-oblong, acute or obtuse at the apex, somewhat narrowed toward the base, green, many-nerved; scape rather stout, about as long as the leaves; flowers 6-12, sessile; bracts lanceolate to ovate-lanceolate, acuminate, $7 \mathrm{~cm}$. long or less; ovary oblong, 1-2 cm. long; perianth-tube $12-16 \mathrm{~cm}$. long; perianth-segments linear, $8-10 \mathrm{~cm}$. long, shorter than the tube; crown about $3 \mathrm{~cm}$. long; style very slender, about as long as the perianth.

In sand, Anguilla Isies and Water Cay:-Florida; Cuba; Haiti; Cayman Islands. Cayman Islands Spider-Lily. Chrysolite Lily.

Hymenocallis caribaèa (L.) Herb. of the Lesser Antilles, is recorded from the Bahamas by Urban (Symb. Ant. 4: 151) and also doubtfully by Schoepf, but has not been found by us in the archipelago. It has been confused with H. declináta.

Hymenocallis crassifolia Herb., of Florida, is recorded by Baker (Amaryl. 126 ) as from the Bahamas, but has not been found by us in the archipelago. Perhaps the specimen studied by him was of $H$. declinata.

\section{Family 5. DIOSCOREÀCEAE Lindl.}

\section{YAM FAMILY.}

Herbaceous or slightly woody twining vines with fleshy or woody rootstocks, slender stems, petioled, mostly cordate, several-nerved and reticulateveined leaves, and small inconspicuous dioecious or monoecious (in' some exotic genera perfect) regular flowers in spikes, racemes or panicles. Perianth 6-parted, that of the pistillate flowers persistent. Staminate flowers with 6 or 3 stamens, sometimes with a rudimentary ovary. Pistillate flowers with an inferior 3-celled ovary, 3 styles and 3 terminal stigmas, sometimes also with 3 or 6 staminodia; ovules 2 (rarely 1 ) in each cavity of the ovary, pendulous, anatropous or amphitropous. Fruit a 3-valved, 3-angled capsule or samaroid. Endosperm of the seed fleshy or cartilaginous, enclosing the small embryo. About 9 genera and 175 species, mostly natives of America, a few in the Old World.

Fruit a 3-celled, 3-winged or 3-angled capsule.

Fruit a 1-seeded samara.

1. Dioscorea.

2. Rajania.

1. DIOSCORÈA L. Sp. Pl. 1032. 1753.

Characters of the family as defined above, the fruit a 3-angled capsule. [Name in honor of the Greek naturalist Dioscorides.] About 160 species, most numerous in tropical regions, a few in the temperate zones. Type species: Dioscorea sativa $\mathrm{L}$.

1. Dioscorea alàta L. Sp. Pl. 1033. 1753.

Glabrous, dioecious, high-climbing from a large tuber, the stem 4-winged or 4-angled. Leaves opposite, the blades broadly ovate, $7-15 \mathrm{~cm}$. long, palmately 
nerved, acuminate at the apex, cordate at the base; petioles slender, as long as the blades or somewhat shorter; staminate flowers in whorled, often panicled spikes, the rachis flexuous, the perianth about $2 \mathrm{~mm}$. broad, the stamens mostly 6 ; pistillate flowers distant in simple spikes; capsule elliptic, 3-winged, 1.5-2 cm. long.

Spontaneous after cultivation, Andros, Eleuthera:-Jamaica; Porto Rico ; Tortola to Trinidad. Generally cultivated in tropical and subtropical countries. Probably native of southeastern Asia.-YAM.

\section{RAJÀNIA L. Sp. Pl. 1032. 1753.}

Twining vines, with alternate, petioled leaves and small, greenish, dioecious, racemose flowers, the staminate ones commonly clustered in the racemes, the pistillate solitary. Staminate flowers with a 6 -cleft perianth and 6 stamens with short filaments, the pistil rudimentary or none. Pistillate flowers with 6 distinct perianth-segments, the styles 2-cleft; staminodia minute or wanting. Fruit samaroid, 1-seeded, indehiscent, the wing terminal, thin. [Commemorates John Ray, 1628-1705, famous English botanist.] Ten species or more, natives of the West Indies. Type species: Rajania hastata $\mathrm{L}$.

\section{Rajania microphýlla Knuth, Enum. 5: 451. 1850.}

Slender, glabrous, often much-branched, 1-2 m. long or longer. Leaves lanceolate to ovate in outline, $2-8 \mathrm{~cm}$. long, acute or acuminate and mucronate at the apex, hastate or cordate at the base, the auricles rounded, the petiole much shorter than the blade; staminate racemes about as long as the leaves; pistillate racemes as long as the leaves or shorter; samaras oblong, obtuse, thin, shining, 8-12 mm. long.

Rocky plains, pine-lands and interior ridges, Abaco, Great Bahama, Andros, New Providence, Cat Island and Great Exuma :-Cuba. SMall RAJANIA. WILD YaM. Referred to $R$. hastata L., by Mrs. Northrop, a species now understood to be restricted to Hispaniola.

\section{Family 6. IRIDÀCEAE Lindl.}

\section{IRIS FAMILY.}

Perennial herbs with narrow equitant 2-ranked leaves and perfect, mostly clustered flowers subtended by bracts. Perianth of 6 segments or 6 -lobed, its tube adnate to the ovary, the segments or lobes in two series, convolute in the bud, withering-persistent. Stamens 3, inserted on the perianth opposite its outer series of segments or lobes; filaments filiform, distinct or united; anthers 2-celled, extrorse. Ovary inferior, mostly 3celled; ovules mostly numerous in each cell, anatropous; style 3-cleft, its branches sometimes divided. Capsule 3-celled, loculicidally dehiscent, 3angled or 3-lobed (sometimes 6-lobed), many-seeded. Endosperm fleshy or horny; embryo straight, small. About 57 genera and 1000 species, of wide distribution.

\section{SISYRÍNCHIUM L. Sp. Pl. 954. 1753.}

Perennial mostly tufted slender herbs with fibrous roots from contracted rootstocks, simple or branched 2-winged or 2-edged stems, and linear grass-like leaves. Flowers from terminal spathes consisting of mostly one pair of opposite conduplicate herbaceous bracts enclosing membranous scales; perianth 
blue, violet or white with a yellow eye, rarely all yellow, the 6 oblong or obovate segments spreading and aristulate; filaments monadelphous; anthers linear or oblong, the sacs distinct at base; style threadform, the branches filiform or obsolete; ovary 3-celled; capsule globose, oval or obovoid, usually trigonous, loculicidally 3 -valved; seeds globose to obovoid, often angled, pitted or smooth. Flowers fugacious, opening successively in sunlight, each usually lasting but a day. Probably not fewer than 125 species, nearly all American. Type species: Sisyrinchium Bermudiana L.

1. Sisyrinchium miamiénse Bicknell, Bull. Torr. Club 26: 226.1899.

Glabrous; stems erect, $2-3 \mathrm{dm}$. high, somewhat longer than the leaves. Leaves 1-2 mm. wide, striate-nerved, acute, serrulate; peduncles $2-4$, slender, 3-7 cm. long; spathes 12-15 mm. long, the bracts keeled, the outer one slightly longer than the inner; flowers blue, about $1 \mathrm{~cm}$. wide; fruiting pedicels exserted, 10-15 mm. long; capsules obovoid, 3-5 mm. long, mucronulate.

Margins of swamps, Great Bahama near West End:-Florida. Miami BlueEYED GRASS.

\section{Order 10. ORCHIDÀLES.}

Monocotyledonous herbs, many tropical species epiphytes. Flowers mostly very irregular, complete and perfect, their parts in 3's or 6's. Ovary inferior, compound. Seeds very numerous and minute, without endosperm.

\section{Family 1. ORCHIDÀCEAE Lindl.}

\section{OrChid FAMILY.}

Perennial herbs, with eorms, bulbs or tuberous roots, sheathing entire leaves, sometimes reduced to seales, the flowers perfect, irregular, bracted, solitary, spiked or racemed. Perianth superior, of 6 segments, the 3 outer (sepals) similar or nearly so, 2 of the inner ones (petals) lateral, alike; the third inner one (lip) dissimilar, often markedly so, usually larger, often spurred, sometimes inferior by torsion of the ovary or pedicel. Stamens variously united with the style into an unsymmetrical column; anther 1 or in Cypripedium 2, 2-celled; pollen in 2-8 pear-shaped, usually stalked masses (pollinia), united by elastic threads, the masses waxy or powdery, attached at the base to a viseid disk (gland). Style often terminating in a beak (rostellum) at the base of the anther or between its saes. Stigma a viseid surface, facing the lip beneath the rostellum, or in a cavity between the anther-saes (clinandrium). Ovary inferior, usually long and twisted, 3 -angled, 1-celled; ovules numerous, anatropous, on 3 parietal placentae. Capsule 3-valved. Seeds very numerous, minute, mostly spindle shaped, the loose coat hyaline, retieulated; endosperm none; embryo fleshy. About 410 genera and 5000 species, of wide distribution, most abundant in the tropies, many of those of warm regions epiphytes.

Flowering stem or peduncle terminal.

Leaves convolute.

Anther blunt, generally rounded, usually much exceeding the rostellum and appressed to or incumbent upon it.

Lip not enclosing the column; flowers erect or ascending; low erect herbs.

Lip enclosing the column; flowers nodding; succulent vines.

1. Carteria.

2. Vanilla. 
Anther, at least the body, about as long as the rostellum and not appressed to it, when beaked, the beak sometlmes exceeding the rostellum.

Pollinia not in distinct masses.

Lip turned outward.

Lateral sepals united at the base into a long spur.

Lateral sepals free.

Flowers in a 1-sided spike which is sometimes splrally twisted, the perianth spreading or nodding; lip not saccate.

Flowers in a many-sided spike, the perianth ascending or erect; lip saccate at the base.

Lip turned upward.

Sepals united at the base; llp adnate to the sepal-tube, the base free from the short column.

Sepals free; llp free from the sepals, the base adnate to the elongate column.

Pollinia in several distinct masses.

Leaves duplicate.

Leaf-blades not plaited.

Leaves not articulated near the base; pollinla unappendaged.

Leaves articulated near the base; pollinia with taillike appendages.

Column with a distinct foot; $11 p$ and lateral sepals about equal in size.

Column without a foot; llp much larger than the lateral sepals.

Ovary not produced into a hollow neck. Pollinia 4.

Plants without pseudobulbs.

Flowers axillary to bracts borne along a rachis.

Flowers in a terminal raceme or panicle or solitary.

Plants with pseudobulbs.

Llp 3-lobed, longitudinally crested or appendaged; sepals and petals not attenuate.

Lip deeply 3-lobed, the middle lobe broad; pseudobulbs terete; scape without a long basal sheath.

Lip obscurely 3 -lobed, the middie lobe minute; pseudobulbs flattened; scape with a long basal sheath.

Lip entire, or undulate, neither crested nor appendaged.

Lip concave, shell-like.

Pollinia 8.

Lip nearly linear.

Ovary produced into a hollow neck.

Leaf-blades plaited.

Flowering stem or peduncle lateral.

Leaves convolute; column elongate.

Column without a foot; llp attached to the base of the column; lateral sepals free.

Column with a distinct foot; lip attached to the apex of the foot; lateral sepals adnate to the column-foot. Leaves duplicate; column very short.
3. Pelexia.

4. Ibidium.

5. Stenorrhynchus.

6. Prescottia.

7. Ponthieva.

8. Physurus.

9. Malaxis.

10. Polystachya.

11. Spathiger.

12. Auliza.

13. Encyclia.

14. Epicladium.

15. Anacheilium.

16. Nidema.

17. Tetramicra.

18. Laeliopsis.

19. Limodorum.

20. Bletia.

21. Govenia.

22. Oncidium.

\section{CARTĖRIA Small, Torreya 10: 187. 1910.}

Caulescent terrestrial orchids with clustered, fleshy tubers and erect simple stems. Leaves various, the basal ones firm, narrow, with plicate blades, the cauline ones mere sheathing scales. Flowers several, erect, axillary to scalelike bracts. Perianth colored. Sepals nearly equal, narrow, longer than the petals. Petals decidedly narrower than the sepals. Lip short, sessile, slightly 
3-lobed at the apex, with the middle lobe much longer than the lateral ones, the body with 5 longitudinal erests. Capsules erect. [Commemorates Joel Jackson Carter, 1843-1912, a diligent American botanical collector.] A monotypic genus.

\section{Carteria corallícola Small, Torreya 10: 188. 1910.}

Stems 2-3.5 dm. tall, rather slender, fleshy. Basal leaves 2-7 cm. long; blades nearly linear, narrowed at both ends, often curved; spike of flowers rather inconspicuous, erect; lateral sepals linear-lanceolate to broadly linear, 6.5-7.5 mm. long, green or greenish-yellow; petals linear or nearly so, yellowish-green or greenish-white; lip oval to orbicular-oval, 6-7 $\mathrm{mm}$. long, the body yellowish, with the crests extending to the base of the middle lobe, the lobes magenta, or magenta-pink at the tips; anther magenta; mature fruit not seen. ORCHID.

Scrub-lands, New Providence along Farringdon Road:-Florida. Carter's

\section{VANÍtLA Juss. Gen. 66. 1789.}

Fleshy, climbing orchids, the leaves broad or reduced to mere scales, the stems giving off aerial roots, the mostly large flowers in axillary spikes or racemes. Sepals nearly alike, distinet, spreading. Petals resembling the sepals. Lip clawed, the claw adnate to and embracing the long column. Stigma borne under the rostellum. Anther convex, its sacs separate; pollinia powdery. Capsule elongated, fleshy, indehiscent or tardily partly dehiscent. [From the Spanish name for the fruit.] About 20 species, of tropical and subtropical regions. Type species: Epidendrum Vanilla L.

Plants leaf-bearing; lip not lobed.

Leaves lanceolate, $4 \mathrm{~cm}$. long or less.

Leaves inear-oblong, $7-12 \mathrm{~cm}$. long, $1.5-25 \mathrm{~cm}$. wide.

Plant leafless, except on youngest shoots ; lip 3-iobed.

1. V. Eggersii.

2. V. phaeantha.

3. $V$. articulata.

1. Vanilla Eggèrsii Rolfe, Jour. Linn. Soc. 32: 472. 1896.

Fleshy, elongated, described as sometimes $30 \mathrm{~m}$. in length and often $10 \mathrm{~m}$. long or longer, the stems terete, 1 -grooved, $1-1.5 \mathrm{~cm}$. thick, the aerial roots 5-8 $\mathrm{cm}$. long, tendril-like. Leaves sessile, oblong-lanceolate, acute or acuminate, 2-8 $\mathrm{cm}$. long, 8-15 mm. wide; peduncle stout, geniculate, 5-10 $\mathrm{cm}$. long, bearing an ovate or oblong, acute bract at each node; spike several-flowered, 6-14 $\mathrm{cm}$. long, its bracts triangular-ovate, about $5 \mathrm{~mm}$. long; ovary cylindric, about as long as the sepals; sepals and petals oblong-lanceolate, obtuse or acutish, 4-6 cm. long; lip about as long as the sepals, rounded, erenate or undulate, not lobed; column $2-2.5 \mathrm{~cm}$. long; capsule fleshy, indehiscent, cylindric or subclavate, 7-12 cm. long, 8-10 mm. thick.

Coastal thickets and coppices, Andros:- Florida: Hisnaniola to Virgin Gorda, EgGers' VANilla. Fawcett and Rendle (Fl. Jam. 2:17) accredit Vanilla claviculata Sw. to the Bahamas, Porto Rico and St. Thomas, presumably including V. Eggersii as a synonym of that specles. This view may be correct, but we do not have specimens to corroborate it. The petais of $V$. claviculata are described as obtuse, while those of $V$. Eggersii are acute.

\section{Vanilla phaeántha Rchb.f. Flora 48: 274. 1865.}

Fleshy, often $6 \mathrm{~m}$. long or longer. Leaves oblong or linear-oblong, nearly sessile, $6-18 \mathrm{~cm}$. long, $1.5-5 \mathrm{~cm}$. wide, acute or obtuse; peduncle stout, $2-8 \mathrm{~cm}$. long, geniculate, leafy-bracted; spike few-several-flowered, its bracts ovate, obtuse, 6-12 mm. long; ovary cylindric, 5-6 cm. long; sepals and petals nar- 
rowly oblong or linear-oblanceolate, acutish, 6-8 $\mathrm{cm}$. long, 1-2 cm. broad; lip broadly ovate, convolute, retuse, crenulate, crested, about $8 \mathrm{~cm}$. long; capsule narrowly cylindric, 7-8 cm. long, about $1 \mathrm{~cm}$. thick.

Coppices, Abaco and Great Bahama:-Florida; Cuba; Jamaica; St. Vincent; Trinidad. Our Bahama specimens are barren; they were determined by Mr. R. A. Rolfe, of Kew. ObloNg-Leaved VANilla.

\section{Vanilla articulàta Northrop, Mem. Torr. Club 12: 31. 1902.}

High-climbing, sometimes $10 \mathrm{~m}$. long or longer, branched, subterete, the stems $2 \mathrm{~cm}$. in diameter or less, only the youngest shoots leaf-bearing, their leaves linear-lanceolate, $2 \mathrm{~cm}$. long or less. Peduncle geniculate, $3-7 \mathrm{~cm}$. long, bearing triangular-ovate bracts 5-7 $\mathrm{mm}$. long; spike few-several-flowered; ovary narrowly cylindric, about $3 \mathrm{~cm}$. long; sepals and petals white or slightly pink, oblanceolate, acutish or obtuse, 3-4 cm. long, about $1 \mathrm{~cm}$. wide; lip broadly obovate, convolute, 3 -lobed, about $3 \mathrm{~cm}$. wide, the middle lobe somewhat crested; capsule subcylindric, 5-7 cm. long.

Thickets and low coppices, Andros, New Providence, Eleuthera, Great Exuma, Great Guana, Watling's and Crooked Islands:-Florida and Cuba. LINK-VINE. WORM-VINE.

\section{PELÉxIA Poit.; L. C. Rich. Mem. Mus. Paris 4: 59. 1818.}

Terrestrial orchids, with thick, clustered roots, petioled basal leaves, the flowers spicate at the summit of a sheathed scape. Sepals narrow, the median one adnate to the petals, the lateral ones united below and prolonged into a spur. Lip concave, elongated, embracing the short column. Column without a foot. Rostellum subulate. Anther narrowly oblong; pollinia powdery. Capsule ellipsoid. [Greek, from the fancied resemblance of the lip to a hatchet.] About 20 species, of tropical and subtropical America. Type species: Neottia adnata Willd.

Perianth $6 \mathrm{~mm}$. long; spur short, adnate.

Perianth 2.5-3 cm. Iong; spur subulate, free.

1. P. adnata.

2. P. setacea.

1. Pelexia adnàta (Sw.) Spreng. Syst. 3: 704. 1826.

Neottia adnata Sw. FI. Ind. Occ. 3: 1409. 1806.

Pelexia spiranthoides Lindl. Bot. Reg. 12: pl. 985. 1826.

Scape pubescent above, 2.5-4 dm. high. Basal leaves 2-5, glabrous, the blades elliptic or ovate-elliptic, 5-12 cm. long, 3-nerved, acute at the apex, rounded at the base, the slender, nearly erect petioles 7-14 cm. long, reddish; sheaths of the scape acuminate, 2-5 $\mathrm{cm}$. long; spike pubescent, many-flowered, 6-12 cm. long; bracts narrowly lanceolate, about as long as the whitish flowers; sepals about $6 \mathrm{~mm}$. long, the median one elliptic, obtuse, concave, the lateral ones linear, acute; petals linear, nearly as long as the sepals; lip tubular below, 5-6 mm. long; capsule about $1.5 \mathrm{~cm}$. long, 6-ribbed.

In shadv coppice, Andros at Conch Sound:-Cuba to Guadeloupe; Jamaica ; Venezuela. Determination based on fruiting specimen only; recorded by Mrs. Northrop as Cranichis sp. SHORT-SPURRED PELExia.

\section{Pelexia setàcea Lindl. Gen. \& Sp. Orch. 482. 1840.}

Scape 3-6 dm. high, puberulent above, bearing several acuminate sheaths $2-4 \mathrm{~cm}$. long. Basal leaves 1-3, the blades elliptic or oval, $8-15 \mathrm{~cm}$. long, acute at the apex, obtuse or rounded at the base, several-nerved, the slender petioles 10-18 cm. long; spike few-several-flowered, pubescent, $15 \mathrm{~cm}$. long or less; bracts ovate-lanceolate, $2-2.5 \mathrm{~cm}$. long, long-acuminate into a filiform tip; ovary fusiform, about $2 \mathrm{~cm}$. long; perianth purplish-green or greenish-white; 
sepals narrowly lanceolate, 2.5-3 cm. long, the spur 8-10 $\mathrm{mm}$. long; petals narrowly lanceolate, about $2 \mathrm{~cm}$. long; lip white; capsule about $2 \mathrm{~cm}$. long, 6-ribbed.

Shady copplces, Great Bahama, Andros and New Providence:-Florida; Cuba to Guadeloupe and Trinldad; Colombia to Brazll. Long-SPURRED PELExia.

\section{IBIDIUM Salisb. Trans. Hort. Soc. Lond. 1: 291.1812.}

Erect terrestrial orchids, with fleshy-fibrous or tuberous roots and slender stems or scapes, leaf-bearing below or at the base. Flowers small, spurless, spiked, 1-3-rowed, the spikes more or less twisted. Sepals free, or more or less coherent, or sometimes united with petals into a galea. Lip concave, erect, embracing the column and often adherent to it, spreading and crisped, or rarely lobed or toothed at the apex, bearing minute callosities at the base. Column arched below, obliquely attached to the top of the ovary. Anther without a lid, borne on the back of the column, erect. Stigma ovate, prolonged into an acuminate beak, at length bifid. Pollinia 2, 1 in each sac, powdery. Capsule ovoid or oblong, erect. About 80 species, natives of temperate and tropical regions. Type species: Ophrys spiralis J. E. Smith.

Flowers white; basal leaves linear.

Flowers green; basal leaves oblong-lanceolate to elliptic.
1. I. tortile.

2. I. lucayanum.

\section{Ibidium tortile (Sw.) House, Muhlenbergia 1: 129.1906.}

Neottia tortilis Sw. Vet. Akad. Handl. 1800: 226. 1800.

Spiranthes tortilis L. C. Rich. Mem. Mus. Par. 4: 59.1818.

Stem slender, erect, 3-6 dm. high, glabrous below, pubescent above, bearing 2-4 bladeless acute sheaths above, and sometimes a narrowly linear leaf 2-7 cm. long, below the middle. Basal leaves 2 or 3 , present at flowering time, linear, 8-30 cm. long, 1.5-2.5 mm. wide; spike erect, 6-13 $\mathrm{cm}$. long, pubescent, the approximate flowers in a single spiral; flowers white; bracts ovate or ovatelanceolate, pubescent, acute or acuminate, 6-7 $\mathrm{mm}$. long, about as long as the ovary; sepals 5-6 mm. long, the median one elliptic, obtuse, the lateral ones oblong, oblique; petals oblong, about as long as the sepals; lip 4-6 mm. long, ovate-elliptic, emarginate, the callosities short; capsule about $5 \mathrm{~mm}$. long.

Savannas and borders of marshes. Great Bahama, Andros and New Providence :-Florida; Louisiana; West Indies. Recorded by Mrs. Northrop as Gyrostachys peruviana Kuntze. SoutherN LADIES-TRESSES.

\section{Ibidium lucayànum Britton, Bull. N. Y. Bot. Gard. 5: 312. 1907.}

Spiranthes lucayana Cogn. in Urban, Symb. Ant. 6: 338. 1909.

Root of cylindric, fleshy tubers $2-5 \mathrm{~cm}$. long, 8-10 mm. thick. Basal leaves present at flowering time, oblong-lanceolate, oblanceolate to elliptic, thin but somewhat fleshy, spreading, 5-nerved, reticulate-veined, at least when dry, 5-17 cm. long, 1-3 cm. wide, acute at the apex, narrowed at the base into a rather slender petiole, which is one half to two thirds the length of the blade; scape slender, including the spike 2-4 dm. high, its several leaves linear or linear-lanceolate, acute or acuminate, appressed, 1-3 cm. long; spike $5-25 \mathrm{~cm}$. long, about $1 \mathrm{~cm}$. thick, usually many-flowered; bracts lanceolate, acuminate, erect, as long as the ovary or longer; flowers green, spreading; sepals linearlanceolate, acutish, 3-4.5 mm. long; petals linear a little shorter than the sepals; lip ovate-oblong, obtusish, concave, 3-5 mm. long, about one third as 
wide as long, with two minute callosities at the base; capsule oblong, blunt, about $5 \mathrm{~mm}$. long.

Coppices and white-lands, Lignum Vitae Cay, Andros, Eleuthera, Cat Island, Long Island, Watling's, Great Exuma, Crooked Island and North Caicos :-Fiorida ; Anegada; Porto Rico. Erroneously recorded by Cogniaux as Spiranthes elata. Green Ladies-tresses.

\section{STENORRHÝNCHUS L. C. Rich. Mem. Mus. Paris 4: 59. 1818.}

Erect, terrestrial orchids, with lanceolate to elliptic basal leaves often wanting at flowering time, the sheathed scape terminated by a spike of rather large, often showy, mostly red or yellow flowers. Sepals nearly equal, the median one adnate to the petals, the lateral ones united below and produced into a sac or spur. Petals mostly shorter than the sepals. Lip entire or nearly so, concave, without callosities. Column with a foot; stigma under the beaked rostellum. Anther oblong or lanceolate; pollinia powdery. [Greek, narrow beak.] About 25 species, of tropical and subtropical America. Type species: Neottia speciosa Willd.

1. Stenorrhynchus lanceolàtus (Aubl.) Griseb. Fl. Br. W. I. 642. 1864.

Limodorum lanceolatum Aubl. Pl. Guian. 2: 821. 1775.

Satyrium orchioides Sw. Prodr. 118. 1788.

Stenorrhynchus orchioides L. C. Rich. Mem. Mus. Paris 4: 59. 1818.

Leaves 1-3, oblong to oblong-lanceolate, bright green, glabrous, 1-3 dm. long, 2-5 cm. wide, acute at the apex, narrowed at the base into margined petioles, wanting at flowering time. Scape rather stout, 3-6 dm. high, erect, scurfy or somewhat glandular-pubescent, bearing several, acuminate, sheathing scales 2-4 cm. long; spike several-many-flowered, 1-2.5 cm. long; bracts lanceolate, acuminate, shorter than the flowers; flowers red or yellow, $2-3 \mathrm{~cm}$. long; ovary oblong, oblique at the apex; sepals glandular, lanceolate, acute, 5-7-nerved; petals oblong-lanceolate, acute, 5-7-nerved; lip lanceolate, acute or acuminate, saccate at about the middle; capsule about $1 \mathrm{~cm}$. long.

Pine-lands and scrub-lands, Great Bahama, Andros and New Providence:Florida; Cuba to Porto Rico and Trinidad; Mexico to Colombla and Paraguay. LEAFLESS BEAKED-ORCHID.

6. PRESCóTTIA Lindl. in Hook. Exot. Fl. pl. 115. 1825.

Terrestrial orchids, with clustered roots, erect, scape-like stems, broad, tufted, basal leaves convolute in the bud, and small flowers in a terminal spike. Sepals broad, connate at the base. Petals narrow, thin, mostly shorter than the sepals. Lip broad, concave, 2-auricled at the base of the blade, erect. Column short; rostellum retuse, as long as the anther or longer. Pollinia powdery. Capsule small, oblong or ovoid. [Commemorates John D. Prescott, English botanist, died 1837.] About 30 species, of tropical and subtropical America. Type species: Prescottia plantaginifolia Lindl.

1. Prescottia oligántha (Sw.) Lindl. Gen. \& Sp. Orch. 454. 1840.

Cranichis oligantha Sw. Prodr. 120. 1788.

Slender, glabrous, 2-4 dm. high. Basal leaves few, ovate to elliptic, 2-7.5 cm. long, acute or obtuse at the apex, obtuse or narrowed at the base, 
about 13-nerved, the petioles $1.5-3 \mathrm{~mm}$. long; scape with several, narrow, acute, bladeless sheaths 1-3 cm. long; spike slender, densely flowered, $2-7 \mathrm{~cm}$. long; bracts ovate-lanceolate, acuminate, 2-3 mm. long; ovary obovoid-oblong; sepals 1-nerved, pinkish, rounded, about $1 \mathrm{~mm}$. long; petals narrowly obovate or oblong, obtuse, a little shorter than the sepals, white or pink; lip 3-nerved, 1-1.5 mm. long, the blade roundish, minutely auricled; capsule about $4 \mathrm{~mm}$. long.

Coppices and shaded stone walls, Andros and New Providence:-Florida; Cuba to Tortola and Guadeloupe; Jamaica. SMall PrescotTia.

7. PONTHIEvA R. Br. in Ait. Hort. Kew. ed. 2, 5: 199.1813.

Terrestrial orchids with fibrous roots, tufted basal leaves, and small, loosely racemose flowers on sheathed, erect scapes. Sepals spreading, the lateral ones slightly inequilateral. Petals clawed, spreading, nearly triangular, adnate to the short column, unsymmetrical. Lip adnate to the column, clawed, concave, ascending, spurless. Anther shorter than the rostellum; pollinia 4, in pairs, powdery, pendulous. Capsule ellipsoid. [Commemorates de Ponthieu, who sent American plants to Sir Joseph Banks.] About 20 species, of tropical and warm temperate America. Type species: Neottia glandulosa Sims.

\section{Ponthieva Bríttonae Ames, Torreya, 10: 90. 1910.}

Roots clustered, slender, villous. Basal leaves about 4, oblong-lanceolate to oblanceolate, $10 \mathrm{~cm}$. long or less, acute at the apex, narrowed into petioles 1-2.5 cm. long; scape slender, 2-4 dm. high, bearing several oblong, acute sheaths, pubescent above; raceme 1-2 dm. long, pubescent, several-manyflowered; bracts oblong, acute or acuminate, about $5 \mathrm{~mm}$. long; pedicels ascending, 8-10 $\mathrm{mm}$. long; sepals about $4 \mathrm{~mm}$. long; petals lanceolate, obtuse, a little longer than the sepals; lip 3-lobed, subsaccate, $4.5 \mathrm{~mm}$. long, the lateral lobes rounded, the median lobe oblong.

Pine-land near Fresh Creek, Andros, Maidenhead Coppice, New Providence :Florida. Mrs. BRitron's Ponthieva.

8. Physurus L. C. Rich. Mem. Mus. Paris 4: 55.1818.

[Erythrodes Blume, Bijdr. Fl. Ned. Ind. 410. 1825.]

Leafy-stemmed, terrestrial orchids, with thick, clustered roots, the leaves broad, petioled, parallel-nerved and reticulate-veined, convolute in the bud, the small flowers in a terminal spike. Sepals distinct, nearly equal, the small petals cohering with the median-one. Lip erect, 3-lobed, embracing the short column, produced below into a blunt pouch-like spur. Anther about as long as the rostellum. Pollinia granular, pendent. Capsule ellipsoid to obong. [Greek, referring to the pouch-like spur.] About 60 species, natives of tropical and subtropical regions. Type species: Orchis plantaginea Willd.

1. Physurus quercetícola Lindl. Gen. \& Sp. Orch. 505. 1840.

Physurus Sagraeanus A. Rich. in Sagra, Hist. Cub. 11: 253.1850.

Stem slender, erect, glabrous, $3 \mathrm{dm}$. high or less. Leaves several, distant, ovate to lanceolate, 2-6 cm. long, acute, acuminate, or the lower ones obtuse at the apex, rounded or subtruncate at the base, the petioles 5-20 mm. long, their 
bases much dilated, sheathing the stem, the upper sheaths bladeless; spike 2-7 cm. long; bracts lanceolate, or ovate-lanceolate, acute, a little shorter than the ovary; sepals about $4 \mathrm{~mm}$. long, linear or linear-lanceolate; lip with a dilated claw and a nearly orbicular blade terminated by a drooping or recurved triangular tip, the pouch-like spur shorter than the ovary.

Under bushes in pine-iands and in savannas. Great Bahama and Andros :Florida to Loulsiana; Cuba; Guadeloupe. Low Physurus.

\section{MALÁXIS Sw. Prodr. 119. 1788.}

Low orchids with a solid bulb, 1-leaved or 2-leaved. Flowers small, white or green, in a terminal raceme. Sepals spreading, separate, the lateral ones equal at the base. Petals filiform or linear, spreading. Lip cordate or eared at the base, embracing the column. Anther erect between the auricles, 2-celled; pollinia 4, smooth and waxy, 2 in each sac, the pairs cohering at the summit, without caudicles or glands. Capsule oval, sometimes nearly globose, beakless. [Greek, in allusion to the soft tissues.] About 140 species, widely distributed, the following typical.

1. Malaxis spicàta Sw. Prodr. 119. 1788.

Microstylis spicata Lindl. Gen. \& Sp. Orch. 19. 1830.

Glabrous, 1-3 dm. high, 2-leaved near the base, and with 1 or 2 sheaths below the leaves. Leaves ovate or elliptic-ovate, $5-10 \mathrm{~cm}$. long, acute, the lower one the larger, the sheathing petioles $1-5 \mathrm{~cm}$. long; raceme narrow, $8 \mathrm{~cm}$. long or less, many-flowered; bracts ovate or ovate-lanceolate, acute, $2-4 \mathrm{~mm}$. long; pedicels 5-9 mm. long; middle sepal about $3 \mathrm{~mm}$. long, ovate-lanceolate, acute or bluntish, the lateral ones about as long, obtuse; petals linear, $2 \mathrm{~mm}$. long; lip about $4 \mathrm{~mm}$. long, its terminal lobe linear-oblong; capsule about 8 mm. long.

Coppice, Crooked Island:-Florida; Cuba to Porto Rico and Martinique; Jamaica. We are indebted to Mr. Oakes Ames for the determination of the Crooked Island specimen. Slender Malaxis.

\section{POIYSTÀCHYA Hook. Exot. Fl. pl. 103. 1825.}

Epiphytic, leafy-stemmed orchids, the stems usually clustered, sheathed at the base, the roots thick-fibrous, the many-nerved leaves conduplicate in the bud, the upper reduced to long, narrow scales, the small flowers in terminal, panicles or spike-like racemes. Median sepal narrower than the lateral ones. Petals narrower than the lateral sepals. Lip jointed with the base of the column, spurless, sessile, bent below, 3-lobed, the lateral lobes small. Column short, with a distinct foot. Anther terminal, lid-like, convex, usually 1-celled; pollinia 4, waxy, broadly ovate or nearly hemispheric, not appendaged. [Greek, many spikes.] About 170 species, mostly of tropical regions. Type species: Cranichis luteola $\mathbf{S w}$. 
1. Polystachya minùta (Aubl.) Britton; Small, Fl. SE. U. S. 328, 1329. 1903.

Epidendrum minutum Aubl. Pl. Guian. 2: 824. 1775.

Dendrobium polystachyum Sw. Act. Holm. 21: 247. 1800.

Cranichis luteola Sw. Fl. Ind. Occ. 3: 1433. 1806.

Polystachya luteola Hook. Exot. Fl. pl. 103. 1825.

Stems rather slender, 2-6 dm. long. Sheaths many-striate, 2-4 cm. long; leaves oblong or linear-oblong, 6-30 cm. long, 1-3 cm. wide, acute or obtuse, shorter than the stem; panicle $3 \mathrm{dm}$. long or less, sometimes reduced to a single raceme; racemes rather densely several-many-flowered; bracts acute, about $2 \mathrm{~mm}$. long; flowers greenish-yellow; buds obliquely 3 -angled; median sepal ovate, 3-4 mm. long, the lateral ones oblique, a little longer; petals narrowly spatulate, shorter than the sepals; lip about $4 \mathrm{~mm}$. long, glandular-hairy within, the median lobe emarginate, the lateral lobes incurved; capsule 10-12 $\mathrm{mm}$. long.

On trees in coppices, Abaco, Andros and New Providence:-Florida; Cuba to Virgin Gorda, south to Trinidad and South America. Large Polystachya. Catesby, 2: $p l$. 55 .

2. Polystachya foliòsa (Hook.) Rehb. f.; Walp. Ann. Bot. 6: 640. 1863.

Stelis foliosa Hook. Ann. Nat. Hist. 2: 330. 1839.

Stems slender, $2 \mathrm{dm}$. long or less. Sheaths striate, 1-3 cm. long; leaves usually 2 , linear or linear-lanceolate, 5-16 $\mathrm{cm}$. long, 3-8 $\mathrm{mm}$. wide, obtuse or minutely 2-3-toothed at the apex, shorter than or equalling the stem; racemes 1-5, narrow, rather densely several-many-flowered; flowers yellow or yellowish; bracts acute or acuminate, 1-2 $\mathrm{mm}$. long; median sepal ovate, about $1.5 \mathrm{~mm}$. long; lateral sepals broadly ovate, about $2 \mathrm{~mm}$. long; petals spatulate, rounded, 1.5-2 mm. long; lip nearly $2 \mathrm{~mm}$. long, obovate, its lateral lobes incurved, not much smaller than the median one.

On tree-trunks, Andros :-Grenada; Trinidad; northern South America. Smal. POLYSTACHYA.

11. SPÀTHIGER Small, Fl. Miami 55. 1913.

Epiphytic, usually branched, creeping or pendent orchids, with slender leafy stems, narrow sessile leaves and small flowers in the axils of spathe-like bracts, forming terminal spikes; pseudobulbs none. Leaves duplicate in the bud, the blades not plaited, jointed at the base. Lateral sepals broader than the median one. Petals scarcely broader than the sepals. Lip reniform or nearly orbicular, concave. Column adnate to the lip. Pollinia 4, appendaged. [Greek, spathe-bearing.] About 10 species of tropical and subtropical America, the following typical.

\section{Spathiger rígidus (Jacq.) Small, Fl. Miami 55. 1913.}

\section{Epidendrum rigidum Jaeq. Enum. 29. 1760.}

Often much branched, $5 \mathrm{dm}$. long or less. Leaves oblong or linear-oblong, subcoriaceous, $3-8 \mathrm{~cm}$. long; flowers greenish-white; lateral sepals ovate, about $6 \mathrm{~mm}$. long; petals narrowly spatulate or oblong; blade of the lip about 3 $\mathrm{mm}$. long, suborbicular, with callosities near the base; capsule about $1.5 \mathrm{~cm}$. long.

On trees, New Providence:-Fiorida; Jamaica; Hispaniola; Guadeloupe to Trinidad; continental tropical America. 
12. AULIzA Salisb. Trans. Hort. Soc. 1: 294. 1812.

Epiphytic or terrestrial orchids, with erect or ascending, leafy, often clustered stems, subcoriaceous sessile leaves with sheathing bases, and rather large pedicelled flowers in terminal racemes or panicles, or solitary; pseudobulbs none. Sepals often elongated. Petals linear to spatulate. Lip various. Column adnate to the base of the lip. Pollinia 4, appendaged. [Greek, perching.] Eighty species or more, of tropical and subtropical America. Type species: Epidendrum ciliare L.

\section{Auliza noctùrna (Jacq.) Small, Fl. Miami 56. 1913.}

Epidendrum nocturnum Jacq. Enum. 29. 1760.

Epiphytic or saxicolouis; stems stiff, clustered, rather slender, usually erect, 3-11 dm. high. Leaves oblong to elliptic, oblong-lanceolate or linearoblong, 7-16 cm. long, acute at the apex, partly clasping at the base, the sheaths cylindric, the lower ones bladeless; flowers solitary or two together, peduncled, the peduncle $2-10 \mathrm{~cm}$. long; bracts ovate or lanceolate, 3-6 $\mathrm{mm}$. long; lateral sepals green, linear-attenuate, $3-6 \mathrm{~cm}$. long, $2-4 \mathrm{~mm}$. wide; petals yellow, similar to the sepals, but a little narrower; lip white, 3 -cleft, the 2 lateral lobes ovate or ovate-oblong, 10-15 mm. long, the middle lobe setaceous, 3-5 cm. long; capsule oblong, narrowed at both ends, $2.5-4 \mathrm{~cm}$. long.

On trees in coppices, Abaco, Andros and New Providence:-Florida; Cuba; Hispaniola; Porto Rico; Jamaica; Trinidad; tropical South America. SLENDER Auliza. Catesby, $2: p l$. 68 .

\section{ENCYัCLIA Hook. Bot. Mag. pl. 2831. 1828.}

Epiphytic or rarely terrestrial orchids, with mostly terete, short or elongsted pseudobulbs, flat, mostly stiff, elongated narrow leaves duplicate in the bud, and rather large, racemose or panicled bracted flowers on a long terminal scape. Lateral sepals broad or narrow, about as wide as the similar median one; petals spatulate to linear. Lip longitudinaly crested or appendaged, 3 -lobed, the middle lobe much wider than the lateral ones, often emarginate. Column usually adnate to the lip at its base and sometimes enclosed by it. Capsules ribbed. [Greek, wrapped around.] Perhaps 75 species, of tropical and subtropical America. Type species: Encyclia viridiflora Hook. These orchids are locally called WILD INDIAN.

Middle lobe of the lip acute or tipped.

Middle lobe of the lip rounded or retuse.

1. E. fucata.

Flowers panicled; middle lobe of the lip rounded, retuse or apiculate.

Column short, $6 \mathrm{~mm}$. long or less.

Sepals obtuse; lip sessile or nearly so.

Sepals acute; lip clawed.

Column long, $7-10 \mathrm{~mm}$. long.

Pseudobulbs ovold, 4-7 cm. long.

Pseudobulbs ovold-oblong, up to $10 \mathrm{~cm}$. long.

Sepals and petals purplish or greenish; leaves $1.5-2.5 \mathrm{~cm}$. wide.

Sepals and petals yellow; leaves $1 \mathrm{~cm}$. wide or less.

Flowers racemose or inflorescence with a few branches.

Leaves broadly linear; middle lobe of the lip cordate.

Leaves norrowly linear; middle lobe of the lip ovate, rounded.

2. E. bahamensis.

3. E. rufa.

4. E. tampensis.

5. E. diurna.

6. E. inaguensis.

7. E. plicata.

8. E. acicularis. 


\section{Encyclia fucàta (Lindl.) Britton \& Millspaugh.}

Epidendrum fucatum Lindl. Bot. Reg. 24: Misc. 15. 1838.

Pseudobulbs slender, ovoid to oblong, 2-5 $\mathrm{cm}$. long. Leaves 1 or 2 , linear, 1-3 dm. long, 1-2.5 cm. wide; scape slender, usually branched, 3-7 dm. long; pedicels slender or filiform, 1-2 cm. long; sepals yellow or brownish yellow, oblong or oblong-oblanceolate, obtuse, 1.5-2 cm. long; petals oblanceolate, similar to the sepals but a little shorter; lip yellow, 3-lobed, the lateral lobes oblong, obtuse, about $1 \mathrm{~cm}$. long, the middle lobe suborbicular, tipped; column wingless; capsule oblong, $1.5-2.5 \mathrm{~cm}$. long.

On trees in coppices and scrub-lands, Abaco, Great Bahama, and Andros:Cuba: recorded from Hispantola and Porto Rico. SMALL-FLowered ENCYCLIA.

A fruiting specimen from Abaco, probably of this species, was determined by $\mathbf{R}$.

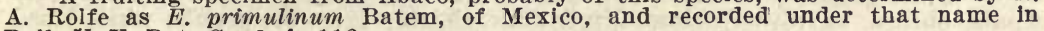
Bull. N. Y. Bot. Gard. 4:116.

\section{Encyclia bahaménsis (Griseb.) Britton \& Millspaugh.}

Epidendrum bahamense Griseb. Fl. Br. W. I. 614.1864.

Pseudobulbs ovoid-oblong, $10 \mathrm{~cm}$. long or less. Leaves 1-3, coriaceous, linear, blunt or acutish, $1.5-5 \mathrm{dm}$. long; $1-3.5 \mathrm{~cm}$. wide; scape usually muchbranched, paniculately many-flowered, 5-9 dm. long; pedicels slender, 1-2 $\mathrm{cm}$. long; sepals oblong, 7-nerved, obtuse or obtusish, 15-19 mm. long; petals obtuse, oblong or spatulate-oblong, narrowed toward the base, about as long as the sepals; lip sessile or nearly so, deeply 3-lobed, 16-19 mm. long, its lateral lobes triangular-ovate, much shorter than the orbicular-obovate, rounded or retuse, nearly sessile, middle one; column narrowly winged to the base; capsule oblong, 1.5-3 cm. long.

On trees, Great Bahama, Abaco, Andros, Eleuthera, Ship Channel Cay, Crooked Island, Little Inagua and Inagua. An Andros specimen was referred to Epidendrum odoratissimum Lindl., by Mrs. Northrop. BaHaMa ENCychia.

\section{Encyclia rùfa (Lindl.) Britton \& Millspaugh.}

Epidendrum rufum Lindl. Bot. Reg. 31: Misc. 33. 1845.

Pseudobulbs "pyriform.", Leaves 2 or 3, ligulate, obtuse, 15-18 cm. long, about $18 \mathrm{~mm}$. wide; scape little branched, paniculately many-flowered, 2-3.5 $\mathrm{dm}$. long; pedicels slender, about $1 \mathrm{~cm}$. long; flowers yellowish-brown; sepals oblong or oblong-spatulate, acute, $19-25 \mathrm{~mm}$. long; petals oblong-cuneate, about as long as the sepals; lip short-clawed, about $2 \mathrm{~cm}$. long, deeply 3 -lobed, the lateral lobes short "acute," much shorter than the obovate, rounded middle one; column narrowly winged to the base.

Bahamas, collected by Skinner (according to Cogniaux) and also attributed to the Bahamas by Grisebach:- Hispaniola. Not known to us from the archipelago. Cogniaux's reference to this species as recorded by Britton from Abaco (Urban, symb. Ant. 6:494) is an error. The type specimen is said by Lindley to have been sent from Rio Janeiro, Brazil. Our specimen from Hispaniola was collected at Bayeux, Haiti, by George V. Nash (No. 300) and determined as Epidendrum rufum Lindl., by R. A. Rolfe at Kew. Rufous Excyclia.

4. Encyclia tampénsis (Lindl.) Small, Fl. Miami 56. 1913.

Epidendrum tampense Lindl. Bot. Reg. 1847: under pl. 35. 1847.

Pseudobulbs narrowly ovoid, terete, 4-7 cm. long. Leaves 1-3, linear or linear-lanceolate, $0.5-2.5 \mathrm{dm}$. long, 8-18 $\mathrm{mm}$. wide, acutish or obtuse, rather rigid; scape slender, branched, often $5 \mathrm{dm}$. long or longer; pedicels rather slender, 7-12 mm. long; lateral sepals yellowish-brown, narrowly oblanceolate, acutish, about $2 \mathrm{~cm}$. long; petals similar to the sepals but somewhat narrower; lip nearly sessile, deeply 3 -lobed, white lined with purple, a little shorter than the petals, the middle lobe reniform-orbicular, short-clawed, rounded or apiculate, the lateral lobes oblong, obtuse; column about $8 \mathrm{~mm}$. long, 2-auricled at the top and narrowly winged.

On trees and shrubs, Abaco, New Providence:-Fiorida; Cuba. Recorded by Coker as Epidendrum fucatum Lindl. TAMPA Excychia. 


\section{Encyclia diùrna (Jacq.) Britton \& Millspaugh.}

Limodorum diurnum Jaeq. Ic. Rar. 3: pl. 603. 1786-93.

Epidendrum gracile Lindl. Bot. Reg. 21: pl. 1765. 1835.

Epidendrum altissimum Batem.; Lindl. Bot. Reg. 24: Mise. 38. 1838.

Epidendrum virens Lindl. in Paxton, Fl. Gard. 1: 152. 1850-51.

Epidendrum diurnum Cogn. in Urban, Symb. Ant. 6: 497. 1910.

Plants usually clustered, sometimes forming large colonies. Pseudobulbs elongated, ovoid-oblong, $10 \mathrm{~cm}$. long or less. Leaves 2 or 3 , linear, rigid, acute or obtuse, $2-5 \mathrm{dm}$. long, $1.5-2.5 \mathrm{~cm}$. wide; scape more or less branched, 5-10 dm. high; pedicels 1-1.5 cm. long; lateral sepals greenish or purplish, narrowly oblong, acute or obtusish, about $2 \mathrm{~cm}$. long; petals similar to the sepals, obtuse, narrowed below; lip a little shorter than the sepals, white lined with purple, deeply 3-lobed, the middle lobe suborbicular or rhomboid-orbicular, rounded or retuse and apiculate, the lateral lobes oblong, obtuse; column claviform, about $1 \mathrm{~cm}$. long; capsule oval, $1.5-3 \mathrm{~cm}$. long.

On the ground, in rocky soll, or sometimes on trees, throughout the archipelago, from Abaco and Great Bahama to Andros, Mariguana, Acklin's and Calcos Islands:Cuba; Mexico to Venezuela. Consists of many races. differing in size of the plant, of the leaves and of the flowers, and in color of the perianth. TALL Excrchia.

\section{Encyclia inaguénsis Nash, sp. nov.}

Stems slender, up to $1 \mathrm{~m}$. tall, usually from a creeping rootstock, the pseudobulbs up to $1 \mathrm{dm}$. long and $1.5 \mathrm{~cm}$. in diameter at the base, gradually narrowed from the base to the apex. Leaves linear, up to $5 \mathrm{dm}$. long and $1 \mathrm{~cm}$. wide, acute; inflorescence up to $6 \mathrm{dm}$. long, paniculate, the branches ascending, the lower ones longer and bearing 2-5 flowers. Flowers $2.5-3 \mathrm{~cm}$. in diameter, fragrant; sepals and petals yellow, irregularly striped with purple, the sepals oblong-elliptic, acute, the petals oblanceolate-spathulate, acute; lip about as long as the sepals, white, the lateral lobes and margin of the middle lobe yelow, all flushed and striped with purple; lateral lobes ascending, oblong, acutish, $8-10 \mathrm{~mm}$. long, the middle lobe almost orbicular, undulate on the margin, retuse, $8-9 \mathrm{~mm}$. in diameter, almost sessile; column white, striped with purple, about $1 \mathrm{~cm}$. long.

On shrubs and trees. Type collected between Northwest Point and Southwest Point, Little Inagua, Oct. 21, 1904 (Nash and Taylor, 1251). A barren specimen from East Caicos (Millspaugh 911i) may be of this species. INAGUA ENCYCLIA.

\section{Encyclia plicàta (Lindl.) Britton \& Millspaugh.}

Epidendrum plicatum Lindl. Bot. Reg. 33: under pl. 10. 1847.

Pseudobulbs ovoid, terete, $8 \mathrm{~cm}$. long or less. Leaves 2 or sometimes 3 , coriaceous, stiff, $1.5-2.5 \mathrm{dm}$. long, $1.5-2.5 \mathrm{~cm}$. wide; scape usually much longer than the leaves, simple or more or less branched; pedicels slender, 1-1.5 $\mathrm{cm}$. long; lateral sepals oblong to oblong-oblanceolate, purplish or greenish, 2.5-3 em. long; petals aimilar to the lateral sepals; lip about as long as the petals, yellowish or whitish striped with purple, deeply 3 -lobed, the middle lobe suborbicular, cordate, emarginate and sometimes cuspidate, the lateral lobes oblonglanceolate, obtuse; column about $15 \mathrm{~mm}$. long; fruit oval, $2-3 \mathrm{~cm}$. long.

On shrubs and trees in thickets, Abaco, Andros, New Providence, Fortune Island, Cat Island, Crooked Island and Inagua :-Cuba. Recorded by Hitchcock as $E$. virens Lindl., and by Mrs. Northrop as $E$. phoeniceum Líndl. Plicate Excyclia. Catesby, $2: p l$. 88 .

\section{Encyclia aciculàris (Batem.) Britton \& Millspaugh.}

Epidendrum aciculare Batem.; Lindl. Bot. Reg. 27: Mise. 46. 1841.

Pseudobulbs ovoid, clustered, 2-3 cm. long; leaves 1 or 2, narrowly linear, 2-7 cm. long, about $5 \mathrm{~mm}$. wide. Scape usually simple, few-several-flowered, longer than the leaves; pedicels very slender, about $1 \mathrm{~cm}$. long; lateral sepals 
narrowly spatulate or oblanceolate, purple, acute, 2-3 cm. long, 2-4 mm. wide; petals similar to the sepals; lip white, lined with rose, a little shorter than the sepals, deeply 3 -lobed, the middle lobe ovate, rounded, the lateral lobes oblong, obtuse; column about $1 \mathrm{~cm}$. long, 2-auricled at the summit.

Bahamas, collected by Skinner, according to Lindley :-Mexico. A plant found on Conocurpus in an open coastal coppice, at Great Bahama at Golden Grove (Britton and Millspaugh 2728), was doubtfully referred to this species by Mr. R. A. Rolfe at Kew. It subsequently produced a few flowers at the New York Botanical Garden which do not wholly agree with those of Mexican specimens. NARROW-LEAVED ENCYCLIA.

Epidendrum papilionàceum Vahl, is doubtfully recorded as Bahamian by Urban and by Cogniaux, the determination based on barren specimens collected by Eggers in New Providence.

\section{EPICLÀDIUMM Small, Fl. Miami 56. 1913.}

An epiphytic orchid, with nearly orbicular flattened pseudobulbs, narrow, erect, flat leaves, duplicate in the bud, the flowering scape subtended by an elongated spathe-like sheath. Flowers racemose or solitary, minutely bracted, showy, mottled. Lateral sepals about as wide as the median one; petals similar to the lateral sepals; lip subrhombic, shorter than the sepals; column without a foot, partly adnate to the lip. Capsules nodding, winged. [Greek, upon a branch.] A monotypic genus.

\section{Epicladium Boothiànum (Lindl.) Small, Fl. Miami 56. 1913.}

Epidendrum Boothianum Lindl. Bot. Reg. 24: Misc. 5. 1838.

Epidendrum erythronioides Small, Fl. SE. U. S. 328. 1903.

Pseudobulbs clustered or solitary on branches, about $2.5 \mathrm{~cm}$. long, less than $1 \mathrm{~cm}$. thick, subtended by ovate, subscarious scales 1-2 $\mathrm{cm}$. long. Leaves oblong-oblanceolate, obtuse or acutish, 6-12 cm. long; flowering stem simple, mostly longer than the leaves, 2-3 times as long as the sheath; flowers 1-several; pedicels $3-5 \mathrm{~mm}$. long; lateral sepals oblong to elliptic-oblanceolate, acute, yellow, mottled with brown, about $13 \mathrm{~mm}$. long; petals spatulate, yellow, brown-mottled, about as long as the sepals; lip yellowish, about $7 \mathrm{~mm}$. long; capsule 2-3 cm. long, oblong, 3-winged.

On trees, Andros:-Florida; Cuba. Epicladium. Catesby, $2: p l$. 74 .

15. ANACHEILIUM Hoffmg. Linnaea 16: Litt. 229. 1842.

Epiphytic orchids, with elongated, somewhat flattened psudobulbs, long flat leaves duplicate in the bud, and nodding racemose bracted flowers on a simple terminal scape. Sepals all nearly alike, elongated, narrow, acuminate. Petals similar to the sepals, but somewhat shorter; lip concave, entire, much shorter than the sepals. Column partly adnate to the lip, footless. Capsules winged, drooping. [Greek, upturned lip.] The genus is probably monotypic.

\section{Anacheilium cochleàtum (L.) Hoffmg. Linnaea, 16: Litt. 229.1842.}

\section{Epidendrum cochleatum L. Sp. Pl. ed. 2, 1351. 1763.}

Pseudobulbs lanceolate to ovate, compressed, 8-12 $\mathrm{cm}$. long, clustered. Leaves 2 or 3 , linear or linear-oblong, acute, 1-4 dm. long ; scape simple, 1.5-6 $\mathrm{dm}$. long, bearing several linear-lanceolate scarious scales 1-3 $\mathrm{cm}$. long and subtendeã by a larger, scarious, spathe-like scale 5-8 cm. long; flowers fewseveral, racemose; bracts small; lateral sepals linear-lanceolate, greenish yellow, 
2-3 cm. long, similar to the petals; lip purple or variegated, about $2 \mathrm{~cm}$. long, abruptly acute, entire; capsule $2-3 \mathrm{~cm}$. long.

On trees in coppices, Abaco, Andros and New Providence:-Florida; Cuba ; Hispaniola; Porto Rico; Jamaica; Mexico to Colombia and Venezuela. Recorded from St. Croix. Catesby, 2: pl. 88. Shell Orchid.

\section{NIDÈMA Britton \& Millspaugh, gen. nov.}

Epiphytic orchids, with flattened 1-leaved pseudobulbs subtended by narrow scales, the leaves narrowly linear, the slender scapes bearing several, rather small, racemose flowers, or but one. Lateral sepals lanceolate or linear-lanceolate, 3-5-nerved, acute or acuminate; petals linear to lanceolate, somewhat shorter than the sepals; lip linear or ligulate, somewhat fleshy, entire or undulate; column free from the lip or but slightly adnate at the base, footless. Capsule oblong. [Anagram of Dinema, a related genus.] Two species or more, natives of the West Indies, the following typical.

\section{Nidema Ottònis (Rchb. f.) Britton \& Millspaugh.}

Epidendrum Ottonis Rchb. f.; Griseb. Fl. Br. W. I. 613. 1864.

Pseudobulbs narrowly oblong, clustered, compressed, 2-3.5 cm. long, 1leaved. Leaf thin in texture, linear, $6-13 \mathrm{~cm}$. long, $5-8 \mathrm{~mm}$. wide, obtuse or acutish; scape very slender, little, if any, longer than the leaf, bearing several linear scales and 3-6 bracted whitish flowers; ovary shorter than the linear bract; sepals lanceolate, acuminate, about $8 \mathrm{~mm}$. long; petals linear, acute, about $6 \mathrm{~mm}$. long; lip linear, acute, undivided, about $5 \mathrm{~mm}$. long; column free, claviform, $4 \mathrm{~mm}$. long, 5-toothed; capsule oblong, about $1 \mathrm{~cm}$. long.

On tree, Blue Hills, New Providence, collected by Eggers (according to Cogniaux), not found by us in the Bahamas:-Jamaica; Cuba; Hispaniola; Porto Rico; Trinidad; Venezuela.

17. TETRAMìCRA Lindl. Gen. \& Sp. Orch. 119. 1831.

Mostly terrestrial orchids, without pseudobulbs, the roots thick fibers, the few subterete fleshy leaves basal, the pink to purple flowers in a simple raceme at the end of a slender sheathed scape. Bracts very small. Sepals about equal, distinct, spreading. Petals similar to the sepals. Lip 3-lobed, spreading, the lobes entire or nearly so. Column 2-winged. Anther convex, imperfectly 4-celled; pollinia 4, waxy, appendaged. Capsule oblong, beakless. [Greek, small four.] About 8 species, of tropical America. Type species: Cymbidium rigidum Willd.

\section{Tetramicra Urbaniàna Cogn. in Urban, Symb. Ant. 6: 551. 1910.}

Roots few, thick, canescent. Leaves 2, lanceolate or oblong-ovate, $3 \mathrm{~cm}$. long or less, acute or acumirate, fleshy; scape very slender, $2-4.5 \mathrm{dm}$. high, its small membranous sheaths appressed; raceme 2-5-flowered, the flowers distant; bracts ovate, membranous, acute, 1-3 mm. long; pedicels $2-3 \mathrm{~mm}$. long; ovary slender, 5-7 mm. long; sepals ovate or oblong, 5-nerved, about $4 \mathrm{~mm}$. long; petals linear, about as long as the sepals; lip 4-6 mm. long, deeply 3lobed, the lobes rounded; column narrowly 2 -winged, $3 \mathrm{~mm}$. long.

On the ground, New Providence near Nassau:-Endemic. Bahama Tetramicra. 
18. LAfLIÓPSIS Lindl. in Paxton, Fl. Gard. 3: 155. 1853.

Epiphytic orchids, with small oblong, 1-leaved or 2-leaved pseudobulbs, the leaves linear or oblong, coriaceous, the few or several large, rose or purple flowers in a terminal, long-peduncled raceme. Sepals equal, distinct, erect or somewhat spreading. Petals similar to the sepals, but a little broader. Lip broad, spreading, sometimes slightly 3-lobed, sessile at the base of the column. Anther terminal, 2-celled; pollinia 8. Capsule oblong to obovoid. [Greek, similar to Laelia.] Three or four species, inhabiting Cuba, Jamaica, Hispaniola and the Bahamas, the following typical.

1. Laeliopsis domingénsis Lindl. in Paxton, Fl. Gard. 3: 155, pl. 105.1853.

Cattleya domingensis Lindl. Gen. \& Sp. Orch. 118. 1831.

Broughtonia lilacina Henfr. in Moore \& Ayres, Gard. Mag. Bot. 3: 201. 1851.

Broughtonia domingensis Rolfe, Gard. Chron. III. 5: 491. 1889.

Cattleyopsis Northropiorum Cogn. in Urban, Symb. Ant. 6: 545. 1910.

Pseudobulbs narrow, 3-7 cm. long, 5-9 mm. in diameter. Leaves linearoblong, 7-14 cm. long, $2 \mathrm{~cm}$. wide or less, obtuse, the margin more or less erose-denticulate, the midvein prominent; peduncle slender, terete, erect, 4-7 $\mathrm{dm}$. long, with several distant scarious appressed sheaths; flowers 4-15; pedicels slender, 1.5-2 $\mathrm{cm}$. long; bracts ovate, acute, about $2 \mathrm{~mm}$. long; sepals lanceolate, acute, 5-7-nerved, $2.5-3 \mathrm{~cm}$. long, 5-7 mm. wide; petals 7-10 $\mathrm{mm}$. wide; lip broadly obovate, 3-4 cm. long, emarginate, undulate; capsule 2-3 em. long.

On trees and shrubs in coastal coppices and pine-lands, Abaco and Great Bahama, Andros, South Bimini and Eleuthera :-Cuba; Hispaniola; Jamaica.

\section{LIMODÒRUM L. Sp. Pl. 950. 1753.}

Scapose terrestrial orchids, with round solid bulbs which arise from the bulb of the previous year, a leaf appearing the first season, succeeded in the following year by the scape. Flowers several in a loose terminal spike or raceme. Sepals and petals nearly alike, separate, spreading. Column elongated, 2-winged above. Anther terminal, operculate, sessile; pollinia solitary, 1 in each sac, loosely granular. Lip spreading, raised on a narrow stalk, dilated at the apex, bearded on the upper side with long club-shaped hairs. [Greek, a meadow-gift.] Five species of the eastern United States, the Bahamas and Cuba. Type species: Limodorum tuberosum $\mathrm{L}$.

\section{Limodorum Símpsoni Small, Fl. SE. U. S. 322. 1903.}

Calopogon pulchellus Simpsoni Ames, Contr. Ames Bot. Lab. 1: 18. Hyponym. 1904.

Scape slender, erect, 3-7 dm. tall, bearing 1 or 2 short basal scales and usually but 1, linear, acute leaf 1-3 dm. long, borne near the base. Spike loosely few-flowered; bracts lanceolate, acute, usually much shorter than the ovary; flowers purple, rarely white; lateral sepals suborbicular, acute, about $18 \mathrm{~mm}$. long; petals ovate-oblong, a little longer than the sepals; middle lobe of the lip 8-10 $\mathrm{mm}$. wide, emarginate; capsule 1.5-2 $\mathrm{cm}$. long.

Savannas and pine-lands, Andros :-Florida; Cuba. Determined by Mrs. Northrop as $L$. tuberosum L., and referred to that species by Cogniaux. SouthenN GRASS-PINK. 
20. BLÈTIA R. \& P. Syst. 229. 1798.

Terrestrial orchids, with globose or ovoid corms, narrow, elongated linear or lanceolate leaves, the slender sheathed scape arising from the side of the corm, the large purple or pink flowers in simple or branched racemes. Sepals nearly alike, ovate to oblong. Petals similar to the sepals. Lip broad, 5-7crested, 3-lobed. Column elongated. Anther 2-celled; pollinia obovate, waxy. Capsules oblong, erect. [Commemorates L. Blet, a Spanish apothecary.] About 45 species, mostly of tropical America. Type species: Bletia catenulata R. \& P.

1. Bletia purpùrea (Lam.) DC. Mem. Soc. Phys. Hist. Nat. Geneve 9: 100. 1841.

Limodorum purpureum Lam. Encycl. 3: 515. 1789.

Limodorum altum Jacq. Ic. Rar. 3: 17, pl. 602. 1786-93. Not. L. 1767. Bletia verecunda R. Br. in Ait. Hort. Kew ed. 2, 5: 206. 1813.

Corm subglobose, 2-3 cm in diameter; scape slender, 3-11 dm. high. Leaves 1.5-5 dm. long, 1-2 cm. wide at about the middle, tapering to both ends, narrowed below into a sheath; sheaths of the scape 1-1.5 $\mathrm{cm}$. long, ovate, appressed; bracts ovate, 4-5 mm. long, acute or acuminate; sepals 11-18 mm. long, acute, the median one ovate-lanceolate, the lateral ones ovate to oblong; petals oval, a little shorter than the sepals; lip 7-crested, nearly as long as the petals, its middle lobe notched, crenate crisped; capsule cylindric, $2.5-4 \mathrm{~cm}$. long.

Pine-lands and scrub-lands, Abaco, Great Bahama, Andros. New Providence, Eleuthera :-Florida; Cuba: Hispaniola; Jamaica. Recorded by Hitchcock as Bletia alta (L.) Hitchc. PuRple Bletia.

\section{GOVÈNIA Lindl. in Lodd. Bot. Cab. pl. 1709. 1831.}

Terrestrial orchids with rootstocks, the leaves few, plaited, the stem erect, the rather small flowers in a simple, terminal, spike-like raceme. Sepals connivent, nearly equal, the median one erect, incurved. Petals similar to the sepals. Lip concave, simple. Column winged, incurved, its foot short. Anther incumbent, convex, 1-celled; pollinia 4, waxy, not appendaged. Capsule oblong. [Commemorates James Robert Gowen, an English botanist, who died in 1862.] About 17 species, natives of tropical America. Type species: Govenia superba Lindl.

1. Govenia utriculàta (Sw.) Lindl. Bot. Reg. 25: Misc. 47. 1839.

Cymbidium utriculatum Sw. Nov. Act. Ups. 6: 75. 1799.

Plant 3-7 dm. high, the stem rather stout, bearing large basal inflated bladeless sheaths and 1 or 2 broad leaves. Basal sheaths usually 2 , mem. branous, 4-20 cm. long; leaves usually 2 , elliptic, 1-2.7 dm. long, 5-9 cm. wide, acute or acuminate at the apex, narrowed at the base, finely many-nerved; cauline sheaths 1 or 2 , obtuse, about $5 \mathrm{~cm}$. long; raceme few-several-flowered, $1.5 \mathrm{dm}$. long or less; pedicels $3-5 \mathrm{~mm}$. long; bracts narrowly lanceolate, 1-2 $\mathrm{cm}$. long; flowers whitish; sepals about $1.5 \mathrm{~cm}$. long, the lateral lanceolate, the median oblong; petals about as long as the sepals; lip ovate, acute, about $9 \mathrm{~mm}$. long; capsules deflexed, $2.5-3 \mathrm{~cm}$. long.

Coppices and pine-barrens, Abaco, Andros:-Cuba; Hispaniola; Porto Rico; Jamaica ; Mexico to South America. Swollen Govenia. 
22. ONCÍDIUM Sw. Vet. Akad. Stock. Handl. 21: 239. 1800.

Mostly epiphytic orchids, with or without pseudobulbs, the leaves flat or 3-edged, elongated or short, the stems short, the peduncles or scapes lateral, the flowers in loose racemes or panicles. Sepals nearly equal, spreading or reflexed, the lateral ones connate in some species. Petals similar to the median sepal. Lip elawed or sessile, 3-lobed, crested or tubercled, the middle lobe broad, notched or 2-cleft. Column short, winged, without a foot. Anther inclined, convex or semiglobose, 1-celled or imperfectly 2-celled; pollinia 2, waxy, not appendaged. Capsule ovoid to fusiform, beaked. [Greek, referring to the tubercled lip.] More than 400 species, natives of tropical and subtropical America. Type species: Oncidium carthaginense (Jacq.) Sw.

Terrestrial; leaves $3-5 \mathrm{dm}$. long; scape $1 \mathrm{~m}$. or more high.

Epiphytic; leaves 1-1.5 dm. long; scape 3-5 dm. long.

Leaves elongated-linear.

Leaves oblong-faicate.

1. O. sphacelatum.

2. O. bahamense.

3. O. lucayanum.

1. Oncidium sphacelàtum Lindl. Sert. Orch. under pl. 48. 1841.

Pseudobulbs nearly cylindric, 8-12 cm. long, $1.5-2 \mathrm{~cm}$. thick. Leaves linear, elongated, 3-10 dm. long, 1-2 cm. wide, flat, finely many-nerved; scape slender, $2 \mathrm{~m}$. long or less, the flowers loosely panicled; bracts linear-lanceolate, 8-15 mm. long; pedicels slender, 1-2.5 cm. long; sepals lanceolate, about $16 \mathrm{~mm}$. long, brownish, barred with yellow; petals similar to the sepals, but somewhat broader and shorter; lip bright yellow, about as long as the petals, its middle lobe 11-14 mm. wide; eapsule oblong, about $2 \mathrm{~cm}$. long.

On the ground in pine-lands and coppices, Abaco, Great Bahama, Andros, New Providence, Watiing's Island, Crooked Island:-Florida; Cuba; Central America.

\section{Oncidium bahaménse Nash, sp. nov.}

A stoloniferous plant, creeping along branches and tree trunks, with equitant leaves which are long, curved and narrow, and a raceme of yellow flowers much exserted beyond the leaves. Leaves up to 8 , crowded at the base, the lower 1 or 2 short, triangular and scale-like, the larger ones up to $2 \mathrm{dm}$. long, 2-3 mm. wide, laterally compressed, acutely angled on the back, channeled on the upper side, smooth and glabrous, linear, acute; scape up to $4.5 \mathrm{dm}$. long, smooth and glabrous, with scattered ovate scarious acute scales 5-7 mm. long; raceme 5-7 cm. long, of 10-15 spreading flowers on slender pedicels up to $1 \mathrm{~cm}$. long, the bracts ovate, acuminate, about $3 \mathrm{~mm}$. long; dorsal sepal obovate-spatulate, concave, much narrowed at the base, emarginate and apiculate at the apex, 1-nerved, 5-6 $\mathrm{mm}$. long, about $3 \mathrm{~mm}$. wide at the broadest part when spread out; lateral sepals united to the apex into an obovate-cuneate concave body about $6 \mathrm{~mm}$. long and $4 \mathrm{~mm}$. wide when spread out, rounded-truncate at the apex, 2-nerved, running out into short apiculations: petals obovate, 5 -nerved, undulate on the margins, apiculate at the apex, $7 \mathrm{~mm}$. long and $5 \mathrm{~mm}$. wide; lip sessile with a broad rounded base, $9-10 \mathrm{~mm}$. long and 10-12 mm. wide, puberulent on the upper surface, of equal width at base and apex, 3-lobed, the lateral lobes spreading and somewhat reflexed, broad, rounded at the apex, irregularly crenulate on the margins, the middle lobe much broader than long, reniform, irregularly lobulate on the margins, strongly emarginate at the apex, apiculate, the crest with two processes, one of them with long lobes, the other smaller and with 3 lobes; column stout, about $2.5 \mathrm{~mm}$. long, the wings puberulent, ovate, rounded at the base, obtuse at the apex, and extending considerably beyond the summit of the column, 3.5 $\mathrm{mm}$. long and about $2 \mathrm{~mm}$. wide.

Type collected by L. J. K. Brace, at Eight Mile Rocks, Great Bahama, April 16May 8, 1905, no. 3689, in the herbarium of the New York Botanical Garden. A 
specimen in the herbarium of Columbia University, collected by John I. and Allce R. Northrop, on Andros Island, in May, 1890, no. 54s, doubtfully determined by Mrs. Northrop as $O$. sylvestre Lindl., is also this species; it was also referred to $O$. sylvestre by Cogniaux. The plant recorded by Eaton and Setchell, and also by Dolley, from Abaco, collected by Herrick, is apparently this species.

This orchid is related to Oncidium sylvestre Lindl., but the longer leaves, smaller flowers, and the differences in the lip at once distinguish it. In o. sylvstre the leaves are not over $4 \mathrm{~cm}$. long, the flowers are fully twice the size, and the lip has the lateral lobes very small; in $O$. bahamense the lip is as broad across the lateral lobes as it is at the apex.

\section{Oncidium lucayànum Nash, sp. nov.}

Plant with short compressed leaves and a few-flowered raceme.' Leaves 4-6, crowded at the base, curved, spreading, acute, compressed, acutely angled on the back, channeled on the upper surface, wrinkled on the upper margins, smooth and glabrous, $1-1.5 \mathrm{~cm}$. long and about $3 \mathrm{~mm}$. wide; scape smooth and glabrous, with a few scattered ovate acute appressed scarious scales $3-4 \mathrm{~mm}$. long; flowers on pedicels $5-7 \mathrm{~mm}$. long; dorsal sepal oblanceolate-cuneate, acutish at the apex, narrowed toward the base, $7 \mathrm{~mm}$. long and $2-2.5 \mathrm{~mm}$. wide, the margins repand; lateral sepals united into a concave 2-nerved oblanceolate-cuneate body which is 2 -toothed at the apex, the teeth rounded and about $0.75 \mathrm{~mm}$. long, about $8 \mathrm{~mm}$. long and 2.5-3 mm. wide; petals lyrate-ovate, acute at the apex, abruptly narrowed below the middle into a claw about $2 \mathrm{~mm}$. long and $1.5 \mathrm{~mm}$. wide, $8 \mathrm{~mm}$. long and $3-3.5 \mathrm{~mm}$. wide, undulate on the margin; lip adnate to the column up to its wings by a bi-lamellate process, $8 \mathrm{~mm}$. long and $7 \mathrm{~mm}$. wide, sessile by a rounded or truncate base, 3 -lobed, the lateral lobes $1.5-2 \mathrm{~mm}$. long and $1.5 \mathrm{~mm}$. wide, somewhat reflexed, rounded or a little acute at the base, merging into a hemispherical somewhat toothed isthmus which joins them to the middle lobe, the middle.lobe flabellate, on a triangular claw, round-truncate and apiculate at the apex, irregularly lobulate on the margins, the crest of 3 lobes, the lateral divaricate, separated by a rounded protuberance, the middle lobe the largest and again 3 -lobed; column 3-3.5 mm. long, the wings semiovate, rounded at the base, acute at the apex, irregularly lobed and extending somewhat beyond the summit of the column.

Type, in the herbarium of Columbia University, collected by John I. and Alice R. Northrop, at Fresh Creek, Andros Island, June 10, 1890, no. 64\%. Resembles $O$. variegatum considerably, but the sepals are nearly as long as the lip, and the middle lobe of the lip fiabellate while in $O$. variegatum the sepals do not exceed one half the length of the lip which has the middle lobe reniform and sessile. Referied by Cogniaux to $O$. Leiboldi Rchb. f.

Oncidium variegatum $\mathrm{Sw}$. is recorded by Cogniaux as collected on Andros (Northrop 587) but our specimens of this number appear to be 0 . lucayanum. We have fruiting specimens of apparently the same plant from Abaco and Great Bahama.

A small Oncidium, collected on Cat Island, died before flowering.

\section{Sub-class 2. DICOTYLÉDONES.}

Embryo of the seed with two cotyledons (in a few genera one only), the first leaves of the germinating plantlet opposite. Stem exogenous, of pith, wood and bark (endogenous in structure in Nymphaeaceae), the wood in one or more layers surrounding the pith, traversed by medullary rays and covered by the bark. Leaves usually pinnately or palmately veined, the veinlets forming a network. Parts of the flower rarely in 3 's or 6's.

Dicotyledonous plants are first definitely known in Cretaceous time. They constitute between two-thirds and three-fourths of the living angiospermous flora. 


\section{Series I. Choripétalae.}

Petals separate and distinct from each other, or wanting.

The series is also known as Archichlamideae, and comprises most of the families formerly grouped under Apetalae (without petals) and Polypetalae (with separate petals). Exceptions to the typical feature of separate petals are found in the Fabaceae, in which the two lower petals are more or less united; in the Fumariaceae, where the two inner petals or all four of them are sometimes coherent; in some Crassulaceae; the Polygalaceae, in which the three petals are united with each other, and with the stamens; Oxalidaceae and Ilicaceae, whose five petals are sometimes joined at the base.

$\ddagger$ Petals none (except in family Portulacaceae and in most Caryophyllaceae, which are herbs with the leaves nearly always opposite, the seeds with endosperm).

Calyx none (except in some of the Santalares, and sometimes in Casuarinaceae). Loosely jointed trees, the leaves reduced to verticillate scales.

Plants not loosely jointed; leaves normai.

Herbs with small perfect flowers in splkes.

Trees or shrubs; staminate flowers, and sometimes also the pistillate, in aments.

Leaves simple.

Leaves odd-pinnate or trifollolate; fruit a nut enclosed in a husk, or drupe-like.

Caiyx present.

Flowers monoecious, dioecious or polygamous, ovary superior, 1-celled.

Order 1. Casuarinales.

Order 2. Piperales.

\section{Order 3. MYricales.}

Order 4. JugLANDALES.

Flowers dioecious or perfect; ovary inferior, at least in part.

Ovary 1-celled.

Ovary several-celled (usually 6-celled) ; flowers perfect.

Flowers mostly perfect; ovary superior.

Embryo straight or nearly so; fruit an achene.

Embryo coiled, curved or annular; fruit not an achene.

Order 5. URTICALES.

Order 6. Santalales.

Order 7. ARIstolochiales.

Order 8. Polygonales.

Order 9. Chenopodiales.

市Petals present (wanting in Ceratophyllaceae, aquatic herbs with whorled dissected leaves; in many Ranunculaceae; in Lauraceae, alternate-leaved aromatic trees and shrubs; in Zanthoxylum, pinnate-leaved trees of the Rutaceae; in many Euphorbiaceae; in some species of Ludvoigia in Onagraceae; in Proserpinaca of the Haloragidaceae).

A. Ovary superior, free from the calyx (partly or wholly inferior in Loasaceae).

Carpels solitary, or several and distinct (united in some Nymphaeaceae); stamens mostly hypogynous and more numerous than the sepals; sepals mostly distinct.

Carpels 2 or more, united into a compound ovary ; stamens hypogynous ; sepals mostly distinct.

Carpels solitary, or several and distinct, or sometimes united; stamens mostly perigynous or epigynous; sepals malnly united or confluent with the concave receptacle (hypanthium).

Carpels united into a compound ovary; sepals mostly distinct.

Stamens few, rarely more than twice as many as the petals.

Stamens as many as the sepals or fewer and opposite them, or more numerous.

Ovules pendulous, the raphe toward the axis of the ovary.

ovules pendulous, the raphe away from the axis of the ovary, or erect, or ascending.

Stamens as many as the sepals and alternate with them, opposite the petals when these are present; ovules erect. Order 10. RANALES.

Order 11. Papaverales.

Order 12. ROSALES.

Order 13. Geraniales.

Order 14. SAPINDALES.

Order 15. RHAMNALES. Violaceae and (except in conspicuous, or none. 
Sepals valvate; placentae united in the axis.

Sepals or calyx-segments imbricated or convolute; placentae mainly parietal, sometimes united in the axis.

Sepals separate.

Sepals united.

Order 16. MaLvales.

Order 17. HYPERICALES,

Order 18. Passiflorales.

B. Ovary inferior, adnate to the calyx, wholly or in part (except in Lythraceae where it is usually merely enclosed by it).

Herbs with barbed or stinging hairs.

Plants without barbed or stinging hairs.

Fleshy spiny plants, with jointed stems, the

leaves mostly very small or none; calyx-segments and petals several or numerous.

Herbs, shrubs or trees, not fleshy or spiny ; calyx-segments rarely more than 5 .

Ovules several or numerous in each cavity of the ovary (except in Haioragidaceae, aquatic herbs).

ovule 1 in each cavity of the ovary.

Order 19. LoAsales.

Order 20. Opuntiales.

Order 21. Myrtales.

Order 22. AmMIALES.

\section{Order 1. CASUARINÀLES.}

Trees or shrubs, with very slender, jointed, angled branches and twigs, the leaves reduced to minute verticillate scales at the nodes, the scales sometimes connate, the small imperfect bracted flowers in terminal spikes or cone-like heads. Staminate flowers with 1 or 2 sepals and 1 stamen with a large anther. Pistillate flowers without a perianth; ovary small, 1-celled; style short, with 2 slender branches; ovules 1 or 2, ascending. Fruit a cone-like mass of acerescent bracts, subtending winged achenes. Seed with a membranous testa and no endosperm, the embryo straight.

\section{Family 1. CASUARINÀCEAE Lindl.}

BeEF-wood FaMiLY.

Only one genus, with about 25 species, most abundant in Australasia.

1. CASUARINA Forst. Char. Gen. Pl. 104. 1776.

Characters of the order. [From the zoological name of the Cassowary.] The following species is typical.

1. Casuarina equisetifòlia Forst. Char. Gen. Pl. 104. 1776.

A tree, reaching in the American tropies a maximum height of about $20 \mathrm{~m}$., with a trunk up to $1 \mathrm{~m}$. in diameter, much larger in Australia, with long and slender branches, the upper ones erect or nearly so, the dark brown bark furrowed. Twigs angular, very slender, drooping; leaves $6-8$ in each whorl, only 1-3 mm. long, acute, appressed, ciliate, decurrent on the twigs; staminate flowers in slender terminal cylindric spikes 1-4 $\mathrm{cm}$. long, the bracts imbricated, the anthers exserted; pistillate flowers in lateral dense subglobose heads which become about $2 \mathrm{~cm}$. in diameter in fruit.

Sandy sea shores, spontaneous after cultivation, Abaco, Andros, New Providence, Eleuthera, Crooked Island, the Caicos, Grand Turk, and Inagua :-A native of Australia more or less naturalized in Florida, the West Indies and Yucatan. Erroneousiy called SPanish CeDAR. BeEF-WOOD. 


\section{Order 2. PIPERÀLES.}

Dicotyledonous plants, with neither petals nor sepals, the spicate flowers bracteolate.

\section{Family 1. PIPERĀCEAE H.B.K.}

\section{Pepper Family.}

Herbs, shrubs or rarely small trees, with alternate, opposite or verticillate leaves, almost always entire-margined, the mostly minute bracteolate flowers in spikes or rarely in racemes. Perianth none. Stamens mostly 2-6, hypogynous; anthers ereet, terminal, their saes distinet or confluent, longitudinally dehiscent. Ovary sessile or rarely stipitate, 1-celled, 1ovuled; style 1 ; ovule erect, orthotropous. Fruit baccate, indehiscent. Seed solitary, the testa membranous, the endosperm copious, the embryo minute. About 6 genera with over 1000 species, mostly of tropical distribution.

\section{PEPERÒMIA R. \& P. Prodr. 8. 1794.}

Herbs, mostly succulent, with alternate, opposite or verticillate leaves, the flowers in slender, solitary or clustered spikes, subtended by circular or elliptic bracts. Stamens 2; filaments short. Ovary mostly sessile, sometimes stalked, sometimes beaked; stigma terminal or lateral. Berry very small, globose, oblong or ellipsoid, viscid. . [Greek, pepper.] Six hundred species or more, mostly of tropical America. Type species: Peperomia secunda R. \& P.

\section{Peperomia spathulifòlia Small, sp. nov.}

Plants mainly terrestrial, strongly aromatic. Stems and branches decumbent, partly creeping; leaf-blades cuneate to spatulate, 6-11 cm. long, rounded, truncate or notched at the apex, glabrous, bright-green, obscurely veined, except sometimes in drying, acuminate at the base or attenuate into long or rather long petioles; inflorescence with a slender often elongate stalk, with one to five slender recurved-nodding branches; spikes mostly 1-2 dm. long, yellowish, the rachis less than $2.5 \mathrm{~mm}$. thick, slender-tipped; bracts orbicular, about $0.3 \mathrm{~mm}$. in diameter; anthers about $0.25 \mathrm{~mm}$. in diameter; berries not densely crowded, broadly ellipsoid or ovoid, nearly $1 \mathrm{~mm}$. long, rounded at the base, the beak much shorter than the body, strongly curved or hooked.

Deep woods, Abaco, in coppice at Eight Mile Bay:-Florida; Haiti. Spatulate-leaved Wild Pepper.

\section{Order 3. MYRICĀLES.}

Shrubs or trees, with simple leaves and small monoecious or dioecious flowers in aments. Perianth none. Ovary 1-celled; style short; stigmas 2. Ovule erect, orthotropous. Endosperm none. Only one family.

\section{Family 1. MYRICÀCEAE Dumort.}

\section{BAYBERRY FAMILY.}

Leaves alternate, mostly coriaceous and aromatic. Flowers soiitary in the axils of the bracts. Staminate flower with 2-16 (usually 4-8) stamens 
inserted on the receptacle; filaments short; anthers ovate, 2-celled, the sacs longitudinally dehiscent. Ovary subtended by $2-8$ bractlets; stigmas linear. Fruit a small drupe or nut, the exocarp often waxy. Seed erect. Cotyledons plano-convex. Radicle short. Two genera and about 36 species.

\section{MYRİCA L. Sp. Pl. 1024. 1753.}

Leaves entire, dentate or lobed, mostly resinous-dotted. Staminate aments oklong or narrowly cylindric, expanding before or with the leaves. Stamens 4-8. Pistillate aments ovoid or subglobose; ovary subtended by $2-4$, mostly short, bractlets. Drupe globose or ovoid, its exocarp waxy. [Ancient Greek name of the Tamarisk.] About 35 species, widely distributed. Type species: Myrica Gale L.

\section{Myrica cerífera L. Sp. Pl. 1024. 1753.}

\section{Cerothamnus ceriferus Small, Fl. Miami 61. 1912.}

A slender dioecious shrub, or a tree, sometimes $12 \mathrm{~m}$. high, with a trunk $5 \mathrm{dm}$. in diameter, the bark gray, nearly smooth. Leaves narrow, oblong or oblanceolate, mostly acute, entire or sparingly dentate, narrowed at the base, fragrant, short-petioled, dark green above, paler and sometimes pubescent beneath, golden-resinous, $2-8 \mathrm{~cm}$. long, unfolding with or before the aments; staminate aments cylindric; pistillate aments short, oblong; ripe drupes globose, bluish white, waxy, tipped with the base of the style, long-persistent.

Sandy thickets, coppices and pine-lands, Abaco, Andros, Great Bahama. New Providence, Eleuthera, Cat Island, and Acklin's Island:- New Jersey southward along the coast to the Florida Kès and to Texas; Bermuda: Cuba; Hispaniola; Porto Rico. BAy-Berry. WAX-Berry. Mickle-Berry. Wild Tea.

\section{Order 4. JUGLANDÀLES.}

Trees with alternate pinnately compound or trifoliolate leaves, and monoecious or dioecious bracteolate flowers, the staminate in long drooping aments, the pistillate solitary or several together. Staminate flowers consisting of 3-numerous stamens with or without an irregularly lobed perianth adnate to the bractlet, very rarely with a rudimentary ovary. Anthers erect, 2-celled, the saes longitudinally dehiscent; filaments short. Pistillate flowers with a $3-5$-lobed calyx or with both calyx and petals, and a 1-celled or 2-4-celled ovary. Ovules solitary or 2, erect, orthotropous; styles 1 or 2. Fruit a drupe with indehiscent or dehiscent, fibrous, fleshy or woody exoearp, enclosing the bony endocarp or nut which is 2-4-celled. Seed large, 2-4-lobed. Endosperm none. Cotyledons corrugated, Two families, that of the Walnuts (Juglandaceae) and the following.

\section{Family 1. PICRODENDRÀCEAE Small.}

Rough-barked trees, or shrubs, with bitter wood, alternate, slenderpetioled, 3 -foliolate leaves, and dioecious flowers, the pistillate ones solitary, axillary, peduncled, the staminate in long drooping aments. Staminate flowers each subtended by 3 bracts, the middle bract the larger; perianth none; stamens many, clustered; filaments glabrous, shorter than the anthers 
or as long; anthers oval, sparingly pubescent. Calyx of the pistillate. flowers small, 4-parted, the lobes or sepals narrow, deciduous; petals none; ovary sessile, 2 -celled; ovules 2 in each cavity; style columnar; stigmas subulate, longer than the style. Drupe globose or oval, stalked. Seed solitary. Only the following genus.

1. PICROdÉNDRON Planch. in Hook. Lond. Jour. Bot. 5: 579. 1846.

Characters of the family. [Greek, bitter tree.] Three species, natives of the Bahamas, Jamaica, Cuba and Hispaniola. Type species: Juglans baccata L. (Picrodendron arboreum Macfad.).

1. Picrodendron macrocárpum (A. Rich.) Britton, Bull. N. Y. Bot. Gard. 4: 139. 1906.

Schmidelia macrocarpa A. Rich. in Sagra, Hist. Cub. 10: 116. pl. 30. 1845.

Picrodendron backatum bahamense Krug \& Urban, Bot. Jahrb. 15: 308. 1893.

A tree, up to $20 \mathrm{~m}$. high, or sometimes a shrub. Petioles minutely pubescent, $2-8 \mathrm{~cm}$. long; leaflets $1.5-9 \mathrm{~cm}$. long, oblong, oval or obovate, usually rounded or emarginate at the apex, narrowed or euneate at the base, finely pubescent, or becoming glabrate, finely reticulate-veined; calyx yellowish, the narrowly linear-lanceolate lobes $2.5-3.5 \mathrm{~mm}$. long; drupe oval or ovoid, 2-2.5 em. long, longer than its stalk.

Rocky coppices, Abaco, Andros, New Providence, Eleuthera, Cat Island, Great Guana Cay, and Long Island:-Cuba. Referred by Dolley to Picrodendron juglans Griseb. Erroneously called Olive. BLACK Wood. Catesby, 2: $p l .32$.

\section{Order 5. URTICÀLES.}

Trees, shrubs or herbs, the flowers with a calyx but without corolla, small, not borne in aments, monoecious, dioecious or polygamous; ovary 1-celled, superior.

Frult not an achene; trees, shrubs or herbs; ovule pendulous.

Trees with alternate leaves, the sap not milky.

Trees with alternate leaves and milky sap.

Frult an achene; herbs with small clustred greenish flowers ovule erect or ascending.

Fam. 1. ULMACEAE. Fam. 2. MoraceAE. Fam. 3. Urticaceat.

\section{Family 1. ULMÀCEAE Mirbel.}

\section{Elm Family.}

Trees or shrubs, with alternate simple serrate petioled pinnately-veined stipulate leaves, the stipules usually fugacious. Flowers small, monoecious, dioecious, perfect or polygamous, elustered, or the pistillate solitary. Perianth 3-9-parted or of 3-9 distinct sepals. Petals none. Stamens in our species as many as the perianth-lobes or sepals and opposite them; filaments straight; anthers ovate or oval, longitudinally dehiscent. Ovary 1-celled (rarely 2-celled), mostly superior; ovule solitary, pendulous, anatropous or amphitropous; styles or stigmas 2. Fruit a samara, drupe or nut. Endosperm of the seed little or none. Embryo straight or eurved; cotyledous mostly flat. About 13 genera and 140 species, widely distributed in temperate and tropical regions. 
1. TRÈMA Lour. Flor. Coch. 562. 1790.

Tall shrubs or trees, unarmed, usually pubescent. Leaves alternate, toothed, 3-nerved at the base, equilateral or only slightly inequilateral, shortpetioled, the stipules lateral. Flowers small, mostly monoecious or polygamous, greenish or whitish, the perfect mostly fertile, in axillary cymes. Sepals of pistillate flowers induplicate-valvate, those of the perfect flowers slightly imbricated. Stamens 4 or 5. Ovary sessile. Stigmas 2, entire. Ovule pendulous. Drupe, ovoid to globose. [Name unexplained.] Some 30 tropical species. Type species: Trema cannabina Lour.

1. Trema Lamarckiàna (R. \& S.) Blume, Mus. Bot. Lugd. 2: 58.1853.

Celtis Lamarckiana R. \& S. Syst. 6: 311. 1820.

Sponia Lamarckiana Decn. Nouv. Ann. Mus. Paris 3: 498. 1834.

Trema Lima Hitch. Rep. Mo. Bot. Gard. 4: 129. 1893.

A tree, up to $8 \mathrm{~m}$. high, the trunk sometimes $3 \mathrm{dm}$. in diameter, or more often a shrub $1.5-3.5 \mathrm{~m}$. high, the twigs slender, rough-pubescent. Leaves ovate to lanceolate, short-petioled, $5 \mathrm{~cm}$. long or less, very rough on the upper side, 3-nerved at the base, reticulate-veined and finely tomentose beneath; flowers only about $2 \mathrm{~mm}$. wide, the staminate clusters sessile, the pistillate shortstalked; fruit ovoid, about $3 \mathrm{~mm}$. long, smooth.

Scrub-lands and coppices, Great Bahama, Andros. Mangrove Cay, St. George's Cay, New Providence, Rose Island, Hog Island, Eleuthera, Great Guana Cay, Watling's, Crooked Island and Marlguana:-Florida; Bermuda; Cuba to Porto Rico; Montserrat to St. Vincent. Lamarck's Trema. PaIN-IN-BACK.

\section{Family 2. MORÀCEAE Lindl.}

\section{MulberRy Family.}

Trees, shrubs or herbs, mostly with milky sap, petioled stipulate leaves, and small monoecious or dioecious axillary clustered flowers, or the pistillate flowers solitary in some exotic genera. Calyx mostly 4-5-parted. Petals none. In Ficus the minute flowers are wholly inclosed in receptacles. Staminate flowers panicled, spicate or capitate, the stamens as many as the calyx-segments. Pistillate flowers capitate, spicate or cymose. Ovary superior, 1-celled in our genus. Ovule solitary, pendulous, anatropous. Styles 1 or 2 . About 55 genera and 925 species, natives of temperate and tropical regions.

\section{FİCUS [Tourn.] L. Sp. Pl. 1059. 1753.}

Woody plants, mostly large trees, with milky sap, weak wood, and alternate leaves with interpetiolar stipules. Flowers minute, wholly enclosed in receptacles, the staminate with 1,2 or 3 stamens with short, stout filaments, the pistillate with a sessile 1-celled ovary, the style lateral, the ovule anatropous. Achenes enclosed in the receptacle. [Latin fig.] Some 600 species, of tropical and warm regions. Type species: Ficus Carica L.

Receptacles normally sessile.

Receptacles peduncled.

Leaves $6 \mathrm{~cm}$. long or less, short-petloled.

Leaves $3-10 \mathrm{~cm}$. long, long-petloled.
1. F. aurea.

2. F. jacquinifolia.

3. $F$. brevifolia. 
1. Ficus aùrea Nutt. Sylva 2: 4. 1846.

Ficus sapotaefolia Kunth \& Bouché, Ind. Sem. Hort. Berol. 1846: 17. 1846.

Ficus dimidiata Griseb. Fl. Br. W. I. 151. 1859.

A tree, attaining a maximum height of about $20 \mathrm{~m}$. with a trunk diameter up to $1.2 \mathrm{~m}$., the stout branches spreading, sending down aerial roots which sometimes reach the ground and form secoudary trunks, the thick, nearly smooth bark gray, the stout twigs yellow, glabrous. Leaves oblong or elliptic, firm in texture, $\tilde{0}-10 \mathrm{~cm}$. long, acute or short-acuminate at the apex, narrowed or obtuse at the base, glabrous, the petioles $1-6 \mathrm{~cm}$. long; figs obovoid, sessile (rarely short-stalked), yellow or red, 6-15 mm. in diameter.

Sandy and rocky soil, Abaco, Great Bahama, Berry Islands, Cat Cay, Andros, New Providence. Eleuthera, Cat Island and Great Exuma:- Fiorida ; Cuba ; Hispanlola; Jamaica. GoLdEN WILD FIG. Erroneousiy called BANYAM.

\section{Ficus jacquinifòlia A. Rich. in Sagra, Hist. Cub. 11: 221. 1850.}

A tree up to $15 \mathrm{~m}$. high with a trunk $1 \mathrm{~m}$. in diameter, usually much smaller and sometimes shrubby, the smooth bark pale gray or nearly white, the branches often emitting many aerial roots, the twigs slender, glabrous. Leaves obovate to oblong, coriaceous, $2-6 \mathrm{~cm}$. long, acute or rounded at the apex, narrowed or obtuse at the base, glabrous, finely many-veined, the petioles $2-5 \mathrm{~mm}$. long; figs globose, in pairs or solitary, $3-5 \mathrm{~mm}$. in diameter, on peduncles $2-4$ $\mathrm{mm}$. long, the ostiolum prominent. The leaves of shoots are sometimes considerably larger than those of older branches.

Copplce and pine-lands, Abaco, Great Bahama, Andros, Mangrove Cay, New Providence and Cat Island:- Cuba. Referred to $F$. pertusa L. f., by Hitchcock, Dolley and Mrs. Northrop. SMall-Leaved WiLd Fig.

3. Ficus brevifòlia Nutt. Sylva 2: 3. 1846.

Ficus populnea bahamensis Warb. in Urban, Symb. Ant. 3: 473. 1903.

A tree, reaching a maximum height of about $15 \mathrm{~m}$. with a trunk up to 5 dm. thick, the branches spreading, the smooth bark brownish, the twigs slender, glabrous, or sparingly pubescent when young. Leaves rather thin, glabrous, ovate or oval, 3-10 cm. long, acute or obtuse at the apex, rounded or cordate at the base, the slender petioles $1.5-4 \mathrm{~cm}$. long; figs globose or globose-obovoid, 7-12 $\mathrm{mm}$. in diameter, on peduncles 4-20 $\mathrm{mm}$. long, red when mature, the ostiolum not prominent.

Rocky and sandy soil, throughout the archipelago from Abaco and Great Bahama to Andros, Caicos Islands and Inagua :- Florida: Cuba: Santo Domingo. Closely related to $F$. laevigata Vahl, of Porto Rico and the Lesser Antllies, to which species it was referred by Hitchcock; recorded by Mrs. Northrop as $F$. pedunculata Willd. SHORT-LEAved WILD Fig. Catesby 2: App. pl. 18.

\section{Family 3. URTICÀCEAE Rehb.}

\section{NeTtLe FAMiLy.}

Herbs (some tropical species shrubs or trees), with watery sap, mostly stipulate simple leaves, and small greenish dioecious, monoecious or polygamous flowers, variously clustered. Calyx 2-5-cleft, or of distinct sepals. Petals none. Stamens in the staminate flowers as many as the lobes or segments of the calyx (sepals) and opposite them, the filaments inflexed and anthers reversed in the bud, straightening at anthesis. Ovary superior, 1-celled; style simple; ovule solitary, erect or ascending, orthotropous, or 
in some genera partly amphitropous. Fruit an achene. Endosperm oily, usually not copious; embryo straight. About 40 genera and 550 species of wide geographic distribution.

Herbs with stinging hairs.

Herbs without stinging hairs.

Stigma penicellate.

Stigma not peniceliate.

1. Fleurya.

2. Pilea.

3. Rousselia.

1. FLeURỲA Gaud. Bot. Voy. Freyc. 497. 1830.

Annual herbs, with stinging hairs similar to those of nettles, alternate petioled dentate leaves, and minute clustered monoecious or dioecious flowers. Staminate flowers with a 4-5-parted perianth, 4 or 5 stamens and a rudimentary ovary. Pistillate flowers with 4 imbricated perianth-segments, a somewhat oblique ovary, the stigma papillose; ovule erect. Fruit an oblique achene. [Commemorates J. F. Fleury, French botanist.] About 8 species, of tropical regions. Type species: Fleurya paniculata Gaud.

\section{Fleurya aéstuans (L.) Gaud.; Griseb. Fl. Br. W. I. 154. 1859.}

Urtica aestuans L. Sp. Pl. ed. '2, 1397. 1763.

Erect or ascending, simple or little-branched, 3-9 dm. high, the stinging hairs copious or few. Leaves thin, ovate or ovate-orbicular, $2-12 \mathrm{~cm}$. broad, coarsely and sharply dentate, acute or acuminate at the apex, rounded or subcordate at the base, the petioles 1-10 $\mathrm{cm}$. long; panicles androgynous, shorter than or equalling the leaves, slender-peduncled; achene ovate, compressed, about $2.5 \mathrm{~mm}$. long.

A weed in waste places. New Providence at Nassau and Grant's Town :Haiti to Tortola and Trinidad; Jamaica; continental tropical America. WEST INDiAN NeTtLe. COW-ITCH.

\section{PİLEA Lindl. Coll. $p l .4 .1821$.}

Herbs, with opposite petioled mostly 3-nerved leaves, connate stipules, and small monoecious or dioecious flowers in axillary clusters. Staminate flowers mostly 4-parted (sometimes 2- or 3-parted) and with a rudimentary ovary. Pistillate flowers 3-parted, the segments in most species unequal, each subtending a staminodium in the form of a concave scale; ovary straight; stigma sessile, penicillate. Achene compressed. Seed-coat thin. Endosperm scanty or none. [Name unexplained.] About 160 species, chiefly in the tropies, most abundant in tropical America. Type species: Pilea muscosa Lindl.

Leaves firm, thick or succulent; stems erect.

1. P. microphylla.

Leaves very thin and flaccid, slender-petioled; stems prostrate.

2. $P$. tenerrima.

1. Pilea microphýlla (L.) Liebm. Vid. Selsk. Skr. V. 2: 296.1851.

Parietaria microphylla L. Syst. ed. 10, 1308. 1759.

Pilea muscosa Lindl. Coll. pl. 4. 1821.

Annual or biennial, slender, glabrous. Stems erect or ascending, or sometimes creeping at the base, 5-30 cm. long, fleshy, simple or mostly branched; leaves elliptic or oblanceolate, 4-10 mm. long, acute or acutish at the apex, entire, acuminate at the base, transversely wrinkled; petioles filiform, shorter than the blades; flower-clusters very small, shorter than the petioles; sepals ovate, very thin, acutish; achenes oblong, lenticular.

On walls and in waste rocky places, New Providence, Eleuthera, Great Exuma :-Bermuda; Florida; West Indies; continental tropical America. LACEPLANT. 
2. Pilea tenérrima Miquel, Linnaea 26: 219. 1854.

Stems very slender or nearly filiform, usually tufted, prostrate or nearly so, somewhat fleshy, 3-10 cm. long, more or less branched. Leaves suborbicular or obovate, usually thin and flaccid, the blades 3-6 $\mathrm{mm}$. long, rounded or obtuse at the apex, obliquely narrowed or obtuse at the base, the raphides linear, 0.3-0.5 mm. long, irregularly transverse, the slender petioles 2-5 $\mathrm{mm}$. long; flowers and achenes similar to those of the preceding species of which it may be a slender, small-leaved race.

Crevices of rocks, Andros, Eleuthera, Rum Cay, Long Isiand, Acklin's and South Caicos:-Florida; Cuba; St. Jan; Anegada ; Curaçao; Jamaica. This plant has been confused with $P$. herniarioides (Sw.) Lindl., of wet mountain rocks in Cuba and Jamaica. SMALL LACE-PLANT.

\section{RoussèuIA Gaud. Bot. Voy. Freyc. 503. 1830.}

A low, diffuse, perennial herb, without stinging hairs, the leaves alternate, entire, the small axillary flowers monoecious. Staminate flowers in small racemes, the calyx 4-parted, the stamens 4 , the ovary rudimentary. Pistillate flowers geminate, 2-bracted, sessile, the bracts foliaceous; calyx ovoid, dentate; ovary straight; style filiform, curved, plumose on one side. Achene flat, ovate, acute, surrounded by the bracts. Seed with a membranous testa and scanty endosperm. [Commemorates H. F. A. de Roussel, professor at Caen.] A monotypic genus.

\section{Rousselia hùmilis (Sw.) Urban, Symb. Ant. 4: 205.1905.}

Urtica humilis Sw. Vet. Akad. Stockh. Handl. 6: 34. 1785.

Urtica lappulacea $\mathrm{Sw}$. loc. cit. 8: 69. 1787.

Rousselia lappulacea Gaud. Bot. Voy. Freyc. 503. 1830.

Pubescent; stems slender, branched, prostrate or ascending, 1-4 dm. long. Leaves ovate, membranous, 3 -nerved, $0.5-3 \mathrm{~cm}$. long, acute or obtuse at the apex, rounded at the base; stipules minute; bracts of the pistillate flowers ovate, 3-4 mm. long, entire; achene shining, about $2 \mathrm{~mm}$. long. SELIA.

On rocks, New Providence at Nassau:-Cuba to St. Thomas; Jamaica. Rous-

\section{Order 6. SANTÀLALES.}

Trees, or shrubs, and a few species herbaceous, many of them parasitic on the roots or branches of other plants, with simple, mostly entire leaves, and inconspicuous clustered perfect or imperfect flowers, the corolla present or wanting. Ovary partly or wholly inferior, compound. Stamens as many or twice as many as the sepals or petals. Fruit various. Seeds mostly with fleshy endosperm. A large order, mostly tropical. 


\section{Family 1. LORANTHÀCEAE D. Don.}

\section{Mistletoe Family.}

Parasitic green shrubs or herbs, containing chlorophyll, growing on woody plants and absorbing food from their sap through specialized roots called haustoria '(a few tropical species terrestrial). Leaves in the following genera opposite, in Razoumofskya reduced to opposite seales. Flowers regular, terminal or axillary, dioecious or monoecious, and perianth simple, or in some genera perfect, and with perianth of both ealyx and corolla. Calyx-tube adnate to the ovary. Stamens 2-6. Ovary solitary, erect; style simple or none; stigma terminal, undivided, obtuse. Fruit a berry. Seed solitary, its testa indistinguishable from the endosperm, which is usually copious and fleshy; embryo terete or angled. About 21 genera and 500 species, widely distributed; most abundant in tropical regions.

Perianth of two series of parts; flowers mostly perfect.

Perianth of one series of parts ; flowers imperfect.

1. Dendropemon.

2. Phoradendron.

\section{DENDROPÈMON Blume, in Schultes, Syst. 7: 1729. 1830.}

Parasitic shrubs, with opposite, coriaceous or somewhat fleshy, mostly flat leaves, and small, axillary, bracteolate flowers in simple axillary spikes or racemes, the bractlets connate, cupulate. Calyx-limb truncate or 4-6 toothed, Petals usually 5 or 6 , small. Stamens short, borne at the base of the petals; anthers dorsifixed. Style short; stigma terminal. Fruit a small, fleshy berry. [Greek, injurious to trees.] About 15. species, natives of the West Indies. Type species: Loranthus parvifolius $\mathrm{Sw}$.

Plants glabrous, not scaly.

Leaves long-petloled; berry oblong to obovoid.

Leaves subsessile; berry subglobose.

Inflorescence scaly.

Leaves mostly acute; twigs angular; inflorescence densely scaly.

Leaves rounded, emarginate or cuspidulate; twigs terete; inflorescence lightly scaly.

1. D. purpureus.

2. D. brevipes.

3. D. bahamensis.

4. D. emarginatus.

1. Dendropemon purpùreus (L.) Krug \& Urban, Bot. Jahrb. 24: 26. 1897.

Viscum purpureum L. Sp. Pl. 1023. 1753.

Loranthus uniflorus A. Rich. Ess. Fl. Cub. 648. 1845. Not. Jacq. 1760.

Smooth, not at all scaly; branches $2-4 \mathrm{dm}$. long, a little flattened when young, soon terete. Leaves obovate or oblanceolate, 3-6 cm. long, obtuse, subtruncate or acute at the apex and usually mucronulate, rarely retuse, narrowed at the base, the petioles 3-12 $\mathrm{mm}$. long; racemes glabrous, several-manyflowered, as long as the leaves or shorter, the peduncles somewhat flattened; pedicels 1-3 mm. long; bractlets connate to about the middle; flowers reddish; berry obovoid-cylindric, blue-black, or red, or black with a red base, 5-8 mm. long.

On trees, Andros, New Providence, Calcos:-Cuba; Hispaniola; Porto Rico. Catesby $2: p l$. 95 . SMOотH Mistletoe.

\section{Dendropemon brévipes Britton, sp. nov.}

Smooth throughout, not at all scaly; young branches slightly flattened, the older terete, $3 \mathrm{dm}$. long or less. Leaves oval to elliptic-obovate, dull green, 
2.5-4 cm. long, 1-2 cm. wide, rounded or minutely apiculate at the apex, narrowed at the base, the midvein prominent on the under side, the lateral venation obscure, the petioles about $0.5 \mathrm{~mm}$. long; inflorescence peduncled, fewflowered, short-racemose; peduncles about one-half as long as the leaves; pedicels 3 or $4 \mathrm{~mm}$. long; bractlets connate to about the middle; calyx truncate; fruit subglobose, bluish purple, 8-9 $\mathrm{mm}$. in diameter.

On Swietenia Mahagoni, Long Island near Clarence Town on Galloway Road Britton \& Millspaugh 6324.) SHORT-STALKED MISTLETOE,

\section{Dendropemon bahaménsis Britton, sp. nov.}

Similar to $D$. emarginatus, but the twigs strongly angled, not scaly. Leaves ovate-elliptic to elliptic-obovate, $5 \mathrm{~cm}$. long or less, $1.5-3 \mathrm{~cm}$. wide, acute, acutish or rounded at the apex, narrowed at the base; petioles stout, about $2 \mathrm{~mm}$. long; rachis of the inflorescence densely white-scaly, $3 \mathrm{~cm}$. long or less; calyx densely white-scaly, broadly triangular, $3 \mathrm{~mm}$. long in fruit, its teeth broadly triangular, horny, glabrous; ripe fruit eylindric with a conic apex, red-brown, $9 \mathrm{~mm}$. long, $5 \mathrm{~mm}$. thick.

On Lysiloma Sabicu, Nassau, New Providence (Britton and Brace 269, type: Brace $342 \%$ ); on the same host, Haynes Road, Great Exuma (Britton d Millspaugh 2975 ) : on Conocarpus erecta, Georgetown, Great Exuma (Britton \& Millspaugh 2906). Presumably recorded by Dolley as Loranthus parviforus Sw. BAHAMA Mistletoe.

4. Dendropemon emarginàtus (Sw.) Steud. Nomencl. ed. 2, 491. 1841.

Loranthus emarginatus Sw. Prodr. 58. 1788.

Dendropemon emarginatus lepidotus Krug \& Urban, Bot. Jahrb. 24: 25. 1897.

Stems rather stout, terete, 3-4 $\mathrm{dm}$. long, the twigs terete or very nearly so, usually scaly. Leaves obovate or elliptic-obovate, $2-7 \mathrm{~cm}$. long, rounded or emarginate at the apex, narrowed or cuneate at the base, the petioles 2-6 $\mathrm{mm}$. long; inflorescence scaly, several-flowered, $2-5 \mathrm{~cm}$. long, the peduncles terete or slightly angular, the pedicels $1 \mathrm{~mm}$. long or less; bracts connate; calyx more or less scaly, its teeth short; berry cylindric, $6-8 \mathrm{~mm}$. long, black, or red with a black base.

On Ficus and Elaphrium Simaruba, Andros:-Cuba; Hispaniola. ScALY Mistletoe.

2. PHORADÉNDRON Nutt. Journ. Acad. Phila. II. 1: 185. 1848.

Shrubs, parasitic on trees, mostly brittle at the nodes, with opposite coriaceous flat leaves, sometimes reduced to scales (cataphyls), terete or angled twigs, and monoecious or äioecious axillary spicate bracted small flowers, solitary or several in the axil of each bract. Staminate flowers with a 3-iobed (rarely 2-4-lobed) calyx, bearing a sessile transversely 2-celled anther at the base of each lobe. Pistillate flowers with a similar calyx adnate to the ovoid inferior ovary; style short; stigma obtu'se or capitate. Fruit a sessile fleshy berry. Endosperm copious. [Greek, tree-thief, from its parasitic habit.] Over 200 species, all American. Type species: Phoradendron californicum Nutt.

Branches distinctly tetragonal ; leaves scarcely petioled or shortpetioled

Leaves oblanceolate to spatulate or oblong-spatulate; pet1oles $3-8 \mathrm{~mm}$. long.

Leaves obovate to obovate-elliptic, $5 \mathrm{~cm}$. long or less, petioles 1-2 mm. long.

Branches terete or nearly so ; leaves distinctly petioled.

Leaves ovate, lanceolate or elliptic, blunt at the apex; berry white.

Leaves obovate, rounded or retuse at the apex; berry red.

1. P. rubrum.

2. $P$. trinervium.

3. $P$. racemosum.

4. P. Northropiae. 
1. Phoradendron rùbrum (L.) Griseb. Fl. Br. W. I. 314. 1860.

Viscum rubrum L. Sp. Pl. 1023. 1753.

Phoradendron spathulifolium Krug \& Urban, Bot. Jahrb. 24: 41.1897.

Branches slender, $5 \mathrm{dm}$. long or less, pseudodichotomous, bearing 2-4 blunt eataphyls near the base, the internodes short, 4-angled, upwardly somewhat enlarged. Leaves oblanceolate to oblong-spatulate, $2-7 \mathrm{~cm}$. long, obtuse at the apex, narrowed or cuneate at the base, scarcely petioled; spikes usually several together, $2 \mathrm{~cm}$. long or less, 2-3-jointed, the joints about 12 -flowered; berry subglobose, about $4 \mathrm{~mm}$. in diameter, smooth, red or sometimes yellow.

On trees, especially mahogany, Abaco, New Providence, Cat Island, Long Island, Fortune Island, Acklin's Island, Crooked Island, Mariguana, Inagua :-Cuba. Catesby, $2: p l$. 81 . Recorded as Phoradendron tetrastichum Griseb. by Hitchcock. NarROW-LEAVED MISTLETOE.

\section{Phoradendron trinérvium (Lam.) Griseb. Fl. Br. W. I. 314.1860.}

Viscum trinervium Lam. Encyc. 3: 57. 1789.

Branches slender, 3-5 $\mathrm{cm}$. long, pseudodichotomous, bearing 1 or 2 pairs of eataphyls near the base, the internodes $3-5 \mathrm{~cm}$. long, 4-angled. Leaves obovate or elliptic-obovate, $2-5 \mathrm{~cm}$. long, rounded at the apex, narrowed or subcuneate at the base, scarcely petioled; spikes usually clustered, 1-2 cm. long, $2-3$-jointed, the joints usually 6 -flowered or 8-flowered; berry oblong when young, subglobose, smooth, orange and 3-4 mm. in diameter when mature.

On various trees, Watling's Island, Great Ragged Island, Acklin's Island:Porto Rico and St. Thomas to Trinidad; Jamaica. Closely related to the preceding species. ANGLEd Miśt T́LETOE.

3. Phoradendron racemòsum (Aubl.) Krug \& Urban, Bot. Jahrb. 24: 46. 1897.

Viscum racemosum Aubl. Pl. Guian. 2: 895. 1775.

Branches elongated, rather stout, 3-6 dm. long, most of the joints bearing 1-3 pairs of cataphyls, the internodes terete or nearly so, somewhat enlarged above, $7-15 \mathrm{~cm}$. long. Leaves various, lanceolate or elliptic or orbicular, 5-16 $\mathrm{cm}$. long, pinnately veined, rounded or obtuse at the apex, abruptly narrowed into winged petioles 1-2 cm. long; spikes often clustered, 3-7 cm. long, 3-5jointed, the long joints several-many-flowered; berry ellipsoid, white, about $4 \mathrm{~mm}$. long.

On Ocotea, Andros at Deep Creek :-Cuba; Hispaniola: Porto Rico: northern South America. Erroneously called Snakeroot. Broad-Leaved Mistletoe. Big MAN.

4. Phoradendron Northròpiae Urban; Northrop, Mem. Torr. Club 12: 33, pl. 4. 1902.

Dichotomously or trichotomously branched, 2-4 $\mathrm{dm}$. long, the subterete branches glabrous, $3-5 \mathrm{~mm}$. thick, usually with eataphyls in all joints, the internodes 4-10 cm. long. Leaves obovate, thick, 3-7 cm. long, 2.5-4 cm. wide, rounded, subtruncate or emarginate at the apex, narrowed at the base, very indistincty few-veined, the petioles 3-7 mm. long; spikes several or numerous at the nodes, $2.5 \mathrm{~cm}$. long or less, short-peduncled, 4-6-jointed; joints 8-18flowered, subfusiform, rather thick; berry subglobose, red.

On Mimusops, Andros, at Conch Sound and Lisbon Creek:-Endemic. Mrs. NorTHROP'S MISTLETOE. 


\section{Family 2. OLACÀCEAE Lindl.}

\section{OLax FamiLy.}

Shrubs, trees or woody vines, mostly with alternate and entire, pinnately veined, estipulate leaves, and regular perfect or polygamous flowers in axillary clusters. Calyx 4-6-toothed or 4-6-parted. Corolla 4-6-lobed or of $4-6$ distinct petals. Disk various. Stamens $4-12$; filaments distinct or rarely monadelphous; anthers 2-celled. Ovary 1-3-celled, inferior, halfsuperior, or partly immersed in the disk; ovules few, anatropous; style short, usually simple; stigma entire or 2-5-lobed. Fruit drupaceous, 1celled. Testa of the seed membranous; endosperm fleshy, or rarely wanting. About 25 genera and 140 species, mostly tropical.

Petals united to above the middle.

Petals nearly separate.
1. Schoepfia.

2. Ximenia.

\section{SCHOEेPFIA Schreb.; Gmel. Syst. 376. 1791.}

Glabrous trees or shrubs, with coriaceous entire leaves and small perfect flowers in axillary cymes. Calyx very small, 4-toothed. Petals united to above the middle, forming a tubular or urceolate, 4-6-lobed corolla, the lobes valvate, recurved. Stamens as many as the corolla-lobes and opposite them; filaments filiform or short; anthers didymous. Ovary sessile, 3-celled, partly immersed in the disk; style slender or short; stigma capitate or 3-lobed; ovules usually 1 in each cavity. Fruit a small drupe nearly enclosed by the acerescent disk. [Commemorates J. D. Schoepf, 1752-1800, German botanist.] About 15 species, of tropical and subtropical America and Asia. Type species: Schoepfia Schreberi Gmel.

\section{Leaves obovate, obtuse.}

Leaves ovate, elliptic or lanceolate, acute.
1. S. obovata.

2. S. chrysophylloides.

1. Schoepfia obovàta C. Wright; Sauv. Anales Acad. Habana 5: 289. 1868.

A glabrous shrub 1-3 m. high, or sometimes a tree up to $10 \mathrm{~m}$. high, the twigs slender, gray, the bark rough in narrow plates. Leaves obovate, oblong or elliptic, coriaceous, $2-4 \mathrm{~cm}$. long, rounded or obtuse at the apex, narrowed or cuneate at the base, few-veined, the petioles 1-3 $\mathrm{mm}$. long; peduncles solitary or few together in the axils, 2-8 mm. long, 1-3-flowered; flowers sessile; corolla ovoid-cylindric, 4-5 mm. long, red to greenish yellow, the lobes ovate or triangular-ovate; fruit globose-obovoid to ellipsoid, 5-8 $\mathrm{mm}$. long; fruit yellow or red when mature.

Thickets and copplces, Abaco, Great Bahama, New Providence, Mariguana and Acklin's :-Cuba ; Hispaniola ; Porto Rico; Anegada. Referred to by Mrs. Northrop as Elaeodendron xylocarpum. WHITE BEEFWOOD.

2. Schoepfia chrysophylloìdes (A. Rich.) Planch. Ann. Sci. Nat. IV. 2: 261. 1854.

Diplocalyx chrysophylloides A. Rich. in Sagra, Hist. Cub. 11: 81. 1850.

A shrub or small tree sometimes up to $8 \mathrm{~m}$. high, with crooked branches and slender glabrous twigs. Leaves subcoriaceous, ovate to lanceolate, $2-6 \mathrm{~cm}$. long, acute or obtusish at the apex, narrowed at the base, glabrous, the margined petioles 4-8 mm. long; flowers solitary or 2 or 3 together in the axils, reddish; calyx about $2 \mathrm{~mm}$. long; corolla narrowly campanulate, about 
$4 \mathrm{~mm}$. long, its lobes reflexed; stamens 4 , borne at the base of the corollalobes, the anthers sessile; drupe ovoid or oval, scarlet, 10-12 mm. long, nearly enclosed by the accrescent calyx.

Coppices, scrub-lands and pine-lands, Abaco, Great Bahama, Andros and Eleuthera :-Fiorida ; Cuba ; Jamaica. WHITt Wood.

\section{XIMÈNIA L. Sp. Pl. 1193. 1753.}

Spinescent shrubs or trees, with entire, often fascicled leaves and small white or yellow, perfect axillary, solitary or cymose flowers. Calyx very small, 4-5-toothed. Petals 4 or 5, united only at the base, coriaceous, valvate, pubescent on the inner side. Stamens 8-10, the filaments filiform, the anthers linear. Ovary 3-celled; style simple; stigma subcapitate; ovules 3 or 4 in each cavity. Drupe with a fleshy exocarp and a woody or crustaceous stone. Embryo of the seed very small. [Commemorates Francesco. Ximenes, a Spanish naturalist.] About 5 species, of tropical distribution, the following typical.

1. Ximenia americàna L. Sp. Pl. 1193. 1753.

Ximenia inermis L. Sp. Pl. ed. 2, 497. 1762.

A thorny shrub or small tree, rarely $6 \mathrm{~m}$. high, with reddish smooth astringent bark, the slender branches spreading. Leaves oblong to orbicular, subcoriaceous, 3-7 cm. long, obtuse or emarginate at the apex, narrowed or rounded at the base, sparingly pubescent when young, mostly glabrous when old, the slender petioles 5-10 mm. long; clusters 2-4-flowered, much shorter than the leaves; calyx about $1 \mathrm{~mm}$. long; corolla-lobes linear, reflexed, $1 \mathrm{~cm}$. long; drupe yellow or red, 12-17 $\mathrm{mm}$. in diameter.

Coastal white-lands and coppices, New Providence, Conception Island, Long Island, Fortune Island, Crooked Island, Caicos and Cay Sal:-Florida: Cuba to Porto Rico and Martinique; Jamaica; Mexico and South America ; Old Worid tropics. When growing on sand dunes this shrub is much depressed and has neariy orbicular, fleshy leaves; when growing in coppices or scrub-lands it is tall, with elongated oblong to oblanceolate leaves. TALLOW Wood. SPANish PLUM.

\section{Order 7. ARISTOLOCHIÀLES.}

Herbs or vines, mostly with cordate or reniform leaves and perfect flowers. Calyx inferior, its tube wholly or partly adnate to the ovary. Corolla none. Ovary several- (mostly 6-) celled. Only the following family.

\section{Family 1. ARISTOLOCHIÀCEAE Blume.}

\section{Birthwort FAMILY.}

Acaulescent plants, or with erect or twining stems. Leaves alternate, often basal, estipulate. Flowers regular or irregular, sometimes clustered. Calyx-limb 3-6-lobed or irregular. Stamens 6-many, adnate to the pistil; anthers 2-celled, their saes longitudinally dehiscent. Ovules numerous in each cavity, anatropous, horizontal or pendulous. Fruit a many-seeded 6-celled capsule. Seeds angled or compressed, with a crustaceous testa and usually with a fleshy or dilated raphe; endosperm fleshy, copious; embryo minute. Six genera and about 200 species of wide distribution in tropical and temperate regions. 


\section{ARISTOLÒCHIA L. Sp. Pl. 960. 1753.}

Perennial herbs or twining vines. Leaves alternate, mostly petioled, or entire, 3-7-lobed cordate or auriculate palmately nerved. Flowers irregular. Calyx adnate to the ovary, at least to its base, the tube usually inflated around the style and contracted at the throat, the limb spreading or reflexed, entire, 3-6-lobed or appendaged. Stamens mostly 6 ; anthers adnate to the short style or stigma, 2-celled, the sacs longitudinally dehiscent. Ovary mostly 6-celled with 6 parietal placentae. Style 3-6-lobed. Capsule naked, septicidally 6-" valved. Seeds very numerous, horizontal, compressed. [Named for its sup[osed medicinal properties.] About 180 species, widely distributed in tropica] and temperate regions. Type species: Aristolochia rotunda $\mathrm{L}$.

Leaves cordate; fruits short-peduncled; peduncles leafy-bracted.

Leaves sagittate to hastate; fruits slender-peduncled; peduncles not bracted.

1. A. pentandra.

2. A. passifloraefolia.

\section{Aristolochia pentándra Jacq. Enum. 30. 1760.}

Stems loosely pubescent or glabrate, trailing or low-climbing, branched, 3 $\mathrm{m}$. long or less. Leaves rather fleshy, glabrous or nearly so, broadly ovate, 4-10 cm. long, entire or 3-lobed, acute or acuminate at the apex, cordate at the base, the slender petioles 1-4 cm. long; peduncles solitary in the axils, shorter than the petioles, leafy-bracted at about the middle, the bract ovate, cordate, sessile, 1-3 cm. long; ovary and calyx pubescent; calyx $2-3 \mathrm{~cm}$. long, expanded to one side, the limb acuminate, veined; stamens 5 ; capsule globose, $1.5-2 \mathrm{~cm}$. in diameter, usually longer than the peduncle.

Maritime sand plains, Abaco, Great Bahama, New Providence, Andros, Eleuthera, Watling's and Long Island:- E'orida; Cuba. CoAstal AristolochiA. Pitcher-plant.

2. Aristolochia passifloraefòlia A. Rich. in Sagra, Hist. Cub. 11: 195. 1850.

A glabrous vine, sometimes becoming $3 \mathrm{~m}$. long, usually not more than 1 m., usually climbing, the stem slender. Leaves sagittate or auriculate to hastate, various, 3-6 $\mathrm{cm}$. long, acute, obtuse or acuminate at the apex, the basal auricles rounded, the petiole shorter than the blade; peduncles solitary in the axils, as long as the leaves or shorter, not bracted; ealyx $3-4 \mathrm{~cm}$. long, brownpurple or greenish yellow, its base obliquely inflated, its tube slender, curved, its limb suborbicular, bearing slender processes $6-10 \mathrm{~mm}$. long; capsule oblong or oblong-globose, 1-2 cm. long.

Pine-lands and scrub-lands, Andros, New Providence and Great Exuma:-Cuba. Slender ARISTOLOCHIA.

\section{Order 8. POLYGONÀLES.}

Herbs, twining vines, shrubs or trees, with alternate, or sometimes opposite or whorled, simple mostly entire leaves, jointed stems, and usually sheathing united stipules (ocreae). Flowers small, regular, perfect, dioecious, monoecious or polygamous. Petals none. Calyx inferior, 2-6-cleft or 2-6-parted, the segments or sepals more or less imbricated, sometimes petaloid, sometimes developing wings in fruit. Stamens 2-9, inserted near the base of the calyx; filaments filiform or subulate, often dilated at the base, distinct or united into a ring; anthers 2-celled, the sacs longitudinally dehiscent. Ovary superior, 1-celled; ovule solitary, orthotropous, erect or 
pendulous; style 2-3-cleft or 2-3-parted, sometimes very short; stigmas capitate or tufted, rarely 2-eleft; fruit a lenticular 3 -angled or rarely 4angled achene, usually invested by the persistent calyx; endosperm mealy; cotyledons accumbent or incumbent; embryo straight or nearly so. Only the following family.

\section{Family 1. POLYGONÀCEAE Lindl.}

\section{Buckwheat FAMILF.}

About 40 genera and 800 species, of wide geographic distribution.

Herbaceous plants.

Erect or ascending herbs.

Ocreae cylindric, truncate.
Ocrea oblique.

Vines; racemes terminating in tendrils.

Trees and shrubs.

1. Persicaria.

2. Fagopyrum.

3. Antigonon.

4. Coccolobis.

\section{PERSICÀRIA [Tourn.] Mill. Gard. Dict. Abr. ed. 4. 1754.}

Herbs, with alternate entire leaves, cylindric ocreae, and flowers in slender spike-like racemes, the ocreolae funnelform, the short pedicels jointed at the base of the calyx. Sepals mostly 5, neither winged nor keeled. Stamens 4-8, included or exserted, the filaments erect or nearly so. Styles 2 or sometimes 3, usually partly united; stigmas capitate. Achene lenticular, or sometimes §-angled, usually black. Endosperm horny; cotyledons accumbent. [From Fersica, the leaves resembling those of the peach.] About 125 species, widely distributed. Type species: Polygonum Persicaria L.

Ocreae ciliate.

Flower clusters contiguous.

Flower clusters separated. Ocreae ecillate.
1. P. hydropiperoides.

2. $P$. punctata.

3. P. portoricensis.

1. Persicaria hydropiperoides (Michx.) Small, Fl. SE. U. S. 378. 1903.

Polygonum hydropiperoides Michx. Fl. Bor. Am. 1: 239. 1803.

Perennial, strigillose; stem erect, decumbent or prostrate, slender, 3-9 dm. long. Leaves narrowly lanceolate or oblcng-lanceolate, varying to linearlanceolate, 5-15 $\mathrm{cm}$. long, short-petioled, acute at apex, ciliate, pubescent with appressed hairs on the midrib beneath; ocreae cylindric, loose, strigose, fringed with long bristles; racemes panicled, terminal, erect, narrow, more or less interrupted, 3-7.5 cm. long; calyx pink or greenish; stamens 8 ; style 3-parted to below the middle; achene 3 -angled, ovoid or oblong, $2-2.5 \mathrm{~mm}$. long, smooth, shining.

Water-holes, Great Bahama at West End:-Continental North America south to Florida and California. MILD WATER PEPPER.

2. Persicaria punctàta (Ell.) Small, Fl. SE. U. S. 379. 1903.

Polygonum punctatum Ell. Bot. S. C. \& Ga. 1: 455. 1817.

Polygonum acre H.B.K. Nov. Gen. 2: 179. 1817. Not Lam. 1778.

Annual or perennial, glabrous or very nearly so ; stem erect or ascending, rarely prostrate, simple or branched, 3-12 dm. long. Leaves lanceolate or oblong-lanceolate, 3-20 cm. long, acuminate at both ends, petioled, ciliate, conspicuously punctate, acrid, the midrib often with a few scattered hairs; ocreae 
cylindric, fringed with long bristles falling away at maturity, racemes narrow, erect or slightly drooping, loosely-flowered, 2-8 cm. long; calyx greenish; stamens 8 ; style 2-3-parted to the base; achene oblong, thick, lenticular or 3 angled, $2.5 \mathrm{~mm}$. long, smooth, shining.

Swampy ground, Andros, along road to Morgan's Biuff :-Bermuda : temperate and tropical continental America; Cuba to Trinidad; Jamaica. WATER SMARTWEeD.

\section{Persicaria portoricénsis (Bert.) Small, Fl. SE. U. S. 377. 1903.}

Polygonum portoricense Bert.; Small, Mem. Bot. Col. Coll. 1: 46.1895.

Polygonum glabrum C. \& S. Linnaea 3: 46. 1828. Not Willd. 1799.

Perennial, more or less scurfy ; stem erect, decumbent or floating, 1-1.5 m. long or longer, branched, enlarged at the nodes. Leaves lanceolate or linearlanceolate, 4-30 cm. long, acuminate at both ends, obscurely punctate, shortpetioled, the nerves prominent beneath; ocreae cylindric, sometimes bristly when young, naked when mature, sometimes hispid; racemes narrow, panicu. late, often in pairs, $2.5-13 \mathrm{~cm}$. long, dense, erect; calyx white or whitish, 5parted to near the base; stamens 6-8, included; style 2-3-cleft, somewhat exserted; achene lenticular and strongly biconvex or 3 -angled, $2-3 \mathrm{~mm}$. long, broadly oblong, orbicular or even broader than high, black, smooth and shining, or minutely granular.

Fresh water swamps and water-holes, Great Bahama, Andros, New Providence, Great Exuma and Cat Island:- southern United States to Mexico and northern South America; Cuba to Martinique; Jamaica. Dense-Flowered Persicaria.

\section{FAGOPỲRUM Gaertn. Fr. \& Sem. 2: 182. 1791.}

Annual or perennial, rather fleshy, usually glabrous leafy herbs, with erect striate or grooved stems. Leaves alternate, petioled, hastate or deltoid, with oblique, cylindric or funnelform ocreae. Flowers small, white or green, in terminal or axillary, usually paniculate racemes, perfect, borne solitary or several together from each ocreola, slender-pedicelled. Calyx about equally 5parted, persistent and unchanged in fruit, the segments petaloid, shorter than the achene. Stamens 8; filaments filiform, glabrous. Ovary 1-celled, 1 ovuled; style 3-parted; stigmas capitate. Achene 3-angled. Embryo central, dividing the mealy endosperm into two parts; cotyledons broad. [Greek, beech-wheat, from the similarity of the grain.] About 6 species, native of Europe and Asia. Type species: Fagopyrum tataricum Gaertn.

\section{Fagopyrum Fagopỳrum (L.) Karst. Deutsch. Fl. 522. 1880-83.}

Polygonum Fagopyrum L. Śp. P1. 364. 1753.

Fagopyrum esculentum Moench, Meth. 290. 1794.

Annual, glabrous except at the nodes, stem 3-9 dm. high. Leaves hastate, 2.5-7.5 cm. long, abruptly narrowed above the middle, acuminate, the nerves on the lower surface slightly. scurfy; ocreae brittle and fugacious; racemes mostly panicled, sometimes corymbose, many-flowered, erect or inclined to droop; pedicels as long as the calyx; calyx-segments white or whitish; stamens included; style-branches deflexed in fruit; achene acute, $5 \mathrm{~mm}$. long, about twice as long as the calyx, its faces pinnately-striate when mature, the angles acute, not crested.

Waste grounds, New Providence:-native of eastern Europe or western Asia. Widely distributed through cultivation. BUCKWHEAT. 


\section{ANTÍGONON Endl.; H. \& A. Bot. Beech. Voy. 308. 1838.}

Vines with alternate petioled cordate entire leaves, the petiole-bases clasping, and small flowers in racemes opposite the leaves or clustered at the summit, the racemes terminating in tendrils. Sepals 5, unequal, the 3 outer ones cordate, ovate, the 2 inner ones oblong. Stamens 8 , equal, the filaments subulate, connate at the base. Ovary 3 -angled; ovule erect; styles 3 , recurved. Achene enclosed in the accrescent calyx. [Greek, opposite the nodes.] Three or four species native of Mexico and Guatemala, the following typical.

\section{Antigonon léptopus H. \& A. Bot. Beech. Voy. 308. 1838.}

Herbaceous, climbing, branched, often $5 \mathrm{~m}$. long or longer, finely pubescent at least above. Leaves thin, broadly ovate, $3-9 \mathrm{~cm}$. long, puberulent, acuminate at the apex, rather deeply cordate at the base, the petioles 1-5 cm. long; racemes several or many, loosely several-flowered, the floriferous part 3-8 $\mathrm{cm}$. long, the tendril as long or shorter; pedicels slender, $10 \mathrm{~mm}$. long or less; flowering calyx pink or sometimes white, about $5 \mathrm{~mm}$. long; fruiting calyx 1-1.5 $\mathrm{cm}$. long, the sepals strongly veined.

Roadways and waste ground, spontaneous after cultivation, New Providence near Nassau :-Cuba to Martinique, and in Jamaica. Native of Mexico. Corallina.

4. COCCOLòbis P. Br. Civ. \& Nat. Hist. Jam. 209. 1756.

Shrubs or trees, with alternate entire leaves, the ocreae cylindric or funrelform, often very small, the small, usually green flowers racemose or spicate, subtended by minute bracts and ocreolae. Calyx-tube accrescent, enclosing the achene, its lobes 5 . Stamens 8 , the filaments slender. Ovary 3-angled; ovule erect; styles 3. Fruit ovoid or globose, the accrescent calyx-tube becoming fleshy and more or less adherent to the achene. Seed-coat thin; endosperm mealy. [Greek, referring to the adherent calyx.] Over 125 species of tropical and subtropical distribution, all American. Type species: Polygonum Uvifera $\mathrm{L}$.

Elowering pedicels $1 \mathrm{~mm}$. long or longer.

Leaves very large, suborbleular, or broader than long, 7-20 cm. wide.

Leaves (except those of shoots) $6 \mathrm{~cm}$. wide or less, ovate to

1. C. Uvifera.

elliptic, obovate or orbicular.

Leaves not reticulate-veined above.

Leaves coriaceous; racemes erect or spreading; fruit 7-10 mm. long.

Leaves chartaceous; racemes long, drooping; fruit about $4 \mathrm{~mm}$. long.

Leaves prominentiy reticulate-veined on both sides when old.

Flowering pedicels less than $1 \mathrm{~mm}$. long.

Inflorescence longer than the leaves, which are fineiy reticulate-veined above.

Inflorescence shorter than the leaves. which are very indistinctly veined above.

2. C. laurifolia.

3. C. bahamensis.

4. C. Northropiae.

5. C. diversifolia.

6. C. Krugii.

1. Coccolobis Uvifera (L.) Jacq. Enum. 19. 1760.

Polygonum Uvifera L. Sp. Pl. 365. 1753.

Coccolobis leoganensis Jacq. Enum. 19. 1760.

A tree, exceptionally up to $15 \mathrm{~m}$. high with a trunk $1 \mathrm{~m}$. in diameter, usually not over $6 \mathrm{~m}$. high, the branches spreading, the smooth bark brown, the twigs stout, finely pubescent when young, soon glabrous. Leaves orbicular or broader than long, coriaceous, $7-20 \mathrm{~cm}$. broad, cordate at the base, very short- 
petioled, their sheaths $1 \mathrm{~cm}$. long or less; flowers numerous, white, in dense narrow glabrous racemes 7-12 $\mathrm{cm}$. long; pedicels $3-4 \mathrm{~mm}$. long; calyx white, about $6 \mathrm{~mm}$. broad, its lobes ovate, rounded; fruits forming drooping clusters somewhat resembling bunches of grapes, globose, purple, 1-2 $\mathrm{cm}$. in diameter, the pulp thin, astringent.

Coastal thickets, throughout the archipeiago from Abaco and Great Bahama to Grand Turk, Inagua, Anguilla Isles and Water Cay:-Bermuda; Florida; West Indies; coasts of tropical continental America. SeA Grape. Catesby, $2: p b, 96$.

\section{Coccolobis laurifòlia Jacq. Hort. Schoen. 3: 9.1797.}

A tree, up to $20 \mathrm{~m}$. high, with a trunk sometimes $7 \mathrm{~m}$. thick, usually much smaller, and often shrubby, the thin gray bark brown mottled, the twigs and leaves glabrous. Leaves ovate, elliptic or obovate, coriaceous, obtuse or acute at the apex, rounded at the base, 4-12 cm. long, or those of young shoots larger, the petioles 5-20 mm. long, the sheaths short; racemes slender, 5-10. $\mathrm{cm}$. long; pedicels 5-8 $\mathrm{mm}$. long; calyx greenish about $5 \mathrm{~mm}$. broad, its lobes suborbicular; fruits subglobose, red, acid, 8-10 mm. in diameter.

Scrub-lands and coppices, throughout the archipelago from Abaco and Great Bahama to Caicos and Inagua :-Florida; Cuba to St. Croix; Jamaica. Very various in size and shape of leaves, the species evidently composed of numerous races, one of which was recorded in Mrs. Northrop's Flora as the Cuban $C$. Wrightii Lindau, a different species ; and another as $C$. tenuifolia L., as also recorded by Dolley and by him also as $C$. punctata L. Pigeon-Plum. Catesby, $2: p l$. 94.

3. Coccolobis bahaménsis Britton, Bull. N. Y. Bot. Gard. 4: 116.1905.

A glabrous shrub, $4 \mathrm{~m}$. high or less. Leaves thin-coriaceous, elliptic to ovate or obovate-elliptic, obtuse to acutish at the apex, obtuse, somewhat narrowed, or subcordate at the inequilateral base, 4-7 cm. long, $5 \mathrm{~cm}$. wide or less, the primary veins 6-8 on each side, minutely but strongly reticulate-nerved on both surfaces, dull, the upper surface bright green, the lower surface paler; petioles 3-5 $\mathrm{mm}$. long; racemes very slender, numerous, recurved-drooping, finely puberulent when very young, in fruit glabrous; pedicels $1 \mathrm{~mm}$. long in fruit, much longer than the ocreolae; flowers bright white, $3-4 \mathrm{~mm}$. broad; sepals oval, obtuse, about as long as the stamens; fruit ovoid, narrowed at the base, bluntish at the apex, $6 \mathrm{~mm}$. long, 3-4 mm. thick, faintly several-ribbed, not coronate.

Coppices, pine-lands and scrub-lands, Andros, New Providence, Great Exuma, Eleuthera, Acklin's Island, Watling's Island, Inagua. Endemic. Reported by Lindau and by Mrs. Northrop as C. obtusifolia Jacq. BaHAMA PIGEON-PLUM.

\section{Coccolobis Northròpiae Britton, sp. nov.}

A shrub, or a tree up to $4 \mathrm{~m}$. high, the bark rough, the twigs and leaves glabrous. Leaves orbicular to obovate or obovate-orbicular, 3-5 cm. long, chartaceous or subcoriaceous, obtuse, rounded or acutish at the apex, narrowed or obtuse at the base, retiulate-veined on both sides when old, the petioles 3-6 $\mathrm{mm}$. long, the ocreae short; racemes mostly as long as the leaves or longer, the rachis puberulent or glabrous; pedicels '2-3.5 mm. long, solitary or 2 or 3 together; perianth about $3 \mathrm{~mm}$. long; ocreolae obliquely truncate, about $1 \mathrm{~mm}$. long; fruit ovoid, about $5 \mathrm{~mm}$. long, short-coronate, the exocarp fleshy.

Coppices and white-lands, Andros, New Providence, Eleuthera and Great Exuma. Type collected near Nassau, New Providence, by A. H. Curtiss in 1903. Referred by Mrs. Northrop to $C$. retusa Griseb. Northrop's PIGEON-PLUM.

\section{Coccolobis diversifòlia Jacq. Enum. 19. 1760.}

A tree up to 10-12 m. high, the bark gray, the many twigs short, glabrous or nearly so. Leaves ovate to elliptic or elliptic-obovate, coriaceous, glabrous, 4-10 cm. long, rounded or obtuse at the apex, obtuse, subcordate, or some of them narrowed at the base, reticulate-veined on both sides, the rather stout 
petioles 8-15 $\mathrm{mm}$. long; ocreae appressed, as long as the petioles or shorter; inflorescence spicate, slender, longer than the leaves; flowers green, very nearly sessile, 2-2.5 mm. long; fruit ovoid, pointed, 6-10 mm. long, coronate, the peri. carp slightly fleshy.

Scrub-lands, plne-lands and coppices, throughout the archlpelago from Abaco and Great Bahama to Calcos Islands and Inagua:-Hispaniola to Porto Rico, Virgin Gorda and Barbadoes; Jamaica, Aruba; Curaço; Bonaire. Leaves and fruit smaller than in specimens from the Windward Islands. TIE-TONGUE.

6. Coccolobis Krùgii Lindau, Bot. Jahrb. 13: 145. 1890.

A glabrous shrub or small tree, sometimes about $8 \mathrm{~m}$. high, the slender twigs short and numerous, the bark smooth, gray. Leaves broadly ovate or nearly orbicular, light green, subcoriaceous, rounded or obtuse at the apex, cordate or subcordate at the base, $6 \mathrm{~cm}$. long or less, inconspicuously veined above, densely finely reticulate-veined beneath, the rather stout petioles 4-8 $\mathrm{mm}$. long, the ocreae appressed, short; spikes very slender, glabrous, mostly as long as the leaves or shorter, loosely flowered; pedicels less than $0.5 \mathrm{~mm}$. long; perianth green, about $1.5 \mathrm{~mm}$. long; stamens white; fruit ovoid or ovoidglobose, 4-6 mm. long, sligntly ribbed, black, capped by the perianth-segments, the perirarp somewhat fleshy.

Scrub-lands and coppices, New Providence, Cat Island, Watling's Island, Crooked Island, Acklin's Island, Fortune Island, Caicos Islands, Inagua :-Porto Rico; Jamaica; Anegada; St. Martin; Barbuda. CraB-Wood. Bow-PIGEoN.

\section{Order 9. CHENOPODIÀLES.}

Herbs, mostly with perfect flowers. Calyx present. Corolla, if present, polypetalous. Ovary superior. Embryo coiled, curved or annular. Fruit not an achene, rarely achene-like.

Fruit not capsular, a utricle, berry, anthocarp or achene-like; corolla none.

Fruit a utricle.

Flowers bractless, or if bracted, the bracts not scarlous.

Flowers with scarlous bracts.

Fruit not a utricle.

Fruit an anthocarp.

Fruit not an anthocarp.

Fruit aggregate.

Fruit not aggregate.

Fruit a capsule, dehiscent by valves or teeth.

Capsule 2-several-celled; corolla none.

Capsule 1-celled; petals mostly present.

Sepals 5 or 4 .

Sepals only 2 .

Fam. 1. Chenopodiaceae.

Fam. 2. Amaranthaceat.

Fam. 3. Nyctaginaceat.

Fam. 4. Batidaceat.

Fam. 5. Phytolaccaceae.

Fam. 6. Aizoaceae.

Fam. 7. Alsinaceat.

Fam. 8. Portulacaceae.

\section{Family 1. CHENOPODIÀCEAE Dumort.}

\section{Goosefoot Family.}

Annual or perennial herbs, rarely shrubs, with angled striate or terete stems. Leaves alternate or sometimes opposite, estipulate, simple, entire, toothed or lobed, mostly petioled (in Salicornia reduced to mere scales). Flowers small, green or greenish, regular or slightly irregular, variously clustered, occasionally solitary in the axils. Petals none. Calyx persistent, 2-5-lobed, 2-5-parted or rarely reduced to a single sepal, wanting in the pistillate flowers of some genera. Stamens as many as the lobes or divisions of the calyx, or fewer, and opposite them; fllaments slender; anthers 2-celled, longitudinally dehiscent. Disk usually none. 
Ovary 1-celled; ovule solitary, amphitropous; styles 1-3; stigmas capitate, or 2-3-lobed or divided. Fruit a utricle, with a thin or coriaceous pericarp. Seed vertical or horizontal; endosperm mealy, fleshy or wanting. About 75 genera and 550 species, of wide geographic distribution.

Embryo annular or horseshoe-shaped; leaves normal, at least the lower broad. Calyx present; fruit not enclosed by bractlets.

Calyx present in staminate flowers only; frult enclosed by bractlets.

Embryo spirally colled.

Leaves thick and fleshy, nearly terete.

Leaves reduced to rudimentary scales or ridges.

1. Chenopodium.

2. Atriplex.

3. Dondia.

4. Salicornia.

\section{CHENOPÒDIUM L. Sp. Pl. 218. 1753.}

Annual or perennial herbs, with alternate petioled leaves. Flowers small, green, perfect, sessile, bractless, clustered. Calyx 2-5-parted or 2-5-lobed, embracing or enclosing the utricle, its segments or lobes often keeled or ridged. Stamens 1-5; filaments filiform or slender. Styles 2 or 3 ; seed horizontal or vertical, sometimes in both positions in different flowers of the same species; endosperm mealy; embryo completely or incompletely annular. [Greek, goosefoot, from the shape of the leaves.] About 60 species, mostly weeds, of wide geographic distribution. Type species: Chenopodium rubrum L.

Embryo a complete ring ; plant not aromatic.

Embryo horse-shoe-shaped; plant aromatic.
1. C. murale.

2. C. ambrosioides.

\section{Chenopodium muràle L. Sp. Pl. 219. 1753}

Annual, somewhat scurfy above; stem 3-8 dm. high, leafy to the summit. Leaves rhombic-ovate, thin, bright green, acute or acuminate, sharply and coarsely sinuate-dentate, cuneate or subtruncate at the base, slender-petioled, 5-10 cm. long; flowers in loose axillary panicles often not longer than the petioles; calyx-segments not entirely enclosing the utricle; seed sharp-edged, horizontal, firmly attached to the pericarp.

A weed of streets and waste grounds, on the inhabited islands of the archipelago, Great Bahama to Watling's, Acklln's, and Long Islands, East Caicos and Grand Turk:-Widely distributed as a weed in temperate and tropical regions. Sowbane. Greens.

2. Chenopodium ambrosioìdes L. Sp. Pl. 219. 1753.

Chenopodium spathulatum Sieb.; Moq. in DC. Prodr. 13²: 73. 1849.

Annual, glabrous or slightly glandular-pubescent, strong-scented; stem leafy. 6-10 dm. high, angular and grooved. Leaves oblong or oblong-laneolate, narrowed to a short petiole, repand-dentate, undulate or the upper entire, 2-9 $\mathrm{cm}$. long, the upper numerous and much smaller; flowers in small dense axillary spikes; calyx usualy 3-parted, completely enclosing the fruit; pericarp readily separable from the horizontal or vertical, shining seed.

A weed, in waste grounds of the larger towns, New Providence, Eleuthera and Cat Island:- Widely distributed as a weed in temperate and troplcal regions. Wormseed. Jerusalem Parsley.

\section{ATRIPLEX L. Sp. Pl. 1052. 1753.}

Herbs or low shrubs, often scurfy-eanescent or silvery. Leaves alternate, or some of them opposite. Flowers dioecious or monoecious, small, green, in pauicled spikes or capitate-clustered in the axils. Staminate flowers bractless, consisting of a 3-5-parted calyx and an equal number of stamens; filaments 
separate or united by their bases; a rudimentary ovary sometimes present. Pistillate flowers subtended by 2 bractlets which enlarge in fruit and are more or less united, sometimes quite to their summits; perianth none; stigmas 2. ¿tricle completely or partially enclosed by the fruiting bractlets. Seed vertical or rarely horizontal; embryo annular; endosperm mealy. [From a Greek name of orache.] About 150 species, of wide geographic disribution. Type species: Artiplex hortensis $\mathrm{L}$.

Leaves, at least some of them, toothed.

Sides of the bracts tubercled or crested.

Sides of the bracts unappendaged. Leaves entire.

1. A. pentandra.

2. A. domingensis.

3. A. arenaria.

1. Atriplex pentándra (Jacq.) Standley, N. A. Fl. 21: 54. 1916.

Axyris pentandra Jacq. Sel. Stirp. Am. 244. 1763.

Atriplex cristata H. \& B.; Willd. Sp. Pl. 4: 959. 1806.

Annual or perennial, branched, the branches procumbent or ascending, 3-8 dm. long, scurfy when young, becoming glabrate. Leaves alternate, sessile or short-petioled, oblong to rhombic or obovate, 1-3 $\mathrm{cm}$. long, obtuse or acute at the apex, mucronate, cuneate at the base, repand-dentate, undulate or the upper entire, white-scurfy beneath, green above; flowers monoecious, the staminate in dense short terminal spikes, the pistillate clustered in the axils; fruiting bracts cuneate-orbicular, about $3 \mathrm{~mm}$. long, united only at the base, sharply dentate, the sides bearing 2 dentate crests or irregularly tubercled; seed brown.

Coastal rocks and sands, throughout the archlpelago from Great Bahama south to Andros, Mariguana, Atwood Cay, and Grand Turk:-Florida; Cuba to St. Jan; Jamaica; Curaçao; Venezuela and Colombia to Peru. Crested Átriplex.

2. Atriplex domingénsis Standley, N. A. Fl. 21: 55.1916.

Annual, woody, much branched, the branches decumbent, spreading, scaly, $2 \mathrm{dm}$. long or longer. Leaves alternate, nearly sessile, deltoid or deltoidoblong, small, 4-6 mm. long, 1-2 $\mathrm{mm}$. wide, denticulate or entire, acute at the apex, crisped, thick, white-scaly on both sides; flowers monoecious, the staminate in terminal spikes, the pistillate $2-4$ together in axillary clusters; bracts cuneate, $2 \mathrm{~mm}$. long, coarsely 5 -toothed above, their sides unappendaged; seed dark brown.

White-lands, Eastern Cay, Turk's Islands:-Hispaniola. Domingan Atriplex.

3. Atriplex arenària Nutt. Gen. 1: 198. 1818.

Atriplex cristata arenaria Kuntze, Rev. Gen. P1. 546. 1891.

Annual, pale, stem densely silvery-scurfy, bushy-branched, 1-4.5 dm. high, the branches ascending or decumbent, angular. Leaves oblong to obovate, entire, short-petioled or sessile, 1-4 cm. long, whitish-scurfy beneath, the lateral veins few and obscure; staminate flowers in terminal or axillary spikes; pistillate flowers in axillary clusters much shorter than the leaves; fruiting bracts triangular wedge-shaped, broadest above, 4-6 $\mathrm{mm}$. wide, united nearly to the several-toothed summits, their margins entire; their sides reticulated, or sometimes crested or tubercled.

Coastal sands, Eleuthera, Anguilla Isles and Water Cay:-Nova Scotia to Texas; Bermuda; Cayo Sabinál, Cuba. SEA-BeACr ATriplex.

3. DóNDIA Adans. Fam. Pl. 2: 261. 1763.

Fleshy herbs or low shrubs, with alternate narrowly linear, thick or nearly terete, entire sessile leaves, and perfect or polygamous bracteolate flowers, 
solitary or clustered in the upper axils. Calyx 5-parted or 5-cleft, the segments in fruit enclosing the utricle. Stamens 5. Styles usually 2, short. Pericarp separating from the seed. Embryo coiled into a flat spiral. Endosperm want. ing or very little. [In honor of Jacopodi Dondi, Italian naturalist of the fourteenth century.] About 50 species, of wide geographic distribution. Type species: Chenopodium altissimum L.

Leaves $2-5 \mathrm{~cm}$. long, elongated-linear; calyx-lobes strongly keeled. 1 . D. linearis. Leaves 1-1.5 cm. long, narrowly oblong; calyx-lobes inflexed, not keeled.

Leaves 2-5 mm. long, oblong; calyx-lobes inflexed, rounded.

2. D. fruticosa. 3. D. insularis.

1. Dondia lineàris (Ell.) Heller, Cat. N. A. Pl. 3. 1898.

Salsola linearis Ell., Bot. S. C. \& Ga. 1: 332. 1821.

Dondia carinata Millsp. Field. Mus. Bot. 2: 297. 1909.

Usually annual, sometimes perennial; stem erect, strict, 3-10 dm. tall, pale green or nearly white, the branches slender, very leafy, erect-asending or sometimes recurved. Leaves of the stem linear-subulate, $2-5 \mathrm{~cm}$. long, those of the branches much shorter, somewhat 3-angled, lanceolate-subulate, widest just above the base, the upper surface flat; calyx-lobes glaucous, acutely keeled or almost winged; seed orbicular, horizontal, black, shining, 1-1.5 mm. broad.

Salina borders and maritime rocks, South Bimini, New Providence, Andros, Eleuthra, Riding Rocks, Inagua, islands of the Cay Sal Bank:-Coast of eastern North America; Cuba. Referred by Mrs. Northrop to D. fruticosa (Forsk.) Northrop. Tall SEA-Blite.

2. Dondia fruticòsa (L.) Northrop, Mem. Torr. Club. 12: 35. 1902.

Chenopodium fruticosum L. Sp. Pl. 221. 1753.

Suaeda intermedia S. Wats. Proc. Am. Acad. 14: 296.1879.

Dondia intermedia Heller, Cat. N. A. Pl. 3. 1898.

Dondia Wilsonii Millsp. Field Mus. Bot. 2: 297. 1909.

Perennial, woody, glabrous or nearly so, somewhat glaucous, much branched, $8 \mathrm{dm}$. high or less, the branches leafy, ascending. Leaves subterete, $1-1.5 \mathrm{~cm}$. long, the upper little shorter than the lower; calyx-lobes rounded on the back, inflexed; seed red-brown or black, $1 \mathrm{~mm}$. broad.

Margins of salt pans, South Calcos Island:-Western United States; Cuba; Virgln Gorda; alkaline regions of Europe, Asia and Africa. Bushy SEA-BLite.

The plant is much out of Its gemeral range on South Caicos; our specimen was referred to $D$. fruticosa by Standley (N. A. F1. 21: 91).

3. Dondia insulàris Britton, Bull. N. Y. Bot. Gard. 4: 138. 1906.

Perennial, shrubby, much branched, $3 \mathrm{dm}$. high or less, glabrous, glaucous, the branches divaricately ascending. Leaves approximate, oblong, thick and fleshy, 2-5 mm. long, 1.5-2 $\mathrm{mm}$. thick, obtuse, narrowed to a subsessile base; flowers axillary to the upper leaves, about $2.5 \mathrm{~mm}$. broad; calyx-lobes ovate, obtuse, rounded on the back; filaments shorter than the calyx; seed vertical, black, shining, $1 \mathrm{~mm}$. long.

In salinas, Grand Turk Island and Ambergris Cay:-Cuba; Santa Lucia. ISLAND SEA-BLITE.

\section{SALICórNIA L. Sp. Pl. 3. 1753.}

Fleshy glabrous herbs with opposite terete branches, the leaves reduced to mere opposite scales, the flowers sunken 3-7 together in the axils of the upper ones forming narrow terminal spikes, perfect or the lateral ones staminate. Calyx obpyramidal or rhomboid, fleshy, 3-4-toothed or truncate, becoming 
spongy in fruit, deciduous. Stamens 2, or sometimes solitary, exserted; filaments cylindric, short; anthers oblong, large. Ovary ovoid; styles or stigmas 2. Utricles enclosed by the spongy fruiting calyx, the pericarp membranous. Seed erect, compressed; embryo conduplicate; endosperm none. [Name Greek, salt-horn; from the saline habitat, and horn-like branches.] About 10 species, natives of saline soil, widely distributed in both the Old World and the New. Type species: Salicornia europaea L.

Perennial; prostrate with erect branches. Annual; erect.

1. S. perennis.

2. S. Bigelovii.

1. Salicornia perénnis Mill. Gard. Dict. ed. 8, no. 2. 1768.

Salicornia ambigua Michx. F1. Bor. Am. 1: 2. 1803.

Perennial by a woody rootstock; stem trailing or decumbent $1.5-6 \mathrm{dm}$. long, rooting, the branches ascending or erect, slender, nearly or quite simple, rather long-jointed. Scales broadly ovate or wider than high, appressed or slightly divergent; fruiting spikes $1-4 \mathrm{~cm}$. long, their joints not longer than thick; flowers all about equally high and about equalling the joints; seeds covered with slender hairs.

Salinas, usualiy on the edge of mangrove colonies, throughout the archipelago from Abaco and Great Bahama to Andros, the Caicos and Turks Isiands and Inagua :- North American coasts, Massachusetts to Florida and west to Texas ; Bermuda; Cuba: St. Croix; Jamaica. An Inagua specimen was referred by Standley (N. A. Fl. 21:83) to the European S. fruticosa L. which this species much resembles. WoOdy Glasswort. Wild Coral. Guinea-Bead.

2. Salicornia Bigelòvii Torr. Bot. Mex. Bound. Surv. 184. 1859.

Salicornia mucronata Bigelow, Fl. Bost. ed. 2, 2: 1824 . Not Lag. 1817.

Annual, stout, erect or nearly so, $5-50 \mathrm{~cm}$. tall, more or less branched, the branches stout. Scales ovate or triangular-ovate, sharply mucronate, 2-3 $\mathrm{mm}$. long, at length spreading; fruiting spikes 1-12 $\mathrm{cm}$. long, their joints not longer than thick; middle flower slightly higher than the lateral ones, reaching very nearly to the end of the joint; seed covered with short hairs.

In saline marshes, Abaco, Andros and Grand Turk :-Nova Scotla to Florida and Texas; Callfornia; Cuba; Porto Rico; Yucatan. Bigelow's Glasswort.

\section{Family 2. AMARANTHĀCEAE J. St. Hil.}

\section{Amaranth Family.}

Herbs, or a few genera low shrubs, with simple, mostly entire, thin leaves. Flowers small, green or white, bracteolate, variously clustered, usually in terminal spikes or axillary heads. Petals none. Calyx herbaceous or membranous, 2-5-parted, the segments distinct, or united at the base, equal, or the inner ones smaller. Stamens 1-5, mostly opposite the calyx-segments, hypogynous; filaments distinct, united at the base, or into a tube. Ovary 1-celled; ovule solitary in the majority of genera, amphitropous, several in some tropical genera; stigmas 1-3. Fruit a utricle, circumscissile, bursting irregularly, or indehiscent, 1-seeded or several-seeded. Seeed mostly smooth; embryo annular; endosperm mealy, usually copious. About 40 genera and 475 species, widely distributed, most abundant in warm regions. 
Anthers 4-celled.

Leaves alternate.

Fruit several-seeded.

Fruit 1-seeded.

Leaves opposite.

Anthers 2-celled.

Stigma capitate.

Stlgma-lobes subulate or filifurm.

Flowers in dense heads.

Stamens 2; perianth sessile.

Stamens 5 ; perianth stalked.

Flowers in panicled spikes.

1. Celosia.

2. Amaranthus.

3. Centrostachys.

4. Achyrainthes.

5. Lithophila.

6. Philoxerus.

7. Iresine.

\section{CELÒsIA L. Sp. Pl. 205. 1753.}

Herbs or shrubs, with alternate leaves and small perfect bracted flowers, in spikes or fascicles. Perianth 5-parted, the segments scarious, striate. Stamens 5; filaments filiform or subulate, connate at the base; anthers 4celled. Ovary 2-many-ovuled; style present or wanting; stigmas 2 or 3. Utricle circumscissile or irregularly rupturing. Seeds 2 to many, lenticular, shining; embryo annular, endosperm starchy. [Greek, burned, from the dry parched flowers of some species.] About 40 species, of tropical and subtropical distribution. Type species: Celosia argentea $\mathrm{L}$.

\section{Celosia nítida Vahl, Symb. 2: 44. 1791.}

Perennial; glabrous. Stem slender, erect or vine-like, $3-15 \mathrm{dm}$. long; petioles slender, 5-20 mm. long; leaves ovate to rhombic-lanceolate, $2-7 \mathrm{~cm}$. long, obtuse, acute or acuminate at the apex, truncate or obtuse and often oblique at the base; inflorescence of panicled spikes, 1-5 cm. long; bracts nearly half as long as the sepals, ovate to lanceolate, keeled, acuminate; sepals elliptic-lanceolate, about $5 \mathrm{~mm}$. long, acuminate, dark brown, strongly parallelveined; style short; utricle globose-ovoid, shorter than the calyx; seeds black, smooth.

Moist soil and thickets, Acklin's Island, Anguilla Isles :-Florida; West Indies ; Texas; Mexico; northern South America. Slender Celosia.

\section{AMARÁNTHUS L. Sp. Pl. 989. 1753.}

Annual branched erect or diffusely spreading glabrous or pubescent herbs, with petioled pinnately veined leaves and small monoecious polygamous or dioecious, green or purplish, mostly 3-bracteolate flowers in dense terminal spikes or axillary clusters. Calyx of 1-5 distinct sepals. Stamens 1-5; anthers longitudinally dehiscent. Styles or stigmas 2 or 3 . Fruit an ovoid or oblong utricle, 1-seeded, 2-3-beaked by the styles. Embryo annular. [Greek, unfading flower, from the dry, unwithering bracts.] About 60 species of wide geographic distribution. Type species: Amaranthus caudatus L.

Flowers all axillary; sepals of pistillate flowers spatulate.

Peduncles short and thick; utricle indehiscent.

Peduncles none; utricle circumscissile.

Staminate flowers mostly in terminal spikes; sepals of pis-

1. A. crassipes.

2. A. polygonoides. tillate flowers oblong or obovate.

Utricle indehiscent. Utricle smooth.
Utricle wrinkled.

Utricle circumscissile or bursting irregularly. Leaf axils with a pair of spines.

Plants not spiny.

Plants glabrous or nearly so.

Plants pubescent or villous.

3. A. viridis.

4. A. gracilis.

5. A. spinosus.

6. A. dubius.

7. A. hybridus. 
1. Amaranthus crássipes Schlecht. Linnaea 6: 757. 1831.

Scleropus amaranthoides Schrad. Ind. Sem. Hort. Goetting. 1835.

Glabrous; stems prostrate or somewhat ascending, rather fleshy, 2-6 dm. long. Petioles slender, $0.5-4 \mathrm{~cm}$. long; leaves ovate to oblong or obovate, $0.5-$ $3.5 \mathrm{~cm}$. long, prominently whitish-veined, rounded and emarginate at the apex, narrowed at the base; flowers monoecious, in dense short-peduncled axillary clusters, the peduncles thickened; bracts very small, ovate, acutish; sepals of the pistillate flowers 4 or 5 , spatulate, scarious, about $1.5 \mathrm{~mm}$. long, obtuse or emarginate; style-branches 2 ; utricle obovoid, compressed, coriaceous, finely tuberculate, indehiscent; seed dark brown or black, smooth, about $1 \mathrm{~mm}$. broad.

Waste places, New Providence, Watling's and South Caicos:-Florida; West Indles; northern South America. Thick-STALKed Amaranth.

2. Amaranthus polygonoìdes L. Pl. Jam. Pug. 27. 1759.

Amblogyna polygonoides Raf. Fl. Tell. 3: 42. 1836.

Stems slender, prostrate or ascending, much branched, 1-5 dm. long, villous above. Petioles $2-7 \mathrm{~mm}$. long; leaves $0.5-2 \mathrm{~cm}$. long, rhombic-ovate to obovate, obtuse and usually emarginate at the apex, narrowed or cuneate at the base, glabrous, or sparingly pubescent beneath; flowers monoecious, in sessile dense axillary small clusters; bracts lanceolate, acuminate, much shorter than the sepals; sepals of the pistillate flowers spatulate, obtuse or apiculate, white, scarious, 3-nerved, connate at the base, those of the staminate flowers oblong, acute; stamens and style-branches 2 or 3 ; utricle circumscissile; seed dark brown or black, shining, less than $1 \mathrm{~mm}$. broad.

Sandy waste places, usually roadsides and paths, Eleuthera and Inagua:Florlda; Texas; Cuba ; Hispaniola; St. 'Thomas to Martinique; Curacao; Jamalca ; Mexico to northern South America. KNoTweed AMARANTH.

3. Amaranthus víridis L. Sp. Pl. ed. 2, 1405. 1763.

Amaranthus emarginatus Salzm.; Uline \& Bray, Bot. Gaz. 19: 319.1894.

Stems slender, prostrate or ascending, glabrous, usually branched, 1-6 dm. long. Leaves slender-petioled, rhombic-ovate, 1-4 cm. long, glabrous, deeply emarginate at the apex, rounded or narrowed at the base; flowers monoecious, in small axillary clusters and usually also in a short terminal spike; bracts ovate to lanceplate, acute, as long as the sepals or shorter; sepals 3 , those of the pistillate flowers oblong or oblong-oblanceolate, obtuse or shorter than the utricle, those of the staminate flowers oblong, acute; stamens and stylebranches 3 ; utricle smooth, indehiscent; seed reddish-brown, shining, nearly 1 $\mathrm{mm}$. broad.

In cultivated ground, New Providence at Nassau:-southern United States ; Cuba; Porto Rico; Jamaica: Guadeloupe; tropical South America and Old World tropics. Notch-leaved amaranth.

\section{Amaranthus grácilis Desf. Tabl. Bot. 43. 1804.}

Glabrous; stem erect, usually branched, 2-9 dm. high. Leaves slenderpetioled, $8 \mathrm{~cm}$. long or less, ovate or rhombic-ovate, mostly obtuse and emarginate at the apex, narrowed or rounded at the base; flowers monoecious, in slender, axillary and terminal, sometimes panicled spikes 4-12 $\mathrm{cm}$. long, and also often in small dense axillary clusters; bracts ovate to lanceolate, acute, scarious, much shorter than the 3 sepals; sepals cuspidate, 1-1.5 mm. long; stamens and style-branches 3 ; utricle wrinkled, indehiscent, as long as the sepals or longer; seed dull, dark brown, $1 \mathrm{~mm}$. broad.

Waste grounds near dwellings, Great Bahama, Andros, New Providence, Eleuthera, Long Island and Watling's:- southeastern United States; West Indies and troplcal and subtroplcal America; Old World tropics. Slender Amaranth. 
5. Amaranthus spinòsus L. Sp. Pl. 991. 1753.

Stem stout, ridged, erect or ascending, glabrous below, somewhat pubescent above, usually much branched, sometimes red, 3-12 dm. high. Leaves ovate, slender-petioled, rhombic-ovate or the upper lanceolate, acute at both ends, 2-8 $\mathrm{cm}$. long, with a pair of rigid stipular spines at each node, the midvein excurrent; flowers monoecious, the pistillate in numerous capitate axillary clusters, the staminate in dense terminal spreading or drooping spikes 2-18 $\mathrm{cm}$. long; bracts lanceolate-subulate, about as long as or longer than the 5 scarious oblong mucronate-tipped 1-nerved sepals, and the thin imperfectly circumscissile utricle; stamens 5 ; style-branches 3 ; seed black, shining, nearly $1 \mathrm{~mm}$. broad.

Waste grounds, Great Harbor Cay. and New Providence:-United States; West Indies; all tropical and warm temperate regions. Spiny Amaranth. Calalue.

\section{Amaranthus dùbius Mart. Hort. Erlang. 197. 1814.}

\section{Amaranthus tristis Willd. Hist. Amar. 21. 1790. Not. L. 1753.}

Glabrous, or somewhat pubescent above; stem erect, often much branched, $1 \mathrm{~m}$. high or less. Leaves long-petioled, the slender petiole $2-9 \mathrm{~cm}$. long, the blade ovate, 2-12 $\mathrm{cm}$. long, acute or obtuse and usually emarginate at the apex, rounded or acute at the base; flowers monoecious, in slender, often drooping and numerous dense, terminal and axillary spikes, $5-25 \mathrm{~cm}$. long, and sometimes in small, dense axillary clusters; bracts ovate or elliptic, acute, shorter than or about as long as the sepals; sepals of the pistillate flowers $1.5-2 \mathrm{~mm}$. long, mucronate, often emarginate, 1-nerved; stamens 5; style-branches 3 ; utricle a little longer than the sepals, rugulose, dehiscent at the middle; seed dark brown or black, circular, sharp-edged, $1 \mathrm{~mm}$. in diameter.

Waste places near dwellings, Abaco, New Providence, Great Guana Cay, Cat Island. Little San Salvador, Fortune Island and Grand Turk :-West Indies: Central and South America; tropical Africa; adventive in Europe. Southern PIGweed.

\section{Amaranthus hýbridus L. Sp. Pl. 990. 1753.}

Stem usually slender, erect, $0.3-2.5 \mathrm{~m}$. tall, often much-branched, villous above. Leaves long-petioled, $1.5 \mathrm{dm}$. long or less, ovate to lanceolate, usually acute; spikes linear-cylindric, 2-12 . cm. long, axillary and forming dense terminal panicles, ascending, or somewhat spreading; bracts lanceolate to ovate, about twice as long as the 5 oblong acute or cuspidate sepals; stamens 5 ; style-branches 3 ; utricle scarcely wrinkled, circumscissile; seed dark brown or black, shining, $1 \mathrm{~mm}$. in diameter.

Waste places, Fortune Isiand, Anguilla Isles :-United States ; Bermuda ; Cuba ; Mexico. A. paniculatus as to Bahamian references. SLENDER PIGWEed.

\section{CENTROSTÁCHYS Wall. in Roxb. Fl. Ind. 2: 497. 1824.}

Herbs, some species somewhat woody, with opposite membranous broad leaves, and small green flowers sessile in slender elongated terminal spikes, the caly $\mathrm{x}$ deflexed after anthesis. Sepals 4 or 5, cartilaginous, narrow, acuminate or aristate. Stamens 4 or 5 ; filaments subulate; anthers 4-celled. Ovary 1-celled; ovule 1; style filiform; stigma capitate. Utricle thin-walled, indehiscent. [Greek, prickly-spike.] About 12 species, of warm and tropical regions. Type species: Centrostachys aquatica Wall. 
1. Centrostachys índica (L.) Standley, Journ. Wash. Acad. Sci. 5: 75.1915.

Achyranthes aspera indica L. Sp. Pl. 204. 1753.

Achyranthes indica Mill. Gard. Dict. ed. 8, no. 2. 1768.

Achyranthes obtusifolia Lam. Encycl. 1: 545. 1785.

Achyranthes aspera obtusifolia Griseb. Fl. Br. W. I. 62. 1859.

Herbaceous, erect or ascending, simple or branched, 6-12 dm. high, rather densely pubescent above. Leaves suborbicular or obovate-orbicular, pubescent, 2-5 cm. long, abruptly short-tipped at the apex, narrowed or cuneate at the base, pinnately veined, the slender petioles 1-3 cm. long; spikes very slender, 2-6 dm. long, densely flowered above, the lower flowers scattered; flowers about $4 \mathrm{~mm}$. long; bracts subulate, horny, glabrous, a little shorter than the calyx, deflexed; sepals acuminate.

A weed in waste places and cultivated soils, throughout the archipelago from Abaco south to Acklin's Island:-a weed in tropical and subtropical regions. Blunt-leaved Centrostachys.

\section{ACHYRÁNTHES L. Sp. Pl. 204. 1753.}

Decumbent or prostrate herbs. Leaves opposite, entire or nearly so. Flowers perfect, in sessile or peduncled, head-like, usually white or silvery spikes. Sepals 5, unequal. Stamens 5, the filaments partially united into a cup-like tube; staminodia surpassing the filaments and 2-celled anthers, or shorter. Ovary 1-celled; stigma capitate. Ovule solitary. Utricle flattened, indehiscent. Seeds lenticular, smooth. [Greek, straw-flower.] Forty species or more, mostly of tropical distribution. Type species: Achyranthes repens L.

Plants succulent: leaves sessile.

Plants not succulent.

Sepals merely acute.

Sepals spinulose-tipped.
1. A. maritima.

2. A. polygonoides.

3. A. repens.

1. Achyranthes marítima (St. Hil.) Standley, Journ. Wash. Acad. Sci. 5: 74. 1915.

Alternanthera maritima St. Hil. Voy. Bras. 2: 437.1833.

Plants glabrous, fleshy. Stems or the branches prostrate, 2-8 dm. long, angled, branched; leaves leathery, cuneate to oblong or elliptic, $1.5-6 \mathrm{~cm}$. long, obtuse, commonly mucronate, entire, sessile or somewhat petioled; spikes dull straw-colored, 6-12 mm. long, sessile, leaving a conspicuous scar when detached; bracts ovate, keeled; calyx $\frac{1}{3}$ longer than the bracts; sepals rigid, ovate, acute and slightly awn-tipped, usually 5-nerved, glabrous; staminodia longer than the filaments, cleft or lacerate at the tip.

Maritime sands at the wave line, Great Bahama, Frozen Cay, South Bimini, Little Mangrove Cay, New Providence and Cat Island:-Bermuda; Florida: Cuba; Guiana to Brazi] : west coast of Africa. Referred to by Doliey and by Herrick as Gomphrena sp. BEACH ACHYRANTHES.

\section{Achyranthes polygonoides (L.) Lam. Encycl. 1: 547. 1785.}

Gomphrena polygonoides L. Sp. Pl. 225. 1753.

Alternanthera paronychioides St. Hil. Voy. Bras. 2: 439. 1833.

Glabrous or sparingly pilose, branched, the branches procumbent or creeping, 1-4 dm. long. Leaves spatulate to elliptic, $2 \mathrm{~cm}$. long or less, obscurely veined, acute or obtuse at the apex, narrowed at the base, the petioles 5-10 mm. long; flowers in dense sessile globose axillary heads 8-12 $\mathrm{mm}$. in diameter; sepals bright white, shining, lanceolate, acute, slightly unequal, about $3 \mathrm{~mm}$. 
long, somewhat longer than the lanceolate bracts; staminodia about as long as the filaments, toothed to the apex; utricle obcordate, included.

Sandy waste places. Great Bahama, New Providence, Grand Turk and Inagua :southeastern United States; Cuba to St. Thomas and to Barbadoes; Jamaica; continental tropical America. KNOTWEed ACHYRANTHES.

3. Achyranthes rèpens L. Sp. Pl. 205. 1753.

Alternanthera Achyrantha R. Br. Prodr. 417. 1810.

Alternanthera repens Kuntze, Rev. Gen. Pl. 2: 540. 1891.

Loosely pilose, branched, the branches prostrate, $5 \mathrm{dm}$. long or less. Leaves spatulate, or obovate to oval or suborbicular, $2 \mathrm{~cm}$. long or less, pinnately veined, obtuse or abruptly tipped, narrowed at the base into short petioles; flowers in dense sessile globose or oblorg heads 6-12 mm. long; sepals 'dull whitish, unequal, about $2 \mathrm{~mm}$. long, longer than the bracts, the outer aristate, villous; staminodia somewhat shorter than the filaments, entire, or fewtoothed below; utricle ovoid, included.

Waste places and cultivated lands, Abaco, St. George's Cay, New Providence, Eleuthera and Long Island:- South Carolina to Florida, Texas and California; Cuba to St. Thomas and to South America; Mexico to Panama, Peru and Argentina; Canary Islands; Madelra; Spain. Cremping Achrranthes. Washerwoman.

\section{๊. IITHÓPHILA Sw. Prodr. 14. 1788.}

Perennial, more or less villous herbs, the leaves mostly in basal tufts, the small perfect bracteolate flowers in spikes or heads. Calyx flattened, 5parted, sessile. Stamens 2; filaments connate below; anthers 2-celled; staminodia 3. Ovary ovoid; style short; stigmas 2, slender; ovule 1, pendulous. Utricle ovoid, compressed. Seed lenticular, smooth. [Greek, rock-loving.] About 4 species, of the West Indies and Galapagos, the following typical.

\section{Lithophila muscoìdes Sw. Prodr. 14. 1788.}

Achyranthes linearifolia Sw. Vet. Acad. Handl. 1825: 48. 1825.

Root woody, often deep; stems few or several, prostrate or ascending, villous, branched, 01.-2 dm. long. Basal leaves several or many, tufted, filiform to oblong-spatulate, $1.5-5 \mathrm{~cm}$. long, $0.3-5 \mathrm{~mm}$. wide, obtuse, villous near the base; cauline leaves few, similar but smaller, glabrous; spikes 3-15 mm. long, about $5 \mathrm{~mm}$. thick, solitary or clustered, terminal or axillary, sessile or nearly so; bracts white, membranous, ovate, acute or acuminate, about one-half as long as the sepals; bractlets similar, nearly as long as the sepals; sepals oblong, 1-2.5 mm. long, the outer obtuse, villous at the base, the inner acute; seed nearly orbicular, brown, shining, $0.5 \mathrm{~mm}$. in diameter.

In trodden sands of roadside paths, and in rocky and sandy soil, throughout the archipelago from Great Bahama to Grand Turk and Ambergris Car :-Cuba to St. Croix, Anegada and Martinique; Bonaire; Curaça. Moss-Like Lithophila.

\section{PHILóXerus R. Br. Prodr. 416. 1810.}

Herbs, mostly fleshy, with opposite entire leaves, the perfect bracteolate flowers in dense heads or short spikes. Calyx compressed, thickened at the base, 5-parted, the segments obtuse. Stamens 5; filaments subulate, connate below; anthers oblong, 2-celled. Ovary ovoid, compressed; style short; stigmas 2, subulate; ovule suspended on a long funicle. Utricle compressed, 
ovoid, indehiscent. Seed lenticular; embryo annular; endosperm starchy. [Greek, dry-loving, some species inhabiting dry situations.] About 10 species of coastal distribution in tropical and subtropical America, Africa and Australasia. Type species: Philoxerus conicus $\mathrm{R}$. $\mathrm{Br}$.

1. Philoxerus vermiculàris (L.) Nutt. Gen. 2: 78. 1818.

Gomphrena vermicularis L. Sp. Pl. 224. 1753.

Lithophila vermiculata Uline, Field Mus. Bot. 2: 39. 1900.

Fleshy, the stems prostrate, branched, 1-8 dm. long, the branches prostrate or ascending, sometimes $1.5 \mathrm{dm}$. high. Leaves thick, or subterete, linear, linear-oblong or clavate, $1-5 \mathrm{~cm}$. long, acutish or blunt at the apex, narrowed to the sessile base; heads subglobose to eylindric, densely many-flowered, bright white, 1-2.5 $\mathrm{cm}$. long, 6-10 $\mathrm{mm}$. thick; sepals about $3 \mathrm{~mm}$. long, obtuse, a little longer than the bracts.

Margins of salt water ponds and on maritime rocks, Abaco and Great $\mathrm{Ba}$ hama to Watling's Island and the Anguilla Isles:-Florida ; West Indies ; northern South America. SAMPIRE. SAIT-WEED.

7. IRESINNE P. Br. Hist. Jam. 358. 1756.

Tall herbs, with opposite broad petioled leaves and small 3-bracted white flowers, in large terminal panicles or panicled spikes. Calyx 5-parted, the pistillate usually woolly. Stamens 5, rarely fewer; filaments united by their bases, filiform; anthers 2-celled. Utricle very small, subglobose, indehiscent. [Greek, in allusion to the woolly pubescence.] About 40 species, natives of warm and temperate regions. Type species: Celosia paniculata L.

Leaves large, broadly ovate-lanceolate, acute.

Leaves lanceolate to ovate-lanceolate, petlolate, obtuse.

Leaves linear, sessile or very nearly so.
1. 1. Celosia.

2. I. flavescens.

3. I. inaguensis.

1. Iresine Celòsia L. Syst. ed. 10, 1291. 1759.

Celosia paniculata L. Sp. Pl. 206. 1753.

Iresine celosioides L. Sp. Pl. ed. 2, 1456. 1763.

Iresine paniculata Kuntze, Rev. Gen. Pl. 2: 542. 1891. Not Poir. 1813.

Annual or perennial; stem erect, ascending or clambering, 0.6-3 m. long, glabrous or nearly so. Leaves ovate, ovate-lanceolate or the upper lanceolate, 0.5-1.5 dm. long, acute or acuminate, the slender petioles 1-6 cm. long; flowers very numerous, $2 \mathrm{~mm}$. broad or less, calyx and bracts silvery; sepals 1-1.5 mm. long; pistillate flowers white-villous at the base, about twice as long as the bracts; utricle shorter than the sepals; seed red, shining, $0.5 \mathrm{~mm}$ in diameter.

Coastal sands and on waste and cultivated lands, Abaco and Great Bahama:southeastern United States; Jamaica; Cuba to Por
Mexico to Brazil and Argentina. NEw-BURN Wred.

2. Iresine flavèscens H. \& B.; Willd. Sp. Pl. 4: 766. 1806.

Alternanthera flavescens Moq. in DC. Prodr. 132: 350. 1849.

Iresine keyensis Millsp. Field Mus. Bot. 2: 148. 1906.

Perennial by a woody root; stems erect, rather stout, $1 \mathrm{~m}$. high or less, glabrous, simple or much branched, the nodes often swollen. Leaves linearoblong to lanceolate or ovate-lanceolate, $2-10 \mathrm{~cm}$. long, $0.4-2.5 \mathrm{~cm}$. wide, mostly obtuse or rounded at the apex, narrowed at the base, glabrous, the petioles $1 \mathrm{~cm}$. lorg or less; panicles narrow, dense, 1-3 dm. long, glabrous; spike.s $0.3-4$ 
cm. long; bracts ovate-orbicular, about one-half as long as the sepals; sepals about $1 \mathrm{~mm}$. long, those of pistillate flowers copiously woolly at the base; utricle shorter than the sepals; seed red-brown, shining, $0.5 \mathrm{~mm}$. long.

Maritime rocks and pine-lands, throughout the archipelago from Abaco, Great Bahama and Great Sturrup southward to Andros, Great Ragged Cay, Acklin's Island and Watling's Island:-Florida: Cuba; Colombla. Referred by Mirs. Northrop and by Coker to I. paniculata; by Hiltchcock to I. celosioides. CoASTAL IRESINE.

\section{Iresine inaguénsis Millsp. Field Mus. Bot. 2: 149. 1906.}

Perennial by a woody root; stems several, erect, rather stout, $3-9 \mathrm{dm}$. high, glabrous, little branched, the branches erect. Leaves many, linear, $6 \mathrm{~cm}$. long or less, 1-2.5 mm. wide, obtuse, glabrous, nearly sessile, sometimes with fascicles of smaller ones in their axils; panicles narrow, 7-14 cm. long, dense, glabrous; spikes densely flowered, 3-12 $\mathrm{mm}$. long; bracts ovate-orbicular, about one-third as long as the sepals; sepals oblong, about $1 \mathrm{~mm}$. long, obtuse, those of the pistillate flowers bearing long hairs at the base; utricle a little shorter than the sepals; seed red, shining, $0.5 \mathrm{~mm}$. long.

Sandy and rocky soil, Castle Island, Atwood Cay, Sheep Cay and Inagua :Endemic. Bahama IRESINe.

\section{Family 3. NYCTAGINĀCEAE Lindl.}

\section{FoUR-o'ClOCK FAMILY.}

Herbs, some tropical genera trees or shrubs, with simple entire leaves, and regular flowers in clusters, in many of the genera subtended by involucres. Petals none. Calyx inferior, usually corolla-like, its limb 4-5lobed or 4-5-toothed. Stamens hypogynons; filaments filiform; anthers 2-celled, dehiscent by lateral slits. Ovary enclosed by the tube of the perianth, 1-celled, 1-ovuled; ovule campylotropous; stigma capitate. Fruit a ribbed, grooved or winged anthocarp. About 25 genera and 350 species, of wide geographic distribution, most abundant in America.

Herbs ; flowers perfect.

Perianth large, tubular-funnelform.

Perianth small, campanulate or funnelform. Fruit 5-angled or 5-ribbed.

Fruit 10-ribbed.

Trees, shrubs or woody vines; flowers dioecious. Fruit drupe-like, fleshy.

Frult dry, with 5 rows of glands.

1. Mirabilis.

2. Boerhaavea.

3. Commicarpus.

4. Torrubia.

5. Pisonia.

\section{MIRÁBILIS L. Sp. Pl. 177. 1753.}

Perennial herbs, with large tuberous-thickened roots and forking stems. Leaves opposite, somewhat fleshy, petioled, or the upper sessile. Flower solitary or many flowers together in a 5-lobed calyx-like involucre. Calyx colored, its tube elongated, constricted above the ovary, its limb expanding, deciduous. Stamens 5 or 6 , unequal; filaments filiform, slender, incurved, united into a fleshy cup at the base. Style filiform. Fruit ribbed. Seed filling the pericarp, to which the testa adheres; endosperm mealy. [Latin, beautiful.] Twenty or more American species, the following typical.

1. Mirabilis Jalàpa L. Sp. Pl. 177. 1753.

Foliage deep green, glabrous or slightly pubescent. Stem erect, 3-7 dm. tall, much branched; leaves ovate, acuminate, sometimes sparingly ciliate, 
entire, truncate or cordate at the base, the petioles about one half as long as the blades; involucres campanulate, $7-8 \mathrm{~mm}$. high, pubescent, 1-flowered, their lobes ovate-lanceolate, twice as long as the tube, acute, bristle-tipped; calyx trumpet-shaped, 3-5 cm. long, deep red to purple or white, often more or less blotched, the edge notched; stamens exserted; fruit ovoid, black, 8-10 mm. long, wrinkled-tuberculate, 5-ribbed.

Waste grounds, spontaneous after cultivation, New Providence, Eleuthera and Fortune Isiand :-Bermuda ; Florida; the West Indies; continental tropicai America north through Mexico. FoUR-o'clock.

\section{BOERHAÀVEA L. Sp. Pl. 3. 1753.}

Slender herbs with forking stems and branches, opposite leaves, and small minutely bracted flowers on jointed pedicels. Calyx campanulate to funnelform, its limb 5-lobed. Stamens 1-5, exserted, the slender filaments united at the base. Ovary oblique; style filiform; stigma peltate. Fruit obovoid or clavate, 5-angled or 5-ribbed. [In honor of Hermann Boerhaave, 1668-1738, a celebrated Dutch scientist.] About 50 species, natives of warm and tropical regions. Type species: Boerhaavea diffusa $\mathrm{L}$.

Fruit with viscid glands.

Fruit not gianduiar.

1. B. coccinea.

2. B. erecta.

1. Boerhaavea coccínea Mill. Gard. Dict. No. 8. 1768.

Boerhaavea paniculata Rich. Act. Soc. Hist. Nat. Paris 1: 105. 1792.

Boerhaavia hirsuta Willd. Sp. Pl. 1: 20. 1797.

Perennial by somewhat fleshy roots; stems 2-10 dm. long, slender, branched, procumbent or ascending, usually pubescent, at least below, the branches glabrous or puberulent. Leaves rhombic-ovate to oblong or nearly orbicular, 2-6.5 $\mathrm{cm}$. long, rounded, obtuse or rarely acute at the apex, rounded or subcordate at the base, slender-petioled, entire or undulate; panicle slender, often $3 \mathrm{dm}$. long, its branches nearly filiform, glabrous or puberulent; flowers reddish, $2 \mathrm{~mm}$. broad, nearly sessile in small glomerules of 2 -several; fruit obovoid, 2.5-4 mm. long, 5-grooved, glandular.

Roadsides and waste piaces, North Bimini, Andros, New Providence, Great Guana Cay, Eleuthera, Cat Isiand, Fortune Island and Inagua:-Fiorida; West Indies; Mexico through Centrai America to northern South America; tropical Africa. VISCID HOG-WEED.

\section{Boerhaavea erécta L. Sp. Pl. 3. 1753.}

Stem erect or ascending, branched; leaves ovate to deltoid-ovate, sometimes inequilateral, 2-8 cm. long, apiculate, repand or undulate, acute to cordate at the base, minutely black-dotted on the lower whitish surface, the petioles usually about one half as long as the blades or longer; peduncles filiform; flowers $2-6$ in a cluster; calyx white to purple, its tube glabrous, the limb campanulate, 1-1.5 mm. long, sparingly pubescent; stamens exserted; fruit obpyramidal, 3.5-4 mm. long, 5-angled, the grooves transversely wrinkled, the top flat.

Waste grounds, New Providence:-southern United States; Bermuda; New Mexico and Cailfornia to Peru and Brazil; the West Indies. SMooth Hog-weED.

\section{COMMICÁRPUS Standley, Contr. Nat. Herb. 12: 373. 1909.}

Perennial herbs, with long forking stems, opposite entire petioled mostly cordate leaves, and smail perfect umbellate flowers. Calyx short-funnelform, 
the limb rather widely expanded. Stamens 5, exserted, the filaments slender. Ovary oblique; style slender. Fruit clavate, 10-ribbed, mucilaginous-glandular, the glands rather large. [Greek, viscid fruit.] About 5 species, natives of tropical and subtropical America, the following typical.

1. Commicarpus scándens (L.) Standley, Contr. Nat. Herb. 12: 373. 1909.

Boerhaavea scandens L. Sp. Pl. 3. 1753.

Glabrous; stems slender, pale, elongated and often vine-like, much branched, sometimes $2 \mathrm{~m}$. long. Leaves ovate, rather thin, somewhat fleshy, 1-4 cm. long, acute, acuminate or obtuse at the apex, cordate or truncate at the base, the petioles $2.5 \mathrm{~cm}$. long or less; peduncles slender, mostly longer than the leaves; umbels several-flowered; pedicels filiform, 5-12 $\mathrm{mm}$. long; calyx greenish, about $6 \mathrm{~mm}$. broad, its tube and teeth short; fruit narrowly clavate, 7-10 $\mathrm{mm}$. long, glandular toward the blunt apex, its ribs low and obseure.

Scrub-lands, thickets and coppices, New Providence, Eleuthera, Cave Cay, Acklin's Island, Grand Turk, Ambergris Cay and Anguilla Isles :- Florida ; Texas and Arizona to Guatemala, Colombia and Peru: Jamaica; Cuba to Virgin Gorda and St. Barts ; Bonaire; Aruba ; Curaçao. CommicarPus.

\section{TORRÙBIA Vell. Fl. Flum. 139. 1825.}

Shrubs or trees, with opposite often somewhat fleshy leaves, and small greenish dioecious panicled flowers. Calyx-limb 5-toothed. Stamens about 10, exserted, the filaments filiform. Ovary sessile; style slender or short. Anthocarp fleshy, drupe-like, obovoid to ellipsoid or subglobose, without glands in rows, enclosing the utricle. [Commemorates José Torrubia, a Spanish raturalist.] Fifteen species or more, of tropical and subtropical America. Type species: Torrubia opposita Vell.

Petioles stout; leaves 6-9 $\mathrm{cm}$. long, coriaceous, reticulate-veined beneath.

Leaves broadiy elliptic, mostiy subcordate at the base.

Leaves obovate, cuneate or narrowed at the base.

Petioles slender; leaves 4-6 cm. long, fleshy-chartaceous, very indistinctly veined.

Fruit globose-obovoid to ellipsoid, little longer than thick; anthocarp 4-6 $\mathrm{mm}$. long.

Fruit oblong-obovoid, twice as long as thick; anthocarp 7-8 $\mathrm{mm}$. long.

1. T. obtusata.

2. T. Cokeri.

1. Torrubia obtusàta (Jacq.) Britton, Bull. Torr. Club 31: 612. 1904.

Pisonia obtusata Jacq. Hort. Schoen. 3: 35. 1798.

Pisonia calophylla Heimerl, Bot. Jahrb. 21: 625. 1896.

A shrub, or a small tree up to $13 \mathrm{~m}$. high, the twigs rather slender, subterete, pale gray, the bark of the trunk white. Leaves ovate or elliptic, coriaceous, 6-9 $\mathrm{cm}$. long, about twice as long as wide, rounded at the apex, rounded, subcordate or some of them narrowed at the base, often involute-margined, the stout petioles 3-7 $\mathrm{mm}$. long; panicles usually many-flowered, as long as the leaves or shorter; flowers sessile, puberulent or glabrate; fruit oblong, bright red, shining, 8-10 $\mathrm{mm}$. long.

Low coppices and scrub-iands, Abaco, Great Bahama. New Providence, Eleuthera, Cat Island. Great Exuma. Acklin's, Crooked and Fortune Islands :-Cuba ; Santo Domingo. BROAD-LEAvED BLOLLY.

2. Torrubia Cỏkeri Britton, Bull. Torr. Club 31: 613. 1904.

Glabrous, the twigs gray. Leaves firm, obovate, $8 \mathrm{~cm}$. long or less, 3-4 $\mathrm{cm}$. wide, rounded at the apex, narrowed or somewhat cuneate at the base; 
petioles stout, about $1 \mathrm{~cm}$. long; flowers sessile, the perianth and paniclebranches minutely tomentulose; staminate perianth about $3 \mathrm{~mm}$. long, bluntly 5 -toothed, about one-half as long as the stamens.

Rocky coppices and scrub-lands, Andros?, Eleuthera and Inagua:-Cuba. Coker's Blolly.

3. Torrubia longifòlia (Heimerl) Britton, Bull. Torr. Club 31: 614. 1904.

Pisonia discolor longifolia Hiemerl, Bot. Jahrb. 21: 627. 1896.

A tree, attaining a maximum height of about $16 \mathrm{~m}$. with a trunk up to 5 dm. in diameter, usually much smaller and often shrubby, the bark scaly, the twigs glabrous, slender. Leaves oblanceolate to obovate or spatulate, firm in texture, 2-6 cm. long, glabrous, rounded or emarginate at the apex, narrowed or cuneate at the base, obscurely veined, the slender petioles 5-15 $\mathrm{mm}$. long; calyx 3-4 mm. long; fruit juicy, obovoid or globose-obovoid, bright red, little longer than thick; anthocarp 4-6 mm. long.

Rocky coppices and scrub-lands, Great Bahama, Andros, North Bimini. New Providence, Rose Island. Eleuthera, Watling's, Acklin's, Inagua and Anguilla Isles :Florida ; Cuba ; Jamaica. NARrow-Leaved Blolly. BeEF-WOOD.

4. Torrubia Bràcei Britton, Bull. Torr. Club 31: 614. 1904.

A slender tree, $5 \mathrm{~m}$. high or less, the bark gray. Leaves thin, green on both sides; petioles very slender, 6-8 $\mathrm{mm}$. long; blades narrowly obovate, $5 \mathrm{~cm}$. long or less, rounded at the apex, cuneate-narrowed at the base; fruiting pedicels about $0.5 \mathrm{~mm}$. long; fruit very juicy, oblong-obovoid, twice as long as thick, claret-red, truncate at the top; anthocarp 7-8 $\mathrm{mm}$. long, $2 \mathrm{~mm}$. thick.

Coppices and scrub-lands, New Providence and Inagua. Endemic. Specimens from Cat Island, Conception, Acklin's and Fortune Islands, showing foliage only, are doubtfully referred to this species. BRACE'S BLOLLY.

\section{PISÒNIA L. Sp. P1. 1026.1753.}

Woody vines, shrubs or trees, with broad entire opposite leaves, and small, mostly dioecious, bracteolate, cymose or panicled flowers. Calyx-limb 5-toothed or 5-lobed. Stamens 6-10; filaments filiform, connate below into a tube or ring; anthers exserted. Ovary sessile; style slender; stigma capitellate. Anthocarp coriaceous, linear or clavate, bearing stalked or sessile glands in rows, enclosing the elongated utricle. [Commemorates William Piso, a physician of Leyden, who travelled in Brazil, and died in 1648.] Twenty species or more, of tropical and subtropical distribution. Type species: Pisonia aculeata $\mathrm{L}$.

Climbing vine with hooked prickles; anthocarp with rows of stalked glands along its whole length.

Shrub or small unarmed tree; anthocarp with rows of stalked glands near its summit.

1. P. aculeata.

2. $P$. rotundata.

\section{Pisonia aculeàta L. Sp. Pl. 1026. 1753.}

A climbing woody vine sometimes $10 \mathrm{~m}$. long, armed with hooked opposite prickles. Leaves ovate to elliptic, rather thin, $2.5-10 \mathrm{~cm}$. long, glabrous, acute, obtuse or short-acuminate at the apex, cuneate or narrowed at the base, the petioles 1-4 cm. long; cymes many-flowered, pubescent; fruit clavate, slender-pedicelled, $8-10 \mathrm{~mm}$. long, 10-ridged, with 5 rows of glands from base to apex.

Coppices and scrub-lands, New Providence:-Fiorida; West Indies and continental tropical America; Philippine Islands. COCK-spur. Hold-BACK. PULL-BACK. 
2. Pisonia rotundàta Griseb. Cat. Pl. Cub. 283. 1866.

Pisonia subcordata rotundata Heimerl, Bot. Jahrb. 21: 630. 1896.

An unarmed shrub, or small tree, up to $5 \mathrm{~m}$. high, in Cuba becoming larger, the twigs and leaves glabrous or finely pubescent. Leaves oval, oblong or obovate, firm in texture, $2.5-7 \mathrm{~cm}$. long, rounded or retuse at the apex, obtuse or broadly cuneate at the base, minutely reticulate-veined beneath, the petioles 3-10 mm. long; cymes many-flowered, rather densely pubescent or gtabrate; fruit clavate, $6-7 \mathrm{~mm}$. long, with 5 rows of short-stalked glands above the middle.

Coppices, pine-lands and scrub-lands, Andros, New Providence, Eleuthera :Florida; Cuba. Round-LEAved PISOxia.

\section{Family 4. BATIDÀCEAE Dammer.}

\section{Saltwort Family.}

Low fleshy much-branched shrubs, with opposite semiterete, linear or club-shaped, entire sessile estipulate leaves, and small dioecious greenish flowers in axillary spikes. Staminate spikes with many persistent imbricated scales, each subtending a flower; calyx 2-lobed; stamens 4 or 5, with stout filaments alternating with staminodia; anthers introrse. Pistillate spikes 4-12-flowered, the scales deciduous; calyx and corolla wanting; ovary sessile, 4-celled; ovule 1 in each cavity, erect, anatropous; stigma sessile, somewhat 2-lobed; fruit aggregate, about 4-seeded. Seeds clubshaped, the testa membranous; endosperm none; cotyledons large. Only the following genus.

1. BÀTIS L. Syst. ed. 10, 1289.1759.

Characters of the family. [Greek, from the fancied resemblance of the fruit to a blackberry.] A monotypic genus.

1. Batis marítima L. Syst. ed. 10, 1289. 1759.

A glabrous shrub $1 \mathrm{~m}$. high or less, the rather stout stems spreading, prostrate or ascending, the branches nearly erect, angular. Leaves acutish, 1-2.5 cm. long; spikes ovoid or oblong, 5-10 $\mathrm{mm}$. long, the staminate sessile, the pistillate short-peduncled; bracts nearly orbicular or reniform, longer than the calyx; stamens exserted, longer than the triangular staminodia; fruit 1-2 cm. long, drooping.

Mangrove mud and saline marshes, Great Bahama, North Bimini, Andros, Watling's. Grand Turk, Inagua and Angulla Isles:-Georgia to Florida; southern California; West Indies; continental tropical America. SAltwort. TURTLE-WEed.

\section{Family 5. PHYTOLACCÀCEAE Lindl.}

\section{Pokeweed Family.}

Herbs, some tropical species shrubs, vines or trees, with alternate entire mostly estipulate leaves, and perfect regular polygamous or monoecious flowers. Calyx 4-5-parted or of 4 or 5 sepals, its segments or sepals imbricated in the bud. Petals wanting. Stamens as many as the calyxsegments or sepals and alternate with them, or more numerous, hypogynous; filaments distinct, or united at the base; anthers 2-celled, the sacs 
longitudinally dehiscent, often nearly separated. Ovary superior, severalcelled in most of the genera; ovulos solitary in the cavities, amphitropous. Styles as many as the carpels, short, or none; stigmas linear or filiform. Fruit a berry or an achene. Endosperm of the seed mealy or fleshy. About 22 genera and 110 species, mostly in the tropies.

Pistll a single carpel.

Frult a globular berry.

Stamens 4 ; style elongated.

Stamens 8-16; style none.

Fruit dry, achene-like, with bristles.

Pistil several-many-carpeled with as many styles as carpels.

1. Rivina.

2. Trichostigma.

3. Petiveria.

4. Phytolacca.

\section{RIVÌNA L. Sp. Pl. 121. 1753.}

Herbs, sometimes woody below, the stems branched, erect, the leaves thin in texture, the small perfect flowers in axillary or terminal, slender racemes. Sepals 4, not enlarging in fruit. Stamens 4, the filaments filiform, the anthers erect. Ovary 1-celled, subglobose; style curved; stigma capitate or 2-lobed. Fruit a small subglobose berry. Seed erect, lenticular, its testa crustaceous, the embryo curved, the endosperm mealy. [Commemorates August Rivinus, 1652-1725, professor in Leipzig.] A few species of tropical regions, the following typical.

1. Rivina hùmilis L. Sp. Pl. 121. 1753.

Rivina laevis L. Mant. 1: 41. 1767.

Glabrous or finely pubescent, branched, 3-8 dm. high. Leaves ovate to oblong or lanceolate, $3-12 \mathrm{~cm}$. long, membranous, flaccid, undulate or entire, acute or acuminate at the apex, narrowed or subtruncate at the base, the slender petioles 1-5 cm. long; racemes $10 \mathrm{~cm}$. long or less, loosely several-manyflowered; pedicels 4-6 $\mathrm{mm}$. long; bracts deciauous; calyx about $6 \mathrm{~mm}$. wide, the sepals oblong-cuneate, obtuse, pink or nearly white; stamens somewhat shorter than the sepals; berries subglobose, red, about $3 \mathrm{~mm}$. in diameter.

Coastal rocks and waste grounds, from Abaco throughout the archipelago to Parrot Cay (Calcos), Inagua, Angullla Isles, and Water Cay:-Florida; West Indies; continental troplcal America. WiLd Tомато.

2. TRICHOSTÍGMA A. Rich. in Sagra, Hist. Cuba 10: 306. 1845.

[Villamilia R. \& P.; Hook. f. in Benth. \& Hook. Gen. Pl. 3: 81. 1880.]

Woody vines, or shrubs, with alternate petioled broad leaves, the small perfect flowers in slender bracted racemes. Sepals 4 , concave, spreading or reflexed. Stamens 8-16; filaments filiform; anthers linear, versatile, 2-cleft. Ovary subglobose, 1-celled; ovule sessile; style none; stigma penicillate. Fruit coriaceous, baccate, subglobose, the pericarp adherent to the erect seed. [Greek, referring to the penicillate stigma.] About 4 species, of tropical America, the following typical.

\section{Trichostigma octándrum (L.) H. Walter, Pflanzenr. 39: 109. 1909.}

Rivina octandra L. Cent. Pl. 2: 9. 1756.

Villamilla octandra Hook. f. in Benth. \& Hook. Gen. Pl. 3: 81. 1880. Trichostigma rivinoides A. Rich. in Sagra, Hist. Cuba 10: 306. 1845.

A woody vine, often $10 \mathrm{~m}$. long or longer, usually climbing on trees, the stem up to $1.5 \mathrm{dm}$. in diameter at the base, the branches long and slender, 
glabrous. Leaves elliptic, oblong, or elliptic-lanceolate, membranous, $5-15 \mathrm{~cm}$. long, acuminate or acute at the apex, narrowed at the base, glabrous, entire, the slender petioles 1-5 cm. long; racemes usually numerous, loosely manyflowered, as long as the leaves or longer; pedicels $2-10 \mathrm{~mm}$. long; flowers white, about $8 \mathrm{~mm}$. broad, the ovate obtuse sepals at length reflexed; berry black, about $6 \mathrm{~mm}$. in diameter.

Waste grounds spontaneous after cultivation, Cat Island, at the Bight:-Florida; West Indies; continental tropical America north to Mexico. Trichostigma.

\section{PETIVìrIA L. Sp. Pl. 342. 1753.}

An erect slender perennial herb with the odor of garlic, the leaves broad, membranous, alternate, entire, the small perfect flowers in slender bracted spikes. Calyx 4-parted, conic at the base, the segments lanceolate, spreading in flower, erect in fruit. Stamens 4-8; filaments subulate; anthers linear, 2 cleft at apex and base. Ovary oblong, flattened, truncate, tomentose, 2-celled, with 1-6 deflexed bristles near the apex; style very short or none; stigma penicillate. Fruit elongated, cuneate, flattened, striate, keeled on both sides, 2-lobed at the top and bearing 1-6 hooked bristles. Seed linear. [In honor of Jacob Petiver, English naturalist and apothecary, who died in 1718.] A monotypic genus.

\section{Petiveria alliàcea L. Sp. Pl. 342. 1753.}

Stem puberulent, at least above, or glabrate, erect, branched, 2-10 dm. high, the branches slender, long, nearly erect or ascending. Leaves elliptic, oblong or obovate, sparingly pubescent or glabrous, $3-12 \mathrm{~cm}$. long, acute or acuminate at the apex, narrowed at the base, short-petioled; spikes very slender, 1-4 dm. long, puberulent; flowers greenish, short-pedicelled; sepals narrowly linear, about $4 \mathrm{~mm}$. long; achene linear-cuneate, about $6 \mathrm{~mm}$. long, appressed to the axis of the spike, the terminal, reflexed bristles about $2 \mathrm{~mm}$. long.

Waste and cultivated grounds, New Providence at Nassau:-Florida; West Indies; continental tropical America north to Mexico. GarLIC-WEed. OBEAH-BUSH.

\section{PHYTOLÁCCA L. Sp. Pl. 441. 1753.}

Tall perennial herbs, with petioled estipulate leaves, and small flowers in terminal racemes, which by the further growth of the stem become opposite the leaves. Pedicels bracted at the base and often 1-3-bracted above. Calyx of 4 or 5 persistent rounded sepals. Stamens $5-15$, inserted at the base of the calyx. Ovary composed of 5-15 distinct or somewhat united carpels. Fruit a depressed-globose 5-15-celled fleshy berry. Seeds 1 in each cavity, erect, compressed; embryo annular in the mealy endosperm. [Name Greek and French, refering to the crimson juice of the berries.] About 24 species, mostly tropical. Type species: Phytolacca americana $\mathrm{L}$.

1. Phytolacca icosándra L. Syst. ed. 10, 1040. 1759.

Phytolacca octandra L. Sp. Pl. ed. 2, 631. 1762.

Erect, glabrous, or puberulent above, branched, somewhat succulent, 1-3 $\mathrm{m}$. high. Leaves elliptic to ovate-lanceolate, membranous, $8-20 \mathrm{~cm}$. long, acute or acuminate at the apex, narrowed at the base, the rather stout petioles 1-5 
cm. long; racemes erect, densely many-flowered, 1-3 dm. long; pedicels 1.5-4 $\mathrm{mm}$. long; flowers greenish white or yellowish, $6-8 \mathrm{~mm}$. broad; sepals rounded; stamens 8-20; carpels 8-20; berry black, depressed-globose, about $8 \mathrm{~mm}$. in diameter.

Waste and cultivated ground, and in copplces, Great Bahama, Andros, New Providence, Eleuthera, Great Exuma:-Cuba ; Jamaica; Hispaniola ; continental tropical America. Southers Poke-Weed or Poke-bush. Pork-Bush.

\section{Family 6. AIZOÀCEAE A. Br.}

\section{Carpet-weed Family.}

Herbs, rarely somewhat woody, mostly prostrate and branching, with (in our species) opposite, more or less fleshy leaves, and perfect small regular flowers. Stipules none or scarious, or the petiole-bases dilated. Calyx 4-5-cleft or 4-parted. Petals small or none in most species. Stamens perigynous. Ovary usually free from the ealyx, 3-5-celled, and ovules numerous in each cell in our genus. Fruit a capsule with loculicidal or eircumscissile dehiscence. Seeds amphitropous; endosperm scanty or copious; embryo slender, curved. About 22 genera and 500 species, mostly of warm regions, a few in the temperate zones.

\section{SESÙVIUM L. Syst. ed. 10, 1058. 1759.}

Fleshy decumbent or prostrate herbs, with opposite leaves and axillary pink or purplish flowers. Stipules none, but the petioles often dilated and connate at the base. Calyx-tube top-shaped, 5-lobed, the lobes oblong, obtuse. Petals none. Stamens 5-60, inserted on the calyx-tube. Filaments filiform, sometimes united at the base. Ovary 3-5-celled. Styles 3-5, papillose along the inner side. Capsule membranous, oblong, 3-5-celled, circumscissile. Seeds round-reniform, smooth; embryo annular. About 4 species, natives of seacoasts and saline regions. Type species: Sesuvium portulacastrum L.

Stamens 5.

Stamens numerous.
1. S. maritimum.

2. S. portulacastrum.

1. Sesuvium marítimum (Walt.) B.S.P. Prem. Cat. N. Y. '20. 1888.

Pharnaceum maritimum Walt. Fl. Car. 117. 1788.

Sesuvium pentandrum Ell. Bot. S. C. \& Ga. 1: 556. 1821.

Annual, glabrous; branches $0.5-3 \mathrm{dm}$. long. Leaves obovate or spatulate, entire, rounded or slightly emarginate at the apex, narrowed into a petiole or the upper sessile, $8-25 \mathrm{~mm}$. long; flowers sessile or nearly so, about $2 \mathrm{~mm}$. broad, mostly solitary; stamens 5 , alternate with the calyx-lobes; capsule ovoid, about $4 \mathrm{~mm}$. high, scarcely longer than the calyx.

Salinas and edges of mangrove swamps, Andros. Ship Channel Cay, Cat Island, Long Island, Little San Salvador and Watling's :-Atlantic coast from Long Island to Florida; Cuba; Porto Rico. SLENDER SEA PuRSLANe.

\section{Sesuvium portulacástrum L. Syst. ed. 10, 1058.1759.}

Perennial, fleshy, glabrous. Stems usually diffusely branched, the branches prostrate, often creeping, forming large patches; leaves oblanceolate to oblong, 1.5-4 cm. long, acute or acutish, the bases clasping; flowers short-pedicelled, solitary in the axils; calyx-lobes lanceolate, 7-10 $\mathrm{mm}$. long, hooded, purple 
within, the back prolonged into an appendage; stamens numerous; capsule conic, 8-10 mm. long.

Sea beaches and saline borders, throughout the archipelago to Turks Isiand and Cay Sal :-Bermuda; North Carolina to Florida; the West Indies; Mexico to Colombla and Venezuela; Old World troples. Plants from saline borders have smaller leaves and seeds than those from sea beaches and coastal rocks. SEA PuRsLaNE.

\section{Family 7. ALSINÀCEAE Wahl.}

\section{CHICKWEED FAMILY.}

Annual or perennial herbs with opposite entire leaves, estipulate or stipulate, and mostly small perfect flowers, solitary or in cymes or umbels. Calyx of 4 or 5 sepals, imbricated, at least in the bud, separate to the base, or nearly so. Petals as many as the sepals, not clawed, rarely wanting. Stamens twice as many as the sepals, or fewer, inserted at the base of the sessile ovary, or on a small disk; filaments distinct, or cohering below; anthers introrse, longitudinally dehiscent. Ovary usually 1-celled; styles 2-5, distinct; ovules several or numerous, amphitropous or campylotropous, borne on a central column. Fruit a capsule, dehiscent by valves or by apical teeth. Embryo mostly curved and with incumbent cotyledons. About 32 genera and 500 species, of wide distribution, most abundant in temperate regions.

\section{DRYMÀRIA Willd; R. \& S. Syst. 5: 406. 1819.}

Low branching herbs, with flat small leaves, small, often fugacious stipules, and small mostly white flowers in eymes or solitary. Sepals 5, distinct. Petals 5, cleft. Stamens 5 or fewer. Ovary 1-celled, many-ovuled; style mostly 3-cleft. Fruit a 5-valved capsule. Seeds globose-reniform, the embryo peripheral. [Greek, pertaining to the forest.] About 20 species, of tropical and subtropical America, one also in the Old World tropics. Type species: Drymaria arenarioides H. \& B.

\section{Drymaria cordàta (L.) Willd.; R. \& S. Syst. 5: 406.1819.}

Holosteum cordatum L. Sp. Pl. 88. 1753.

Annual, glabrous or puberulent above; stems very slender, diffuse, 1-4 $\mathrm{dm}$. long. Leaves orbicular or broader than long, 6-20 mm. wide, membranous, palmately veined, obtuse or cuspidulate at the apex, subcordate at the base, short-petioled; peduncles filiform, usually much longer than the leaves, often forked; cymes few-several-flowered; pedicels as long as the bractlets or shorter; sepals 1.5-3 mm. long, oblong-lanceolate, acute; petals 2-cleft; stamens 2 or 3 ; capsule about as long as the sepals.

Waste grounds, New Providence:-Florida; West Indles and continental tropical America. Drymaria.

\section{Family 8. PORTULACÁCEAE Rehb.}

\section{Purslane Family.}

Herbs, rarely somewhat woody, with regular perfect but unsymmetrical flowers. Sepals commonly 2 (rarely 5). Petals 4 to 6, rarely more, 
hypogynous, imbricated. Stamens hypogynous, equal in number to the petals or fewer, rarely more; filaments filiform; anthers 2-celled, longitudinally dehiscent. Ovary 1-celled; style 2-3-cleft or 2-3-divided, the divisions stigmatic on the inner side: ovules $2-\infty$, amphitropous. Capsule circumscissile, or dehiscent by 3 valves. Seeds $2-\infty$, reniform-globose or compressed: embryo curved. About 20 genera and 180 species, mostly natives of America.

1. PORTULÀCA L. Sp. Pl. 445.1753.

Diff use or ascending, glabrous or pubescent sueculent herbs, with terminal flowers. Sepals 2, united at the base and partly adnate to the ovary. Petals 4-6 (mainly 5), inserted on the calyx, fugacious. Stamens $7-\infty$, also on the calyx. Ovary many-ovuled; style deeply 3-9-cleft or parted. Capsule membranous, dehiscent by a lid, many-seeded. [Latin, in allusion to the purging qualites of some species.] A genus of about 20 species, all but 2 or 3 natives of America. Type species: Portulaca oleracea L.

Leaves flat: flowers yellow.

Leaves subterete.

Flowers yellow; seeds brown.

Flowers purple; seeds black.
1. P. oleracea.

2. P. phaeosperma.

3. $P$. gagatosperma.

\section{Portulaca oleràcea L. Sp. Pl. 445. 1753.}

Annual, usually prostrate, branching from a deep root; branches 1-7.5 dm. long. Leaves alternate and clustered at the ends of the branches, obovate or cuneate, 6-20 mm. long, rounded at the apex, very fleshy; flower-buds flat; flowers solitary, sessile, 4-10 $\mathrm{mm}$. broad, yellow, opening in bright sunshine; sepals broad, keeled, acutish; style 4-6-parted; capsule 6-10 $\mathrm{mm}$. long; seeds finely rugose.

Cultivated soll, waste places and maritime rocks, throughout the archipelago:all temperate and troplcal regions. Includes several races differing in size of leaves and flowers, and of a prostrate or ascending habit. PURsLANE.

\section{Portulaca phaeospérma Urban, Symb. Ant. 4: 233. 1905.}

Fleshy, branched, $1.5 \mathrm{dm}$. high or less, with tufts of brownish hairs at the nodes. Leaves linear-oblong, subterete, acute or obtuse, $5-10 \mathrm{~mm}$. long, about $2 \mathrm{~mm}$. thick, alternate and clustered at the ends of the branches; flowers yellow, 6-10 $\mathrm{mm}$. broad; petals oblong to obovate, obtuse; capsule about $3 \mathrm{~mm}$. in diameter, circumscissile at about the middle; seeds brown.

Dry or rocky soil, throughout the archipelago from Great Bahama and Andros to Mariguana, Turk's Islands and Inagua :- Florida; Cuba to St. Croix and Virgin Gorda; Jamaica. Referred by Mrs. Northrop and by Coker to $P$. halimoides L.; by Hitchcock and by Coker to $P$. pilosa L. Brown-semend Portulaca.

\section{Portulaca gagatospérma Millsp. Field. Mus. Bot. 2: 299. 1909.}

Fleshy, diffusely branched, 5-10 $\mathrm{cm}$. high, with tufts of whitish hairs at the nodes. Leaves alternate, subterete, acute, 6-12 $\mathrm{mm}$. long, about $2 \mathrm{~mm}$. thick, short-petioled; flowers sessile at the ends of the branches; sepals broadly ovate, apiculate; petals purple, emarginate; capsule about $4 \mathrm{~mm}$. in diameter, circumscissile below the middle; seeds jet black, $0.6 \mathrm{~mm}$. in diameter.

In moist solls and mud of lake borders, Great Bahama, New Providence, Grand Turk, Salt Cay (Turk's Islands) and Inagua, attaining its highest development in our region on the dry rocks of East and Ambergris Cays of the Turk's Island group :-Endemic. Referred by Hitchcock to $P$. pilosa L., which it resembles. BAHAMA PORTULACA. 


\section{Order 10. RANÀLES.}

Herbs, shrubs or trees. Calyx present, usually of separate sepals. Corolla usually present and of separate petals. Ovary or ovaries superior, free from the calyx; carpels 1 to many, usually separate. Stamens mostly hypogynous and more numerous than the sepals.

Aquatic herbs, the leaves peltate or with a basal sinus. Fam. 1. NympHaeaceae. Terrestrial plants.

Stamens many; sepals distinct.

Flowers perfect (in the Bahama species).

Carpels distinct; sepals 4 or 5 ; petals, when present about as many (none in Clematis). Carpels more or less coherent; sepals 3 ; petals 6 ; trees or shrubs.

Flowers dioecious, small; cllmbing vines.

Stamens 9 or 12 in 3 or 4 series of 3 each; sepals more or less united.

Shrubs or trees with broad leaves; fruit borne on the calyx-tube.

Leafless vines; frult enclosed by the accrescent calyx-tube.

Fam. 2. Ranunculaceae.

Fam. 3. Annonaceae.

Fam. 4. MENISPERMACEAE.

Fam. 5. Lauraceae.

Fam. 6. Cassythaceae.

\section{Family 1. NYMPHAEÀCEAE DC.}

\section{WATER LiLy FAMily.}

Aquatic perennial herbs, with horizontal rootstocks, floating, immersed or rarely emersed leaves, and solitary axillary flowers. Sepals

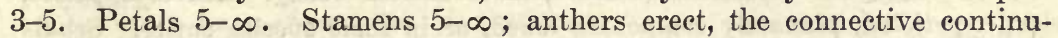
ous with the filament. Carpels $3-\infty$, distinct, united, or immersed in the receptacle. Stigmas distinct, or united into a radiate or annular disk; ovules $1-\infty$, orthotropous. Fruit indehiscent. Seeds enclosed in pulpy arils, or rarely naked; cotyledons fleshy; hypocotyl very short. Five genera and about 55 species, widely distributed in fresh water.

\section{CASTÀIIA Salisb. Par. Lond. 1: pl. 14. 1805.}

Herbs with horizontal perennial rootstocks, floating leaves and showy flowers. Sepals 4. Petals in several rows, or but few, inserted on the ovary, gradually passing into stamens; stamens $\infty$, the exterior with large petaloid filaments and short anthers, the interior with linear filaments and elongated anthers. Carpels $\infty$, united into a compound pistil with radiating linear projecting stigmas. Fruit globose, covered with the bases of the petals, ripening under water. [A spring of Parnassus.] About 40 species, of wide geographic distribution. Type species: Castalia magnifica Salisb.

\section{Castalia pulchélla (DC.) Britton, Bull. N. Y. Bot. Gard. 4: 138. 1906.}

Nymphaea pulchella DC. Syst. 2: 51. 1821.

Nymphaea ampla pulchella Casp. in Mart. Fl. Bras. 42: 159. 1878.

Rootstock 2-4 cm. thick. Petioles 5-10 mm. thick, various in length, depending upon the depth of water; leaf-blades suborbicular, rather thin, 1-3 dm. broad, glabrous, undulate or repand, green on both sides, very coarsely reticulate-veined beneath, the basal sinus rather narrow, the lobes acute; peduncles about as long and as thick as the petioles; sepals 4, lanceolate, 
acutish, $6 \mathrm{~mm}$. long or less; petals $4-8$, white, acute; stamens 50 or fewer; fruit $2-3 \mathrm{~cm}$. in diameter.

Fresh water swamps and water-holes, New Providence, Cat Island, Great Exuma, Acklin's Island and Inagua :-Cuba to Halti and St. Crolx; South AmerIca. Referred to by Coker as C. ampla.(DC.) Greene. White Water-LiLY.

\section{Family 2. RANUNCULÀCEAE Juss.}

Crowfoot Family.

Herbs, or rarely climbing shrubs, with acrid sap. Leaves alternate (except in Clematis and Atragene). Stipules usually none, but the base of the petiole often sheathing. Pubescence, when present, composed of simple hairs. Sepals 3-15, generally caducous, often petal-like, imbricate, except in Clematis and Atragene. Petals about the same number (occasionally more), or wanting. Stamens $\infty$, hypogynous, their anthers innate. Carpels $\infty$ or rarely solitary, 1-celled, 1-many-ovuled. Ovules anatropous. Fruit achenes, follicles or berries. Seeds with endosperm. About 35 genera and 1100 species, distributed throughout the world, not abundant in the tropies.

\section{CLÉmatis L. Sp. Pl. 543. 1753.}

Climbing vines or perennial herbs, more or less woody. Leaves opposite, slender-petioled, pinnately compound, lobed, or in some species entire. Sepals 4 or 5 , valvate in the bud, petaloid. Petals none. Stamens $\infty$. Pistils $\infty$. Achenes 1-seeded. Style long, persistent, plumose, silky or naked. [Greek name for some climbing plant.] About 25 species of very wide geographic distribution, most abundant in temperate regions. Type species: Clematis Vitalba L.

1. Clematis bahàmica (Kuntze) Britton, Bull. N. Y. Bot. Gard. 4: 117. 1905.

Clematis dioica bahamica Kuntze, Verh. Bot. Ver. Prov. Brand. 26: 102. 1895.

Vine slender, trailing or high-climbing, the young plants sparingly and loosely pubescent. Leaves trifoliolate or the uppermost simple; leaflets slenderstalked, $4 \mathrm{~cm}$. long or less, various in form even on the same vine, ovate to oval or nearly orbicular, acute or obtuse and mucronulate at the apex, quite glabrous when mature, entire, or often 3 -lobed, firm in texture and strongly veined on the under side; achenes plump, only $3 \mathrm{~mm}$. long, the filiform plumose style 3-5 cm. long; flowers few, in small leafy-bracted panicles; pedicels loosely pubescent; sepals oblong-lanceolate, about $5 \mathrm{~mm}$. long, loosely pubescent, in a Mariguana specimen coherent and falling away as a cap.

Rocky thickets, pine-lands and sink-holes, Abaco, Great Bahama, Andros, Fleuthera, Cat Island, Great Exuma, and Mariguana.' Endemic. Referred by Mrs. Northrop to $C$. dioica; by Hitcheock to $C$. flammulastrum, and by Dolley to $C$. Vitalba. BAHAMA VIRGIN'S-BOWER. 


\section{Family 3. ANNONÄCEAE DC.}

\section{CUSTARD-APPLE FAMily.}

Trees or shrubs, generally aromatic, with alternate entire leaves. Stipules none. Sepals 3 (rarely 2), valvate or rarely imbricate. Petals about 6, arranged in 2 series. Stamens $\infty$; anthers adnate, extrorse. Carpels $\infty$, separate or coherent, mainly fleshy in fruit. Seeds large, anatropous; embryo minute; endosperm copious, wrinkled. About 46 genera and 550 species, mostly in the tropies, a few in the temperate zones.

\section{ANNÒNA L. Sp. Pl. 536. 1753.}

Mostly trees, with coriaceous or chartaceous leaves, and perfect, usually solitary and axillary, nodding, peduncled flowers. Sepals 3, valvate, deciduous. Petals usually 6 , valvate, the 3 outer larger than the 3 inner. Receptacle hemispheric. Anther-sacs contiguous. Pistils borne at the top of the receptacle; ovaries 1-ovuled; stigma sessile or nearly so. Fruit compound, aggregate, many-seeded; seeds arillate. [Name said to be derived from Malayan.] I'ifty species or more, of tropical and subtropical distribution. Type species: Annona muricata L.

Outer netals broad, ovate, the inner as. long, or somewhat shorter; fruit smooth. 1 . A. glabra.

Outer petals linear-oblong, the inner minute.

Fruit tubercled.

Fruit reticulated or areolate.

2. A. squamosa. 3. A. reticulata.

1. Annona glàbra L. Sp. Pl. 537. 1753.

Annona palustris L. Sp. Pl. ed. 2, 757. 1762.

Anona laurifolia Dunal, Monogr. Anon. 65. 1817.

A tree, up to $12 \mathrm{~m}$. high, with a trunk 4 or $5 \mathrm{dm}$. in diameter, usually smaller, sometimes shrubby, the fissured bark reddish brown, the twigs glabrous. Leaves ovate to oblong, subcoriaceous, $8-18 \mathrm{~cm}$. long, acute or short-acuminate at the apex, usually rounded at the base, the petioles 1-4 cm. long; flowers solitary in the axils, nodding, short-peduncled, yellowish green, $2-3.5 \mathrm{~cm}$. long; sepals broader than long, slightly united; petals thick, concave, the outer a little larger than the inner; fruit ovoid, 6-13 $\mathrm{cm}$. long, smooth, rounded at apex, impressed at base, yellowish brown; seeds 1-2 cm. long.

Ponds and water-holes. Great Bahama, Andros, New Providence, Cat Island, Watling's Island, Crooked Island?-Florida; West Indies; northern South America. Catesby, 2: $p l .6 \%, 6 \%$. POND-APPLE.

\section{Annona squamòsa L. Sp. Pl. 537. 1753.}

A tree, up to about $12 \mathrm{~m}$. high, the young twigs densely pubescent. Leaves elliptic, lanceolate to oblong, chartaceous, 6-12 cm. long, pubescent, at least when young, sometimes glabrous when old, acute at the apex, narrowed at the base, the petioles 5-12 $\mathrm{mm}$. long; peduncles about as long as the petioles; flowers greenish, about $2 \mathrm{~cm}$. long; sepals triangular, acute, pubescent, $1.5 \mathrm{~mm}$. long; outer petals linear-oblong, puberulent; fruit globose, $5-9 \mathrm{~cm}$. in diameter, strongly tubercled, greenish, the tubercles rounded, the pulp white; seeds oblong, brown, shining.

Scrub-lands. New Providence, probably introduced:-Cuba to Virgin Gorda and St. Vincent; Jamaica; widely cultivated in tropical regions. SugAR-APPLE. 
3. Annona reticulàta L. Sp. Pl. 537. 1753.

A small tree, sometimes $8 \mathrm{~m}$. high, usually smaller, the young twigs puberulent. Leaves oblong, oblong-lanceolate, or narrowly lanceolate, chartaceous, 8-15 cm. long, 2-4 cm. wide, puberulent when young, glabrous when old, acuminate at the apex, narrowed at the base, the rather stout petioles $2 \mathrm{~cm}$. long or less; peduncles longer than the petioles; flowers greenish, about $2 \mathrm{~cm}$. long; sepals triangular-ovate, $2-3 \mathrm{~mm}$. long; outer petals narrowly oblong, puberulent; fruit globose, 8-12 $\mathrm{cm}$. in diameter, yellowish brown, glabrous, coarsely reticulated, the pulp yellowish, the oblong, brown seeds shining.

Sink-holes, Great Bahama at Eight Mile Rocks:-West Indies. Widely cultivated. Custard APPLE. Catesby, 2: pl. 86.

\section{Familỳ 4. MENISPERMÀCEAE DC.}

\section{Moonseed Family.}

Vines, shrubs or trees, with alternate leaves, no stipules, and small dioecious panicled racemose or eymose flowers. Sepals 4-12, or fewer. Petals 6 , imbricated in 2 rows, sometimes fewer, or none. Stamens about the same number as the petals or fewer. Carpels $3-\infty$ (generally 6), 1ovuled, separate; styles commonly recurved. Fruit drupaceous. Embryo long, eurved. About 55 genera and 150 species, mainly of tropical distribution, a few extending into the temperate zones.

\section{CISSÁMPelos L. Sp. P1. 1031. 1753.}

Slender vines, often high-climbing, the leaves broad, mostly entire and cordate, palmately veined, the staminate flowers cymose-paniculate, the pistil- late clusters racemose, bracted. Staminate flowers with 4 sepals, the petals united below into a cup, the 2-4 anthers sessile on the peltate top of the stamen-column. Pistillate flowers with a rudimentary scale-like perianth of 1 sepal and 1 petal and a single carpel with a 3-cleft or 3-toothed style. Drupe subglobose, convex; stone compressed, tubercled on the back, concave on both sides. [Greek, ivy-grape.] Perhaps 25 species, of tropical America and tropical and southern Africa. Type species: Cissampelos Pareira L.

\section{Cissampelos tomentòsa DC. Syst. 1: 535. 1818.}

Climbing, often $5 \mathrm{~m}$. long or longer, the young branches, petioles, inflorescence and under leaf-surfaces densely tomentose. Leaves suborbicular, 2-10 $\mathrm{cm}$. broad, cordate or truncate at the base, not peltate, the petioles 1-7 $\mathrm{cm}$. long; racemes of pistillate flowers $5-8 \mathrm{~cm}$. long, the bracts orbicular, cordate or subcordate, $5-15 \mathrm{~mm}$. broad, the pedicels several at each bract, densely tomentose, about $2 \mathrm{~mm}$. long, the sepals about $1 \mathrm{~mm}$. long; panicles of staminate flowers $8 \mathrm{~cm}$. long or less, the flowers usually very numerous, about $1 \mathrm{~mm}$. broad, on filiform short pedicels.

Old fields and coppices, Andros, near Nicol's Town :-Cuba; Jamaica ; Mexico and Central America. Velvety Cissampelos. 


\title{
Family 5. LAURÃCEAE Lindl.
}

\author{
Laurel Family.
}

Aromatic trees and shrubs, with alternate (very rarely opposite) mostly thick, punctate estipulate leaves. Flowers small, perfect, polygamous, dioecious, or sometimes monoecious, usually fragrant, yellow or greenish, in panicles, corymbs, racemes or umbels. Calyx 4-6-parted, the segments imbricated in 2 series in the bud. Corolla none. Stamens inserted in 3 or 4 series of 3 on the ealyx, distinct, some of them commonly imperfect or reduced to staminodia; anthers opening by valves. Ovary superior, free from the calyx, 1-celled; ovule solitary, anatropous, pendulous; stigma discoid or capitate. Fruit a 1-seeded drupe or berry. Endosperm none. Cotyledons plano-convex, accumbent. About 40 genera and 1000 species, widely distributed in tropical regions; a few in the temperate zones.

Staminodia of the fourth series small or none.

Staminodia of the fourth series large, sagittate.
1. OCOTEA

2. Persea.

1. OCOTÈA Aubl. Pl. Guian. 2: 780. 1775.

[NECTANDRA Roland; Rottb. Deser. Pl. Surinam. 10. 1776.]

Evergreen trees, rarely shrubs, with alternate coriaceous leaves and small, perfect or polygamous flowers in axillary or terminal panicles. Perianthsegments 6 , nearly equal. Perfect stamens 9 , in 3 series; stamens of the first and second series eglandular, their anthers introrsely 4-celled; stamens of the third series with extrorsely 4-celled anthers; staminodia, representing a fourth series of stamens, are present in some species. Ovary wholly or partly enclosed by the perianth-tube; style short. Berry oblong to globose, partly enclosed by the enlarged perianth-tube. [Guiana name.] Probably 300 species, mostly natives of tropical America. Type species: Ocotea guianensis Aubl.

\section{Ocotea coriàcea (Sw.) Britton.}

Laurus coriacea Sw. Prodr. 65. 1788.

Laurus Catesbyana Michx. Fl. Bor. Am. 1: 244. 1803.

Nectandra coriacea Griseb. Fl. Br. W. I. 281. 1860.

Ocotea Catesbyana Sargent, Sylva 7: 11.1895.

An evergreen tree, up to $12 \mathrm{~m}$. high, the trunk sometimes $3 \mathrm{dm}$. in diameter, the nearly smooth bark light gray, the twigs slender, glabrous, the wood brown. Leaves oblong or oblong-lanceolate, coriaceous, 6-15 $\mathrm{cm}$. long, acute or acuminate at the apex, narrowed at the base, dark green and shining above, dull beneath, glabrous or very nearly so, reticulate-veined, the petioles $5-15 \mathrm{~mm}$. long; panicles axillary, peduncled, puberulent, several-many-flowered; pedicels 4-7 mm. long; calyx white, its 6 lobes oblong or ovate-oblong, obtuse, about $4 \mathrm{~mm}$. long; stamens shorter than the calyx; drupe oval or subglobose, dark blue or nearly black, $10-18 \mathrm{~mm}$. long, the persistent red or yellow calyx-base 3-4 mm. long.

Coppices and scrub-lands, Great Bahama, Andros, New Providence, Eleuthera, Cat Island, Watling's, Crooked Island and North Calcos:- Forida: West Indles. Referred by Grisebach, Dolley, Mrs. Northrop and by Hitchcock to Nectandra sanguinea Rottb. Catesby, 2: pl. 28. Bastard 'Torch. BLACK TORCH. SweEt TORCHWOOD. 


\section{PÉRSEA Gaertn. Fr. \& Sem. 3: 222. 1805.}

Leaves alternate, coriaceous, persistent, entire. Calyx 6-parted, persistent. Stamens 12 , in 4 series of 3 , the inner series reduced to gland-like staminodia, the 3 other series anther-bearing, their anthers 4-celled, 4-valved, those of the third series extrorse and the others introrse in our species. Staminodia large, cordate, stalked. Fruit a berry. [Ancient name of some oriental tree.] About 50 species, natives of America. Type species: Persea gratissima Gaertn.

1. Persea pubéscens (Pursh) Sargent, Silva N. A. 7: 7. 1895.

Tamala pubescens Small, Fl. SE. U. S. ed. 2, 822, 1375. 1913.

Laurus carolinensis pubescens Pursh, Fl. Am. Sept. 276. 1814.

A tree, with maximum height of about $14 \mathrm{~m}$. the trunk up to $3.5 \mathrm{dm}$. in diameter, the twigs densely short-pubescent, the thin brown bark fissured. Leaves lanceolate to oblong-lanceolate or oval, subcoriaceous, $0.5-2 \mathrm{dm}$. long, acute, obtuse or acuminate at the apex, narrowed at the base, glabrous, bright green and shining above, pale and pubescent beneath, the pubescent petioles $2 \mathrm{~cm}$. long or less; peduncles pubescent, shorter than the leaves; pedicels very short; inner sepals 5-6 mm. long, twice as long as the outer; filaments pubescent; drupe dark blue, glaucous, oval or subglobose, $8-15 \mathrm{~mm}$. in diameter. BAT.

Palmetto-lands, Great Bahama at Barnett's Point:-Virginia to Florida. RED

\section{Family 6. CASSYTHÀCEAE Dumont.}

\section{Love-vine FAMILY.}

Vines, trailing, or parasitic by papillae on shrubs or on trees, the leaves none, or reduced to scales, the small regular and perfect flowers spicate, racemose, or capitate. Calyx 6-cleft, the lobes imbricated, in 2 series, the outer ones shorter than the inner. Corolla none. Perfect stamens 9 , with 2-celled anthers; staminodes 3 . Pistil 1; ovary 1-ovuled, becoming enclosed by the enlarging calyx-base; style simple; stigma small, mostly capitate. Fruit berry-like, fleshy. Only the following genus.

1. CASSỲTHA L. Sp. Pl. 35. 1753.

Characters of the family. About 15 known species, of tropical regions. [Synonym of Cuscuta.] Type species: Cassytha filiformis L.

1. Cassytha americàna Nees. Syst. Laur. 644. 1836.

Cassytha filiformis Jacq. Sel. Amer. 115. 1763. Not L. 1753.

Slender, branched, often $5 \mathrm{~m}$. long or more, sometimes matted, yellow or yellowish green, the stems about $2 \mathrm{~mm}$. thick. Leaves mere ovate or lanceolate, acute scales 1-2 mm. long, few and distant; spikes peduncled, few-severalflowered, 1-2 cm. long; flowers white, about $2 \mathrm{~mm}$. broad, the inner sepals ovate, larger than the outer; fruit globose, white, 5-7 $\mathrm{mm}$. in diameter.

Coastal sand dunes and maritime rocks, throughout the archipelago from Abaco and Great Bahama south to Mariguana, Inagua and the Caicos and Anguilla Isles :Florida; West Indies; Mexico and continental tropical America. WoE-VINE. 


\section{Order 11. PAPAVERÀLES.}

Mostly herbs, with clustered, regular and perfect flowers. Petals, with very rare exceptions, present, separate. Sepals usually separate. Stamens hypogynous. Ovary superior, free from the calyx, compound, composed of two united carpels, or more.

Sepals 2 (very rarely 3 or 4 ) ; endosperm fleshy.

Sepals or calyx-segments 4-8; endosperm none.

Capsule 2-celled by a longitudinal partition, usually 2-

valved, rarely indehiscent; sepals and petals 4 .

Capsule 1-celled, of 2-6 carpels.

Style short or wanting; seeds wingless.

Style elongated; seeds winged.

Fam. 1. Papaveraceat.

Fam. 2. BRASSICACEAE.

Fam. 3. Capparidachat.

Fam. 4. Moringaceae.

\section{Family 1. PAPAVERÀCEAE B. Juss.}

\section{Poppy FAMily.}

Herbs, with milky or colored sap, and alternate leaves or the upper rarely opposite. Stipules none. Flowers perfect, regular. Sepals 2 (rarely 3 or 4 ), caducous. Petals $4-6$ or rarely more, imbricated, often wrinkled, deciduous. Stamens hypogynous, distinct; filaments filiform; anthers longitudinally dehiscent. Ovary 1, many-ovuled, mainly 1-celled; style short; ovules anatropous. Fruit a capsule, generally dehiscent by a pore, or by valves, rarely indehiscent. About 23 genera and 115 species, widely distributed, most abundant in the north temperate zone.

\section{ARGEMÒNE L. Sp. Pl. 508. 1753.}

Glaucous herbs, with yellow sap, spiny-toothed leaves and large flowers. Sepals 2 or 3 . Petals 4-6. Stamens $\infty$. Placentae 4-6, many-ovuled. Style very short. Stigma dilated, 3-6-radiate. Capsule prickly, oblong, dehiscent at the apex by valves. Seeds numerous, cancellate. [Greek, an eye disease, supposed to be relieved by the plant so called.] A genus of about 10 species, natives of the warmer parts of America. Type species: Argemone mexicana L.

\section{Argemone mexicàna L. Sp. Pl. 508. 1753.}

Stem 3-6 dm. high, spiny or sometimes nearly unarmed. Leaves sessile, clasping by a narrowed base, 1-2.5 dm. long, glaucous, runcinate-pinnatifid, spiny-toothed and more or less spiny on the veins; flowers orange or yellow, sessile or subsessile, $2-8 \mathrm{~cm}$. broad; sepals acuminate, bristly-pointed; capsule $2.5 \mathrm{~cm}$. long or more; stigma sessile.

A weed of waste places near dwellings, throughout the archipelago from Great Bahama south to Grand Turk, Salt Cay, Inagua :- Bermuda; southern United States; West Indies; continental tropical America; Old World tropics. Donker Thistle. Mexican Poppy.

\section{Family 2. BRASSICÀCEAE Lindl.}

\section{Mustard Family.}

Herbs, rarely somewhat woody, with watery acrid sap, alternate leaves, and racemose or corymbose flowers. Sepals 4, deciduous, or rarely persistent, the 2 outer narrow, the inner similar, or concave, or saccate 
at the base. Petals 4, hypogynous, cruciate, nearly equal, generally clawed. Stamens 6, rarely fewer, hypogynous, tetradynamous. Pistil 1 , compound, consisting of 2 united carpels, the parietal placentae united by a dissepiment; style generally persistent, sometimes none; stigma discoid or usually more or less 2-lobed. Fruit a silique or silicle, generally 2-celled, rarely 1-celled, in a few geenra indehiscent. Seeds attached to both sides of the septum; endosperm none; cotyledons incumbent, accumbent or conduplicate. About 200 genera and 1800 species, of wide geographic distribution.

Pod a sllique or silicle, dehiscent into 2 valves.

Pod a flattened sillicle.

Pod a short or long sillque, not flattened.

Flowers yellow; leaves lobed or toothed. Pod elongated, beaked.

Pod conic-beaked, its valves 1-3-nerved.

Pod stout-beaked, its valves 3-5-nerved. Pod short, beakless.

Pod indehiscent.

Flowers white; leaves entire.

Pod suborblcular, didymous.

Pod elongated, of 2 separating joints.

1. Lepidium.

2. Brassica.

3. Sinapis.

4. Radicula.

5. Conringia.

6. Carara.

7. Cakile.

\section{LEPÍDIUM L. Sp. Pl. 643. 1753.}

Erect or rarely diffuse herbs, with pinnatifid lobed or entire leaves and racemose white or whitish flowers. Stamens often fewer than 6. Petals short, sometimes none. Silicles oblong to orbicular, flattened contrary to the partition, winged or wingless; valves keeled, dehiscent. Seeds solitary in each cell, flattened; cotyledons incumbent or rarely accumbent. [Greek, a little scale, from the flat scale-like pods.] About 65 species, widely distributed. Type species: Lepidium latifolium $\mathrm{L}$.

\section{Lepidium virgínicum L. Sp. Pl. 645. 1753.}

Annual, erect, glabrous. Basal leaves obovate or spatulate in outline, pinnatifid, generally with a large terminal lobe and numerous small lateral ones, all dentate, glabrous or slightly pubescent; stem-leaves lanceolate or oblong-linear, sessile, or the lower stalked; flowers 1-2 mm. broad, white; petals generally present, sometimes wanting in the later flowers; pedicels slender, spreading, 4-6 mm. long in fruit; pod flat, short-oval or orbicular, minutely winged above; cotyledons accumbent.

A weed of waste grounds and cultivated solls, throughout the archipelago from Abaco and Great Bahama to Andros, Turk's Islands, Ambergris Cay and Inagua:-Bermuda: native of continental North America; widely naturalized as a weed in the West Indies, Mexico and Central America. Wild Pepper-Grass.

\section{BRÁSSICA L. Sp. Pl. 666.1753.}

Erect branching herbs, with pinnatifid basal leaves, and showy yellow flowers in elongated racemes. Siliques elongated, sessile, terete or 4-sided, tipped with an indehiscent conic, usually 1-seeded beak. Valves convex, 1-3nerved. Seeds in 1 row in each cell, oblong, marginless; cotyledons conduplieate. [Latin name of the cabbage.] About 80 species, natives of Europe, Asia and northern Africa. Type species: Brassica oleracea L. 
1. Brassica integrifòlia (West) O. E. Schulz, in Urban Symb. Ant. 3: 509. 1903.

Sinapis integrifolia West Bidr. St. Croix, 296. 1793.

Glabrous or sparingly pilose below, pale green, slightly glaucous, $8 \mathrm{dm}$. high or less. Basal and lowest cauline leaves broadly obovate, or ellipticobovate, coarsely dentate, obtuse, long-petioled, often 2-lobed near the base; upper leaves oblong to linear, few-toothed or entire, mostly acute, shortpetioled or sessile; racemes loosely several-many-flowered, erect; pedicels filiform, 6-12 $\mathrm{mm}$. long; petals light yellow, 6-9 $\mathrm{mm}$. long, broadly obovate, clawed; pods erect-spreading, 3-4 $\mathrm{cm}$. long, about $2 \mathrm{~mm}$. thick, the slender beak 4-7 mm. long.

Cultivated soll, New Providence; Great Exuma at Georgetown:-Porto Rico to St. Jan and Trinidad; Jamaica; Yucatan; native of Asia. Recorded by Dolley as Sinapis brassicata I. WILD MUSTARD.

\section{SINÀPIS L. Sp. Pl. 668. 1753.}

Annual or biennial, usually erect, branching more or less hispid herbs, with pinnatifid or lobed leaves, and rather large, mostly yellow flowers in terminal racemes. Siliques linear, nearly terete, constricted between the seeds, sessile in the calyx, tipped with a flat sword-like beak which sometimes contains a seed near its base, its valves 3-5-nerved. Seeds oblong or subglobose, not winged nor margined. Cotyledons conduplicate. [Name Greek, said to come from the Celtic for turnip.] About 5 species, natives of southern Europe. Type species: Sinapis alba $\mathrm{L}$.

\section{Sinapis arvénsis L. Sp. Pl. 668. 1753.}

\section{Brassica Sinapistrum Boiss. Voy. Esp. 2: 39 . 1839-45.}

Erect, 3-6 dm. high, hispid with scattered stiff hairs, or glabrate. Leaves oblong to elliptic, dentate, denticulate or subpinnatifid; flowers 1-1.6 cm. broad; pedicels stout; pods glabrous, spreading or ascending, somewhat constricted between the seeds, 1-1.6 $\mathrm{cm}$. long, $2 \mathrm{~mm}$. wide, tipped with a flattened elongatedconic often 1-seeded beak 10-12 mm. long, the valves strongly nerved.

Waste grounds near Nassau, New Providence, Native of Europe; naturalized in continental North America and also in Bermuda and Jamaica. CHARLOcK.

\section{RAdículA Hill, Brit. Herb. 264. 1756.}

Branching herbs, with simple or pinnate, lobed dissected or rarely entire leaves, and small yellow flowers. Sepals spreading. Stamens 1-6. Pods short, terete or nearly so. Stipe none. Valves nerveless or 1-nerved. Style short or slender. Stigma 2-lobed or nearly entire. Seeds turgid, minute, in 2 rows in each cell or very rarely in 1 row. Cotyledons accumbent. [Name Latin, diminutive of radix, root.] About 50 species, of wide geographic distribution, most abundant in the north temperate zone. Type species: Sisymbrium amphibium L. 
1. Radicula brévipes (DC.) Britton, Torreya 6: 30. 1906.

Nasturtium palustre brevipes DC. Syst. 2: 192. 1821.

Nasturtium brevipes Griseb. Mem. Amer. Acad. II. 8: 154. 1860.

Annual, glabrous or sparingly pubescent below, branched from the base, the branches usually prostrate or nearly so, sleuder, $3 \mathrm{dm}$. long or less. Leaves pinnately divided into several or numerous, oblong, ovate or suborbicular dentate segments, or the upper segments confluent; racemes several-manyflowered, 6-12 cm. long; pedicels about $1 \mathrm{~mm}$. long; flowers about $1.5 \mathrm{~mm}$. long; petals minute or wanting; pods linear, 7-12 mm. long, about $1.5 \mathrm{~mm}$. wide.

Sink-holes, Andros, near Fresh Creek:-Cuba, Hispaniola, Porto Rico. The Andros specimens show follage only and are referred to this specles with hesitation. SHORT-STALKED YELLOW-CRESS.

\section{CONRÍNGIA [Heist.] Adans. Fam. Pl. 2: 418. 1763.}

An erect glabrous annual herb, with elliptic or ovate entire leaves, sessile and cordate at the base, and middle-sized yellowish white flowers in terminal racemes. Sepals and petals narrow. Style 2-lobed or entire. Siliques elongated-linear, angled, the valves firm, 1-3-nerved. Seeds in 1 row in each cell, oblong, marginless; cotyledons incumbent. [In honor of Hermann Conring, 1606-1681, Professor at Helmstädt.] About 7 species, natives of Europe and Asia, the following typical.

1. Conringia orientàlis (L.) Dumort. Fl. Belg. 123. 1827.

Brassica orientalis L. Sp. Pl. 666. 1753.

Stem 3-9 dm. high. Leaves light green, obtuse, 5-13 cm. long; racemes elongating in fruit; pedicels $8-16 \mathrm{~mm}$. long; petals about $1.2 \mathrm{~cm}$. long, nearly twice as long as the sepals; pods $7-13 \mathrm{~cm}$. long, about ' $2 \mathrm{~mm}$. wide, 4 -angled, spreading.

Waste grounds, New Provdence, 1916. Widely distributed as a weed in temperate North America; Introduced from the Old World. HARE'S-EAR.

6. CARÀra Medic. Pflg. 1: 34. 1792.

[Coronopus Gaertn. Fr. \& Sem. 2: 293. 1791. Not Mill. 1754.]

Annual or biennial, diffuse herbs, with mostly pinnatifid leaves, and small whitish flowers. Silicles small, didymous, laterally compressed, sessile. Stamens often only 2 or 4 . Valves of the capsule oblong or subglobose, obtuse at each end, indehiscent, falling away from the septum at maturity. Seeds 1 in edch cell; cotyledons narrow, incumbent or conduplicate. [Greek, erow-foot, Irom the shape of the leaves.] About 6 species, of wide distribution. Type opecies: Cochlearia Coronopus L.

1. Carara dídyma (L.) Britton, in Britton \& Brown, Ill. Fl. ed. 2, 2: 167. 1913.

Lepidium didymum L. Mant. 92. 1767.

Coronopus didymus J. E. Smith, Fl. Brit. 2: 691. 1800.

Tufted, spreading on the ground, sparingly pubescent. Stems $0.5-4 \mathrm{dm}$. long; leaves deeply 1-2-pinnatifid; flowers white, racemose; pedicels slender, 2-3 mm. long in fruit; pod about $2 \mathrm{~mm}$. broad and slightly more than $1 \mathrm{~mm}$. high; valves obtuse at each end and readily separating into 2 ovoid nutlets.

Streets and waste grounds, New Providence, Eleuthera:-Bermuda; southern United States; Antlgua; Martinique; South America; wldely distributed in the Old World. STAR-OF-THE-EARTH. 
7. CAKİLe [Tourn.] Mill. Gard. Dict. Abr. ed. 4. 1754.

Annual glabrous fleshy herbs, with purplish or white flowers. Siliques elongated, sessile, flattened or ridged, indehiscent, 2-jointed, the joints 1-celled and usually 1-seeded. Style none; cotyledons accumbent. [Old Arabic name.] A genus of about 3 species, natives of sea and lake shores of Europe and North America. Type species: Bunias Cakile L.

1. Cakile lanceolàta (Willd.) O. E. Schulz, in Urban, Symb. Ant. 3: 504.1903.

Raphanus lanceolatus Willd. Sp. Pl. 3: 562. 1801.

Cakile aequalis L'Her. DC. Syst. 2: 430. 1821.

Erect or ascending, often much branched, $8 \mathrm{dm}$. high or less. Basal and lower leaves broadly oblong, obtuse, $5-8 \mathrm{~cm}$. long, coarsely crenate-dentate; upper leaves smaller, narrowly obovate to oblong, crenate-dentate or entire; flowers pale purplish, 6-10 mm. broad; fruiting racemes often $3 \mathrm{dm}$. long; fruiting pedicels stout, ascending, 4-6 mm. long; pod 1.5-2.5 cm. long, its upper joint $1 \frac{1}{2}-4$ times as long as the lower.

Maritime sands and white-lands, Abaco and Great Bahama southward throughout the archipelago to Salt Cay (Grand Turk), Inagua, the Anguilla Isles and Water Cay :-Bermuda; southern United States; the West Indies and northern South America. Southern Sea-rocket. Gardena. Pork Bush.

\section{Family 3. CAPPARIDĀCEAE Lindl.}

\section{Caper Family.}

Herbs or shrubs (rarely trees), with alternate or very rarely opposite leaves, and regular or irregular, mostly perfect flowers. Sepals 4-8. Petals 4 (rarely none). Receptacle elongated or short. Stamens $4-\infty$, not tetradynamous, inserted on the receptacle; anthers oblong. Style generally short; ovules $\infty$, on parietal placentae. Fruit a capsule, or indehiscent, or irregularly rupturing. Seeds various; endosperm none; embryo generally coiled. About 35 genera and 450 species, mostly of warm regions.

Herbs : fruit a longitudinally dehiscent capsule.

Shrubs and trees ; fruit indehiscent or irregularly rupturing.

1. Cleome.

2. Capparis.

\section{CLEÒME L. Sp. Pl. 671. 1753.}

Herbs or low shrubs. Leaves digitately 3-5-foliolate, or simple. Flowers mostly racemose. Calyx 4 -divided or of 4 sepals, often persistent. Petals 4, cruciate, nearly equal, entire, more or less clawed. Receptacle short, slightly prolonged above the petal-bases. Stamens 6 (rarely 4 ), inserted on the receptacle. Ovary stalked, with a gland at its base. Capsule elongated, manyseeded. [Derivation uncertain.] About 75 species, mainly natives of tropical regions, especially American and African. Type species: Cleome gynandra L.

1. Cleome gynándra L. Sp. Pl. 671. 1753.

Cleome pentaphylla L. Sp. Pl. ed. 2, 938. 1763.

Pedicellaria pentaphylla Schrank; Roem. \& Ust. Mag. Bot. 8: 11.1790. Gynandropsis pentaphylla DC. Prod. 1: 238. 1824.

Annual, bright green, clammy-pubescent. Stem 5-10 dm. tall, branching; leaf-blades palmately 3-5-foliolate; petioles longer than the leaflets; leaflets 
2-6 cm. long, oval to obovate, acute or short-acuminate, serrulate; racemes 1-4 dm. long; bracts suborbicular, oval or broadly obovate; sepals lanceolate, 4-5 $\mathrm{mm}$. long, acuminate; petals white or pink, 5-10 $\mathrm{mm}$. long; blades suborbicular, longer than the claws; stamens 6 ; capsules linear, 4-6 cm. long, surpassing the glandular pedicel in length; seeds $1-5 \mathrm{~mm}$. broad, coarsely rugose and muricate.

Waste and cultivated lands, New Providence at Grant's Town:-Bermuda; southern United States; West Indies and tropical continental America. Native of the Old World tropics. SMALL SPIDER-FLOWER.

\section{CÁPPARIS L. Sp. Pl. 503. 1753.}

Trees or shrubs, with simple, mostly coriaceous leaves, sometimes stipulate on young or barren shoots, and large corymbose, mostly white flowers. Sepals 4, distinct or partly united, often with a gland at the base. Petals 4, distinct, imbricated. Stamens several or usually many, the filaments filiform, the anthers short. Ovary stalked, 1-4-celled; ovules few or many, usually on 2 parietal placentae; style none; stigma depressed. Fruit elongated-linear, or oblong, or short and subglobose, indehiscent, or irregularly rupturing. Seeds without endosperm; embryo convolute; cotyledons fleshy. [From the Greek name of the Caper-tree, Capparis spinosa L., of Europe.] About 150 species, natives of tropical and subtropical regions. Type species: Capparis spinosa $\mathrm{L}$.

Leaves densely scaly beneath. Leaves glabrous.
1. C. cynophallophora.

2. C. flexuosa.

\section{Capparis cynophallóphora L. Sp. Pl. 504. 1753.}

Capparis jamaicensis Jacq. Enum. 23. 1760.

A shrub or a tree up to about $15 \mathrm{~m}$. high, with a trunk diameter reaching 2 or $3 \mathrm{dm}$., the bark brown, furrowed, the slender, angular twigs densely scaly. Leaves elliptic or oblong, coriaceous, 4-12 cm. long, 2-6 cm. wide, or those of shoots narrowly linear, sometimes $3 \mathrm{dm}$. long and only $5-10 \mathrm{~mm}$. wide, acute obtuse or emarginate at the apex, narrowed at the base, glabrous and shining above, densely silvery-scaly and with the lateral venation obsolete beneath, the scaly petioles 1-3 cm. long; corymbs few-several-flowered; pedicels stout, scaly, 0.5-3 cm. long; flowers fragrant; flower-bud 4-angled; sepals distinct, valvate, 8-12 mm. long, densely scaly, reflexed, nearly as long as the white petals; stamens numerous, purplish, 2-3 times as long as the petals, the anthers yellow; fruit narrowly linear, torulose, drooping, $8 \mathrm{~cm} .-4 \mathrm{dm}$. long, 6-8 mm. thick, irregularly rupturing, scarcely fleshy, often much longer than the gynophore.

Scrub-lands and thickets, Andros, Long Island, Cat Island, Watling's, Atwood Cay, Acklin's, Fortune, Crooked, Mariguana, Caicos and Inagua:-Florida; Cuba to Tortola and Barbadoes; Jamaica. BLACK WILLOW.

2. Capparis flexuòsa L. Sp. Pl. ed. 2, 722. 1762.

\section{Capparis cynophallophora L. Syst. ed. 10, 1071. 1759.}

A glabrous shrub, or a tree up to $8 \mathrm{~m}$. high, with a trunk $2 \mathrm{dm}$. in diameter, the bark brown, the branches slender, sometimes vine-like. Leaves elliptic to oblong, lanceolate to linear, coriaceous, 4-9 cm. long, obtuse, emarginate or sometimes acute at the apex, obtuse or narrowed at the base, reticulate-veined on both sides, the rather stout petioles $2-6 \mathrm{~mm}$. broad, with a small sessile, oblong or subglobose gland in the axil; corymbs few-flowered; pedicels stout, $12 \mathrm{~mm}$. long or less; flowers fragrant; sepals suborbicular, 5-8 mm. broad, slightly united at the base, the outer a little smaller than the inner; petals white to rose, obovate, $1.5-2 \mathrm{~cm}$. long; stamens numerous, about 3 times as long. 
as the petals, the filaments white; fruit long-linear, 6-20 cm. long, $1-1.5 \mathrm{~cm}$. thick, more or less torulose, about twice as long as the slender gynophore, tardily opening longitudinally, its pulp scarlet.

Scrub-lands and thickets, Andros, Exuma Chain, Long and Acklin's Island:Florida; Cuba to Virgin Gorda and Barbadoes; continental tropical America. CAPEi-TREe.

Crataeva Tapia L., reported by Dolley, we have been unable to find in the archipelago. It is natlve of Jamaica, Martinlque and of troplcal continental America, and is unllkely to have been found in the Bahamas, unless planted.

\section{Family 4. MORINGÀCEAE Dumort.}

\section{HorSERAdish-TREe FaMily.}

Trees with alternate, 2-3-pinnate, deciduous leaves, and perfect, slightly irregular flowers in large axillary panicles. Sepals 5, unequal, imbricated, reflexed or spreading, slightly united at the base. Petals 5, somewhat unequal, the lower one reflexed. Stamens 5, with slender flaments and 1-celled anthers, alternating with as many staminodia. Ovary 1-celled, with 3 parietal placentae, bearing numerous pendulous ovules; style slender; stigma minute. Capsule elongated, angled, beaked, 3-valved. Seeds 3winged or wingless; endosperm none; embryo straight, the cotyledons large. Only the following genus.

1. MORÌNGA Adans. Fam. Pl. 2: 318. 1763.

Characters of the family. [Malabar name.] Three known species, natives of Asia and Africa, the following typical.

1. Moringa Morìnga (L.) Millsp. Field Mus. Bot. 1: 490. 1902.

Guilandina Moringa L. Sp. Pl. 381. 1753.

Moringa pterygosperma Gaertn. Fr. \& Sem. 2: 314. 1791.

A tree, up to $9 \mathrm{~m}$. high, the bark corky, rough, the puberulent twigs slender. Leaves 3-6 dm. long, their segments and leaflets opposite; leaflets numerous, thin, oblong to obovate, 1-2 $\mathrm{cm}$. long, obtuse, entire; flowers numerous, fragrant; pedicels 5-10 $\mathrm{mm}$. long; sepals linear to linear-oblong, 9-13 mm. long, reflexed; petals nearly white, a little larger than the sepals; capsule linear, 3 -angled, pendulous, $2-4.5 \mathrm{dm}$. long, 1-2 cm. thick; seeds winged, $2.5-3 \mathrm{~cm}$. long.

Thickets, spontaneous after cultivation, New Providence, near Nassau; Grand Turk:- Florlda ; West Indies; Mexico to Panama. Native of the East Indies. HORSERADISH-TREE.

\section{Ordẹ 12. ROSÀLES.}

Herbs, shrubs or trees, the flowers usually petaliferous and the petals distinct. Stamens mostly perigynous or epigynous. Sepals mainly united or confluent with the concave receptacle. Carpels one or more, distinct or sometimes united into a compound ovary.

Endosperm coplous, fleshy; leaves without stipules. Endosperm little or none; leaves with stlpules.

Flowers regular.

Ovary 2-ovuled; fruit a drupe; leaves simple.

Ovary several-ovuled; frult a legume; leaves compound.

Flowers Irregular ; fruit a legume or a loment.

Upper petal enclosed by the lateral ones in the

Upper petal enclosing the lateral ones in the bud.

Fam. 1. Crassulaceae.

Fam. 2. Amygdalaceae.

Fam. 3. Mimosaceae.

Fam. 4. Caesalpinaceae.

Fam. 5. FABACEAE. 


\section{Family 1. CRASSULÀCEAE DC.}

\section{Orpine Family.}

Herbs, or somewhat shrubby pilants, mostly fleshy or succulent, with cymose or rarely solitary regular or symmetrical flowers. Stipules none. Calyx persistent, free from the ovary or ovaries, 4-toothed or 4-parted in our species. Petals or corolla-lobes equal in number to the calyx-lobes or calyx-segments, usually persistent, rarely wanting. Stamens of the same number or twice as many as the petals or corolla-lobes; anthers longitudinally dehiscent. Receptacle with a scale at the base of each carpel. Carpels equal in number to the sepals or calyx-lobes, distinct, or united below; styles subulate or filiform; ovules numerous, arranged in 2 rows along the ventral suture. Follicles 1-celled, dehiscent along the ventral suture. Seeds minute; endosperm fleshy; embryo terete; cotyledons short. About 30 genera and 600 species, of wide geographic distribution.

Calyx inflated, 4-toothed. Calyx 4-parted.
1. Bryophyllum. 2. Kalanchoë.

1. BRYOPHÝLLUM Salisb. Par. Lond. pl. 3. 1805.

Upright herbs. Leaves opposite, simple or pinnately compound, the leaflets mostly toothed. Flowers perfect, often showy, nodding, in cymes or panicles opposite the branches. Calyx inflated, 4-toothed. Corolla nearly campanulate, or urn-shaped, the narrow limb with 4 spreading lobes. Stamens 8 , in 2 series, adnate to about the middle of the corolla-tube; filaments filiform; anthers mostly exserted. Carpels 4, distinct or partially united. Ovules many. Follicles 4. Seeds numerous. [Greek, sprouting leaf.] Four known species of South Africa, Asia and Madagascar, the following typical.

1. Bryophyllum pinnàtum (Lam.) Kurz, Jour. Asiat. Soc. Beng. 402: 52. 1871.

Cotyledon pinnata Lam. Encyc. 2: 141. 1786.

Bryophyllum calycinum Salisb. Par. Lond. pl. 3. 1805.

Perennial, fleshy, glabrous. Stamens 4-15 dm. tall, branched; leaf-blades often pinnately compound, 1-3 dm. long; leaflets oblong, oval or elliptic, obtuse, crenate, the terminal one several times longer than the lateral ones; panicles 1-4 dm. long, conspicuous; calyx bladder-like, finally oblong-campanulate, 3-3.5 $\mathrm{cm}$. long, glabrous; corolla reddish, twice as long as the calyx or shorter, its lobes lanceolate or narrowly ovate, acute.

Waste grounds near old dwellings, throughout the archipelago from Great Bahama southward to Long Island:-Bermuda; Florida; West Indies; Mexico. Probably a native of Asia. Life PLANT.

\section{KALANCHÒ̈̈̈ Adans. Fam. Pl. 2: 248. 1763.}

Frect herbs, sometimes a little woody, with opposite leaves and panicled flowers, often showy. Calyx 4-parted, shorter than the corolla. Corolla salverform, with a swollen tube and a spreading, 4-parted limb. Stamens usually 8, in 2 series on the corolla-tube, the filaments very short. Carpels 4, lanceolate, adnate to the base of the corolla-tube; ovules many. Follicles many-seeded. [Chinese name.] Twenty species or more, all but the following natives of Asia and Africa. Type species: Cotyledon laciniata L. 
1. Kalanchoë brasiliénsis Camb. in St. Hil. Fl. Bras. Mer. 2: 196.1829.

Herbaceous, perennial, 3-10 dm. high, glandular-pubescent above. Leaves ovate to obovate, short-petioled, $5-10 \mathrm{~cm}$. long, faintly pinnately veined, crenate-dentate, or the upper pairs lanceolate, much smaller and entire; inflorescence 1-3 dm. long, cymose-paniculate, its branches nearly erect; the bracts very small; flowers yellow, 12-16 mm. long; sepals lanceolate, glandular-pubescent, acute; corolla-tube $2-3$ times as long as the calyx, the limb spreading; stamens borne on the corolla-tube a little above the middle, not exserted; follicles about $6 \mathrm{~mm}$. long, the brown seeds oblong.

Spontaneous after cultivation, pine-lands near Deep Creek, Andros :-Naturalized in Cuba and in the Virgin Isiands. Native of Brazil. Brazilian KaI.ANCHOE.

\section{Family 2. AMYGDALACEAE Rehb.}

\section{Plum Family.}

Trees or shrubs, the bark exuding gum, the foliage, bark and seeds often containing prussic acid, bitter. Leaves alternate, petioled, serrate, the small stipules early deciduous, the teeth and petiole often glandular. Flowers regular, mostly perfect. Calyx inferior, deciduous, free from the ovary, 5-lobed. Disk annular. Calyx-lobes imbricated in the bud. Petals 5 , inserted on the calyx. Stamens numerous, inserted with the petals. Pistil 1 in our genera; ovary 1-celled, 2-ovuled; style simple; stigma mostly small and capitate. Fruit a drupe. Seed 1, suspended; endosperm none; cotyledons fleshy. About 10 genera and 120 species, widely distributed, most abundant in the north temperate zone.

Style terminal.

Style basal or lateral.
1. Laurocerasus.

2. Chrysobalanus.

\section{LAUROCÉRASUS Roem. Syn. Mon. 3: 89. 1847.}

Evergreen trees or shrubs, with coriaceous or subcoriaceous leaves and small flowers in axillary racemes. Calyx 5-lobed, the lobes deciduous. Petals 5, white, deciduous. Stamens 15-30, the filaments slender. Ovary sessile; ovules pendulous; style terminal. Drupe subglobose, 1-seeded, the flesh thin, not pulpy. [Laurel-cherry.] About 20 species, of temperate and tropical regions. Type species: Prunus Laurocerasus L.

1. Laurocerasus myrtifòlia (L.) Britton, N. A. Trees, 510. 1908.

Celastrus myrtifolius L. Sp. Pl. 196. 1753.

Prunus sphaerocarpa Sw. Prodr. 80. 1788.

Prunus myrtifolia Urban, Symb. Ant. 5: 93.1904.

A tree attaining a maximum height of about $12 \mathrm{~m}$. with a trunk up to $4 \mathrm{dm}$. thick, the nearly smooth bark reddish brown. Leaves subcoriaceous, elliptic or elliptic-ovate, 5-10 cm. long, acute, bluntish, or acuminate at the apex, narrowed or obtuse at the base, glabrous, shining above, dull beneath, entire-margined, the petioles about $1 \mathrm{~cm}$. long; racemes mostly shorter than the leaves, rather densely flowered; pedicels 4-12 $\mathrm{mm}$. long; calyx-lobes toothed; petals broadly obovate, much longer than the calyx; stamens about as long as the petals; drupes globose, 9-12 mm. in diameter, orange-brown.

In coppices, Great Bahama and New Providence:-Florida; Cuba; Hispaniola; Jamaica. WEST INDIAN LACREL-CHERRY. 
2. CHRYSOBATÀNUS L. Sp. Pl. 513. 1753.

Trees or shrubs, with coriaceous, entire or undulate-margined leaves, and small, white or greenish, perfect flowers in terminal or axillary eymes or panicles. Calyx with a campanulate or turbinate tube and a 5-lobed limb, the lobes imbricated, nearly equal. Petals 5, deciduous. Stamens numerous, with slender filaments. Ovary inferior, sessile, 1-celled; ovules 2, erect; style filiform, basal or lateral. Drupe pulpy, with a hard 5-6-ridged stone. [Greek, golden date.] About 3 species, 2 of them American, the other African. Type species: Chrysobalanus Icaco L.

Fruit oval or globose; petals cuneate. Fruit obovoid; petals spatulate.
1. C. Icaco.

2. C. pellocarpus.

1. Chrysobalanus Icàco L. Sp. Pl. 513. 1753.

An evergreen tree or shrub, attaining a maximum height of about $10 \mathrm{~m}$., with a trunk sometimes $3 \mathrm{dm}$. in diameter, the thin bark brownish, the twigs glabrous or nearly so, reddish brown. Leaves elliptic to obovate or nearly orbicular, 4-8 cm. long, glabrous, rounded, obtuse or emarginate at the apex, narrowed at the base, dark green and shining above, dull beneath, the petioles short, stout; cymes peduncled, several-many-flowered, shorter than the leaves; calyx pubescent, its lobes triangular-ovate, acute, about $2.5 \mathrm{~mm}$. long; petals white, cuneate-spatulate, twice as long as the calyx-lobes; drupes various, globose or oval, pink, white or purple, $2-4 \mathrm{~cm}$. long.

Coastal thickets and woodlands and especially on the borders of swamps. Great Bahama, Andros, New Providence, Rose Island, Great Guana, Great Exuma, Eleuthera, Cat Island, Watling's, Crooked Island, Inagua, Dellis' Cay (Caicos) and Ambergris Cay (Turk's Islands):-Florida; West Indies; Mexico to northern continental South America; troplcal Africa. Pork-fat Apple. Coco Plum. Catesby, 1: pl. 25 .

2. Chrysobalanus pellocárpus G. F. W. Meyer, Prim. Fl. Esseq. 193.1818.

Chrysobalanus Icaco pellocarpus DC. Prodr. 2: 525.1825.

Similar to the preceding species, but not attaining as large size, usually a shrub $2 \mathrm{~m}$. high or less, sometimes a small tree. Leaves usually smaller, $6 \mathrm{~cm}$. long or less, rounded or abruptly acute at the apex; cymes shorter than the leaves; petals spatulate; drupe mostly obovoid, or oblong-obovoid, $1.5-2 \mathrm{~cm}$. long, purple.

Borders of swamps, Great Bahama, Andros, New Providence and Great Exuma :-Florida; Cuba to Porto Rico; Guadeloupe; South America. Probably a race of $C$. Icaco.

\section{Family 3. MIMOS̀ACEAE Rehb.}

\section{Mimosa Family.}

Herbs, shrubs or trees, with alternate, commonly 2-3-pinnate leaves, the stipules various, and small regular mostly perfect flowers in heads, spikes or racemes. Calyx 3-6-toothed or 3-6-lobed, the teeth or lobes mostly valvate in the bud. Corolla of as many distinct or united petals, also valvate. Stamens distinct, or monadelphous. Ovary 1-celled; style simple. Fruit a legume. Seeds without endosperm; cotyledons fleshy. About 40 genera and 1500 species, mostly tropical.

A. Stamens numerous, at least more than 10 .

Stamens united below into a tube.

Pods not elastically dehiscent. 
Valves of the pod not separating from the continuous margin. Valves of the pod thick, colling in dehiscence in our species.

Valves o1 the pod flat and papery.

Valves of the pod separating from the continuous margins.

Pods elastically dehiscent from the base.

1. Pithecolobium.
2. Albizzia.

3. Lysiloma.

4. Anneslia.

Stamens distinct.

Seeds in one row ; ovary stipitate.

Seeds in two rows; ovary sessile.

B. Stamens only as many or twice as many as the corolia-

5. Acacia.

6. Vachellia. segments.

Anthers without glands.

Valves of the pod separating from the continuous margin.

Valves of the pod not separating from the margins.

Shrubs or trees; seeds transverse.

Herbs ; seeds longitudinal or oblique.

Anthers tipped by glands (at least in the bud).

Herbs; flowers capitate; pods flat.

Trees; flowers spicate; pods nearly terete.

7. Mimosa.

8. Leucaena.

9. Acuan.

16. Neptunia.

11. Prosopis.

\section{PITHECOLòBIUM Mart. Hort. Monac. 188. 1829.}

Shrubs or trees, often spiny, with 2-pinnate leaves, and small, mostly per fect flowers in heads or spikes. Calyx 5-6-toothed. Corolla 5-6-lobed. Stamens many, long-exserted, the filaments partly united into a tube, the anthers small. Ovary several-many-ovuled; style slender; stigma small, capitate. Pods flattened, mostly contorted or curved, 2-valved. Seeds mostly arillate. [Greek, referring to the contorted pods of the typical species.] Perhaps 100 species, widely distributed in tropical and subtropical regions. Type species: Mimosa Unguis-cati L. The original spelling of the genus is Pithecellobium.

Pinnae with 1 or 2 pairs of leaflets.

Leaflets 1-6 cm. long or ionger.

Leaflets chartaceous; petioles of at least the lower leaves longer than the petiolules.

Leaflets coriaceous; petioles shorter than the petiolules or as long.

Petioles and petiolules stout, thick, the petiolules often 2-3 cm. long; leaflets large, $2.5-7 \mathrm{~cm}$. long.

Petioles and petiolules slender, 2-5 mm. long; leaflets $1-3 \mathrm{~cm}$. long.

Leaflets strongly spinulose-mucronate; shrub or small tree with erect branches.

Leaflets rounded, or merely mucronulate; low shrubs with divergent branches.

Leaflets $2-8 \mathrm{~mm}$. long; petioles $6 \mathrm{~mm}$. long or less. Pinnae with 3-6 pairs of leaflets.

1. 1'. Unguis-cati.

2. F. guadalupense.

3. $P$. mucronatum.

4. F. bahamense.

5. 1\%. Hystrix.

6. I'. discolor.

\section{Pithecolobium Únguis-cáti (L.) Mart. Hort. Monac. 188. 1829.}

Mimosa Unguis-cati L. Sp. Pl. 517. 1753.

Pithecolobium flavovirens Britton, Bull. N. Y. Bot. Gard. 3: 442. 1905.

A shrub up to $6 \mathrm{~m}$. high, rarely a small tree $8 \mathrm{~m}$. high, usually armed with stipular spines $2 \mathrm{~cm}$. long or less, the foliage glabrous. Petiole 5-20 mm. long, bearing a round gland at the summit; pinnae 2, each with one pair of obliquely obovate or oblong, obtuse, thin leaflets, 1-5 $\mathrm{cm}$. long; heads slender-peduncled, in terminal racemes; flowers sessile; calyx about $2 \mathrm{~mm}$. long; corolla 5-6 $\mathrm{mm}$. long; stamens 10-15 mm. long, yellowish or pinkish; pod coiled or curved, red, compressed, somewhat constricted between the seeds, 5-10 cm. long, about 7 mm. wide; seeds nearly black, shining, 4-6 mm. broad.

Scrub-lands, Watling's Island, Acklin's Island, Mariguana, Grand Turk and Inagua :-Florida; West Indies; Yucatan; northern South America. CAT'S-CLAW.

The characters thought to differentlate $P$. flavovirens specifically do not seem constant, since specimens from other islands obtained during subsequent exploration appear to connect them with those of $P$. Unguis-cati. 
2. Pithecolobium guadalupénse Chapm. Fl. S. U. S. 116.1860.

Pithecolobium keyense Britton; Coker, in Shattuck, Bah. Isl. 255. Hyponym. 1905.

A usually unarmed shrub or small tree, sometimes $6 \mathrm{~m}$. high with a trunk up to $1.5 \mathrm{dm}$. in diameter, the bark gray, slightly fissured, the twigs and leaves glabrous. Petioles $2-3 \mathrm{~cm}$. long, bearing a round gland at the summit; pinnae 2 , stalked, each bearing a single pair (rarely 2 pairs) of sessile leaflets, which are obliquely obovate or nearly orbicular, firm in texture, 3-7 $\mathrm{cm}$. long, rounded or notched at the apex, or rarely short-pointed, the margins somewhat revolute; peduncles slender, glabrous, as long as the leaves or shorter, sometimes panicled; flowering heads $2-3 \mathrm{~cm}$. in diameter; calyx about $1.5 \mathrm{~mm}$. long, 5-toothed; corolla about $3 \mathrm{~mm}$. long; stamens pink, about 3 times as long as the corolla; ovary pubescent; pod coiled or much curved, brown, 6-15 cm. long, 8-10 mm. broad; seeds black, shining.

Coppices and scrub-lands, throughout the archipelago from Abaco and Andros to Mariguana, Caicos, Inagua and the Anguilla Isles:-Florida; Cuba. BLACK-BEAD. RAM'S-HORN.

\section{Pithecolobium mucronàtum Britton; Coker, in Shattuck, Bah. Isl. 254.} 1905.

A shrub, about $2 \mathrm{~m}$. high, the young twigs and peduncles sparingly pubescent. Petiole $1 \mathrm{~cm}$. long or less, longer than or equalling the stiff sharp stipular spines, the gland stout-stalked; pinuae a single pair, stalked, each bearing a single pair of leaflets, which are coriaceous, rather narrowly obovate, 1-2 cm. long, glabrous, bright green and shining above, dull beneath, the midvein excurrent; peduncles much longer than the upper leaves; flowering heads about $1.5 \mathrm{~cm}$. in diameter; calyx puberulent, its lobes ovate, acute; corolla about $6 \mathrm{~mm}$. long, puberulent, 2-3 times as long as the calyx; stamens about $12 \mathrm{~mm}$. long.

Coastal thickets, Long Island, near Clarence Harbor. Endemic. PoINTED CAT'S-Claw. Catesby, 2: pl. 97.

The records by Schoepf and by Bentham of $P$. circinale (L.) Benth., a plant of Hispaniola, as Bahamian, collected by Catesby, refer to this species.

\section{Pithecolobium bahaménse Northrop, Mem. Torr. Club 12: 38.1902.}

A shrub, $3 \mathrm{~m}$. high or less, the branches slender, glabrous. Petioles 1-10 $\mathrm{mm}$. long, bearing a stout-stalked gland at the summit; stipular spines sharp, 3-7 mm. long; pinnae a single pair; petiolules as long as the petioles or shorter; leaflets 1 pair or sometimes 2 pairs, sessile, obliquely oblong, oblanceolate or obovate, subcoriaceous, $1-2.5 \mathrm{~cm}$. long, glabrous, obtuse or mucronate at the apex, shining above, dull beneath; peduncles $2-3 \mathrm{~cm}$. long; flowering heads 2-3 cm. in diameter; calyx about $2 \mathrm{~mm}$. long, its 5 ovate teeth acute; corolla about $4 \mathrm{~mm}$. long, pink or crimson; stamens pink or crimson, 2-3 times as long as the corolla; ovary puberulent; pod coiled or much curved, 8-12 $\mathrm{cm}$. long, about $1 \mathrm{~cm}$. wide; seeds black.

Scrub-lands, pine-lands, savannas and coppices, Andros, New Providence and Great Exuma :-Cuba. BaHaMa Cat's-CLAw.

5. Pithecolobium Hýstrix (A. Rich.) Benth. in Hook. Icon. Pl. pl. 1168. 1876.

Inga hystrix A. Rich. Ess. Fl. Cub. 1: 471. 1845.

Pithecolobium calliandriflorum C. Wright; Griseb. Cat. Pl. Cub. 83. 1866.

An intricately branched shrub, 0.5-2 m. high, the twigs very slender, but stiff, puberulent or glabrate, the internodes mostly short. Stipular spines acicular, 4-12 $\mathrm{mm}$. long; petioles 1-6 $\mathrm{mm}$. long; pinnae a single pair; petiolules 
mostly shorter than the petioles; leaflets obliquely obovate, $2-8 \mathrm{~mm}$. long, sessile, subcoriaceous, rounded at the apex, rather strongly few-veined, shining above, dull beneath; peduncles 4-20 mm. long; heads few-several-flowered; calyx $2 \mathrm{~mm}$. long, sharply 5 -toothed; corolla about $5 \mathrm{~mm}$. long; stamens rose, or pink, 2-3 times as long as the corolla; pod curved into a nearly or quite complete circle, 6-12 $\mathrm{cm}$. long, 5-8 $\mathrm{mm}$. wide.

Coppices and pine-lands, Andros, New Providence and Great Exuma:-Cuba. BRISTLY CAT'S-CLAW.

\section{Pithecolobium díscolor Britton, Bull. Torr. Club 41: 4. 1914.}

A shrub, or a small tree up to $7 \mathrm{~m}$. high, the young twigs and leaves densely puberulent, the old leaves glabrous or somewhat puberulent, 1-2 dm. long; petioles stout, 1-2 cm. long; pinnae 3 or 4 pairs, the glands on the rachis between them small and orbicular; leaflets 3-6 pairs, obovate, chartaceous, 1.5-2.5 cm. long, dark green above, pale beneath, reticulate-veined, obtuse or retuse; peduncles axillary, 5-11 cm. long; flowers short-racemose; pedicels puberulent; calyx 4-5 mm. long, puberulent; corolla puberulent, 7-8 mm. long; stamens 1.5-2 cm. Jong; pod coiled, 6-8 cm. long, 8-10 mm. wide; seeds blue and white, shining, orbicular, $4 \mathrm{~mm}$. broad.

Margin of coppice, Abaco at Old Kerr's Polnt, perhaps introduced:-Cuba.

2. ALBÍzzIA Durazz. Mag. Tose. 34: 11. 1772.

Unarmed trees, or some species shrubs, with bipinnate leaves and solitary or panicled heads, umbels, or rarely spikes of small, mostly perfect flowers. Calyx 5-tocthed. Corolla furnelform, the petals united to about the middle into a tube. Stamens numerous, united below, long-exserted; anthers small; pollen-grains agglomerate. Pod broadly linear, flat, thin, not pulpy within. Seeds suborbicular to oblong. [In honor of the Italian naturalist Albizzi.] About 50 species, natives of the Old World. Type species: Albizzia Julibrissin Durazzini.

1. Albizzia Lébbeck (L.) Benth. Lond. Jour. Bot. 3: 87. 1844.

Mimosa Lebbeck L. Sp. P1. 516. 1753.

Acacia Lebbeck Willd. Sp. Pl. 4: 1066. 1806.

A tree, up to $15 \mathrm{~m}$. high, often flowering when not over $5 \mathrm{~m}$., the foliage glabrous or sparingly puberulent. Leaves large, often $4 \mathrm{dm}$. long; petioles 2-10 cm. long, bearing an oblong, sessile gland; pinnae 2-4 pairs; leaflets 4-9 pairs on each pinna, thin, nearly sessile, obliquely oblong or the terminal pair obovate, obtuse, 2-4 cm. long, reticulate-veined; peduncles $3-10 \mathrm{~cm}$. long; umbels subglobose; pedicels pubescent, $2-5 \mathrm{~mm}$. long; calyx narrowly campanulate, pubescent, about $4 \mathrm{~mm}$. long, its teeth short; corolla about $6 \mathrm{~mm}$. long; stamens yellowish, about $3 \mathrm{~cm}$. long; pod straight, broadly linear, narrowed at each end, $1.5-3 \mathrm{dm}$. long, $2-4 \mathrm{~cm}$. wide, glabrous, shining; seeds about $1.5 \mathrm{~cm}$. broad.

Roadsides spontaneous after cultivation, New Providence near Nassau :Widely planted and established in the West Indies; native of tropical Asia and Africa. Woman's-Tongur. Tree. Singer-tree. Whistuing-Bean.

3. LYSILÒMA Benth. Lond. Jour. Bot. 3: 82. 1844.

Unarmed trees or shrubs, with slender branches, bipinnate leaves, the small flowers in heads or spikes. Calyx campanulate, 5-lobed. Corolla 5-lobed. 
Stamens numerous, more than twice as many as the corolla-lobes, the filaments united below into a tube. Ovary sessile or short-stalked; style slender or filiform; ovules several or numerous. Pods flat, linear or oblong, the valves separating from the continuous margins. Seeds transverse, flattened. [Greek, referring to the separating of the pod-valves from the margins.] About 10 species of tropical and subtropical America. Type species: Lysiloma bahamensis Benth.

Leaflets few, obovate-oval ; stipules obovate; pod obtuse.

Leaflets many, oblong or lanceolate; stlpules ovate; pod acute.

1. L. Sabicu.

2. L. bahamensis.

\section{Lysiloma Sábicu Benth. Kew Jour. Bot. 6: 236.1854.}

Acacia latisiliqua paucifoliola DC. Prodr. 2: 467. 1825.

Acacia formosa A. Rich. Ess. Fl. Cub. 463. 1845. Not Kunth. 1822.

Lysiloma formosa Hitchc. Rep. Mo. Bot. Gard. 4: 83. 1893.

Lysiloma paucifoliola Hitchc.; Northrop, Mem. Torr. Club. 12: 38.1902.

A tree, attaining in Cuban forests a height of $60 \mathrm{~m}$. or more, usually much smaller, the gray bark somewhat scaly, the slender twigs glabrous. Stipules obovate, rounded; leaves 1-2 dm. long, the petiole bearing a small circular gland; pinnae 2-4 pairs; leaflets 3-7 pairs, oval or obovate, 1-2.5 $\mathrm{cm}$. long, rounded at the apex, rounded or narrowed at the base, glabrous, reticulateveined, short-petioled; heads about $1.5 \mathrm{~cm}$. in diameter, solitary and longpeduncled in the axils; flowers greenish white; calyx about $1 \mathrm{~mm}$. long; corolla about twice as long as the calyx, its lobes villous above; stamens 15-20, 2-3 times as long as the corolla; pod oblong, 7-15 cm. long, 2-3 cm. wide, rounded at the apex; seeds brown, flat, 6-10 mm. long.

Copplces and scrub-lands, Andros, New Providence, Eleuthera, Great Guana Cay, Great Exuma and Fortune Island:-Cuba; Hispaniola. Horseflesh. SABICU.

\section{Lysiloma bahaménsis Benth. Lond. Jour. Bot. 3: 82. 1844.}

Acacia bahamensis Griseb. Fl. Br. W. I. 221. 1860.

Lysiloma latisiliqua A. Gray; Sauv. Anales Acad. Habana 5: 406.1869.

A tree, attaining a maximum height of about $16 \mathrm{~m}$. with a trunk up to 1 $\mathrm{m}$. in diameter, the smooth, gray bark splitting into scales, the branches spreading, the twigs slender, glabrous; stipules ovate, acuminate; leaves $8-14 \cdot \mathrm{cm}$. long, the petiole bearing a large gland near the lowest pair of pinnae; pinnae 2-5 pairs, 3-8 cm. long; leaflets 10-33 pairs, oblong or oblong-lanceolate, sessile, 8-15 mm. long, obtuse at the apex, unequally rounded at the base, glabrous; heads $1.5-2 \mathrm{~cm}$. in diameter, racemose, globose, on peduncles $2-4 \mathrm{~cm}$. long; flowers white, mostly perfect; calyx campanulate, about $1 \mathrm{~mm}$. long; corolla twice as long as the calyx, its lobes reflexed; stamens about 20 , twice as long as the corolla; pod linear-oblong, 8-15 cm. long, 2-2.5 cm. wide, nearly straight, pointed; seeds flat, about $12 \mathrm{~mm}$. long, dark brown, shining.

Coppices and scrub-lands, Abaco and Great Bahama throughout the archipelago to Caicos and Inagua:-Florida; Cuba; Yucatan. WILD TAMARIND.

\section{ANNÉSLIA Salisb. Parad. Lond. pl. 64. 1807.}

Shrubs, or small trees, with bipinnate leaves and capitate flowers, the heads peduncled, axillary, or in terminal racemes. Calyx 5-toothed or 5-lobed. Corolla funnelform or campanluate, 5-lobed, the petals being united to the middle or above the middle. Stamens numerous; filaments united below, long-ex- 
serted; anthers small, glandular-hirsute or glabrous, the pollen grains agglomerate. Ovary many-ovuled; style filiform. Pod linear, usually narrowed below the middle, flat, not pulpy within, straight or nearly so, elastically dehiscent from the base, the valves stiff with raised margins. Seeds obovate or orbicular, compressed. [In honor of George Annesley, 1769-1844, English traveler and botanist.] Over 100 species, of tropical and subtropical distribution. Type species: Annestia falcifolia Salisb.

Flowers red to purple; pod appressed-pubescent. Flcwers white; pod glabrous.
1. A. haematostoma.

2. A. formosa.

1. Anneslia haematostòma (Bert.) Britton, Mem. Brooklyn Bot. Gard. 1: 50. 1918.

Acacia haematomma Bert.; DC. Mem. Leg. 448. 1825.

Calliandra haematomma Benth. Lond. Jour. Bot. 3: 103.1844.

A much-branched shrub $3 \mathrm{~m}$. high or less, the twigs sparingly pilose or glabrous. Leaves small, $1-3 \mathrm{~cm}$. long; petioles short; pinnae 1 pair; leaflets 3-8 pairs, oblong to obovate, 4-8 $\mathrm{mm}$. long, obtuse or mucronate, strongly fewnerved, coriaceous; peduncles mostly pubescent, usually shorter than the leaves, commonly clustered toward the ends of the branches; calyx striate, about $2 \mathrm{~mm}$. long; corolla silky-pubescent, 5-7 mm. long; stamens red, 1-2 $\mathrm{cm}$. long; pod pubescent, $5-8 \mathrm{~cm}$. long, 6-8 $\mathrm{mm}$. wide.

Scrub-lands and coppices, Abaco, Great Bahama, Rum Cay, Conception Island, Fortune Island, Watling's, Cailcos and Inagua :-Cuba to St. Thomas. REp ANNesLIA.

\section{Anneslia formòsa (Kunth) Britton \& Millspaugh.}

Acacia formosa Kunth, Mim. 102. 1822.

Calliandra formosa Benth. in Hook. Lond. Jour. Bot. 3: 98.1844.

Calliandra formosa cubensis Macbride, Contr. Gray Herb. II. 59: 4. 1919.

A branched shrub, 0.5-2.5 m. high, glabrous throughout. Leaves 7-15 cm. long; petioles $1-3 \mathrm{~cm}$. long; pinnae 2 or 3 pairs; leaflets $6-11$ pairs, oblong to oblong-obovate, inequilateral, 10-22 mm. long; obtuse at the apex, obliquely subtruncate at the base, subchartaceous, few-veined; peduncles slender, shorter than the leaves; calyx about $2 \mathrm{~mm}$. long; corolla glabrous, about twice as long as the ealyx; stamens white, 1-1.5 cm. long; pod glabrous, 5-9 $\mathrm{cm}$. long, about $1 \mathrm{~cm}$. wide, attenuate at the base.

Scrub-lands, coppices and thickets, throughout the archipelago from Abaco and the Berry Islands to South Caicos, Inagua and the Anguilla Isles:-Cuba; Mexico. Recorded by Hitchcock as Calliandra gracilis Griseb. and by Dolley as Calliandra portoricensis Benth. WHITE ANNESLIA.

\section{ACACIA Willd. Sp. Pl. 4: 1049. 1806.}

Shrubs or trees, with bipinnate leaves, the ultimate leaflets usually small and numerous, or the leaves in many exotic species modified into flat simple phyllodes. Flowers small, in heads or spikes. Calyx campanulate, usually 4-5-toothed, or of 4 or 5 distinct sepals. Petals mostly 4 or 5 , or wanting. Stamens distinct, exserted ; flaments filiform ; pollen-grains cohering in 2 's-6 's. Pod linear, oblong or oval, flat or swollen, often constricted between the seeds. [Greek, point, or thorn, many species being thorny.] About 450 species, chiefly in subtropical regions. Type species: Acacia nilotica Delile. 
Foliage glabrous.

Leaflets linear-oblong; base of trunk armed with clusters of long spines.

Leaflets obovate to oblong and elliptic; unarmed tree. Foliage pubescent; leaflets many, linear.

1. A. acuifera.

2. A. choriophylla.

3. A. macracantha.

1. Acacia acuìfera Benth. in Hook. Lond. Journ. Bot. 1: 496. 1842.

A glabrous, much-branched shrub or small tree up to about $4 \mathrm{~m}$. high, the base of the trunk armed with clusters of rigid sharp spines 4-10 $\mathrm{cm}$. long, the slender twigs warty. Stipules spinescent, 2-20 mm. long; petiole $3-10 \mathrm{~mm}$. long, bearing a sessile, nearly flat gland at the end, between the single pair of short-stalked pinnae; pinnae 5-9 $\mathrm{cm}$. long, the rachis bearing small glands between the pairs of leaflets; leaflets $8-17$ pairs, oblong, coriaceous, $5-15 \mathrm{~mm}$. long, obtuse at the apex, obliquely truncate at the sessile base, shining above, dull beneath; peduncles solitary or fascicled, slender, $2-3.5 \mathrm{~cm}$. long; flowers yellow in dense globose heads about $8 \mathrm{~mm}$. in diameter; stamens about twice as long as the corolla; pod fleshy, linear, curved, 5-7 $\mathrm{cm}$. long, 5-7 mm. thick, slightly impressed between the seeds.

Coppices and scrub-lands, Eleuthera, Cat Island, Rum Cay, Fortune Island, Acklin's, Grand Turk, Caicos Islands, Inagua and Little Inagua. Endemic. BAHama ACACIA. ROSEWOOD. CASSIP. PORK-AND-DOUghbOY.

2. Acacia choriophýlla Benth. in Hook. Lond. Journ. Bot. 1: 495.1842.

An unarmed tree, up to 8 or $9 \mathrm{~m}$. high, the twigs and leaves glabrous. Stipules minute, subulate; petioles rather stout, $8-15 \mathrm{~mm}$. long, glandular; leaves 1-2 dm. long; pinnae 1-3 pairs, short-stalked; leaflets 3-7 pairs, sessile, oblong to obovate, subcoriaceous, $1.5-3 \mathrm{~cm}$. long, 8-15 $\mathrm{mm}$. wide, rounded or slightly emarginate at the apex, mostly obtuse at the base; peduncles mostly clustered in the axils, slender, glabrous, often numerous, 2-3.5 cm. long; flowers yellow, in dense globose heads $6-8 \mathrm{~mm}$. in diameter, the corolla puberulent; stamens about twice as long as the corolla; pod stipitate, woody, oblong, straight or somewhat curved, compressed, $4-8 \mathrm{~cm}$. long, $1.5-2.5 \mathrm{~cm}$. wide, about $8 \mathrm{~mm}$. thick, short-pointed, glabrous, tardily dehiscent.

Coppices and scrub-lands, throughout the archipelago from Abaco and Great Bahama to Andros, Mariguana and Inagua :-Cays of northern Cuba. Recorded by Hitchcock as Pithecolobium asplenifolium Griseb. CINNECORD.

\section{Acacia macracàntha H. \& B.; Willd. Sp. PI. 4: 1080. 1806.}

A widely branched tree, 5-15 $\mathrm{m}$. high, or sometimes a shrub, the young twigs slender, tomentose or pubescent, the tortuous branches armed with stipular spines $6 \mathrm{~cm}$. long or less, or sometimes unarmed. Leaves tomentose or pubescent, the short petiole bearing a sessile depressed gland; pinnae 8-40 pairs, short-stalked, 2-4 cm. long; leaflets $15-40$ pairs, linear, 2-5 mm. long, obtuse, sessile, glabrous or nearly so; peduncles clustered or solitary in the upper axils, slender, pubescent, 1-3 cm. long; flowers yellow, capitate; heads globose, 8-10 mm. in diameter; pod linear, tomentulose, turgid-compressed, 6-10 cm. long, straight or a little curved, continuous or more or less torulose, somewhat pulpy.

Rocky plain, Salt Cay, Turk's Islands : in a yard, Matthew Town, Inagua :Jamaica; Cuba ; Hispaniola; Vieques ; St. Thomas to Tortola, Martinique and Venezuela. LONG-SPINEd ACACIA.

\section{VACHÉLLIA W. \& A. Prodr. 272. 1834.}

Spiny shrubs or small trees, with bipinnate leaves, numerous, small leaflets, the polygamous flowers in globular heads. Calyx 5-lobed; corolla tubularfunnelform, 5-lobed. Stamens numerous, the filaments distinct. Ovary sessile; 
style filiform. Pod woody, swollen, nearly terete, very tardily dehiscent or indehiscent, pulpy within. Seeds in two rows, immersed in the pulp. [Commemorates C. H. Vachell, an English missionary and botanical collector in China.] A monotypic genus.

1. Vachellia Farnesiàna (L.) W. \& A. Prodr. 272. 1834.

Mimosa Farnesiana L. Sp. Pl. 521. 1753.

Acacia Farnesiana Willd. Sp. Pl. 4: 1083. 1806.

A shrub or small tree up to about $9 \mathrm{~m}$. high, its thin brown bark scaly, the slender branches spreading, the twigs armed with stiff paired whitish spines 1-2.5 cm. long. Leaves glabrous or more or less pubescent, evenly bipinnate, 4-8 cm. long, short-petioled; pinnae 3-8 pairs, sessile or nearly so; leaflets 10-25 pairs, linear-oblong, 2-6 $\mathrm{mm}$. long, bluntish at the apex; peduncles axillary, slender, mostly shorter than the leaves; heads 8-12 mm. in diameter; flowers yellow, fragrant; calyx about half as long as the corolla; corolla about $1.5 \mathrm{~mm}$. long; stamens 2-3 times as long as the corolla; pod straight or a little curved, $3-7.5 \mathrm{~cm}$. long, about $1.5 \mathrm{~cm}$. thick, pointed, dark brown; seeds shining, $6 \mathrm{~mm}$. long.

Waste and schub-iands and coastal thickets, Andros, New Providence, Eleuthera, Cat Island, Watling's, Great Exuma, Fortune Island. Grand Turk and Caicos:Florida; Cuba to Virgin Gorda and Tobago; Jamalca ; continental tropical America and old World tropics. Recorded by Dolley as Acacia tortuosa Willd., a Jamaican species. Aroma. Cashia. Opoponax.

\section{MIIMÒSA L. Sp. Pl. 516. 1753.}

Herbs, shrubs or rarely trees, mostly with 2-pinnate, often sensitive leaves, the small regular, mostly 4-5-parted, perfect or sometimes polygamous flowers in axillary, peduncled heads or spikes. Calyx small, its teeth short. Petals valvate, connate below, hypogynous. Stamens as many as the petals or twice as many, distinct; exserted; filaments mostly filiform; anthers small, eglandular. Ovary 2-many-ovuled; style slender or filiform; stigma terminal, small. Pod linear or oblong, usually flat, often transversely jointed, 2-valved with the continuous margins persistent. Seeds compressed. [Greek, referring to the sensitive leaves of some species.] Over 300 species, natives of tropical and warm regions. Type species: Mimosa sensitiva $\mathrm{L}$.

Low, sensitive-leaved herb.

Shrub, the leaves not sensitive.
1. M. pudica.

2. M. bahamensis.

\section{Mimosa pùdica L. Sp. Pl. 518. 1753.}

Herbaceous, or a little woody, loosely pubescent with long hairs or glabrate, branched, $5 \mathrm{dm}$. high or less, the stems and branches armed with rather stout, somewhat curved prickles 2-4 mm. long. Stipules lanceolate, striate, acuminate, 3-6 mm. long; petioles slender, with a pulvinus at the base, 2-6 $\mathrm{cm}$. long, deflexed when touched; pinnae 1 pair or 2 approximate pairs, also with a pulvinus at base, 2-6 cm. long; leaflets $15-25$ pairs, thin, linear, 6-10 $\mathrm{mm}$. long, 1.5-2 mm. wide, folding when touched, acutish at the apex, obliquely rounded at the base; heads ovoid, axillary; peduncles $1-2 \mathrm{~cm}$. long; calyx minute; petals and stamens 4 ; stamens pink; pods linear-oblong, 2-5-jointed, 1-1.5 $\mathrm{cm}$. long, $3 \mathrm{~mm}$. wide, constricted at the joints, the margins armed with slender straight prickles, otherwise glabrous.

Andros at Mastic Point, coilected oniy by Keith:- West Indies; continentai tropical America; naturailzed in the East Indies. Cuitivated on New Providence. Sensitive Plant. 
2. Mimosa bahaménsis Benth. in Hook. Journ. Bot. 4: 408. 1842.

A much-branched shrub $1.5-3.5 \mathrm{~m}$. high, or a small tree about $4 \mathrm{~m}$. high, the branches armed with short hooked prickles, the twigs densely brown-tomentulose. Petioles, rachis and peduncles tomentulose or rachis glabrate; leaves $4-7 \mathrm{~cm}$. long; petioles 5-20 mm. long; pinnae 2-4 pairs; leaflets 2-6 pairs, oval or obovate, $2-6 \mathrm{~mm}$. long, subcoriaceous, glabrous or nearly so, rounded at the apex, subcordate or nearly truncate at the base, the midvein prominent, the lateral venation obscure; heads $1 \mathrm{~cm}$. broad, short-peduncled, axillary and in terminal racemes; calyx about $0.5 \mathrm{~mm}$. long; corolla about $1.5 \mathrm{~mm}$. long, 4-cleft; stamens 8, pink, 2-3 times as long as the corolla; pod linear-oblong, compressed, 4-7 cm. long, 12-14 mm. wide, densely brown-tomentulose, 6-10-jointed, both sutures narrowly winged, the wings lacerate or nearly entire; seeds ovalquadrate, smooth, brown, 4-6 mm. long.

Scrub-lands and thickets, Watling's Island, Rum Cay, Fortune Island, Acklin's Island, Caícos Islands; Inagua. Endemic. Bahama Mimosa. Haulback.

The plant recorded by Schoepf as Mimosa arborea has not been Identified.

\section{IEUCAÈNA Benth, in Hook. Journ. Bot. 4: 416. 1842.}

Unarmed trees or shrubs, with bipinnate leaves, the white flowers in peduncled heads. Calyx narrowly campanulate, 5-toothed. Petals 5, distinct, valvate. Stamens 10, distinct, exserted, the anthers not gland-bearing, often pilose. Ovary stipitate; ovules numerous; style filiform; stigma minute. Pod broadly linear, flat, membranous, completely 2-valved, the ovate or obovate flat seeds transverse. [Greek, referring to the white flowers.] About 10 species, mostly of tropical America, the following typical.

\section{Leucaena glaùca (L.) Benth. in Hook. Journ. Bot. 4: 416. 1842.}

\section{Mimosa glauca L. Sp. Pl. 520. 1753.}

Usually a shrub 2-3 m. high. but sometimes a small tree, in Porto Rico becoming a tree $20 \mathrm{~m}$. high, the young twigs puberulent. Leaves 1-2 dm. long ; petiole 3-6 cm. long, with or without a gland; pinnae 3-10 pairs, the upper ones little shorter than the lower; leaflets 10-20 pairs to each pinna, oblong or lanceolate, thin, 8-15 $\mathrm{mm}$. long, inequilateral, acute at the apex, obliquely narrowed at the base, light green above, pale beneath; heads globular, axillary or terminal, mostly clustered, 1.5-3 cm. in diameter; peduncles stout, puberulent or pubescent, 2-3 cm. long; calyx obconic, $1 \mathrm{~mm}$. long, its short teeth blunt; petals linear-spatulate, pubescent; stamens about 3 times as long as the petals; ovary pubescent; pods several or numerous, linear, $10-15 \mathrm{~cm}$. long, about $1.5 \mathrm{~cm}$. wide, abruptly acute or mucronate, tapering at the base, the thin valves with raised margins.

Pastures, coppices, waste-lands and thickets, throughout the archipelago from Abaco and Great Bahama to the Caicos and Inagua:-Bermuda; Florida; West Indles; tropical America; Old World troplcs. Probably native of continental tropical America. Jumbie BeAN. Jimbay. Cow-Bush. Catesby 2: pl. 42.

\section{9. ÁCUAN Medic. Theod. 62. 1786.}

Perennial herbs or shrubs, with bipinnate leaves, small stipules, and greenish or whitish small regular flowers in axillary peduncled heads or spikes. Flowers perfect, sessile, or the lowest sometimes staminate, neutral or apetalous. Calyx campanulate, its teeth short. Petals valvate, distinct, or slightly united or coherent below. Stamens 10 or 5, distinct, mainly exserted; anthers all alike. Ovary nearly sessile; ovules $\infty$. Pod linear, straight or curved, acute, 
flat, several-seeded, 2-valved, the valves coriaceous or membranous. About 10 species, natives of warm and tropical America, one widely distributed in tropical regions of the Old World. Type species: Mimosa virgata L.

Pods 6-9 cm. long; plant erect or ascending.

1. A. virgatum.

Pods 4-5 cm. long; plant diffuse.

2. A. depressum.

1. Acuan virgàtum (L.) Medic. Theod. 62. 1786.

Mimosa virgata L. Sp. Pl. 519. 1753.

? Mimosa pernambucana L. Sp. Pl. 519. 1753.

Desmanthus virgatus Willd. Sp. Pl. 4: 1047. 1806.

Desmanthus strictus Bertol. Giorn. Arcad. 21: 190. 1824.

Stem erect or ascending, glabrous or sparingly pubescent above, branched, 0.5-2 m. high. Stipules subulate, $2.5-4 \mathrm{~mm}$. long; leaves $2-8 \mathrm{~cm}$. long, shortpetioled, the petiole and rachis sometimes pubescent; pinnae 1-7 pairs, the gland between the lower pair usually oblong, conspicuous; leaflets $10-20$ pairs, linear or linear-oblong, 4-9 $\mathrm{mm}$. long, thin, obtuse or apiculate at the apex, subtruncate at the base; heads few-several-flowered; peduncles solitary in the axils, slender, $2-5 \mathrm{~cm}$. long; flowers white; stamens 10 , about twice as long as the petals; pod straight or slightly curved, 4-7.5 $\mathrm{cm}$. long, 3-4 mm. wide, acute or apiculate, smooth.

Thickets and scrub-lands, Great Sturrup Cay, Andros, New Providence, Eleuthera, Long Island, Acklin's, Fortune Island and Inagua:-Florida; Bermuda ; West Indies; continental tropical America. Virgate Mimosa.

2. Acuan depréssum (H. \& B.) Kuntze, Rev. Gen. Pl. 1: 158. 1891.

Desmanthus depressus H. \& B.; Willd. Sp. Pl. 4: 1046.1806.

Diffusely branched, seldom over $3 \mathrm{dm}$. high, glabrous or sparingly pubescent. Stipules subulate, $3.5 \mathrm{~mm}$. long or less; leaves short-petioled, $1.5-4 \mathrm{~cm}$. long; pinnae 1-5 pairs, the gland between the lowest pair small, mostly orbicular; leaflets $10-20$ pairs, linear, $3-5 \mathrm{~mm}$. long, thin, obtuse at the apex, obtuse or subtruncate at the base; heads few-flowered, on solitary axillary peduncles; stamens 10, about $6 \mathrm{~mm}$. long, twice as long as the petals; pod straight or slightly curved, $2-5 \mathrm{~cm}$. long, about $3 \mathrm{~mm}$. wide.

Roadsides and waste places, Andros, Mangrove Cay, New Providence, Long Island, Ambergris Cay and Inagua :-Florida; Cuba to Tortola and Grenada; Tamaica; Mexico to continental tropical America. Low Mimosa.

\section{NEPTÙNIA Lour. Fl. Coch. 653. 1790.}

Prostrate, diffuse or floating perennial herbs, some species a little woody, with bipinnate leaves, and axillary solitary, long-peduncled heads of more or less imperfect and perfect flowers. Calyx campanulate, with 5 short teeth. F'etals 5, distinct, or united below the middle. Stamens mostly 10, distinct, exserted, the anthers bearing a stalked gland. Ovary stipitate, several-manyoruled; style filiform with a terminal capitate stigma. Pods broadly linear or narrowly oblong, stipitate, flat, commonly recurved, impressed between the ovate transverse seeds, 2-valved, the valves thin-coriaceous. [Dedicated to Neptune.] About 10 species, of America, tropical Asia and Australia. Type species: Neptunia oleracea Lour. 
1. Neptunia plèna (L.) Benth. in Hook. Jour. Bot. 4: 355. 1842.

Mimosa plena L. Sp. Pl. 519. 1753.

Glabrous, the slender branches prostrate or ascending, 3-6 dm. long. Stipules ovate to lanceolate, thin, oblique, 4-6 mm. long; leaves 4-10 $\mathrm{cm}$. long, with slender petioles; pinnae 2-4 pairs; leaflets $12-20$ pairs, linear, thin, faintly veined, 4-10 mm. long, obtuse; peduncles 6-12 $\mathrm{cm}$. long, usually bearing 1 or 2 cordate bracts at or below the middle; heads ovoid; flowers yellow, the upper ones perfect, the lower staminate, or neutral with exserted staminodia; pods $2-5 \mathrm{~cm}$. long, about $8 \mathrm{~mm}$. wide, acute or apiculate, thickened on the margins.

Scrub-land opening, New Providence; Inagua, near a fresh water pond west of Great Salt Lake :-Cuban Cays; Haiti; Porto Rico; Antigua to Grenada; Jamaica; continental troplcal America. Neprunia.

\section{PROSÒPIS L. Mant. 1: 10. 1767.}

Trees, with bipinnate leaves, and small, nearly or quite sessile flowers, in axillary spikes or rarely capitate. Calyx campanulate, 5-toothed. Petals 5, valvate. Stamens 10, distinct, the anthers usually bearing a deciduous gland. Ovary many-ovuled; style filiform; stigma small and terminal. Pod linear, subterete or somewhat flattened, coriaceous, indehiscent, the mesocarp spongy. Seeds flattened. [Greek name of some plant.] About 15 species, natives of tropical and subtropical regions. Type species: Prosopis spicigera L.

1. Prosopis juliflòra (Sw.) DC. Prodr. 2: 447. 1825.

Mimosa juliflora Sw. Prodr. 85. 1788.

A tree, up to $13 \mathrm{~m}$. high, but usually smaller, with widely spreading branches, armed with stipular slender straight spines, 1-4 cm. long, the slender twigs glabrous or nearly so. Leaves glabrous, or when young sparingly ciliate, 0.7-2 dm. long; petioles slender, 1-4 cm. long; pinnae 1 or 2 pairs, shortstalked; leaflets 12-20 pairs, linear-oblong, sessile, 7-16 $\mathrm{mm}$. long, strongly few-veined, obtuse or mucronulate at the apex, obliquely obtuse at the base; flowers greenish or yellowish, in dense cylindric peduncled spikes, 5-10 cm. long, 7-8 $\mathrm{mm}$. thick; calyx about $1 \mathrm{~mm}$. long, its teeth short; petals about 2.5 $\mathrm{mm}$. long, acute, villous within; ovary villous; pod compressed, falcate, $7-20$ cm. long, 8-10 mm. wide, 5-7 mm. thick when mature.

Waste places, Introduced but not planted, Inagua, near Mathew Town :-Cuba ; Hispaniola ; Tortola; Montserrat; Jamaica ; Bonaire; Curacao; Aruba ; continental tropical America. Naturalized in the Philipplne Islands. MEsquite.

\section{Family 4. CAESALPINIÀCEAE KI. \& Garcke.}

\section{Senna Family.}

Trees, herbs or shrubs, with alternate, simple or compound, mostly stipulate leaves. Flowers mostly clustered and perfect, sometimes monoecious, dioecious or polygamous, nearly regular, or irregular. Calyx mostly of 5 sepals or 5-toothed. Petals usually 5, imbricated, and the upper (unpaired) one enclosed by the lateral ones in the bud. Stamens 10 or fewer in our genera, the filaments distinct, or more or less united. Ovary 1-celled, 1-many-ovuled. Fruit a legume, mostly dehiscent into 2 valves. Seeds with or without endosperm. About 90 genera and 1000 species, mostly of tropical distribution. 
Leaves once pinnate.

Anthers dorsifixed, longitudinally dehiscent; larger petals 3 .

1. Tamarindus.

Anthers basifixed, mostly opening by terminal pores or slits; petals 5 .

Pod not elastically dehiscent; seeds with long funicles.

Pod elastically 2-valved; seeds with short funicles.

Leaves twice pinnate.

Petiole very short, termlnating in a spine.

Petioles well developed.

Stlgma not peltate; pod not winged.

Pod splitting through the middle of the valves.

Pod splitting along the sutures.

Woody vines; pods broad, thick, mostly prickly. Trees or shrubs; pods narrow, unarmed.

Calyx-lobes imbricate; shrubs and low trees.

Stamens and pistils little longer than the corolla.

Stamens and pistlls much longer than the corolla.

Calyx-lobes not imbricated; large introduced tree.

Stigma peltate; pod flat, thin, winged.

2. Cassia.

3. Chamaecrista.

4. Parkinsonia.

5. Haematoxylum.

6. Guilandina.

7. Caesalpinia.

8. Poinciana.

9. Delonix.

10. Peltophorum.

1. TAMARÍNDUS L. Sp. Pl. 34. 1753.

An unarmed tree, with erenly pinnate leaves, numerous and small leaflets, the stipules caducous, and pink to yellow racemose flowers. Calyx-tube turbinate, its 4 segments imbricated. Petals very unequal, the 3 upper ones large, nearly alike, the 2 lower ones minute, scale-like. Perfect stamens 3 , monadelphous; anthers longitudinally dehiscent; staminodia minute. Ovary stipitate, few-many-ovuled, the stipe adnate to the calyx-tube; style long; stigma terminal, subcapitate. Pod linear or linear-oblong, curved, little compressed, indehiscent, the thin epicarp crustaceous, the mesocarp pulpy, the coriaceous endocarp septate between the obovate-orbicular seeds. Endosperm none; cotyledons thick. [Latin name of the tree.] A monotypic genus.

1. Tamarindus índica L. Sp. Pl. 34. 1753.

A large tree, sometimes $20 \mathrm{~m}$. high or higher, with a trunk up to $1.5 \mathrm{~m}$. thick, the branches widely spreading, the young twigs slender, puberulent. Leaves 6-12 cm. long, short-petioled, glabrous or nearly so; leaflets 10-18 pairs, thin, reticulate-veined, oblong, $12-25 \mathrm{~mm}$. long, rounded or retuse at the apex, obliquely obtuse or subtruncate at the base; racemes few-several-flowered, mostly terminal and shorter than the leaves; pedicels slender, 6-10 $\mathrm{mm}$. long; calyx 8-10 mm. long; larger petals a little longer than the sepals; stamens a little longer than the petals; pod 5-15 cm. long, about $2 \mathrm{~cm}$. thick, the epicarp brown, scaly, the flesh acid, the brown shining seeds about $1 \mathrm{~cm}$. broad.

Spontaneous after cultivation: Andros, New Providence and Inagua :-Probably native of tropical Afrlca; widely naturalized in troplcal America. TAMARIND.

2. CÁSSIA [Tourn.] L. Sp. Pl. 376. 1753.

Herbs, shrubs, or some tropical species trees, with evenly pinnate leaves, and mainly (in all our species) vellow flowers. Calyx-teeth nearly equal, generally longer than the tube. Corolla nearly regular; petals 5 , spreading, nearly equal, imbricated, clawed. Stamens usually 10, sometimes 5, often unequal and some of them imperfect; anthers all alike, or those of the lower stamens larger, opening by 2 pores at the summit. Ovules $\infty$. Pods various. Seeds often rumerous. [Ancient name.] About 200 species, of wide distribution in.warm and temperate regions. Type species: Cassia Fistula $\mathrm{L}$. 
Pods not jointed.

Pods terete or turgid.

Pods turgid, stralght.

Suture indistinct; seeds in a single row.

Suture indistinct; seeds in a double row. Pods not turgid, strongly curved, narrow.

1. C. Sophera.

2. C. bicapsularis.

3. C. Tora.

Pods flat, or the valves lightly convex; suture distinct.

Petiolar gland situated near the leaf base. Gland wart-like.

Gland elongated, pointed.

Petiolar gland at the first pair of leaflets. Gland wart-like.

Pods jointed. Gland elongated.

Joints continuous.

Joints moniliform.

4. C. occidentalis.

5. C. ligustrina.

6. C. bahamensis.

7. C. biflora.

8. C. uniflora.

9. C. villosa

1. Cassia Sóphera L. Sp. 379. 1753.

A shrub, 1-2.3 m. high, nearly glabrous throughout, with slender branches. Leaves 1-1.5 dm. long; petiole $1-3 \mathrm{~cm}$. long, bearing a sessile round gland near the base; leaflets 5-10 pairs, ciliate, at least when young, membranous, lanceolate to oblong-lanceolate, acute or acuminate at the apex, mostly rounded at the base; flowers in short racemes in the upper axils; pedicels $8-15 \mathrm{~mm}$. long; calyx about $8 \mathrm{~mm}$. long; petals about twice as long as the sepals; pod linear, straight, turgid or subterete, 5-10 $\mathrm{cm}$. long, 7-9 mm. thick, pointed, glabrous; seeds dull, brown, 4-5 mm. long.

Waste grounds, New Providence, near Nassau, Eleuthera, Cat Island:-West Indies; continental tropical America; Old World tropics. KASONDI SENNA.

\section{Cassia bicapsulàris L. Sp. Pl. 376. 1753.}

A shrub, up to $3.5 \mathrm{~m}$. high, glabrous, or nearly so, throughout, the branches slender, sometimes vine-like. Stipules small, early deciduous; leaves $5-9 \mathrm{~cm}$. long, slightly fleshy, bearing an oblong gland narrowed toward the base, between the lowest pair of leaflets; leaflets 3-5 pairs, 1-4 cm. long, short-stalked, rounded at the apex, the upper pair obovate, narrowed at the base, the others oblong to suborbicular, rounded at both ends; racemes axillary, few-flowered, as long as the leaves or longer; pedicels $3-8 \mathrm{~mm}$. long; sepals oblong, obtuse, faintly veined, 8-12 mm. long; petals yellow, veiny, oblong-obovate, somewhat longer than the sepals; pod turgid, subterete, $8-15 \mathrm{~cm}$. long, about $1 \mathrm{~cm}$. thick, longitudinally dehiscent; seeds Jenticular, obliquely oval, brown, shining, about $5 \mathrm{~mm}$. long, horizontal.

Scrub-lands and loose rocky soil, North Calcos, Grand Turk Island:-Bermuda (naturalized); Cuba to Tortola and Grenada; Jamaica; continental tropical America. Christmas-Bush. Wild Raisin.

3. Cassia Tòra L. Sp. Pl. 376. 1753.

Cassia obtusifolia L. Sp. Pl. 377. 1753.

Annual, glabrous, 4-6 dm. high. Stipules linear-subulate, deciduous; leaves petioled, the gland borne between or above the lowest pair of leaflets; leaflets 2-4 pairs, thin, obovate, obtuse and mucronate at the apex, 2-4 cm. long; flowers 1-2.5 cm. broad, few, in short axillary racemes; calyx-lobes oblong, obtuse; stamens 10, the anthers of the upper 3 imperfect; pod linear, very slender, subterete, strongly curved, 1-1.5 dm. long, about $3 \mathrm{~mm}$. wide.

Waste grounds, New Providence, Eleuthera:-Central and southern United States; throughout tropical and subtropical America; Old World tropics.' Low SENNA.

4. Cassia occidentàlis L. Sp. Pl. 377. 1753.

Annual, glabrous, much branched, 1.4-2 m. high. Stipules caducous; gland borne near the base of the petiole; leaflets $8-12$, rounded at the base, $2-5 \mathrm{~cm}$. 
long, 8-18 $\mathrm{mm}$. wide; flowers $14-18 \mathrm{~mm}$. broad, in short axillary racemes; stamens 10, the upper 3 imperfect; calyx-lobes oblong, obtuse; pod linear, glabrous, 1-1.5 dm. long, about $6 \mathrm{~mm}$. wide, nearly flat, somewhat curved, its margins thickened.

Waste and cultivated ground, North Blmini, Andros, New Providence, Eleu thera, Watllng's, Long, Fortune, and Acklin's Islands and Inagua - Bermuda ; southern United States; throughout tropical America; Old World tropics. CoFrEE SENNA.

5 Cassia ligustrìna L. Sp. Pl. 378. 1753.

Perennial, shrubby, glabrous or somewhat pubescent, branched, 5-20 dm. high, the branches nearly terete. Stipules linear, fugacious or wanting; leaves petioled, 1-2.5 dm. long, bearing a linear-oblong gland on the petiole; leaflets 5-8 pairs, short-petioluled, lanceolate or oblong-lanceolate acuminate at the apex, rounded or narrowed at the base, $2.5-6 \mathrm{~cm}$. long; racemes few-severalflowered, peduncled, axillary and forming a terminal corymb; pedicels slender; calyx about $8 \mathrm{~mm}$. long; petals yellow, fading whitish, twice as long as the sepals; perfect stamens 10; pod linear, flat, glabrous, curved, 7-15 $\mathrm{cm}$. long, 6-10 $\mathrm{mm}$. wide; seeds compressed, parallel with the valves.

Waste grounds, pine and scrub-lands, Abaco, Great Bahama, Andros and New Providence :-Bermuda; Florida; Jamaica; Cuba ; Hispaniola; Guiana. PriveT SÉNNA.

6. Cassia bahaménsis Mill. Gard. Dict. ed. 8, no. 9. 1768.

Cassia bahamensis latifolia Benth. Trans. Linn. Soc. 27: 541. 1871.

A shrub, 1-3 m. high, the stems simple or branched, glabrous or somewhat pubescent. Leaves $7-15 \mathrm{~cm}$. long; leaflets $3-5$ pairs, rather firm in texture, oblong or elliptic to ovate-elliptic, acute or mucronate, $2.5-6 \mathrm{~cm}$. long, the petiolar gland large, sessile, wart-like, orbicular or subglobose, the linear stipules caducous; flowers corymbose-paniculate; pedicels slender, 8-20 mm. long; calyx 6-8 mm. long; petals obovate, 10-15 mm. long; pods linear, flat, slightly curved, 7-10 $\mathrm{cm}$. long, 4-8 $\mathrm{mm}$. wide, the seeds transverse.

Scrub-lands, copplces, thlckets and pine-lands, Berry Islands, Andros, New Provldence, Exuma Chain, Long Island, Great Ragged Island, Eleuthera, Cat Island, I.ttle San Salvador, Watling's Rum Cay, Crooked Island, Fortune Island, South Calcos:-Florida; Cays of northern Cuba. Specimens from Fortune Island and South Caicos have broadly ovate-elliptic leaflets (var. latifolia Benth.). BAHAMA Senna. Stinking Pea.

7. Cassia biflòra L. Sp. Pl. 378. 1753.

Cassia angustisiliqua Lam. Encycl. 1: 649. 1783.

Cassia biflora angustisiliqua Lam.; Griseb. Fl. Brit. W. Ind. 208.1860.

A shrub or rarely a small tree up to $4 \mathrm{~m}$. high, the slender twigs glabrous or pubescent, the subulate stipules deciduous. Leaves $5-10 \mathrm{~cm}$. long, bearing a cylindric sessile gland, 3-6 $\mathrm{mm}$. long, between the lowest pair of leaflets; leaflets 4-11 pairs, oblong to obovate-oblong, 1-3 cm. long, glabrous or sparingly pubescent, membranous or subchartaceous, obtuse, acutish, or slightly emarginate and commonly mucronulate at the apex, rounded or narrowed at the base; flowers in small corymbs; pedicels very slender, 8-20 mm. long; calyx 5-7 mm. long; petals obovate, about three times as long as the calyx; pod linear, flat, membranous, sparingly pubescent or glabrous, 5-10 cm. long, 4-9 mm. wide, somewhat impressed between the seeds.

Scrub and open lands, New Providence, Eleuthera, Cat Island, Great Exuma, Watling's, Atwood Cay, Fortune Island, Calcos and Inagua:- Jamaica: Cuba; Hispanlola: Grenada; Florida; continental tropical America. Bushy Senva. MosQUiTo Bush. 
8. Cassia uniflòra Mill. Gard. Dict. ed. 8, no. 5. 1768.

Cassia sericea Sw. Fl. Ind. Occ. 2: 724. 1800.

Annual, appressed-villous with brownish long hairs, simple or branched, 3-10 dm. high. Stipules narrowly linear, 5-20 mm. long; leaves $6-15 \mathrm{~cm}$. long, petioled, bearing long-stalked glands between one or more of the pairs of leaflets; leaflets $2-4$ pairs, thin, nearly sessile, oblong to obovate, $2-5 \mathrm{~cm}$. long, rounded or acutish and mucronate at the apex, rounded or narrowed at the base, glabrate above, appressed-silky beneath; peduncles axillary, 1-few-flowered, as long as the petioles or shorter; sepals rounded, about $6 \mathrm{~mm}$. long; petals about twice as long as the sepals; perfect stamens 7 ; pod narrowly linear, $2.5-5 \mathrm{~cm}$. long, about $4 \mathrm{~mm}$. wide, compressed, deeply impressed between the oblong truncate seeds, the margins continuous.

Roadsides and waste places, New Providence, Long Island and Inagua :-Cuba ; Hispaniola; Jamaica; Margarita; Mexico southward to Venezuela. SILKY SENNA.

9. Cassia villòsa Mill. Gard. Dict. ed. 8, no. 4. 1768.

Shrubby, densely stellate-pubescent all over, $6 \mathrm{dm}$. high or higher, branched, the branches terete. Leaves petioled, $7-15 \mathrm{~cm}$. long; stipules wanting, or very early fugacious; leaflets 3-5 pairs, with a short-stalked gland between the lowest pair, very short-petioluled, lanceolate or oblong-lanceolate, acuminate at the apex, narrowed or rounded at the base, inequilateral; flowers few or several, in peduncled axillary racemes shorter than the leaves; pedicels slender, 6-10 $\mathrm{mm}$. long; calyx 7-8 mm. long; petals yellow, veiny, about twice as long as the sepals; perfect stamens 7 ; pod linear, 5-8 cm. long, compressed, moniliform, the joints 1-seeded.

Waste places, New Providence. Native of Mexico. Mexican Sexna.

Cassia emarginata L., a tree of tropical America, recorded by Schoepf as seen by him on New Providence in 1784 is not otherwise known from the Bahamas.

\section{CHAMAECRÍSTA Moench, Meth. 272. 1794.}

Herbs or low shrubs, with evenly pinnate leaves, often sensitive to the touch, mostly persistent strongly nerved stipules, and yellow flowers in small axillary clusters or solitary in the axils. Calyx-lobes acuminate. Corolla somewhat irregular, three of the five petals smaller than the others. Stamens 5-10, all usually with perfect anthers opening by terminal pores. Pods linear, flat, more or less elastically dehiscent, the valves twisting. [Greek, low crest.] About 100 species, widely distributed in temperate and tropical region. Type species: Chamaecrista nictitans (L.) Moench.

Herbs ; leaves membranous.

Pubescence appressed; pod $3 \mathrm{~mm}$. wide or less.

Pubescence spreading; pod 3.5-4 mm. wide.

1. C. Chamaecrista. Low shrubs; leaves coriaceous.

Glands short-stipitate; leaflets shining.

Branches densely pubescent.

Branches glabrous or slightiy pubescent.

Leaflets lanceolate to oblong, acute or mucronate.

Leaflets narrowly obovate to obovate-oblong, obtuse. 5. C. inaguensis.

Glands strictly sessile; leaflets dull.

2. C. riparia.

3. C. Iucayana.

4. C. caribaea.

6. C. lineata.

1. Chamaecrista Chamaecrísta (L.) Britton, Bull. Torr. Club 44: 12. 1917.

Cassia Chamaecrista L. Sp. Pl. 379. 1753.

Low, slightly woody, diffusely branched, the branches slender, ascending, spreading or prostrate, pubescent or glabrate, sometimes $2-3 \mathrm{dm}$. long. Stipules lanceolate, acuminate, strongly few-veined, 3-6 $\mathrm{mm}$. long; petioles about as long 
as the stipules, bearing a solitary small, slender-stalked gland; leaflets 5-16 pairs, linear, 5-12 mm. long, inequilateral, thin, pubescent or glabrate, often ciliate, mucronate; peduncles 1 -flowered, not longer than the petioles; sepals thin, lanceolate, 3-4 mm. long; petals obovate, slightly longer than the sepals; stamens 5-7; pod linear, loosely pubescent or glabrate, $1.5-3 \mathrm{~cm}$. long, $3 \mathrm{~mm}$. wide or less.

Sandy and rocky soil, New Providence, South Caicos:-Cuba to St. Jan, St. Kitts and Grenada; Margarita ; Bonalre; Curaçao; Jamaica.

2. Chamaecrista ripària (H.B.K.) Britton, Bull. Torr. Ciub 44: 11. 1917.

Cassia riparia H.B.K. Nov. Gen. 6: 369. 1824.

Erect, slightly woody, 2-5 dm. high, the stem, the ascending branches and leaf-rachis villous with long, spreading, brownish hairs. Stipules lanceolate or linear-lanceolate, striate-veined, 4-10 $\mathrm{mm}$. long; petioles villous, mostly shorter than the stipules, bearing a solitary, rather stout-stalked gland; leaflets 6-25 pairs, linear, 6-12 mm. long, inequilateral, aristate, glabrous or very nearly so; peduncles 1-flowered, shorter than the petioles; sepals lanceolate, loosely villous, about $5 \mathrm{~mm}$. long; larger petals $7-8 \mathrm{~mm}$. long; pod linear, loosely villous, 1.5-3 cm. long, 3-4 mm. wide.

Pine and scrub-lands, Andros, New Providence, Eleuthera :-Grand Cayman. Referred by Dolley to Cassia glandulosa L.; by Hitchcock to Cassia nictitans L.; by Mrs. Northrop to Cassia mimosoides L., and by Britton (Bull. N. Y. Bot. Gard. 3: 443) doubtfully to Cassia aspera Muhl.

3. Chamaecrista lucayàna Britton, Bull. Torr. Club 44: 8. 1917.

Cassia lucayana Britton, Bull. N. Y. Bot. Gard. 4: 138. 1906.

A much-branched shrub, $1.5 \mathrm{~m}$. high or less, the twigs densely pubescent, very leafy. Petiole 6-12 $\mathrm{mm}$. long, somewhat pubescent, bearing a stout flattopped gland below the lowest leaflets; rachis sparingly pubescent or glabrous; leaflets 4-9 pairs, coriaceous, glabrous, minutely papillate, inequilateral, ovate to ovate-oblong, sessile, obliquely cordate or subcordate at the base, obtuse to acutish and distinctly cuspidate at the apex, 1-2 $\mathrm{cm}$. long, 4-12 $\mathrm{mm}$. wide, finely many-veined, the veins parallel, somewhat anastomosing; stipules lanceolate-subulate, $3-4 \mathrm{~mm}$. long; peduncles 1 or 2 in the axils, $3-4 \mathrm{~cm}$. long, pubescent; legume linear, flat, narrowed at the base, abruptly short-tipped, nearly glabrous or with a few scattered hairs when mature, 4-5 cm. long, 5-7 $\mathrm{mm}$. wide, imperfectly septate between the seeds; seeds obliquely quadrate, compressed, dull, 4-5 mm. long,-about $2 \mathrm{~mm}$. broad.

Rocky scrub-iands, Exuma Chain from a cay north of wide opening to Great Exuma, Cat Island, Conception Island and Rum Cay. Endemic.

4. Chamaecrista caribaèa (Northrop) Britton, Bull. Torr. Club 44: 8. 1917.

Cassia caribaea Northrop, Mem. Torr. Club 12: 39. pl. 6. 1902.

A branched shrub, $1 \mathrm{~m}$. high or less, the young twigs sparingly appressedpubescent or glabrate. Petiole $2-7 \mathrm{~mm}$. long, bearing a nearly cylindric gland or glandless; leaflets 2-4 pairs, coriaceous, glabrous, shining, inequilateral, oblong to narrowly elliptic or oblong-lanceolate, sessile, acute and mucronate at the apex, obliquely rounded at the base, strongly veined, $1.5-2.5 \mathrm{~cm}$. long; stipules lanceolate-subulate, about $4 \mathrm{~mm}$. long; flowers solitary in the axils, rarely 2, peduncles glabrous, very slender, $2-3 \mathrm{~cm}$. long; calyx about $1 \mathrm{~cm}$. long; the outer sepals pilose on the back; petals about twice as long as the sepals, obovate; pod linear, 3-5.5 $\mathrm{cm}$. long, 5-7 $\mathrm{mm}$. wide, sparingly shortpubescent.

Rocky scrub and pine-lands, Andros, New Providence and Cat Island. En- 
5. Chamaecrista inaguénsis Britton, Bull. Torr. Club 44: 8. 1917.

Cassia inaguensis Britton, Bull. N. Y. Bot. Gard. 3: 443.1905.

A much-branched shrub, 6-12 dm. high, the twigs pubescent. Leaflets 1 or 2 pairs, glabrous, coriaceous, rigid, shining, oblong to obovate, strongly and finely many-veined, emarginate or rounded at the apex, narrowed but not cuneate at the base, more or less inequilateral, 1.5-3 cm. long, 5-13 mm. wide; petiole 2-6 $\mathrm{mm}$. long, sparingly pubescent, bearing a stipitate gland near the top; stipules lanceolate-subulate, 2-4 mm. long, pubescent, persistent; flowers solitary in the axils, numerous, the filiform sparingly pubescent peduncles 2-3 cm. long; sepals pubescent, at least at the base, obliquely lanceolate, acuminate, $1 \mathrm{~cm}$. long or less; petals golden yellow, about $1.5 \mathrm{~cm}$. long; young legume densely pubescent.

Open scrub-land, Grand Turk Island, Caicos and Inagua. Endemic.

\section{Chamaecrista lineàta (Sw.) Greene, Pitt. 4: 31. 1899.}

Cassia lineata Sw. Prodr. 66. 1788.

A usually much-branched shrub, 3-10 dm. high, the twigs finely pubescent or glabrate. Leaflets 3-8 pairs, oblong, linear-oblong, oblanceolate or obovate, coriaceous, 6-20 mm. long, 2-7 mm. wide, rounded and mucronulate at the apex, dull, rather strongly pinnately veined, glabrous or puberulent, the petiole 3-8 $\mathrm{mm}$. long, bearing a sessile gland; stipules lanceolate, acuminate, as long as the petioles or shorter; flowers solitary in the axils, 2-3 cm. broad; petals obovate; sepals lanceolate, acuminate, 7-10 mm. long; legume linear, pubescent, 2.5-6 cm. long, 5-6 mm. wide, short-beaked.

Scrub, paimetto, and pine-lands, throughout the archipelago from Abaco and Great Bahama to Watling's, North Caicos, Ambergris Cay and Inagua:-Cuba; Hispaniola; Anegada; Jamaica. Reported by Hitchcock and by Mrs. Northrop as Cassia polyadena DC., and also referred to that specles by Bentham; reported by Dolley as Cassia Chamaecrista L.

\section{PARKINSÒNIA L. Sp. Pl. 375. 1753.}

Spiny shrubs or small trees, with nearly sessile, bipinnate leaves, the common petiole very short and spinulose-tipped, the 1 or 2 pairs of pinnae elongated, with several-many, small leaflets, the showy, yellow flowers in racemes. Calyx-tube short, the 5 narrow segments nearly equal. Petals 5, spreading, nearly equal. Stamens 10, distinct; filaments villous at the base; anthers all alike, versatile, the saes longitudinally dehiscent. Ovary shortstipitate, many-ovuled; style nearly filiform; stigma small and terminal. Pod linear, coriaceous, torulose, striate-veined, 2-valved. Seeds oblong, longitudinally placed, hard; endosperm horny; cotyledons flat. [Commemorates John Parkinson, an English botanist, herbalist to James I, who died in 1750.] Three known species, of tropical and subtropical America and Africa, the following typical.

\section{Parkinsonia aculeàta L. Sp. Pl. 375. 1753.}

A shrub, or a tree up to about $9 \mathrm{~m}$. high, with nearly smooth brown bark, and slender, spreading or drooping branches, the young twigs pubescent, the stipular spines $2 \mathrm{~cm}$. long or less. Pinnae 1 or 2 pairs, appearing like sessile pinnate leaves, 2-4 dm. long, the rachis flat, narrowly winged, bearing 10-25 pairs of short-petioluled, linear to obovate leaflets $1.5-8 \mathrm{~mm}$. long, or sometimes without leaflets; racemes few-several-flowered, as long as the leaves or 
shorter; pedicels very slender, $0.5-2 \mathrm{~cm}$. long; calyx $6-8 \mathrm{~mm}$. long; petals nearly orbicular, about twice as long as the calyx; stamens about one-half as long as the petals; pods drooping, linear-cylindric, 5-15 cm. long, much constricted between the seeds, which are oblong-cylindric, about $1 \mathrm{~cm}$. long.

Scrub-lands, Grand Turk :- southern United States; Cuba to Virgin Gorda and Trinidad; Jamaica; continental tropical America; introduced into the Oid Woria tropics. Parkinsonia. Horsebean.

\section{HAEMATÓXYLUM L. Sp. Pl. 384. 1753.}

Trees or shrubs, with yellow wood, evenly pinnate leaves, the leaflets obcordate, the spinescent stipules persistent or deciduous, the showy yellow minutely bracted flowers in loose axillary racemes. Calyx-tube very short, its 5 segments imbricated, somewhat unequal. Petals 5, oblong, spreading, somewhat unequal. Stamens 10, distinct; filaments pilose at the base; anthers all alike. Ovary short-stipitate, 2-3-ovuled; style filiform; stigma terminal, small. Pod flat, membranous, oblong or lanceolate, not dehiscent along the sutures, but splitting through the middle of the valves. Seeds transverse, oblong; endosperm none; cotyledons 2-lobed. [Greek, bloodwood.] Two known species, the following typical.

\section{Haematoxylum campechiànum L. Sp. Pl. 384. 1753.}

A glabrous tree up to about $8 \mathrm{~m}$. high, or sometimes shrubby, with spreading branches, the trunk ridged, the bark smooth and light gray, the twigs slender. Stipular spines 5-15 mm. long; leaves petioled, 5-10 $\mathrm{cm}$. long; petioles very short; leaflets 2-4 pairs, chartaceous, cuneate-obovate, 1-3 cm. long, finely many-veined, usually rather deeply emarginate, shining above; racemes several-many-flowered, short-peduncled, 2-5 cm. long; pedicels filiform, spreading, 4-6 mm. long; calyx 3-4 mm. long, its segments oblong-lanceolate, acute, unequal; petals obtuse, 4-6 mm. long; stamens about as long as the petals; pod oblong, delicately veined, 2-5 $\mathrm{cm}$. long, 8-12 $\mathrm{mm}$. wide, very thin, pointed at both ends.

Coastal thickets, hillsides and borders of salines, Andros, New Providence, Exuma Chain, Cat Island, Conception Island, Long Island, Crooked Island :-West Indies and Central America. LoGwood. Catesby, 2: pl. 66.

\section{GUILANDINA L. Sp. Pl. 381. 1753.}

Woody vines, the stems and branches mostly armed with stout recurved prickles. Leaves large, petioled, bipinnate, the leaflets often punctate. Flowers rather large, yellow, racemose or paniculate, the narrow bracts deciduous. Calyx-lobes 5, imbricated, longer than the tube. Petals 5, nearly alike, spreading. Stamens 10, the filaments pubescent below, the anthers longitudinally dehiscent. Pods oval or elliptic, not much longer than wide, subcoriaceous, compressed, usually prickly, splitting along the sutures. Seeds hard, globose or ovoid, yellow, gray or black, smooth, scarcely flattened. [Commemorates Melchior Guilandinus, a German traveller and botanist who died in 1590.] About 12 species, mostly West Indian. Type species: Guilandina Bonduc L.

Seeds gray; stipules large.

Seeds yellow; stlpules small or wanting.

Leaflets ovate, acute or acuminate.

Leaflets elliptic to suborbicular, obtuse or emarginate.
1. G. Crista.

2. G. Bonduc.

3. $G$. ovalifolia. 
1. Guilandina Crísta (L.) Small, Fl. SE. U. S. 591. 1903.

Caesalpinia Crista L. Sp. Pl. 380. 1753.

Guilandina bonducella. L. Sp. Pl. ed. 2, 545. 1762.

Caesalpinia bonducella Fleming, Asiat. Researches 11: 159. 1810.

A vine, up to $6 \mathrm{~m}$. long, trailing or climbing, the twigs and leaves armed with hooked prickles, the twigs also more or less densely bristly. Stipules usually foliaceous, thin, usually incised, persistent, sometimes $5 \mathrm{~cm}$. broad; leaves 3-8 dm. long, more or less pubescent; pinnae 4-8 pairs, short-stalked; leaflets 4-8 pairs, oblong to ovate-oblong or elliptic, rather thin, 2.5-7 cm. long, obtuse, retuse or short-acuminate and often mucronate at the apex, nearly sessile, rounded or subcordate at the base; racemes axillary, pubescent, sometimes bristly, many-flowered, sometimes $3 \mathrm{dm}$. long; bracts linear-acuminate, reflexed or spreading, $1-1.5 \mathrm{~cm}$. long, deciduous; pedicels $1 \mathrm{~cm}$. long or less; calyx 7-9 mm. long; petals oblong-ovate, about $1 \mathrm{~cm}$. long; pod 5-10 cm. long, $6 \mathrm{~cm}$. wide or less, usually densely prickly; seeds gray, shining, obovoid-oval, slightly compressed, $2-2.5 \mathrm{~cm}$. long, about $1.5 \mathrm{~cm}$. wide.

Coastal thickets, throughout the archipelago from Abaco and Great Bahama to Mariguana, Inagua, Grand Turk and the Anguilla Isles:-Bermuda; Florida ; West Indies; coasts of continental tropical America and of the Old World tropics. Gray Nickers. BRIFR.

\section{Guilandina Bónduc L. Sp. Pl. ed. 2, 545. 1762.}

Caesalpinia Bonduc Roxb. Hort. Beng. 32. Hyponym. 1814. Guilandina major Small, Fl. SE. U. S. 591, 1331. 1903.

A trailing or climbing vine, armed with hooked prickles. Stipules none; leaves often $6 \mathrm{dm}$. long, stout-petioled; pinnae 3-6 pairs; leaflets 4-8 pairs, ovate to elliptic-ovate, $4-8 \mathrm{~cm}$. long, acute or short-acuminate at the apex, rounded or obtuse at the base, subcoriaceous, somewhat shining above, glabrous or very nearly so when old; racemes $3 \mathrm{dm}$. long or less, many-flowered; bracts linear-lanceolate, erect, early deciduous; pedicels 4-8 $\mathrm{mm}$. long; calyx about $6 \mathrm{~mm}$. long; petals $1.5 \mathrm{~cm}$. long or less; pod 6-12 $\mathrm{cm}$. long, about one-half longer than wide, rather loosely prickly; seeds bright yellow, 1.5-2.5 cm. long.

Coastal thickets and scrub-lands, Abaco, Great Bahama, Andros, and Rum Cay :-Florida ; Cuba ; Jamaica ; East Indies.' LARGE Yellow Nickers.

3. Guilandina ovalifòlia (Urban) Britton, Bull. N. Y. Bot. Gard. 4: 118. 1905.

Caesalpinia ovalifolia Urban, Symb. Ant. 2: 273. 1900.

Caesalpinia lucida Urban, Symb. Ant. 2: 275. 1900.

Climbing, $4 \mathrm{~m}$. long or longer, the young branches prickly, puberulent. Leaves 2-3 dm. long, the rachis puberulent; leaflets 5-8 pairs, oval or elliptic, glabrous or nearly so, shining, rounded at the apex, rounded to narrowed at the base, their terminal mucro often $2 \mathrm{~mm}$. long; racemes densely puberulent, solitary or in pairs, 1.5-2 dm. long; bracts narrowly lanceolate, attenuateacuminate, $8 \mathrm{~mm}$. long, soon spreading; pedicels 1-1.5 cm. long; sepals oblong, obtuse, densely tomentulose, 6-7 $\mathrm{mm}$. long, $1.5-2 \mathrm{~mm}$. wide, soon reflexed; petals bright yellow, about as long as the sepals, oblong to oblong-spatulate, obtuse; pod obliquely obovate, $6-8 \mathrm{~cm}$. long, $4 \mathrm{~cm}$. wide, $2 \mathrm{~cm}$. thick, shining, armed with numerous rather distant yellow stiff bristles $6 \mathrm{~mm}$. long or less, its sharp stout beak about $1 \mathrm{~cm}$. long; seeds globular, yellow-brown, shining, $1.6 \mathrm{~cm}$. in diameter.

Coastal thickets, Great Sturrup Cay, New Providence, and Hog Island, Rose Isiand, Eleuthera, Great Guana Cay, Long Island and Acklin's Island:-Florida. SMALL YELLOW NiCKERS.

We are unable to distinguish a difference between the two above species of Prof. Urban in specimens gathered, after thorough search, in the type localities he mentions which are only separated by the narrow harbor of Nassau. 
7. CAESALPINIA L. Sp. Pl. 380. 1753.

Unarmed or prickly shrubs or trees, with bipinnate leaves and racemose yellow bracted flowers, the bracts commonly early deciduous. Calyx-tube short, its 5 segments imbricated. Petals 5, broad, imbricated, more or less unequal. Stamens 10, distinct, declined, short-exserted; anthers all alike, longitudinally dehiscent. Ovary sessile, glabrous or pubescent; style mostly filiform; stigma terminal. Pod linear to oblong, dehiscent or indehiscent, flat or swollen. Seeds transverse; endosperm none. [Commemorates Andreas Caesalpini 1519-1603, famous Italian physician and botanist.] Thirty species or more, of tropical and subtropical regions. Type species: Caesalpinia brasiliensis L.

Leaflets few pairs, obovate.

Legume indehiscent.

Legume dehiscent.

Prickly throughout; leaflets scarcely reticulated.

Unarmed or with a few prickles at the base; leaflets strongly reticulated.

Leaflets many pairs, linear-oblong.

1. C. vesicaria.

2. C. bahamensis.

3. C. reticulata.

4. C. coriaria.

\section{Caesalpinia vesicària L. Sp. Pl. 381. 1753.}

\section{Caesalpinia bijuga Sw. Obs. 166. 1791.}

A much-branched shrub or tree up to about $7 \mathrm{~m}$. high, the twigs and leaves glabrous, armed with few prickles 4-8 mm. long, or unarmed. Leaves 1-2.5 dm. long; petioles 1-3 cm. long; pinnae 2 or 3 pairs, stalked; leaflets $1-3$ pairs, obliquely cuneate-obovate, subcoriaceous, 1-4 cm. long, subtruncate or emarginate at the apex, narrowed or obtuse at the base, dark green and shining above, pale and rather dull beneath; racemes simple or compound, mostly as long as the leaves or longer; pedicels slender, jointed near the top, 6-9 $\mathrm{mm}$. long; calyx 8-9 mm. long; petals a little longer than the calyx; stamens about as long as the petals, the filaments densely villous; pod oblong, straight, coriaceous, indehiscent, 4-6 cm. long, 12-20 mm. wide, about $4 \mathrm{~mm}$. thick, pubescent when young, becoming glabrous; seeds few, orbicular, shining, brown.

Coastal thickets and rocky coppices, Great Guana Cay, Long Isiand and Great Ragged Island :-Cuba; Jamaica; Yucatan. BRAsILETTo.

\section{Caesalpinia bahaménsis Lam. Encycl. 1: 461. 1783.}

Caesalpinia Crista Griseb. Fl. Br. W. I. 205. 1860. Not L. 1753. Caesalpinia Rugeliana Urban, Symb. Ant. 2: 278. 1900.

A prickly shrub, $1.5-2.5 \mathrm{~m}$. high, or rarely a small tree up to $4 \mathrm{~m}$. high, the young twigs and leaves brownish tomentulose or glabrate, becoming glabrous, the leaves unarmed, or bearing a few prickles. Leaves $8-25 \mathrm{~cm}$. long; petioles 1-3 cm. long; pinnae 2-4 pairs, stalked, $15 \mathrm{~cm}$. long or less; leaflets 3-6 pairs, short-petioluled, obovate to elliptic, 1-4 cm. long, subcoriaceous, emarginate or rounded at the apex, narrowed or obtuse at the base, reticulate-veined, shining above, dull beneath; racemes mostly as long as the leaves or longer; pedicels $1-2.5 \mathrm{~cm}$. long, jointed above; calyx about $9 \mathrm{~mm}$. long; petals yellowish green, shorter than the calyx; stamens curved, 2-3 times as long as the calyx; pod flat, broadly linear, 5-7 cm. long, about $1.5 \mathrm{~cm}$. wide, glabrous, short-stipitate, acuminate.

Coppices and scrub-iands, Andros, New Providence, Eleuthera, Great Guana Cay :-Cuba. Recorded by Schoepf as $C$. brasiliensis L. BAHAMA CaEsalpinia. Catesby, 2: $p l$. 51 . 
3. Caesalpinia reticulàta Britton, Bull. N. Y. Bot. Gard. 4: 118.1905.

A shrub or small tree, $4 \mathrm{~m}$. high or less, similar to $C$. bahamensis. Stem and branches unarmed in all specimens observed; young shoots puberulent; leaflets 2 to 4 pairs, obliquely oval or obliquely obovate, coriaceous, glabrous when mature, strongly finely reticulate-nerved and shining above, dull and less prominently nerved beneath, rounded, truncate or slightly emarginate at the apex, narrowed or obtuse at the base, $1.5-5 \mathrm{~cm}$. long, $3 \mathrm{~cm}$. wide or less, very inequilateral; petiolules $2-3 \mathrm{~mm}$. long; racemes solitary or 2 or 3 together, $2 \mathrm{dm}$. long or less; flowers yellowish white; pedicels ascending, 1-2 cm. long; becoming very stout in fruit; calyx stipitate, the tube nearly hemispheric; stamens long-exserted; pod flat, smooth, 6-9 $\mathrm{cm}$. long, $1.5 \mathrm{~cm}$. wide, its stipe somewhat longer than or equaling the persistent calyx-tube.

Scrub-lands, Watling's, Acklin's, Crooked Island and Inagua. Endemic. Slightly but apparently constantly distinct from $C$. bahamensis and of different distribution; perhaps a race of that species. Net-veined Caesalpinia.

4. Caesalpinia coriària (Jacq.) Willd. Sp. Pl. 2: 532.1799.

Poinciana coriaria Jacq. Sel. Amer. 123. 1763.

Libidibia coriaria Schl. Linnaea 5: 193. 1830.

A widely branched unarmed tree, 5-10 m. high, with slender twigs, puberulent when young, soon glabrous. Leaves 1-2 dm. long; petioles and rachis finely tomentulose; pinnae 4-10 pairs, short-stalked; leaflets numerous and small, 12-26 pairs, 4-6 mm. long, very nearly sessile, oblong-linear, obtuse at the apex, subcordate or truncate at base, glabrous and dull on both surfaces, usually with one or more black dots beneath; flowers yellow, in small panicles or racemes shorter than the leaves; pedicels glabrous, 2-4 $\mathrm{mm}$. long; calyx about $5 \mathrm{~mm}$. long, its segments nearly alike; petals spatulate, about as long as the calyx; stamens about as long as the petals ; pod oblong, compressed, 3-6 $\mathrm{cm}$. long, 1-2 $\mathrm{cm}$. wide, laterally incurved.

Spontaneous after cultivation, New Providence, near Nassau :-Santo Domingo; Jamaica; St. Thomas to Trinidad; Curaçao; continental tropical America. Divi-Divi.

\section{POINCIÀNA L. Sp. Pl. 380. 1753.}

Shrubs or small trees, sometimes prickly, with evenly bipinnate leaves, and orange red or yellow, showy flowers in panicles or racemes, the bracts early deciduous or none. Calyx-tube short, the 5 lobes imbricated, unequal, the lowest one the largest. Petals 5, unequal. Stamens 10, distinct, long-exserted; anthers longitudinally dehiscent. Ovary sessile, several-ovuled; style slender; stigma small, terminal. Pod linear or linear-oblong, flat, 2-valved. Seeds transverse; endosperm none. [In honor of Poinci, a governor of the West Indies.] A few species, of tropical and subtropical distribution, the following typical.

\section{Poinciana pulchérrima L. Sp. PI. 380. 1753.}

Caesalpinia pulcherrima Sw. Obs. 166. 1791.

A glabrous shrub or small tree up to about $5 \mathrm{~m}$. high, the branches prickly. Leaves $3 \mathrm{dm}$. long or less, unarmed, the petiole and lower part of the rachis stout, the upper part of the rachis very slender; pinnae 3-9 pairs, short-stalked; leaflets 5-12 pairs, thin, very short-stalked, oblong to oblong-obovate, bright green above, pale beneath, 1-2 $\mathrm{cm}$. long, 7-10 $\mathrm{mm}$. wide, rounded or subtruncate and mucronulate at the apex, obtuse at the base; racemes large, terminal, 
and axillary; pedicels slender, 5-8 $\mathrm{cm}$. long; sepals unequal, the larger about $1.5 \mathrm{~cm}$. long; petals orange or yellow, $1.5-2.5 \mathrm{~cm}$. long; stamens $5-6 \mathrm{~cm}$. long; pod flat, broadly linear, $12 \mathrm{~cm}$. long or less, 14-18 $\mathrm{mm}$. wide, somewhat oblique, pointed at both ends, its valves subcoriaceous, glabrous, twisting after dehiscence; seeds compressed.

Spontaneous in waste places, and in coppices, Andros, New Providence and Inagua :-Cuba to St. Thomas and to Trinidad; continental tropical America; Old World tropics. Barbadoes Pride.

9. DELÒNIX Raf. Fl. Tell. 2: 92.1836.

Unarmed trees, with evenly bipinnate, estipulate leaves of numerous small leaflets, and large, showy, orange to scarlet flowers in terminal or axillary corymbose racemes. Calyx deeply 5-lobed, the nearly equal lobes valvate. Petals 5, long-clawed, the blade nearly orbicular. Stamens 10, declined; filaments distinct; anthers longitudinally dehiscent. Ovary sessile, many-ovuled; style slender or short; stigma truncate, ciliolate. Pod broadly linear, flat, woody, 2-valved, nearly solid between the oblong transverse seeds. Endosperm present; cotyledons thick. [Greek, referring to the long-clawed petals.] About 3 species, natives of Africa, the following typical.

\section{Delonix règia (Bojer) Raf. Fl. Tell. 2: 92.1836.}

Poinciana regia Bojer; Hook. Bot. Mag. pl. 2884. 1829.

A widely branched tree, reaching a maximum height of about $12 \mathrm{~m}$., with a trunk up to $9 \mathrm{dm}$. in diameter, the thin bark gray-brown, the twigs somewhat pubescent. Leaves 3-5 dm. long; petiole stout, reddish or yellow, $7-12 \mathrm{~cm}$. long; pinnae 10-25 pairs, short-stalked, 8-1:5 $\mathrm{cm}$. long, the rachis pubescent; leaflets 20-40 pairs, oblong, puberulent on both sides, 4-10 mm. long, inequilateral, rounded at both ends; pedicels stout, 4-8 cm. long; ealyx about $2 \mathrm{~cm}$. long; petals spreading and reflexed, $5-7 \mathrm{~cm}$. long, orange to scarlet and mottled; stamens shorter than the petals; pod 4-6 dm. long, 5-7 cm. wide, dark brown.

Spontaneous after cuitivation, New Providence, near Nassau :-Widely cuitivated and spontaneous after cultivation throughout the West Indies and in southern Florida. Native of Madagascar. Royal Poinciana. Flamboyant.

\section{PELTÓPHORUM Vogel; Walp. Rep. 1: 811.1842.}

Unarmed trees, with bipinnate leaves of numerous small leaflets, the small stipules caducous, and yellow flowers in panicled racemes. Calyx-tube short, its 5 segments nearly equal or the lower one somewhat larger than the others. Petals 5, orbicular, spreading, imbricated, slightly unequal. Stamens 10, distinct, declined; filaments pilose below; anthers all alike. Ovary sessile, fewmany-ovuled; style filiform; stigma peltate. Pod oblong, flat, indehiscent, narrowed at both ends. Seeds 1-4, flat, transverse; endosperm none. [Greek, shield-bearing; from the peltate stigma.] About 7 species, of tropical distribution. Type species: Peltophorum Vogelianum Walp.

\section{Peltophorum adnàtum Griseb. Fl. Br. W. I. 206.1860.}

A tree, in the Bahamas up to about $12 \mathrm{~m}$. high, in the Cuban forests reaching a height of $50 \mathrm{~m}$., the twigs, petioles, rachis, inflorescence, calyx, and lower leaf-surfaces densely brown-tomentose or villous. Leaves petioled, 1-3 dm. 
long; pinnae 6-12 pairs, opposite, very nearly sessile, narrowly lanceolate, 5-10 em. long; leaflets 12-36 pairs, opposite, coriaceous, linear-oblong, 5-10 mm. long, revolute-margined, glabrous and shining above, obtuse at the apex, truncate at the sessile base; panicles terminal, many-flowered, often $3 \mathrm{dm}$. long; pedicels slender, 12-20 mm. long; calyx subglobose in bud, 5-6 mm. long, its obovate segments imbricated, nearly equal; petals obovate, 7-10 $\mathrm{mm}$. long; stamens shorter than the petals; pod $4-5 \mathrm{~cm}$. long, $12-15 \mathrm{~mm}$. wide at the middle. BUSH,

Scrub-lands and coppices, Andros, Great Exuma, Long Island:-Cuba. Horse-

\section{Family 5. FABÀCEAE Rchb.}

\section{Pea Family.}

Herbs, shrubs, vines or trees, with alternate mostly compound stipulate leaves, and irregular (papilionaceous) perfect or sometimes polygamodioecious flowers, mainly in spikes, heads, racemes or panicles. Calyx 4-5toothed, or 4-5-cleft, sometimes 2-lipped. Petals more or less united, or separate, perigynous or hypogynous, usually consisting of a broad upper one (standard, banner), two lateral ones (wings), and two front ones more or less united (forming the keel); the standard enclosing the wings in the bud. Stamens monadelphous, diadelphous, or sometimes separate, 10 in most of the genera, sometimes 9 , rarely 5 . Pistil simple, superior; ovary mainly 1-celled, sometimes 2-celled by the intrusion of the sutures, or several-celled by cross-partitions; style simple; ovules 1-many, anatropous or amphitropous. Fruit a legume, 1-many-seeded, dehiscent into 2 valves, or indehiscent, in one tribe a loment. Seeds mostly without endosperm; cotyledons thick. About 325 genera and over 5000 species, most abundant in temperate and warm regions.

Filaments ail separate.

Petal oniy 1; pod flat, short, winged.

Corolla papilionaceous; pod turgid, elongated.

Filaments monadelphous or diadelphous. Herbs, shrubs or trees.

Fruit 2-vaived.

Leaves mostly trifoliolate.

Leaflets entire.

Leaflets serrulate.

Leaves pinnate.

Leaves unequaliy pinnate.

Pods 4-angled or turgid. Pods flat.

Leaves equally pinnate.

Standard broad, longer than the keel-petals; calyx-lobes acute or acuminate.

Standard narrow, shorter than the keel-petals;

Fruit a loment calyx-lobes low and broad.

Stamens ail united into a tube.

Vexillar stamen free from the others. Joints of the loment flat. Joints of the loment thick, fleshy.

Fruit indehiscent.

Leaves 1-follolate; pod suborbicular; vine-like shrubs. Leaves pinnate; pod elongated, 4-winged; tree.

Vines, our species herbaceous (Phaseolus lathyroides an erect herb ; Cajan erect and half-shrubby).

Keel of the corolla not curved nor coiled (somewhat bent in Canavali).

Leaves equally pinnate, terminated by a bristie.

Leaves trifoliolate, rarely unifolioiate. Style bearded along the inner side.

Style glabrous or sparingly pubescent below

1. Ateleia.

2. Sophora.

(somewhat bearded in Dolichos).

3. Crotalaria.

4. Trifolium.

5. Indigofera.

6. Cracca.

7. Sesban.

8. Agati.

9. Stylosanthes.

10. Meibomia.

11. Alysicarpus.

12. Ecastophyllum. 13. Ichthyomethia.

14. Abrus.

15. Clitoria. 
Standard spurred at the base.

Standard not spurred at the base.

Pod covered with stinging hairs.

Pod without stinging hairs, pubescent or glabrous.

Rachis of the inflorescence thickened at the nodes.

Calyx-lobes unequal.

Calyx 2-lipped.

Rachis of the inflorescence not thickened at the nodes.

Erect; half-shrubby ; seeds numerous. Herbaceous, our species vines; seeds only 2 or 3.

Keel of the corolla coiled or curved.

Keel spirally colled.

Keel not spirally colled, incurved.

Stigma terminal.

Stigma oblique or iateral.

16. Bradburya.

17. Mucunci.

18. Galactia.

19. Canavali.

20. Cajan.

21. Dolicholus.

22. Phaseolus.

23. Dolichos.

24. Vigna.

1. ATELEì Moc. \& Sesse; Benth. Ann. Wien. Mus. 2: 101.1837.

Unarmed shrubs or small trees, with unevenly pinnate leaves, and small white or greenish flowers, in narrow, simple or branched, axillary racemes. Stipules minute or none. Bracts minute. Calyx truncate or minutely 5-toothed. Wings and keel-petals wanting; standard hooded, clawed. Stamens 10, distinct; anthers ovate, all alike. Ovary short-stipitate, 2-ovuled; stigma inflexed, nearly sessile. Pod irregularly obovate-orbicular, stipitate, flat, indehiscent, the upper suture narrowly winged. Seed flat, reniform; cotyledons fleshy; radicle inflexed. [Greek, defective.] Three known species of Central America and the West Indies. Type species: Pterocarpus Ateleia DC.

1. Ateleia cubénsis Griseb. Mem. Am. Acad. II. 8: 180.1860.

Swartzia multijuga A. Rich. in Sagra, Hist. Cub. 10: 201. pl. 42. 1845. Not Vogel. 1837.

Ateleia multijuga Hiteh. Rep. Mo. Bot. Gard. 4: 80. 1893.

A shrub or small tree up to $5 \mathrm{~m}$. high, the slender twigs glabrous, gray, the inflorescence and young foliage densely brown-pubescent. Leaves 1-2 dm. long, 5-11-foliolate, glabrous or nearly so when old; leaflets oblong to elliptic or oblong-obovate, densely and finely reticulate-veined, subcoriaceous, entire, 3-6 $\mathrm{cm}$. long, 1-2 $\mathrm{cm}$. wide, sessile, obtuse or emarginate at the apex, narrowed at the base; racemes spike-like, shorter than the leaves, or as long; pedicels very short; calyx broadly campanulate, truncate, $2-3 \mathrm{~mm}$. long; standard about 3 $\mathrm{mm}$. long; pod slender-stipitate, glabrous, $1.5-2 \mathrm{~cm}$. long, 1-1.5 cm. wide, veiny, cuneate-narrowed at the base.

Thickets, coppices, pine-land̆s and scrub-lands, Great Bahama, Andros, New Providence, Eleuthera, Cat Island and Caicos Islands :- Cuba. STINking-PEA Root.

\section{SOPHÒRA L. Sp. Pl. 373. 1753.}

Leaves odd-pinnate. Flowers white, yellow or violet, in terminal racemes or panicles. Calyx generally campanulate, its teeth short. Standard obovate or orbicular; wings obliquely oblong; keel oblong, nearly straight. Stamens all distinct or very nearly so; anthers versatile. Ovary short-stalked; style incurved. Pod stalked, coriaceous or fleshy, terete, constricted between the seeds, mainly indehiscent. [Name Arabic, yellow.] About 25 species, natives of warm and tropical regions. Type species: Sophora alopecuroides $\mathrm{L}$. 
1. Sophora tomentòsa L. Sp. Pl. 373. 1753.

A shrub 1-3 m. tall, with silky-tomentose foliage. Leaves 1-2 dm. long; leaflets 11-17, the blades leathery, oblong, oblong-obovate or oval, inequilateral, becoming glabrous and revolute-margined; racemes elongating, 1-4 dm. long; pedicels 5-10 $\mathrm{mm}$. long; calyx oblong or oblong-funnelform, 5-8 $\mathrm{mm}$. long, constricted at the base, undulate or indistinctly 5-lobed; corolla yellow; standard with an ovate blade fully $1 \mathrm{~cm}$. broad, and over $1.5 \mathrm{~cm}$. long; keel-petals $20 \mathrm{~mm}$. long; pods 5-10 cm. long, strongly constricted between the seeds, long-stalked.

Coastal thickets, coppices and white-lands, throughout the archipelago from Great Bahama through Andros and Eleuthera to Caicos, Grand Turk, Inagua and Angullla Isles :-Bermuda: Florida; Cuba to Virgin Gorda and St. Vincent ; Jamaica; Aruba; Old World tropics. CoAst Sophora.

\section{CROTALÀrIA L. Sp. Pl. 714. 1753.}

Herbs, sometimes slightly woody, with simple, or in many tropical species 3-7-foliolate leaves, and racemose yellow flowers. Calyx 5-toothed, slightly 2-lipped; standard orbicular or ovate, often cordate; wings oblong or obovate; keel curved. Stamens monadelphous, their sheath deeply cleft; anthers of 2 forms, alternating with each other, the one small, versatile, the other larger; style more or less curved; pod oblong or globose, inflated, many-seeded, the seeds loose at maturity. [Greek, a rattle.] About 250 species, mainly of tropical regions. Type species: Crotalaria lotifolia L.

Leaves simple.

Flowers blue, variegated.

Flowers yellow.

Leaves 3 -follolate.

Flowers $1 \mathrm{~cm}$. wide or less; pod about $1 \mathrm{~cm}$. long.

Flowers large, $1.5 \mathrm{~cm}$. wide or more; pod $2-3.5 \mathrm{~cm}$. long. Herbaceous annual; pods pilose.

Somewhat woody perennial; pods puberulent.

1. C. verrucosa.

2. C. retusa.

3. C. pumila.

4. C. incana.

5. C. lotifolia.

\section{Crotalaria verrucòsa L. Sp. Pl. 715. 1753.}

Annual, 3-8 dm. high, branched, the branches zigzag, angled, finely appressed-pubescent. Leaves simple, broadly ovate or ovate-elliptic, obtuse, rounded or acute and mucronulate at the apex, narrowed at the base, 3-7 cm. long, glabrous or nearly so above, finely appressed-pubescent beneath, shortpetioled, the rounded stipules 3-6 $\mathrm{mm}$. long; racemes several-flowered, longer than the leaves, the peduncle and rachis angled; calyx deeply cleft, its upper lobes ovate, the lower lanceolate; corolla blue, variegated, 1-1.5 cm. long, about twice as long as the corolla; pod sessile, oblong, beaked, appressed-pubescent with long hairs, 3-4 $\mathrm{cm}$. long, 9-12 $\mathrm{mm}$. thick.

Waste and cultivated ground, New Providence, Long Island and Crooked Island:-St. Thomas to Virgin Gorda and Barbadoes; Jamaica ; Cuba ; continental tropical America. Native of the East Indies. Purple Ratrlebox.

\section{Crotalaria retùsa L. Sp. Pl. 715. 1753.}

Annual, appressed-pubescent, usually branched, 4-10 dm. high. Stipules minute or wanting; leaves simple, oblanceolate, spatulate or oblong, shortpetioled, 4-8 $\mathrm{cm}$. long, rounded or retuse at the apex, cuneate at the base, glabrous above, appressed-pubescent beneath; racemes terminal, peduncled, loosely several-many-flowered, $2 \mathrm{dm}$. long or less; pedicels $6-10 \mathrm{~mm}$. long; calyx 2-lipped, about $10 \mathrm{~mm}$. long; petals nearly twice as long as the calyx, yellow, the standard variegated; pod oblong, $2.5-3.5 \mathrm{~cm}$. long, about $1 \mathrm{~cm}$. thick, short-beaked, glabrous.

Waste and cultivated land, New Providence and Great Exuma:-Florida; Bermuda; West Indies; continental tropical America. Naturalized from the old World. LARGE Yellow RatTlebox. 


\section{Crotalaria pùmila Ortega, Hort. Matr. 23. 1797.}

Perennial, woody below, finely pubescent or glabrate, branched, the slender branches decumbent or ascending, 1-9 dm. long. Stipules 1-2 mm. long, deciduous, subulate; petioles very slender, $0.5-2 \mathrm{~cm}$. long; leaflets 3 , oblong, oblanceolate or obovate, thin, 5-15 mm. long, rounded or emarginate at the apex, narrowed or cuneate at the base, glabrous above, more or less pubescent beneath; racemes few-flowered, mostly terminal, much longer than the leaves; pedicels slender, $2-5 \mathrm{~mm}$. long; calyx 5 -cleft to about the middle, the lobes acute or acuminate; petals yellow, the standard 7-9 $\mathrm{mm}$. long, twice as long as the calyx, the keel with a short horizontal beak; pod oblong, sessile, 10-15 mm. long, about $5 \mathrm{~mm}$. thick.

Pine and palmetto-lands, Abaco, Great Bahama, Andros, New Providence, Eleuthera, Cat Island, Watling's Island, Great Guana Cay, Exuma and Crooked Island :-Florida; Cuba; Hispianola; St. Kitts to Barbadoes; Jamaica; Mexico to Venezuela. Low RAtTlebox.

\section{Crotalaria incàna L. Sp. Pl. 716. 1753.}

Annual or biennial, herbaceous, usually branched, $1.3 \mathrm{~m}$. high or less, the branches, petioles and racemes densely pubescent. Stipules subulate, $5 \mathrm{~mm}$. long or less, deciduous, or wanting; petioles $2-8 \mathrm{~cm}$. long; leaflets 3 , obovate, oval or obovate-orbicular, short-stalked, 1-5 cm. long, thin, obtuse and often mucronulate at the apex, obtuse or narrowed at the base, pubescent beneath, glabrate above; racemes terminal, long-peduncled, several-flowered; calyxsegments lanceolate, acuminate, $7-9 \mathrm{~mm}$. long; corolla yellow or greenishyellow, 10-13 mm. long; pods oblong, pendent, pubescent, $2-3.5 \mathrm{~cm}$. long, about $1 \mathrm{~cm}$. thick.

Waste and cultivated grounds, New Providence and Hog Island:- Southern United States; West Indies and continental tropical America north to Mexico; old World tropies. Velvety RatTlebox.

\section{Crotalaria lotifòlia L. Sp. Pl. 715. 1753.}

Shrubby, branched, $6 \mathrm{dm} .-2 \mathrm{~m}$. high, slender and sometimes vine-like and up to $3 \mathrm{~m}$. long, the branches and petioles appressed-pubescent. Stipules minute, deciduous; petioles slender, $2-6 \mathrm{~cm}$. long; leaflets 3 , oblong to elliptic, thin, 1-4 cm. long, obtuse at the apex, mostly narrowed at the base, shortstalked, silky-pubescent or glabrate beneath, usually glabrous above; racemes axillary, short-peduncled, few-flowered, as long as the leaves or shorter; calyxsegments lanceolate, acuminate, 5-7 mm. long; corolla yellow, about twice as long as the calyx, the standard reddish veined; pod narrowly oblong, beaked, 2-3 cm. long, about $6 \mathrm{~mm}$. thick, finely appressed-pubescent.

Open scrub-lands, New Providence and Eleuthera:-Cuba to Anegada and Barbădoes; Jamaica. Reported from tropical Africa. Bushy RATtLeBox.

Dolley reports Crotalaria stipularis Desv. from the Bahamas; Mr. Brace has not seen the species nor have our collectors returned it from the archipelago.

\section{TRIFÒLIUM L。 Sp. Pl. 764. 1753.}

Herbs, with mostly 3-foliolate (occasionally 4-11-foliolate) denticulate leaves, the flowers in dense heads or spikes. Stipules adnate to the petiole. Calyx-teeth nearly equal. Petals commonly persistent, their claws adnate to the stamen-tube. Stamens diadelphous, or the tenth one separate for only a portion of its length. Ovary few-ovuled. Pod often included in the calyx, membranous, indehiscent or tardily dehiscent by 1 suture, 1-6-seeded. [Latin, referring to the 3 leaflets.] About 275 species, most abundant in the north temperate zone. Type species: Trifolium pratense $\mathbf{L}$. 
1. Trifolium rèpens L. Sp. Pl. 767. 1753.

Perennial, glabrous or with a few scattered hairs, the branches often rooting at the nodes, 1-3 dm. long. Leaves long-petioled; stipules ovatelanceolate, membranous, acute, 4-12 mm. long; leaflets short-stalked, obovate, emarginate or obcordate, broadly cuneate at the base, denticulate, 8-20 $\mathrm{mm}$. long; heads long-peduncled; flowers 7-12 $\mathrm{mm}$. long; pedicels $2-5 \mathrm{~mm}$. long, finally reflexed; corolla 2-3 times as long as the calyx; calyx-teeth acuminate, somewhat shorter than the tube; pod about 4-seeded.

Wayside ditches and dooryards, New Providence, at Nassau :-Bermuda; Cuba ; Jamaica; naturallzed throughout temperate North America. Native of the Old World. White Clover.

\section{Trifolium praténse L. Sp. Pl. 768. 1753.}

Perennial, pubescent, 1.5-6 dm. high. Leaves long-petioled; stipules ovate, strongly veined, subulate-tipped, 12-20 mm. long; leaflets short-stalked, oval, oblong or obovate, narrowed at base, hardly cuneate, obtuse and sometimes emarginate at the apex, often dark-spotted near the middle, finely denticulate, 1-3.5 cm. long; heads globose or ovoid, rarely slightly peduncled, about $2.5 \mathrm{~cm}$. long; flowers red (rarely white), about $12 \mathrm{~mm}$. long, remaining erect in fruit; calyx sparingly hairy, its subulate teeth shorter than the corolla.

Dooryard, New Providence at Nassau:-Bermuda; Cuba. Widely naturalized in temperate North America. Native of the Old World. RED CLover.

\section{INDIGÓFERA L. Sp. Pl. 751. 1753.}

Herbs, or rarely shrubs, often canescent with hairs affixed by the middle, with odd-pinnate leaves, small stipules, and pink or purple, spicate or racemose flowers. Calyx-teeth oblique, nearly equal, or the lower longer; standard ovate or orbicular, sessile or clawed; wings oblong; keel erect, somewhat gibbous, or spurred; stamens mainly monadelphous; ovary $1-\infty$-ovuled; style slender; pod linear, 4-angled or subterete, septate between the seeds. [Name from the yield of indigo by some species.] About 275 species, natives of warm and temperate regions. Type species: Indigofera tinctoria $\mathrm{L}$.

1. Indigofera suffruticòsa Mill. Gard. Dict. ed. 8, no. 2. 1768.

\section{Indigofera Anil L. Mant. 2: 272. 1771.}

A shrub, 1-2 m. high, usually much-branched, the branches slender, tough, whitish appressed-pubescent and grooved when young. Leaves 5-12 cm. long; stipules filiform-setaceous, very small; petiole 1-2.5 cm. long; leaflets 9-17, oblong or oblong-obovate, $3 \mathrm{~cm}$. long or less, obtuse or acutish and mucronate at the apex, mostly narrowed at the base, pale green, appressed-pubescent on both sides, or glabrous above, darkening in drying; racemes narrow, severalmany-flowered, 2-5 $\mathrm{cm}$. long; pedicels about $1 \mathrm{~mm}$. long, about equalling the campanulate, pubescent calyx, reflexed in fruit; corolla yellowish, $3.5-4.5 \mathrm{~mm}$. long; pod falcate, appressed-pubescent when young, glabrous when old, 8-15 $\mathrm{mm}$. long, $2 \mathrm{~mm}$. thick, ridged on the sutures, 4-8-seeded.

Waste and cultivated lands, Abaco, Great Bahama, New Providence, Eleuthera, Great Guana, Exuma, Cat Island, Watling's, Long Island, Acklin's and Inagua :Bermuda; southern United States; West Indies; Mexico to continental tropical South America. I. argentea of Schoepf. WILD INDIgo. 
6. CRÁCCA L. Sp. Pl. 752. 1753.

[TePhrosia Pers. Syn. 2: 328. 1807.]

Herbs, sometimes slightly shrubby, with odd-pinnate not punctate leaves, and purple red or white flowers in racemes or short clusters. Stipules small; leaflets entire. Calyx-teeth usually nearly equal. Petals all clawed; standard orbicular or broadly ovate; wings obliquely obovate or oblong; keel curved; stamens monadelphous or diadelphous; ovules several or many. Pod linear, flat, 2-valved, several-seeded. [Latin, vetch.] About 120 species, mainly natives of warm and tropical regions. Type species: Cracca villosa L.

Racemes short-peduncled; leaflets blunt, mucronate.

Racemes long-peduncled; leaflets emarginate, mucronulate.
1. C. cinerea.

2. C. cathartica.

1. Cracca cinèrea (L.) Morong, Ann. N. Y. Acad. Sci. 7: 79. 1892.

Galega cinerea L. Pl. Jam. Pug. 19. 1759.

Tephrosia cinerea Pers. Syn. 2: 328. 1807.

Rootstock thick, sometimes.long, woody; stems slender, usually branched, ascending, erect or diffuse, $5 \mathrm{dm}$. long or less, more or less pubescent. Leaves 5-8 cm. long; petioles $1.5 \mathrm{~cm}$. long or less; stipules subulate; leaflets 9-15, mostly oblanceolate, sometimes narrowly oblong, $1.5-2.5 \mathrm{~cm}$. Iong, obtuse or acutish at the apex, often mucronate, cuneate or narrowed at the base, ap. pressed-pubescent, at least beneath; racemes few, several-flowered, peduncled, mostly opposite the leaves; calyx about $5 \mathrm{~mm}$. long, its teeth acuminate; petals about twice as long as the calyx, purple or purplish, the standard about $10 \mathrm{~mm}$. broad; pod 3-6 $\mathrm{cm}$. long, 2.5-4 mm. wide, finely pubescent, containing 10 seeds or fewer.

Shaded white-lands, Cave Cay, Great Exuma, Rum Cay, Long Island, Acklin's, Grand Turk and Inagua :-West Indies; Mexlco to South Ámerica. The plant referred to by Hitchcock proved to be the following species. SLExder Goats-RUL.

\section{Cracca cathàrtica (Moc. \& Sesse) Britton \& Millspaugh.}

Galega cathartica Moc. \& Sesse, Fl. Mex. ed. 2: 175.1894.

Cracca Schottii Vail, Bull. Torr. Club 22: 25. 1895.

Tephrosia cathartica Urban, Symb. Ant. 4: 283. 1905.

Root deep, elongated; stem often much branched, $8 \mathrm{dm}$. high or less, the branches ascending or diffuse, slender, tough, $2-4 \mathrm{dm}$. long. Leaves $5-8 \mathrm{~cm}$. long; petioles slender, $2 \mathrm{~cm}$. long or less; stipules linear-subulate; leaflets 5-9, oblong-obovate, 1.5-4 cm. long, appressed-pubescent on both sides or glabrate above, mostly retuse at the apex, cuneate-narrowed at the base; racemes terminal and opposite the leaves, few-flowered, short or elongated; calyx about 4 $\mathrm{mm}$. long, its teeth acuminate; petals purple or red-purple, the standard about $8 \mathrm{~mm}$. broad; pod 3-4 cm. long, 4-5 mm. wide, 5-7-seeded.

Coastal white-lands, Elbow Cay, Andros; Eleuthera :-Cuba ; Hispaniola ; Porto Rico; Virgin Gorda to St. Kitts ; Trinidad; Cayman Islands ; Island of Ruatan, Cartagena; Colombla. BUSHY Goats-RUE.

\section{SÉSBAN Adans. Fam. Pl. 2: 327. 1763.}

Herbs or shrubs, with evenly pinnate leaves, the leaflets numerous, entire, not stipellate, or the stipels minute. Flowers in axillary racemes, the slender pedicels with 2 deciduous bractlets under the calyx. Calyx campanulate, nearly equally 5-toothed. Standard broad, ovate or orbicular; wings oblong, falcate; keel blunt. Stamens diadelphous (9 and 1). Ovary mostly stipitate, many- 
ovuled; style glabrous; stigma small. Pod elongated-linear, wingless, rompressed, partitioned between the oblong seeds. [Name Arabic.] About 15 species, natives of warm and tropical regions. Type species: Aeschynomene Sesban L.

Leaflets apiculate, glabrous above, silky pubescent beneath.

1. S. sericea.

Leaflets mucronate, sparingly pubescent above, glabrous beneath. 2 . S. occidentalis.

1. Sesban serícea (Willd.) DC. Prodr. 2: 266. 1825.

Coronilla sericea Willd. Enum. 773. 1809.

Agati sericea Hitchc. Rep. Mo. Bot. Gard. 4: 75. 1893.

Stem slightly woody, 1-2 m. tall, silky-pubescent, at least above. Leaves 1-2.5 dm. long, the rachis pubescent; leaflets 10-20 pairs, linear-oblong, 1.5$2.5 \mathrm{~cm}$. long, obtuse and mucronate at the apex, usually densely silky pubescent beneath, glabrous or nearly so above, sometimes nearly glabrous on both sides; peduncles few-flowered, much shorter than the leaves; pedicels very slender, $1 \mathrm{~cm}$. long or less; calyx about $4 \mathrm{~mm}$. long, its teeth triangular, very acute; standard 10-12 mm. long, yellow, black-spotted; pod 10-16 $\mathrm{cm}$. long, biconvex, $3 \mathrm{~mm}$. wide, short-beaked, not constricted between the seeds.

Waste places, usually roadsides, New Providence and Rum Cay:-Haiti to St. Thomas and to Martinique; Jamaica. Silky Sesban.

\section{Sesban occidentàlis (Willd.) Pers. Syn. 2: 316. 1807.}

Coronilla occidentalis Willd. Sp. Pl. 3: 1147. 1803.

Shrubby, $3 \mathrm{~m}$. high or less, branched, glabrous, or sparingly pubescent above when young. Leaves 1-2 dm. long; leaflets 10-20 pairs, linear-oblong, obtuse at both ends, $1.5-2.5 \mathrm{~cm}$. long, mucronate at the apex; racemes shorter than the leaves, few-several-flowered; pedicels slender, 8-12 $\mathrm{mm}$. long; calyx broadly campanulate, 6-7 $\mathrm{mm}$. long, its triangular teeth very acute; corolla about $2 \mathrm{~cm}$. long, the standard vellow, purple-dotted; pod 1.5-2.5 dm. long, 2-3 mm. wide, biconvex, slightly constricted between the seeds when young.

Fields, Inagua, near Mathew Town:-Cuba to Porto Rico; Trinidad; Jamaica. The Inagua specimen is in fruit only, and is referred to this species with some hesitation. Smooth Sesban.

\section{AGÁTI Adans. Fam. Pl. 2: 326. 1763.}

Rapid-growing and short-lived small trees or shrubs, with equally pinnate leaves of many pairs of oblong, entire leaflets, and large, variously colored flowers in axillary racemes. Calyx large, campanulate, its lobes short and broad. Standard ovate to oblong; wings narrow, longer than the standard; keel petals curved, separate at base and apex. Stamens diadelphous ( 1 and 9 ); anthers all alike. Ovary stipitate; style subulate, curved, the small terminal stigma capitate; pod linear, elongated, flat, septate between the seeds. [Malabar name.] A monotypic genus.

1. Agati grandiflòra (L.) Desv. Journ. Bot. 1: 120. 1813.

Robinia grandiflora L. Sp. Pl. 722. 1753.

Aeschynomene grandiflora L. Sp. Pl. ed. 2: 1060. 1763.

Sesban grandiflorus Poir. in Lam. Encyc. 7: 127. 1806.

A tree, up to $12 \mathrm{~m}$. high, with a trunk up to $3 \mathrm{dm}$. thick, glabrous, or very nearly so throughout, or the young foliage finely pubescent, the bark rough. 
Leaves 2-3.5 dm. long, short-petioled; leaflets 10-30 pairs, oblong, 2-4 cm. long, obtuse or retuse at the apex, inequilaterally narrowed at the base; racemes $2-5$-flowered, shorter than the leaves; calyx $2-2.5 \mathrm{~cm}$. long, its broadly triangular lobes much shorter than the tube; corolla red to white, 6-10 cm. long; pod 2-4 dm. long, about $8 \mathrm{~mm}$. wide, beaked at the apex, narrowed at the base into a long stout stipe.

Waste places, spontaneous after cultivation, Fortune and Acklin's Islands :a native of the East Indies, spontaneous after cultivation in Fiorida, the West Indies and Yucatan. Agati. Flamingo-bill.

\section{STYLOSÁNTHES Sw. Prodr. 108. 1788.}

Perennial herbs, mainly with villous or viscid pubescence, 3 -foliolate leaves, and yellow terminal or axillary spicate or capitate flowers. Calyx-tube campanulate, its teeth membranous, the 4 upper ones more or less united. Petals and stamens inserted at or near the summit of the tube; standard orbicular; wings oblong; keel curved, beaked. Stamens monadelphous; anthers alternately longer and shorter. Ovary nearly sessile; ovules 2 or 3 ; style filiform. Pod sessile, flattened, 1-2-jointed, reticulate, dehiscent at the summit. [Greek, column-flower, alluding to the column-like calyx-tube.] About 30 species, of warm and temperate regions. Type species: Stylosanthes procumbens $\mathbf{S w}$.

Foliage not viscld; leaflets oblong, nearly glabrous. Foliage viscid; leaflets elliptic, pubescent.

1. S. hamata. 2. S. viscosa.

1. Stylosanthes hamàta (L.) Taubert, Monogr. Stylos. '22. 1889.

Hedysarum hamatum L. Syst. ed. 10: 1170. 1759.

Stylosanthes procumbens Sw. Prodr. 108. 1788.

Somewhat pubescent, branched, the branches spreading or ascending, $0.5-5$ dm. long. Stipules adnate to the petioles, with free subulate apices. Leaflets oblong or narrowly oblong, longer than the petioles, $17 \mathrm{~mm}$. long or less, nearly glabrous, acute at both ends, strongly pinnately veined, mucronate; flowers about $6 \mathrm{~mm}$. wide, in short dense bracted spikes; loment commonly 2-jointed, the persistent hooked style-base pubescent.

Dry and moist open rocky and sandy places, Great Bahama and Little Harbor Cay, and throughout the islands from New Providence to the Caicos, Grand Turk and Jnagua :- Fiorida; West Indies; the Cayman Islands; Mexico southward to Colombia. Common Pexcil-FLower.

\section{Stylosanthes viscòsa Sw. Prodr. 108. 1788.}

Viscid-pubescent, usually much-branched, 1.5-3 dm. high the branches spreading or ascending. Stipules adnate to the petioles, their tips free, subulate; leaflets elliptic or oblong-elliptic, pubescent and ciliate, pinnately veined, acute and mucronate; flowers few, in short dense bracted spikes, the bracts villous and ciliate; loment 1-2-jointed, tipped by the hooked style-base.

Scrub-lands, New Providence:-Cuba; Jamaica. Viscid Pencil-Flower.

10. MEIBÒMIA Heist.; Fabr. Enum. Pl. Hort. Helmst. 168. 1759.

Perennial herbs, sometimes woody at the base, with stipellate 3-foliolate or in some species 1- or 5-foliolate leaves, and usually small flowers in racemes or panicles. Calyx-tube short, its teeth more or less united into 2 lips, the upper one 2-toothed, the lower teeth acute or attenuate. Standard oblong; ovate or orbicular, narrowed or rarely elawed at the base; wings obliquely oblong; 
keel nearly straight, obtuse. Stamens monadelphous or diadelphous (9 and I); anthers all alike. Ovules $2-\infty$. Loment flat, 2-several-jointed, the joints mainly coriaceous and pubescent or muricate, indehiscent or rarely partially dehiscent, readily separable. [Named for Dr. Brandus Meibom; died at Helmstadt, 1740.] About 160 species, natives of warm and temperate regions. Type species: Hedysarum canadense $\mathrm{L}$.

Upper suture of the loment straight or nearly so.

1. M. supina.

Both sutures of the loment undulate.

Loment several-jointed, moniliform.

Loment 2-jointed; upper joint much larger than the lower.

2. M. tortuosa.

3. M. mollis.

1. Meibomia supina (Sw.) Britton, Ann. N. Y. Acad. Sci. 7: 83. 1892.

Hedysarum supinum Sw. Prodr. 106. 1788.

Hedysarum incanum Sw. Prodr. 107. 1788.

Desmodium incanum DC. Prodr. 2: 332. 1825.

Stems erect or ascending, somewhat woody, 3-9 dm. high, puberulent or short-pubescent. Stipules lanceolate, acuminate, connate below, or at length distinct, mostly shorter than the petioles; leaflets 3 or often only 1 , various in form, mostly elliptic, but also lanceolate, obovate, nearly linear, or orbicular, sometimes several forms on the same plant, glabrous or nearly so and dark green above, finely pubescent and pale beneath, $2-7.5 \mathrm{~cm}$. long; stipels subulate; racemes $2-8 \mathrm{~cm}$. long; bracts linear-lanceolate, pubescent, shorter than the pedicels, deciduous; pedicels 6-12 $\mathrm{mm}$. long; calyx small, about $3 \mathrm{~mm}$. long, its teeth ovate-lanceolate, acute; corolla purple or purplish, 2-3 times as long as the calyx; loment 3-8-jointed, $3 \mathrm{~cm}$ : long or less, its upper suture continuous, the lower margin deeply undulate, the oblong joints densely pubescent.

Dry or moist places in scrub, coppices, pine-lands, waste or cultivated lands, throughout the archipelago from Abaco and Great Bahama to Andros, Watling's, Crooked Island and East Caicos:-Florida; West Indies ; continental tropical America; tropical Africa. Recorded by Schoepf as Hedysarum canescens. Common TICK-IREFOIL.

2. Meibomia tortuòsa (Sw.) Kuntze, Rev. Gen. Pl. 198. 1891.

Hedysarum tortuosum Sw. Prodr. 107. 1788.

Desmodium tortuosum DC. Prodr. 2: 332. 1825.

Erect, branched, $1.5 \mathrm{~m}$. high or less, the stem and branches finely and rather densely pubescent, striate. Stipules lanceolate, acuminate, half-cordate at base, $6-15 \mathrm{~mm}$. long; leaflets 3 , ovate to oblong or elliptic, $2-10 \mathrm{~cm}$. long, sparingly pubescent with appressed hairs, or glabrous above, mostly obtuse at the apex and narrowed at the base, as long as the petioles or longer; stipels subulate; racemes simple, or sparingly branched, 1.5-3 dm. long; pedicels filiform, 1-2 cm. long; bracts narrowly lanceolate, 2-3 times as long as the calyx, deciduous; calyx about $2 \mathrm{~mm}$. long, its teeth subulate; corolla blue to purple, about $5 \mathrm{~mm}$. long; loment nearly sessile, at first much twisted, at length flat, 3-6-jointed, both margins deeply undulate, the oval-orbicular joints 4-5 $\mathrm{mm}$. long.

Waste places and roadsides, New Providence and Eleuthera :-Florida; Texas; Jamaica; Cuba to Tortola and Grenada; continental tropical America. TwISTED TICK-TREFOIL.

3. Meibomia móllis (Vahl) Kuntze, Rev. Gen. Pl. 198. 1891.

Hedysarum molle Vahl, Symb. 2: 83. 1791.

Desmodium molle DC..Prodr. 2: 332. 1825.

Stem erect, rather stout, branched, $2 \mathrm{~m}$. high or less, softly pubescent. Stipules triangular-subulate, $2-6 \mathrm{~mm}$. long; leaflets 3 , rarely only 1 , ovate, $2-10$ 
em. long, acute or acutish at the apex, obtuse at the base, pubescent on both sides, as long as the pubescent petioles or shorter; stipels subulate; racemes 1-2 dm. long, commonly branched; pedicels filiform, 3- $\delta \mathrm{mm}$. long; bracts ovate, about $1 \mathrm{~mm}$. long, deciduous; calyx $2.5-3 \mathrm{~mm}$. long, its teeth linearlanceolate; corolla blue, little longer than tho calyx; loment nearly sessile, 2jointed, the lower joint small, twisted, the upper one elliptic or subreniform, 6-8 $\mathrm{mm}$. long, finely reticulate-veined, sparingly pubescent or glabrate.

Waste places, Andros, Fortune Island, Acklin's Island :-Cuba to Virgin Gorda and Martinique; Cüraçao; continental tropical America. Recorded from Jamaica. Velvety 'TiCK-TREFCIL.

\section{AIYSICÁRPUS Neck.; DC. Prodr. 2: 35̃2. 1825.}

Herbs, our species with 1-foliolate leaves and small purplish or blue flowers in short terminal racemes, the scarious bracts deciduous. Calyx narrow, deeply cleft, the lobes lanceolate, acuminate, chartaceous, striate, the two upper ones partly united. Standard suborbicular, clawed; wings obliquely oblong, adnate to the blunt incurved keel. Stamens diadelphous (9 and 1). Ovary nearly sessile, several-ovuled; style filiform, its apex incurved; stigma terminal, capitate. Loment nearly terete, several-jointed, the joints indehiscent. [Greek, chain-fruit.] About 16 species, natives of the Old World tropics. Type species: Alysicarpus bupleurifolius (L.) DC.

\section{Alysicarpus nummularifỏlius (L.) DC. Prodr. 2: 353. 1825.}

Hedysarum nummularifolium L. Sp. Pl. 746. 1753.

Alysicarpus vaginalis DC. Prodr. 2: 353. 1825.

Perennial, branched at the base, the branches slender, diffuse, glabrous or nearly so, spreading or ascending, $5 \mathrm{~cm} .-6 \mathrm{dm}$. long. Stipules scarious, striate, lanceolate, acuminate, 4-6 mm. long; petioles very slender, $1 \mathrm{~cm}$. long or less; leaves glabrous, or sparingly pubescent, the lower orbicular to oval, 5-12 $\mathrm{mm}$. long, the upper oblong to lanceolate, 1-3.5 cm. long; racemes $1-3 \mathrm{~cm}$. long; pedicels very short, pubescent; calyx 4-5 mm. long; corolla little longer than the calyx; loment 1-2 cm. long, its puberulent or glabrous joints truncate. slightly wrinkled. Waste places, New Providence, near Nassau :-West Indies. Native of southern
Asia. FALse Money Wort.

12. ECASTAPHÝLLUM [P. Br.] Adans. Fam. Pl. 2: 320. 1763.

Woody vines, or widely branching shrubs, with alternate, 1-foliolate or unevenly pinnate leaves, the leaflets estipellate, and small white bracted flowers mostly in axillary clusters. Calyx subcampanulate, its 2 upper teeth broad. Standard broadly ovate or suborbicular; wings oblong; keel blunt, incurved, its petals connate on the back near the apex. Stamens all united into a cleft sheath, or the upper one separate or wanting; anthers erect, their sacs dehiscent by terminal slits. Ovary 2-ovuled, stipitate; style nearly straight; stigma terminal. Pod nearly orbicular to short-elliptic, nearly flat, 1-seeded, subligneous, indehiscent. [Greek, referring to the unifoliolate leaves of the following typical species.] Five or six species, natives of tropical and subtropical America. 
1. Ecastaphyllum Ecastaphýllum (L.) Britton, Mem. Brooklyn Bot. Gard. 1: 55. 1918.

Hedysarum Ecastaphyllum L. Syst. ed. 10, 1169. 1759.

Ecastaphyllum Brownei Pers. Syn. 2: 277. 1807.

Hecastophyllum Brownei Griseb. Fl. Br. W. I. 202. 1860.

Dalbergia Ecastophyllum Taubert in Engl. \& Prantl. Nat. Pfl. $3^{3}$ : 335. 1894.

Dalbergia Brownei Schinz, Bull. Herb. Boiss. 6: 731. 1898.

A widely branched, spreading or vine-like shrub $2-4 \mathrm{~m}$. high, rarely treelike and described as sometimes reaching a height of $8 \mathrm{~m}$., the branches elongated, the young twigs finely pubescent. Stipules lanceolate, silky-pubescent, acuminate, about $1 \mathrm{~cm}$. long; leaves 1-foliolate; petioles stout, pubescent, 5-12 $\mathrm{mm}$. long; petiolule 2-3 mm. long; leaflet ovate, 6-12 $\mathrm{cm}$. long, rounded or subcordate at the base, short-acuminate at the apex, glabrous or nearly so above, finely and densely pubescent beneath, at least when young; panicles axillary, pubescent, usually little longer than the petioles; pedicels $2-4 \mathrm{~mm}$. long; calyx pubescent, about $5 \mathrm{~mm}$. long; corolla about $1 \mathrm{~cm}$. long; stamens 10, diadelphous; pod suborbicular to broadly oval, $1.5-3 \mathrm{~cm}$. long, finely pubescent.

Borders of coppices and coastal thickets, Abaco, Great Bahama, North Bimini, Andros, New Providence, Watling's and Crooked Island :-Florida; Cuba to Virgin Gorda and to Trinidad: Jamaica; continental tropical America; coast of tropical Africa. TI-TI. Catesby, 2: pl. 24.

\section{ICHTHYOMÈTHIA P. Br. Hist. Jam. '296. 1756.}

Trees, with unevenly pinnate leaves, the short-stalked leaflets large, opposite, estipellate, the pink to purplish, rather large flowers in lateral panicles, often appearing before the leaves. Calyx obliquely campanulate, 5 -toothed, the 2 upper teeth connate. Standard suborbicular; wings oblong, somewhat falcate, adherent to the keel; keel obtuse, its petals coherent on the back. Stamens monadelphous, but the upper one free at the base; anthers versatile. Ovary many-ovuled; style filiform, incurved; stigma terminal, small. Pod linear, flattened, indehiscent, with 4 broad membranous wings, several-many-seeded. [Greek, fish-killing.] A few species of tropical and subtropical America, the following typical.

\section{Ichthyomethia Piscìpula (L.) Hitchcock, Gard. \& For. 4: 472. 1891.}

Erythrina Piscipula L. Sp. Pl. 707. 1753.

Piscidia Erythrina L. Syst. ed. 10, 1155. 1759.

A tree, usually low, rarely $20 \mathrm{~m}$. high, the twigs finely puberulent. Leaves 2-3 dm. long; leaflets 5-9 (rarely 3), elliptic, oblong, or the lower pair ovate, 4-12 cm. long, obtuse or acutish at the apex, rounded at the base, glabrous above, at least when mature, finely pubescent beneath; panicles many-flowered, as long as the leaves or shorter; ultimate pedicels short, puberulent; calyx about $6 \mathrm{~mm}$. long, its teeth triangular-ovate; corolla silky, about $1.5 \mathrm{~cm}$. long; pod 5-15 cm. long, its wings 7-12 mm. wide, lacerate, transversely veined; seeds black.

Coastal thickets and scrub-lands, Great Bahama, Lignum Vitae Cav, Andros, Mangrove Cay, New Providence, Eleuthera, Cat Island, Watling's, Acklin's and An-
guilla Isles :-Florida ; West Indies; continental tropical America. Fish-PoIson. DOGWOOD. Consists of several races differing mostly in pubescence and in form of the leaflets. 


\section{4. ÁBRUS L. Syst. ed. 12, 2: 472 . 1767.}

Slender, somewhat woody vines, with evenly pinnate leaves, the numerous small estipellate leaflets entire, the rachis terminating in a small bristle, the small rose to white flowers clustered at the nodes of axillary or terminal racemes. Calyx subtruncate, its teeth very short. Standard ovate, with a broad and short claw; wings oblong, falcate; keel curved, larger than the wings. Stamens 9, monadelphous. Ovary nearly sessile, several-many-ovuled; style short, curved; stigma terminal. Pod flat, 2-valved, partitioned between the subglobose, shining seeds. [Greek, graceful.] Five known species, of tropical regions, the following typical.

1. Abrus Abrus (L.) W. F. Wight, Contr. U. S. Nat. Herb. $9: 171.19$. 1.

Glycine Abrus L. Sp. Pl. 753. 1753.

Abrus precatorius L. Syst. ed. 12, 2: 472. 1767.

Stems woody below, nearly herbaceous above, climbing or twining to a length of 2-3 m., glabrous, or the young parts sparingly pubescent. Stipules linear, acute, 3-5 mm. long; petioles short, mostly less than $1 \mathrm{~cm}$. long; leaves 5-10 cm. long, the very slender rachis sparingly pubescent; leaflets 8-15 pairs, $8-20 \mathrm{~mm}$. long, oblong or the upper ones obovate, glabrous above, sparingly puberulent beneath, rounded and mucronulate at the apex, rounded at the base, very short-stalked, readily detached when dry; racemes peduncled, $3-8 \mathrm{~cm}$. long; corolla red to purple, rarely white, $8-10 \mathrm{~mm}$. long; pod oblong, beaked, 2-3.5 $\mathrm{cm}$. long, about $1 \mathrm{~cm}$. wide; seeds scarlet with a black base.

Scrub-lands and waste places, Andros, New Providence, Eleuthera, Cat Island and Great Exuma :-West Indies; continental tropical America; Old World tropics. C'RAB's-eyes. BlaCK-EYED StSAN.

\section{CLITÒRIA L. Sp. Pl. 753. 1753 .}

Woody vines, or erect or climbing herbs, with pinnately 3 -foliolate or sometimes 5-9-foliolate leaves, persistent stipules, and large axillary flowers. Calyx tubular, 5-toothed, the upper teeth more or less united; standard large, erect, retuse, narrowed at the base, not spurred; wings oblong, curved; keel acute, shorter than the wings; stamens more or less monadelphous; anthers all alike; ovary stipitate; style elongated, incurved, hairy along the inner side; pod stalked in the calyx, linear or linear-oblong, flattened, 2-valved, partly septate between the seeds. About 30 species, natives of warm and temperate regions. Type species: Clitoria Ternatea L.

\section{Clitoria Ternàtea L. Sp. Pl, 753. 1753.}

Perennial, herbaceous or slightly woody below, slender, twining to a height of $2 \mathrm{~m}$. or more, or, if without support, prostrate, pubescent, at least on the younger parts. Stipules linear-lanceolate, acuminate, $5-8 \mathrm{~mm}$. long; petioles slender, pubescent, 1-3 cm. long; leaflets 5-9 (usually 5), ovate or oval, shortstalked, $2-3.5 \mathrm{~cm}$. long, mostly obtuse at the apex, obtuse or narrowed at the base, thin, glabrous above, somewhat pubescent beneath; peduncles 1 -flowered, 1-2 cm. long; bracts ovate-orbicular, obtuse, 5-7 mm. long; ealyx about $1.7 \mathrm{~cm}$. long, its lanceolate lobes acuminate; corolla large, blue and white, the standard $3-4 \mathrm{~cm}$. long; pod nearly sessile, flat, linear, beaked, pubescent, $13 \mathrm{~cm}$. long or less, about $1 \mathrm{~cm}$. wide; seeds compressed, subreniform, mottled, 5-6 mm. long.

Fields and waste places, spontaneous after cultivation, New Providence and Inagua :-a native of tropical Africa; spontaneous after cultivation throughout the West Indies and troplcal America, and in Florida. BLUE-PEA. 
16. BRADBÙrYA Raf. Fl. Ludov. 104. 1817.

Slender vines, with pinnately 3 -foliolate leaves (rarely 5-7-foliolate), persistent stipules, and large axillary flowers. Calyx campanulate, its teeth or lobes nearly equal; standard orbicular, nearly flat, spurred on the back near its base, clawed; wings obovate, curved; keel curved; stamens more or less diadelphous (9 and 1); style incurved, bearded at the apex around the stigma; pod linear, flattened, nearly sessile, partially septate between the seeds, 2valved, the valves thick-edged, longitudinally finely nerved along their margins. [In honor of John Bradbury, who travelled in America early in the last century.] About 30 species, natives of America. Type species: Bradburya scandens Raf.

Pods 4.5-5.5 mm. wide,; seeds cylindric, 7.5-8 mm. long, black or yellow with black blotches.

Pods 3.5-4 mm. wlde; seeds cuboid-cylindric, 3.5-4 mm. long, red-brown or with lighter blotches.

1. B. floridana.

2. B. virginiana.

\section{Bradburya floridàna Britton, Torreya 4: 142. 1904.}

Stems glabrous or nearly so, $1 \mathrm{~m}$. long or more. Stipules long-acuminate; leaflets lanceolate to oval, glabrous, reticulate-veined on both sides, $8 \mathrm{~cm}$. long or less, obtuse and aristulate at the apex, rounded at the base, the glabrous petioles $2-5 \mathrm{~cm}$. long; peduncles pubescent, or glabrous, $\hat{0}-6 \mathrm{~cm}$. long; bracts acute, pubescent, $1 \mathrm{~cm}$. long or less; corolla nearly white or violet striped with lavender or yellow, 2.5-4 cm. long; pod 8-12 cm. long, 4.5-5.5 mm. wide, longtipped, glabrous; seeds black or yellow with black markings.

Scrub-lands and white-lands, Abaco, Rose Island, Berry Islands, Eleuthera, Conception Island. Exuma Chain, Long Island, Great Ragged Island, Acklin's and Crooked Islands :-Florida. FLORIDA BUTTERFLY-PEA.

\section{Bradburya virginiàna (L.) Kuntze, Rev. Gen. Pl. 164. 1891.}

Clitoria virginiana L. Sp. Pl. 753. 1753.

Centrosema virginianum Benth. Ann. Mus. Wien. 2: 120. 1838.

Centrosema virginianum angustifolium Griseb. F1. Br. W. I. 193. 1860.

Perennial, glabrous or finely rough-pubescent, 6-12 dm. long. Stipules linear, acute; leaflets ovate, oblong-lanceolate or linear, stipellate, rounded at the base, reticulate-veined, $2.5-5 \mathrm{~cm}$. long; peduncles about equalling the petioles, 1-4-flowered; bracts ovate, acute, finely striate; flowers $2.5-4 \mathrm{~cm}$. long; corolla violet; calyx-lobes linear; pod 10-13 $\mathrm{cm}$. long, 3.5-4 mm. wide, longacuminate, its margins much thickened.

Scrub, rocky and grassy lands, throughout the archipelago from Abaco and Great Bahama to Grand Turk and Inagua:- New Jersey to Florlda and Texas ; Mexico to Bolivia and Brazll; West Indies. A species composed of a large number of insignificantly differing races with leaflets varying from linear to broadly ovate; widely differing plants often growing close together in the same colony. SPURRED BUTTERFY-PEA. LADY'S SliPPER.

\section{MUCÙNA Adans. Fam. Pl. 2: 325. 1763.}

Herbaceous or woody vines, with pinnately 3-foliolate leaves, and large pedicelled flowers in axillary, long-peduncled clusters. Calyx campanulate, its two upper teeth connate. Standard folded, auricled at the base; wings incurved, longer than the standard; keel as long as the wings or longer, its apex cartilaginous or acute. Stamens diadelphous (9 and 1); anthers alternately longer and shorter. Ovary sessile, villous; ovules few; style naked, filiform; stigma terminal and small. Pod thick, coriaceous, linear or oblong, 2-valved, 
usually covered by stinging hairs, at least when young. Seeds orbicular or oblong, few, large. [Brazilian name.] About 25 species, mostly tropical, the following typical.

\section{Mucuna prùriens (L.) DC. Prodr. 2: 405.1825.}

Dolichos pruriens L. Syst. ed. 10, 1162. 1759.

Slender, high-climbing, pubescent. Petioles as long as the leaflets or shorter; leaflets thin, appressed-pubescent, somewhat silvery beneath, the terminal one rather long-stalked, ovate or rhombic-ovate, the lateral ones short-stalked, obliquely ovate, inequilateral; racemes several-many-flowered, elongated; calyx silvery-silky, about $1 \mathrm{~cm}$. long, 4-cleft; corolla blue or purple; standard ovate; wings and keel about twice as long as the standard, 2-3 cm. long; pod narrowly oblong, slightly curved, about $6 \mathrm{~cm}$. long and $1 \mathrm{~cm}$. thick, densely covered with brittle stinging hairs.

Thickets and scrub-lands, New Providence near Nassau:-Cuba to St. Thomas and Tobago; Jamalca; continental tropical America; Old World tropics. Dolley reports Mucuna urens L., from the Bahamas but the plant has not been returned in any of the collectlons we have seen; the record probably refers to $M$. pruriens. COW-ITCH.

\section{GALÁCTIA P. Br.; Adans. Fam. Pl. 2: 322. 1763.}

Perennial vines (some species erect and shrubby), mainly with pinnately 3-foliolate leaves, small and deciduous stipules, and small or large axillary racemose flowers. Calyx 4-lobed, bracteolate, the lobes acute, often as long as the tube. Standard orbicular or obovate. Wings narrow, obovate, adherent to the narrow, nearly straight keel. Stamens diadelphous or nearly so (9 and 1). Ovary nearly sessile; ovules $\infty$; style filiform, not bearded. Pod linear, straight or slightly curved, usually flattened, 2-valved, several-seeded. Fleshy few-seeded pods are sometimes produced from subterranean apetalpus flowers. [Greek, milk-yielding, the typical species described as having milky branches.] About 70 species natives of warm and temperate regions, most abundant in America. Type species: Glycine Galactia L.

Corolla about $2 \mathrm{~cm}$. long; standard parallel with the wings. Corolla $1.5 \mathrm{~cm}$. long or less; standard erect or ascending.

Leaflet only one.

Leaflets three.

Leaflets large, ovate to elliptic, $4-8 \mathrm{~cm}$. long.

Leaflets small, oblanceolate to obovate or oval, $1-4 \mathrm{~cm}$. Iong.

Inflorescence longer than the leaves; leaves glabrous or nearly so.

Inflorescence not exceeding the leaves; leaves densely appressed-pubescent.
1. G. rudolphioides.

2. G. monophylla.

3. G. spiciformis.

4. G. bahamensis.

5. G. uniflora.

1. Galactia rudolphioìdes (Griseb.) Benth. \& Hook.; Sauv. Anales Acad. Habana 5: 337. 1869.

Dioclea rudolphioides Griseb. Mem. Am. Acad. II. 8: 178. 1860.

Slender, twining or trailing, woody below, 1-3 m. long, glabrous or sparingly appressed-pubescent. Petioles $2-5 \mathrm{~cm}$. long; stipules triangular or lanceolate, about $2 \mathrm{~mm}$. long; leaflets 3 , oblong, oblong-lanceolate or ovateoblong, 2-4 cm. long, obtuse, acutish or emarginate at the apex, rounded or narrowed at the base, glabrous on both sides, revolute-margined, the short petiolules villous; racemes slender-peduncled, longer than the leaves; bracts linear-subulate, 1-2 mm. long; bractlets ovate or lanceolate, acute, about 1.5 
mm. long; pedicels pubescent, $2-6 \mathrm{~mm}$. long; calyx about $1.3 \mathrm{~cm}$. long, appressed-pubescent; corolla red or the standard violet, nearly $2 \mathrm{~cm}$. long; standard obovate, parallel with the wings; pod 3-5 cm. long, 7-9 mm. wide, densely villous, several-seeded.

Scrub and pine-lands and in copplces, from Abaco and Great Bahama to Andros, New Providence, Eleuthera, Cat Island, Watling's, and Exuma Chain to Fortune and Crooked Islands :-Cuba. Recorded by Dolley as G. pendula Persoon. RED MILK-PEA. Catesby, $2: p l . .28$.

\section{Galactia monophýlla Griseb. Cat. Pl. Cub. 75. 1866.}

Slender, herbaceous, appressed-pubescent with short hairs, $8 \mathrm{dm}$. long or less, twining or trailing. Stipules narrowly lanceolate or subulate, 1-3 $\mathrm{mm}$. long; petioles slender, $0-15 \mathrm{~mm}$. long; leaflet only 1 , oblong to ovate, 1-3 cm. long, thin in texture, rounded or emarginate at the apex, rounded or subcordate at the base, glabrous or sparingly pubescent abcve, appressed-pubescent beneath, the petiolule about $1 \mathrm{~mm}$. long; inflorescence 1 -few-flowered, not longer than the leaf; pedicels 2-3 mm. long; calyx sparingly pilose, about $6 \mathrm{~mm}$. long, its lanceolate teeth longer than the tube; corolla purplish, about $1 \mathrm{~cm}$. long, the standard obovate, erect; pod 3-5 cm. long, about $5 \mathrm{~mm}$. wide, appressed-pilose.

Pine-lands, Great Bahama at Barnett's Point:-Cuba. Slender Milk-PEA.

\section{Galactia spicifòrmis T. \& G. Fl. N. A. 1: 288.1838.}

Slender, herbaceous, twining, densely pubescent or glabrate, $2 \mathrm{~m}$. long or less. Petioles 1-7 cm. long; stipules subulate, 2-4 mm. long; leaflets 3 , ovate to elliptic or elliptic-obovate, chartaceous or subcoriaceous, 4-7 cm. long, glabrous or nearly so above, appressed-pubescent or velvety beneath, obtuse or acute at the apex, obtuse or rounded at the base; inflorescence usually as long as the leaves or longer, several-many-flowered, sessile or peduncled; pedicels 1-2 $\mathrm{mm}$. long; calyx pubescent, about $6 \mathrm{~mm}$. long, its lanceolate teeth $2-3$ times as long as the tube; corolla purplish, pink or nearly white, about $11 \mathrm{~mm}$. long, the broadly obovate standard erect; pod 4-7 $\mathrm{cm}$. long, 6-10 $\mathrm{mm}$. wide, often somewhat curved, more or less pubescent.

Rocky and sandy scrub-lands and coppices, throughout the islands from Abaco and Great Bahama to Andros, New Providence, Eleuthera, Watling's, and the Exuma Chain to Great Ragged Island and the Anguilla Isles:-Florida; Cuba. Referred by Mrs. Northrop to $G$. cubensis H.B.K.; recorded by Dolley as $G$. fll formis Bth. The Teramnus uncinatus referred to by Hitchcock, proves to be this plant. SPICIFORM MILK-PEA.

\section{Galactia bahaménsis Urban, Symb. Ant. 2: 331. 1900.}

Very slender, twining, somewhat woody, glabrate or reddish puberulent, 5-8 dm. long. Stipules linear-subulate, 1-2 mm. long, deciduous; petioles very slender, $0.5-2.5 \mathrm{~cm}$. long; leaflets 3 , chartaceous, nearly equally short-petioluled, oval to elliptic or obovate, $1-2.5 \mathrm{~cm}$. long, rounded or emarginate at the apex, narrowed, rounded or the terminal one cuneate at the base, glabrous and reticulate-veined on both sides, or sparingly pubescent beneath; inflorescence mostly longer than the leaves, several-flowered; pedicels $2-7 \mathrm{~cm}$. long; calyx pubescent, $6-8 \mathrm{~mm}$. long, its lanceolate lobes longer than the tube; corolla about $1 \mathrm{~cm}$. long, rose-purple, the nearly orbicular standard erect; pod 3-5 cm. long, 7-10 mm. wide, appressed-pubescent.

Scrub-lands and thickets, Rum Cay, Conception Island, Watling's, Crooked, Acklin's, Fortune, Grand Turk and Inagua :- Endemic. Recorded by Hitchcock as Galactia galactioides (Griseb.) Hitche. BAHAMA MILK-PEA.

5. Galactia uniflòra Urban, Symb. Ant. 2: 325. 1900.

Slender, twining, somewhat woody below, densely whitish pubescent, sometimes $1 \mathrm{~m}$. long. Stipules narrowly lanceolate, acuminate, about $2 \mathrm{~mm}$. long; 
petioles slendèr, pubescent, 5-17 $\mathrm{mm}$. long; leaflets 3 , chartaceous, $1-4 \mathrm{~cm}$. long, narrowly oblong to oblong-obovate, reticulate-veined, rounded or emarginate at the apex, narrowed at the base, sparingly pubescent or glabrous above, densely appressed-pubescent beneath, the terminal one with a petiolule $2-5 \mathrm{~mm}$. long, the lateral ones nearly sessile; inflorescence 1-2-flowered, shorter than the leaves; pedicels $2-4 \mathrm{~mm}$. long; calyx about $6 \mathrm{~mm}$. long, its teeth longer than the tube; corolla pink; standard obovate, 9-10 $\mathrm{mm}$. long, short-clawed; pod linear, 3-4 cm. long, 4-5 $\mathrm{mm}$. wide, densely pubescent.

Scrub-lands, New Providence, Eleuthera, Calcos, Grand Turk and Inagua :Endemic. Recorded by Hitchcock as Galactia angustifolia Kth. and as Galactia tenuiflora (Willd.) W. \& A. ONE-FLOWERED MILK-PDA.

\section{CANAVÀII Adans. Fam. Pl. 2: 325. 1763.}

Perennial herbs, with prostrate or twining stems. Leaves pinnately 3foliolate; leaflets chartaceous or thick. Flowers large, in axillary peduncled racemes. Calyx 2-lipped, the upper lip truncate or 2-lobed, the lower one entire or 3-lobed. Standard reflexed, suborbicular; wings curved or twisted; keelpetals incurved, broader than the wings, obtuse or with an inflexed or spiral beak. Stamens diadelphous (9 and 1 ) or monadelphous to the middle. Style glabrous, incurved. Ovules several. Pod flat or slightly swollen, oblong or broadly linear, 2-valved. Seeds white, red or krown. [Aboriginal name in the South Sea Islands.] About 15 species, natives of tropical regions. Type species: Dolichos ensiformis L.

Leaflets fleshy, obtuse.

Leaflets chartaceous, acute or acutish.

Leaflets ovate. $8-15 \mathrm{~cm}$. long.

Leaflets oblong to oblong-lanceolate, $4-7 \mathrm{~cm}$. long.
1. C. lineata.

2. C. gladiata.

3. C. bahamensis.

1. Canavali lineata (Thunb.) DC. Prodr. 2: 404. 1825.

Dolichos lineatus Thunb. Fl. Jap. 280. 1784.

Dolichos obtusifolius Lam. Encyc. 2: 295. 1786.

Canavalia obtusifolia DC. Prodr. 2: 404. 1825.

Foliage finely strigillose. Stems prostrate or climbing, 1-5 m. long, branching; leaflets leathery, suborbicular to oval or obovate, 4-10 $\mathrm{cm}$. long, obtuse at the apex, rounded or broadly cuneate at the base; racemes surpassing the subtending leaves; peduncles often longer than the racemes; pedicels spur-like; calyx helmet-like, 14-17 mm. long, constricted at the base; corolla pink; pods broadly linear, 10-12 cm. long; seeds oblong, brown.

Coastal sands, rocks and thickets, throughout the islands from Abaco and Great Bahama to Watling's, Inagua and the Anguilla Isles:-Bermuda; Florida to Texas, Mexico and contlnental troplcal South America; West Indies; Old World tropics. BAY-BEAN. HORSE-BEAN.

\section{Canavali gladiàta (Savi) DC. Prodr. 2: 404. 1825.}

Malocchia gladiata Savi, Nuov. Giorn. Pisa 8: 116. 1824.

Climbing or trailing, sometimes $10 \mathrm{~m}$. lcng or longer, glabrous, or when young finely pubescent. Leaflets thin, ovate or oblong-ovate, 5-12 cm. long, acute or short-acuminate at the apex, obtuse at the base; racemes severalmany-flowered, mostly longer than the leaves; pedicels short, thick, $5 \mathrm{~mm}$. long or less; calyx 1-1.5 cm. long; corolla white to purple, longer than the calyx; pod broadly linear, flat, 1-2.5 dm. long, about $2 \mathrm{~cm}$. wide; seeds oblong.

Waste places spontaneous after cultivation, New Providence, and Inagua :native of the East Indies, spontaneous after cultivation in tropical America. A specimen from Nassau referied to this by Hitchcock proves to be Dolichos Lablab L. HORSE-BEAN. 
3. Canavali bahaménsis Britton, Bull. N. Y. Bot. Gard. 4: 119. 1905.

A long vine. Leaflets thin, oblong-lanceolate to ovate-oblong, 5-8 cm. long, firm, glabrous, faintly veined, narrowed or obtuse at the base but not cordate, the apex bluntly acute; racemes stout-peduncled, slightly pubescent, longer than the leaves, nodose, pendent, 5-8 $\mathrm{cm}$. long; pedicels curved, erect, $2-4 \mathrm{~mm}$. long; bractlets at base of calyx oricular, $1 \mathrm{~mm}$. broad, lacerate; calyx very oblique, 6-8 $\mathrm{mm}$. long, with one small acute tooth opposite the keel-petals, the much larger upper lip with three short broad teeth; corolla about twice as long as the calyx, the standard purple, the wings and strongly curved keel pink; legume linear-oblong, compressed, about $12 \mathrm{~cm}$. long, $3 \mathrm{~cm}$. wide, 1-1.5 cm. thick, short-pointed, narrowed at the base, not constricted, the stout stipe 1-2 cm. long, the valves rather membranous; seeds oval, $1.5 \mathrm{~cm}$. long, $1 \mathrm{~cm}$. thick, redbrown, shining.

Climbing over coastal shrubs, and in coppices, Abaco, Andros and Eleuthera :Endemic. BAHAMA BAY-BEAN.

\section{CÁJAN Adans. Fam. Pl. 2: 326. 1763.}

A perennial stiff, slightly woody herb, finely puberulent or pubescent, with pinnately 3-foliolate leaves, and showy yellow flowers in stalked axillary racemes. Calyx narrowly campanulate, its lobes acute, the 2 upper ones partly united. Standard nearly orbicular, reflexed; wings obliquely obovate; keel with a blunt incurved tip. Ovary many-ovuled; style thickened above; stigma oblique. Pod linear, flattened, acute and long-tipped, its valves impressed between the seeds. [From the Malayan name.] A monotypic genus.

1. Cajan Cájan (L.) Millsp. Field Mus. Bot. 2: 53.1900.

Cytisus Cajan L. Sp. Pl. 739. 1753.

Cajanus indicus Spr. Syst. 3: '248. 1826.

Bushy, branched, $2 \mathrm{~m}$. high or less. Leaves petioled; leaflets oblong or oblong-lanceolate, $2.5-8 \mathrm{~cm}$. long, acute at both ends or obtuse at the base, velvety on both sides, dark green above, pale beneath; racemes few-flowered, as long as the leaves or longer; pedicels, rachis and calyx brown-pubescent; flowers 12-16 mm. broad; pods 5-8 cm. long, 10-12 mm. wide, 4-7-seeded; seeds whitish, somewhat flattened, about $4 \mathrm{~mm}$. thick,

Waste and cultivated solls, spontaneous after cultivation, throughout the islands from Andros and New Providence to Mariguana :-Native of the Old World tropics; widely spontaneous in all American tropical regions. PIgeoN Pea.

\section{DoLÍchoLUs Medic. Vorles. Chur. Phys. Ges. 2: 354. 1787.}

\section{[RHYNCHOSIA Lour.]}

Perennial twining trailing or erect herbs, with pinnately 1-3-foliolate leaves, and yellow, mostly axillary and racemose flowers. Leaflets generally punctate with resinous dots, not stipellate. Calyx 4-5-lobed, somewhat 2-lipped; standard obovate or orbicular, spreading or reflexed; wings narrow; keel incurved at the apex or falcate; stamens diadelphous (9 and 1). Ovary nearly sessile; ovules 2 , rarely 1 ; style filiform. Pod flat, oblong or obliquely orbicular, 2-valved, 1-2-seeded. [Greek, diminutive of Dolichos.] About 200 species, natives of warm and temperate regions. Type species: Dolichos minimus L.

Leaves prominently reticulate-veined beneath; long vine. Leaves not prominently reticulate-veined; small vines.

Leaflets acuminate; pods $3-4 \mathrm{~cm}$. long; seeds red.

Leaflets obtuse or acutish; pods $1-2 \mathrm{~cm}$. long; seeds ollve.
1. D. reticulatus.

2. D. Swartzii.
3. D. minimus. 
1. Dolicholus reticulàtus (Sw.) Millsp. Field Mus. Bot. 2: 53. 1900.

Glycine reticulata Sw. Prodr. 105. 1788.

Rhynchosia reticulata DC. Prodr. 2: 385. 1825.

A pubescent or tomentose twining or trailing vine often $5 \mathrm{~m}$. long. Leaves petioled, 3-foliolate; leaflets ovate to ovate-lanceolate or ovate-elliptic, 5-10 $\mathrm{cm}$. long, reticulate-veined, acuminate, acute or obtuse at the apex, obtuse or rounded at the base, the terminal one long-stalked, the lateral ones nearly sessile; racemes several-many-flowered, shorter than the leaves; pedicels very short; calyx 7-12 $\mathrm{mm}$. long, deeply 4-cleft, the lobes lanceolate, acuminate; corolla yellow, a little longer than the calyx-lobes; pod flat, lunate, 2-2.5 cm. long, 6-9 $\mathrm{mm}$. wide; seeds nearly black.

Scrub-lands, Watling's Island between Graham's Harbor and Cockburn Town :Cuba to Virgin Gorda and Grenada; continental tropical America. NET-veINED DOLICHOLUS.

Leaflets less densely reticulate-veined than in plants from some other West Indian islands, the apex obtuse.

2. Dolicholus Swártzii Vail, Bull. Torr. Club 26: 108. 1899.

Rhynchosia Gundlachii Urban, Symb. Ant. 5: 374. 1908.

Rhynchosia caribaea Chapm. F. S. U. S. 104. 1860. Not Glycine caribaea Jacq. 1786.

A pubescent, resinous-dotted, somewhat woody, trailing or twining vine 0.5-1.5 m. long, the stems slender, little branched except at the base. Stipules narrowly lanceolate, about $4 \mathrm{~mm}$. long, deciduous; petioles 1-3 $\mathrm{cm}$. long; leaflets 3 , rhombic-ovate, membranous, acuminate at the apex, obtuse or subtruncate at the base, pubescent on both sides; the terminal one slender-stalked, 4-6 cm. long, the lateral ones short-stalked, smaller, inequilateral; racemes fewflowered, mostly shorter than the petioles or little longer; pedicels $2-4 \mathrm{~mm}$. long; calyx about $3 \mathrm{~mm}$. long, its lobes shorter than the tube; corolla yellow, the standard obovate, about $8 \mathrm{~mm}$. long; pod falcate, 2-4 cm. long, 5-7 mm. wide, acute, pubescent; seeds red, 5-6 mm. long.

Coppices, Great Bahama, New Providence, Cat Island. Crooked Island:-Florida; Cuba. Swartz's Dolicholus. Bonaner-BEan.

3. Dolicholus minimus (L.) Medic. Vorles. Chur. Phys. Ges. 2: 354. 1787.

Dolichos minimus L. Sp. Pl. 726. 1753.

Rhynchosia minima DC. Prodr. 2: 385. 1825.

A slender, puberulent or pubescent, resinous-dotted, more or less branched vine, 3-12 dm. long, trailing or twining. Stipules subulate, about $2 \mathrm{~mm}$. long, caducous; petioles very slender, 1-4 cm. long; leaflets 3 , rhombic-ovate or rhombic-orbicular, obtuse or acute at the apex, obtuse at the base, the terminal one slender-stalked, 1-3 cm. long, the lateral ones short-stalked, smaller or as large, inequilateral; racemes slender, several-flowered, mostly as long as the leaves or longer; pedicels very short; calyx 2-3 mm. long, its lobes lanceolatesubulate; corolla yellow; standard orbicular-obovate, retuse, 5-6 mm. long; pods falcate, 10-17 $\mathrm{mm}$. long, about $4 \mathrm{~mm}$. wide, puberulent; seeds brown, mottled.

Waste grounds and pine-lands, Abaco, Andros, New Providence, Eleuthera, Cat Island, Acklin's Island, Fortune Island, North Caicos and Inagua:-South Carolina to Florida and Texas; throughout the West Indies and tropical and warm temperate continental America; Old World tropics. SMALL Dolicholus.

\section{PHASEOUUS L. Sp. P1. 723. 1753.}

Vines, rarely erect herbs, with pinnately 3 -foliolate leaves, and axillary racemose flowers. Calyx 5-toothed or 5-lobed, or the 2 upper teeth more or less united. Standard orbicular, recurved, spreading or somewhat contorted; wings 
mainly obovate; keel spirally coiled, linear or obovoid. Stamens diadelphous (9 and 1). Style longitudinally bearded; stigma oblique or lateral; ovary sessile or nearly so; ovules $\infty$. Pod various, 2-valved, several-seeded, tipped with the persistent style. Seeds mostly with rounded ends. Rachis thickened at the bases of the pedicels. [Ancient name of the Kidney bean.] About 170 species, of warm and temperate regions. Type species: Phaseolus vulgaris $\mathrm{L}$.

Erect; herbaceous; flowers red or purple. Climbing vine; flowers white.
1. P. lathyroides.

2. P. lunatus.

1. Phaseolus lathyroìdes L. Sp. Pl. ed. 2, 1018. 1763.

Phaseolus semierectus L. Mant. 1: 100. 1767.

Herbaceous, erect, simple or somewhat branched, silky pubescent or glabrate, 3-6 dm. high. Stipules narrowly lanceolate, acuminate, $1.5 \mathrm{~cm}$. long or less; petioles slender; leaflets various, membranous, ovate to lanceolate or linear-lanceolate, 2-6 cm. long, acute, obtuse or acuminate at the apex, acute or obtuse at the base; racemes elongated, several-many-flowered, 1-3 dm. long in fruit; pedicels very short; calyx 4-5 mm. long, its upper teeth ovate, the lower lanceolate, acuminate; corolla red or purple; standard 12-15 mm. long; pods narrowly linear, straight or a little curved, reflexed-spreading, 7-12 cm. long, about $3 \mathrm{~mm}$. thick.

Waste places and molst solls in open places, Andros, New Providence, Acklin's, East Caicos and Inagua :- West Indies; continental tropical America; Old World tropics. WILD BusH BEAN.

\section{Phaseolus lunàtus L. Sp. Pl: 724. 1753.}

A usually annual, herbaceous, sparingly pubescent vine up to $3 \mathrm{~m}$. long or longer, twining or trailing. Leaves 3 -foliolate, petioled; leaflets ovate, ovatelanceolate or rhombic-ovate, thin in texture, 4-7 cm. long, acute at the apex, obtuse or subtruncate at the base, the terminal one long-stalked, equilateral, the others short-stalked, inequilateral; racemes peduncled, about as long as the leaves, sometimes longer, several-many-flowered; pedicels slender, mostly less than $1 \mathrm{~cm}$. long; calyx about $3 \mathrm{~mm}$. long, its teeth short, ovate; bractlets oblong, about one-half as long as the calyx; corolla greenish white, the standard about $7 \mathrm{~mm}$. broad; pod flat, subfalcate, $3-7 \mathrm{~cm}$. long, 1-1.5 $\mathrm{cm}$. wide (larger in cultivated races); seeds oblong or subquadrate, flattened.

In a coppice near Staniard Creek, Andros, spontaneous after cultivation:West Indies; continental tropical America. LIMA BEAN.

\section{DóLICHOS L. Sp. Pl. 725. 1753.}

Climbing or trailing vines, with 3-foliolate stipellate leaves, and white to purple flowers variously clustered or sometimes solitary, their bracts small or caducous. Calyx eampanulate, its two upper teeth united. Standard suborbicular; wings obovate, curved, adnate to the incurved keel. Stamens 9 and 1 , their anthers all alike. Ovary several-many-ovuled; style bearded or penicillate below the terminal stigma. Pod flat, mostly somewhat curved, beaked. Seeds subglobose or flattened. [Greek name of some bean, referring to its long pods.] About 30 species, of tropical distribution. Type species: Dolichos Lablab L.

Pods serrulate on the margins; seeds somewhat compressed; style not penicillate.

Pods entire on the margins; seeds globular; style penicllate.

1. D. Lablab.

2. D. insularis. 
1. Dolichos Làblab L. Sp. Pl. 725. 1753.

Sparingly pubescent, climbing or trailing, $5 \mathrm{~m}$. long or less. Leaves longpetioled. Leaflets ovate, acute or acuminate, 4-10 $\mathrm{cm}$. long, the terminal one equilateral and long-stalked, the others inequilateral and short-stalked; racemes axillary, several-flowered, longer than the leaves; flowers short-pedicelled, 1.5$2 \mathrm{~cm}$. broad, white to purple; pods about $7.5 \mathrm{~cm}$. long, nearly $2.5 \mathrm{~cm}$. wide, the upper edge nearly straight, the lower curved and glandular-serrulate; seeds somewhat compressed, black with a white linear strophiole, about $1 \mathrm{~cm}$. long.

Spontaneous after cultivation. New.Providence and Eleuthera. Native of the old World tropics. Widely planted and spontaneous in tropical America. BLAcK BEAN.

\section{Dolichos insulàris Britton sp. nov.}

Nearly glabrous, climbing or trailing, up to $7 \mathrm{~m}$. long or longer. Leaflets ovate, thin, 4-7 cm. long, acute, obtuse or acuminate, sparingly pubescent near the base beneath, the terminal one equilateral, rather long-stalked, the lateral ones inequilateral, short-stalked; racemes axillary, thyrsoid, many-flowered, stout-peduncled, longer than the leaves; pedicels pubescent, 4-6 $\mathrm{mm}$. long; bractlets obtuse, $2 \mathrm{~mm}$. long; calyx unequally 5-lobed, about $7 \mathrm{~mm}$. long, the lobes rounded; corolla purplish; standard wider than long, about $1 \mathrm{~cm}$. long, nearly sessile, emarginate; wings ovate, obtuse, stalked, about $11 \mathrm{~mm}$. long, keel obliquely curved, stalked, acuminate, about $9 \mathrm{~mm}$. long; ovary puberulent; style penicillate; pods elliptic-obovate, 2-3-seeded, compressed, 5-7 $\mathrm{cm}$. long, about $3 \mathrm{~cm}$. wide, rather stout-beaked, the valves yellowish puberulent, entire-margined; seed globular, about $1 \mathrm{~cm}$. in diameter, black, with a white linear strophiole.

Old field, Great Cistern, Abaco:-Cuba; Mexico. Type from Cayo Ballenato Grande, Cuba (Shafer 1026). IsLAND BEAN.

\section{VÍGNA Savi, Mem. Phas. 3: 7. 1826.}

Herbaceous vines, or sometimes erect herbs, with pinnately 3 -foliolate stipulate leaves, the leaflets broad. Flowers clustered at the ends of long axillary peduncles, yellowish or purplish, the rachis of the head or raceme knotty, the bracts and bractlets early deciduous. Calyx 5-toothed, or the 2 upper teeth united. Standard nearly orbicular, auricled at the base; wings shorter than the standard; keel about equalling the standard, slightly incurved. Stamens diadelphous (9 and 1). Ovary sessile; ovules numerous; style bearded along the inner side; stigma oblique. Pod linear, nearly terete, 2-valved. [In honor of Domenico Vigna, a commentator on Theophrastus.] About 30 species, natives of warm and tropical regions. Type species: Dolichos luteolus Jacq.

1. Vigna rèpens (L.) Kuntze, Rev. Gen. Pl. 212. 1891.

Dolichos repens L. Syst. ed. 10: 1163. 1759.

Dolichos luteolus Jacq. Hort. Vind. 1: 39. 1770.

Vigna luteola Benth. in Mart. Fl. Bras. 151: 194. 1859.

Foliage usually pubescent with appressed hairs. Stems trailing or climbing, branching, when pubescent the hairs reflexed; leaflets 3 , ovate to lanceolate or linear, $2-8 \mathrm{~cm}$. long, acute, more or less distinctly reticulated, short-stalked; petioles usually longer than the leaflets; peduncles surpassing the leaves, retrorsely pubescent at the top; pedicels 1-3 mm. long, corymbose; calyx campanulate, oblique, its lobes triangular to lanceolate; corolla yellowish brown; standard nearly reniform, notched, less than $2 \mathrm{~cm}$. long; pods linear, 4-5 $\mathrm{mm}$. long, nearly terete, pubescent.

Moist roadsides, Abaco and Andros:-Bermuda; Florida to Texas ; Mexico to Panama and throughout South America to Argentina; West Indies; Old World tropics. YeLLOW VIGNA. 
Brya Ebenus (L.) DC. referred to by Dolley has not been returned from the islands by any of our expeditions. It is native of Jamaica and Cuba. The record probably applies to Pera bumeliaefolia, locally called Black Ebony.

Erythrina corallodéndron L. Recorded for the Bahamas by Catesby, by Dolley and by Mrs. Northrop is known to us only as planted on New Providence. Catesby, 2: $p l .49$.

Erythrina velutina Willd. was observed planted at West End, Great Bahama.

Foliage of a species of Lonchocarpus was collected from a tree growing near an old house at Deep Creek, Andros.

\section{Order 13. GERANIÀLES.}

Herbs, shrubs or trees, usually with petals, and these separate (wanting in most Euphorbiaceae, and in some species of Zanthoxylum in Rutaceae); sepals mostly distinct; stamens few, rarely more than twice as many as the sepals, opposite them when as many; ovary superior, mostly compound; ovules pendulous, the raphe toward the axis of the ovary.

Petals present, usually as many as the sepals.

Flowers regular or very nearly so.

Tissues of the plant devoid of secreting cells or glands.

- Filaments united below or at the base.

Stamens twice as many as the sepals. Petals unappendaged; leaves compound.

Petals appendaged; leaves simple. Stamens as many as the sepals. Fllaments separate.

Styles united; leaves mostly compound. Styles separate; leaves simple.

Tissues of the plant with secreting cells or glands.

Leaves punctate.

Leaves not punctate.

Carpels separate.

Carpels united.

Fllaments separate.

Trees or shrubs with bltter, ollbearing bark.

Resiniferous trees and shrubs.

Filaments united.

Flowers very irregular; petals 3 ; stamens mostly 8.

Flowers often apetalous, monoecious; carpels mostiy 3.

Fam. 1. Oxalidaceat.

Fam. 2. ERYTHRoxylaceae.

Fam. 3. LINACEAE.

Fam. 4. ZyGOPHYLIACEAT.

Fam. 5. Malpighiaceae.

Fam. 6. Retaceae.

Fam. 7. Surianaceae.

Fam. 8. Simaroubaceae.

Fam. 9. BURSERACEAE.

Fam. 10. MeliaCEAE.

Fam. 11. Polygallaceae.

Fam. 12. EuphorbiaceaE.

\section{Family 1. OXALIDACEAE Lindl.}

\section{WOOD-SORREL FAMILY.}

Leafy-stemmed or acaulescent herbs, or rarely shrubs, often with rootstocks, or sealy bulbs, the sap sour. Leaves mostly palmately 3 -foliolate, in some tropical species pinnate, or entire and peltate; stipules commonly present as scarious expansions of the petiole-bases; leaflets mostly obcordate. Flowers perfect, in umbel-like or forking cymes, or sometimes solitary; peduncles mostly long. Sepals 5, often unequal. Petals 5, white, pink, purple or yellow. Stamens 10-15, sometimes unequal. Ovary 5celled, 5-lobed; styles coherent or distinct; ovules 2-many in each cavity; fruit a loculieidal globose or columnar capsule, rarely baccate. Embryo 
straight, in fleshy endosperm. About 15 genera and over 300 species, chiefly of tropical distribution.

Plants acaulescent, with coated bulbs; flowers not yellow.

Plants caulescent, with rootstocks; flowers mostly yellow.

1. Ionoxalis.

2. Xanthoxalis.

\section{IONÓXALIS Small, Fl. SE. U. S. 665. 1903.}

Low, perennial acaulescent herbs the leaves and scapes arising from coated scaly bulbs, the petioles long, the blades palmately 3 -several-foliolate, the violet, blue or white flowers in umbel-like cymes. Sepals 5, bearing apical tubercles in pairs. Petals 5. Stamens 10, the filaments united at the base. Ovary elongated; styles distinct. Capsules narrow, erect. [Greek, purple Oxalis.] Over 100 species natives of America. Type species: Oxalis violacea $\mathrm{L}$.

1. Ionoxalis intermèdia (A. Rich.) Small, N. A. Fl. 25: 43. 1907.

Oxalis intermedia A. Rich. Ess. Fl. Cub. 315. 1845.

Scape 1-3 dm. high, sparingly pubescent, slender, as long as the leaves or longer. Petioles sparingly pubescent; leaflets 3 , obdeltoid, $2-6 \mathrm{~cm}$. wide, bright green and glabrous above, paler and somewhat pubescent beneath, 2-lobed, the lobes ovate; cymes 4-13-flowered; pedicels glabrous, 1-2 cm. long; sepals 4-5 $\mathrm{mm}$. long, bearing 1 pair of apical tubercles; petals violet, 11-14 $\mathrm{mm}$. long; shorter filaments slightly. pubescent, the longer ones copiously pubescent.

Waste and cultivated lands, New Providence, at Nassau :-Cuba; Virgin Islands ; Guadaloupe; Martinique. CCBAN PURPLE WOOD-SORReL.

\section{XANTHóXALIS Small, Fl. SE. U. S. 666. 1903.}

Caulescent, annual or perennial herbs, rarely shrubs, with alternate, longpetioled, 3 -foliolate leaves, the leaflets sessile, notched or obcordate, the yellow flowers in peduncled cymes. Sepals 5. Petals 5. Stamens 10, the filaments united into a tube at the base. Ovary oblong to linear; styles filiform or subulate. Capsule oblong or columnar, usually narrowed to the summit, erect. Seeds transversely ridged or tubercled. [Greek, yellow Oxalis.] About 50 species, widely distributed. Type species: Oxalis corniculata L.

1. Xanthoxalis corniculàta (L.) Small, Fl. SE. U. S. 667. 1903.

Oxalis corniculata L. Sp. Pl. 435. 1753.

Pubescent or nearly glabrous, annual or perennial, deep-green, freely branching from the base; stem 2.5-15 $\mathrm{cm}$. long, the branches diffuse, mainly procumbent and often ereeping. Leaflets $8-12 \mathrm{~mm}$. wide; petioles dilated at the base into oblong rounded or truncate stipules; peduncles 1-3-flowered; flowers $5-10 \mathrm{~mm}$. wide; pedicels strigillose, more or less reflexed; capsule oblong, 1-1.8 cm. long, appressed-pubescent; seeds compressed, transversely ridged.

Waste and cultivated lands, New Providence at Nassau and Grant's Town :widely distributed in temperate and tropical reglons of both hemispheres. Referred by Mrs. Northrop to Oxalis corniculata repens Zucc. Yellow Procumbent WOOD-SORREL. 


\title{
Family 2. ERYTHROXYLÄCEAE A. Rich.
}

\author{
Coca FAMILY.
}

Glabrous trees or shrubs, with mostly alternate simple stipulate entire-margined, petioled leaves and small, often heterostylous, pedicelled flowers solitary or fascicled in the axils, the pedicels bracted at the base. Calyx persistent, mostly 5-cleft. Petals as many as the calyx-lobes, appendaged by a 2-lobed ligule within. Stamens 10, in 2 series, their filaments united below into a tube. Ovary 3-celled, rarely 4-celled; ovules 1 , rarely 2 , in each cavity, pendulous; styles 3 , rarely 4 ; stigmas capitellate. Fruit a drupe, usually 1-celled and 1-seeded. Seed-coat thin; endosperm farinaceous; embryo straight. Only the following genus and the African Aneulophus.

1. ERYTHRÓXYLON L. Syst. ed. 10, 1035. 1759.

Leaves alternate. Petals short-clawed. [Greek red-wood.] About 200 species of tropical and subtropical distribution. Type species: Erythroxylon areolatum $\mathrm{L}$.

Leaves $0.5-2.5 \mathrm{~cm}$. long, pale beneath.

Leaves $3 \mathrm{~cm}$. long, or longer.

Leaves conspicuously areolate beneath.

Flowering pedicels as long as the petioles, or shorter; leaves $\mathbf{5}-\mathbf{1 3} \mathrm{cm}$. long.

Flowering pedicels, or some of them, much longer than the petioles; leaves $3-4 \mathrm{~cm}$. long.

Leaves not areolate beneath, or only very faintly areolate, obovate, 3-7 cm. long.

1. E. rotundifolium.

2. E. areolatum.

3. E. reticulatum.

4. E. confusum.

1. Erythroxylon rotundifòlium Lunan, Hort. Jam. 2: 116. 1814.

Erythroxylon obovatum Macf. Fl. Jam. 1: 143. 1837.

Erythroxylon suave O. E. Schulz, in Urban, Symb. Ant. 5: 197. 1907.

Erythroxylon suave aneurum O. E. Schulz, loc. eit. 199. 1907.

A shrub or a small tree up to $7 \mathrm{~m}$. high, with slender flexible branches, the bark smooth. Leaves obovate to oblong-obovate or elliptic, firm in texture, 0.5-3 cm. long, obtuse or emarginate, dark green above, pale beneath, inconspicuously reticulate-veined, the petioles $2.5-5 \mathrm{~mm}$. long; stipules ovate or ovate-lanceolate, acute or acuminate, 1-1.5 mm. long; flowers 1-4 in the axils; pedicels mostly as long as the petioles or longer; calyx cleft to about the middle, about $1 \mathrm{~mm}$. long, its lobes triangular-ovate, acute; petals white, oblong, 1.5-2.5 mm. long, obtuse, the ligule about one-third as long as the blade, its lobes irregularly toothed; drupes oblong, red, obtuse, 4-6 $\mathrm{mm}$. long.

Rocky plains, pine-lands and coppices, throughout the archipelago from Abaco and Great Bahama to Andros, North Caicos, Grand Turk and Inagua :-Cuba to Porto Rico; Jamaica. Consists of several races differing in size, shape and thickness of the leaves. Referred by Hitchcock, Coker, Dolley, and by Mrs. Northrop to $E$. brevipes DC.; formerly referred by O. E. Schulz to E. spinescens A. Rich. Round-LeAVED ERYTHROXYION. RAT-WOOD.

\section{Erythroxylon areolàtum L. Syst. ed. 10, 1035.1759.}

A shrub or a small tree up to $6 \mathrm{~m}$. high. Leaves oblong to obovate, rather thin, 5-13 cm. long, 3-5.5 $\mathrm{cm}$. wide, obtuse or emarginate at the apex, narrowed at the base, dark dull-green above, pale beneath and areolate by two lines parallel with the prominent midvein, the petioles 4-6 $\mathrm{mm}$. long; stipules triangular, acute, about $2 \mathrm{~mm}$. long; pedicels fascicled, as long as the petioles or shorter; flowers appearing with the leaves of the season, or before them, fra- 
grant; calyx cleft to about the middle, nearly $2 \mathrm{~mm}$. long, its triangular-ovate lobes acute; petals white or yellowish white, oblong, obtuse, $2-3 \mathrm{~mm}$. long, the ligule about one-fourth as long as the blade; drupes red, oblong, 6-9 mm. long.

Copplces, thickets and scrub-lands, Andros, Mangrove Cay, Eleuthera, Cat Isiand, Watling's and Long Islands :-Cuba to Porto Rico; Jamaica; Colombia. THIN-LEAVED ERYTHROXYLON.

3. Erythroxylon reticulàtum Northrop, Mem. Torr. Club 12: 43, pl. 8. 1902.

A tall shrub, with slender, reddish brown branches. Leaves oblong-oblanceolate to obovate, rather firm in texture, $3-4 \mathrm{~cm}$. long, obtuse or retuse at the apex with the midvein slightly excurrent, cuntate-narrowed at the base, finely and distinctly reticulate-veined, dark-green above, pale and prominently areolate beneath, the petioles $2-3 \mathrm{~mm}$. long; stipules triangular, acuminate, $2 \mathrm{~mm}$. long; flowers solitary or 2 or 3 together in the axils; pedicels slender, 5-8 mm. long, thickened above; calyx about $2 \mathrm{~mm}$. long, its ovate-lanceolate lobes acute; petals oblong, white, $3-3.5 \mathrm{~mm}$. long, the ligule-lobes contorted; young drupes oblong, purplish black, pointed, $5 \mathrm{~mm}$. Jong.

White-lands and coppices, Andros at Deep Creek and near Conch Sound:Endemic. Bahama ERYthroxylon.

\section{Erythroxylon confùsum Britton.}

?Erythroxylon affine A. Rich. in Sagra, Hist. Cub. 10: 106. 1845. Not St. Hil. 1829.

Erythroxylon obovatum Griseb. Fl. Br. W. I. 113. 1859. Nat Macf. 1837.

A tree, 4-8 m. high, with a trunk-diameter of $1 \mathrm{dm}$. or more, the pale bark fissured. Leaves obovate or oblong-obovate, rather firm in texture, 3-7 cm. long, $3 \mathrm{~cm}$. wide or less, rounded or emarginate at the apex, narrowed or cuneate at the base, dull-green above, pale-green beneath, not areolate, or but faintly so, not prominently reticulate-veined, the petioles $4-9 \mathrm{~mm}$. long; stipules lanceolate, $2-4 \mathrm{~mm}$. long; pedicels fascicled in the axils, or some of them solitary, shorter than the petioles; calyx about $2 \mathrm{~mm}$. long, cleft to about the middle, the ovate-lanceolate lobes acute; petals oblong, obtuse, about $3 \mathrm{~mm}$. long, the ligule about one-third as long as the blade, its lobes acute; drupes sblong, red, somewhat longer than the pedicels.

Rocky coppices, scrub-lands and palmetto-lands, Andros, Mangrove Cay, New Providence and Great Exuma:-Cuba; Jamaica. OBovate-Leaved ErytiroxyloN.

\section{Family 3. LINÀCEAE Dumort.}

\section{Flax Family.}

Herbs or shrubs, with perfect regular nearly symmetrical flowers. Stipules mostly small or none. Sepals 5, rarely 4, imbricated, persistent. Petals of the same number and alternate with the sepals, imbricated, generally contorted. Stamens of the same number, alternate with the petals; filaments monadelphous at the base; anthers versatile, 2-celled. Ovary 2-5-celled, or by false septa 4-10-celled. Ovules anatropous. Styles 2-5. Fruit mainly capsular. Seeds 1 or 2 in each cavity, oily; endosperm little or none; embryo straight; cotyledons flat. About 14 genera and about 160 species of wide distribution.

1. CATHARTOLINUM Rehb. Handb. 307. 1837.

Annual or perennial, branched herbs. Leaves alternate or occasionally opposite, without stipules but sometimes with stipular glands, entire or serru- 
late, sometimes ciliate or glandular-margined. Sepals 5, all, or only the inner ones, with gland-tipped teeth. Petals 5, yellow or white, unappendaged but sometimes pubescent within. Stamens 5 ; filaments united at the base, the free portions dilated at the base, without staminodia, or with a short staminodium in each sinus. Gynoecium 5-carpellary, or rarely 2-carpellary; styles filiform, distinct or united; stigmas distinct, capitate. Capsule 5-celled, or rarely 2-celled and with firm septa, or completely or incompletely 10-celled by false septa, the carpels not ribbed on the back. Seeds flattened, often lunate. [Greek, referring to the medicinal qualities of some of the species.] About 70 species of wide geographic distribution. Type species: Linum catharticum L.

Staminodia wanting.

Staminodia present.

Androecium pubescent or ciliate.

Stem and leaves pubescent; annual.

Stem and leaves glabrous.

Staminodia lanceolate; capsules ovoid; perennial.

Staminodia deltoid; capsules spheroidal ; annual.

Androecium glabrous; leaves cillate; perennial.

1. C. Curtissii.

2. C. corallicola.

3. C. bahamense.

4. C. Bracei.

5. C. lignosum.

1. Cathartolinum Curtíssii Small, N. A. Fl. 25: 72.1907.

Linum Curtissii Small, Bull. N. Y. Bot. Gard. 3: 424. 1905.

Annual; glabrous; stems solitary, $5 \mathrm{dm}$. high or less, simple or corymbosely branched above. Leaves thickish, erect or ascending, the lower opposite or alternate, oblanceolate or spatulate, $1.5 \mathrm{~cm}$. long or less, the upper all alternate, linear, acute or acuminate; bracts entire; outer sepals ovate, acute or acuminate, 2.5-3 mm. long, usually with a few glardular teeth; inner sepals ovate, rather broader than the outer, copiously glandular-toothed; petals yellow; staminodia none; capsules subglobose, about $2.5 \mathrm{~mm}$. thick.

Borders of brackish marshes and in palmetto-lands, New Providence :-Florida. CURTISS' FLAX.

\section{Cathartolinum corallícola Small, N. A. Fl. 25: 74. 1907.}

Annual; stem sparingly branched above, minutely hirsute, 2-4 dm. high. Leaves oblong to linear, 6-12 mm. long, alternate or the lower opposite, distant, rather thin, acute or acuminate, finely pubescent, glandular-ciliate; bracts lanceolate to subulate, closely glandular-ciliate; outer sepals oblong-ovate, 5 $\mathrm{mm}$. long, glandular-toothed, pubescent, the inner similar, slightly broader and shorter; filaments pubescent below the middle; staminodia deltoid, ciliate; petals yellow; styles distinct; eapsules ovoid, about $2 \mathrm{~mm}$. long, much shorter than the sepals.

Rocky pine-barrens, Andros, at Mastic Point. Endemic. RocK FlAx.

3. Cathartolinum bahaménse (Northrop) Small, N. A. Fl. 25: 75. 1907.

Linum bahamense Northrop, Mem. Torr. Club 12: 42. 1902.

Perennial, glabrous and glaucous; stems ridged, corymbosely branched above, $6 \mathrm{dm}$. high or less, the branches ascending. Leaves approximate, erect or ascending, linear to linear-lanceolate, thick, 5-12 mm. long, acute, pale green on both sides; bracts lanceolate to subulate, glandular-toothed; outer sepals ovate, 3-3.5 mm. long, acute or acuminate, glandular-toothed, the inner similar, acuminate, slightly shorter; petals yellow; filaments pubescent below the middle; staminodia lanceolate, ciliate; styles distinct; capsules ovoid, about $2 \mathrm{~mm}$. long.

White-lands, pine-lands and borders of marshes, Abaco, Andros, New Providence and Eleuthera. Endemic. Recorded by Dolley as Linum virginicum L. BAHAMA FLAX. 


\section{Cathartolinum Bràcei Small, N. A. Fl. 25: 75. 1907.}

Annual, pale green or glaucescent, glabrous; stem corymbosely branched above, $1.5-3.5 \mathrm{dm}$. high, somewhat striate, the very slender branches ascending. Leaves few and distant, ascending, rather thin, spatulate to linear-oblong, 6-14 $\mathrm{mm}$. long, acute, entire, eiliate, only the lower opposite; bracts lanceolate, glandular-toothed; outer sepals oval to ovate-oblong, acute; $3.5-4 \mathrm{~mm}$. long, glandular-toothed, the inner similar, slightly shorter; petals yellow; filaments pubescent below the middle; staminodia deltoid, glabrous; styles distinct; capsule depressed, about $2 \mathrm{~mm}$. long.

White-lands and moist situations, Abaco and Great Bahama. Endemic. Brace's Flax.

\section{Cathartolinum lignosum Small, N. A. Fl. 25: 75. 1907.}

Apparently perennial; stem woody, branched, with long, prominently striate branches, $3 \mathrm{dm}$. high. Leaves numerous, but not erowded, linear or nearly so, 4-11 mm. long, sessile, acuminate, glandular-ciliate; outer sepals ovate, 3-3.5 mm. long, glandular-toothed, acuminate, the inner broader than the outer; petals yellow; filaments and staminodia glabrous; styles distinct.

Scrub-lands under low bushes in partial openings, Great Bahama at Eight Mile Rocks. Endemic. WOODY Flax.

A specles of Linum, perhaps L. Lewisii Pursh, was collected by Mr. Brace in foliage only on New Providence in 1916.

\section{Family 4. ZYGOPHYLLÀCEAE Lindl.}

\section{Caltrop Family.}

Herbs, shrubs, or some tropical species trees, the branches often jointed to the nodes. Leaves mostly opposite, stipulate, pinnate, or 2-3-foliolate, the leaflets entire. Stipules persistent. Flowers perfect, axillary, peduncled. Sepals usually 5, distinct, or united by their bases. Petals the same number as the sepals, or none. Stamens as many as the petals, or 2-3 times as many, inserted on the base of the receptacle, the alternate ones sometimes longer; anthers versatile, longitudinally dehiscent; filaments usually with a small scale at the base or near the middle. Ovary 4-12celled; style terminal; stigma usually simple; ovules 1-numerous in each eavity, pendulous or ascending. Fruits various, dry or quite fleshy. About 20 genera and 160 species, widely distributed in warm and tropical regions.

Trees or shrubs; flowers blue or purple.

Herbs ; flowers yellow.

Carpels spinose.

Carpels tuberculate.

\section{Guaiacum.}

2. Tribulus.

3. Kallstroemia.

\section{GUAIÀCUM L. Sp. Pl. 381. 1753.}

Evergreen trees or shrubs, with hard resinous wood, the branches stout, the nodes often swollen. Leaves opposite, petioled, abruptly pinnate, the leaflets 2-several pairs, entire, inequilateral, reticulate-veined, the stipules minute. Flowers clustered, peduncled, the peduncles subtended by minute deciduous bracts. Sepals 4 or 5, somewhat united at the base. Petals 4 or 5 , blue or purple. Stamens 8 or 10; filaments filiform; anthers cordate or sagittate. Ovary stalked, 2-5-lobed, 2-5-celled; style subulate; ovules 8-10 in each cavity, anatropous. Fruit coriaceous, with $2-5$ wing-like angles. Seeds ovoid 
or ellipsoid; embryo nearly straight. [From the aboriginal name.] About 8 species, natives of tropical and subtropical America. Type species: Guaiacum officinale $\mathrm{L}$.

Petals tomentulose; fruit broadly obcordate; leaflets mostly 4. Petals glabrous; fruit broadly obovold; leaflets mostly 6-10.

1. G. officinale. 2. G. sanctum.

\section{Guaiacum officinàle L. Sp. Pl. 381. 1753.}

A tree up to $10 \mathrm{~m}$. high, the bark smooth and gray, the branches flexuous. Leaves 3-9 em. long; leaflets 4 or 6 , mostly 4 , oval to obovate, glabrous, $1-5$ $\mathrm{cm}$. long, rounded at the apex, sessile or nearly so, coriaceous at maturity; stipules $1 \mathrm{~mm}$. long, pubescent, caducous; flowers few or many, terminal, the slender peduncles pubescent; sepals ovate to orbicular, $5-7 \mathrm{~mm}$. long, tomentulose on both sides; petals blue, narrowly obovate, about $12 \mathrm{~mm}$. long, tomentulose at the apex, rounded or mucronate; fruit usually 2-carpellary, broadly obcordate, yellowish, 17-20 mm. long; seeds ellipsoid, the aril cream-colored.

Coppices and scrub-lands, South Caicos:-Cuba to St. Thomas and to Trinidad; Jamaica ; Panama to northern South America. Lignum Vitae.

2, Guaiacum sánctum L. Sp. Pl. 382. 1753.

A tree, sometimes $10 \mathrm{~m}$. high, the bark pale, the branches spreading or pendulous. Leaves $4-10 \mathrm{~cm}$. long; leaflets $4-10$, oblong to obovate or oblanceolate, $2-3.5 \mathrm{~cm}$. long, sessile, glabrous, coriaceous at maturity, usually apiculate or mucronate; stipules about $3 \mathrm{~mm}$. long, pubescent, usually caducous; flowers solitary or several, on pubescent peduncles shorter than the leaves; sepals obovate or oblong-obovate, 5-7 mm. long, pubescent; petals blue or purple, broadly obovate, $7-11 \mathrm{~mm}$. long, glabrous, rounded at the apex; fruit broadly obovoid, yellow to orange, 14-17 mm. long; seeds ellipsoid, the aril scarlet.

Coppices and scrub-lands, throughout the islands from Abaco and Great Bahama to Watling's, Inagua, Anguilla Isles and North Caicos:-Florida; Cuba to Porto Rico; Yucatan. Lignum Vitam.

\section{TRÍBULUS L. Sp. Pl. 386. 1753.}

Herbs, with evenly pinnate leaves and peduncled axillary yellow flowers. Sepals 5, persistent. Petals 5, deciduous. Stamens 10, the alternate ones somewhat longer. Ovary sessile, 5-lobed, 5-celled, hairy, the hairs erect; style short; stigma 5-ridged; ovules 3-10 in each eavity, pendulous. Fruit 5-angled, spiny, splitting into 5, 3-5-seeded segments. [Greek, three-pronged, Caltrop, from the resemblance of the fruit to that implement.] About 12 species, of warm and tropical regions. Type species: Tribulus terrestris L.

\section{Tribulus cistoìdes L. Sp. Pl. 387. 1753.}

Tribulus terrestris cistoides Oliver, F1. Trop. Afr. 1: 284. 1868.

Perennial; roots thick, woody; stems diffuse, procumbent, 3-10 dm. long, pubescent, becoming glabrate. Leaves 1-5 cm. long; leaflets $6-8$ pairs, obliquely oblong or elliptic, acutish or obtuse and mucronulate, 4-15 mm. long, silky-pubescent beneath; stipules subulate, $5-8 \mathrm{~mm}$. long; peduncles about as long as the leaves or longer; sepals lanceolate, half as long as the petals; petals yellow, about $2 \mathrm{~cm}$. long; carpels tubercled, each with 2 stout divergent spines and several scattered smaller ones.

Sandy waste places, Fortune Island, Grand Turk and Inagua:-Georgia and Florida; Cuba to Virgin Gorda; Guadeloupe and Martinique; Jamaica; Panama north to the islands off the Callfornia coast. LARGE YelLOW CALTROP. BUTtERCUP. 
3. KALLSTROÈMIA Scop. Int. 212. 1777.

Mostly annual pubescent herbs, with opposite stipulate, evenly pinnate leaves, and solitary axillary peduncled yellow flowers. Sepals usually 5. Petals the same number, obovate or oblanceolate, deciduous. Stamens twice as many as the petals. Ovary sessile, 10-12-celled; ovule 1 in each cavity, pendulous; style long, or short, 10-12-grooved, persistent; stigma mostly 10-12-ridged. Fruit 10-12-lobed, not spiny, often tubercled, splitting into 10-12 1-seeded segments. [In honor of Kallstroem.] About 20 species, widely distributed in warm and tropical regions. Type species: Tribulus maximus L.

\section{Kallstroemia màxima (L.) T. \& G. Fl. N. A. 1: 213.1838.}

Tribulus maximus L. Sp. Pl. 386. 17 อ̃3.

Branches slender, prostrate, 1.5-4.5 dm. long. Leaves short-petioled; stipules subulate; leaflets 3-5 pairs, oval or oblong, inequilateral, rounded or subcordate at the base, $8-20 \mathrm{~mm}$. long; peduncles slender, $1.2-5 \mathrm{~cm}$. long in fruit; flowers $2.5 \mathrm{~cm}$. broad, or less; sepals linear-lanceolate, very pubescent, persistent, shorter than the petals; fruit ovoid-conic, about $6 \mathrm{~mm}$. in diameter, about as long as the stout persistent style, the segments tubercled.

A weed in waste and cultivated solis, New Provldence and Fortune Island:Georgia and Fiorida; West Indies; Mexico to Colombia. Greater Caltrop.

\section{Family 5. MALPIGHIACEAE Velit.}

\section{Malpighia Family.}

Shrubs, trees or woody vines, mostly with opposite leaves, and perfect clustered, or sometimes solitary, nearly regular flowers. Calyx of 5, usually glandular sepals. Corolla of 5, usually elawed petals. Stamens 5 or 10 ; filaments united below, or distinct. Ovary sessile, mostly 3-carpellary; styles distinct or united; stigmas minute. Fruit various. About 60 genera, including over 700 species, natives of tropical and subtropical regions.

Frult nut-like, winged, lateraliy attached to the pyramidal receptacie.

Mature carpeis winged all around, the wings lobed, the body crestless.

Mature carpels winged dorsally, the wings entire, the body crested.

Fruit fleshy, wingiess, basaliy attached to the flat or hollow

1. Triopteris.

2. Stigmaphyllon. receptacle.

Styles distinct.

Inflorescence congested; stigmas thick.

Inflorescence elongated; stigmas subulate.

Styies united.

3. Malpighia.

4. Byrsonima.

5. Bunchosia.

1. TRIÓPTERIS L. Sp. Pl. 428. 1753.

Vines, glabrous or nearly so, twining or reclining, with opposite coriaceous, mostly shining, short-petioled leaves, and small clustered flowers. Receptacle py:amidal. Calyx 8-glandular, the broad sepals persistent. Petals 5, the blac'es usually undulate. Stamens 10, all antheriferous; filaments subulate; anthers very short. Ovary 3 -lobed; styles 3 , distinct, nearly equal. Samaras 3 together, each 3-winged, Y-shaped, the two upper wings longer than the lower one. [Greek, three wings.] About 4 species, natives of the West Indies. Type species: Triopteris jamaicensis $\mathrm{L}$. 
1. Triopteris jamaicénsis L. Sp. Pl. 428. 1753.

Banisteria microphylla Jacq. Obs. Bot. 3: 7. pl. 56.1768.

Triopteris rigida Sw. Prodr. 75. 1788.

Triopteris lucida H.B.K. Nov. Gen. \& Sp. 5: 167. pl. 451.1822.

Triopteris havanensis H.B.K. Nov. Gen. \& Sp. 5: 168.1822.

Triopteris parvifolia A. Juss. Ann. Sci. Nat. Bot. II. 13: 266.1840.

A slender vine, sometimas $10 \mathrm{~m}$. long. Leaves various, linear to cuneate or obovate, 1-2.5 cm. long, striate-veined, emarginate or mucronate at the apex, mostly obtuse at the base; flowers racemose or paniculate; sepals ovate, $2-2.5$ $\mathrm{mm}$. long; petals violet, the larger ones 4-5 $\mathrm{mm}$. long, the suborbicular or ovate-orbicular blades undulate; samaras 12-26 $\mathrm{mm}$. long, the upper wings oblong, the lower one ovate.

Scrub-lands and pine-lands, Great Bahama, Andros, New Providence, Eleuthera, Cat Island, Cave Cay, Watling's Island, Rum Cay, Acklin's Island, Fortune Island, Crooked Island :-Cuba; Hispaniola; (?) Jamaica. Apparently recorded by Schoepf as Banisteria angulosa L. TrIOPTERIS.

2. STIGMAPHYLLON A. Juss. in A. St. Hil. Fl. Bras. Merid. 3: 48. 1833.

Woody vines, with opposite, coriaceous or membranous, petioled leaves, and bright yellow flowers, in axillary peduncled umbel-like corymbs. Receptacle pyramidal. Calyx 8-glandular; sepals persistent. Petals 5, their blades erose or fimbriate. Stamens 10, only 6 of them antheriferous; filaments unequal, united at the base or up to the middle; anthers short. Ovary 3-lobed; styles 3, distinct, unequal, sometimes foliaceous above. Samaras 2 or 3 together or solitary, with a flat dorsal wing. [Greek, leafy stigma.] About 50 species, natives of tropical America. Type species: Banisteria auriculata Cav.

1. Stigmaphyllon Sagraeànum A. Juss. Ann. Sci. Nat. Bot. II. 13: 290. 1840.

Stigmaphyllon reticulatum A. Juss. Ann. Sci. Nat. Bot. II. 13: 290.1840.

Stigmaphyllon Faustinum C. Wright; Sauv. Anales Acad. Habana 5: 244. 1868.

A rather stout vine up to $12 \mathrm{~m}$. long, usually shorter. Leaves various, oblong to linear, ovate, or obovate, coriaceous, 2-10 $\mathrm{cm}$. long, usually mucronate, glabrous or nearly so when old, strongly reticulate-veined beneath, rounded or cordate at the base, short-petioled; peduncles and pedicels sparingly pubescent or glabrous; pedicels jointed at the base; sepals ovate, about $4 \mathrm{~mm}$. long; larger petals 10-12.5 mm. long; samaras 1.5-2.2 cm. long, the ventral edge of the wing auricled at the base, the body one-third to one-half as long as the wing.

Pine-lands and scrub-lands, Andros, Long Island:-Cuba. SAGRA's StigMaPHYLLON.

\section{MALPÍGHIA L. Sp. Pl. 425. 1753.}

Shrubs or small trees, with opposite leaves usually bearing stinging hairs beneath, the white pink or red flowers in axillary peduncled corymbs. Calyx 6-10-glandular, persistent. Petals 5, the blades undulate or fimbriate. Stamens 10, all antheriferous; filaments united to the middle or below; anthers short, often didymous. Ovary glabrous, 3-lobed; styles distinct; stigmas small. Fruit a fleshy drupe, usually depressed-globose. [In honor of Marcello Malpighi, 1628-1693, Italian botanist.] Over 30 species, of tropical and sub. tropical America. Type species: Malpighia glabra L. 
1. Malpighia polytricha A. Juss. Ann. Sci. Nat. Bot. II. 13: 336.1840.

A shrub, up to $3 \mathrm{~m}$. high, usually much branched. Leaves oblong, oval or obovate, subcoriaceous, $1.5-3 \mathrm{~cm}$. long, rounded, truncate or retuse and usually mucronulate at the apex, cuneate to subcordate at base, sinuate-dentate or entire, reticulate-veined, glabrous above when mature, mostly pubescent with stinging hairs beneath and on the margins, short-petioled; cymes sessile or nearly so, several-flowered; calyx 10-glandular; sepals oblcng to ovate, about $3 \mathrm{~mm}$. long; corolla pink to scarlet, the larger petals $8-10 \mathrm{~mm}$. long; styles unequal, hooked at the apex; drupe red, subglobose or globose-ovoid, 7-10 mm. in diameter.

Scrub-lands, coppices and pine-lands, throughout the archipelago from Abaco and Andros to Caicos and Inagua. Endemic. Consists of many races, the leafforms various and the stinging hairs abundant, few or none. Recorded by Dolley and Hitcheock as $M$. setosa Spreng.; also as such by Mrs. Northrop; and by Hitchcock as $M$. punicifolia L. Bahama Malpighia. Touch-Me-Not. Wild-cherry.

4. BYRsonima Rich.; A. Juss. Ann. Mus. Paris 18: 481. 1811.

Shrubs or trees, with opposite petioled or sessile leaves, the flowers in terminal panicles or racemes. Calyx 10 -glandular, or glandless, of $\overline{5}$ broad persistent sepals. Petals 5, the blades suborbicular to reniform. Stamens 10, all antheriferous; filaments short, slightly united at the base. Ovary 3-lobed; styles 3, slender; stigmas subulate. Drupes ovoid to globose. [Greek, tanning.] About 100 species, of tropical and subtropical America. Type species: Malpighia spicata Cav.

1. Byrsonima cuneàta (Turcz.) P. Wilson, Bull. N. Y. Bot. Gard. 8: 394. 1917.

Malpighia lucida Sw. Prodr. 74. 1788. Not Miller. 1768.

Bursonima lucida DC. Prodr. 1: 580. 1824.

Malphighia cuneata Turez. Bull. Soc. Imp. Nat. Mose. 31¹: 390. 1858.

Usually a shrub, $2.5 \mathrm{~m}$. high or less, sometimes a small tree up to $8 \mathrm{~m}$. high, the twigs slender, mostly short. Leaves spatulate to obovate, rather thin in texture, flat, $1.5-5.5 \mathrm{~cm}$. long, glabrous, rounded or abruptly acute at the apex, rarrowed or cuneate at the base, reticulate-veined and shining above, dull beneath, the petioles $2-5 \mathrm{~mm}$. long; pedicels sparingly pubescent or glabrous; sepals ovate or oblong, about $3 \mathrm{~mm}$. long; petals white to red, the larger $5-7$ $\mathrm{mm}$. long; drupes globose, brown, 9-12 $\mathrm{mm}$. in diameter.

Coastal coppices, borders of swamps and in wet places in pine-lands, Abaco, Great Bahama, Andros, New Provldence, Eleuthera, Cat Island, Crooked Island, Fortune Island, Acklln's Island, Inagua:-Florida; Cuba to Anegada and Barbadoes. LocUst-Berry. GUANA-BCRry. CANDLE-BERry.

\section{BUNCHOSIA Rich.; A. Juss. Ann. Mus. Paris 18: 481.1811.}

Shrubs or trees, with opposite, usually coriaceous, petioled or nearly sessile leaves, and yellow or white flowers in terminal panicles. Calyx 8-10-glandular, the 5 sepals persistent. Petals 5, their broad blades undulate or toothed. Stamens 10, all antheriferous; filaments partly united, glabrous; anthers short. Ovary 2-3-lobed; styles united; stigma 3-lobed or capitate. Drupe ovoid, globose or reniform. [Said to be derived from an Arabic name for coffee.] Thirty species or more, of tropical and subtropical America. Type species: Malpighia odorata Jacq. 
1. Bunchosia glandulòsa (Cav.) DC. Prodr. 1: 581. 1824.

Malpighia glandulosa Cav. Diss. 8: 411. pl. 239. f. 2. 1789.

A shrub, or sometimes a tree up to $8 \mathrm{~m}$. high. Leaves oblong to oblanceolate or elliptic-obovate, glabrous, $3-11 \mathrm{~cm}$. long, obtuse or acute at the apex, narrowed or acute at the base, bright-green, somewhat paler beneath than above, the petioles 5-12 m. long; panjeles often many, as long as the leaves or shorter; pedicels finely pubescent when young, becoming glabrous; sepals oblong or ovate-oblong, about $3 \mathrm{~mm}$. long; petals yellow, the larger 6-7.5 $\mathrm{mm}$. long, with suborbicular, erose or denticulate blades; ovary and style glabrous; drupes ovoid, red or orange, 2-lobed, 9-15 $\mathrm{mm}$. in diameter.

Scrub-lands, Andros, New Providence, Eleuthera, Great Exuma, Watiing's Island :-Hispaniola; Porto Rico; St. Thomas to Martinique; Yucatan. BunchosIA.

\section{Family 6. RUTACEAE Juss.}

\section{Rue Family.}

Trees or shrubs, rarely herbs, with heavy-scented and glandular-punctate foliage, mainly compound estipulate leaves, and perfect or polygamodioecious flowers. Sepals 4 or 5, or none. Petals 4 or 5, hypogynous or perigynous. Stamens of the same number, or twice as many, distinct, inserted on the receptacle; anthers 2-celled, mostly versatile. Disk annular. Pistils 1-5, distinct, or 1 and composed of 2-5 carpels, inserted on the receptacle. Fruit various, a eapsule, berry or samara. Seeds oblong or reniform; endosperm generally fleshy, sometimes none. About 110 genera and 950 species, most abundant in South Africa and Australia.

Fruit dry, capsular or samarold; stamens $\mathbf{3 - 5}$.

Fruit dehiscent, not winged; flowers whitish or greenish.

Fruit indehiscent, winged; flowers red or pinkish.

Fruit pulpy, drupaceous; stamens 8 or 10 .

1. Zanthoxylum.

2. Spathelia.

3. Amyris.

\section{ZANTHÓXYLUM [Catesby] L. Sp. Pl. 270. 1753.}

Trees or shrubs with alternate pinnate leaves, the twigs and petioles commonly prickly. Flowers axillary or terminal, cymose, whitish or greenish, mostly small. Sepals 4 or 5 , or none. Petals imbricated. Staminate flowers with 4 or 5 hypogynous stamens. Pistillate flowers with 1-5 distinct pistils, rarely with some stamens. Carpels 2-ovuled. Pods 2-valved, 1-2-seeded. Seeds oblong, black and shining. [Greek, yellow-wood.] About 150 species, of temperate and tropical regions. Type species: Zanthoxylum Clava-Herculis $\mathrm{L}$.

Petiole and rachis winged; inflorescence lateral or axillary, shortspicate.

Petiole and rachis wingiess; inflorescence mostly terminal, panicu-

1. Z. Fagara.

late or corymbose-panicuiate.

Sepais, petais and stamens 3 ; leaflets obovate. Ovary 3-carpellary. Ovary 1-carpeliary.

Sepais, petais and stamens 5 , rarely 4 ; leaflets lanceoiate to ovate.

2. Z. coriaceum. 3. Z. cubense.

4. Z. flavum.

\section{Zanthoxylum Fagàra (L.) Sarg. Gard. \& For. 3: 186.1890.}

Schinus Fagara L. Sp. Pl. 389. 1753.

Fagara Pterota L. Syst. ed. 10, 897. 1759.

Fagara lentiscifolia H. \& B.; Willd. Enum. Hort. Berol., 165. 1809.

Zanthoxylum Pterota H. B. K. Nov. Gen. \& Sp. 6: 3. 1823.

Fagara Fagara Small, Fl. SE. U. S. 675. 1903. 
Usually a shrub, sometimes a small tree up to $10 \mathrm{~m}$. in height, intricately branched, the branches armed with hooked prickles, or occasionally unarmed, the young twigs puberulent. Leaves $2.5-10 \mathrm{~cm}$. long, odd-pinnate; leaflets $5-13$, obovate to elliptic or suborbicular, 7-25 mm. long, rounded or emarginate at the apex, mostly cuneate or narrowed at the base, crenulate, bright-green and shining above, the petiole and rachis grooved and winged; inflorescence lateral, axillary, short-spicate; sepals 4 , not more than $0.5 \mathrm{~mm}$. long; petals 4 , yellowishgreen, 2-3 mm. long; staminate flowers with 4 stamens, longer than the petals; pistillate flowers with a sessile ovary and slender styles; follicles globose, 3-4 $\mathrm{mm}$. in diameter; seeds black, shining.

Scrub-lands and coppices, Elbow Cay, Great Bahama, Berry Islands, North Cat Cay, Andros, New Providence, Eleuthera to Watling's, Great Guana Cay, Great Exuma, Long Island, Acklin's and North Caicos:-Florida; Texas; Mexico; Central and South America; West Indies. WIID Lime. SATIN-WOOD.

2. Zanthoxylum coriàceum A. Rich. Ess. Fl. Cub. 326. 1845.

Fagara coriacea Krug \& Urban, Bot. Jahrb. 21: 591. 1896.

A prickly aromatic shrub or small tree up to $7 \mathrm{~m}$. high, the old wood bearing many corky conic cushions. Leaves $2 \mathrm{dm}$. long or less, glabrous, mostly evenly pinnate; leaflets $4-13$, obovate or oblong-obovate, $2-6.5 \mathrm{~cm}$. long, obtuse, emarginate or bluntly acuminate at the apex, narrowed or cuneate at the base, dark-green and shining above, pale-green and often prickly beneath; cymes terminal, rarely axillary; flowers yellowish-white; sepals, petals and stamens 3 ; ovary 3-carpellary; petals of the pistillate flowers about $4 \mathrm{~mm}$. long, a little larger than those of the staminate; follicles subglobose to ellipsoid, $\overline{0}-6 \mathrm{~mm}$. long, apiculate, brown, rough ; seeds 1 in each follicle, subglobose, black, shining, 3-4 mm. long.

Coppices or sometimes in the white-lands, throughout the archipelago from Abaco and Great Bahama to North Bimini, Caicos and Inagua :-Florida; Cuba ; Grand Cayman and Hispaniola. Referred by Dolley and Hitchcock to Zanthoxylum emarginatum Sw. Hercules' CLUB. DOCTOR'S CLUB.

3. Zanthoxylum cubénse P. Wilson, Torreya 9: 32. 1909.

Zanthoxylum juglandifolium A. Rich. Ess. Fl. Cub. 332. 1845. Not Willd. 1806.

A prickly glabrous shrub or tree up to $13 \mathrm{~m}$. high. Leaves odd-pinnate; leaflets $3-9$, obovate, $5-8 \mathrm{~cm}$. long, obtuse, short-acuminate, or emarginate at the apex, narrowed at the base, shining above, rather dull beneath; inflorescence terminal, paniculate; sepals, petals and stamens 3 ; petals about $1.6 \mathrm{~mm}$. long, 4-5 times as long as the calyx; ovary 1-carpellary; follicles solitary, sessile, globose, apiculate, about $4 \mathrm{~mm}$. in diameter. woor.

Coppices and pine-lands, near Deep Creek, Andros:-Cuba. Cuban Yellow-

\section{Zanthoxylum flàvum Vahl, Eclog. 3: 48. 1807.}

Xanthoxylon cribrosum Spreng. Syst. 1: 946.1825.

Fagara flava Krug. \& Urban, Bot. Jahrb. 21: 571. 1896.

An unarmed tree, reaching a maximum height of about $12 \mathrm{~m}$. with a trunk about $5 \mathrm{dm}$. in diameter, usually smaller, sometimes shrubby, the light grey bark nearly smooth, the twigs finely stellate-pubescent when young, soon glabrous. Leaves 1-2.5 dm. long, odd-pinnate, finely stellate-canescent when young; leaflets $3-11$, mostly 5 or 7 , subcoriaceous, ovate or lanceolate to elliptic, very nearly. sessile, obtuse or acutish at the apex, mostly rounded at the base, crenate or nearly entire, pellucid-punctate; panicles terminal, many-flowered, 5-15 cm. long; pedicels and rachis stellate-canescent; calyx about $1.5 \mathrm{~mm}$. broad; petals $2.5-4 \mathrm{~mm}$. long; staminate flowers with 5 , rarely 4 stamens about 
as long as the petals; pistillate flowers with a glandular-punctate ovary and short styles; follicles obovoid, 5-9 mm. long; seeds black, shining, 4-5 mm. long.

White-lands and low coppices, throughout the archipelago from Abaco and Great Bahama to Grand Turk and Ambergris Cay, Inagua and the Anguilla Isles :-Bermuda; Florida; Cuban Cays; Jamaica, Santo Domingo to St. Lucia. Referred by Dolley to Zanthoxylum fraxineum Willd. YEllow-wood. SATIN-WOOD.

The occurrence of Zanthoxylum Clava-Herculis L. in the Bahamas as recorded by Dolley is extremely doubtful; both $Z$. coriaceum and Caesalpinia bahamensis are locally known through the archipelago as "Hercules' Club."

\section{SPATHÈLIA L. Sp. P1. ed. 2, 386. 1762.}

Trees, with slender unbranched trunks, the leaf-scars long-persistent, the pinnate leaves tufted at the summit, the polygamous flowers in large terminal erect panicles. Leaflets pellucid-punctate. Sepals 5. Petals 5, imbricated. Stamens 5, alternating with the petals. Ovary 3-celled, 3-angled; stigma 3lobed; ovules 2 in each cavity. Fruit dry, 3-celled, 3-winged, each cavity containing one seed. Endosperm fleshy; radicle straight. [Greek, staff-like.] About 5 species, natives of the West Indies. The trees die after once flowering and fruiting. Type species: Spathelia simplex L.

1. Spathelia vernicòsa Planch. in Hook. Lond. Jour. Bot. 5: 581.1846.

Trunk 3-5 m. high, 5-8 cm. in diameter. Leaves several, 1.5-4.5 dm. long, the rachis narrowly wing-margined; leaflets $25-35$, oblong or oblong-elliptic, 1-5 $\mathrm{cm}$. long, subsessile, obtuse at the apex, rounded or broadly cuneate at the base, glabrous, dark-green above, paler beneath, shining on both sides, coarsely erenulate with gland-tipped teeth; panicle $9 \mathrm{dm}$. long or less; pedicels $3-8 \mathrm{~mm}$. long; flowers red; sepals oblong, 4-う mm. long; petals oblong-obovate, 5-6 $\mathrm{mm}$. long; filaments with wing-like appendages at the base; fruit 10-13 mm. long, 7-10 $\mathrm{mm}$. wide, the triangular body narrowly winged; seeds angled.

Rocky scrub-lands, Cat Island:-Cuba. Low Spathelia.

3. AMỲRIS L. Syst. ed. 10, 996, 1000. 1759.

Shrubs or trees, with compound (sometimes unifoliolate), petioled leaves, and small white perfect flowers in terminal and axillary corymbiform panicles, the pedicels 2-bracteolate. Calyx urn-shaped, 4-5-lobed. Petals 4 or 5. Stamens twice as many as the petals, borne on the disk; filaments filiform; anthers longitudinally dehiscent. Ovary 1-celled; ovules 2, pendulous; style short or none; stigma capitate or flat. Fruit a small drupe. Seed-coat membranous; cotyledons thick, fleshy. [Greek, much balsam.] About 15 species, natives of tropical and subtropical America. Type species: Amyris balsamifera L:

1. Amyris elemifera L. Syst. ed. 10, 1000. 1759.

Amyris maritima Jacq. Enum. 19.1760.

A shrub or tree, sometimes $17 \mathrm{~m}$. high, glabrous or the young twigs and inflorescence hispidulous. Leaves opposite, or mostly so; leaflets 3 or 5 , coriaceous, lanceolate to ovate or rhombic-ovate, $2-7 \mathrm{~cm}$. long, acute, acuminate or rounded at the apex, cuneate, rounded or subtruncate at the base, crenulate or entire, short-stalked; panicles several-many-flowered; calyx-lobes ovate; petals 
obovate or oval, $2-3.5 \mathrm{~mm}$. long; ovary glabrous; stigma sessile; drupe globose to ellipsoid, black, 5-8 mm. long, glaucous.

Coastai thickets and scrub-lands, throughout the archipelago from Abaco and Great Bahama to Caicos and Inagua:-Fiorida; West Indies and Central America. Referred by Dolley to Amyris sylvatica Jacq. Torchwood. WHITE Torch. Catesby, 2: $p l$. 33 .

Amyris bijuga of Schoepf is listed by him as a name only and not identified; his record of $A$. sylvatica has not been substantiated.

The Glycosmis pentaphylla recorded by Dolley, is Amyris elemifera L. according to the specimen collected by Brace.

\section{Family 7. SURIANÀCEAE Lindl.}

\section{Bay Cedar Family.}

The family consists only of the following genus.

1. SURIANA L. Sp. Pl. 284. 1753.

A branching shrub or small tree, with simple alternate entire leaves, the perfect flowers in terminal clusters or solitary. Calyx of 5 persistent sepals. Corolla of 5 imbricated petals. Stamens 10; filaments nearly distinct, those opposite the petals shorter than the others. Disk adnate to the base of the calyx, or obsolete. Carpels 5, distinct; ovules 2, collateral, ascending; styles 5, lateral, filiform; stigmas capitate. Fruits achene-like. Embryo thick, horseshoe-shaped. [Named for Joseph Donat Surian, of Marseilles.] A monotypic genus.

\section{Suriana marítima L. Sp. Pl. 284. 1753.}

Usually a shrub $2 \mathrm{~m}$. high or less, sometimes a small tree up to $8 \mathrm{~m}$. high, the twigs densely leafy, and densely pubescent. Leaves linear-spatulate, 1-4 $\mathrm{cm}$. long, 2-6 $\mathrm{mm}$. wide, rather fleshy, sessile, densely pubescent, obtuse; flowers few, in short clusters; sepals lanceolate to ovate, $6-10 \mathrm{~mm}$. long, acuminate; petals obovate, yellow, 7-9 $\mathrm{mm}$. long, erose near the apex; fruiting carpels 4-5 $\mathrm{mm}$. long, finely pubescent.

Maritime sands and rocks, throughout the archipelago from Abaco and Great Bahama to Sand Cay (Grand Turk), Inagua, the Anguilla Isles and Cay Sal :Bermuda; Florida ; the West Indies; shores of the Gulf of Mexico and Caribbean Sea; Old World tropical coasts. Bay Cedar. Tassel Plant.

\section{Family 8. SIMAROUBÀCEAE DC.}

\section{Quassia Fanilly.}

Trees and shrubs, the bark usually bitter and containing oil-sacs, with pinnate (rarely simple), mostly alternate leaves and small, dioecious or polygamous, panicled racemose, or sometimes solitary, axillary flowers. Calyx of 3-7 sepals. Corolla of as many petals, or wanting. Stamens as many or twice as many as the petals, rarely more numerous. Carpels $2-5$, distinct or united; styles distinct, united or none; ovules mostly 1 or 2 in each cavity. Fruit various, usually 1 -seeded. About 30 genera, comprising some 150 species, mostly tropical, a few in the temperate zones. 
Fruit drupaceous or baccate; petals usually present.

Leaves 5-9-foliolate; carpels 2-ovuled.

Leaves 9-21-foliolate; carpels 1-ovuled.

Fruit samaroid; leaves 19-51-foliolate; petals none.

1. Picramnia.

2. Simarouba.

3. Alvaradoa.

1. PICRÁMINIA Sw. Fl. Ind. Oce. 1: 217. 1797.

Trees or shrubs, with alternate, unequally pinnate leaves, and small dioecious flowers in narrow panicles. Sepals 3-5, slightly united at the base. Petals 3-5, or sometimes wanting. Stamens 3-5, in the pistillate flowers represented by small staminodia; filaments slender, unappendaged; anthers broad. Ovary 2-3-celled, sessile; stigmas 2 or 3 , spreading; ovules 2 in each eavity, pendulous. Fruit baccate, globose to oblong or obovoid, the pulp juicy. [Greek, bitter shrub.] Some thirty species, of tropical and subtropical America. Type species: Picramnia Antidesma Sw.

1. Picramnia pentándra Sw. Fl. Ind. Occ. 1: 220. 1797.

A shrub, or a small tree up to $10 \mathrm{~m}$. high, the young twigs and leaves finely appressed-pubescent. Leaflets 5-9, chartaceous, oblong to ovate or lanceolate, 3-12 cm. long, acute, acuminate, or obtuse at the apex, narrowed at the base, shining above, becoming glabrous on both sides, the petiolules short; panicles slender, loosely branched, 7-15 $\mathrm{cm}$. long; sepals 5 , ovate, acute, about $2 \mathrm{~mm}$. long; petals linear-lanceolate, about as long as the sepals; stamens 5 ; berries globose to oblong or obovoid, red or scarlet, 9-15 mm. long.

Coppices and scrub-lands, Abaco, Great Bahama, Andros, New Providence, Eleuthera, Cat Island, Watling's, Atwood Cay, Acklin's, Long Island, Mariguana and North Caicos:-Florida; Cuba to Trinidad. BitTer Bush. SNake-root.

\section{SIMMAROÙBA Aubl. Pl. Guian. 2: 859. 1775.}

Shrubs or trees, usually with bitter bark, the leaves alternate, pinnate, the leaflets entire, the small, terminal or axillary panicled flowers monoecious or dioecious. Sepals 4-6, partly united. Petals 4-6, much longer than the calyx. Stamens 8-12, often represented by dilated staminodia in the pistillate flowers; filaments subulate, appendaged at the base; anthers narrow. Ovary sessile, usually 5-celled; carpels distinct. Fruit drupaceous. [Guiana name.] About 5 species of tropical and subtropical America. Type species: Simarouba amara Aubl.

1. Simarouba glaùca DC. Ann. Mus. Paris 17: 424.1811.

Quassia Simaruba W. Wright, Trans. Roy. Soc. Edin. 2: 73. 1790. Not L. f. 1781 .

Simaruba amara Hayne, Arzneipfl. 9. pl. 15. 1825. Not Aubl. 1775.

Simaruba officinalis Macf. Fl. Jam. 1: 198. 1837. Not DC. 1811.

Simarouba medicinalis Endl. Medic. Pfl. 528. 1842.

Simaruba officinalis forma glabra Krug \& Urban, in Engl. Bot. Jahrb. 15: 305. 1893.

A tree, up to $16 \mathrm{~m}$. high, or shrubby, the rather stout nearly terete twigs glabrous, the bark red-brown. Leaves $2-4 \mathrm{dm}$. long, unequally pinnate; leaflets $7-21$, oblong or oblong-obovate, $5-11 \mathrm{~cm}$. long, rounded, retuse or abruptly pointed at the apex, cuneate at the base, glabrous, or with short spreading hairs beneath, bright green above, pale and more or less glaucous beneath, the petiolules very short; panicle 1-4 dm. long, widely branched, the staminate flowers more numerous than the pistillate; flowers short-pedicelled; sepals ovate 
to triangular-ovate, eiliolate; petals oblong to ovate, 4-6 mm. long; drupe oval, 14-20 mm. long, scarlet to dark-purple.

Coppices, Abaco, Great Bahama, Andros, and New Providence :-Fiorida ; Cuba ; Hispaniola; Jamaica; Mexico to Panama. PARAdise-rree.

\section{ALVARADÒA Liebm. Kjob. Vidensk. Meddel. 1853: 100. 1854.}

Shrubs or small trees, with alternate, unequally pinnate leaves clustered near the ends of the slender branches, the leaflets small and numerous, the small dioecious flowers in narrow, spreading or drooping racemes. Sepals 5, short, slightly united at the base. Petals none. Stamens 5, exserted; filaments filiform, pubescent; anthers short. Ovary sessile, 2-3-celled; ovules 2 in each cavity; styles 2 or 3 , recurved; stigmas very small. Fruit a 2-3-winged samara. [Commemorates Petro de Alvarado, a Mexican explorer.] Five or six species, of Florida, the West Indies, Central and South America, the following typical.

1. Alvaradoa amorphoìdes Liebm. Kjob. Vidensk. Meddel. 1853: 100. 1854.

A shrub or small tree up to $10 \mathrm{~m}$. high, the twigs puberulent. Leaves 1-2 dm. long, the rachis very slender and flexible; leaflets 19-51, thin, $0.5-2.5 \mathrm{~cm}$. long, the lower orbicular to obovate, the upper ovate to oblong, all rounded or retuse at the apex, dark-green and glabrous above, finely appressed-pubescent beneath, the petiolules short; sepals ovate to ovate-orbicular, 1.5-2 $\mathrm{mm}$. long, obtuse or acutish; samaras lanceolate or oblong-lanceolate, 1-1.5 cm. long, narrowed to the apex.

Scrub-iands, coppices and pine-lands, Andros, New Providence, Great Exuma and Cat Island:-Florida; Cuba; Mexico. ALvARADOA.

\section{Family 9. BURSERÀCEAE Kunth.}

\section{Gumbo-limbo Family.}

Shrubs or trees, mostly resiniferous or aromatic, with alternate, mostly pinnate, deciduous leaves, and small regular perfect or polygamo-dioecious flowers, usually panicled. Sepals $3-5$, somewhat united below. Petals as many as the sepals and alternating with them. Stamens twice as many as the petals; filaments distinct, short; anthers 2-celled. Ovary superior, mostly 3-5-celled; ovules normally 2 in each eavity, pendulous; style usually very short; stigma broad. Fruit drupaceous. Seed-coat membranous; endosperm none. Abont 20 genera and over 300 species, mostly of tropical distribution.

\section{ELÁPHRIUM Jacq. Enum. 3. 1760.}

\section{[Terebinthus P. Br. Hist. Jam. 345. 1756. Not Miller 1754.]}

Leaves various, compound or simple. Inflorescence axillary. Flowers polygamo-dioecious. Calyx 4-5-lobed, the lobes spreading. Petals 4 or 5, ovate to oblong, much larger than the calyx-lobes, imbricated in the bud, inserted at the base of the disk. Stamens 8 or 10, distinct, inserted with the petals. Disk an entire ring. Ovary sessile, 3-celled. Fruit a globose or 3-angled drupe, the 
epicarp splitting into 2 or 3 coriaceous valves, the bony stone enclosed in fleshy pulp. [Greek, light, the wood is light in weight.] About 80 species, of tropical and subtropical America. Type species: Elaphrium tomentosum Jacq.

Leaflets narrow, oblong to oblanceolate; angles of seed 4, keeled. 1. E. inaguense. Leaflets broad, oval to obovate, acute; angels of seed 1-3, acute. 2. E. Simaruba.

\section{Elaphrium inaguénse (Britton) Rose, N. A Fl. 25: 245. 1911.}

Bursera inaguensis Britton, Bull. N. Y. Bot. Gard. 3: 443. 1905.

Terebinthus inaguensis Britton, Bull. Torr. Club 35: 342. 1908.

A shrub or small tree, $3.3 \mathrm{~m}$. high or less, the twigs gray, the foliage glabrous. Petiole slender, terete, $2-5 \mathrm{~cm}$. long; leaflets $3-7$, thin but firm, light green on both sides, not strongly veined, oblong to oblanceolate or obovate, acute or obtuse at the mucronate apex, narrowed or cuneate at the base, $6 \mathrm{~cm}$. long or less, 1-2 cm. wide, the upper surface faintly shining, the under side dull; lateral leaflets sessile or with petiolules 1-2 $\mathrm{mm}$. long, the terminal one with a petiolule $3-8 \mathrm{~mm}$. long; panicles several, axillary, as long as the leaves or shorter, the slender peduncles 1-6 $\mathrm{cm}$. long; pedicels $2-3 \mathrm{~mm}$. long; calyxlobes broadly triangular, acute; petals oblong-lanceolate, acute, $2.5 \mathrm{~mm}$. long; fruit 6-8 mm. long, only one cavity seed-bearing; seed 4-6 mm. long, acute, short-stipitate.

Scrubslands, Eleuthera, Great Guana Cay, Great Exuma, Long Island, Ambergris Cay, Inagua and Little Inagua :- northern Cuban Cays. Referred by Hitchcock to Bursera angustata C. Wright. Bahama Elaphriun.

2. Elaphrium Simarùba (L.) Rose, N. A. Fl. 25: 246. 1911.

Pistacia Simaruba L. Sp. PI. 1026. 1753.

Bursera gummifera L. Sp. Pl. ed. 2, 471. 1762.

Bursera gummifera glabrata Griseb. Fl. Br. W. I. 173. 1859.

Bursera gummifera pubescens Engler, in DC. Mon. Phan. 4: 40. 1883.

Bursera Simaruba Sarg. Gard. \& For. 3: 260. 1890.

Terebinthus Simaruba W. F. Wight; Rose, Contr. U. S. Nat. Herb. 10: 122. 1906.

A tree, reaching a maximum height of about $20 \mathrm{~m}$. with a trunk up to $1 \mathrm{~m}$. in diameter, usually much smaller, the branches spreading, the thick red-brown, smooth and shining bark peeling off in thin layers. Leaves glabrous or sometimes pubescent, petioled, 1-2 dm. long; leaflets $3-7$, ovate to obovate, firm in texture, $3-8 \mathrm{~cm}$. long, acute or acuminate; racemes glabrous or pubescent, 5-10 $\mathrm{cm}$. long; pedicels 4-8 mm. long; calyx-lobes about $1 \mathrm{~mm}$. long; petals greenish, 2-2.5 mm. long, ovate to oblong-lanceolate; drupes oblong, 3-angled, 5-10 mm. long, splitting into 3 valves; seed white.

Coppices, throughout the archipelago from Abaco and Great Bahama to Turk's Islands, Anguilla Isles and Cay Sal :-Florida; West Indies; Mexico and tropical continental America. GuMbo-Limbo, West INDIAN BIRCH, GuM-elemi. Catesby, 1 : pl. 30 .

Hedwigia balsamifera Sw., reported by Dolley, has not been found in the Bahamas by any of our collectors; the record is probably erroneous.

\section{Family 10. MELIÀCEAE Vent.}

\section{Mahogany Family.}

Shrubs, trees, or sometimes shrubby herbs. Leaves alternate, without stipules, pinnately compound, sometimes thrice pinnate. Inflorescence 
paniculate. Flowers perfect or polygamo-dioecious, regular. Calyx of $3-5$, distinct or partly united valvate sepals. Corolla of 3-5 distinet or somewhat united petals which are sometimes adnate to the stamen-tube. Stamens S-10, or rarely fewer or more, inserted at the base of the disk; filaments united into a tube; anthers sessile or stalked. Carpels 3-5, united; ovary 3-5-celled, free; styles united. Ovules 2-many in each cavity, anatropous. Fruit a berry, capsule or drupe. Seeds sometimes winged; endosperm wanting or fleshy; embryo with leafy cotyledons. About 50 genera, including some 700 species, mostly tropical.

Leaflets membranous, serrate to incised; fruit a drupe; seeds wing-

Leaflets chartaceous, entire; frult a woody capsule; seeds winged.

1. Melia.

2. Swietenia.

\section{MÈLIA L. Sp. Pl. 384. 1753.}

Trees, with alternate, pinnate or pinnately compound leaves, the leaflets stalked and serrate, the showy white to purple flowers numerous, in large axillary panicles. Calyx 5-6-parted, the lobes imbricated. Petals as many as the calyx-lobes, narrowly spatulate, spreading. Stamen-tube nearly cylindric, dilated and cleft above, bearing 10 or 12 erect anthers. Disk annular. Ovary 3-6-celled; ovules 2 in each cavity; style slender; stigma 2-6-lobed or capitate. Fruit a small drupe, its stone 1-5-celled, with 1 seed in each cell. [A Greek name of the Ash.] About 25 Asiatic species, the following typical.

1. Melia Azédarach L. Sp. Pl. 384. 1753.

Melia sempervirens Sw. Prodr. 67. 1788.

A tree, sometimes $20 \mathrm{~m}$. high, with a trunk up to $2 \mathrm{~m}$. in diameter, usually much smaller, the bark furrowed, the branches spreading. Leaves bipinnate, petioled, glabrous, or nearly so, $2-4 \mathrm{dm}$. long, deciduous; leaflets numerous, ovate to elliptic, thin, acuminate at the apex, rounded or narrowed at the base, $3-7 \mathrm{~cm}$. long, sharply serrate and sometimes lobed; panicles peduncled 2-3 dm. long; pedicels slender, 4-10 mm. long; sepals acute, about $2 \mathrm{~mm}$. long; petals purplish, oblong, obtuse, about $10 \mathrm{~mm}$. long; drupes yellow, globose, smooth, 1.5-2 cm. in diameter.

Waste and scrub-lands, spontaneous after cultivation, Eleuthera, Cat Island and Inagua :- southeastern United States; Bermuda; West Indles; Mexico and tropical America generally; native of southeastern Asia. PRIDE-OF-INDIA.

\section{SWIETÈNIA Jacq. Enum. 4, 20. 1760.}

Large evergreen trees, with hard reddish brown wood, and pinnate leaves with opposite acuminate leaflets, the small flowers in terminal and axillary panicles. Calyx 5-cleft, its lobes imbricated. Petals 5, spreading. Filaments united into an urn-shaped, 10-toothed tube; anthers 10. Disk annular. Ovary ovoid, 5-celled; stigma discoid, 5-rayed; ovules many, pendulous on the axis. Capsule large, woody, 5-celled, septicidally こ̌-valved. Seeds many, imbricated in 2 series. [Named for Gerard von Swieten, 1700-1772.] Three known species, two of tropical and subtropical America, one African, the following typical.

1. Swietenia Mahàgoni Jacq. Enum. 20. 1760.

A large tree, sometimes $25 \mathrm{~m}$. high with a trunk $4 \mathrm{~m}$. in diameter, buttressed at the base, the reddish bark scaly, the branches spreading, the angular twigs 
smooth. Leaves evenly pinnate, 1-2 dm. long, the slender petiole enlarged at the base; leaflets 4-8, coriaceous, ovate or ovate-lanceolate, inequilateral, 3-8 cm. long, dark-green, glabrous and shining above, paler green and glabrous or sparingly pubescent beneath; panicles axillary, $6-15 \mathrm{~cm}$. long; calyx-lobes rounded; petals white, spreading, about $4 \mathrm{~mm}$. long; stamen-tube glabrous; ovary ovoid; style erect; stigma 5-rayed; capsule ovoid, woody, 6-12 cm. long, splitting from the base into 5 thick valves, the 5 -winged axis persistent; seeds about $18 \mathrm{~mm}$. long, the wing obtuse.

Coppices and scrub-lands, Abaco, Great Bahama, Lignum Vitae Cay, Andros, New Providence, Great Guana Cay, Exuma, Long Island, Eleuthera to Watling's, Acklin's, Crooked Island, Mariguana, the Caicos and Inagua:-Florida; West Indies; Mexico to Peru. MaHogany. Madeira. Catesby, $2: p l$. 81.

Cedrela odorata L., recorded by Dolley from the Bahamas, is unknown by us from any island or cay in the archipelago. It may have been planted.

\section{Family 11. POLYGALÀCEAE Rehb.}

\section{Milkwort Family.}

Herbs, rarely shrubs or small trees in tropical regions. Stipules none. Pedicels generally 2-bracted at the base. Flowers perfect, irregular. Sepals 5 , the two lateral inner ones (wings) large, colored, the others smaller. Petals 3 (or 5), hypogynous, more or less united into a tube, the lower one often crested. Stamens generally 8 , united in 1 or 2 sets. Ovary 2-celled; style simple; stigma curved, dilated or lobed; ovules 1 in each cavity, anatropous. Fruit mainly capsular. Seeds generally caruncled; embryo straight. About 10 genera and 1000 species, widely distributed.

Wings much larger than the other sepals and petalold; lateral petals partially adnate to the androecium; the Bahama species herbs.

Wings somewhat larger than the other sepals, not petaloid; lateral petals coherent to the androecium at the base; shrubs or trees.

1. Polygala.

2. Badiera.

\section{POLYGATA L. Sp. Pl. 701. 1753.}

Herbs or shrubs. Flowers racemose, spicate or capitate, rarely solitary and axillary, sometimes also cleistogamous and subterranean. Sepals very unequal. the two lateral ones (wings) large and petaloid. Petals 3, united into a tube which is split on the back, and more or less adnate to the stamens. Stamens 8 or 6, monadelphous below, or diadelphous; capsule membranous, compressed, dehiscent along the margin. Seeds 1 in each cavity, generally hairy. [Greek, much milk.] A genus of about 450 species, of wide distribution. Type species: Polygala vulgaris L. The following descriptions were contributed by Dr. J. K. Small.

The two lower sepals wholly or partly united.

Sepals with marginal stipitate glands.

Sepals glandless.

Sepals distinct.

Racemes sessile or nearly so, permanently short; sepals with marginal glands; bracts persistent.

Racemes long-peduncled, elongate or elongating; sepals without marginal glands; bracts deciduous.

Racemes slender. interrupted in anthesis; stems slender, wiry; capsules suborbicular; seeds oblong-ovold.

Racemes stout, not interrupted ; stems stout, fleshy; capsules oblong-obovoid; seeds broadly clavate.

1. P. bahamensis.

2. P. Krugii.

3. P. spathulata.

4. P. Wightiana.

5. P. Wilsoni. 
1. Polygala bahaménsis Blake, Contr. Gray Herb. II. 47: 64. 1916.

Plant annual with slender roots. Stems erect, 1-4 dm. tall, branched above, and sometimes branched from near the base, the branches glabrous or nearly so; leaves glabrous at maturity, the blades various, those of the lower leaves narrowly obovate to oblong-obovate, those of the upper leaves oblong to linear, 1.5-3.5 cm. long, longer than the lower ones, obtuse or acute, all short-petioled, the midrib prominent beneath; racemes loosely flowered; sepals about 1.5-2 $\mathrm{mm}$. long, the upper one ovate, ciliate, and with gland-tipped hairs; wings $3-4$ $\mathrm{mm}$. long, the blades orbicular-flabellate, several-veined, short-clawed, greenish and purple-tinged; keel about $3 \mathrm{~mm}$. long or rarely larger; petals $2.5-3 \mathrm{~mm}$. long, the blades orbicular-obovate; capsules oval or oval-orbicular, 3-3.5 $\mathrm{mm}$. long, glabrous; seed-body with spreading or reflexed-spreading hairs.

Pine-land, borders of marshes, and roadsides, Great Bahama, New Providence, Andros. Endemic. Referred by Mrs. Northrop to $P$. brizoides St. Hil., and by Small (F). Miami 102) to $P$. corallicola Small, of Florida. Perhaps not distinct from the next following species.

2. Polygala Krùgii Chodat, Mem. Soc. Phys. Hist. Nat. Geneve 31²: 63. 1893

Plant annual with slender root. Stems erect, 3-6 dm. tall, sparingly branched, especially above, the branches glabrous; leaves glabrous, the blades various, those of the lower leaves oblong-obovate to narrowly oblong, those of the upper ones narrowly oblong, oblong-elliptic to almost linear, or rarely somewhat broadened upward, 1.5-3.5 $\mathrm{cm}$. long, longer than the lower ones, all obtuse or acutish, short-petioled, the midrib and lateral veins prominent beneath when dry; racemes very loosely flowered; sepals about $1.5 \mathrm{~mm}$. long, the upper one ovate, ciliate especially near the apex and glandless; wings $3.5-4 \mathrm{~mm}$. long, the blades depressed-orbicular, rounded, few-veined, purple-tinged, shortclawed; keel 4.5-5 mm. long; petals about $3 \mathrm{~mm}$. long, the blades flabellate; capsules oval or nearly so, about $3.5 \mathrm{~mm}$. long, glabrous; seed-body about 1.5 mm. long, with spreading hairs.

Scrub-lands, pine-lands, and savannas, Great Bahama, New Providence, Andros. Endemic. KRUG's POLYGaLA.

\section{Polygala spathulàta Griseb. Cat. Pl. Cub. 13. 1866.}

Plant perennial or sometimes annual, deep-green, glabrous. Stems slender, usually several or many from a woody base, spreading, $0.3-2.8 \mathrm{dm}$. long; leaves numerous, whorled in 4 's, the blades cuneate to obovate or somewhat spatulate, sometimes nearly as wide as long, 7-9 mm. long or rarely longer, abruptly pointed, entire or obscurely toothed, obscurely punctate, glabrous, sessile or nearly so; racemes few-flowered, rather slender, permanently short, the bracts persistent, ovate, about $0.5 \mathrm{~mm}$. long; pedicels about as long as the bracts, deciduous; flowers spreading; sepals bright-green, the upper one ovate or ovalovate, the lower ones ovate, glandular-ciliate, ali about $1 \mathrm{~mm}$. long; wings fully $2.5 \mathrm{~mm}$. long, the blade obovate or oblong-obovate, acute or acutish, whitish with green veins, short-clawed; corolla about $2 \mathrm{~mm}$. long, the petals broad, united to above the middle, often erose; capsules oblong, fully $2 \mathrm{~mm}$. long, nearly as long as the wings or shorter; seeds narrowly oblong-ovoid, less than $2 \mathrm{~mm}$. long, with spreading or reflexed hairs, the aril-lobes much more than $\frac{1}{2}$ as long as the seed-body.

Rocks, pine-lands, palm-lands, and borders of coppices, Great Bahama, New Providence, Andros, Great Exuma :-Cuba. Spatulate-Leaved Polygala.

4. Polygala Wightiàna Blake, Contr. Gray Herb. II. 47: 87. 1916.

Plant annual, not fleshy, slender, glabrous, dark-green. Stems solitary or several together arising from a slender root, simple above or sparingly branched, the branches very slender; leaves few, whorled at the principal nodes, occa- 
sionally opposite or alternate, the blades oblanceolate to spathulate, acute, or those of the upper leaves linear or nearly so, 1-1.5 $\mathrm{cm}$. long, longer than those of the lower leaves, acute; racemes slender, spike-like, elongate in age, acute at the apex, the bracts caducous, and the pedicels deciduous at maturity; pedicels about $0.5 \mathrm{~mm}$. long; flowers spreading or ascending; sepals pale-green and scarious-margined, the upper one broadly ovate, the lower ones narrowly ovate, all $1 \mathrm{~mm}$. long or less; wings about $1.5 \mathrm{~mm}$. long, the blade oval, shortclawed, the center greenish, the margins whitish; corolla about $1.5 \mathrm{~mm}$. long, the petals very broad, united at the base, obtuse; capsules suborbicular, 1.5-2 $\mathrm{mm}$. long, as long as the wings or slightly longer; seeds oblong-ovoid, about 1.5 $\mathrm{mm}$. long, covered with short spreading hairs, the caruncle less than $\frac{1}{2}$ the length of the body.

Swampy grounds, marly shores, and limestone rocks, New Providence, Andros, Acklin's Island, Crooked Island and Mariguana. Endemic. Wight's Polygala.

\section{Polygala Wilsoni Small, sp. nov.}

Plant annual, fleshy, stout, glabrous, bright-green. Stems usually several or many together arising from the top of the stout root, simple or occasionally branched, usually near the base or near the inflorescence; leaves numerous, whorled on the lower part of the stem, alternate above, the blades of the lower leaves cuneate or obovate, obtuse, mucronate or apiculate, those of the upper leaves spatulate, oblong or linear, mostly 1-2 cm. long, longer than those of the lower leaves, minutely spine-tipped; racemes stout, greatly elongate in age, acute at the apex, the bracts fugacious and the mature pedicels deciduous from the rachis; pedicels about $1 \mathrm{~mm}$. long; flowers not drooping; sepals bright green, the upper one ovate, the lower ones lanceolate, all less than $2 \mathrm{~mm}$. long; wings about $3 \mathrm{~mm}$. long, the blade oval or obovate, short-clawed, the center greenish-yellow, the margins white; corolla about $2.5 \mathrm{~mm}$. long, the petals very broad, united to near the apex, rounded; capsules oblong-ovoid, 4-5 mm. long, much surpassing the wings; seeds broadly clavate, about $3 \mathrm{~mm}$. long, covered with spreading hairs, the caruncle less than one half the length of the body.

Type collected on the Angulla Isles, Salt Key Bank, Bahamas, May, 1909, Wilson 8030. Related to Polygala praetervisa Chodat; differing in the very fleshy foliage, the relatively larger parts throughout, the narrower ipper sepal, and the capsule, which is long-exserted beyond the wings. Wilson's Polygala.

\section{BADIÈRA DC. Prodr. 1: 334. 1824.}

Evergreen shrubs or trees, with alternate entire subcoriaceous leaves, and small or minute greenish or white flowers in short axillary racemes. Sepals distinct, nealy equal, the two inner (wings) somewhat larger than the others, but not petal-like. Petals 3, the upper ones about twice as long as the wings, adnate to the stamen-tube at the base. Stamens 8 , the filaments united into a tube. Ovary 2-celled, often pubescent. Capsule 2-celled, but one of the cells often abortive, coriaceous, margined, compressed. Seeds pubescent or nearly glabrous. [Dedicated to Badier, an early French botanical collector.] About 10 species, of the West Indies. Type species: Polygala diversifolia L.

\section{Badiera oblongàta Britton, Bull. N. Y. Bot. Gard. 5: 314. 1907.}

Polygala oblongata Blake, Contr. Gray Herb. II. 47: 13. 1916.

A shrub, $1.5 \mathrm{~m}$. high, or less, with long slender appressed-puberulent branches. Leaves coriaceous, dull, $1.7-3 \mathrm{~cm}$. long, 0.8-1.8 cm. wide, oblong or obovate-oblong, somewhat revolute-margined in drying, the midvein rather prominent, the lateral veins few and inconspicuous, sparingly pubescent with 
short appressed hairs on both sides when young, becoming glabrous or nearly so when old, rather bright-green above, pale-green beneath, acute at the base, obtuse or emarginate at the apex, the pubescent petioles about $2 \mathrm{~mm}$. long; flowers clustered in the axils, puberulent, on pedicels $2 \mathrm{~mm}$. long or less; exterior sepals about $0.7 \mathrm{~mm}$. long, suborbicular, green; corolla white, about 2.5 $\mathrm{mm}$. long; carina unguiculate, obtuse; capsule nearly triangular, shallowly emarginate, about $8 \mathrm{~mm}$. long and wide, subacute at the base.

Scrub-lands and coppices, Andros, New Providence; Cat Island; Acklin's Island; Crooked Island; Watling's Island; North Calcos ; Providenclales :-Cuba. Recorded by Dolley as Badiera domingensis Jacq. ObLong-Leaved Badiera.

\section{Family 12. EUPHORBIÀCEAE J. St. Hil.}

\section{SPURge FAMily.}

Monoecious or dioecious herbs, shrubs or trees, with acrid often milky sap. Leaves opposite, alternate or verticillate. Flowers sometimes much reduced and subtended by an involucre which resembles a calyx (Euphorbiae), the number of parts in the floral whorls often differing in the staminate and pistillate flowers. Ovary usually 3-celled; ovules 1 or 2 in each cavity, pendulous; styles mostly 3, simple, divided, or many-cleft. Fruit mostly a 3-lobed capsule, separating, often elastically, into 3, 2-valved carpels from a persistent axis. Seeds anatropous; embryo in fleshy or oily endosperm, the broad cotyledons almost filling the seed-coats. About 250 genera and over 4000 species, of wide distribution.

A. Ovules 2 in each ovary-cavity; plants not milky.

1. Fowers petaliferous.

2. Flowers apetalous.

a. Fruit capsular or baccate; styles slender.

* Staminate flowers with a rudimentary ovary; spiny shrub or tree.

* Staminate flowers without a rudimentary ovary. Trees, shrubs or woody vines.

Leaves normal; branches not flattened into phyllodia.

Flowers in leafy-bracted panlcles; frult indehiscent, baccate.

Flowers axillary ; fruit dehiscent.

Leaves obsolete; branches flattened into phyllodia.

Annual or perennial herbs.

b. Fruit drupaceous; styles dllated.

B. Ovule 1 in each ovary-cavity.

1. Flowers not in an involucre, or involucre closed. (SeePera.)

a. Fllaments inflexed at the top.

b. Fllaments stralght.

* Flowers in forked cymes.

Petals coherent; tree or shrub with cordate leaves.

Petals distinct; shrubs or herbs.

** Flowers not in forked cymes.

t Lobes of the staminate calyx valvate.

Staminate flowers with petals.

Flowers of both kinds apetalous.

Stamens few or many, distinct or united. Flowers not in a closed involucre.

Anther-sacs globose to oblong.

Shrubs or trees; anther-sacs oblong.

Pubescence of simple halrs. Pubescence stellate.

Herbs; anther-sacs globose.

Anther-sacs elongated, often flexuous.

Flowers in a globose closed involucre when young.

1. Savia.

\section{Securinega.}

\section{Cicca.}

4. Margaritaria.

5. Xylophylla.

6. Phyllanthus.

7. Drypetes.

\section{Croton.}

9. Curcas.

10. Adenoropium.

11. Argythamnia.
12. Adelia.

13. Lasiocroton.

14. Mercurialis.

15. Acalypha.

16. Pera. 
Stamens very numerous, the filaments re-

2. Flowers in a caiciform or cyathiform involucre.

Involucre calciform, the glands internal.

Involucre regular, the glands external. trees. peatedly forked.

†† Lobes of the staminate calyx imbricated, or calyx wanting.

Flowers in branched racemes.

Flowers spicate or in simple racemes.

Bracts small; shrubs or trees. Calyx of the staminate flowers cieft or lobed.

Filaments distinct.

Filaments connate.

Anthers 2; ovary 6-9-celled. Anthers 3 ; ovary 3-celled.

Calyx of the staminate flowers none or rudimentary.

Bracts large, membranous, at first enclosing the inflorescence; large tree.

Glands of the involucre inframarginal; shrubs or

Glands of the involucre marginal.

Plants leafless or leaves small and rudimentary. Plants fleshy, cactus-like; bractlets foliaceous.

Plants woody, jointed; bractlets not foliaceous.

Plants normally leafy; herbs, rarely shrubs or

17. Ricinus.

18. Manihot.

19. Bonania.

20. Hippomane.

21. Grimmeodendron.

22. Gymnanthes.

23. Hura.

24. Pedilanthus.

25. Adenorima.

26. Euphorbia.

27. Arthrothamnus. trees.

Inflorescence terminai.

Stem topped by an umbel; stipules none. 28. Tithymalus.

Stem not topped by an umbel; stipules gland-like.

Inflorescence axillary or axillary and terminal.

Leaves equilateral, ternate or verticillate; shrubs or trees.

Leaves inequilateral, opposite; mostiy herbs.

\section{Poinsettia.}

30. Aklema.

31. Chamaesyce.

\section{SÀvIA Willd. Sp. Pl. 4: 771. 1806.}

Trees or shrubs, with alternate stipulate leaves, the inflorescence racemose or short-cymose. Flowers petaliferous, dioecious or monoecious. Male flowers: sepals 5, subequal, imbricated; petals small; stamens 5, alternate with the petals; filaments separate above their insertion; anthers erect; rudimentary ovary slightly 3 -fid. Calyx of the female flowers as in the male. Capsule 3 celled, the cocci 2-valved; seeds exarillate; endosperm fleshy; cotyledons plane. [Commemorates Gattano Savi, professor at Pisa, died 1844.] About 6 West Indian species. Type species: Croton sessiliflorum $\mathbf{S w}$.

\section{Savia bahaménsis Britton, Torreya 4: 104. 1904.}

A shrub or tree up to $5 \mathrm{~m}$. high with ascending branches. Leaves oblongobovate, thick, obtuse and rounded at the apex, narrowed at the base, $7 \mathrm{~cm}$. long or less, 1.5-3 $\mathrm{cm}$. wide, dark green, shining and strongly reticulated above, pale green and inconspicuously reticulated beneath; petioles stout, about $4 \mathrm{~mm}$. long, about as long as the dense clusters of male flowers; fruit glabrous, depressed-globose, slightly and obtusely 3 -lobed, about $8 \mathrm{~mm}$. in diameter.

In thickets, from Abaco southward to Inagua :-Florida; Cuba ; Jamaica. Recorded by Mrs. Northrop as S. erythroxyloides Griseb., of Cuba, which it resembles. MAIDEN-BUSH.

2. SECURINEGA Comm.; Gmel. Syst. 1008. 1791.

Shrubs, the leaves alternate, entire, often small, the flowers clustered or solitary in the axils, monoecious or dioecious, apetalous. Male flowers: 
sepals 5, imbricate; lobes of the disk, or glands, 5, alternate with the stamens; stamens 5 or rarely fewer, filaments free, opposite the sepals; anthers erect, their cells distinct, longitudinally dehiscent; rudimentary ovary more or less evident, slightly or markedly 2-3-fid. Female calyx like the male, the disk subentire; ovary 3-celled; styles distinct, recurved, 2 -fid; ovules 2 in each cell. [Greek, referring to the hard wood of the typical species.] About 8 species of tropical and subtropical distribution. Type species: Securinega durissima Gmel.

1. Securinega Acidòton (L.) Fawcett, Journ. Bot. 57: 68. 1919.

Adelia Acidoton L. Syst. ed. 10, 1298. 1759.

Securinega Acidothamnus Muell. Arg. in DC. Prodr. 15: 451.1866.

Flueggia Acidothamnus Griseb. Nachr. Gesell. Wiss. Goett. 1865: 164. 1865.

An intricately much-branched shrub $3 \mathrm{~m}$. high or less. Branches strongly flexuous, delicately and sharply spinous; stipules ovate-lanceolate, minute, caducous; leaves petiolate, broadly obovate, obtusely rotund, rigid, densely and prominently reticulate-veiny, pale beneath, 6-8 $\mathrm{mm}$. long, 2-6 $\mathrm{mm}$. broad; male flowers glomerate-fasciculate; female flowers solitary; styles connate below, bifid, the branches broadly $2-3$-lobed; fruit at first fleshy, obtusely trigonal; seeds smooth, pallid.

Coppices and scrub-lands, Andros, New Provldence, Cat Island, Great Exuma and Long Island:-Cuba to St. Jan and St. Crolx; Jamaica. Securinega.

\section{CICCA L. Mant. 1: 17, 124. 1767.}

A tree with distichous entire leaves and small monoecious flowers in leafybracted lateral panicles. Calyx 4-parted, the segments unequal, imbricated. Petals none. Male flowers with 4 distinct stamens, the anthers extrorse. Female flowers with a several-delled ovary, the styles 2 -cleft; ovules 2 in each cell. Fruit baccate, indehiscent. Seeds angular, pendulous. [Greek, wonderful tree.] A monotypic genus.

1. Cicca dísticha L. Mant. 1: 124. 1767.

Phyllanthus distichus Muell. Arg. in DC. Prodr. 15: 413.1866.

A tree, up to $12 \mathrm{~m}$. high. Leaves ovate, pointed, 5-7.5 $\mathrm{cm}$. long. Flowers panicled, the panicles many-flowered, lateral, arranged along aphyllous branches, the male and female mixed in the same fascicles; filaments alternating with exterior glands; ovary $4(3)$-celled; fruit depressed-globose, angled, the angles as many as there are seeds; seeds smooth.

Adventitlous after cultivation at Fresh Creek, Andros:- Spontaneous after cultivation in Florida and the West Indies; native of southern Asla. OTAHEITE Gooseberry. Gooseberry-tree.

\section{MARGARITÀRIA L. f. Suppl. 66, 428. 1781.}

Trees, shrubs or woody vines, with glabrous alternate entire leaves, and small dioecious flowers, solitary or few together in the axils. Calyx usually 4-parted. Disk urceolate. Staminate flowers usually with 4 distinct stamens. Pistillate flowers with a 3-5-celled ovary and 3-5 distinct styles; ovules 2 in each cavity. Fruit capsular, 3-5-lobed. [Greek, pearl-like.] Four known species, of tropical and subtropical America. Type species: Margaritaria nobilis L. $\mathrm{f}$. 


\section{Margaritaria bahaménsis (Urban) Britton \& Millspaugh.}

Phyllanthus bahamensis Urban, Symb. Ant. 3: 289. 1902.

A small tree about $7 \mathrm{~m}$. high. Leaves obovate-elliptic, oblong or lanceolate, $2.5-8 \mathrm{~cm}$. long, 8-25 mm. broad, obtuse or acute, shining above, pallid beneath; flowers produced from between the stipules on short, few-leaved branchlets; outer sepals ovate, inner orbicular, margin membranous; disk beyond the stamens plane, the margin free and undulate-crenate; anthers orbicular-ovate; styles 3, spreading, each 2-lobed; fruit solitary, shortpeduncled, depressed-globose, 3-lobed, about $8 \mathrm{~mm}$. broad.

Coppices, scrub-lands and pine-lands, Abaco, Andros, New Providence and Eleuthera. Endemic. Reported by Coker as Phyllanthus virens Muell. Arg. BaHAMA Margaritaria.

\section{XYLOPHÝLLA L. Mant. 2: 147, 221. 1771.}

Aphyllous tree-like shrubs, with flat leaf-like coriaceous branches (phyllodia). Male and female flowers mingled in glomerate or fasciculate clusters in the serratures of the phyllodia; calyx 5-6-parted; staminal column entire or divided, surrounded by as many glands as stamens; anthers transversely dehiscent; ovules 2 in each ovary-cavity; styles 3 , depressed, laciniate or 2-cleft. Fruit capsular. Seedlings, and sometimes shoots from stumps, bear small normal leaves. [Greek, woody-leaf.] About 10 species of the West Indies and Brazil, the following typical.

1. Xylophylla Epiphyllánthus (L.) Britton; Small, Fl. Florida Keys 76. 1913.

Xylophylla latifolia L. loc. eit. 1771.

Phyllanthus falcatus Sw. Fl. Ind Occ. 1115. 1800.

A shrub, .75-2 m. high. Phyllodia subcompressed, scattered or distichous, lanceolate to rhomboid, serrate above, $5-13 \mathrm{~cm}$. long, $0.8-2 \mathrm{~cm}$. broad; sepals red; staminal column entire or trifid, anthers subsessile, spreading, the cells distinct, ovoid-globose; styles slender, recurved above, 2-4-fid; capsule sessile, subglobose, about $3 \mathrm{~mm}$. in diameter.

Rocky places near the coast, Andros and the Biminis southward to Grand Turk Island:-West Indies. Referred by Dolley to Phyllanthus angustifolius Sw. of Jamaica. Abraham-rush. HARDHEad. Scipio-bush. Sword-bush. Races differ widely in size and shape of the phyllodia. Catesby, 2: pl. 26.

\section{PHYLLÁNTHUS L. Sp. Pl. 981. 1753.}

Annual or biennial herbs. Leaves alternate, entire, often so arranged as to appear like the leaflets of a compound leaf. Flowers monoecious, apetalous, a staminate and a pistillate one often together in the axils. Calyx mostly 5-6parted, the lobes or sepals imbricated. Stamens usually 3 . Ovules 2 in each cavity; styles 3, each usually 2-cleft. [Greek, leaf-flower.] Over 50 species, of wide distribution. Type species: Phyllanthus Niruri L.

Stem and branches straight.

Seeds longer than broad, evenly ridged.

Seeds as broad as long, unevenly papillate-lined. Stem and branches zlgzag.

1. P. Niruri.

2. P. pruinosus.

3. P. pentaphyilus.

\section{Phyllanthus Nirùri L. Sp. Pl. 981. 1753.}

Annual; herbaceous. Leaves distichous, 1.5-2 mm. long, subsessile, obovateoblong, rounded at the apex or mucronate, glabrous, pale beneath; stipules setaceous, persistent; pedicels axillary, from 1-6 times exceeded by the leaf; 
calyx-segments 5, ovate; anthers sessile on the top of the column, globose, contiguous; styles short, included; eapsule depressed-globose, $2 \mathrm{~mm}$. broad; seeds evenly striated on the back.

Sandy nlaces and cultivated grounds from Andros to Turks Islands :-Bermuda ; Florida; West Indies and continental tropical America; Old World tropics. GaLEOF-WIND.

2. Phyllanthus pruinòsus Poepp.; A. Rich. in Sagra, Hist. Cub. 11: 216. 1850.

Phyllanthus saxicola Small, Bull. N. Y. Bot. Gard. 3: 428. 1905.

Annual or perennial, glabrous; stem $0.5-4 \mathrm{dm}$. tall, simple or irregularly branched. Leaves relatively numerous, erect or nearly so, leathery, oblong, oblong-obovate or cuneate, 4-12 mm. long, obtuse, entire, bright-green, shortpetioled; flowers very short-pedicelled; calyx of the female flowers less than $3 \mathrm{~mm}$. wide at maturity its lobes obovate; disk rather angular; capsule spheroidal, barely $2 \mathrm{~mm}$. wide; seeds less than $1 \mathrm{~mm}$. long and nearly as wide, urevenly papillate-lined.

From Great Bahama southward to Acklin's Island:-Florida; Jamaica; Cuba. Recorded as $P$. radicans in Field Mus. Bot. $2: 151$. Rock PHyLlanthus.

3. Phyllanthus pentaphýllus C. Wright; Griseb. Nachr. Ges. Wiss. Goett. 1865: 167. 1865.

Annual; stems terete, wiry, slender, nearly prostrate, divaricately branched, zig-zag. Leaves obovate, $8-12 \mathrm{~mm}$. long, the base acute, the apex rounded or obtuse, the margin entire and slightly revolute; petiole about $1 \mathrm{~mm}$. long; male flowers glomerate, the clusters about 8-12-florous, short-pedicelled; sepals ovate, obtuse, white; anthers 2 ; female flowers solitary, pedicellate, the pedicels bisetaceous at the base; sepals not white-margined; styles very short, 2-lobed, recurved; capsule small, depressed, about as long as the fruiting pedicel; seed minutely striate, the faint lines more scaly than papillate.

Low sandy meadows, Eleuthera and Mariguana:-Florida; Cuba. TuFted Phyllanthus.

\section{DRYPÈTES Vahl, Eclog. 3: 49. 1807.}

Shrubs or trees. Leaves coriaceous, glabrous; stipules deciduous; flowers axillary, fasciculate, dioecious. Calyx 4-6-partite, its lobes imbricated. Petals none. Stamens 4-6(8-2), distinct; anthers ovoid, introrse. Ovary 2-1-celled its cells 2-ovuled. Fruit drupaceous, usually monospermous by abortion. [Greek, a drupe.] About 10 species, of Florida, the West Indies and Brazil. Type species: Drypetes glauca Vahl.

Sepals 4, ovary 2-celled; frult 6-11 mm. in diameter.

Sepals 8 , ovary 1-celled; fruit about $2 \mathrm{~cm}$. in diameter.

Leaves ovate, mostly blunt.

Leaves lanceolate, aristo-mucronate.

1. D. lateriflora.

2. D. diversifolia.

3. D. mucronata.

1. Drypetes lateriflòra (Sw.) Krug \& Urban, Bot. Jahrb. 15: 357. 1892.

Schaefferia lateriflora Sw. Prodr. 38. 1788.

Shrub, or sometimes a tree $9.5 \mathrm{~m}$. high. Leaves petiolate, oblong or elliptic, 5-11.5 $\mathrm{cm}$. long, acute or short-acuminate at base and apex, entire, shining, delicately reticulate-veined beneath; flowers in dense axillary clusters; pedicels shorter than the petioles; calyx campanulate; sepals oblong to ovate, obtuse, pubescent without; stamens 4; drupe subglobose, 6-11 mm. in dia. meter, dark brown, tomentulose.

Copplces, Great Harbor Cay, Andros, New Provldence, Hog Island, and Cay north of Wide Opening:-Florida; Cuba; Hispaniola; Jamaica. GUIANA PLUM. 
2. Drypetes diversifòlia Krug \& Urban, Bot. Jahrb. 15: 353. 1892.

Drypetes keyensis Krug \& Urban, loc. cit. 354. 1892.

Tree up to $6 \mathrm{~m}$. high; branches terete, grayish, secreting drops of resin in the axils. Leaves of two forms: the lower long-petioled, margin spinosedentate and spinous-acuminate, base rounded; the upper longer-petioled, margin entire, obtuse or subacuminate, the base rounded or obtuse and slightly protracted down the petiole; all ovate, $7-9 \mathrm{~cm}$. long, $3.2-3.8 \mathrm{~cm}$. broad. Inflorescence few-flowered, the pistillate flowers sometimes solitary; calyx yellowish; sepals oblong or cval, sometimes slightly rhomboid, obtuse, pubescent without; stamens 8 ; stigmas slightly oblique; drupe broadly oblong or ovoid, 1.9-2.5 cm. long, tomentulose.

Copplces, Great Bahama, through the larger Berry Islands to Andros and Cay Sal Bank: New Providence; Little San Salvador to Watling's Island; Great Exuma through the Crooked Island Group to Inagua :-Florida Keys. WHITEwood.

3. Drypetes mucronàta C. Wright; Griseb. Nachr. Ges. Wiss. Goett. 1865: 165. 1865.

Shrub 4-5 m. high; branches terete, lenticillate. Leaves petioled, bicolorate, $3.8-7 \mathrm{~cm}$. long, $2.5-3.2 \mathrm{~cm}$. wide, both surfaces strongly reticulateveined, the base obtuse or slightly decurrent on the petiole, rarely slightly inequilateral, the apex mucro-spinescent; female flowers subsolitary; male glomerate or fasciculate; calyx of both sexes about $2 \mathrm{~mm}$. long, pubescent within; stamens longer than the calyx; filaments and anthers pubescent; ovary reddish-hairy; fruit globose, about $2 \mathrm{~cm}$. long, obscurely golden-tomentose.

Rocky copplces of Great Bahama and Andros :-Cuba. SHARP-LEaved Drypetes.

\section{CRÒTON L. Sp. Pl. 1004. 1753.}

Herbs, shrubs or trees, strong-scented, often stellate-pubescent. Leaves mostly alternate, sometimes with two glands at the base of the blade. Flowers spicate or racemose. Staminate flowers uppermost: calyx 4-6-parted (usually 5 -parted); petals usually present but small or rudimentary, alternating with glands; stamens 5 or more. Pistillate flowers: calyx 5-10-parted; petals usually wanting; ovary mostly 3 -celled; ovule 1 in each cavity; styles once, twice or many times cleft. Fruit capsular. Seeds carunculate. [Greek name of the Castor-oil plant.]. Over 600 species, widely distributed. Type species: Croton Tiglium L.

A. Leaves entire or dentate; shrubs.

Leaves discolor.

Leaves narrowly linear, not over $2 \mathrm{~cm}$. long.

Leaves linear to oblong, 3.5-12 cm. long.

Leaves ovate-lanceolate.

Leaves stellate beneath.

Leaves silvery lepidote.

Leaves unicolor.

$\begin{array}{ll}\text { Leaves elliptic-lanceolate, glabrous. } & \text { 5. C.lucidus. } \\ \text { Leaves narrowly lanceolate, stipitate-glandular. } & \text { 6. C.bahamensis. }\end{array}$

B. Leaves deeply lobed; herbaceous.

1. C. rosmarinoides.

2. C. linearis.

3. C. flocculosus.

4. C. Eluteria.

5. C. lucidus.

7. C. lobatus.

\section{Croton rosmarinoides Millsp.}

Croton rosmarinifolius Griseb. Nachr. Ges. Wiss. Goett. 1865: 174.1865. Not Salisb. 1796.

A densely branching shrub 1.25-2 m. high. Leaves subsessile, sublinear, rigid, 8-12 $\mathrm{mm}$. long, obtuse, the margin entire and strongly incurved, densely lepidote beneath; stipules obsolete; inflorescence terminal on very short branch- 
lets. Female flowers: sepals spathulate-lanceolate, obtuse; ovary densely lepidote; styles 4-fid to the middle. Male flowers: petals obovate; stamens 6 ; filaments villous below. Capsule ellipsoid-globose,j densely lepidote; seeds smooth and shining.

Scrub-lands, Cat Island, Great Exuma, Long Island and Atwood Cay :-Cuba. ROSEMARY CROTON.

2. Croton lineàris Jacq. Enum. 32. 1760.

Croton Cascarilla L. Sp. Pl. ed. 2: 1424. 1763.*

Croton Cascarilla linearis Willd. Sp. Pl. 4: 532. 1805.

Croton Cascarilla Benn. Jour. Linn. Soc. 4: 30. As to specimen and deser. 1860.

Croton Fergusonii Small, Fl. SE. U. S. 695. 1903.

A shrub 1-2 m. high, with yellowish, densely stellate twigs. Leaves shortpetiolate, narrowly linear (on young shoots often oblong) $3.8-7 \mathrm{~cm}$. long, 2-6 $\mathrm{mm}$. wide, obtuse, dark and smooth above, silvery or golden with stellate tomentum beneath, narrowing to the biglandular base. Inflorescence racemose, the male 4-8 mm. or more long, the female shorter. Male flowers: sepals 5-6, triangular; petals spatulate, obtuse, ciliate, longer than the sepals; stamens about 15 . Female flowers: sepals narrow, acuminate; petals obsolete or rudimentary. Capsule subglobose, yellowish-floccose; seeds broadly oblong, dark greenish brown, minutely and very shallowly puncticulate, $3 \mathrm{~mm}$. long, $2.8 \mathrm{~mm}$. broad.

Coastal rocks and plains throughout the archipelago to Caicos and Turks Islands:- Florida; Jamalca; Hispanlola. Referred to in Field Mus. Bot. 2: 152 and by Coker as $C$. discolor Willd. Linear-leated Croton. Bay Wormwood. GRANNY-BUSH.

\section{Croton flocculòsus Geisl. Crot. Monog. 14. 1807.}

A low shrub with yellowish-tomentose branchlets. Leaves long-petioled, ovate or ovate-lanceolate, $3.8-10 \mathrm{~cm}$. long, 2-3.5 cm. wide, stellate-scabrous above, stellate-downy beneath, entire, acuminate, the base obtuse, biglandular; glands globose-scutelliform, sessile; inflorescence terminal, racemose, $3.5 \mathrm{~cm}$. long; seeds ovoid-lenticular, dark grayish green, scattered shallow-poculate, $2 \mathrm{~mm}$. long, $1 \mathrm{~mm}$. broad.

Waste places near Nassau, New Providence:-Hispaniola; Guadeloupe; Martinique; Barbados. Referred by Dolley to $C$. flavens $\mathrm{L}$., which it resembles.' Rock BALSAM.

4. Croton Elutèria (L.) Sw. Prodr. 100. 1788.

Clutia Eluteria L. Sp. Pl. 1042 (ante). 1753.

Clutia Cascarilla L. loc. cit. (post). 1753.

Croton Cascarilla Benn. loc. cit. 30, as to references.* 1860.

A silvery-shining shrub or small tree, $2-4 \mathrm{~m}$. high, with a rich spicy odor; branchlets rusty-lepidote. Leaves ovate-lanceolate, entire or repand, bluntpointed, long-petioled, $3.2-7.6 \mathrm{~cm}$. long, 12-16 $\mathrm{mm}$. broad near the rounded base, dark and glabrous above, minutely silvery-lepidore beneath, minutely pellucid-punctate; stipules early deciduous. Inflorescence in terminal racemes 3.7-5 cm. long. Female flowers: petals white, villous on the margin; styles bipartite, the branches 2-fid. Male flowers: stamens 10-12. Seeds oval-oblong, biconvex, opaque, blotched, $8 \mathrm{~mm}$. long, $6 \mathrm{~mm}$. broad.

Coppices, becoming scarce, Great Harbor Cay of the Berry Group southward to Mariguana. Endemic. CAScarilla Bark. SWEeTwood BarK. Eleuthera Bark. Catesby, 2: $p l$. 46.

* For a detailed consideration of Croton Cascarilla see Field Mus. Bot. 2 : 306-8. 
5. Croton lùcidus L. Syst. ed. 10, 1275. 1759.

Croton Hjalmarsonii Griseb. Fl. Br. W. I. 40. 1859.

Croton lucidus pubigerus Griseb. loc. cit. 1859.

A broad shrub 1.5-2 m. high; branchlets glabrous or glabrescent. Leaves elliptic to oblong-lanceolate, 5-15 $\mathrm{cm}$. long, 2-4 $\mathrm{cm}$. wide, glabrous or pubescent, minutely pellucid-punctate, entire, narrowing to a roundish base and apex; petiole about one-fourth the length of the blade; stipules ephemeral. Inflorescence in terminal racemes. Male flowers: sepals ovate, imbricative, much smaller than those of the female, ciliate on the margin; female flowers: calyxlobes oblong, blunt, margin reduplicate, somewhat persistent at the base; styles 4-partite, the branches bifid to near the base. Seeds ovoid-oblong, shining, flattish on the ventrum, the dorsum convex.

Rocky thickets and openings, throughout the archipelago from Great Sturrup Cay south to Grand Turk Island:-Cuba; Porto Rico; Jamalca and the Caymans. Croton glabellum of Schoepf. FIRE-BUSH.

An examination of the type, and many specimens, indicates that $C$. Hjalmarsonii is but a race of this species which develops many interspersing races, differing in the size of the leaves and in pubescence, both in Jamaica and in the Bahamas.

6. Croton bahaménsis Millsp. Field Mus. Bot. 2: 308. 1909.

A shrub 1-2 m. high with a peppery odor; branchlets white stellatetomentose. Leaves lanceolate, 3-7 cm. long, 7-17 $\mathrm{mm}$. broad, acuminate, mucronate, base slightly oblique and rounded, with 2 patellate glands, green above and equidistantly stellate-pubescent, densely stellate-pubescent beneath, the margin subentire or crenate-dentate with stipitate glands in the sinuses; stipules fimbriate and stipitate-glandular. Inflorescence in dense terminal racemes. Female flowers: calyx-segments oblong, stellate-pilose; styles 4-fid to the base and villous with moniliform hairs. Male flowers: calyx nonglanduliferous; petals white, cymbiform, the apex minutely fimbriate; stamens 35-50. Capsule globose, deeply sulcate, glabrous below but long-pilose in the sulci and at the apex; seeds brownish black, the rugae rib-like.

Open pastures and in thickets bordering openings, Eleuthera and Long Island to Mariguana. Endemic. Referred to in Field Mus. Bot. 2: 153, and by Hitchcock as C. humilis L.; by Grisebach and by Dolley as C. humilis origanifolius. BAHAMA CROTON. PEPPER-BUSH.

\section{Croton lobàtus L. Sp. Pl. 1005. 1753.}

A low herb, 3-6 dm. high, the branches and branchlets pilose, the longer hairs simple. Leaves membranous, 3-5-lobed, glabrous, papillate, the segments elliptic to elliptic-lanceolate, acuminate, serrate; petioles nearly as long as the blades. Female flowers: calyx-lobes spathulate-lanceolate, glanduliferous and with a few long acicular hairs; styles free or nearly so, 3-8-fid at the apex. Male flowers: sepals glabrous; petals lanceolate. Capsule globose-ellipsoid, the cocci with a number of scattered acicular hairs; seeds ochre-color, quadrangularcylindric, $5 \mathrm{~mm}$. long, $3 \mathrm{~mm}$. broad, the dorsum apiculate at the caruncle, all the facets marked by incomplete and more or less transverse ridges.

Adventitious in waste places, New Providence, near Nassau :-West Indies; continental tropical America. IOBED CroToN. neous.

Schoepf's record of Croton argenteum L., as Bahamian, is, presumably, erro-

\section{CúRCAS Adans. Fam. Pl. 2: 356. 1763.}

Glabrous or nearly glabrous trees or shrubs with petioled, lobed or entire leaves, and monoecious flowers in compound or simple cymes. Calyx 5-lobed or 5-parted. Corolla gamopetalous, the petals united to or above the middle. Stamens about 10, in 2 series. Ovary 2-3-celled; ovules 1 in each cavity. Fruit a capsule, splitting into 2 or 3 valves. [Malabar name.] Perhaps 10 species, natives of tropical regions, the following typical. 
1. Curcas Cúrcas (L.) Britton \& Millspaugh.

Jatropha Curcas L. Sp. Pl. 1006. 1753.

Curcas indica A. Rich. in Sagra, Hist. Cub. 11: 208. 1850.

A small tree or sometimes shrubby, 2-5 m. high. Leaves subcordate, roundish, angular or obsoletely 3-5-lobed, glabrous or glabrate, the petiole about as long as the blade; stipules deciduous; inflorescence in contracted cymes; calyx 5-partite; corolla yellow, 5-partite, villous within, twice as long as the calyx; stamens 10-15; styles bifid, cohering below; capsule oval, slightly fleshy, 3-4 cm. long; seeds oblong, nearly $2 \mathrm{~cm}$. long.

Waste grounds, New Providence :-Bermuda; West Indies; continental tropical America ; Old World tropics.

\section{ADENÒROPIUM Pohl, Pl. Bras. 1: 12. 1827.}

Monoecious or rarely dioecious perennial herbs, or shrubs, with entire lobed or divided leaves, the flowers in eymes. Staminate flowers on the upper parts of the cymes, with a corolla-like 5-lobed calyx, 5 distinct petals, the stamens usually several or numerous. Pistillate flowers in the lower forks of the cymes; capsule ovoid or subglobose, easily separating into 2-valved carpels. [Greek, glandular bush.] Eighty species or more of tropical and subtropical distribution. Type species: Adenoropium ellipticum Pohl.

\section{Adenoropium gossypifòlium (L.) Pohl, Pl. Bras. 1: 16. 1827.}

Jatropha gossypifolia L. Sp. Pl. 1006. 1753.

Herbaceous; stem 6-10 dm. high, branched. Leaves ciliate or glanduliferous on the margin, 3-5-partite or 3-5-lobed, pubescent, glabrescent beneath or glabrous, the segments ovate, pointed, denticulate or entire; petiolar and stipular glands branched; inflorescence in contracted cymes; calyx 5-parted; corolla twice as long as the calyx; petals obovate, deep purple, spreading; stamens 8-12; stigmas 2-branched; capsule truncate at both ends, 3-sulcate, about $1 \mathrm{~cm}$. in diameter. America.

Waste grounds, New Providence:-Florida; West Indies; continental tropical

\section{ARGYTHÁMnIA Sw. Prodr. 39. 1788.}

Low shrubs containing purple pigment. Leaves simple, entire or dentate, stipulate. Inflorescence in few-flowered, axillary subsessile racemes; flowers short-pedicellate, the 1-3 inferior pistillate. Flowers monoecious. Calyx 4-5parted, valvate. Petals of staminate flowers 4 or 5 ; stamens 4 or 5 cohering at the very base and surrounding a central rudiment, anthers subglobose, introrse; discal glands 4 or 5. Styles cut into 3-8 branches. Capsule 3-coccous. [Greek, silvery bush.] Some 35 species, all American. Type species: Argythamnia candicans Sw.

Leaves lanceolate to oblanceolate or obovate.

Leaves entire, subsessile, yellow-sericeous ; styles 3-4-fid.

Leaves denticulate, petiolate, silvery-sericeous ; styles 2-fid.

Leaves ovate to ov́ate-lanceolate.

1. A. sericea.

2. A. argentea.

3. A. lucayana.

1. Argythamnia serícea Griseb. Fl. Br. W. I. 44. 1859.

A low leafy shrub entirely covered with silky down. Leaves obovate, mucronate, entire, subsessile, sericeous, $1.5-3 \mathrm{~cm}$. long, 10-17 $\mathrm{mm}$. broad, the 
principal veins 3 or 4 on each side, straightish, prominulous, parallel to the cuneate leaf-base; stipules lanceolate, setaceous, persistent, $1 \mathrm{~cm}$. long; inflorescence in contracted scorpioid racemes. Male flowers 3 or 4 , one above the other, 2-3-bracteolate, short-pedicellate, $2 \mathrm{~mm}$. long; calyx 5-parted, the segments lanceolate; petals reddish, lanceolate, cut at the obtuse apex; glands of the disk alternate with the petals; stamens 5, as long as and opposite the petals, the filaments slightly cohering at the base. Female flowers subsolitary, inferior, short-pedicellate; calyx as in the male; petals none; styles $3-4$-fid with linear, unequal branches. Capsule depressed, carpels subglobose; seeds punctate-scabrous, $1 \mathrm{~mm}$. in diameter.

Open white-lands and dunes, Fortune Island and Inagua. Endemic. SiLky ARgYTHAMNIA.

\section{Argythamnia argéntea Millsp. Field Mus. Bot. 2: 154. 1906.}

Argithamnia lanceolata Pax \& K. Hoffm. Pflanzenreich 147: 79. 1912.

A small shrub, branching from the base; branches canescent, densely leafy. Leaves lanceolate, attenuate at both ends, short-petioled, 1.5-3.5 $\times .6-1 \mathrm{~cm}$., margin sparingly and slightly dentate above, silvery-sericeous; stipules broad, cuspidate. Inflorescence in axillary racemes. Male flowers 3 ; sepals 4 , ovatelanceolate; petals 4, thick; sepals similar, shorter; bract 1, scaphoid. Female flowers 3 ; sepals elongate-lanceolate; petals minute, ligulate, alternate with the glands of the disk; styles 3 , bifurcate nearly to the base, the apex bilobed; orary canescent. Capsule and seeds unknown.

Scrub-lands, Inagua, Castle Island, Grand Turk and South Caicos :-Hispaniola. SILVERY ARGYTHAMNIA.

\section{Argythamnia lucayàna Millsp. Field Mus. Bot. 2: 154. 1906.}

A small branching ascending or prostrate shrub, the branches minutely sericeous, sparsely leaved, 3-5 dm. long. Leaves sessile, elliptic- or obovatelanceolate, bluish green, $2.5-3.5 \times 1-1.5 \mathrm{~cm}$., the apex acute or short-acuminate, the margin entire or very minutely and remotely glandular-denticulate, sparsely and minutely strigose-pilose when young, glabrous when mature; racemes 6-10 $\mathrm{mm}$. long, 4-6-flowered. Male flowers: sepals deltoid-lanceolate equaling the spatulate, pilose petals; stamens 4 , glabrous. Female flowers: lobes lanceolate, acuminate; petals minute, narrowly-lanceolate, obtuse, paleaceous, many times shorter than the sepals; ovary villous; styles villous, 2-3-dichotomous, the terminal divisions short. Seeds globose, dark brown, apiculate, $1.5 \mathrm{~mm}$. diam., anastomose-reticulate, the surface coated with a hydnum-like porous integument.

Rocky and sandy coppices, Berry Islands and Andros to Eleuthera, Long Island, Caicos and Inagua. Bahama specimens previously referred to $A$. candicans Sw., to which the specles is related, belong here. Endemic. BaHama Argrthamnia.

\section{ADÈLIA L. Syst. ed. 10, 1298. 1759.}

[Bernardia P. Br. Hist. Jam. 361. Hyponym. 1756.]

Shrubs with serrate stipulate leaves pubescent with simple hairs and dioecious flowers. Male flowers in axillary amentaceous spikes, each flower sessile in the axil of a bract; calyx 3-5-parted; stamens 15-20, distinct, the interior central and mixed with some glands; anthers cruciate-globose, 4-celled, 2 cells anterior. Female flowers few or solitary, subterminal, 3-bracteate; calyx 5-6parted, biseriate; styles 3, short, lacerate-crenate. [Greek, referring to the inconspicuous flowers.] A few species of tropical America, the following typical. 
1. Adelia Bernárdia L. Syst. ed. 10, 1298. 1759.

Bernardia carpinifolia Griseb. Fl. Br. W. I. 45. 1859.

Berrardia dichotoma Müll. Arg. Linnaea 34: 172. 1865.

Bernardia Bernardia Millsp. Fiel.7 Mus. Bot. 2: 58. 1900.

A tomentose shrub .75-3 m. high. Leaves petioled, ovate-oblong, 4-8 cm. long, rounded at the biglandular base, tapering from the middle to a bluntish point, obtusely serrate, tomentose beneath, primary veins distant, prominulous beneath; stipules setaceous, $2 \mathrm{~mm}$. long. Male spikes sessile, 6-12 mm. long, tomentose; bracts oval, acute; calyx-lobes $3-5$, ovate, acute, nearly equalling the stamens; central disk minute; anthers yellow. Capsule densely appressedpubescent; seed ovate, acute, $5 \times 4 \mathrm{~mm}$., nearly smooth, brown with darker brown markings, the dorsum strongly keeled, ventral surface flattened, a small rounded prominence on each side of the hilum above and a minute dark raised point at the extremity of the keel.

Coppices and thickets, Eleuthera, Cat Island, Watling's Island, Rum Cay, Fortune and Acklin's Islands:-Cuba to Porto Rico; Jamaica. Referred by Hitchcock to Bernardia mexicana (H. \& A.) Muell-Arg. AdeliA.

\section{LASIOCRÒTON Griseb. Fl. Br. W. I. 46. 1859.}

Shrubs or trees, with broad stellate-tomentose leaves. Inflorescence monoe. cious, in axillary spikes, the female flowers few and inferior. Male calyx 4-partite; stamens 7-14, inserted upon a minute disk; anthers oblong, adnate, the cells curved, introrse. Ovary globose, markedly 3-carpellate. Seeds globose, ecarunculate. [Greek, velvety Croton.] A few West Indian species. Type species: Lasiocroton macrophyllus Griseb.

1. Lasiocroton bahaménsis Pax \& K. Hoffm. Pflanzenreich, 63: 61. 1914.

Lasiocroton micranthus Pax \& K. Hoffm. loc. cit. 1914.

A high leafy tomentose shrub, or a tree up to about $8 \mathrm{~m}$. high. Leaves long-petioled, roundish or ovate to ovate-lanceolate, $5 \times 2.3-10 \times 7 \mathrm{~cm}$., truncate to cordate at the base, bluntish, entire or repand on the thickish subrevolute margin, pale green above, golden-tomentose beneath; secondary veins transverse, strongly reticulate; petioles articulated at the estipulate base. Inflorescence densely many-spicate near and at the ends of the branchlets; spikes short-pedunculate; bracts including a glomerule of 3-5 male flowers. Male flowers densely tomentose; calyx valvate; sepals 3 -angular; stamens distinct, included; filaments purple, as long as the anthers. Female flowers sparse, scattered near the base of the spike, densely pubescent; calyx-lobes 5 , unequal, reflexed, ovate, blunt; disk large, flat, 5-crenate; styles 2-3, thick, entire, spreading. Capsule tomentose; seeds smooth, ashen; raphe distinct, delicate.

Rocky plains, Andros, Eleuthera, Great Ragged Island :-Cuba. Referred by Mrs. Northrop to L. macrophyllus (Sw.) Griseb., of Jamaica. WILD OAK. LIGHTWOOD. BITTERS.

\section{MERCURIÀIIS L. Sp. Pl. 1035. 1753.}

Annual or perennial herbs or shrubs, the leaves opposite, often dentate. Inflorescence mostly dioecious, the male in more or less elongate spikes or racemes. Flowers apetalous. Male flowers: calyx membranous, sepals 3 , valvate; stamens 8-20; filaments distinct; anthers subglobose, opening lengthwise. Female flowers: sepals 3 ; ovary 2-celled; styles 2, distinct or nearly so; stigmas entire. Capsule generally 2-carpelled; seeds solitary in each carpel; testa smooth or tuberculate. [The herb of Mercury.] About 7 species, natives of the Old World, the following typical. 
1. Mercurialis ánnua L. Sp. Pl. 1035. 1753.

A weak glabrous annual 2-6 dm. high. Leaves thin, ovate to lanceolate, $3-6 \times 1.5-2.5 \mathrm{~cm}$., narrowed at the base, acute or acuminate at the apex, crenate or serrate with rounded teeth; petioles somewhat less than half the length of the blade; male flowers in interrupted spikes longer than the leaves; female flowers clustered in the axils. Capsule 2-carpelled, 4-5 mm. broad, hispid; seeds ovoid, $2.5 \times 2 \mathrm{~mm}$., grayish green, densely shallow-pitted.

Adventitlous in waste grounds near Nassau, New Provldence:-Bermuda; Delaware to Texas. Native of Europe. Herb Mercury.

\section{ACALỲPHA L. Sp. Pl. 1003. 1753.}

Herbs or shrubs. Stems mostly erect. Leaves alternate, stipulate. Flowers in spikes or spike-like racemes; staminate cluster often peduncled, each flower in the axil of a minute bractlet, with a 4-parted calyx and 8-16 stamens united at their bases. Pistillate flowers subtended by a foliaceous bract, which often equals or overtops the staminate, the calyx 3-5-parted; petals wanting in both kinds of flowers; capsule usually of 3, 2-valved carpels, each 1-seeded. [Greek, nettle.] About 250 species, mostly tropical and subtropical. Type species: Acalypha virginica $\mathrm{L}$.

Inflorescence densely cylindric.

Inflorescence loosely splcate.

Female bracts cleft to about the middle.

Plants perennial, prostrate.

Plants annual, erect.

Female bracts cleft to the base.

\section{A. alopecuroidea.}

2. A. chamaedrifolia.

3. A. ostryaefolia.

4. A. setosa.

\section{Acalypha alopecuroìdea Jacq. Ic. Rar. 3: 19. 1793.}

Herbaceous, annual, 1-3 dm. high. Leaves broadly ovate, $5-7 \times 3-4.5 \mathrm{~cm}$., appressed-pubescent, membranous, flaccid, truncate or slightly cordate at the base, $\overline{5}$-nerved, cuspidate-acuminate, serrate, the petiole as long as the blade or longer; spikes terminal, closely flowered, $5 \mathrm{~cm}$. long; female bracts 1-flowered, membranous, ovate-triangular, 7-9 $\mathrm{mm}$. long, 3-5-lacerate to the base; calyxlobes ovate, acute; ovary hirsute above; styles elongated, delicate, attenuate, entire or shortly bifid; earpels slightly keeled; seeds ovoid, apiculate, $1 \times .8$ $\mathrm{mm}$., reddish-brown; testa densely and minutely pitted-cellular; caruncle waxen, longitudinal, linear.

Adventitious in waste places, Abaco and New Providence :-Cuba ; Porto Rico; Jamaica; Mexico; Central America; Caribbean coast of South America. Referred by Dolley to Acalypha polystachya Jacq. SPICATE ACALYPHA.

2. Acalypha chamaedrifòlia (Lam.) Muell. Arg. in DC. Prodr. 15²: 879. 1866.

Croton chamaedrifolius Lam. Encycl. 2: 215. 1786.

Acalypha reptans Sw. Prodr. 99. 1788.

A prostrate herbaceous or suffrutescent perennial, pubescent or glabrate, with branches $1-3 \mathrm{dm}$. long. Leaves ovate, .8 $\times .5-3.5 \times 1.5 \mathrm{~cm}$., base blunt or rounded, apex acute, margin crenate-dentate; petioles about one-third the length of the blades; inflorescence in cylindric terminal subsessile androgynous racemes, male above and few-flowered female below, sometimes with similar superaxillary racemes or female clusters, the flowers sessile; bracts roundish, dentate or crenate, the teeth ovate, seeds ovate-globose, apiculate, brown, $3 \times 1 \mathrm{~mm}$.; testa very minutely pitted-cellular; caruncle longitudinal, waxen, wrinkled.

Red-lands and rocky copplces, Eleuthera :-Florida; Cuba; Hispaniola to Tortola and Guadeloupe; Jamaica. Prostrate Acalypha. 
3. Acalypha ostryaefòlia Ridd. Syn. Fl. W. States 33. 1835.

Acalypha caroliniana Ell. Bot. S. C. \& Ga. 2: 645. 1824. Not Walt. 1788. Acalypha persimilis Mueli. Arg. Linnaea 34: 25. 1865.

An erect, rather stout annual, dark green, minutely pubescent, 2-8 dm. tall. Leaves thin or membranous, ovate, 5-10 cm. long, base obtuse or cordate, apex short-acuminate, margin closely and sharply serrate; petiole often as long as the blade; inflorescence spiciform, the male and female separate; male bracts minute, the female conspicuous, lobed; capsule strongly depressed, short, thick, 2-6-laciniate above; seeds reddish-brown, ovoid-globose, apiculate, the testa warty-wrinkled; caruncle flat, papyraceous, fusiform.

Waste grounds near Nassau, New Providence:-New Jersey to Kansas; Southeastern United States to Mexico; Cuba ; Porto Rico. Hornbea ACALYPHa.

\section{Acalypha setòsa A. Rich. in Sagra, Hist. Cuba 11: 204.1850.}

An erect annual 3-6 dm. tall, the younger parts hirtulo-pubescent. Leaves ovate, thin, 3-5-nerved, $4-7 \times 2.5-5 \mathrm{~cm}$., base obtuse or slightly cordate, apex short-acuminate, margin finely-serrate; inflorescence monoecious, in cylindric spikes, the male axillary, lax-flowered, the female terminal, dense-flowered, 3-5 cm. long; female bracts 2-flowered, ovate, 5-6 mm. long, 7-13-partite, the divisions laciniate, papillo-scabrous; calyx-lobes ovate-lanceolate, ciliate; styles short, thick, 2-6-laciniate above; seeds reddish-brown, ovoid-globose, apiculate, $1.4 \times 1 \mathrm{~mm}$.; testa densely papillo-punctate; caruncle a single straight membranous line.

Waste grounds near Nassau, New Providence:-Cuba; Hispaniola; Porto Rico; Mexico to Costa Rica. Setosn ACalypha.

\section{PÈrA Mutis, Vet. Akad. Stockh. 5: 299.1784.}

Glabrous or pubescent trees, the leaves alternate, short-petioled, entire, coriaceous, penninerved. Inflorescence dioecious or rarely monoecious, pisiform, in the axils of the leaves and at old nodes, short-pedicelled or subsessile, 2-3bracteate. Flowers sessile in small involueres, very small, apetalous; involucres globose, gaping or valvate in anthesis; disk none. Male flowers: calyx minute, valvate, 2-3-fid, or rudimentary or wanting; stamens $2-6$; filaments connate at or near the base; anthers dorsally fixed at or near the base, the cells longitudinally contiguous and dehiscent. Female flowers: calyx none or reduced to scales; ovary 3-celled; styles short; stigmas thick, peltate, disciform, or 3lobed; ovules solitary in each cell. Capsule globose or pyriform; pericarp firm, dehiscent into 3, 2-cleft valves; seeds ovoid or obovate, compressed; testa crustaceous, black and shining; endosperm thick, fleshy; cotyledons plane, broad. [Greek, a pouch.] About 25 species, of tropical America. Type species: Pera arborea Mutis.

\section{Pera bumeliaefòlia Grisè. Nachr. Ges. Wiss. Goett. 1865: 180. 1865.}

A small tree up to $12 \mathrm{~m}$. high, or shrubby, with slender branches, the petioles and involucres densely ferrugineous-lepidote. Leaves olive-green, $7-9 \times 2-3 \mathrm{~cm}$., elliptic-lanceolate, obtusely acuminate, narrowed to the petiole, shining above, dull and sparsely lepidote-punctate beneath; petioles about 1.5 cm. long, slender; male calyx globose-ellipsoid, 4-5-lacerate-dentate (as many toothed as there are anthers); capsule oliviform, the pericarp transversely sharp-wrinkled when dry; seeds flattened-pyriforrs, gaping open at the apex, black and shining, minutely shallow-punctate, $5 \times 3.5 \mathrm{~mm}$.

Coppices of Andros and New Providence:-Cuba. Pera. Black Ebovy. 


\section{RÍCINUS L. Sp. Pl. 1007. 1753.}

A tall stout monoecious herb, glabrous and glaucous, with alternate large peltate palmately lobed leaves, and numerous small apetalous greenish flowers in terminal racemes, the pistillate above the staminate. Staminate flowers with a 3-5-parted calyx, the segments valvate, and numerous crowded stamens; filaments repeatedly branched. Pistillate flowers with a caducous calyx. Capsule subglobose, or oval, separating into 3, 2-valved carpels. Endosperm fleshy and oily. [Latin name of the plant.] A monotypic genus.

\section{Ricinus commùnis L. Sp. Pl. 1007. 1753.}

Stem erect, 1-5 m. tall, more or less branched, becoming tree-like in warm regions. Leaves nearly orbicular in outline, 1-6 dm. broad, 6-11-palmately lobed and peltate, the lobes toothed, acute or acuminate; capsule $12-16 \mathrm{~mm}$. in diameter, usually spiny; seeds shining, smooth, black, variegated with white, or mottled with gray and brown markings.

Adventitious in waste places on New Providence and Cat Islands:-Bermuda; North Carolina to Florida, Texas and Mexico; West Indles; continental tropical America. Native of the Old World tropics. Castor-oil Plant.

\section{MÁNIHOT Adans. Fam. Pl. 2: 356. 1763.}

Monoecious herbs or shrubs of vigorous growth, generally with glaucous glabrous leaves. Leaves alternate, the blades entire or palmately 3-7-lobed, the segments membranous or leathery, entire or lobed. Flowers apetalous, in branched racemes, the staminate with a calyx of 5 partially united sepals; stamens 10, in 2 series; filaments slender, those of the inner series attached to the lobes of the disk; anthers opening lengthwise. Pistillate flowers with a calyx similar to that of the staminate but the tube often shorter; ovary 3 celled; styles 3, slightly united at the base; ovules solitary in each cell. Capsule 3-celled; seeds solitary in each carpel. [Name Brazilian.] About 80 species of South America, the following typical.

1. Manihot Mánihot (L.) Cockerell, Bull. Torr. Club 19: 95. 1892.

Jatropha Manihot L. Sp. Pl. 1007. 1753.

Herbaceous; stems 0.8-1.5 m. high, more or less branched. Leaves 3-7parted, the segments linear to elliptic or slightly broadest above the middle, acute or acuminate, entire; petiole about as long as the blade or longer; bracts shorter than the pedicels; calyx campanulate, 6-8 $\mathrm{mm}$. long, its lobes ovate, obtuse, about as long as the tube; calyx of the pistillate flowers with a shorter tube than that of the staminate.

Reappearing after cultivation, Andros and Eleuthera:-Widely cultivated and more or less persistent in tropical and subtropical regions. Native of South America. Cassava.

\section{BONÀNIA A. Rich. in Sagra, Hist. Cuba 11: 201. 1850.}

Low glabrous shrubs with alternate coriaceous leaves and axillary spicate monoecious flowers. Leaves short-petioled, small, entire or glandular-dentate or serrate. Disk none. Male flowers 3 from each bract, subsessile; calyx membranous, the margin truncate or broadly and slightly 2-3-lobed. Stamens 2 (rarely 3 ); filaments free, short; anthers small, the cells dis- 
tinct, ovoid, parallel-contiguous; rudimentary ovary none. Female flowers solitary at the base of the spike, sessile or pedicelled; calyx 3-fid; ovary 3 -celled; styles 3 , distinct or slightly connate at the base, slender, recurvedspreading, entire; ovule 1 in each cell. Capsule globose; cocci 2-valved; seeds globose, estrophiolate. [Commemorates Sebastian Bonani.] About 6 species of Cuba and the Bahamas. Type species: Bonania cubana A. Rich.

1. Bonania cubàna A. Rich. in Sagra, Hist. Cub. 11: 201, pl. 68. 1850.

Excoecaria cubana Muell. Arg. Linnaea 32: 122. 1863.

A much branched shrub about $2 \mathrm{~m}$. high with shining leathery glabrous leaves. Leaves $12-18 \times 6-11 \mathrm{~mm}$., ovate, obtuse, sometimes slightly emarginate, distinctly nerved, glandular-crenate; petioles short; stipules ovate; male spikes 12-16 mm. long, slender; bracts 1-3-flowered; calyx sessile, about $1 \mathrm{~mm}$. long, urceolate, its lobes short, entire; anthers subincluded; capsule flattenedglobose, smooth, slightly 3-sulcate; seed globular, grayish, $3 \mathrm{~mm}$. in diameter, smooth, flecked with a few minute, scarcely perceptible, yellowish markings.

Thickets, coppices and rocky plains, Andros, New Providence, Eleuthera, Cat Island, Great Exuma and Long Island:-Cuba. BoNANIA.

\section{HIPPOMÀNE L. Sp. Pl. 1191. 1753.}

Trees with glabrous leaves and acrid poisonous milky juice. Leaves alternate, coriaceous, with rather long petioles. Flowers in terminal monoecious amentaceous spikes, the rachis stout, the male above the female in clusters of $8-15$, subtended by 2-glandular bracts; calyx membranous, 2-3lobed; stamens 2-3, exserted; filaments more or less united; anthers erect, extrorse. Female flowers: calyx ovoid, 3-parted, closely surrounding the ovary and furnished with several glands; ovary 6-8-celled, sessile; styles 6-8, recurved, stigmatic on the inner surface; ovules 1 in each cell, pendulous, anatropous. Drupe slightly 6-8-ridged, variegated, the pulp milky, the endocarp bony, 6-8-celled; seeds elongated, flattened. [Greek, horse-poison.] A monotypic genus.

\section{Hippomane Mancinélla L. Sp. Pl. 1191. 1753.}

An evergreen tree 4-20 m. high. Leaves shining, glabrous, thickish, ovate or oval, 4-10 cm. long, blunt or somewhat narrowed at the base, acute or short-acuminate, undulate or slightly shallow-serrate; principal veins at nearly right angles to the midrib; veinlets delicately reticulate; petioles slender, somewhat shorter, or at times longer, than the blades; stipules 4-8 mm. long; bracts broader than long, crenulate; male calyx with 3 unequal acute lobes; female calyx of ovate or orbicular sepals; drupe spheroidal when fresh, $2.5-3.5$ $\mathrm{cm}$. in diameter, yellowish; nut depressed, often bearing numerous grouped thorn-like projections.

Rocky coppices and white-lands, Abaco, Andros, Great Guana Cay, Atwood Cay, Fortune Island, Inagua, Providenciales and Anguilla Islands :-FIorida ; West Indies ; Mexico and continental tropical America. ManchionesL. Catesby, 2: pl. 95.

\section{GRIMMEODÉNDRON Urban, Symb. Ant. 5: 397. 1908.}

Glabrous trees or shrubs. Leaves alternate, petiolate, crenate-serrate. Inflorescence in terminal monoecious spikes; flowers apetalous; disk none. Male flowers: calyx 3-lobed or 3-fid, membranous, the lobes valvate; stamens 3; 
filaments coalescent near the apex of the column; anthers exserted beyond the calyx, their sacs ovoid, longitudinally contiguous and dehiscent; rudimentary ovary absent. Female flowers: calyx 3 -fid; ovary 3 -celled; styles coalescent below, patent above, thick, undivided at the apex. Capsule spherical or depressed, sessile, 3-sulcate. Seeds ovate-globose. [Greek, Grimm's tree.] Two known species, the following typical, the other endemic in Jamaica.

\section{Grimmeodendron eglandulòsum (A. Rich.) Urban, Symb. Ant. 5: 398.} 1908.

Stillingia eglandulosa A. Rich. in Sagra, Hist. Cub. 11: 202. 1850.

Excaecaria Sagraei Muell. Arg. Linnaea 32: 121.1863.

Excaecaria eglandulosa Muell. Arg.; DC. Prodr. 15: 1209. 1866.

A shrub or a tree up to $8 \mathrm{~m}$. high. Leaves shining, oblong to oblong-lanceolate, $3-8 \times 1-2.5 \mathrm{~cm}$., base obtuse or narrowed to the mostly 2-glandular petiole, apex bluntly pointed, margin subserrulate with hooked-spinous teeth; male flowers 2 or 3 ; capsule $5-7 \times 8-9 \mathrm{~mm}$; seeds ovoid-globose, $4 \times 3.2 \mathrm{~mm}$., cinnamon-brown, marked with dark brown blotches and points.

Low copplces, Andros, New Provldence, Great Exuma and Watling's Island:Cuba. Porson Bush.

\section{GYMNÁNTHeS Sw. Prodr. 95. 1788.}

Evergreen trees or shrubs with glabrous leaves and milky juice, the leaves alternate. Flowers monoecious or rarely dioecious, the male in slender axillary bracteolate racemes, the female solitary, long-peduncled, arising from the axils with the male; perianth rudimentary or lacking. Stamens 2 or 3 ; filaments distinct or united at the base, subtended by the rudimentary perianth of 3 , scale-like parts. Styles 3, recurved. Capsule 3-carpelled; seeds pendulous, the testa membrano-crustaceous. [Greek, naked flower.] About 12 species, of tropical America. Type species: Gymnanthes elliptica $\mathbf{S w}$.

1. Gymnanthes lùcida Sw. Prodr. 96. 1788.

Excoecaria lucida Sw. Fl. Ind. Oce. 2: 1122. 1800.

An evergreen shrub or tree often $10 \mathrm{~m}$. high. Leaves petioled, glabrous, coriaceous, oblong or lanceolate-spatulate, $5-11 \mathrm{~cm}$. long, narrowed at the base, shining above, the margin undulate and generally obscurely toothed near the apex; racemes shorter than the leaves, continuous; bracts reniform; stamens 2 or 3 , subtended by bractlets; female flowers solitary on curved peduncles somewhat shorter than the racemes; ovary stipitate; capsule depressed, about $1 \mathrm{~cm}$. broad; carpels rounded; seeds ovoid, $5 \times 4 \mathrm{~mm}$., gray, striped longitudinally with fine golden-brown lines of irregular width and form.

Coppices, from Allen's Cay throughout the archipelago to Inagua and Atwood Cay :- Florida and the West Indies. CraB-wood.

\section{HÙRA L. Sp. Pl. 1008. 1753.}

Large glabrous trees with milky juice, and large many-carpelled, flattenedglobose fruits, the broad cordate leaves shining, biglandular above the base of the blade. Inflorescence monoecious, in terminal, oval or oblong, long-peduncled spikes; male flowers densely imbricated above, the female at the base or in the inferior axils. Calyx cupuliform, irregularly toothed; staminate column central, bearing below its verticillate projections an indefinite number of sessile 
extrorse anthers. Style simple, infundibuliform at the apex; stigma manylobed, with hanging subulate branches. Capsule deeply sulcate into many cocci; seeds rounded, compressed. [Aboriginal name.] Two or three species of tropical America, the following typical.

\section{Hura crépitans L. Sp. Pl. 1008. 1753.}

A high, umbrageous tree, the trunk and branches often prickly. Leaves variable in shape, roundish, about $5-7 \mathrm{~cm}$. in diameter, cordate at the base, abruptly acuminate, serrate or subentire, the blade often shorter than the petiole; stipules linear-lanceolate, pubescent; anthers usually 1-3-seriate; stigma large, violet-red; capsule concave at both ends, splitting noisily when ripe and dry, 7-8 $\mathrm{cm}$. broad, 3-4 $\mathrm{cm}$. high.

Planted in Nassau, New Providence, and perhaps spontaneous after cultivation :West Indies and Mexico to tropic America. SANDBox-TrEe.

\section{PEDILÁNTHUS Poit. Ann. Mus. Paris 19: 390. 1812.}

Shrubs with fleshy branches and milky juice, alternate leaves with the midrib thickened beneath (rarely leafless), glandular stipules (if present), opposite floral leaves, and cymose terminal or axillary involucres. Involucres oblique, shoe-shaped, the tube more or less fissured superiorly and notched inferiorly at the bilabiate apex or throat, with 2 lateral and 1 median accessory lobes more or less closing the fissure, the tube bearing an appendix on the superior side of its posterior extremity. Appendix gibbous and interiorly glandular, its lip notched or 2-3-lobed and extending anteriorly above the posterior end of the fissure of the tube. Flowers pedicellate, the male numerous, ecalyculate, sometimes with linear bracteoles at the base; female single with the long style finally protruding and generally declinate from the throat of the tube; stigmas 3, connate, often separate at the apex and frequently 2-lobed. Seeds ecarunculate. [Greek, slipper-flower.] About 30 species. Type species: Euphorbia tithymaloides L.

Leafy ; appendix 4-glandular.

Leafless; appendix 2-glandular.
1. P. tithymaloides.

2. P. bahamensis.

\section{Pedilanthus tithymaloides (L.) Poit. Ann. Mus. Paris 19: 390. 1812.}

Euphorbia tithymaloides L. Sp. Pl. 453. 1753.

Branched, 1.2-1.8 m. high; leaves glabrous, subsessile, cuneate at the base, ovate or oblong, $3.5-7.5 \mathrm{~cm}$. long, apex acute often recurved, margin subundulate, the mid-vein prominently undulate-carinate beneath. Cymes terminal, dense; floral leaves ovate, long-acuminate, slightly longer than the peduncles, early deciduous; involucres purple, 1.1-1.3 $\mathrm{cm}$. long; tube thin, smooth; appendix 4-glandular the lobe linear short; male pedicels hairy, the female glabrous; style shortly bifid; capsule $7.5 \mathrm{~mm}$. long, $9 \mathrm{~mm}$. broad, truncate at base and apex; cocci keeled; seeds ovate, $5 \mathrm{~mm}$. long.

Waste places and in coppices, Andros and Cat Island:-Florida; West Indies ; Mexico; Central and Caribbean South America. Slipper-plant. FiddLe-flower.

\section{Pedilanthus bahaménsis Millsp. Field Mus. Bot. 2: 359. 1913.}

Glabrous, 1-1.5 m. high, leafless, irregularly branched, the branches gray, roughened with transverse ridges. Inflorescence terminal; bracts cucullate, one third to one quarter the length of the peduncles; involucres about $9 \mathrm{~mm}$. long, 
puberulent, madder-lake in color; inferior cleft of the tube shallow, the superior fissure open half the length of the tube; main lobes blunt, finely erose-lacerate, the two lateral lobes minute, free only at the apex, the fifth lobe flabelliform, free half its length; anthers glabrous; female pedicel puberulent; style very slightly trifid; appendix narrow, about one half the length of the tube, sarcous, usually sigmoid, the lobe blunt, slightly notched, strongly gibbous at the base; glands 2, stipitate; capsule flattened-globose; seeds trigonal, olivaceous, the dorsal angle quite prominent, apiculate and with a minute raised pimple at the apex, $3 \times 2.5 \mathrm{~mm}$.

Stony floor of scrub-lands, Deep Creek, Andros, Atwood Cay, Acklin's Isiand, Inagua, South Caicos and Grand Turk to Salt Cay. Endemic. BAHAMA FIDDLEFLOWER. MONKEY-FIDDLE.

\section{ADENORIMA Raf. Fl. Tellur. 4: 112. 1838.}

Trees with thick branches and profuse thick milky juice. Leaves clustered at the ends of the branches, entire. Cymes corymbose, terminal and superaxillary. Involucres large; glands 4, on the outer wall of the involucre below its lip. Styles more or less connate below, bifid into long branches, the apices rarely thickened. Capsule 3-coccus; seeds smooth, ecarunculate. [Greek, gland-pit.] Fifteen species, or more, of the West Indies and Mexico. Type species: Euphorbia punicea $\mathrm{Sw}$.

\section{Adenorima gymnonòta (Urban) Millsp.}

Euphorbia gymnonota Urban, Symb. Ant. 5: 396.1908.

Euphorbiodendron gymnonotum Millsp. Field. Mus. Bot. 2: 305.1909.

A tree, 6-6.5 m. high, the branches fleshy, dichotomous. Leaves alternate, linear-oblanceolate, $4-8 \times .8-1 . .4 \mathrm{~cm}$., entire, membranous, narrowed to the sessile base, the apex rounded-mucronate or acute-mucronate; inflorescence 5-7flowered, terminal; bracts crimson, ovate; involucre urceolate, the margin entire or sparingly crenate-dentate; glands 4, ovate to ovate-oblong, vertically placed at or just above the middle of the tube, exappendiculate, fleshy, concave; style short, 3-fid; capsule 3-angled, smooth; seed globose, gray, $4 \mathrm{~mm}$. in diameter, the outer gray coat broken through in places revealing the inner dark, irregular markings.

Margins of thickets, Watling's Island, Crooked, Fortune and Acklin's Isiands ; Little and Great Inagua; South Calcos; Ambergris Cay. Endemic. Referred to in various Bahama publications as Euphorbia punicea Sw. BAHAMA ADENORIMA.

\section{EUPHóRBIA Linn. Sp. Pl. 450. 1753..}

Cactus-like shrubs with thick fleshy, generally angular stems, and few reduced true leaves or none. Leaves and stipules generally represented by spines but often by small or minute caducous bracts. Cymes lateral or terminal, subsessile, often few-flowered or even single-flowered; involucres subtended by dilated bractlets; glands of the involucre entire, exappendiculate. Capsules thick, often ligneous; seeds ecarunculate. [Commemorates Euphorbus, King Juba's physician.] About 30 species, of the Old World. Type species: Euphorbia antiquorum $\mathbf{L}$.

1. Euphorbia láctea Haw. Syn. Pl. Succ. 127. 1812.

A tall, dark-green, many-branched, spinous milky-juiced shrub, 2-5 m. high, the branches 3 -angled, the faces $3-8 \mathrm{~cm}$. broad, plano-convex, the angles 
repand-dentate, compressed on the margin; spines short, thick, divergent, 4-6 mm. long.

Widely established in many places, often forming dense thickets, New Providence, Cat Island, Watling's, Long Island and Inagua:-Florida; West Indies; Mexico. Naturalized from India and the Moluccas. Referred by Hitchcock and Mrs. Northrop to Euphorbia antiquorum L. MOTTLED SPURG.

27. ARTHROTHÁMNUS Kl. \& Gke. Monats. Akad. Berlin 1859: 251. 1859.

Leafless; shrubby plants with jointed branches. Involucres not subtended by dilated bractlets. Leaves reduced to opposite sessile scales glandular on both surfaces; stipules none. Involucres minute, terminal, campanulate, dioecious, minutely bibracteate at the base. Glands transverse, thick, orbicular or semiorbicular, spreading, plane, entire. Bracteoles plumose. Styles 3, bifid, revolute. Seeds ovate-tetragonal, scrobiculate. [Greek, jointed bush.] About 10 species, of tropical America and southern Africa. Type species: Euphorbia Tirucalli L.

1. Arthrothamnus cassythoìdes (Boiss.) Millsp. Field Mus. Bot. 2: 306.1909.

Euphorbia cassythoides Boiss. Cent. Euph. 20. 1860.

Plant 1-2 m. high, the branches white-barked, verticillate below, dichotomous above; branches with internodes $8-15 \mathrm{~cm}$. long and 6-7-angled, the nodes gummy. Cymes terminal, dichotomous; involucres produced between small thick triangular bractlets; tube short-campanulate, glabrous within; lobes triangular-ovate, 4-5-dentate, hairy; glands fleshy; styles short, hairy, bilobate at the apex; capsule ovoid; cocci subcarinate; seeds white, each facet 2-3foveolate. SPURGE.

Sandy soll near Deep and Fresh Creeks, Andros:-Cuba. Leafless Cuban

\section{TITHYMÀLUS [Tourn.] Adans. Fam. 2: 355. 1763.}

Annual or perennial milky herbs or shrubby plants with simple or branched stems topped by several-rayed cyme-like umbels. Leaves below the umbel scattered or alternate, estipulate, often broadened upward; bracts of the umbel quite different from the stem-leaves, entire or toothed. Involucres sessile or peduncled, the lobes often toothed; glands 4, transversely oblong and appearing reniform by the cornuate extremities or appendages. Capsule smooth or tuberculate; cocei rounded or more or less carinate. Seeds variously pitted, often carunculate. [Greek, referring to the milky juice.] About 250 species, of wide geographic distribution. Type species: Euphorbia dendroides L.

1. Tithymalus trichòtomus (H.B.K.) Kl. \& Gke. Monats. Akad. Berlin 1860: 81. 1860.

Euphorbia trichotoma H.B.K. Nov. Gen. 2: 60. 1817.

Perennial, glabrous. Stem commonly branched and more or less woody at the base, the branches erect or ascending, 1-4 dm. tall, widely forking above. Leaves numerous, rather approximate, small, thickish, cuneate to oblong, obtuse or acutish, 5-12 mm. long, minutely erose when mature; inflorescence trichotomous; involucres campanulate, sessile or nearly so, $2 \mathrm{~mm}$. long; glands reniform, $1 \mathrm{~mm}$. long, yellow; capsule tricoccous, the cocci rounded; seeds white, globose, $2 \mathrm{~mm}$. in diameter, smooth; caruncle thin, circular.

Coastal sands. Allen's Cay, Great Bahama and Andros:-Florida; Cuba ; the Cayman Islands. ForKING SPURGE. 


\section{POINSÉtitiA R. Graham, Edin. N. Phil. Jour. 20: 412. 1836.}

Herbs, rarely shrubs, the inflorescence clustered at the tips of the branches, often subtended by highly colored leaves, the leaves alternate below, opposite above, the blades similar throughout or very various in form. Involucral lobes fimbriate; glands sarcous, concave, saucer-, eup- or goblet-shaped, solitary or rarely 3 or 4, marginal, exappendiculate. Capsule exserted, its cocci rounded; seed narrowed upward, generally tuberculate, ecarunculate or with a mere indication of a caruncular body. [In honor of Joel Roberts Poinsette of South Carolina.] About 12 species, mostly American. Type species: Euphorbia pulcherrima Willd.

1. Poinsettia heterophýlla (L.) Kl. \& Gke. Monats. Akad. Berlin 1859: 253. 1859.

Euphorbia heterophylla L. Sp. Pl. 453. 1753.

Euphorbia havanensis Willd.; Boiss. in DC. Prodr. 15: 73, as synonym. 1862.

Euphorbia graminifolia Michx. Fl. Bor. Am. 2: 210.1803.

Annual or perennial, bright green, pubescent or nearly glabrous, mostly erect, 3-10 dm. tall, woody below; branches ascending or the lower often spreading, leafy at the ends. Leaves various even on the same stem, from linear through all shapes to orbicular, entire, dentate, sinuate or even panduriform; involucre-lobes ovate or oblong, laciniate; gland 1, sessile, exappendiculate; seeds ovoid-oblong, pointed, grayish, $2.8 \times 2 \mathrm{~mm}$., minutely and irregularly tuberculate in more or less transverse lines.

Good soil of grassy places and cultivated fields, Abaco and Great Bahama southward to Grand Turk :-Bermuda; Illinois to Montana and southward through the American tropics; West Indies. JACOB's LADDER. GOVERNOR GRANT'S LiverY.

\section{AKLÉmA Raf. Fl. Tellur. 4: 114. 1838.}

Shrubby or rarely herbaceous, the branches jointed. Leaves equilateral, entire, penninerved, cuneate at the base, ternate or verticillate (sometimes opposite), long-petioled; stipules glanduliform. Cymes axillary and terminal, corymbose or paniculate (rarely reduced to a single involucre), the terminal involucres generally hermaphrodite, often many-flowered; glands of the involucre appendiculate; bracteoles between the male flowers numerous, plumose. Capsule depressed, deeply trisulcate; seeds irregularly scrobiculate, ecarunculate. [Greek, not explained.] A few species of tropical America. Type species: Euphorbia nudiflora Jacq.

1. Aklema petiolàre (Sims) Millsp. Ann. Mo. Bot. Gard. 2: 43. 1915.

Euphorbia petiolaris Sims, Bot. Mag. pl. 883. 1805.

Alectoroctonum petiolare Kl. \& Gke. Monats. Akad. Berlin 1859: 248. 1859.

Shrubby or tree-like and $7 \mathrm{~m}$. high, the branches glabrous, swollen at the nodes. Leaves ternate, ovate or orbicular, 1-1.5 cm. long, truncate or almost peltate at the base, obtuse or slightly emarginate, entire, the petiole slender, twice or more the length of the blade; inflorescence subtrifloral, shorter than the leaves; involucres long-pedicelled (6-10 mm.), hemispheric, smooth; lobes ovate, short-fimbriate; glands transverse, ovate, stipitate; styles divaricate, bifid, not thickened at the apex; capsule smooth; cocci obtusely carinate; 
seeds ovoid-globose, $3 \times 2.4 \mathrm{~mm}$, pointed, white, foveolate with numerous large shallow irregular pits.

In a sisal field on South Calcos Island:-Hispaniola; Mona: Porto Rico; Culebra; Vieques; St. Thomas; St. Jan; St. Martin; Anegada ; Tortola ; Martinique and Tobago. BROAD-LeAved SPURGe.

\section{CHAMAESỲCE S. F. Gray, Nat. Arr. Brit. Pl. 2: 260.1821.}

Annual or perennial herbs or shrubs, the stems often diffuse at the base; the branches prostrate or ascending, forking. Leaves opposite, inequilateral, more or less oblique at the base, entire or toothed; stipules minute, entire or lacerate. Inflorescence solitary or capitulate, axillary and terminal; involucre toothed, glandular on the margin; glands 4, naked or appendaged (the 5th gland represented by a sulcus in the margin of the involucral tube). Capsule more or less globose, 3-coccous, the cocci sharply angled or rounded; seeds minute, ovoid or elongated-ovoid, more or less quadrangular, the facets smooth or transversely ridged. [Greek, ground fig.] About 225 species, widely distributed. Type species: Chamaesyce maritima S. F. Gray.

Suffrutescent; leaves thick, mostly entire.

Leaves ovate to elliptlc or oblong.

Inflorescence terminal-axillary; plants glabrous.

Inflorescence throughout the upper axils. Leaves glabrous.

Leaves entire.

Stipules deltoid, acicular-bristled.

Stipules not bristled.

Leaves dentate.

Stipules broad, fimbriate-ciliate.

Stipules narrow, entire, aristate.

Leaves densely tomentose.

Leaves canescent, entire.

Leaves linear or narrowly oblong.

Leaves 2-4 cm. long, involucres peduncled.

Leaves 8-12 $\mathrm{mm}$. long, involucres sessile.

Herbaceous; leaves thin, mostly serrate.

Leaves glabrous.

Inflorescence clustered; leaves oblong, acute, sharply serrate.

Leaves broadly falcate; seeds red.

Leaves narrowly falcate; seeds black.

Inflorescence solitary; leaves ovate, blunt, dentate or entire.

Capsule glabrous.

Capsule hairy on the angles.

Leaves hairy.

Inflorescence clustered.

Leaves ovate to lanceolate, sharp-serrate, acute.

Leaves ovate, crenate-dentate, obtuse.

Inflorescence solitary; leaves orbicular to elliptic, entire or apically denticulate.

1. C. buxifolia.

2. C. Wilsoni.

3. C. lecheoides.

4. C. insulae-salis.

5. C. exumensis.

6. C. cayensis.

7. C. Bracei.

8. C. articulata.

9. C. vaginulata.

10. C. hypericifolia.

11. C. brasiliensis.

12. C. Blodgettii.

13. C. prostrata.

14. C. hirta.

15. C. Berteriana.

16. C. Brittonii.

1. Chamaesyce buxifòlia (Lam.) Small, Fl. SE. U. S. 711. 1903.

Euphorbia buxifolia Lam. Encyc. 2: 421. 1788.

Low, generally erect, glabrous, shrubby, fleshy, 2-5 dm. high; branches usually many. Leaves glabrous, thick, wrinkling in drying, ovate or broadly oblong, 8-12 mm. long, obliquely subcordate at the base, acutish, margin entire, involute; petioles about $1 \mathrm{~mm}$.; involucres campanulate, about $1.5 \mathrm{~mm}$., as long as the peduncles or shorter; glands transversely oblong; appendages a mere whitish bordering line; capsule broad, glabrous; seeds white, ovoid-quadrangular, somewhat apiculate, $1.2 \times 1 \mathrm{~mm}$., the angles very blunt; facets very shallowly broad-pitted by indistinct and irregularly anastomosing transverse ridges.

Maritime sands throughout the archipelago:-Bermuda; Fiorida; coasts of the Gulf of Mexico and the Caribbean Sea. CoAst SPurge. 


\section{Chamaesyce Wilsònii Millsp. Field Mus. Bot. 2: 301. 1909.}

Prostrate, spreading, matted, purplish-cinereous; branches densely numerous, wiry, divaricate. Leaves small, fleshy, ovate, $2-4 \times 1.5-2.5 \mathrm{~mm}$., obliquely auriculate-cordate at the base, obtuse, the margin entire; petioles very short; stipules deltoid, stiff-ciliate; involueres solitary in the upper forkings, cylindric-campanulate, short-pedicellate, the tube glabrous without, densely crisped-pilose within; lobes aristate; glands 4, orbicular, convex, the fifth represented by a large, triangular lobe; appendages rudimentary; styles short; stigmas bilobed; capsule ovoid; cocci slightly carinate; seeds white, ovoid-quadrangular, $1 \times .7 \mathrm{~mm}$., angles comparatively sharp, facets indistinctly marked by low irregular transverse ridges.

White-lands of Castle Island and Grand Turk. Endemic. Wilson's Spurge.

\section{Chamaesyce lecheoìdes Millsp. Field Mus. Bot. 2: 301. 1909.}

Euphorbia lecheoides Millsp. Field Mus. Bot. 2: -163. 1906.

Erect, shrubby, slender, profusely branching, grayish farinose, perennial, 2-3 dm. high; branches diffuse, dichotomous, the inferior internodes about 1 $\mathrm{cm}$. long, the upper branchlets virgate, wiry. Leaves short-petioled, deltoidovate, triangular-ovate or elliptic, $2.5-5 \times 1-2.5 \mathrm{~mm}$., abruptly attenuate at the apex, the margin thickened and revolute; stipules broadly ovate, stiffciliate; involucres solitary, turbinate, short-pedicellate, the tube glabrous without, barbellate at the throat within; lobes triangular, acute, ciliate; glands dark, flattened, orbicular, the face pock-marked; appendages minute, fleshy, or obsolete; stigmas bifurcate to the middle; filaments barbellate; capsule glabrous; seeds reddish-brown, ovoid-quadrangular (the ventral angle indistinct), apiculate, $.8 \times .5 \mathrm{~mm}$., the facets indistinctly transversely rugose.

Scrub-lands of the southwest extremity of Watling's Island, Mariguana, Inagua, South Caicos and Grand Turk to Salt Cay. Endemic. PIN-WEed SPURG.

\section{Chamaesyce insulae-sàlis Millsp. Field Mus. Bot. 2: 395. 1914.}

Perennial, erect, $7-10 \mathrm{~cm}$. high, from a densely nodular rootstock; branches densely tufted, wiry, glabrous, the internodes $1.5-2 \mathrm{~cm}$. long. Inflorescence solitary, terminal and terminal-axillary; leaves opposite, sarcous, glabrous, $2-4 \times 1.5-3 \mathrm{~mm}$., marked only by the thickish midrib, subcordate, acute, entire or in the lowermost indistinctly denticulate, petioles about $1 \mathrm{~mm}$. often with a tuft of ciliae between the base and the stipule; stipules of many forms from deltoid and entire through lanceolate, bifid, and lance-aristate to a mere tuft of ciliae; involucres campanulate, sessile or nearly so, the outer surface smooth, the inner densely woolly; lobes triangular-aristate, densely woolly on the inner recurved surface; glands transversely oval; appendages greenish white, entire or nearly so, about the width of the glands; styles bifid to half their length; capsule glabrous, strongly tricoccous; seed ovoid-quadrangular, $1 \times .7 \mathrm{~mm}$., white, acute, the angles sharp (except the ventral), facets smooth or with a few irregular indistinct ridges.

Sands of Salt Cay (Cay Sal Bank). Endemic. Cay SAL SPurge.

5. Chamaesyce exuménsis Millsp. Field Mus. Bot. 2: 301. 1909.

Perennial, $3 \mathrm{dm} .-1.5 \mathrm{~m}$. high, purplish- or greenish-cinereous; stem erect or reclinate-prostrate; branches strict, denuded below, the nodes somewhat swollen; branchlets subtenuous, divaricate. Leaves thick, ovate, .8-1.1 $\times .6-.8$ mm., short-petioled, obliquely cordate, obtuse or acutish, entire or slightly and remotely dentate near the apex; stipules aristate; involucres terminal and in the upper forkings, turbinate, short-pedicellate, glabrous without, densely barbellate within; lobes triangular, setaceous at the apex; glands 4 (the fifth represented by a larger involucral lobe), ovate, plane; appendages white, 
entire; stamens 5; flaments cristate-barbellate at the base; styles short, deeply bifid; capsule ovoid; cocci acutely carinate; seeds ovoid-quadrangular, the ventral angle obtuse, pinkish gray, $1.1 \times .8 \mathrm{~mm}$., facets slightly and indistinctly anastomose and transversely ridged.

Coastal sands, white-lands and sand-pockets in coastal rocks, Eleuthera, the Exumas, southward to Fortune Island. Endemic. Referred by Mueller to $E u$ phorbia Balbisii Boiss; by Coker to Euphorbia cayensis Millsp.; and in Field Mus. Bot. 2: 161 to Euphorbia flexuosa Kth. ExUMA SPURGe.

6. Chamaesyce cayénsis Millsp. Field. Mus. Bot. 2: 301. 1909.

Euphorbia cayensis Millsp. Torreya 4: 172. 1904.

Low, densely white-canescent; stems stout, ligneous, multinodal, branching below, $2-3 \mathrm{dm}$. high, spreading above. Leaves thick, oval, 4-6 $\times 3-4 \mathrm{~mm}$., obliquely cordate at the base, entire, eanescent alike on both surfaces; petioles 1-1.5 mm.; involucres campanulate, short-peduncled, $1.5 \mathrm{~mm}$., canescent, bearded in the throat; glands green, transversely oblong, thick, tumid, .7 $\mathrm{mm}$. broad (fifth gland represented by a large, deltoid tooth on the involucral margin); appendages lineal, hardly distinguishable; capsule canescent; cocei bluntly keeled; seeds pinkish ashen, ovoid-quadrangular, the ventral angle slight, $1 \times .8 \mathrm{~mm}$., facets distinctly transversely anastomose-ridged.

Coastal white-lands, Man-o'-War Cay (Abaco), the Berry Islands and Joulter's Cays, Anguilla and Water Cays (Cay Sal Bank). Endemic. BaHama Spurge.

\section{Chamaesyce Bràcei Millsp. Field Mus. Bot. 2: 302. 1909.}

Euphorbia Bracei Millsp. Field Mus. Bot. 2: 159. 1906.

Nearly prostrate, branching from the base; branches ligneous, canescent. Leaves thickish, oblong to ovate, $5-8 \times 3-5 \mathrm{~mm}$., very short-canescent and dotted with amber-like resin globules on both surfaces, the base narrowing to the petiole, the apex obtuse, the margin entire, revolute; petiole one-fifth the length of the blade; stipules triangular, 2-toothed or more, the teeth tipped with a stalked dark globular gland; involucres upper-axillary, cup-shaped, the pedicels equalling the tube, canescent without, eiliate within, the inner wall with 5 alate columns from the base to the glands; lobes triangular, acute; glands 4 (the fifth represented by a broader, longer involucral tooth), minute, transversely-ovate; appendages very narrow, crenate, or wanting; stigmas bifurcate to the base; capsule acicular-hairy; seeds ovoid-quadrangular, $.9 \times .7$ $\mathrm{mm}$., very slightly anastomosely transverse-ridged.

White-lands of Abaco and Man-o'-War Cay. Endemic. Brace's Sperge.

8. Chamaesyce articulàta (Aubl.) Britton, Mem. N. Y. Bot. Gard. 6: 574. 1916.

Euphorbia articulata Aubl. Pl. Guian. 1: 480. 1775.

Euphorbia linearis Retz. Obs. 3: 32. 1783.

Shrubby, glabrous, 3-6 m. high, the branches divaricate. Leaves glabrous or slightly canescent, ligulate to oblong-linear or narrowly oblong, 2-6 $\mathrm{cm}$. $X$ 4-6 mm., rounded or narrowed at the oblique base, acute or blunt, mucronulate, entire, glaucous beneath; petioles short; stipules interpetiolar, broadly deltoid, ciliate; involucres single, terminal-axillary; peduncles more or less winged; tube thick, glabrous without, minutely appressed-silky within; involucral lobes wanting, the margin of the tube thickened; glands 4, cup-shaped, with a nipplelike projection at the inner edge (resembling the tip of an elephant's proboscis); bracteoles very numerous, ligulate below, brush-like above; stigma 3 -furcate above the middle; capsule glabrous, strongly 3 -coccous; seed pinkashen, ovoid-quadrangular, $1.5 \times 1 \mathrm{~mm}$., facets transversely anastomose-rugose.

Low scrub-lands near Jacksonville, East Caicos:-Porto Rico to Anegada and St. Vincent. Bushy SPURGe. 
9. Chamaesyce vaginulàta (Griseb.) Millsp. Field Mus. Bot. 2: 302. 1909.

Euphorbia vaginulata Griseb. Fl. Br. W. I. 52. 1859.

A low, densely branched shrub, $2 \mathrm{dm}$. to $2 \mathrm{~m}$. high, the branchlets closely ringed with the old persistent stipular sheaths, giving the whole shrub an ashen hue. Leaves small, 3-15 $\times 1 \mathrm{~mm}$., fleshy, linear (in some specimens globular), glabrous, entire, obtuse, very short-petioled, springing from a broad scaphoid sheath-like stipule with a ciliate margin; involucres solitary, terminal on the branchlets, turbinate, short-pedicelled; tube thick-walled, glabrous without and within; lobes triangular, ciliate; glands 4 , large, orbicular, sarcous, dark purple, the fifth represented by a larger involucral lobe; bracteoles ligulate, glabrous; capsule glabrous, strongly 3-coccous, the cocci mottled with fine dark confluent punctae; seeds ovoid-quadrangular, bluish white, $1.2 \times .8 \mathrm{~mm}$., blunt-pointed, smooth, the testa minutely punctate.

Rocky white-lands of Watling's Island, Castle Island, the Inaguas and throughout the Caicos and Turk's Islands. Endemic. SHEATHed SPURGe.

10. Chamaesyce hypericifòlia (L.) Millsp. Field Mus. Bot. 2: 302.1909.

Euphorbia hypericifolia L. Sp. Pl. 454. 1753.

Annual, erect or ascending, 2-8 dm. Leaves oblong or oblong-lanceolate, often falcate, $1.5-3 \mathrm{~cm} . \times 5-10 \mathrm{~mm}$., obliquely truncate at the base, blunt, more or less sharp-serrate on the upper third, short-petioled, glabrous or somewhat hairy; stipules ovate, acute, thin, dentate and ciliate on the margin; inflorescence densely cymose in the axils of the upper and terminal leaves, the floral bracts linear and often white-margined; involueres turbinate, thin, glabrous without, hirtellous at the throat within; lobes lanceolate-triangular, lacerate into 3-5 teeth; glands small, roundish, stalked, the fifth gland represented by a deep sinus flanked by a larger, inore triangular lobe; appendages white, orbicular or ovate; styles short, deeply bifid; capsule glabrous, strongly 3 -coccous, the cocci carinate; seeds ovoid-quadrangular, red, $.8 \times .6 \mathrm{~mm}$., the angles prominent, the facets marked with many transverse broken ridges.

Open grassy places throughout the archipelago:-Bermuda; Gulf of Mexico region of the United States; Mexico; Central and South America; West Indies. Referred by Mrs. Northrop to Euphorbia nutans Lag. HYPERICU M-LEAVED SPURGE.

\section{Chamaesyce brasiliénsis (Lam.) Small, Fl. SE. U. S. 712. 1903.}

Euphorbia brasiliensis Lam. Encyc. 2: 423. 1788.

Annual, erect or ascending, similar in habit to the last, but with more filiform branchlets, smaller and more falcate leaves, fewer-flowered cymes, and black seeds. Stipules broadly deltoid, bifurcate into lacerate lobes; involucres glabrous without and within, very short-pedicelled; lobes triangular, mostly entire; glands minute, long-stalked, the fifth represented by a very shallow sinus flanked by two larger involucral lobes; capsule glabrous, strongly 3-coccous; seeds ovoid-quadrangular, black, $1.2 \times .9 \mathrm{~mm}$., the strong, but rounded, angles white-edged, dorsal facets marked by 3 complete transverse ridges, ventral 2 -ridged.

Open places and grassy coverts, New Providence and Eleuthera:-Florida to Arizona; Bermuda; Central America to Brazil; West Indies. Braziliax SPURG.

12. Chamaesyce Blodgéttii (Engelm.) Small, Fl. SE. U. S. 712. 1903.

Euphorbia Blodgettii Engelm.; Hitch. Rep. Mo. Bot. Gard. 4: 126.1893.

Annual, glabrous, prostrate or ascending, branching at the base, the branches 1-4 dm. long, forking. Leaves oblong or nearly so, 3-8 mm. long, minutely serrate toward the apex, oblique at the base, obtuse, petiolate; stipules broadly triangular, acute, ciliate-margined; involucres solitary in the 
upper axils, eampanulate, less than $1 \mathrm{~mm}$. long, short-pedunculate, glabrous without, ciliate at the throat within; lobes triangular; glands 4, slightly stalked, orbicular to ovate, the fifth represented by a sinus with a rounded fundus and flanked by two larger, nearly quadrilateral lobes; appendages nearly as broad as the glands, entire or 2-3-crenate; capsule bluntly tricoccous, glabrous; seeds ovoid-quadrangular, pinkish or brownish, $1 \times .8 \mathrm{~mm}$, angles prominent, facets slightly transversely ridged.

On rocks, in sand and in pot-holes, from the southern coast of Great Bahama to Ambergris Cay:- Florida; Bermuda; Cuba; Jamaica; Cavmans. Referred by Mrs. Northrop and by Dolley to Euphorbia serpens Kth., and by Dolley again to Euphorbia maculata L. BLODGETT'S SPURGE.

13. Chamaesyce prostràta (Aiton) Small, Fl. SE. U. S. 713. 1903.

Euphorbia prostrata Aiton, Hort. Kew. 2: 139. 1789.

Annual, prostrate, more or less pubescent, or $\cdot$ glabrate; stems branched at the base; branches slender, .5-15 dm. long, forking. Leaves thin, oblong or ovate, strongly oblique at the base, 4-7 mm. long, obtuse, more or less serrulate toward the apex, minutely pubescent on both sides, petiolate; stipules thin, papyraceous, broadly deltoid, ciliate at the acute apex; involucres glabrous, axillary, minute; lobes elongate-triangular, ciliate on the margin; glands 4, transversely oval, the fifth replaced by a small extra glabrous tooth on the involueral margin; appendages about the width of the glands, finely manyerenate; capsule strongly tricoccous, glabrous except on the keels of the cocei which bear a fringe of long hairs; seeds pink, elongated-ovoid-quadrangular, pointed, 1 ×.5 mm., strongly and sharply sculptured by numerous, strictly transverse, ridges which include the angles.

Grassy places on New Providence and Grand Turk Island:-Bermuda; North Carolina to Missouri and southward to Brasil and Peru; West Indies. Prostrate SPURGe.

14. Chamaesyce hírta (L.) Millsp. Field Mus. Bot. 2: 303.1909.

Euphorbia hirta L. Sp. Pl. 454 (ante). 1753.

Euphorbia pilulifera L. loc. cit. (post). 1753.

Annual, prostrate or ascending, pubescent with amber-colored, multicellular hairs; stems branching from the base, 1-4 dm. long, forking or simple. Leaves ovate to oblong-lanceolate, more or less falcate, 1-3 cm. long; sometimes blotched with deep-red, strongly oblique at the base, acute, sharply serrate above the middle, petiolate; stipules long cylindro-aristate, hairy; involucres densely capitulate in peduncled clusters, turbinate; lobes large, triangular, densely long-ciliate; glands 4, stipitate, the fifth replaced by a shallow, rounded sulcus in the involueral margin; appendages none; capsule strongly 3-coccous, with short crisped multicellular hairs; seeds salmon-pink, elongated-ovoid-quadrangular, $.8 \times .5 \mathrm{~mm}$., the angles sharp, facets strongly marked with numerous, mostly incomplete, transverse ridges.

Rocks, path-sides and cultivated grounds, Andros and New Providence to Inagua :-Bermuda; Florida; Mexico; West Indies; Central America; American and Old World tropics. HAIRx SPURGE.

15. Chamaesyce Berteriàna (Balbis) Millsp. Field Mus. Bot. 2: 303. 1909.

Euphorbia Berteriana Balbis; Spreng. Syst. 3: 794. 1826.

A low, prostrate or ascending, densely pubescent annual, with a clustered terminal inflorescence. Leaves oblong-ovate, obtuse, 1-1.5 $\times .4-6 \mathrm{~mm}$., strongly inequilateral and oblique at the base, obtusely or crenately denticulate; stipules cylindro-aristate with a broadened base, glabrous; inflorescence corymbose at the apices of the smaller branchlets; involucres minute, oblongturbinate, glabrous below, long-eiliate-hairy at the throat without and within; 
lobes triangular, ciliate; glands 4, minute, orbicular, stipitate, with or without narrow white, entire or bi-crenate, appendages; styles thick, bifurcate to the middle, the branches somewhat swollen at the tips; capsule crisped-hairy; oocci distinct; seed white or pinkish, elongated-ovoid-quadrangular, angles sharp and prominent, facets with a few prominent broad, mostly incomplete, transverse ridges.

Red-lands of Great Exuma, Long Island, Atwood Cay, Mariguana and Castle Island :-Hispaniola to Martinique. BERTERo's SPURGE.

16. Chamaesyce Brittònii Millsp. Field Mus. Bot. 2: 303. 1909.

Euphorbia Brittonii Millsp. Field Mus. Bot. 2: 159. 1906.

A low, slender, erect herb branching from the base, 5-7 cm. high; branches wiry, ascending. Leaves thick, short-petioled, rotund or oblong-elliptic, $4 \times 3$ $\mathrm{mm}$., slightly oblique-cordate, entire or subdentate, revolute, midrib prominent beneath, under surface glaucous, pilose; stipules triangular, more or less equally fimbriate; involucres solitary in the axils, campanulate, pedicellate, glabrous without, densely tomentose at the throat within; glands ovate, greenish; appendages large, orbicular, white; stamens pilose; stigmas bifureate above; capsule smooth; seeds roseate-cinereous, ovoid-quadrangular, the ventral angle flattened, facets slightly transverse-rugose.

White-lands near Nassau, New Providence. Endemic. Britrox's Sptrae.

[Sapium laurifolium Griseb., reported by Dolley as Bahamian, has not been seen on the islands by any of our investigators; his record is presumably erroneous.]

\section{Order 14. SAPINDÀLES.}

Mostly trees or shrubs. Petals usually present and separate. Sepals mostly distinct. Stamens rarely more than twice as many as the sepals, when as many or fewer, opposite them. Ovary superior, compound. Ovules pendulous, with the raphe away from the axis of the ovary, or erect or ascending.

Petals wanting.

Petals present.

Ovary mostly 1-celled; plants with resin-bearing tissues. Fam. 2. Anacardiaceae.

Ovary 2-several-celled.

Leaves simple, pinnately veined.

Ovule 1 in each ovary-cavity.

Ovules 2 or more in each ovary-cavity.

Flowers with a disk and petals.

Disk obsolete; corolla wanting.

Leaves compound; fruit various.

Fam. 1. BuXACEAE.

Fam. 3. ILICACEAE.

Fam. 4. Celastraceae.

Fam. 5. DOdonaeaceas.

Fam. 6. SAPINDACEAE.

\section{Family 1. BUXÀCEAE Dumort.}

\section{Box FAMILY.}

Monoecious or dioecious trees, shrubs or perennial herbs, with simple mostly evergreen leaves, the sap not milky. Flowers regular, bracted. Petals none. Staminate flowers with 4-7 distinet stamens, the anthers 2-celled; sometimes with a rudimentary pistil. Pistillate flowers with a 2-4-celled (mostly 3-celled) ovary, with 2 or 1 anatropous ovules in each cavity; styles as many as the ovary-cavities, simple. Fruit a capsule or drupe, its carpels 1-2-seeded. Embryo straight; endosperm fleshy, or almost wanting. About 6 genera and 40 species of both the Old World and the New. 


\section{TRICERÀ Sw.; Schreb. Gen. 630. 1791.}

Evergreen shrubs or small trees, with opposite entire coriaceous shortpetioled leaves, and small monoecious flowers in small, axillary or terminal, sessile or short-stalked clusters, the bracts small, herbaceous or coriaceous. Terminal flowers of the clusters usually pistillate, the lower staminate. Pistillate flowers usually with 6 imbricated sepals, the ovary 3-celled, the 3 styles separate, or connate below; ovules 2 in each ovary-cavity, pendulous. Staminate flowers with 4 sepals, 4 stamens with oblong anthers and a rudimentary ovary. Capsule 2-3-horned. [Greek, three-horned.] About 23 species, natives of the West Indies. Type species: Crantzia laevigata $\mathrm{Sw}$.

1. Tricera bahaménsis (Baker) Britton, Bull. N. Y. Bot. Gard. 4: 139. 1906.

Buxus bahamensis Baker, in Hook. Ic. Pl. 19: pl. 1806. 1889.

A much-branched shrub, 1-2 m. high, rarely a small tree about $3 \mathrm{~m}$. high, glabrous throughout, the angulate twigs rather densely leafy. Leaves oblong to elliptic, rigid, 2-4 cm. long, 2-3 times as long as wide, sharply acute at the apex, narrowed at the base, the midvein rather prominent, the lateral venation very obscure, the petioles $1-3 \mathrm{~mm}$. long; inflorescence axillary, nearly sessile, much shorter than the leaves; bracts ovate, acute, 1-2 $\mathrm{mm}$. long; pistillate flowers 1 or few; staminate flowers usually several, pedicelled, about $2 \mathrm{~mm}$. long; stamens longer than the sepals; capsule 6-7 $\mathrm{mm}$. long; style distinct.

Scrub-lands, pine-lands and coppices, Andros, New Providence, Exuma Chain, Cat Island to Caicos, Grand Turk and Inagua :-Cuban Cays and Jamaica. BAHAMA Tricera.

\section{Family 2. ANACARDIÀCEAE Lindl.}

\section{Sumac Family.}

Trees or shrubs, with acrid resinous or milky sap, alternate or rarely opposite leaves, and polygamo-dioecious or perfect, mainly regular flowers. Calyx 3-7-cleft. Petals of the same number, imbricated in the bud, or rarely none. Disk generally annular. Stamens as many or twice as many as the petals, rarely fewer, or more, inserted at the base of the disk; filaments mostly separate; anthers commonly versatile. Ovary in the staminate flowers 1-celled. Ovary in the pistillate flowers 1- or sometimes 4-5celled; styles 1-3; ovules 1 in each cavity. Fruit generally a small drupe. Seed-coat bony or crustaceous; endosperm little or none; cotyledons fleshy. About 60 genera and 500 species, most abundant in warm or tropical regions, a few extending into the temperate zones.

Leaves pinnate or trifollate; drupes small.

Stone of the subglobose drupe hard, ribbed; our species a vine.

Stone of the oblong drupe parchment-like; tree. Leaves simple; drupes large.

1. Toxicodendron.

2. Metopium.

3. Mangifera.

\section{TOXICODÉNDRON [Tourn.] Mill. Gard. Dict. Abr. Ed. 4. 1754.}

Shrubs, small trees, or vines climbing by aerial rootlets, with 3 -foliolate or pinnate leaves poisonous to the touch, and axillary panicles of small, greenish or white polygamous flowers. Calyx 5-cleft; petals and stamens 5; ovary 1-ovuled; style terminal. Drupes small, glabrous, or sparingly pubescent when young, the stone striate. [Greek, poison-tree.] About 20 species, natives of North America and Asia. Type species: Rhus Toxicodendron L. 
1. Toxicodendron radicans (L.) Kuntze, Rev. Gen. Pl. 153. 1891.

Rhus radicans L. Sp. Pl. 266. 1753.

Rhus Blodgettii Kearney, Bull. Torr. Club 21: 486. 1894.

Toxicodendron Blodgettii Greene, Leaflets 1: 126.1905.

A woody vine, climbing by numerous aerial rootlets, or bushy and erect, the stem sometimes $7-10 \mathrm{~cm}$. in diameter. Leaves petioled; leaflets ovate or rhombic, $2.5-15 \mathrm{~cm}$. long, entire or sparingly dentate or sinuate, acute or shortacuminate, the lateral sessile or short-stalked, inequilateral, the terminal one stalked; flowers green, $3 \mathrm{~mm}$. broad, in loose axillary panicles $2-8 \mathrm{~cm}$. long; drupes subglobose, $3-5 \mathrm{~mm}$. in diameter, grayish-white.

Moist depressions in pine- and scrub-lands, and in savannas, Andros, Abaco, Great Bahama, North Cat Cay and New Providence:- continental North America, south to Mexico. Recorded by Dolley as Rhus Toxicodendron L. PoIsoN IvY.

\section{MetòpiUM P. Br.; Engler, in DC. Mon. Phan. 4: 367. 1883.}

Poisonous trees, with alternate petioled pinnate leaves, the several leaflets entire, subcoriaceous, the small greenish dioecious flowers in axillary panicles. Sepals 5, imbricated. Petals 5, imbricated, longer than the sepals. Disk annular. Stamens 5, the filaments short, subulate, the anthers longitudinally dehiscent. Ovary 1-celled; style short; stigma 3-lobed; ovule one. Drupe oblong, glabrous, pointed, containing a parchment-like stone. [Greek, forehead, significance not explained.] Three species, natives of the West Indian region. Type species: Rhus Metopium L.

1. Metopium toxìferum (L.) Krug \& Urban; Urban, Bot. Jahrb. 21: 612. 1896.

Amyris toxifera L. Syst. ed. 10, 1000. 1759.

A poisonous tree, up to $14 \mathrm{~m}$. high with a trunk sometimes $2 \mathrm{dm}$. in diameter, the thin bark reddish-brown without, orange within, splitting into large scales, the branches widely spreading. Leaves $3 \mathrm{dm}$. long or less, glabrous; leaflets $3-7$, ovate to suborbicular or obovate, chartaceous, $2.5-10 \mathrm{~cm}$. long, acute, obtuse or emarginate at the apex, narrowed to cordate at the base, bright green and shining above, dull beneath, the petiolules $1-3 \mathrm{~cm}$. long; panicles many-flowered, as long as the leaves or longer; pedicels rather stout, 2-4 mm. long; sepals obtuse, much shorter than the ovate obtuse yellowishgreen petals; drupes oblong, orange-yellow, 1-1.5 $\mathrm{cm}$. long, in spreading or drooping panicles.

Pine-lands and scrub-lands and coppices, throughout the archipelago from Abaco and Great Bahama to Calcos, Inagua and the Anguilla Isles:-Florida; Cuba; Haltl: Porto Rico. Referred by Hitchcock and by Dolley to Rhus Metopium L.; by Mrs. Northrop to Metopium Metopium (L.) Small. Porson-TreE. Catesby, 1: pl. 40.

3. MANGIFERA L. Sp. Pl. 200. 1753.

Trees, mostly large, with alternate petioled entire coriaceous leaves, and small polygamous flowers in terminal panicles. Calyx 4-5-parted, deciduous, the lobes imbricated. Petals 4 or 5, narrow, imbricated. Stamens 1-5, unequal, all polleniferous or some sterile, the filaments sometimes connate below. Ovary sessile, superior, 1-celled, 1-ovuled; style lateral, curved; stigma simple. Drupe ovoid, oblique, large, fleshy, the stone fibrous. Seed flattened, its testa thin, the cotyledons plano-convex, usually lobed, the radicle ascending. [Latin, mango-bearing.] About 14 species, natives of tropical Asia, the following typical. 
1. Mangifera índica L. Sp. Pl. 200. 1753.

A large tree, sometimes $20 \mathrm{~m}$. high or more, with a trunk up to $2.5 \mathrm{~m}$. in diameter, the branches spreading, the stout twigs glabrous. Leaves coriaceous, lanceolate or oblong-lanceolate, 15-25 cm. long, acute, acuminate or sometimes blunt at the apex, narrowed at the base, glabrous, dark green above, the petioles about $2.5 \mathrm{~cm}$. long; panicles large, terminal, pubescent, the flowers very numerous, green, about $4 \mathrm{~nm}$. wide; fruit pendulous, usually 8-12 $\mathrm{cm}$. long, smooth, greenish or yellowish, the flesh soft and juicy.

Wood-lands, New Providence. Naturalized. Native of tropical Asia. Widely naturallzed in the West Indies and troplcal continental America. Maxgo.

Conocladia integrifolia L., recorded by Dolley, has not been found by us on any of the cays or islands of the archipelago; it is only known to inhablt Jamaica and Hispaniola.

Anacardium occidentalle L. and Spondias luttea L., recorded as Bahamian by Dolley, have not been found by us in a wild state within the archipelago.

\section{Family 3. ILICÀCEAE Lowe.}

\section{Holly Family.}

Shrubs or trees, with watery sap, and alternate petioled simple leaves. Flowers axillary, small, white, mainly polygamo-dioecious, regular. Stipules minute and deciduous, or none. Calyx 3-6-parted, generally persistent. Petals 4-6 (rarely more), separate, or slightly united at the base, hypogynous, deciduous, imbricated. Stamens hypogynous, as many as the petals, or sometimes more; anthers oblong, cordate. Disk none. Ovary 1, superior, 3-several-celled; stigma discoid or capitate; style short or none; ovules 1 or 2 in each cavity. Fruit a small berry-like drupe, enclosing several nutlets. Seed pendulous; endosperm fleshy; embryo straight. Three genera and about 300 species, of temperate and tropical regions.

\section{1. İLEX L. Sp. Pl. 125. 1753.}

Leaves minutely stipulate. Flowers cymose or solitary, perfect or polygamous. Calyx small, 4-5-cleft or toothed. Petals 4-9, somewhat united at the base, oblong, obtuse. Stamens of the same number, adnate to the base of the corolla. Berry-like drupe globose, with $4-8$ bony or crustaceous nutlets. [Ancient name of the Holly Oak.] About 280 species, mostly natives of America. Type species: Ilex Aquifolium L.

Leaves dark green above, pale béneath.

leaves dark green above and beneath.

Leaves obovate, obtuse or emarginate.

Leaves ovate-elliptic to ovate-lanceolate, acuminate.
1. I. Cassine.

2. I. repanda.

3. I. Krugiana.

\section{Ilex Cassine L. Sp. Pl. 125. 1753.}

A shrub, or small tree. Twigs pubescent; leaves oblanceolate or oblong. obovate, $5-10 \mathrm{~cm}$. long, $1.25-2.5 \mathrm{~cm}$. wide, acute at the base, glabrous and dark green above, pale and usually pubescent beneath; petioles 6-8 $\mathrm{mm}$. long; staminate cymes several- or many-flowered; peduncles and pedicels pubescent; fertile cymes commonly 3-flowered; calyx-lobes ciliate; drupes red, globose, 4-6 $\mathrm{mm}$. in diameter.

Palmetto-lands, and coppices, Great Bahama, at Barnett's Point; Andros, near Staniard Creek :-Virginla to Florida and Loulsiana; Cuba. DAHOoN HoLLY. 
2. Ilex repánda Griseb. Mem. Am. Acad. II. 8: 172. 1860.

A shrub or small tree up to $8 \mathrm{~m}$. tall, the leaves and twigs glabrous. Leares obovate or elliptic-obovate, 4-7 cm. long, 2-4 cm. wide, rounded, obtuse or emarginate at the apex, acute at the base, dark-green and shining above, duil beneath, sparingly repand-dentate or entire, the petioles $3-5 \mathrm{~mm}$. long; cymes several-flowered; pedicels $3-5 \mathrm{~mm}$. long, glabrous; calyx obtusely 4-lobed; drupes subglobose or obovoid, about $5 \mathrm{~mm}$. in diameter.

Coppices and scrub-lands, Abaco, Great Bahama, Andros, New Providence and Eleuthera :-Cuba. Recorded by Dolley as Ilex montana Griseb. CuBaN HoLLy.

\section{Ilex Krugiàna Loes. Bot. Jahrb. 15: 317. 1892.}

A tree, attaining a height of $15 \mathrm{~m}$. and a trunk-diameter of $3 \mathrm{dm}$., usually smaller, and sometimes shrubby, the slender twigs gray, becoming nearly white, the bark thin, smooth, nearly white. Leaves elliptic to ovate-lanceolate, chartaceous, 5-10 cm. Iong, acuminate at the apex, rounded or narrowed at the base, entire, revolute-margined, glabrous, shining above, dull beneath, the slender petioles 1-2 cm. long; flowers few or several in axillary clusters; peduncles about $1 \mathrm{~cm}$. long; pedicels very short; calyx-lobes triangular, acute; corolla about $2.5 \mathrm{~mm}$. broad, its lobes ovate; drupes purplish, usually containing 4 nutlets, about $4 \mathrm{~mm}$. in diameter.

Copplces, pine-lands and scrub-lands, Abaco; Great Bahama, Andros and New Providence :-Florida; Hispanlola. Recorded by Dolley as Ilex Macoucoua Pers. KRUG'S HOLLY.

Schoepf records a New Providence plant as Ilex cuneata, giving the name only without description or reference, therefore not Identified.

\section{Family 4. CELASTRÁCEAE L.}

\section{StafF-tree FAMILY.}

Trees or shrubs, some species climbing. Leaves simple. Stipules, when present, small and eaducous. Flowers regular, generally perfect, small. Pedicels commonly jointed. Calyx 4-5-lobed or -parted, persistent, the lobes imbricated. Petals 4 or 5, spreading. Stamens inserted on the disk. Disk flat or lobed. Ovary sessile, mostly 3-5-celled; style short, thick; stigma entire or 3-5-lobed; ovules 2 in each eavity, anatropous. Fruit drupaceous or capsular. Seeds with or without an aril; embryo large; cotyledons foliaceous. About 45 genera, and 375 species, widely distributed.

Fruit a dehiscent capsule; seeds arlllate.

1. Maytenus.

Fruit indehiscent; seeds not arlllate.

Cells of the ovary 1-ovuled.

Sepals connate near the base.

Sepals distinct or nearly so.

Leaves opposite; ovule pendulous.

Leaves alternate; ovule erect.

Cells of the ovary 2-ovuled.

2. Rhacoma.

3. Gyminda.

4. Schaefferia.

5. Elaeodendrum.

\section{MAYTÈNUS Molina, Sagg. Chile 177. 1782.}

Unarmed, evergreen shrubs or trees, with alternate petioled coriaceous serrate leaves, and small polygamous axillary flowers, solitary or in clusters. Calyx 5-lobed. Stamens 5, the filaments subulate. Disk orbicular, undulate. Ovary immersed in the disk, 2-4-celled; ovules 1 or 2 in each cavity, erect; style slender or none; stigma 2-4-lobed. Fruit a small coriaceous capsule, 1-3-celled, loculicidally 2-3-valved. Seeds erect, the testa crustaceous; the aril fleshy; cotyledons foliaceous. [From the Chilean name.] Type species: Maytenus Boaria Molina. 
1. Maytenus lucayàna Britton, Bull. N. Y. Bot. Gard. 4: 140. 1906.

A white-barked shrub, the twigs angular. Leaves orbicular-ovate, $1.5-3 \mathrm{~cm}$. long, 1.5-2.7 cm. wide, coriaceous, rounded at the apex, cordate at the base, shining above, dull beneath, bright-green, the midvein slender and impressed in both surfaces, the few lateral veins more slender and similarly impressed, the stout petiole only 1-1.5 mm. long; pedicels solitary or few together at defoliated axils, about $2 \mathrm{~mm}$. long; petals not seen; calyx-lobes ovate, acute, nearly $1 \mathrm{~mm}$. long; young fruit ovoid, pointed, tipped by a style $0.5 \mathrm{~mm}$. long; stigmas 2.

Rocky margins of ponds, Great Bahama at West End. Endemic. BaHAMa MAYTENUS.

2. Maytenus buxifòlia (A. Rich.) Griseb. Cat. Pl. Cub. 53. 1866.

Monteverdia buxifolia A. Rich. in Sagra, Hist. Cub. 10: 142, pl. 36. 1845.

A shrub or a tree up to $10 \mathrm{~m}$. high, the trunk up to $2.5 \mathrm{dm}$. in diameter, the twigs gray, glabrous, becoming nearly terete. Leaves oblong to obovate or oblong-spatulate, 1-4 cm. long, 4-20 mm. wide, coriaceous, obtuse or subtruncate at the apex, obtuse, narrowed, or cuneate at the base, short-petioled, faintly shining above, dull beneath, the midvein impressed on both sides, the lateral venation obsolete; flowers few in the clusters; pedicels 1-4 $\mathrm{mm}$. long; calyxlobes semiorbicular, $0.5 \mathrm{~mm}$. long; petals greenish yellow, nearly $2 \mathrm{~mm}$. long, ovate, obtuse; fruit globose-obovoid, red or orange, 5-9 $\mathrm{mm}$. long.

Thickets and scrub-lands, throughout the archipelago from Abaco and Great Bahama to Caicos and Inagua:-Cuba; Hispanlola. BoX-Leaved MaYtenus.

\section{RHÁCOMA L. Syst. ed. 10, 896. 1759.}

Shrubs or low trees, with coriaceous small evergreen leaves, and small perfect greenish axillary flowers. Calyx 4-5-lobed. Disk depressed, 4-5lobed. Petals 4 or 5, inserted under the disk. Stamens 4 or 5. Ovary 4celled; stigmas 4 ; ovules 1 in each eavity of the ovary, erect. Drupe with a somewhat fleshy, thin exocarp and a bony stone. [Name used by Pliny for some Old World plant.] About 12 species, of warm and tropical America. Type species: Rhacoma Crossopetalum L.

Leaves entire or crenulate.

Inflorescence nearly sessile; leaves entire.

Inflorescence slender-peduncled; leaves crenulate at least toward the apex.

Leaves spinulose-serrulate.

Leaves long spinulose-toothed; fruit nearly sessile.

Leaves short spinulose-toothed; fruit slender-pedicelled.

1. R. coriacea.

2. R. Crossopetalum.

3. R. aquifolia.

4. R. ilicifolia.

\section{Rhacoma coriàcea (Northrop) Urban, Symb. Ant. 5: 71. 1904.}

Crossopetalum coriaceum Northrop, Mem. Torr. Club 12: 48. 1902.

A low shrub, $6 \mathrm{dm}$. high or less, the quadrangular twigs densely leafy, glabrous. Leaves opposite, coriaceous, glabrous, obovate or oblong-obovate, 1-3 cm. long, 7-12 $\mathrm{mm}$. wide, rounded or obtuse at the apex, narrowed at the base, entire, dull green on both sides; inflorescence 1-5-flowered, sessile or nearly so; calyx-lobes 4, half-orbicular; petals 4, ovate to orbicular, reddish, $1 \mathrm{~mm}$. long; disk 4-lobed; stamens 4 ; drupe obovoid, red, about $4 \mathrm{~mm}$. long.

Low copplces, sand-dunes and savannas, Andros, New Providence, Eleuthera, Great Guana. Endemic. BaHAMA RHACOMA. 
2. Rhacoma Crossopétalum L. Syst. ed. 10, 896. 1759.

Myginda Rhacoma Sw. Prodr. 39. 1788.

Myginda pallens J. E. Smith in Rees Cycl. 25: no. 4. 1813.

Crossopetalum pallens Kuntze, Rev. Gen. Pl. 116. 1891.

Crossopetalum Rhacoma Hitche. Rep. Mo. Bot. Gard. 4: 70. 1893.

Rhacoma pallens Maza, Anal. Soc. Esp. Hist. Nat. 19: 239. 1900.

A shrub or tree up to $8 \mathrm{~m}$. high, with smooth grey bark and angular twigs. Leaves opposite or whorled, linear to oblong or obovate, short-petioled, 1-4 cm. long, somewhat crenate, glabrous, acutish or blunt at the apex, narrowed at the base, paler green beneath than above; flowers clustered in the axils, the clusters slender-peduncled; calyx urceolate, with 4 obtuse lobes; petals 4 ; disk 4 -lobed; stamens 4 , inserted between the lobes of the disk; ovary 4-celled; drupe about $6 \mathrm{~mm}$. long, slightly oblique, red.

Copplces, thlckets and scrub-lands, throughout the archipelago from Abaco and Great Bahama to Grand Turk, Inagua and the Anguilla Isles:-Florida; Bermuda ; West Indies; Colombla. Species composed of a large number of races, the leaf-form from linear-spathulate to suborblcular. Poison CherRy. WILd CherRy.

3. Rhacoma aquifòlia (Griseb.) Urban, Symb. Ant. 5: 77. 1904.

Myginda aquifolia Griseb. Cat. Pl. Cub. 55. 1866.

Crossopetalum aquifolium Hitche. Rep. Mo. Bot. Gard. 4: 70. 1893.

A shrub, $3 \mathrm{dm}$. high or less, branched at the base, the branches prostrate or nearly so, 1-3 dm. long, the young twigs densely pilose. Leaves coriaceous, sessile or very short-petioled, opposite, ovate in outline, 1-3 cm. long, spinulosedentate with long rigid teeth, densely puberulent on both sides or becoming glabrous above, strongly pinnately veined; inflorescence glomerate, few-flowered, nearly sessile in the axils; sepals semiorbicular; petals greenish, about $1 \mathrm{~mm}$. long; fruit obliquely obovoid, red, 4-7 mm. long. RHACOMA.

Mangrove swamps and pine-lands, Andros and Eleuthera:-Cuba. Sinin-Leaved

4. Rhacoma ilicifòlia (Poir.) Trelease in A. Gray, Syn. Fl. 1¹: 399. 1897.

Myginda ilicifolia Poir. in Lam. Encycl. 4: 396. 1796.

Crossopetalum ilicifolium Kuntze, Rev. Gen. Pl. 116. 1891.

Crossopetalum floridanum Gardner; Small, F1. SE. U. S. 736. 1903.

A low, nearly glabrous shrub, $3 \mathrm{dm}$. high or less, branched from the base, the branches ascending or nearly prostrate, $2-4 \mathrm{dm}$. long, the young twigs puberulent. Leaves subcoriaceous, mostly opposite, very short-petioled, ovate to elliptic, 1-2.5 cm. long, acute at the apex, narrowed or obtuse at the base, pinnately veined, sharply dentate with spinulose-tipped teeth; cymes axillary, short-peduncled, few-several-flowered; sepals half-orbicular; petals red, ovate to suborbicular, 1-1.5 mm. long; fruit obovoid, oblique, 3.5-5 mm. long. RHACOMA.

Copplces and pine-lands, Great Bahama:-Florida; Hispaniola. HollY-Leaved

\section{GYMÍNDA Sargent, Gard. \& For. 4: 4. 1891.}

Trees or shrubs, with opposite, short-petioled leaves, and small greenish dioecious flowers in axillary cymose clusters. Calyx deeply 4-lobed. Petals 4, longer than the calyx. Staminate flowers with 4 stamens about as long as the petals, and a minute abortive ovary. Pistillate flowers with a 2-celled ovary, each cavity with a single pendulous ovule; style none; stigma peltate. Fruit a small drupe. Seeds usually solitary, with copious endosperm. [Anagram of Myginda.] Two known species, the following typical one, the other Costa Rican. 
1. Gyminda latifòlia (Sw.) Urban, Symb. Ant. 5: 80. 1904.

Myginda latifolia Sw. Prodr. 39. 1788.

Gyminda Grisebachii Sargent, Gard. \& For. 4: 4. 1891.

A shrub, or a tree with maximum height of about $9 \mathrm{~m}$., the thin bark reddish brown, the trunk seldom over $1.5 \mathrm{dm}$. in diameter, the young twigs 4-angled, glabrous. Leaves oblong or oblong-obovate, subcoriaceous, glabrous, 2-6 cm. long, obtuse or emarginate at the apex, narrowed at the base, the petioles very short; peduncles slender, 6-15 mm. long; petals about $2 \mathrm{~mm}$. long; drupe ellipsoid, obtuse, 4-8 $\mathrm{mm}$. long.

Scrub-lands and coppices, throughout the archipelago from Abaco and Great Bahama to Andros, Caicos, Grand Turk and Inagua :-Florida; Cuba to St. Thomas and to St. Vincent; Jamaica; Mexico. Gyminda. False Boxwood. Walla-berry.

\section{SCHAEFFìrIA Jacq. Enum. 10, 33. 1760.}

Shrubs or trees, with alternate or fascicled, entire, chartaceous or subcoriaceous leaves (in one species reduced to small scales), and small, mostly dioecious, white or greenish flowers, solitary or clustered in the axils, the peduncles short. Calyx 4-parted, the lobes rounded, imbricated. Petals 4, obtuse. Stamens 4. Dise inconspicuous. Ovary sessile, ovoid, 2-celled; ovules 1 in each cavity, erect; style short; stigma 2-parted, large. Fruit coriaceous, indehiscent. Seeds erect, exarillate, with little endosperm and flat cotyledons. [Commemorates J. C. Schaeffer, a German naturalist.] Five known species, of tropical and subtropical America, the following typical.

1. Schaefferia frutéscens Jacq. Enum. 33. 1760.

A tree, up to $14 \mathrm{~m}$. high, with a maximum trunk diameter of about $3 \mathrm{dm}$., usually much smaller, commonly a shrub, the thin bark gray, the slender twigs glabrous. Leaves obovate, spatulate or oblong, chartaceous, glabrous, veiny, 2.5-6 $\mathrm{em}$. long, acute, obtuse or rarely emarginate at the apex, narrowed at the base, the petioles $3-8 \mathrm{~mm}$. long; flowers greenish, about $3 \mathrm{~mm}$. wide; peduncles slender, mostly somewhat longer than the petioles; fruit globose or oval, orange-red, grooved, apiculate, 5-6 $\mathrm{mm}$. long.

Scrub-lands, Great Bahama, Andros, New Providence and Eleuthera to Mariguana and Inagua:-Florida; Cuba to Virgin Gorda and Grenada; Jamaica. COMMON SCHAEFFERIA.

\section{ELAFODÉNDRUM Jacq. f.; Murray, Syst. 241. 1784.}

Evergreen trees or shrubs, with opposite or alternate coriaceous leaves, the very small stipules caducous, and small, often dioecious, greenish or white flowers in small axillary clústers. Calyx 5-parted. Petals 5, spreading. Stamens 5, inserted under the disk; filaments short; anthers globose. Ovary adnate to the disk, 2-5-celled; style short; stigma 2-5-lobed, ovules 2 in each ovary-cavity. Fruit a rather large drupe. [Greek, olive-wood; the fruit resembles an olive in form.] About 35 species, natives of tropical regions. Type species: Elaeodendron orientale Jacq.

1. Elaeodendrum attenuàtum A. Rich. Ess. F1. Cub. 2: 343.1845.

Cassine attenuata Kuntze, Rev. Gen. Pl. 114. 1891.

Elaeodendron xylocarpum bahamense Urban, Symb. Ant. 5: 88. 1904.

A tree, with maximum height of about $16 \mathrm{~m}$., usually much smaller and often shrubby, the bark gray, the twigs and leaves glabrous. Leares pale green, 
obovate to elliptic, 3-8 $\mathrm{cm}$. long, remotely low-dentate or entire, rounded or obtuse at the apex, narrowed at the base, revolute-margined, the stout petioles 2-10 mm. long; flowers greenish yellow; sepals about $1 \mathrm{~mm}$. long; petals about $2 \mathrm{~mm}$. long, those of staminate flowers a little longer than those of pistillate; drupe ovoid or subglobose, yellow, pointed or rounded, $1.5-2.5 \mathrm{~cm}$. long, the stone very hard.

Scrub-lands and copplces, Abaco, New Providence, Watling's Island, Crooked Island, Fortune Island, Grand Turk and Inagua :-Cuba. Referred by Mrs. Northrop to $E$. xylocarpum DC. OLIVE-WOoD.

\section{Family 5. DODONAEÀCEAE H.B.K.}

\section{Dodonaea Family.}

Shrubs or trees, commonly sticky with a resinous excretion. Leaves alternate, without stipules. Flowers clustered, polygamous or polygamodioecious. Sepals 3-5, nearly equal. Corolla and disk wanting. Androecium of 5-8 regularly inserted stamens; filaments distinet; anthers 4angled. Gynoecium of 3 or 4 united earpels, wholly superior. Ovary 3-4-celled; styles united. Ovules 2 in each cavity, half-anatropous, often superposed, the upper one ascending and the lower one pendulous. Capsule membranous or leathery, reticulated, 2-6-angled, the angles obtuse, or winged, opening septicidally by $2-6$ valves. Seed subglobose or flattened, without an aril; endosperm none; embryo spiral. Only the following genus.

\section{DODONAغ̇A Jacq. Enum. 19. 1760.}

Characters of the family, as given above. [In honor of Rembert Dodoens, 1518-1585, Dutch herbalist.] About 50 species, of tropical and subtropical regions. Type species: Dodonaea viscosa Jacq.

\section{Dodonaea Ehrenbérgii Schl. Linnaea 18: 36. 1844.}

Dodonaea viscosa obovata Hitchc. Rep. Mo. Bot. Gard. 4: 73. 1893.

A nearly glabrous shrub or small tree sometimes $5 \mathrm{~m}$. high, the foliage slightly viscid, the twigs slender. Leaves oblanceolate to obovate, $1.5-6 \mathrm{~cm}$. long, obtuse, rounded or emarginate at the apex, cuneate-narrowed at the base, the petioles $1 \mathrm{~cm}$. long or less; panicles terminal, rather densely many-flowered, puberulent, not longer than the leaves; pedicels short; flowers yellowish green, about $5 \mathrm{~mm}$. broad; anthers oblong; capsule-wings finely veined, obtuse, 5-8 $\mathrm{mm}$. wide, papery, shining.

White-lands and scrub-lands, throughout the archipelago from Abaco to Grand Turk, Ambergris Cay and Inagua :-Cuba; Hispaniola; Mona; Anegada; Desirade. DOGWOOD.

\section{Family 6. SAPINDÀCEAE.}

\section{SOAPBERRY FAMILY.}

Trees or shrubs, with watery sap, rarely vines. Leaves alternate (opposite in one Chilian genus), mostly pinnate or palmate, without stipules. Flowers polygamo-dioecious, regular or slightly irregular. Sepals or calyx-lobes 4 or 5 , mostly imbricated. Petals $3-5$. Disk fleshy. Stamens 5-10 (rarely fewer or more), generally inserted on the disk. Ovary 1, 2-4lobed or entire, 2-4-celled; ovules 1 or more in each cavity. Fruit various. 
Seeds globose or compressed; embryo mainly convolute; endosperm none. About 125 genera, including over 1,000 species, widely distributed in tropical and warm regions.

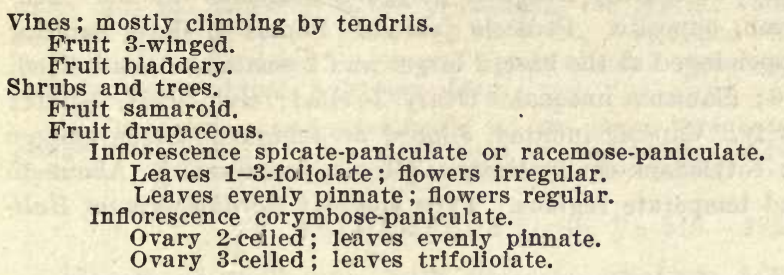

1. Serjania.

3. Thyana.

4. Allophylus.

5. Melicocca.

6. Exothea.

7. Hypelate.

\section{SERJÀNIA Plum.; Schum. Skr. Natur. Selsk. Kjoeb. 32: 125.1794.}

Woody vines, with alternate petioled, mostly biternately compound leaves, and small polygamous white or yellowish flowers, in axillary racemes or panicles, which often bear tendrils. Sepals 5, imbricated. Petals 4, with small scales between. Disk undulate or sometimes glanduliferous. Stamens 8 , the filaments sometimes united at the base. Ovary 3-celled; styles partly united; stigmas 3, small; ovules 1 in each eavity. Fruit of 3 samaras attached by their backs, each bearing a seed near the apex. [Commemorates Paul Sergeant.] About 175 species, of tropical and subtropical America. Type species: Serjania sinuata (L.) Schum.

Leaflets strongly reticulate-veined, few-toothed or entire; seed not enclosed in the wing.

Leaflets not strongly reticulate-veined, dentate; seed encloseu in the wing.

1. S. subdentata.

2. S. diversifolia.

1. Serjania subdentàta Juss.; Poir. in Lam. Encycl. 5: 102.1804.

Climbing on trees or shrubs; sometimes $7 \mathrm{~m}$. long, usually shorter; young twigs sulcate, glabrous, or sparingly pubescent. Leaflets elliptic to oblonglanceolate or ovate, coriaceous, $3-8 \mathrm{~cm}$. long, mostly acute or acuminate at the apex, narrowed or rounded at the base, sharply dentate with few or several teeth, shining above; panicles commonly longer than the leaves, puberulent; pedicels $2-5 \mathrm{~mm}$. long; petals obovate, about $4 \mathrm{~mm}$. long; fruit $1.2-2 \mathrm{~cm}$. long, the seeds not enclosed in the ends of the samara-wings.

Rocky copplces, scrub-lands and thickets, Andros, Mangrove Cay, New Providence, Eleuthera, Cat Island, Rum Cay, Great Guana Cay and Great Exuma :-Cuba. Referred by Hitchcock to S. paniculata H.B.K. FowL-Foot.

2. Serjania diversifòlia (Jacq.) Radlk. Mon. Serj. 136. 1875.

Paullinia diversifolia Jacq. Enum. 36. 1760.

Slender, often high-climbing on trees, sometimes $10 \mathrm{~m}$. long, the young twigs puberulent. Leaflets ovate to obovate, $3-8 \mathrm{~cm}$. long, coriaceous, acute or obtuse, few-toothed near the apex or entire, shining above, dull beneath; panicles puberulent, commonly longer than the subtending leaves; pedicels $5-8 \mathrm{~mm}$. long; petals oblong-obovate, about $5 \mathrm{~mm}$. long; fruit rather broadly ovate, 1.5-2 $\mathrm{cm}$. long, the seeds enclosed in the upper part of the samara-wings.

Thickets and scrub-lands, Green Turtle Cay, Andros, New Providence, Eleuthera, Cat Island, Watling's and Long Island:-Cuba; Hispaniola. Referred by Hitchcock to $S$. lucida Schum, and recorded by Schoepf as Paullinia Seriana L. FowI-FOOT. 
2. CARDiospÉrimuM L. Sp. Pl. 366. 1753.

Vines, with alternate bipinnate or decompound leaves, and small axillary tendril-bearing corymbs of slightly irregular polygamo-dioecious flowers. Tendrils 2 to each corymb, opposite. Pedicels jointed. Sepals 4, the 2 exterior smaller. Petals 4, appendaged at the base, 2 larger and 2 smaller. Disk 1-sided, undulate. Stameńs 8; filaments unequal. Ovary 3-celled; style short, 3-cleft; ovules 1 in each cavity. Capsule inflated, 3-lobed or 3-angled. Seeds globose with a large hilum; cotyledons conduplicate. [Greek, heart-seed.] About 15 species, of warm and temperate regions. Type species: Cardiospermum Halicacabum L.

Capsules longer than broad, 3-3.5 cm. long. Capsules broader than long, about $1 \mathrm{~cm}$. broad.
1. C. Halicacabum. 2. C. microcarpum.

1. Cardiospermum Halicácabum L. Sp. Pl. 366. 1753.

Annual or biennial, slender, glabrous or slightly pubescent, $0.6-5 \mathrm{~m}$. long. Leaves petioled, 5-10 cm. long; segments stalked, ovate or oblong, acute or acuminate, sharply serrate; peduncles commonly longer than the leaves; flowers white, $6-8 \mathrm{~mm}$. broad; petals obovate; filaments pubescent; capsule about $3 \mathrm{~cm}$. long, globose-pyriform, pubescent. seeds globose, nearly black, about $5 \mathrm{~mm}$. thick, the large white hilum cordate.

Scrub-lands and cultivated grounds, New Providence and Eleuthera:-New Jersey to Missourl, Florida, and Texas; West Indies; Mexico to tropical South America. BaLloon-vine.

\section{Cardiospermum microcárpum H.B.K. Nov. Gen. 5: 104. 1821.}

Climbing to a length of 1.5-3 m., branched, finely pubescent, slender, the stem grooved. Leaves thin, biternately compound, slender-petioled, 7-15 $\mathrm{cm}$. long and about as broad as long, the ultimate segments ovate to lanceolate in outline, coarsely lobed, cleft or incised; peduncles slender, about as long as the leaves; corymbs several-flowered; flowers white, about $4 \mathrm{~mm}$. broad, the upper petals 3 times as long as the, sepals; capsule subglobose, 3-lobed, pubescent, veiny, depressed at the top, about $1 \mathrm{~cm}$. thick; seeds similar to those of the preceding species but smaller.

Waste-lands, Abaco and New Providence:-Bermuda; Florida; West Indies; continental tropical America. SMall Balloon-vine.

\section{THYÀNA Hamilt. Prodr. 36. 1825.}

[Thournia Poit. Ann. Mus. Paris 3: 70. 1804. Not L. f. 1781.]

Shrubs or trees, with alternate 3-foliolate or 1-foliolate leaves and small, mostly white, regular clustered polygamous or dioecious flowers. Calyx 4-5parted. Petals 4 or 5 or wanting. Dise annular, lobed. Stamens 8-10, distinct, the filaments pilose. Ovary 3-lobed, 3-celled; ovules 1 in each eavity; style slender, 3-cleft or entire. Fruit samaroid, the samaras usually 3, coriaceous, at length separating from the axis. Seeds exarillate. [From the Greek name of an odioriferous tree.] About 15 species, natives of tropical America. Type species: Thyana simplicifolia (Poit.) Hamilt.

1. Thyana díscolor (Griseb.) Hitchc. Rep. Mo. Bot. Gard. 4: 72. 1893.

Thouinia discolor Griseb. Fl. Br. W. I. 127. 1859.

A shrub, up to $2.5 \mathrm{~m}$. high, or a small tree, sometimes $5 \mathrm{~m}$. high, the rather slender twigs and the inflorescence whitish-tomentose. Petioles $2.5 \mathrm{~cm}$. long or 
less, tomentose; leaflets 3 , nearly sessile, thin, narrowly elliptic to obovate, entire, obtuse or rounded at the apex, narrowed or cuneate at the base, $2-8 \mathrm{~cm}$. long, glabrous and green above, white-tomentose beneath, or becoming green when old, the midvein rather prominent, the lateral veins few and slender; racemes many-flowered, peduncled, $2-6 \mathrm{~cm}$. long; pedicels filiform, 4-5 mm. long, single or fascicled; calyx and petals about $1 \mathrm{~mm}$. long; samaras glabrous, shining, veiny, obtuse, 8-10 mm. long.

Rocky coppices and scrub-lands, on the larger islands throughout the archipelago from Abaco and Great Bahama to Mariguana, Inagua and North Caicos. Endemic. QUicksilver-BUSH. NAKED-WOOD. HARD-BARK.

\section{ALLOPHYLUS L. Sp. Pl. 348. 1753.}

Shrubs or smalb trees, with alternate estipulate 1-3-foliolate leaves, the leaflets broad, usually punctate or lineate, the small subglobose, somewhat irregular, polygamous or dioecious flowers in axillary, simple or compound racemes. Sepals 4, in 2 pairs, imbricated, hooded, the outer smaller than the inner. Petals 4, small, or sometimes wanting. Disk unilateral, lobed or 4-glandular. Stamens short. Ovary excentric, compressed, 2-celled or rarely 3 -celled; ovules 1 in each cavity; style stout, 2-3-lobed, or styles 2 or 3 . Fruit small, dry, leathery or fleshy. Seed with a short fleshy aril; cotyledons 2-plicate. [Greek, exotic.] Eighty species or more, mostly of tropical America. Type species: Allophylus zeylanicus L.

\section{Allophylus Cominia (L.) Sw. Prodr. 62. 1788.}

Rhus Cominia L. Syst. ed. 10, 964. 1759.

A shrub or small tree or sometimes up to about $15 \mathrm{~m}$. high, the twigs, petioles, lower leaf-surfaces and inflorescence brownish-tomentose. Petioles rather slender, 2-7 cm. long; leaflets 3 , short-stalked, elliptic to ovate-elliptic, low-serrate 4-15 cm. long, acute or acuminate at the apex, narrowed or rounded at the oblique base, the lateral ones inequilateral; racemes very slender, longpeduncled, densely many-flowered, simple or few-branched, 5-8 $\mathrm{cm}$. long, the flowers fascicled; pedicels 1-1.5 mm. long; flowers greenish yellow, about $1 \mathrm{~mm}$. long; fruits subglobose, about $5 \mathrm{~mm}$. in diameter, red or orange. PHYLUS.

Coppices, Abaco and New Providence:-Cuba; Hispaniola; Jamaica. Allo-

\section{MELICÓCCA L. Sp. Pl. ed. 2, 495. 1762.}

Trees, with alternate estipulate equally pinnate leaves, and small polygamous or dioecious, regular flowers in compound or simple racemes at the ends of the branches. Calyx 4-5-lofed, the lobes nearly orbicular, thin, imbricated. Petals 4 or 5, obovate or orbicular. Disk flattened, 4-5-lobed. Stamens 8; filaments filiform, distinct, glabrous; anthers small. Ovary 2-3-celled; ovules 1 or 2 in each cavity; style short; stigma 2-3-lobed. Fruit a somewhat fleshy drupe. Seed erect, the testa coriaceous, the aril large, pulpy; cotyledons thick. [Greek, honey-berry.] Two known species, the following typical, the other South American.

1. Melicocca bijùga L. Sp. Pl. ed. 2, 495. 1762.

A large tree, sometimes becoming $25 \mathrm{~m}$. high, with a trunk up to $1.7 \mathrm{~m}$. in diameter, the branches spreading, the slender twigs, the leaves and the inflorescence glabrous. Leaves petioled; rachis winged or wingless; leaflets 2 
pairs, opposite, elliptic or ovate-elliptic, thin, 4-10 $\mathrm{cm}$. long, mostly acute or acuminate at the apex, obliquely narrowed at the base, sessile, pinnately veined; racemes narrow, many-flowered, 6-10 cm. long, often numerous in terminal panicles; pedicels spreading, 4-6 $\mathrm{mm}$. long; flowers very fragrant; calyxsegments about $2 \mathrm{~mm}$. long; petals obovate, obtuse, greenish white, ciliate, 3-4 $\mathrm{mm}$. long; drupe green, edible, pleasantly acid, subglobose, $2-4 \mathrm{~cm}$. in diameter.

New Providence, apparently spontaneous after cultivation:-West Indles; Central America and northern South America. GENIP.

6. EXOTHÈA Macf. Fl. Jam. 1: 232. 1837.

Trees or shrubs, with alternate petioled evenly pinnate leaves, and small white somewhat irregular, dioecious or polygamous, panicled flowers. Sepals 5, partly united, imbricated. Petals 5, short-clawed, unappendaged. Stamens 7 or 8 , those of staminate flowers about as long as the petals, those of pistillate flowers shorter. Ovary 2-celled, sessile; ovules 2 or 3 in each cavity; style very short, simple, the stigmas glabrous. Fruit a small, globose berry-like drupe, the exocarp slightly fleshy. Seed exarillate. [Greek, to expel, the genus having been taken from Melicocca.] The genus is probably monotypic. Type species: Exothea oblongifolia Macf.

1. Exothea paniculàta (Juss.) Radlk.; Durand Index Gen. Phan. 81. 1888.

Melicocca paniculata Juss. Mem. Mus. Paris 3: 187. 1817.

Hypelate paniculata Camb. Mem. Mus. Paris 18: 32.1829.

Exothea oblongifolia Macf. Fl. Jam. 1: 232. 1837.

A tree, attaining a maximum height of about $20 \mathrm{~m}$., with a trunk up to 5 dm. thick, the thin, reddish brown bark scaly. Leaves short-petioled; leaflets 2 , 4 , or 6 (rarely 1 or 3 ), oblong to elliptic-obovate, $5-13 \mathrm{~cm}$. long, glabrous or nearly so, entire, dark green and shining above, pale green beneath, acute, obtuse or emarginate at the apex, narrowed to the nearly sessile base; panicles terminal and axillary, pubescent; sepals ovate, about $3 \mathrm{~mm}$. long; petals oblongovate, about as long as the sepals; ovary pubescent; drupes 10-13 $\mathrm{mm}$. in diameter, purple, the juicy pulp orange.

Coppices and scrub-lands, Abaco, Great Bahama, Goat Cay, Andros, Eleuthera, Cat Island and Watling's Island:-Florida; Cuba; Jamaica; Hispaniola ; Porto Rico. Butter Bough.

7. HYPELÀTE P. Br.; Sw. Prodr. 61. 1788.

A tree or shrub, with alternate 3 -foliolate petioled leaves, and small, white or greenish white, panicled, monoecious or polygamo-dioecious flowers. Sepals 5, imbricated. Petals 5, unappendaged, sessile. Stamens 8-10 in the staminate flowers, wanting or imperfect in the pistillate; filaments glabrous. Pistillate flowers with a 3-celled, sessile ovary, the style short, the stigmas capitate; ovules 2 in each cavity, superimposed. Fruit a small drupe, with thin flesh. [Greek name for Ruscus, the Butcher's Broom.] A monotypic genus.

\section{Hypelate trifoliàta Sw. Prodr. 61. 1788.}

A tree, sometimes $13 \mathrm{~m}$. high with a trunk up to $5 \mathrm{dm}$. in diameter, usually smaller, sometimes shrubby, the thin gray bark smooth or nearly so. Petioles 1-5 cm. long; leaflets obovate or spatulate, firm in texture, $2-5 \mathrm{~cm}$. long, entire, glabrous, shining above, rather dull beneath, finely veined, the apex obtuse, 
emarginate or acutish; sepals ovate, ciliate; petals suborbicular, about $2 \mathrm{~mm}$. long, ciliate, about as long as the sepals; drupes ovoid, black, 5-7 mm. long.

Copplces and scrub-lands, Andros, New Providence, Eleuthera, Cat Island, Watling's Island, Great Exuma, Long Island, Acklin's Island, Crooked Island, Fortune Island and Inagua :-Florida; Cuba to Porto Rico; St. Martin and Anguilla; Jamalca. WHITE IRONWOOD. EBoNy.

\section{Order 15. RHAMNÀLES.}

Shrubs, vines, or small trees, with nearly always alternate leaves. Flowers small, regular. Sepals mostly more or less united. Petals distinct or wanting. Stamens as many as the sepals or calyx-lobes and alternate with them, opposite the petals when these are present. Ovary compound, superior; ovules erect.

Shrubs, small trees, or vines ; petals 4 or 5 , or none ; fruit a drupe or capsule.

Vines, climbing by tendrils, rarely shrubs; petals caducous; fruit a berry.

Fam. 1. RHAMNaceat.

Fam. 2. Vitaceae.

\section{Family 1. RHAMNÀCEAE Dumort.}

\section{BUCKTHORN FAMILY.}

Erect or climbing shrubs, or small trees, often thorny. Leaves simple, stipulate, mainly alternate, often 3-5-nerved. Stipules small, deciduous. Inflorescence commonly of cymes or panicles. Flowers small, regular, perfect or polygamous. Calyx-limb 4-5-toothed or 4-5-lobed. Petals 4-5, inserted on the calyx, or none. Stamens 4-5, inserted with the petals and opposite them; anthers short, versatile. Disk fleshy. Ovary sessile, free from or immersed in the disk, 2-5- (often 3-) celled; ovules 1 or 2 in each cavity, anatropous. Fruit often 3-celled. Seeds solitary in the cavities, erect; endosperm fleshy, rarely none; embryo large; cotyledons flat. About 50 genera and 600 species, of temperate and warm regions.

Fruit drupaceous.

Petals none; plants unarmed.

Endosperm ruminated; pit of the drupe thick-walled.

Endosperm none; pit of the drupe thin-walled.

Petals 5; young twigs spiny.

Fruit dry, separating into nutlets.

Trees and shrubs; fruit seated in the calyx.

Woody vines; nutlets winged.

\section{Reynosia. \\ 2. Krugiodendron. \\ 3. Sarcomphalus. \\ 4. Colubrina. \\ 5. Gouania.}

\section{REYNÒsIA Griseb. Cat. Pl. Cub. 33. 1866.}

Shrubs or small trees, with entire short-petioled opposite leaves, and small perfect yellowish green flowers in axillary clusters. Calyx-lobes valvate, spreading. Disk fleshy. Petals none. Stamens 5 ; filaments subulate. Ovary 2-3-celled; styles short and thick; stigma 2-3-lobed; ovules 1 in each cavity, erect. Fruit a drupe with thin flesh and a hard stone. [Dedicated to Alvaro Reynoso, a Cuban chemist and agriculturist, who died in 1888.] About 9 species, of the West Indies and Florida. Type species: Reynosia retusa Griseb.

Leaves obovate to elliptic ; petioles $1.5-3 \mathrm{~mm}$. ; drupe subglobose or ovold.

1. R. septentrionalis.

Leaves oblong to lanceolate; petioles 5-7 mm.; drupe ellipsold. 2 . $R$. Northropiana. 
1. Reynosia septentrionàlis Urban, Symb. Ant. 1: 356. 1899.

Reynosia latifolia Chapm. FI.S. U.S., ed.2, 612. 1883. Not Griseb. 1866.

Usually a shrub, sometimes a tree up to $9 \mathrm{~m}$. high, with a trunk diameter of $2 \mathrm{dm}$., the bark reddish-brown, splitting into thin plates, the wood dense and heavy. Leaves opposite, elliptic to oval or obovate, 2-4 cm. long, coriaceous, glabrous, rounded or emarginate at the apex, narrowed at the base, finely reticulate-veined, revolute-margined, the petioles short; flowers yellowish green, about $5 \mathrm{~mm}$. wide in small axillary umbels; pedicels $4-5 \mathrm{~mm}$. long; calvx-lobes ovate, acute; drupe ovoid, dark purple, 1-1.5 cm. long, tipped with the base of the style, the thin pulp edible, the stone hard.

Scrub-lands and copplces, throughout the archipelago from Great Sturrup Cay, the Biminis and Eleuthera, to Grand Turk, Inagua and Cay Sal :-Florida. Recorded by Hitchcock as Rhamnidium revolutum C. Wright. CoMmoN ReYNosia.

2. Reynosia Northropiàna Urban, Symb. Ant. 3: 315. 1902.

A shrub, 1-2 m. high, the slender young twigs puberulent, soon becoming glabrous. Stipules triangular, connate, lanceolate, 1-2 mm. long; leaves opposite, subcoriaceous, oblong, elliptic or oblong-lanceolate, $3-8 \mathrm{~cm}$. long, 1-2.5 cm. wide, rounded or emarginate at the apex, rounded or narrowed at the base, obsoletely crenate or entire, dark green above, pale green beneath, finely reticulate-veined on both sides, the petioles 3-7 mm. long: cymes short-peduncled; few-several-flowered; calyx about $2.5 \mathrm{~mm}$. long, its 5 lobes triangular-ovate, acute; petals half-orbicular, emarginate, nearly $1 \mathrm{~mm}$. long; drupe ellipsoid, obtuse, $6-8 \mathrm{~mm}$. long.

Thickets and coppices, Andros, New Providence, Eleuthera, Cat Island and Great Exuma. Endemic. BaHAma Reynosia.

\section{KRUGIODÉNDRON Urban, Symb. Ant. 3: 313. 1902.}

An unarmed evergreen tree or shrub, with entire short-petioled leaves, and small perfect flowers subumbellate in the axils. Calyx mostly 5-parted, the lobes much longer than the tube. Petals wanting. Stamens as many as the calyx-lobes; filaments subulate; anthers obtuse. Disc annular, crenate. Ovary short-conic; style short; stigmas 2 , small; ovules '2. Drupe small, ovoid, the pit thin-walled. Testa of the seed adherent to the endocarp; cotyledons semiglobose, fleshy; endosperm none. [Greek, Krug's tree, in honor of Leopold Krug, a student of the West Indian flora.] A monotypic genus.

1. Krugiodendron férreum (Vahl) Urban, Symb. Ant. 3: 314. 1902.

Rhamnus ferreus Vahl in West, St. Croix 276. 1793.

Ceanothus ferreus DC. Prodr. 2: 30. 1825.

Scutia ferrea Brongn. Ann. Sci. Nat. I. 10: 363. 1827.

Condalia ferrea Griseb. Fl. Br. W. I. 100. 1859.

Rhamnidium ferreum Sargent, Gard. \& Flor. 4: 16. 1891.

A tree, attaining a maximum height of about $10 \mathrm{~m}$., with a trunk diameter up to $\tilde{\mathrm{d}} \mathrm{dm}$., usually much smaller, often shrubby, the bark ridged, the branches spreading, the young twigs tomentulose. Leaves mostly opposite, ovate to oval, rather thin, $2-5 \mathrm{~cm}$. long, abtuse or emarginate at the apex, rounded or narrowed at the base, bright green above, dull beneath, nearly glabrous when mature, the petioles $3-6 \mathrm{~mm}$. long; flowers yellow-green, about $4 \mathrm{~mm}$. wide, in axillary clusters much shorter than the leaves; calyx-lobes triangular-ovate; stamens a little shorter than the calyx; drupes globose or ovioid, black, 5-8 mm. long, the stone bony.

Coastal scrub-lands and thickets, Lignum Vitae and Great Harbor Cays, South Cat Cay, Andros, New Providence, Eleuthera, Watling's, Great Guana Cay, Great Exuma, Long Island, Fortune, Crooked, Acklin's and Inagua :-Florida; Cuba to Porto Rico, Anegada and St. Vincent; Jamaica; Bonaire. 
3. SARCóMPHALUS P. Br.; Raf. Sylva Tell. 29. 1838.

Shrubs or trees, often spinescent, with flat glabrous coriaceous entire petioled leaves, and small perfect bractless flowers in terminal panicles. Calyx 5-cleft, the lobes spreading. Petals 5, with a slender claw and a hooded limb. Disk undulate. Stamens 5, distinct, not longer than the petals; anthers extrorse. Ovary immersed in the disk, ovoid, superior; styles 2; stigma obtuse. Fruit a small, nearly dry, ovoid or oblong drupe, the bony pit 2-celled, 2-seeded. [Greek, fleshy navel.] About 8 species, natives of the West Indies. Type species: Sarcomphalus retusus Raf.

1. Sarcomphalus Tàylori Britton, Bull. N. Y. Bot. Gard. 3: 445.1905.

A glabrous, densely branched shrub, $2 \mathrm{~m}$. high or less, or a tree up to $6 \mathrm{~m}$. high, some of the branches long and prostrate, the bark gray, the twigs green, angled, unarmed, or occasionally with a spine $1-2 \mathrm{~cm}$. long in the upper axils. Leaves alternate, obovate, bright green on both sides, but a little paler beneath than above, $1.5-2.5 \mathrm{~cm}$. long, $2 \mathrm{~cm}$. wide or less, emarginate or rounded at the apex, narrowed at the base, 3-nerved just above the base, the veins elevated on the upper surface, and impressed on the lower; petioles about $2 \mathrm{~mm}$. long; flowers in small clusters at the ends of the branches, green, glabrous, $3 \mathrm{~mm}$. broad, on pedicels $2 \mathrm{~mm}$. long; calyx campanulate, 5 -lobed, the lobes ovate, acute, $1 \mathrm{~mm}$. long; petals clawed, hooded, about as long as the calyx-lobes and the stamens; ovary oblong, tipped with two slightly divergent styles; fruit oblong, about $8 \mathrm{~mm}$. long.

Low rocky copplces and rocky scrub-lands, Allen's Cay, Rose Island, Eleuthera, Little San Salvador, Cat Island, Conception, Watling's, Ship Channel Cay, Cay north of Wide Opening, Great Exuma, Fortune Island, East Calcos, South Caicos, Grand Turk, Little Inagua and Inagua:-Mona. TAYLOR'S SARComphaLUs.

\section{COLUBRINA Rich.; Brongn. Ann. Sci. Nat. I. 10: 368. 1827.}

Trees or shrubs, with alternate, petioled leaves, and small perfect yellow or greenish flowers in axillary clusters. Calyx-tube hemispheric, the 5 lobes spreading. Disk angled or lobed. Petals 5, hooded. Stamens 5, the short filaments slender. Ovary immersed in the disk, 3-celled. ovules, 1 in each cavity; styles 3, united below; stigmas blunt. Drupe small, 3-lobed or 3-grooved, splitting into 3 nutlets, its flesh thin. Seeds smooth and shining, the endosperm thin. [Latin, coluber, a serpent.] About 15 species, 1 of them Asiatic, the others of tropical America. Type species: Colubrina ferruginosa Brongn.

Leaves thin, elliptic to ovate-lanceolate acute, glabrous, or nearly so. 1. C. reclinata. Leaves thick.

Leaves oblong or elliptlc, velutinous on both sides.

Leaves ovate to elliptic, pointed, smooth above, ferruginous beneath.

2. C. cubensis.

3. C. colubrina.

1. Colubrina reclinàta (L'Her.) Brongn. Ann. Sci. Nat. I. 10: 369. 1827.

Ceonothus reclinatus L'Her. Sert. Angl. 6. 1788.

A tree, sometimes $20 \mathrm{~m}$. high with a trunk diameter up to $1.5 \mathrm{~m}$., usually much smaller, with orange-brown furrowed bark which exfoliates in thin layers, the young twigs finely pubescent. Leaves elliptic to ovate-lanceolate, rather thin, 4-8 cm. long, acute or bluntish at the apex, rounded or narrowed at the 2-glandular base, the slender petioles 5-15 mm. long; flower-clusters pubescent, 
as long as the petioles or shorter; calyx-lobes acute; petals hooded, shorter than the calyx-lobes; style slender; fruit globose, orange-red, 8-10 $\mathrm{mm}$. in diameter.

Rocky scrub-lands and coppices, Andros, Mangrove Cay, New Providence, Eleuthera, Cat Island, I.ong Island and Grand Turk:-Florida; Cuba to Anegada and to Martinique; Jamaica. SMOOTH SNAKE-BARK. Catesby, 1: $p l .10$.

2. Colubrina cubénsis (Jacq.) Brongn. Ann. Sci. Nat. I. 10: 369. 1827.

Rhamnus cubensis Jacq. Enum. 16. 1760.

Ceanothus cubensis Lam. Tabl. Encyc. 2: 90. 1797.

A shrub or a small tree up to $5 \mathrm{~m}$. high, the twigs, leaves, and inflorescence densely velvety-pubescent. Leaves oblong or elliptic, 4-10 $\mathrm{cm}$. long, 1-5 cm. wide, rather thick, rounded or acute at the apex, rounded or obtuse at the base, strongly pinnately veined, the petioles 5-15 $\mathrm{mm}$. long; flower-clusters peduncled, longer than the petioles; pedicels 4-9 $\mathrm{mm}$. long; ealyx densely pubescent, its lobes triangular-ovate, acute, about $2 \mathrm{~mm}$. long; petals yellow, about as long as the calyx-lobes; fruit globose, about $7 \mathrm{~mm}$. in diameter.

Scrub-lands, Andros, near Nicoll's Town:-Florida; Cuba; Hispaniola. CuBAN SNAKE-BARK.

3. Colubrina colubrìna (Jacq.) Millsp. Field Mus. Bot. 2: 69. 1900.

Rhamnus colubrinus Jacq. Enum. 16. 1760.

Colubrina ferruginosa Brongn. Ann. Sci. Nat. I. 10: 369. 1827.

?Celastrus ovata Hill, Veg. Syst. 13: 62, pl. 12. 1768.

A shrub or tree, $8 \mathrm{~m}$. high or less, or in Jamaica sometimes forming a tree up to $15 \mathrm{~m}$. high, the twigs and young leaves brownish tomentulose. Leaves ovate to elliptic, subcoriaceous, 5-10 cm. long, obtusish, acute or short-acuminate at the apex, rounded or subcordate at the base, the pubescent petioles 5-20 $\mathrm{mm}$. long, the upper surface glabrous when mature, the under surface permanently tomentulose; flower-clusters pubescent, mostly shorter than the petioles; calyx-lobes ovate, obtuse; petals spatulate, yellow, shorter than the calyx-lobes, notched; fruit obovoid-globose, 8-9 mm. in diameter, nearly black.

Rocky coppices, scrub-lands and pine-lands, Abaco, Great Bahama, Andros, Green Cay, New Providence, Cat Island, Rum Cay, Great Exuma, Long Island, Great Ragged Island, Acklin's, Mariguana, Inagua, Angullla Isles, Cay Sal and Grand Turk :-Florida ; Cuba to Virgin Gorda, St. Crolx and Saba; Barbadoes; Jamaica; Cayman Islands. COMMON SNAKE-BARK. BITTERS.

\section{GOUÀNIA Jacq. Stirp. Sel. Am. 263. 1763.}

Woody vines, climbing by tendrils, with alternate petioled broad leaves, and small polygamous flowers in panicled spikes or narrow racemes. Calyx obconic, with 5 spreading lobes. Disk 5-angled or 5-horned. Petals 5, hooded. Stamens 5, short. Ovary immersed in the disk, 3-celled; ovules 1 in each cavity; styles 3 , united at the base; stigmas very small. Fruit dry, 3-winged, separating into 3 nutlets. Seeds shining. [Commemorates Antoine Gouan, 1733-1821, professor in Montpellier.] Type species: Gouania tomentosa Jacq.

1. Gouania lupuloìdes (L.) Urban, Symb. Ant. 4: 378. 1910.

Banisteria lupuloides L. Sp. Pl. 427. 1753.

Gouania domingensis L. Sp. Pl. ed. 2, 1663. 1763.

Gouania glabra Jacq. Stirp. Sel. Am. 264. 1763.

A woody vine, sometimes $7 \mathrm{~m}$. long, climbing by coiled tendrils, the branches glabrous below, loosely pubescent above. Leaves ovate to elliptic, thin, 3-9 cm. long, glabrous or sparingly pubescent, serrate with blunt teeth, 
acute or short-acuminate at the apex, subcordate or rounded at the base, the veins slender, the petioles $5-15 \mathrm{~mm}$. long; racemes slender, pubescent, $5-15 \mathrm{~cm}$. long; pedicels clustered, pubescent, 1-3 mm. long; calyx pubescent, about 1.5 $\mathrm{mm}$. long; corolla yellowish, $2-3 \mathrm{~mm}$. wide, the petals ovate, acute; fruit reticulate-veined, 3-winged, $8-10 \mathrm{~mm}$. broad including the wings which are broader than the body, rarely wingless.

Coppices, Andros, New Providence:-Florida; Cuba to Tortola and Grenada; Jamaica; continental tropical America. CHew-stick.

\section{Family 2. VITÀCEAE Lindl.}

\section{Grape FAMily.}

Climbing vines or erect shrubs, with copious watery sap, nodose joints, alternate petioled leaves, and small regular greenish perfect or polygamodioecious flowers, in panicles, racemes or cymes. Calyx entire or 4-5toothed. Petals 4-5, separate or coherent, valvate, caducous. Filaments subulate, inserted at the base of the disk or between its lobes; disk sometimes obsolete or wanting; anthers 2-celled. Ovary 1, generally immersed in the disk, 2-6-celled; ovules 1-2 in each cavity, ascending, anatropous. Fruit a 1-6-celled berry (commonly 2-celled). Seeds erect; testa bony; raphe generally distinct; endosperm cartilaginous; embryo short. About 10 genera and over 500 species, widely distributed.

Hypogynous disk of the flower annular or cup-shaped; leaves simple or 3-folloiate.

Petals cohering into a caducous cap.

Petals distinct, spreading.

Hypogynous disk wanting or obsolete; leaves digitately 5-7.

follolate in our species.

1. Vitis.

2. Cissus.

3. Parthenocissus.

\section{VİTIS [Tourn.] L. Sp. Pl. 202. 1753.}

Woody vines, rarely shrubby, mostly with tendrils. Leaves simple, usually palmately lobed or dentate. Stipules mainly small, caducous. Flowers mostly dioecious, or polygamo-dioecious, rarely perfect. Petals hypogynous or perigynous, coherent in a cap and deciduous without expanding. Disk annular or cup-shaped. Ovary 2-celled, rarely 3-4-celled; style very short, conic; ovules 2 in each cavity. Berry globose or ovoid, few-seeded, pulpy, edible in most species. [The ancient Latin name.] About 40 species, natives of warm and temperate regions. Type species: Vitis vinifera $\mathrm{L}$.

1. Vitis Munsoniàna Simpson; Planch. in DC. Monogr. 5: 615. 1887.

Muscadinia Munsoniana Small, Fl. SE. U. S. 75̄7. 1903.

A vine up to $6 \mathrm{~m}$. long or more, the young twigs glabrous, the bark smooth, the pith continuous through the nodes. Leaves suborbicular or reniform, thin, but rather firm in texture, 4-8 $\mathrm{cm}$. broad, coarsely dentate, cordate at the base, glabrous above, pubescent in the axils of the veins beneath, the petioles as long as the blades or shorter; tendrils simple, very slender when young; panicles $2-8 \mathrm{~cm}$. long; berries globose, $1-1.5 \mathrm{~cm}$. in diameter, nearly black, acid, the skin thin, the seeds $3-5 \mathrm{~mm}$. long.

Coppices, pine-lands and scrub-lands, Abaco, Great Bahama, Andros, New Providence :- Georgia ; Florida. Reported by Dolley as $V$. caribaea DC.; recorded by Hitchcock, Coker and Mrs. Northrop as V. rotundifolia Michx. Wild Grape. 


\section{Císsus L. Sp. Pl. 117. 1753.}

Mostly climbing vines with fleshy foliage. Leaves 3 -foliolate or simple, when compound the leaflets commonly separating in drying. Flowers mostly perfect. Petals usually 4, spreading. Disk cup-shaped, adnate to the base of the ovary, mostly 4-lobed. Disk cup-like, 4-lobed. Stamens 4. [Greek, ivy.] A large genus, mostly tropical. Type species: Cissus vitiginea L.

Leaves simple.

Leaves trifollolate.

Fruit tubercled; leaflets 3-6 $\mathrm{cm}$. long.

Fruit smooth; leaflets $1-3 \mathrm{~cm}$. long.

Leaflets ovate to obovate, deeply and sharply serrate, very fleshy.

Leaflets oblong to oblong-lanceolate, sparingly toothed, slightly fleshy.
1. C. sicyoides.

2. C. tuberculata.

3. C. trifoliata.

4. C. intermedia.

\section{Cissus sicyoìdes L. Syst. ed. 10, 897. 1759}

A vine, climbing to a height of $6 \mathrm{~m}$. or more, the foliage pubescent or nearly glabrous. Leaves simple, petioled, ovate or ovate-oblong, 2-8 cm. long, acute or acuminate at the apex, truncate or cordate at the base, serrate, the teeth acute or bristle-tipped, the petioles 1-4 cm. long; tendrils slender, often as long as the leaves; cymes peduncled; berries subglobose, black, 8-10 mm. in diameter; seeds 4-5 $\mathrm{mm}$. long.

Rocky coppices and scrub-lands, Andros, New Provldence and Eleuthera :-Bermuda; Florida; the West Indies and continental tropical America. Common Cissus.

\section{Cissus tuberculàta Jacq. Hort. Schoen. 1: 14. pl. 32. 1797.}

A somewhat woody, rather fleshy vine, up to $6 \mathrm{~m}$. long or longer, glabrous or nearly so, the stems usually tuberculate. Leaves long-petioled, 3-foliolate; leaflets ovate to elliptic or oblong-lanceolate, $3-6 \mathrm{~cm}$. long, obtuse or acute at the apex, narrowed or rounded at the base, low-serrate or nearly entire, the lateral ones oblique; cymes compound, slightly and sparingly pubescent; pedicels $10 \mathrm{~mm}$. long or less; petals red or pink, reflexed, ovate, acute; berry obovoid, tubercled or at length smooth, black, 6-8 $\mathrm{mm}$. in diameter.

Rocky open places and coppices, Great Bahama, Andros, New Providence and Eleuthera :-Cuba. Reported by Mrs. Northrop and by Coker as C. microcarpa Vahl. WARTY Cissus. Catesby, $2: p l$. 48.

3. Cissus trifoliàta L. Syst. ed. 10, 897. 1759.

Sicyos trifoliata L. Sp. Pl. 1013. 1753.

Cissus acida L. Sp. Pl. ed. 2, 170. 1762.

A very fleshy vine up to $5 \mathrm{~m}$. long, glabrous throughout. Leaves 3 -foliolate; leaflets ovate to obovate or suborbicular, 1-3 cm. long, sharply toothed above the middle, narrowed or cuneate at the base; flowers in compound cymes; berries globose to ovoid, dark purple, apiculate, $5-7 \mathrm{~mm}$. in diameter, the fruiting pedicels recurved; seeds obovoid.

Rocky plains and scrub-lands, Long Island, Acklin's, East Caicos and Little Inagua :-Florlda ; Jamaica ; Cuba to Vilgin Gorda and St. Croix; recorded south to Martinique and from northern South America. THICK-LEAved Cissus.

4. Cissus intermédia A. Rich. Ess. Fl. Cub. 1: 311. 1845.

A slender, slightly fleshy vine, sometimes $2 \mathrm{~m}$. long or longer, the branches and leaves glabrous, the stems and branches sometimes warty or tuberculate. Leaves slender-petioled, trifoliolate; leaflets oblong to oblong-lanceolate, 1.5-3 cm. long, mostly acute, sparingly serrate, the terminal one equilateral, 
mostly cuneate-narrowed at the base, the lateral ones oblique; cymes compound, glabrous; pedicels $2-6 \mathrm{~mm}$. long; petals red, reflexed, ovate-lanceolate, acute; berry subglobose, black, about $7 \mathrm{~mm}$. in diameter, smooth.

Rocky places, Andros, New Providence, Eleuthera, Grand Turk:-Cuba. Recorded by Mrs. Northrop as Cissus sp. BuLL-viNe.

3. PARTHENOCISSUS Planch. in DC. Mon. Phan. 5² 447. 1887.

Woody vines, the tendrils often tipped with adhering expansions (disks), or sometimes merely coiling, our species with digitately compound leaves. Flowers perfect, or polygamo-monoecious, in compound cymes or panicles. Petals 5, spreading. Stamens 5. Ovary 2-celled; ovules 2 in each cavity; style short, thick. Berry 1-4-seeded, the flesh thin, not edible. About 10 species, natives of Eastern North America and Asia, the following typical.

1. Parthenocissus quinquefòlia (L.) Planch. in DC. Mon. Phan. 5²: 448. 1887.

Hedera quinquefolia L. Sp. Pl. 202. 1753.

Ampelopsis quinquefolia Michx. F1. Bor. Am. 1: 160. 1803.

Parthenocissus quinquefolia latifolia Rehder, Trees and Shrubs 1: 184. 1905.

Tendrils usually numerous, and provided with terminal adhering expansions, the vine sometimes supported also by aerial roots; leaflets oval, elliptic, or oblong-lanceolate, 5-15 cm. long, narrowed at the base, coarsely toothed, at least above the middle, glabrous or somewhat pubescent; panicles ample, erect or spreading in fruit; berries blue, 6-10 mm. in diameter, usually 2-3. seeded; peduncles and pedicels red.

Coppices and scrub-lands, Abaco, Great Bahama, Andros, New Providence, Great Exuma :- Quebec to Manitoba; Florida and Mexico; Bermuda; Cuba. Consists of several races. Virginia Cremper.

\section{Order 16. MALVÀLES.}

Herbs, shrubs or trees, with simple, mostly alternate leaves. Flowers regular, usually perfect. Sepals separate, or more or less united, valvate. Petals separate, very rarely wanting. Stamens usually numerous. Ovary superior, compound, the placentae united in its axis. Disk inconspicuous or none.

Stamens twice as many as the sepals, or more.

Stamens in several sets; anthers 2-celled; embryo straight. Fam. 1. Tiliaceae.

Stamens monadelphous; anthers 1-celled; embryo curved.

Style branches as many or twice as many as the carpels or ovary-cavities.

style entire, or merely lobed.

Stamens as many as the sepals.

Fam. 2. Malvaceat.

Fam. 3. BOMBACACEAE.

Fam. 4. Sterculiaceae.

\section{Family 1. TILIÀCEAE Juss.}

\section{Linden Family.}

Trees, shrubs or herbs, with alternate (rarely opposite) simple leaves, mostly small and deciduous stipules, and solitary cymose or paniculate, usuallv perfect flowers. Sepals 5, rarely 3 or 4 , valvate, deeiduous. Petals of the same number, or fewer, or none, mostly imbricated in the bud. Stamens $\infty$, mostly 5 -10-adelphous. Ovary 1 , sessile, $2-10$-celled; ovules 
anatropous; styles united. Fruit 1-10-celled, drupaceous or baccate. Cotyledons ovate or orbicular; endosperm fleshy, rarely wanting. About 35 genera and 275 species, widely distributed, the Bahama species herbs or low shrubs.

Fruit a loculicidal capsule without prickles.

Fruit indehiscent, prickly, separating into its carpels at maturity.

1. Corchorus.

2. Triumfetta.

\section{CóRCHORUS [Tourn.] L. Sp. Pl. 529. 1753.}

Herbs or low shrubs, with alternate serrate leaves, and yellow, solitary or clustered flowers, axillary or opposite the leaves. Sepals and petals 5, rarely 4 . Stamens twice as many as the petals or more numerous; filaments filiform, simple; anthers introrse. Ovary superior, 2-5-celled; ovules numerous in each eavity; stigma dilated, undulate. Capsule linear or oblong, many-seeded. [Greek, for some bitter plant.] About 40 species of tropical and subtropical distribution. Type species: Corchorus olitorius L.

Capsule glabrous or pubescent.

Capsule 5-ceiled, with 5 short points; basal serratures of leaves long-bristled.

Capsule 2-celled, with 2 bifid teeth; basal serratures of leaf not bristled.

Capsule densely woolly.

1. C. olitorius.

2. C. siliquosus.

3. C. hirsutus.

\section{Corchorus olitòrius L. Sp. P1. 529. 1753.}

Herbaceous, glabrous, 1.5-3 m. high. Stipules setaceous, 1-2 cm. long; leaves oblong-lanceolate or ovate-oblong, 5-12 cm. long, acute or acuminate at the apex, mostly obtuse at the base, serrate all around, the basal teeth recurved, tipped by a filiform appendage 1-2 cm. long; flowers mostly solitary at the nodes, short-peduncled; sepals 5-6 $\mathrm{mm}$. long, subulate-tipped; petals a little longer than the sepals; capsule linear, 4-5 cm. long, 3-4 mm. thick, 5-celled, tipped by $\tilde{5}$ short teeth, its cells septate.

Waste and cultivated land, naturalized, New Providence, near Nassau :-Naturalized from tropical reglons of the Old World; also in Jamaica and Trinidad. INDIAN CORCHORUS. GRANIGRAIN.

\section{Corchorus siliquòsus L. Sp. P1. 529. 1753.}

Shrubby, branched, 3-10 dm. high, glabrous, or the young branches and leaves puberulent or pubescent, the branches often with a line of hairs. Leaves ovate to oblong-lanceolate, 1-5 cm. long, serrate, acute or acuminate at the apex, mostly rounded or obtuse at the base, the short petioles slender; flowers solitary or 2 together, short-peduncled, the pedicels about as long as the peduncles; sepals linear, acute, about $6 \mathrm{~mm}$. long; petals obovate, about $5 \mathrm{~mm}$. long; capsule linear, glabrous, or when young somewhat pubescent, 5-8 cm. long, about $3 \mathrm{~mm}$. thick, 2 -celled, tipped by ' 2 short bifid teeth.

Waste and cultivated land, coppices and scrub-lands, Abaco, Andros, Great Bahama, New Providence, Eleuthera, Crooked Island, Acklin's, Fortune Islands and North Caicos:- Florida; Cuba to Tortola and Trinidad; Texas to Colombla and Guiana; Jamaica. Sмоотн Corchorus.

3. Corchorus hirsùtus L. Sp. Pl. 530. 1753.

A shrub, $2 \mathrm{~m}$. high or Jess, usually erect, but on rocks sometimes nearly prostrate, the young twigs, the leaves and the inflorescence dencely pale scurfytomentulose. Leaves short-petioled, ovate to oblong-lanceolate, crenate-dentate, 2-6 cm. long, mostly obtuse; flowers in small umbels opposite the leaves, the peduncle about as long as the pedicels; sepals tomentulose, 5-6 $\mathrm{mm}$. long; 
petals obovate, bright yellow, about as long as the sepals; capsule oblong, densely tomentose, obtuse, 4-celled, as long as the curved pedicels or longer, about $6 \mathrm{~mm}$. thick.

A common shrub in pastures, coppices and scrub-lands, throughout the archpelago from Abaco, Great Bahama and Andros to Grand Turk and Inagua :-West Indies; Mexico to tropical South America. Recorded by Dolley as Cenchrus hirsutus. WOOLLY CORCHORUS. MALLET. JACK SWITCH.

\section{TRIUMFËTTA L. Sp. Pl. 444. 1753.}

Herbs or low shrubs, with alternate broad petioled leaves, and yellow clustered flowers, axillary or opposite the leaves. Sepals 5. Petals 5, pitted at the base, or wanting in some species. Stamens numerous, borne on an elongated receptacle, the filaments filiform, the anthers introrse. Ovary borne in the cup-shaped top of the receptacle, 2-5-celled; stigma 2-5-lobed; ovules 2 in each eavity. Capsule subglobose, echinate. [In honor of G. B. Triumfetti, an Italian botanist.] About 70 species, of trcpical and warm regions. Type species: Triumfetta Lappula L.

\section{Triumfetta semitríloba Jacq. Enum. 22. 1760.}

\section{Triumfetta althaeoides Lam. Encycl. 3: 420. 1791.}

Annual, stellate-tomentulose. Stems 1-1.5 m. tall, branched; leaves ovate, rhombic or suborbicular in outline, $3-6 \mathrm{~cm}$. long, serrate, angulate or often 3 -lobed, rounded or truncate at the base; petioles as long as the blades or shorter; panicles narrow, elongated; sepals lanceolate, 5-6 $\mathrm{mm}$. long, appendaged below the apex; petals cuneate-spatulate, slightly pubescent at the base; stamens often 15; fruit 1-5 mm. in diameter, 2-celled, copiously prickly, the prickles about as long as the diameter of the body, hooked at the apex.

A weed in waste and cultivated land, Abaco, Andros, New Providence, Eleuthera and Watling's Island :-Bermuda; Florida; West Indies; continental tropical America. A species represented by many races, differing in leaf-form and in minor intermixed characters. BURR BUSH.

\section{Family 2. MALVÀCEAE Neck.}

\section{Mallow Family.}

Herbs or shrubs (sometimes trees in tropical regions), with alternate leaves. Stipules small, deciduous. Flowers regular, usually perfect, often large. Sepals 5 (rarely 3 or 4 ), more or less united, usually valvate; calyx often bracted at the base. Petals 5, hypogynous, convolute. Stamens $\infty$, hypogynous, forming a central column around the pistil, united with the bases of the petals; anthers 1-celled. Ovary severalcelled; styles united below, distinct above, and generally projecting beyond the stamen-column, mostly as many as the cavities of the ovary. Fruit capsular (rarely a berry), several-celled, the carpels falling away entire or else loculicidally dehiscent. Seeds reniform, globose or obovoid; embryo curved; cotyledons large, plicate or conduplicate. About 45 genera and 900 species, widely distributed.

Frult of several or many radiately arranged carpels which mostly separate from each other at maturity.

Carpels as many as the stigmas.

Carpels 2-several-seeded.

Involucre present.

1. Phymosia. 
Involucre none.

Carpels leathery or chartaceous.

Carpels membranous, bladdery.

Carpels only 1 -seeded.

Flowers with an involucre.

Flowers without an involucre.

Carpels separating at maturity.

Carpels permanently united.

Carpels half as many as the stigmas.

Carpels dry, achene-like.

Carpels with a dorsal spine.

Carpels not spined.

Carpels fleshy, the fruit drupe-like.

Fruit a loculicidal capsule, or rarely indehiscent.

Styles distinct.

Herbs and shrubs; capsule without faise partitions.

Calyx 5-toothed or 5-cleft.

Calyx spathaceous.

Tree; capsule with false partitions.

Styles united.

Bractlets of the involucre entire, small ; fruit indehiscent.

Bractlets of the involucre lacinate, large; capsule loculicidally dehiscent.

2. Abutilon.

3. Gayoides.

4. Malvastrum.

5. Sida.

6. Bastardia.

7. Pavonia.

8. Malache.

9. Malvaviscus.
10. Hibiscus.

11. Abelmoschus.

12. Pariti.

13. Thespesia.

14. Gossypium.

1. PHYMòsiA Desv. in Hamilt. Prodr. 49. 1825.

Herbs or shrubs. Bractlets 3 , distinct, or united at the base. Stamencolumn anther-bearing at the summit. Cavities of the ovary 5- $\infty, 2-3$-ovuled. Style-branches the same number as the ovary-cavities, stigmatic at the apex; carpels 2-valved, not septate between the seeds, separating from the axis at maturity. Seeds reniform. [Greek, swollen, referring to the somewhat inflated carpels of the following typical species.] About 40 species, natives of America and South Africa.

1. Phymosia abutiloìdes (L.) Desv. in Hamilt., Prodr. 50. 1825.

Malva abutiloides L. Sp. Pl. ed. 2, 971. 1763.

Sphaeralcea abutiloides G. Don, Gen. Hist. 1: 465. 1831.

Abutilon Eggersii E. Baker, Jour. Bot. 31: 75. 1893.

An erect, sparingly branched shrub up to about $3 \mathrm{~m}$. high, densely stellatetomentose. Leaves nearly orbicular in outline, the lower often $2 \mathrm{dm}$. broad, sharply 5-7-lobed, the lobes serrate, acute or acuminate, the stout petioles shorter than the blades; upper leaves much smaller; flowers corymbose in the upper axils, or forming a terminal panicle; involucel-bractlets linear, deciduous, shorter than the calyx; calyx 5-toothed, its teeth triangular-ovate, acute; petals pink or rose, white-veined, red-streaked at base, 1-1.5 cm. long; carpels about 20, stellate-tomentose on the back, at length glabrous, reniform, obtuse, $1 \mathrm{~cm}$. long; seeds black.

Scrub-lands and coppices, Abaco, Great Bahama, New Providence, Eleuthera. Endemic. Bahama Phymosia. Catesby, $1: p l$. 7 .

\section{ABÙTILON [Tourn.] Mill. Gard. Dict. Abr. Ed. 4. 1754.}

Herbs or shrubs, sometimes trees in tropical countries, mostly soft-pubescent, with cordate angular or lobed leaves and axillary flowers. Involucels none. Calyx 5-cleft. Cavities of the ovary 5- $\infty, 3-9$-ovuled. Style-branches the same number as the ovary-cavities, stigmatic at the apex; carpels 2-valved, often rostrate, falling away from the axis at maturity. Seeds reniform, the upper ascending, the lower pendulous or horizontal. [Name given by the celebrated Arabian physician Avicenna (Ibn Sina), died 1037.] About 100 species, natives of warm and tropical regions. Type species: Sida Abutiton L. 
Carpels 15-30, thin, merely acute.

1. A. hirtum.

Carpels 5-10, chartaceous to coriaceous, subulate-beaked.

Carpels attenuate-beaked, flowers $2-2.5 \mathrm{~cm}$. broad.

Leaves not strongly retlculate-veined beneath; carpels 1 $\mathrm{cm}$. long.

Leaves distinctly reticulate-veined beneath; carpels 1.5 $\mathrm{cm}$. long.

Carpels abruptly minutely beaked.

Carpels puberulent.

Carpels villous.

2. A. permolle.

3. A. abutiloides.

4. A. trisulcatum.

5. A. pauciftorum.

1. Abutilon hírtum (Lam.) Sweet, Hort. Brit. 1: 53.1827.

Sida hirta Lam. Encycl. 1: 7. 1783.

Abutilon indicum hirtum Griseb. Fl. Br. W. I. 78. 1859.

Perennial, velvety-canescent and villous-viscid, branched, 1-5 dm. high. Leaves ovate or nearly orbicular, $15 \mathrm{~cm}$. long or less, cordate at the base, irreg. ularly crenate, the petioles as long as the blades or shorter; peduncles mostly shorter than the petioles, sometimes as long; calyx somewhat enlarged in fruit, its ovate lobes acute or acuminate; petals yellow, commonly with a purple base, 1.5-2 cm. long; carpels 15-30, very thin, a little longer than the calyx, 8-10 $\mathrm{mm}$. long, mueronulate.

Waste lands, Harbor Island; New Provldence (?):-Florida; Cuba to St. Thomas and Barbadoes; Jamalca; Old World tropics. Recorded by Dolley as Abutilon indicum G. Don. HAIRY ABUTILON.

2. Abutilon permólle (Willd.) Sweet, Hort. Brit. 1: 53. 1827.

Sida permollis Willd. Enum. Hort. Berol. 723. 1809.

Perennial, velvety, 0.6-1.5 m. high, branched, the branches slender. Leaves ovate, $2.5-10 \mathrm{~cm}$. long, acuminate at the apex, rather deeply cordate at the base, crenulate, white-tomentulose beneath, the petioles as long as the blades or shorter; calyx scarcely enlarged in fruit, its ovate or ovate-lanceolate, acuminate lobes longer than the tube; petals yellow, obovate, 1-1.5 cm. long. earpels $7-10$, slender-beaked, longer than the calyx, nearly $1 \mathrm{~cm}$. long.

Waste places and scrub-lands, Little Harbor Cay, New Providence, Eleuthera, Little San Salvador, the Exumas to Long Island, Crooked Island, Fortune Island, Inagua, East Caicos and Anguilla Isles:-Florida; Cuba; Jamalca. VeLvery ABUTILON.

3. Abutilon abutiloides (Jacq.) Garcke, Bot. Jahrb. 15: 485.1893.

Sida abutiloides Jacq. Obs. 1: 17. 1764.

Abutilon lignosum G. Don, Gen. Hist. 1: 501. 1831.

A shrub, up to $1.5 \mathrm{~m}$. high, the twigs densely stellate-tomentose. Leaves broadly ovate, $2-8 \mathrm{~cm}$. long, serrate nearly al! around, stellate-tomentulose on both sides, reticulate-veined beneath, acuminate at the apex, cordate at the base, the petioles somewhat shorter than the blades; peduncles longer than the petioles; calyx little enlarged in fruit, its broadly ovate acuminate tomentulose lobes sharply acuminate; petals bright yellow, about $1 \mathrm{~cm}$. long; carpels 7-10, slender-beaked, about. $1.5 \mathrm{~cm}$. long.

Waste places, Harbor Island, Long Island:-Cuba; Hispaniola; Jamaica; Mexico. Bushy ABUTiLON.

4. Abutilon trisulcàtum (Jacq.) Britton \& Millspaugh.

Sida trisulcata Jacq. Enum. 26. 1760.

Abutilon triquetrum Presl, Reliq. Haenk. 2: 115. 1835.

A shrub, 1-1.6 m. high, with slender ascending densely tomentulose branches. Leaves ovate, slender-petioled, 4-12 cm. long, crenate or crenulate, finely velvety on both sides, the upper ones much smaller than the lower; 
flowers solitary and slender-peduncled in the axils of leaf-like bracts, or subpaniculate; calyx 4-5 mm. long, its lobes triangular-ovate, acuminate; petals yellow, reddish blotched at the base, 5-7 $\mathrm{mm}$. long; carpels about 5 , stellatepuberulent, short-tipped, about $8 \mathrm{~mm}$. long.

Scrub-lands, New Providence and Great Exuma :-Cuba; Mexico.

\section{Abutilon pauciflòrum St. Hil. Fl. Bras. Mer. 1: 206. 1825.}

A densely stellate-tomentose shrub, $6 \mathrm{dm}$. high, or higher. Leaves orbicular-ovate, 5-7 cm. long, obtuse, acute or short-acuminate at the apex, deeply cordate at the base, crenate, the petiole as long as the blade or shorter; peduncles axillary, about as long as the petioles; calyx 10-12 mm. long; its lobes ovate, acute or acuminate; petals somewhat longer than the calyx; carpels 8-10, densely villous, 2-cuspidate.

Waste grounds, Long Island, at Clarence Town:-Florida; Jamaica; Cuba ; Mexico to Paraguay. Woolly ABUtilos.

\section{GAYOIDES Small, FI. SE. U. S. 764. 1903.}

A slender perennial finely velvety and often also villous herb, with petioled ovate cordate leaves and solitary axillary filiform-peduncled, whitish flowers. Involucels none. Calyx deeply 5-cleft. Petals 5, distinct. Carpels numerous, 1-celled, membranous and inflated in fruit, the apex rounded; styles slender; stigmas terminal; ovules $2-6$ in each carpel. Seeds glabrous. [Similar to the genus Gaya.] A monotypic genus.

1. Gayoides críspum (L.) Small, Fl. SE. U. S. 764. 1903.

Sida crispa L. Sp. Pl. 685. 1753.

Abutilon crispum Medic. Malv. 29. 1787.

Usually much branched, the branches diffuse or ascending, 3-10 dm. long. Leaves thin, broadly ovate, 2-7 cm. long, acute or acuminate at the apex, deeply cordate at the base, crenate or crenulate, the petioles equalling the blades, or shorter, sometimes very short; peduncles as long as the leaves, or shorter, jointed below the flower; calyx velvety and often villous, its lobes ovate or ovate-lanceolate, acute, 4-6 mm. long; petals pale yellow or whitish, obovate, about twice as long as the calyx; fruiting head of carpels $12-20 \mathrm{~mm}$. thick, the inflated carpels somewhat pubescent.

Waste and cultivated lands, throughout the archipelago from Abaco and Great Bahama to Caicos, Grand Turk, Ambergris Cay, Inagua and the Anguilla Isles and Water Cay :- Southern United States; West Indies, east to St. Thomas, south to Grenada; Mexico to tropical America; Old World tropics. Recorded by Dolley as Abutilon filiforme Jacq. Low ABuTiLoN.

\section{MALvÁstrum A. Gray, Mem. Am. Acad. II. 4: 21.1849.}

Herbs, with entire cordate or divided leaves, and solitary or racemose, short-pedicelled perfect flowers. Calyx 5-cleft. Bractlets of the involucels

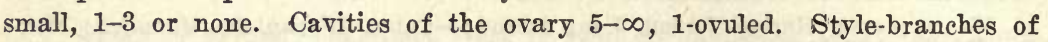
the same number, stigmatic at the summit only, forming capitate stigmas; carpels indehiscent or imperfectly 2-valved, falling away from the axis at maturity, their apices pointed or beaked. Seed ascending. [Greek, star-mallow.] About 75 species, natives of America and S. Africa. Type species: Malvastrum coccineum (Pursh) A. Gray.

Carpels with a short flliform awn; flowers mostly solitary. 1. M. coromandelianum. Carpels not awned; flowers mostly capitate. 
1. Malvastrum coromandeliànum (L.) Garcke, Bonplandia 5: 297.1857.

Malva coromandeliana L. Sp. Pl. 687. 1753.

Malvastrum tricuspidatum A. Gray, Pl. Wright. 1: 16. 1852.

Malvastrum americanum Torrey, Bot. Mex. Bound. Surv. 38. 1859.

Perennial, strigose-pubescent, branched, 3-10 dm. high. Leaves ovate to oblong-ovate, slender-petioled, $2-8 \mathrm{~cm}$. long, acute, sharply serrate, the hairs of the upper surfaces mostly simple; flowers mostly solitary in the axils, on peduncles shorter than the petioles; involucels of 3 small bractlets; calyx-lobes triangular, acute, longer than its tube; petals pale yellow, somewhat longer than the calyx, obliquely truncate; carpels 8-12, hirsute on top, with an awn near the inflexed apex and 2 beaks on the back.

Waste grounds and cultivated soils, Great Bahama, North Bimini, Eleuthera, Watling's :-Bermuda; Florida to Texas; the West Indies; continental tropical America; tropical and subtropical Asia. FALSE MALLOW.

2. Malvastrum corchorifòlium (Desr.) Britton; Small, Fl. Miami 119. 1913.

Malva corchorifolia Desr. in Lam. Encycl. 3: 755. 1791.

Malvastrum Rugelii S. Wats. Proc. Am. Acad. 17: 367. 1882.

Similar to the preceding species, about as pubescent and the leaves much alike in both, the hairs of the upper surfaces mostly forked. Flowers mostly in terminal heads 1-2 cm. long, or some of them solitary in the axils; calyxlobes triangular-ovate, acuminate; petals orange or yellow, longer than the calyx; carpels about 10 or fewer, hispidulous, beakless, or sometimes with a blunt protuberance.

Waste and cultivated lands. Abaco, New Providence, Eleuthera, Cat Island, Fortune Island, Acklin's, Grand Turk, Inagua and Anguilla Isles :-Florida ; Cuba ; Virgin Gorda; Jamalca. RUGEL'S FALse MAILOW.

\section{SİDA L. Sp. Pl. 683. 1753.}

Herbs, with serrate crenate or lobed leaves, and perfect flowers. Bractlets of the involucels none. Calyx 5-toothed or 5-cleft. Cavities of the ovary 5- $\infty$, 1-ovuled; style-branches of the same number, stigmatic at the summit. Carpels indehiscent, or at length 2-valved at the apex. Seed pendulous. [Greek, used by Theophrastus.] About 75 species, natives of the warmer parts of America, Asia, Africa and Australasia. Type species: Sida alnifolia L.

Flowers capitate, congested at the aplces of the branches, their peduncles adnate to the long-ciliate bracts.

Flowers solltary or variously clustered, not adnate to the floral

1. S. ciliaris.

bracts.

Calyx angular.

Leaves narrowed or rounded at the base.

Leaves short-petioled.

Leaves long-petioled.

Leaves distinctly cordate at the base.

Plants prostrate, creeping, leaves sub-orbicular.

Plants erect or diffuse, leaves ovate to ovate-lanceolate.

Flowers glomerate, very short-pedicelled; plants with stinging hairs.

Flowers solitary or few together, slender-pedicelled. Leaves acuminate, plants erect.

Calyx-tube terete.

Leaves obtuse or merely acutish, plants diffuse.

2. S. carpinifolia.

3. S. spinosa.

4. S. hederaefolia.

5. S. urens.

6. S. glutinosa.

7: S. procumbens.

8. S. acuminata.

1. Sida ciliàris L. Syst. ed. 10, 1145. 1759.

Perennial, strigose-pubescent, diffusely branched at the base from a deep woody root, the slender branches prostrate or ascending, 1-3 dm. long. Leaves 
oblong or elliptic, $0.7-3.5 \mathrm{~cm}$. long, obtuse or emarginate at the apex, mostly obtuse at the base, serrate, mostly above the middle, slender-petioled, usually glabrous above and stellate pubescent beneath; flowers clustered at the ends of the branches, their short peduncles adnate to the petioles of the foliaceous bracts; stipules linear or linear-spatulate, long-ciliate, about as long as the petioles; calyx hirsute, its triangular acute lobes about as long as the nearly terete tube; petals red, yellow or purplish, blotched at the base, 6-12 mm. long; carpels 5-8, wrinkled or tubercled, 2 -beaked.

Rocky soils and cultivated grounds, Great Sturrup Cay to New Providence, Eleuthera, Atwood's, Fortune Island, East Caicos, and Inagua :-Florlda; West Indies; tropical continental America. FrINGED SIDA.

\section{Sida carpinifòlia L. f. Suppl. 307. 1781.}

Sida acuta carpinifolia K. Schum. in Mart. F1. Bras. 123: 326.1891.

Sida antillensis Urban, Symb. Ant. 5: 418. 1908.

Puberulent or glabrous. Stems erect, 3-9 dm. tall, branching; leaves lanceolate, oblong-ovate or ovate, $2-10 \mathrm{~cm}$. long, acute or acuminate, irregularly serrate, obtuse or subcordate at the base, the petioles 3-7 mm. long; stipules conspicuous, narrowly linear to lanceolate, surpassing the petioles; peduncles mostly shorter than the pedicels, 1-7 mm. long; calyx 5-10-ribbed, its lobes triangular, slightly acuminate, about as long as the tube; petals yellow to white, 6-12 $\mathrm{mm}$. long. carpels reticulate-wrinkled, 2-beaked.

Fields and waste places, Abaco, Great Sturrup Cay, Andros, New Providence, Eleuthera to Watling's, Great Exuma, Long Isiand, Grand Turk and Inagua :Bermuda; North Carolina to Florida and Texas: West Indies and tropical continental America. Referred by Hitchcock to Sida glomerata Cav. WIRE-WEEd.

3. Sida spinòsa L. Sp. Pl. 683.1753.

Sida angustifolia Lam. Encycl. 1: 4. 1783.

Sida spinosa angustifolia Griseb. Fl. Br. W. I. 74. 1859.

Annual, finely pubescent, 3-6 dm. high. Leaves ovate to oblong-lanceolate, 2-5 cm. long, petioled, truncate or cordate at the base, crenate-dentate; flowers axillary, short-peduncled, yellow; peduncles shorter than the petioles; calyxteeth triangular, acute; carpels 5 , dehiscent at the apex into 2 beaks; stipules linear; petioles of the larger leaves with a small spine-like tubercle at the base.

Waste and cuitivated lands, Great Bahama, Great Sturrup Cay, New Providence, Eleuthera, Cat Island, Watling's, Great Exuma, Long Island, Fortune Island, East Calcos, Inagua and the Anguilla Isies :-New York to Kansas, Florida and Texas; West Indies; tropical continental America. FALSE MALLow.

\section{Sida hederaefòlia Cav. Diss. 1: 8. 1785.}

Loosely stellate-pubescent or glabrate; stems branched at the base, the slender, trailing branches 3-5 dm. long. Leaves nearly orbicular, slenderpetioled, 1-3 cm. broad, cordate, crenate-dentate, the petioles often longer than the blades; peduncles solitary in the axils, filiform, sometimes longer than the leaves; calyx about $4 \mathrm{~mm}$. long, angled, its broadly ovate acute teeth about as long as the tube; petals yellow, somewhat longer than the calyx; carpels 2aristate.

Waste piaces and roadsides, Great Bahama at Eight Mile Rocks :-Cuba to Porto Rico. IVy-Leaved Sida.

\section{Sida ùrens L. Syst. ed. 10, 1145. 1759.}

Harshly hirsute, erect, ascending, weak, branched or sometimes simple, 3-15 $\mathrm{dm}$. high. Leaves ovate or ovate-lanceolate, $2.5-8 \mathrm{~cm}$. long, acute or acuminate at the apex, cordate at the base, slender-petioled, serrate, loosely stellatepubescent; flowers subsessile in axillary and terminal, usually dense clusters, 
or some of them axillary, solitary and short-pedicelled; calyx hirsute, 5-cleft, angular, 6-7 $\mathrm{mm}$. long, its triangular-ovate, acute or acuminate teeth about as long as the tube; petals yellow, reddish at base; carpels 5, glabrous, 2 denticulate.

Waste and cultivated land, New Providence at Nassau:-Cuba to Porto Rico and Trinidad; continental tropical America; Old World tropics. STICKY SIDA.

6. Sida glutinòsa Comm.; Cav. Diss. 1: 16. 1785.

Sida nervosa DC. Prodr. 1: 465. 1824.

Erect, 5-10 dm. high, branched, the stem and branches densely tomentulose, somewhat glutinous, sometimes also with long spreading hairs. Leaves ovate to lanceolate, $8 \mathrm{~cm}$. long or less, acuminate at the apex, cordate at the base, crenulate, the lower long-petioled, the upper usually much smaller than the lower and shorter-petioled; flowers 1-several in the axils or in terminal panicles; pedicels filiform, mostly much longer than the calyx, pubescent; calyx angled, 3-4 mm. long, its 5, broadly ovate, sharply acute teeth shorter than the tube; petals yellow, about twice as long as the calyx; carpels 5, pubescent above, 2-aristate.

Waste and cultivated land, New Providence at Nassau:-Cuba to Porto Rico, St. Jan and 'Trinldad; continental tropicai America; Old World tropics. STICKX SIDA.

7. Sida pròcumbens Sw. Prodr. 101. 1788.

Sida supina L'Her. Stirp. Nov. 1092. 1789.

Branched at the base, the branches slender, prostrate or nearly so, 1-6 dm. long, densely puberulent, glabrate or pilose. Leaves ovate or ovate-orbicular, 1-2.5 cm. long, slender-petioled, crenate, obtuse at the apex, cordate at the base, densely puberulent on both sides; peduncles axillary, solitary, about as long as the leaves or shorter, or longer, filiform, sometimes pilose; calyx about $4 \mathrm{~mm}$. long, puberulent or pilose, its 5 ovate acuminate lobes somewhat shorter than the angled tube; petals pale yellow or white, 4-6 $\mathrm{mm}$. long; carpels mostly 5, reticulate, 2-beaked, about $2 \mathrm{~mm}$. long.

Fields, pastures and waste places, New Providence, Eleuthera, Long Island, Fortune Island, South Caicos, Ambergris Cay and Inagua :-Florida; West Indies; continental tropical America. Creeping SIDA.

8. Sida acuminàta DC. Prodr. 1: 462. 1824.

Sida acuminata Bracei E. Baker, Journ. Bot. 30: 295. 1892.

Densely stellate-pubescent, usually branched, somewhat woody, erect, 5-8 dm. high, branched or sometimes simple. Leaves ovate to ovate-lanceolate, rather short-petioled, 2-7 cm. long, acute, obtuse or acuminate at the apex, rounded, or subcordate at the base, low crenate-serrate; flowers few or solitary in the axils, and often in small terminal clusters, nearly sessile or filiformpeduncled, the peduncles sometimes $2-3 \mathrm{~cm}$. long; calyx 5-6 mm. long, terete, its 5 , broadly ovate, acute teeth somewhat shorter than the tube; petals yellow, 4-5 mm. long; carpels 5-8, stellate-pubescent, scarcely beaked.

Roadsides and waste places, Abaco, New Providence, Eleuthera, Cat Island, Rum Cay, Great Exuma, Long Island, Crooked Island, Fortune Island, Acklin's and Mariguana, East Caicos:-Cuba to Virgin Gorda and Antigua; Central America. Races differ in the number and size of the flowers. VELvETY SidA.

6. BASTARDIA H.B.K. Nov. Gen. 5: 254. 1821.

Velvety-pubescent or tomentose shrubs or perennial herbs, with petioled cordate leaves, and small yellow peduncled flowers, solitary or few in the axils. Involucel none. Calyx 5-toothed or 5-cleft. Petals 5. Stamen-column 
divided into several or many filaments at the apex. Ovary 5-celled; ovules 1 in each cavity, pendulous; style-branches 5; stigmas capitate. Capsule depressed-globose, 5-grooved, 3-5-valved. [Commemorates the French botanist T. Bastard.] Six known species, of tropical America. Type species: Bastardia parvifolia H.B.K.

1. Bastardia viscòsa (L.) H.B.K. Nov. Gen. \& Sp. 5: 256.1822.

Sida viscosa L. Syst. ed. 10, 1145.1759.

Finely velvety-pubescent and viscid, sometimes also pilose, erect, branched, 3-7 dm. high. Leaves ovate, 1-6 $\mathrm{cm}$. long, acute or acuminate at the apex, cordate at the base, irregularly denticulate, the slender petioles as long as the blades or shorter; pedicels nearly filiform, longer than the petioles, often longer than the leaves, rarely not longer than the calyx; calyx about $4 \mathrm{~mm}$. long, its 5, ovate-lanceolate, acuminate teeth about as long as the tube; petals yellow, 4-5 mm. long; capsule about as long as the calyx, its carpel-valves beakless.

Waste lands, Eleuthera and Long Island:-West Indies; Mexico to Colombia and Peru. Hitchcock's plant referred to this specles is Sida glutinosa Comm. Viscid BASTARDIA.

7. PAvònIA Cav. Diss. 3: 132. 1787.

Shrubs or shrubby herbs. Leaves alternate, stipulate, angled or lobed. Flowers perfect, commonly solitary on axillary peduncles. Involucel of 5-15 bractlets. Calyx 5-lobed. Petals 5. Carpels 5, 1-celled; styles 10; stigmas capitate; ovules solitary. Mature carpels separating from axis, 1-3-spined on the back, more or less deeply 2-valved. Seeds solitary, ascending. [In honor of Joseph Pavon, Spanish botanist and explorer.] Sixty species or more, mostly of tropical distribution, the following typical.

1. Pavonia spínifex (L.) Cav. Diss. 3: 133. 1787.

Hibiscus spinifex L. Syst. ed. 10, 1149. 1759.

A branching shrub, 1-3 m. tall, hirsute and strigillose. Leaves ovate or oblong-ovate, 5-10 cm. long, acute or somewhat acuminate, doubly crenatedentate, truncate or subcordate at the base, the petioles densely pubescent; peduncles axillary, much longer than the petioles; bractlets of the involucel 5, linear to lanceolate, acute, nearly $1 \mathrm{~cm}$. long; calyx about as long as the bractlets, its lobes lanceolate to ovate-lanceolate; petals yellow, $2.5 \mathrm{~cm}$. long, cuneate; carpels 5-6 mm. high, with 1 medial and 2 lateral retrorsely barbed awns.

Waste lands, New Provldence and Long Island:-Bermuda; South Carolina to Florida; the West Indies and tropical continental America. PAvonia.

8. MALĀCHE B. Vogel; Trew, Pl. Sel. 50. 1772.

Tall shrubs or small trees, with alternate broad, lobed or nearly entire leaves, and large peduncled flowers solitary in the axils. Involucre of several bractlets. Calyx 5-lobed. Petals 5, broad. Carpels mostly 5, 1-celled; styles 10. Ovules solitary. Carpels 2-valved, knobbed on the back, not spined, coriaceous, tardily dehiscent. [Greek, mallow.] Three known species, the following, and one in Jamaica. Type species: Malache scabra B. Vogel. 
1. Malache scábra B. Vogel; Trew, Pl. Sel. 50. 1772.

Pavonia spicata Cav. Diss. 3: 136. 1787.

Pavonia racemosa Sw. Fl. Ind. Occ. 2: 1215. 1800.

An erect, usually little-branched shrub, 1-5 m. high, the branches and inflorescence densely roughish-pubescent. Leaves ovate to oblong-ovate, firm in texture, 5-15 cm. long, palmately veined, repand-dentate or entire, acuminate at the apex, subcordate or rounded at the base, the petioles $3-6 \mathrm{~cm}$. long; racemes loosely several-flowered; pedicels ascending, $2-5 \mathrm{~cm}$. long; involucelbractlets oblong-lanceolate, about $1 \mathrm{~cm}$. long; calyx as long as or a little longer than the bractlets, its lobes ovate, acute; petals yellowish, about twice as long as the calyx, finely pubescent, longer than the stamen-column; carpels somewhat shorter than the calyx, with 2 short blunt beaks on the upper margins and a short terminal crest.

Borders of mangrove swamps, Andros at Conch Sound :-Florida; Cuba to Porto Rlco and Trinidad; Jamaica; coasts of tropical continental America. SWAMP BUSH.

\section{Malache bahaménsis (Hitchc.) Britton \& Millspaugh.}

Pavonia bahamensis Hitchc. Rep. Mo. Bot. Gard. 4: 63. 1893.

Malvaviscus Cokeri Britton; Coker in Shattuck, Bahama Islands, 259. 1905.

A shrub, or small tree, up to $4 \mathrm{~m}$. high, with round glabrous branchlets. Leaves ovate or nearly orbicular, acuminate, cordate, thin, 7-nerved, entire or slightly repand, the upper surface glabrous but papillose, the under side glabrous except for tufts of hairs in the axils of the principal veins, and a few scattered ones on the veins, the blades 4-7 cm. long, 3-6 $\mathrm{cm}$. wide, the petioles slender, 1.5-2.5 cm. long; peduncles slender, puberulent, 2 or 3 times as long as the petioles; involucrel-bractlets narrowly linear, acuminate, glabrous, $1 \mathrm{~cm}$. long, $1.5 \mathrm{~mm}$. wide, about as long as the calyx; calyx-lobes triangular-ovate, acuminate, about one-half as long as the tube, woolly within; petals about $2 \mathrm{~cm}$. long; stamen-column $3 \mathrm{~cm}$. long or more; carpels with 2 compressed rounded terminal lobes and a central crest.

Rocky coastal thickets, Watling's Island, Crooked Island, Fortune Island, Acklin's Island and Plne Cay (Caicos). Endemic. BaHama Swamp-Bush.

\section{MALVAVISCUS Dill.; Adans. Fam. Pl. 2: 399. 1763.}

Shrubs or small trees, with broad usually dentate or lobed, petioled leaves, and red flowers. Involucel of several narrow bractlets. Calyx 5-cleft. Petals erect-connivent. Stamen-column truncate or 5-toothed, bearing numerous stamens. Ovary 5-celled; ovules 1 in each cavity; style-branches 10, stigmatic at the capitate summit. Fruit baceate, the indehiscent carpels finally separating. [Latin-Greek, similar to Malva.] About 10 species of tropical America. Type species: Hibiscus Malvaviscus $\mathrm{L}$.

1. Malvaviscus Sagraeànus A. Rich. in Sagra, Hist. Cub. 10: 46.1845.

Malvaviscus arboreus Sagraeanus Griseb. Fl. Br. W. I. 83. 1859.

A branching shrub, 2-4 m. high, the twigs finely pubescent or glabrate, slender. Leaves ovate to ovate-lanceolate, irregularly crenate, sometimes 3 . lobed, 5-15 cm. long, acuminate at the apex, rounded or subcordate at the base, glabrous, or with a few scattered hairs, the slender pubescent petioles shorter than the blades; involucel-bractlets linear-spatulate, 8-10 $\mathrm{mm}$. long, about as ?ong as the calyx, glabrous or pubescent; corolla red to scarlet, about $2 \mathrm{~cm}$. long; fruit depressed-globose, about $1 \mathrm{~cm}$. in diameter.

Scrub-lands of Abaco and Great Bahama:-Cuba. Sagra's Malvaviscus. 


\section{HIBÍsCUS L. Sp. Pl. 693. 1753.}

Herbs, shrubs, or in tropical regions even small trees, with dentate or lobed leaves, and showy, mostly campanulate flowers. Bractlets numerous, narrow. Calyx 5-cleft or 5-toothed. Column of stamens anther-bearing below along much of its length. Ovary 5-celled, the cavities 3-several-ovuled; style-branches 5, stigmatic at the capitate summit. Capsule 5-valved. Seeds reniform. [An ancient name, used by Dioscorides for the Marsh Mallow.] About 180 species, widely distributed. Type species: Hibiscus Trionum L.

\section{Hibiscus bahaménsis Britton, Bull. N. Y. Bot. Gard. 4: 120. 1905.}

A shrub, the leaves, calyx, peduncles and twigs densely and finely stellatepubescent. Leaves ovate in outline, palmately veined, $10 \mathrm{~cm}$. long or less, firm in texture, cordate to truncate at the base, 3 -lobed or 5 -lobed with the middle lobe much the longest and acuminate, the lateral lobes acute or obtuse, irregularly dentate; upper leaves varying to lanceolate, and merely dentate; petioles as long as the blades or shorter; peduncles stout, solitary in the axils, longer than the subtending petioles, jointed near the middle; bractlets linear-lanceolate, acuminate, very unequal, the longer about $1.5 \mathrm{~cm}$. long; calyx 2-2.5 cm. long, densely stellate-pubescent, its oblong lcbes strongly veined, acuminate; petals brownish, $3.5 \mathrm{~cm}$. long, densely pubescent, without, oblanceolate, obtusish; capsule oval, $2.5 \mathrm{~cm}$. long, $2 \mathrm{~cm}$. thick, densely silky.

Rocky scrub-lands and coppices, Abaco, Andros, Eleuthera, Cat Island, Conception Island, Rum Cay, Acklin's. Endemic. Recorded by Mrs. Northrop as H. cryptocarpus Rich. Erroneously called wild cotton. BaHama Hiriscus.

\section{ABELMóschus Medic. Malv. 45. 1787.}

Tall herbs, with broaf, lobed leaves, and large axillary and terminal flowers. Bractlets several or numerous, narrow. Calyx spathaceous, splitting along one side, deciduous. Stamen-column bearing numerous anthers. Ovary 5-celled, its cavities several-ovuled; style-branches 5 , stigmatic at the summit. Capsule elongated, 5-valved. [Name said to be Arabic.] A few species, natives of the Old World. Type species: Abelmoschus moschatus Medic.

\section{Abelmoschus esculéntus (L.) Moench, Meth. 617. 1794.}

\section{Hibiscus esculentus L. Sp. P1. 696. 1753.}

Annual, erect, little-branched, 1-2 m. tall, sparingly hirsute. Leaves longpetioled, nearly orbicular in outline, 1-3 dm. broad, deeply 5-7-lobed, the lobes lanceolate to obovate, irregularly serrate, acute or obtuse; peduncles stout, 1-3 cm. long; bractlets linear, bristly-hirsute, about $1.5 \mathrm{~cm}$. long; calyx about $2 \mathrm{~cm}$. long; petals broad, yellowish, purple-blotched at the base, $3-4 \mathrm{~cm}$. long; capsule angled, $2 \mathrm{dm}$. long or less, long-tipped.

Waste-lands, spontaneous after cultivation; Cat Island and Fortune Island :spontaneous in most tropical and subtropleal regions; native of the Old World troples. OKRA.

\section{PARÍtI Adans. Fam. Pl. 2, 401. 1763.}

Trees, with broad cordate petioled leaves, large deciduous stipules, and large, terminal or axillary flowers, solitary or few together, the petals yellow or changing to red. Involucre 8-10-toothed. Calyx 5-toothed. Style pubescent 
above, 5-cleft, the stigmas broad. Capsule loculicidally 5-celled, many-seeded, the cells vertically partitioned by a dissepiment which splits at dehiscence into two membranes. [Name said to be Malabaric.] A few species of tropical regions, the following typical.

1. Pariti tiliàceum (L.) St. Hil. Fl. Bras. Merid. 1: 256. 1827.

Hibiscus tiliaceus L. Sp. Pl. 694. 1753.

A tree, sometimes $18 \mathrm{~m}$. high, the young foliage velvety-tomentose. Leaves long-petioled, the blades $7-20 \mathrm{~cm}$. broad, nearly orbicular, cordate at base, abruptly acuminate at apex, shallowly dentate or subentire, the venation prominent beneath; involucre 10 -cleft, about $12 \mathrm{~mm}$. long; petals yellow, obovate, 5-6 $\mathrm{cm}$. long; calyx about $2 \mathrm{~cm}$. long; capsule ovoid, tomentose, $15-18 \mathrm{~mm}$. long; seeds glabrous or minutely downy.

Coastal thickets, Abaco, Andros, New Providence, Cat Island, Pine Cay (Caicos) : -Bermuda; Florida; throughout the West Indies and tropical continental America; old World tropics. Manoe. Catesby, 2: pl. 90.

\section{THESPĖsIA Soland.; Correa, Ann. Mus. Paris 9: 290. 1807.}

Shrubs or trees. Leaves alternate, entire or merely angulately lobed, commonly ample, usually cordate, petioled. Flowers perfect, showy. Involucel of 3-5 narrow deciduous bractlets. Calyx truncate or nearly so. Petals 5. Ovary sessile, 5-celled; styles 5, united or rarely distinct; stigmas decurrent on the styles. Ovules few in each eavity. Capsule firm, woody-leathery, 5celled, indehiscent. Seeds glabrous or pubescent. [Greek, marvellous.] About 8 tropical species, the following typical.

1. Thespesia popúlnea (L.) Soland.; Correa, Ann. Mus. Paris 9: 290. 1807.

Hibiscus populneus L. Sp. Pl. 694. 1753.

A tree, sometimes $7 \mathrm{~m}$. high, with a trunk up to $2 \mathrm{dm}$. in diameter, usually smaller, often a shrub, the stout twigs scurfy when young. Leaves firm in texture, slightly fleshy, ovate-orbicular, 5-12 cm. long, acuminate at the apex, cordate at the base, undulate-margined; petioles nearly as long as the blades; peduncles shorter than the petioles; calyx subhemispheric, nearly truncate; petals 4-7 $\mathrm{cm}$. long, yellow with a purple base, changing to purple; fruit depressed-globose, leathery ${ }_{2} 3-4.5 \mathrm{~cm}$. in diameter, 1.5-2 $\mathrm{cm}$. high; seeds pubescent.

Borders of marshes, and in sandy scrub-lands, New Providence and Grand Turk: -Florida; the West Indies and tropical continental America; Old World troplcs. Sea-side Mahoe. Cork-tree. Spanish Cork.

\section{GOSSỲPIUM L. Sp. Pl. 693. 1753.}

Herbs, shrubs or small trees, with alternate petioled, usually lobed leaves, and large, mostly solitary, peduncled, yellow or white to purple flowers subtended by 3 broad, often cordate, incised bracts. Calyx truncate or 5-lobed. Stamen-column usually naked below. Ovary 5-celled; ovules numerous in each cavity; style club-shaped, 5-grooved; stigmas 5. Capsule coriaceous, loculicidally 5-valved. Seeds usually densely covered with long white hairs (cotton); endosperm thin or none; cotyledons plicate. [Latin for cotton, perhaps of Arabic origin.] About 40 species, of tropical distribution. Type species: Gossypium arboreum L. 
Cotton readily separable from the seed.

Cotton adherent to the seed.

1. G. barbadense.

2. G. punctatum.

1. Gossypium barbadénse L. Sp. Pl. 693. 1753.

Perennial, shrubby, flowering as an annual, glabrous or nearly so, 1-2.5 m. high. Leaves suborbicular in outline, $7.5-20 \mathrm{~cm}$. broad, rather deeply $3-5$ cleft, the lanceolate or ovate-lanceolate lobes acuminate, the basal sinus narrow; petals $6-10 \mathrm{~cm}$. long, yellow, or with orange or red bases, fading pink; capsules 3-5 cm. long; cotton readily separated from the seed.

Scrub-lands and waste lands, apparently spontaneous after cultivation only, Abaco, New Providence, Cat Island, Great Gaillot Cay, Fortune Island and Inagua :North Carolina to Florida; widely spontaneous after cultivation in tropical and subtropical regions. COTTON.

2. Gossypium punctàtum Sch. \& Thon. Besk. Guin. Pl. 309. 1827.

A shrub, or small tree, up to $4 \mathrm{~m}$. high, the young twigs pubescent or glabrate. Leaves ovate-orbicular or suborbicular in outline, cordate or nearly truncate at the base, usually 3-lobed, rarely 5-lobed, or some of them entire, the lobes short, ovate, acuminate, pubescent beneath, at least when young, nearly glabrous above; petals $3-6 \mathrm{~cm}$. long, white or yellowish, sometimes crimsonblotched at the base, fading pink or purplish; capsules $2-2.5 \mathrm{~cm}$. long; cotton firmly attached to the seed.

Rum Cay, at Port Nelson:- Southern Florida; Jamaica; Cuba; Porto Rico; Grenada. Recorded from other West Indian islands. Cultivated in tropical reglons of the New World and the Old. WILD CoTron.

\section{Family 3. BOMBACÀCEAE Schumann.}

\section{BOMBAX FAMILY.}

Trees, mostly with palmately compound leaves and large and showy perfect flowers. Calyx inferior, mostly 5-toothed. Petals 5. Stamens commonly very numerous, with long filaments and short anthers. Ovary 2-5-celled; style simple; stigmas as many as the ovary-cavities. Fruit various, dry or fleshy. Seeds usually woolly. About 20 genera and 150 species, of tropical distribution.

1. CEİBA Adans. Fam. Pl. 2: 399. 1763.

Large deciduous trees, with alternate petioled palmately compound leaves, and large clustered axillary flowers, the trunk buttressed at the base, the branches and young trunks spiny. Calyx 5-lobed. Petals tomentose without, glabrous within. Column 5-divided, each division bearing 2 or 3 unilocular anthers at the top. Capsule 5-celled, loculicidally dehiscent, many-seeded. Seeds long-woolly. [Aboriginal name.] About 12 species, the following typical.

1. Ceiba pentándra (L.) Gaertn. Fr. \& Sem. 2: 244.1791.

Bombax pentandrum L. Sp. Pl. 511. 1753.

Eriodendron anfractuosum DC. Prodr. 1: 479. 1824.

A tree, reaching a maximum height of $60 \mathrm{~m}$. or more, the trunk above the often immense buttress sometimes $3 \mathrm{~m}$. in diameter. Petioles slender, glabrous, 5-15 cm. long; leaflets 5-7, stalked, or nearly sessile, glabrous, entire or serrate, 
oblong to oblanceolate, $8-15 \mathrm{~cm}$. long, mostly acute or acuminate at the apex and narrowed at the base; flowers in many axillary clusters, often appearing before the leaves; pedicels 4-6 $\mathrm{cm}$. long; calyx obconic, about $1 . \overline{\mathrm{cm}}$. long; petals about $3 \mathrm{~cm}$. long, about as long as the stamens; stigma capitate; capsule oblong, woody, 8-12 $\mathrm{cm}$. long.

Waste-lands, spontaneous after cultivation, New Providence, near Nassau; planted for shade and for ornament:- Cuba to St. Jan and Barbadoes; northern South America; Old Worid tropics. Silk-cotTon Tree.

\section{Family 4. STERCULIÀCEAE H.B.K.}

\section{Chocolate Family.}

Herbs, shrubs or trees, with alternate, often stellate-pubescent leaves, the flowers regular, mostly perfect, in a few genera polygamous or unisexual, clustered or rarely solitary, usually axillary. Calyx deeply 5-cleft, usually persistent, the lobes or sepals valvate. Petals 5, hypogynous, or wanting. Stamens 5 or more; filaments more or less united below into a cup or tube; anthers mostly 2-celled, extrorse; staminodia present in some genera. Ovary superior, 2-5-celled, or sometimes monocarpellary; styles usually as many as the ovary-cavities, distinct or more or less united. Fruit mostly capsular or follicular, rarely indehiscent. Seeds various, the cotyledons commonly foliaceous. About 45 genera and over 600 species, mostly tropical.

Petals with flat blades.

Gynoecium of 5 united carpeis.

Fruit of 5 dehiscent follicles.

Capsule pyramidal or fruit 5-coccous.

Fruit a 5-angled capsule.

Fruit 5-coccous.

Gynoecium of a single carpei.

Petals with hooded biades; capsule 5-celled, muricate.

1. Helicteres.

2. Moluchia.

3. Melochia.

4. Waltheria.

5. Ayenia.

\section{HELÍCTERES L. Sp. Pl. 963. 1753.}

Pubescent shrubs or trees, the pubescence stellate or of branched hairs, with broad leaves and axillary or terminal, clustered or solitary flowers, the bractlets small, or distant from the calyx. Calyx tubular, 5-cleft or 5-toothed, somewhat 2-lipped. Petals 5, clawed. Stamen-column slender, elongated, bearing 5 or 10 sessile or short-stalked anthers; anther-sacs divergent or confluent. Ovary borne within the ring of stamens, 5-celled, 5-lobed, the cells many-ovuled; style 5, or united into 1 ; stigma small, capitate. Carpels distinct at maturity, twisted cr straight, follicular, dehiscent along the ventral suture, many-seeded. Seeds warty or smooth; endosperm little; cotyledons foliaceous. [Greek, referring to the coiled carpels of some species.] Thirty species or more, of tropical distribution. Type species: Helicteres Isora L.

Capsule giabrous; carpels straight.

Capsule lanate; carpels twisted into a spiral.
1. H. semitriloba.

2. H. jamaicensis.

\section{Helicteres semitriloba Bertero; DC. Prodr. 1: 476. 1824.}

A branched shrub 1-3 m. high, rarely a small tree up to $5 \mathrm{~m}$. high, the young twigs, petioles, lower leaf-surfaces; pedicels, calyx and ovary densely stellate-tomentulose. Leaves broadly ovate to orbicular, subcoriaceous, $3-8 \mathrm{~cm}$. long, undulate-dentate or somewhat 3-lobed, obtuse or acute at the apex, cordate or truncate at the base, becoming glabrous above, the petiole as long as the blade or shorter; flowers usually numerous in terminal compound corymbs; 
pedicels short; bractlets linear; calyx campanulate, 5 -toothed, 2-lipped, 5-6 mm. long; petals white, fading reddish, 8-9 mm. long; column slender, glabrous, 3-5 cm. long; anther-sacs oblong; fruit linear, straight or a little curved, 1.5-4 cm. long, separating into 5 , glabrous, pointed follicles.

Coppices and scrub-lands, Andros, New Providence, Eleuthera, Cat Island, Watling's, Great Exuma, Crooked Island, Acklin's, Fortune Island, North Caicos and Inagua :-Cuba ; Hispaniola. Strraighit-Fruited Helicteres. Wild Salve.

\section{Helicteres jamaicénsis Jacq. Enum. 30. 1760.}

Helicteres spiralis Northrop, Mem. Torr. Club 12: 50, pl. 11. 1902.

A shrub, 1.5-3 m. high, or a small tree sometimes 6-7 m. tall, the foliage densely stellate-tomentose. Leaves ovate to ovate-lanceolate or ovate-oblong, 5-17 cm. long, mostly acute or acuminate at the apex, cordate or sometimes rounded at the more or less oblique base, crenulate nearly all around, the stout petioles 0.5-2.5 cm. long, the upper surface darker green than the lower; peduncles stout, 2-3 cm. long, 1-few-flowered; pedicels short; calyx 1.5-2 cm. long, 5-toothed, somewhat 2-lipped, densely tomentose; petals white, inequilateral, somewhat longer than the calyx; column 6-10 cm. long, declined; stamens 10; staminodia 5; ovary tomentose; carpels about 10, spirally twisted, densely tomentose, forming a cone-like, oblong fruit $2.5-5 \mathrm{~cm}$. long.

Coppices, thlckets and white-lands, Abaco, Great Bahama, Andros, Mangrove Cay, New Providence, Eleuthera, Cat Island, Mariguana, Atwood Cay, Great Guana Cay, Great Exuma, Long Island, Great Ragged Island, Crooked Island, Acklin's, Fortune Island, Watling's Island and the Inaguas:-Cuba to Tortola, St. Martin and St. Croix; Jamaica. Recorded by Schoepf as H. Isora L. Cow-BUsh. SalzBUSH. BLIND-EYE BUSH.

\section{MOLÚCHIA Medic. Malv. 10. 1787.}

Herbs, shrubs or small trees, with alternate toothed leaves, and small, terminal or axillary, mostly clustered, perfect flowers, the petals flat, marcescent. Involucels none. Calyx 5-cleft, usually campanulate. Petals 5, narrow. Stamens 5, the filaments somewhat united below, opposite the petals; staminodia none, or minute. Ovary 5-celled, each cavity 2-ovuled; styles 5, distinct, at least above; stigmas clavate. Capsule pyramidal, loculicidally 5valved, 5-seeded, the seeds obovoid, ascending. Endosperm fleshy; embryo straight; cotyledons flat. [Name altered from Melochia.] About 6 species, of tropical and subtropical regions. Type species: Moluchia fruticosa Medic.

Foliage stellate-tomentose or stellate-puberulent; capsules with rounded angles.

Foliage nearly glabrous; capsules with sharply acute angles. $\quad 2$. M. pyramidata.

1. Moluchia tomentòsa (L.) Britton, Mem. Brooklyn Bot. Gard. 1: 69. 1918.

Melochia tomentosa L. Syst. ed. 10, 1140. 1759.

A branched shruh, $2 \mathrm{~m}$. high or less, rarely a small tree up to $4 \mathrm{~m}$. high, the slender twigs, the leaves, inflorescence, calyx and capsule densely stellatepubescent or tomentose. Leaves chartaceous, ovate to oblong-lanceolate, 1-6 $\mathrm{cm}$. long, obtuse or acute at the apex, rounded, truncate or cordate at the base, crenate or serrate, the petioles shorter than the blades; peduncles at the axils of upper leaves or terminal, few-several-flowered; calyx-lobes lanceolate; petals blue, violet or purple, obovate, 10-12 mm. long; capsule-body 6-8 mm. long, subulate-beaked, its angles rounded, knobbed.

White-lands, scrub-lands and coppices, Abaco, Andros, Mangrove Cay, New Providence, Eleuthera, Little San Salvador, Cat Island, Watling's, Atwood Cay, Rum Cay, 
Great Guana Cay, Long Island, Great Ragged Island, Acklin's, East Caicos, Grand Turk, Ambergris Cay, and Inagua:-Texas ; West Indies ; North Mexico to continental tropical America. The species is represented by many races of various leaf-forms and sizes, finding their smallest development in the plants of Grand Turk, Ambergris Cay and Inagua; these are the subject of Grisebach's Melochia crenata, not $\boldsymbol{M}$. crenata Vahl. Velvery Moldchia.

2. Moluchia pyramidàta (L.) Britton, Mem. Brooklyn Bot. Gard. 1: 69. 1918. Melochia pyramidata L. Sp. Pl. 674. 1753.

Subherbaceous, nearly glabrous, the young foliage somewhat pubescent; stems slender, branched, ascending, decumbent or nearly erect, 2-6 dm. long, the young branches with a line of pubescence. Leaves membranous, lanceolate, ovate, or the lower nearly orbicular, 2-6 dm. long, sharply serrate, acute or acuminate at the apex, mostly rounded or subtruncate at the base, the slender petioles much shorter than the blades; peduncles pubescent, 1-few-flowered, about as long as the petioles, terminal or opposite the leaves; calyx-lobes lanceolate, 3-4 mm. long; petals pink, red or lavender, about $6 \mathrm{~mm}$. long, obovate; capsule inflated, membranous, 6-7 mm. long, sharply 5-angled, short-beaked, each angle cuspidate at the base.

Waste places and roadsides, New Providence:-Texas; West Indies east to Tortola, south to Grenada; Curaçao; Mexico; continental tropical America. and old World tropics. SMOотH MoLUCHIA.

\section{MELOCHIA [Dill.] L. Sp. PI. 674. 1753.}

Herbs or shrubs, often stellate-pubescent, with petioled, serrate leaves and small, sometimes involucellate, perfect flowers in axillary or terminal glomerules or panicles. Sepals or calyx-segments little enlarged in fruit. Petals convolute, marcescent. Stamens opposite the petals; filaments more or less united below; staminodia none, or rarely present and minute. Ovary 5-celled; ovules 2 in each cavity; styles distinct, or united near the base. Fruit a small 5 coccous capsule, loculicidally dehiscent. Seeds with fleshy endosperm. [Arabic name.] About 50 species, natives of tropical and subtropical regions. Type species: Melochia corchorifolia L.

\section{Melochia nodiflòra Sw. Prodr. 97. 1788.}

Mougeotia nodiflora H.B.K. Nov. Gen. 5: 330. 1823.

A shrub, $2 \mathrm{~m}$. high or less, with slender ascending branches, the young twigs sparingly pubescent. Leaves thin, ovate, $3-10 \mathrm{~cm}$. long, serrate, glabrous or nearly so, acute or acuminate at the apex, rounded, truncate, or subcordate at the base, the slender pubescent petioles $1-3 \mathrm{~cm}$. Iong; flowers nearly sessile, in dense axillary subglobose clusters; calyx-lobes triangular-lanceolate, acuminate, 2-3 mm. long; petals rose, a little longer than the calyx; filaments united; styles distinct; ovary 5-celled; young fruit deeply 5-lobed, at length separating into 5 pubescent carpels about $3 \mathrm{~mm}$. long. Melochia.

Waste places, New Provldence:-West Indies; tropical continental America.

\section{WALTHEेRIA L. Sp. Pl. 673. 1753.}

Herbs, shrubs or trees, with stellate or simple pubescence. Leaves toothed; stipules narrow. Flowers small, perfect, usually in axillary clusters or small eymes. Involucel of 3 deciduous bracts. Sepals 5, united at the base into a turbinate 10-nerved tube. Petals 5, spatulate, convolute, witheringpersistent. Stamens 5; filaments united below, not accompanied by staminodia; 
anthers with parallel sacs. Ovary 1-celled, sessile; style simple, not central; stigma club-shaped or brush-like. Ovules 2 in a cavity. Follicles 1-celled, 2 valved lengthwise. Seed solitary, ascending. Endosperm fleshy. Embryo straight, axile. [In honor of A. F. Walther, Professor in Leipzig.] About 35 American species, mostly tropical. Type species: Waltheria americana L.

Pubescence densely tomentose.

Finely stellate-pubescent.

1. W. americana.

2. W. bahamensis.

1. Waltheria americàna L. Sp. Pl. 673. 1753.

Foliage tomentose. Stems 6-12 dm. tall, stiff; leaves ovate to oblong, 1-5 cm. long, serrate, rounded or cordate at the base, stout-petioled; flowers in dense sessile or peduncled axillary clusters; sepals subulate, about $5 \mathrm{~mm}$. long, villous-hirsute, similar to the bractlets; petals yellow, slightly longer than the sepals; follicles $2 . \overline{-}-3 \mathrm{~mm}$. long, pubescent at the top.

Rocky scrub-lands, fields and cultivated soil, Abaco and Great Bahama to South Bimini, Andros, the Crooked Island group and to North and East Caicos:-Florida; Bermuda; the West Indies and tropical continental America; Old World tropics; Oceanica. Common Waltheria.

\section{Waltheria bahaménsis Britton, Torreya 3: 105. 1903.}

Branched from the base, stellate-puberulent, the branches $6 \mathrm{dm}$. long or less. Leaves oblong to ovate-oblong, 1-2 cm. long, sharply dentate, strongly veined, dark-green above, pale green beneath, stellate-pubescent on both surfaces, obtuse at both ends, or the base subcordate, the slender petioles half as long as the blades or less; flower-clusters sessile or nearly so in the axils, dense, less than $1 \mathrm{~cm}$. broad; bractlets sharply toothed; petals thin, spatulate, $3-5 \mathrm{~mm}$. long, obtuse or slightly notched; filaments united into a tube.

Sandy and rocky fields, scrub-lands and pine-lands, Abaco, Great Bahama, Great Harbor Cay, Little Harbor Cay, Andros, New Providence, Eleuthera, Cat Island, Rum Cay and Great Guana Cay. Endemic. Bahama Waltheria.

\section{AYÈNIA Loefl. Iter. 257. 1758.}

Shrubs, some species subherbaceous, with serrate petioled leaves, and axillary, mostly clustered, pedicelled flowers. Calyx 5-parted. Petals 5, concave or hooded, long-clawed, the tip inflexed, adnate to the stamen-cup. Filaments united into a short cup, the anthers solitary in its sinuses, its truncate or rounded lobes alternate with the petals; anthers 3-celled. Ovary 5-celled, its cavities 2-ovuled; style short; stigma capitate or somewhat 5-lobed. Capsule subglobose, muricate, splitting into 5 earpels, each 2-valved. Seeds rugose; endosperm none; cotyledones spirally convolute. [In honor of the French botanist Ayen.] About 10 species, natives of tropical America. Type species: Ayenia sidaeformis Loefl.

1. Ayenia pusilla L. Syst. ed. 10, 1247. 1759.

A low shrub or suffrutescent perennial herb, usually much-branched at the base, the slender branches ascending, erect or prostrate, 1-4 dm. long, puberulent. Leaves lanceolate, ovate, oval or suborbicular, $0.8-3 \mathrm{~cm}$. long, puberulent or glabrate, sharply serrate, acute or obtuse at the apex, rounded or cordate at the base, the petioles $1-5 \mathrm{~mm}$. long; pedicels longer than the petioles, sometimes $10 \mathrm{~mm}$. long; calyx about $2 \mathrm{~mm}$. long, its lobes lanceolate; claw of the petal much longer than the hooded limb; lobes of the stamen-cup longer than the anthers; capsule depressed-globose, densely muricate, 4-6 mm. in diameter. 
In red soil pockets and red-lands, New Providence, Cat Island, Great Exuma, Long Island, Great Ragged Island, Fortune Island, Acklin's, Crooked Island, Mariguana and Ambergris Cay:- the Florida Keys and Texas to California; West Indies, south to Guadelope; continental tropical America. Common AYeNIA.

\section{Order 17. HYPERICÀLES.}

Herbs, shrubs, or trees, the flowers mostly complete, perfect and regular (irregular in Violaceae). Sepals distinct, or more or less united, imbricated or convolute. Petals present and distinct or wanting. Stamens usually numerous. Ovary compound, superior; placentae mostly parietal.

Styles none ; trees or shrubs with small imbricated leaves. Styles present, separate or united.

Styles separate or partly united.

Stigmas not brush-like; endosperm little or none.

Herbs or low shrubs, rarely trees; flowers perfect; stamens distinct.

Trees or shrubs; stamens mostly united.

Flowers dioecious or polygamous ; placentae axile.

Flowers perfect; placentae parietal.

Stigmas brush-like; endosperm coplous.

Styles completely united; endosperm fleshy.

Fam. 1. TAMARICACEAf.

Fam. 2. HyPericaCEAE.

Fam. 3. Clusiachap.

Fam. 4. Canellaceaf.

Fam. 5. TurNeraceaE.

Fam. 6. Fla courtiaceae.

\section{Family 1. TAMARICÀCEAE Lindl.}

\section{TAMARISK FAMILY.}

Shrubs or trees. Leaves alternate, without stipules, relatively small or scale-like, entire, often imbricated. Flowers mainly perfect, regular, usually in spikes or racemes. Calyx of 5 , or rarely 4 or 6 , imbricated sepals. Corolla of 5 , or rarely 4 or 6 , distinct imbricated petals. Disk 10 -lobed or obsolete. Stamens 5 to many; filaments distinct, free; anthers opening lengthwise. Ovary 1-celled, superior, with $3-5$ basal placentae. Stigmas 3-5, distinct. Ovules 2-many on each placenta. Fruit a capsule. Seeds erect, terminating in a coma. Four genera and about 100 species, natives of the Old World.

\section{TÁMARIX L. Sp. Pl. 270. 1753.}

Shrubs or trees, with irregularly and widely branching stems, the wood firm. Leaves small, scale-like, clasping or sheathing. Flowers in dense spikes, racemes or panicles. Sepals 4 or 5, rarely 6, distinct. Petals white or pink, inserted under the lobed disk, distinct. Stamens 5-10; filaments not adnate to the corolla. Stigmas 2-5, short. Seeds numerous. Endosperm wanting. [Latin name.] About 60 species, of the Old World, the following typical.

\section{Tamarix gállica L. Sp. Pl. 270. 1753.}

A shrub or a small tree, with slender spreading branches, the branchlets very numerous, approximate or clustered, completely clothed with the imbricated, scale-like, acute leaves which are $1 \mathrm{~mm}$. long or less; spikes numerous, in panicles; sepals triangular, about $0.5 \mathrm{~mm}$. long; petals white or pinkish; capsule pyramidal, about $1 \mathrm{~mm}$. long.

Waste places, spontaneous after cultivation, South Caicos and Grand Turk Island :- Naturalized from southern Europe in various localities from New York to New Mexico and southward, and in Bermuda and the West Indies. Tamarisk. 


\section{Family 2. HYPERICÀCEAE Lindl.}

\section{St. JoHn's-WORT FAMILY.}

Herbs or shrubs, sometimes small trees in tropical regions, with opposite, or rarely verticillate, simple entire or rarely glandular-ciliate or dentate leaves, no stipules, and solitary or cymose-paniculate flowers. Foliage pellucid-punctate or black-dotted. Flowers regular and perfect. Sepals 5 or 4 , imbricated. Petals of the same number, hypogynous, generally oblique or contorted. Stamens $\infty$, hypogynous, often in sets of 3 or 5 ; anthers versatile or innate, 2-celled, longitudinally dehiscent. Ovary 1-7-celled, composed of 1-7 carpels; styles as many as the carpels; ovules $\infty$, in 2 rows in each cavity, anatropous. Fruit mainly capsular with septicidal dehiscence; seeds mainly straight; endosperm none. About 10 genera and more than 300 species, mainly of temperate and warm regions.

\section{1. ÁSCYRUM L. Sp. Pl. 787. 1753.}

Leafy glabrous low shrubs, with small narrow entire black-punctate leaves, the flowers bright yellow. Sepals 4, in 2 pairs, the exterior ones broad and round, the interior smaller and narrower. Petals 4, oblique or slightly contorted, deciduous. Stamens $\infty$, distinct, or united in clusters. Ovary 1celled, with 2-4 parietal placentae; styles 2-4. Capsule 1-celled, 2-4-valved, dehiscent at the placentae. [Greek, not rough.] About 6 species, natives of eastern North America, Central America and the West Indies. Type species: Ascyrum hypericoides L.

1. Ascyrum linifòlium Spach, Hist. Veg. Phan. 5: 459. 1836.

An erect shrub, 3-6 dm. high, much branched, the twigs very slender, densely leafy. Leaves linear to linear-oblong or linear-spatulate, nearly sessile, obtuse, 1-2 cm. long, 1-3 mm. wide; flowers solitary at the ends of the twigs, very short-peduncled; outer sepals oblong, acute, 6-8 $\mathrm{mm}$. long, the inner petal-like; petals widely spreading nearly in one plane, as long as or somewhat longer than the outer sepals; capsule linear-oblong, beaked, about as long as the outer sepals.

Pine-lands and palmetto-lands, Abaco, Great Bahama, Andros and New Provldence :-Florida to Texas. St. ANDREW's Cross.

\section{Family 3. CLUSIÀCEAE Lindl.}

\section{Cuusia Family.}

Shrubs or trees, sometimes epiphytic, with resinous sap, opposite coriaceous estipulate entire leaves, the small or large, regular, polygamous, dioecious or rarely perfect flowers usually clustered, sometimes bracteolate. Sepals 2-6, rarely more, strongly imbricated. Petals usually as many as the sepals, sometimes more, hypogynous. Staminate flowers with numerous hypogynous stamens, the filaments united or distinct, with or without a rudimentary ovary. Pistillate flowers with a 2-several-celled ovary, and as many sessile or sub-sessile stigmas as there are ovary-cavities; staminodes or some perfect stamens usually present. Fruit baccate, drupaceous or capsular, usually fleshy. Seeds often arillate; endosperm none. About 25 genera and over 250 species, mostly tropical: 
1. CLÙsIA L. Sp. Pl. 509. 1753.

Evergreen trees or shrubs with resinous sap, often epiphytic or halfclimbing on other trees and sometimes strangling them, the leaves opposite, entire, the usually polygamous, large flowers solitary or cymose. Sepals 4-16, imbricated. Petals 4-9, also imbricated. Stamens many in the staminate flowers, fewer in the pistillate ones; anthers linear. Pistillate flowers with several or many staminodes; ovary 4-12-celled; stigmas sessile, radiating; ovules many in each cavity. Capsule leathery or fleshy, at length dehiscent. Seeds arillate, the embryo small, the cotyledons plano-convex. [Commemorates Charles de 1'Ecluse, a French botanist of the sixteenth century.] About 80 species, of tropical and subtropical America. Type species: Clusia major L.

\section{Clusia ròsea Jacq. Enum. 34. 1760.}

A tree attaining a maximum height of about $16 \mathrm{~m}$., the stout twigs glabrous. Leaves obovate, glabrous, thick, coriaceous, rigid, 10-15 $\mathrm{cm}$. long, $7-12 \mathrm{~cm}$. wide above the middle, closely pinnately many-veined, rounded at the apex, cuneate at the base, the stout petioles about $1 \mathrm{~cm}$. long; flowers solitary or sometimes 2 together, short-peduneled; sepals 6 , rounded, 1-1.5 $\mathrm{cm}$. broad; petals white or rose, broadly obovate or nearly orbicular, 3-4 $\mathrm{cm}$. long, broadly cuneate at the base; stigmas $7-9$; fruit glcbose, nearly white, 5-8 cm. in diameter, fleshy.

Coastal coppices, Andros, New Providence, Inagua and East Caicos:-Florida; Cuba to Tortola, and to Trinidad; Jamaica; continental tropical America. Catesby, 2: pl. 99. PITCH APPLE.

Clusia flava Jacq., a tree similar to $C$. rosea, with cuneate-obovate leaves and yellow flowers, is recorded by Schoepf, as seen by him on New Providence in 1784.

\section{Family 4. CANELLÀCEAE Mart.}

\section{Canella Family.}

Aromatic trees or shrubs, with alternate pinnately veined, coriaceous or subcoriaceous, entire estipulate petioled leaves, and corymbose regular perfect flowers. Sepals 3, distinct, imbricated. Petals 4-12, or wanting. Stamens many, the filaments united into a tube, the anthers extrorse. Ovary superior, 1-celled, with 2-5 parietal placentae; ovules 2-several, nearly anatropous; style stout; stigma 2-5-lobed. Fruit baceate. Seeds with a smooth erusteaceous testa; embryo subcylindric, in copious fleshy endosperm. Five genera and seven known species, of tropical America and Africa.

1. CANÉlLA P. Br. Hist. Jam. 275. 1756.

An evergreen tree, glabrous throughout, with coriaceous leaves and terminal bracteolate corymbs of purple, red or violet flowers, the bark and leaves pleasantly aromatic. Petals 5. Stamens 10-20, the filament-tube not appendaged by scales, the anthers contiguous, longitudinally dehiscent. Ovary with 2 or 3 parietal placentae each bearing 2 ovules; style short; stigma 2-3. lobed. Berry globose, its gelatinous pulp enclosing few, obovoid to orbicular seeds. [Latin, cinnamon.] A monotypic genus. 
1. Canella Winteràna (L.) Gaertn. Fr. \& Sem. 1: 373.1788.

Laurus Winterana L. Sp. Pl. 371. 1753.

Winterana Canella L. Syst. Ed. 10, 1045. 1759.

Canella alba Murray, Syst. Veg. 443. 1784.

A tree up to $10 \mathrm{~m}$. high, usually much smaller, sometimes shrubby, the trunk up to $2.5 \mathrm{dm}$. thick, the bark grey. Leaves oblanceolate or spatulate, 3-10 cm. long, dark green and somewhat shining above, rather dull beneath, rounded or obtuse at the apex, not prominently veined, the slender petioles about $1 \mathrm{~cm}$. long; corymbs few-several-flowered; pedicels slender; sepals reniform-orbicular, thick, about $3 \mathrm{~mm}$. long, ciliolate; petals obovate, obtuse, nearly twice as long as the sepals; stamen-tube 3-4 mm. long; anthers yellow; berry crimson or nearly black, about $1 \mathrm{~cm}$. in diameter; seeds black.

White-lands, scrub-lands and thickets, Great Bahama, Andros, New Providence, Eleuthera, Rum Cay, Atwood Cay, Long Island, Acklin's Island, Crooked Island and Little Inagua :-Florida and the West Indies. CANELla. WILd CinNaMoN. WHITEWOOD BARK. CiNNAMON BarK. Catesby, 2: $p l$. 50.

\section{Family 5. TURNERĀCEAE H.B.K.}

\section{Turnera Family.}

Herbs or shrubs, with alternate simple leaves mostly serrate and often 2-glandular at the base, the flowers regular, mostly perfect. Calyx-lobes or sepals 5, imbricated. Petals 5, thin, convolute, fugacious. Stamens 5, distinet, opposite the sepals; filaments compressed or subulate; anthers oblong. Ovary superior, 1-celled, with 3 parietal placentae; styles 3 , filiform, simple or 2-cleft; stigmas usually flabellate and many-cleft; ovules many, anatropous. Fruit a 1-celled capsule, partly or completely 3-valved. Seeds foveolate, with fleshy endosperm and a membranous aril. Four genera and about 80 species, of tropical and subtropical distribution.

\section{TÚRNERA L. Sp. Pl. 271. 1753.}

Herbs or low shrubs, with toothed leaves and solitary axillary yellow flowers, the peduncles often adnate to the petioles. Calyx 5-cleft. Petals obovate to spatulate, borne on the calyx-throat. Stamens borne below the petals, sometimes hypogynous. Ovary sessile; styles filiform; stigmas severalmany-cleft. Capsule 3-ralved to the base, mostly many-seeded, the seeds borne near the middle of the valves, oblong or cylindric, curved, the aril narrow. [In honor of William Turner, herbalist, the "Father of English Botany," died 1568.] About 75 species, nearly all of tropical and subtropical America. Type species: Turnera ulmifolia $\mathrm{L}$.

Calyx 5-fid or 5-partite; styles penicellate, multifid; capsule 3 valved above; leaves large.
Calyx 5-dentate; styles 6-fid at summit; capsule 3 -valved to the Calyx 5-dentate; styles
base ; leaves small.

1. T. ulmifolia.

2. T. diffusa.

\section{Turnera ulmifòlia L. Sp. Pl. 271. 1753.}

Shrubby, erect, branched, 3-9 dm. high, more or less pubescent. Leaves lanceolate to ovate-oblong, thin, short-petioled, $2-8 \mathrm{~cm}$. long, serrate, acute or acuminate at the apex, mostly narrowed at the 2-glandular base; peduncles short; bractlets as long as or longer than the calyx; calyx deeply 5-lobed, its 
segments lanceolate, acute or acuminate; petals obovate, 1-3 cm. long; capsules 6-10 $\mathrm{mm}$. long, much shorter than the bractlets, 3-valved above.

Rocky plains and white-lands, Abaco and Great Bahama to Andros, the Caicos Islands, Grand Turk and Inagua:-Bermuda; Florida; the West Indies; Mexico to tropical South America. Consists of numerous races, differing in leaf-form, pubescence and size of flowers. Buttercups. Yellow Alder. LARge-leaved TUrNera.

\section{Turnera diffùsa Willd.; Schultes, Syst. 6: 679. 1820.}

Triacis microphylla Griseb. F1. Br. W. I. 297. 1860.

A pubescent, much-branched shrub, $2 \mathrm{dm}$. to $1.3 \mathrm{~m}$. high, the branches slender, spreading. Leaves small, $5-20 \mathrm{~mm}$. long, spatulate or oblanceolate, firm in texture, coarsely few-toothed, nearly sessile, deeply impressed-veined and glabrous above, pubescent beneath, mostly obtuse at the apex, attenuate to the base, the margin revolute; peduncles very short; calyx 5-toothed; petals spatulate, 3-8 $\mathrm{mm}$. long, much longer than the calyx-teeth; stamens very short; capsule subglobose, about $1.5 \mathrm{~mm}$. in diameter, 3-valved to the base.

Rocky plains and white-lands, Whale Cay, Joulter's Cay, New Providence, Eleuthera, Cat Island, Rum Cay, Great Guana Cay, Great Exuma, Crooked Island, Acklin's and Inagua :-Cuba to Virgin Gorda and St. Crolx. SMall-Leaved Turnera.

\section{Family 6. FLACOURTIÀCEAE Lindl.}

\section{Flacourtia family.}

Trees or shrubs, with alternate simple, usually dentate leaves, the stipules minute or wanting, the small regular flowers usually clustered, perfect, dioecious or polygamous. Calyx 3-7-lobed or of 3-7 distinct sepals. Petals as many as the calyx-lobes or sepals, or rarely more, or wanting. Stamens few or numerous, in some genera alternating with staminodia; filaments distinct or connate; anthers 2-celled. Ovary superior, 1-celled; ovules few or numerous, on parietal placentae. Fruit capsular or baccate. About 70 genera, including over 500 species, of tropical regions.

Petals present.

Petals none.

Stamens hypogynous; leaves not punctate.

Stamens perigynous; leaves mostly punctate. Style none; stamens numerous.

Style present; stamens 6-15.
1. Banara.

2. Myroxylon.

3. Zuelania.

4. Casearia.

\section{BANÀrA Aubl. Pl. Guian. 1: 547. 1775.}

Shrubs or trees with alternate petioled, somewhat inequilateral, usually glandular-dentate and punctate leaves, small stipules, and small perfect flowers in racemes, corymbs or panicles. Calyx persistent, 3-5-lobed, the lobes valvate. Petals as many as the calyx-lobes and similar to them, persistent, imbricated. Stamens many, with filiform filaments; staminodia none. Ovary superior, 1-celled or by intrusion of the placentae nearly several-celled; ovules many; style slender; stigma capitate. Fruit a fleshy or leathery, indehiscent, many-seeded berry. Seeds striate, the endosperm fleshy. [Guiana name.] About 15 species, natives of tropical America. Type species: Banara guianensis Aubl. 
1. Banara reticulatta Griseb. Cat. Pl. Cub. 8. 1866.

A glabrous shrub, 1-3 m. high or a small tree up to about $8 \mathrm{~m}$. high, the slender twigs terete. Leaves oblong or ovate-oblong, coriaceous, $2.5-7 \mathrm{~cm}$. long, somewhat inequilateral, low-serrate with blunt teeth, rounded, obtuse or some of them acute at the apex, mostly rounded or subcordate at the base, densely and strongly reticulate-veined, shining above, the petioles 4-8 $\mathrm{mm}$. long; corymbs several-many-flowered, 3-6 cm. broad; pedicels 5-10 $\mathrm{mm}$. long, thickened in fruit; calyx about $5 \mathrm{~mm}$. long, its segments broadly ovate, rounded, puberulent and eiliolate; petals yellowish, about as long as the calyx; fruit ovoid, red, about $8 \mathrm{~mm}$. long, tipped by the style.

Rocky pine-lands, Andros, New Providence, Eleuthera and Great Exuma :-Cuba. BANARA. Catesby, $2: p l$. 42 .

2. MYROXYLON Forst. Char. Gen. 126. 1776.

Shrubs or trees, usually spiny, with usually toothed, sometimes spinulosedentate leaves and small, dioecious or polygamous flowers, fascicled or shortracemose in the axils. Sepals 4 or 5, imbricated. Petals wanting. Stamens several or numerous, borne on a glandular disk, the anthers versatile. Ovary with 2-6 parietal placentae; ovules few or several; style simple or cleft, sometimes very short; stigmas dilated, rarely lobed. Fruit a small, 2-several-seeded berry, the seeds obovoid. [Greek, balsam wood.] About 30 species, tropical and subtropical in distribution. Type species: Myroxylon suaveolens Forst.

Leaves shining above; frult globose.

I eaves dull above; fruit obovoid-oblong.
1. M. ilicifolium.

2. M. bahamense.

1. Myroxylon ilicifòlium (Northrop) Britton, Bull. N. Y. Bot. Gard. 4: 141. 1906.

Xylosma ilicifolia Northrop, Mem. Torr. Club 12: 51. 1902.

A shrub, $3 \mathrm{~m}$. high or less, much branched, the twigs slender, the stem and branches usually armed with slender, often branched spines. Leaves oval to obovate or oblanceolate, coriaceous, short-petioled, $2-3 \mathrm{~cm}$. long, entire or with 1-3 spinulose-tipped teeth, the apex acute and spinulose, the base narrowed, the upper surface strongly shining, the lateral venation obscure; fascicles fewflowered; pedicels of staminate flowers slender, 2-4 mm. long; sepals yellow or greenish, ciliate, about $1 \mathrm{~mm}$. long; pedicels of pistillate flowers 1-2 mm. long; berry bluish-black, globose, about $5 \mathrm{~mm}$. in diameter.

Coppices, and pine-lands, Andros, New Providence, Eleuthera, Cat Island. Endemic. Holly-Leated Mrroxylon. Recorded by Dolley as Xylosma nitidum A. Gray and as $X$. buxifolium; and by Hitchcock as $M$. buxifolium pauciflorum.

\section{Myroxylon bahaménse Britton, Bull. N. Y. Bot. Gard. 4: 141. 1906.}

An intricately branched shrub or small tree $4 \mathrm{~m}$. high or less, the trunk and larger limbs densely armed with branched spines $5 \mathrm{~cm}$. long or less. Wood yellowish-white, very hard and dense; twigs armed with subulate spines $1.5 \mathrm{~cm}$. long or less; leaves ovate or oblong to oblanceolate, coriaceous, $6-30 \mathrm{~mm}$. long, scarcely shining above, dull and paler green beneath than above, entire or with 1 to 4 blunt teeth, the apex acute, the base rounded, or narrowed, the petiole about $1 \mathrm{~mm}$. long; fruit obovoid-oblong, obtuse, $6 \mathrm{~mm}$. long, $3 \mathrm{~mm}$. in diameter.

Scrub-lands and coppices, Abaco, Great Bahama, New Providence. Endemic. BAHAMA MYROXYLON. 
3. ZUELÀNIA A. Rich. Ess. Fl. Cub. 88. 1845.

Trees or shrubs with alternate petioled serrate punctate leaves, and small fascicled flowers, the pedicels jointed, bracted at the base. Calyx 1-5lobed, the lobes imbricated. Petals wanting. Stamens 20-40, alternating with staminodia. Ovary superior; ovules numerous, on parietal placentae; stigma almost sessile, peltate. Fruit a large globose fleshy, berry-like capsule, at length dehiscent Seeds numerous, arillate, with fleshy endosperm. [Commemorates José Maria Valenzuela, a Cuban botanical collector.] One or two West Indian species, the following typical.

\section{Zuelania Guidònia (Sw.) Britton \& Millspaugh.}

Laetia Guidonia Sw. Prodr. 83. 1788.

Zuelania laetioides A. Rich. Ess. Fl. Cub. 88. 1845.

Casearia laetioides Northrop, Mem. Torr. Club 12: 55. 1902.

A tree, up to about $30 \mathrm{~m}$. high, usually much smaller, the stout twigs densely pubescent when young. Lieaves thin, deciduous, oblong to oblong-lanceolate or elliptic, 7-20 cm. long, low-erenate or nearly entire, strongly pinnately veined, acute or acuminate at the apex, obtuse or rounded and mostly somewhat oblique at the base, glabrous or nearly so above, pubescent beneath, the petioles $1 \mathrm{~cm}$. long or less; fascicles many-flowered; pedicels pubescent, 6-10 $\mathrm{mm}$. long; sepals pubescent, suborbicular, about $7 \mathrm{~mm}$. long; staminodia about one-half as long as the stamens; fruit subglobose, $3-5 \mathrm{~cm}$. in diameter. ZUELANIA.

Coppices and scrub-lands, Abaco, Andros and New Providence:-Cuba; Jamaica.

\section{CASEÀrIA Jacq. Enum. 4, 21. 1760.}

Shrubs or trees, sometimes spinescent, with alternate, mostly toothed and punctate or lineate leaves, small stipules, and small regular green or yellowish flowers in bracted, lateral fascicles or umbels, the pedicels jointed at or above the base. Calyx-lobes 4-6, imbricated. Petals wanting. Stamens 6-15; filaments distinct or united below, alternating with staminodia. Ovary superior; ovules many, borne on parietal placentae; style short, undivided or 3-cleft; stigma capitate. Capsule dry or fleshy, 3-4-valved, several-many-seeded. Seeds with a fleshy aril, the testa coriaceous; endosperm fleshy. [Commemorates John Casearius, a Dutch missionary of the seventeenth century.] Over 75 species, natives of tropical and subtropical regions. Type species: Casearia nitida (L.) Jacq.

Leaves ovate, glabrous, shining; flowers in stalked glabrous cymes. 1. C. bahamensis. Leaves obovate to elliptlc, pubescent at least when young; cymes sessile or very nearly so, densely puberulent.

2. C. spinescens.

\section{Casearia bahaménsis Urban, Symb. Ant. 3: 322. 1902.}

A glabrous shrub or small tree sometimes 4-5 m. high, much-branched, the twigs slender and terete. Leaves ovate to elliptic, subcoriaceous, $1.5-7 \mathrm{~cm}$. long, obtuse, acute or acuminate at the apex, obtuse or subcordate at the base, crenulate, shining, above, and finely reticulate-veined, the petioles 6-12 $\mathrm{mm}$. long; cymes axillary, peduncled, several-flowered; pedicels slender, 5-10 mm. long; calyx about $5 \mathrm{~mm}$. long, densely short-pilose within; stamens shorter than the calyx; staminodia $1-1.5 \mathrm{~mm}$. long, short-pilose; fruit subglobose, yellow, 5-6 $\mathrm{mm}$. in diameter, 1-5-seeded.

Scrub-lands and copplces, Andros, New Providencc and Great Exuma:-Cuba. Recorded by Dolley as Casearia serrulata Sw. SMooth Casearia. 
2. Casearia spinéscens (Sw.) Griseb. Cat. Pl. Cub. 10. 1866.

Samyda spinescens Sw. Prodr. 68. 1788.

A shrub, $3 \mathrm{~m}$. high or less, or a small tree about $4 \mathrm{~m}$. high, unarmed, or with short spinescent spurs, the branches sometimes elongated and vine-like, the young twigs appressed-pubescent. Leaves obovate to oval or elliptic, membranous, $2-7 \mathrm{~cm}$. long, obtuse or acute at the apex, narrowed at the base, low-crenate, pubescent on both sides when young, becoming glabrate, the petioles 2-8 $\mathrm{mm}$. long; cymes several-flowered, pubescent, sessile in the axils or on leafless twigs; pedicels stout; calyx pubescent, 5-6 mm. long, green, about as long as the pedicel, its rounded segments ovate or elliptic, obtuse; staminodia ovate, broad, a little shorter than the stamens; fruit oblong, $1.5-2 \mathrm{~cm}$. long.

Coppices, New Providence, at Waterloo: Andros, near Crow Hill :-Cuba ; Hispaniola ; Tobago ; Trinidad; Guiana. Recorded in Buil. N. Y. Bot. Gard. 5: 316, as C. alba A. Rich., following Grisebach. SPINY CASEARIA.

\section{Order 18. PASSIFLORÀLES.}

Herbs, tendril-bearing vines, shrubby plants, or succulent trees with a milky sap. Leaves alternate, entire or lobed. Flowers perfect, or when dioecious, the staminate and pistillate very different. Calyx of 5 more or less united sepals. Corolla of 5 distinet or partially united petals, sometimes accompanied by a fringed erown. Stamens 5 or 10 in 2 unequal rows. Ovary superior, 1-eelled, with 3-5 parietal placentae. Stigmas entire, notched or forked. Fruit a berry or capsule.

Corolla accompanied by a crown (corona) ; flowers perfect, all alike.

Corolla not accompanied by a crown; flowers mainly dioeclous, the staminate and pistillate different.

Fam. 1. PAssifloraceat.

Fam. 2. Caricaceae.

\section{Family 1. PASSIFLORÀCEAE Dumort.}

PASSION-FLOWER FAMILY.

Vines, climbing by tendrils, or rarely erect herbs, with petioled usually palmately-lobed leaves, and perfect regular flowers. Calyx-tube persistent. Petals usually 5 , inserted on the throat of the calyx, distinct, or in some species united. Stamens 5. Throat of the ealyx erowned with a double or triple fringe. Filaments subulate or filiform, monadelphous, or separate. Ovary free from the calyx, 1-celled; placentae 3-5, parietal; styles 1-5. Fruit a berry or capsule, usually many-seeded. About 18 genera and 350 species, of warm and tropical regions, most abundant in South America.

\section{PASSIFLÒRA L. Sp. P1. 955. 1753.}

Climbing tendril-bearing vines, with alternate or rarely opposite leaves, and large axillary flowers, on jointed, often bracted peduncles. Calyx-tube cup-shaped or campanulate, 4-5-lobed, the lobes narrow, imbricated in the bud, its throat crowned with a fringe called the corona. Petals 4 or 5 (rarely none), inserted on the throat of the calyx. Ovary oblong, stalked. Filaments monadelphous in a tube around the stalk of the ovary, separate above; an- 
thers narrow, versatile. Fruit a many-seeded berry. Seeds pulpy-arilled, flat, ovate; endosperm fleshy. [Flower of the Cross, or Passion, as emblematic of the crucifixion.] About 300 species, mostly of tropical America, a few in A sia and Australia. Type species: Passiflora incarnata $\mathrm{L}$.

Calyx subtended by an involucre of 3 pectinate or incised bracts.

Bracts pectinate into filform segments.

Plant villous-pubescent; leaves flaccid.

Plant glabrous or somewhat glandular; leaves firm in texture.

Bracts linear-lanceolate, irregularly incised-pectinate.

Calyx not subtended by an involucre.

Petals none.

Petals 5.

Leaves softly pubescent or glabrate.

Leaves oblong, entire.

Leaves broader than long, 2-lobed, cordate.

Leaves glabrous.

Leaves 2-lobed, wider than long.

Leaves ovate-oblong, narrower than long.

\section{P. foetida.}

2. P. bahamensis.

3. P. pectinata.

4. P. pallida.

5. P. multiflora.

6. P. rubra.

7. P. biflora.

8. P. cupraea.

\section{Passiflora foètida L. Sp. Pl. 959. 1753.}

Herbaceous, villous and glandular-viscid, trailing or climbing, sometimes $2.5 \mathrm{~m}$. long. Leaves slender-petioled, broadly ovate or ovate-orbicular in outline, 3-lobed or 3-angled, flaccid, irregularly low-dentate, 3-12 cm. long, cordate or subcordate at the base, acute at the apex, the stipules 5-10 $\mathrm{mm}$. long, pinnatisect; peduncles $1-3$ in the axils, mostly longer than the petioles, not jointed; involucre of 3 finely pinnatisect bracts $2-4 \mathrm{~cm}$. long, the ultimate segments nearly filiform, gland-tipped; calyx 5-parted, $1.5-2.5 \mathrm{~cm}$. long; petals white or pinkish, about as long as the calyx; crown pink, of three series of segments; berry ovoid, 2-4 cm. long, nearly dry when mature.

Roadsides, New Providence:-West Indies and tropical continental America, north to Texas. VISCID PASSION-FLOWER.

\section{Passiflora bahaménsis Britton, Bull. N. Y. Bot. Gard. 5: 315.1907.}

Stems slender, purple, usually trailing, sometimes climbing on low shrubs, 0.5-1.5 m. long. Tendrils wiry, mostly as long as the leaves or longer; petioles 1-3 cm. long, bearing scattered stalked glands, rarely glandless; stipules small, glandular-fimbriate; leaf-blades firm in texture, panduriform, $7 \mathrm{~cm}$. long, or less, 3-lobed, cordate at the base, shining above, dull beneath, the basal lobes rounded or somewhat angled, one fourth to one half as long as the acute middle one, the margin with stalked glandular hairs all around; peduncles glabrous, longer than the petioles; involucre-segments bipinnatisect, 2-3 cm. long, with very numerous stalked glands; calyx-segments ovatelanceolate, acute; petals ovate-oblong, about $2 \mathrm{~cm}$. long; crown purple, its outer segments about three fourths as long as the petals; berry globose, about $2 \mathrm{~cm}$. in diameter, bright red and shining when ripe, its stalk above the persistent involuere $6-8 \mathrm{~mm}$. long; seeds oblong, rough, $4 \mathrm{~mm}$. long.

Pine-lands, coppices, white-lands and sandy soil, Andros; New Providence; Cat Island. Endemic. Referred by Grisebach and by Dolley to the Jamaican $P$. ciliata Ait., and by Mrs. Northrop to P. pectinata Griseb. BAHAMA PASSION-FLOWER.

\section{Passiflora pectinàta Griseib. Fl. Br. W. I. 294.1860.}

Glabrous, high-climbing or trailing. Leaves ovate, rather firm in texture, 3-8 cm. long, crenate, 5-7-nerved, somewhat contracted near the middle, cordate at the base, acute or blunt at the apex, with minute glands at the ends of the veins, the petioles $2.5 \mathrm{~cm}$. long or less, eglandular; tendrils slender, as long as the leaves, or longer; flowers solitary in the upper axils, about $6 \mathrm{~cm}$. broad, on peduncles longer than the petioles; involucre of 3 linear pectinate 
or pinnatifid bracts about $2.5 \mathrm{~cm}$. long; crown about one half as long as the oblong white sepals; fruit ellipsoid, red, slightly fleshy, about $2.5 \mathrm{~cm}$. long; seeds rough.

Littoral sands and savannas, Little San Salvador, Cat Island, Conception Island, Watling's Island, Cave Cay, Great Guana Cay, Great Ragged Island, Acklin's Island, Crooked Island, Fortune Island, Green Cay, South Calcos, Grand Turk, Little Ambergris Cay, and the Inaguas:-Bermuda; Hispaniola. The plant recorded by Hitchcock as $\boldsymbol{P}$. ciliata viparia Wr. proves to be the above specles. PeCTINATw PASSION-FLOWER. WILD APRICOT.

\section{Passiflora pallida L. Sp. Pl. 955.1753.}

Passiflora minima L. Sp. Pl. 959. 1753.

Passiflora suberosa L. Sp. Pl. 958. 1753.

Passiflora angustifolia Sw. Prodr. 97. 1788.

A slender vine, with nearly glabrous or pubescent foliage. Leaves ovate to linear, 6-15 cm. long, ciliate, 5-nerved at the broadly cuneate or cordate base, entire, toothed, or 3 -lobed to abore the middle, the lobes ovate or triangular, acute or acuminate, the middle one much the larger; petioles 5-15 $\mathrm{mm}$. long, each with 2 glands at or above the middle; peduncles surpassing the petioles, commonly in pairs; calyx greenish, $2-2.5 \mathrm{~cm}$. broad; sepals lanceolate or linear-lanceolate; 8-12 mm. long; corolla wanting; crown-filaments purple at the base, shorter than the sepals; berries subglobose or oval, 10-12 $\mathrm{mm}$. in diameter.

Coppices and scrub-lands, throughout the archipelago from Abaco and the Berry Islands to East Calcos, Grand Turk and Inagua:-Bermuda; Florida; West Indies; continental tropical America.

The species consists of a large number of races, glabrous or pubescent, the leaves varying from linear-lanceolate to nearly orbicular, and the fruit from globose to ellipsoid. Referred to by Hitchcock as $P$. villosa Macf. Juniper-Berry. SMall PASSION-FLOWER. Catesby, 2: pl. 51 .

\section{Passiflora multiflòra L. Sp. Pl. 956. 1753.}

A somewhat woody, slender vine, climbing to a length of $6 \mathrm{~m}$. or more, the stems and leaves finely pubescent or sometimes glabrous. Leaves oblong or ovate-oblong, 5-12 cm. long, entire, pinnately veined and triplinerved, reticulate-veined beneath, obtuse or acute and mucronulate at the apex, obtuse, rounded or subcordate at the base, the short petiole 2-glandular at the top; peduncles 2-6 together in the axils, slender, jointed near the middle, 5-15 $\mathrm{mm}$. long; involucre none; sepals oblong-lanceolate, greenish-yellow, about 6 $\mathrm{mm}$. long; petals linear, white, shorter than the sepals; carpophore none; berry globose, 6-10 $\mathrm{mm}$. in diameter.

Copplces and scrub-lands, Andros; New Providence; Eleuthera:-Florida ; Cuba to Tortolo. OBLONG-LEAVED PASSION-FLOWER.

\section{Passiflora rùbra L. Sp. Pl. 956. 1753.}

A softly pubescent, slightly woody vine, sometimes $2 \mathrm{~m}$. long or more. Leaves thin, eglandular, broader than long, 7-12 $\mathrm{cm}$. broad, 5-nerved, deeply cordate at the base, broadly 2-lobed or subtruncate, the lobes ovate, acute or acutish, the midvein excurrent, the petioles $1-4 \mathrm{~cm}$. long; peduncles solitary or 2 in the axils, slender or filiform, longer than the petioles, jointed below the flower; flowers 3-5 cm. broad, greenish-white, the 5 sepals somewhat longer than the 5 petals; erown of 3 series of subulate processes, about as long as the petals; berry oval or subglobose, pubescent, 6 -ribbed, $2-4 \mathrm{~cm}$. in diameter, longer than the carpophore.

Open fields and scrub-lands, Abaco; New Providence:-Cuba to Porto Rico and Trinidad; Jamaica; continental tropical America. BroAd-LeAved PASSION-FLOWER. 
7. Passiflora biflòra Lam. Encycl. 3: 36. 1789.

Passiflora lunata Willd. Sp. Pl. 3: 612. 1801.

Glabrous, somewhat woody, $1 \mathrm{~m}$. long or longer. Leaves chartaceous, 2-lobed, mostly broader than long, 5-8 cm. broad, ocellate beneath, strongly 3 -nerved, reticulate-veined on both surfaces, subcordate or obtuse at the base. shining above, dull beneath, the lobes obtuse or rounded, the slender glandless petioles $1-4 \mathrm{~cm}$. long; flowers white, about $2 \mathrm{~cm}$. broad, solitary or in pairs in the axils, the peduncles as long as the petioles or longer; flowertube campanulate; crown white or yellowish, its outer segments spreading, nearly as long as the petals, dilated above; berry subglobose, about $2 \mathrm{~cm}$. in diameter, fleshy.

Pine-lands, Abaco, New Providence:-Jamaica; tropical continental America. TWO-LOBED PASSION-FLOWER. Apparently recorded by Shoepf as P. Vespertilio L.

\section{Passiflora cupraèa L. Sp. Pl. 955. 1753.}

A somewhat woody, glabrous vine, 1-2 m. long. Leaves ovate to elliptic, rather thin, short-petioled, 3-5 cm. long, 3-nerved, dark green, rounded and mucronulate at the apex, rounded or subcordate at the base, reticulate-veined on both sides, with a few distant flat circular glands beneath; peduncles longer than the petioles, jointed at about the middle; calyx white to red or purple, $2-3 \mathrm{~cm}$. long; petals narrowly oblong, shorter than the calyx; crownsegments few, linear; earpophore $2-3 \mathrm{~cm}$. long; berry globose, $1.0-20 \mathrm{~mm}$. in diameter, dark purple.

Scrub-lands, copplces, and coastal thickets, Abaco and the Berry Islands to South Bimini, Andros, Inagua, North Calcos, the Anguilla Isles and Cay Sal :-Cuba. Devil's PuMpKin. WILD WATERMelon. SMOOTH PASSION-Flower. Catesby, $2: p l .93$.

\section{Family 2. CARICÀCEAE Dumort.}

\section{PaPaw Family.}

Trees, with milky sap, ample broad palmately 7-9-lobed leaves and unisexual, or rarely perfect flowers. Calyx short. Staminate flowers with a salver-shaped corolla, its tube slender; the lobes 5 , valvate or convolute; stamens 10, inserted in the throat of the corolla; filaments short; anthers adnate to the filaments, 2-celled. Pistillate flowers with 5 distinct petals and no staminodia; ovary compound, 1-celled, or sometimes imperfectly 5 -celled, free, sessile; stigmas 5, sessile; ovules numerous, in two or many series on the 5 placentae. Fruit a large fleshy berry. Seeds numerous, flattened, with a roughened testa; endosperm fleshy; embryo axile. There are two genera, the following composed of about 25 species of tropical and subtropical distribution, and Jacaratia of tropical Africa and America, which differs from Carica by having the stamens partly united.

1. CARİCA L. Sp. Pl. 1036. 1753.

Characters of the family. [Named from the fancied resemblance of the fruit to that of the Fig.] Type species: Carica Papaya L.

1. Carica Papàya L. Sp. Pl. 1036. 1753.

A small tree, with a simple wand-like stem, 3-6 m. tall, leafy at the top. Laves large, thick, suborbicular in outline, 2-6 dm. broad, mostly palmately 
7-lobed, pale or glaucous beneath, each lobe pinnately lobed, the segments obtuse or acute, or the larger ones acuminate; petioles stout; staminate flowers in slender panicles 1-several $\mathrm{dm}$. long; calyx of the staminate flowers 1-1.5 $\mathrm{mm}$. long, that of the pistillate flowers 5-10 mm. long, the lobes longer than the tube; corolla yellow, that of the staminate flowers $2.5-3 \mathrm{~cm}$. long, its tube slender, dilated near the top, its lobes lanceolate or elliptic-lanceolate, barely as long as the tube; corolla of the pistillate flowers longer, the petals distinct, lanceolate, twisted; berries oblong to subglobose, $0.6-3 \mathrm{dm}$. long, yellow or orange, with a milky juice.

Scrub-iands, spontaneous after cultivation, Eleuthera, on the margin of the salt pond about half way between the Glass Window and Gregory Town, Andros and Inagua:- -naturalized in many places in the West Indian Islands, and in Florida, its native home unknown, but, doubtless, in tropical America. PAPAW.

\section{Order 19. LOASÀLES.}

Herbs, often armed with hooked stinging or viscid hairs, with estipulate leaves, and regular perfect white yellow or reddish flowers. Calyx-tube adnate to the ovary, its limb $4-5$-lobed, persistent. Petals 4 or 5, inserted on the throat of the calyx. Stamens $\infty$, inserted with the petals; filaments filiform, commonly arranged in clusters opposite the petals; anthers introrse. Ovary 1-celled (rarely 2-3-celled), with 2-3 parietal placentae; ovules anatropous. Capsule usually 1-celled, crowned with the ealyx-limb. Seeds mostly numerous; endosperm scanty.

\section{Family 1. LOASÀCEAE Rchb.}

\section{LOasa Family.}

Characters of the order. About 20 genera and 250 species, all but 1 natives of America.

\section{MENTŻ̀LIA L. Sp. Pl. 516. 1753.}

Erect or straggling herbs, with entire, lobed or pinnatifid leaves, and terminal, cymose or solitary flowers. Calyx-tube cylindric, linear or clubshaped, the limb usually 5-lobed. Petals 5, convolute in the bud, spreading, deciduous. Stames 20-100. Ovary 1-celled; styles 3, more or less united; stigmas small, obtuse. Capsule dehiscent at the summit, few-many-seeded. Seeds mostly prismatic, rough or striate. [In honor of C. Mentzel, a German botanist, died 1701.] About 35 species, natives of America. Type species: Mentzelia aspera $\mathrm{L}$.

\section{Mentzelia floridàna Nutt.; Torr. \& Gray, Fl. N. Am. 1: 533. 1840.}

Ascending or diffusely branched, 3-6 dm. high, the slender stem and branches rough-pubescent. Leaves ovate or triangular-ovate, scabrous-pubescent, rather firm in texture, short-petioled, $2-9 \mathrm{~cm}$. long, acute or acuminate at the apex, subtruncate or broadly cuneate at the base, dentate, sometimes 3-lobed; flowers sessile and solitary in the upper axils; sepals lanceolate or linear-lanceolate, $5-6 \mathrm{~mm}$. long; petals yellow, about 3 times as long as the sepals; ovary obconic, densely hispid; capsule hispid, 1-1.5 cm. long.

Sandy waste grounds, Eleuthera, near Governor's Harbor:-Fiorida. Florida MENTZelia. 


\section{Order 20. OPUNTIÀLES.}

Fleshy plants, with continuous or jointed stems, mostly leafless, or with small leaves, generally abundantly spiny, the spines developed from cushions of hairs or bristles (areolae). Flowers mostly solitary and sessile, perfect, regular, showy. Calyx-tube adnate to the ovary, its limb manylobed. Petals numerous, imbricated in several rows, mostly distinet. Stamens numerous, inserted on the throat of the calyx. Filaments filiform; anthers small. Ovary 1-celled; ovules numerous, anatropous, borne on several parietal placentae. Style terminal, elongated; stigmas numerous. Fruit a berry, mostly fleshy, sometimes dry. Seeds smooth, or tubercled, the testa usually crustaceous or bony; endosperm little, or copious. Only one family.

\section{Family 1. CACTÃCEAE Lindl.}

\section{Cactus Family.}

Characters of the order. About 100 genera and not less than 1000 species, natives of America.

Areoles with splnes but without glochides; corolla not rotate.

Plants tall or long, erect or climbing.

Plants tall, mostly erect, with ribbed, columnar branches.

Flowers short-campanulate, the style exserted; fruit smooth.

Flowers elongated-campanulate, the style included; fruit tubercled when young.

Plants climbing or tralling, with aerial roots ; flowers nocturnal, large, widely campanulate.

Joints sharply trigonous; corolla-tube not woolly.

Jolnts terete, ribbed or 4-8-angled; corolla-tube woolly.

Plants globose or ovold, not more than twice as high as thick.

Plants ribbed, surmounted by a woolly cephalium which bears the flowers.

Plants with no cephalium, tubercled, the areoles bearing

spines and flowers.
Areoles with or without splnes, but with glochides; corolla rotate.

1. Cephalocerus.

2. Harrisia.

3. Hylocereus.

4. Selenicereus.

5. Cactus.

6. Coryphantha. 7. Opuntia.

\section{CEPHALOCÈREUS Pfeiffer, Allg. Gartenz. 6: 142.1838.}

[PILOCEReus Lemaire, Cact. Gen. Nov. \& Spec. 6. 1839.]

Large, simple or branched, erect, columnar cacti, the joints leafless, elongated, ribbed and grooved, the upper areoles often densely lanate or longkristly. Flowers solitary at upper areoles, nocturnal, fleshy, rather small, the tube short-funnelform or campanulate, the segments not very widely expanding; ovary subglobose, naked or bearing a few scales, spineless; style usually short-exserted. Fruit a globose or depressed-globose. smooth berry; seeds small and numerous, black or brown. [Greek, head-Cereus.] Forty species or more, of tropical and subtropical America. Type species: Cactus senilis Haw.

Flowering areoles with wool as long as the splnes or longer; plant pale-pruinose.

Flowering areoles without wool or the wool much shorter than the splnes; plant dull green, not pruinose.

1. C. Millspaughii.

2. C. bahamensis. 
1. Cephalocereus Millspaùghii Britton, Contr. U. S. Nat. Herb. 12: «17. 1909.

Stem branched, 2-6 m. high, $20 \mathrm{~cm}$. thick at the base, the branches nearly erect, 8-12 $\mathrm{cm}$. thick, pale grayish green, pruinose, 8-13-ribbed, the ribs acutish, about as wide as high or a little wider; areoles $1-2 \mathrm{~cm}$. apart; spines about 20, acicular, widely radiating, 1-2 cm. long, or at the flower-bearing (upper) areoles 3-7 $\mathrm{cm}$. long, the old ones gray brown, the young ones yellow or yellow-brown, with darker bases; upper areoles on one side of the plant with large tufts of whitish wool often as long as the spines or longer; flowers $6 \mathrm{~cm}$. long.

Rocky hillsides, coppices and thickets, Cave Cay, Cat Isiand, Conception Island, Watling's, Acklin's, Mariguana, Long Island, Caicos Islands, Cotton, Salt and Ambergris Cays, and Little Inagua :-Cuban Cays. Recorded by Dolley and by Hitchcock as Cereus Swartzii Griseb.; by Coker as Pilocerus lanuginosus. MILLspadgh's Dildo. Wild Fig. OLd Man Cactus.

2. Cephalocereus bahaménsis Britton, Contr. U. S. Nat. Herb. 12: 415.1909.

Plant 3-4 m. high, often $20 \mathrm{~cm}$. thick at the base, the branches divergentascending, 7-9 cm. thick, dull green, not pruinose, 10 - or 11-ribbed, the ribs blunt or acutish, rather higher than wide; areoles $1-1.5 \mathrm{~cm}$. apart; spines 1520, acicular, radiately spreading and ascending, gray-brown to yellow-brown when old, 1-1.5 cm. long, the young ones yellowish with darker bases, the uppermost 2.5-3 $\mathrm{cm}$. long; wool very short (shorter than the spines), or none; flower 5-6 cm. long, brownish outside, the petals creamy-white.

Rocky hillsides, Frozen Cay, Andros, Eleuthera, and Crooked Isiand. Endemic. Recorded by Mrs. Northop as Cereus Swartzii Griseb. BAHAMA DiLDo.

\section{HARRISIA Britton, Bull. Torr. Club 35: 561. 1908.}

Night-flowering cacti, mostly with upright branched cylindric stems, the branches fluted, with from 8-10 rounded ribs, separated by shallow grooves and bearing leafless areoles at frequent intervals, each areole with acicular spines. Flowers borne singly, at areoles near the ends of the branches, funnelform, large, with a cylindric scaly but spineless tube as long as the limb or longer; buds globose, ovoid, or obovoid, densely scaled, the scales subtending long or short woolly hairs; sepals pink or greenish, linear-lanceolate; petals white; stamens shorter than the petals; style somewhat longer than the stamens; fruit globose to ovoid-globose, green to yellow, tubercled or becoming smooth, spineless, with mostly deciduous seales; corolla withering-persistent; seeds very numerous, small. [In honor of William Harris, Superintendent of Public Gardens and Plantations of Jamaica, distinguished for his contributions to the knowledge of the flora of that island.] About 8 species, natives of Florida and tropical America. Type species: Cereus gracilis Mill.

\section{Harrisia Broòkii Britton, Bull. Torr. Club 35: 564. 1908.}

Plant $5 \mathrm{~m}$. high, much branched, light green; branches $3-4 \mathrm{~cm}$. thick, 10 -ribbed, the ribs sometimes prominent, with deep depressions between them. Areoles about $2 \mathrm{~cm}$. apart; spines 6-12, the longer ones $2-2.5 \mathrm{~cm}$. long; bud ovoid, prominently long-pointed, its scales with few curled white hairs 7-10 $\mathrm{mm}$. long; fruit yellowish, subglobose or ellipsoid, about $8 \mathrm{~cm}$. in diameter, rounded at both ends, or narrowed above, the tubercles very 10w, with tips only $1.5 \mathrm{~mm}$. high, the linear scales persistent.

Scrub-lands, Long Island at Clarence Town. Endemic. Recorded by Dolley as Cereus repandus Haw, and aiso as Cereus pellucidus (presumably). Named in honor of Herbert M. Brook, for many years Registrar of the Bahamas, who greatiy facilitated our expiorations. At the place of publication Clarence Town was inadvertentiy printed George Town. Brook's Dildo. 
3. HYLOCÈREUS (Berger) Britton \& Rose, Contr. U. S. Nat. Herb. 12: 428. 1909.

Climbing or trailing cacti, with 3-winged or 3-angled, mostly stout stems and branches emitting aerial roots, but bearing no leaves, the areoles borne on the wings or angles and armed with few or several short spines. Flowers nocturnal, very large, regular, the ovary and tube bearing large, ovate to linear-lanceolate scales, usually without spines or hairs, the perianth-segments numerous, linear or narrowly lanceolate, widely spreading, the outer green, the inner mostly bright white. Stamens very many. Fruit a scaly berry, not spiny nor bristly. [Greek, forest-cereus.] About 20 species, natives of tropical America. Type species: Cereus triangularis L.

1. Hylocereus undàtus (Haw.) Britton \& Rose; Britton, Fl. Berm. 256. 1918.

Cereus undatus Haw. Phil. Mag. 7: 110. 1830.

Cereus tricostatus G'osselin, Bull. Soc. Bot. France 54: 664. 1907.

Stems stout, fleshy, glabrous, sometimes $7 \mathrm{~m}$. long, often climbing on trees, the branches 3-12 dm. long, green, 3-winged, the wings flat, 1-2.5 $\mathrm{cm}$. broad, coarsely crenate, their margins with a narrow horny border; spines 2-5 at each areole, brownish, 3-4 $\mathrm{mm}$. long; flowers about $3 \mathrm{dm}$. long, the tube about $3 \mathrm{~cm}$. thick, rather shorter than the limb, bearing several linearlanceolate scales $3-8 \mathrm{~cm}$. long; ovary $2.5-5 \mathrm{~cm}$. long, bearing several ovate acute scales $2.5 \mathrm{~cm}$. long or less; style stout, about as long as the stamens; berry oblong, red, pulpy, about $8 \mathrm{~cm}$. long, covered with ovate scales.

On trees and walls, spontaneous or persistent after cultivation, New Providence :-Bermuda; Fiorida : the West Indies; continental tropical America; native of Mexico. Has been confused with Cereus triangularis L., of Jamaica. NIGHTBLOOMING CeReus.

4. SELENICìREUS (Berger) Britton \& Rose, Contr. U. S. Nat. Herb. 12: 429. 1909.

Climbing or trailing, vine-like cacti, the joints several-ribbed, fluted or angled, giving off aerial roots, the large funnel-form flowers nocturnal; the stem-areoles bearing conic or acicular spines, but no leaves. Ovary and flowertube bearing small scales, usually with long hairs and bristles or spines in their axils. Perianth segments numerous, narrow, spreading or recurved, the inner white. Stamens numerous. Fruit a globose or ovoid berry, usually large, bearing clusters of deciduous spines. [Greek, moon-cereus.] About 14 species, natives of tropical Ámerica. Type species: Cactus grandiflorus L.

Stems fluted; spines about $2 \mathrm{~mm}$. long, shorter than the wool.

Stems 4-6-angled, or ribbed; spines 6-8 mm. long, much longer than the wool.

1. S. Boeckmani.

2. S. grandiflorus.

1. Selenicereus Boéckmanni (Otto) Britton \& Rose, Contr. Nat. Herb. 12: 429. 1909.

Cereus Boeckmanni Otto; Salm-Dyck, Cact. Hort. Dyck. 1849: 217.1850.

Stems light green, 1-2 cm. thick, several-ribbed or angled. Spines 3-6 at the areoles, subconic, about $2 \mathrm{~mm}$. long, brownish or yellowish; flowers about $3 \mathrm{dm}$. long; outer perianth-segments and scales of the flower-tube linear, brown or brownish; inner perianth-segments oblanceolate, about $10 \mathrm{~cm}$. long 
and $3 \mathrm{~cm}$. wide; wool of the areoles of ovary and flower-tube brown, silky; style greenish; ovary strongly tubercled; fruit globose, 5-6 cm. in diameter.

On walls, persistent or spontaneous after cultivation, New Providence:-Cuba ; Hispaniola ; east coast of Mexico. QUEEN-OF-THE-NIGHT.

2. Selenicereus grandiflorus (L.) Britton \& Rose, Contr. U. S. Nat. Herb. 12: 430. 1909.

Cactus grandiflorus L. Sp. Pl. 467. 1753.

Cereus grandiflorus Mill. Gard. Dict. ed. 8, no. 11. 1768.

Stems light green, but often becoming deep purple, up to $3 \mathrm{~cm}$. in diameter; ribs 4-8, rather prominent but less so on the older branches; areoles small, white; spines acicular, $1 \mathrm{~cm}$. long or less, yellowish; deflexed bristles or hairs from the lower part of the areoles several, white, often longer than the spines; flowers $2 \mathrm{dm}$. long; outer perianth-segments and scales of the tube linear, greenish or brownish, sometimes nearly rose-colored; inner perianth-segments acute, rather broad; style cream-colored, stout; areoles of ovary and flowertube bearing short wool and long silky whitish hairs and white bristles; ovary tubercled; fruit ovoid, about $8 \mathrm{~cm}$. long.

Thickets, Cave Cay, persistent after cultivation:-Cuba; Jamaica. QueEn-oFTHE-NIGHT. Often cultivated.

\section{CÁCTUS L. Sp. Pl. 466.1753.}

Subglobose ovoid or short-cylindric, ribbed leafless cacti, the spinebearing areoles borne on the ribs, the flowering areoles confluent into a terminal, densely woolly and bristly cephalium. Flowers with a cylindric tube, sometimes enlarged at the base, the limb several-many-lobed, the lobes imbricated. Stamens several or numerous, the filaments capillary, the anthers oblong. Ovary smooth; style filiform; stigma-rays few or many; ovules many. Fruit an obovoid or subclavate, fleshy and juicy berry, at length protruded from the cephalium, crowned by the withering perianth. Seeds many, small, black, without endosperm. About 20 species, natives of tropical America. Type species: Cactus Melocactus L.

1. Cactus íntortus Mill. Gard. Dict. ed. 8, no. 2. 1768.

Plant depressed-globose when young, when old ovoid, 3-4 dm. high and often $3 \mathrm{dm}$. in diameter, rather light dull green, 15-20-ribbed, the ribs 2-4 cm. high, crenate, the areoles bearing 7-13, stout subulate spines $1.5-4 \mathrm{~cm}$. long; cephalium at first nearly flat, at length cylindric, about $10 \mathrm{~cm}$. in diameter, sometimes $3 \mathrm{dm}$. high, densely white-woolly and brown-bristly; flowers pink or rose, 1-1.6 $\mathrm{cm}$. long; inner perianth-segments acute or cuspidate; fruit red or rose, narrowly obovoid, $2-2.5 \mathrm{~cm}$. long.

Rocky soll, Long Island, Acklin's Island, Mariguana, East and South Caicos, Turks Islands, Eastern Cay, Cotton Cay, Ambergris Cay, Little Inagua and Inagua:Mona to Virgin Gorda and Antigua. Recorded by Dolley as Melocactus communis DC. TURK'S-CAP.

6. CORYPHÁNTHA Lemaire, Cact. 32. 1868.

[Mammillaria Haw. Syn. Pl. Suce. 177. 1812. Not Stackh. 1809.]

Stems globose or ovoid, tubercled. Tubercles conic or cylindric, woolly and with clusters of spines at the apex. Leaves none. Flowers borne in areolae at the bases of the tubercles. Calyx-tube prolonged beyond the ovary, which 
is often hidden between the tubercles. Petals in several rows. Ovary smooth, ovoid; style filiform. Berry emersed, crowned by the withering corolla. [Greek name of some prickly plant.] About 300 described species, natives of warm and tropical America. Type species: Mammillaria sulcolanata Lemaire.

1. Coryphantha nivòsa (Link.) Britton, Anfnals Mo. Bot. Garđ. 2: 45.1915. Mammillaria nivosa Link; Pfeiff. Enum. 11. 1837.

Plants globose or globose-oblong, solitary or tufted, becoming 10-12 $\mathrm{cm}$. in diameter, and sometimes $1.5 \mathrm{dm}$. long. Tubercles many, dull green, oblongconic, 1-1.5 cm. high, obtuse; areoles bearing several yellow or yellowish brown, acicular spines $2 \mathrm{~cm}$. long or less, and when young, tufts of bright white wool; flowers cream-color, about $1 \mathrm{~cm}$. broad; perianth-segments acute or acuminate; berry obovoid or oblong-obovoid, obtuse, 1-1.5 $\mathrm{cm}$. long, red. WoolLy NIPPLECACTUS.

Rocky places, South Caicos and Inagua :-Mona; Culebra to Tortola and Antigua. Recorded by Dolley as Echinocactus sp.

\section{OPÚNTIA [Tourn.] Mill. Gard. Dict. Abr. ed. 4. 1754.}

Succulent plants, with jointed branching stems, the joints flat, or cylindric, and small, mostly subulate, deciduous leaves, the areolae usually spine-bearing. Flowers usually lateral. Calyx-tube not prolonged beyond the ovary, its lobes spreading. Petals numerous, slightly united at the base. Stamens very numerous. Ovary cylindric, exserted; style cylindric, longer than the stamens; stigma 2-7-rayed. Berry globose to obovoid, often spiny. [Named from a town in Greece where some species grew.] About 250 species, natives of America. Type species: Cactus Opuntia L.

Plants with erect continuous stems branching into flat joints at the summit.

Plants abundantly spiny.

Branches erect or ascending; areoles not pitted.

Branches widely spreading; areoles pitted, spineless except at and near the edges of the joints.

Plants nearly or quite spineless.

Plants bushy-branching from the base.

Joints much longer than wide, the spines pale yellow.

Joints little or somewhat longer than wide; spines dark jellow or jellow-brown.

Affinity uncertain.

1. O. Nashii.

2. O. Millspaughii.

3. O. bahamana.

4. O. lucayana.

5. O. Dillenii

6. D. Darrahiana.

1. Opuntia Náshii Britton, Bull. N. Y. Bot. Gard. 3: 446. 1905.

Tree-like, dull green. Main axis round, 1-4 m. high, 5-12 cm. in diameter, spiny; branches flat or becoming round below, the principal ones continuous, $1 \mathrm{~m}$. long or more, $6 \mathrm{~cm}$. wide or less, crenate, blunt; lateral branches opposite or alternate, oblong to linear-oblong, often $3 \mathrm{dm}$. long, and $8 \mathrm{~cm}$. wide, only about $6 \mathrm{~mm}$. thick, blunt, crenate; areoles. 1-3 cm. apart, slightly elevated; spines mostly 5 at each areole (2-5), divergent, slender, straight, light gray, pungent, the longer $3-5 \mathrm{~cm}$. long; glochides very small, brownish; ovary $3 \mathrm{~cm}$. long, $1.5 \mathrm{~cm}$. thick, somewhat clavate, tubercled, the tubercles bearing areoles and spines similar to those of the joints, but the spines somewhat shorter; flowers $1.5 \mathrm{~cm}$. broad when expanded, red; petals broadly oval to obovate, blunt, about $8 \mathrm{~mm}$. long, much longer than the stamens.

Scrub-lands and rocky plains, Andros, Ship Channel Cay, Atwood Cay, Fortune Island, Crooked Island. North and South Caicos, Grand Turk, Eastern Cay, Turk's Islands and Inagua. Endemic. Recorded by Mrs. Northrop and by Hitchcock as opuntia spinosissima; and by Coker and presumably by Dolley as 0 . triacantha.

NASH'S PRICKLY-PEAR. 
2. Opuntia Millspaùghii Britton, Smiths. Misc. Coll. 50: 513. 1908.

Trunk terete, $7 \mathrm{~cm}$. thick at base, $5 \mathrm{~cm}$. thick at top, $6 \mathrm{dm}$. high or less, branching at the summit, the branches divaricate-ascending, narrowly oblong, much compressed, $40 \mathrm{~cm}$. long or less, 5 to $10 \mathrm{~cm}$. wide, 1 to $1.5 \mathrm{~cm}$. thick, light green. Branchlets obliquely lanceolate, obtuse, as wide as the branches, but shorter, $1 \mathrm{~cm}$. thick or less, floriferous at and near the apex; areoles of the older branches pitted, about $1 \mathrm{~cm}$. apart, those of very young shoots slightly elevated, the glochides very short, yellow-brown; spines of the trunk $15 \mathrm{~cm}$. long or less, very numerous and densely clothing the trunk, very slender, gray, mostly strongly reflexed, pungent, those of the branches and branchlets restricted to the areoles on their edges, shorter than those of the trunk, but similar, those of the fruit yellow-gray, $2 \cdot \mathrm{cm}$. long or less; flowers cupulate, crimson-lake, $1 \mathrm{~cm}$. wide; sepals fleshy, ovate, acute, $4 \mathrm{~mm}$. long and wide; petals erect-ascending, obovate, mucronulate, about $4 \mathrm{~mm}$. wide; stamens half as long as the corolla; style about as long as the corolla; stigma oblong, yellowish crimson; fruit compressed-obovoid, $2 \mathrm{~cm}$. long, $1.5 \mathrm{~cm}$. thick, bearing one or two spines at most of the areoles.

On nearly flat and smooth limestone rocks, Eleuthera, at Rock Sound; Long Island, on Thatch Cay; Great Ragged Island:-Cuban Cays. MiluspaUgh's PrickLYPEAR.

\section{Opuntia bahamàna Britton \& Rose, Oactaceae 1: 203, f. 254, 255. 1919.}

Branched from a short trunk, bushy, about $1.5 \mathrm{~m}$. high. Joints oblong to lanceolate, flat and thin, 1-5 dm. long, 4-10 cm. wide, dull green, obtuse, scarcely undulate; areoles $1.5-3 \mathrm{~cm}$. apart, scarcely elevated, about $2 \mathrm{~mm}$. in diameter, spineless, or bearing 1-4 acicular yellow spines $2 \mathrm{~cm}$. long or less; glochides few and short; corolla about $6 \mathrm{~cm}$. broad; petals obovate, rose-tinted below, yellowish-rose above; sepals dark rose, whitish-margined.

Rocky places, Cat Island at The Bight. Endemic. Tentatively referred to 0 . lanceolata Haw., in Smith. Mísc. Coll. 50: 525. Bahama Prickly-Pear.

\section{Opuntia lucayàna Britton, Bull. N. Y. Bot. Gard. 4: 141. 1906.}

Stems ascending, often forming dense clumps. Joints various, linearoblong to obovate, often $10 \mathrm{dm}$. long, 6-15 cm. wide, olive-green, slightly lustrous, more or less crenate, about $1.5 \mathrm{~cm}$. thick, knobbed at the areoles; areoles distant, nearly $1 \mathrm{~cm}$. broad, white-velvety; glochides numerous, yellow, $6 \mathrm{~mm}$. long or less, mostly borne at the upper margins of the areoles; spines 3-8 at each areole, light-yellow, flattened on the upper side, subulate, straight, often somewhat twisted, the longer ones $12 \mathrm{~cm}$. long or less; flowers yellow, 7-8 $\mathrm{cm}$. broad; stamens about half as long as the petals; ovary narrowly pyriform, 4-5 cm. long, its upper areoles bearing 1-3 subulate pale-yellow spines $2.5 \mathrm{~cm}$. long or less, which are sometimes persistent on the fruit; berry pyriform, 5-6 cm. long, 2-3 cm. in diameter.

Scrub-lands, Grand Turk Island. Endemic. TuRK's IsLands PRICKLy-Pear.

The reference to Opuntia Tuna at the place of original publication of this species is erroneous; as now understood, $O$. Tuna grows naturally only in Jamaica. $O$. lucayana may be a hybrid between $O$. Dillenii and 0 . Nashii.

\section{Opuntia Dillènii (Ker-Gawl.) Haw. Suppl. Pl. Suce. 79. 1819.}

Cactus Dillenii Ker-Gawl. Bot. Reg. 3: pl. 255. 1818.

Bushy-branched, 0.5-1.8 m. high, often forming masses $2 \mathrm{~m}$. in diameter. Joints green, glabrous, mostly obovate and 1-2.5 dm. long, about $8 \mathrm{~mm}$. thick, crenate, the areoles $2-6 \mathrm{~cm}$. apart, somewhat elevated, bearing 1-4, stout yellow spines 1-4 cm. long, or spineless, the numerous glochides yellowish to brownish, $6 \mathrm{~mm}$. long or less; flowers solitary at the areoles, often abundant, bright 
yellow, about $7.5 \mathrm{~cm}$. broad; ovary obovoid, with glochide-bearing areoles; petals obovate; stamens much shorter than the petals; fruit pyriform, red or purple, edible, $5-8 \mathrm{~cm}$. long.

Maritime and coastal rocks, Abaco and Great Bahama to Grand Turk and Inagua :-Bermuda; Florida: West Indies; eastern coast of Mexico. Recorded by litchcock, Coker, Mrs. Northrop and Dolley, as O. Tuna (L.) Mill. and by Schoepf as Cactus Tuna L. Common Prickly-PEAR.

6. Opuntia Darrahiàna Weber, Bull. Mus. Hist. Nat. Paris 10: 388. 1904.

Forming tufts $2-2.5 \mathrm{dm}$. high and $4 \mathrm{dm}$. in diameter, much-branched. Joints green, 7-8 cm. long, 4-5 cm. wide; areoles 1-2 cm. apart; glochides none; spines about 6 , the longer $4-4.5 \mathrm{~cm}$. long, the shorter not more than $1 \mathrm{~cm}$. long, all white or grayish-white, brownish at the tip, straight, acicular, rigid.

Obtained by Darrah from Turk's Islands according to Weber; known to us only from the description; neither the flowers nor the frult are described. DARRAH's PRICKLY-PEAR.

\section{Order 21. MYRTÀLES.}

Herbs, shrubs or trees, unarmed, sometimes aquatic or amphibious. Leaves alternate or opposite. Flowers regular or irregular, complete, and often showy, or reduced to a stamen and pistil adnate to the hypanthium. Hypanthium merely enclosing the ovary or adnate to it. Stamens few or many. Anthers opening by slits, valves or pores. Stigma terminating the style, or sessile. Fruit capsular or baccate, or resembling an achene.

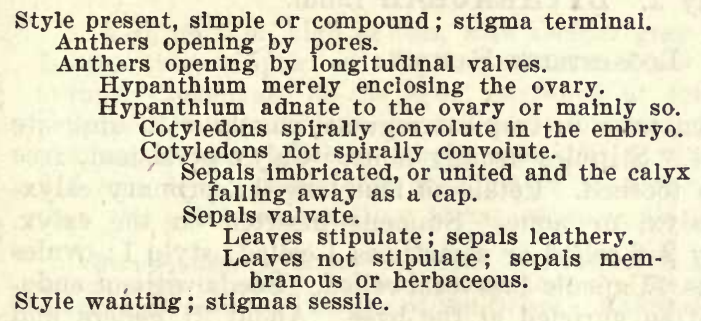

Fam. 1. Melastomaceae.

Fam. 2. Lythraceat.

Fam. 3. Terminaliaceae.

Fam. 4. Mrrtaceat.

Fam. 5. RhizophoraceaE.

Fam. 6. Onagraceae.

Fam. 7. HaLoragidaceat.

\section{Family 1. MELASTOMĀCEAE R. Br.}

\section{Meadón-Beauty Family.}

Herbs, or many shrubs or trees in tropical regions, with opposite 3-9nerved leaves, and regular perfect often showy but rarely odorous flowers. Stipules none. Calyx-tube usually 4-5-lobed, the lobes imbricated. Petals as many as the lobes of the calyx and inserted on its throat, imbricated. Stamens twice as many, or equal in number to the petals, often inclined or declined, the alternate ones sometimes shorter. Ovary 2-several-celled (often 4-celled); style terminal, simple; ovules $\infty$, anatropous. Fruit included in the calyx-tube, capsular or baccate. Seeds mainly small, with no endosperm. About 150 genera and 2500 species, widely distributed in tropical regions, most abundant in South America. 
1. Tetrazìgia L. C. Rich.; DC. Prodr. 3: 172.1828.

Trees or shrubs, the foliage often scurfy, with petioled, entire or toothed leaves, and rather small flowers in terminal panicles or corymbs. Calyx constricted above the ovary, its limb $4-5$-lobed or subtruncate. Petals 4 or 5 , obovate. Stamens 8 or 10 , nearly equal; filaments subulate; anthers linear, opening by a pore. Ovary 4-5-celled; style curved, filiform; stigma minute. Fruit a 4-5-celled fleshy berry. [Greek, referring to the 4-parted flowers of the type species.] About 16 species of the West Indian region. Type species: Tetrazygia tetrandra (Sw.) DC.

1. Tetrazygia bícolor (Mill.) Cogn. in DC. Monogr. Phan. 7: 724. 1891.

Melastoma bicolor Mill. Dict. ed. 8, No. 6. 1768.

A shrub or small tree up to $6 \mathrm{~m}$. high, with sealy bark, the young twigs scurfy. Leaves lanceolate to oblong-lanceolate, 0.8-2 dm. long, strongly 3ribbed and with many widely spreading lateral veins, entire, acuminate at the apex, mostly obtuse at the base, green above, whitish-scurfy beneath, the slender scurfy petioles 2-4 cm. long; panicles peduncled, 1-2 dm. long, several-many-flowered; pedicels slender, 5-10 mm. long; calyx-limb subtruncate; petals 4 , white, 7-8 $\mathrm{mm}$. long; berry subglobose, purple or black, 8-10 $\mathrm{mm}$. in diameter.

Scrub-lands, plne-lands and coppices, Abaco, Great Bahama, Andros, New Providence and Eleuthera:-Florida: Cuba. Reported by Grisebach and by Dolley as T. angustiflora Griseb. and by Schoepf as Melastoma discolor L. TETRAzYGIA.

\section{Family 2. LYTHRÀCEAE Lindl.}

\section{LOOSESTRIFe FAMILX.}

Herbs, shrubs, or often trees in tropical regions, mostly with opposite leaves and perfect flowers. Stipules usually none. Calyx persistent, free from the ovary, the limb toothed. Petals as many as the primary calyxteeth, inserted on the ealyx, or none. Stamens inserted on the calyx. Anthers versatile. Ovary 2-6-celled or sometimes 1-celled; style 1; ovules $\infty$, rarely few, anatropous. Capsule 1-several-celled. Seeds without endosperm; cotyledons flat, often auricled at the base. About 21 genera and 400 species, of wide distribution.

Fruit globose; flowers regular.

$\begin{array}{ll}\text { Herbs with axillary inflorescence. } & \text { 1. Ammannia. } \\ \text { Shrubs or small trees with terminal inflorescence. } & \text { 2. Lawsonia. }\end{array}$ Fruit elongated; flowers irregular.

2. Lawsonia.

3. Parsonsia.

\section{AMMÁNNIA [Houst.] L. Sp. Pl. 119. 1753.}

Annual glabrous or glabrate herbs, mostıy with 4-angleā stems, opposite sessile narrow leaves, and small axillary flowers. Calyx campanulate, globose or ovoid, 4-angled, 4-toothed, often with small accessory teeth in the sinuses. Petals 4, deciduous or none. Stamens 4-8, inserted on the calyx-tube. Ovary nearly globular, 2-4-celled. Capsule bursting irregularly. [Named for Johann Ammann, 1699-1741, a German botanist.] About 20 species, of wide distribution. Type species: Ammannia latifolia L. 
1. Ammannia latifòlia L. Sp. Pl. 119. 1753.

Erect, 2-11 dm. high, the branches nearly erect, or ascending. Leaves linear-lanceolate or linear-oblong, 2-7 cm. long, 2-10 mm. wide, acute or blunt at the apex, sessile, clasping the stem by an auricled base; flowers minute, green, sessile and solitary or few together in the axils; calyx about $2 \mathrm{~mm}$. long; petals none; style short; capsule about $4 \mathrm{~mm}$. in diameter, enclosed by the calyx.

Borders of fresh-water holes and marshes, Great Bahama, Andros, New Providence, Eleuthera, Cat Island, Watling's, Long Island, Acklin's, Crooked Island, North Caicos and Inagua:-Florida; the West Indies; Mexico and continental tropical America. AMMANNIA.

2. LAWSÒNIA L. Sp. Pl. 349. 1753.

A glabrous shrub, the terete branches sometimes spinescent, the small leaves opposite and entire, the numerous small white flowers corymbose. Calyx turbinate, 4-angled, the 4 lobes spreading. Petals 4 , sessile. Stamens 8 , borne near the base of the calyx-tube; filaments subulate; anthers oblong. Ovary subglobose, 4-celled; ovules numerous; style filiform; stigma capitate. Capsule subglobose, 4-celled, irregularly rupturing, many-seeded. Seeds 4angled, cuneate, truncate; cotyledons orbicular. [Commemorates Isaac Lawson, English physician and botanist, died 1747.] A monotypic genus.

\section{Lawsonia inérmis L. Sp. Pl. 349. 1753.}

Lawsonia alba Lam. Encycl. 3: 106. 1789.

A shrub $5 \mathrm{~m}$. high or less, with slender gray branches, unarmed or spiny. Leaves thin, elliptic or elliptic-lanceolate, 1-4.5 $\mathrm{cm}$. long, acute, obtuse or abruptly acuminate at the apex, narrowed or cuneate at the base, the short petioles slender; corymbs several-many-flowered, forming a terminal panicle; pedicels slender, scarcely longer than the flowers; calyx-lobes ovate, acute, 2-3 mm. long; petals somewhat longer than the calyx-lobes; stamens longer than the petals or equalling them; capsules about $6 \mathrm{~mm}$. in diameter.

Scrub-iands, spontaneous after cultivation, Inagua near Matthew Town :spontaneous in many localities throughout the West Indies, Mexico, and tropical continental America. Native of the Orient. HenNa PLANT.

3. PARsónsia P. Br.; Adans. Fam. Pl. 2: 234. 1763.

[CupheA P. Br.; Adans. loc. cit. Hyponym. 1763.]

Herbs (some shrubs in tropical regions), with opposite or verticillate leaves. Flowers axillary, irregular and unsymmetrical. Calyx-tube elongated, 12-ribbed, gibbous or spurred at the base, oblique at the mouth, with 6 primary teeth and usually as many accessory ones. Petals 6, unequal. Stamens 6-11, inserted on the throat of the calyx, unequal; filaments short. Ovary with a curved gland at its base, unequally 2-celled; style slender; stigma 2lobed. Capsule oblong, 1-celled, laterally dehiscent. Seeds flattened. [In honor of James Parsons, M. D., a Scotch botanist.] About 180 species, natives of America. Type species: Lythrum Parsonsia L. 
1. Parsonsia Parsónsia (L.) Britton; Northrop, Mem. Torr. Club 12: 53. 1902.

Lythrum Parsonsia L. Syst. ed. 10, 1045. 1759.

Cuphea Parsonsia R. Br., Steud. Nom. 1: 245. 1821.

Parsonsia radicans Hitche. Rep. Mo. Bot. Gard. 4: 87. 1893.

Annual; herbaceous; stem little-branched, the branches prostrate or ascending, 1-3 dm. long, rough-pubescent. Leaves ovate or oblong, 1-2 cm. long, very short-petioled, acute or obtuse at the apex, mostly narrowed at the base, scabrous or nearly smooth; flowers solitary in upper axils, shortpeduncled; calyx about $4 \mathrm{~mm}$. long, gibbous at the base, its teeth very small; petals pale purple, about $2 \mathrm{~mm}$. long; stamens 6 , included; filaments glabrous; capsule about $5 \mathrm{~mm}$. long, few-seeded.

Dry coral rocks and sink-holes, New Providence and Great Exuma :-Cuba to Porto Rico and Martinique; Jamaica; Mexico. PUrple Parsonsia.

\section{Family 3. TERMINALIÀCEAE J. St. Hil.}

\section{White Mangrove Family.}

Trees, shrubs, or vines, with petioled, usually simple and entire, estipulate leaves, and regular, perfect or rarely polygamo-dioecious flowers, mostly spicate, racemose or capitate. Tube of the calyx adnate to the ovary, the limb 4-8-cleft. Petals usually small or none. Stamens various; filaments filiform; anthers didymous or 2-celled, the saes dehiscent longitudinally or by valves. Ovary 1-celled; ovules 1-several; style usually straight; stigma simple. Fruit various, mostly indehiscent, coriaceous or baceate. About 15 genera and some 275 species, mostly tropical.

\section{Fruit terete.}

Petals wanting.

Petals 5 ; calyx persistent.

Fruit an ellipsoid, flattened drupe; petals none.

Fruit a cone-like mass of scale-like drupes; petals none.
1. Bucida.

2. Laguncularia.

3. Terminalia.

4. Conocarpus.

\section{BUCİDA L. Syst. ed. 10, 1025. 1759.}

Trees or shrubs, sometimes spinescent, with coriaceous entire alternate leaves clustered at the ends of the twigs, and small spicate or capitate flowers, some perfect, some staminate. Calyx broadly campanulate, slightly 5toothed, persistent. Corolla none. Stamens 10, in 2 series; filaments slender, exserted. Fruit a small, slightly fleshy drupe, erowned by the at length deciduous calyx. [Latin; slender horn-like galls develop from the fruit after it is bitten by a mite.] Two species, natives of the West Indian region. Type species: Bucida Buceras L.

Flowers spicate; tree; drupe $8 \mathrm{~mm}$. long.

Flowers capitate; spinescent shrub or tree; drupe $3-4 \mathrm{~mm}$. long.

1. B. Buceras.

2. B. spinosa.

1. Bucida Bucèras L. Syst. ed. 10, 1025. 1759.

A tree, attaining a maximum height of about $25 \mathrm{~m}$., the trunk up to 1 $\mathrm{m}$. in diameter or more, the young twigs and leaves pubescent, becoming glabrous. Leaves clustered at the ends of twigs, spatulate to elliptic, 3-9 $\mathrm{cm}$. long, obtuse or emarginate at the apex, narrowed at the base, shortpetioled; spikes peduncled, slender, pubescent, 3-10 $\mathrm{cm}$. long; calyx-lobes tri- 
angular, acute; stamens exserted; drupe ovoid-conic, about $8 \mathrm{~mm}$. long, tomentulose, slightly curved, the persistent calyx at length deciduous.

Thickets and scrub-iands. Andros, New Providence, North and South Caicos and Inagua :-Florida; West Indies; Panama. Referred to by Hitchcock as Buceras angustifolia (DC.) Hitchcock. Erroneously called OAK. BLACK OLIVE.

\section{Bucida spinòsa (Northrop) Jennings, Ann. Carn. Mus. 11: 201. 1917.}

Terminalia spinosa Northrop, Mem. Torr. Club 12: 54. 1902.

A shrub or flat-topped tree, 4-8 $\mathrm{m}$. high, with spreading branches, the trunk 1.5-2 dm. in diameter, the twigs divaricate, spiny. Leaves fascicled, subsessile, oblanceolate to spatulate, 1-2.5 $\mathrm{cm}$. long, 4-6 $\mathrm{mm}$. wide, firm in texture, glabrous, entire, obtuse or retuse at the apex, narrowed at the base; spines slender, 3-7 mm. long, mostly in 3 's at the ends of the twigs; flowers few, greenish, in axillary short peduncled spikes; calyx campanulate, about $3 \mathrm{~mm}$. long, subtruncate, villous within; stamens 8 or 9 , about $3 \mathrm{~mm}$. long; drupe ovoid, 3-4 $\mathrm{mm}$. long, the calyx rather early deciduous.

Coastal and savanna coppices and scrub-lands, Great Bahama and Andros:Cuba. SPINy Black OLIVE. Brier-tree. P'RICKLY-Tree.

\section{LAGUNCULARIA Gaertn. f. Fr. \& Sem. 3: 209.1805.}

A halophytic tree or shrub, with opposite entire leaves, the petioles 2 glandular, and small greenish flowers in clustered spikes. Flowers polygamous or perfect. Calyx-tube terete, 5-lobed. Petals 5, minute. Stamens 10, short, the filaments subulate, the anthers cordate. Ovary with a scalloped epigynous disk; style short, glabrous; stigma somewhat 2-lobed; ovules 2 in each cavity. Drupes coriaceous, ribbed or angled. Seed solitary, germinating within the drupe. [Latin, from the fancied resemblance of the drupe to a flask.] A monotypic genus.

\section{Laguncularia racemòsa (L.) Gaertn. f. Fr. \& Sem. 3: 209. 1805.}

Conocarpus racemosa L. Syst. ed. 10, 930. 1759.

A tree, reaching a maximum height of about $20 \mathrm{~m}$. with a trunk up to $8 \mathrm{dm}$. in diameter, usually much smaller, and often shrubby, the reddish brown, glabrous twigs thickened at the nodes. Leaves oblong, oval or obovate, $2-7$ $\mathrm{cm}$. long, emarginate or rounded at the apex, rounded, narrowed or subcordate at the base, the stout petioles $0.5-2 \mathrm{~cm}$. long; spikes $3-6 \mathrm{~cm}$. long, fewseveral-flowered; calyx tomentulose, its lobes rounded; petals 5 , orbicular, not longer than the calyx; drupes oblong to obovoid, reddish, 1.5-2 $\mathrm{cm}$. long, constricted below the persistent calyx-lobes.

Borders of mangrove mud and in sea-shallows, Great Bahama, Great Sturrup Cay, Little Harbor Cay, Andros, New Providence, Ship Channel Cay, Great Guana Cay, Great Exuma, Eleuthera, Cat Island, Fortune Island, Grand Turk, and the Anguilla Isles :-Florida; West Indies; tropic continental American coasts. White mangrove. Bastard Butronwood. Green Turtle Bough.

\section{TERMINALIA L. Mant. 1: 21, 128. 1767.}

Trees or shrubs, with kroad alternate entire leaves, usually clusteed at the ends of the banches, and small spicate flowers. Calyx-tube terete, ribless, the lobes deciduous. Corolla none. Stamens 10 to 20 , exserted, the filaments slender, the anthers cordate. Fruit a drupe. [Latin, referring to the clustered leaves at the ends of the branches.] About 100 species, mostly of the Old World tropies. Type species: Terminalia Catappa L. 
1. Terminalia Catáppa I. Mant. 1: 128. 1767.

Buceras Catappa Hitchc. Rep. Mo. Bot. Gard. 4: 85. 1893.

A tree, up to $24 \mathrm{~m}$. high, with a trunk diameter of $1.5 \mathrm{~m}$., usually much smaller, the spreading branches whorled, the twigs stout, glabrous. Leaves clustered at the ends of the twigs, obovate or broadly oblanceolate, 1-3 dm. long, short-petioled, glabrous, rounded, or short-pointed at the apex, cuneate at the base, dark green and shining above, pale green beneath; spikes slender, many-flowered, 5-15 cm. long; calyx 8-10 mm. long, pubescent, its ovate lobes about as long as the tube or longer; drupe ellipsoid, compressed, glabrous, 2-edged, pointed, 4-7 cm. long; seed 3-4 cm. long.

In coppices, spontaneous after cuitivation; planted and sometimes spontaneous near towns on all the larger islands :- spontaneous after cultivation in Florida, in many of the West Indian islands and most inhabited parts of continental tropical America. Native of the Old World tropics. INDIAN ALMOND. ALMOND-TREE.

\section{CONOCÀRPUS L. Sp. Pl. 176. 1753.}

A shrub or tree of the seacoast, with alternate entire leathery leaves, the petioles 2-glandular, the small greenish perfect flowers in racemose or panicled heads. Calyx-tube flattened, not prolonged beyond the ovary; sepals 5, deciduous. Petals none. Stamens mostly 5, with slender elongated filaments and cordate anthers. Style pubescent. Ovules 2. Drupes scale-like, densely aggregated. Seeds flat; cotyledons convolute. [Greek, referring to the cone-like heads of fruit.] A monotypic American genus.

\section{Conocarpus erécta L. Sp. Pl. 176. 1753.}

A glabrate or silky-pubescent shrub or tree, sometimes $20 \mathrm{~m}$. tall, sometimes less than $1 \mathrm{~m}$. high, with angled or winged twigs. Leaves $2-5 \mathrm{~cm}$. long, elliptic to oval, acute or acuminate at both ends, entire, short-petioled; racemes 3-5 $\mathrm{cm}$. long, peduncled; heads $5-8 \mathrm{~mm}$. in diameter at flowering time; hypanthium funnel-like, greenish, a little over $1 \mathrm{~mm}$. long; sepals triangular-ovate, about as long as the limb of the hypanthium, pubescent; stamens and style conspicuously exserted; heads of fruit 9-14 mm. long; drupes scale-like, 2-winged, 4-7 $\mathrm{mm}$. long.

Coastal mud, savannas and salina-borders, throughout the archipelago to Cay Sal :-Bermuda; Florida; West Indies and continental tropical America. A species of many races, several of which have received varietal distinction from herbarium specimens; the distinctive characters are, however, not maintained in the field. ButTonwood. Catesby, $2: p l$. 33.

\section{Family 4. MYRTÁCEAE R. Br.}

\section{Mrrthe Family.}

Trees or shrubs, with simple, usually opposite and entire, pellucidpunctate, estipulate leaves, the regular and perfect, often bracteolate flowers mostly panicled. Calyx-tube (hypanthium) adnate to the ovary, the limb usually 4-5-cleft. Petals usually 4 or 5, imbricated, rarely wanting. Disc mostly annular and fleshy. Stamens usually numerous, sometimes only as many as the petals; filaments filiform, distinct, or united at the base; anthers small, 2-celled. Ovary inferior, 2-several-celled, or rarely 1-celled, style simple; stigma terminal, small; ovules usually 2-several in each cavity. Fruit drupaceous or baccate, often crowned by the calyxlimb, or in some genera capsular. Seeds various; endosperm usually wanting. About 60 genera, including over 1700 species, mostly tropical in distribution. 
Calyx of several, persistent, valvate sepals; petals present.

Calyx of regularly separating sepals.

Inflorescence centripetal, flowers in racemiform, umbelli-

form, or contracted clusters.

Inflorescence centrifugal; flowers in cymes.

Embryo spiral.

Embryo annular.

Calyx of irregularly separating sepals.

Calyx lid-like, deciduous; petals none.

1. Eugenia.

2. Pimenta.

3. Anamomis.

4. Psidium.

5. Calyptranthes.

\section{EUGÈNIA L. Sp. PI. 470.1753.}

Shrubs or trees, with usually glabrous foliage. Leaves opposite, commonly leathery, pinnately-veined, the flowers axillary, solitary or in umbellike, raceme-like or congested clusters. Calyx-lobes 4 or 5 . Petals 4 or 5, white. Stamens numerous; filaments filiform, distinct and in several series, or aggregated into 4 groups and slightly united. Ovary sessile, 2-3-celled. Ovules several in each cavity. Berries crowned by the calyx-lobes. Seeds often 1-4. Embryo with thick cotyledons and a short radicle. [Named in honor of Prince Eugene of Savoy (1663-1736), a patron of botany and horticulture.] About 600 species, of tropical distribution. Type species: Eugenia uniflora $\mathrm{L}$.

Pedicels short, shorter than the flowers or as long, at least shorter than the fruits. Leaves ovate to lanceolate; fruit subglobose.

Leaves obovate to oblanceolate; fruit longer than broad.

Pedicels as long as or longer than the flowers, mostly longer than the fruits.

Leaves long-acuminate, shining above.

Leaves bluntly acuminate, dull above.

1. E. axillaris.

2. E. buxifolia.

Pedicels $1-1.5 \mathrm{~cm}$. long or less; fruit less than $1 \mathrm{~cm}$. in diameter.

Pedicels $2-5 \mathrm{~cm}$. long; fruit $2 \mathrm{~cm}$. in diameter, edible.

Flowers unknown; leaves small, linear.

3. E. confusa.

4. E. rhombea.

5. E. uniflora.

6. E. androsiana.

\section{Eugenia axillàris (Sw.) Willd. Sp. Pl. 2: 970. 1800.}

Myrtus axillaris Sw. Prodr. 78. 1788.

Eugenia axillaris microcarpa Krug. \& Urban, Bot. Jahrb. 19: 641. 1895.

A shrub or tree, reaching a height of $8 \mathrm{~m}$., with a maximum trunk diameter of about $3 \mathrm{dm}$., the bark shallowly fissured, the branchlets terete. Leaves elliptic-ovate to ovate-lanceolate or nearly elliptic, unpleasantly odorous, 3-5 $\mathrm{cm}$. long, revolute-margined, paler beneath than above and black-dotted, the petioles $2-5 \mathrm{~mm}$. long, margined; racemes short, eluster-like, axillary; pedicels short, pubescent; calyx-lobes 4, rounded; corolla $3-4 \mathrm{~mm}$. broad; petals 4, surpassing the calyx-lobes, glandular-punctate; fruit depressed-globose, 10-12 $\mathrm{mm}$. in diameter, black, smooth, glandular-punctate, sweet.

Coppices and scrub-lands, throughout the archipelago from Great Bahama to Caicos, Inagua and the Angullia Isles:-Bermuda; Florida ; Cuba to Porto Rico and Guadeloupe; Jamaica. Referred by Dolley, by Mrs. Northrop, and by Hitchcock to E. monticola Griseb. WHITE STOPPER. WATtLe.

\section{Eugenia buxifòlia (Sw.) Willd. Sp. Pl. 2: 960.1800.}

Myrtus buxifolia Sw. Prodr. 78. 1788.

A small tree, becoming about $6 \mathrm{~m}$. high, with a trunk up to $3 \mathrm{dm}$. in diameter, usually smaller, often shrubby, the bark reddish-brown, scaly, the slender twigs sparingly pubescent or glabrous. Leaves obovate, oblanceolate or nearly oblong, glabrous, $2-4 \mathrm{~cm}$. long, rounded or obtuse at the apex, narrowed at the base, short-petioled, dark green above, pale green beneath; 
racemes axillary or lateral, few-flowered; pedicels pubescent, very short; calyx 4-lobed, the lobes obtuse; petals oblong, 2-3 $\mathrm{mm}$. long; fruits oval to subglobose, black, 5-7 $\mathrm{mm}$. in diameter.

Scrub-lands and coppices, throughout the archipelago from Abaco and Great Bahama to Caicos Islands, Inagua and the Anguilla Isles: Florida; Cuba to St. Thomas and St. Croix; Jamaica. Referred by Dolley to $E$. lateriflora Griseb. SPANISH STOPPER. BLACK WATTLE.

\section{Eugenia confùsa DC. Prodr. 3: 279. 1828.}

Eugenia filiformis Macf. Fl. Jam. 2: 116. 1850.

A tree, attaining a maximum height of about $18 \mathrm{~m}$, with a trunk up to $5 \mathrm{dm}$. in diameter, usually much smaller, the bark sealy, the slender twigs glabrous. Leaves ovate to lanceolate, coriaceous, glabrous, $3-6 \mathrm{~cm}$. long, longacuminate at the apex, narrowed or obtuse at the base, dark green and shining above, dull green beneath, pinnately many-veined, the slender petioles 5-10 mm. long; flowers umbellate or solitary in the axils, on filiform pedicels 2-3 times as long as the petioles; calyx-lobes broadly ovate, $1.5-2 \mathrm{~mm}$. long; petals ovate, about twice as long as the calyx-lobes; fruit subglobose, orange to searlet, 5-6 mm. in diameter.

Coppices and scrub-lands, Great Bahama, Iignum Vitae Cay, Andros, New Providence, Great Guana Cay, Eleutbera, Watling's and Crooked Islands :-Florida; Cuba; Porto Rico to Dominica; Jamaica. The record of $E$. pseudopsidium by Schoepf may apply to this species. InONwood.

\section{Eugenia rhómbea (Berg) Krug \& Urban, Bot. Jahrb. 19: 644. 1895.}

Eugenia foetida rhombea Berg, Linnaea 27: 212. 1856.

A small tree, sometimes $8 \mathrm{~m}$. high with a trunk up to $3 \mathrm{dm}$. in diameter, the twigs slender, the smooth bark gray, the foliage glabrous. Leaves ovate to elliptic or rhombic-ovate, rather thin, inconspicuously veined, 3-6 $\mathrm{cm}$. long, bluntly acuminate or acute at the apex, obtuse or narrowed at the base, shortpetioled; flowers in sessile axillary umbel-like clusters, often appearing on twigs from which the leaves have fallen, the slender glabrous pedicels 8-15 $\mathrm{mm}$. long; calyx-tube shorter than the 4 rounded lobes; petals ovate, about $5 \mathrm{~mm}$. long, about twice as long as the calyx-lobes; fruit depressed-globose, orange, red or nearly black, $0.8-1.5 \mathrm{~cm}$. in diameter.

Scrub-lands, Cave Cay, Long Island, Great Ragged Island, Acklin's, Inagua and the Anguilia Isies:-Florida; Cuba to Guadeloupe; Jamaica. RED STOPPER.

\section{Eugenia uniflòra L. Sp. Pl. 470. 1753.}

A shrub or small tree up to $5 \mathrm{~m}$. high, with slender branches. Leaves ovate to ovate-lanceolate, dark green and shining above, paler beneath, bluntly acute or acuminate at the apex, rounded at the base, dotted, thin in texture, 2.5-6 cm. long; pedicels solitary or few together, very slender, glabrous, about $2.5 \mathrm{~cm}$. long, bracted at the base and 2-bracteolate near the summit; ealyx-lobes linear-oblong, obtusish; petals about twice as long as the calyxlobes; fruit subglobose, longitudinally furrowed, 8-10 $\mathrm{mm}$. in diameter, bright red, spicy, edible.

Apparently only spontaneous after cultivation, though recorded as indigenous by Dolley, and admitted into the Bahamas by Grisebach. New Providence:-Bermuda; Cuba to Trinidad and South America; Jamaica; Cayman Islands ; introduced into the Old Worid tropics. Native of South America. Surinam CHERry.

6. Eugenia androsiàna Urban, Repert. 13: 467. 1915.

A glabrous shrub, about $1 \mathrm{~m}$. high, diffusely branched, the twigs very slender. Leaves linear or linear-oblong, 1-2 $\mathrm{cm}$. long, 1.5-3 $\mathrm{mm}$. wide, acute 
or obtuse at the apex, narrowed at the base, finely punctate, the margins slightly revolute, the petioles $0.5-0.8 \mathrm{~mm}$. long.

Near Lisbon Creek, Mangrove Cay, Andros. Endemic. When flowers of this shrub are obtained, they may show it to belong to one of the other genera of Myrtaceae.

Eugenia ligustrina Willd., West Indian, recorded as Bahamian by Grisebach and by Dolley, was not found during our exploration of the archipelago; the specimen cited by Grisebach as collected in the Bahamas by Swainson was not found in the Kew Herbarium when search was made for it there in 1911. We regard the records as probably erroneous.

\section{PIMENTA Lindl. Coll. under pl. 19. 1821.}

A tree, with nearly smooth bark, oblong or elliptic, petioled aromatic pinnately veined leaves, and small white 4-parted flowers, borne in compound eymes in the upper axils. Calyx-tube campanulate, its lobes spreading, persistent. Petals spreading. Stamens numerous, in several series. Stigma peltate; ovary 2-celled; ovules mostly solitary in each cavity. Fruit berry-like, aromatic. Seeds few, subglobose; embryo spiral. [Greek, rich in oil.] A monotypic genus of the West Indies and Central America.

1. Pimenta Piménta (L.) Cockerell, Bull. Torr. Club 19: 95. 1892.

Myrtus Pimenta L. Sp. Pl. 472. 1753.

Pimenta officinalis Lindl. Coll. under pl. 19. 1821.

Pimenta vulgaris Lindl. in Loudon Encycl. 418. 1829.

Becoming $13 \mathrm{~m}$. high or more, glabrous, except the puberulent inflorescence. Leaves coriaceous, 7-15 $\mathrm{cm}$. long, mostly obtuse at the apex, narrowed at the base, with petioles about $1 \mathrm{~cm}$. long, the veins rather prominent beneath; cymes stalked, many-flowered; flowers about $6 \mathrm{~mm}$. broad; calyx-lobes blunt; ovary puberulent; berries subglobose, about $6 \mathrm{~mm}$. in diameter, usually 2 -seeded.

Thickets and coppices, spontaneous after cultivation, New Providence, at Grant's Town and near Lake Cunningham. Native of Jamaica and Cuba; spontaneous after cultivation in Bermuda and in Central America. Erroneously called Cinnamon. Allspice.

\section{ANAMOMIS Griseb. Fl. Br. W. I. 240. 1860.}

Evergreen aromatic trees or shrubs, with opposite coriaceous leaves and axillary peduncled flowers, in cymes or solitary, when in cymes the central flower sessile or stalked. Calýx-lobes 4 or 5 . Petals 4 or 5 . Stamens many, with filiform filaments and short anthers. Ovary 2-celled or 4-celled, about as long as the calyx-tube; ovules several in each cavity; style slender or filiform. Berry oval or subglobose, 1-several-seeded, crowned by the calyx-lobes. [Greek, like Amomis.] About 8 species, natives of the West Indies and Florida. Type species: Anamomis fragrans (Sw.) Griseb.

Leaves shining above, not revolute-margined; flowers mostly solitary ; calyx

Petals orbicular; leaves mostly $2 \mathrm{~cm}$. wide or less, acute, acutish or rounded at the base.

Petals oblong-orblcular; leaves mostly over $2 \mathrm{~cm}$. wide, obtuse and rounded or subcordate at the base.

Leaves dull above, revolute-margined (at least when old) ; flowers several (rarely solitary); calyx pubescent.

1. A. longipes.

2. A. bahamensis.

3. A. Iucayana. 
1. Anamomis lóngipes (Berg) Britton; Small, Fl. Miami 132. 1913.

Eugenia longipes Berg, Linnaea 27: 150. 1856.

A glabrous shrub or small tree up to $4 \mathrm{~m}$. high, the branches slender, erect-ascending, or diffuse. Leaves flat, ovate, oval or oblong-lanceolate, 1-3.5 $\mathrm{cm}$. long, 1-2 cm. wide, shining above, acute or obtuse at the apex, acute or rounded at the base, reticulate-veined, the petioles 1-2 cm. long; peduncles usually 1-flowered, as long as the leaves or longer, when several-flowered the terminal flower of the cyme long-stalked; calyx-lobes about $2 \mathrm{~mm}$. long; petals orbicular, white or pink, 5-6 mm. long; berry 6-10 $\mathrm{mm}$. in diameter, red, several-seeded.

Coppices, pine-lands, palmetto-lands and scrub-lands, Abaco, Great Bahama, Andros, New Providence:-Florida. LONG-STALKED STOPPER.

\section{Anamomis bahaménsis (Kiearsk.) Britton; Small, Fl. Florida Keys 104. 1913.}

Eugenia bahamensis Kiearsk. Bot. Tidsk. 17: 226. 1890.

A glabrous shrub, usually straggling or diffusely branched and $1 \mathrm{~m}$. high or less, rarely a small tree. Leaves elliptic or ovate-elliptic, 3-6 em. long, shining above, dull beneath, rounded or obtuse at the apex, subcordate or rounded at the base, the petioles $2-8 \mathrm{~mm}$. long; leaves of shoots sometimes linear-oblong, 2-3 cm. long, 4-8 $\mathrm{mm}$. wide; peduncles slender, compressed, as long as the leaves or somewhat longer; cymes 3 -flowered or flowers solitary; calyx-lobes rounded, about $3 \mathrm{~mm}$. long; petals oblong-orbicular, $5-7 \mathrm{~mm}$. long; berries 8-10 $\mathrm{mm}$. in diameter.

Coastal rocky plains, scrub-lands, coppices and white-iands, throughout the archipelago from Abaco, the Berry Islands and Andros to South Caicos, Dellis Cay and Inagua. Recorded from Big Plne Key, Florida, apparently erroneously. Endemic. Individual specimens are separable only with difficulty from the preceding species, but typical specimens are widely different. BAHAMA STOPPER. WILD GUAVA.

\section{Anamomis lucayàna Britton, sp. nov.}

A shrub or a small tree up to 6.5 meters high, the bark grayish-white, the young twigs appressed-pubescent to glabrate. Leaves oblong to elliptic, pale green, but darker above than beneath, dull, revolute-margined, obtuse or emarginate at the apex, narrowed at the base, 3-5 cm. long, 1-2.5 $\mathrm{cm}$. wide, the midvein impressed above, prominent beneath, the lateral veins few anu obscure, the stout petioles $2-4 \mathrm{~mm}$. long; peduncles slender, as long as the leaves or longer, sparingly pubescent or glabrous; cymes $3-7$-flowered, the lateral pedicels slender, $1 \mathrm{~cm}$. long or less, each central flower sessile; hypanthium obconic, glabrate or pubescent, 1.5-2 mm. high; sepals suborbicular, pubescent and ciliate, or nearly glabrous, $2-2.5 \mathrm{~mm}$. wide; petals broadly obovate, 4-5 mm. long; stamens about as long as the petals, the style a little longer; fruit red, subglobose, 7-9 $\mathrm{mm}$. in diameter.

Scrub-lands and copplces, Andros, New Providence, Eleuthera, Cat Island, Great Guana, Great Exuma, Long Island, Crooked Island, Acklin's, North Caicos and the Inaguas:- Cuban Cays. Type, Nash \& Taylor, 1426, Inagua. Referred by Coker as Eugenia punctata Vahl, and by Mrs. Northrop as Myrtus punctata Griseb. The Bahamian record of Eugenia fragrans by Urban (Symb. Ant. 4:452), probably refers to this specles. PALE STOPPER. NAKED-WOOD.

\section{PSÍDIUM L. Sp. Pl. 470. 1753.}

Trees or shrubs with pinnately veined leaves and large, axillary or lateral, solitary or clustered flowers. Calyx-tube somewhat prolonged beyond the ovary, its 4 or 5 lobes often united in the bud, irregularly parting at 
anthesis. Petals 4 or 5, spreading. Stamens numerous, with-filiform filaments in several series. Ovary 4-5-celled; ovules several or many in each cavity. Berries crowned by the calyx-lobes. Seeds several or many. Embryo curved, with small cotyledons and a long radicle. [Greek, referring to the edible fruit.] A large genus, of which about 100 species have been described, the following typical.

1. Psidium Guajàva L. Sp. Pl. 470. 1753.

Psidium Guava Griseb. Fl. Br. W. I. 241. 1860.

A shrub, or a small tree, sometimes $5 \mathrm{~m}$. tall, with pubescent 4-angled branchlets. Leaves firm-leathery, oblong or nearly so, 4-8 cm. long, mostly obtuse, pubescent beneath, with prominent rib-like nerves, short-petioled; calyx-lobes 1-1.5 cm. long, united in the bud; petals $1.5-2 \mathrm{~cm}$. long; berries globular or pyriform, $3-6 \mathrm{~cm}$. in diameter.

Scrub-lands, roadsides and waste places, spontaneous after cultivation; planted and spontaneous near towns on all the larger islands:- spontaneous after cultivation in Florida and in Bermuda; West Indies; continental tropicai America. GUAVA.

\section{CALYPTRÁNTHES Sw. Prodr. 79. 1788.}

[Chytraculia P. Br. Hist. Jam. 239. Hyponym. 1756.]

Evergreen shrubs or trees, with opposite coriaceous or subcoriaceous leaves, and small panicled cymose or rarely solitary flowers. Calyx closed at anthesis, circumscissile, the top falling away like a cap or calyptra. Petals none. Stamens numerous, in several series; filaments filiform; anthers longitudinally dishiscent. Ovary 2-3-celled; ovules 2 in each cavity. Fruit a 1-few-seeded berry, crowned by the basal part of the calyx. [Greek, referring to the eap-like lid of the calyx.] About 75 species, of tropical and subtropical America. Type species: Calyptranthes Chytraculia (L.) Sw.

Inflorescence glabrous; leaves short-petioled.

Inflorescence tomentulose; leaves distinctly petioled.
1. C.Zuzygium.

2. C. pallens.

1. Calyptranthes Zuzỳgium (L.) Sw. Prodr. 79. 1788.

Myrtus Zuzygium L. Syst. ed. 10, 1056. 1759.

Chytraculia Suzygium Kuntze, Rev. Gen. Pl. 1: 238.1891.

A tree, up to about $12 \mathrm{~m}$. high, glabrous throughout, the twigs terete, slender. Leaves elliptic, or elliptic-obovate, 4-7 cm. long, abruptly blunttipped or obtuse at the apex, narrowed at the base, delicately veined, somewhat shining above, dull beneath, the petioles $3 \mathrm{~mm}$. long or less; panicles mostly somewhat longer than the leaves; flowers several or many; pedicels 4-7 $\mathrm{mm}$. long; ealyx ovoid, about $4 \mathrm{~mm}$. long, its lid mammillate; berries subglobose, 8-10 $\mathrm{mm}$. in diameter.

Coppices, New Providence at Waterloo; Andros, near Lisbon Creek:-Florida ; Cuba; Hispaniola; Jamaíca. MYRTLE-OF-THE-RIVEl.

\section{Calyptranthes pállens (Poir.) Griseb. Kar. 67. 1857.}

Eugenia pallens Poir. in Lam. Encycl. Suppl. 3: 122.1813.

A tree, attaining a maximum height of about $10 \mathrm{~m}$., with a trunk sometimes $1.5 \mathrm{dm}$. in diameter, usually smaller and sometimes shrubby, the bark thin and light gray, the young twigs pubescent, soon becoming glabrous. Leaves elliptic to oblong-elliptic, $3-8 \mathrm{~cm}$. long, acuminate at the apex, nar- 
rowed at the base, shining above, the petioles $5-12 \mathrm{~mm}$. long; panicles as long as the leaves or longer, pubescent, many-flowered, the flowers sessile or nearly so, about $3 \mathrm{~mm}$. broad; fruit subglobose or oval, 5-7 $\mathrm{mm}$. in diameter.

Coppices and scrub-lands, Andros, Great Exuma, Eleuthera, Cat Island, Watling's, Acklin's, Crooked Island and Mariguana:-Florida; Cuba to St. Crolx and Guadeloupe; Jamaica; Cayman Islands. SPICE-Wood. White STopPer.

\section{Family 5. RHIZOPHORÀCEAE Lindl.}

Mangrove Family.

Shrubs or trees, with terete branches and usually glabrous foliage. Leaves usually opposite, leathery, with stipules. Flowers perfect, solitary in the axils or in spikes, racemes, cymes or panicles. Calyx with 3 or 4 valvate sepals. Petals as many as the sepals, 2-cleft or lacerate. Stamens twice or four times as many as the petals, or rarely of the same number, inserted at the base of a disk; filaments short or elongated; anthers 2celled, opening lengthwise. Ovary inferior, or partly inferior, usually 3-5-celled or rarely 1-celled; styles united; stigmas sometimes lobed. Ovules 2 or rarely 4 or more in each cavity, pendulous. Fruit leathery, erowned with the calyx, indehiscent or tardily septicidal. The family consists of about 15 genera, containing some 50 species, natives of tropical and subtropical regions.

\section{RHIZÓPHORA. L. Sp. Pl. 443. 1753.}

Evergreen trees, with an astringent bark, and stout pithy twigs. Leaves opposite, entire; stipules elongated, interpetiolar, caducous. Flowers creamcolored or yellow, 2 or several on forking peduncles. Calyx-tube short, adnate to the base of the ovary, the 4 lobes leathery. Petals 4 , emarginate, leathery. Stamens 4-12, alternate with the petals; filaments short. Ovary 2-celled, halfinferior, produced into a fleshy cone. Stigma 2-lobed. Ovules 2 in each cavity. Fruit pendulous, 1-celled, leathery. Seed solitary, germinating in the persistent fruit, the elongating radicle sometimes reaching the ground before the fruit falls. Endosperm wanting. [Greek, root-bearing.] Three known species, the following typical, the others natives of the Old World tropies.

\section{Rhizophora Mángle L. Sp. Pl. 443. 1753.}

A shrub or tree, reaching a height of $10 \mathrm{~m}$. or more, forming impenetrable thickets by the greatly elongating radicles of the embryo and the numerous roots. Leaves 5-15 cm. long, leathery, elliptic or elliptic-obovate, obtuse, with a stout midrib; petioles $0.5-1.5 \mathrm{~cm}$. in length; peduncles $1-4 \mathrm{~cm}$. long, 2-3flowered; pedicels stout, 5-10 $\mathrm{mm}$. long; bractlets scale-like; calyx-tube fleshy, turbinate or campanulate the lobes $3-5 \mathrm{~mm}$. long; sepals lanceolate, about $1 \mathrm{~cm}$. long, involute, keeled within, very firm, recurved at maturity; petals pale yellow, linear or nearly so, cleft at the tip, involute above the middle, cobwebby along the edges; anthers clustered around the style; fruit $2-3 \mathrm{~cm}$. long, curved, the radicle protruding as a narrowly clavate pendent body.

Maritime shores and salinas, throughout the archipelago:-Bermuda; Florida ; West Indies; Mexico to Brazil; west coast of Africa; Pacific islands. MANGrove. Catesby, $2: p l$. 63 . 


\section{Family 6. ONAGRÀCEAE Dumort.}

\section{Evening-Primrose Family.}

Herbs, or rarely shrubs, with alternate or opposite leaves, no stipules or mere glands in their places, and generally perfect flowers. Calyx-tube adnate to the ovary, the limb 2-6-lobed (usually 4-lobed). Petals 2-9 (usually 4), convolute in the bud, rarely none. Stamens usually as many or twice as many as the petals. Ovary 1-6-celled (usually 4-celled); styles united; stigma capitate, discoid or 4-lobed; ovules generally anatropous. Fruit a capsule or small nut. Endosperm very little or none. Forty genera and about 350 species of wide geographic distribution, most abundant in America.

\section{Stamens 4.}

Leaves opposite.

Leaves alternate. Stamens 8-12 in 2 series.

1. Isnardia.

2. Ludvigia. 3. Jussiaea.

\section{ISNÁRdiA L. Sp. Pl. 120. 1753.}

Succulent herbs. Stems creeping or floating; leaves opposite, relatively few, petioled. Flowers axillary, sessile, not yellow. Calyx-segments 4, shorter than the tube or slightly longer. Filaments very short. Ovary very short; styles often almost wanting. Capsule obovoid or turbinate, straight. [In honor of Antoine Dante Isnard, a French botanist, and a member of the Academy of Sciences, died 1724.] About 4 species in North America, Mexico and the West Indies. Type species: Isnardia palustris L.

1. Isnardia répens (Sw.) DC. Prodr. 3: 60. 1828.

Ludwigia repens Sw. Prodr. 33. 1788.

Ludwigia natans Ell. Bot. S. C. \& Ga. 1: 581. 1821.

Isnardia natans Small, Fl. SE. U. S. 825. 1903.

Stems $6 \mathrm{dm}$. long or less, branched or simple. Leaves elliptic, oval, or obovate, 2-6 $\mathrm{cm}$. long, acute or blunt at the apex, narrowed at the base into rather slender petioles; flowers solitary, sessile or short-peduncled; bractlets linear, acute, shorter than the fruiting calyx; calyx-lobes 4 or 5 , sharply triangular, acute, longer than the petals; capsule 6-8 $\mathrm{mm}$. long, bluntly tetragonal, narrowed at the base, 3 times as long as the calyx-lobes.

Sink-holes and fresh-water swamps, Great Bahama and New Providence:North Carolina to Florida, Mexico and California; Bermuda; Cuba; Hispaniola; Jamaica. Larger Marsh PuRsLane.

\section{LUDWÍGIA L. Sp. Pl. 118. 1753.}

Perennial or annual herbs, with alternate usually entire leaves, and axillary or terminal flowers. Stems erect or ascending, sometimies angled, or winged. Calyx-lobes generally persistent. Petals usually 4. Stamens usually 4. Ovary 4-5-celled. Capsule terete, ribbed or winged, septicidally dehiscent, or opening by an apical pore. [Named in honor of C. G. Ludwig, 1709-1773, Professor of Botany at Leipsic.] About 25 species, natives of warm and temperate regions, most abundant in North America. Type species: Ludwigia alternifolia L. 
1. Ludwigia microcàrpa Michx. Fl. Bor. Am. 1: 88. 1803.

Perennial; glabrous; stems erect or diffuse, simple or branched, 1-4 dm. long. Leaves obovate or spatulate, entire, pinnately few-veined, $0.5-3 \mathrm{~cm}$. long, obtuse or apiculate at the apex, narrowed into short petioles; flowers solitary and sessile in the axils; calyx-lobes triangular-ovate, about $1 \mathrm{~mm}$. long; petals none; capsule obpyramidal, about $2 \mathrm{~mm}$. long.

Fresh-water marshes, Great Bahama :-North Carolina to Florida and Mississippi ; Cuba ; Jamaica. SMall-FruIted LUdWigia.

\section{JUSSIAÈA L. Sp. Pl. 388. 1753.}

Perennial herbs, some species woody, with alternate, mostly entire leaves and solitary axillary flowers, the petals usually yellow. Calyx-tube cylindric or prismatic, not prolonged beyond the ovary, the limb 4-6-parted, its lobes persistent. Petals 4-6, mostly longer than the calyx-lobes. Stamens 8-12, in 2 series. Ovary 4-6-celled. Capsule narrowly cylindric, prismatic or clavate, ribbed, the pericarp deteriorating. Seeds numerous and minute. [In honor of Bernard de Jussieu, 1699-1777, eminent French botanist and physician.] About 50 species, of tropical distribution, mostly American. Type species: Jussiaea repens $\mathrm{L}$.

\section{Jussiaea suffruticòsa L. Sp. Pl. 388. 1753.}

Jussiaea angustifolia Lam. Encycl. 3: 331. 1789.

Jussieua palustris Meyer, Prim. Fl. Esseq. 173. 1818.

Erect, 6-10 dm. high, somewhat branched, more or less pubescent, at least above. Leaves linear to oblong-lanceolate, entire, short-petioled, $2.5-10 \mathrm{~cm}$. long, acute at the apex, narrowed at the base; peduncles mostly not longer than the petioles; calyx-lobes 4, rarely 5, lanceolate or ovate-lanceolate, acute or acuminate, 6-12 mm. long; petals obovate, bright yellow, 2-3 times as long as the calyx-lobes; capsule 3-6 $\mathrm{cm}$. long, subcylindric, tapering to the base.

Fresh-water marshes and sink-holes, Great Bahama, New Providence, Eleuthera, Cat Island, Great Exuma, Acklin's Island and Crooked Island :-North Carollna to Florida and Texas; West Indies and continental tropical America; Old World tropics. BUSHY Jussiáa.

\section{Family 7. HALORAGIDĀCEAE Kl. \& Garcke.}

\section{WATER-MILFOIL FAMILY்.}

Perennial or rarely annual herbs, mainly aquatic, with alternate or verticillate leaves, the submerged ones often pectinate-pinnatifid. Flowers perfect, or monoecious, or dioecious, axillary, in interrupted.spikes, solitary or clustered. Calyx-tube adnate to the ovary, its limb entire or 2-4-lobed. Petals small, 2-4, or none. Stamens 1-8. Ovary ovoid-oblong, or shortcylindric, 2-8-ribbed or winged, 1-4-celled; styles 1-4; stigmas papillose or plumose. Fruit a nutlet, or drupe, compressed, angular, ribbed or winged; indehiscent, of 2-4 one-seeded carpels. Endosperm fleshy; cotyledons minute. Eight genera and about 100 species, of wide distribution.

\section{PROSERPINÀCA L. Sp. Pl. 88. 1753.}

Aquatic herbs. Leaves alternate, lanceolate, dentate or pectinate-pinnatifid. Flowers perfect, axillary. Tube of the calyx adnate to the triquetrous ovary, the limb 3-4-parted. Petals none. Stamens 3 or 4 . Styles 3 or 4, 
cylindric or conic-subulate, stigmatic above the middle. Fruit bony, 3-4-celled, with 1 seed in each cavity. [Middle Latin, forward-creeping.] Four known species of North and Central America and the West Indies. Type species: Proserpinaca palustris $\mathrm{L}$.

1. Proserpinaca platycárpa Small, Bull. N. Y. Bot. Gard. 3: 432.1905.

Perennial, glabrous, 1-3.5 dm. long, densely leafy. Leaves oblong or elliptic, $1.5-5.5 \mathrm{~cm}$. long, sharply serrate; flowers solitary and sessile in the axils; calyx wing-angled, its deltoid teeth about $1 \mathrm{~mm}$. long; fruit 4-5 mm. wide, constricted above the middle, its 3 angles dilated.

Fresh-water swamps and sink-holes, Great Bahama, New Providence, Eleuthera and Cat Island. - Florida. Recorded by Schoepf as $P$. palustris L. SoutherN MERMAID-WEED.

\section{Order 22. AMMIÀLES.}

Herbs, shrubs or trees, almost always with petaliferous flowers. Calyxsegments and petals usually 5 . Stamens 4 or 5 . Ovary inferior, adnate to the calyx, compound; ovules 1 in each cavity.

\section{Family 1. AMMIÀCEAE Presl.}

\section{Carrot Family.}

Herbs, with alternate compound or sometimes simple leaves, the petioles often dilated at the base. Stipules none, or rarely present and minute. Flowers small, generally in compound or simple umbels, rarely in heads or capitate clusters, often polygamous. Umbels and umbellets commonly involucrate or involucellate. Calyx-tube adnate to the ovary, its margin truncate or 5-toothed, the teeth seldom conspicuous. Petals 5, inserted on the margin of the calyx, usually with an inflexed tip, often emarginate or 2-lobed, those of the outer flowers sometimes larger than those of the inner. Stamens 5, inserted on the epigynous disk; filaments filiform; anthers versatile. Ovary inferior, 2-celled; styles 2, filiform, persistent, often borne on a conic or depressed stylopodium; ovules 1 in each cavity, pendulous, anatropous. Fruit dry, composed of 2 carpels (mericarps), which generally separate from each other at maturity along the plane of their contiguous faces. (the commissure). Fruit either flattened laterally (at right angles to the commissure), or dorsally (parallel to the commissure), or nearly terete (not flattened). Carpels after parting from each other supported on the summit of a slender axis (the carpophore), each with 5 primary ribs in their pericarps (rarely ribless), and in some genera with 4 additional secondary ones, the ribs or some of them often winged. Pericarp membranous or corky-thickened, usually containing oil-tubes between the ribs, or under the ribs and on the commissural sides, sometimes irregularly scattered, sometimes none. Seeds 1 in each carpel, usually adnate to the pericarp; seed-coat thin; endosperm cartilaginous; embryo small, placed near the hilum; cotyledons ovate, oblong or linear. About 170 genera and 1600 species, of wide distribution. The mature fruit is necessary for the certain determination of most of the genera and many of the species. 
Leaf-blades orbicular or ovate, merely toothed; flowers white. Involucre none.

Involucre conspicuous.

Leaf-blades pinnatifid into filiform segments.

Fruit margined, flat; flowers yellow.

Frult not margined.

Flowers yellow.

Flowers white.

1. Hydrocotyle.

2. Centella.

3. Anethum.

4. Foeniculum.

5. Helosciadium.

\section{HYDROCOTỲLE L. Sp. Pl. 234. 1753.}

Perennial herbs, prostrate and commonly rooting at the joints, with palmately lobed or veined, often peltate leaves, the bases of the petioles with 2 seale-like stipules, and small white flowers in umbels opposite the leaves. Bracts of the involucre few, or none. Calyx-teeth minute. Petals entire. Disk flat. Fruit laterally compressed, orbicular or broader than high. Carpels with 5 primary ribs, the lateral ones usually curved; no large oil-tubes but an oil-bearing layer of tissue beneath the epidermis. [Greek, water-cup.] About 75 species of wide distribution. Type species: Hydrocotyle vulgaris $\mathrm{L}$.

Plant glabrous.

Leaves and inflorescence villous-pubescent.
1. H. verticillata.

2. H. hirsuta.

1. Hydrocotyle verticillàta Thunb. Diss. Hydrocot. 5. 1798.

Glabrous; leaves orbicular, peltate; inflorescence proliferous, $2-5 \mathrm{~cm}$. long; verticils 2-6-flowered; pedicels usually less than $1 \mathrm{~mm}$. long; fruit about $2 \mathrm{~mm}$. long, 3-4 $\mathrm{mm}$. broad, rounded or truncate at each end; intermediate ribs not corky-thickened, the dorsal one acute.

Wet palmetto-lands, Great Bahama at Barnett's Point; Andros at Couch Sound : -Bermuda; Jamalca; Cuba; Hispaniola; Porto Rico; Guadeloupe; southern Africa; Massachusetts to Florida and Arizona. Recorded by Mrs. Northrop as $H$. pygmaea Wright. Determination of the Bahama plant is from leaf-specimens only. Whorled Malish Pennywort.

\section{Hydrocotyle hirsùta Sw. Prodr. 54. 1788.}

\section{Hydrocotyle spicata Lam. Encycl. 3: 153. 1789.}

Stems creeping, rooting at the nodes, very slender, glabrous or nearly so, 0.5-3 dm. long. Petioles villous, 1-8 cm. long; leaf-blades suborbicular or reniform, 1-3 cm. broad, erenate, rather deeply cordate, villous on both sides, densely so beneath; spikes peduncled, interrupted, usually longer than the leaves, sometimes $8 \mathrm{~cm}$. long, the peduncles and rachis villous; fruits sessile, glabrous, emarginate at top and bottom, about $1.5 \mathrm{~mm}$. broad.

Grassy places, New Providence near Nassau:-Cuba; Hispaniola; Porto Rico; Curaça. hairy Marsh Pennywort.

Hydrocotyle umbellata $\mathrm{L}$. recorded for the Bahamas by Dolley has not been found by us anywhere in the islands; Mr. Brace thinks that the reference really applied to Centella asiatica.

\section{CENTÉLLA L. Sp. Pl. ed. 2, 1393. 1763.}

Perennial herbs (some African species shrubby), ours with prostrate stems rooting and sending up tufts of petioled leaves at the nodes, together with 1-3 long-rayed umbellets of small white flowers, the true umbel sessile. Petiolebases sheathing. Bracts of the involucels 2-4, mostly prominent. Calyx-teeth none. Disk flat, or slightly concave. Styles filiform. Fruit somewhat flattened laterally, rather prominently ribbed, the ribs mostly anastomosing; oiltubes none. [Latin, diminutive of centrum, a prickle.] About 20 species, of 
wide distribution, abundant in South Africa. Type species: Centella villosa L.

1. Centella asiàtica (L.) Urban in Mart. Fl. Bras. 11: 287. 1879.

Hydrocotyle asiatica L. Sp. Pl. 234. 1753.

Hydrocotyle repanda Pers. Syn. 1: 302. 1805.

Centella repanda Small, Fl. SE. U. S. 859. 1903.

Stem 2-15 cm. long. Petioles $0.5-3 \mathrm{dm}$. long, sometimes pubescent; blades ovate, rather thick, rounded at the apex, broadly cordate at the base, not peltate, 2-4 cm. long, repand-dentate; pedicels much shorter than the leaves, 1-5 cm. long; umbellets capitate, 2-4-flowered, subtended by 2 ovate bracts; flowers nearly sessile; fruit $4-5 \mathrm{~mm}$. broad, about $3 \mathrm{~mm}$. high, prominently ribbed and reticulated.

Moist ground, Abaco, Great Bahama, Andros, New Providence, Great Exuma, Eleuthera, Fortune Island and North Caicos:-Bermuda; Maryland to Florida and Texas; Jamaica; Cuba ; Hispaniola ; Guadeloupe; Martinique; continental tropical America; Old World tropics. Recorded by Dolley presumably as Hydrocotyle umbellata L. Ovate-leaved Marsh Pennywort.

\section{ANÈTHUM [Tourn.] L. Sp. Pl. 263. 1753.}

Erect, mostly annual, glabrous herbs, with decompound leaves and small yellow flowers in many-rayed compound umbels. Involucre and involucels none, or of very few bracts. Calyx teeth obsolete. Petals suborbicular. Stylopodium small, conic. Fruit elliptic or ovate, flat, margined; carpel-ribs slender; oil-tubes solitary in the intervals. [Greek, like anise.] A few European and Asiatic species, the following typical.

\section{Anethum gravèolens L. Sp. Pl. 263. 1753.}

Stem terete, simple or branched, slender, 3-9 dm. high. Leaves tripinnately dissected into nearly filiform segments, the petiole somewhat sheathing; umbel $12 \mathrm{~cm}$. wide or less; involucre and involucels none; rays slender, 4-7 cm. long; umbellets several-many-flowered; petals bright yellow; fruit ovateelliptic, about $6 \mathrm{~mm}$. long, distinctly margined.

Waste and cultivated grounds, escaped from cultivation, Andros, Harbor Island, Eleuthera, Long Island and Delli's' Cay:-escaped in Guadeloupe, Martinique and other West Indian Islands and in Florida. Native of Europe. Dillweed.

\section{FOENÍcULUM Adans. Fam. Pl. 2: 101. 1763.}

Erect glabrous herbs, with pinnately decompound leaves, the segments linear or eapillary, and compound umbels of yellow flowers. Involucre and involucels none. Calyx-teeth obsolete. Stylopodium large, conic. Fruit linearoblong, glabrous, terete, or nearly so. Carpels half-terete, dorsally flattened, prominently ribbed; oil-tubes solitary in the intervals. Seed-face flat, or slightly concave. [Latin, diminutive of foenum, hay, from its odor.] About 4 species, of the Old World. Type species: Anethum Foeniculum L.

\section{Foeniculum Foenículum (L.) Karst. Deutsch. Fl. 837. 1882.}

Anethum Foeniculum L. Sp. Pl. 263. 1753.

Foeniculum vulgare Gaertn. Fr. \& Sem. 1: 105. 1788.

Perennial, 6-12 dm. high. Leaves dissected into capillary segments; petioles broad, clasping; umbels large, 9-25-rayed, the rays rather stout, somewhat glaucous, $2-8 \mathrm{~cm}$. long in fruit; pedicels $2-8 \mathrm{~mm}$. long; fruit about $6 \mathrm{~mm}$. long. 
Waste places, New Providence at Grant's Town:-Bermuda; New Jersey and Pennsylvania to Florida, Texas and California; locally in the West Indies and in continental tropical America. Native of the Old World. FENNEL.

5. HELOSCIADIUM Koch, Nov. Act. Nat. Cur. 12 : 125.1824.

Low herbs, with decompound or dissected leaves, and compound umbels of small white flowers mostly opposite the leaves. Involucre and involucels wanting in the following species. Calyx-teeth very small or obsolete. Petals entire. Stylopodium depressed. Style short. Fruit ovate or oblong, laterally compressed. Carpels with 5 filiform ribs, the oil-tubes solitary in the intervals, 2 on the commissural side. [Greek, marsh-parasol, some of the species inhabiting marshes.] Six species or more, natives of the Old World. Type species: Helosciadium nodiflorum (L.) Koch.

\section{Helosciadium Ámmi (L.) Britton, Fl. Bermuda 279. 1918.}

Sison Ammi L. Sp. Pl. 252. 1753.

Apium Ammi Urban in Mart. Fl. Bras. 11': 341. 1879.

Slender, glabrous, much-branched, 0.7-6 dm. high. Leaves ternately pinnatisected, the ultimate segments narrow, often incised; umbels $1-4 \mathrm{~cm}$. broad, opposite the leaves, sessile, the umbellets filiform-stalked; fruit ovate, glabrous, about $2 \mathrm{~mm}$. long, the ribs equal and prominent.

Waste grounds, New Providence, at Grant's Town:-Bermuda; southern United States; Cuba; Hispaniola; Guadeloupe; Martinique; Barbadoes ; Jamaica ; Mexico to Paraguay; Australia. Fine-Leaved Marsh Parslex.

\section{Series 2. Gamopétalae.}

Petals partly or wholly united, rarely separate or wanting.

The coherence of the petals is sometimes slight or they are quite separate, as in some Primulaceae, Plumbaginaceae, Asclepiadaceae, Oleaceae and Cucurbitaceae. From this condition the coherence varies through all stages to the tubular or funnelform corollas of some Convolvulaceae, Caprifoliaceae and Carduaceae.

¥ Ovary superior.

Stamens borne on the corolla, as many as its lobes and opposite them, or twice as many, or more.

Herbs, shrubs or trees ; ovary 1-celled.

Shrubs or trees; ovary several-celled.

Stamens borne on the corolla, as many as its lobes or fewer, and alternate with them (in Forestiera of the Oleaceae there is no corolla).

Corolla not scarious, nerved.

Ovaries 2, distinct (except in some Loganiaceae, and in Gentianaceae in which the ovary is compound with 2 cavities or rarely more, or with 1 cavity and 2 placentae); flowers regular: stamens mostly adnate to only the lower part of the corolla; leaves mostiv opposite.

Ovary 1, compound (2-divided in Dichondra; in Boraginaceae and Lamiaceae mostly deeply 4-lobed around the style); flowers regular or irregular; stamens mostly adnate to the middle of the corolla-tube or beyond; leaves opposite or alternate.

Corolla scarlous, nerveless.

Anthers distinct.

$+\div$ Ovary inferior.

Anthers united (except in Ambrosiaceae).
Order 1. Primulales.

Order 2. EBenales.

Order 3. Gentianales.

Order 4. Polemoniales.

Order 5. Plantaginales.

Order 6. RUBIA.LES.

Order 7. Campanulales. 


\section{Order 1. PRIMULÀLES.}

Herbs, shrubs or trees. Corolla usually present, gamopetalous. Calyx mostly free from the ovary. Stamens borne on the corolla, as many as its lobes, or twice as many, or more.

Style 1.

Shrubs or trees, the fruit drupaceous or baccate.

Staminodes none; fruit 1 -seeded.

Corolla bearing staminodes at the sinuses; fruit several-many-seeded.

Herbs ; fruit capsular.

Styles 5; herbs; fruit an achene or utricle.

Fam. 1. Mrrsinaceae.

Fam. 2. Theophrastaceae. Fam. 3. Primulaceae.

Fam. 4. Plumbaginaceae.

\section{Family 1. MYRSINÀCEAE Lindl.}

\section{Mrrsine Family.}

Trees or shrubs, usually glabrous, the leaves mostly alternate, punctate in lines, estipulate, the small regular flowers variously clustered. Calyx inferior, persistent, 4-6-parted. Corolla mostly rotate or salverform, rarely tubular or of separate petals. Stamens as many as the corolla-segments and opposite them; filaments usually short, distinct or sometimes united; anthers longitudinally dehiscent; staminodes none. Ovary superior, 1celled; style short or long; stigma various; ovules few, usually immersed in the central placenta. Fruit small, baceate, 1-seeded, sometimes nearly dry. Seed subglobose, the testa thin, the endosperm fleshy or horny. About 20 genera and over 450 species, mostly tropical in distribution.

Inflorescence paniculate.

Inflorescence short, umbellate, lateral.

1. Icacorea. 2. Rapanea.

\section{ICACORÈA Aubl. Pl. Guian. 2: Suppl. 1. 1775.}

Shrubs or trees, with alternate, mostly entire leaves and perfect or polygamo-dioecious white or pink flowers in cymes or panicles. Calyx campanulate, 4-5-parted. Corolla nearly rotate, usually 5-parted, the segments spreading or reflexed. Stamens usually 5; filaments short or slender, borne at the top of the short corolla-tube; anthers acute or acuminate. Ovary globose; stigma discoid or truncate; ovules sereral or few. Berry little fleshy. [Guiana name.] Over 200 species, of tropical and subtropical regions. Type species: Icacorea guianensis Aubl.

Style fillform, much longer than the ovary.

Style subulate, not longer than the ovary.

1. I. paniculata.

2. I. guadalupensis.

1. Icacorea paniculàta (Nutt.) Sudw. Gard. \& For. 6: 324. 1893.

Cyrilla paniculata Nutt. Am. Jour. Sci. 5: 290. 1822.

Ardisia Pickeringia Torr. \& Gray; DC. Prodr. 8: 124.1844.

A shrub or small tree, attaining a maximum height of about $7.5 \mathrm{~m}$. with a trunk up to $1.5 \mathrm{dm}$. in diameter, the bark white, scaly, the twigs rather stout, puberulent or glabrous. Leaves coriaceous, glabrous, short-petioled, oblanceolate, obovate or elliptic, 6-16 $\mathrm{cm}$. long, yellowish or dark green above, pale green beneath, the midvein prominent, the lateral veins slender, the apex obtuse or acute, the base narrowed; panicles terminal, densely many-flowered, 
5-12 cm. long; pedicels short, slender; calyx $2 \mathrm{~mm}$. long, its 5 segments ovate, acute, unsymmetrical, ciliate; corolla rotate, its 5 oblong or obovate segments reflexed, 3-4 mm. long, white, with purplish lines and dots; anthers orange; fruit globose, black, shining, 7-9 $\mathrm{mm}$. in diameter, tipped by the filiform style.

Coppices and scrub-lands, Abaco, Great Bahama, New Providence and Eleuthera :- Florida; Cuba; Mexico. MarLBERRY. DOG-Berry.

2. Icacorea guadalupénsis (Duchass.) Britton; Wilson, Bull. N. Y. Bot. Gard. 8: 401. 1917.

Ardisia guadalupensis Duchass; Griseb. Kar. 89. 1857.

A glabrous shrub 1-3 m. high, or a tree up to $15 \mathrm{~m}$. high, the stout twigs light grey. Leaves elliptic to elliptic-obovate, coriaceous, 10-15 cm. long, obtuse or acutish at the apex, narrowed or cuneate at the base, paler green beneath than above, delicately veined, the stout petioles 7-12 $\mathrm{mm}$. long; panicles terminal, densely many-flowered, $10-15 \mathrm{~cm}$. long; pedicels $2-4 \mathrm{~mm}$. long, rather stout; calyx about $2 \mathrm{~mm}$. long, its 5 segments oblong, obtuse, punctate; corolla white, rotate, its 5 segments ovate or ovate-elliptic, obtuse, symmetrical, more or less punctate or lineolate; fruit subglobose or depressedglobose, black when mature, $6-8 \mathrm{~mm}$. in diameter, tipped by the short style.

Coppices, North Caicos :-Porto Rico to Virgin Gorda and Santa Lucia. GUADELOUPE MARLBERRY.

\section{RAPANÈA Aubl. Pl. Guian. 1: 121. 1775.}

Shrubs or small trees, with alternate coriaceous leaves, and small bracted polygamo-dioecious flowers in lateral or axillary fascicles. Calyx mostly 4-5cleft, persistent. Corolla 4-5-parted, or rarely of 4 or 5 separate petals, the segments spreading or recurved. Stamens borne on the bases of the corollasegments; filaments short; anthers obtuse. Ovary globose or ovoid; style short or slender; stigma various; ovules few or many. Fruit a globose, nearly dry, small 1-seeded berry. [Guiana name.] Over 80 species, mostly of tropical regions, the following typical.

\section{Rapanea guianénsis Aubl. Pl. Guian. 1: 121. 1775.}

A shrub or small tree up to $6 \mathrm{~m}$. high, the trunk sometimes $1.5 \mathrm{dm}$. in diameter, the foliage glabrous, the bark smooth and gray. Leaves mostly clustered near the ends of the rather slender twigs, short-petioled, obovate or oblong, 4-10 $\mathrm{cm}$. long, obtuse at the apex, narrowed at the base, bright green and somewhat shining above, dull green beneath, the midvein prominent, the lateral veins faint; flowers green, about $4 \mathrm{~mm}$. broad, nearly sessile on the twigs below the leaves; sepals ovate, about $1.5 \mathrm{~mm}$. long; corolla-lobes oblong, glandular-ciliate, 2-3 times as long as the sepals, somewhat unequal; fruit globose, black when mature, about $4 \mathrm{~mm}$. in diameter.

Coppices, pine-iands and scrub-lands, Abaco, Great Bahama, Andros, New Providence, Cat Island, Crooked Island and Mariguana:-Florida; Cuba to Porto Rico and to Trinidad; Jamaica; northern South America. Recorded by Dolley as Myrsine laeta DC. MYRSINE.

\section{Family 2. THEOPHRASTÀCEAE D. Don.}

\section{Theophrasta Family.}

Trees or shrubs, with evergreen coriaceous estipulate leaves, and regular, perfect or polygamo-dioecious flowers in axillary or terminal clusters or solitary. Calyx inferior, mostly 5-parted, the segments obtuse, imbricated. 
Corolla gamopetalous, rotate-campanulate or cylindric-campanulate, mostly 5 -lobed, the lobes imbricated. Stamens 5, rarely 4, borne near the base of the corolla-tube; filaments subulate or flattened; anthers mostly extrorse. Staminodia 5. Ovary superior, 1-celled; style short or slender; stigma eapitate or discoid; ovules numerous. Fruit coriaceous or fleshy, indehiscent, few-several-seeded. Five genera and about 50 species, of tropical distribution.

\section{JACQUÍNIA L.; Jacq. Enum. 2, 15. 1760.}

Evergreen shrubs or small trees, with opposite or verticillate coriaceous leaves, and small perfect white or yellow, racemed, corymbed or panicled flowers. Sepals 5, imbricated. Corolla salverform or short-campanulate, 5lobed, the lobes imbricated in the bud, spreading at anthesis. Staminodia 5, borne on the corolla-tube. Stamens 5, borne on the base of the corolla-tube. Ovary 5-carpellary; style short; ovules usually many. Fruit ovoid or globose, coriaceous. Seeds compressed, with cartilaginous endosperm. [Commemorates Nicolas Joseph von Jacquin, 1727-1817, distinguished Austrian botanist.] About 25 species of tropical America. Type species: Jacquinia ruscifolia Jacq.

Flowers single in the upper axils and in small terminal clusters. Flowers in terminal racemes.
1. J. Berterii. 2. J. keyensis.

\section{Jacquinia Bertèrii Spreng. Syst. 1: 668. 1825.}

Jacquinia Berterii retusa Urban, Symb. Ant. 1: 378. 1899.

A much-branched shrub, 1-3 m. high, or tree up to about $7 \mathrm{~m}$. high, the bark whitish, the young twigs scurfy-lepidote. Leaves various in form, oblong to obovate or oblong-lanceolate, coriaceous, $2-4 \mathrm{~cm}$. long, rounded, retuse or acute at the apex, cuneate at the base, usually inconspicuously veined, the petioles 1-2 $\mathrm{mm}$. long; inflorescence terminal or in the uppermost axils, 1-6flowered, much shorter than the leaves; pedicels $5-8 \mathrm{~mm}$. long, thickened upwardly in fruit; sepals nearly orbicular, 1.5-2 mm. long, glabrous; corolla about $3 \mathrm{~mm}$. long, its lobes reflexed; staminodia much shorter than the corollalobes, somewhat longer than the stamens; fruit ovoid to subglobose, orange or yellow, 6-8 $\mathrm{mm}$. in diameter.

Coppices, Cat Island, Watling's, Long Island, Acklin's and Stubb's Cay, Caicos Islands :- Cuba to Anegada and Guadeloupe. BERTER's JACQUINIA.

\section{Jacquinia keyénsis Mez in Urban, Symb. Ant. 2: 444. 1901.}

A tree, up to $6 \mathrm{~m}$. high, with a trunk sometimes $2.5 \mathrm{dm}$. in diameter, the nearly smooth bark light gray, the young twigs finely pubescent, somewhat angled, densely leafy. Leaves oblong-obovate to spatulate, 3-7 cm. long, obtuse or retuse and apiculate at the apex, narrowed at the base, glabrous, shining above, dull beneath; the petioles short; racemes $6 \mathrm{~cm}$. long or less; pedicels stout, about $1 \mathrm{~cm}$. long; sepals ovate-orbicular, obtuse; flowers very fragrant; corolla salverform, about $1 \mathrm{~cm}$. broad, its lobes longer than the tube; stamens shorter than the staminodia; berry subglobose, orange-red, 8-10 $\mathrm{mm}$. in diameter, hard.

Coastal rocks, coppices and scrub-lands, throughout the archipelago from Abaco and Great Bahama to Grand Turk, Inagua and the Angullla Isles:-Florida; Cays of northern Cuba; Jamaica. Referred by Herrick, by Dolley and by Hitchcock to Jacquinia armillaris Jacq. JOE-WOOD. JoE-BUsH. IRONWOOD. Catesby 1: pl. 98. 


\section{Family 3. PRIMULÀCEAE Vent.}

\section{Primrose Familit.}

Herbs, with perfect regular flowers. Calyx free from the ovary (adnate to its lower part in Samolus), usually 5-parted, persistent or rarely deciduous. Corolla gamopetalous in our species, usually 5-cleft, deciduous. Stamens as many as the corolla-lobes and opposite them, hypogynous or rarely perigynous, inserted on the corolla; filaments distinet or connate at the base; anthers introrse, 2-celled, the sacs longitudinally dehiscent. Disk obsolete, or none. Ovary superior (partly inferior in Samolus), 1-celled; placenta central, free; ovules anatropous, or amphitropous; style 1; stigma simple, mostly capitate, entire. Capsule 1-celled, 2-6-valved, rarely circumscissile or indehiscent. Seeds few or several, the testa adherent to the fleshy or horny copious endosperm; embryo small, straight; cotyledons obtuse. About 28 genera and 400 species of wide distribution.

\section{SÁMolú L. Sp. Pl. 171. 1753.}

Perennial glabrous herbs, with alternate entire leaves, or the basal ones rosulate. Flowers small, white, in terminal racemes or panicles in our species. Calyx persistent, its tube adnate to the ovary below, its limb 5-cleft. Corolla perigynous, subcampanulate, 5-lobed or 5-parted, the lobes obtuse. Stamens 5, inserted on the tube of the corolla, opposite its lobes, alternating with as many staminodia (these wanting in S. ebracteatus), filaments short; anthers cordate. Ovary partly inferior; ovules amphitropous. Capsule 5-valved from the summit. Seeds minute. [Name Celtic.] About 10 species, of wide distribution. Type species: Samolus Valerandi L.

Stems leafly to the inflorescence. Stems scapose, leafy below.
1. S. floribundus. 2. S. ebracteatus.

1. Samolus floribúndus H.B.K. Nov. Gen. 2: 224. 1818.

Samolus Valerandi americanus A. Gray, Man. ed. 2, 274. 1856.

Erect or ascending, 1.5-6 dm. high. Leaves $2-8 \mathrm{~cm}$. long, obovate, obtuse; flowers less than $2 \mathrm{~mm}$. broad, in elongated panicled racemes; pedicels filiform, spreading, 8-25 mm. long, bracteolate near the middle; calyx-lobes acute, shorter than the corolla; corolla-lobes longer than the tube; staminodia 5; capsule 2-3 $\mathrm{mm}$. in diameter.

Moist soil, New Providence:-throughout temperate North America to Florida, Texas, Callfornia and Mexico; Cuba. WATER PiMPE RNel.

2. Samolus ebracteàtus H.B.K. Nov. Gen. 2: 223. 1818.

Samodia ebracteata Baudo, Ann. Sci. Nat. II. 20: 350. 1843.

Erect, $4 \mathrm{dm}$. high or less. Leaves 4-12 $\mathrm{cm}$. long, spatulate or obovate, obtuse or the upper acute; flowers white, 6-7 $\mathrm{mm}$. broad, in long-stalked simple or sometimes branched racemes; pedicels ascending, very slender, 15-25 $\mathrm{mm}$. long; calyx-lobes ovate, acute, about one-half as long as the corolla; corollalobes shorter than the tube; staminodia none; capsule $3-4 \mathrm{~mm}$. in diameter.

Moist ground, Andros, at Red Bays :-Florida to Texas and New Mexico; Cuba. LARger WATER Pimpernel. 


\section{Family 4. PLUMBAGINĀCEAE Lindl.}

\section{Plumbago Family.}

Perennial herbs or shrubs, with basal or alternate leaves, and perfect and regular elustered flowers. Calyx inferior, gamosepalous, 4-5-toothed, plaited at the sinuses, the tube 5-15-ribbed. Corolla of 4 or 5 hypogynous clawed segments connate at the base, or united into a tube. Stamens 4 or 5 , opposite the corolla-segments, hypogynous; anthers 2-celled, attached by their backs to the filaments, the saes longitudinally dehiscent. Disk none. Ovary superior, 1-celled; ovule solitary, anatropous, pendulous; styles 5 . Fruit a utricle or achene, enclosed by the calyx, rarely a dehiscent capsule. Seed solitary; testa membranous; endosperm mealy, or none; embryo straight; cotyledons entire. About 10 genera and 350 species, of wide distribution, many in saline situations.

Calyx glandular; claws of the petals united into a tube.

Calyx not glandular; claws of the petals distinct or nearly so.
1. Plumbago.

2. Limonium.

\section{PLUMBAGO L. Sp. Pl. 151. 1753.}

Perennial herbs, shrubs or vines, with alternate, often clasping leaves, the purple blue red or white flowers in bracted spikes. Calyx tubular, 5-ribbed, glandular, with 4 or 5 erect lobes. Petals 4 or 5 , their claws united into a tube, their blades entire, spreading, the corolla thin, salverform. Stamens 5, distinct, the filaments dilated at the base, the anthers linear. Styles filiform, stigmatic on the inner side, partly united. Fruit capsular. [Latin, leadwort.] About a dozen species, natives of southern Europe and Westcentral Asia and tropical America. Type species: Plumbago europaea L.

1. Plumbago scándens L. Sp. Pl. ed. 2, 215. 1762.

A perennial woody herb, the branches often elongated and vine-like, glabrous, sometimes $1 \mathrm{~m}$. long. Leaves ovate to oblong-lanceolate, membranous, glabrous, 3-10 $\mathrm{cm}$. long, acute or acuminate at the apex, narrowed at the base, the petioles $1 \mathrm{~cm}$. long or less; spikes slender, peduncled, severalmany-flowered, 5-12 cm. long; bracts lanceolate, acuminate, persistent, about $5 \mathrm{~mm}$. long; calyx about $1 \mathrm{~cm}$. long, beset with long-stalked glands; corolla white, its filiform tube about $2 \mathrm{~cm}$. long, its obovate mucronate spreading lobes 5-7 $\mathrm{mm}$. long.

Waste and cuitivated grounds, New Providence, Harbor Island, Cat Island and Grand Turk:-Florida to Arizona; West Indies and continental tropical America. White Plumbago. Doctor-Bush.

\section{IIMÒNIUM Adans. Fam. Pl. 2: 283. 1763.}

Herbs, mostly with flat basal leaves, and numerous small flowers cymosepaniculate on bracted scapes, in 1-3-flowered bracteolate clusters, forming onesided spikes. Calyx campanulate or tubular, the limb scarious, 5-toothed, the tube usually 10-ribbed. Petals 5, clawed. Stamens adnate to the bases of the petals. Styles 5, separate in our species, stigmatic along the inner side. Fruit a utricle. [Ancient name of the wild beet.] About 120 species widely distributed. Type species: Statice Limonium L. 
1. Limonium bahaménse (Griseb.) Britton, Bull. N. Y. Bot. Gard. 4: 142. 1906.

Statice bahamensis Griseb. F1. Br. W. I. 389. 1861.

Perennial by a deep root; scapes several or many, erect, slender, much branched, 2-4 dm. high, glabrous but scaly, fleshy, terete. Leaves linear or narrowly spathulate, $5 \mathrm{~cm}$. long or longer, mostly wanting at flowering time; scales of the scape triangular-acuminate, scarious-margined, $2-4 \mathrm{~mm}$. long; spikes 1.5-4 $\mathrm{cm}$. long, the flower-clusters densely aggregated; lower bractlet ovate, obtuse, much shorter than the scarious-margined upper one; flowers purple, about $5 \mathrm{~mm}$. long.

Salinas, South Caicos and Grand Turk Island. Endemic. Bahama Sea LavenDER. HEATHER.

\section{Order 2. EBENÀLES.}

Shrubs or trees, with alternate simple leaves, the flowers mostly regular. Calyx free from the ovary (inferior) or more or less adnate to it. Corolla gamopetalous or sometimes polypetalous. Stamens borne on the tube or base of the corolla, as many as its lobes, and opposite them, or more numerous.

Stamens as many as the corolla-lobes.

Stamens twice as many as the corolla-lobes, or more.

Fam. 1. Sapotaceae. Fram. 2. EBenaceat.

\section{Family 1. SAPOTÀCEAE Reichenb.}

\section{Sapodilla Family.}

Shrubs or trees, the sap often milky, the leaves mostly alternate, entire, estipulate, often finely veined, the perfect or rarely polygamous flowers clustered. Sepals 4-12, imbricated. Corolla lobed, often appendaged between the lobes. Stamens as many as the corolla-lobes, often alternating with broad staminodia; filaments distinct. Ovary sessile, 4-12-celled; styles united; ovules solitary in each cavity, anatropous. Fruit a berry, often large. Seeds shining, smooth; embryo straight. About 35 genera, comprising over 400 species, mostly of tropical distribution.

Calyx 4-5-parted.

Flowers without staminodia or corolla-appendages.

Flowers with staminodia.

Corolla without appendages.

Seeds with abundant endosperm. 2 . Sideroxylon.

Seeds without endosperm. $\quad 3$. Lucuma.

Corolla with appendages.

Ovary smooth; endosperm copious. $\quad$ 4. Dipholis.

Calyx 6-12-parted.

Ovary hairy; endosperm little or none. $\quad 5$. Bumelia.

Seeds only 1 or 2.

Seeds 4 or 5 .

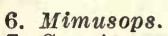

7. Sapota.

1. CHRYSOPHÝLLUM L. Sp. Pl. 192. 1753.

Unarmed evergreen trees, with alternate coriaceous leaves, and small, mostly 5-parted flowers, in axillary or lateral fascicles, the sap milky. Sepals nearly alike. Corolla-lobes unappendaged. Stamens included; staminodia none. Ovary pubescent; style short. Fruit a large or small, drupe-like berry. Seeds with a hard, often shining testa and fleshy endosperm. [Greek, refer- 
ring to the lustrous pubescence on the under side of the leaves of some species.] Sixty species or more, mostly of tropical America. Type species: Chrysophyllum Cainito L.

1. Chrysophyllum olivifórme L. Syst. ed. 10, 937. 1759.

Chrysophyllum monopyrenum Sw. Prodr. 49. 1788.

A tree, reaching a maximum height of about $10 \mathrm{~m}$., with a trunk up to 3 $\mathrm{dm}$. in diameter, the bark fissured, the young twigs brownish-pubescent. Leaves oblong to ovate, $3-10 \mathrm{~cm}$. long, acutish or short-acuminate at the apex, rounded or narrowed at the base, green, glabrous and shining above, densely reddish or brownish-pubescent beneath, the petioles 8-12 $\mathrm{mm}$. long; fascicles fewflowered; pedicels $5-10 \mathrm{~mm}$. long; sepals silky, about $1.5 \mathrm{~mm}$. long; corolla white, 4-6 mm. wide; filaments very short; berry oval, 1-2 $\mathrm{cm}$. long, purple, usually 1-seeded.

Coppices and scrub-lands, Andros, New Providence, and North Caicos:-Florida ; Cuba to Porto Rico; Jamaica. C. Cainito of Schoepf. Satinleaf. SAFrron-Tree.

\section{SIDERÓXYLON L. Sp. Pl. 192. 1753.}

Unarmed, hard-wooded, evergreen trees or shrubs, with alternate coriaceous, slender-petioled leaves, and small, 5-parted, greenish-yellow or white flowers in dense axillary or lateral fascicles. Sepals mostly obtuse, imbricated. Corolla nearly rotate, its lobes obtuse, not appendaged. Stamens borne near the middle or top of the corolla-tube, included, opposite the lobes; filaments slender; anthers extrorse; staminodia entire or toothed, alternating with the filaments. Ovary 5-celled or sometimes 2-3-celled; ovules ascending; style short or slender. Berry ovoid or subglobose, usually 1-seeded. Seed with a crustaceous testa and cartilaginous endosperm. [Greek, referring to the hard wood.] About 75 species, natives of warm and tropical regions. Type species: Sideroxylon inerme $\mathrm{L}$.

\section{Sideroxylon foetidíssimum Jacq. Enum. 15. 1760.}

Sideroxylon mastichodendron Jacq. Coll. 2: 253. 1788.

A tree, attaining a maximum height of about $25 \mathrm{~m}$., with a trunk up to $1.5 \mathrm{~m}$. in diameter, the bark splitting into scale-like plates, the twigs rather slender, glabrous. Leaves oblong to oblong-ovate or oval, 5-15 cm. long, sparingly pubescent when young, becoming glabrous, mostly rounded at the apex, rounded or narrowed at the base, lustrous, the slender petioles 2-7 $\mathrm{cm}$. long; fascicles several-many-flowered, shorter than the petioles; pedicels 4-10 mm. long; sepals nearly orbicular, obtuse, glabrous, about $2 \mathrm{~mm}$. long; corolla greenish-yellow, about $7 \mathrm{~mm}$. broad, its lobes oblong, obtuse; staminodia lanceolate, acuminate, $1 \mathrm{~mm}$. long; berry drupe-like, yellow, oval, $2-2.5$ cm. long, glabrous, acid.

Coppices and scrub-lands, Abaco, Berry Islands, South Cat Cay, Andros, New Providence, Exuma Chain, Eleuthera, Cat Island, Watling's and Crooked:-Florida; Cuba to St. Thomas and to Barbadoes; Jamaica. Catesby, $2: p l$. 75 . MASTIC-BULLX.

3. LUCÙMA Molina, Sagg. Chile 186. 1782.

Trees, or some species shrubs, the leaves mostly coriaceous, the small flowers in axillary or lateral glomerules, or solitary. Calyx-segments usually 4 or 5 , strongly. imbricated. Corolla urn-shaped, the tube short, the 4,5 or 6 
lobes imbricated. Stamens 4, 5 or 6 , borne on the corolla-tube opposite its lobes, the filaments short or slender. Staminodes linear or scale-like, borne at the sinuses of the corolla. Ovary 2-6-celled, mostly villous; style subulate or conic. Fruit a berry, the pericarp fleshy or thin. Seeds 1-5. [Peruvian name.] Fifty species or more, mostly of tropical America, a few Australasian. Type species: Lucuma bifera Molina.

\section{Lucuma Serpentària H.B.K. Nov. Gen. 3: 242.1819.}

Lucuma pauciflora A. DC. in DC. Prodr. 8: 168. 1844.

A tree, up to about $10 \mathrm{~m}$. high, the bark gray, the rather stout twigs puberulent when young. Leaves oblong-obovate, coriaceous, $5-13 \mathrm{~cm}$. long, glabrous, somewhat shining above, rounded at the apex, narrowed at the base, reticulate-veined, the puberulent petioles 3-15 $\mathrm{mm}$. long; peduncles solitary or 2 together in the axils, stout, puberulent, about as long as the petioles or a little longer; calyx-segments round-ovate, puberulent, 6-8 $\mathrm{mm}$. long; corolla about twice as long as the calyx, 6-lobed, the lobes rounded, as long as the tube; ovary 6-celled, tomentose; berry globose, $2-3 \mathrm{~cm}$. in diameter, 3-6-seeded; seeds $1.5-2 \mathrm{~cm}$. long.

Coppices, Andros and New Providence:-Cuba. Referred by Coker to L. multiflora A. DC. EGG-FRUIT.

\section{DÍPHolis A. DC. in DC. Prodr. 8: 188. 1844.}

Evergreen unarmed shrubs or trees, with alternate leaves, and small, mostly 5-parted, greenish, often fragrant flowers in axillary or lateral fascicles. Sepals ovate to nearly orbicular, imbricated. Corolla rotate or funnelform, its lobes with 2 appendages at each sinus. Stamens borne on the corolla-tube, opposite the lobes, exserted, the filaments filiform, the anthers extrorse; staminodia 5, often petaloid, alternating with the stamens. Ovary glabrous, 5celled; ovules ascending; style slender. Fruit an ovoid, subglobose or oblong berry, usually 1-seeded. Seed with a coriaceous testa, and fleshy endosperm. [Greek, referring to the appendages of the corolla.] About 10 species, natives of the West Indian region, the following typical.

1. Dipholis salicifòlia (L.) A. DC. in DC. Prodr. 8: 188. 1844.

Achras salicifolia L. Sp. Pl. ed. 2: 470. 1762.

A slender tree, reaching a maximum height of about 16 m., with a trunk up to $5 \mathrm{dm}$. in diameter, the bark scaly,the slender young twigs appressedpubescent. Leaves subcoriaceous, oblong to elliptic-oblanceolate, slenderpetioled, 6-12 $\mathrm{cm}$. long, acute or acuminate at the apex, narrowed at the base, somewhat silky-pubescent when young, soon glabrous, dark green and shining above, dull green beneath; flower-clusters mostly shorter than the petioles; pedicels $2-3 \mathrm{~mm}$. long; sepals silky-pubescent, $1.5 \mathrm{~mm}$. long, ovate or oblong, obtuse; corolla about $4 \mathrm{~mm}$. broad, its lobes oval, obtuse, about as long as the tube, the appendages about one-half as long; staminodia ovate, irregularly toothed; berry ovoid or subglobose, black, 6-8 $\mathrm{mm}$. in diameter.

Coppices and scrub-iands, Great Bahama, Andros, New Providence, Great Exuma, Eleuthera to Mariguana and Caicos Islands :-Florida; Cuba to St. Jan and Guadeloupe; Barbadoes; Jamaica; Mexico. Bustic. WILd Cassada. Cassada-Wood. 


\section{BUMELIA Sw. Prodr. 49. 1788.}

Shrubs or trees, the branches often spinescent, the wood very hard. Leaves sometimes clustered at the nodes. Flowers small, pedicelled, green or white, fascicled in the axils. Calyx deeply 5-parted, the sepals unequal. Corolla 5-lobed, with a pair of lobe-like appendages at each sinus, its tube short. Stamens 5, inserted near the base of the corolla-tube; anthers sagittate. Staminodia 5, petaloid. Ovary 5-celled; style filiform. Berry small, the pericarp fleshy, enclosing a single erect seed. Seed shining, the hilum at the base. [Greek, ox (large) ash.] About 35 species, natives of America. Type species: Bumelia retusa $\mathbf{S w}$.

Leaves narrow, linear to spatbulate, 2-10 $\mathrm{mm}$. wide, wider only on shoots; fruit oblong-cylindric.

Leaves obovate to oblanceolate, $1-4 \mathrm{~cm}$. wide, fruit globose to ovold.

Pedicels little if at all longer than the petioles; leaves obovate or oblanceolate, or on shoots suborbicular.

Pedicels much longer than the petioles; leaves spathulate to oblanceolate.

1. B. angustifolia.

2. B. loranthifolia.

3. B. bahamensis.

1. Bumelia angustifòlia Nutt. Sylv. 3: 38, t. 93. 1849.

Bumelia Eggersii Pierre in Urban, Symb. Ant. 5: 146. 1904.

A glabrous shrub or small tree, reaching a maximum height of about $8 \mathrm{~m}$. Leaves linear to spatulate, or those of shoots obovate, $2-4 \mathrm{~cm}$. long, mostly obtuse at the apex, narrowed at the base, short-petioled; fascicles few-manyflowered; pedicels 3-6 $\mathrm{mm}$. long; sepals ovate, about $2 \mathrm{~mm}$. long, obtuse, the inner wider than the outer; corolla-lobes orbicular, erose-denticulate, the lanceolate appendages acuminate; staminodia ovate to ovate-lanceolate, $2 \mathrm{~mm}$. long, erose; fruit oblong to oblong-cylindric, 1-2 . $\mathrm{cm}$. long, purple-black.

Palmetto-lands, coastal thickets, borders of salinas, Great Bahama, Cat Cay, Andros, New Providence, and Rose Island:-Florlda; Cuban Cays. Recorded by Mrs. Northrop and by Coker as B. microphylla Griseb. NARRow-LeAved BUmelia.

\section{Bumelia loranthifòlia (Pierre) Britton, Bull. N. Y. Bot. Gard. 3: 447.} 1905.

Bumelia retusa loranthifolia Pierre in Urban, Symb. Ant. 5: 145.1904.

A shrub, 1-3 m. high, or sometimes straggling, or a tree up to $8 \mathrm{~m}$. high, the young twigs densely brown-tomentulose. Leaves obovate or oblanceolate, coriaceous, 1-5 cm. long, glabrous and shining above, brown-tomentulose beneath when young, becoming glabrous, rounded or somewhat retuse at the apex, cuneate at the base, the petioles $2-5 \mathrm{~mm}$. long; pedicels as long as the petioles or a little longer; sepals suborbicular, $2-3 \mathrm{~mm}$. long, the outer ones tomentulose; corolla about twice as long as the sepals, its lobes about as long as the tube; staminodia lanceolate; fruit globose, oblong or ovoid, 6-9 mm. in diameter, black.

Coppices, pine-lands, white-lands and scrub-lands, throughout the archipelago from Abaco and Great Babama to Inagua, Mariguana, Cotton Cay and the Anguilla Isles. Endemic. Referred by Hitchcock and by Dolley to B. retusa Sw.; recorded by Mrs. Nortbrop as B. cubensis Griseb. WILD SAFFroN. MILK-BERRY.

3. Bumelia bahaménsis Britton, Bull. N. Y. Bot. Gard. 3: 447. 1905.

A shrub with slender puberulous twigs, related to $B$. loranthifolia. Leaves spatulate-oblanceolate, coriaceous, revolute-margined, $8 \mathrm{~cm}$. long or less, 1.5$2.5 \mathrm{~cm}$. wide, rounded at the apex, narrowly cuneate at the base, dull green and glabrous above, densely brown-tomentulose beneath, rather strongly pinnately veined, the veins ascending at a narrow angle; petioles stout, $5 \mathrm{~mm}$. long or 
less; flowers about 6 in each axillary cluster; pedicels brown-furfuraceous, stout, 8-10 $\mathrm{mm}$. long, three times as long as the calyx.

Coastal thickets and scrub-lands, New Provldence, Rose Island and Long Island. Endemic. Perhaps a long-leaved, long-pedicelled race of the preceding species. BAHAMA BUMELIA.

6. MÍMUsops L. Sp. Pl. 349. 1753.

Evergreen milky trees, with coriaceous leaves, and lateral, axillary or terminal flowers. Sepals 6-12, in 2 series: Corolla 18-24-lobed, its tube short. Stamens 6-12, borne on the corolla-tube, the filaments short, the anthers lanceolate; staminodia 6-12, petal-like, toothed or lacerate. Ovary hirsute, 6-12celled. Berry sub-globose, the epicarp usually crustaceous. Seeds 1 or 2, oblique, compressed. [Greek, aspect of an ape.] About 40 species, mostly tropical in distribution. Type species: Mimusops Elengi L.

\section{Mimusops emarginàta (L.) Britton, Torreya 11: 129.1911.}

Sloanea emarginata L. Sp. Pl. 512. 1753.

Achras Zapotilla parvifolia Nuttall, Sylv. 3: '28. 1849.

Mimusops parvifolia Radlk. Sitz. Akad. Wiss. Muench. 12: 344. 1882.

Achras bahamensis Baker, in Hook. Ic. 18: pl. 1795. 1888.

Mimusops floridana Engl. Bot. Jahrb. 12: 524. 1890.

Mimusops bahamensis Pierre, Not. Sapot. 37. 1891.

Manilkara parvifolia Dubard, Ann. Mus. Col. Marseille III. 3: 16.1916.

A tree, up to $10 \mathrm{~m}$. high, the trunk sometimes $3 \mathrm{dm}$. in diameter, the twigs stout, the young foliage finely pubescent. Leaves clustered at the ends of the twigs, oblong, 3-10 $\mathrm{cm}$. long, emarginate at the apex, narrowed or rounded at the base, glabrous or nearly so when old, the petioles $1-2 \mathrm{~cm}$. long; flowers several or many in the clusters, on tomentose nodding pedicels 1-3 cm. long; sepals tomentose, lanceolate; corolla $1.5-2 \mathrm{~cm}$. broad, light yellow, its linear lobes often toothed at the apex; appendages similar to the corolla-lobes, about one-half their length; staminodia triangular; berry depressed-globose, nearly $3 \mathrm{~cm}$. in diameter, scaly.

Scrub-lands, throughout the archipelago from Abaco and Great Bahama to East Caicos, Ambergris Cay and Inagua:-Florida; Cuba.

Recorded by Grisebach, by Dolley and by Mrs. Northrop as Mimusops dissecta R. Br.; recorded by Hitchcock, by Small and by Coker as Mimusops Sieberi DC. Wild Dilly. Catesby, 2 : $p l .8 \%$.

7. SAPÒTA [Plum.] Mill. Gard. Dict. ed. 7. 1759.

An unarmed evergreen tree, with alternate coriaceous, oblong to elliptic leaves, and rather large, peduncled, mostly 6-parted, whitish flowers solitary in the axils, the sap milky. Calyx-lobes in 2 series. Corolla urceolate, scarcely longer than the calyx; anthers sagittate; staminodia little shorter than the corolla-lobes. Ovary 10-12-celled; ovules ascending; style slender, exserted; stigma small. Fruit a large, rough-skinned berry. Seeds black, shining, the endosperm fleshy. [Aboriginal West Indian name.] A monotypic genus.

1. Sapota Áchras Mill. Gard. Dict. ed. 8. no. 1. 1768.

Achras Zapota L. Syst. ed. 10, 988. 1759. Not A. Zapota L. Sp. Pl. 1190. 1753.

A tree up to about $15 \mathrm{~m}$. high, the bark dark brown, the twigs rather stout, the petioles, peduncles and calyx brownish pubescent. Leaves mainly clustered 
at the ends of the twigs, 5-12 $\mathrm{cm}$. long, the lateral veins nearly transverse, delicate, close together, the apex obtuse, the base mostly narrowed, the slender petioles 5-20 mm. long; peduncles about as long as the petioles; sepals 8-10 $\mathrm{mm}$. long; corolla-lobes about half as long as the tube; staminodia longer than the stamens; fruit globose or ovoid, 3-8 $\mathrm{cm}$. in diameter, rough, brown, the flesh sweet, brownish, milky; seeds usually several, flattened, about $2 \mathrm{~cm}$. long, with a white scar on the inner edge.

Scrub-lands, spontaneous after cultivation, in various localities in the Bahamas: -Florida; West Indles; Mexico and northern South America. SapodiluA.

\section{Family 2. EBENÀCEAE Vent.}

\section{EBony FamiLy.}

Trees or shrubs with very hard wood, entire estipulate leaves, and dioecious polygamous, or rarely perfect, regular flowers, solitary or cymose in the axils. Calyx inferior, 3-7-lobed, commonly accrescent and persistent. Corolla gamopetalous, deciduous, 3-7-lobed, the lobes usually convolute in the bud. Stamens $2-3$ times as many as the lobes of the corolla in the sterile flowers, and inserted on its tube, usually some imperfect ones in the pistillate flowers; anthers introrse, ereet. Disk none. Ovary superior, several-celled; in the staminate flowers rudimentary or none; ovules 1-3 in each eavity, suspended; styles 2-8, distinct, or united below; stigmas terminal, sometimes 2-parted. Fruit a berry. Seeds oblong, the testa bony; endosperm copious, cartilaginous; embryo small; cotyledons large, foliaceous. About 6 genera and 275 species, mostly tropical.

\section{MÀBA Forst. Char. Gen. Pl. 121. 1776.}

Hard-wooded trees or shrubs, with alternate petioled leaves, and dioecious (rarely monoecious) axillary, mostly 3-parted flowers, usually solitary, or the staminate ones in small clusters. Calyx campanulate or tubular-campanulate, accrescent and persistent in fruit. Corolla campanulate or tubular. Staminate flowers with few or several stamens, the filaments separate or connate, the anthers oblong or linear, the ovary rudimentary. Pistillate flowers with a 3 -celled or 6-celled ovary, and 3 styles or a 3-cleft style, sometimes with staminodia. Fruit baceate, somewhat fleshy or dry. Seeds 1-6, the endosperm commonly ruminated. [Tonga Islands name.]. Sixty species or more, natives of tropical regions. Type species: Maba elliptica Forst.

\section{Maba crassinérvis (Krug \& Urban) Urban, Symb. Ant. 7: 329. 1912.}

Maba caribaea crassinervis Krug \& Urban, Bot. Jahrb. 15: 327. 1893.

A shrub 1-3 m. high, or a small tree up to about $7 \mathrm{~m}$. high, the branches slender, gray, stiff, the young twigs pubescent. Leaves obovate to elliptic, coriaceous, 3-7 cm. long, rounded, subtruncate or obtuse at the apex, obtuse or narrowed at the base, glabrous, dark green and shining above, pale, strongly and densely reticulate-veined and pubescent beneath, the stout pubescent petioles 2-7 $\mathrm{mm}$. long; staminate flowers 3 together on short axillary peduncles; calyx 3-4-toothed, densely pubescent, about $4 \mathrm{~mm}$. long; corolla glabrous within, densely pubescent without; stamens 9 ; pistillate flowers solitary; fruit solitary and short-peduncled in the axils, globose, yellowish, 1.5-2.3 cm. in diameter, the persistent calyx 1-2 cm. wide; seeds about $1 \mathrm{~cm}$. long, ovoid, oblique. 
Coppices and rocky scrub-lands, Andros, New Providence, Great Guana Cay; Great Exuma, Eleuthera, Watling's, Atwood Cay, Great Ragged Island, Fortune, Acklin's and Crooked Islands :-Cuba ; Hispaniola. Recorded by Coker as Macreightia caribaea A. DC., and referred by Hitchcock to Diospyros halesioides Griseb. Feather-Bed. BOA-WOOD.

\section{Order 3. GENTIANÀLES.}

Herbs, shrubs, vines or trees. Leaves opposite, or rarely alternate. Flowers regular. Corolla gamopetalous, rarely polypetalous, nerved, wanting in Forestiera of the Oleaceae. Stamens mostly borne on the lower part of the corolla when this is present, as many as its lobes or fewer and alternate with them. Ovaries 2, distinct, or 1 with 2 cavities (rarely more), or 2 placentae.

a. Stamens (usually 2), fewer than the corolla-lobes,

b. Stamens as many as the corolla-iobes.

Stigmas distinct; juice not milky ; ovary 1, compound.

Ovary 2-celled; leaves stipulate, or their bases connected by a stipular line.

Ovary 1-celled; leaves not stipulate.

Leaves opposite, rarely verticillate; corolla-lobes convolute or imbricated in the bud.

Leaves tufted or alternate; corolla-lobes induplicate-valvate in the bud; Bahama species aquatic.

Stigmas united; juice milky ; ovaries usually 2.

Styles united; stamens distinct; pollen of simple grains.

Styles distinct; stamens mostly monadelphous; pollen-grains united into waxy masses.
Fam. 1. Oleaceat.

\author{
Fam. OLEACEAE.
}

Fam. 2. Loganiaceae.

Fam. 3. Gentianaceae.

Fam. 4. Mentanthaceae.

Fam. 5. APOcynaceat.

Fam. 6. Asclepiadacean.

\section{Family 1. OLEÀCEAE Lindl.}

\section{OLIve FAMILY.}

Trees or shrubs (a few genera almost herbaceous) with opposite or rarely alternate, simple or pinnate, estipulate leaves and regular 2-4-parted flowers in panicles, cymes or fascicles. Calyx inferior, usually small, sometimes none. Corolla various, or none. Stamens 2-4; filaments separate; anthers ovate, oblong or linear, 2-celled, the sacs longitudinally dehiscent. Ovary superior, 2-celled; ovules few in each cavity, anatropous or amphitropous; style usually short or none. Fruit a capsule, samara, berry or drupe. Endosperm fleshy, horny or wanting; embryo straight, rather large; radicle usually short. About 21 genera and 525 species, of wide distribution in temperate and tropical regions.

Corolla none; frult a drupe.

Corolla large, conspicuous.

Corolla salverform ; fruit fleshy, didymous.

Petals distinct; fruit drupaceous.

1. Forestiera.

2. Jasminum. 3. Mayepea.

1. FORESTIÈRA Poir. in Lam. Encycl. Suppl. 2: 664. ' 1812.

Shrubs or trees, with opposite deciduous simple leaves, and very small, clustered, incomplete and commonly imperfect flowers axillary or on twigs of the previous season. Calyx-tube short, the limb deeply 4-6-lobed. Corolla none (rarely of 1 or 2 small petals). Stamens 2 or 4 . Ovary 2-celled; stigmas thick, sometimes 2-lobed; ovules 2 in each cavity, pendulous. Drupe commonly 
1-seeded. Endosperm fleshy. [Commemorates Charles Le Forestier, a French physician.] About 10 American species. Type species: Forestiera acuminata (Michx.) Poir.

1. Forestiera segregàta (Jacq.) Krug \& Urban, Bot. Jahrb. 15: 339. 1893.

Myrica segregata Jacq. Coll. 2: 273. 1788.

Adelia porulosa Michx. Fl. Bor. Am. 2: 224. 1803.

Adelia segregata Kuntze, Rev. Gen. Pl. 410. 1891.

Foresteria cassinoides Poir. in Lam. Encycl. Suppl. 2: 665. 1812.

Forestiera segregata stenocarpa Krug \& Urban, Bot. Jahrb. 15: 340. 1893.

A shrub, or a small tree up to $7 \mathrm{~m}$. high and a trunk diameter of $1.5 \mathrm{dm}$., the branches slender. Leaves rather firm in texture, oblong to lanceolate or obovate, $1.5-6 \mathrm{~cm}$. long, obtuse or acutish at the apex, narrowed at the base, shining above, pale and reticulate-veined beneath, punctate when dry, shortpetioled; flowers very small, yellowish green; drupes oblong to oval, 6-10 mm. long, short-pedicelled, purplish, the stone longitudinally ribbed.

Scrub-lands, throughout the islands from Abaco and Great Bahama to Mariguana and Grand Turk:-Bermuda; Florida; Cuba to St. Croix; Tortola; Jamaíca. FLORIDA PRIVET. INK-BUSh.

\section{JASMINUM L. Sp. Pl. 7. 1753.}

Shrubs or woody vines, with mostly opposite, simple or compound leaves, and large, elustered or solitary flowers. Calyx lobed or parted. Corolla salverform, its tube cylindric, its limb lobed or parted, the lobes imbricated. Stamens 2, included; filaments short; anthers laterally dehiscent. Ovary 2-celled; style very slender; stigma capitate or 2 -lobed; ovules mostly 2 in each cavity. Fruit didymous, fleshy. Seeds without endosperm. [Ancient name, of Arabic origin.] About 100 species, natives of the Old World. Type species: Jasminum officinale $\mathrm{L}$.

1. Jasminum Sámbac (L.) Soland.; Ait. Hort. Kew. 1: 8. 1789.

Nyctanthes Sambac L. Sp. Pl. 6. 1753.

A shrub, 1-2 m. high, the young shoots sparingly pubescent. Leaves ovate to elliptic, membranous, deciduous, 3-7 cm. long, acute, obtuse or shortacuminate at the apex, rounded or obtuse at the base, glabrous and finely reticulate-veined on both sides, the pubescent petioles 3-6 $\mathrm{mm}$. long; cymes peduncled, terminal, few-several-flowered, pubescent; pedicels 6-12 mm. long; calyx-segments numerous, linear, about $1 \mathrm{~cm}$. long; corolla white, fragrant, its tube somewhat longer than the calyx, its limb. about $2 \mathrm{~cm}$. wide, the lobes obtuse.

Presumably spontaneous after cultivation, New Providence, collected by Cooper in 1859 :-Escaped from cultivation in various West Indian Islands and in South America. Native of the East Indies. ARABIAN Jasmine.

\section{MAYEPÈA Aubl. Pl. Guian. 1: 81. 1775.}

Trees or shrubs, with opposite entire leaves, the rather large, mostly white bracteolate flowers usually panicled. Calyx small, 4-cleft or 4-toothed. Petals 4 , distinct or very nearly so, narrow. Stamens 2, rarely 4, borne at the bases of the petals; filaments short; anthers ovate to linear. Ovary 2-celled; ovules 
2 in each eavity; style short; stigma oblong to globose. Fruit a small oblong drupe, with thin flesh and hard endocarp. [Guiana name.] About 50 species, natives of tropical regions. Type species: Mayepea guianensis Aubl.

1. Mayepea bumelioìdes (Griseb.) Krug \& Urban, Bot. Jahrb. 15: 344. 1893.

Linociera bumelioides Griseb. Cat. Pl. Cub. 169. 1866.

A tree, up to $10 \mathrm{~m}$. high, the branches erect or ascending, the bark pale, the twigs slender, pale gray, glabrous. Leaves elliptic to oblong or obovateoblong, subcoriaceous, 5-10 cm. long, $1.5-5 \mathrm{~cm}$. wide, coarsely reticulate-veined, glabrous, bright green and shining above, pale green beneath, the petioles 1-2 $\mathrm{cm}$. long; panicles axillary and terminal, as long as the leaves or shorter, several-many-flowered, puberulent; bractlets ovate, acute, 1-1.5 $\mathrm{mm}$. long; pedicels about as long as the bractlets; calyx $1.5-2 \mathrm{~mm}$. long, its teeth ovate, acute; petals linear, white, 6-8 $\mathrm{mm}$. long; filaments about $2 \mathrm{~mm}$. long; anthers ovate-oblong.

Coppices near Nicholl's Town and Crow Hill, Andros:-Cuba. BLACK EBony.

An opposite-leaved shrub, found in foliage only near Stanlard Creek, Andros (Small and Carter 8898), may be of this genus.

\section{Family 2. LOGANIÀCEAE Dumort.}

\section{Logania Family.}

Herbs, shrubs, vines or some tropical genera trees, with opposite or verticillate simple stipulate leaves, or the leaf-bases connected by a stipular line or membrane, and regular perfect 4-5-parted flowers. Calyx inferior, the tube campanulate, sometimes short or none, the segments imbricated, at least in the bud. Corolla gamopetalous, funnelform, campanulate, or rarely rotate. Stamens inserted on the tube or throat of the corolla; anthers 2-celled, the saes longitudinally dehiscent; pollen-grains simple. Disk usually none. Ovary superior, 2-celled (rarely 3-5-celled); ovules anatropous or amphitropous. Fruit a 2-valved capsule in our species. Embryo small, usually straight; endosperm copious; radicle terete or conic. About 30 genera and 400 species, widely distributed in warm and tropical regions.

Corolla-lobes valvate.

Corolla funnelform or salverform, styles united.

Corolla urn-shaped, styles soon distinct.

Corolla-lobes imbricated.

1. Spigelia.

2. Cynoctonum.

3. Polypremum.

1. SPIGÈLIA L. Sp. Pl. 149. 1753.

Herbs, with opposite membranous entire, pinnately veined leaves, small stipules, or the leaf-bases connected by a stipular line, and red yellow nearly white or purple flowers, in scorpioid eymes or unilateral spikes, or terminal and in the forks of the branches. Calyx deeply 5-parted. Corolla 5-lobed, the tube finely 15-nerved. Stamens 5, inserted on the corolla-tube; anthers 2-lobed at the base. Ovules numerous, on peltate placentae; style filiform, jointed near the middle; stigma obtuse. Capsule didymous, 2-celled, somewhat flattened contrary to the dissepiment, circumscissile, the 2 carpels becoming 2 -valved. Seeds peltate, not winged. [Named for Adrian von der Spigel, 1558-1625, physician.] About 35 species, all American. Type species: Spigelia Anthelmia L. 
1. Spigelia Anthélmia L. Sp. Pl. 149. 1753.

Annual, simple or branched, $5 \mathrm{dm}$. high or less. Leaves lanceolate, 3-10 $\mathrm{cm}$. long, acute or acuminate, pale beneath, finely ciliolate; inflorescence subtended by a whorl or pair of lanceolate or ovate bracts larger than the leaves; flowers small, in slender unilateral spikes 5-12 cm. long; calyx-lobes narrowly lanceolate, about $2 \mathrm{~mm}$. long; corolla purplish white, 5-9 $\mathrm{mm}$. long; capsules 5-6 $\mathrm{mm}$. broad, tubercled.

Moist soils, Abaco, Andros, New Providence, Great Exuma, Eleuthera, Cat Island, Watling's, Acklin's, Crooked and Fortune Islands and Mariguana:-Florida; West Indies; continental tropical America. SpIgelia. PINK.

2. CYNó́toNUM J. F. Gmel. Syst. 443. 1791.

Herbs, our species annual, with opposite entire leaves, and minute stipules, or the leaf-bases connected by a stipular line. Flowers small, whitish, in onesided spikes forming eymes. Calyx 5-parted. Corolla urn-shaped, 5-lobed. Stamens 5, included; filaments short; anthers cordate. Ovules numerous, on peltate placentae; style short, 2 -divided below, united above by the common stigma, the divisions becoming separate. Capsule 2-lobed at the summit; carpels divaricate, dehiscent along the inner side. Seeds numerous, small, tuberculate. [Greek, dog-killing.] About 5 species, of warm and tropical regions. Type species: Cynoctonum sessilifolium Gmel.

1. Cynoctonum Mitrèola (L.) Britton, Mem. Torr. Club 5: 258. 1894.

Ophiorrhiza Mitreola L. Sp. Pl. 150. 1753.

Mitreola petiolata T. \& G. Fl. N. A. 2: 45. 1841.

Stem glabrous, erect, terete, 3-6 dm. high. Leaves lanceolate to ovate, petioled, 2.5-8 cm. long, 6-25 mm. wide, acute at both ends, glabrous; cymes terminal and often also in the upper axils, slender-peduncled; flowers about $2 \mathrm{~mm}$. broad, numerous, sessile or nearly so; capsule deeply 2-lobed, compressed, the lobes at length widely diverging, acute.

Savannas, brackish marshes, palmetto-lands and borders of mangrove swamps, Great Bahama, Andros and New Providence :-Virginia to Florida, Texas and Mexico; Cuba to Porto Rico and to Trinidad; Jamaica. The Andros plant recorded by Mrs. Northrop as Cynoctonum sessilifolia (T. \& G.) Britton, proves to be better referable to this species. MITREwORT.

\section{POLYPRÈMUMM L. Sp. Pl. 111. 1753.}

A glabrous diffusely branched annual herb, with opposite linear-subulate leaves, their bases connected by, a stipular membrane, and small white flowers in terminal bracted cymes. Calyx deeply 4-parted (rarely 5-parted), the segments subulate. Corolla campanulate, bearded in the throat, shorter than the calyx, 4-lobed (rarely 5-lobed). Stamens 4 (rarely 5), inserted on the corolla, included; filaments short; anthers ovoid-globose. Ovules numerous, on oblong placentae; style short; stigma capitate or obscurely 2-lobed. Capsule slightly compressed, didymous, loculicidally 2 -valved, the carpels at length septicidal. Seeds minute, smooth. [Greek, many-stemmed.] A monotypic genus.

1. Polypremum procúmbens L. Sp. Pl. 111.1753.

Stems tufted, somewhat rigid, 4-angled, 5-30 $\mathrm{cm}$. long. Leaves 1-4 cm. long, 1-2 mm. wide, acute, sessile, minutely rough-toothed on the margins, often 
with smaller ones fascicled in their axils; flowers solitary, sessile in the forks of the cymes and along their branches, leafy-bracted; corolla $2 \mathrm{~mm}$. long or less; capsule crustaceous, didymous, about $2 \mathrm{~mm}$. in diameter, slightly 2-lobed, the lobes obtuse.

Scrub-lands, Inagua at Matthew Town:-New Jersey to Kentucky, Florida, Mexico and Colombia; Cuba; Jamaica. PolypremuM.

\section{Family 3. GENTIANÀCEAE Dumort.}

\section{Gentian Family.}

Bitter mostly glabrous herbs, with opposite (rarely verticillate) estipulate entire leaves, reduced to scales in Leiphaimos, and regular perfect flowers in elusters, or solitary at the ends of the stem or branches. Calyx inferior, persistent, 4-12-lobed, toothed or -divided (of 2 sepals in Obolaria), the lobes imbricated or not meeting in the bud. Corolla gamopetalous, often marcescent, 4-12-lobed or -parted. Stamens as many as the lobes of the corolla, alternate with them, inserted on the tube or throat; anthers 2 celled, longitudinally dehiscent. Disk none, or inconspicuous. Ovary superior in our genera, 1-celled or partly 2-celled; ovules numerous, anatropous or amphitropous; stigma entire, or 2-lobed, or 2-cleft. Capsule mostly dehiscent by 2 valves. Endosperm fleshy, copious; embryo small, terete or conic. About 70 genera and 700 species, widely distributed.

Corolla-lobes convolute in the bud; leaves broad or narrow.

Stigmas roundish, much shorter than the style.

Corolla-tube surpassing the calyx.

Corolla-tube much shorter than the calyx.

Stigmas linear or nearly so, about as long as the style.

Corolla-lobes imbricated in the bud; leaves reduced to scales.

1. Centaurium.

2. Eustoma.

3. Sabbatia.

4. Leiphaimos.

\section{CENTAURIUM Hill, Brit. Herbal 62. 1756.}

Herbs, mostly annual or biennial, with sessile or amplexicaul leaves, and pink white or yellow flowers in cymes or spikes. Calyx tubular, 5-4-lobed or -divided, the lobes or segments narrow, keeled. Corolla salverform, 5-4-lobed, the lobes spreading, contorted, convolute in the bud. Stamens 5 or 4 , inserted on the corolla tube; filaments short-filiform; anthers becoming spirally twisted. Ovary 1-celled, the placentae sometimes intruded; style filiform; stigma 2-lobed. Capsule 2-valved. Seed-coat reticulated. [Latin, 100 gold pieces, referring to supposed medicinal value.] About 25 species, both in the Old World and the New. Type species: Gentiana Centaurium L.

\section{Centaurium Brittònii Millsp. \& Greenm. Field Mus. Bot. 2: 308.1909.}

Annual, glabrous, much-branched, 5-18 $\mathrm{cm}$. high, the branches very slender, quadrangular. Basal and lower leaves obtuse or oblong-spatulate; upper leaves sessile, oblong-lanceolate to linear, acute, $1.8 \mathrm{~cm}$. long or less; peduncles nearly filiform, much longer than the upper leaves; flowers white with a yellowish eye, 3-5-parted (mostly 4-parted); calyx 5-6 mm. long, its segments narrowly linear, acute; corolla 6-10 mm. long, its lobes oblong, about one-half as long as the tube; capsule linear-elliptic, 6-8 $\mathrm{mm}$. long.

Dry sandy roadsides and sandy edge of marshes, Eleuthera, Watling's and Great Exuma:-Anegada. BrItTon's Centaury. 
2. EUSTÒMA Salisb. Parad. Lond. pl. 34. 1806.

Glabrous, often glaucous, annual herbs, with opposite, sessile or clasping, entire leaves. Flowers large, blue, purple or white, long-peduncled. Calyx deeply 5-6-cleft, the lobes lanceolate, acuminate, keeled. Corolla deeply 5-6lobed, the lobes oblong or obovate, convolute in the bud. Stamens 5-6, inserted on the throat of the corolla; filaments filiform; anthers oblong, versatile. Ovary 1-celled; stigma 2-lamellate. Capsule 2-valved. Seeds small, numerous, foveolate. [Greek, open-mouth, referring to the corolla.] Four or five species, natives of the southern United States, Mexico and the West Indies. Type species: Eustoma silenifolium Salisb.

\section{Eustoma exaltàtum (L.) Griseb. Fl. Br. W. I. 422.1861.}

Gentiana exaltata L. Sp. Pl. ed. 2, 331. 1762.

Erect, slightly fleshy, 1-9 dm. high, large plants often much-branched and many-flowered, small plants simple and 1-flowered. Leaves oblong or oblonglanceolate, somewhat clasping, sessile, $1.5-9 \mathrm{~cm}$. long, the lower obtuse, the upper acute; calyx-lobes nearly filiform-acuminate, 1-2 cm. long; corolla blue or nearly white, sometimes light blue above and dark blue below within, $2-4 \mathrm{~cm}$. broad, its lobes obovate, irregularly dentate; style about twice as long as the stigma-lobes; capsule oblong, obtuse, $2-2.5 \mathrm{~cm}$. long.

Brackish borders of marshes and savannas, North Bimini, Andros, New Providence, Great Exuma, Long Island, Cat Island and Acklin's:-Florida to Texas, Mexico and south to northern South America; Cuba; Hispaniola; Jamaica. MARSH Gentian.

3. SABBÀTtA Adans. Fam. Pl. 2: 503. 1763.

Annual or biennial erect glabrous herbs, with opposite or sometimes verticillate, sessile or rarely petioled or clasping leaves, and terminal pink rose or white flowers. Calyx 4-12-parted or -divided, the tube campanulate, sometimes very short, the lobes or segments usually narrow. Corolla rotate, deeply 4-12parted. Stamens 4-12, inserted on the short tube of the corolla; filaments filiform short; anthers curved, revolute or coiled in anthesis. Ovary 1-celled, the placentae intruded; style 2-cleft or 2-parted, its lobes filiform, stigmatic along their inner sides. Capsule 2-valved, many-seeded. Seeds small, reticulated. [In honor of L. Sabbati, an Italian botanist.] About 18 species, natives of eastern North America, Mexico and the West Indies. Type species: Gentiana dodecandra $\mathrm{L}$.

Corolla 2-3 cm. wide, rose-pink; stigmas oblong-linear.

Corolla less than $2 \mathrm{~cm}$. wide, pure white; stigmas spatulate.

1. S. campanulata.

2. S. simulata.

1. Sabbatia campanulàta (L.) Torrey, F. U. S. 1: 217. 1824.

Chironia campanulata L. Sp. Pl. 190. 1753.

Sabbatia gracilis Salisb. Parad. Lond. pl. 32. 1806.

Stem 3-6 dm. high. Leaves linear or linear-lanceolate, 2-4 cm. long, sessile, acute or the lowest much shorter, obtuse, oblong or oblanceolate, the uppermost almost filiform; flowers pink with a yellow eye, about $2.5 \mathrm{~cm}$. broad, mostly 5-parted; calyx-lobes filiform-linear, equalling the oblong-obovate corolla-segments, or somewhat shorter; stigmas oblong-linear; capsule obovoid, about $5 \mathrm{~mm}$. high.

Brackish marshes, Abaco and Great Bahama:-Eastern Massachusetts to Florida and Louisiana:-Cuba. Slender Marsh PINK. 
2. Sabbatia simulàta Britton, Bull. N. Y. Bot. Gard. 3: 448. 1905.

Similar to $S$. campanulata but more slender than that species and with smaller white flowers. Plant $4 \mathrm{dm}$. high or less, the upper leaves narrowly linear, 1-3 cm. long, about $1 \mathrm{~mm}$. wide, the lower spatulate, acute, $4 \mathrm{~cm}$. long or less, $2-5 \mathrm{~mm}$. wide, the basal ones spatulate to orbicular; calyx-lobes narrowly linear, less than $1 \mathrm{~mm}$. wide, nearly as long as the corolla or shorter; corolla 1-2 cm. broad, its segments oval, obtuse; capsule ovoid, about $6 \mathrm{~mm}$. long, tipped by the short style; stigmas narrowly spatulate.

Savannas, palmetto-lands and edges of brackish pools, Abaco, Andros, New Providence, Eleuthera and Cat Island. Endemic. Referred by Mrs. Northrop and hy Coker to S. campanulata (L.) Torr., and listed by Dolley as S. gracilis Salisb. White Marsh Pink.

\section{LEIPHÀIMOS Schl. \& Cham. Linnaea 6: 387. 1831.}

Small saprophytic pale simple-stemmed herbs, without chlorophyll, the stems white or yellowish, bearing opposite sessile scales or the lower scales alternate, the flowers terminal, cymose or solitary. Calyx bracteolate at the base, 4-5-toothed. Corolla salverform or funnelform, 4-5-lobed, small. Stamens 4 or 5 , included; filaments mostly short; anthers introrse. Ovary 1-celled, with 2 parietal placentae; style one; stigma capitate or dilated. Capsule oblong or linear, septicidally dehiscent at the middle. [Greek, pallid.] About 20 species, mostly of tropical America, the following typical.

1. Leiphaimos parasitica Schl. \& Cham. Linnaea 6: 387. 1831.

Voyria mexicana Griseb. Gen. et Spec. Gent. 208. 1838.

Stem somewhat fleshy, whitish, 1-4 dm. high, erect, slender, simple or little-branched, bearing few opposite scales $3-5 \mathrm{~mm}$. long. Calyx-lobes lanceolate, obtuse; corolla whitish or yellowish, $6-8 \mathrm{~mm}$. long, its triangular acute lobes about one-fourth as long as the tube; capsule 5-6 $\mathrm{mm}$. long.

Floor of coppices in leaf mold, Abaco, Great Bahama, Andros, New Providence, Eleuthera, Watling's, Crooked Island and North Caicos:-Florida ; Cuba ; Jamaica ; Mexico. Leiphaimos.

\section{Family 4. MENYANTHÀCEAE G. Don.}

\section{BUCKBEAN FAMILY.}

Perennial aquatic or marsh herbs, with basal or alternate leaves, and clustered regular perfect flowers. Calyx inferior, deeply 5-parted, persistent. Corolla 5-lobed or 5-cleft, the lobes induplicate-valvate, at least in the bud. Stamens 5, borne on the corolla, and alternate with its lobes; anther-sacs longitudinaly dehiscent; pollen-grains 3-angled. Ovary 1celled, the 2 placentae sometimes intruded. Fruit a capsule, or indehiscent. Five genera and about 35 species, widely distributed.

\section{NYMPHOİDES Hill, Brit. Herbal 77. 1756.}

[Limnanthemum S. G. Gmel. Nov. Act. Acad. Petrop. 14²: 527. 1769.]

Aquatic herbs, with slender rootstocks. Leaves petioled, ovate or orbicular, entire or repand, or the primary ones different; flowers yellow, or white, umbellate at the summit of filiform stems at the bases of the petioles, or axillary. Calyx 5-parted. Corolla nearly rotate, deeply 5-cleft, the lobes induplicate- 
valvate in the bud, sometimes fimbriate on the margins. Stamens 5, inserted on the base of the corolla; anthers sagittate, versatile. Ovary 1-celled; style short or none; stigma 2-lamellate. Capsule indehiscent or irregularly bursting. [Greek, resembling Nymphaea.] About 20 species, widely distributed. Type species: Nymphoides flava Hill.

\section{Nymphoides aùreum Britton.}

Limnanthemum aureum Britton, Bull. N. Y. Bot. Gard. 4: 142. 1906.

Rootstock $1 \mathrm{~cm}$. thick, 3-4 cm. long. Stolons rather slender, purple-dotted, 2-3 dm. long, or longer, bearing a petioled floating leaf and an umbel of slender-pedicelled flowers at its summit but no tufts of tubers; leaves subpeltate, floating, ovate-orbicular, $8 \mathrm{~cm}$. long or less, entire, or irregularly repand, thick, dull-green above, purple and densely dotted beneath, the basal sinus narrow, acute, or the obtuse lobes somewhat overlapping; petioles stout, $2-4 \mathrm{~cm}$. long, inserted on the leaf-blade 1-3 mm. from the sinus; umbel several-flowered; pedicels slender, $3-5 \mathrm{~cm}$. long in fruit; sepals oblong-lanceolate, acutish, 5-6 $\mathrm{mm}$. long; corolla-segments about $8 \mathrm{~mm}$. long, golden-yellow, their margins fimbriate; capsule oblong-ovoid, as long as the sepals; style subulate, persistent, 2-3 mm. long; seeds compressed-globose, wingless, smooth, $1 \mathrm{~mm}$. broad and about one half as thick as wide.

Ponds on Great Exuma, near Georgetown and on Andros near Nicholl's Town. Endemic. Bahama Floating Heart.

\section{Family 5. APOCYNÀCEAE Lindl.}

\section{Dogbane Family.}

Perennial herbs, shrubs, vines, or some tropical genera trees, mostly with an acrid milky juice, with simple estipulate leaves, and perfect regular 5-parted flowers. Calyx inferior, persistent, the lobes imbricated in the bud. Corolla gamopetalous, its lobes convolute in the bud and often twisted. Stamens as many as the lobes of the corolla, alternate with them, inserted on the tube or throat; anthers 2-celled; pollen-grains simple. Ovary superior, or its base adherent to the calyx, of 2 distinct carpels, or: 1-celled, with 2 parietal placentae, or 2-celled; ovules anatropous or amphitropous; style simple, or 2-divided; stigma simple. Fruit usually of 2 follicles or drupes. Seeds often appendaged; endosperm fleshy; embryo straight; radicle terete, usually shorter than the cotyledons. About 130 genera and 1100 species, very widely distributed, mostly in tropical regions.

Fruit follicular.

Trees, shrubs, or shrubby herbs.

Woody trees or shrubs.

Seeds with a wing.

Seeds with a coma.

Herbaceous plant, shrubby at the base.

Vines; seeds with a coma.

Corolla-tube subcylindric.

Corolla-tube narrowly campanulate above the short, cylindric base.

Calyx-lobes short.

Fruit fleshy.

Calyx-lobes long, linear-acuminate.

1. Plumiera.

2. Neobracea.

3. Catharanthus.

4. Echites.

5. Rhabdadenia.

6. Urechites.

7. Cerbera.

8. Rauwolfia.

9. Vallesia.

Leaves alternate; corolla large, funnelform.
Leaves opposite or whorled; corolla small, salverform.

Shrub; leaves alternate; corolla salverform. 


\section{PLUMIÈrRA L. Sp. Pl. 209. 1753.}

Trees or shrubs, with very stout branches, copious milky sap, alternate petioled feather-veined leaves, and large bracted flowers in terminal, peduncled cymes. Calyx small, fleshy, 5-cleft, eglandular. Corolla salverform, the tube subcylindric, the 5 lobes sinistrorse. Stamens borne near the base of the corolla-tube, included; anthers obtuse, their sacs unappendaged. Carpels 2, distinct; ovules many in each carpel; style very short; stigma oblong, not annulate, obtusely 2-lobed at the apex. Follicles 2, coriaceous, usually linear and divaricate, many-seeded. Seeds flat, winged, the endosperm fleshy. [Commemorates Charles Plumier, a distinguished French botanist, born 1646.] About 45 species, of tropical America. Type species: Plumiera rubra L.

Leaves glabrous or very nearly so.

Leaves obtuse or emarginate.

Corolla-tube as long as the lobes; leaves oblong to oblongobovate.

Corolla-tube shorter than the lobes; leaves obovate.

1.P. obtusa.

2. P. inaguensis.

Leaves acute or mucronate.

Leaves lanceolate to linear-lanceolate; color of flowers unknown.

Leaves broadly elliptic to obovate; flowers red or purple. Leaves densely pubescent beneath.

3. P. bahamensis.

4. P. rubra.

5. P. sericifolia.

\section{Plumiera obtùsa L. Sp. Pl. 210. 1753.}

A tree, 4-6 m. high, often flowering when not more than $1.5 \mathrm{~m}$. high, the stout twigs, the leaves and the inflorescence glabrous. Leaves oblong to oblongoblanceolate or oblong-obovate, 7-20 $\mathrm{cm}$. long, rounded or emarginate at the apex, mostly narrowed or somewhat cuneate at the base, the lateral veins nearly straight and rather widely spreading, the slender petioles $2-6 \mathrm{~cm}$. long; panicles few-several-flowered; peduncle as long as the leaves or shorter; pedicels short; calyx about $3 \mathrm{~mm}$. long; corolla white with a yellow eye, the lobes obovate or oblong-obovate, rounded at the apex, $1.5-2 \mathrm{~cm}$. long, about as long as the tube; follicles $7-12 \mathrm{~cm}$. long, about $1 \mathrm{~cm}$. in diameter.

Scrub-lands and coppices, Abaco and Great Bahama to Andros, Watling's, Providenciales, Caicos and Grand Turk:-Cuba; Hispaniola; Mona; recorded from Jamaica. Hitchcock's Governor's Harbor specimen referred to $P$. emarginata is this species. Recorded by Schoepf as $P$. alba L. Blunt-leated Plemiera. FrangiPANNI. Catesby, 2: pl. 93 .

\section{Plumiera inaguénsis Britton, Bull. N. Y. Bot. Gard. 3: 448. 1905.}

A glabrous tree, $5 \mathrm{~m}$. high or less. Leaves obovate, rather thin, the blade 6-10 $\mathrm{cm}$. long, 4-6 $\mathrm{cm}$. wide, emarginate or rounded at the apex, narrowed or cuneate at the base, dark green and shining above, bright green and dull beneath, the numerous veins diverging from the midrib at an angle of about $80^{\circ}$, the midrib impressed on the upper surface, elevated beneath; petioles stout, 1-2 cm. long; peduncle stout, 4-10 cm. long; cyme compound, $8 \mathrm{~cm}$. broad or less, densely many-flowered; pedicels slender, 8-12 mm. long; calyx shortcampanulate, slightly 5-lobed, the lobes broad, rounded; corolla white, its tube slender, about $1 \mathrm{~cm}$. long, its 5 lobes narrowly obovate, rounded or slightly emarginate, somewhat longer than the tube; stamens about one-third the length of the corolla-tube; follicles linear, terete, $9 \mathrm{~cm}$. long, $8 \mathrm{~mm}$. in diameter.

Scrub-lands, Fortune Island and the Inaguas. Endemic. INagua Plumiera.

3. Pulmiera bahaménsis Urban, Symb. Ant. 1: 387. 1900.

A small tree, about $3 \mathrm{~m}$. high, the twigs about $1 \mathrm{~cm}$. thick. Leaves lanceolate or linear-lanceolate, glabrous, $8-16 \mathrm{~cm}$. lcng, 1-3.5 cm. wide, chartaceous, acute or acuminate at the apex, narrowed at the base, the midvein impressed 
above, prominent beneath, the lateral veins numerous, straight ascending; follicles (Brcce no. 4275 from Acklin's island, the type locality) about $10 \mathrm{~cm}$. long and $12 \mathrm{~mm}$. in diameter; corolla (Brace, Fortune Island) about $2 \mathrm{~cm}$. broad, the slender tube about as long as the lobes.

Rocky scrub-lands, Acklin's and Fortune Islands. Endemic. Bahama Plumiera.

\section{Plumiera rùbra L. Sp. .Pl. 209. 1753.}

A tree, 5-8 m. high, the young twigs, peduncles and pedicels pubescent. Leaves elliptic-oblong to elliptic-obovate, 1.5-4 dm. long, acute or short-acuminate at the apex, narrowed at the base, glabrous on both sides, the lateral veins rather distant and widely spreading, the petioles $3-6 \mathrm{~cm}$. long; panicles severalmany-flowered, mostly shorter than the leaves; pedicels stout, thickened above, $1.5-3 \mathrm{~cm}$. long; calyx about $3 \mathrm{~mm}$. long; corolla purple or red, $5-7 \mathrm{~cm}$. broad, the tube rather shorter than the limb, the lobes broadly elliptic, obtuse; follicles $1.5-2.5 \mathrm{~cm}$. long, about $2.5 \mathrm{~cm}$. in diameter.

Open scrub-lands, Mangrove Cay:-Porto Rico to Trinidad; Jamaica. JESSAmine. Spanish Jasmine. Red Plumiera. Red Frangipanin.

5. Plumiera sericifòlia C. Wright; Griseb. Cat. Pl. Cub. 171. 1866.

A small tree, sometimes $5 \mathrm{~m}$. high, the stout twigs pubescent when young. Leaves oblong or oblong-obovate, coriaceous, 7-15 cm. long, emarginate or rounded at the apex, narrowed or obtuse at the base, dark green and glabrous or nearly so above, pale and densely pubescent beneath, the stout pubescent petioles 1-4 cm. long; peduncles stout, pubescent, 1-2.5 dm. long; cymes several-many-flowered; pedicels about $1 \mathrm{~cm}$. long or less; calyx-teeth very short, broad; corolla white, the sparingly pubescent tube about $1.5 \mathrm{~cm}$. long, the narrowly obovate or oblong, obtuse lobes $1.5-2 \mathrm{~cm}$. long; follicles glabrous, $2 \mathrm{dm}$. long or less.

Scrub-lands, Inagua :-Cuba. HaIry Plumiera.

\section{NEOBRÀCEA Britton.}

[BraceA Britton, Bull. N. Y. Bot. Gard. 3: 448. 1905. Not King. 1898.]

A shrub, with thick oblanceolate or oblong petioled leaves. Flowers solitary or two together in the upper axils, white or reddish, peduncled. Calyx deeply 5-cleft, its lobes narrowly lanceolate, acute. Corolla nearly salverform, the short tube slightly and gradually dilated above, about as long as the 5 obliquely ovate lobes. Stamens 5 , borne near the base of the corolla-tube; filaments short; anthers sagittate, hairy on the back. Follicles long-linear, slightly torulose. Seeds comose. [In honor of L. J. K. Brace, a diligent collector of the Bahamian flora.] A monotypic genus.

\section{Neobracea bahaménsis Britton.}

Bracea bahamensis Britton, Bull. N. Y. Bot. Gard. 3: 448. 1905.

About $1 \mathrm{~m}$. high, with grayish brown branches leafy only near the ends, the young twigs pubescent. Leaves firm in texture, revolute-margined, oblongoblanceolate, obtuse or slightly emarginate at the apex, narrowed at the base, 4-10 cm. long, 1-2.5 cm. wide, bright green above, densely and finely tomentose with the veins prominently reticulated beneath; petioles 4-7 $\mathrm{mm}$. long; flowers appearing with the leares; peduncles tomentose, about $1 \mathrm{~cm}$. long; calyx-lobes tomentose, $3 \mathrm{~mm}$. long; corolla white with a reddish throat, pubescent outside, smooth within, about $2 \mathrm{~cm}$. broad; follicles $15 \mathrm{~cm}$. long or less, $2 \mathrm{~mm}$. thick, pubescent, striate, pendent. 
Coastal thickets, pine-lands and borders of brackish swamps, Great Bahama, Andros, New Providence, Cat Island, Great Exuma, Fortune Island and Crooked Island. Endemic. Bahama Neobracea.

\section{CATHARANTHUS G. Don, Gen. Syst. 4: 95.1838.}

Herbs or low shrubs, with opposite leaves, and large axillary flowers, solitary or 2 together. Calyx eglandular, 5-cleft, the lobes narrow. Corolla salverform, its cylindric tube slightly enlarged above, its 5 broad lobes sinistrorse. Stamens included; anthers not appendaged. Disk of 2 large glands. Carpels 2 , distinct; style very slender; stigma thick, pilose; ovules many in each carpel. Follicles narrowly eylindric, many-seeded. Seeds small, unappendaged. [Greek, pure flower.] Three known species, the following typical one native of tropical America, widely distributed through cultivation, one East Indian, the other of Madagascar.

1. Catharanthus ròseus (L.) G. Don, Gen. Syst. 4: 95. 1838.

Vinca rosea L. Syst. ed. 10, 944. 1759.

Ammocallis rosea Small, F1. SE. U. S. 936. 1903.

Somewhat woody, usually branched, pubescent, $8 \mathrm{dm}$. high or less. Leaves oblong to oblong-oblanceolate, $3-8 \mathrm{~cm}$. long, obtuse or retuse at the apex, mucronulate, narrowed at the base into short petioles; peduncles very short, pubescent; calyx-lobes linear-subulate, 3-4 mm. long, pubescent; corolla white or pink, the finely pubescent tube $2.5-3 \mathrm{~cm}$. long, the oblique lobes somewhat shorter than the tube; follicles cylindric, pubescent, $2-3 \mathrm{~cm}$. long.

Waste grounds, naturalized, Great Cay, Andros, New Providence, Eleuthera, Cat Island, Acklin's, Long Island, Grand Turk, Salt Cay and Inagua :-Florida; West Indies; continental tropical America, Old World tropics. Erroneously called Tulip and Sweer William. Red Periwinkle. Old Maid.

\section{ECHITES Jacq. Enum. 2, 13. 1760.}

Twining, somewhat woody vines, with opposite petioled leaves, and rather large flowers in cymes. Calyx 5-lobed, glandular. Corolla salverform, the cylindric tube somewhat swollen, the lobes spreading. Stamens included, the anthers appendaged at the base. Fruit of 2 spreading follicles, many-seeded. [Greek, an adder, referring to the twining stem.] About 40 species, of tropical and subtropical America. Type species: Tabernaemontana Echites L.

\section{Echites Echites (L.) Britton; Small, Fl. Miami 147. 1913.}

Tabernaemontana Echites L. Syst. ed. 10, 945. 1759.

Echites umbellata Jacq. Enum. 13. 1760.

A glabrous, somewhat woody vine, 1-2 $\mathrm{m}$. long, the stems sometimes warty below. Leaves rather thick, ovate or broadly elliptic, 3-10 cm. long, shortpetioled, pinnately veined; cymes axillary, few-flowered, peduncled; pedicels stout, 1-2.5 cm. long; calyx 1.5-2.5 mm. long, its lobes ovate-lanceolate, acute; corolla greenish white, its tube 4-6 $\mathrm{cm}$. long, cylindrie below, swollen at about the middle, narrowed above, its lobes obliquely obovate, $1-2.5 \mathrm{~cm}$. long; anthers acuminate; follicles spreading, 1-2 dm. long, subcylindric.

Scrub-lands and sandy places, throughout the archipelago from Abaco and Great Bahama to Fast Caicos, Grand Turk, Inagua, Anguilla Isles and Water Cay :Florida; Cuba to Porto Rico; Jamaica. Devil's Potato-root. Wild Potato. RubBer-viNe. DANish. Catesby, 1: $p l$. 58. 


\section{RHABDAdÈnIA Muell. Arg. in Mart. Fl. Bras. 6 ${ }^{1}: 173.1860$.}

Woody vines, rarely erect shrubs, with opposite petioled leaves, and large flowers in small racemes or solitary. Calyx 5-cleft. Corolla tubular-campanulate, with a short cylindric oase and a spreading 5 -lobed limb, the lobes broad, dextrorse. Stamens short, included, borne near the top of the corolla-tube; anthers oblong, connivent around the stigma, the sacs with short obtuse appendages at the base. Carpels 2, distinct; style slender; stigma thick, its base dilated into a reflexed membrane; ovules many in each carpel. Follicles linear, parallel or little divergent, many-seeded. Seeds linear, comose. [Greek, wandgland, probably referring to the fruit.] About 10 species, of Florida, the West Indies and S'outh America. Type species: Rhabdadenia Pohlii Muell. Arg.

Corolla white; leaves slender-petloled.

Corolla yellow; leaves very short-petioled.

1. R. paludosa.

2. R. Sagraei.

1. Rhabdadenia paludòsa (Vahl) Miers. Apoc. S. Am. 119. 1878.

Echites paludosa Vahl, Eclog. 2: 19.1798.

A glabrous, somewhat woody vine, often $6 \mathrm{~m}$. long or longer. Leaves oblong or elliptic, slightly fleshy, 3-9 $\mathrm{cm}$. long, obtuse or acutish and mucronate at the apex, mostly narrowed at the base, faintly pinnately veined, the slender petioles 8-15 mm. long; cymes long-peduncled, 1-few-flowered; pedicels slender; calyx-segments narrowly oblong, 6-9 $\mathrm{mm}$. long, apiculate, one-third to one-half as long as the narrowly cylindric part of the corolla-tube; corolla white, 5-6 $\mathrm{cm}$. long, the limb about $4 \mathrm{~cm}$. wide; follicles linear, 10-16 cm. long, about 4 $\mathrm{mm}$. thick.

Mangrove swamps, Great Bahama, Andros, New Providence and Crooked Island : -Florlda; Cuba; Hispaniola; Jamalca; western tropical continental America. Referred by Schoepf and Mrs. Northrop to Echites biflora Jacq. and by Coker and by Small to Rhabdadenia biflora (Jacq.) Muell. Arg. Mangrove Swamp Vine.

\section{Rhabdadenia Sagraèi (A. DC.) Muell. Arg. Linnaea 30: 435. 1860.}

Echites Sagraei A. DC. in DC. Prodr. 8: 450. 1844.

A slender, slightly woody vine, usually less than $1 \mathrm{~m}$. long, pubescent above. Leaves oblong, 1-3 cm. long, subcoriaceous, faintly pinnately veined, obtuse and mucronulate at the apex, obtuse, rounded or subcordate at the base, the margins somewhat revolute, the petioles 1-2 mm long; cymes few-several-flowered; pedicels very slender; calyx-segments ovate, acute, $1.5-3 \mathrm{~mm}$. long, one-fourth to one-third as long as the linear cylindric part of the corolla; corolla bright yellow, 2-3 cm. long, the limb about $2 \mathrm{~cm}$. wide; follicles linear, 7-11 cm. long, $1.5-2 \mathrm{~mm}$. thick.

Scrub-lands. coppices and pine-lands, Abaco and Great Bahama to Andros and Mariguana and North Caicos:-Cuba. LICE-ROOT.

Echites jamaicensis Griseb., recorded from the Bahamas by Grisebach as collected by Swalnson, is otherwise unknown to us from the archipelago. It may have been mistaken for the preceding species.

\section{URECHITtes Muell. Arg. Linnaea 30: 440. 1860.}

Somewhat woody, twining vines, with opposite petioled leaves, and large mostly yellow, cymose flowers. Calyx-lobes 5, narrow; calyx-tube 5-glandular within. Corolla cylindric below, expanded into a narrowly campanulate throat, the limb 5-lobed, somewhat spreading. Anthers appendaged at the base, partly adherent to the stigma. Fruit of 2 long, linear follicles. Seeds narrow, 
comose. [Greek, tailed-Echites.] A few species, of tropical America. Type species: Urechites Karwinskii Muell. Arg.

1. Urechites lùtea (L.) Britton, Bull. N. Y. Bot. Gard. 5: 316. 1907.

Vinca lutea L. Cent. Pl. 2: 12.1756.

Echites suberecta Jacq. Enum. 13. 1760.

Echites Catesbaei G. Don, Gen. Syst. 4: 74. 1838.

Echites Andrewsii Chapm. F1. So. U. S. 359. 1860.

Urechites Andrewsii Small, Fl. SE. U. S. 936. 1903.

Echites neriandra Griseb. Fl. Br. W. I. 415. 1861.

Pubescent or glabrous, slender, often $3 \mathrm{~m}$. long or more. Leaves oblong to obovate or suborbicular, herbaceous, $2-8 \mathrm{~cm}$. long dark green above, pale green beneath, mostly obtuse at the apex and narrowed at the base, the slender petioles about $1 \mathrm{~cm}$. long; cymes few-several-flowered; pedicels slender; calyxlobes narrowly lanceolate, acuminate, 8-12 mm. long; corolla yellow, 3-4 cm. long; anthers mostly tipped by filiform appendages; follicles linear, 10-15 $\mathrm{cm}$. long, 4-5 mm. thick.

Scrub-lands and coppices, throughout the archipelago from Abaco and Great Bahama to Andros, Grand Turk and Inagua :-Florida; Cuba to Tortola and St. Kitts; Jamaica. Species composed of several races, the follage and inflorescence either glabrous or pubescent, the flowers differing much in size and the pods much in length. Wild Unction. CATESBY's Vine. Catesby $2: p l$. 58.

\section{CÉrbera L. Sp. Pl. 208. 1753.}

Glabrous trees or shrubs, with alternate, 1-nerved and pinnately veined leaves, and large yellow flowers in terminal peduncled cymes. Calyx 5-parted, many-glandular within at the base. Corolla funnelform, the tube cylindric below, bearing pilose scales at the top within, abruptly expanded into a campanulate throat, the 5 broad rounded lobes sinistrorse. Stamens borne with the scales at the top of the tube; anther-sacs unappendaged. Disk wanting. Ovary 2-lobed, 2-celled; style filiform; stigma discoid, its small tip 2-lobed; ovules 2 in each cavity of the ovary. Fruit a compressed drupe, broader than high, the flesh thin, the bony endocarp 2-celled. Seeds with a thick testa and no endosperm. [Named for Cerberus, the three-headed dog of mythology.] About 7 species, natives of tropical America. Type species: Cerbera Ahouai L.

\section{Cerbera Thevètia L. Sp. Pl. 209. 1753.}

Thevetia nereifolia Juss.; Steud. Nom. ed. 2, 2: 680. 1841.

Thevetia Thevetia Millsp. Field Mus. Bot. 2: 83. 1900.

A shrub or small tree up to about $10 \mathrm{~m}$. high, glabrous throughout. the twigs rather stout, densely leafy. Leaves linear, 7-15 cm. long, 5-10 $\mathrm{mm}$. wide, narrowed at both ends, very nearly sessile, bright green and shining above, rather dull beneath, the midvein prominent, the lateral venation obscure; calyx-segments about $7 \mathrm{~mm}$. long, ovate-lanceolate, acuminate; corolla yellow, about $7 \mathrm{~cm}$. long, funnelform with the tube shorter than the limb; drupe triangular-compressed, 3-4 cm. broad, about $2 \mathrm{~cm}$. high, and 1-1.5 $\mathrm{cm}$. thick, nearly truncate, the flesh thin.

Thickets, spontaneous after cultivation, New Providence near Nassau :-Florida ; Cuba to Porto Rico and Grenada; Jamaica; continental tropical America. LDCKYNUT. Cathartic-Bark. French Trumpet-Flower. LUCK-Seed. 
8. RAUWÓLFIA L. Sp. Pl. 208. 1753.

Shrubs or trees with whorled or opposite leaves, and small flowers in peduncled cymes. Calyx eglandular, 5-cleft or 5-parted. Corolla salverform, the tube subcylindric, the 5 lobes sinistrorse. Stamens included; anthers obtuse, their sacs not appendaged. Disc annular or cup-shaped. Carpels 2, distinct or connate; style filiform; stigma thick, annular or with a reflexed membrane at the base; ovules 2 in each carpel. Fruit of 2 drupes, usually connate, the fruit thus usually emarginate and 2-grooved. Seeds ovoid with fleshy endosperm. [Commemorates Leonh. Rauwolf, a German botanist.] Forty species or more, natives of tropical regions and of South America. Type species: Rauwolfia tetraphylla L.

\section{Rauwolfia tetraphýlla L. Sp. Pl. 208. 1753.}

Rauwolfia nitida Jacq. Enum. 14. 1760.

A glabrous shrub or tree, up to $20 \mathrm{~m}$. high, the twigs slender. Leaves oblong-lanceolate or elliptic-lanceolate, verticillate in 4 's or some of them opposite, acuminate or acute at the apex, tapering at the base, shining above, rather dull beneath, the lateral veins numerous, widely spreading, the petioles $6-12 \mathrm{~mm}$. long; peduncles shorter than the leaves; cymes many-flowered; pedicels very short; calyx 5-lobed, $2 \mathrm{~mm}$. long, its lobes ovate; corolla white, its tube cylindric, 2-3 times as long as the calyx, its lobes about one-half as long as the tube; fruit 1-1.5 $\mathrm{cm}$. broad, 8-10 mm. high, red, its lobes ovoid, rounded.

Coastal thickets and scrub-lands, New Providence, at Delaport:-Cuba to Tortola and St. Croix; Jamaica; recorded from St. Bart's. SMOоTH RAUWOLFIA.

\section{VAILesiA R. \& P. Fl. Per. 2: 26. 1799.}

Branching shrubs or small trees, with alternate, short-petioled leaves, the small flowers in long-peduncled cymes opposite the leaves. Calyx 5-lobed, the lobes short. Corolla salverform, the tube swollen above, constricted at the mouth, the 5 equilateral lobes shorter than the tube, sinistrorsely convolute. Anthers unappendaged, free from the stigma, cordate; filaments borne on the corolla-throat. Stigma clavate. Fruit a 1-2-seeded drupe. Seeds naked. [Commemorates Francisco Valles, physician to Philip II. of Spain.] Two known species, the following typical.

1. Vallesia glàbra (Cav.) Link, Enum. Hort. Berol. 1: 207.1821.

Rauwolfia glabra Cav. Ic. 3: 50. 1794.

Vallesia dichotoma R. \& P. Fl. Per. 2: 26. 1799.

A glabrous shrub or small tree, $6 \mathrm{~m}$. high or less, the slender branches sometimes elongated and vine-like. Leaves oblong or oblong-lanceolate, somewhat fleshy, shining above, dull beneath, 3-6 cm. long, short-petioled, mostly acute at both ends; cymes few-several-flowered, often forked; pedicels slender; calyx about $1 \mathrm{~mm}$. long, its lobes ovate, acute; corolla white, about $6 \mathrm{~mm}$. long, its narrow lobes one-third to one-half as long as the tube; fruit oblong, rounded at apex, narrowed at the base, about $10 \mathrm{~mm}$. long and $4 \mathrm{~mm}$. thick.

Scrub-lands and white-lands New Providence, Rose Island, Eleuthera, Cat Island, Conception Island, Great Exuma, Long Island and Anguilla Isles:-Florida; Cuba; Jamaica; tropical Mexico to Bolivia. Vallesia. 


\section{Family 6. ASCLEPIADĀCEAE Lindl.}

\section{MiLKWEed FamiLy.}

Perennial herbs, vines or shrubs, mostly with milky juice, with estipulate leaves, and cymose or umbellate, perfect regular flowers. Calyx inferior, its tube very short, or none, its segments imbricated or separate in the bud. Corolla campanulate, urceolate, rotate or funnelform, 5-lobed or 5-cleft, the segments commonly reflexed. A 5-lobed or 5-parted crown (corona) between the corolla and the stamens and adnate to one or the other. Stamens 5, inserted on the corolla; filaments short, stout, mostly monadelphous, or distinct; anthers attached by their bases to the filaments, introrsely 2-celled, connivent around the stigma, or more or less united with each other; anther-sacs tipped with an inflexed or erect scarious membrane, or unappendaged at the top, sometimes appendaged at the base; pollen coherent into waxy or granular masses, one or rarely two such masses in each sac, connected with the stigma in pairs or fours, by 5 glandular corpuscles alternate with the anthers. Disk none. Ovary of 2 carpels; styles 2 , short, connected at the summit by the peltate discoid stigma; ovules numerous in each carpel, mostly anatropous, pendulous. Fruit of 2 follicles. Seeds compressed, usually appendaged by a long coma; endosperm cartilaginous; embryo nearly as long as the seed; cotyledons flat. About 220 genera and 2,000 species of wide distribution.

Pollinia granular; vines.

Pollinia waxy.

Erect herbs, shrubs or trees.

Corona-segments with an internal horn.

Vines.

Corona-segments spurred on the back.

1. Cryptostegia.

Corona simple.

Corona double.

2. Asclepias.

3. Calotropis.

4. Metastelma.

5. Philibertella.

1. CRYPtostègia R. Br. Bot. Reg. pl. 435. 1820.

Glabrous, high-climbing vines, with broad opposite leaves and large flowers in terminal cymes. Calyx 5-parted, the segments lanceolate. Corolla funnelform, the tube short, the throat campanulate, the limb 5-lobed, the lobes dextrorsely twisted; corona-scales 5, subulate, entire or 2-lobed. Stamens borne at the base of the corolla-tube; filaments filiform, short; anthers connivent around the convex stigma, acute; pollen granular, the grains cohering in small masses. Follicles thick, woody, divergent, ribbed and 3 -winged. Seeds comose. [Greek, hidden integument.] Two known species, the following typical, the other native of Madagascar.

1. Cryptostegia grandifiòra R. Br. Bot. Reg. pl. 435. 1820.

A stout vine, $2 \mathrm{~m}$. long or longer, the twigs glabrous or nearly so. Leaves elliptic, subcoriaceous, 5-9 cm. long, acute or short-acuminate at the apex, obtuse or somewhat narrowed at the base, glabrous on both sides, the rather stout petioles 1-2 cm. long; inflorescence puberulent; cymes few-several-flowered; sepals broadly lanceolate, acuminate, puberulent, about $1.5 \mathrm{~cm}$. long; corolla pink-purple without, white within, 5-6 $\mathrm{cm}$. long, its lobes ovate; follicles widely divergent, glabrous, pointed, 10-12 $\mathrm{cm}$. long.

Scrub-lands, escaped from cultivation, New Providence and Inagua:-Escaped from cultivation in Cuba and in Florida. Native home unknown, probabiy East Indian. RUBBER-VINE. 


\section{ASCLÉPIAS L. Sp. Pl. 214. 1753.}

Perennial herbs, with entire leaves, and middle-sized or small flowers in umbels. Calyx 5-parted or 5-divided, usually small, the segments or sepals acute, often glandular within. Corolla deeply 5-parted, the segments mostly valvate, reflexed in anthesis. Corona-column generally present. Corona of 5 concave hoods, each bearing within a slender or subulate incurved horn. Filaments connate into a tube; anthers tipped with an inflexed membrane, winged, the wings broadened below the middle; pollen-masses solitary in each sac, pèndulous on their caudicles. Stigma nearly flat, 5-angled or 5-lobed. Follicles acuminate. Seeds comose in all but one species. [Dedicated to Æsculapius.] About 95 species, mostly natives of the New World. Type species: Asclepias syriaca I.

1. Asclepias curassávica L. Sp. Pl. 215. 1753.

Asclepias curassavica concolor Krug \& Urban; Urban, Symb. Ant. 1: 389. 1899.

Glabrous, or finely pubescent above, $8 \mathrm{dm}$. high or less. Leaves opposite, oblong to oblong-lanceolate, thin, 5-12 $\mathrm{cm}$. long, acute or acuminate, the petioles 5-15 mm. long; umbels usually several, few-several-flowered; pedicels 1-2 cm. long; corolla-lobes sed-purple, 6-8 mm. long, ovate to oblong; column distinct; hoods erect, ovate, about $4 \mathrm{~mm}$. high, obtuse, flattened, shorter than the flat, curved horn; fruiting pedicels erect; follicles fusiform, glabrous or minutely pubescent, $3-10 \mathrm{~cm}$. long; seeds $6 \mathrm{~mm}$. long, the coma $3-4 \mathrm{~mm}$. long.

Waste grounds and coppices, Abaco, Great Bahama, Andros, New Providence and Eleuthera, throughout the archipelago to Grand Turk and Inagua :-Bermuda ; Florida and Louisiana; West Indies and continentai tropical America; Old Worid tropics. Recorded by Herrick and by Dolley as A. paupercula. WILD IPECAC. HIPPO.

3. CALótropis R. Br. in Ait. f. Hort. Kew. ed. 2, 2: 78. 1811.

Shrubs or trees, with broad, nearly sessile, opposite leaves, and rather large flowers in terminal or axillary umbel-like cymes. Calyx 5-parted, bearing several-many glands at the base within. Corolla subrotate, 5 -cleft, with broad lobes; corona-scales 5, fleshy, adnate to the stamen-tube, lobed or toothed, short-spurred. Stamens borne at the base of the corolla; filaments connate, forming a short tube; anthers tipped by an inflexed membrane; pollinia solitary in each sac, pendulous. Follicles thick, pointed. Seeds comose. [Greek, beautiful keel.] Three species, natives of the Old World tropies, the following typical.

1. Calotropis pròcera (Ait.) R. Br. in Ait. f. Hort. Kew. ed. 2, 2: 78. 1811. Asclepias procera Ait. Hort. Kew. 1: 305. 1789.

Arboreous, 1-5 m. high, branched, with the aspect of a gigantic herb. Leaves bovate-oblong to broadly elliptic or nearly orbicular, mostly cuspidate at the apex, cordate at the base, white-felted when young, glabrous when old; the stout petiole $1 \mathrm{~cm}$. long or less; cymes $5-8 \mathrm{~cm}$. broad, several-many-flowered, on stout peduncles 4-8 cm. long; pedicels 1-3 cm. long; calyx-segments ovate, about $4 \mathrm{~mm}$. long; corolla white, tinged with red, $2-2.5 \mathrm{~cm}$. broad; follicles swollen, $3-8 \mathrm{~cm}$. long.

Flelds and waste places, spontaneous after cuitivation, New Providence, Eleuthera, Littie San Salvador, Cat Island, Long Island, Fortune Isiand, East Caicos, Dellis' Cay, Salt Cay and Grand Turk:- West Indies and continental tropical America; Old Worid tropics. GIANT MILK-WEed. ST. Thomas Bush. Wild Down. WILD COTTON. 
4. Metastélma R. Br. Mem. Wern. Soc. 1: 52.1809.

Slender perennial vines, with small opposite leaves, and small white or greenish flowers in axillary cymes. Calyx-lobes 5; usually with a gland in each sinus. Corolla subrotate or campanulate, rather deeply 5-lobed. Corona simple, 5-parted, its segments narrow. Pollinia waxy. Gynostegium sessíle or stipitate. Stigma flat. Follicles small, slender, smooth. [Greek, referring to the parted corona.] Fifty species or more, natives of tropical and subtropical America. Type species: Cynanchum parviflorum $\mathrm{Sw}$.

Gynostegium long-stipitate.

Gynostegium sessile or subsessile.

Corona longer than the gynostegium.

Corona as long as the gynostegium or shorter.

Corolla-iobes papillose-pubescent or villous within.

Corolla-lobes papillose-pubescent within. Leaves ovate to oblong or lanceolate. Leaves oblanceolate to spatulate. Corolla-lobes villous within.

Leaves linear to linear-oblong.

Leaves elongated-linear, $1.5 \mathrm{~mm}$. wide.

Leaves linear to linear-oblong, 2-3 $\mathrm{mm}$. wide. Leaves obovate to spatulate. Leaves obovate to spatulate.
Corolla-lobes glabrous; cymes long-peduncled; corolla- 7. M. Marbatum. lobes acute; leaves linear.
1. M. Northropiae.

2. M. hamatum.

3. M. bahamense. 4. M. inaguense.

5. M. linearifolium.

8. M. palustre.

1. Metastelma Northròpiae Schltr. in Urban, Symb. Ant. 5: 468.1908.

A slender glabrous vine, 1-2 m. long. Leaves ovate to oblong or oblonglanceolate, $1.5-3 \mathrm{~cm}$. long, acute at the apex, rounded or narrowed at the base, the slender petiole 3-8 mm. long; cymes few-flowered, on peduncles about as long as the petioles; calyx-lobes ovate, obtuse or acutish; corolla about $5 \mathrm{~mm}$. long, 5-lobed, glabrous without, pubescent within, its lobes oblong, obtuse; gynostegium long-stipitate; corona-segments linear, acute; follicles linear, glabrous, 5-6 cm. long.

White-lands, coppices and scrub-lands. Andros and Great Bahama to Cat Island and Little San Salvador; Florida; Cuba. Referred by Mrs. Northrop to $M$. bahamense Griseb., which it much resembles, except in its long-stipitate gynostegium. Northrop's Metastelma.

2. Metastelma hamàtum Griseb. Cat. Pl. Cub. 173. 1866.

A slender glabrous vine. Leaves ovate to oblong or linear, acute at the apex, rounded or narrowed at the base, 1-2 $\mathrm{cm}$. long, 2-7 $\mathrm{mm}$. wide, the petiole 2-6 $\mathrm{mm}$. long; cymes few-flowered, short-peduncled; calyx-lobes ovate, obtuse or acutish; corolla deeply 5-lobed, the lobes oblong-lanceolate, obtuse or acutish, puberulent within; corona-segments linear-lanceolate, about twice as long as the sessile gynostegium.

White-lands and rocky soll, Cat Cay, Littie Inagua, Castle Island, Caicos Islands, Grand Turk :-Cuba.

3. Metastelma bahaménse Griseb. Cat. Pl. Cub. 174. 1866.

Metastelma cubense Griseb. Fl. Br. W. I. 417. 1861. Not Dene. 1844. Epicion bahamense Small, Fl. Miami 149, 200. 1912.

A slender glabrous vine, sometimes $3 \mathrm{~m}$. long. Leaves oblong, ovate or ablong-lanceolate, 1-3 cm. long, acute or mucronate at the apex, mostly rounded at the base, the petiole 3-7 mm. long; cymes few-several-flowered, short-peduncled; calyx-lobes oblong to ovate, acutish or obtuse; corolla deeply 5-cleft, 3-5 mm. long, its lobes oblong, papillose-puberulent on the inner side; corona-segments oblong-lanceolate, acuminate, about as long as the shortstipitate gynostegium; follicles linear, 4-7 cm. long.

Scrub-iands and white-lands, throughout the archipelago from Abaco and the Berry Islands to Mariguana and the Anguilla Isles.-Florida ; Cuba.

Prof. Coker's doubtful record of $M$. brachystephanum Griseb. probabiy refers to this species; his specimen is imperfect. Referred by Hitchcock to $M$. Schlechtendahtit Dene. BaHama Metastelma. 
4. Metastelma inaguénse Vail, Bull. N. Y. Bot. Gard. 4: 142. 1906.

A glabrous vine. Stems slender, terete; leaves $2-4 \mathrm{~cm}$. long, obovate, oblong-obovate or linear-obovate to linear-oblanceolate, obtuse, rounded and apiculate at the apex, tapering to a short petiole (or when linear-lanceolate acute at each end); cymes short-peduncled; calyx-segments ovate, obtuse, glabrous; corolla deeply 5-parted, the segments 3-3.5 $\mathrm{mm}$. long, oblong or linear-oblong, obtuse, glabrous outside, papillose-puberulent except in the center and towards the base within; corona-segments subulate, acute.

Scrub-lands, sand-dunes and white-lands. Conception Island, Watling's Island and Inagua. Endemic. Inagua Metastelma.

5. Metastelma linearifòlium A. Rich. in Sagra, Hist. Cub. 11: 96.1850.

A very slender glabrous vine, 3-10 $\mathrm{dm}$. long. Leaves narrowly linear, 2-4 $\mathrm{cm}$. long, 1-1.5 mm. wide, acute, the petioles 1-2 $\mathrm{mm}$. long; cymes umbel-like, several-flowered, short-peduncled, the flowers short-pedicelled; calyx-segments ovate, obtuse; corolla white, campanulate, about $3 \mathrm{~mm}$. long, deeply 5 -lobed, the lobes oblong, obtuse, white-villous on the inner side; corona-segments about half as long as the nearly sessile gynostegium; follicles about $5 \mathrm{~cm}$. long.

Pine-lands, Great Bahama, at Eight Mile Rocks:-Cuba. NARRow-LEAved METASTELMa.

\section{Metastelma barbàtum Northrop, Mem. Torr. Bot. Club 12: 58.1902.}

A slender glabrous vine, $1 \mathrm{~m}$. long or less، Leaves linear, linear-lanceolate, or linear-oblong, 1-3.5 cm. long, acute or obtuse and cuspidate at the apex, obtuse at the base, the petioles $2-4 \mathrm{~mm}$. long; cymes few-several-flowered, short-peduncled; pedicels 1-3 mm. long; calyx-lobes ovate, obtuse; corolla greenish-white, deeply 5-cleft, the lobes oblong-lanceolate, obtuse, densely villous within; corona-segments ligulate, about as long as the gynostegium; follicles slender, 3-4 cm. long.

Borders of brackish marshes and savannas, coppices and pine-lands, Great Bahama, Andros and New Providence. Endemic.

\section{Metastelma Éggersii Schltr. in Urban, Symb. Ant. 1: 258. 1899.}

A rather stout vine, sometimes $2 \mathrm{~m}$. long, the branches glabrous or densely puberulent, often flexuous, somewhat woody. Leaves oblong-spatulate to obovate, $0.7-1.5 \mathrm{~cm}$. long, obtuse or retuse at the apex, narrowed at the base, glabrous, subcoriaceous, usually fascicled, the midvein distinct, the lateral venation obscure, the petioles very short; flowers mostly solitary in the axils, yellowish-green or whitish, the glabrous or puberulent pedicels about as long as the calyx; calyx-lobes oblong, obtuse; corolla-lobes oblong, obtuse, villous within, 3-1 mm. long; corona-segments lanceolate; follicles 3-4 cm. long.

White-lands and scrub-lands, Whale Cay, Eleuthera, Cat Island, Mariguana, Atwood Cay, Great Ragged Island, Fortune Island, Castle Island, Crooked Island, Calcos Islands, Grand Turk and Inagua. Endemic. Referred to by Dolley as Oxypetalum sp. EGgers' METASTELMa.

8. Metastelma palùstre (Pursh) Schltr. in Urban, Symb. Ant. 1: 258. 1899.

Ceropegia palustris Pursh, Fl. Am. Sept. 1: 184. 1814.

Lyonia maritima Ell. Bot. S. C. \& Ga. 1: 316. 1817.

Seutera maritima Dene. in DC. Prodr. 8: 590. 1844.

Vincetoxicum palustre A. Gray, Syn. Fl. 21: 102.1878.

Lyonia palustris Small, Fl. Miami 149, 200. 1912.

A slender glabrous vine, 5-10 dm. long. Leaves narrowly linear, acute, short-petioled, 2-8 cm. long, 1.5-3 mm. wide; peduncles slender, mostly shorter than the leaves; cymes several-flowered; calyx 2-2.5 mm. long, its lobes lanceolate or ovate-lanceolate, acute; corolla purplish or greenish-white, about 8 
$\mathrm{mm}$. broad, its lobes ovate, acuminate; crown-lobes $1.5-2 \mathrm{~mm}$. long, retuse; anther-wings $1 \mathrm{~mm}$. long; follicles $4.5-7 \mathrm{~cm}$. long, slender, about $5 \mathrm{~mm}$. thick.

Borders of sallnas and salt marshes, Frozen Cay, Andros, New Providence, Eleuthera, Cat Island, Watling's, Long Island, Fortune Island, Mariguana, Green Cay and Inagua :- North Carolina to Florida and Texas; Cuba. Marsh Metasterma.

\section{PHILIBERTÉLldA Vail, Bull. Torr. Club 24: 305. 1897.}

Twining vines, with opposite leaves and cymose axillary flowers, their buds 5-angled. Calyx small, 5-parted. Corolla subrotate or widely campanulate, 5-lobed. Corona double, the exterior one annular, adnate to the base of the corolla, the interior one of 5 scales. Stamens borne on the base of the corolla, the filaments united into a short tube, the anthers with a terminal inflexed membrane. Pollinia solitary in each cell, oblong, waxy. Follicles elongated, smooth. [Commemorates J., C. Philibert.] About 30 species of tropical and subtropical America. Type species: Philibertella clausa (Jacq.) Vail.

1. Philibertella claùsa (Jacq.) Vail, Bull. Torr. Club 24: 306. 1897.

Asclepias clausa Jacq. Enum. 17. 1760.

Sarcostemma Brownei Meyer; Spreng. Syst. 1: 854. 1825.

Philibertia clausa Schum, in Engl. \& Prantl, Nat. Pflanzf. 4²: 229. 1895.

A somewhat fleshy, herbaceous vine often $3 \mathrm{~m}$. long or longer. Leaves oblong to oblong-lanceolate or ovate-oblong, short-petioled, 3-8 cm. long, glabrous, acute or acuminate at the apex, rounded or subcordate at the base; peduncles glabrous, longer than the leaves; umbels several-flowered; pedicels slender, puberulent, 7-12 $\mathrm{mm}$. long; calyx puberulent, $4 \mathrm{~mm}$. long, its lobes oblonglanceolate; corolla white, $10-12 \mathrm{~mm}$. broad, its lobes oblong or ovate; follicles glabrous, 5-8 $\mathrm{em}$. long.

Wet places, Great Bahama and New Providence:-Florida; Cuba; Hispanlola ; Jamalca; Grenada. MruK ViNe.

Marsdenia foribunda (Brongn.) Schltr. (Stephanotis floribunda Brongn.) recorded by Dolley as cultivated in gardens is not known to us as having become spontaneous at any place in the islands.

Fruiting specimens of an undetermined asclepiadaceous vine, with lanceolate leaves and a fuslform follicle, were collected by Small \& Carter, in pine-lands near Lisbon Creek, Mangrove Cay, Andros, perhaps a specles of Astephanus.

\section{Order 4. POLEMONIÀLES.}

Mostly herbs; rarely shrubs or trees. Corolla almost always gamopetalous, regular or irregular. Stamens adnate to the corolla-tube usually to the middle or beyond, as many as the corolla-lobes, or fewer and alternate with them. Ovary 1, superior, compound (in Boraginaceae and Lamiaceae deeply 4-lobed around the style).

\section{a. Corolla regular.}

1. Ovary not 4-lobed, the carpels not separating as distinct nutlets at maturity.

Ovary 2-celled, rarely 3-4-celled.

Leaves and flowers mostly large; plants not parasitic.

Ovary 2-4-celled.

Ovary 2-divided.

Leaves none; flowers very small ; slender parasitlc vines.

Ovary 1-celled; style 1, 2-lobed, or 2-parted.

2. Ovary deeply 4-iobed around the style, or not lobed;

carpels mostly separating as distinct nutlets.

Ovary not lobed; styles terminal.

Style arising from between the ovary-lobes.

Fam. 1. Convolvulaceae.

Fam. 2. DiCHONDRACEAE.

Fam. 3. Cuscutachae.

Fam. 4. HYDROPHYLLACEAE.

Fam. 5. Ehretiaceae.

Fam. 6. BORAGINACEAE. 
b. Corolla irregular, more or less 2-lipped (regular in SolanAceAt, and nearly or quite so in Verbena and Callicarpa of the VerbenACEAE).

1. Carpels 1-2-seeded.

Ovary not lobed, 2-4-celled, the style apical; carpels separating into 1-seeded nutlets or fruit drupaceous. Fam. 7. Verbenackat. Ovary 4-lobed around the style, the lobes ripening into 1 -seeded nutlets.

Fam. 8. LAMIACEAE.

2. Carpels several-many-seeded (2-seeded in some Acanthaceae).

¥ Fruit a berry, or more commonly a capsule which is $1-2$-celled, 2-valved, circumscissile, or irregularly bursting, not elastically dehiscent.

Placentae axile.

Flowers regular; fertile stamens 5 (4 in Petunia) ; fruit a berry or capsule.

Flowers more or less Irregular; fertile stamens 2 or 4 ( 5 in Verbascum) ; fruit a capsule. Ovary 2-celled, rarely $3-5$-celled.

Ovary 1-celled; marsh or aquatic herbs with flowers on scapes.

Placentae parietal.

Trees, shrubs, or woody vines; capsule 2-celled.

Herbs, annual or perennial.

Ovary 2-celled or falsely 4-celled; flowers axil-

Ovary 1-celled; flowers in terminal racemes.

Fam. 9. Solanaceae.

Fam. 10. Scrophulariaceat.

Fam. 11. Lentibulariaceae.

Fam. 12. BignoniaceaE.

Fam. 13. Pedaliaceae.

Fam. 14. MARTX NiAceas.

$\ddagger$ Capsule completely 2-celled, elastically loculicidally dehiscent; opposite-leaved herbs; placentae axile. Fam. 15. ACANTHACEAz.

3. Ovary 2-celled with 1 ovule in each cavity; trees or shrubs with alternate leaves. Fam. 16. MYoporaceia.

\section{Family 1. CONVOLVULÀCEAE Vent.}

\section{MORNING-GLORY FAMILY.}

Herbs or vines, some tropical species shrubs or trees, with alternate estipulate leaves, and regular perfect axillary cymose or solitary flowers. Calyx inferior, 5-parted or 5-divided, usually persistent, the segments or sepals imbricated. Corolla gamopetalous, the limb 5-angled, 5-lobed or entire. Stamens 5, inserted low down on the tube of the corolla and alternate with its lobes, all anther-bearing, the filaments filiform, or dilated at the base; anthers 2-celled, the sacs longitudinally dehiscent. Disk annular or none. Ovary superior, sessile, 2-3-celled, with 2 ovules in each cavity, or falsely 4-6-celled with a single ovule in each cavity, usually entire; styles 1-3, terminal, ovules anatropous. Fruit mostly a 2-4-valved capsule. Seeds erect, the testa villous, pubescent or glabrous; embryo plaited or crumpled; cotyledons foliaceous; endosperm fleshy or cartilaginous, usually seanty. About 45 genera and probably 1,000 species, of wide distribution.

Pericarp dehiscent.

Styles separate nearly or quite to the base.

Styles united up to the stigma or stigmas.

Stigmas oval to oblong, flattened.

Stigmas globose.

Stamens and style exserted.

Corolla-limb very broad, the tube cylindric.

Corolla funnelform or salverform.

Ovary 4-celled; herbaceous vines.

Ovary 2-celled; vines woody at the base.

Stamens and style included.
Pericarp indebiscent; sepals spreading in fruit.

1. Evolvulus.

2. Jacquemontia.

3. Calonyction.

4. Quamoclit.

5. Exogonium.

6. Ipomoea.

7. Turbina.

1. EvótvUuUs L. Sp. Pl. ed. 22, 391. 1762.

Mostly silky-pubescent or pilose herbs, with small leaves, and axillary small flowers. Sepals nearly equal. Corolla funnelform, eampanulate or rotate, the 
limb plaited, 5-angled or 5-lobed. Filaments filiform; anthers ovate or oblong. Ovary entire, 2-celled; styles separate to the base, or near it, each division deeply 2-cleft; stigmas linear-filiform. Capsule 2-4-valved, 1-4-seeded. Seeds glabrous. [Latin, unrolling.] About 85 species, of warm and tropical regions. Type species: Evolvulus nummularius L.

Erect low shrubs with small linear or scale-like leaves.

Leaves scale-like; calyx-lobes ovate.

Leaves linear, 6-15 mm. long; calyx-lobes lanceolate.

Prostrate, creeping or erect herbs.

Leaves ovate, $3-6 \mathrm{~mm}$. long; plant silvery-pubescent.

Leaves linear, or oblong to orbicular; plants glabrous or pubescent.

Leaves suborbicular to orbicular-obovate, rounded or notched at the apex.

Leaves linear to oblong, acute or mucronate.

Peduncles 1-flowered, very short, much shorter than the leaves.

Peduncles filiform, elongated, 1-several-flowered, mostly as long as the leaves or longer.

Leaves oblong-obovate, mucronulate; sepals about one-third as long as corolla.

Leaves linear to oblong, acute or obtusish ; sepals at least one-half as long as corolla. Plant pilose-pubescent; leaves oblong to oblong-lanceolate, bluntish.

Plant sparingly pubescent or glabrate; leaves linear-lanceolate or linear-oblong, acute.

1. E. squamosus.

2. E. bahamensis.

3. E. Bracei.

4. E. nummularius.

5. E. sericeus.

6. E. glaber.

7. E. alsinoides.

8. E. linifolius.

1. Evolvulus squamòsus Britton, Bull. N. Y. Bot. Gard. 3: 449.1905.

An intricately branched erect shrub, $3 \mathrm{dm}$. high or less, the slender terete twigs densely appressed-pubescent. Leaves scattered, reduced to mere lanceolate-acuminate scales, $2 \mathrm{~mm}$. long or less, appressed-pubescent; flowers solitary in the upper axils, on appressed-pubescent peduncles, which are about as long as the calyx; calyx-lobes ovate, acute, appressed-pubescent, one-half as long as the white corolla, or less; corolla about $6 \mathrm{~mm}$. broad, slightly 5 -lobed, the broad lobes a little emarginate; stamens a little shorter than the corolla, their filaments filiform, their anthers oval, short; ovary densely pubescent, oblong; styles 2, 2-cleft to about the middle.

Rocky coppices and scrub-lands, Andros, New Providence, Eleuthera, Cat Island, Cay north of Wide Opening, Great Guana Cay and Great Exuma :-Anegada. Recorded as $E$. arbuscula Poir. by Mrs. Northrop and by Dolley. Broom-BUSH.

\section{Evolvulus bahaménsis House, Bull. Torr. Club 35: 89. 1908.}

Shrubby, erect, intricately branched, appressed-pubescent, 4-10 dm. high, the branches wiry. Leaves linear, 6-15 mm. long, about $1 \mathrm{~mm}$. wide, ascending or appressed; flowers axillary, solitary, on peduncles about $5 \mathrm{~mm}$. long; calyxlobes lanceolate or ovate-lanceolate, long-acuminate, 2-3 $\mathrm{mm}$. long; corolla white, 1.2-2 cm. broad, its limb nearly entire; stamens nearly as long as the corolla.

Rocky plains and scrub-lands, Eleuthera, Conception Island, Watling's, Mariguana, North Calcos, Ambergris Cay, Great Ragged Island, Fortune Island, Crooked Island, Acklin's and Inagua. Endemic. Referred to $E$. arbuscula Poir. in Bull. N. Y. Bot. Gard. 3 : 450, 1905 ; also by Hitchcock, by Coker and by Grisebach. BAHAMA Evolvelus.

\section{Evolvulus Bràcei House, Bull. Torr. Club 35: 90.1908.}

Perennial by woody roots; stems several, 5-20 cm. long, simple or branched, prostrate or ascending, appressed-pubescent with long white hairs when young. Leaves close together, ovate or elliptic-ovate, 3-6 $\mathrm{mm}$. long, acute or shortacuminate at the apex, rounded or narrowed at the base, nearly sessile, loosely long-pubescent above, densely so beneath; flowers solitary and short-peduncled in the upper axils; calyx-lobes lanceolate, acuminate, about $2.5 \mathrm{~mm}$. long; 
corolla white or pale blue, about $7 \mathrm{~mm}$. broad; capsule globose, about $2.5 \mathrm{~mm}$. in diameter; seeds brown.

Red soil in open places, Mangrove Cay, Andros, Crooked Island, Mariguana and North Caicos:-Cuba. BRACE's Evolvelus.

4. Evolvulus nummulàrius L. Sp. Pl. ed. 2, 391. 1762.

Diffuse, herbaceous, the stems $5-20 \mathrm{~cm}$. long, branched, the branches rooting at the nodes, pilose or glabrate. Leaves orbicular or broadly oval, 4-20 mm. long, rounded or retuse at the apex, obtuse or subcordate at the base, short-petioled, pilose or glabrate; peduncles 1-flowered, much shorter than the leaves; sepals oblong or oblong-obovate, obtuse, about $2 \mathrm{~mm}$. long; corolla pale blue or white, 5-8 $\mathrm{mm}$. in diameter; capsule globose, $2 \mathrm{~mm}$. in diameter.

Shaded moist places and red-lands, New Providence, Eleuthera, Cat Island, Watling's, Mariguana, Great Exuma, Crooked Island and North Caicos:-Cuba to St. Jan and Grenada; Mexico to Colombia. Moneywort Evolvulus.

5. Evolvulus serìceus Sw. Prodr. 55. 1788.

Herbaceous, erect or ascending, usually branched from near the base, slender, silky-pubescent, 1-3 dm. high. Leaves linear, lanceolate or narrowly oblanceolate, nearly sessile, $1-2.5 \mathrm{~cm}$. long, about $3 \mathrm{~mm}$. wide or less, acute or acuminate; peduncles 1-flowered, much shorter than the leaves, often shorter than the calyx; sepals lanceolate to ovate-lanceolate, acute or acuminate, 3-4 $\mathrm{mm}$. long; corolla white or pale blue, 6-10 $\mathrm{mm}$. broad; capsule subglobose, about as long as the calyx.

Pine-lands and palmetto-lands, Great Bahama and New Providence:-southeastern United States ; Jamaica ; Cuba to Anegada and St. Vincent. SILKY EvolvulUs.

6. Evolvulus glàber Spreng. Syst. 1: 862. 1825.

Evolvulus mucronatus Sw.; Wikstr. Vet. Akad. Handl. Stockh. 1827: 61. 1827.

Finely silky-pubescent when young, becoming glabrate, branched, the branches very slender, prostrate or ascending, $4 \mathrm{dm}$. long or less. Leaves oblong to obovate, 1-3 cm. long, mucronate, short-petioled; peduncles nearly filiform, as long as the leaves or longer; pedicels longer than the flowers; sepals oblong or ovate-oblong, acute, $3-4.5 \mathrm{~mm}$. long; corolla rotate, white, 7-10 $\mathrm{mm}$. broad; capsule subglobose, $2-2.5 \mathrm{~mm}$. in diameter.

Margins of salinas and salt ponds, Long Island, Fortune Island, Acklin's, Mariguana, Caicos, Grand Turk and Inagua :-Florida ; Cuba ; West Indies and northern South America. SMooth Evolvulus.

\section{Evolvulus alsinoides L. Sp. Pl. ed. 2, 392. 1762.}

Villous; stems usually several from a deep root, slender, simple or branched, prostrate or ascending, 1-4 $\mathrm{dm}$. long. Leaves oblong or oblong-lanceolate, 0.8$2.5 \mathrm{~cm}$. long, more or less pubescent with long hairs, blunt or acutish at the apex, rounded or narrowed at the base, the petioles 1-2 $\mathrm{mm}$. long; peduncles filiform, 1-5-flowered, mostly longer than the leaves; pedicels filiform; sepals lanceolate or ovate-lanceolate, acuminate, about $2 \mathrm{~mm}$. long; corolla pale blue or white, 6-8 $\mathrm{mm}$. broad; capsule somewhat longer than the calyx.

Waste and cultivated ground, Andros, New Provldence, Eleuthera, Cave Cay, Great Exuma, Long Island, Great Ragged Island, Crooked Island, Mariguana, Inagua and Anguilla Isles:-Florlda to Texas; Cuba; Hispaniola; Aruba; Curaço; Mexico and . South America; Old World tropics. CHICKWEED EvolvULUS.

\section{Evolvulus linifòlius L. Sp. Pl. ed. 2, 392. 1762.}

Pubescent or glabrate; stems several or many from a rather slender root, simple or few-branched, diffuse or nearly erect, $4 \mathrm{dm}$. long or less. Leaves lanceolate, linear-lanceolate or linear-oblong, 1-2 cm. long, acute or mucronate, 
nearly sessile; peduncles filiform, 1-3-flowered, mostly longer than the leaves; sepals lanceolate, acute or acuminate, $2-3 \mathrm{~mm}$. long; corolla white or pale blue, ग-6 $\mathrm{mm}$. broad; capsule longer than the calyx.

Bahamas (according to Grisebach):-Jamaica; continental tropical America; old World tropics. NARROW-LEAVED EvolvUlus.

\section{JACQUEMóntia Choisy, Mem. Soc. Phys. Gen. 6: 476. 1833.}

Trailing or climbing vines, mostly herbaceous, the leaves usually entire, the mostly small, violet blue or white flowers cymose or subcapitate. Sepals nearly equal or the outer ones larger than the inner. Corolla campanulate or rotate-campanulate, the limb 5-angled. Stamens shorter than the corolla; filaments filiform, or their bases dilated; anthers oblong. Ovary 2-celled; ovules mostly 4; united styles filiform; stigmas 2. Capsule small, 2-celled. [Commemorates Victor Jacquemont, a French botanical traveller, died 1828.] Thirty species or more, mostly of tropical and subtropical America. Type species: Convolvulus coeruleus Schum.

Corolla only 3-4 mm. broad; cymes sessile or nearly so.

Corolla 1-5 cm. broad.

Corolla white; leaves not cordate; cymes short-peduncled. Leaves linear to oblong-lanceolate.

Leaves ovate-oval to suborblcular, thick and fleshy.

Corolla usually blue; leaves cordate or subcordate; cymes long-peduncled.

1. J. verticillata.

2. J. jamaicensis. 3. J. cayensis.

4. J. pentantha.

1. Jacquemontia verticillàta (L.) Urban, Symb. Ant. 3: 339. 1902.

I pomoea verticillata L. Syst. ed. 10, 924. 1759.

Convolvulus micranthus R. \& S. Syst. 4: 276. 1819.

Jacquemontia micrantha G. Don. Gen. Syst. 4: 283. 1838.

Stems very slender, appressed-pubescent at least above, $2 \mathrm{~m}$. long or less. Leaves oblong to lanceolate, membranous, repand or entire-margined, $1 . \overline{-}-4 \mathrm{~cm}$. long, mucronate at the apex, cordate or subcordate at the base, more or less pubescent, short-petioled; cymes sessile or very short-peduncled, several-flowered; pedicels about as long as the sepals; sepals ovate-lanceolate, acute, 2.5-3 $\mathrm{mm}$. long: corolla $3-4 \mathrm{~mm}$. broad, purple or pink, its limb 5-cleft; capsule globose, about $2 \mathrm{~mm}$. in diameter; seeds brownish, rugulose.

Waste and cultivated ground, Andros and New Providence:-Cuba; Hispaniola; Jamaica. SMALL-FLOWERED JACQUEMONTIA.

2. Jacquemontia jamaicénsis (Jacq.) Hallier f.; Solereder, Syst. Anat. 641. 1899.

Convolvulus jamaicensis Jacq. Obs. 3: 6. 1768.

Finely pubescent or glabrate; stems slender, 1-2 m. long. Leaves lanceolate to oblong, entire, rather firm in texture, short-petioled, $1.5-4 \mathrm{~cm}$. long, obtuse, mucronulate or acute at the apex, narrowed or rounded at the base, sparingly pubescent or glabrate; cymes 1-several-flowered, short-peduncled; sepals broad, ovate, acute, about $2 \mathrm{~mm}$. long; corolla white or purplish, 1-1.5 $\mathrm{cm}$. broad, the limb 5-cleft, the narrow segments acute; capsule subglobose, about $4 \mathrm{~mm}$. long; seeds rough.

Pine-lands and scrub-lands, throughout the archipelago from Great Bahama and the Berrv Islands to Marlguana, the Inaguas, and the Angullia Isles:-Florida; Cuba to St. Thomas and St. Croix; Jamaica. Recorded from Bermuda. The species evidently consists of a large number of races differing greatly in leaf-form and in pubescence: none of the Bahamlan plants collected are exactly identical with the typical race from Jamaica. Common JACQUEmontia. 


\section{Jacquemontia cayénsis Britton, sp. nov.}

Stem rather stout, somewhat woody, branched, trailing or ascending, 0.5$2.5 \mathrm{~m}$. long, finely pubescent or glabrate. Leaves fleshy, oblong to broadly ovate, entire, 1-3 cm. long, obtuse, retuse or acute at the apex, narrowed or rounded at the base, short-petioled, sparingly pubescent or glabrous; peduncles shorter than the leaves; cymes few-flowered; sepals ovate, apiculate, about 2 $\mathrm{mm}$. long; corolla white or yellowish, 5-cleft, 8-12 mm. broad; capsule ovoidglobose, about $5 \mathrm{~mm}$. long.

Coastal rocks, white-lands and sands, Abaco and Great Bahama to Grand Turk, Inagua and Cay Sal :-Cuba; Anegada. Type from Castle Island (Wilson 7791). Referred in Bull. N. Y. Bot. Gard. 4: 121 to J. reclinata House, of Florida, which proves to be distinct. Fleshy JACQuemontia.

\section{Jacquemontia pentántha (Jacq.) G. Don, Gen. Syst. 4: 283. 1838.}

Convolvulus pentanthos Jacq. Coll. 4: 210. 1790.

Jacquemontia violacea Choisy, Mem. Soc. Phys. Genéve 8: 61. 1838.

Slender, glabrate or densely pubescent, 0.5-2 m. long, sometimes much branched. Leaves ovate, $2-4 \mathrm{~cm}$. long, slender-petioled, entire or slightly repand, acute or acuminate at the apex, cordate at the base; peduncles slender, mostly as long as the leaves or longer; cymes dense, several-flowered; pedicels usually shorter than the calyx; sepals ovate to lanceolate, acute or acuminate, 5-7. $\mathrm{mm}$. long, the outer broader than the inner; corolla blue, rarely white, 2-3 em. broad; capsule subglobose, about as long as the sepals or a little shorter.

Angullia Isles:-Florida; West Indies and continental tropical America. BLue JACQUEMONTIA.

3. CALONÝCtron Choisy, Mem. Soc. Phys. Genéve 6: 441. 1833.

Long twining vines, with large, entire or 3-lobed leaves and large white nocturnal flowers. Sepals herbaceous or subcoriaceous, the outer appendaged or unappendaged. Corolla long-salverform with a nearly cylindric tube. Stamens and style exserted. Styles united; stigmas globose. Fruit a dehiscent oval or oblong capsule. [Greek, night-beauty.] A few species, of tropical regions. Type species: Calonyction speciosum Choisy.

Outer sepals with infraterminal tall-like appendages; stems more or less aculeate.

Outer sepals without appendages; stems not aculeate.

1. C. aculeatum.

2. C. Tuba.

1. Calonyction aculeàtum (L.) House, Bull. Torr. Olub 31: 590. 1904.

Convolvulus aculeatus L. Sp. Pl. 155. 1753.

Ipomoea bona-nox L. Sp. Pl. ed. 2, 228. 1762.

Glabrous, trailing or high-climbing, sometimes $20 \mathrm{~m}$. long or longer, the sap milky. Leaves orbicular-ovate, membranous, 5-15 cm. long, entire, repand or sometimes 3-lobed, long-petioled, acuminate at the apex, deeply cordate at the base; peduncles 1-several-flowered, stout, shorter than the leaves; sepals about $1 \mathrm{~cm}$. long, appressed, the outer subulate-appendaged; corolla-tube slender, 10-12 $\mathrm{em}$. long, the limb 8-10 cm. wide, each lobe with a broad green median band terminating in a cusp; capsule ovoid, pointed, about $2 \mathrm{~cm}$. long; seeds glabrous or nearly so.

New Providence and Acklin's Island:-Florida: Cuba to Porto Rico; Guadeloupe; Martinque; Jamalca; Trinidad; Curaçao; Mexico to Panama. Moon-vinE. 
2. Calonyction Tùba (Schlecht.) Colla, Nov. Sp. Calon. 15. 1840.

Convolvulus Tuba Schlecht. Linnaea 6: 735. 1831.

Calonyction grandiflorum Choisy, Mem. Soc. Phys. Genéve 6: 442.1833.

Ipomoea tuba G. Don. Gen. Syst. 4: 271. 1838.

Calonyction album House, Bull. Torr. Club 31: 591. 1904. Not Ipomoea alba L. 1753.

Glabrous, fleshy, usually climbing, sometimes $10 \mathrm{~m}$. long. Leaves ovateorbicular, slender-petioled, 6-10 cm. long, acute or short-acuminate at the apex, deeply cordate at the base; peduncles stout, 1-2-flowered, shorter than the leaves; sepals ovate-oblong, obtuse, appressed, about $2 \mathrm{~cm}$. long; corolla white, its tube stout, cylindric, 5-6 $\mathrm{cm}$. long, the limb 5-6 $\mathrm{cm}$. broad, with 5 narrow greenish bands; capsule subglobose, $2-2.5 \mathrm{~cm}$. in diameter; seeds densely puberulent, villous on the angles and at the hilum.

Sandy shores, Abaco, Frozen Cay, South Cat Cay, Andros, New Providence, Ship Channel Cay, Eleuthera, Conception, Watling's, Rum Cay, Irong Isiand, Mariguana, Inagua, Gibb's Cay, Anguilla Isles, Water Cay and Cay Sal:-Florida : Cuba to St. Jan and Martinique; Jamaica; continental tropical America and Old World tropics. Recorded by Mrs. Northrop as Ipomoea grandiflora Lam. COAST MooN-viNE.

\section{QUÁMOCLIT [Tourn.] Moench, Meth. 453. 1794.}

Twining herbaceous vines, with petioled leaves, and peduncled axillary flowers. Sepals 5, herbaceous, equal, acuminate, mucronate or appendaged. Corolla salverform (scarlet in the following species), the tube longer than the spreading limb. Stamens and united styles exserted; stigma capitate; ovary 2-celled or falsely 4-celled, 4-ovuled. Capsule usually 4-celled and 4-seeded. [Greek, dwarf kidney-bean.] About 10 species, of warm and tropical regions. Type species: Ipomoea coccinea $\mathrm{L}$.

Leaves pinnately parted into very narrow segments.

Leaves cordate, acuminate, entire or angulate-lobed.

1. Q. Quamoclit.

2. Q. cocinea.

1. Quamoclit Quámoclit (L.) Britton, in Britton \& Brown, Ill. Fl. 3: 22.1898.

Ipomoea Quamoclit L. Sp. Pl. 159. 1753.

Quamoclit vulgaris Choisy, in DC. Prodr. 9: 336. 1845.

Annual, glabrous. Leaves ovate in outline, 5-18 $\mathrm{cm}$. long, pinnately parted into segments less than $2 \mathrm{~mm}$. wide; peduncles 1-6-flowered; pedicels thickening in fruit; sepals obtuse, usually mucronulate, 4-6 $\mathrm{mm}$. long; corolla $2.5-4$ $\mathrm{cm}$. long, the tube expanded above, the limb nearly flat, the lobes ovate, acutish; ovary 4-celled; capsule ovoid, 4-valved, about $1 \mathrm{~cm}$. high, twice as long as the sepals.

Waste and cuitivated ground, Abaco near Marsh Harbor:-Virginia to Florida, Kansas and Texas; West Indies; Mexico to continental tropical America ; Old World tropics. CYPRESS VINE.

2. Quamoclit coccinea (L.) Moench, Meth. 453. 1794.

Ipomoea coccinea L. Sp. Pl. 160. 1753.

Annual. Leaves ovate to orbicular, long-acuminate, 5-15 cm. long, entire or angulate-lobed, slender-petioled; peduncles few-several-flowered; sepals obtuse, about $4 \mathrm{~mm}$. long, subulate-appendaged; corolla $2-4 \mathrm{~cm}$. long, the limb obscurely 5-lobed; ovary 4-celled; capsule globose, 4-valved, 6-8 $\mathrm{mm}$. in diameter.

Waste grounds, New Providence, near Nassau :-Pennsylvania to Arizona, Texas and Florida; West Indies; Mexico and continental tropical America. SMALL RED MORNING-GLORY. 
5. ExOGònIUM Choisy, Mem. Soc. Phys. Genéve 6: 443.1833.

Vines, woody at the base, with alternate leaves and showy, cymose or solitary, axillary flowers. Sepais 5, obtuse, somewhat unequal. Corolla salverform or funnelform. Ovary 2-celled; styles united; stigmas globose. Stamens more or less exserted. Fruit a capsule. [Greek, referring to the exserted stamens and styles.] Some 25 species or more, of tropical and subtropical America. Type species: Ipomoea bracteata Cav.

1. Exogonium microdáctylum (Griseb.) House, Bull. Torr. Club 35: 102. 1908.

Ipomoea microdactyla Griseb. Cat. Pl. Cub. 204. 1866.

Exogonium microdactylum integrifolium House, Bull. Torr. Club 35: 103. 1908.

Glabrous, slightly succulent, the stem sometimes spinulose toward the base, 1-3.3 m. long, arising from a large tuber-like root. Leaves various, slenderpetioled, 3-10 cm. long, ovate to lanceolate, entire or palmately several-lobed; cymes few-flowered, short-peduncled; pedicels as long as the peduncle or shorter; sepals orbicular-ovate, about $6 \mathrm{~mm}$. long; corolla scarlet to carmine, its slender tube $2.5-4 \mathrm{~cm}$. lorg, its limb about $2.5 \mathrm{~cm}$. wide, the lobes ovate; capsule subglobose, pointed, 10-12 mm. thick; seeds brown-hairy.

Pine-lands and scrub-lands, throughout the archipelago from Abaco and Great Bahama to Mariguana and Caicos:- Florida; Cuba. Recorded by Grisebach and by Dolley as Ipomoea arenaria Steud. SALVEREORM MORNING-GLORY. Catesby $2: p l$. $8 \%$.

\section{IPOMOÈA L. Sp. Pl. 159. 1753.}

Twining trailing or rarely erect herbs, with large showy axillary flowers. Corolla funnelform or campanulate, the limb entire, 5-angled or 5-lobed, the tube plaited. Stamens included. Ovary entire, 2-4-celled, 4-6-ovuled; styles united, included; stigmas 1 or 2, capitate or globose. Capsule usually septifragally 2-4-valved, 2-4-seeded. [Greek, worm-like.] About 400 species, of wide distribution. Type species: Ipomoea Pes-tigrinus L.

Sepais herbaceous, elongated.

Sepais long-hirsute.

Sepals not long-hirsute.

Leaves silky-pubescent beneath.

Leaves glabrous or nearly so.

Sepals short, coriaceous or membranous.

Stems prostrate or creeping, not twining ; fleshy littoral species.

Flowers purple; leaves suborbicular, notched.

Flowers creamy-white; leaves varlous, oblong to lanceolate and entire or pinnately lobed.

Stems twining, at least their tips.

Seeds with a coma, or covered with long hairs.

Seeds glabrous or pubescent, without a coma.

Roots not fleshy and edible.

Leaves 5-7-parted, the segments toothed or pinnatifid.

Leaves entire, sagittate or 3-lobed.

Leaves sagittate.

Leaves cordate, entire or 3-lobed.

Corolla $2 \mathrm{~cm}$. long or less.

Corolla $5-7 \mathrm{~cm}$. long.

Roots fleshy, edible; leaves various.

1. I. hederacea.

2. I. villosa.

3. I. cathartica.

4. I. Pes-caprae.

5. I. stolonifera.

6. I. carolina.

7. I. dissecta.

8. I. sagittata.

9. I. triloba.

10. I. tiliacea.

11. I. Batatas.

\section{Ipomoea hederàcea Jacq. Icon. Rar. 1: 4, pl. 36. 1786.}

Stem 6-15 dm. long, slender, retrorsely hairy. Leaves ovate-orbicular in outline, long-petioled, deeply 3-lobed, 5-13 cm. long, the lobes ovate, acuminate; peduncles 1-3-flowered, much shorter than the petioles; flowers opening in early morning, soon closing; sepals lanceolate with long linear often recurved tips, ciensely hirsute below, sparingly so above, $1.5-2.5 \mathrm{~cm}$. long; corolla funnelform, 
the tube usually nearly white, the limb light blue or purple; capsule depressedglobose, 3-valved, about as long as the lanceolate portion of the sepals.

Roadsides, New Provldence at Nassau :-continental tropical America. Naturalized in the eastern United States. IVY-LEAVED MORNING-GLORY.

2. Ipomoea villòsa R. \& P. F1. Per. 2: 12. 1799.

Pubescent, twining. Leaves thin, slender-petioled, the blades $7-15 \mathrm{~cm}$. long, pubescent on both sides, entire or 3-lobed, long-acuminate at the apex, deeply cordate at the base; peduncles 1-4-flowered, axillary, as long as the petioles or shorter; bracts linear-lanceolate, 1.5-2.5 cm. long; sepals lanceolate, acuminate, pubescent, about $2.5 \mathrm{~cm}$. long; corolla purple, about $7.5 \mathrm{~cm}$. long.

Sea-beach, Andros, along road to Little Creek:-Bermuda; Trinidad; northern South America; Old World tropics. Included in this flora with doubt, the specimen showing follage only. Villous MORNING-GLORX.

\section{Ipomoea cathártica Poir. in Lam. Encycl. Suppl. 4: 633. 1816.}

Pharbitis cathartica Choisy, in DC. Prodr. 9: 342. 1845.

Perennial, minutely strigillose or glabrate. Stems more or less twining, branching. Leaves broadly ovate, 5-9 $\mathrm{cm}$. long, entire or 3-lobed, acuminate, cordate; peduncles shorter than the subtending petioles; sepals glabrate, linear-lanceolate or ovate-lanceolate, 1-2 cm. long, acuminate ; corolla pinkpurple or erimson, the limb 6-8 $\mathrm{cm}$. broad, undulate; capsules spheroidal, about $1 \mathrm{~cm}$. broad; seeds glabrous, about $3 \mathrm{~mm}$. in diameter.

Scrub-lands, Abaco, Great Bahama, Blminis, Andros, New Providence, Eleuthera, Long Island, Crooked Island and Anguilla Isles:-Bermuda ; Florida ; throughout the West Indies and continental tropical America. The record of. I. purpurea Lam., by Dolley, for the Bahamas, probably refers to this specles, which was entered in Mrs. Northrop's List, in part, as I. jamaicensis Don. Referred by Mrs. Northrop to $I$. commutata R. \& S., and also so referred by Hitchcock. PURPLE MORNING-GLORY. GLORY-MORNING.

\section{Ipomoea Pes-cáprae (L.) Roth, Nov. Sp. 109. 1821.}

Convolvulus Pes-caprae L. Sp. Pl. 159. 1753.

Convolvulus brasiliensis L. Sp. Pl. 159. 1753.

Perennial, glabrous, succulent. Stems prostrate, creeping, sometimes $20 \mathrm{~m}$. long or more, branching; leaves suborbicular, 6-10 $\mathrm{cm}$. broad, usually notched at the apex, rounded or cordate at the base; petioles as long as the blades or shorter; peduncles stout, 1-several-flowered; pedicels more slender than the peduncles; sepals glabrous, oval or suborbicular, about $1 \mathrm{~cm}$. long, obtuse; corolla purple, 4-5 cm. long, its tube broadly funnelform, its limb undulatelylobed, 5-8 cm. broad; capsules broadly ovoid or globose-ovoid, $1.5 \mathrm{~cm}$. high; seeds pubescent.

Sea-beaches and coastal rocks, throughout the archlpelago from Abaco and Great Bahama to Watllng's Island, Inagua, Anguilla Isles and Elbow Cay :-Bermuda; Georgia and Florida; coasts of the West Indies ; continental tropical America and old World troples. BAY HOPS. BAY WINDERS.

\section{Ipomoea stolonífera (Cyrill.) Poir. in Lam. Encycl. 6: 20. 1804.}

Convolvulus littoralis L. Syst. ed. 10, 924. 1759. Not Ipomoea littoralis Blume. 1826.

Ipomoea littoralis Boiss. Fl. Orient. 4: 112.1879.

Stem slender, buried in sand, sending up branches which rise $0.5-2 \mathrm{dm}$. above the surface, glabrous and fleshy. Leaves ovate to ovate-oblong, or broader, long-petioled, fleshy, glabrous, $3-7 \mathrm{~cm}$. long, entire or variously lobed, narrowed at the base or the later ones rounded or cordate; flowers few or solitary; peduncles mostly shorter than the leaves; sepals oval or oblong, 10-15 $\mathrm{mm}$. long, mucronate; corolla white, funnelform-campanulate, 4-5 cm. long; capsules globose, 1-1.5 cm. long; seeds smooth. 
Creeping in littoral sands, North Bimini, Eleuthera, Great Guana Cay, Watling's Island, Mariguana, Delectable Cay :- South Carolina to Florida, Texas, Mexico and South America; Cuba to Culebra and Martinique ; Jamaica (according to Grisebach). Old World tropics. BEACH MORNING-GLORY.

\section{Ipomoea carolìna L. Sṕ. Pl.. 160. 1753. Not Pursh. 1814.}

Ipomoea heptaphylla Griseb. Mem. Am. Acad. II. 8: 527. 1862.

Glabrous, slightly fleshy, climbing, sometimes $8 \mathrm{~m}$. long. Petioles slender, 3-6 cm. long; leaves pedately 4-7-divided, the segments oblanceolate, entire, 3-6 $\mathrm{cm}$. long, obtuse or acute at the apex, cuneate at the base, slender-stalked; peduncles somewhat shorter than the petioles; cymes several-flowered; pedicels short and stout; sepals ovate, obtuse, about $1 \mathrm{~cm}$. long; corolla tubular-campanulate, 3.5-4.5 cm. long; capsule ovoid, 8-10 mm. long; seeds woolly.

Pine-lands and thickets, Andros, New Providence:-Cuba. Catesby, Hist. Carol., 2 : pl. 91. A specimen from Andros (Brace 4950), with foliage only. is referred to this species with doubt. Pedate-leaved Morning-glory.

\section{Ipomoea dissécta (Jacq.) Pursh, Fl. Am. Sept. 145. 1814.}

Convolvulus dissectus Jacq. Obs. 2: 4. 1767.

Ipomoea sinuata Ortega, Hort. Matr. Dec. 84. 1798.

Operculina dissecta House, Bull. Torr. Club 33: 500. 1906.

Perennial, villous-hirsute, or glabrate. Stems twining, branching; leaves suborbicular, 3-10 $\mathrm{cm}$. in diameter, 5-7-parted, the segments oval to oblong or lanceolate, coarsely toothed or pinnatifid; petioles as long as the blades or longer, villous-hirsute; sepals glabrate, oblong to oblong-oval, 1-2.5 $\mathrm{cm}$. long; obtuse; corolla white with purple throat, its tube funnelform, $2-3 \mathrm{~cm}$. long, its limb 3-5 em. broad; capsules about $1.5 \mathrm{~cm}$. long; seeds smooth and glabrous.

Climbing on walls or bushes, Andros, New Providence, Eleuthera, Cat Island and Parrot Cay, Caicos Islands :-Bermuda; Florida to Texas; West Indies and continental tropical America. NoYAU Vine.

\section{Ipomoea sagittàta Lam. Tabl. Encycl. 1: 466. 1791.}

Perennial, glabrous. Stems twining, up to $2 \mathrm{~m}$. long, or longer, branching, relatively slender. Leaves $3-10 \mathrm{~cm}$. long, sagittate or hastate-sagittate, the lobes linear or lanceolate, the lateral about one half as long as the terminal one; petioles about as long as the basal lobes; peduncles usually 1-flowered; sepals glabrous, oblong to suborbicular, 6-9 $\mathrm{mm}$. long, obtuse or cuspidate; corolla purple, 5-6 $\mathrm{cm}$. long, the tube funnelform, the limb 6-7 $\mathrm{cm}$. broad; capsules ovoid, 1-1.5 cm. long; seeds villous.

Palmetto lands and wet sands, Great Bahama, New Providence:-Bermuda ; North Carolina to Florida, Texas and Mexico; Cuba. ARRow-Leaved Morning-GLory.

\section{Ipomoea tríloba L. Sp. Pl. 161. 1753.}

Somewhat pubescent or glabrate; stem herbaceous, slender, 5-10 dm. long, usually trailing. Leaves usually very deeply 3-5-lobed, sometimes entire, ovate, 2-10 cm. long, acute or acuminate at the apex, cordate at the base, the petioles slender; peduncles mostly longer than the petioles, 1-few-flowered; pedicels 1-2 cm. long, thickening in fruit; sepals oblong, acute or mucronate, pilose, 5-6 $\mathrm{mm}$. long; corolla red or purple, funnelform-campanulate, about $1.5 \mathrm{~cm}$. broad; capsule subglobose, pilose, 2 -celled, about $7 \mathrm{~mm}$. in diameter; seeds glabrous.

Waste and cuitivated grounds, throughout the archipelago from Abaco and Great Bahama to Andros, Grand Turk and Inagua :-Florida; West Indies ; continental tropical America; tropical Asia. CrenpiNg MorNing-GLory. 
10. Ipomoea tiliàcea (Willd.) Choisy, in DC. Prodr. 9: 375.1845.

Convolvulus tiliaceus Willd. Enum. 1: 203. 1809.

Convolvulus fastigiatus Roxb. Hort. Beng. 13. 1814.

Ipomoea cymosa G. F. W. Meyer, Prim. FI. Esseq. 99. 1818.

Ipomoea fastigiata Sweet, Hort. Brit. 288. 1826.

Ipomoea gracilis House, Ann. N. Y. Acad. Sci. 18: 248. 1908. Not R. Br. 1810.

Glabrous or sparingly pubescent, twining, up to $2 \mathrm{~m}$. long or longer, the root sometimes tuberiferous. Leaves ovate, 5-8 $\mathrm{cm}$. long, membranous, acute at the apex, cordate at the base, the slender petioles sometimes half as long as the blades; peduncles as long as the petioles or longer; cymes few-severalflowered; pedicels short; sepals oblong, mucronate or aristulate, about $8 \mathrm{~mm}$. long; corolla purple, pink or rarely white, usually with a dark eye, funnelformcampanulate, 5-6 cm. long; capsule 2-celled, subglobose, 8-10 mm. in diameter ; seeds glabrous.

Swampy scrub-lands, Great Bahama and Andros:-Florida; the West Indies ; continental tropical America. DARK-EYED MORNING-GLORY.

11. Ipomoea Batàtas (L.) Lam. Encycl. 6: 14. 1804.

Convolvulus Batatas L. Sp. Pl. 154. 1753.

Rootstocks large, fleshy, a well-known vegetable. Stems glabrous or nearly so, trailing, $1 \mathrm{~m}$. long or longer. Leaves various, ovate to suborbicular, entire, dentate or lobed, acuminate at the apex, cordate at the base, $5-15 \mathrm{~cm}$. long; peduncles as long as the petioles or shorter, few-flowered; sepals oblong, acute, cuspidate, somewhat unequal, 7-10 $\mathrm{mm}$. long; corolla pale purple or nearly white, about $5 \mathrm{~cm}$. long; ovary and capsule 2-celled; seeds glabrous.

Thickets and cultivated solls, spontaneous after cultivation, Abaco, Andros, New Providence and Eleuthera:- spontaneous after cultivation, Florida to Arkansas and Texas; West Indies; continental tropical America, and old World tropics. Native habitat unknown. Catesby, $2: p l$. 60. SweET Potato.

\section{TURBÌNA Raf. Fl. Tell. 4: 81. 1838.}

Vines with cordate leaves, and axillary peduncled clusters of large or middle-sized flowers. Sepals ovate to lanceolate. Corolla campanulate or funnelform. Ovary 2-celled or 4-celled; stigmas 2. Fruit dry, woody, indehiscent, subglobose or ovoid, 1-celled, mostly 1-seeded, the seeds smooth. [Latin, from the supposed top-shaped fruit.] About 20 species, natives of tropical regions, the following typical.

\section{Turbina corymbòsa (L.) Raf. F'. Tell. 4: 81. 1838.}

Convolvulus corymbosus L. Syst. ed. 10, 923.1759.

Convolvulus domingensis Desv. in Lam. Encycl. 3: 554. 1791.

Convolvulus sidaefolius H.B.K. Nov. Gen. 3: 99.1818.

Ipomoea sidaefolia Choisy, Mem. Soc. Phys. Genéve, 6: 459. 1833.

Ipomoea antillana Millsp. Field Mus. Bot. 2: 84. 1900.

High-climbing or trailing, 'glabrous. Leaves slender-petioled, ovate, entire, 4-10 $\mathrm{cm}$. long, acute or acuminate at the apex, cordate at the base; peduncles axillary, as long as the leaves or longer, corymbosely or paniculately severalmany-flowered, the pedicels slender; sepals oblong, persistent, the 3 inner ones 8-12 $\mathrm{mm}$. long, nearly twice as long as the two outer; corolla white, $2.5-3 \mathrm{~cm}$. long; capsule ovoid, acute, about half as long as the longer sepals, 1-seeded.

Coppices, walls and thickets, Andros, New Providence, Cat Island, Watling's Island :- Florida; Bermuda; Cuba to Guadeloupe; Barbadoes; Jamaica ; Mexico to northern South America. Recorded by Mrs. Northrop as Ipomoea fastigiata Sweet. Christmas-vine. Christmas-Flower. 


\section{Family 2. DICHONDRĀ EEAE Dumont.}

\section{DichoNdra FAMILY.}

Prostrate or creeping slender herbs, with nearly orbicular, cordate or reniform, petioled entire leaves, and small solitary axillary peduncled flowers. Sepals nearly equal. Corolla open-campanulate, deeply 5-lobed. Stamens shorter than the corolla; filaments filiform. Ovary villous, deeply 2-parted, each lobe 2-celled; styles 2, simple, arising from the bases of the ovary-lobes; stigmas capitate. Fruit of two pubescent, 2-valved or indehiscent, 1-2-seeded capsules. Only the following genus.

\section{DICHóNDRA Forst. Char. Gen. 39. 1776.}

Characters of the family. [Greek, two-grained, referring to the capsules.] About 5 species, of warm and tropical regions. Type species: Dichondra repens Forst.

1. Dichondra carolinénsis Michx. Fl. Bor. Am. 1: 136. 1803.

Somewhat pubescent, or glabrous; stems almost filiform, rooting at the nodes, 1.5-6 dm. long. Leaves orbicular to reniform, deeply cordate, $6-30 \mathrm{~mm}$. in diameter, palmately veined, the petiole often much longer than the blade; flowers 2-4 mm. broad; peduncles filiform; sepals obtuse, spatulate or obovate, villous; corolla yellow to white, shorter than the sepals, its lobes ovate to oblong; capsule $3 \mathrm{~mm}$. high or less.

Waste places and cultivated soils, Great Bahama, New Providence, Eleuthera, Great Exuma and Crooked Island :-Bermuda; Virginia to Florida and Texas. Referred by previous authors to Dichondra repens Forst. CAROLINA DICHONDRA. SHREP-Grass.

\section{Family 3. CUSCUTÀCEAE Dumort.}

\section{DODDER FAMILY.}

White, red or yellow slender parasites, dextrorsely twining, the leaves reduced to minute alternate scales. Calyx inferior, 5-lobed or 5-parted (rarely 4-lobed or 4-parted), or of 5 distinct sepals. Corolla 5-lobed (rarely 4-lobed), the tube bearing as many fimbriate or crenulate scales as there are lobes and alternate with them, or these sometimes obsolete. Stamens as many as the corolla-lobes, inserted in the throat or sinuses above the scales; anthers short, ovate or oval, obtuse, 2-celled, the sacs longitudinally dehiscent. Ovary, 2-celled; ovules 2 in each cavity; styles 2, terminal, separate, or rarely united below; stigmas linear or capitate. Capsule globose or ovoid, circumscissile, irregularly bursting or indehiscent, 1-4-seeded. Seeds glabrous; embryo linear, terete, curved or spiral, its apex bearing 1-4 minute alternate scales; endosperm fleshy; cotyledons none.

\section{CÚSCUTA [Tourn.] L. Sp. PI. 124. 1753.}

Characters of the family. The filiform twining stems are parasitic on herbs and shrubs by numerous minute suckers. The seeds germinate in the soil and the plantlet attaches itself to its host, its root and lower portion soon perishing. The subsequent nutrition of the parasite is apparently wholly through its suckers. Indications of a small amount of green coloring matter, 
possibly chlorophyll, have been observed in some species. [Name from tho Arabic.] About 100 species, of wide distribution. Type species: Cuscuta europaea L.

Capsule circumscissile; corolla-lobes obtuse; plant orange. Capsule indehiscent; corolla-lobes acute; plant yellow.

1. C. americana.

2. C. pentagona.

1. Cuscuta americàna L. Sp. Pl. 124. 1753.

Plant orange, the stems slender, the inflorescence glandular. Flowers short-pedicelled in dense or rather loose clusters; calyx-lobes 5, ovate-orbicular, obtuse; corolla about $2 \mathrm{~mm}$. long, its 5 lobes obtuse, shorter than the tube, the broad scales fringed all around; capsules subglobose, about $3 \mathrm{~mm}$. in diameter, circumscissile near the base.

Parasitic on various plants, Frozen Cay, Eleuthera, Cat Island, Watling's Island, Cave Cay, Great Exuma, Acklin's, Fortune Island, Grand Turk and Angulla Isles :West Indies and troplcal continental America. Reported by Dolley as C. obtusiflora. LOVE-VINE.

2. Cuscuta pentàgona Engelm. Am. Journ. Sci. 43: 340. 1842.

Cuscuta arvénsis Beyr.; Hook. Fl. Bor. Am. 2: 77. As synonym. 1834.

Plant pale yellow; stems filiform, the flowers nearly sessile in small clusters. Calyx broad, 5-lobed, the lobes obtuse; corolla nearly campanulate, 5 -lobed, the lobes acute or acuminate, as long as the tube, their tips reflexed, the scales large, ovate, densely fringed all around with short irregular processes; stamens not exserted; style shorter than the ovary; stigmas capitate; capsule depressed-globose, indehiscent.

Parasitic on various weeds, Great Bahama, Andros, Eleuthera and Cat Island :New York and Canada to Florida and Texas; Jamaica; Cuba; Porto Rico. Referred by Mrs. Northrop to $C$. americana L. FIELD DODDER.

\section{Family 4. HYDROPHYLLÀCEAE Lindl.}

\section{WATER-LEAF FAMILY.}

Herbs, mostly hirsute, pubescent or scabrous, with alternate or basal, rerely opposite leaves, and perfect regular 5-parted flowers, in scorpioid cymes, spikes or racemes, or rarely solitary. Calyx inferior, deeply cleft or divided. Corolla gamopetalous. Stamens 5, inserted on the corolla, and alternate with its lobes; filaments filiform; anthers mostly versatile, 2-celled, the sacs longitudinally dehiscent. Disk annular, or none. Ovary superior, 2-celled, or 1-celled with 2 placentæ; styles 2, separate, or partly united; stigmas small, terminal; ovules anatropous or amphitropous. Capsule 1-2-celled, mostly loculicidally 2-valved. Seeds usually pitted, rugose or reticulated; endosperm fleshy or cartilaginous; embryo small; cotyledons half-terete or plano-convex. About 17 genera and 175 species, mostly natives of western North America.

\section{MARIIAUNIDIUM Kuntze, Rev. Gen. Pl. 434. 1891.}

Branching pubescent herbs, with alternate entire leaves, the flowers solitary in the axils. Calyx 5-cleft. Corolla funnelform or salverform. 5lobed, the lobes imbricated in the bud. Stamens mostly included, borne on the corolla-tube. Ovary 1-celled, or incompletely 2-celled; ovules numerous. Fruit a 2-valved capsule. [In honor of Dr. Anton Kerner, Knight of Marilaun.] About 20 species, natives of America, the following typical. 
1. Marilaunidium jamaicénse (L.) Kuntze, Rev. Gen. Pl. 434.1891.

Nama jamaicense L. Syst. ed. 10. 950. 1759.

Annual, much branched, the branches prostrate, $0.7-4 \mathrm{dm}$. long. Leaves thin, spatulate or obovate, $1-5 \mathrm{~cm}$. long, obtuse or apiculate, narrowed to a sessile, somewhat decurrent base; peduncles $6 \mathrm{~mm}$. long or less; calyx-segments hirsute, linear, 6-8 mm. long; corolla white or purplish, about as long as the calyx, its lobes broad; capsule oblong, a little longer than the calyx.

Waste grounds, Great Bahama, Little Hárbor Cay, New Providence, Eleuthera, Watling's, Great Ragged Island, Crooked Island, South Caicos and Grand Turk:Bermuda; Florida ; Texas ; Cuba to St. Thomas and Martinique ; Barbadoes ; Jamaica ; Curaço; Mexico to Venezuela. Jamaica WeEd.

\section{Famiiy 5. EHRETIÀCEAE Schrad.}

\section{Ehretia FAmily.}

Shrubs, trees or rarely herbs, with alternate, estipulate, simple and mostly entire leaves, and perfect regular flowers in heads, spikes or cymes. Calyx 2-5-lobed, persistent. Corolla gamopetalous, mostly 5-lobed, the lobes spreading. Stamens mostly 5, borne on the base of the corolla-tube, the anthers introrse. Ovary superior, 1-4-celled; styles 2, distinct or rarely united, or 4, united in pairs; ovules 1 or 2 in each cavity of the ovary. Fruit a drupe. Seeds 1-4. About 20 genera, including some 350 species, of tropical and warm-temperate regions.

Styles twice bifid.

Calyx wholly adnate to the large drupe; corolla large, orange to red; trees.

Calyx rupturing at the top or regularly dentate, not wholly adnate to the drupe; shrubs or small trees.

Styles bifid or connate.

Corolla salverform.

Corolla rotate.

1. Sebesten.

2. Varronia.

3. Bourreria.

4. Rochefortia.

\section{SEBÉsteN Adans. Fam. Pl. 2: 177. 1763.}

Trees or shrubs with alternate broad petioled, entire or few-toothed leaves, and large showy flowers in terminal cymes or rarely solitary. Calyx tubular, 3-5-toothed. Corolla salverform, the tube nearly cylindric, the limb speading, 5-15-lobed. Stamens borne on the corolla-tube, as many as the corolla-lobes; anthers sagittate. Ovary 2-4-celled; styles usually 2, each 2-cleft; stigmas capitate. Drupe ovoid, adnate to the accrescent calyx and enclosed by it, the stone bony. Seeds without endosperm. [Name Arabic, originally applied to a different tree.] About 12 species, of tropical and subtropical America, the following typical.

1. Sebesten Sebéstena (L.) Britton; Small, Fl. Miami 158. 1913.

Cordia Sebestena L. Sp. Pl. 190. 1753.

A tree, reaching a maximum height of about $10 \mathrm{~m}$., with a trunk up to $1.5 \mathrm{dm}$. in diameter, the scaly bark dark brown, the young twigs brownhairy. Leaves ovate to oblong-ovate, thick, $8-20 \mathrm{~cm}$. long, repand-dentate or entire, dark green and scabrcus above, paler green beneath, acuminate, acute or obtuse at the apex, rounded or subcordate at the base, the petioles $3-5 \mathrm{~cm}$. long; cymes compound, several-many-flowered; pedicels $5-15 \mathrm{~mm}$. long; calyx strigose, cylindric, $1-1.8 \mathrm{~cm}$. long, its lobes short; corolla orange, its tube twice 
as long as the calyx, its limb $2.5-4 \mathrm{~cm}$. broad; drupe round, 5-lobed, white, pointed, 2-4 cm. long, the flesh thin.

Scrub-lands, Abaco, North Bimini, Gun Cay, Andros, New Providence, Eleuthera, Long Island, Crooked Island, Fortune Island, Inagua, Grand Turk, Cay Sal and Water Cay :-Florida ; Cuba to Tortola and to Trinidad; Mexico. Catesby, 2: pl. 91. Geiger Tree. ANA CONDA. SPANish Cordia.

\section{VARRòNIA P. Browne, Hist. Jam. 172. 1756.}

Shrubs, or small trees, with scabrous or pubescent leaves, the small, usually white flowers variously clustered, mostly sessile in heads, spikes or glomerules. Calyx 4-5-toothed. Corolla salverform or funnelform, the limb 4-5-lobed. Stamens as many as the corolla-lobes, mostly included. Ovary 4-celled. Styles 2-cleft; stigmas small, capitate. Fruit a small, slightly fleshy drupe, often little longer than the calyx-tube and sometimes enclosed by it, containing 4 nutlets or fewer. [In honor of Marcus Varro, a distinguished Roman, born 116 B.C., died 27 B.C.] Seventy species or more, of tropical and subtropical America. Type species: Lantana corymbosa L.

Flowers in globose heads.

Calxy-teeth filiform; leaves coarsely serrate.

Calyx-teeth trianguiar with linear tips; leaves entire or with a few teeth.

Flowers in spikes.

Leaves linear-oblong to oblanceolate; filaments pilose at the base.

Leaves spatulate-obovate; filaments glabrous.

1. V. globosa.

2. V. bahamensis.

3. V. Brittonii.

4. V. lucayana.

1. Varronia globòsa Jacq. Enum. 14. 1760.

Cordia globosa H.B.K. Nov. Gen. 3: 76. 1818.

A usually much-branched shrub, 1-3 m. high, the slender twigs hispid. Leaves ovate to ovate-lanceolate or ovate-oblong, $1.5-6 \mathrm{~cm}$. long, rather coarsely serrate, short-petioled, rough and papillose-hispid above, pubescent and strongly veined beneath, acute or bluntish at the apex, narrowed or obtuse at the base; flowers in dense globular peduncled heads, the peduncles mostly shorter than the leaves; calyx hispid, 5-cleft, 6-8 mm. long, its teeth nearly filiform; corolla white, about $6 \mathrm{~mm}$. long; drupe red, about $4 \mathrm{~mm}$. long.

Scrub-lands, Andros, New Providence, Long Island, and Watling's :-Florida ; Cuba to Porto Rico and Trinldad; Jamaica; Cayman Islands; Curaço; Mexico to northern South America. CAPITATt VARRONIA.

2. Varronia bahaménsis (Urban) Millsp. Field Mus. Bot. 2: 310.1909.

Cordia bahamensis Urban, Symb. Ant. 1: 392. 1900.

A usually much-branched shrub, 1-2 m. high, rarely a small tree 3-4 m. high, the branches slender, the young shoots appressed-setulose. Leaves various, linear-oblong to elliptic or obovate-elliptic, '2-10 cm. long, $0.5-5 \mathrm{~cm}$. wide, acute, obtuse or rounded at the apex, narrowed or obtuse at the base, entire or fewtoothed, subcoriaceous, setulose-scabrous above, pilose beneath, at least on the veins, the petioles 4-20 mm. long; peduncles as long as the leaves or shorter; flowers capitate; heads several-many-flowered; calyx loosely pubescent, 4-5lobed, the lobes triangular with slender tips $2-3 \mathrm{~mm}$. long; corolla white, subcylindric, 4-5-lobed, 3-4 mm. long, its lobes ovate, obtuse; drupe ovoid, obtuse, red to black, about $4 \mathrm{~mm}$. long.

Scrub-lands, coppices and savannas, throughout the archipelago from Abaco and Great Bahama to Andros, Mariguana, North Caicos and Inagua:-Cuban Cays; Anegada. Recorded by Grisebach, by Mrs. Northrop, and by Dolley as Cordia Lima R. \& S., and by Hitchcock as Cordia globosa H.B.K., and Cordia sp. The species is composed of several races with leaves varying from linear and quite entire to broadly ovate or obovate and slightly toothed. Rough VArRonia. CocoBer. 
3. Varronia Brittònii Millsp. Field Mus. Bot. 2: 311.1909.

Cordia Brittonii Macbride, Contr. Gray Herb. II. 49: 16. 1917.

A usually much-branched shrub, $2.5 \mathrm{~m}$. high or less, the young twigs puberulent. Leaves linear-oblong or oblanceolate, viscid in drying, sparingly crenulate or entire, rounded or acutish at the apex, narrowed at the base, puberulent and resinous-dotted on both sides, 1.5-3 $\mathrm{cm}$. long, the petioles only 1-1.5 mm. long; spikes slender, peduncled, densely several-many-flowered, 2-3 cm. long; calyx $2.5-3 \mathrm{~mm}$. long, campanulate, its 5 teeth ovate-deltoid; corolla white, about $4 \mathrm{~mm}$. long, its 5 lobes irregularly dentate; filaments short, pilose, borne above the middle of the corolla-tube; drupe $2-2.5 \mathrm{~mm}$. long.

Coppices and scrub-lands, Great Bahama, Andros, Eleuthera, Cat Island and Long Island :-Cuba. Recorded by Coker as Cordia cylindrostachya R. \& S., and referred by Mrs. Northrop to $C$. angustifolia R. \& S. BRITTON's VARRONIA.

4. Varronia lucayàna Millsp. Field Mus. Bot. 2: 311. 1909.

A much-branched shrub, 1-2 m. high, with terete branches, the young twigs densely puberulent. Leaves spatulate or narrowly obovate, thin, $2 \mathrm{~cm}$. long or less, crenate, repand or subentire, rounded or truncate at the apex, cuneate or narrowed at the base, puberulent and resinous-dotted on both sides, the petioles 1-2 mm. long; flowers few, in terminal spikes 1-1.5 $\mathrm{cm}$. long, the peduncles 5-20 mm. long; calyx campanulate, its 5 teeth ovate-triangular; corolla white, about $5 \mathrm{~mm}$. long, its 5 unequal lobes irregularly crenate; filaments glabrous, borne near the top of the corolla-tube; drupe $2.5-3 \mathrm{~mm}$. long.

Rocky plains, Acklin's Island, Mariguana, South Caicos, and Inagua. Endemic. BAHAMA VARRONIA.

\section{BOURRÈRIA P. Browne; Jacq. Enum. 2, 14. 1760.}

Shrubs or small trees, with alternate petioled entire leaves, and white flowers in terminal corymb-like cymes. Calyx campanulate, 2-5-lobed, the lobes valvate. Corolla salverform, the limb 5-lobed. Stamens 5, borne on the corolla-tube, the filaments filiform. Ovary sessile, 2-celled or incompletely 4-celled; styles 2-cleft or connate; stigmas flattened. Fruit a drupe, with thin flesh, inclosing 4 bony nutlets ridged on the back. [Commemorates J.A. Beurer, a Nuremberg apothecary.] About 25 species of tropical America. Type species: Bourreria succulenta Jacq.

1. Bourreria ovàta Miers, Ann. Mag. Nat. Hist. IV. 3: 203.1869.

A shrub or small tree up to $10 \mathrm{~m}$. high or perhaps higher, with a trunk sometimes $1.5 \mathrm{dm}$. in diameter; the bark reddish-brown, the twigs and leaves glabrous or very slightly pubescent, or shoots from stumps sometimes with pubescent foliage. Petioles rather stout, $4 \mathrm{~cm}$. long or less; leaves oblanceolate, oval or nearly orbicular, 4-12 cm. long, subcoriaceous, rounded or emarginate at the apex, mostly narrowed at the base; cymes commonly many-flowered, 5-10 cm. broad; pedicels short; calyx 5-6 mm. long, irregularly 5-lobed; corolla about $10 \mathrm{~mm}$. long, its lobes nearly orbicular; styles connate; filaments glabrous; drupe orange-red, 10-15 $\mathrm{mm}$. in diameter, subglobose.

Scrub-lands and coppices, throughout the archipelago from Abaco and the Berry Islands to Grand Turk, Inagua, the Anguilia Isles and Cay Sal :- Florida; Cuba.

The specles is composed of a number of races with the leaves varying from oblanceolate to suborbicular; the leaves are usually quite glabrous but those on shoots from cut stumps are pubescent. The species is distinct from $B$. tomentosa (Lam.) Griseb, to which it has been referred by Grisebach and by Dolley; it was referred to $B$. havanensis Miers, by Hitchcock and by Mrs. Northrop, and recorded by Schoepf as Ehretia tinifolia and $E$. Beureria. Catesby, 2: $p l$. 79 . Closely related to B. succulenta Jacq. STroNG-BACK. 
4. ROCHEFóRTIA Sw. Prodr. 53. 1788.

Shrubs or small trees, mostly armed with short spines, the leaves entire, petioled, often fascicled, the small flowers cymose or glomerate. Calyx 4-5parted, the lobes imbricated. Corolla subrotate, the tube very short, the 4 or 5 lobes broad, imbricated. Stamens 4 or 5 , borne on the corolla-tube, exserted; filaments filiform; anthers ovate. Dise thick. Ovary 2-celled or falsely 4-celled; styles 2, terminal, filiform; stigmas dilated. Drupe fleshy, globose, containing 4 hard nutlets. [Commemorates César de Rochefort, a French naturalist of the seventeenth century.] About 8 species, natives of the West Indies and northern South America. Type species: Rochefortia cuneata Sw.

\section{Rochefortia bahaménsis Britton, Bull. N. Y. Bot. Gard. 5: 317. 1907.}

A shrub or small tree up to $4 \mathrm{~m}$. high, with a trunk $6 \mathrm{dm}$. thick, the bark scaly, the branches spreading, the twigs gray-green, flexuous, sometimes with spines 4-6 mm. long at the nodes. Young foliage sparingly puberulent, soon glabrous; leaves coriaceous, obovate to orbicular, $2-6 \mathrm{~cm}$. long, obtuse or emarginate at the apex, obtuse to cuneate at the base, the midvein prominent, the few lateral veins inconspicuous, the upper surface dark-green and dull or faintly shining, the under surface somewhat lighter green, the petioles 2-10 $\mathrm{mm}$. long, green or yellowish; cymes axillary, 2-4-flowered, their peduncles pubescent, $5 \mathrm{~mm}$. long or less; calyx sparingly pubescent, obconic, about $4 \mathrm{~mm}$. long, its 5 lobes nearly orbicular, ciliate; corolla greenish-white, $6 \mathrm{~mm}$. long, cleft to about the middle, its lobes oblong, obtuse; filaments about as long as the anthers; ovary ovoid, about $3 \mathrm{~mm}$. long, the two styles erect or a little incurved.

Scrub-lands and rocky coppices, Watling's, Crooked, Acklin's and Fortune Islands. Endemic. BAHAMA ROchefortia.

Cordia gerascanthoides Kunth, referred to by Dolley as Bahamian, has not been found by us in the archipelago. The record is, presumabiy, erroneous.

Cordia alba (Jacq.) R. \& S. is doubtfully recorded as Bahamian by Urban (Symb. Ant. $4: 516)$ from his examination of a barren specimen, which proves to be Sebesten Sebestena.

\section{Family 6. BORAGINÀCEAE Lindl.}

\section{BoRAGE FAMILY.}

Herbs or shrubs. Leaves alternate, rarely opposite or verticillate, estipulate, mostly entire and hispid, pubescent, scabrous or setose. Flowers perfect, usually regular, in one-sided scorpioid spikes, racemes, cymes, or sometimes scattered. Calyx inferior, mostly 5-lobed, 5-cleft, or 5-parted, usually persistent. Corolla gamopetalous, mostly regular and 5-lobed, rarely irregular. Stamens as many as the corolla-lobes and alternate with them, inserted on the tube or throat; anthers 2-celled, the saes longitudinally dehiscent. Disk commonly inconspieuous. Ovary superior, of 2, 2-ovuled carpels, entire, or the carpels commonly deeply 2-lobed, making it appear as of 4, 1-ovuled carpels; style simple, entire or 2-cleft; ovules anatropous or amphitropous. Fruit mostly of 4, 1-seeded nutlets, or of 2, 2-seeded carpels. Endosperm fleshy, copious, or none; cotyledons mostly flat or plano-convex; radicle short. About 85 genera and 1,500 species, of wide distribution.

Fruit drupaceous.

Fruit hollowed at base ; coastal canescent shrub.

Fruit not hollowed at base; Bahama species vines.

1. Mallotonia. Fruit separating into nutlets.

2. Tournefortia.

3. Heliotropium. 
1. MALLotònIA [Griseb.] Britton, Ann. Mo. Bot. Gard. 2: 47. 191E.

Silvery-silky shrubs of the seacoast, with alternate leaves and small white flowers in dense, 1-sided cymes, the fruits almost capitate. Calyx mostly 5parted; corolla salverform, the 5 -lobed limb shorter than the nearly cylindric tube, the lobes broad, valvate. Stamens short, included. Style simple. Drupe dry and bony, ovoid-conic, hollowed at the base, 2-pyrenous, the dissepiments solid. [Latin, related to Mallota.] One species, or perhaps 2, of tropical and subtropical distribution, the following typical.

1. Mallotonia gnaphalòdes (L.) Britton, Ann. Mo. Bot. Gard. 2: 47. 1915.

Heliotropium gnaphalodes L. Syst. ed. 10, 913. 1759.

Tournefortia gnaphalodes R. Br.; R. \& S. Syst. 4: 538. 1819.

A somewhat fleshy shrub, 3-12 dm. tall, with silky-tomentose foliage, much branched and often forming large clumps, the twigs densely leafy. Leaves numerous, linear-spatulate, 4-10 cm. long, obtuse; cymes with 2-4 recurved branches; calyx campanulate, its lobes $2-3 \mathrm{~mm}$. long, oblong; corolla surpassing the calyx; fruit ovoid, $5 \mathrm{~mm}$. high, black, with 2 nutlets.

Coastal rocks and sands, throughout the archipelago from Abaco and Great Bahama to Calcos and Turk's Islands, Inagua, the Angulla Isles, Cay Sal and Water Cay :-Bermuda; Florida; West Indies; coast of tropical Mexico. BAY LAVENDER.

\section{TOURNEFÓRTIA L. Sp. Pl. 140. 1753.}

Trees, shrubs or vines, with alternate entire leaves, and small secund flowers in terminal, often forked cymes, the cyme-branches usually elongated. Calyx persistent, 5-parted. Corolla mostly salverform, the tube cylindric, swollen above, the lobes spreading. Stamens 5, borne on the corolla-tube, included; filaments short; anthers ovate to lanceolate. Ovary 4-celled; style terminal, 2-lobed at the apex. Drupe small, the exocarp fleshy or corky, containing 4 nutlets or fewer. [Commemorates Joseph Pitton de Tournefort, 1656-1708, renowned French botanist.] Over 100 species, of tropical and subtropical regions. Type species: Tournefortia hirsutissima L.

Leaves glabrous or somewhat pubescent. Leaves densely white-pubescent beneath.
1. T. volubilis.

2. T. poliochros.

\section{Tournefortia volùbilis L. Sp. Pl. 140. 1753.}

A slender woody vine, sometimes $3.5 \mathrm{~m}$. long, the branches and leaves pubescent, puberulent or glabrate. Leaves ovate to oblong or oblong-lanceolate, $2-7 \mathrm{~cm}$. long, thin, acute or acuminate at the apex, narrowed or obtuse at the base, the slender petioles $5-15 \mathrm{~mm}$. long; inflorescence slender-peduncled, of several very slender, secund spikes $2-4 \mathrm{~cm}$. long; ealyx about $1 \mathrm{~mm}$. long, its lobes ovate-lanceolate, acute; corolla greenish-white, twice as long as the ealyx, its lobes linear-subulate, shorter than the tube; anthers ovate, included; fruit depressed, 2-3 mm. broad, of 2-4 rounded nutlets.

Scrub-lands and copplces, Berry Islands, Andros, New Providence and Eleuthera to Calcos, Grand Turk, Inagua, and Anguilla Isles:-Florida; Texas; Cuba ; St. Jan to Grenada; Jamaica. The Bahama plant is usually less pubescent than that of Jamalca. Slender Green-leaved Todrnefortia. SOLdier-BUSH. 


\section{Tournefortia polióchros Spreng. Syst. 1: 644. 1825.}

A canescent slender woody vine $2 \mathrm{~m}$. long or less, or sometimes shrubby. Leaves lanceolate to ovate, $3-7.5 \mathrm{~cm}$. long, thin, acuminate or acute at the apex, narrowed or obtuse at the base, rather dark green and densely appressedpubescent above, densely white-pubescent beneath, the petioles 5-15 mm. long; inflorescence rather short-peduncled, of few or several slender secund spikes 3-7 cm. long; calyx 1-1.5 mm. long, pubescent, its lobes lanceolate or ovatelanceolate; corolla 2-3 times as long as the calyx, pubescent, its lobes lanceolate, acute or acuminate; anthers included; fruit depressed, 3-4 $\mathrm{mm}$. broad, of 4 rounded nutlets or fewer.

Scrub-lands, Eleuthera, Cat Island, Fortune Island, Great Ragged Island :Cuba; Hispaniola; Jamalca. Referred to T. tomentosa Mill. in Bull. N. Y. Bot. Gard. 5 : 317. WHITE-LEAVED TOURNEFORTIA.

\section{HELIOTRÒPIUM [Tourn.] L. Sp. Pl. 130. 1753.}

Herbs or shrubs, with alternate mostly entire leaves, and small blue or white flowers, in scorpioid spikes, or scattered. Calyx-lobes or segments lanceolate, ovate, or linear. Corolla salverform or funelform, naked in the throat, its tube eylindic, its lobes imbricated, plicate or induplicate in the bud. Stamens included; filaments short, or none. Stigma conic or annular. Fruit 2-4-lobed, separating into 4, 1-seeded nutlets, or into 2, 2-seeded carpels. [Greek, sunturning, $i$. e., turning to or with the sun.] About 125 species, widely distributed. Type species: Heliotropium europaeum L.

Nutlets conic, strongly ribbed, united in pairs; flowers pale blue. Nutlets subglobose or ovoid, smooth or rugose; flowers white or nearly white.

Nutlets united in pairs.

The four nutlets separating.

Plants glabrous, fleshy.

Plants pubescent.

Annual ; flowers spicate.

Leaves obtuse.

Leaves acute or short-acuminate.

Perennials.

Flowers short-spicate; low shrub.

Flowers solitary in the axils; depressed perennials.

Plants densely covered with appressed white hairs.

Leaves imbricated.

Leaves oblong or elliptic.

Leaves lanceolate.

Leaves scattered, linear.

Plant loosely strigose.
1. H. indicum.

2. H. parviflorum.

3. H. curassavicum.

4. $H$. inundatum.

5. H. Eggersii.

6. H. ternatum.
7. H. nanum.

8. H. inaguense.

9. H. diffusum.

10. H. Nashii.

1. Heliotropium índicum L. Sp. Pl. 130. 1753.

Annual, hirsute or hispid; stem 3-9 dm. high. Leaves ovate or oval, obtuse, rounded or subcordate at the base, 5-15 $\mathrm{cm}$. long, repand or undulatemargined, petioled; flowers blue, 4-6 mm. broad, sessile in terminal dense bractless, usually solitary, scorpioid spikes; calyx-segments acute, shorter than the strigose corolla-tube; style very short, deciduous; fruit deeply 2-lobed, glabrous, about $2.5 \mathrm{~mm}$. long.

Waste and cultivated grounds, New Providence, near Nassau :-Florida, the West Indies and continental troplcal America. Naturalized from the old World troples. INDIAN HELIOTROPE.

2. Heliotropium parviflòrum L. Mant. 2: 201. 1771.

Annual, or sometimes of longer duration, loosely pubescent, branched, 2-8 $\mathrm{dm}$. high, or vine-like and $1 \mathrm{~m}$. long. Leaves oblong-lanceolate to elliptic, 7 
cm. long or less, acute or short-acuminate at the apex, narrowed at the base, the petioles 5-15 mm. long; spikes solitary or 2 together, slender, $5-15 \mathrm{~cm}$. long; calyx-lobes acute; corolla white, bearded in the throat, about $2 \mathrm{~mm}$. broad, its tube about as long as the calyx; fruit didymous, depressed, 3-4 mm. broad, finely pubescent.

Waste grounds, street sides, coppices, and scrub-lands, Great Sturrup, Little Harbor Cay, North Cat Cay, Andros, New Providence, Eleuthera, Cat Island, Watling's, Great Guana, Great Exuma, Long Island, Great Ragged Island, Fortune Island, East Caicos and Inagua:- Florida; West Indies and continental tropical America. HORSE-BUSH. SORE-BUSH. SCORPION-TAIL.

\section{Heliotropium curassávicum L. Sp. Pl. 130. 1753.}

Annual, fleshy, more or less glaucous, diffuse, the branches $1.5-4.5 \mathrm{dm}$. long. Leaves linear, or linear-oblong, entire, inconspicuously veined, $2-5 \mathrm{~cm}$. long, 3-6 $\mathrm{mm}$. wide, obtuse, narrowed into petioles, or the upper sessile; scorpioid spikes dense, bractless, mostly in pairs; flowers about $4 \mathrm{~mm}$. broad; calyx-segments acute; corolla white with a yellow eye or changing to blue; stigma umbrella-shaped; anthers acuminate; fruit globose.

Salinas, sea-beaches, margins of sait-ponds, Gun Cay, Andros, New Providence, Eleuthera, Little San Salvador, Cat Island, Watling's, Great Exuma, Long Island, Fortune Island, Acklin's, Grand Turk, Inagua, and Cay Sal :-Bermuda; Florida to Texas; coasts of the West Indies and continental tropical America. SEASIDE Heliotrope. POND-WEED.

\section{Heliotropium inundàtum Sw. Prodr. 40. 1788.}

Annual, often branched from the base, 1-6 dm. tall, the stems and leavea gray-strigose. Leaves oblong to oval or oblong-spatulate, $2-5 \mathrm{~cm}$. long, obtuse at the apex, narrowed at the base, short-petioled; spikes 1 or few, slender, at length 3-6 cm. long; calyx 2-3 mm. long, its lobes linear-lanceolate; corolla white, about as long as the calyx, its lobes lanceolate; nutlets subglobose, about $1 \mathrm{~mm}$. in diameter.

Dry soll, Acklin's Island, Inagua :-Louisiana to California, Panama and Paraguay; Cuba; Hispaniola; Porto Rico; Jamaica ; Trinidad. Recorded from Guadeloupe. Slender Heliotrope. Erroneously called WiLd THyme.

\section{Heliotropium Eggérsii Urban, Symb. Ant. 5: 481. 1908.}

Annual, branched from the base, procumbent, $2 \mathrm{dm}$. long or less, the pubescence appressed or spreading. Leaves oblong-elliptic, 5-10 mm. long, densely sericeous, acute or short-acuminate at the apex, narrowed at the base, the slender petioles $1-3 \mathrm{~mm}$. long; spikes solitary or rarely in pairs, $4 \mathrm{~cm}$. long or less, many-flowered, pilose; sepals unequal, four of them linear and $1 \mathrm{~mm}$. long, the fifth oblong and $1.5 \mathrm{~mm}$. long; corolla $1.5 \mathrm{~mm}$. long, its lobes suborbicular, much shorter than the tube; nutlets about $1.3 \mathrm{~mm}$. in diameter, strigose, twice as wide as long.

Fortune Island. Endemic. EgGers' Heliotrope.

b. Heliotropium ternàtum Vahl, Symb. 3: 21. 1794.

Tournefortia humilis L. Sp. Pl. 141. 1753. Not H. humile Lam. 1791.

A strigose-pubescent, bushy-branched shrub $6 \mathrm{dm}$. high or less, the branches slender, ascending. Leaves lanceolate or linear, sessile, subverticillate in 3 's, or opposite, or alternate, 1-3 cm. long, 1.5-8 $\mathrm{mm}$. wide, acutish, revolutemargined, rough-strigose on both sides; flowers white, in short terminal spikes; calyx about $3 \mathrm{~mm}$. long, its lobes ovate, acute; corolla-tube somewhat longer than the calyx, the limb 3-4 $\mathrm{mm}$. wide; nutlets subglobose.

Scrub-lands, Great Ragged Island :-Cuba to Virgin Gorda and Martinique ; continental tropical America. BUSHY HeLIOTROPE. 
7. Heliotropium nànum Northrop, Mem. Torr. Club 12: 61. 1902.

Shrubby, usually much branched, densely strigose-canescent, 8-15 cm. high, the branches nearly erect or ascending, slender. Leaves oblong or elliptic, sessile, appressed, about $2 \mathrm{~mm}$. long, acute; flowers solitary at the axils, scattered, a little shorter than the leaves; calyx-lobes lanceolate, acute; corolla white, somewhat longer than the calyx, its lobes short, ovate-oblong; stamens borne at about the middle of the corolla-tube; style short; stigma annular; fruit depressed-globose, 4-lobed, separating into 4 pubescent nutlets.

Savannas, white-lands and sand dunes, Little Harbor Cay, Andros, New Providence. Endemic. Low Ashy HELIOTROPE.

8. Heliotropium inaguénse Britton, Bull. N. Y. Bot. Gard. 4: 122.1905.

A low shrub, 5-20 cm. high, intricately much-branched, very densely appressed-strigose all over with nearly white hairs. Leaves opposite, ascending or appressed, lanceolate or oblong-lanceolate, 3-5 $\mathrm{mm}$. long, about $1 \mathrm{~mm}$. wide, sessile, acutish, somewhat revolute-margined, mostly longer than the internodes; flowers few, solitary and very nearly sessile in the upper axils; sepals similar to the upper leaves; corolla white, its tube $2 \mathrm{~mm}$. long, its 5 ovate acute lobes about $1 \mathrm{~mm}$..long, spreading; stamens nearly sessile on the corolla. tube below the middle; style very short, stout; stigma 4-lobed.

White-lands, scrub-lands and sand dunes, Exuma Chain, Eleuthera, Cat Island, Concention Island, Little San Salvador, Long Island, Fortune Island, Great Ragged Island, Caicos, Turk's Islands and Inagua. Endemic. INAGUA HeLIotropt. WHitb PUSsley.

9. Heliotropium diffùsum Britton, Bull. N. Y. Bot. Gard. 4: 122.1905.

Perennial by a slender deep root. Stem slender, $4 \mathrm{~cm}$. high or less, the branches diffusely spreading, very slender, longer than the stem, $8 \mathrm{~cm}$. long or less, appressed-strigose; leaves linear, 3-4 mm. long, about $1 \mathrm{~mm}$. wide, sessile, acute, appressed-strigose; flowers white, minute, enclosed in the tufts of upper leaves; sepals lanceolate to ovate-lanceolate, acute, about $2 \mathrm{~mm}$. long, very hairy; ovary deeply 4-lobed; fruít 4-lobed, depressed, about $1 \mathrm{~mm}$. wide, and about one half as high as wide, the very short style capped by a broad abruptlytipped stigma.

Molst scrub-lands, Rum Cay, Acklin's, Mariguana, South Caicos, Grand Turk, Sand Cay, Little Inagua. Endemic. DIFFUSE LOW HELIOTROPE.

\section{Heliotropium Náshii Millsp. Field Mus. Bot. 2: 309. 1909.}

Heliotropium brevicaule Urban, Repert. 13: 474. 1915.

Diffusely branched, perennial, the branches very slender, prostrate or nearly so, the young twigs appressed-pubescent. Leaves sessile, ovate, about $2 \mathrm{~mm}$. long and $1 \mathrm{~mm}$. wide, acute, appressed-pubescent on both sides, the margins flat; flowers solitary and sessile in the upper axils; calyx a little more than $1 \mathrm{~mm}$. long, its lobes ovate-lanceolate, acutish; corolla white, 1.5-2 mm. broad, its lobes ovate, acute; fruit about $1 \mathrm{~mm}$. in diameter.

Scrub-lands, Inagua, near Matthew Town. Endemic. Referred by Hitchcock to H. microphyllum Sw. NASH'S HELIOTROPE.

\section{Family 7. VERBENÀCEAE J. St.Hil.}

\section{Vervain Family.}

Herbs, shrubs or some tropical genera trees, with opposite verticillate or rarely alternate leaves, and perfect irregular, or sometimes regular flowers, in spikes, racemes, cymes or panicles. Calyx inferior, mostly 
persistent, usually 4-5-lobed or 4-5-cleft. Corolla reguiar, or 2-lipped, the tube usually cylindric and the limb 4-5-eleft. Stamens 4 , didynamous, rarely only 2 , or as many as the corolla-lobes, inserted on the corolla and alternate with its lobes; anthers 2-celled, the saes longitudinally dehiseent. Ovary superior, 2-4-celled (rarely 8-10-celled), composed of 2 carpels, each carpel with 2 anatropous or amphitropous ovules, thus in 4-celled ovaries 1 ovule in each eavity; style terminal; stigmas 1 or 2. Fruit dry, separating at maturity into 2-4 nutlets, or a drupe containing the 2-4 nutlets. Endosperm little or none, or rarely fleshy; embryo straight. About 75 genera and 1,300 species, of wide geographic distribution.

A. Inflorescence centripetal, in splkes, heads or racemes.

Inflorescence splcate or capitate.

Spikes terminal.

Flowers partly buried in the rachis; stamens 2 .

Flowers not buried in the rachis; stamens 4.

Calyx elongated, cylindric in fruit.

Calyx globular or ovoid in fruit.

Splkes axillary and terminal.

Rachis slender.

Flowers scattered along the axis ; fruit dry, horned.

Flowers densely or loosely capitate or spicate.

Fruit dry.

Fruit fleshy.

Rachis thick; flowers capitellate.

Inflorescence racemose; racemes peduncled.

Drupe 2-pyrenous, 4-spermous ; stigma 2-lobed.

Drupe 4-pyrenous, 8-spermous; stigma 4-lobed.

B. Inflorescence centrifugal, cymose.

Pyrenae separate.

Cymes short-peduncled; drupes 4-pyrenous.

Cymes long-peduncled.

Drupe 1-pyrenous, 4-locularis.

Drupe 2-pyrenous, 2-locularis.

Pyrenae cohering in pairs.

Cymes axillary, short-peduncled; spiny shrub.

Cymes terminal; unarmed herbs or shrubs.

C. Inflorescence in pedunculate thyrsold corymbs; fruit capsular.

\section{Valerianoidcs.}

2. Bouchea.

3. Priva.

4. Ghinia.

5. Lippia.

6. Lantana.

7. Nashia.

8. Citharexylum.

9. Duranta.

10. Callicarpa.

11. Petitia.

12. Pseudocarpidium.

13. Volkameria.

14. Clerodendrum.

15. Avicennia.

1. VALERIANOİdes [Boerh.] Medic. Phil. Bot. 1: 177. 1789.

Annual or perennial herbs, or shrubs. Leaves opposite or alternate, toothed. Flowers spicate, solitary and sessile in the axils of bracts, or imbedded in excavations of the thick rachis. Calyx membranous or herbaceous, its lobes 5, usually unchanged at maturity. Corolla-tube sometimes slightly dilated above, the limb spreading, 5-lobed. Stamens 2, included; anthers with unappendaged connectives; staminodia 2, small. Ovary 2-celled. Ovules solitary in each cavity. Fruit included in the calyx, separating into 2 nutlets. [Signifies similarity to Valeriana, but this is obscure.] More than 40 species, of tropical and subtropical America. Type species: Verbena jamaicensis L.

Shrub; leaves apically serrate, punctate; spikes short, $6-15 \mathrm{~cm}$. Herb; leaves serrate throughout, not punctate; splkes long, 12$45 \mathrm{~cm}$.
1. V. fruticosa.

2. . jamaicensis.

1. Valerianoides fruticòsa Millsp. Field Mus. Bot. 2: 178. 1906.

Stachytarpheta fruticosa B. L. Robinson, Proc. Am. Acad. 51: 531. 1916.

A glabrous shrub, $2 \mathrm{~m}$. high or less, the branches slender, the twigs 4 sided. Leaves lanceolate to oblong, ovate-lanceolate or oblanceolate, punctate, 4-8 cm. long, serrate above the middle, acute at the apex, narrowed at the base into petioles $5-10 \mathrm{~mm}$. long; spikes 5-15 $\mathrm{cm}$. long, 3-4 mm. thick; bracts 
ovate-lanceolate or lanceolate, acuminate, 5-7 $\mathrm{mm}$. long; calyx compressed, 2-cleft; corolla purple; fruit obpyriform, about $6 \mathrm{~mm}$. long.

Rocky plains and scrub-lands, Great Bahama, Rose Island, Cay north of Wide Opening, Eleuthera, Rum Cay, North Caicos, Grand Turk, Cotton Cay and Inagua. Endemic. BAHAMA Vervain.

2. Valerianoides jamaicénsis (L.) Kuntze, Rev. Gen. Pl. 509. 1891.

Verbena jamaicensis L. Sp. Pl. 19. 1753.

Stachytarpheta jamaicensis Vahl, Enum. 1: 206. 1805.

Abena jamaicensis Hitchc. Rep. Mo. Bot. Gard. 4: 117. 1893.

Annual, often purplish, with sparingly pubescent or glabrate foliage. Leaves alternate or opposite, oblong, ovate or oval, 2-8 cm. long, coarsely serrate, narrowed at the base, the petioles margined, as long as the blades or shorter; spikes stiff, $1.5-5 \mathrm{dm}$. long; bracts imbricated, lanceolate to oblonglanceolate, acuminate, serrulate, 5-8 mm. long; flowers in depressions of the rachis; calyx-lobes triangular or triangular-ovate; corolla blue, somewhat irregular, 8-11 mm. long, its tube slightly curved, the limb $8 \mathrm{~mm}$. broad; nutlets $3 \mathrm{~mm}$. long, buried in the rachis.

Waste places, coppices and scrub-lands, throughout the archipelago from Great Bahama and the Berry Islands to Andros, East Caicos, Grand Turk and Inagua:Bermuda; Florida: West Indies, and continental tropical America; old World troples. JAMAICA Vervain. BLUE-FLOWER.

\section{BOUCHÈA Cham. Linnaea 7: 252. 1832.}

Herbs or low shrubs, with opposite petioled toothed leaves, and small flowers in terminal bracted spikes or narrow racemes. Calyx tubular, 5toothed, 5-ribbed, eylindric in fruit. Corolla-tube cylindric, slender, the limb obliquely spreading, 5-cleft, the lobes nearly equal. Stamens 4, didynamous, borne on the corolla-tube at or above the middle; filaments short; anthers ovate. Ovary 2-celled; ovules 1 or 2 in each cavity, erect; style filiform, subclavate above. Fruit linear or oblong, dry, enclosed in the calyx, separating into 2 linear nutlets. [Commemorates P. C. Bouché and C. D. Bouché, German gardeners.] About 15 species of tropical and warm temperate regions. Type species: Verbena Pseudogervao St. Hil.

\section{Bouchea prismática (IL.) Kuntze, Rev. Gen. Pl. 502. 1891.}

Verbena prismatica L. Sp. Pl. 19. 1753.

Bouchea Ehrenbergii Cham. Linnaea 7:253. 1832.

Annual, erect, simple or few-branched, finely pubescent, $2-5 \mathrm{dm}$. high, the branches ascending. Leaves ovate, slender-petioled, 2-6 $\mathrm{cm}$. long, serrate all around, acute at the apex, obtuse or subtruncate at the base; racemes narrow, elongated, often $2 \mathrm{dm}$. long or longer; pedicels very short, about $1 \mathrm{~mm}$. long, erect; calyx narrowly cylindric, appressed to the axis of the raceme, about 10 $\mathrm{mm}$. long, its teeth linear-subulate, about one-third as long as the tube; corolla violet or purplish, about $10 \mathrm{~mm}$. long; fruit a little longer than the calyx.

A weed in waste places, New Providence and Cat Island:-Cuba to St. Thomas and Antigua; Barbadoes; Jamaica; Curaçao; Mexico to Venezuela. NARrow-FruITED VERVAIN.

3. PRIVA Adans. Fam. Pl. 2: 505. 1763.

Perennial caulescent herbs. Leaves opposite, membranous, toothed, the flowers in slender peduncled racemes. Calyx-tube 5-ribbed; lobes 5. Corolla 
salverform, its tube straight or incurved, slightly dilated above, its limb spreading, oblique, slightly 2-lipped, with 5 short lobes. Stamens 4, didynamous, included; anthers with parallel or slightly divergent sacs. Ovary 2celled, each cavity with more or less well developed septa. Ovules 2, or by abortion 1, at base of each carity. Fruit enclosed in the calyx, separating into 2 nutlets. [Name unexplained.] About 10 species, of tropical distribution, the following typical.

1. Priva lappulàcea (L.) Pers. Syn. 2: 139. 1806.

Terbena lappulacea L. Sp. Pl. 19. 1753.

Priva echinata Juss. Ann. Mus. Par. 7: 69. 1806.

More or less pubescent. Stems 2-6 dm. tall, branching; leaves ovate, $2-10$ cm. long, acute or acuminate, serrate, truncate or cordate at the base, the petioles much shorter than the blades; racemes loosely flowered, 5-15 cm. long; pedicels 1-2 mm. long; calyx cylindric-prismatic, $2-3 \mathrm{~mm}$. long, accrescent, pubescent; corolla slightly surpassing the calyx, salverform, with short rounded lobes; fruit ovoid-pyramidal, 5-7 $\mathrm{mm}$. long; nutlets included in the calyx, spiny-tuberculate on the back, 3-4 $\mathrm{mm}$. long.

Waste places, coppices and cultivated ground, Abaco, Andros, New Providence, Eleuthera, Watling's, Parrot Cay and Inagua :-Fiorida; West Indies ; Mexico to Brazil. Erroneously referred by Dolley to Teucrium inflatum Sw. Bur Vervain. CAT'S-TONGUE.

4. GHINIA Schreb. Gen. 19. 1789.

[TAMonk̀a Aubl. Pl. Guian. 2: 659, pl. 268. 1775.

Not Aubl. 1: 441, pl. 175. 1775.]

Herbs or low shrubs, with slender stiff branches, opposite, nearly sessile, dentate or incised leaves, and small bracted flowers in terminal and axillary slender spikes. Calyx tubular, subtruncate, 5-ribbed, the ribs excurrent as short teeth. Corolla with a cylindric tube slightly enlarged above, and an oblique, spreading, 5-cleft limb. Stamens 4, didynamous, borne on the corollatube, included; anther-sacs parallel, the connective with a gland-like appendage. Ovary nearly completely 4-celled; ovule 1 in each cavity; style short; stigma oblong. Fruit small, hard, mostly 4-horned, 4-celled. Seeds usually 4, without endosperm; [Guiana name.] Four or five species, of tropical America. Type species: Tamonea spicata Aubl.

1. Ghinia curassávica (L.) Millsp. Field Mus. Bot. 2: 174.1906.

Verbena curassavica L. Sp. Pl. 19. 1753.

Tamonea curassavica Pers. Syn. Pl. 2: 139. 1806.

Tamonea scabra Cham. \& Schl. Linnaea 5:99. 1830.

Erect, simple or branched, roughish, 2.5-6 dm. high, slender. Leaves ovate, short-petioled, membranous, sparingly puberulent, 2-4 cm. long, serrate, acute at the apex, mostly obtuse at the base; racemes long-peduncled, very slender, the flowers distant; pedicels shorter than the calyx; calyx oblong, about $4 \mathrm{~mm}$. long, distended by the ripening fruit and becoming obconic, its teeth linear, about $1 \mathrm{~mm}$. long; corolla 5-6 mm. long; fruit 4-5 mm. long, its spines 1-2 $\mathrm{mm}$. long. VERVAIN.

A weed in waste places, New Providence:-Cuba; Mexico. Spiny-Fruited

5. LIPPİA L. Sp. Pl. 633. 1753.

Perennial herbs, or shrubs, with opposite, or rarely alternate leaves, and small bracted flowers, in spikes or heads. Calyx small, ovoid, campanulate or 
compressed and 2-winged, 2-4-toothed or 2-4-cleft. Corolla-tube cylindric, the limb oblique, somewhat 2-lipped, 4-cleft. Stamens 4, didynamous; anthers ovate, not appendaged, the sacs nearly parallel. Ovary 2-celled; ovules 1 in each cavity; style short; stigma oblique or recurved. Fruit dry, with a membranous exocarp, at length separating into 4 nutlets. [Named in honor of Auguste Lippi, 1678-1703, a French naturalist.] About 100 species, most abundant in tropical America. Type species: Lippia americana L.

Shrubs, erect or ascending.

Leaves lanceolate, sharply serrate.

Leaves ovate or oblong. crenate.

Prostrate or ascending herbs.

Leaves inconspicuously veined.

Leaves usually prominently velned.

1. L. stoechadifolia.
2. L. geminata.

3. L. nodiflora.

4. L. reptans.

1. Iippia stoechadifòlia (L.) H.B.K. Nov. Gen. 2: 265. 1818.

Verbena stoechadifolia L. Sp. Pl. 19. 1753.

Phyla stoechadifolia Small, Bull. N. Y. Bot. Gard. 36: 162.1909.

Shrubby, loosely appressed-strigose, ascending or suberect, usually little branched, 2-4 dm. high. Leaves narrowly lanceolate or oblong-lanceolate, rather firm in texture, $2.5-6 \mathrm{~cm}$. long, strongly pinnately veined, sharply and evenly serrate, acute at the apex, narrowed into short petioles; peduncles axillary or lateral, mostly longer than the leaves; heads at first subglobose, at length oblong-cylindric, 1-2 cm. long, obtuse; bracts suborbicular, mucronate; calyx 2-toothed, compressed; corolla about $4 \mathrm{~mm}$. long, longer than the bracts, its tube twice as long as the calyx.

Borders of fresh-water pockets and ponds, New Providence, Cat Island, Watling's, Great Exuma, Long Island and Fortune Island :-Cuba ; Porto Rico ; Guadeloupe; Jamaica; Mexico. MARSh LipPia.

\section{Lippia geminàta H.B.K. Nov. Gen. 2: 266. 1818.}

Lippia geminata microphylla Griseb. Fl. Br. W. I. 495. 1861.

An aromatic, densely puberulent shrub $1 \mathrm{~m}$. high or less, usually much branched, the branches slender. Leaves ovate or oblong, 1.5-7 cm. long, acute or obtuse at the apex, narrowed at the base, crenate or crenulate, puberulent, rugose above, the petioles 3-8 $\mathrm{mm}$. long; peduncles axililary mostly much shorter than the leaves; heads subglobose, or short-oblong, 8-12 mm. long; bracts ovate, puberulent, acute, about $3 \mathrm{~mm}$. long, nearly as long as the corolla; calyx 2-toothed; corolla purple, violet or white, its tube about 3 times as long as the calyx.

Turk's Islands (according to Grisebach), not found there by us :-Cuba ; Jamaica ; Porto Rico; Antigua to Trinidad; continental tropical America. Often planted for its fragrant follage. BUSHY LIPPIA.

3. Lippia nodifiòra (L.) Michx. Fl. Bor. Am. 2: 15. 1803.

Verbena nodiflora L. Sp. Pl. 20. 1753.

Phyla nodiflora Greene, Pittonia 4: 46. 1899.

Minutely and rather densely puberulent, herbaceous, creeping, or the branches ascending, 3-9 dm. long. Leaves thickish, spatulate, oblanceolate, or obovate, 1-6 $\mathrm{cm}$. long, $0.6-2.5 \mathrm{~cm}$. wide, inconspicuously veined, mostly cbtuse, narrowed into a cuneate entire base, sharply serrate above the middle; heads at length cylindric and 1-2.5 $\mathrm{cm}$. long; corolla purple to white, little longer than the bracts.

Palmetto lands and moist waste places, Great Bahama, North Cat Cay, New Providence, Mariguana, Acklin's, Fortune Island, Grand Turk and Inagua :-Bermuda ; North Carolina to Texas; West Indies: Mexico to northern South America ; warmtemperate and tropical parts of the Old World. Referred by Mrs. Northrop and by

Coker to $L$. canescens H.B.K. CAPE-WEed. CREePING LIPPIA. 
4. Lippia réptans H.B.K. Nov. Gen. 2: 263. 1818.

Similar to L. nodiflora, densely appressed-strigilose, herbaceous, the stems prostrate or ascending, 2-5 dm. long. Leaves obovate, $2-6 \mathrm{~cm}$. long, obtuse or acutish at the apex, cuneate at the base, coarsely and sharply dentate above the base, usually rather prominently veined, the petioles $5-10 \mathrm{~mm}$. long; peduncles mostly longer than the leaves; heads ovoid, becoming subcylindric and $2 \mathrm{~cm}$, long or less; corolla white.

Margins of brackish marshes, savannas and pools, Eleuthera and Inagua :-Cuba to St. Croix and to Barbadoes; Jamaica; Mexico to Brazll. This species is, apparently, not certainly distinct from the preceding. LARGER CREEPING LiPPIA.

\section{LANTÀNA L. Sp. Pl. 626. 1753.}

Shrubs, or rarely herbs, with pubescent foliage, the stems sometimes armed with prickles. Leaves opposite, toothed. Flowers in dense peduncled heads or spikes. Calyx membranous, with a truncate or sinuate border. Corolla-tube slender, often curved, sometimes slightly dilated above, the limb more or less 2-lipped, the lobes 4 or 5 . Stamens 4, didynamous; filaments adnate to about the middle of the corolla-tube. Ovary 2-celled; stigma oblique; ovules solitary in each cavity. Fruit small, drupe-like. Nutlets 2celled or separating into 2 one-seeded nutlets. [Named from fancied similarity to Viburnum Lantana.] About 60 species, natives of tropical and warm regions. Type species: Lantana Camara $\mathrm{L}$.

Flowers yellow or orange or changing to orange or red, not involucrate.

Leaves ovate, truncate or subtruncate at the base; straggling shrub.

Leaves ovate to lanceolate, narrowed at the base ; erect shrubs. Corolla orange, changing to red; bracts half as long as the corolla-tube.

Corolla yellow, changing to orange; bracts one-third as long as the corolla-tube.

Flowers white to lilac, often with a yellow eye or throat, involucrate.

Leaves $2-4 \mathrm{~cm}$. long.

Leaves ovate to elliptic or obovate, not more than twice as long as wide.

Leaves oblong to oblanceolate, 2.5 to 3 times as long as wide.

Leaves $10 \mathrm{~mm}$. long or less.

1. L. ovatifolia.

2. L. Camara.

3. L. bahamensis.

4. L. involuorata.

5. L. demutata.

6. L. balsamifera.

1. Lantana ovatifòlia Britton, Bull. N. Y. Bot. Gard. 4: 123.1905.

Stems woody, little branched, diffusely spreading, $7 \mathrm{dm}$. long or less, bluntly 4-angled, very rough-pubescent with stiff appressed hairs. Leaves ovate, thick, short-petioled, $5 \mathrm{~cm}$. long or less, very scabrous on the upper surface, rough-pubescent with stiff hairs beneath, especially on the 4 to 6 principal veins on each side of the prominent mid-vein, acute at the apex, abruptly cuneate-narrowed at the obtuse or subtruncate base, the margin low-crenate nearly all around; petioles rather stout, rough, 3-5 $\mathrm{mm}$. long; peduncles axillary, slender, about $4 \mathrm{~cm}$. long, smooth or nearly so when old; corolla-tube orange-red, the limb yellow, about $6 \mathrm{~mm}$. broad; fruit subglobose, about 4 $\mathrm{mm}$. in diameter, black, shining.

Pine-lands, copplces and scrub-lands, Great Bahama and Andros :-Florida. Andros plants were referred by Mrs. Northrop to $L$. crocea Jacq. Ovate-LEA vED LANTANA.

2. Lantana Camàra L. Sp. Pl. 627. 1753.

A branching shrub 1-1.5 m. tall, rigid-pubescent, nearly or quite unarmed. Leaves ovate to oblong-ovate, 4-12 cm. long, obtuse, acute, or short-acuminate, 
finely crenate-serrate, rounded or narrowed at the base; bracts oblong to lanceolate, 4-7 mm. long; ealyx very thin, $3 \mathrm{~mm}$. long; corolla orange-yellow or orange, changing to red, the tube about $1 \mathrm{~cm}$. long, puberulent, slightly curved, barely enlarged above the middle; limb 6-8 mm. wide; drupes black, about $3 \mathrm{~mm}$. in diameter.

Waste grounds, Eleuthera, Watling's, Long Island and Inagua:-Bermuda ; Georgia to Florida and Texas; West Indies and continental tropical America. Referred to by Coker as $L$. crocea as to his Eleuthera plant. LANTANa. Red SAgE-BUSh."

\section{Lantana bahaménsis Britton, Bull. N. Y. Bot. Gard. 3: 450. 1905.}

Shrub $1 \mathrm{~m}$. high or less, with slender striate branches, which are smooth or sometimes bear minute prickles less than $0.5 \mathrm{~mm}$. long, the twigs minutely pubescent; leaves thin, oblong-lanceolate, varying from acute to blunt at the apex, more or less narrowed at the base, and somewhat decurrent on the petiole, minutely short-pubescent on both sides, or becoming glabrous above, closely crenate, the primary veins rather conspicuous on the under side; blades $5 \mathrm{~cm}$. long or less, $1.5-2 \mathrm{~cm}$. wide; petioles very slender, $2 \mathrm{~cm}$. long or less; peduncles terminal and axillary, shorter than the leaves; bracts lanceolate, acutish, very pubescent, about $4 \mathrm{~mm}$. long; flowers $8-15$ in the heads; calyx $2 \mathrm{~mm}$. long, pubescent, the 2 short lips about equal; corolla yellow, changing to orange, its tube pubescent, enlarged above, about $8 \mathrm{~mm}$. long, its limb about $4 \mathrm{~mm}$. wide, irregularly labed; fruit globose, black, shining, about $3 \mathrm{~mm}$. in diameter.

Scrub-lands and coppices, Andros, New Providence, Eleuthera, Cat Island, Watling's, Rum Cay, Great Exuma, Long Island, Acklin's and North and East Caicos :Cuban Cays. The New Providence plants were referred by Mrs. Northrop to $L$. Camara, and by Hitchcock, Grisebach and Dolley to the Jamaican L. crocea. Erroneously called GOLDEN-ROD. BaHAMA LANTANa.

\section{Lantana involucràta L. Cent. Pl. 2: 22. 1756.}

Lantana odorata L. Syst. ed. 12, 418. 1767.

A pubescent, much branched shrub, 6-15 dm. high, the branches stiff, nearly terete. Leaves elliptic or ovate, petioled, 1-4 cm. long, crenulate, obtuse at the apex, narrowed or obtuse at the base, scabrous above, pubescent beneath; peduncles 1-5 cm. long, slender; heads several-flowered, involucrate by several ovate or ovate-lanceolate bracts $3-6 \mathrm{~mm}$. long; corolla lilac or nearly white, its tube $6-8 \mathrm{~mm}$. long; drupes about $4 \mathrm{~mm}$. in diameter; drupes blue, about $3 \mathrm{~mm}$. in diameter.

Scrub-lands, thickets and pine-lands, throughout the archipelago from Allen's Cay and Great Bahama to Grand Turk, Little Ambergris Cay, Inagua, the Anguilla Isles and Cay Sal:-Florida; Bermuda; Cuba to Virgin Gorda and Guadeloupe; Jamaica. Wild Sage. Big Sage.

\section{Lantana demutàta Millsp. Field Mus. Bot. 2: 175. 1906.}

A widely branched shrub, 1-2 dm. high, the young twigs densely puberulent, the older ones glabrous. Leaves oblong or oblanceolate, short-petioled, 1-2 cm. long, crenate, puberulent on both sides, rugose and scabrous above; peduncles slender, puberulent, 2-4 cm. long; heads 5-8-flowered, involucrate by ovate or oblong obtuse bracts about $4.5 \mathrm{~mm}$. long; flowers white; corollatube about $3 \mathrm{~mm}$. long; drupes blue, pubescent, 2-3 $\mathrm{mm}$. long.

Scrub-lands, Harbor Island, Eleuthera, Cat Island, Great Exuma and Long Island. Endemic. BAHAMA SAGE-BUSH.

\section{Lantana balsamifera Britton, Bull. N. Y. Bot. Gard. 4: 123.1905.}

A shrub, $1.6 \mathrm{~m}$. high or less, forming large masses, with a balsamic odor, the slender bluntly angular branches ascending, puberulent; the internodes short. Leaves elliptic to ovate elliptic or nearly orbicular, 5-10 mm. long, 5 $\mathrm{mm}$. wide or less, puberulent, acute or obtuse, firm, crenulate, rugose-reticulated above, paler and rather strongly veined beneath, the petioles 1-1.5 mm. long; 
peduncles slender, thickened above, $8-15 \mathrm{~mm}$. long in fruit; heads about $6 \mathrm{~mm}$. broad, several-flowered; bracts lanceolate, puberulent, obtusish, $2.5-3 \mathrm{~mm}$. long; calyx 2-toothed, pubescent, $1 \mathrm{~mm}$. long, its teeth blunt; corolla purple, its slightly gibbous tube about $3 \mathrm{~mm}$. long, its spreading limb with 5 unequal obtuse lobes; stamens borne near the top of the corolla-tube, the anthers as long as the filaments or longer.

Scrub-lands, Little Inagua, at Moujean Harbor. Endemic. INAGUA SAgr-BuSH. A small-leaved shrub, growing in sand alongside typical $L$. involucrata on Whale Cay, Berry Islands, appearing very distinct from $1 t$, and a simikar specimen from Eleuthera, first referred by us to this species, may represent another race or species; these specimens are barren.

7. NÁSHIA Millsp. Field Mus. Bot. 2: 176. 1906.

Pubescent aromatic shrubs, with rather stout branches, opposite or fascicled leaves and small capitate bracteolate, white or greenish flowers. Calyx short, annular, subtruncate. Corolla tubular-campanulate, its limb nearly equally 4-lobed. Stamens 4, didynamous, nearly equal in length. Ovary 2-celled. Fruit drupaceous, small, the bony nutlets coherent. [Dedicated to George Valentine Nash.] Two or three species of the Bahamas and Cuba, the following typical.

1. Nashia inaguénsis Millsp. Field Mus. Bot. 2: 177. 1906.

Lippia inaguensis Urban, Symb. Ant. 7: 353. 1912.

A much-branched shrub $2 \mathrm{~m}$. high or less, the bark gray, the branches widely spreading, the young twigs densely short-pubescent, elliptic to obovate or spatulate, 5-10 $\mathrm{mm}$. long, obtuse at the apex, narrowed at the base, rugose and sparingly pubescent above, tomentose beneath, the margin entire, revolute, the petioles about $1 \mathrm{~mm}$. long; heads axillary, sessile, few-flowered; bracts ciliate, apiculate, longer than the flowers; corolla white, about $2 \mathrm{~mm}$. long; drupes pyriform, about $4 \mathrm{~mm}$. long; nutlets smooth.

Scrub-lands, Inagua, near Matthew Town. Endemic. Moujean Tea.

\section{CITHARÉXYLUM L. Sp. Pl. 625. 1753.}

Trees or shrubs, with alternate leaves and small flowers in terminal or axillary spikes or racemes, the pedicels subtended by minute bracts. Calyx narrowly campanulate, minutely 5-lobed, persistent. Corolla salverform, its limb slightly oblique, 5-lobed. Stamens 4 or 5, adnate to the corolla-tube, the fifth one mostly sterile or rudimentary; filaments filiform. Ovary sessile, incompletely 4-celled; ovules solitary, anatropous; stigma 2-lobed. Drupes berry-like, the fleshy pulp enclosing a bony stone which separates into 2,2 seeded nutlets. [Greek, fiddle-wood; French, bois fidèle.] About 20 species, of tropical America. Type species: Citharexylum spinosum L.

Flowers subsessile; nutlets 2-celled.

Flowers with pedicels longer than the bracts; nutlets 1-celled.

1. C. fruticosum.

2. C. caudatum.

1. Citharexylum fruticòsum L. Syst. ed. 10, 1115. 1759.

Citharexylum cinereum L. Sp. P1. ed. 2, 872. 1763.

Citharexylum villosum Jacq. Icon. Rar. 1: 12. 1786.

Citharexylum subserratum Sw. Prodr. 91. 1788.

Citharexylum bahamense Millsp. Bull. N. Y. Bot. Gard. 3: 450. 1905.

A tree, attaining a maximum height of about $10 \mathrm{~m}$., with a trunk up to $2 \mathrm{dm}$. in diameter, the nearly smooth bark light brown, the twigs slender and 
angled, the foliage glabrous or pubescent. Leaves oblong to obovate, various, 5-15 cm. long, 1-4 cm. wide, acute, obtuse or emarginate at the apex, narrowed at the base, reticulate-veined, shining above, dull beneath, the petioles $2.5 \mathrm{~cm}$. long or less; spikes slender, 5-12 cm. long; pedicels $1 \mathrm{~mm}$. long or less ; calyx narrowly campanulate, about $3 \mathrm{~mm}$. long; corolla white, its tube somewhat longer than the calyx, its spreading limb about $6 \mathrm{~mm}$. wide; drupe subglobose, 6-10 mm. in diameter, reddish brown to black; nutlets 2-celled.

Coppices and scrub-lands, Abaco and Andros to Mariguana, East Caicos and Inagua :-Florida ; Cuba to Virgin Gorda and Guadeloupe; Jamaica. Referred by Mrs. Northrop to $\boldsymbol{C}$. Berterii Spreng, by Coker to $C$. quadrangulare Jacq. The species consists of a large number of races, the leaves varying from glabrous to pubescent and from narrowly lanceolate or oblanceolate to obovate, occasionally dentate. SPICATE FIDDLEWOOD. LONG TOM.

\section{Citharexylum caudàtum L. Sp. Pl. ed. 2, 872. 1763.}

Citharexylum Berterii Spreng. Syst. 2: 763. 1825.

Citharexylum lucidum Cham. Linnaea 5: 97. 1830.

A shrub, or a tree up to $20 \mathrm{~m}$. high, the nearly terete, slender twigs glabrous. Leaves oblong, rather thin, $7-15 \mathrm{~cm}$. long, mostly obtuse at the apex, narrowed at the base, shining above, dull beneath, the petioles $1-2 \mathrm{~cm}$. long; racemes narrow, elongated, 4-8 dm. long; pedicels 1.5-3 mm. long; calyx campanulate, about $3 \mathrm{~mm}$. long, nearly truncate; corolla white, its tube about twice as long as the calyx, its limb spreading, 4-5 mm. wide; drupe globose-oblong, black, shining, 2-3 times as long as the calyx; nutlets 1-celled.

Coastal coppices, Andros, at Conch Sound:-Cuba; Hispaniola; Porto Rico; Mexico. RACEMOSE FIDDLEWOOD.

\section{DURÁNTA L. Sp. Pl. 637. 1753.}

Shrubs or small trees, the branches sometimes armed. Leaves opposite or whorled, entire or toothed. Flowers small, in elongated or short, terminal or axillary racemes. Calyx-tube campanulate or tubular, truncate or minutely 5-lobed. Corolla funnelform or salverform, its tube cylindric, straight or incurved, its limb spreading, oblique or of 5 equal lobes. Stamens 4 , didynamous, included; anthers with unappendaged connectives, the sacs distinct. Ovary partially or imperfectly 8-celled. Stigma oblique, sometimes unequally 4-lobed. Ovules solitary or 2 in each cavity. Drupe included in the calyx, of 4 nutlets. Seeds without endosperm. [In honor of Castor Durante, a physician of Rome.] About 8 species, of tropical America, the following typical.

\section{Duranta rèpens L. Sp. Pl. 637. 1753.}

Duranta Ellisia Jacq. Enum. 26. 1760.

Duranta Plumieri Jacq. Select. Am. 186. 1763.

A shrub or small tree reaching a height of $6 \mathrm{~m}$., with glabrate or finely pubescent foliage and unarmed or spiny, slender, often drooping or trailing branches. Leaves numerous, ovate-elliptic, oval or obovate, $1.5-5 \mathrm{~cm}$. long, obtuse or apiculate, entire or serrate above the middle, short-petioled; racemes 5-15 cm. long, recurving; pedicels 1-5 mm. long; calyx 3-4 mm. long, angled, its lobes acute, shorter than the tube; corolla lilac, the tube surpassing the calyx, the limb 7-9 mm. broad; fruit yellow, globular, 7-11 mm. in diameter, enclosed by the accrescent yellowish calyx which is produced into a curved beak.

Pine-lands and scrub-lands, Abaco, Great Bahama, Andros, New Providence, Eleuthera, Cat Island, Acklin's and Mariguana :-Bermuda; Florida; West Indies and Mexico to northern South America. PIGEON-BERRY. 
10. CALLICĀrPA. L. Sp. Pl. 111. 1753.

Shrubs or trees, with opposite leaves, and small blue purple or white flowers in axillary cymes. Calyx short, campanulate, 4-toothed (rarely 5toothed), or truncate. Corolla-tube short, expanded above, the limb 4-cleft (rarely 5-cleft), the lobes equal. Stamens 4, equal, exserted; anther-sacs parallel. Ovary incompletely 2-celled; ovules 2 in each cavity, laterally attached, amphitropous; style slender; stigma capitate, or 2-lobed. Fruit a berry-like drupe, much longer than the calyx, containing 1-4 nutlets. [Greek, handsome fruit.] About 35 species of Asia, Africa and America. Type species: Callicarpa americana $\mathrm{L}$.

1. Callicarpa Hitchcóckii Millsp. Field Mus. Bot. 2: 312. 1909.

A shrub, 2-3 m. high, with weak elongated vine-like branches, the slender twigs densely brown-scurfy. Leaves oblanceolate or linear-oblanceolate, subcoriaceous, 2-3 cm. long, 5-7 mm. wide, revolute-margined, rugose, glabrous and dark-green above, densely brown-scurfy beneath, obtuse at the apex, narrowed at the base, entire, the petioles about $4 \mathrm{~mm}$. long; cymes few-severalflowered, much shorter than the leaves; calyx glabrous, obscurely toothed; corolla white; fruit subglobose, bluish, resinous-dotted, about $5 \mathrm{~mm}$. in diameter.

Scrub-lands, pine-lands and savannas, Andros, New Providence and Cat Isiand :Cuban Cays. Referred by Hitchcock, and in Field Col. Mus. Bot. 2: 180, to C. fuiva A. Rich. BOAR-HOG BusH.

\section{PETI'rIA Jacq. Enum. 1, 12. 1760.}

Trees or shrubs, with large opposite entire petioled tomentulose leaves, and small axillary cymose-paniculate flowers. Calyx campanulate, 4-toothed or subtruncate. Corolla short-salverform, the limb spreading, 4-eleft, the lobes imbricated. Stamens 4, borne near the top of the corolla-tube, equal; filaments very short; anthers ovate. Ovary 2 -celled; ovules 2 in each cavity; style 2-cleft at the apex. Fruit a small drupe, the endocarp 2-4-celled. [Commemorates François Petit, 1664-1741, a French physician.] Two or three species of the West Indies and Mexico, the following typical.

1. Petitia domingénsis Jacq. Enum. 12. 1760.

Petitia Poeppigii Schauer, in DC. Prodr. 11: 639. 1847.

A tree, up to $22 \mathrm{~m}$. high, usually much smaller or sometimes a shrub, the slender twigs, the petioles and the inflorescence densely brownish-tomentulose. Leaves elliptic-oblong or elliptic-lanceolate, $7-15 \mathrm{~cm}$. long, rather thin, acute or acuminate at the apex, obtuse or rounded at the base, dark green, dull and glabrous or nearly so above, rusty-tomentulose beneath, the slender petioles $7 \mathrm{~cm}$. long or less; panicles many-flowered, as long as the leaves or shorter; calyx about $1.5 \mathrm{~mm}$. long; corolla whitish, its tube about twice as long as the calyx, its limb 4-5 mm. broad; flowers fragrant; drupes nearly black, globose to obovoid, 4-5 mm. in diameter.

Pine-barrens, coppices and scrub-lands, Abaco, Great Bahama, Andros, New Providence, Eleuthera, and Cat Island:-Cuba; Hispaniola ; Porto Rico; Jamaica; Cayman Isiands. Recorded from St. Croix. PETItia. BASTARD STOPPER.

12. PSEUdOCARPIDIUM Millsp. Field Mus. Bot. 2: 181. 1906.

Shrubs or trees, with opposite petioled simple subcoriaceous, spinulosedentate or entire leaves, and small axillary panicled flowers. Calyx campanu- 
late, equally 5-dentate. Corolla tubular-funnelform or salverform, the limb 2-lipped, 5-lobed. Stamens 4, exserted. Ovary at length 4-celled; style simple; stigma 2-cleft. Fruit dry or slightly fleshy, 3-4-lobed. [Greek, false carpid.] Six known species, of Cuba and the Bahamas. Type species: Vitex ilicifolia A. Rich.

1. Pseudocarpidium Wríghtii Millsp. Field Mus. Bot. 2: 182. 1906.

A shrub or small tree up to $5 \mathrm{~m}$. high, the young twigs and the inflorescence puberulent, the bark light gray or nearly white. Leaves elliptic to obovate or ovate-lanceolate, $2-5 \mathrm{~cm}$. long, obtuse at the apex, rounded or subcordate at the base, spinulose-dentate, glabrous, shining and reticulate-veined above, puberulent at least on the veins beneath, the petioles $3-5 \mathrm{~mm}$. long; panicles peduncled, several-many-flowered, mostly exceeding the leaves; calyx 2-3 mm. long, its teeth ovate, acute; corolla violet, about 4 times as long as the calyx; fruit depressed, about $8 \mathrm{~mm}$. broad, its lobes rounded.

Copplces and scrub-lands, Andros and Mangrove Cay:-Cuba. Recorded by Mrs. Northrop as Vitex ilicifolia A. Rich., which it resembles. Wright's PseudoCARPIDIUM.

13. VOLKAMÈRIA L. Sp. Pl. 637. 1753.

A vine-like, spiny shrub, with opposite petioled entire leaves, and white flowers in axillary cymes. ('alyx campanulate, 5-toothed. Corolla salverform, with a slender tube, the limb 5-lobed. Stamens 4, exserted, somewhat unequal. Style filiform. Stigma 2-lobed. Fruit a subglobose drupe, the 2 nutlets each 2-celled. [In honor of J. C. Volkamer, a Nuremberg botanist, who died in 1720.] Only the following species, native of tropical America.

1. Volkameria aculeàta L. Sp. Pl. 637. 1753.

Clerodendron aculeatum Griseb. Fl. Br. W. I. 500. 1861.

Ovieda aculeata Hitchc. Rep. Mo. Bot. Gard. 4: 118. 1893.

Climbing to a length of $3 \mathrm{~m}$. or more, or nearly erect, the slender branches densely puberulent, armed with stout oposite spreading spines $8 \mathrm{~mm}$. long or less. Leaves thin, slender-petioled, oblong to elliptic-obovate, obtuse or acute at. the apex, narrowed to the base, 2-5 cm. long; cymes stalked, fewseveral-flowered; pedicels slender, puberulent, 6-14 $\mathrm{mm}$. long; calyx about 3 $\mathrm{mm}$. long, puberulent, its teeth triangular-ovate, acute; tube of the corolla about $18 \mathrm{~mm}$. long, its limb about $12 \mathrm{~mm}$. broad; stamens purple; drupe 4grooved, 6-8 $\mathrm{mm}$. in diameter.

Scrub-lands, New Providence and Inagua :-Bermuda ; Cuba to Virgin Gorda and Martinique; Jamaica; continental tropical America. PRICKLY MYrTLE.

\section{CLERODÉNDRUM [Burm.] L. Sp. Pl. 637. 1753.}

Shrubs, vines or perennial herbs, with opposite entire leaves, and flowers in terminal or axillary cymes or panicles. Calyx 5-toothed or 5-lobed. Corolla salverform or funnelform, the tube mostly longer than the 5-lobed limb. Stamens 4, borne on the corolla-tube, exserted, somewhat unequal. Stigma 2lobed; ovary 4-celled. Fruit a drupe, enclosing 4, 1-seeded nutlets. [Greek, tree of fortune.] Probably 100 or more species, mostly natives of tropical regions. Type species: Clerodendrum infortunatum $\mathbf{L}$. 
1. Clerodendrum fràgrans Vent. Jard. Malm. pl. 70. 1804.

Ovieda fragrans Hitchc. Rep. Mo. Bot. Gard. 4: 118. 1893.

Half-shrubby, finely pubescent, 6-15 $\mathrm{dm}$. high, the stout branches angled. Leaves very broadly ovate, 1-2 dm. long, acute at the apex, cordate or nearly truncate at the base, coarsely dentate, long-petioled; flowers white, fragrant, double in all American specimens examined, in dense terminal cymes, the corolla about $2.5 \mathrm{~cm}$. broad; calyx 5-cleft, its lanceolate lobes acuminate; corolla-lobes rounded.

Roadside, New Providence :-Bermuda; Florida; West Indies and continental tropical America. Naturalized from the tropics of Asia. ODOROUs CLERODENDRON. WILD JESSAMINE.

15. AVICÉNNIA L. Sp. Pl. 110. 1753.

Evergreen trees, sometimes shrubby, with nodose twigs, opposite entire leathery leaves without stipules, and peduncled clusters of white bracted flowers. Calyx cup-shaped, silky, with 5 persistent lobes. Corolla campanulate, its short tube nearly cylindric, its limb spreading, 4-lobed. Stamens 4, adnate to the corolla-tube, the anthers introrse. Ovary sessile, 1-celled; ovules 4 , on a central placenta; style short, 2 lobed. Fruit capsular, oblique, apiculate. Seeds without endosperm, usually germinating in the capsule. [In honor of Avicenna (980-1036) of Bokhara, a distinguished oriental physician.] Three known species of tropical and subtropical seacoasts. Type species: Avicennia officinalis $\mathrm{L}$.

\section{Avicennia nítida Jacq. Enum. 25. 1760.}

A tree, up to about $16 \mathrm{~m}$. high, with shallowly fissured dark scaly bark, orange-red within, the young twigs finely pubescent. Leaves pubescent when young, soon becoming glabrous above, oblong or oblong-lanceolate, $3-8 \mathrm{~cm}$. long, obtuse or apiculate at the apex, finely canescent beneath, narrowed at the base into short petioles; panicles 2-5 cm. long; corolla 10-14 mm. broad, its lobes rounded; capsule oblong or elliptic, $2-5 \mathrm{~cm}$. long, light green, slightly pubescent.

In mangrove mud and shallows of the sea, throughout the archipelago from Abaco and Great Bahama to Grand Turk, Inagua and Cay Sal :-Bermuda; Florida to Texas; West Indies and continental tropical America. Catesby, 1: pl. 85. BLACK MANGROVE. GREEN TURTLE BOUGH.

\section{Family 8. LAMIÀCEAE Lindl.}

\section{Mint FaMiLy.}

Aromatic punctate herbs, or shrubs (a few tropical species trees), mostly with 4-sided stems and simple opposite leaves; stipules none. Flowers irregular, perfect, clustered, the inflorescence typically cymose, usually bracteolate. Calyx inferior, persistent, 5-toothed or 5-lobed (rarely 4-toothed), mostly nerved. Corolla with a short or long tube, the limb 4-5-lobed, mostly 2-lipped, regular in a few genera; upper lip 2-lobed, or sometimes entire; lower lip mostly 3-lobed. Stamens borne on the corolla-tube, typically 4 and didynamous, sometimes 2 , rarely equal; filaments separate, alternate with the corolla-lobes; anthers 2-celled, introrse, or confluently 1-celled, or sometimes of a single sac. Disk usually present, fleshy. Ovary 4-lobed, or 4-parted, superior, each lobe or division with 1 mostly anatropous ovule; style arising from the centre of the lobed or 
parted ovary, 2-lobed at the summit. Fruit of 4, 1-seeded nutlets. Seed erect (transverse in Scutellaria); endosperm seanty, or none; embryo mostly straight; radicle short, inferior. About 160 genera and 3,200 species, of wide distribution.

Ovary of 4 united carpels, 4-lobed; style not basal.

Ovary of 4 distinct or nearly distinct carpels; style basal.

Calyx with a crest on the upper side.

Calyx without a crest.

Corolla distinctly 2-lipped, the lips different, the upper one concave.

Anther-bearing stamens 4.

Calyx-lobes 5 .

Calyx-lobes 8-10.

Anther-bearing stamens 2.

Corolla nearly regular, or if 2 -llpped, the upper lip not concave.

Filaments converging under the upper lip of the corolla. Lower pair of flaments appressed to the lower lip of the corolla.

Lobes of the calyx nearly equal.

Upper lobe of the calyx broad, decurrent.

1. Melosmon.

2. Scutellaria.

\section{MELÓSMON Raf. Fl. Tell. 3: 85. 1837.}

Herbs with incised or pinnatifid leaves, the white or blue pedicelled flowers solitary in the axils of leaf-like bracts. Calyx with a short, 10-ribbed tube and 5 long nearly equal lobes. Corolla irregular, the upper lip small, the lower lip 3-lobed, its middle lobe much longer than the lateral ones. Stamens 4, exserted. Ovary 4-lobed, of 4 partly united carpels; style not basal. Nutlets laterally attached, roughened or smooth. [Greek, of uncertain application.] A few species, natives of temperate and tropical America. Type species: Melosmon bicolor Raf.

1. Melosmon cubénse (Jacq.) Small, Fl. SE. U. S. 1019, 1337. 1903.

Teucrium cubense Jacq. Enum. 25. 1760.

Annual (?) ; sparingly pubescent or glabrate; stems often branched near the base, slender, $2-5 \mathrm{dm}$. high, the branches ascending. Leaves ovate to spatulate in outline, 1-3 cm. long, incised, the lobes mostly entire; bracts similar to the leaves; pedicels $2-5 \mathrm{~mm}$. long; ealyx 4-5.5 $\mathrm{mm}$. long, its linearlanceolate pubescent acuminate lobes several times longer than the tube; corolla bluish-white, 11-14 $\mathrm{mm}$. long; nutlets about $2 \mathrm{~mm}$. long, irregularly roughened.

Waste places and cultivated solls, Great Bahama, New Providence, Eleuthera to Long Island, Inagua :-Alabama, Texas and Mexlco; Cuba. West INDiAí Germander.

\section{SCUTELLÀRIA L. Sp. P1. 598. 1753.}

Bitter herbs, some species shrubby. Flowers blue to violet, in bracted, mostly secund, spike-like racemes, or solitary or 2-3 together in the axils. Calyx campanulate, gibbous, 2-lipped, the lips entire, the upper one with a crest or protuberance upon its back and often deciduous in fruit. Corolla recurved-ascending, dilated above into the throat, glabrous within, the limb 2-lipped; upper lip arched, entire or emarginate; lower lip spreading or deflexed, its lateral lobes small and somewhat connected with the upper, its middle lobe broad. Stamens 4, didynamous, all anther-bearing, ascending under the upper lip, the upper pair somewhat the shorter, their anthers 2 - 
celled, ciliate; anthers of the lower pair of stamens 1-celled, also ciliate. Nutlets papillose or tuberculate. [Latin, a dish, from the appendage to the fruiting calyx.] About 100 species of wide distribution. Type species: Scutellaria peregrina L.

1. Scutellaria havanénsis Jacq. Enum. 25. 1760.

Scutellaria cubensis A. Rich. in Sagra, Hist. Cub. 11: 158. 1850.

Scutellaria longiflora Small, Bull. N. Y. Bot. Gard. 3: 437. 1905.

Perennial; stems very slender, often branched near the base, erect or ascending, $3 \mathrm{dm}$. high or less, pubescent or puberulent. Leaves ovate or ovateorbicular, short-petioled, 3-9 $\mathrm{mm}$. long, puberulent on both sides, few-toothed or entire; flowers solitary in the axils on ascending peduncles $3-7 \mathrm{~mm}$. long; flowering calyx about $1.5 \mathrm{~mm}$. long; corolla dark blue, about $1.5 \mathrm{~cm}$. long, the middle lobe of the upper lip emarginate, the lower lip 3-lobed; fruiting calyx about $3 \mathrm{~mm}$. long.

Rocky places, red-lands and pine-lands, Great Bahama, Eleuthera, Cat Island, and Great Exuma:-Florida ; Cuba ; Hispaniola ; Porto Rico. SkullcaP.

Scutellaria purpurascens Sw. mentioned by Hitchcock as occurring on Eleuthera was not found in his collections; the record is probably based on the above species.

\section{LEONÙRUS L. Sp. Pl. 584. 1753.}

Tall herbs, with palmately cleft, parted or dentate leaves, and small white or pink flowers verticillate in dense axillary clusters. Calyx tubular-campanulate, 5-nerved, nearly regular and equally 5-toothed, the teeth rigid, subulate or aristate. Corolla-limb 2-lipped; upper lip erect, entire; lower lip spreading or deflexed, 3-lobed, the middle lobe broad, obcordate or emarginate. Anthers 2-celled, the sacs mostly parallel. Nutlets 3-sided, smooth. [Greek, lion'stail.] About 10 species, of Europe and Asia. Type species: Leonurus Cardiaca L.

\section{Leonurus sibíricus L. Sp. Pl. 584. 1753.}

Biennial, puberulent or glabrate; stem 6-18 dm. high. Leaves longpetioled, 3-parted into ovate or lanceolate, acute or acuminate, cleft and incised segments, the lobes lanceolate or linear, acute, the uppermost linear or lanceolate; clusters dense, usually all axillary; calyx campanulate, $6 \mathrm{~mm}$. long, glabrous or minutely puberulent; corolla purple or red, densely puberulent without, 8-12 mm. long, its tube naked within; anther-sacs divergent.

Waste places, New Providence and Harbor Island:-Bermuda; Delaware and Maryland; West Indies; continental tropical America. Naturalized from the Old World tropics. LION'S TAIL. PIPE-SHANK.

\section{LEONÒTIS R. Br. in Ait. Hort. Kew ed. 2, 3: 409.1811.}

Annual or perennial caulescent herbs or shrubby plants, the leaves opposite, broad, toothed, petioled, the flowers in dense whorls, short-pedicelled. Calyxtube 10-nerved, oblique at the mouth, its lobes 8-10, unequal, bristle-tipped. Corolla yellow, orange or scarlet, 2-lipped, the tube dilated above, curved; upper lip erect, rather long; lower lip with 3 lobes, the middle lobe scarcely longer than the lateral. Stamens 4 ; filaments all anther-bearing; anthers 2celled; sacs diverging. Nutlets 3-angled, smooth. [Greek, lion's-ear.] About 12 species, natives of Africa. Type species: Leonotis Leonitis (L.) R. Br. 
1. Leonotis nepetaefòlia (L.) R. Br. in Ait. Hort. Kew ed. 2, 3: 409. 1811. Phlomis nepetaefolia L. Sp. Pl. 586. 1753.

Annual, softly pubescent. Stems 3-20 dm. tall, rather stout, simple or branched; leaves ovate to ovate-deltoid, 4-12 $\mathrm{cm}$. long, coarsely crenate, cuneate or subcordate at the base; flower-clusters dense, 4-6 $\mathrm{cm}$. in diameter; pedicels 1-2 $\mathrm{mm}$. long; calyx puberulent, becoming at least $2 \mathrm{~cm}$. long, its tube reticulated above the middle, its lobes 8 , awn-tipped; corolla scarlet or orange-yellow, 2-2.5 cm. long, villous-hirsute, its tube curved, the upper lip as long as the tube, the lower lip much shorter than the upper, with 3 narrow lobes; nutlets $3 \mathrm{~mm}$. long, sharply angled.

Waste places, New Providence, Eleuthera, Acklin's Island, Mariguana, Grand Turk and Inagua :- Bermuda ; Tennessee to Florida and Loulsiana ; West Indies ; Texas to Brazll; Old World tropics. LION's-EAR.

\section{SÁLVIA L. Sp. Pl. 23. 1753.}

Herbs, or some species shrubs, with clustered flowers, the clusters mostly spiked, racemed, or panicled. Calyx mostly naked in the throat, 2-lipped; upper lip entire or 3-toothed; lower lip 2-cleft or 2-toothed. Corolla strongly 2lipped; upper lip entire, emarginate or 2-lobed; lower lip spreading, 3-cleft or 3-lobed. Anther-bearing stamens 2 (the posterior pair wanting or rudimentary); connective of the anthers transverse, linear or filiform, bearing a perfect anther-sac on its upper end, its lower end dilated, capitate or sometimes bearing a small or rudimentary one. Nutlets smooth, usually developing mucilage and spiral tubes when wetted. [Latin, salvus, safe, from its healing virtues.] About 500 species, of wide distribution. Type species: Salvia officinalis $\mathrm{L}$.

Corolla blue to white, 4-10 mm. long.

Leaves cuneate-narrowed at base.

Leaves rounded or cordate at base. Corolla red or scarlet, $2-2.5 \mathrm{~cm}$. long.

1. S. occidentalis.

2. S. serotina.

3. S. coccinea.

\section{Salvia occidentàlis Sww. Prodr. 14. 1788.}

Annual ; stems ascending, decumbent or prostrate, branched, densely pubescent at least above, $0.5-2 \mathrm{~m}$. long. Leaves ovate, $2-5 \mathrm{~cm}$. long, serrate, shortpetioled, acute or acuminate at the apex, narrowed or subtruncate at the base; panicles narrow, 0.5-3 dm. long, the clusters few-flowered, the lower ones distant, the upper elose together; calyx about $3 \mathrm{~mm}$. long densely glandularpubescent, ribbed, the upper lip obtuse, the lobes of tLi 'orrer lip acute; corolla blue, about $5 \mathrm{~mm}$. long, its tube a little shorter than the calyx; nutlets about $2 \mathrm{~mm}$. long.

Waste places and copplces, Andros, New Providence, Eleuthera and Great Exuma : Florida; West Indies and continental tropical America; recorded from Bermuda. WEST INDIAN SAgE.

2. Salvia serotìna L. Mant. 1: 25. 1767.

Salvia micrantha Vahl, Enum. 1: 235. 1805.

Perennial, finely pubescent; stems 1.5-7 dm. tall, much branched. Leaves ovate or orbicular-ovate, $1-4 \mathrm{~cm}$. long, obtuse, crenate-serrate, rounded or subcordate at the base, slender-petioled; panicles 2-10 $\mathrm{cm}$. long; calyx longer than the pedicels, glandular-hirsute, becoming 5-8 $\mathrm{mm}$. long; lips about $\frac{1}{3}$ as long as the long-campanulate tube; corolla 6-10 mm. long, white or blue, its tube included; style glabrous; nutlets fully $2 \mathrm{~mm}$. long. 
Waste places and scrub-lands, throughout the archipelago from Abaco and Great Bahama to Andros, The Caicos, Grand Turk and Inagua :-Bermuda; Florida; West Indies; continental tropical America. Consists of many races differing in pubescence, the corolla blue to white. Apparently referred to S. tenella Sw. by Hitchcock. Erroneousiy called CatNeP. Listed by Dolley as Nepeta Cataria L. SMaLL White SAGE.

3. Salvia coccínea Juss, in Murray, Comm. Gott. 1: 86.1778.

Annual, softly pubescent; stems erect, 3-7 dm. tall, simple or sparingly branched. Leaves ovate or deltoid-ovate, $3-6 \mathrm{~cm}$. long, obtuse or acutish, crenate-serrate, truncate to subcordate at the base; panicles 5-20 cm. long; pedicels 2-6 mm. long, slender; calyx minutely pubescent, 10-12 $\mathrm{mm}$. long, its tube many-ribbed, the upper lip reniform, abruptly pointed, the lower lobes ovate-apiculate; corolla deep scarlet, $2-2.5 \mathrm{~cm}$. long, puberulent, the tube contracted above the base, then gradually enlarged, the lower lip 7-8 $\mathrm{mm}$. broad, merely notched at the apex; nutlets $2.5 \mathrm{~mm}$. long, slightly variegated.

Waste places, Watling's Island, at Cockburn Town :-Bermuda ; South Caroilna to Florida, Texas and Mexico; West Indies and continental tropical America. ScARLeT SAGE. COUNTRY Belle.

\section{MICROMÈRIA Berth. Bot. Reg. 15: under pl. 1282. 1829.}

Shrubs or perennial herbs, with entire or dentate leaves and small axillary clustered or solitary flowers. Calyx tubular, its tube mostly 13-ribbed, its 5 lobes nearly equal. Corolla 2-lipped; upper lip erect, often very small; lower lip 3-lobed, the middle lobe commonly emarginate. Stamens 4, converging under the upper corolla-lip; anthers 2-celled, the sacs divergent. Ovary 4carpellary; style basal. Nutlets smooth, basally attached. [Greek, referring to the small flowers.] Sixty species or more, natives of temperate and tropical regions. Type species: Sabbatia corymbosa Moench.

1. Micromeria Brownei (Sw.) Benth. Lab. 372. 1834.

Thymus Brownei Sw. Prodr. 89. 1788.

Satureia Brownei Briquet, in E. \& P. Nat. Pflanzf. 4 ${ }^{3 a}$ : 300. 1896.

Perennial, glabrous or nearly so; stems branched near the base, very slender, the branches prostrate and creeping, 1-4 dm. long. Leaves broadly ovate or orbicular, $5-12 \mathrm{~mm}$. broad, crenulate, obtuse or acute at the apex, truncate or subcordate at the base, the petioles 1-6 mm. long; flowers mostly solitary in the axils; pedicels filiform, 3-12 mm. long, as long as the upper leaves or longer; calyx narrowly turbinate, $4-5 \mathrm{~mm}$. long, its triangular-ovate, ciliolate lobes about one-half as long as the tube; corolla white, 7-8 $\mathrm{mm}$. long, its upper lip ovate, sometimes emarginate.

Moist solis at fresh-water holes, Abaco and Great Bahama southward to Crooked Island :- Florida; Jamaica. Recorded by Dolley as Nepeta coerulea L. WeST INDIAN THYME.

\section{HYPTIS Jacq. Coll. 1: 101. 1786.}

[Mesosphaerum P. Br. Hist. Jam. 257. Hyponym. 1756.]

Herbs, mostly erect and branched, the leaves usually dentate, the flowers variously clustered. Calyx tubular, ovoid or campanulate, equally 5-lobed, the lobes acute or aristate. Corolla 2-lipped, the upper lip erect or spreading, the lower saccate and drooping. Stamens 4, declined, all antheriferous, the filaments distinct, the anthers 2-celled. Ovary 4-carpellary; style basal. Nutlets 
smooth or rough. [Greek, bent backward.] About 300 species, mostly of tropical America. Type species: Hyptis verticillata Jacq.

Flowers in secund spiked cymes; calyx $3-4 \mathrm{~mm}$. long.

Flowers in axillary clusters; calyx 8-10 mm. long.

1. H. pectinata.

2. H. suaveolens.

\section{Hyptis pectinàta (L.) Poit. Ann. Mus. Paris 7: 474. 1806.}

Nepeta pectinata L. Syst. Ed. 10, 1097. 1759.

Perennial, densely puberulent; stems erect, 3-20 dm. high. Leaves ovate, 2-8 $\mathrm{cm}$. long, serrate, acute at the apex, mostly obtuse or subcordate at the base, the petioles $4.5 \mathrm{~cm}$. long or less; flowers in secund spiked cymules, the inflorescence elongated; calyx 3-4 mm. long, puberulent, its subulate lobes nearly as long as the tube; corolla whitish, little longer than the calyx, the upper lip 2-lobed, the lower 3-lobed; nutlets granular, about $1 \mathrm{~mm}$. long.

Waste places, Andros, Cat Island, and Inagua :-Florida; West Indies and continental troplcal America. Pectinate Hrptis.

\section{Hyptis suaveòlens (L.) Poit. Ann. Mus. Paris 7: 472.1806.}

Ballota suaveolens L. Syst. ed. 10, 1100. 1759.

Annual \& Stem stout, often much branched, loosely pilose, 3-8 dm. high. Leaves ovate or ovate-orbicular, slender-petioled, $4 \mathrm{~cm}$. long or less, acute or obtuse at the apex, obtuse or subcordate at the base, low-serrate, sparingly pubescent on both sides; flowers 2-5 together, nearly sessile, in short-peduncled, axillary clusters, or the clusters crowded in a terminal panicle and subtended by small leaves; calyx campanulate, strongly ribbed, at length $8-10 \mathrm{~mm}$. long, its subulate teeth shorter than the tube; corolla 5-6 mm. long, bluish.

Waste and cultivated solls, New Provldence, Eleuthera and Great Exuma :-West Indies; continental tropical America; East Indies. Pilose Hrptis. Wild Basil.

\section{8. ÒCIMUIM L. Sp. Pl. 597. 1753.}

Herbs or low shrubs, with erect or ascending branched stems, usually dentate petioled leaves and clustered flowers. Calyx deflexed in fruit, its tube campanulate or ovoid, 5-lobed, the lobes unequal, the lower ones somewhat united. Corolla white or nearly white, its tube usually shorter than the calyx, its lobes nearly equal. Stamens 4, didynamous, the lower pair appressed to the lower lip of the corolla; filaments naked or appendaged. Ovary 4-carpellary; style basal. Nutlets smooth or rugose. [Greek, odorous.] About 40 species widely distributed in warm and tropical regions. Type species: Ocimum basilicum L.

1. Ocimum micrànthum Willd. Enum. Hort. Berol. 630. 1809.

Annual, pubescent; stem erect, branched, 2-5 dm. high. Leaves ovate or oblong-ovate, 1-5 cm. long, serrate, acute at the apex, narrowed or subtruncate at the base, the petioles 5-20 mm. long; panicles 2-10 $\mathrm{cm}$. long; flowers several in the clusters; pedicels 4-7 $\mathrm{mm}$. long; calyx puberulent, $6-7 \mathrm{~mm}$. long in fruit, the upper lip concave, the lower of 4 narrow subulate-tipped lobes; corolla about $4 \mathrm{~mm}$. long, its tube dilated above, its upper lip with 2 rounded lobes, the lower lip with 2 ovate lateral lobes and a notched middle one; nutlets about $1 \mathrm{~mm}$. long.

Waste and cultivated grounds, New Providence and Eleuthera:-Florida; West Indies; Jamaica; Mexlco to continental tropical America. Wild Basil. PotMargin. the islands.

Marrubium vulgare L., listed by Dolley, has not been found by our collectors on 


\section{Family 9. SOLANÀCEAE Pers.}

\section{Potato Familix.}

Herbs, shrubs, vines, or some tropical species trees, with alternate or rarely opposite estipulate leaves, and perfect regular, or nearly regular, cymose flowers. Calyx inferior, mostly 5-lobed. Corolla gamopetalous, mostly 5-lobed, the lobes induplicate-valvate or plicate in the bud. Stamens as many as the lobes of the corolla and alternate with them, inserted on the tube, all perfect in the following genera; anthers various, 2-celled, apically or longitudinally dehiscent. Ovary superior, 2-celled (rarely 3-5-celled); ovules numerous on the axile placentæ, anatropous or amphitropous; style slender, simple; stigma terminal; fruit a berry or capsule. Seeds numerous; endosperm fleshy; cotyledons semiterete. About 75 genera and 1,750 species, most abundant in tropical regions.

Fruit a berry.

Corolla plicate.

Berry enclosed in the accrescent calyx.

Berry not enclosed in the calyx.

Corolla not plicate, or scarcely plicate.

Corolla rotate.

Corolla salverform to funnelform.

Stamens unequal; filaments adnate to the mouth of the corolla-tube.

Stamens equal or nearly so; filaments adnate to about the middle of the corolla-tube.

Fruit a capsule.

Calyx tubular, at length circumscissile.

Calyx ovold or campanulate, 5 -cleft.

1. Physalis.

2. Solanum.

3. Capsicum.

4. Lycium.

5. Cestrum.

6. Datura.

7. Nicotiana.

\section{PHÝSALIS L. Sp. PI. 182. 1753.}

Herbs, sometimes a little woody below, with entire or sinuately toothed leaves. Peduncles slender, in our species solitary in the axils. Calyx campanulate, 5-toothed, in fruit enlarged and bladdery-inflated, membranous, 5-angled, or prominently 10-ribbed and reticulate, wholly enclosing the pulpy berry. Corolla often with a brownish or purplish center, open-campanulate, or rarely campanulate-rotate, plicate. Stamens inserted near the base of the corolla; anthers oblong, opening by longitudinal slits. Style slender, somewhat bent; stigma minutely 2-cleft. Seeds numerous, kidney-shaped, flattened. [Greek, bladder, referring to the inflated calyx.] The number of recognized species is about 50, widely distributed. Type species: Physalis Alkekengi L.

Fruiting calyx 5-angled; leaves narrowed at the base.

Fruiting calyx 5-winged; leaves cordate, rounded or obtuse at the base.

Glabrous, or nearly so.

Densely pubescent.

1. P. angulata.

2. P. turbinata.

3. P. pubescens.

\section{Physalis angulàta L. Sp. Pl. 183. 1753.}

Physalis Linkiana Dunal, in DC. Prodr. 13': 448. 1852.

Erect, 4-9 dm. high, glabrous; stem angled; leaves ovate, usually with cuneate base and long-acuminate teeth, $5-6.5 \mathrm{~cm}$. long, on slender petioles, thin, the veins not prominent; peduncles slender, 2-3 cm. long, erect, in fruit often reflexed but seldom exceeding the fruiting calyx; calyx-teeth triangular to lanceolate, generally shorter than the tube; corolla $5-10 \mathrm{~cm}$. in diameter; anthers purplish tinged; fruiting calyx about $3 \mathrm{~cm}$. long, ovoid, not prominently angled, at last nearly filled by the yellow berry.

Waste places, Andros and New Providence:-Bermuda; southern United States ; West Indies and continental tropical America. CUT-Leaved Ground-Cherry. Poppers. 
2. Physalis turbinàta Medik. in Act. Acad. Theod. Palat. 4: 188, t. 5, fig. 2. 1780.

Annual, glabrous, or minutely puberulent when young. Stems rather stout, acutely angled and divaricately branched; leaves broadly ovate, obtuse or cordate and slightly oblique at the base, thin and dark green, repand-dentate, short-acuminate; peduncles short, in fruit about $1.5 \mathrm{~cm}$. long, calyx-lobes lanceolate, acuminate; corolla $8-10 \mathrm{~mm}$. wide, yellow with a purplish eye; fruiting calyx $3-3.5 \mathrm{~cm}$. long, long-attenuate, almost pyramidal, deeply retuse at the base.

Waste and cultivated grounds, Acklin's Island and Caicos Islands :-Bermuda ; southern United States; West Indies and continental tropical America. SMO0TH GROUND-CHERRY.

\section{Physalis pubèscens I. Sp. Pl. 183. 1753.}

Physalis barbadensis Jacq. Misc. 2: 359. 1781.

Annual, pubescent and viscid. Stems tall and erect, or widely spreading, acutely 3-4-angled; leaves 3-6 cm. long, heart-shaped, acute, or usually abruptly acuminate, sharply repand-dentate, pubescent with short hairs; peduncles short, at maturity sometimes $2 \mathrm{~cm}$. long; calyx generally densely viscid-hirsute, its lobes lanceolate, acuminate; corolla 5-10 $\mathrm{mm}$. in diameter, yellow, with a purplish eye; anthers purplish; fruiting calyx $2.5-3 \mathrm{~cm}$. long, attenuate, reticulate, retuse at the base.

Waste grounds, Andros and New Providence:-West Indies; continental tropical and temperate America. $P P$. curassavica of Schoepf. HAIRY GROUND-CHERRY.

\section{SOLÀNUM L. Sp. Pl. 184. 1753.}

Herbs or shrubs, often stellate-pubescent, sometimes climbing. Flowers cymose, umbelliform, paniculate, or racemose. Calyx campanulate or rotate, mostly 5-toothed or 5-cleft. Corolla rotate, the limb plaited, 5-angled or 5lobed, the tube very short. Stamens inserted on the throat of the corolla; filaments short; anthers linear or oblong, acute or acuminate, connate or connivent into a cone, each sac dehiscent by a terminal pore, or sometimes by a short introse terminal slit, or sometimes also longitudinally. Ovary usually 2-celled; stigma small. Berry mostly globose, the calyx either persistent at its base or enclosing it. [Name, according to Wittstein, from solamen, quieting.] About 900 species, of wide geographic distribution. Type species: Solanum nigrum L.

Pubescence not stellate.

Plants coplously armed with long slender prickles.

Plants unarmed.

Pubescence densely stellate.

Leaves large, lanceolate to obovate.

Inflorescence racemose.

Inflorescence corymbose.

Inflorescence terminal; plants unarmed. Corolla-lobes ovate. Corolla-lobes lanceolate.

Inflorescence subaxillary; plants usually with some prickles.

Leaves minute, not over $3 \mathrm{~mm}$. long.

1. S. aculeatissimum.

2. S. nigrum.

3. S. bahamense.

4. S. verbascifolium. 5. S. Blodgettii.

6. S. torvum.

7. S. didymacanthum.

1. Solanum aculeatíssimum Jacq. Coll. 1: 100. 1786.

Perennial, slightly woody, usually much branched, 6-12 dm. high, somewhat pilose, or becoming glabrous, the branches, petioles, leaf-blades and peduncles armed with straight yellow prickles. Leaves thin, broadly ovate in outline, 7-15 cm. long, pinnately lobed or repand; cymes few-flowered, lateral; 
calyx armed with stout prickles, about one-third as long as the corolla, its lobes ovate, acute; corolla white, about $12 \mathrm{~mm}$. broad; anthers ovate-lanceolate; berry globose, scarlet, glabrous, 1-2 cm. in diameter.

Waste and cultivated ground, Great Bahama, Andros, New Providence, Eleuthera and Cat Island; recorded from Green Turtle Cay :- southern United States; Bermuda; West Indies and continental troplcal America. Cockroach Berry.

\section{Solanum nigrum L. Sp. Pl. 186. 1753.}

Solanum nodiflorum Dunal, Hist. Sol. 151. 1813. Not Jacq. 1793.

Solanum americanum Mill. Gard. Dict. ed. 8, no. 5. 1768.

Solanum purpuratum Bitter, Repert. 12: 85. 1913.

Annual, glabrous, or somewhat pubescent with simple hairs, 3-8 dm. high. Leaves ovate, petioled, more or less inequilateral, 2-8 cm. long, thin, acute, acuminate or acutish at the apex; peduncles lateral, umbellately 3-10-flowered; pedicels 6-14 mm. long; flowers $8-10 \mathrm{~mm}$. broad; calyx-lobes oblong, obtuse, much shorter than the corolla, persistent at the base of the berry; filaments somewhat pubescent; anthers obtuse; berries glabrous, globose, 8-10 mm. in diameter, black, on nodding peduncles.

Waste and cuitivated grounds, throughout the archipelago from Great Bahama to Watling's, East Calcos, Grand Turk and Inagua :-all temperate and troplcal regions of both hemispheres. Consists of many races differing in length of pedicels and size of flowers, the leaves varying from entire to coarsely toothed. Recorded by Hitchcock as Solanum nigrum oleraceum; by Small as Solanum gracile Link. BLACK NIGHTSHADE. INK-BERRY. GOOMA-BUSH.

\section{Solanum bahaménse L. Sp. Pl. 188. 1753.}

Solanum bahamense lanceolatum Griseb. Fl. Br. W. I. 440. 1861.

Solanum subarmatum Willd. Enum. Hort. Berol. 240. 1809.

A prickly or unarmed shrub, $2 \mathrm{~m}$. high or less, the twigs, leaves and inflorescence stellate puberulent, the prickles slender. Leaves oblong to lanceolate, 4-12 cm. long, slender-petioled, acute or obtuse at the apex, narrowed or obtuse and often oblique at the base, the margin entire or somewhat undulate, the veins rather distant; peduncles lateral, longer than the petioles; inflorescence racemiform, sometimes forked, few-several-flowered; pedicels slender, thickened upward, 6-12 mm. long, nodding in fruit; calyx $1.5 \mathrm{~mm}$. long, its lobes ovate; corolla blue, rarely white, $10-15 \mathrm{~mm}$. broad; berry red, globose, 6-8 $\mathrm{mm}$. in diameter.

White-lands and scrub-lands throughout the archipelago from Abaco and Great Bahama through the Blminis and Andros to Grand Turk Islands, Ambergris Cay and Inagua :-Florida; Cuba; Hispaniola; Jamalca. Consists of many races, unarmed or very prickly, with the leaves entire or toothed, and the flowers and fruits varylng considerably in size. Recorded by Dolley and by Hitchcock as Solanum ignaeum L. BaHAMa Solanum. CaNker-BERry.

\section{Solanum verbascifòlium L. Sp. Pl. 184. 1753.}

A stellate-tomentulose unarmed shrub, 1-3 m. high, rarely forming a small tree up to $10 \mathrm{~m}$. high, with a trunk up to $1.5 \mathrm{dm}$. in diameter. Leaves ovate to elliptic, rarely obovate, 1-3 dm. long, entire or very slightly repand, acute, acuminate or obtuse at the apex, rounded or narrowed at the base, the stout petioles $7 \mathrm{~cm}$. long or less; cymes terminal, several-many-flowered, longpeduncled; pedicels stout, 6-12 $\mathrm{mm}$. long; calyx 5-7 $\mathrm{mm}$. long, densely stellate, its lobes triangular-ovate; corolla white, $10-15 \mathrm{~mm}$. wide, its lobes ovateoblong; berry subglobose, 1-2 cm. in diameter, yellow.

Waste places, scrub-lands, coppices and old flelds, throughout the archlpelago from Great Bahama, Abaco and Andros to Mariguana and Dellis' Cay (Caicos) :Florida; West Indles: Mexico and Central America; Old World tropics. Mulleinheaved Solanum. Wild Tobacco. Salve-bush. 
5. Solanum Blodgéttii Chapm. Fl. So. U. S. 349. 1860.

An unarmed shrub, 0.5-1.5 m. high, the branches spreading, the young twigs, leaves and inflorescence stellate-tomentulose. Leaves oblong, $5-15 \mathrm{~cm}$. long, entire or undulate, obtuse or acute at the apex, mostly obtuse at the base, the petioles 1-3 $\mathrm{cm}$. long; peduncles longer than the leaves; panicles dense, short, several-many-flowered; pedicels $3-7 \mathrm{~mm}$. long; calyx about 3 $\mathrm{mm}$. long, its teeth minute, deltoid; corolla white or blue, its lobes linear or linear-lanceolate, 6-7 $\mathrm{mm}$. long, pubescent without; anthers linear, apically dehiscent; ovary glabrous; berries red, $4-6 \mathrm{~mm}$. in diameter.

Scrub-lands, North Cat Cay, Biminis :-Florida. Blodgetr's Solanum.

\section{Solanum tórvum Sw. Prodr. 47. 1788.}

A stellate-tomentulose shrub, 1-4 m. high, the rather stout branches sparingly armed with short flattened, nearly straight prickles, or unarmed. Leaves broadly ovate in outline, $\overline{0}-20 \mathrm{~cm}$. long, stout-petioled, angular-lobed or sinuate-margined, acute or obtuse at the apex, truncate or subcordate at the base, sometimes with a few prickles on the petiole and on the midvein beneath, the upper surface scabrous; cymes lateral, short-peduncled, severalflowered; flowering pedicels slender, glandular, 5-8 $\mathrm{mm}$. long, thickening in fruit; calyx glandular, about $4 \mathrm{~mm}$. long, 5-cleft, its lobes ovate, acute; corolla white, 5-cleft, 10-15 $\mathrm{mm}$. broad; berry globose, 10-14 mm. in diameter, yellow.

Waste and cultivated grounds near Nassau, New Providence:-Bermuda (according to Grisebach); West Indies and continental tropical America. BUSHY WHITw SOLANUM.

\section{Solanum didymacánthum Millsp. Field Mus. Bot. 2: 183.1906.}

Branches stellate-pilose, prickly; leaves minute, entire, stellate-pilose on both surfaces. Plants shrubby, branched, 1-2 m. high; prickles needle-like, in pairs at the nodes, 2-3 times as long as the leaves, slightly recurved, divaricately horizontal, reddish brown, thickened at the base, somewhat less than $12 \mathrm{~mm}$. long; leaves fasciculate, petiolate, oblong or obovate, entire, about $3 \mathrm{~mm}$. long, the base acute, the apex acute or obtuse; inflorescence terminal, solitary, single-flowered; peduncles, calyx and corolla stellate-pilose, unarmed; calyx 5-dentate; corolla white, 5-partite, the lobes liguliform, about $8 \mathrm{~mm}$. long, somewhat shorter than the corolla; ovary globose; style filiform, longer than the stamens; berry sessile, globose, compressed at the base and apex, yellow, translucent, not exceeding the persistent calyx. Coppices and scrub-lands, Cat Island near Port Howe, Great Exuma on Haynes
Road. Endemic. CAT'S-PAw.

\section{CÁPSICUM L. Sp. Pl. 188. 1753.}

Annual or perennial herbs or shrubs, with forking stems. Leaves flat, entire or repand. Flowers solitary in the axils, or in small cymes. Calyx scarcely accrescent, somewhat 5-lobed. Corolla usually white, nearly rotate, its lobes 5, imbricated. Stamens 5, adnate to the base of the corolla; anthers bluish, the sacs opening lengthwise. Ovary 2-3-celled; stigma club-shaped or dilated. Berries red, yellow or green, often nodding, pungent. Seeds flattened. [Latin, capsa, a box, referring to the shape of the fruit in forms of the typical species.] About 30 species, natives of America. Type species: Capsicum annuum $\mathrm{L}$. 
1. Capsicum baccàtum L. Mant. 1: 47. 1767.

Shrubby, more or less pubescent. Stems 1-3 m. tall, sometimes vine-like, widely branching; leaves ovate, oblong-ovate or ovate-lanceolate, $2-5 \mathrm{~cm}$. long, acute or acuminate, entire, abruptly narrowed or truncate at the base; petioles one half as long as the blades or shorter; pedicels narrowly clubshaped, 1-2 cm. long; calyx 2.5-3 mm. long, its lobes as long as the tube or somewhat shorter; berries globose to ellipsoid, 5-10 mm. long, red, obtuse.

Scrub-lands, Little Harbor Cay, New Providence and Eleuthera to Mariguana, Dellis' Cay (Caicos), Inagua and the Anguilla Isles:- southern United States ; West Indies; continental tropical America; Old World tropics. C. frutescens of Hitchcock, from Inagua, and of Dolley, is this species. BIRD PEPPER.

\section{LÝCIUM L. Sp. Pl. 191. 1753.}

Shrubs, or woody vines, often spiny, with small alternate entire leaves, commonly with smaller ones fascicled in their axils, and white greenish or purple, solitary or clustered flowers. Calyx campanulate, 3-5-lobed or -toothed, not enlarged in fruit, presistent. Corolla-tube short or slender, the limb 5lobed (rarely 4-lobed), the lobes obtuse. Stamens 5 (rarely 4); filaments filiform, sometimes dilated at the base; anther-sacs longitudinally dehiscent. Ovary 2-celled; style filiform; stigma capitate or 2-lobed. Berry globose, ovoid, or oblong. [Named from the country Lycia.] About 75 species, widely distributed. Type species: Lycium afrum $\mathrm{L}$.

\section{Iycium spathulifòlium Britton, Bull. N. Y. Bot. Gard. 3: 451.1905.}

A glabrous shrub, $1.3 \mathrm{~m}$. high or less, with long slender drooping branches, some of the twigs tipped by. spines, $2-4 \mathrm{~mm}$. long, the bark gray. Leaves 2-4 together at the nodal cushions, or solitary, spatulate, fleshy, entire, 6-15 mm. long, 1.5-3 mm. wide, obtuse, long-attenuate from above the middle to the base; flowers few, solitary; peduncle filiform, $5 \mathrm{~mm}$. long, gradually thickened above; calyx campanulate, 2-2.5 $\mathrm{mm}$. long, somewhat scurfy, its teeth broadly ovate, obtuse, whitish-lanate; corolla funnelform, white, its tube 4-5 mm. long, its 4 oblong obtusish lobes two thirds as long as the tube.

Coppices at upper savannah, Inagua; rocky plains, East Caicos and Ambergris Cay. Endemic. INAGUA I,xcIUM.

\section{CÉSTRUM L. Sp. Pl. 191. 1753.}

Shrubs or trees, with alternate entire petioled leaves, the mostly yellow or white flowers in eymes or panicled. Calyx 5-lobed or 5-toothed. Corolla salverform or funnelform, the tube long, slender, the 5 lobes spreading. Stamens borne on the corolla-tube, included; filaments filiform, often pilose below, sometimes with a tooth-like appendage; anthers small, their sacs parallel. Ovary 2-celled, usually short-stipitate; ovules few; style filiform; stigma dilated, entire or 2-lobed. Fruit a small berry. Seeds oblong, smooth. [Greek, hammer, referring to the filaments.] Perhaps 150 species, natives of tropical America. Type species: Cestrum nocturnum L.

\section{Cestrum bahaménse Britton, Bull. N. Y. Bot. Gard. 4: 123. 1905.}

A shrub $3 \mathrm{~m}$. high or less, glabrous throughout, the bark light gray. Leaves ovate to ovate-elliptic, pale green on both sides, but slightly darker green above than beneath, $5-10 \mathrm{~cm}$. long, $5 \mathrm{~cm}$. wide or less, firm in texture, acute at both ends, or the apex obtusish, faintly 7-9-veined on each side of the 
mid-vein; petioles slender, 1-1.5 cm. long; cymes axillary, few-several-flowered, their peduncles much shorter than the petioles; pedicels $1.5-3 \mathrm{~mm}$. long; calyx oblong-campanulate in flower, $4 \mathrm{~mm}$. long, its teeth triangular-lanceolate, $1.5 \mathrm{~mm}$. long; corolla-tube greenish yellow, 9-13 $\mathrm{mm}$. long, narrowly obconic, its lobes lanceolate, acuminate, purplish, 4-5 $\mathrm{mm}$. long, white-lanose within; stamens inserted on the tube of the corolla just below the lobes, the free part of the filament scarcely longer than the anther; berry blue-black, shining, obovoid, about $12 \mathrm{~mm}$. long, 5-6 mm. thick; fruiting calyx broadly obconic, loosely enclosing the narrowed base of the berry.

Coppices, savannas and scrub-lands, Great Bahama and Abaco to Andros, Cat Island and Long Island :-Cuban Cays. Referred by Grisebach, Dolley, Mrs. Northrop and Hitchcock to Cestrum pallidum Lam.; recorded by Coker as Solanum havanense Jacq. and by Schoepf as Cestrum vespertinum. BAHAMA CESTRUM. dence.

Centrum didrnum L., recorded by Dolley, has been cultivated on New Provl-

\section{DATÙRA L. Sp. Pl. 179. 1753.}

Tall narcotic herbs, some tropical species shrubs or trees, with alternate petioled leaves, and large solitary erect, short-peduncled, white purple or violet flowers. Calyx elongated-tubular or prismatic, its apex 5-cleft or spathe-like, in the following species circumscissile near the base which is persistent and subtends the prickly capsule. Corolla funnelform, the limb plaited, 5-lobed, the lobes broad, acuminate. Stamens included or little exserted; filaments filiform, very long, inserted at or below the middle of the corolla-tube. Ovary 2-celled, or falsely 4-celled; style filiform; stigma slightly 2-lobed. Capsule 4-valved from the top, or bursting irregularly. [The Hindoo name, dhatura.] About 12 species, of wide distribution. Type species: Datura Stramonium L.

Spines of the capsule subulate.

Capsules erect.

Capsules nodding.

Spines of the capsule short, deltoid.

1. D. Stramonium.

2. D. Metel.

3. D. fastuosa.

\section{Datura Stramònium L. Sp. Pl. 179. 1753.}

\section{Datura Tatula L. Sp. Pl. ed. 2, 256. 1762.}

Annual, glabrous or the young parts sparingly pubescent; stem stout, $3-15 \mathrm{dm}$. high. Leaves thin, ovate, acute or acuminate, mostly narrowed at the base, 0.7-2 dm. long, irregularly sinuate-lobed, the lobes acute; flowers white, about $1 \mathrm{dm}$. high; calyx prismatic, less than one-half the length of the corolla; capsule ovoid, erect, densely prickly, about $5 \mathrm{~cm}$. high.

Waste places, Great Bahama, Lignum Vitae Cay, Eleuthera and Acklin's Island:Bermuda ; temperate and tropical America ; West Indies; Old World. THORN-APPLE. WASHWOMAN'S BUSH.

\section{Datura Mètel L. Sp. Pl. 179. 1753.}

Annual, finely glandular-pubescent, 1-3 m. high. Leaves broadly ovate, acute, inequilateral, rounded or subcordate at the base, 1-2.5 dm. long; flowers white, 1.5-1.8 dm. high; ealyx about one-half as long as the corolla; capsule globose or ovoid-globose, nodding, obtuse, prickly and pubescent, $2 . \overline{0}-4$ $\mathrm{cm}$. in diameter.

Waste grounds, Andros and Inagua:-southern United States; West Indies; Mexico and tropical America; Old World tropics. PRICKLY-BUR.

3. Datura fastuòsa L. Syst. ed. 10, 932. 1759.

Annual, nearly glabrous; stem erect, branched, 1-2 m. high. Leaves ovate-lanceolate to elliptic, 5-17 $\mathrm{cm}$. long, acute or acuminate, undulate or 
repand-dentate, the slender petioles $3-7 \mathrm{~cm}$. long; ealyx about $6 \mathrm{~cm}$. long, its ovate lobes acute or short-acuminate; corolla violet without, white within, 14-18 cm. long; capsule ovoid, erect, 4-6 cm. long, its stout prickles corrugated at the base.

Waste places at Port Howe. Cat Island :-southern United States : West Indies; continental tropical America; Old World tropics. GaRden Datura. Bell-Flower.

\section{NICOTIÀNA [Tourn.] L. Sp. Pl. 180. 1753.}

Viscid-pubescent narcotic herbs or shrubs, with large alternate entire or slightly undulate leaves, and white yellow greenish or purplish flowers, in terminal racemes or panicles. Calyx tubular-campanulate or ovoid, 5-cleft. Corolla-tube usually longer than the limb, 5-lobed, the lobes spreading. Stamens 5 , inserted on the tube of the corolla; filaments filiform; anthersacs longitudinally dehiscent. Ovary 2-celled (rarely 4-celled); style slender; stigma capitate. Capsule 2-valved, or sometimes 4-valved at the summit. Seeds numerous, small. [Named for John Nicot, French ambassador to Portugal, who sent some species to Catherine de Medici, about 1560.] About 50 species, mostly natives of America, the following typical.

\section{Nicotiana Tabácum L. Sp. Pl. 180. 1753.}

Annual, 1-2 m. high, little branched or simple-stemmed. Leaves oblong to oblong-lanceolate, 1-3 dm. long, sessile, acute or acuminate at the apex, narrowed at the base, the lower ones decurrent on the stem; calyx about 12 $\mathrm{mm}$. long, its lobes ovate; corolla funnelform, about $5 \mathrm{~cm}$. long, pink, its lobes triangular-subulate; capsule longer than the calyx.

Spontaneous in waste places, Great Bahama :-widely cultivated and spontaneous after cultivation in warm and tropical regions. Native of South America. ToBACCO.

\section{Family 10. SCROPHULARIÀCEAE Lindl.}

\section{Figwort Family.}

Herbs, shrubs or trees, with estipulate leaves, and perfect, mostly complete and irregular flowers (corolla wanting in one species of Synthyris). Calyx inferior, persistent, 4-5-toothed, -cleft, or -divided, or sometimes split on the lower side, or on both sides, the lobes or segments valvate, imbricate or distinct in the bud. Corolla gamopetalous, the limb 2-lipped, or nearly regular. Stamens 2, 4 or 5, didynamous, or nearly equal, inserted on the corolla and alternate with its lobes; anthers 2-celled; the sacs equal, or unequal, or sometimes confluent into one. Disk present or obsolete. Pistil 1, entire or 2-lobed; ovary superior, 2-celled, or rarely 1-celled; ovules anatropous or amphitropous, on axile placentæ; style slender, simple; stigma entire, 2-lobed or 2-lamellate. Fruit mostly capsular and septicidally or loculicidally dehiscent. Seeds mostly numerous; endosperm fleshy; embryo small, straight or slightly curved; cotyledons little broader than the radicle. About 165 genera and 2,700 species, widely distributed.

Upper lip or lobes of the corolla external in the bud, or wanting.

Corolla-tube with a sac on the lower side; vines.

Corolla-tube without a sac.

Flowers cymose; our species a shrub.

Flowers solitary, racemose or spicate; herbaceous plants. Anther-bearing stamens 4 (rarely 5); corolla 2-lipped

1. Maurandya.

2. Russellia. or nearly regular. 
Sepals equal or nearly so.

Sepals very unequal.

Corolla nearly regular.

Corolla manifestly 2-lipped.

Anther-bearing stamens 2 ; corolla of only 1 lip; minute herbs.

I.ower lip or lobes of the corolla external in the bud (except in Cupraria and Scoparia).

Sepals distinct or nearly so.

Corolla-lobes 5 ; leaves alternate.

Corolla-lobes 4 ; leaves opposite.

Sepals more or less united below into a tube.

Corolla campanulate to funnelform; capsule not enclosed in the calyx.

Stamens equal or nearly so.

Stamens manifestly didynamous.

3. Stemodia.

4. Bramia.

5. Mecardonia.

6. Hemianthus.

Corolla salverform: capsule nearly enclosed by the calyx. 11. Agalinis.

1. MAURÁNDYA Ort. Hort. Matr. Dec. 21. 1797.

Annual or perennial vines, the leaves alternate, or opposite below, flat, hastate, angulate or coarsely toothed. Flowers on axillary peduncles. Sepals partially united. Corolla showy, pink, purple or violet, irregular, its tube scarcely gibbous at the base, with 2 often pubescent lines or plaits in the throat. Stamens 4, included; filaments thickened at the apex; anther-sacs often confluent. Styles with 2 dilated lobes at the apex. Ovules numerous. Capsule short, opening by transverse or irregular chinks. Seeds sometimes winged, wrinkled or tuberculate. [In honor of Maurandy, a botanist of Cartagena.] About 6 species, natives of warm and tropical America. Type species: Usteria scandens Cav.

1. Maurandya antirrhinaefiòra H. \& B.; Willd. Hort. Berol. pl. 83. 1807.

Antirrhinum antirrhiniflora Hitehe. Rep. Mo. Bot. Gard. 4: 113. 1893.

Very slender, climbing or trailing, sometimes to a length of $3 \mathrm{~m}$. or more, glabrous throughout. Leaves triangular-hastate, acute, 1-2.5 cm. long, slender-petioled; peduncles very slender, mostly longer than the petioles; sepals linear-lanceolate, acuminate, nearly as long as the corolla-tube; corolla purple, $1.5 \mathrm{~cm}$. long, its limb much shorter than its tube; capsule depressed-globose, about $1 \mathrm{~cm}$. in diameter.

Roadsides, walls and thickets, New Providence:-southwestern United States and Mexico; naturalized in F'lorida, Bermuda and in Jamaica. Roving SAILOR.

\section{RUSSÉILIA Jacq. Enum. 6, 25. 1760.}

Shrubby plants, with cpposite or whorled leaves, sometimes reduced to mere scales, and cymose or panicled, mostly showy flowers. Calyx-lobes ovate. Corolla tubular, or tubular-funnelform, the tube long, the lobes short, somewhat unequal. Stamens 4, with divergent anther-saes; no staminodes. Capsule ovoid to globose. [In honor of Alexander Russell, English physician and traveller, who died in 1768.] About 15 species, natives of tropical America. Type species: Kussellia sarmentosa Jacq.

\section{Russellia equisetifórmis Schl. \& Cham. Linnaea 6: 377.1831.}

Russellia juncea Zuce. Flora 15: Beibl. 99. 1832.

A glabrous, much-branched shrub, 4-12 dm. high, with spreading or arching striate branches, the twigs very slender. Leaves of the stem and branches, or most of them, reduced to acute scales about $2 \mathrm{~mm}$. long, those of sterile 
twigs spatulate, $1.5 \mathrm{~cm}$. long or less; calyx about $4 \mathrm{~mm}$. long; corolla bright red, about $2.5 \mathrm{~cm}$. long, its lobes ovate, 4-6 mm. long; capsule ovoid.

Roadsides, New Providence, St. George's Cay, Cat Island. Native of Mexico. Naturalized in Florida, Bermuda, Jamaica and from Porto Rico to Tortola ; Barbadoes. Russellia. Fountain-Plant.

\section{STEMÒdIA L. Syst. ed. 10, 1118. 1759.}

Herbs or low shrubs, mostly glandular-pubescent and odorous, with opposite or verticillate leaves, the flowers solitary in the axils or in terminal, often leafy-bracted spikes or racemes. Calyx 5-parted, the segments imbricated, nearly distinct and equal. Corolla with a nearly cylindric tube and a 2lipped limb, the upper lip notched or entire, erect, external in the bud, the lower 3-lobed. Stamens 4, didynamous, included; filaments filiform; anthersacs distinct, stipitate. Ovules many; style usually 2-lobed. Capsule 2 valved, the valves 2 -cleft. Seeds striate or reticulated, small. [Greek, double stamens.] About 30 species, of tropical and subtropical regions, the following typical.

\section{Stemodia maritima L. Syst. ed. 10, 1118. 1759.}

Perennial (q), pubescent or puberulent and somewhat viscid, usually much branched, $6 \mathrm{dm}$. high or less, the branches decumbent or ascending, leafy. Leaves opposite, oblong or cblong-lanceolate, 1-2.5 cm. long, serrate, sessile, acutish at the apex, cordate at the base; flowers nearly sessile in the axils, solitary, shorter than the leaves; calyx about $2 \mathrm{~mm}$. long; corolla purplish, longer than the calyx, its upper lip nearly entire.

Moist ground and marshes, Andros, New Providence, Eleuthera, Cat Island, Watling's Island, Fortune Island, Acklin's Island, Mariguana, Great Exuma :-Cuba to Porto Rico: Jamaica; Curaça; South America. Recorded by Hitchcock from Cat Island as S. durantifolia (L.) Sw. COAST STEMOdA.

\section{BRÀMIIA Lam. Encycl. 1: 439. 1785.}

Diffuse or prostrate herbs, with opposite, mostly entire, obtuse, palmately veined leaves, and small peduncled flowers, mostly solitary in the axils. Calyx subtended by 2 bracts, 5-parted, the upper segment the broadest. Corolla nearly regular, the tube cylindric, the limb nearly equally 5-lobed. Stamens 4, didynamous, included. Style slender; stigma capitate, or 2-lobed. Seeds numerous. [From Brami, a Malabar name.] About 20 species of warm and tropical regions. Type species: Bramia indica Lam.

1. Bramia Monnièri (L.) Drake, Pl. Polyn. Franc. 142. 1892.

Lysimachia Monnieri L. Cent. Pl. 2: 9. 1756.

Gratiola Monnieri L. Syst. ed. 10, 851. 1759.

Herpestis Monnieria H.B.K. Nov. Gen. 2: 366. 1818.

Monniera Brownei Pers. Syn. 2: 166. 1806.

Monniera Monniera Britton, Mem. Torr. Club 5: 292.1894.

Bacopa Monnierá Wettst. in E. \& P. Nat. Pflanz. 4 ${ }^{3 \mathrm{~b}}$ : 77. 1891.

Perennial, glabrous, fleshy; stem creeping, rooting at the nodes, $1.5-5 \mathrm{dm}$. long. Leaves spatulate or cuneate-obcordate, sessile, rounded at the apex, entire, or sparingly denticulate, $6-20 \mathrm{~mm}$. long; peduncles mainly in alternate axils, 2-bracteolate at the summit, in fruit longer than the leaves; flowers pale blue, about $1 \mathrm{~cm}$. long; upper calyx-segment ovate, acute; corolla ob- 
scurely 2-lipped; stamens nearly equal; capsule ovoid, acute, shorter than the calyx.

Wet places, Great Bahama, Abaco, Andros, New Providence, Eleuthera to Watling's Island and Long Island :-Bermuda; southeastern United States; West Indies; continental tropical America and Old World tropics. MONNIER's HEDGE-HYSSOP.

\section{MECARDÒNIA Ruiz \& Pavon, Syst. 164. 1798.}

Perennial, erect or diffuse, low herbs, with opposite serrate pinnately veined leaves, and solitary axillary slender-peduncled flowers. Sepals 5, unequal, the upper one the largest. Corolla 2-lipped, the upper lip emarginate. Stamens 4, borne on the throat of the corolla. Disc wanting. Stigma 2. lobed. Capsule septicidally dehiscent. Seeds numerous. [Commemorates Meca y Cardona, a founder of the Botanical Garden of Barcelona.] About 4 species of tropical and subtropical America. Type species: Mecardonia ovata Ruiz \& Pavon.

1. Mecardonia procúmbens (Mill.) Small, Fl. SE. U. S. 1065, 1338. 1903.

Erinus procumbens Mill. Gard. Dict. ed. 8, no. 6. 1768.

Glabrous, usually branched from the base, the branches decumbent or suberect, 1.5-4 dm. long. Leaves ovate or oval, 1-2 cm. long, serrate, shortpetioled, darkening in drying; peduncles slender, as long as the leaves or longer, sometimes 3 times as long; upper sepal at length 8-10 mm. long; corolla white or pink, about $10 \mathrm{~mm}$. long; capsule oblong, 6-10 $\mathrm{mm}$. long.

Sandy copplces and clearings, Great Bahama:-Florida; Cuba to St. Croix; Antigua; Grenada to Trinidad; Jamaica; continental tropical America.

\section{HEMIÀNTHUS Nutt. Journ. Acad. Phila. 1: 119. 1817.}

Diminutive prostrate herbs, often rooting at the nodes, with opposite entire 3-nerved leaves, and minute solitary, nearly sessile or peduncled flowers. Calyx deeply cleft, 4-lobed. Corolla (in our species) 1-lipped, the lip 3-lobed, its middle lobe somewhat longer than the lateral ones. Stamens 2, borne on the throat of the corolla; filaments short, with a basal appendage; staminodes none. Style 2-cleft above the middle. Capsule globose, 2-valved, membranous. Seeds several or many, few-ribbed and transversely striate. [Greek, referring to the deficient corolla.] A few species of the West Indies and the eastern United States. Type species: Hemianthus micranthemoides Nutt.

1. Hemianthus callitrichoìdes Griseb. Mem. Am. Acad. II. 8: 522.1862.

Hemianthus multiflorus C. Wright; Griseb. Cat. Pl. Cub. 185. 1866.

Glabrous ; matted ; stems filiform, 2-4 cm. long. Leaves elliptic, membranous, sessile, about $3 \mathrm{~mm}$. long, rounded or obtuse at the apex; peduncles filiform, 1-3 mm. long; calyx about $1 \mathrm{~mm}$. long; lobes of the corolla-lip oblong.

Creeping on wet soil and mud, Andros, Cat Island, Acklin's Island :-Cuba. WATER-STARIORT HEMIANTHUS.

7. CAPRÀrIA L. Sp. Pl. 628. 1753.

Perennial herbs or shrubby plants. Leaves alternate, longer than broad, toothed. Flowers on axillary pedicels. Calyx of 5 narrow, almost equal 
sepals. Corolla white, eampanulate, with 5 flat lobes. Stamens usually 4; anther-sacs 2, divergent, confluent. Stigmas dilated or 2-lobed. Capsule short, 2-grooved, loculicidally dehiscent. Seeds reticulated. [Latin, from capra, a nanny-goat.] About 4 species, of tropical and subtropical America, the following typical.

1. Capraria biflòra L. Sp. Pl. 628. 1753.

Capraria biflora pilosa Griseb. F1. Br. W. I. 427. 1861.

Stems 3-9 dm. tall, branching, sometimes pubescent. Leaves oblanceolate, cuneate or oblong, 1-4 cm. long, acute, sharply serrate above the middle; pedicels solitary or 2 together, shorter than the leaves; sepals linear-lanceolate to linear-subulate, 4-6 $\mathrm{mm}$. long; corolla about $1 \mathrm{~cm}$. long, the tube campanulate, the lobes lanceolate, about as long as the tube; capsules oval or ovalovoid, about as long as the sepals.

Roadsides, waste grounds and costal dunes, Abaco and Andros to Grand Turk, Ambergris Cay and Inagua :-Bermuda; Florida, Texas, south through continental tropical America; West Indies. GOAT-WEed. STOW-WEed.

\section{SCOPÀRIA L. Sp. Pl. 116. 1753.}

Herbs or low shrubs, mostly branched, with opposite or verticillate, punctate leaves, and small bractless pedicelled flowers solitary or in pairs in the axils. Calyx 4-5-parted, the segments nearly distinct, imbricated. Corolla nearly rotate, 4-cleft, densely bearded in the throat, its lobes nearly equal, obtuse. Stamens 4, nearly equal; filaments filiform; anther-saes distinct, parallel or divergent. Style clavate above; stigma truncate or notched; ovules many. Capsules septicidally dehiscent, its valves entire, membranous. Seeds many, angular. [Latin, a broom.] About 6 species, of tropical and subtropical America, the following typical one also widely distributed in warm and tropical parts of the Old World.

\section{Scoparia dúlcis L. Sp. Pl. 116. 1753.}

Annual, glabrous, often much branched, 3-10 dm. high, the branches slender. Leaves ovate to oblong-lanceolate, opposite or verticillate in 3 's or 4 's, serrate or the upper ones entire, short-petioled, acute at the apex, narrowed or cuneate at the base, the lower $2-3 \mathrm{~cm}$. long, the upper smaller; pedicels filiform, as long as the upper leaves or shorter, often borne in most of the axils; sepals oblong or oblong-obovate, acute, sometimes ciliolate, about $1.5 \mathrm{~mm}$. long; corolla white, 3-4 mm. wide; capsule ovoid-globose, a little longer than the sepals.

Waste places, New Providence, Great Exuma :-southern United States ; West Indies; tropical and subtropical continental America; Old World tropics. Scoparia.

\section{AFZìliA Gmel. Syst. 2: 927. 1791.}

Erect branched herbs, mostly with opposite leaves, at least the lower 1-2pinnately parted or dissected, and yellow flowers solitary in the axils, or in terminal bracted spikes or racemes. Calyx campanulate, 5-cleft or 5-parted. Corolla slightly irregular, campanulate or rotate, the tube short, the limb 5 lobed, the lower lobe exterior in the bud. Stamens 4, slightly unequal; filaments short, villous, at least near the base; anthers 2-celled, the sacs parallel, distinct. Capsule acute and more or less compressed at the summit. Seeds 
numerous, reticulated. [Named for Adam Afzelius, 1750-1812, botanical professor at Upsala.] About 10 species, of the southern United States and Mexico, the following typical one reaching the Bahamas.

1. Afzelia cassioìdes (Walt.) Gmel. Syst. 2: 927.1791.

Anonymos cassioides Walt. Fl. Car. 171. 1788.

Puberulent, much branched, 0.5-1.2 m. high, the very slender branches ascending. Leaves approximate, sessile or nearly so, 1-2.5 cm. long, dissected into filiform segments; flowers in long narrow racemes terminating the branches and usually also in the upper axils; pedicels filiform, $3-7 \mathrm{~mm}$. long; calyx-tube $1 \mathrm{~mm}$. long, the lobes filiform, 1-2 mm. long; corolla glabrous, about $8 \mathrm{~mm}$. broad; capsule 5-6 $\mathrm{mm}$. long, its acute tip flattened.

Pine-lands of Great Bahama:-southeastern United States. AFzelis.

\section{AGALìnIS Raf. N. Fl. 2: 61. 1837.}

Erect herbs, mainly with opposite and sessile narrow leaves. Flowers showy, usualy large, purple, pink or white, in loose bracted racemes. Calyx campanulate, 5-toothed or 5-lobed. Corolla somewhat irregular, campanulate, or funnelform, the tube broad, the limb 5-lobed, slightly 2-lipped, the lower lobes exterior in the bud. Stamens 4, didynamous, included; filaments pubescent; anthers 2 -celled, their sacs obtuse or mucronate at the base; style filiform. Capsule loculicidally dehiscent, many-seeded. Seeds mostly angled. Type species: Agalinis palustris Raf.

Pedicels short, not longer than the calyx.

Pedicels as long as the calyx or longer, at least in fruit.

1. A. Harperi.

2. A. spiciflora.

\section{Agalinis Hárperi Pennell; Small, Fl. Miami 167, 200. 1913.}

Annual, glabrous or nearly so, little-branched, $8 \mathrm{dm}$. high or less. Leaves narrowly linear, $1.5-3.5 \mathrm{~cm}$. long, spreading; bracts similar to the leaves, the lower often as long as the flowers; racemes 8-20-flowered, the flowers mostly opposite; pedicels shorter than the calyx, 2-3 mm. long; calyx-lobes triangularlanceolate, about $1 \mathrm{~mm}$. long; corolla 15-18 mm. long, pubescent without, pinkish purple, with 2 yellow lines within, the lobes rounded or truncate, ciliate; stamens woolly; capsule subglobose, 4-5 mm. long.

Borders of marshes and in scrub-lands, Great Bahama, Abaco, Andros and Eleuthera :-Florida. Reported by Mrs. Northrop and also by Dolley as Gerardia purpurea $\mathrm{L}_{\text {. ; }}$ recorded as Gerardia domingensis Spreng. in Bull. N. Y. Bot. Gard. 4: 125.

2. Agalinis spicifiòra (Engelm.) Pennell, Proc. Acad. Nat. Sci. Philad. 71: 277. 1920.

Gerardia spiciflora Engelm. Bost. Jour. Nat. Hist. 5: 227. 1845.

Annual, fleshy, glabrous, branched or simple, 2-6 dm. high, erect or usually so Leaves linear, 1-4 cm. long, spreading; bracts similar to the upper leaves, but much smaller, often not longer than the pedicels; racemes distantly 4-12-flowered; pedicels 4-12 mm. long, ascending, longer than the calyx, thickened upward; calyx-lobes triangular, about $1 \mathrm{~mm}$. long; corolla $15-20$ $\mathrm{mm}$. long, pink, puberulent without, jts lobes rounded or emarginate, ciliate; stamens woolly; capsule globose or ovoid-globose, $4.5-6 \mathrm{~mm}$. long.

Marshy places, Abaco. Great Bahama, Andros, New Providence and Eleuthera :southern United States : Cuba. Reported by Mrs. Northrop and by Coker as Gerardia maritima Raf., and as Gerardia purpurea L. bV Dolley. MARsh AgaLINIS. 


\section{BÚCHNERA L. Sp. Pl. 630. 1753.}

Erect, perennial or biennial, strict hispid or scabrous herbs, blackening in drying, the lower leaves opposite, the upper sometimes alternate. Flowers rather large, white, blue, or purple, in terminal bracted spikes, the lower commonly distant. Calyx tubular, or oblong, 5-10-nerved, 5-toothed. Corolla salverform, its tube cylindric, somewhat curved, its limb nearly equally 5-cleft, spreading, the lateral lobes exterior in the bud. Stamens 4, didynamous; anther-sacs confluent into 1. Style slender, thickened or club-shaped above; stigma small, entire or emarginate. Capsule loculicidally dehiscent. Seeds numerous, reticulated. [Named for J. G. Buchner.] About 30 species, of warm and temperate regions. Type species: Buchnera americana $\mathrm{L}$.

\section{Buchnera elongàta Sw. Frodr. 92. 1788.}

Stems rough-hispidulous, 2-5 dm. high, simple or branched above, slender. Leaves scabrous, sparingly toothed or entire, the basal ones obovate or oblong, short-petioled, $1-3 \mathrm{~cm}$. long, those of the stem oblong to linear, $1.5-8 \mathrm{~cm}$. long; spikes slender, distantly-flowered; calyx 5-6 mm. long, hispidulous, its upper lobes triangular, acute; corolla blue or white, 9-12 mm. long, its tube somewhat pubescent; capsules ovoid, 5-7 $\mathrm{mm}$. long.

Pine-lands and savannas, Great Bahama, Andros and New Providence :-Florida ; Jamaica ; Cuba ; Hispaniola ; continental tropical America. BUCHNERA.

Verbascum pulverulentum Mill. is recorded from Green Turtle Cay, Abaco, by Herrick. The specimen cannot be found among his plants nor has any species of the genus been seen by our collectors in the archipelago.

LiNaria volgaris Mill. is reported by Dolley to be naturalized in the Bahamas. While this may be possible neither Mr. Brace, nor any of our other collectors, has seen the plant on the islands. It may have been cultivated.

\section{Family 11. LENTIBULARIÀCEAE LindI.**}

\section{Bladderwort Family.}

Aquatic plants, or terrestrial on moist ground, with the leaves basal and tufted, or borne on branching stems. Seapes erect. Flowers perfect, irregular. Calyx inferior, 2-5-parted. Corolla 2-lipped, spurred or saccate at the base. Stamens 2; anther-sacs confluent into 1. Ovary superior, ovoid or globose, 1-celled, with a free-central placenta; ovules numerous; style short or none; stigma 2-lamellate. Fruit a capsule, irregularly bursting, or dehiscent by valves. Seeds reticulate, or variously sculptured or appendaged; endosperm none. About 16 genera and 300 species, widely distributed.

Scape with scales, or bracts, or both, 1-many-flowered; calyx 2-parted; corolla with a prominent palate, closing the throat.

Pedicels several times as long as the bracts at their bases; bractlets none.

Bracts attached by the base; lower corolla-lip faintly lobed. Bracts peltate; lower corolla-lip divergently 3 -lobed.

Pedicels barely if at all exceeding the bracts; a pair of lateral

bractlets as well as a bract at the base of each pedicel.

Scape naked. 1-flowered; calyx 5-parted; corolla with a subulate palate within the tube, or none, the throat open.

\section{Utricularia. \\ 2. Setiscapella. \\ 3. Stomoisia.}

4. Pinguicula.

* Contributed by Dr. John H. Barnhart. 


\section{UTRICULÀriA L. Sp. Pl. 18. 1753.}

Aquatic herbs, the submersed stems with finely divided leaves bearing minute bladders. Flowers racemose or solitary at the summits of the scapes, each pedicel with a single bract at its base. Calyx 2-parted, the lobes herbaceous. Corolla strongly 2 -lipped, the lower lip with a prominent 2-lobed palate. [Latin, utriculus, a little bag.] About 75 species, of wide distribution. Type species: Utricularia vulgaris $\mathrm{L}$.

Stems free-floating; scapes many-flowered; pedicels recurved in fruit. Stems creeping on the bottom in shallow water; scapes 1-4-flowered; pedicels straight, ascending in fruit.

1. U. foliosa.

2. U. pumila.

1. Utricularia foliòsa L. Sp. Pl. 18. 1753.

Stems elongate, up to $25 \mathrm{dm}$. or more long, free-floating except for a single point of attachment. Leaves $3-10 \mathrm{~cm}$. long, forked at the base, each fork pinnately dissected into numerous capillary segments, often copiously bladder-bearing; scapes solitary, 1-3 dm. high, 10-20-flowered; pedicels recurved in fruit; corolla yellow, 15-20 mm. broad; spur slenderly conic, shorter than the lower lip; capsules few-seeded.

Fresh water of a palmetto swamp at Barnett's Point, Great Bahama:-Florida to Louisiana; Cuba; Haiti; Jamaica. LEAFY BLADDERWORT.

2. Utricularia pùmila Walt. Fl. Car. 64. 1788.

Stems short, creeping on the bottom in shallow water, radiating from the base of the scape. Leaves less than $1 \mathrm{~cm}$. long, dichotomously divided into few capillary segments, bladder-bearing; scapes solitary or 2 together, 5-12 cm. high, 1-4-flowered; pedicels erect-ascending in fruit; corolla yellow, 12-15 $\mathrm{mm}$. broad; spur slenderly conic or subulate, equalling or usually exceeding the lower lip; capsules many-seeded.

In shallow water, Great Bahama, Andros, New Providence, Great Exuma :eastern United States. Specimens from Andros, without flowers, were doubtfully determined by Morong as $U$. foliosa L. and as $U$. gibba L.; the former is certainly, the latter probably, referable to this species. TWO-FLOWERED BLADDERWORT.

\section{SETISCAPÉTLA Barnh, in Small, Fl. Miami 170. 1913.}

Terrestrial herbs, with short root-like branches from the base of the scape, the delicate and evanescent leaves and minute bladders rarely seen. Flowers in zig-zag racemes or solitary at the summits of the wiry scapes, each pedicel with a single peltate bract at its base. Calyx 2-parted, the lobes scarious, ribbed. Corolla 2-lipped, the lower lip divergently 3-lobed, with a prominent 2-lobed palate. [Latin, seta, bristle, and scapus, scape.] About 12 species, in Asia, Africa and America, the following typical.

1. Setiscapella subulàta (L.) Barnh. in Small, Fl. Miami 170. 1913.

Utricularia subulata L. Sp. P1. 18. 1753.

Stems and leaves usually evanescent before flowering-time. Scapes 3-20 $\mathrm{cm}$. high, filiform, bronze-colored, 1-12-flowered; pedicels ascending; corolla yellow, 4-6 mm. broad; spur appressed to the lower lip and nearly or quite equalling it in length.

In mud, near Deep Creek, Andros:-eastern United States; Cuba; Porto Rico; northern and eastern South America. ZIG-ZAG BLADDERWoRT. 
3. STOMOISIA Raf. Fl. Tellur. 4: 108. 1838.

Terrestrial herbs, with short root-like branches from the base of the scape, the delicate and evanescent leaves and minute bladders rarely seen. Flowers racemose, often subscapose, or solitary at the summits of the slender scapes, each pedicel with a bract and a pair of bractlets at its base. Calyx 2-parted, the lobes thin and veiny. Corolla strongly 2-lipped, the upper lip with a distinct claw, the lower consisting chiefly of the helmet-shaped, laterally compressed palate. [Greek, hairy mouth.] About 50 species, of wide distribution, the following typical.

1. Stomoisia cornùta (Michx.) Raf. Fl. Tellur. 4: 108. 1838.

Utricularia cornuta Michx. Fl. Bor. Am. 1: 12. 1803.

Stem and leaves inconspicuous, rarely seen. Scapes stiffly erect, 1-4 dm. high, 2-5-flowered, the flowers approximate; pedicels usually shorter than the bracts; corolla yellow, the lower lip 12-15 mm. long; spur subulate, pendent, about $12 \mathrm{~mm}$. long.

In a large sink-hole, near Deep Creek, Andros:-eastern North America; Cuba. HORNED BLADDERWORT.

\section{PINGUÍcULA L. Sp. Pl. 17. 1753.}

Terrestrial herbs, with fibrous roots, and the entire leaves in a basal rosette. Flowers solitary at the summits of the naked scapes. Calyx 5-lobed, more or less 2-lipped. Corolla more or less 2-lipped, the spreading limb sometimes almost equally 5-lobed. Capsule 2-valved. [Latin, pinguis, fat, the leaves of some species being greasy to the touch.] About 30 species, of wide distribution. Type species: Pinguicula vulgaris $\mathrm{L}$.

1. Pinguicula pùmila Michx. Fl. Bor. Am. 1: 11. 1803.

Leaves elliptic-obovate, 1-3 cm. long, rounded at the apex, narrowed at the base but scarcely petioled, faintly veined. Scapes very slender, erect, 0.5-2 dm. high; calyx-lobes $2-3 \mathrm{~mm}$. long, oblong, obtuse; corolla pale violet or white, somewhat 2-lipped but the 5 lobes subequal, 1-2 $\mathrm{cm}$. broad; spur subulate, about $3 \mathrm{~mm}$. long, longer than the sac-like base of the corolla; capsule subglobose, a little longer than the calyx-lobes.

Savannas, Andros:-southeastern United States. Low Butrerwort.

\section{Family 12. BIGNONIÀCEAE Pers.}

\section{Trumpet-CREeper FAmILY.}

Trees, shrubs or woody vines, a few species herbaceous, with opposite (rarely alternate) leaves, and mostly large and showy, clustered, more or less irregular flowers. Calyx inferior, gamosepalous. Corolla gamopetalous, 5-lobed, somewhat 2-lipped, at least in the bud. Antherbearing stamens 2 or 4 , inserted on the tube of the corolla and alternate with its lobes; anthers 2-celled, the sacs longitudinally dehiscent. Disk annular or cup-like. Ovary mostly 2-celled; plancentæ parietal, or on the partition-wall of the ovary; ovules numerous, horizontal, anatropous; style slender; stigma terminal, 2-lobed. Capsule 2-valved. Seeds flat, 
transverse, winged in many genera; endosperm none; cotyledons broad and flat, emarginate or 2-lobed; radicle short, straight. About 60 genera and over 500 species of wide distribution in tropical regions, a few in the temperate zones.

Fruit a capsule.

Capsule elongated, terete.

Corolla funnelform.

Leaves simple or digitate.

Leaves pinnate.

Corolla short-campanulate.

Capsule short, flat, woody.

Fruit indehiscent.
1. Tabebuia.
2. Tecoma.
3. Macrocatalpa.
4. Jacaranda.
5. Crescentia.

1. TABEBÙIA Gomez, .Obs. 2: 7, pl. 2. 1803.

Trees or shrubs, with opposite petioled, digitately 1-7-foliolate or simple leaves, the large showy flowers in terminal cymes or panicles. Calyx tubular, variously toothed or cleft. Corolla funnelform or funnelform-campanulate, the limb spreading, slightly 2-lipped or nearly regular, the 5 lobes rounded. Stamens 4, didynamous, included; filaments slender, curved; anthers oblong or linear, glabrous. Ovary sessile; ovules many, in 2 -several series. Capsule linear or linear-oblong, nearly terete, loculicidally dehiscent, its valves membranous or coriaceous, convex. Seeds numerous, winged. [Brazilian name.] Seventy-five species or more, natives of tropical America. Type species: Bignonia Tabebuya Vell.

Leaflets mostly 3, green on both sides; lateral leaflets sessile or nearly so.

Leaflets mostly 5, white-lepidote beneath; all the leaflets peti-

1. T. lepidota.

2. T. bahamensis.

1. Tabebuia lepidòta (H.B.K.) Britton, Bull. Torr. Club 42: 377. 1915.

Bignonia lepidota H.B.K. Nov. Gen. 3: 139. 1818.

Tecoma lepidota DiC. Prodr. 9: 220. 1845.

A shrub, 1-3 m. high, or in Cuba sometimes a tree up to about $6 \mathrm{~m}$. high, the young twigs more or less lepidote. Leaves mostly 3-foliolate, rarely 1-2foliolate, or those of shoots 5-foliolate; petioles 1-2.5 cm. long; leaflets oblanceolate to oblong-obovate, about $5 \mathrm{~cm}$. long or less, coriaceous, rounded or retuse at the apex, narrowed at the base, the terminal one stalked, the lateral ones sessile, all somewhat lepidote, at least beneath; flowers usually few, pink, 5-7 cm. long; calyx lepidote, oblique; capsule 6-12 cm. long.

Scrub-lands, Andros:-Cuba. The specimens are incomplete and are referred to this species with hesitation.

2. Tabebuia bahaménsis (Northrop) Britton, Bull. Torr. Club 42: 379. 1915.

Tecoma bahamensis Northrop, Mem. Torr. Club 12: 65. 1902.

Bignonia pentaphylla L. Sp. Pl. ed. 2, 870. 1763. Not Tabebuia pentaphylla (Juss.) Hemsl. 1882.

A shrub or small tree up to $10 \mathrm{~m}$. high, the young twigs lepidote. Leaves 3-5-foliolate, long-petioled; leaflets oblong to elliptic, stalked, 2-7 cm. long, entire, rounded or retuse at the apex, mostly obtuse at the base, densely white-lepidote beneath, sparingly lepidote or elepidote above; panicles severalflowered; pedicels rather stout, brown-lepidote, $12 \mathrm{~mm}$. long or less; calyx narrowly campanulate, brown-lepidote, irregularly 2-lipped, 1-1.5 cm. long; corolla pink, 4-6 cm. long, its lobes rounded, slightly undulate; capsule 8-12 em. long, about $7 \mathrm{~mm}$. thick.

Scrub-lands, plne-lands and coppices, Great Bahama, Abaco, South Bimini and Andros to Crooked Island, North Calcos and Inagua:-Cuba. BEEF-BUSH. GUNwood. ABove-All. Whitw Cedar. Referred by Grisebach and by Dolley to Tecoma Leucoxylon Mart. Catesby, 1: pl. s\%. 


\section{TÉCOMA Juss. Gen. 139. 1789.}

Shrubs or trees, with opposite, pinnate or rarely simple leaves, and large flowers racemose or panicled at the ends of the branches. Calyx tubularcampanulate, 5-toothed. Corolla funnelform-campanulate, the limb slightly 2-lipped, 5-lobed, the lobes nearly equal. Stamens 4, didynamous. Ovary sessile or nearly sessile; ovules mostly in one series on the placentae. Capsule linear, loculicidally dehiscent, many-seeded, the seeds winged. [From the Aztec name Tecomaxochitl.] About 10 species, natives of tropical and warmtemperate America, the following typical.

\section{Tecoma stáns (L.) H.B.K. Nov. Gen. 3: 144. 1818.}

Bignonia stans L. Sp. Pl. ed. 2, 871. 1763.

Stenolobium stans Seem. Journ. Bot. 1: 88. 1863.

A shrub, or small tree up to about $8 \mathrm{~m}$. high, glabrous throughout. Leaves 1-3 dm. long, petioled; leaflets 5-13, lanceolate, oblong-lanceolate or elliptic, short-stalked, serrate, acute or acuminate at the apex, mostly narrowed at the base; racemes several-many-flowered; pedicels slender, $1 \mathrm{~cm}$. long or less; calyx 3-5 mm. long, its teeth triangular-ovate, acute; corolla bright yellow, $3.5-5 \mathrm{~cm}$. long, the cylindric part of its tube about twice as long as the calyx, its lobes broad; capsule 1-2 dm. long, 5-6 mm. in diameter, beaked.

Waste places, scrub-lands and borders of copplces, New Providence, Cat Island, Watling's Island, Grand Turk and Inagua :- Florida; continental tropical America and the West Indies. TRUMPET-FLOWER. YELLOW ELDER.

\section{MACROCATÁLPA Britton, Journ. N. Y. Bot. Gard. 19: 8. 1918.}

[CATALPA, sect. Macrocatalpa Griseb. Cat. Pl. Cub. 191. 1866.]

Trees, with opposite or verticillate, simple, ovate to oblong-lanceolate, slender-petioled entire leaves, and medium-sized flowers panicled at the ends of the branches. Calyx closed in bud, 2-cleft at anthesis. Corolla mem. branous, obliquely campanulate, the short tube much expanded above, the limb 2-lipped, 5-lobed, the lobes broad, obtuse, undulate. Stamens 2, included, the filaments slender, the anthers glabrous; staminodia 3, small. Ovary sessile; style filiform; stigma 2-lamellate; ovules in several series. Capsule linear, very long, subterete. Seeds compressed, linear, long-pilose. [Greek, great Catalpa.] Two or three species, natives of the West Indies, the following typical.

1. Macrocatalpa punctàta (Gríseb.) Britton, Journ. N. Y. Bot. Gard. 19: 8. 1918.

( \&) Echites macrocarpa A. Rich. in Sagra, Hist. Cub. 11: 94. 1850.

Catalpa punctata Griseb. Cat. Pl. Cub. 192. 1866.

A tree, sometimes $10 \mathrm{~m}$. high, the branches spreading, the young shoots puberulent. Leaves opposite or some of them verticillate in 3 's, oblong to elliptic, subcoriaceous, 5-7 cm. long, obtuse, rounded, or acutish at the apex, mostly rounded at the base, finely reticulate-veined beneath and lepidotepuncticulate when young, dull and glabrous above, the petioles $1-3 \mathrm{~cm}$. long, puberulent when young; panicles few-several-flowered, slender-peduncled; pedicels very slender, $8-20 \mathrm{~mm}$. long; calyx-lobes lepidote, obtuse, about $7 \mathrm{~mm}$. long; corolla light yellow with orange and brown bands in the throat, $1.2-2 \mathrm{~cm}$. long; capsule 3-4 dm. long.

Copplces, Andros:-Cuba. Cuban Catalpa. 
[MACROCATAlPa LONGíssima (Jacq.) Britton (Catalpa longissima Jacq.) is reported by Hitcheock from Cat Island, and a speciment of the species so labeled is in his collections. We judge, however, that there is an error in this report and in the labeling of the specimen, as Prof. Hitchcock admits the possibility of error and does not remember the exact locality where the specimen may have been collected, nor could we find the tree in passing over his exact route with the native who accompanied him. The Jamaica specimen in his collection is a counterpart of the one labeled Cat Island. Prof. Rothrock, who was with him, returns no specimen from Cat Island though his collections contain a counterpart of Prof. Hitchcock's from Jamaica.]

\section{JACARÁNDA Juss. Gen. 138. 1789.}

Trees, with opposite, mostly bipinnate leaves, and showy panicled blue or violet flowers. Calyx campanulate or tubular-campanulate, 5-toothed. Corolla obliquely funnelform, the tube cylindric below, expanded above, the limb somewhat 2-lipped, with 5 spreading rounded lobes. Stamens 4 , didynamous, included; anthers glabrous; staminodium about as long as the stamens, clavate, usually villous. Ovary 2-celled, sessile; ovules borne in 1 or 2 series. Capsule oblong to suborbicular, compressed, loculicidally dehiscent, its flat valves coriaceous or ligneous. Seeds flat, winged. [Brazilian name.] About 20 species, natives of tropical America, the following typical.

\section{Jacaranda coerùlea (L.) Griseb. Fl. Br. W. I. 446. 1861.}

Bignonia coerulea L. Sp. Pl. 625. 1753.

Jacaranda caroliniana Pers. Syn. 2: 174. 1806.

Jacaranda bahamensis R. Br. Bot. Mag. under pl. 232\%. 1822.

A tree, attaining a maximum height of about $12 \mathrm{~m}$., the foliage glabrous. Leaves evenly bipinnate, petioled, often $3 \mathrm{dm}$. long; pinnae 4-13 pairs, stalked; leaflets 17-35, obliquely oblong, sessile, 1-2.5 cm. long, acutish at the apex, narrowed at the base; panicle many-flowered, 1-2 dm. long, puberulent; pedicels short; calyx puberulent, 5-6 mm. long, its teeth triangular, acute; corolla puberulent, about $4 \mathrm{~cm}$. long; capsule oval, glabrous, 4-6 $\mathrm{cm}$. long, emarginate.

Scrub-lands and coppices, Andros, New Providence, Eleuthera, Cat Island, Great Guana Cay, and Great Exuma:-Cuba ; recorded from Martinique. Boxwood. CANCERTREE. WHAT O'CLOCK. Catesby, 1: pl. 42.

\section{CRESCÉNTtA L. Sp. P1. 626. 1753.}

Trees, with glabrous simple alternate or fascicled leaves, and large, solitary or clustered, lateral or axillary flowers. Calyx leathery, closed in bud, 2-parted or 5-cleft at anthesis. Corolla with a subcampanulate swollen tube and an oblique lacerate or 5-lobed limb. Stamens 4, didynamous, included or a little exserted; anthers glabrous. Ovary 1-celled, sessile; ovules many, on 2 parietal placentae. Fruit globose or ovoid, large, indehiscent, the shell hard. Seeds numerous, wingless, compressed, borne on spongy placentae. [Commemorates Petrus de Crescentius, a celebrated Italian, born in 1230.] About 5 species, natives of tropical America, the following typical.

1. Crescentia Cujète L. Sp. Pl. 626. 1753.

A tree, attaining a maximum height of about $10 \mathrm{~m}$., the trunk up to 2 $\mathrm{dm}$. in diameter, with long spreading branches. Leaves spatulate to oblance- 
olate, fascicled, 5-15 cm. long, obtuse, acute or short-acuminate at the apex, narrowed to the nearly sessile base; flowers stout-peduncled; calyx $2-2.5 \mathrm{~cm}$. long, its lobes broad, rounded or obtuse; corolla yellowish-purple, 5-6 cm. long, its lobes lacerate, much shorter than the tube; fruit subglobose to oval, 1.5-3 $\mathrm{dm}$. in diameter, its rind hard.

Jumble Hole, Acklin's Island:-Florida; West Indies; continental tropical America. Often planted for its valuable frult. CALABASH.

\section{Family 13. PEDALIÀCEAE Lindl.}

\section{Pedalium Family.}

Mostly herbs, often mucilaginous, the leaves opposite or the upper alternate, and axillary, solitary or sometimes fascicled, perfect irregular flowers. Calyx 5-cleft or 5-parted. Corolla with a subcylindric tube and a usually short, obscurely 2-lipped, 5-lobed limb. Stamens mostly 4 and didynamous, included; anthers dorsifixed, the saes parallel, or in some genera distinct. Disk fleshy. Ovary sessile, 2-4-celled; ovules several or many, anatropous; style filiform. Fruit various. Seeds without endosperm. About 14 genera, including some 45 species, natives of the Old World.

\section{SÉSAMUM L. Sp. Pl. 634. 1753.}

Herbs, usually erect, the lower leaves opposite, the upper alternate, or all sometimes alternate, the violet to white, short-peduncled flowers solitary in the axils. Calyx 5-parted. Tube of the corolla oblique at the base, somewhat gibbous, the limb 5-lobed, slightly 2-lipped, the lobes spreading. Stamens 4 , didynamous, borne near the base of the corolla; anthers sagittate. Ovary 2celled; ovules many in each eavity, superimposed in a single series. Fruit an oblong, 4-sided loculicidal capsule. [Arabic name.] About 12 species, natives of tropical Africa and Asia, the following typical.

\section{Sesamum orientàle L. Sp. Pl. 634. 1753.}

Sesamum indicum L. Sp. Pl. 634. 1753.

Erect, simple or branched, more or less pubescent, $0.7-2 \mathrm{~m}$. high. Leaves lanceolate or ovate-lanceolate, $7-15 \mathrm{~cm}$. long, acuminate at the apex, mostly narrowed at the base, papillate beneath, the petioles 1-5 $\mathrm{cm}$. long; peduncles about $4 \mathrm{~mm}$. long; sepals linear-lanceolate, about $1 \mathrm{~cm}$. long; corolla pale rose, 2-3 cm. long; capsule linear-oblong, short-beaked, 4-grooved, $2-3 \mathrm{~cm}$. long.

Spontaneous after cultivation, - Eleuthera and Cat Island :-Florida; West Indies and continental tropical America. Native of the East Indies. SESAMR BENNY-SEDD.

\section{Family 14. MARTYNIÀCEAE Link.}

\section{UNICORN-PLANT FAMILY.}

Herbs, with opposite leaves, or the upper alternate, and perfect irregular flowers. Calyx inferior, 4-5-cleft or 4-5-parted, or sometimes split to the base on the lower side. Corolla gamopetalous, irregular, the tube oblique, the limb slightly 2 -lipped, 5 -lobed, the lobes nearly equal, the 2 upper ones exterior in the bud. Anther-bearing stamens 4, didynamous, or 2, or the posterior pair sterile; anthers 2-celled, the sacs longitudinally dehiscent. 
Ovary 1-celled, with 2 parietal placentæ expanded into broad surfaces, or 2-4-celled by the intrusion of the placentæ or by false partitions; ovules anatropous; style slender; stigma 2-lobed or 2-lamellate. Seeds compressed; endosperm none; embryo large; cotyledons fleshy, flat; radicle short, straight. Three genera and about 12 species, mainly tropical.

1. MARTÝNIA L. Sp. Pl. 618. 1753.

Coarse glandular-pubescent and viscid strong-scented herbs, with longpetioled leaves, and large flowers in short terminal racemes. Calyx 1-2bracteolate at the base, campanulate, inflated, deciduous. Corolla funnelformcampanulate. Anthers gland-tipped, their sacs divergent. Ovary 1-celled, the 2 parietal placentae intruded and expanded in the center of the cavity into broad surfaces bearing the orules in 1 or 2 rows. Fruit an incurved beaked loculicidally 2-valved capsule, the exocarp somewhat fleshy, the endocarp fibrous, woody, crested below or also above, 4-celled by the extension of the placentae. Seeds numerous, tuberculate. [Named for John Martyn, 16931768, profesor of botany at Cambridge, England.] About 8 species, natives of America. Type species: Martynia annua $\mathrm{L}$.

\section{Martynia ánnua L. Sp. Pl. 618. 1753.}

Martynia diandra Glox. Obs. Bot. 14. 1785.

Viscid-pubescent, branched, $5-8 \mathrm{dm}$. high, the stem and branches rather stout. Leaves thin, flaccid, opposite, long-petioled, ovate-orbicular, 8-15 cm. long, sinuate-deritate, palmately veined, acute at the apex, cordate at the base; racemes short-peduncled, several-flowered; pedicels 1-2 cm. long, slender, thickening and recurved in fruit; calyx very deeply 5 -cleft, about $1.5 \mathrm{~cm}$. long, its segments acute; stamens 2; corolla pink, or nearly white, $3-5 \mathrm{~cm}$. long, its rounded lobes purple-blotched; capsule obliquely ovcid, compressed, 2-2.5 em. long, viscid, tipped with a hooked beak about $3 \mathrm{~mm}$. long.

Waste places, Nassau, New Providence:-Cuba to Porto Rico, St. Thomas and Antigua; Martinique and Bequia; continental tropical America. SMALL-Fruited MARTYNIA.

\section{Family 15. ACANTHÀCEAE J. St. Hil.}

\section{ACANTHUS FAMiLy.}

Herbs, or some tropical genera shrubs or small trees, with opposite simple estipulate leaves, and irregular, or nearly regular, perfect flowers. Calyx inferior, persistent, 4-5-parted or 4-5-cleft, the sepals or segments imbricated. Corolla gamopetalous, nearly regularly 5-lobed, or 2-lipped. Anther-bearing stamens 4, didynamous, or 2 only; anther-sacs longitudinally dehiscent. Disk annular, or cup-like. Ovary 2-celled; ovules 2-10 in each cavity, anatropous or amphitropous; style filiform, simple; stigmas 1 or 2. Capsule dry, 2-celled, loculicidally elastically 2-valved. Seeds not winged, borne on curved projections (retinacula) from the placentæ, the testa close, mostly roughened, often developing spiral threads and mucilage when wetted. About 175 genera and 2,000 species, natives of temperate and tropical regions.

Herbs or shrubs.

Stamens 4, didynamous.

Caulescent herbs or shrubs.

Flowers in densely bracted terminal spikes.

Flowers solitary or cymose.

Acaulescent herbs with splcate flowers.

1. Blechum

2. Ruellia.

3. Gerardia. 
Fertlle stamens only 2.

Shrubs with opposite spines; staminodia 2.

Unarmed herbs or shrubs; staminodia none.

Seeds 6-12.

Seeds 2-4.

Capsule oblong.

Capsule ovate or orbicular.

Twining vines; flowers solltary, axillary, subtended by 2 large bracts ; stamens 4 .

4. Anthacanthus.

5. Andrographis.

6. Justicia.

7. Diapedium.

8. Thunbergia.

1. BLÉCHUM P. Br.; Juss. Ann. Mus. Paris 9: 269.1807.

Perennial herbs, with repand-dentate or entire, petioled leaves, and small flowers in dense terminal spikes, the large foliaceous bracts imbricated. Calyx 5-parted, the slightly unequal segments linear-subulate. Corolla with a slender tube little expanded above and a spreading, nearly equally 5-lobed limb, the lobes rounded. Stamens 4, didynamous, borne at or above the middle of the corolla-tube; anthers oblong, their sacs parallel. Ovules few or several in each ovary-cavity; style with a subulate apex. Capsule ovate or suborbicular with a short, narrowed base. Seeds orbicular. [Name Greek, originally applied to some different plant.] About 4 species, natives of tropical America. Type species: Ruellia Blechum L.

\section{Blechum Brównei Juss. Ann. Mus. Paris 9: 270. 1807.}

Annual, puberulent, erect or ascending, 2-7 dm. high, branched, the branches slender. Leaves orate, thin, petioled, $2-7 \mathrm{~cm}$. long, acute at the apex, obtuse or narrowed at the base; spikes dense, 4 -sided, $3-6 \mathrm{~cm}$. long; bracts ovate, pinnately veined, $1-1.5 \mathrm{~cm}$. long, loosely strigose and ciliate, acutish at the apex, rounded at the base; corolla whitish, a little longer than the subtending bract; capsule oblong, puberulent, about $6 \mathrm{~mm}$. long.

Waste places in good soll, Abaco, Andros, New Providence and Eleuthera :West Indies and continental tropical America; Philippine Islands. BLECHUM.

\section{RUÉLLIA L. Sp. Pl. 634. 1753.}

Perennial herbs, or shrubs, mostly pubescent, with entire or rarely dentate leaves and large flowers, solitary or clustered in the axils, or cymose in terminal panicles. Calyx 5-cleft or 5-parted, the segments narrow. Corolla funnelform or salverform, the tube usually narrow, slightly enlarged above, the limb spreading, 5-lobed, the lobes obtuse. Stamens 4, didynamous. Anthersaes not mucronate at the base. Apex of the style recurved; stigma simple, or of 2 unequal lobes. Capsule oblong or club-shaped. Seeds compressed, ovate or orbicular, attached by their edges to the retinacula. [Named for I. De la Ruelle, 1474-1537, an early French herbalist.] About 200 species, mainly of tropical America. Type species: Ruellia tuberosa L.

\section{Ruellia tuberòsa L. Sp. Pl. 635. 1753.}

Roots narrowly fusiform, clustered; stem erect or ascending, branched or simple, 2-6 dm. high, finely pubescent. Leaves ovate or oblong, $10 \mathrm{~cm}$. long or less, undulate, finely pubescent, narrowed into margined petioles; cymes several-flowered, peduncled; bracts narrow, small; calyx hispid-pubescent, its linear lobes 12-20 mm. long; corolla purple, 4-6 $\mathrm{cm}$. long, its tube rather abruptly expanded above; capsules puberulent, about $1.5 \mathrm{~cm}$. long.

Shaded grounds, New Providence, Eleuthera and Cat Island:- -southern United States: West Indles and continental tropical America. TUberous RUELlia. 


\section{GERÁRdiA [Plum.] L. Sp. Pl. 610. 1753.}

[STENANDRIUM Nees, in Lindl. Introd. Nat. Syst. ed. 2, 444. 1836.]

Low and small pubescent perennial herbs, acaulescent or nearly, so, the leaves in a basal tuft, the pink or purple flowers spicate on bracted scapes. Calyx-lobes 5, narrow, nearly equal. Corolla with a slender tube, enlarged into a slightly curved throat, the oblique 5-lobed limb spreading, the lobes unequal and imbricated. Stamens 4, didynamous, included, the anthers 1-celled. Ovules 2 in each cavity of the ovary; stigma 2-lobed. Capsule fusiform or narrowly oblong. Seeds flattened, rough or pubescent. [Commemorates John Gerardi, 1545-1607, famous English herbalist.] About 25 species, of tropical and subtropical America. Type species: Gerardia tuberosa L.

Bracts linear to linear-lanceolate, the lower 3-7 $\mathrm{mm}$. Iong; leaves entire.

Bracts lanceolate, the lower $1 \mathrm{~cm}$. long; leaves repand-dentate or undulate.

1. G. droseroides.

2. G. bracteosa.

\section{Gerardia droseroides (Nees) Blake, Rhodora 20: 68. 1918.}

Stenandrium droseroides Nees, in DC. Prodr. 11: 284. 1847.

Pubescent all over with soft hairs. Basal leaves forming small tufts, membranous, oblong, entire, 3-4.5 $\mathrm{cm}$. long, rounded or obtuse at the apex, the petioles as long as the blades or shorter; scapes slender, 8-15 cm. high; spikes slender, several-many-flowered; bracts linear to linear-lanceolate, 3-7 mm. long, acuminate; calyx-lobes linear, 2-3 mm. long; corolla white, its tube 3-4 $\mathrm{mm}$. long, about as long as the lips; filaments very short; capsule oblong, acute, glabrous, 4-5 mm. long; seeds suborbicular.

Pine-lands, Abaco and New Providence:-Cuba.. Sundew Gerardia.

\section{Gerardia bracteòsa Britton \& Millspaugh, sp. nov.}

Pubeseent all over with long soft hairs. Basal leaves in large tufts, $7 \mathrm{~cm}$. long or less, firm in texture, the flat petioles of the larger ones as long as the blades or longer, the blades oblong to oblong-obovate, $2-3.5 \mathrm{~cm}$. long, 8-18 $\mathrm{mm}$. wide, undulate or nearly entire, obtuse or acutish at the apex, narrowed at the base; scapes rather stout, 10-20 $\mathrm{cm}$. high, naked toward the base, but floriferous for nearly two-thirds their length; bracts lanceolate or linear-lanceolate, acute or acuminate, 8-12 $\mathrm{mm}$. long; calyx-lobes linear, acute about $6 \mathrm{~mm}$. long; corolla pink, about $17 \mathrm{~mm}$. long, the tube somewhat shorter than the larger lobes of the limb; anthers nearly sessile; capsule oblong, about $8 \mathrm{~mm}$. long; seeds suborbicular.

Fields and copplces, Mariguana ( $P$. Wilson 7472, type; 7440 ).

Apparently the same as Egger's 3969, from Acklin's Island, referred by Lindau to stenandrium rupestre (Sw.) Nees=Gerardia tuberosa L. BRACTED GeraRDIA.

\section{ANTHACÁNTHUS Nees; DC. Prodr. 11: 460. 1847.}

Slender, much-branched shrubs armed with opposite axillary, eurved or straight spines, the leaves small, entire, often fascicled in the axils, the solitary or fascicled flowers axillary, slender-peduncled. Calyx 5-cleft. Tube of the small corolla cylindric, somewhat enlarged above, the limb spreading, unequally 5-lobed. Stamens 2; filaments short; anthers oblong, 2-celled; staminodia 2, clavate or filiform. Style filiform; ovules 2 in each cavity of the ovary. Capsule oblong, stipitate. Seeds 4 or fewer, compressed, tubercled. [Greek, spiny flower.] About 6 species, natives of the West Indies. Type species: Justicia spinosa Jacq. 
1. Anthacanthus spinòsus (Jacq.) Nees, in DC. Prodr. 11: 460. 1847.

Justicia spinosa Jacq. Enum. 11. 1760.

A shrub, erect or diffuse, $2 \mathrm{~m}$. high or less, the long slender branches pubescent or glabrous, the stiff subulate spines more or less recurved, 4-12 mm. long. Leaves coriaceous, glabrous or nearly so, ovate to oblong, elliptic or oblanceolate, 3-20 mm. long, obtuse, acute or emarginate at the apex, narrowed or obtuse at the base, the midvein rather prominent, the lateral venation obscure, the petioles very short; flowers few or solitary at the axils; peduncles 6-10 mm. long; calyx 3-4 mm. long, its lobes lanceolate, acute; corolla purple or violet, puberulent or glabrous, its tube about $8 \mathrm{~mm}$. long, its oblong lobes about as long as the tube; style filiform, about $10 \mathrm{~mm}$. long; capsule about $2 \mathrm{~cm}$. long; seeds wrinkled, $2-3 \mathrm{~mm}$. in diameter.

Scrub-lands and thickets, throughout the archipelago from Great Bahama and Andros to Eleuthera, Watling's Island, Caicos Islands and Inagua:-Jamaica; Cuba to Virgin Gorda, and Martinique. Recorded by Mrs. Northrop, by Coker, and by Lindau as A. acicularis (Sw.) Nees, which is known to us only from Jamaica. Races differ in pubescence, in size and shape of leaves, and in length of spines. PRICKLY BUSH.

\section{ANDROGRÁPHIS Wall. Pl. Asiat. Rar. 3: 77, 116. 1832.}

Herbs, erect or diffuse, the small flowers in panicles or cymes, with small bracts and bractlets. Calyx 5-parted. Corolla with a short tube, somewhat expanded above and a 2-lipped limb. Stamens 2; filaments sometimes bearded above; anthers 2-celled. Capsule linear to oblong, scarcely stipitate. Seeds 6-12, flattened. [Greek, bearded-stamens.] About 15 species, natives of the East Indies. Type species: Andrographis paniculata (Burm.) Nees.

1. Andrographis paniculàta (Burm.) Nees; Wall. Pl. Asiat. Rar. 3: 116. 1832.

Justicia paniculata Burm. Fl. Ind. 9. 1768.

Annual, erect, glabrous below, glandular above, 3-6 dm. high, simple or branched, the stem 4-sided. Leaves lanceolate or oblong-lanceolate, membranous, 4-10 $\mathrm{cm}$. long, acuminate at the apex, narrowed at the base into short petioles; racemes commonly numerous, slender, often branched, or paniculate; flowers secund, distant, purple; pedicels slender, 4-8 $\mathrm{mm}$. long; calyx about $3 \mathrm{~mm}$. long, its segments linear-lanceolate, acuminate; corolla 3-4 times as long as the calyx; capsule about $1.5 \mathrm{~cm}$. long.

Waste grounds on New Providence :-Cuba; Dominica to Barbadoes; Jamaica ; Panama; naturalized from the East Indies. ANDrograpHIS.

\section{JUSTícIA [Houst.] L. Sp. Pl. 15. 1753.}

Herbs, or shrubs, with entire leaves, the flowers variously clustered. Calyx deeply cleft, its segments narrow, nearly equal. Corolla-tube mostly shorter than the 2-lipped limb, the upper lip '2-cleft, the lower 3-cleft. Stamens 2 , borne in the throat of the corolla; anthers 2-celled; staminodes none; lower anther-sac minutely appendaged. Style filiform; ovules 2 in each ovary. cavity. Capsule oblong. [In honor of James Justice, a Scotch gardener.] Over 100 species, of tropical distribution. Type species: Justicia Adhatoda L.

\section{Justicia carthaginénsis Jacq. Enum. 11. 1760.}

Herbaceous, erect, branched, 0.5-1.5 m. high, the branches and leaves glabrous or very sparingly pubescent. Leaves ovate or elliptic-ovate, membranous, 5-12 cm. long, acuminate at the apex, narrowed or rounded at the base, some- 
what decurrent on the petioles; flowers violet to purple, in dense terminal bracted spikes 3-7 $\mathrm{cm}$. long; bracts oblong, pubescent or ciliate, $12 \mathrm{~mm}$. long or less, the lower pointed, the upper truncate and euneate; bractlets narrower than the bracts; calyx-segments lanceolate, about $1 \mathrm{~cm}$. long; corolla-tube about $1.5 \mathrm{~cm}$. long, the upper lip about as long as the tube, the lower somewhat longer; capsule 1.5-2 cm. long, acute, pubescent.

Waste places, New Providence and Long Island:-Hispaniola; St. Thomas to Barbadoes and Grenada; continental tropical America. JUSTICIA.

7. DIAPÈdIUM Konig; Konig \& Sims, Ann. Bot. 2: 189. 1805.

[Dicliptera Juss. Ann. Mus. Paris 9: 267. 1807.]

Herbs, with entire petioled leaves, and blue, red, or violet flowers subtended by involucres of 2-4 bracts, the inflorescence mostly cymose or spicate, the involucres subtending 1 flower or several. Calyx 4-5-cleft, the lobes linear or subulate. Corolla-tube slender, slightly enlarged above; upper lip erect, concave, interior in the bud; lower lip spreading, entire or 3-toothed. Stamens .2 ; anther-sacs parallel, sometimes unequal, separated by a narrow connective. Style filiform; ovules 2 in each eavity of the ovary. Capsule flattened, ovate or suborbicular, 2-4-seeded. Placentae separating elastically from the walls of the capsule. Seeds compressed, nearly orbicular. About 60 species, of warm and tropical regions. Type species: Justicia chinensis L.

1. Diapedium assúrgens (L.) Kuntze, Rev. Gen. Pl. 485. 1891.

Justicia assurgens L. Syst. ed. 10, 850. 1759.

Dicliptera assurgens Juss. Ann.' Mus. Paris 9: 269. 1807.

Erect, often much branched, glabrous or somewhat puberulent, 3-15 dm. high. Leaves ovate to oblong-lanceolate, 4-10 $\mathrm{cm}$. long or the upper smaller, acute or obtuse at the apex, obtuse or narrowed at the base, the petioles slender; flowers in small bracted clusters, in slender interrupted, simple or branched spikes 5-15 $\mathrm{cm}$. long; bracts lanceolate or spatulate, 8-15 $\mathrm{mm}$. long; calyx about $4 \mathrm{~mm}$. long, its linear-lanceolate lobes as long as the tube or longer; corolla scarlet or red, $2-2.5 \mathrm{~cm}$. long, its tube curved, its lips lanceolate; capsule 5-6 $\mathrm{mm}$. long.

Waste grounds, scrub-lands and thickets, throughout the archipelago from Abaco and Great Bahama to the Anguilla Isles and Crooked Island :-Florida; West Indies ; continental troplcal Amerlca. DIAPEDrum. Erroneously called HoNeYsuckL.

\section{THUNBÉRgIA Retz. Phys. Sallsk. Handl. 1: 163. 1776.}

Herbs or herbaceous vines, with opposite, mostly hastate or cordate leaves, and large 2-bracted flowers solitary in the axils or in terminal racemes. Bracts foliaceous, large. Calyx short, annular. Corolla with an oblique, more or less flattened tube enlarged above, and a spreading 5-lobed limb, the lobes rounded, contorted, nearly equal. Stamens 4, didynamous, borne near the base of the corolla-tube, the filaments thickened below, the anthers with an apiculate connective. Disk fleshy. Ovary fleshy; style dilated at the apex; ovules 2 in each cavity. Capsule coriaceous, globose, abruptly beaked, loculicidally dehiscent. [Commemorates Karl P. Thunberg, 1743-1828, eminent Swedish traveller and botanist.] About 40 species, natives of the Old World tropies. Type species: Thunbergia capensis Retz. 
1. Thunbergia frágrans Roxb. Pl. Corom. 1: 47. 1795.

Thunbergia volubilis Pers. Syn. 2: 179. 1806.

A slender, finely pubescent vine, often $2 \mathrm{~m}$. long, usually climbing. Leaves ovate or ovate-lanceolate, 5-10 $\mathrm{cm}$. long, remotely few-toothed toward the base or entire, acuminate at the apex, subtruncate, hastate or cordate at the base, the slender petioles $1-4 \mathrm{~cm}$. long; peduncles rather stout, $2-7 \mathrm{~cm}$. long; bracts lanceolate or ovate-lanceolate, pubescent, acuminate, $1.5-2 \mathrm{~cm}$. long; calyx deeply cleft, much shorter than the bracts; corolla white, $2.5-3 \mathrm{~cm}$. long, its lobes crenate, nearly as long as the tube; capsule depressed-globose, pubescent, about $8 \mathrm{~mm}$. in diameter, tipped by a stout subulate beak $1-1.5 \mathrm{~cm}$. long.

Spontaneous after cultivation, New Providence near Nassau:-Cuba to Porto Rico, Tortola and Trinidad; Jamaica. Naturalized from Asia. White Thunbergia.

2. Thunbergia alàta Bojer; Sims, Bot. Mag. pl. 2591. 1825.

A pubescent vine, usually not more than $1 \mathrm{~m}$. long, trailing or climbing. Leaves ovate or triangular-ovate, $4-8 \mathrm{~cm}$. long, remotely few-toothed or entire, acute at the apex, cordate or hastate at the base, the wing-margined petioles as long as the blades or shorter; peduncles slender, mostly longer than the petioles; bracts ovate-lanceolate, acute or acuminate, pubescent, about $1.5 \mathrm{~cm}$. long; calyx cleft to about the middle; corolla yellow or white, usually with a purple eye, 2.5-4 cm. long; capsule depressed-globose, pubescent, $8-10 \mathrm{~mm}$. in diameter, its stout beak about $1 \mathrm{~cm}$. long.

Waste places near Nassau, New Providence:-Cuba to Tortola and Trinidad; Jamaica; Mexico to continental tropical America. Naturalized from eastern Africa. WINGED THUNBERGIA.

\section{Family 16. MYOPORÀCEAE Lindl.}

\section{MYOPORUM FAMILY.}

Shrubs or trees, with alternate or opposite, entire estipulate leaves, and perfect, more or less irregular flowers, solitary or clustered in the axils. Calyx inferior, 5-parted. Corolla gamopetalous, its limb 2-lipped. or oblique. Stamens 4, mostly didynamous, borne on the corolla-tube, the filaments filiform. Ovary usually 2-celled; style terminal; stigma terminal and small; ovules 1 in each ovary-cavity. Fruit a drupe. Five genera anå 80 species or more, most Australian, only the following American.

\section{BÓNTIA L. Sp. Pl. 638. 1753.}

A tree or shrub, with alternate narrow fleshy entire pointed leaves, and rather small, purplish peduncled flowers, solitary or clustered in the axils. Calyx 5-parted, the segments imbricated. Tube of the corolla straight, cylindric, the limb deeply 2-lipped, the posterior lip concave, 2-cleft, the anterior lip recurved, 3-cleft, its middlo lobe densely bearded. Stamens 4, didynamous; filaments thickened and villous near the base. Ovary 2-celled; ovules 4 in each cavity, superimposed in pairs; style very slender. Drupe ovoid, the exocarp fleshy, the endocarp bony, 2-celled. Seeds small, ovoid, with little endosperm. [Commemorates Peter Bontius, a Duteh naturalist and traveller of the seventeenth century.] A monotypic West Indian genus.

\section{Bontia daphnoìdes L. Sp. Pl. 638. 1753.}

A shrub or small tree, sometimes $9 \mathrm{~m}$. high, nearly glabrous throughout, with terete, rather slender twigs. Leaves oblong or oblong-lanceolate, falling 
away from the twigs in drying, $10 \mathrm{~cm}$. long or less, acuminate at the apex, narrowed at the base, the slender midvein prominent, the lateral venation obscure, the petioles 1-2 cm. long; peduncles slender, 1-3 cm. long; calyx-segments broadly ovate, subulate-tipped, about $3 \mathrm{~mm}$. long, ciliolate; corolla about $2 \mathrm{~cm}$. long, yellow, purple-blotched, or the lip purple within; drupe pointed, yellow, 1-1.5 cm. long.

Scrub-lands and palmetto-lands, Great Bahama, South Caicos, Grand Turk:Cayman Islands; Cuba to Tortola and Barbadoes; Curaçao; Aruba; Guiana. Bontia. Erroneously called OLIVE.

\section{Order 5. PLANTAGINÀLES.}

Only the following family:

\section{Family 1. PLANTAGINÀCEAE Lindl.}

\section{Plantain Family.}

Herbs, with basal, or, in the caulescent species, opposite or alternate leaves, and small perfect polygamous or monœcious flowers, bracteolate in spikes or heads, or rarely solitary. Calyx 4-parted, inferior, persistent, the segments imbricated. Corolla hypogynous, scarious or membranous, mostly marcescent, 4-lobed. Stamens 4 or 2 (only 1 in an Andean genus), inserted on the tube or throat of the corolla; filaments filiform, exserted or included; anthers versatile, 2-celled, the sacs longitudinally dehiscent. Ovary sessile, superior, 1-2-celled, or falsely 3-4-celled. Style filiform, simple, mostly longitudinally stigmatic. Ovules 1 -several in each cavity of the ovary, peltate, amphitropous. Fruit a pyxis, circumscissile at or below the middle, or an indehiscent nutlet. Seeds 1-several in each cavity of the fruit; endosperm fleshy; cotyledons narrow; radicle short, mostly straight. Three genera and over 225 species, of wide distribution.

\section{PLANTÀGo L. Sp. Pl. 112. 1753.}

Leafy-stemmed, short-stemmed or acaulescent herbs, with opposite, alternate or basal leaves, bearing axillary or terminal spikes or heads of small greenish or purplish flowers (flowers solitary in a few exotic species). Calyxsegments equal, or two of them larger. Corolla salverform, the tube eylindric, or constricted at the throat, the limb spreading in anthesis, erect, spreading or reflexed in fruit, 4-lobed or 4-parted. Stamens 4 or 2 . Ovary 2-celled, or falsely 3-4-celled; ovules 1-several in each cavity. Fruit a membranous pyxis, mostly 2-celled. Seeds various, sometimes hollowed out on the inner side. [The Latin name.] Over 200 species, of wide geographic distribution. Type species: Plantago major L. The following are acaulescent weeds.

Leaves ovate; seeds many.

Leaves oblong-lanceolate; seeds 2.
1. P. major.

2. P. lanceolata.

\section{Plantago màjor L. Sp. Pl. $112^{\circ} 1753$.}

Perennial, glabrous or pubescent; rootstock short, thick, erect. Leaves long-petioled, mostly ovate, ertire, or coarsely dentate, $2.5-25 \mathrm{~cm}$. long, 3-11ribbed; scapes 0.5-9 dm. high; spike linear-cylindric, usually dense, commonly blunt, 5-25 $\mathrm{cm}$. long, 6-8 $\mathrm{mm}$. thick; flowers perfect, proterogynous; sepals broadly ovate to obovate, scarious margined, one-half to two-thirds as long as the obtuse or subacute, 5-16-seeded pyxis; stamens 4.

Roadsides and waste places, Abaco, Great Bahama, Andros and New Providence : -Bermuda; United States; West Indies; Central and South America. Naturalized from the Old World. Greater Plantain. 
2. Plantago lanceolàta L. Sp. Pl. 113. 1753.

Perennial or biennial, pubescent; rootstock short, erect, with tufts of brown kairs at the bases of the leaves. Leaves narrowly oblong-lanceolate, shorter than the scapes, entire, acute or acuminate, gradually narrowed into petioles, 3-5-ribbed, 5-30 cm. long; scapes slender, channeled, sometimes 7.5 dın. tall; spikes dense, at first ovoid, becoming cylindric, blunt and 1-10 cm. long in fruit, $8-12 \mathrm{~mm}$. thick; flowers perfect, proterogynous; sepals ovate, with a narrow green midrib and broad searious margins, the two lower ones commonly united; corolla glabrous; filaments white; pyxis.oblong, very obtuse, 2 -seeded, slightly longer than the calyx, circumscissile at about the middle.

Roadsides, New Providence:-Bermuda; North America; Cuba ; Jamaica. Naturalized from the Old World. RIBWORT.

\section{Order 6. RUBIÀLES.}

Corolla gamopetalous. Anthers separate, the stamens as many as the corolla-lobes and alternate with them (one fewer in Linnaea of the Caprifoliaceae) or twice as many. Ovary compound, inferior, adnate to the calyx-tube. Ovules 1 or more in each cavity of the ovary. Leaves opposite or verticillate.

Leaves stipulate, usually blackening in drying.

Leaves usually estipulate, not blackening in drying.

Fam. 1. RUBIACEAE.

Fam. 2. CAPRIFOLIACEAE.

\section{Family 1. RUBIÀCEAE B. Juss.}

\section{Madder Family.}

Herbs, shrubs, or trees, with simple, opposite or sometimes verticillate, mostly stipulate leaves, and perfect, often dimorphous or trimorphous, regular and nearly symmetrical flowers. Calyx-tube adnate to the ovary, its limb various. Corolla funnelform, club-shaped, campanulate, or rotate, 4-5-lobed. Stamens as many as the lobes of the corolla and alternate with them, inserted on its tube or throat. Ovary 1-10-celled; style simple or lobed; ovules $1-\infty$ in each eavity. Fruit a capsule, berry, or drupe. Seeds various; seed-coat membranous or crustaceous; endosperm fleshy or horny (rarely wanting in a few genera); cotyledons ovate, cordate, or foliaceous. A large family of some 340 genera and about 6,000 species, of wide distribution.

4. Cavities of the ovary with several or many ovules; seeds severai or many.

Fruit dry, capsular.

Herbs.

Shrubs or trees.

Seeds wingless; leaves linear, grooved.

Seeds winged; leaves broad.

1. Oldenlandia.

Fruit pulpy, baccate.

Fruit 2-celled.

Flowers in cymes.

Flowers solitary.

Corolla-lobes 5, convolute.

Fruit 5-celled.

B. Cavities of the ovary with a single ovule; seeds solitary.

2. Rachicallis.

3. Exostema.

Ovule pendulous.

Filaments wholly or partly adnate to the corolla-tube. Calyx-limb deciduous, though often tardily so. Calyx-1imb persistent, crowning the fruit.

Fllaments not adnate to the corolla-tube. Inflorescence terminal, or sometimes also axillary. Inflorescence axillary.

4. Casasia.

5. Randia.

6. Catesbaea.

7. Hamelia.

8. Guettarda.

9. Stenostomum.

10. Erithalis. 
Orule not pendulous.

Stamens exserted, filaments distinct.

Stamens included, filaments monadelphous at base.

Calyx-tube ovold, limb 5-dentate; corolla-lobes valvate.

Calyx-tube oblong, limb 4-partite; corolla-lobes imbricated.

Corolla-lobes imbricated.

Corolla-lobes valvate.

Orule or seed with a basal attachment.

Ovule or seed with a lateral attachment.

Shrubs or trees; fruit a syncarp.

Herbs or low shrubs ; fruit not syncarpous.

Stipules relatively small or inconsplcuous, more or less cleft.

Fruit drupaceous, carpels neither dehiscent nor separating.

Fruit not drupaceous, carpels dehiscent or separating.

Fruit septlcidal, both carpeis ventraily dehiscent.

Fruit separating into carpels, one dehiscent the other indehiscent.

Stipules follaceous, usually resembling the leaves.

11. Phialanthus.

12. Chiococca.

13. Scolosanthus.

14. Strumpfia.

15. Psychotria.

16. Morinda.

17. Ernodea.

18. Borreria.

19. Spermacoce.

20. Galium.

\section{OLDENLÁNDIA L. Sp. Pl. 119. 1753.}

Herbs, with opposite leares, and small white or pink flowers. Calyx-tube obovoid or subglobose, the limb 4-5-toothed. Corolla rotate or salverform, 4-5-lobed. Stamens 4 or 5, inserted on the throat of the corolla; anthers oblong. Ovary 2-celled; ovules numerous in each cavity; style slender, 2-lobed. Capsule small, ovoid, top-shaped or hemispheric, wholly adnate to the calyxtube, loculicidally dehiscent at the summit. Seeds angular, not peltate; endosperm fleshy; embryo club-shaped. [Named for H. B. Oldenland, a Danish botanist.] About 175 species, mostly of tropical distribution. Type species: Oldenlandia corymbosa $\mathrm{L}$.

1. Oldenlandia callitrichioìdes Griseb. Mem. Am. Acad. II. 8: 506.1862.

Stems filiform, creeping, glabrous, $2-10 \mathrm{~cm}$. long, rooting at the nodes. Leaves ovate-orbicular, very thin, petioled, the blades 1-4 $\mathrm{mm}$. long, glabrous or with a few long hairs, obtuse or acutish at the apex, contracted into slender petioles of about the same length; stipules minute or obsolete; peduncles solitary in the axils, filiform, 2-3 times as long as the leaves; calyx 4-5-toothed, the teeth ovate to lanceolate, bearing a few long hairs, much shorter than the tube; corolla white, funnelform, 1.5-2 mm. long, the 4 or 5 lobes shorter than the tube; capsule turbinate, about $2 \mathrm{~mm}$. long.

Moist ground, Rum Cay :-Cuba ; Guadeloupe. Recorded from St. Crolx. SMaLL OLDENLANDIA.

\section{RACHICÁLIIS DC. Prổr. 4: 433. 1830.}

A low, white-wooly, densely and intricately branched shrub, with small opposite. fleshy linear imbricated leaves, persistent connate stipules, and small opposite sessile solitary flowers half-inclosed by the stipular sheaths. Calyx-tube very short, its 4 lanceolate teeth with smaller accessary ones between them. Corolla salverform, with 4 oblong imbricated lobes. Stamens 4 ; filaments short. Ovary 2-celled, half-superior; styles thick, slightly 2-lobed; ovules numerous in each cavity. Fruit capsular; seeds angled. [Greek, beauty of rocky shores.] A monotypic genus. 
1. Rachicallis americàna (Jacq.) Hitchc. Rep. Mo. Bot. Gard. 4: 92.1893.

Hedyotis americana Jacq. Enum. 12. 1760.

Hedyotis rupestris Sw. Prodr. 29. 1788.

Rachicallis rupestris DC. Prodr. 4: 434. 1830.

Rigid, erect, or prostrate, the short stout twigs densely woolly, bearing the leaves in tufts at the ends. Leaves bright green, 4-9 $\mathrm{mm}$. long, about 1 $\mathrm{mm}$. wide, thick, grooved on the back, glabrous, sharply mucronate; stipules broadly ovate, mucronate, densely pubescent and eiliate; corolla 5-6 mm. long, villous-pubescent, its obtuse lobes about one third as long as the tube. Plant fragrant when dry.

Maritime rocks and coastal coppices, throughout the archipelago:-Cuba; Hispaniola ; Jamaica; the Caymans ; Cozumel. Reported from Bermuda, perhaps erroneously. Hog-bush. Sandfly-bush. Saltwater-bush. Sea-weed. Wild Thyme.

\section{EXosTÈMA Kich.; H. \& B. P1. Aeq., 1: 131. 1808.}

Shrubs or trees, with opposite petioled leaves, deciduous stipules, and solitary or panicled flowers. Calyx-tube cylindric to turbinate, with 5 linear lobes. Corolla salverform, the slender tube elongated, the limb with 5 long imbricated lobes. Stamens 5, borne near the base of the corolla; filaments filiform, long; anthers narrowly linear, basifixed, exserted. Ovary 2-celled; style filiform, exserted; ovules numerous in each cavity. Fruit a 2-valved capsule, many-seeded; seeds broadly winged. [Greek, exserted stamens.] Thirty species or more, natives of tropical America. Type species: Exostema parviflorum A. Rich.

1. Exostema caribaèum (Jacq.) R. \& S. Syst. 5: 18.1819.

Cinchona caribaea Jacq. Enum. 16. 1760.

A glabrous shrub or small tree up to $8 \mathrm{~m}$. high, with a trunk sometimes $1 \mathrm{dm}$. in diameter, the bark bitter. Leaves oblong-lanceolate to elliptic, rather thin, 3-8 cm. long, 1-3 cm. wide, acuminate or acute at the apex, narrowed at the base, the midvein prominent, the few lateral veins obscure, the slender petioles about one-fourth as long as the blades; stipules broadly ovate, acuminate, about $1.5 \mathrm{~mm}$. long; flowers solitary in the axils; peduncles slender, about as long as the calyx; calyx clavate-cylindric, 4-5 $\mathrm{mm}$. long, its teeth short; corolla white or pinkish, its tube $2-3 \mathrm{~cm}$. long, slightly longer than the lobes; anthers long-exserted; capsule oblong, smooth, woody, 10-15 mm. long.

Coppices, pine-lands and scrub-lands, throughout the archipelago from Abaco, Great Bahama and Andros to Caicos Islands :-Florida; Cuba to Anegada, St. Martin and Grenada; Jamaica; Central America and northern South America. Princewood.

4. CASASIA A. Rich. in Sagra, Hist. Cub. 11: 9. 1850.

Shrubs or trees, with terete branches. Leaves opposite, leathery; stipules deciduous. Flowers perfect, in short-peduncled cymes. Calyx turbinate or campanulate, truncate or with 5 or 6 obtuse sepals, persistent. Corolla white or yellow, salverform or nearly rotate, pubescent in the throat, its lobes 5 or 6 , spreading, contorted. Stamens 5 or 6 , adnate to the mouth of the corollatube; anthers sessile. Disk cup-like. Ovary 1-2-celled; styles stout. Ovules numerous in each cavity. Fruit a thick pulpy berry. Seeds numerous, angled, flattened, the testa somewhat fibrous. [In honor of Luis de las Casas, Captain General of Cuba.] About 8 species, natives of Florida and the West Indies. Type species: Casasia calophylla A. Rich. 
1. Casasia clusiaefỏlia (Jacq.) Urban, Symb. Ant. 5: 505. 1908.

Gardenia clusiaefolia Jacq. Coll. 5: 37. 1796.

Genipa clusiaefolia Griseb. Fl. Br. W. I. 317. 1861.

A branching shrub, 1-3 m. tall, the foliage glabrous, turning black in drying. Leaves clustered, leathery, obovate to cuneate, 5-15 $\mathrm{cm}$. long, rounded or retuse at the apex, lustrous, often mucronate, entire, short-petioled; calyxtube 8-10 $\mathrm{mm}$. long, turbinate, the lobes subulate, shorter than the tube; corolla fleshy, glabrous, its tube $1.5-2 \mathrm{~cm}$. long, its lobes lanceolate or oblonglanceolate, shorter than the tube; berries ovoid to obovoid, 5-7 $\mathrm{cm}$. long.

Coastal rocks, Berry Islands, the Biminis, Andros, New Providence, Eleuthera to Watling's, Calcos, Inagua and the islands of the Cay Sal Bank:-Florida; Bermuda; Cuba. Seven-year APPIB. Catesby, 1: $p l$. 59.

\section{RÁNDIA L. Sp. Pl. 1192. 1753.}

Evergreen, often spiny shrubs or trees, with oposite leaves and perfect solitary, usually axillary flowers. Calyx-lobes 4. Corolla funnelform, salverform or campanulate, its lobes 5, convolute. Stamens 5, adnate to the throat of the corolla; filaments short or nearly wanting. Disk annular or cushionlike. Ovary 2-celled or very rarely 3-4-celled; ovules several or many in each cavity; styles usually united, stout, terminating in a club-shaped, spindleshaped or rarely cleft stigma. Berry usually 2-celled. Seeds free or in a pulp; testa thin, the endosperm horny. [In honor of Isaac Rand, English apothecary.] About 100 species, natives of tropical regions. Type species: Randia mitis $\mathrm{L}$.

\section{Randia mitis L. Sp. Pl. 1192. 1753.}

Randia aculeata L. Sp. Pl. 1192. 1753.

A virgate branching shrub, 1-3 m. tall, or a small tree up to $7 \mathrm{~m}$. high, usually spiny, the foliage glabrous or nearly so. Leaves often elustered, spatulate, obovate, elliptic, oval or suborbicular, 1-5 cm. long, narrowed into short petioles; flowers axillary, short-stalked; calyx-lobes triangular or ovate; corolla white, 6-8 mm. long, its lobes oblong, shorter than the tube; berries subglobose or oval, white, 8-12 $\mathrm{mm}$. long.

Scrub-lands and copplces, throughout the archipelago from Abaco, Great Bahama and Andros to Turk's Islands and Inagua :-Bermuda; Florida; West Indies and Mexico. Races differ in size and shape of leaves and in size of fruit. Box BrIAR.

\section{CATÉsbafa L. Sp. Pl. 109. 1753.}

Spinescent shrubs or small trees, with terete twigs and small glabrous, often fascicled leaves, the small stipules deciduous. Flowers white, solitary and short-peduncled in the axils. Calyx subcampanulate, with 4 narrow persistent lobes. Corolla funnelform or campanulate, its 4 lobes valvate. Stamens 4 , borne near the base of the corolla. Ovary 2-celled; stigma 2-lobed. Ovules several or many. Fruit a white berry. Seeds with fleshy endosperm. [In honor of Mark Catesby, 1679-1749, traveller and naturalist.] About 8 species, natives of Florida and the West Indies. Type species: Catesbaea spinosa L.

Flowers very large, drooping.

Flowers very small, nearly concealed among the leaves.

Leaves 3-10 mm. long, suborblcular to oblanceolate.

Leaves 8-13 mm. long, linear to obovate-spatulate.
1. C. spinosa.

2. C. parviflora. 3. C. foliosa. 
1. Catesbaea spinòsa L. Sp. Pl. 109. 1753.

A glabrous shrub, 2-3 cm. high, or a small tree up to $5 \mathrm{~m}$. high, with very spiny slender branches, the spines opposite, axillary, $1.5-3.5 \mathrm{~cm}$. long. Leaves ovate-elliptic, thin, $0.6-3 \mathrm{~cm}$. long, acute or acutish at both ends, mostly shorter than the spines, short-petioled; peduncles mostly shorter than the leaves, about as long as the calyx; calyx-teeth subulate; corolla 10-15 cm. long, yellow, nodding, the very slender tube tapering into the throat above the middle, the short lobes ovate, acute; berry globose to ovoid, $1.5-5 \mathrm{~cm}$. long.

Scrub-lands and copplces, Andros, New Providence, Eleuthera and Long Island: Cuba. Catesby, 2 : pl. 100. LARge-Flowered Catesbya. Prickly-apple. Spanish GUAVA。

2. Catesbaea parvifiòra Sw. Prodr. 30. 1788.

Catesbaea campanulata Sagra; DIC. Prodr. 4: 401. 1830.

Catesbaea parviflora septentrionalis Krug \& Urban; Urban, Symb. Ant. 1: 429.1899.

Catesbaea fasciculata Northrop, Mem. Torr. Club 12: 66. 1902.

A much-branched shrub, $2 \mathrm{~m}$. high or less, the branches long and slender, usually copiously armed with slender spines 5-20 mm. long, rather densely leafy. Leaves coriaceous, obovate to suborbicular or oblanceolate, 3-10 $\mathrm{mm}$. long, rounded at the apex, rarrowed at the base into short petioles; flowers sessile or nearly so in the axils; calyx-teeth subulate; corolla about $6 \mathrm{~mm}$. long, its 4 lobes obtuse; berry globose, white, about $2 \mathrm{~mm}$. in diameter.

White-lands, savannas and coppices, Abaco, Berry Islands, Andros, New Providence, Eleuthera, Little San Salvador, Exuma Chain to Great Ragged Island, Green Cay :-Florida; Cuba; Porto Rico; Jamaica. SMaLl-Flowered CaTESBYa.

3. Catesbaea foliòsa Millsp. Field. Mus. Bot. 2: 312. 1909.

A stout-branched, spreading shrub, 1-2 m. high, with or without spines, the bark loose and grayish-white; branchlets densely and minutely resinous, setose. Leaves thick, 8-13 $\mathrm{mm}$. long, 2-6 $\mathrm{mm}$. wide, linear-spatulate to obovate, dark green, subsessile, the apex obtuse, rarely mucronulate, the margin revolute, the upper surface appearing as if varnished; flowers pedicellate; calyx-teeth subulate, obtuse, about $1 \mathrm{~mm}$. long, minutely setulose; berry white, globose, $2-3 \mathrm{~mm}$. in diameter; seeds reddish, ovate, umbonate in the center on both sides.

White-lands and scrub-lands, Conception Island, Watling's Island, Atwood Cay, Crooked Island, Fortune Island, Acklin's Island, Mariguana, Caicos Islands, Grand Turk, Ambergris Cay and Inagua. Referred to in Field Col. Mus. Bot. 2: 167 as C. campanulata, and possibly a large-leaved race of the preceding species though appearing distinct. LEAFY CatesBy .

\section{HAMÈLIA Jacq. Enum. 2, 16. 1760.}

Shrubs, or small trees, with opposite or verticillate, petioled leaves, narrow deciduous stipules, and red or yellow flowers secund on the branches of terminal compound cymes. Calyx-tube ovoid to turbinate, its 5 short lobes persistent. Corolla tubular, or narrowly campanulate, constricted at the base, the limb 5-lobed, the lobes short, imbricated. Stamens 5, borne near the base of the corolla; filament short; anthers basifixed, linear, scarcely exserted, or included, the connective appendaged. Ovary 5-celled; style filiform; stigma narrowly fusiform; ovules rumerous in each cavity. Berry small, ovoid, 5lobed, 5-celled. Seeds very small, angled. [In honor of H. L. du Hamel de Monceau, 1700-1782, French botanist.] About 25 species of tropical and subtropical America. Type species: Hamelia erecta Jacq. 
1. Hamelia erécta Jacq. Enum. 16. 1760.

Hamelia patens Jacq. Enum. 16. 1760.

A shrub, or small tree up to about $4 \mathrm{~m}$. high, with slender branches, the twigs, leaves and inflorescence puberulent. Leaves opposite, or verticillate in 3 's to 5 's, thin, elliptic to ovate-elliptic, $5-15 \mathrm{~cm}$. long, acute or acuminate at the apex, mostly narrowed at the base, the slender petioles one-fourth to one-half as long as the blades; stipules lance-subulate, $2-3 \mathrm{~mm}$. long; eymes 3-5-rayed; flowers numerous, very short-pedicelled; corolla crimson to scarlet, tubular, 12-20 mm. long, its lobes very short; berries dark red or purple, 5-6 $\mathrm{mm}$. long, a little produced beyond the calyx.

Coppices, New Providence:-Florida; West Indies; contlnental tropical America. Scarlet Hamelia.

\section{GUETTÁRDA L. Sp. Pl. 991.1753.}

Trees or shrubs, with opposite leaves and deciduous stipules, the axillary cymose, or sometimes solitary flowers, perfect or polygamo-dioecious. Calyx with an ovoid or globose tube, the limb tubular, rarely persistent, mostly truncate or irregularly toothed. Corolla salverform, the tube elongated, sometimes curved, the limb with 4-9 obtuse imbricated lobes. Stamens as many as the corolla-lobes, borne on the corolla-tube; filaments very short or none; anthers linear. Ovary 4-9-celled; ovules 1 in each cavity, pendulous; style filiform; stigma capitate or 2-lobed. Fruit drupaceous. [In honor of Jean Etienne Guettard, 1715-1786, French botanist.] Sixty' species or more, mostly of tropical America. Type species: Guettarda speciosa L.

Leaves corlaceous.

Leaves scabrous above; fruit 4-6 $\mathrm{mm}$. in diameter.

Leaves smooth above; fruit 9-12 $\mathrm{mm}$. in diameter.

1. G. scabra.

2. G. Krugii.

Leaves chartaceous or membranous.

Leaves strongly reticulate-veined, and densely pale-pubescent beneath; corolla $1-3 \mathrm{~cm}$. long.

Inflorescence several-many-flowered.

Leaves 9-12 cm. long, acute at apex; corolla $2 \mathrm{~cm}$, lono.

Leaves $5 \mathrm{~cm}$. long or less, rounded at apex; corolla $1 \mathrm{~cm}$. long.

Flowers solltary in the upper axils: corolla $3 \mathrm{~cm}$. long.

Leaves not reticulate-veined, finely pubescent or glabrate beneath; corolla about $6 \mathrm{~mm}$. long.

3. G. Nashii.

4. G. Taylori.

5. G. inaguensis.

6. G. elliptica.

1. Guettarda scábra (L.) Lam. Tabl. Encycl. 2: 218.1819.

Matthiola scabra L. Sp. Pl. 1192. 1753.

A shrub or tree up to $10 \mathrm{~m}$. high, the young twigs villous-tomentose. Leaves elliptic to ovate or obovate, coriaceous, 3-15 $\mathrm{cm}$. long, obtuse or shortpointed and mucronate at the apex, subcordate or obtuse at the base, usually very rough (rarely becoming smooth) above, densely reticulate-veined and finely pubescent beneath, the stout pubescent petioles $0.5-2 \mathrm{~cm}$. long; stipules triangular-lanceolate, acute, $2-3 \mathrm{~mm}$. long; peduncles few-flowered, $2-10 \mathrm{~cm}$. long; calyx finely pubescent, about $3 \mathrm{~mm}$. long; corolla 1.5-2 cm. long, appressed-pubescent, white, its oblong lobes much shorter than the tube; fruit globose, red, finely pubescent, 4-6 mm. in diameter, the calyx-limb at length wholly deciduous. Flowers fragrant.

Scrub-lands and coppices, Abaco, Great Bahama, Andros, New Providence, Eleuthera, Cat Island, Crooked Island, Mariguana, Caicos and Inagua :-Florida; Cuba to VIrgin Gorda and Martinique; Jamaica; continental troplcal America. G. speciosa of Schoepf.? ROUGH VELVET-SEED. VELVET-BERRY. 
2. Guettarda Krùgii Urban, Symb. Ant. 1: 431. 1899.

A shrub, 1-4 m. high, in Porto Rico sometimes becoming a tree up to 10 m. high, the twigs stout, the young ones densely tomentulose, the older gray and glabrous. Stipules ovate, abtuse or acutish, brownish villous, deciduous; leaves ovate to suborbicular or elliptic-obovate, coriaceous, or those of shoots subchartaceous, obtuse, rounded or acutish at the apex, rounded or cordate at the base, smooth and glabrous above, densely pubescent, strongly and densely reticulate-veined beneath, 3-11 $\mathrm{cm}$. long, the stout, villous and tomentose petioles 6-15 mm. long, or those of shoots larger and longer-petioled; cymes 1-few-flowered in the upper axils; peduncles $1 \mathrm{~cm}$. long or less; calyx brownish villous, 5-6 mm. long, its limb irregularly subtruncate; corolla white, appressed-villous, about $1.5 \mathrm{~cm}$. long, its lobes about one-fourth as long as the tube; fruit globose, densely tomentulose, 9-12 $\mathrm{mm}$. in diameter.

Scrub-lands and rocky coppices, Abaco, Eleuthera, Exuma Chain, Cat Island and Watling's to Grand Turk, Ambergris Cay and Inagua :-Yorto Rico. Recorded by Hitchcock as G. calyptrata A. Rich. Some of our specimens are barren and are referred to this species with hesitation. KRUG'S VELVET-SEED. FroGWOOD.

\section{Guettarda Náshii Britton \& Millspaugh, sp. nov.}

A large shrub or small tree, with slender branches, the young twigs, petioles and peduncles densely tomentulose. Stipules oblong-lanceolate, acute, appressed-villous, deciduous, 10-12 $\mathrm{mm}$. long; leaves elliptic to elliptic-obovate, or rhombic-elliptie, chartaceous, 9-12 $\mathrm{cm}$. long, sharply acute at the apex, rounded or truncate at the base, pubescent on the veins but otherwise glabrous above, densely reticulate-veined and pilose-tomentulose beneath, the rather slender, tomentulose petioles $1.5-2 \mathrm{~cm}$. long; peduncles axillary, rather slender, tomentulose, 2.5-3.5 cm. long; cymes 8-12-flowered, their branches 1-2 cm. long; flowers sessile; calyx tomentulose, obliquely truncate, 6-7 $\mathrm{mm}$. long; bracts linear, longer than the calyx; corolla white, appressed-pubescent with long hairs, $2 \mathrm{~cm}$. long, the cblong obtuse lobes about one-fourth as long as the tube.

Scrub-lands, Matthew Town, Inagua (Nash \& Taylor, 1369). NASH'S VelveT-SEed.

\section{Guettarda Taylòri Britton \& Millspaugh, sp. nov.}

A small tree, up to $4 \mathrm{~m}$. high, with slender branches, the young twigs densely tomentulose. Stipules broadly ovate-elliptic, obtuse, densely tomentulose and appressed-villous, 8-10 $\mathrm{mm}$. long; leaves elliptic, ovate-elliptic or obovate, membranous, $3-5 \mathrm{~cm}$. long, obtuse and rounded at the apex, rounded or subcordate at the base; pubescent on the veins, but otherwise glabrous above, densely tomentulose, appressed-villous on the veins, and reticulateveined beneath, the slender villous petioles 8-12 $\mathrm{mm}$. long; peduncles slender, axillary, tomentulose, about twice as long as the petioles; cymes compact, 5-8. flowered; flowers sessile; bracts linear, longer than the calyx; calyx tomentulose, $5 \mathrm{~mm}$. long, pointed in bud; corolla white, appressed-strigose, $1 \mathrm{~cm}$. long, its lobes more than one-half as long as the tube.

Matthew Town, Inagua (Nash \& Taylor, 918). TAYLOR'S VeLVET-SEED.

\section{Guettarda inaguénsis Britton \& Millspaugh, sp. nov.}

A small tree, up to $4 \mathrm{~m}$. high, with slender stiff straight glabrous kranches, the joung twigs tomentose. Leaves membranous, broadly elliptic, $3-5 \mathrm{~cm}$. long, obtuse or rounded at the apex, cordate to truncate at the base, sparingly pubescent with long scattered hairs above, densely tomentulose, finely reticulate-veined and appressed-villous on the midvein beneath, the rather stout, villous petioles 5-10 $\mathrm{mm}$. long; stipules ovate, obtuse, tomentulose and villous, about $8 \mathrm{~mm}$. long, deciduous; flowers solitary, sessile in the axils: calyx narrowly campanulate, 2-lobed, 5-6 mm. long, densely pubescent; 
corolla nearly $3 \mathrm{~cm}$. long, densely pubescent, its very slender tube 5-6 times as long as the oblong lobes; fruit subglobose, densely puberulent, 10-11 mm. in diameter.

Matthew Town, Inagua (Nash \& Taylor, 919). INAGUA Velvet-SEed.

6. Guettarda ellíptica Sw. Prodr. 59. 1788.

A shrub or a tree up to $8 \mathrm{~m}$. high, with slender branches, the young twigs loosely pubescent. Leaves chartaceous, elliptic to ovate-elliptic or ellipticlanceolate, $2-7 \mathrm{~cm}$. long, obtuse, acutish or apiculate at the apex, narrowed, obtuse, or (on young shoots) rarely subcordate at the base, sparingly pubescent or glabrate above, finely appressed-silky beneath, the petioles 3-8 $\mathrm{mm}$. long, or those of shoot-leaves longer; stipules lanceolate, 4-10 mm. long; peduncles slender, pubescent, shorter than the leaves, few-several-flowered; bracts lanceolate or oblong, shorter than the ealyx; calyx about $2 \mathrm{~mm}$. long, puberulent, nearly truncate; corolla white or yellowish-white, above $6 \mathrm{~mm}$. long, silky-pubescent, its 4 oblong lobes about one-fourth as long as the tube; fruit globose, red, turning black, 6-8 $\mathrm{mm}$. in diameter, the calyx-limb at length deciduous.

Copplces and scrub-lands, throughout the archipelago from Abaco, Great Bahama and Andros to the Caicos Islands and Inagua:- Florida; Cuba; Jamaica; Hispaniola; Mona; St. Thomas. Common Velvet-Seed.

\section{STENóSTOMUM Gaertn. f. Fr. \& Sem. 3: 69. 1805.}

Mostly glabrous shrubs or trees, often resinous, with opposite leaves and small, sessile or short-pedicelled flowers secund on the branches of axillary peduncled cymes. Calyx-tube mostly ovoid, its 4-5-toothed or nearly truncate Jimb persistent. Corolla salverform or funnelform, its 4 or 5 lobes imbricated. Stamens 4 or 5 , borne on the throat of the corolla; filaments short or filiform; anthers linear. Ovary 2-6-celled; ovules 1 in each cavity; style slender; stigma capitate or lobed. Fruit a small, 2-6-celled drupe. [Greek, narrow mouth.] About 15 species, ratives of the West Indies. Type species: Stenostomum lucidum (Sw.) Gaertn. f.

Leaves thin, manifestly petioled.

Leaves thick, sessile or nearly so.

Leaves elliptic to obovate-oblong, $3 \mathrm{~cm}$. long or less.

Leaves oblong-lanceolate, 4-9 $\mathrm{cm}$. long.

1. S. Iucidum.

2. S. myrtifolium. 3. S. densiflorum.

1. Stenostomum lùcidum (Sw.) Gaertn. f. Fr. \& Sem. 3: 69. 1805.

Laugeria lucida Sw. Prodr. 48. 1788.

Antirrhoea lucida Benth. \& Hook. Gen. Pl. 2: 100. 1873.

A smooth-barked tree, 5-13 m. high, or often a shrub, with slender spreading glabrous gray branches. Leaves elliptic to oblong, chartaceous, glabrous, 4-10 cm. long, obtuse or acutish at the apex, obtuse or narrowed at the base, bright green, shining, pinnately veined, the petioles 4-10 $\mathrm{mm}$. long; stipules narrowly lanceolate, puberulent, about $8 \mathrm{~mm}$. long; inflorescence glabrous, shorter than or equalling the leaves, the branches of the cyme few, very slender; flowers sessile; calyx turbinate, 5-toothed, about $2.5 \mathrm{~mm}$. long, the teeth rounded; corolla white, 4-5 $\mathrm{mm}$. long, with 5 rounded lobes; drupe oblong, red to black, 5-7 $\mathrm{mm}$. long, crowned by the calyx-limb.

Coppices and scrub-lands, Andros, New Providence and Cat Island to Great Ragged Island, Inagua and Mariguana :-Cuba to St. Thomas and St. Croix ; Jamaica ; recorded south to Trinidad. Shining Stenostomum. 
2. Stenostomum myrtifòlium Griseb. Fl. Br. W. I. 334. 1861.

Antirrhoea myrtifolia Urban, Symb. Ant. 1: 440. 1899.

A much-branched, resinous rigid shrub, 6-13 dm. high, the young twigs pubescent. Leaves clustered at the ends of the twigs, coriaceous, viscid, oblong to elliptic or elliptic-obovate, $3 \mathrm{~cm}$. long or less, 8-17 $\mathrm{mm}$. wide, obtuse or short-pointed at the apex, narrowed or rounded at the base, finely reticulate-veined, glabrous or nearly so, the stout puberulent petioles about $2 \mathrm{~mm}$. long; stipules deltoid-ovate; peduncles 2-3-flowered, pubescent, much shorter than the leaves; flowers sessile; calyx about $2 \mathrm{~mm}$. long, the limb 5 toothed; corolla white, 6-8 $\mathrm{mm}$. long, its 5 oblong obtuse lobes much shorter than the tube; drupe globose-ellipsoid, black, $4 \mathrm{~mm}$. long.

White-lands, pine-lands, coppices, and scrub-lands, Berry Islands, North Bimini, Andros, New Providence and Eleuthera to North Caicos and Inagua:-Cuban Cays. MYRTLE STENOSTOMUM.

\section{Stenostomum densiflòrum Griseb. Cat. Pl. Cub. 132. 1866.}

Laugeria densiflora Hitchc. Rep. Mo. Bot. Gard. 4: 93.1893.

Guettarda densiflora Maza, Ann. Soc. Esp. Hist. Nat. 23: 290. 1894.

A shrub, usually 1-3 mm. high, or sometimes a small tree up to $5 \mathrm{~m}$. high, the bark smooth, the slender, glabrous branches ascending. Leaves coriaceous, viscid-resinous at least when young, oblong to elliptic-lanceolate, acute at both ends, dark green and shining above, dull and paler beneath, the petioles very short, the short-ovate stipules connate, ciliate, persistent; peduncles several-flowered, as long as the leaves or shorter, the cyme usually 2-forked; flowers sessile; calyx about $1 \mathrm{~mm}$. long; corolla about $4 \mathrm{~mm}$. long, its oblong lobes shorter than the tube; drupe globose or globose-ellipsoid, pink to blue-black, $3-4 \mathrm{~mm}$. long.

Scrub-lands and coppices, Abaco, Andros, New Providence:-Cuba. Viscid Stexosi MUM.

\section{ERITHÀLIS P. Br.; L. Syst. ed. 10, 930. 1759.}

Glabrous shrubs or small trees, with broad, dark green, opposite petioled leaves, connate stipules, and small flowers in corymbose panicles. Calyx-tube globose to ovoid, the short limb truncate or 4-5-toothed. Corolla nearly rotate or salverform, its 5-10 narrow lobes valvate, recurved or spreading. Stamens $5-10$, borne at the base of the corolla; filaments filiform; anthers basifixed, narrow. Ovary 5-10-celled; ovules solitary in each eavity, pendulous; style stout. Fruit a small drupe, containing 5-10 nutlets. [Greek, very green.] About 6 species, of the West Indies, Florida and Central America. Type species: Erithalis fruticosa $\mathrm{L}$.

\section{Erithalis fruticòsa L. loc. cit. 1759.}

Erithalis odorifera Jacq. Select. Am. 72. 1763.

A shrub, $6 \mathrm{dm}$. to $4 \mathrm{~m}$. high, or a tree up to $8 \mathrm{~m}$. high, with terete branches. Leaves elliptic to oblong, obovate or suborbicular, subcoriaceous, dark green, shining, 4-15 cm. long, rounded or short-pointed at the apex, mostly narrowed at the base, the petioles 4-16 $\mathrm{mm}$. long; stipules connate, mucronate, the sheath persistent, 1-2 mm. long; panicles peduncled, severalmany-flowered; calyx 1-2 mm. long, the limb repand-denticulate; corolla 4-10 $\mathrm{mm}$. long, deeply 5-parted, its lobes linear-oblong; anthers as long as the filaments or longer; drupe globose or depressed-globose, 5-10-furrowed, 2-5 
$\mathrm{mm}$. in diameter, black when mature. Consists of many races, differing in size of the plant, leaves, fruit and flowers, and length of the calyx-limb.

Scrub-lands, copplces and coastal thickets, throughout the archlpelago:-Florida; West Indies; Central America. In Bulletin N. Y. Bot. Gard. 3: 452, E. odorifera was referred to as distinct from $E$. fruticosa, but the differences observed do not now appear to be sufficient to maintain the two as species. Referred to $E$. rotundata Griseb. by Mrs. Northrop. BLACK TORCH.

\section{PHIALÁNTHUS Griseb. Fl. Br. W. I. 335. 1861.}

Resiniferous shrubs or small trees, with terete branches, coriaceous opposite short-petioled, oblong to lanceolate leaves, and small axillary clustered, sessile or short-pedicelled flowers, the stipules connate. Calyx turbinate, with 4 or 5 persistent lobes. Corolla funnelform, its 4 or 5 lobes obtuse, valvate. Stamens 4 or 5 , borne on the base of the corolla-tube. Ovary 2-celled; style filiform; stigma obtuse; ovules 1 in each eavity, pendulous. Fruit drupaceous. [Greek, urn-flower.] Four known West Indian species. Type species: Phialanthus myrtilloides Griseb.

\section{Phialanthus myrtilloìdes Griseb. Fl. Br. W. I. 335. 1861.}

A shrub, or rarely a small tree, 1-3 m. high. Leaves oblong to oblongspatulate, $1.5-5 \mathrm{~cm}$. long, $0.5-2 \mathrm{~cm}$. wide, obtuse or bluntly acute at the apex, narrowed at the base, the midvein rather prominent, the lateral venation almost wholly obscure; fascicles of flowers mostly opposite, very shortpeduncled; calyx-tube narrowly turbinate, $1.5-2 \mathrm{~mm}$. long, the 4 persistent thin, oblong to spatulate, obtuse lobes $2-2.5 \mathrm{~mm}$. long.

Coppices, pine-lands, and scrub-lands, Andros, New Providence, Cat Island, Exuma, Crooked and Fortune Islands, the Inaguas and Caicos Islands :- Cuba. MYrTLE Phillanthus. Candlewood.

\section{CHIOcócCA P. Br.; L. Syst. ed. 10, 917. 1759.}

Woody vines, or shrubs, with broad opposite subcoriaceous or chartaceous leaves, broad stipules, and small, yellow or white flowers in axillary, simple or compound racemes. Calyx-tube ovoid to turbinate, the limb 5-toothed, persistent. Corolla funnelform or narrowly campanulate, with 5 valvate reflexed or spreading lobes. Stamens 5 , borne toward the base of the corollatube; filaments mostly pubescent, connate at the base; anthers linear, basifixed, not exserted. Ovary 2-celled, rarely 3-celled; style filiform; ovules solitary in each cavity, pendulous. Drupe flattened, leathery, white. Seedcoat membranous; endosperm fleshy. [Greek, snowberry.] About 10 species, natives of Florida, Bermuda and tropical America. Type species: Chiococca racemosa $\mathrm{L}$.

Leaves bright green, mostly 4-8 cm. long; corolla bright yellow; fruit $6-8 \mathrm{~mm}$. broad.

Leaves dark green, mostly 2-4 cm. long; corolla white or purple to pale yellow; frult about $5 \mathrm{~mm}$. broad.

1. C. alba.

2. C. pinetorum.

1. Chiococca álba (L.) Hitche. Rep. Mo. Bot. Gard. 4: 94. 1893.

Lonicera alba L. Sp. Pl. 175. 1753.

Chiococca racemosa L. Syst. ed. 10, 917. 1759.

Chiococca parvifolia Wullschl.; Griseb. Fl. Br. W. I. 337. 1861.

A glabrous shrub, 1-3 m. high, with slender spreading branches, or a vine $5 \mathrm{~m}$. long or more. Leaves elliptic, oblong, ovate or ovate-lanceolate, 
2-8 $\mathrm{cm}$. long, acute, acuminate or bluntish at the apex, narrowed at the base, the midvein prominent, the lateral veins few and obscure, the slender petioles 4-12 mm. long; racemes several-many-flowered, as long as the leaves, or longer, or shorter; corolla 5-lobed nearly to the middle, yellow, 6-9 $\mathrm{mm}$. long; drupes bright white, orbicular, $5-8 \mathrm{~mm}$. broad.

Coppices, scrub-lands and pine-lands, throughout the archipelago from Abaco, Great Bahama and Andros to Mariguana, North Caicos and Inagua :-Florida; West Indies; continental tropical America. Consists of many races differing in size of corolla, shape of leaves and with calyx-teeth deltoid to deltoid-lanceolate, the anther tips either included or somewhat exserted beyond the corolla-tube. WEST INDIAN SNOWBERRY. SNAKEROOT.

2. Chiococca pinetòrum Britton; Millsp. Field Mus. Bot. 2: 171.1906.

A vine, creeping or low-climbing, sometimes $1.5 \mathrm{~m}$. long, usually shorter. Branches short; leaves ovate, lanceolate or elliptic, small, $2-4.5 \mathrm{~cm}$. long, varying from acute to obtuse at the apex, narrowed at the base, coriaceous, dark green and shining above, paler and dull beneath, the midvein impressed on the under side, the lateral veins few and obscure, the petiole slender, 2-3 $\mathrm{mm}$. long; racemes few-flowered, shorter than the leaves or about equalling them; pedicels about as long as the calyx, or sometimes a little longer; calyx campanulate $2 \mathrm{~mm}$. long; corolla funnelform-campanulate, about $5 \mathrm{~mm}$. long, white or purple changing to yellow; berry white, somewhat compressed, 4-6 $\mathrm{mm}$. in diameter.

Pine-lands and scrub-lands, Abaco, Great Bahama, Andros, New Providence. Cat Island and Watling's :-Florida. PINELAND SNow BERrY.

\section{SCOLOSÁNTHUS Vahl, Eclog. 1: 11.1796.}

Shrubs, often spiny, with opposite petioled coriaceous leaves, and small or minute, axillary, solitary or clustered, peduncled flowers. Calyx-tube short, the limb 4-cleft, the lobes narrow. Corolla small, funnelform, its 4 short spreading lobes imbricated. Stamens 4, included, the filaments filiform, the anthers linear. Ovary 2-celled; style slender, pilose;. stigma notched or 2cleft; ovules solitary in each ovary-cavity, pendulous. Fruit a small drupe. [Greek, curved flower, of no obvious application.] About 7 species, natives of the West Indies. Type species: Scolosanthus versicolor Vahl.

\section{Scolosanthus bahaménsis Britton, Bull. N. Y. Bot. Gard. 3: 452.1905.}

An intricately branched, somewhat resinous shrub, $8 \mathrm{dm}$. high or less, with gray-brown bark, the young twigs greenish, densely papillose, 4-angled, armed with slender scattered pungent solitary spines $1 \mathrm{~cm}$. long or less. Leaves opposite or fascicled, $2-5 \mathrm{~mm}$. long, thick, papillose, ovate to elliptic, revolute-margined, obtuse, very short-petioled, dark green above, paler beneath; flowers not seen; fruits solitary, oblong to globose, white, soft, $2-4 \mathrm{~mm}$. long.

Coppices and pine-lands, Andros, New Providence and Cat Island. Endemic. BAHAMA SCOLOSANTHUS.

\section{STRÚMPFIA Jacq. Enum. 8, 28. 1760.}

A low, much-branched shrub, with linear, revolute-margined, coriaceous, very short-petioled leaves verticillate in 3 's, and crowded near the ends of the short-jointed branches, the small white flowers in short axillary racemes, the small stipules persistent. Calyx ovoid, the limb 5-cleft, the lobes persistent. Corolla deeply 5-cleft, the lobes lanceolate, imbricated, the tube very short. Stamens 5, borne at the base of the corolla-tube; filaments short, slightly 
united at the base; anthers narrowly oblong, connate. Ovary 2-celled; ovules 1 in each cavity, erect, anatropous; style pubescent; stigma 2-lobed. Fruit a small fleshy drupe, containing 1 or 2 stones. Seed oblong; endosperm fleshy; embryo minute. [Named for Karl Strumpf, professor in Halle.] A monotypic West Indian genus.

\section{Strumpfia maritima Jacq. Enum. 28. 1760.}

A shrub $2 \mathrm{~m}$. high or less, the rather stout twigs densely pubescent or puberulent, scarred by the persistent stipule-bases. Leaves 1-2.5 cm. long, apiculate, pubescent when young, the margins revolute so as to meet and cover the under surface; peduncles pubescent, 2-10 $\mathrm{mm}$. long; calyx about $1 \mathrm{~mm}$. long; calyx-lobes triangular-ovate, acute; corolla pubescent, 3-4 mm. long, its short tube campanulate, its lobes much longer than the tube; drupes white or red, 3-6 $\mathrm{mm}$. in diameter.

Coastal rocks and rocky plains, throughout the archipelago from Abaco, Great Bahama and Andros to Grand Turk and Inagua :-Florida; West Indies and Cozumel. StrRU MPFia.

\section{PSYCHÒTRIA L. Syst. ed. 10, 929. 1759.}

Shrubs or trees, rarely perennial herbs, with opposite or rarely verticillate leaves, the stipules persistent or deciduous, the small flowers in terminal corymbs or panicles, rarely in axillary fascicles. Calyx short, the limb 4-5toothed. Corolla funnelform or subcampanulate, the limb 4-5-lobed, the lobes valvate. Stamens 5, borne on the corolla-tube, the filaments mostly short, the anthers linear or oblong. Ovary 2-celled; ovules 1 in each cavity, erect, anatropous; style short or elongated; stigma 2-cleft. Fruit a globose to oblong drupe containing 2 pyrenae, smooth, angled or ribbed. Seed convex; endosperm fleshy or cartilaginous. [Greek, to give life, from supposed medicinal properties.] A very large genus, containing 500 species or more, natives of tropical and subtropical America. Type species: Psychotria asiatica L., of Jamaica.

Fruit subdidymous, broader than long; pyrenae angled. Fruit ellipsoid; pyrenae furrowed.

Panicles sessile.

Panicles stalked.

1.P.pubescens.

2. P. undata.

3. P. ligustrifolia.

\section{Psychotria pubéscens Sw. Prodr. 44. 1788.}

Myrstiphyllum pubescens Hitche. Rep. Mo. Bot. Gard. 4: 95.1893.

A shrub, $3 \mathrm{~m}$. high or less, rarely a small tree $5 \mathrm{~m}$. high, the branches slender, sometimes constricted at the nodes, the twigs, leaves and inflorescence finely pubescent or puberulent, rarely glabrous. Leaves membranous, elliptic to oblong-lanceolate, $7-15 \mathrm{~cm}$. long, acuminate at the apex, narrowed at the base, prominently pinnately veined, the slender petioles 8-18 $\mathrm{mm}$. long, the subulate geminate stipules united by their broad bases; panicles peduncled, usually many-flowered; pedicels very short; calyx about $1 \mathrm{~mm}$. long, its teeth ovate; corolla yellow, whitish or pinkish, 4-5 mm. long, usually puberulent outside, pubescent in the throat, its oblong lobes shorter than the tube; drupe subglobose, black, 3-4 mm. in diameter, the pyrenae angled.

Pine-lands and coppices, Abaco, Great Bahama, Andros and New Providence :Cuba to St. Thomas; St. Kitts; Jamaica. HAIRY WILd CoFFEe. 
2. Psychotria undàta Jacq. Hort. Schoen. 3: 5. 1798.

Psychotria lanceolata Nutt. Am. Journ. Sci. I. 5: 290. 1822.

Myrstiphyllum undatum Hitch. Rep. Mo. Bot. Gard. 4: 95. 1893.

A shrub, 0.5-3 m. high, the twigs, leaves and inflorescence usually glabrous, sometimes pubescent. Leaves elliptic to oblong-elliptic, chartaceous, 6-12 cm. long, strongly pinnately veined, acuminate at the apex, narrowed at the base, bright green abov?, pale-green beneath, the slender petioles $15 \mathrm{~mm}$. long or less, the stipules connate-sheathing, deciduous; panicle sessile, severalmany-flowered; flowers sessile or very nearly so; calyx about $1 \mathrm{~mm}$. long, its limb nearly truncate; corolla white, about $4 \mathrm{~mm}$. long, its lobes shorter than the tube; drupe red, ellipsoid, blunt, 5-7 $\mathrm{mm}$. long; pyrenae grooved.

Pine-lands, scrub-lands and coppices, throughout the archipelago from Abaco, Great Bahama, the Biminis and Andros to Watling's and Long Island :-Florida and the West Indies; Central America. PP. asiatica of Schoepf. WILD Coffee.

3. Psychotria ligustrifỏlia (Northrop) Millsp. Field Mus. Bot. 2: 172. 1906.

Myrstiphyllum ligustrifolium Northrop, Mem. Torr. Club 12: 68. 1902.

Psychotria bahamensis Millsp.; Britton, Bull. N. Y. Bot. Gard. 3: 451. 1905.

A nearly glabrous shrub, rarely more than $2.5 \mathrm{~m}$. high. Leaves thin, lanceolate to oblanceolate, broadest at or above the middle, narrowed to the apex and to the petiole, slightly pilose beneath, especially along the mid-rib; stipules large, orbicular, dimidiate-sheathing, apiculate; inflorescence paniculate, peduncled, 4-chotomous, exceeded by the leaves; calyx with 5 short deltoid teeth; corolla-tube glabrous without, bearded in a ring at the insertions of the filaments within, its lobes 5, elliptic, acute, strongly deflexed, nearly as long as the tube; fruit ellipsoid, red, about $5 \mathrm{~mm}$. long; pyrenae planoconvex, grooved.

Pine-lands and scrub-lands, throughout the archipelago from Abaco, Great Bahama, the Biminis and Andros to Mariguana, North Caicos and Inagua :-Florida; Bermuda; Cuba; Hispaniola; Porto Rico. SMooth WILD CoFfer.

\section{MORÍNDA L. Sp. Pl. 176.1753.}

Shrubs, vines or trees, with opposite or verticillate leaves, and mostly perfect, white or red flowers in dense terminal or axillary capitate clusters. Calyx truncate or obscurely toothed. Corolla funnelform or salverform, its 4-7 lobes valvate. Stamens as many as the corolla-lobes, the short filaments adnate to the throat of the corolla. Ovary mostly 2-celled; styles connate; stigmas slender; ovules 1 in each cavity, ascending. Fruit a fleshy syncarp. [Latin, Indian Mulberry.] Forty species or more, of tropical distribution, the following typical.

\section{Morinda Roỳoc L. Sp. Pl. 176. 1753.}

A shrub, $3 \mathrm{~m}$. high or less, with slender straggling branches, or a vine up to $7 \mathrm{~m}$. long, glabrous or very nearly so throughout. Leaves oblong to oblongoblanceolate, thin, but somewhat fleshy, 5-10 cm. long, acute or acuminate at the apex, narrowed or cuneate at the base, darkening in drying, the petioles 5-10 mm. long, the broad persistent stipules subulate-tipped; flowers white or pinkish, in axillary, short-peduncled heads; corolla 6-8 $\mathrm{mm}$. long, its oblong lobes shorter than the tube; syncarp subglobose, 8-25 $\mathrm{mm}$. in diameter, yellow.

Coastal rocky plains, Abaco, Great Bahama, Andros and Eleutbera:-Florida; Cuba; Hispaniola; Jamaica; Bonaire; Curacao; Aruba; South Mexico to Colombia; recorded from Bermuda. Called RHubarb. Wild MulberRy. 
17. ERNÒDEA* Sw. Prodr. 29. 1788.

Glabrous, or somewhat pubescent, low shrubs, the branches erect, decumbent or trailing, with opposite, linear to lanceolate, nearly sessile leaves, the stipules connate into a sheath; flowers small, solitary and sessile in the axils. Calyx-tube short, the limb 4-6-parted, the lobes triangular to linear or subulate, persistent. Corolla white to pink, the tube nearly cylindric, the 4-6 lobes narrow, revolute, valvate. Ovary 2-celled; style slender; stigma subcapitate; ovules 1 in each ovary-cavity. Drupe fleshy, grooved, containing 2 cartilaginous, 1-seeded pyrenes. [Greek, a shoot or off-shoot.] Only the following species are known. Type species: Ernodea littoralis $\mathbf{S w}$.

Calyx-lobes nearly as long as the frult or longer.

Leaves lanceolate to elliptic, oblanceolate or oblong-lanceolate, 5-10 mm. wide.

Corolla white to pink; leaves relatively broad; plant mostly of coasts.

Corolla red to scarlet; leaves relatively narrow; plant mostly of pine-lands.

Leaves narrowly linear, 1-3 mm. wide.

Calyx-lobes much shorter than the fruit.

Leaves oblong-lanceolate, 6-8 $\mathrm{mm}$. wide.

Leaves narrowly linear to linear-oblanceolate, 1-3 $\mathrm{mm}$. wide.

Leaves bristle-tlpped; calyx-lobes half as long as the fruit.

Leaves merely mucronate; calyx-lobes one-third as long as the fruit.

1. E. littoralis.

2. E. angusta.

3. E. Cokeri.

4. E. Millspaughii.

5. E. Taylori.

6. E. Nashii.

1. Ernodea littoràlis Sw. Prodr. 29. 1788.

A glabrous or glandular-puberulent shrub, 1-16 dm. high, erect, or nearly or quite prostrate, the branches 4-angled, usually densely leafy. Leaves 3-5nerved, shining, somewhat fleshy, oblong, elliptic, linear-oblong or oblanceolate, 2-3.5 cm. long, 4-10 mm. wide; entire or glandular-serrulate; stipules 1.5-2 $\mathrm{mm}$. long; calyx-lobes linear-lanceolate, longer than the tube; corolla white or pink, its tube 1-1.5 cm. long ; fruit subglobose, yellow, 4-6 mm. in diameter, about as long as or somewhat shorter than the calyx-lobes.

Coastal rocks and sands within the influence of ocean spray, throughout the archipelago from Great Bahama, Abaco and Andros to Mariguana and Inagua :F'lorida; Cuba to Porto Rico and Anegada; St. Croix; Guadeloupe; Jamalca. Races differ in habit, pubescence, size and width of leaves. Common ERNodra.

2. Ernodea angústa Small, Bull. N. Y. Bot. Gard. 3: 438. 1905.

Similar to prostrate races of $E$. littoralis, glabrous or nearly so. Leaves linear, coriaceous, 2-4 cm. long, 1.5-6 mm. wide; calyx-lobes linear-lanceolate, acute, about one-half as long as the corolla-tube; corolla mostly pink or red to scarlet, its tube 8-10 mm. long; fruit oval, 5-6 mm. long.

Coastal pine-lands of Garden Cay, Great Bahama, Andros, New Providence:Florida. Pineland ERnodea.

\section{Frnodea Còkeri Britton; Coker in Shattuck, The Bahama Islands 264. 1905.}

Stems very slender, trailing, branched, finely pubescent, 3-9 dm. long. Leaves narrowly linear, 2-3 $\mathrm{cm}$. long, 1-3 mm. wide, acute, rough-pubescent, 1-nerved. narrowed at the base into short petioles; stipules about $2 \mathrm{~mm}$. long; fruit globose-obovoid, about $4 \mathrm{~mm}$. long; calyx-lobes subulate, 6-7 $\mathrm{mm}$. long; fruit oval, about $5 \mathrm{~mm}$. long.

Tralling on sand dunes and in scrub-lands of Abaco, Great Bahama and Andros. Endemic. COKER's ERNODEA.

* For a study of the species and races see Bulletin of the Torrey Botanical Club

35 : 203-8. 1908. 
4. Ernodea Millspaùghii Britton, Bull. Torr. Club 35: 207. 1908.

A shrub, 6-12 dm. high, the twigs and leaves glabrous. Leaves oblongcblanceolate, sharply pointed, $2-3 \mathrm{~cm}$. long, 5-8 $\mathrm{mm}$. wide, the short broad stipules cuspidate; flowering calyx obovoid, about $3 \mathrm{~mm}$. long, the triangular lobes only one-fifth to one-fourth as long as the ovary; corolla white, $1 \mathrm{~cm}$. long, its lobes about one-half as long as the tube; fruit nearly oval, $5 \mathrm{~mm}$. long, the calyx-lobes triangular-lanceolate, $1.5-2 \mathrm{~mm}$. long.

Coastal sands of Long Island, Great Ragged Island, and Grand Turk. Endemic. MillsPAUGH'S ERNODEA.

\section{כ. Ernodea Tàylori Britton, Bull. Torr. Club 35: 208. 1908.}

Spreading, with long slender branches, glabrous. Leaves narrowly linear, stiff, $1.5-2.5 \mathrm{~cm}$. long, 1.5-2 mm. wide, revolute-margined, spinulose-tipped, the stipules triangular-subulate; flowers not seen; fruit golden-yellow, oval, 5 $\mathrm{mm}$. long, the calyx-lobes narrowly linear, $2 \mathrm{~mm}$. long.

On white-lands at Tenados, Inagua. Endemic. TaYlor's Ernodea.

\section{Ernodea Náshii Britton, Bull. Torr. Club 35: 208. 1908.}

Prostrate, glabrous throughout, the branches $6 \mathrm{dm}$. long, or more, the branchlets erect or ascending, 0.5-2 $\mathrm{dm}$. high, the twigs very densely clothed with leaves. Leaves linear-oblanceolate, leathery in texture, $2-2.5 \mathrm{~cm}$. long, 2-3 mm. wide, mucronulate; flowering calyx $4.5 \mathrm{~mm}$. long, its lobes acute, 1.5 $\mathrm{mm}$. long; corolla $1.5 \mathrm{~cm}$. long, its lobes white within, brown without, about one-third as long as the tube; fruit ovoid-oval, $5 \mathrm{~mm}$. long, the persistent acute calyx-lobes $1.5 \mathrm{~mm}$. long.

White-lands at Moujean Harbor, Little Inagua and at the west end of that island. Endemic. NASH'S ERNodEA.

\section{BORRÈrIA G.' F. W. Meyer, Prim. Fl. Esseq. 79. 1818.}

Annual or perennial herbs, or shrubby plants, with opposite entire leaves, the stipules sheathing, the flowers perfect, solitary in the axils, or in axillary or terminal clusters. Calyx-tube obovoid or turbinate, its lobes persistent, sometimes accompanied by small teeth. Corolla white, pink or blue, funnelform or salverform, the lobes 4, valvate, spreading. Stamens 4, adnate to the corolla-tube, sometimes up to its throat. Disk obsolete or cushion-like. Ovary 2-celled; styles wholly or partially united; ovules solitary in each eavity, amphitropous. Fruit leathery or crustaceous, the 2 carpels opening along their inner faces. [In honor of W. Borrer, British lichenologist.] About 90 species, natives of tropical and warm regions. Type species: Borreria suaveolens Meyer.

\section{Annual herbs.}

Calyx-teeth ovate, much shorter than the tube.

Calyx-teeth subulate, nearly as long as the tube.

1. B. laevis.

Shrubs or woody perennial herbs.
Stems more or less pubescent : leaves cillate.

Stem-pubescence short, stiff.

Stem-pubescence loose, floccose.

Stems glabrous; leaves not clllate or but slightly ciliate. Leaves linear-oblong, $1.5-3 \mathrm{~mm}$. Wide ; corolla $4.5-5 \mathrm{~mm}$. long.

Leaves linear, $0.8-1.2 \mathrm{~mm}$. wide ; corolla $2.5-4 \mathrm{~mm}$. long. Calyx-lobes long-clliate; corolla $4 \mathrm{~mm}$. long.

Calyx-lobes glabrous; corolla $2.5 \mathrm{~mm}$. long or less.

Leaves firm in texture, $1-1.5 \mathrm{~cm}$. long; internodes of branches short; calyx-lobes mostly 2 or 3 .

Leaves thin in texture, $1-3 \mathrm{~cm}$. long; internodes of branches elongated; calyx-lobes 4 .

2. B. ocimoides.

3. B. thymifolia.

4. B. inaguensis.

5. B. saxicola.

6. B. Wilsonii.

7. B. bahamensis.

8. B. savannarum. 
1. Borreria laèvis (Lam.) Griseb. Fl. Br. W. I. 349. 1861.

Spermacoce laevis Lam. Tabl. Eneycl. 1: 273. 1791.

Slightly pubescent, branched, the branches spreading or ascending, 1.5-3 $\mathrm{dm}$. long, somewhat angled. Leaves oblong to elliptic-lanceolate, $2-4 \mathrm{~cm}$. long, acute or acuminate at the apex, narrowed at the base into short petioles, pinnately veined; stipular sheath subtruncate, bearing several bristles 4-6 $\mathrm{mm}$. long; flowers white, about $3 \mathrm{~mm}$. wide, capitate-clustered in the axils; calyxlobes 4, ovate, minute; fruit obovoid, about $2 \mathrm{~mm}$. long; seeds oblong, striate.

Sink-holes, pine-lands and meadows, Great Bahama and New Providence to Watling's and Inagua:-Bermuda; West Indies and continental tropical America. BurroNWEED.

2. Borreria ocimoìdes (Burm. f.) DC. Prodr. 4: 544. 1830.

Spermacoce ocimoides Burm. f. FI. Ind. 34. 1768.

Borreria parviflora G. F. W. Meyer, Prim. Fl. Esseq. 83. 1818.

Annual, $6 \mathrm{dm}$. high or less, slender, erect or sometimes diffusely "branched, glabrous, the stem and branches 4-angled. Leaves linear to oblong-elliptic, or the lower spatulate, $0.5-2.5 \mathrm{~cm}$. long, 1-8 $\mathrm{mm}$. wide, acute, short-petioled; stipular sheath with setaceous teeth 2-3 mm. long; glomerules several-manyflowered, 6-8 mm. in diameter; calyx-teeth 4, subulate, about $0.7 \mathrm{~mm}$. long; corolla white, a little shorter than the calyx-teeth, its lobes ovate; fruit ellipsoid to obovoid, pubescent, nearly $1 \mathrm{~mm}$. long.

South Caicos, Mariguana :-Florida; West Indies ; continental tropical America ; East Indies. SLENDER BORRERIA.

\section{Borreria thymifòlia Griseb. Fl. Br.W. I. 350. 1861.}

Perennial, suffrutescent; stems bushy-branched, forming clumps up to 1 $\mathrm{m}$. broad, $3.5 \mathrm{dm}$. high or less, the internodes short, the 4-angled branches loosely rather stiff-pubescent. Leaves linear, channeled, stiff, ciliate, 2-6 mm. long, sessile, the apex spinulose-apiculate; smaller leaves are commonly fascicled in the axils of the larger ones; stipular sheath ciliate; flowers few together in small terminal head's subtended by the upper leaves; calyx-lobes 2 or 3 , oblong-lanceolate, sparingly ciliate, acute; corolla white, about $3 \mathrm{~mm}$. long, its lobes deltoid-ovate.

Sandy and rocky soil, Turk's Islands. Endemic.

\section{Borreria inaguénsis Britton, sp. nov.}

Intricately branched from a stout woody root, forming clumps $4 \mathrm{dm}$. in diameter or more, about $2 \mathrm{dm}$. high, the branches very slender, 4-angled, loosely soft-pubescent, the internodes mostly longer than the leaves. Leaves linear, rather stiff, channeled, ciliolate, 1.5-3 mm. long, spinulose-tipped, often with smaller ones fascicled in their axils; flowers few or solitary at the ends of the branches subtended by the upper leaves; calyx-lobes 4, linearlanceolate, acuminate, $1 \mathrm{~mm}$. long, with minute accessary teeth; corolla white, nearly $2 \mathrm{~mm}$. long, its lobes ovate-elliptic, obtuse.

Scrub-lands, Moujean Harbor, Little Inagua (Nash \& Taylor, 2124).

\section{Borreria saxícola Britton, sp. nov.}

Shrubby, loosely branched, 3-4 dm. high, the twigs slender, glabrous, 4-sided, the internodes mostly longer than the leaves. Leaves linear-oblong, glabrous, rather firm in texture, 10-18 mm. long, 1:5-3 $\mathrm{mm}$. wide, acute or acuminate at the apex, slightly narrowed toward the base, usually with smaller ones fascicled in the axils; stipular sheath sparingly puberulent, the stipules short, acute; flowers capitate at the ends of the twigs, subtended by the upper leaves; calyx-teeth 3 or 4 , triangular-lanceolate, acuminate, glabrous, 1.5-2 $\mathrm{mm}$. long; corolla 4.5-5 mm. long, its lobes ovate, obtuse.

Loose rocky soil, South Caicos (type, Millspaugh, 9242). Endemic. 


\section{Borreria Wílsonii Britton, sp. nov.}

Perennial with a tap-root 1.5-2 dm. long, bushy-branched, about $1.5 \mathrm{dm}$. high and as broad as high, the slender quadrangular twigs glabrous or very nearly so, the internodes about as long as the leaves or somewhat longer. Leaves linear, glabrous, 4-7 $\mathrm{mm}$. long, about $1 \mathrm{~mm}$. wide, apiculate, shining, straight or somewhat curved with smaller ones fascicled in their axils; stipular sheath with a few subulate teeth; flowers few together at the ends of the twigs; calyx-lobes 4, lanceolate, acuminate, long-ciliate, $1.5 \mathrm{~mm}$. long; corolla $4 \mathrm{~mm}$. long, its lobes ovate, obtuse.

Castle Island (Wilson, 7787). Endemic.

\section{Borreria bahaménsis Britton, sp. nov.}

A low much-branched glabrous shrub, 1.5-3.5 dm. high, the internodes mostly less than $2 \mathrm{~cm}$. long. Leaves linear, rather stiff, 8-15 mm. long, mucronate, $0.5-1.5 \mathrm{~mm}$. wide, usually with smaller ones fascicled in the axils; stipular sheath few-toothed; flowers capitate at the ends of the branches, subtended by the upper leaves, the heads about $5 \mathrm{~mm}$. in diameter; calyxlobes 2 or 3 , rarely 4 ; corolla white, $2-2.5 \mathrm{~mm}$. long, its lobes ovate, acute.

Sandy and rocky soil, Cat Island, Crooked Island, Fortune Isiand, Rum Cay, Ambergris Cay and Inagua. Type from Crooked Island (Brace, 4749). Recorded by Hitchcock as B. thymocephala Griseb., and listed by Coker as Bourreria thymifolia. Endemic.

\section{Borreria savannàrum Britton, sp. nov.}

A much branched glabrous shrub 3-10 dm. high, with very slender, elongated, 4-angled branches, the internodes mostly longer than the leaves. Leaves linear-filiform, 1-3 cm. long, about $0.5 \mathrm{~mm}$. wide, thin in texture, apiculate, darkening in drying, often with smaller ones fascicled in their axils; stipular sheath with several subulate teeth; flowers capitate at the ends of the branches, the heads $3-4 \mathrm{~mm}$. in diameter, subtended by the uppermost leaves; calyx with 4 linear lobes about as long as the tube; corolla white, $2.5 \mathrm{~mm}$. long, its lobes ovate, abtuse.

Savannas, Inagua (type Nash \& Taylor, 1320) ; also on Acklin's Island and Fortune Island. Endemic.

\section{SPERMACòCE L. Sp. Pl. 102. 1753.}

Herbs, with 4-sided stems, opposite stipulate leaves, and small white flowers, in dense axillary, and terminal clusters. Calyx-tube obovoid, or obconic, its limb 4-toothed. Corolla funnelform, 4-lobed. Stamens 4, inserted on the tube of the corolla. Ovary 2-celled; ovules 1 in each cavity; style slender; stigma capitate, or slightly 2-lobed. Capsule coriaceous, didymous, of 2 carpels, one dehiscent," the other usually indehiscent. Seeds oblong, convex on the back; endosperm horny; embryo central; cotyledons foliaceous. [Greek, seed-point, from the sharp calyx-teeth surmounting the earpels.] Two or three species, natives of America. Type species: Spermacoce tenuior L.

Glabrous or nearly so ; leaves $2-6 \mathrm{~mm}$. wide. Pubescent with long halrs; leaves $8-20 \mathrm{~mm}$. wlde.
1. S. tenuior.

2. S. tetraquetra.

\section{Spermacoce tenùior L. Sp. Pl. 102. 1753.}

Glabrous or nearly so. Stems simple and erect or more or less diffusely branched from the base, the branches 1-3 dm. long; leaves linear, oblong or oblong-lanceolate, 2-5 cm. lorg, acute or acuminate at both ends, narrowed into short petioles; calyx-lobes subulate or lanceolate-subulate; corolla white, 
twice or thrice as long as the calyx-lobes, its lobes broad, rounded, the fruit about $2 \mathrm{~mm}$. long.

Waste grounds and sink-holes, throughout the archipelago from Abaco, Great Bahama and Andros to Watling's, Crooked, Inagua and Caicos Isiands :-Bermuda ; southern United States; West Indies and continental tropical America.

2. Spermacoce tetraquètra A. Rich. in Sagra, Hist. Cub. 11: 29. 1850.

Stouter and larger than $S$. tenuior, sometimes $6 \mathrm{dm}$. high, densely pubescent nearly all over with long, whitish hairs. Leaves lanceolate to oblonglanceolate, rather strongly veined, acute at the apex, narrowed or obtuse at the base, $2-8 \mathrm{~cm}$. long, $2 \mathrm{~cm}$. wide or less; calyx-lobes. lanceolate, acuminate; corolla white, about twice as long as the calyx-lobes; fruit about $2 \mathrm{~mm}$. long. Cuba.

Waste grounds, Andros, New Providence, Inagua:-Bermuda (naturalized) ;

\section{GÀIIUM L. Sp. Pl. 105. 1753.}

Herbs, with 4-angled slender stems and branches, apparently verticillate leaves, and small flowers, mostly in axillary or terminal cymes or panicles. Flowers perfect, or in some species dioecious. Calyx-tube ovoid or globose, the limb minutely toothed, or none. Corolla rotate, 4-lobed (rarely 3-lobed). Stamens 4, rarely 3; filaments short; anthers exserted. Ovary 2-celled; ovules one in each cavity. Styles 2, short; stigmas capitate. Fruit didymous, separating into 2 indehiscent carpels, or sometimes only 1 of the carpels maturing. Endosperm horny; embryo curved; cotyledons foliaceous. [Greek, milk, from the use of $G$. verum for curdling.] About 250 species, of wide distribution. The leaves are really opposite, the intervening members of the verticils being stipules. Type species: Galium Mollugo L.

\section{Galium bermudénse L. Sp. Pl. 105. 1753.}

Galium hispidulum Michx. Fl. Bor. Am. 1: 79. 1803.

Relbunium bermudense Britten, Journ. Bot. 47: 42. 1909.

Perennial, much branched, hirsute, hispid or nearly glabrous, 3-6 dm. high. Leaves in 4's, 1-nerved, oval, mucronate, rather thick, 6-20 mm. long, 3-8 $\mathrm{mm}$. wide, the margins more or less revolute in drying; flowers few, terminating the branchlets, white; pedicels $6-8 \mathrm{~mm}$. long, rather stout, becoming deflexed in fruit; fruit fleshy, minutely pubescent, about $4 \mathrm{~mm}$. broad.

Pine-lands and copplees, Abaco, Great Bahama, Andros, New Providence and Eleuthera :- Bermuda: southeastern United States. 'Plants glabrous or very pubescent. Reported by Dolley as Galium hypocarpium.

\section{Order 7. CAMPANULÀLES.}

Herbs, rarely shrubs, the corolla gamopetalous, or petals sometimes separate in Cucurbitaceae. Stamens as many as the corolla-lobes (fewer in the Cucurbitaceae); anthers united (except in Ambrosiaceae). Ovary inferior.

Flowers not in involucrate heads; juice mostiy milky.

Endosperm none; flowers regular, monoeclous or dioecious; our specles vines.

Endosperm present, fleshy ; flowers perfect, irregular. Stigma not indusiate.

Stigma indusiate.

Flowers in involucrate heads.

Fam. 1. Cucurbitaceae.

Fam. 2. Lobeliaceae.

Fam. 3. GOODENIACEAE. 
Flowers all expanded into rays (ligulate) ; juice milky. Flowers all tubular, or the outer expanded into rays; julce very rarely milky.

Stamens distinct, or nearly so.

Stamens united by their anthers into a tube around the style.
Fam. 4. Cichoriaceae.

Fam. 5. Ambrostaceat.

Fam. 6. Carduaceae.

Family 1. CUCURBITÀCEAE B. Juss.

\section{Gourd FAMILY.}

Herbaceous vines, usually with tendrils. Leaves alternate, petioled, generally palmately lobed or dissected. Flowers monœcious or diœcious. Calyx-tube adnate to the ovary, its limb usually 5-lobed, the lobes imbricated. Petals usually 5, inserted on the limb of the calyx, separate, or united into a gamopetalous corolla. Stamens mostly 3 (sometimes 1), 2 of them with 2-celled anthers, the other with a 1-celled anther; filaments short, often somewhat monadelphous. Ovary 1-3-celled; style terminal, simple, or lobed; ovules anatropous. Fruit a pepo, indehiscent, or rarely dehiscent at the summit, or bursting irregularly; or sometimes dry and membranous. Seeds usually flat; endosperm none. About 90 genera and 700 species, mainly of tropical regions.

Ovules horizontal.

Anther-sacs flexuous.

Anther-sacs straight or curved, not flexuous.

Stamens 3 ; an annular disk at the base of the style. Stamens 2 ; disk none, or obscure. Ovules ascending.

1. Momordica.

2. Melothria.

3. Anguria.

4. Cayaponia.

1. MOMÒRDICA L. Sp. Pl. 1009. 1753.

Herbaceous, climbing or prostrate vines, with simple or forked tendrils, and dioecious or monoecious mostly yellow flowers, the staminate solitary or clustered, the pistillate solitary. Staminate flowers with a 5-lobed calyx, a nearly rotate, 5-parted or 5-lobed corolla, and usually 3 stamens with short distinct filaments. Pistillate flowers with calyx and corolla like those of the staminate, a 1-celled ovary with 3-placentae, the numerous ovules horizontal, the style slender, the stigmas 3. Fruit ovoid to cylindric, 3-valved or indehiscent. [Latin, of uncertain application.] About 25 species, natives of the Old World tropics. Type species: Momordica Balsamina L.

\section{Momordica Charántia L. Sp. Pl. 1009. 1753.}

Stem slender, more or less pubescent, 1-2 m. long, with simple filiform tendrils opposite the leaves. Leaves thin, reniform or suborbicular in outline, 4-12 cm. broad, deeply pedately 5-7-lobed, glabrate or pubescent, the lobes dentate, acute or obtuse, the slender petioles 3-6 cm. long; peduncles with an ovate entire cordate bract at or below the middle; sepals oval or ovate, 3-4.5 $\mathrm{mm}$. long; corolla-segments obtuse or emarginate, $1.5-2 \mathrm{~cm}$. long, yellow; fruit ovoid or oblong, bright yellow, tubercled, 2-12 $\mathrm{cm}$. long; seeds flat, 12-16 mm. long.

Waste grounds, New Providence at Nassau :- southern United States; West Indies and continental tropical America; Old World troples. Recorded by Dolley as Momordica Balsamina L. WILD BALSAM-APPLE.

\section{MELOTHRIA L. Sp. Pl. 35. 1753.}

Slender vines, with simple or rarely bifid tendrils, thin leaves, and small, white or yellow, monoecious flowers, the staminate clustered, the pistillate often 
solitary. Calyx campanulate, 5-toothed. Corolla campanulate, deeply 5-parted. Stamens 3 in the staminate flowers, the anthers distinct or slightly united, the pistil wanting or rudimentary. Fertile flowers with 1 pistil; ovary ovoid, constricted below the corolla; placentae 3 ; ovules numerous; style short; stigmas 3, linear. Fruit small, berry-like, pulpy. [From the Greek for some vine, probably Bryonia cretica.] About 64 species, natives of warm and tropical regions. Type species: Melothria penaula L.

1. Melothria guadalupénsis (Spreng.) Cogn. in DC. Mon. Phan. 3: 580. 1881.

Bryonia guadalupensis Spreng. Syst. 3: 15. 1826.

Melothria pervaga Griseb. Fl. Br. W. I. 289. 1860.

A slender glabrous vine, sometimes $2 \mathrm{~m}$. long, climbing by filiform tendrils. Leaves various, ovate, or ovate-lanceolate in outline, $3-7 \mathrm{~cm}$. long, scabrous, repand or 3-5-lobed with the middle lobe often longer than the lateral ones, acute or acuminate at the apex, deeply cordate at the base; petioles slender, 1-4 cm. long; staminate racemes few-flowered, peduncled; peduncle of the pistillate flower 2-4 cm. long; calyx-teeth subulate, minute; corolla short-villous, about $4 \mathrm{~mm}$. broad, its lobes obtuse; pepo ovoid, 1-1.5 cm. long, red or purple.

Pine-lands and cultivated grounds, Abaco, New Provldence, Eleuthera:-West Indles and continental troplcal America. GUADALOUPE CREEPING-CUCUMBER.

\section{ANGÙRIA Jacq. Enum. 9, 31. 1760.}

Climbing vines, with slender simple tendrils, the leaves various, the polygamous flowers mostly small, clustered at the end of a long peduncle, the calyx and corolla of staminate and pistillate flowers similar. Calyx with an elongated, more or less swollen tube and a 5-cleft or 5-toothed limb. Corolla 5 -parted, rotate. Staminate flowers with 2 included stamens, the filaments short, the anther-sacs narrow. Pistillate flowers with 2 rudimentary stamens, an ovoid ovary, a slender 2-cleft style, the stigmas 2-cleft. Fruit manyseeded, ovoid or oblong. [Greek, similar to water melons.] Species 40 or 50, all American. Type species: Anguria pedata Jacq.

\section{Anguria pedàta Jacq. Enum. 31. 1760.}

Anguria Keithii Northrop, Mem. Torr. Club 12: 69. 1902.

A glabrous monoecious vine, trailing or climbing, $3 \mathrm{~m}$. long or longer, the root elongated, the stem grooved, somewhat woody below. Leaves deeply 5-7divided, reniform-orbicular in outline, usually divided into 3 short-stalked segments, the 2 lateral ones again 2-3-divided, the segments lanceolate or oblong, acute or obtuse, few-toothed or entire; peduncles slender, about as long as the leaves; staminate racemes several-flowered; pedicels 5-16 $\mathrm{mm}$. long; calyx ovoid, 5-7 mm. long, its tube ovate or lanceolate, acute, one-third to one-half as long as the tube; petals orange, $1-1.5 \mathrm{~cm}$. long; pistillate flowers solitary or in pairs; fruit ovoid, short-beaked, about $3 \mathrm{~cm}$. long.

Copplces, Conch Sound, Lisbon Creek and Mangrove Cay, Andros, Eleuthera :Cuba to Porto Rico; recorded from Panama. Referred to by Dolley as Cucumis Anguria $\mathrm{L}$.

4. CAYAPÒNIA Manso, Enum. Subst. Bras. 31. 1836.

Climbing herbaceous vines, with entire toothed lobed or palmately divided leaves, simple or divided tendrils, and rather large, monoecious or 
dioecious, mostly panicled or racemose flowers. Calyx campanulate, its limb 5-cleft. Corolla 5-parted, rotate or subcampanulate. Staminate flowers with 3 distinct stamens, the anther-saes flexuous, the rudimentary ovary 3-lobed. Pistillate flowers often with 3 rudimentary stamens; ovary 3 -celled; ovules 1 or 2 in each cavity; style 3-cleft, the 3 stigmas dilated. Fruit rather small, slightly fleshy, mastly 3-seeded. [Brazilian name.] About 60 species of trop. ical and subtropical America, one in tropical Africa. Type species: Cayaponia diff usa Manso?

Calyx 3-4 mm.long, its teeth triangular ; corolla-lobes 3-5 mm. long. 1. C. racemosa. Calyx 6-9 mm. long, its teeth lanceolate; corolla-lobes 12-15 mm. long. 2 . C. americana.

1. Cayaponia racemòsa (Sw.) Cogn. in DC. Mon. Phan. 3: 768.1881.

Bryonia racemosa Sw. Prodr. 116. 1788.

Trianospermum racemosum Griseb. Cat. Pl. Cub. 112. 1866.

A somewhat woody, often high-climbing vine, up to $7 \mathrm{~m}$. long, the stem and branches glabrous. Leaves ovate-orbicular in outline, 6-13 $\mathrm{cm}$. long, variously lobed, or the upper entire or nearly so, acute or acuminate at the apex, cordate or subreniform at the base, scabrous above, puberulent or hispidulous beneath, the rather slender petioles $2-7 \mathrm{~cm}$. long; flowers racemose or racemose-paniculate, distant; pedicels $3-6 \mathrm{~mm}$. long; calyx campanulate, 3-4 mm. long, its teeth triangular-ovate, very small; corolla about $1 \mathrm{~cm}$. broad; pepo oblong, red, 1-2 $\mathrm{cm}$. long.

Copplces and clearings, Abaco, New Providence:-Cuba to Tortola; Tobago; Trinidad and continental tropical America. RACEMOSE CAYAPONIA.

2. Cayaponia americàna (Lam.) Cogn. in DC. Mon. Phan. 3: 785. 1881.

Bryonia americana Lam. Encycl. 1: 498. 1785.

A long vine, glabrous, similar to C. racemosa, the leaves various, 3-5lobed or nearly entire, the petioles $2-7 \mathrm{~cm}$. long. Flowers few, clustered in short racemes or panicles, or sometimes solitary; pedicels $2-6 \mathrm{~mm}$. long; calyx campanulate-cylindric, 6-9 $\mathrm{mm}$. long, its teeth lanceolate, 2-4 $\mathrm{mm}$. long; corolla 2-3 $\mathrm{cm}$. broad; pepo oblong to ellipsoid, 14-18 $\mathrm{mm}$. long.

Coppice, Conch Sound, Andros :-Cuba to Tortola and St. Vincent. Recorded by Mrs. Northrop as Trianosperma racemosum. PANICLED Cayaponia.

\section{Family 2. LOBELIĀCEAE Dumort.}

\section{Lobelia FAMily.}

Herbs, or in tropical regions rarely shrubs or trees, often with milky sap which contains a narcotic-acid poison, with alternate estipulate simple entire, toothed or pinnately parted leaves, and solitary spicate racemose or paniculate flowers. Calyx-tube adnate to the ovary, its limb 5 -lobed or 5-parted, the lobes equal or unequal. Corolla gamopetalous, irregular, often bilabiate, its tube open on one side nearly or quite to the base, its limb 5-lobed; stamens 5, inserted with the corolla; filaments sometimes cohering into a tube; anthers united. Ovary 2-5-celled; style single; stigma fringed; ovules numerous, sessile, horizontal, anatropous. Fruit a 1-5-celled capsule, or a berry. Seeds numerous, with a smooth or furrowed testa. Endosperm fleshy. About 20 genera and 600 species, of wide geographic distribution 
1. LOBÈLIA L. Sp. Pl. 929. 1753.

Herbs (some tropical species shrubs), with alternate or basal leaves, and racemose spicate or paniculate, often leafy-bracted, red yellow blue or white flowers. Calyx-tube turbinate, hemispheric or ovoid, adnate to the ovary. Corolla-tube straight, oblique, or incurved, divided to the base on one side, 2-lipped in our species, the lobe on each side of the cleft erect or recurved, turned away from the other 3 which are somewhat united. Stamens free from the corolla-tube, monadelphous, at least above, 2 or all the 5 anthers with a tuft of hairs at the tips, 3 of them usually larger than the other 2, all united into a tube or ring around the style. Ovary 2-celled, the 2 placentae manyovuled; stigma 2-lobed or 2-cleft. Capsule loculicidally 2-valved. [Named after Matthias de L'Obel, 1538-1616, a Flemish botanist.] About 250 species of wide geographic distribution. Type species: Lobelia Dortmanna L.

\section{Lobelia lucayàna Britton \& Millspaugh, sp. nov.}

Annual, slender, pilose with strap-shaped hairs. Stems simple, scapiform, erect, 3-12 cm. high; basal leaves rosulate, small, 1-2 cm. long, ovate or orbicular, obtuse, attenuate to the petiole, erenate-dentate, the teeth mucronulate; cauline leaves infrequent, spatulate or oblanceolate, sessile or shortpetioled; racemes few-flowered, 2-7 cm. long; flowers long-pedicelled, the pedicels slender, much longer than the bracts; corolla blue, about $4 \mathrm{~mm}$. long, bilabiate, the tube elongate-cylindric, deeply fissured; inferior lip 3-lobed, the lobes equal; superior lip 2-lobed, the lobes lanceolate, divergent; mature capsule $3 \mathrm{~mm}$. long; seeds orbicular, biconvex, about $2.5 \mathrm{~mm}$. in diameter, dark and shining.

Type from North Caicos, in the vicinity of Kew, Wilson 7713 in herb. N. Y. Botanical Garden; shady places in rich soil, Watling's Island at the southeast end. Habitally like L. Feayana A. Gray, of southern Florida, but in our species the seeds are lenticular, dark brown and polished, while in $L$. Feayana they are oblong and tuberculate. BAHAMA LOBELIA.

\section{Family, 3. GOODENIÀCEAE Dumort.}

\section{Goodenia Family.}

Herbaceous or shrubby plants, with watery sap. Leaves alternate or sometimes opposite, without stipules, entire, toothed or rarely pinnatifid. Flowers perfect. Calyx 5-toothed, an entire border, or sometimes obsolete. Corolla 5-lobed, split on one side. Stamens 5, distinct, the anthers opening lengthwise. Ovary mostly inferior, 1-2-celled; styles usually united. Stigma surrounded with an indusium. Ovules 1 or 2 , or more in each cavity, mostly erect or ascending. Fruit dupaceous, berry-like or eapsular. Seeds usually one in each eavity; embryo straight in the axis of the fleshy endosperm. About 12 genera and over 200 species, mostly Australian.

1. SCAFvòta L. Mant. 2: 145. 1771.

Fleshy stout herbs or shrubs, with alternate or rarely opposite, mostly entire leaves, the flowers irregular, axillary, in dichotomous cymes or rarely solitary. Calyx 5-lobed, or a mere border. Corolla white or blue, its lobes winged, its tube split to the base on one side, villous within. Stamens epigynous. Ovary inferior or nearly so, 2-celled or rarely 1-celled; stigma sur- 
rounded by a ciliate indusium. Ovules 1 in each cavity, or 2 in 1-celled ovaries, erect. Berry with a fleshy exocarp and a bony or woody endocarp. [Latin, referring to the irregular flowers.] About 60 species, mostly Australian, the following typical.

1. Scaevola Plumièrii (L.) Vahl, Symb. 2: 36. 1791.

Lobelia Plumierii L. Sp. Pl. 929. 1753.

Scaevola Lobelia Murr. Syst. ed. 13, 178. 1774.

Perennial, nearly glabrous, more or less shrubby, 6-15 dm. high, much branched and straggling. Leaves alternate, obovate, $4-6 \mathrm{~cm}$. long, entire, shining, narrowed into very short winged petioles, or nearly sessile, with a tuft of silky hairs in each axil; peduncles shorter than the leaves; calyx-lobes much broader than high, rounded; corolla glabrous without, about $2.5 \mathrm{~cm}$. long, the tube shorter than the lobes, the lobes nearly linear, with broad crisped wings; stamens nearly as long as the corolla-tube, hanging through the cleft; berry oval, black, juicy, 2-seeded, 10-14 $\mathrm{mm}$. long.

Coastal rocks and sands, throughout the archipelago:-Bermuda; Florida; West Indies and Caribbean Mexico; tropical Africa. INkBbrry. Buack Soap. Cátesby, $1: p l .79$.

\section{Family 4. CICHORIÀCEAE Reichenb.}

\section{Chicory Family.}

Herbs (two Pacific Island genera trees), almost always with milky, acrid or bitter juice, alternate or basal leaves, and yellow, rarely pink, blue, purple, or white flowers in involuerate heads (anthodia). Bracts of the involucre in 1 to several series. Receptacle of the head flat or flattish, naked, scaly (paleaceous), smooth, pitted, or honeycombed. Flowers all alike (heads homogamous), perfect. Calyx-tube completely adnate to the ovary, its limb (pappus) of scales, or simple or plumose bristles, or both, or wanting. Corolla gamopetalous, with a short or long tube, and a strapshaped (ligulate) usually 5-toothed limb (ray). Anthers connate into a tube around the style, the sacs sagittate or auricled at the base, not tailed, usually appendaged at the summit, the simple pollen-grains usually 12sided. Ovary 1-celled; ovule 1, anatropous; style very slender, 2-cleft, or 2-lobed, the lobes minutely papillose. Fruit an achene. Seed erect; endosperm none; radicle narrower than the cotyledons. About 70 genera and 1,500 species, of wide geographic distribution.

Achenes truncate.

Achenes narrowed or beaked at the summit.

1. Sonchus.

2. Lactuca.

\section{SóNCHUS L. Sp. Pl. 793. 1753.}

Annual or perennial succulent herbs, with alternate, mostly auriculateclasping, entire dentate lobed or pinnatifid, prickly-margined leaves, and large or middle-sized, peduncled, corymbose or paniculate heads of yellow flowers. Involucre ovoid or campanulate, usually becoming thickened and more or less conic at the base when old, its bracts herbaceous or membranous, imbricated in several series, the outer successively smaller. Receptacle flat, naked. Rays truncate and 5-toothed at the apex. Anthers sagittate at the base. Stylebranches slender. Achenes oval, oblong, or linear, more or less flattened, 10- 
20-ribbed, somewhat narrowed at the base, truncate. Pappus of very copious soft white simple capillary bristles, usually falling away connected, sometimes with 1 or 2 stouter ones which fall separately. [The Greek name of the Sowthistle.] About 45 species, of the Old World. Type species: Sonchus oleraceus $\mathrm{L}$.

\section{Sonchus oleràceus L. Sp. Pl. 794. 1753.}

Annual, with fibrous roots; stem leafy below, nearly simple, $3-30 \mathrm{dm}$. high. Basal and lower leaves petioled, lyrate-pinnatifid, 10-25 cm. long, the terminal segment commonly large and triangular, the margins denticulate with mucronate or scarcely spiny teeth; upper leaves pinnatifid, clasping by an auricled or sagittate base; uppermost leaves often lanceolate and entire; heads several or numerous, pale yellow, 18-30 mm. broad.

Waste places and cultivated fields, Abaco, Great Bahama, the Biminis, New Providence and Eleuthera to Acklin's Island and Grand Turk:-Bermuda; the United States to continental tropical America; West Indies. Naturalized from Europe. Sow-ThistLe.

2. LACTÙCA L. Sp. Pl. 795. 1753.

Tall leafy herbs, with small panicled heads of yellow, white or blue flowers, and alternate leaves. Involucre cylindric, its bracts imbricated in several series, the outer shorter, or of 1 or 2 series of principal nearly equal inner bracts, and several rows of short outer ones. Receptacle flat, naked. Rays tuncate and 5-toothed at the summit. Anthers sagittate at the base. Style-branches mostly slender. Achenes oval, oblong or linear, fiat, 3-5-ribbed on each face, narrowed above or contracted into a narrow beak, which is somewhat expanded at the summit into a small disk bearing the copious soft capillary, white or brown pappus-bristles. [The ancient Latin name, from lac, milk, referring to the milky juice.] About 95 species, natives of the northern hemisphere. Type species: Lactuca sativa L.

\section{Lactuca intybàcea Jacq. Ic. Rar. 1: 16. pl. 162. 1786.}

Annual, glabrous; stem terete, simple and leafy below, paniculately branched and nearly leafless above, 3-10 dm. high. Leaves thin, 0.5-2 dm. long, runcinate or irregularly lobed and toothed, the lower oblanceolate or obovate, petioled, the upper lanceolate, acuminate, sessile and clasping; heads solitary or in small clusters on the branches, distant, short-peduncled; involucre narrowly eylindric, 10-12 mm. long, its outer bracts ovate or lanceolate, broadly scarious-margined, much shorter than the linear acute inner ones; rays yellow or white; achenes linear, muricate, $3 \mathrm{~mm}$. long; pappus white, plumose.

Waste places and cultivated ground, Eleuthera, Cat Island, Conception Isiand, Great Exuma, Long Island, Acklin's Island, Grand Turk, Inagua and Angullla Isles: Fiorida ; Cuba to Tortola and to Trinidad; Jamaica ; Margarita ; Curaçao ; Bonaire ; Mexico to Venezuela. WILD LeTtuce.

\section{Family 5. AMBROSIÀCEAE Reichenb.}

\section{RAGWEed FAMILY.}

Herbs, monœcious, or sometimes diœcious, many of them weeds, rarely shrubby, with alternate leaves, or the lower opposite, and small heads of greenish or white flowers subtended by an involucre of few, separate or 
united bracts, the pistillate heads sometimes larger and nut-like or bur-like. Staminate and pistillate flowers in the same, or in separate heads. Receptacle chaffy. Pistillate flowers with no corolla, or this reduced to a short tube or ring; ealyx adnate to the 1-celled ovary, its limb none, or a mere border; style 2-cleft. Staminate flowers with a funnelform tubular or obconic 4-5-lobed corolla; stamens mostly 5, separate, or their anthers merely connivent, not truly syngenesious, with short inflexed appendages; ovary rudimentary; summit of the style often hairy or penicillate. Eight genera and about 60 species, mostly natives of America.

Staminate and pistillate flowers in different heads.

Bracts of staminate involucres distinct.

Bracts of staminate involucres united.

Staminate and pistlllate flowers in the same heads.

1. Xanthium.

2. Ambrosia.

3. Iva.

\section{XANTHIUM L. Sp. Pl. 987. 1753.}

Monoecious annual branching coarse rough or spiny herbs, with alternate lobed or dentate leaves, and rather small heads of greenish discoid flowers, the staminate ones capitate-clustered at the ends of the branches, the pistillate axillary. Staminate heads with a short involucre of 1 to 3 series of distinct bracts; receptacle cylindric, chaffy; corollas tubular, 5-toothed; anthers not coherent, mucronate at the apex; filaments monadelphous; style slender, undivided. Pistillate heads of an ovoid or oblong, closed involucre, covered with hooked bristles, 1-2-beaked, 2-celled, each cavity containing one obovoid or oblong achene; corolla none; pappus none; style 2-cleft, its branches exserted. [Greek, yellow, from its yielding a yellow hair-dye.] About 25 species, of wide geographic distribution. Type species: Xanthium strumarium Linn.

1. Xanthium chinénse Mill. Gard. Dict. ed. 8, no. 4. 1768.

Xanthium longirostre Wallr. Beitr. Bot. $1^{2}$ : 237. 1844.

Hispidulous, $1 \mathrm{~m}$. high or less. Leaves broadly ovate-reniform in outline, slender-petioled, 8-15 cm. long and about as wide as long, acute or acuminate at the apex, rather thin, coarsely irregularly toothed and usually 3-5-lobed, scabrous on both sides, the base triangular-cuneate; staminate heads numerous, about $5 \mathrm{~mm}$. in diameter; fruit oblong, its body $2 \mathrm{~cm}$. long or less, 5.5-8 $\mathrm{mm}$. thick, hispidulous and glandular or sometimes glabrous; bristles rather slender, 3-4.5 mm. long, hispidulous toward the base; beaks stout, 4-6 $\mathrm{mm}$. long, somewhat incurved.

Waste places in New Providence:-Bermuda; Cuba to Tortola and Martinique; Jamaica; United States and Central America. Reported by Dolley and by Hitchcock as $X$. strumarium L. WEST INPIAN COCKLEBUR.

2. AMBRòsta L. Sp. Pl. 987. 1753.

Monoecious (rarely dioecious) branching herbs, with alternate or opposite, mostly lobed or divided leaves, and small heads of green flowers, the staminate spicate or racemose, the pistillate solitary or clustered in the upper axils. Involucre of the pistillate heads globose, ovoid or top-shaped, closed, 1-flowered, usually armed with 4-8 tubercles or spines; corolla none; stamens none; style-branches filiform; achenes ovoid or obovoid; pappus none. Involucre of the staminate heads mostly hemispheric or saucer-shaped, 5-12-lobed, open, many-flowered; receptacle nearly flat, naked, or with filiform chaff; corolla 
funnelform, 5 -toothed; anthers searcely coherent, mucronate-tipped; style undivided, penicillate at the summit. [The ancient classical name.] About 15 species, mostly natives of America. Type species: Ambrosia maritima $\mathrm{L}$.

Annual ; erect; pubescent or puberulent.

Perennial; repent; hirsute or hispid.
1. A. paniculata.

2. A. hispida.

1. Ambrosia paniculàta Michx. Fl. Bor. Am. 2: 183.1803.

Annual, pubescent or puberulent, paniculately branched, 3-12 dm. high. Leaves thin, 1-2-pinnatifid, petioled, 5-8 cm. long, the upper alternate, the lower mostly opposite, pale or canescent beneath, the lobes oblong or lanceolate, obtuse or acute; racemes of sterile heads numerous, 2-12 cm. long, the involucres hemispheric, about $3 \mathrm{~mm}$. broad, erenate; fertile heads few, obovoid or subglobose, 2-3 mm. long, short-beaked, pubescent.

Waste places at Nassau, New Providence :-Florida ; Cuba ; Hispaniola ; Jamalca ; continental tropical America. Referred by Dolley and by Hitchcock to $A$. artemisiaefolia L. SOUTHERN RAGWEED.

\section{Ambrosia híspida Pursh, Fl. Am. Sept. 743. 1814.}

Ambrosia crithmifolia DC. Prodr. 5: 525. 1836.

Perennial, hirsute or hispid; stems branched at the base, the branches diffusely spreading or ascending, 2-8 dm. long, leafy. Leaves opposite, 2-3pinnately divided, rather firm in texture, 4-12 $\mathrm{cm}$. long, short-petioled; racemes of sterile heads elongated, mostly solitary, the involucres spiny-pubescent; fertile heads clustered, $2.5-3 \mathrm{~mm}$. long, short-beaked, usually tubercled.

Sea-beaches, throughout the archipelago:-Florida; Cuba; Hispaniola; Porto Rico; Virgin Gorda to Barbadoes; Mexico. SWEet-bay. Bay Geranidm. Bay Taxsy.

\section{3. İVA L. Sp. Pl. 988. 1753.}

Puberulent or scabrous herbs or shrubs, with thick opposite leaves, or the upper alternate, and small nodding, axillary and solitary, spicate racemose or paniculate heads of greenish flowers. Involucre hemispheric or cup-shaped, its bracts few, rounded. Receptacle chaffy, the linear or spatulate chaff enveloping the flowers. Marginal flowers 1-6, pistillate, fertile, their corollas short, tubular or none. Disk-flowers perfect, sterile, their corollas funnelform, 5lobed, their styles undivided, dilated at the apex. Anthers entire at the base, yellow, scarcely coherent with each other, tipped with mucronate appendages. Achenes compressed, obovoid, glabrous. Pappus none. [Named after Ajuga Iva, from its similar odor.] About 12 species, natives of America. Type species: Iva annua $\mathrm{L}$.

Involucres about $5 \mathrm{~mm}$, broad; plant glabrous; leaves mostly alternate.

Involucres 3-4 mm. broad; plant pubescent; leaves opposite.

1. I. imbricata.

2. I. cheiranthifolia.

\section{Iva imbricàta Walt. FI. Car. 232. 1788.}

Perennial by woody roots, glabrous or nearly so throughout, fleshy; stem 3-6 dm. high, simple, or sparingly branched. Leaves all but the lowest alternate, sessile, oblong-spatulate, or lanceolate, obtusish, mucronulate, entire, or rarely serrate, obscurely 3-nerved, the larger 3-5 $\mathrm{cm}$. long, 6-10 $\mathrm{mm}$. wide; heads short peduncled or nearly sessile, the upper ones longer than their subtending leaves; involucre broadly campanulate, about $5 \mathrm{~mm}$. broad, its bracts $6-9$, somewhat imbricated in 2 series; fertile flowers 2-4, their corollas tubular, the staminate ones much more numerous.

Sea-strands, Great Bahama, Great Harbor Cay, Andros, New Providence and Inagua :-Virginia to Florida and Louisiana; Cays of northern Cuba. BEACH IVA. 
2. Iva cheiranthifòlia H.B.K. Nov. Gen. 4: 276. 1820.

A much-branched shrub, 1-2 m. high, the slender twigs, the leaves and the involucres densely and finely pubescent. Leaves opposite, narrowly oblong to oblong-lanceolate or the lower obovate, 3-9 cm. long, obtuse or acute at the apex, narrowed at the base, 3-nerved, the petioles $3-15 \mathrm{~mm}$. long, the upper ones much smaller; peduncles shorter than the involucres; heads nodding, numerous; involucre $3-4 \mathrm{~mm}$. broad, its bracts $3-5$, nearly orbicular; fertile flowers $3-5$; staminate flowers 5-8.

Waste places and scrub-lands, Great Bahama, the Berry Islands, the Biminis, Andros, New Providence and Eleuthera to Long Island :-Cuba. BusH Iva.

\section{Family 6. CARDUÀCEAE Neck.}

\section{Thistle Family.}

Herbs, rarely shrubs (some tropical forms trees), with watery or resinous (rarely milky) sap, and opposite alternate or basal estipulate leaves. Flowers perfect, pistillate, or neutral, or sometimes monoecious or dioecious, borne on a common receptacle, forming heads, subtended by an involucre of few to many bracts arranged in one or more series. Receptacle naked, or with chaffy scales subtending the flowers, smooth, or variously pitted or honeycombed. Calyx-tube completely adnate to the ovary, the limb (pappus) of bristles, awns, teeth, scales, or crownlike, or cup-like, or wanting. Corolla tubular, usually 5-lobed or 5-cleft, the lobes valvate, or that of the marginal flowers of the head expanded into a ligule (ray); when the ray-flowers are absent the head is said to be discoid; when present, radiate; the tubular flowers form the disk. Stamens usually 5 , borne on the corolla and alternate with its lobes, their anthers united into a tube (syngenesious), often appendaged at the apex, sometimes sagittate or tailed at the base; pollen-grains globose, often rough or prickly. Ovary 1-celled; ovule 1, anatropous; style of fertile flowers 2cleft; stigmas marginal; style of sterile flowers commonly undivided. Fruit an achene. Seed erect; endosperm none; embryo straight; hypocotyl inferior. About 800 genera and not less than 10,000 species, of wide geographic distribution.

Perfect flowers with regular corollas.

Stigmatic lines at the base of the stigma or below the middle.

Stigmas filiform or subulate, hispidulous.

Stigmas more or less clarate, papillose-puberulent.

Stigmatic lines extending to the tip of the stigma or to the appendages.

Anthers without elongated appendages at the tip. Anther-sacs talled at the base.

Anther-sacs not tailed at the base.

Receptacle naked.

Bracts of the involucre well imbricated. Stigmas of the perfect flowers with terminal appendages.

Stigmas of the perfect flowers with truncate, hairy or papillose tips.

Bracts of the involucre little if at all imbricated except when the broad outer overlap the inner.

Receptacle chaffy; bracts of the involucre

Anthers with elongated, cartilaginous, mostly connate appendages.

Perfect flowers, or all, with bilabiate corollas.

Tribe I. Vernonieae.

Tribe II. EUPATORIFAE.

Tribe IV. INULEaE.

Tribe III. Astereat.

Tribe VI. Helenieate.

Tribe VII. SENECIONEAD.

Tribe V. Heliantheas.

Tribe VIII. Cynareat.

Tribe IX. MUtisina. 
Tribe I. Vernonieak.

Pappus of 2 series; bracts of involucre usually not appendaged. 1. Vernonia.

Tribe II. Eupatorieae.

Pappus of scales.

Pappus of capillary bristles.

Involucre of more than 4 bracts, 5-many-flowered.

Involucre of 4 (rarely more) bracts, 4 -flowered.

2. Ageratum.

3. Eupatorium.

4. Mikania.

Tribe III. Astereae.

Ray-florets present; plants not dioecious.

Ray-florets ligular.

Ligules yellow; pappus copious, ray-achenes flattened.

Ligules white or colored (not yellow).

Involucral bracts in $3-5$ series.

Ligules long and narrow; bracts mainly herbaceous.

Ligules short and broad; bracts not herbaceous. Involucral bracts in 1-2 series.

Ligules longer than the diameter of the disk.

Ligules shorter than the diameter of the disk.

Ray-florets tubular; pappus 2-serial.

Ray-florets wanting; plants dioecious.

Tribe IV. INULEAE.

Bracts broad; plants leafy throughout.

Bracts narrow; plants leafy only at the base.

12. Pluchea.

Tribe V. Heuiantheae.

Disk-florets perfect but not fruit-producing.

Achenes not flattened.

Fruit unarmed; achenes quadrangular.

Fruit armed with hooked prickles.

Achenes markedly flattened.

Disk-florets fruit-producing.

Ray-florets persistent on the achenes.

Ray-florets not persistent on the achenes or wanting.

Pappus a mere crown or cap, or of few teeth, awns or bristles.

Achenes not compressed.

Chaff of the receptacle mere awns or bristles.

Chaff of the receptacle concave or clasping.

Pappus of slender caducous awns.

Pappus wanting.

Âchenes sharp-edged, 4-6-angled.

Achenes of the disk neither sharp-edged, margined nor winged.

Achenes acutely 4-angled.

Achenes indistinctly 4-angled.

Achenes of the disk broadiy white-winged.

Achenes markedly flattened parallel with the involucral bracts.

Involucre singie.

Involucre double.

Pappus of 2 short cornuate awns.

Pappus of 2-4 long barbed awns.

Pappus of numerous plumose cillate scales.

5. Chrysopsts.

6. Aster.

7. Gundlachia.

8. Erigeron.

9. Leptilon.

10. Eschenbachia.

11. Baccharis.

13. Sachsia.

14. Tetranthus.

15. Acanthospermum.

16. Parthenium.

17. Crassina.

18. Verbesina.

19. Melan thera.

20. Isocarpha.

21. Borrichia

22. Wedelia.

23. Ximenesia.

24. Synedrella.

25. Salmea.

26. Bidens.

27. Tridax.

Tribe VI. Henenieae.

Plant-tissues without oll glands; bracts of the involucre united below.

Plant-tissues with oil glands; bracts separate.

Involucrai bracts 2-seriate; pappus a crown.

Involucral bracts 1-seriate.

Pappus of copious capillary bristles.

Pappus of a few sharp awns.

28. Flaveria.

29. Neothymopsis.

30. Porophyllum.

31. Pectis.

32. Neurolaena.

33. Emilia.

34. Erechthites.

Bracts of the involucre markediy overlapping.

Bracts of the involucre slightly if at all overiapping. Achenes elongated, sharply 5-ribbed.

Achenes short, pilose-striate. 
Tribe VIII. CrNareaE.

Bracts of the involucre spined at the apex; leaves prickly.

35. Cirsium.

Tribe IX. Mutisieat.

Heads homogamous; achenes conic, pubescent; leafy shrubs. 36. Anastraphia. Heads heterogamous; ; chenes 5-ribbed, rostrate; herbs.

37. Chaptalia.

\section{VERNÒNIA Schreb. Gen. PI. 2: 541. 1791.}

Erect branching perennial herbs, or some tropical species shrubby, with alternate (rarely opposite), entire or toothed, sessile or petioled leaves, and discoid cymose-paniculate heads of purple, pink, or white tubular flowers. Involucre hemispheric, campanulate or oblong-cylindric, its bracts imbricated in several or many series. Receptacle flat, naked. Corolla regular, 5-cleft. Anthers sagittate at the base, not caudate. Style-branches subulate, hispidulous their whole length. Achenes 8-10-ribbed, truncate. Pappus in 2 series, the inner of numerous roughened capillary bristles, the outer of much shorter small scales or stout bristles. [Named after William Vernon, English botanist.] Over 500 species, of wide distribution in warm-temperate regions, most abundant in South America. Type species: Vernonia noveboracensis (L.) Willd.

Shrubs or perennial herbs.

Heads scorpiold, solitary in the axils of the upper leaves; canescent or tomentulose shrubs.

Leaves broadest at or near the middle, not conspicuously attenuate at the base.

Leaves broadest above the middle, attenuate at the base. Leaves broadly obcordate. Ieaves spatulate to elliptic.

Heads cymose, long-peduncled; plant nearly glabrous; leaves elongated-linear; herbaceous perennial. Annual herb; heads in terminal cymes.

1. $\nabla$. arbuscula.

2. V. obcordata.

3. V.bahamensis.

4. V. insularis. 5. V. cinerea.

1. Vernonia arbúscula Less. Linnaea 6: 664. 1831.

Vernonia arctata Gleason, Bull. Torr. Club 33: 185.1906.

A shrub, up to $8 \mathrm{dm}$. high, usually lower, more or less branched, the main branches nearly erect, the twigs tomentose, rather densely leafy. Leaves elliptic to oblong-obovate, $1-2 \mathrm{~cm}$. long, acute or mucronate at the apex, narrowed or obtuse at the base, tomentose beneath, glabrate above, the petioles $3-7 \mathrm{~mm}$. long; heads crowded at the ends of the twigs, several or numerous, sessile or short-peduncled; involucre campanulate, 4-5 mm. long, its bracts lanceolate, tomentose; achenes $2.5 \mathrm{~mm}$. long, pubescent; pappus nearly white.

Plne-lands of New Providence and Andros. Endemic. Recorded as $\nabla$. bahamensis by Coker and by Mrs. Northrop. The plant was erroneously attributed to Mauritius by Lessing. (See Ekman, West Indian Vernoniae 58). Low BUsHr VERNONIA.

2. Vernonia obcordàta Gleason, Bull. Torr. Club 33: 187. 1906.

A much-branched shrub 6-9 $\mathrm{dm}$. high, the branches crooked, the young twigs angled, tomentose. Leaves crowded near the ends of the twigs, broadly obcordate, $1.5 \mathrm{~cm}$. long or less, about as wide as long, grey-tomentose, especially beneath, narrowed into petioles about $5 \mathrm{~mm}$. long; heads few, sessile among the leaves, 8-13-flowered; involucre campanulate, 4-5 $\mathrm{mm}$. long, its bracts ovate-lanceolate, tomentose, acute; achenes hirsute, about $2 \mathrm{~mm}$. long; pappus yellow.

Rocky scrub-lands at Moujean Harbor, Little Inàgua: Endemic. INAGUA VERNONIA. 
3. Vernonia bahaménsis Griseb. Fl. Br. W. I. 352. 1861.

A shrub, 0.5-2 m. high, dichotomously branched, the twigs and leaves pale-tomentulose. Young twigs angled; leaves spatulate to elliptic, $1.5-5 \mathrm{~cm}$. long, entire, obtuse, mucronate or retuse at the apex, narrowed into slender petioles 5-10 $\mathrm{mm}$. long; heads few, sessile on the twigs among the upper leaves, 7-13-flowered; involucre campanulate, 3-4 $\mathrm{mm}$. long, its bracts ovatelanceolate, acute, tomentose, imbricated' in few series; achenes hirsute, '2-2.5 $\mathrm{mm}$. long; pappus nearly white, 4-5 mm. long.

Scrub-lands, rocky plains and whlte-lands, Crooked Island,* Fortune Island, Acklin's Isiand, Castle Island, Mariguana, Caicos Islands, Cotton Cay and Salt Cay, Turk's Islands and Inagua. Endemic. BAHAMA VERNONIA.

4. Vernonia insulàris Gleason, Bull. Torr. Club 33: 184. 1906.

Perennial by a horizontal rootstock; stem erect, glabrous, or puberulent above, $1 \mathrm{~m}$. high or less, simple or little-branched. Leaves narrowly linearoblong, 6-10 cm. long, 8-12 $\mathrm{mm}$. wide, entire, glabrous or very nearly so, acutish or obtuse and mucronate at the apex, narrowed to the sessile base; heads 4-25, cymase, the peduncles $4 \mathrm{~cm}$. long or less; involucre about $5 \mathrm{~mm}$. high, its bracts glabrous, acuminate, the outer lanceolate, the inner oblong; achenes $2 \mathrm{~mm}$. long, striate; pappus tawny, $6 \mathrm{~mm}$. long, the outer bristles minute.

Pine-lands of Great Bahama and Abaco. Endemic. Long-leaved Vernonia.

5. Vernonia cinèrea (L.) Less. Linnaea 4: 291. 1829.

Conyza cinerea L. Sp. P1. 862. 1753.

Annual, simple or little-brar.ched, erect, 3-10 dm. high, appressed-pubescent, leafy nearly to the base. Leaves flaccid, ovate to lanceolate, repand or entire, acute or obtuse, the lower petioled, 4-7 $\mathrm{cm}$. long, the upper much smaller and sessile; heads numerous, slender-peduncled, in terminal compound leafless cymes; involucre about $3.5 \mathrm{~mm}$. high, its bracts narrowly lanceolate, sharply acuminate, pubescent, the outermost minute; flowers purple; achenes pubescent; pappus white.

Waste and cultivated grounds, New Provldence and North Caicos:-Florida, West Indies and continental tropical America; Old World tropies. Hennaceous VERNONIA.

2. AGERÀTUM L. Sp. Pl. 839. 1753.

Annual or perennial herbs, or shrubs, with mostly toothed leaves, the small heads in terminal corymbs or cymes, the flowers all tubular. Involucre campanulate or subhemispheric, its narrow bracts nearly equal, imbricated in 2 or 3 series, sometimes with 1-31 smaller outer ones. Receptacle flat to conic. Corolla 5-toothed, white, blue, violet or purple. Anthers linear to oblong. Achenes 5-angled. Pappus of awned or awnless scales, distinct or connate. [Greek name of some similar plant.] About 25 species, mostly of tropical distribution. Type species: Ageratum conyzoides L.

\section{Ageratum latifỏlium Cav. Icon. 4: 33. pl 35\%. 1797.}

Ageratum muticum Griseb. Fl. Br. W. I. 356. 1861.

Loosely villous or pubescent, erect or ascending, annual, simple or branched, 1-6 dm. high. Leaves ovate, membranous, 2-5 $\mathrm{cm}$. long, crenate-dentate,

*H1tchcock's reference to the species on Cat Island is, apparently, an error, his label reads "Crooked Island." 
acute or obtuse at the apex, mostly rounded or obtuse at the base, the slender petioles 5-15 mm. long; heads several in the corymb; peduncles 5-10 $\mathrm{mm}$. long; involucre about $4 \mathrm{~mm}$. high, its bracts oblong-lanceolate, acute; flowers violet or white; pappus scales lanceolate, ciliolate, awnless or some of them bristletipped, about one-third as lorg as the achene.

Waste places and cultivated fields, Abaco, Great Bahama and Andros to Acklin's Island, Caicos and Turk's Islands and Inagua :-Cuba; Jamaica; Hispanionla ; continental tropical America. Specimens from New Providence and Harbour Island, referred by Dr. B. L. Robinson (Proc. Am. Acad. 49: 463) to Ageratum conyzoides inaequipaleaceum Hieron., do not appear to be specifically distinct from A. latifolium.

Recorded by Schoepf, Dolley, Hitchcock and Mrs. Northrop as A. conyzoides L., which it closely resembles. WiLd AgERAtum. GOAT-BUSH.

\section{EUPATÒRIUM [Tourn.] L. Sp. Pl. 836. 1753.}

Erect herbs or shrubs, with opposite or verticillate, or sometimes alternate, often punctate leaves, and, in most species, cymose-corymbose discoid heads of white, blue or purple flowers. Involucre oblong, ovoid, campanulate, or hemispheric, the bracts imbricated in 2-several series. Receptacle naked. Corolla regular, its tube slender, its limb 5-lobed or 5-toothed. Anthers obtuse and entire at the base, appendiculate at the apex. Style-branches elongated, flattened, or thickened above, stigmatic at the base. Achenes 5-angled, truncate. Pappus of numerous capillary, usually scabrous bristles arranged in 1 row. [Named for Mithridates Eupator. i. e., of a noble father.] Over 500 species, mostly of warm or tropical regions. Type species:Eupatorium cannabinum $\mathrm{L}$.

Leaves dissected into flliform segments.

Heads not secund; plants coplously pubescent.

Heads secund; plants essentially glabrous.

1. E. capillifolium.

2. E. leptophyllum.

Leaves entire or dentate.

Scales of the campanulate involucre in 1-3-series.

Plants glabrous.

Plants finely pubescent.

Scales of the cylindric involucre imbricated in several series.

Scales without densely pubescent tips; leaves entire, serrate, or crenulate.

Leaves acute or acuminate, serrate.

Leaves rounded or obtuse, entire or crenulate. Involucre 2-2.5 mm. thick; scales narrow, 3striate.

Involucre 3-4 mm: thick; scales broad, 5-striate.

Scales with densely pubescent tips; leaves coarsely crenate.

3. E. havanense.

4. E. villosum.

\section{E. odoratum.}

6. E. bahamense.

7. E. lucayanum

8. E. corymbosum.

1. Eupatorium capillifòlium (Lam.) Small, Mem. Torr. Club 5: 311. 1894.

Artemisia capillifolia Lam. Encyc. 1: 267. 1783.

Eupatorium foeniculaceum Willd. Sp. Pl. 3: 1750. 1804.

Erect, paniculately much branched, with the aspect of an Artemisia, the stem finely pubescent, 1-3 m. high. Leaves crowded, dissected into filiform segments, alternate, the lower petioled, the upper sessile; heads very numerous, about $3 \mathrm{~mm}$. high, short-peduncled, racemose-paniculate, 3-6-flowered; bracts of the involucre in about 2 series, linear, cuspidate, narrowly scarious-margined, glabrous; flowers greenish white.

Moist places, in coppices and scrub-lands, Great Bahama, Abaco, North Cat Cay, Andros, New Providence. Great Guana Cay, Eleuthera, Cat Island, Watling's Island and Fortune Island:-Bermuda; southern United States: Cuba. DoG-FENNEL.

2. Eupatorium leptophýllum DC. Prodr. 5: 176. 1836.

Erect, usually much branched above, 4-15 dm. high, similar to the preceding species, but glabrous. Leaves numerous, mostly alternate, dissected into 
filiform segments; heads numerous, $3 . \overline{-}-4.5 \mathrm{~mm}$. high, short-peduncled, in terminal secund racemes $2-10 \mathrm{~cm}$. long; bracts of the involucre in about 2 series, linear, cuspidate or aristate; flowers nearly white.

Border of marsh at Adelaide, New Providence:-South Carolina; Florida; Cuba. SMOOTH DOG-FENNEL.

3. Eupatorium havanénse H.B.K. Nov. Gen. 4: 128.1820.

\section{Eupatorium ageratifolium DC. Prodr. 5: 173.1836.}

Shrubby, branched, glabrous or nearly so, the branches spreading. Leaves opposite, ovate to ovate-lanceolate or deltoid-ovate, $2-8 \mathrm{~cm}$. long, acute or obtuse, coarsely dentate or crenate-dentate, obtuse to subcordate at the base, petioled; heads commonly numerous; involucre 10-30-flowered, 4-5 mm. high; its bracts linear to linear-spatulate; flowers white; achenes $2-3 \mathrm{~mm}$. long.

Coppices, pine-lands and scrub-lands, Abaco, Great Bahama, Andros, New Providence, Eleuthera :-Cuba; Texas and Mexico. Cat-Tongue. Havana ThoroughWORT.

\section{Eupatorium villòsum Sw. Prodr. 111. 1788.}

A branching shrub, $2 \mathrm{~m}$. high or less, the leaves and branches tomentulose. Leaves opposite, petioled, ovate, $1.5-7 \mathrm{~cm}$. long, obtuse, repand-dentate or entire; heads small, usually numerous; involucre about $3 \mathrm{~mm}$. high, 8-15flowered, its bracts oblong or linear-oblong, obtuse; flowers white or purplish; achenes 1.5-2 $\mathrm{mm}$. long.

Scrub-lands, coppices and plne-lands, Abaco, Great Bahama and Andros to Crooked Island and Atwood Cay :- Florida; Cuba; Jamaica and the Cayman Islands. VELVETY THOROUGHWORT. JACKMADA.

\section{Eupatorium odoràtum L. Syst. ed. 10, 1205. 1759.}

Eupatorium conyzoides Vahl, Symb. 3: 96.1794.

Shrubby, much branched, more or less pubescent, erect, or in thickets halfclimbing, 1-3 m. high. Leaves thin, ovate to ovate-lanceolate, 5-15 $\mathrm{cm}$. long, 3-nerved, dentate, often with large acute teeth, acuminate at the apex, usually cuneate at the base, the slender petioles 1-4 $\mathrm{cm}$. long; heads in terminal corymbs 5-10 $\mathrm{cm}$. broad, cylindric, 8-12 $\mathrm{mm}$. long; involucre-bracts imbricated in about 4 series, striate-nerved, glabrous or nearly so, shining, all obtuse, or the inner acute or acutish; flowers 10-20, white to blue; achenes rough-angled.

Rocky plains and scrub-lands from Andros, New Providence and Eleuthera southward to Cay Sal islets and the Caicos group :- southern United States; West Indies and continental tropical America. Recorded from Bermuda. BUSHY TropICAL THOROUGHWORT. TONKA-BEAN. BITTER-BUSH. Erroneously called VANILLA.

\section{Eupatorium bahaménse Northrop, Mem. Torr. Club 12: 70. 1902.}

Shrubby, branched, 1-1.6 m. high, the twigs puberulent. Leaves ovate to lanceolate, rather firm in texture, punctate, glabrous or sparingly puberulent, 2-7 cm. long, obtuse at the apex, cuneate to subtruncate at the base, entire or sparingly crenate, 3 -nerved, the petioles $2 \mathrm{~cm}$. long or less; corymbs dense, $2-5 \mathrm{~cm}$. broad, the heads sessile or short-peduncled; involucre cylindric, 8-10 $\mathrm{mm}$. high, 2-2.5 $\mathrm{mm}$. thick, its scales imbricated in 4 or 5 series, oblong to lanceolate, obtuse, 3-nerved; flowers pale blue or lavender; achenes 3-4 $\mathrm{mm}$. long, 3-5-angled, tapering to the base.

Sand-dunes, coppices and scrub-lands, Little Harbor Cay of the Berry Islands, Andros, New Providence, Eleuthera and Great Guana Cay of the Exuma Chain. Endemic. Recorded by Dolley and by Eaton and Setchell as $E$. integrifolium Bert. BAHAMA THOROUGHWORT. 


\section{Eupatorium lucayànum Britton, sp. nov.}

A much-branched shrub, 4-6 dm. high, the young branches finely puberulent. Leaves ovate, short-petioled, $4 \mathrm{~cm}$. long or less, obtuse or rounded at the apex, obtuse or subtruncate at the base, entire-margined, puberulent, at least on the veins beneath, copiously punctate, somewhat fleshy, 3-nerved, the puberulent petioles 3-7 mm. long; corymbs dense, 3-6 $\mathrm{cm}$. broad, the heads sessile on their branches; involucre oblong-cylindric, 7-9 $\mathrm{mm}$. high, 3-4 $\mathrm{mm}$. thick, its scales in 5 or 6 series, suborbicular to oblong, obtuse, puberulent, strongly 5-striate; flowers lilac or pale purple; achenes narrowly obpyramidal, about $4 \mathrm{~mm}$. long.

Rocky soil and coastal rocks, Abaco, Frozen Cay, Berry Islands, Acklin's Island, Crooked Island, Mariguana and East Caicos. Type from Mariguana (Wilson, 7425). Recorded by Dolley and by Hitchcock as Eupatorium repandum Willd.

8. Eupatorium corymbòsum Aubl. Pl. Guian. 2: 799.1775.

Eupatorium atriplicifolium Lam. Encycl. 2: 407. 1788.

Eupatorium repandum Willd. Sp. Pl. 3: 1767. 1804.

A shrub about $6 \mathrm{dm}$. high, the young shoots, petioles and branches of the inflorescence densely puberulent. Leaves firm in texture, slightly fleshy, 4.5 $\mathrm{cm}$. long or less, the blades reniform-cordate to suborbicular, rounded at the apex, mostly about as wide as long, coarsely crenate, glabrous or nearly so above, puberulent and pitted beneath with the midvein rather prominent, the lateral veins few; corymbs several, dense, 3-4 $\mathrm{cm}$. broad, the heads sessile on the short branches; involucre cylindric with a somewhat narrowed base, 6-7. $\mathrm{mm}$. high, 1.5-2 mm. thick; scales in four series, oblong to linear-oblong, strongly striate-nerved, obtuse, their tips pubescent; flowers light purple; achenes obpyramidal, 3-3.5 $\mathrm{mm}$. long; pappus brownish.

Sand-dunes, Clarence Town and Water Cay, Long Island :-Porto Rico to Tortola; Virgin Gorda; St. Crolx; Martinique; northern South America.

\section{MIKÀNIA Willd. Sp. Pl. 3: 1742. 1804.}

Herbaceous twining vines, or some tropical species shrubs, with opposite, petioled leaves, and discoid, mostly cymose-paniculate heads of white or pink flowers. Heads 4-flowered. Involucre oblong, of 4 slightly unequal narrow bracts. Receptacle small, naked. Corolla regular, its tube slender, the limb eampanulate, 5-cleft. Anthers entire and obtuse at the base. Style-branches elongated, acutish. Achenes truncate, 5-angled. Pappus of numerous capillary roughish bristles in 1 or 2 series. [In honor of J. G. Mikan, 1743-1814, professor at Prague.] About 150 species, natives of America. Type species: Mikania hastata (L.) Willd.

1. Mikania scándens (L.) Willd. Sp. Pl. 3: 1743. 1804.

Eupatorium scandens L. Sp. P1. 836. 1753.

Mikania batatifolia D.C. Prodr. 5: 197. 1836.

Mikania orinocensis H.B.K. Nov. Gen. 4: 134. 1820.

Willoughbya scandens Kuntze, Rev. Gen. Pl. 372. 1891.

Willugbaeya heterophylla Small, Fl. SE. U. S. 1170, 1338. 1903.

A vine, glabrous or nearly so, $1.5-4.5 \mathrm{~m}$. long. Leaves ovate or hastate, deeply cordate, acuminate, repand or obtusely dentate, 5-10 cm. long, 2-5 cm. wide; petioles slender, shorter than the blades; heads in compound clusters 
borne at the ends of the branches; involucre about $6 \mathrm{~mm}$. long, its bracts lanceolate, acuminate or apiculate; flowers white or pink; achenes resinous.

Marshes, Great Bahama, Andros, and New Providence :-eastern continental North America; West Indies; continental America south to Argentina. CuIMBING HEMPWEED.

\section{CHRYSÓPsIS Nutt.; Ell. Bot. S. C. \& Ga. 2: 333.1824.}

Perennial herbs, with alternate sessile entire leaves, or the basal ones dentate, and large many-flowered heads of both tubular and raciate yellow flowers (rays wanting in some western species), loosely corymbose, or solitary at the ends of the branches. Involucre campanulate to hemispheric, its bracts narrow, imbricated in several series, the outer shorter. Receptacle usually flat, foveolate. Ray-flowers pistillate. Disk-flowers mostly all perfect. Pappus double in both the disk- and ray-flowers, the inner of numerous rough capillary bristles, the outer of smaller or minute scales or bristles. Achenes flattened, oblong-linear or obovate. Style-branches narrow, somewhat flattened, their appendages linear or subulate. [Greek, golden aspect.] About 20 species, of North America and Mexico. Type species: Inula gossypina Michx.

1. Chrysopsis graminifòlia (Michx.) Ell. loc. cit. 334. 1824.

Inula graminifolia Michx. Fl. Bor. Am. 2: 122. 1803.

Slender, corymbosely branched above. Leaves 3-5-nerved, shining, the basal ones 7-30 cm. long, 4-10 $\mathrm{mm}$. wide, the upper much smaller, and the uppermost subulate and erect; heads several or numerous, about $1 \mathrm{~cm}$. broad, solitary at the ends of the branches; involucre eampanulate, its bracts glabrate; achenes linear-fusiform.

Pine-lands of Great Bahama:- southeastern United States. Grass-Leaved GOLDEN ASTER.

\section{6. ÀSTER L. Sp. Pl. 872. 1753.}

Perennial or rarely annual, mostly branching herbs, with alternate leaves, and corymbose or paniculate (rarely racemose or solitary) heads of both tubular and radiate flowers. Involucre hemispheric, campanulate or turbinate, its bracts various, imbricated in several series, the exterior usually smaller and shorter. Receptacle flat or convex, generally foveolate. Ray-flowers white, pink, purple, blue, or violet, pistillate. Disk-flowers tubular, perfect, their corollas 5-lobed, usually yellow and changing to red, brown, or purple. Anthers obtuse and entire at the base. Style-branches flattened, their appendages subulate, lanceolate or ovate, acute. Pappus-bristles slender, numerous, scabrous or denticulate, usually in 1 series, sometimes in 2 series. Achenes mostly flattened and nerved. [Greek, star.] A genus of not less than 250 species, most abundant in North America. Type species: Aster Amellus L.

Rootstocks tuberous.

Inflorescence sub-racemose or narrowly thyrsoid; leaves oblong. 1. A. lucayanus.

Inflorescence corymbose; leaves, except lower, reduced to appressed scales.

Rootstocks not tuberous ; roots of thick fibres.

Leaves all linear, fleshy.

Involucral bracts abruptly acute.

Involucral bracts gradually acuminate.
Leaves not fleshy; the basal ones oblong to oblong-lanceolate. 5 . A. Aahailis. 
1. Aster lucayànus Britton, Bull. N. Y. Bot. Gard. 4: 143.1906.

Rootstock short, tuber-like; stems erect, 5-7 dm. high. Leaves reticulateveined, entire, sessile (basal ones not seen), the lower oblanceolate, obtuse, those above the middle of the stem lanceolate to oblong-lanceolate, acuminate, 2-3.5 $\mathrm{cm}$. long, 5-8 $\mathrm{mm}$. wide, those of the inflorescence similar, smaller; heads racemose or racemose-campanulate, about $2 \mathrm{~cm}$. broad; peduncles slender, sericeous; involucre turbinate-campanulate, its bracts loose, narrowly oblonglanceolate, acuminate, sericeous, the inner 5-7 $\mathrm{mm}$. long; rays purple, $2 \mathrm{~mm}$. wide; achenes sericeous, $3 \mathrm{~mm}$. long, half as long as the whitish pappus.

Pine-lands of Great Bahama. Endemic. Pine-Land Aster.

2. Aster adnàtus Nutt. Jour. Acad. Sci. Phila. 7: 82. 1834.

Rootstock tuberous; stem 2-8 dm. high, hispidulous, branched. Leaves various, the basal ones obovate, $1.5-2.5 \mathrm{~cm}$. long, those of the stem numerous, oblong to lanceolate, 3-12 $\mathrm{mm}$. long, scabrous, sessile, those of the branches reduced to very small scales; heads few, terminating the branches; involucre 4-6 $\mathrm{mm}$. high, its linear bracts with slightly spreading green tips; rays numerous, violet, $7-10 \mathrm{~mm}$. long; achenes glabrous.

Pine-lands of Great Bahama :- southeastern United States. Scale-Leaved ASter.

3. Aster Bràcei Britton; Small, Fl. Miami 190. 1913.

Annual? Fleshy, glabrous, roots several coarse fibres; stem rather slender, often zigzag, branched above, the branches divaricately ascending; leaves all narrowly linear, thick, entire, acute, somewhat narrowed toward the clasping base, the lower ones and those of shoots $10 \mathrm{~cm}$. long or less, 3-4 mm. wide, the upper much shorter, those of the branches few, linear-subulate, very small; heads mostly solitary at the ends of the slender branches; involucre campanulate-cylindric, $3-4.5 \mathrm{~mm}$. high; bracts in 3 or 4 series, light green, linear to linear-lanceolate, abruptly acute or short-acuminate; rays pinkish, 4-5 mm. long; achenes 1-1.5 mm. long, rough on the angles.

Brackish marshes and savannas, Abaco, Great Bahama, Andros, New Providence :- Florlda ; Cuba. Recorded as A. tenuifolius by Coker. BRACE'S ASTER.

4. Aster exilis Ell. Bot. S. C. \& Ga. 2: 344.1824.

Annual, glabrous, somewhat fleshy, erect, 3-12 dm. high, usually much branched, the branches slender. Stem-leaves linear or linear-lanceolate, 2-10 $\mathrm{cm}$. long, entire, acute, sessile or nearly so, $2-5 \mathrm{~mm}$. wide, those of the branches subulate, $2-10 \mathrm{~mm}$. long, the basal ones oblong-lanceolate, petioled; heads usually many, loosely panicled; involucre 5-6 mm. high, its linear-subulate, appressed bracts imbricated in 3 or 4 series; rays several, $2-4 \mathrm{~mm}$. long, purplish or white, longer than the pappus; achenes pubescent.

Wet grounds, Andros:-southeastern United States; Cuba. Slim Aster.

5. Aster bahaménsis Britton, Bull. Torr. Club 41: 14.1914.

Stout, fibrous-rooted, slightly fleshy, glabrous, 3-20 dm. high. Lower leaves and those of sterile shoots with sheathing petioles $4-7 \mathrm{~cm}$. long, the blades oblong to linear-oblong or oblong-lanceolate, obtuse or acute, 4-8 cm. long, 5-20 mm. wide, sparingly crenate-dentate or entire, narrowed into the petiole, the midvein prominent, the lateral veins obscure; upper stem-leaves linear, entire, $6 \mathrm{~cm}$. long or less, those of the branches nearly subulate, 3-12 $\mathrm{mm}$. long; heads numerous, paniculate; involucre nearly cylindric, 6-8 $\mathrm{mm}$. high, its bracts linear, acuminate, about $0.7 \mathrm{~mm}$. wide, green with scarious margins, or the inner merely green-tipped; rays purple, 4-5 $\mathrm{mm}$. long; achenes columnar, $2.5 \mathrm{~mm}$. long, the angles roughened; pappus brownish, twice as long as the achene.

Moist grounds aind marshes, Great Bahama, Andros, Eleuthera and Cat Island :Cuba. BAHAMA Aster. 
7. GUNDIÁCHIA A. Gray, Proc. Am. Acad. 16: 100. 1880.

Somewhat viscid, leafy shrubs, with alternate entire, linear to oblanceolate leaves, and numerous small heads of both discoid and radiate white flowers in terminal thyrses or compound corymbs. Ray-flowers few, pistillate; disk-flowers somewhat more numerous, perfect. Involucre obconic, its bracts coriaceous, imbricated in 4 or 5 series, the outer much shorter than the inner. Achenes nearly terete, 5-nerved. Pappus a single series of capillary bristles. [In honor of John Gundlach, 1810-1896, traveller and naturalist.] A few species, natives of the West Indies. Type species: Gundlachia domingensis (Spreng.) A. Gray.

1. Gundlachia corymbòsa (Urban) Britton; Boldingh, Fl. Ned. West-Ind. 391. 1913.

Gundlachia domingensis corymbosa Urban, Symb. Ant. 3: 406. 1903.

Nearly glabrous, viscid above, bushy-branched, 6-12 dm. high. Leaves oblanceolate to oblong-lanceolate, $3-8 \mathrm{~cm}$. long, 5-20 mm. wide, fleshy, obtuse and rounded at the apex, or emarginate or mucronulate, narrowed at the base, short-petioled, the midvein rather prominent, the lateral veins few and obscure; corymbs dense, convex, 3-10 cm. broad; heads short-peduncled; involucre about $5 \mathrm{~mm}$. high, its bracts acute or acutish, the outer ovate, the inner linearlanceolate; rays spreading, 4-5 $\mathrm{mm}$. long.

Sand-dunes, scrub-lands, pine-lands and borders of saline marshes, Andros, Eleuthera to Acklin's, Grand Turk and Inagua:-Porto Rico; Anegada; Saba ; Barbuda ; Desirade: Montererat ; Curaçao ; Aruba. Horse-Bush. Broom-BUSH. Soldier's-BUSH.

\section{ERÍGERON L. Sp. Pl. 863. 1753.}

- Branching or scapase herbs, with alternate or basal leaves, and corymbose, paniculate or solitary, peduncled heads, of both tubular and radiate (rarely all tubular) flowers. Involucre hemispheric or campanulate, its bracts narrow, nearly equal, imbricated in but 1 or 2 series in most species. Receptacle nearly flat, usually naked. Ray-flowers usually numerous, white, violet or purple, pistillate. Disk-flowers yellow, tubular, perfect, their corollas mostly 5-lobed. Anthers obtuse and entire at the base. Style-branches more or less flattened, their appendages short, mostly rounded or obtuse. Achenes flattened, usually 2-nerved. Pappus-bristles fragile, slender, scabrous or denticulate, in 1 series, or often an additional outer shorter series. [Greek, early-old, alluding to the early hoary pappus.] A genus of some 130 species, of wide distribution. Type species: Erigeron acre $\mathrm{L}$.

\section{Erigeron quercifòlium Lam. Tabl. Encyc. 3: 258.1823.}

Perennial, pubescent; stems 1-7 dm. high, commonly branched above, erect, slender. Basal and lower leaves spatulate, oblanceolate or oblong, 4-12 $\mathrm{cm}$. long, sinuate-pinnatifid, narrowed into margined petioles, the upper oblanceolate to lanceolate, distant, smaller, mostly sessile; heads rather few; involucre about $3 \mathrm{~mm}$. high, its bracts linear, acute or acuminate; rays many, white or purplish, $3-4 \mathrm{~mm}$. long.

Moist grounds, Abaco, Great Bahama, Andros, New Providence, Eleuthera :Florida. Referred to E. tenuis T. \& G. by Dolley. Southern Fleabane. 
9. LÉPTILON Raf. Am. Month. Mag. 2: 268. 1818.

Annual or biennial herbs, with small racemose, thyrsoid or panicled heads of white flowers, the rays small, usually shorter than the diameter of the disk or none. Involucre mostly campanulate, its narrow bracts in 2 or 3 series. Receptacle naked. Ray-flowers pistillate; disk-flowers perfect, their corollas usually 4-lobed or 4-toothed, the anthers obtuse at the base; style-branches somewhat flattened, their appendages short. Achenes flattened. Pappus of numerous simple fragile bristles in 1 series. [Greek, referring to the small heads.] About 20 species, natives of America and Asia. Type species: Erigeron divaricatum Michx.

Bracts of the involucre very pubescent; plant hirsute. Plant glabrous or nearly so throughout.

1. L. linifolium. 2. L. pusillum.

1. Leptilon linifòlium (Willd.) Small, Fl. SE. U. S. 1231, 1340. 1903.

Erigeron linifolius Willd. Sp. Pl. 3: 1955. 1804.

Hirsute; stem slender, branched or simple, $7 \mathrm{dm}$. high or less. Leaves linear or linear-spatulate, $1.5-10 \mathrm{~cm}$. long, the upper entire, sessile, the lower mostly incised-serrate, and petioled; heads paniculate or subracemose, several or numerous; involucre about $5 \mathrm{~mm}$. high, its bracts linear, acuminate, pilose; achenes glabrous; pappus tawny, about 3 times as long as the achene.

Waste grounds, New Providence at Nassau:-Bermuda; southeastern United States; Cuba; Old World troples and subtropics. HAIRY HORSEWEed.

2. Ieptilon pusillum (Nutt.) Britton, Torreya 14: 198. 1914.

Erigeron pusillus Nutt. Gen. 2: 148. 1818.

Stem glabrate, 7-30 dm. high, the larger plants paniculately much branched. Leaves usually ciliate, the basal and lower spatulate, petioled, mostly entire, $2-10 \mathrm{~cm}$. long, obtuse or acutish, those of the stem linear and mainly entire; heads few or numerous, about $4 \mathrm{~mm}$. broad; involucre, $2-3 \mathrm{~mm}$. high, its bracts linear, acute, glabrate, often purplish-tipped; rays numerous, white, shorter than the pappus and mostly shorter than their tubes.

Pine-lands, cultivated grounds, sandy soil and scrub-lands, Great Bahama, Abaco and Andros to Watling's Island, North Caicos and Inagua:-Bermuda: continental eastern North America; West Indies. Formerly included in Erigeron cana. densis L., and thus recorded by previous authors. SMOOTH HORSEWEED.

\section{ESCHENBÁCHIA Moench, Meth. 573. 1794.}

Herbs, with alternate leaves, and mostly corymbose or panicled heads of tubular flowers. Involucre campanulate, several-many-flowered, its narrow bracts imbricated in 2-several series, the outermost usually much smaller than the others. Receptacle convex or flat, mostly naked. Marginal flowers pistillate with narrow or filiform, 2-3-toothed corollas; disk-flowers tubular, perfect, 5-toothed. Anthers obtuse at the base. Achenes flattened, their sides nerveless or 1-nerved. Pappus of 1 or 2 series of bristles. [Commemorates J. F. Eschenbach, German botanist.] Perhaps 50 species, of tropical and warmtemperate regions. Type species: Erigeron aegyptiacum L. 


\section{Eschenbachia lyràta (H.B.K.) Britton \& Millspaugh.}

Conyza lyrata H.B.K. Nov. Gen. 4: 70. 1820.

Perennial, erect, branched, viscid-pubescent, 4-9 dm. high, the branches ascending. Basal and lower leaves obovate, coarsely dentate, 4-8 cm. long, obtuse, narrowed into margined petioles; upper leaves much smaller than the lower, oblong to obovate, dentate or lyrate, sessile or nearly so; heads few or solitary at the ends of the branches, slender-peduncled; involucre campanulate, about $8 \mathrm{~mm}$. high, its bracts linear, acuminate.

Waste grounds, Long Island, at Clarence Town; Great Exuma, near Georgetown :-Cuba ; Mexico to Colombla. STICKY-WEed.

\section{BÁCCHARIS L. Sp. Pl. $860 . \quad 1753$.}

Dioecious shrubs; with alternate leaves, and small, paniculate or corymbose heads of tubular flowers. Involucre campanulate or oblong, its many bracts imbricated in several series, the outer shorter. Receptacle flat, naked, commonly foveolate. Corolla of the pistillate flowers slender, that of the staminate tubular, 5-lobed. Anthers obtuse and entire at the base. Style-branches narrow or subulate, those of the fertile flowers smooth, exserted, those of the sterile flowers rudimentary, tipped with an ovate pubescent appendage. Achenes more or less compressed, ribbed. Pappus of the fertile flowers copious, capillary, that of the sterile flowers short. [Named for Bacchus; originally applied to some different shrubs.] About 300 species, all American, most abundant in South America. Type species: Baccharis ivifolia L.

Leaves linear to narrowly oblanceolate, the lower often dentate. Leaves obovate to elliptic or oblanceolate.

At least the lower leaves dentate.

Leaves all entire.

1. B. angustifolia.

2. B. halimifolia.

3. B. dioica.

\section{Baccharis angustifòlia Michx. Fl. Bor. Am. 2: 125.1803.}

A branching shrub, $2.5 \mathrm{~m}$. high or less, the foliage resinous. Leaves mostly linear, sessile, 1-8 cm. long, entire, or the lower denticulate; heads numerous, glomerate in peduncled clusters, or solitary; involuere of the staminate heads campanulate, about $2.5 \mathrm{~mm}$. high, that of the pistillate ones oblong, 4-5 $\mathrm{mm}$. high, its bracts ovate to lanceolate, obtuse or acutish; achenes about $1 \mathrm{~mm}$. long; pappus white, twice as long as the involucre.

Borders of marshes, Abaco, Great Bahama, Andros, New Providence :-southeastern United States. NARROW-LEAVED GROUNDSEL-BUSH.

\section{Baccharis halimifòlia L. Sp. Pl. 860. 1753.}

A branching glabrous shrub, 1-3 dm. high, the branchlets angled, sometimes minutely scurfy. Leaves thick, those of the stem and larger branches 2-7 cm. long, 1-5 cm. wide, those of the branchlets oblanceolate, short-petioled or sessile, entire, or few-toothed toward the apex; heads in terminal peduncled clusters of 1-5, those of the sterile plant nearly globose when young, the bracts of the involucre oblong-ovate, obtuse, glutinous, appressed, the inner ones of the pistillate heads lanceolate, acute or acutish; pappus bright white, $6-8 \mathrm{~mm}$. long, much exceeding the involucre.

Borders of marshes, Great Bahama, Andros, New Providence:-Coast of the eastern and southeastern United States. The Andros specimen (Brace 5203) may represent the variety angustior DC., abundant in Cuba. GROUNDSEL-BUSH. 
3. Baccharis dioìca Vahl, Symb. 3: 98. 1794.

Baccharis Vahlii DC. Prodr. 5: 411. 1836.

Glabrous, branched, $2 \mathrm{~m}$. high or less, shrubby, somewhat glutinous, the twigs striate, densely leafy, sometimes granular. Leaves obovate or cuneateobovate, $2-4 \mathrm{~cm}$. long, 1-2 $\mathrm{cm}$. wide, obtuse or subtruncate and mucronulate at the apex, narrowed at the base into short petioles, the midvein rather prominent, the lateral venation obscure; heads clustered at the ends of the twigs; involucre 4-7 mm. high, its bracts oblong, imbricated in 4 or 5 series; pappus of the pistillate heads about as long as the corollas; achenes 10-ribbed, glabrous.

Scrub-lands and coppices, Great Bahama, Abaco, Andros, New Providence, Eleuthera, Cat Island, Inagua :-Florida; Cuba; Hispaniola ; St. Croix ; Montserrat ; Jamaica. VAHL'S GrodNdSEL-BUSH. BROOM-BUSH.

\section{PLÙCHEA Cass. Bull. Soc. Philom. 1817: 31.1817.}

Pubescent or glabrous herbs, or some tropical species shrubby, with alternate dentate leaves, and small heads of tubular flowers in terminal corymbose cymes. Involucre ovoid, eampanulate, or nearly hemispheric, its bracts appressed, herbaceous, imbricated in several series. Receptacle flat, naked. Outer flowers of the head pistillate, their corollas filiform, 3-cleft or dentate at the apex. Central flowers perfect, but mainly sterile, their corollas 5-cleft. Anthers sagittate at the base, the auricles caudate. Style of the perfect flowers 2-cleft or undivided. Achenes 4-5-angled. Pappus a single series of capillary scabrous bristles. [Named for the Abbé N. A. Pluche, of Paris.] About 35 species, widely distributed in warm and temperate regions. Type species: Conyza marilandica Michx.

Plants shrubby.

Plants herbaceous.

Perennial; leaves sessile.

Annual; leaves petioled.
1. P. odorata.

2. P. foetida.

3. P. purpurascens.

1. Pluchea odoràta (L.) Cass. Dict. Sci. Nat. 4: 3. 1826.

Conyza odorata L. Syst. ed. 10, 1213. 1759.

A densely and finely pubescent shrub, up to $3 \mathrm{~m}$. high. Leaves oblong, entire, or undulate-serrate with small blunt teeth, 8-20 cm, long, $1 . \overline{-}-5 \mathrm{~cm}$. wide, rather dark green, loosely pubescent, becoming nearly glabrous above, finely and densely pubescent and pale beneath, acute or acuminate at the apex, narrowed at the base, the petioles $1-4 \mathrm{~cm}$. long; corymbs mostly large; peduncles and involucre densely pubescent; involucre about $5 \mathrm{~mm}$. high, its bracts ovate to lanceolate, acute to acuminate; flowers creamy pink or whitish.

Rocky scrub-lands, coppices and clearings throughout the archipelago from Great Bahama and Andros to Grand Turk and Inagua:-Bermuda; Florida; West Indies; Mexico to northern South America. Bushy Fleabane. Wild Tobacco. Sour-Bush. COUGH-BUSH.

2. Pluchea foètida (L.) B.S.P. Prelim. Cat. N. Y. 28. 1888.

Baccharis foetida L. Sp. Pl. 861. 1753.

Pluchea bifrons DC. Prod. 5: 451. 1836.

Perennial; stem simple or sparingly branched at the summit, puberulent and slightly viscid, 4-9 dm. high. Leaves oblong, ovate or ovate-lanceolate, sharply denticulate, sessile, pubescent or puberulent, 5-10 $\mathrm{cm}$. long, 1-4 cm. 
wide, reticulate-veiny; clusters of heads compact, leafy-bracted; involucre 5-6 $\mathrm{mm}$. high, its bracts lanceolate, acute, viscid-puberulent.

Marshy places, Great Bahama, Andros, New Providence, Eleuthera :- southeastern United States to Texas and North Mexico; Cuba. Perennial Marsh Fleibane.

3. Pluchea purpuráscens (Sw.) DC. Prodr. 5: 452. 1836.

Conyza purpurascens Sw. Prodr. 112. 1788.

Herbaceous, annual; stems rather stout, finely pubescent at least above, simple or branched, 3-12 dm. high. Leaves ovate to ovate-lanceolate, sparingly finely pubescent or glabrate, dentate or crenate-dentate, acute or acuminate at the apex, narrowed or obtuse at the base, 5-12 $\mathrm{cm}$. long, the petioles $3 \mathrm{~cm}$. long or less, the upper ones smaller, nearly sessile; heads usually numerous; involucre 4-5 $\mathrm{mm}$. high, its bracts ovate to lanceolate, acute, pubescent; flowers pink.

Brackish swamps and borders of coppices, Great Bahama and Andros to Fortune Island and Inagua:- southeastern United States ; Bermuda; West Indies, south to Guadeloupe; Mexico and Central America. Reported by Mrs. Northrop as $P$. camphorata DC. to which it is closely related. ANNUAL MARSH Fleabane.

\section{SÁCHSIA Griseb. Cat. Pl. Cub. 150. 1866.}

Perennial scapose herbs, with tufted basal serrate leaves and loosely corymbose or panicled small heads of tubular and radiate flowers, the rays white. Involucre campanulate, its bracts imbricated in several series, acute, rigid, the outer successively smaller. Receptacle naked, flat or convex. Rayflowers fertile, with filiform 2-3-toothed corollas; disk-flowers tubular, regular, fertile, or the inner sterile. Achenes compressed, 4-5-angled; pappus a single series of capillary barbed bristles. [In honor of F. G. J. von Sachs, German plant physiologist.] Four known species of Cuba, Florida and the Bahamas. Type species: Sachsia polycephala Griseb.

\section{Sachsia bahaménsis Urban, Symb. Ant. 3: 408. 1903.}

Scape slender, erect, villous at the base, rough-glandular above, bearing 2-5 very small and distant leaves. Basal leaves several, spatulate to oblongobovate, firm in texture, $7 \mathrm{~cm}$. long or less, obtuse at the apex, narrowed at the base into short petioles, repand-dentate, minutely glandular and sparingly pubescent beneath; inflorescence loosely corymbose-paniculate; peduncles slender, mostly longer than the heads; involucre about $7 \mathrm{~mm}$. high, its bracts in about 6 series, the outer ovate to lanceolate, densely glandular, the inner narrowly linear; outer flowers in several series, their filiform corollas 3-toothed; achenes linear, striate, about $2 \mathrm{~mm}$. long; short-pilose; pappus yellowish-white, about $4 \mathrm{~mm}$. long.

Pine-lands and savannas of Great Bahama, Andros and New Providence:Florida. BAHAMA SACHSIA.

\section{TETRANTHUS Sw. Prodr. 116. 1788.}

Small prostrate herbs, with opposite petioled leaves, and very small discoid heads solitary and peduncled in the axils, usually 4-flowered, with 2 flowers fertile and 2 sterile. Bracts of the involucre 4, sometimes with 4 minute exterior ones. Receptacle naked. Corolla tubular with a somewhat campanulate 5-lobed limb. Anthers obtuse. Achenes oblong, angled or striate; pappus short, crown-like. [Greek, four-flowered.] Four known species, natives of the West Indies. Type species: Tetranthus littoralis Sw. 
1. Tetranthus bahaménsis Britton, Bull. N. Y. Bot. Gard. 5: 318. 1907.

Stems smooth, slender, creeping, 3-6 $\mathrm{cm}$. long. Leaves ovate, about $4 \mathrm{~mm}$. long and $3 \mathrm{~mm}$. wide, obtuse at the apex, rounded or subcordate at the base, glabrous on both sides, the veins very obscure, the petioles about $3 \mathrm{~mm}$. long, sparingly pilose; heads solitary, 4-flowered, on sparingly pilose peduncles, about $1 \mathrm{~cm}$. long; involucre bracts 4 , obovate, about $1.5 \mathrm{~mm}$. long, and $1 \mathrm{~mm}$. wide, 3-nerved, sparingly pilose without and slightly ciliate; corolla about 1 $\mathrm{mm}$. long, glabrous, the lobes slightly shorter than the tube; anthers large, apiculate; style glabrous, $0.5 \mathrm{~mm}$. long, its branches glandular-pilose; achenes bluntly quadrangular, glabrous, $0.5 \mathrm{~mm}$. long.

In crevices of rocks under shrubs, Great Ragged Island, Acklin's Island, Mariguana. Endemic. BaHAMa TEtranthus.

15. ACANTHOSPERMUM Schrank, Pl. Rar. Hort. Monac. pl. 53. 1819.

Annual rather coarse herbs, with pubescent foliage and erect or creeping stems, opposite broad, often leathery, toothed leaves, and radiate but inconspicuous heads, axillary to leaf-like bracts. Involucre double, an outer one of flat herbaceous bracts, and an inner one of several smaller bracts which become bur-like and fall away enclosing an achene at maturity. Receptacle concave or convex. Ray-flowers few, in 1 series, the rays very small, yellowish, concave or hooded. Disk-flowers perfect, sterile. Anthers entire at the base. Achenes broadest above the middle, slightly curved. Pappus wanting. [Greek, thorn-seed, from the prickly, bur-like fruits.] About 3 species, natives of tropical America. Type species: Acanthospermum brasilium Schrank.

\section{Acanthospérmum hùmile (Sw.) DC. Prodr. 5: 522.1836.}

Melampodium humile Sw. Prodr. 114. 1788.

Villous-pubescent, branched, erect, 3-9 dm. high. Leaves ovate, $2-4 \mathrm{~cm}$. long, very coarsely dentate, obtuse or acute at the apex, obtuse or subtruncate at the base, the broadly margined petioles 1-2 $\mathrm{cm}$. long, often coarsely toothed; heads sessile or nearly so; pistillate flowers $3-7$; inner bracts of the involucre bearing short hooked prickles and 2 rigid subulate beaks $2-3 \mathrm{~mm}$. long.

A weed in cultivated and waste grounds near Nassau, New Providence:- - southeastern United States; Cuba ; Hispaniola ; Culebrita ; St. Martln; Tobago ; Jamaica. SPINY-BUR.

\section{PARTHÈNIUM L. Sp. Pl. 988. 1753.}

Erect, mostly pubescent or canescent herbs, or shrubs, with alternate leaves, and small corymbose or paniculate heads of both tubular and radiate white or yellow flowers. Involucre broadly campanulate or hemispheric, its bracts imbricated in 2 or 3 series, obtuse, appressed, nearly equal. Receptacle convex or conic, chaffy, the chaff membranous, surrounding the disk-flowers. Ray-flowers about 5, pistillate, fertile, their ligules s̀ort, broad, 2-toothed or obcordate. Disk-flowers perfect, sterile, their corollas 5-toothed, the style undivided. Anthers entire at the base. Acheres compressed, keeled on the inner face, margined, bearing the persistent rays on the summit. Pappus of 2-3 scales or awns. [Greek, virgin.] About 10 American species. Type species: Parthenium Hysterophorus L. 
1. Parthenium Hysteróphorus L. Sp. Pl. 988. 1753.

Annual, strigose-pubescent or somewhat villous, usually much branched, 3-7 dm. high. Leaves ovate to oblong in outline, 1-2-pinnately parted into linear or lanceolate, toothed or pinnatifid segments, thin, and flaccid; heads numerous, 5-6 mm. broad; involucre saucer-shaped, its bracts concave, the outer ones rhombic, the inner broader; ray-flowers few; rays reniform, white, about $1 \mathrm{~mm}$. wide; achenes obovate, about $1 \mathrm{~mm}$. long.

Waste places and pine-lands, Andros, New Providence, Eleuthera to Watling's Island, Long Island and Inagua :-Bermuda; United States to continental tropical America; West Indies. SANTA MARIA.

\section{CRAssina Scepin, Acido Veg. 42. 1758.}

[ZinnIA L. Syst. ed. 10, 1221. 1759.]

Annual or perennial herbs, some species shrubby, with opposite entire, or sparingly serrate, mostly narrow and sessile leaves, and large or middle-sizedheads of both tubular and radiate flowers. Ray-flowers pistillate, yellow or variegated, persistent on the achene. Disk-flowers perfect, fertile; corolla cylindraceous, its lobes villous. Involucre campanulate to nearly cylindric, its bracts obtuse, dry, firm, appressed, imbricated in 3 series or more, the outer gradually shorter. Receptacle conic or cylindris, chaffy, the chaff subtending and enwrapping the disk-flowers. Style-branches elongated, not appendaged. Achenes of the ray-flowers somewhat 3 -angled, those of the disk flattened. Pappus of few awns or teeth. [In honor of Paul Crassus, an Italian botanist of the 16th century.] About 12 species, natives of western America. Type species: Chrysogonum peruvianum $\mathbf{L}$.

1. Crassina multiflòra (L.) Kuntze, Rev. Gen. 331. 1891.

Zinnia multiflora L. Sp. Pl. ed. 2, 1269. 1763.

Annual, erect, simple or branched, 1-6 dm. high, the branches nearly erect, sparingly hispid. Leaves lanceolate, rough-hispid, thin, entire, $2-7 \mathrm{~cm}$. long, acute or acuminate at the apex, rounded at the nearly sessile base; peduncles thickened upward, 1-6 cm. long; involucre campanulate, about $1.5 \mathrm{~cm}$. high, its bracts oblong, dark-margined above; rays obovate, $1-2 \mathrm{~cm}$. long; receptaclescales obtuse, entire; disk-achenes 1-awned.

Bahamas, collected by Swainson:-Cuba to Porto Rico and Guadeloupe; Mexico to Brazil and Peru. ZinNia.

\section{VERBESINA. L. Sp. Pl. 901.1753.}

Erect or diffuse, branching, pubescent or hirsute herbs, with opposite leaves, and small peduncled terminal and axillary heads of tubular and radiate whitish flowers. Involucre hemispheric or broadly campanulate, its bracts imbricated in about 2 series, nearly equal, or the outer longer. Receptacle flat or convex, chaffy, the chaff awn-like, subtending the achenes. Ray-flowers pistillate, fertile. Disk-flowers perfect, mostly fertile, their corollas tubular, 4-toothed or rarely 5-toothed. Anthers entire or minutely 2-toothed at the base. Achenes thick, those of the rays 3-sided, those of the disk compressed. Pappus none, or of a few short teeth. [Name changed from Verbena.] About 4 species, the following typical. 
1. Verbesina álba L. Sp. Pl. 902.1753.

Eclipta erecta L. Mant. 2: 286. 1771.

Eclipta alba Hassk. Pl. Jav. Rav. 528. 1848.

Annual, appressed-pubescent, erect or diffuse, 1.5-9 dm. high. Leaves lanceolate, oblong-lanceolate or linear-lanceolate, acute or acuminate, denticulate or entire, narrowed to a sessile base, or the lower petioled, $2-12 \mathrm{~cm}$. fong, 4-20 mm. wide; heads commonly numerous, 6-12 $\mathrm{mm}$. broad, nearly sessile, or slender-peduncled; rays short, nearly white; anthers brown.

Wet or moist soll, New Providence, Great Exuma and Long Island:-Bermuda ; the United States from New York, Illinois and Nebraska, southward to temperate South America; West Indies; all warm temperate and tropical regions. EcLIPTA.

\section{MELANTHËA Rohr, Skrift. Nat. Selsk. 2: 213.1792.}

Perennial herbs, often quite woody, with opposite petioled dentate, sometimes hastate leaves, and peduncled heads of small white yellowish or violet tubular flowers. Involucre low-hemispheric, its few ovate to lanceolate, nearly equal bracts imbricated in ' 2 or 3 series. Receptacle convex or low-conic, scaly. Corollas subcylindric, with an expanded throat, 5-toothed. Anthers sometimes black, truncate or subsagittate at the base. Style-branches long. Achenes 4-angled; pappus of distinct caducous awns. [Greek, black anther.] About 10 species, of tropical and subtropical America. Type species: Bidens nivea L.

1. Melanthera deltoìdea Michx. Fl. Bor. Am. 2: 107. 1803.

Melanthera brevifolia O. E. Schulz, in Urban, Symb. Ant. 7: 123. 1911. Melanthera crenata O. E. Schulz, loc. cit. 1911.

Sparingly appressed-pubescent, scabrate, branched, 5-8 dm. high, the branches ascending. Leaves ovate or hastate-ovate, scabrate, $2-7 \mathrm{~cm}$. long, serrate, incised or crenate, acute, obtúse or acuminate at the apex, narrowed or subtruncate at the base, the petioles $0.5-3 \mathrm{~cm}$. long; heads slender-peduncled, solitary or few together, 6-8 $\mathrm{mm}$. in diameter; bracts of the involucre ovate or oblong-ovate, $3-4.5 \mathrm{~mm}$. long, obtuse or acutish; corolla white, 5-6 mm. long.

Waste and cultivated grounds, throughout the archipelago from Abaco, Great Bahama and Andros to Watling's, Fortune Island and the Cay Sal bank:-Florida; Cuba ; Jamaica. Referred by Schcepf to Bidens nivea L., by Mrs. Northrop to A mellus aspera (Jacq.) Kuntze. Recorded by Hitchcock as Eleutheranthera ruderalis. Consists of several races differing in leaf-form and serration. MELANTHera.

2. Melanthera hastàta (Walt.) Michx. Fl. Bor. Am. 2: 107. 1803.

Athanasia hastata Walt. E1. Car. 201. 1788.

Similar to $M$. deltoidea, but with acute or acuminate involucre-bracts, the fruiting heads about $10 \mathrm{~mm}$. in diameter, the leaves often more deeply incised or lobed.

Water Cay, Cay Sal Bank:-southeastern United States; Cuba; Mexico to Panama. Hastate Melanthera.

\section{ISOCÁRPHA R. Br. Trans. Linn. Soc. 12: 110. 1817.}

Branched slender herbs, with alternate or opposite, entire or toothed leaves, and many-flowered, small heads of tubular white, perfect and fertile flowers, solitary or clustered at the end of the branches. Involucre-bracts imbricated in 2-4 series, slightly unequal. Receptacle oblong or conic, chaffy, 
the chaff enveloping the flowers. Corollas regular, the limb 5-lobed. Anthers truncate, entire. Achenes glabrous, truncate, angled; pappus none. [Greek, equal chaff.] About 5 species, of tropical America, the following typical.

1. Isocarpha oppositifòlia (L.) R. Br.; DC. Prodr. 5: 107. 1836.

Calea oppositifolia L. Sp. Pl. ed. 2, 1179. 1763.

Isocarpha angustata Griseb. Fl. Br. W. I. 376. 1861.

Perennial, usually pubescent, stem rather stiff, divaricately branched, 3-6 $\mathrm{dm}$. high. Leaves opposite, sessile or nearly so, linear to lanceolate, 3-nerved, entire, acutish or obtuse at the apex, narrowed at the base; heads solitary or few together at the ends of slender naked peduncle-like branches; involucre 4-5 mm. high, its bracts oblong, strongly striate, acute and mucronate.

White-lands and rocky places, Andros, Great Guana Cay, Great Exuma, Long Island, Great Ragged Island and Atwood Cay :- Cuba; Jamaica ; Tobago; Trinidad; Curaça; Margarita; Texas through Mexico to Venezuela. Boston CatNeP.

\section{BORRICHIA Adans. Fam. Pl. 2: 130.1763.}

Fleshy, more or less canescent, branching shrubs of the seacoast, with opposite, entire or denticulate, cuneate oblong spatulate or obovate, 1-3-nerved leaves, and terminal large long-peduncled heads of both tubular and radiate yellow flowers. Involucre hemispheric, its bracts slightly unequal, imbricated in 2 or 3 series, the inner ones coriaceous. Receptacle convex, chaffy, the chaff rigid, concave, subtending or enwrapping the disk-flowers. Ray-flowers pistillate, fertile. Disk-flowers perfect, the corolla tubular, 5-toothed, the stylebranches elongated, hispid. Achenes of the ray-flowers 3-sided, those of the diskflowers 4-sided. Pappus a short dentate crown. [Named for Olaf Borrick, a Danish botanist.] About 5 species, natives of America. Type species: Buphthalmum frutescens $\mathrm{L}$.

1. Borrichia arboréscens (L.) DC. Prodr. 5: 489. 1836.

Buphthalmum arborescens L. Syst. ed. 10, 1227. 1759.

Borrichia argentea DC. Prodr. 5: 489. 1836.

Borrichia glabrata Small, Fl. SE. U. S. 1263, 1340. 1903.

A branching shrub, $1.3 \mathrm{~m}$. high or less, densely white silky-canescent, or green and glabrous. Leaves fleshy, oblanceolate to spatulate, entire, $6 \mathrm{~cm}$. long or less, $6-15 \mathrm{~mm}$. wide, acute or obtuse and cuspidate at the apex, narrowed to the base, sessile, obscurely veined; heads mostly solitary, rarely 2 together; peduncle '2-5 cm. long; involucre 1-1.5 cm. high, its bracts obtuse, or acute, appressed; rays few, $6-9 \mathrm{~mm}$. long.

Coastal rocks and sands and margins of brackish ponds throughout the archipelago:- Florida; Bermuda ; Jamaica; Cuba to Anegada and Guadeloupe; Yucatan. Foliage either white-canescent or green and glabrous, sometimes on the same plant. Bay Marigold. Sea Ox-eye. Sea-busi. Catesby, 1: pl. 93.

\section{WEDÈLIA Jaeq. Enum. 8, 28. 1760.}

Herbs or shrubs, with opposite, toothed or entire leaves, and peduncled heads of both radiate and discoid yellow flowers. Involucre ovoid to hemispheric, its bracts in about 2 series, the outer somewhat foliaceous. Receptacle flat or convex, its scales enveloping the disk-flowers. Ray-flowers pistillate. Disk-flowers perfect, their corollas tubular with a cylindric to campanulate limb. Achenes oblong to obovate, smooth, pilose or tubercled, truncate or conic 
at the top; pappus cup-like, toothed or divided, or obsolete. [Commemorates George Wolfgang Wedel, 1645-1721, Professor at Jena.] About 50 species, of warm-temperate and tropical regions. Type species: Wedelia fruticosa Jacq.

Herbaceous, prostrate with erect branches, nearly glabrous, some-

what fleshy.

Erect, shrubby, strigose-hairy.

1. W. trilobata.

2. W. bahamensis.

1. Wedelia trilobàta (L.) Hitchc. Rep. Mo. Bot. Gard. 4: 99. 1893.

Silphium trilobatum I. Syst. ed. 10, 1233. 1759.

Wedelia carnosa L. C. Rich. in Pers. Syn. 2: 490. 1807.

Stemmodontia trilobata Small, Fl. SE. U. S. 1262, 1340. 1903.

Herbaceous, prostrate or with ascending branches, sparingly strigosepubescent, often rooting at the nodes, 3-10 dm. long. Leaves somewhat fleshy, elliptic to obovate, $2-12 \mathrm{~cm}$. long, obtuse or acute at the apex, dentate, often several-lobed, narrowed or cuneate at the base, triplinerved and pinnately veined, sessile or nearly so; peduncles solitary in the upper axils, 2-14 $\mathrm{cm}$. long; involucre 7-12 mm. long, its bracts oblong-obovate, foliaceous; rays about 10, bright yellow, 10-15 $\mathrm{mm}$. long; achenes $5 \mathrm{~mm}$. long, tuberculate.

Moist places along the coast, New Providence:-Florida; West Indies; Honduras to Colombia. Trailing Wedelia.

2. Wedelia bahaménsis (Britton) O. E. Schulz, in Urban, Symb. Ant. 7: 106. 1911.

Stemmodontia bahamensis Britton, Bull. N. Y. Bot. Gard 4: 126.1905.

Perennial, erect, densely strigose-pubescent all over, pale green, 6-10 dm. tall, the branches striate. Leaves lanceolate to ovate, $5-12 \mathrm{~cm}$. long, $1.5-3 \mathrm{~cm}$. wide, acute to long-acuminate at the apex, narrowed at the base, rather firm in texture, sparingly low-serrate or entire, 3-nerved above the base, the short stoutish petioles mostly not orer $1 \mathrm{~cm}$. long; heads solitary or 2 or 3 together, on erect peduncles 2 or $3 \mathrm{~cm}$. long; outer bracts of the involucre oblong to ovate-oblong, apiculate or acutish, about $9 \mathrm{~mm}$. long, faintly many-nerved, a little longer than the inner; rays bright yellow, oblong, $1 \mathrm{~cm}$. long or less, emarginate, about 3 times as long as wide; achenes linear, appressed-pubescent, at least $3.5 \mathrm{~mm}$. long.

Coastal thickets, coppices and scrub-lands, Andros, New Providence and Eleuthera to Caicos and Grand Turk. Endemic. Recorded by Grisebach, Dolley and Hitchcock as $W$. buphthalmoides Griseb. BAHAMA WEDhlia. RONG-BUSH. Erroneously called Marigold. Catesby, 1: pl. 92.

\section{XIMENĖSIA Cav. Icon. 2: 60. 1793.}

Pubescent caulescent herbs, with alternate or sometimes opposite, simple, toothed or somewhat laciniate leaves, and solitary or few, radiate showy peduncled heads. Involucre rather flat, of narrow spreading bracts. Receptacle convex, chaffy. Ray-flowers pistillate, fertile, numerous, the rays yellow. Disk-flowers numerous, perfect, fertile. Anthers somewhat sagittate at the base. Style-branches with slender pubescent appendages. Achenes flat, winged. Pappus of short and straight awns. [In honor of Joseph Ximenes, a Spanish botanist.] About 4 species, natives of America, the following typical. 
1. Ximenesia encelioìdes Cav. Icon. 2: 60. 1793.

Verbesina encelioidés Benth. \& Hook.; A. Gray, Bot. Cal. 1: 350.1876.

Annual; stem densely puberulent, much branched, 3-6 dm. high. Leaves deltoid-ovate or deltoid-lanceolate, thin, 5-10 cm. long, acuminate, acute or blunt at the apex, coarsely dentate, or even laciniate, green and minutely pubescent above, pale and densely canescent beneath, all alternate, or the lowest opposite, narrowed at the base into naked or wing-margined petioles, which are often provided with dilated appendages at the base; heads several or numerous, $2.5-5 \mathrm{~cm}$. broad; involucre hemispheric, about $12 \mathrm{~mm}$. high, its bracts lanceolate, canescent; rays 12-15, bright golden yellow, 3-toothed; achenes of the disk-flowers obovate, winged, pubescent, their pappus of 2 subulate awns, those of the ray-flowers rugose, thickened, often wingless.

Waste grounds, Eleuthera, Fortune Island, Great Ragged Island:- southwestern United States and Mexico; introduced into Key West (Florida), Cuba and Porto Rico. GOLDEN CrowNBEARD.

\section{SYNEDRÉLLA Gaertn. Fr. et Sem. 2: 456. 1791.}

Annual pubescent herbs, with opposite dentate petioled leaves, and small, solitary or glomerate, axillary or terminal heads of radiate and discoid flowers. Involucre oblong, of few bracts, the outer 1 or 2 foliaceous, the inner paleaceous. Receptacle small, the scarious narrow chaff subtending the diskflowers. Ray-flowers pistillate, with a filiform tube and a short 2-3-toothed limb; disk-flowers perfect, the corolla tubular, 4-cleft. Ray-achenes compressed, 2-winged, the wings produced into awns, those of the disk-flowers narrower, 2-3-aristate. [Greek, referring to the clustered flower-heads.] Two known species, natives of tropical America, the following typical.

1. Synedrella nodiflòra (L.) Gaertn. Fr. \& Sem. 2: 456. 1791.

Verbesina nodiflora L. Cent. Pl. 1: 28. 1755.

Ucacou nodiflorum Hitche. Rep. Mo. Bot. Gard. 4: 100. 1893.

Stem appressed-pubescent above, glabrate below, rather widely branched, 3-8 dm. high. Leaves thin, ovate to elliptic, 3-10 $\mathrm{cm}$. long, triplinerved, lowserrate, acute at the apex, narrowed at the base into short margined petioles, loosely appressed-pubescent above, rather densely appressed-pubescent beneath; heads few or several, together in nearly sessile, axillary or terminal clusters; involucre about $8 \mathrm{~mm}$. high, its 1 or 2 outer bracts pubescent, oblong-lanceolate, the inner narrower, glabrous; achenes 4-5 mm. long, those of the rayflowers with ascending marginal bristles and 2 short awns, those of the diskflowers with 2 subulate awns.

Waste places, Abaco, New Providence and Crooked Island:-Florida; West Indies and continental tropical America. NODEWEED.

25. SÀLMEA DC. Cat. Hort. Monsp. 140. 1813.

Shrubs or woody vines, the branches terete or nearly so, the leaves opposite and petioled. Heads small, corymbose, discoid. Involucre campanulate or turbinate, its bracts appressed, imbricated in few series. Receptacle conic, its scales enveloping the flowers. Flowers white, all perfect and fertile; corollas with a narrowly campanulate or funnelform limb. Achenes laterally compressed, mostly margined or narrowly winged. Pappus of 2 awns. [In honor of Count Salm-Salm, patron of Palermo.] About 7 species, of Mexico and the West Indies. Type species: Salmea Eupatoria DC. 
1. Salmea petrobioìdes Griseb. Fl. Br. W. I. 375. 1861.

A much-branched shrub, $2 \mathrm{~m}$. high or less, the twigs slender, erect-ascending, glabrous. Leaves obovate or elliptic-obovate, ${ }^{-12}-5 \mathrm{~cm}$. long, $8-25 \mathrm{~mm}$. wide, rounded or apiculate at the apex, narrowed or cuneate at the base, fleshy, the midvein prominent, the lateral veins obscure, the petioles $1.5-3 \mathrm{~mm}$. long; heads numerous, in terminal compound, nearly flat-topped corymbs; involucre glutinous, narrowly campanulate, about $4 \mathrm{~mm}$. high, its bracts in 2 series, oblong to oval, obtuse, the outer much smaller than the inner; receptacle acute; achenes oblong, glabrous except at the apex.

Coastal rocks, white-lands, sand-dunes and coppices, throughout the archipelago from Abaco, Great Bahama and the Bimlnis to Cat Island, Long Island and Grand Caicos :-Cuban Cays ; Cayman Islands. Bushy Salmea. Shanks. Catesby, 1: pl. 72.

\section{BİDENS L. Sp. Pl. 831. 1753.}

Annual or perennial herbs, with opposite serrate lobed divided or dissected leaves, or the uppermost alternate, and mostly large heads of both tubular and radiate flowers, or the rays none, or rudimentary. Involucre campanulate or hemispheric, its bracts in 2 series, distinct or slightly united at the base; the outer often foliaceous and much larger than the inner. Receptacle flat or nearly so, chaffy, the chaff subtending the disk-flowers. Rays, when present, neutral, mostly entire, yellow in our species. Disk-flowers perfect, fertile, their corollas tubular, 5-toothed. Anthers entire, or minutely sagittate at the base. Style-branches with short or subulate tips. Achenes flat, quadrangular or nearly terete, cuneate, oblong, or linear. Pappus of $2-6$ teeth or subulate awns, upwardly or downwardly barbed or hispid. [Latin, twotoothed, referring to the achenes.] About 75 species of wide geographic distribution. Type species: Bidens tripartitus $\mathrm{L}$.

Achenes 4-awned; rays yellow, small; leaves pinnatisect.

Achenes 2-awned; rays white or none; leaves 3-5 pinnately divided.

1. B. cynapiifolia.

2. B. pilosa.

\section{Bidens cynapiifòlia H.B.K. Nov. Gen. 4: 235. 1820.}

Annual; stem quadrangular, erect, branched, 0.2-2 m. high. Leaves thin, petioled, 1-3-pinnately dissected into ovate or oblong, toothed or lobed segments; heads usually numerous, long-peduncled, 4-8 $\mathrm{mm}$. broad; involucre narrow, its outer bracts linear, ascending, nearly as long as the broader erect inner ones; rays 3-4, yellow, short, sometimes none; achenes curved, linear, 4-angled, narrowed upward, 7-17 $\mathrm{mm}$. long, the outer ones commonly shorter than the inner; pappus of 4-6 downwardly barbed, slightly spreading awns, much shorter than the achene.

Waste and cultivated grounds, New Providence and Eleuthera:-West Indies; continental tropical America. Recorded by Dolley and by Hitchcock as B. bipinnata L., which it resembles. BEGGAR-TICKS.

\section{Bidens pilòsa L. Sp. Pl. 832. 1753.}

Corcopsis leucantha L. Sp. Pl. ed. 2, 1282. 1763.

Bidens leucantha Willd. Sp. P1. 3: 1719. 1804.

Annual, glabrous or somewhat pubescent, 3-10 dm. high, more or less branched. Leaves petioled, 3-divided, their segments ovate to lanceolate, 2-8 $\mathrm{cm}$. long, serrate, acute or acuminate, the uppermost sometimes undivided; involucre campanulate, about $8 \mathrm{~mm}$. high, its outer bracts linear-oblong, usually 
shorter than the inner; rays, when present, white, 1-2 cm. long, 2-3-lobed; achenes fusiform, unequal, the inner longer than the involucre; pappus of 2-4 yellow, downwardly barbed awns.

Waste and cultivated ground, New Providence, Great Bahama, Andros, South Cat Cay, Eleuthera, Cat Island, Fortune Island and East Caicos:-southern United States; West Indies and Bermuda; continental tropical America. WHITE BEGGARTICKS. SHEPHERD'S-NEEDLE.

\section{TRIDAX L. Sp. P1. 900. 1753.}

Perennial herbs, with opposite, dentate or incised leaves and long-peduncled heads of tubular and radiate flowers, the disk-flowers perfect and fertile, the ray-flowers pistillate, the rays often 3-lobed. Involucre ovoid to hemispheric, its nearly equal bracts in few series, or the outer smaller than the inner. Receptacle flat or convex, the chaff subtending the disk-flowers. Anthers auricled at the base or sagittate. Style-branches of the disk-flowers subulate-appendaged. Achenes silky-villous. Pappus of many aristate plumose scales. [Greek, referring to the ö-lobed rays.] About a dozen species, natives of tropical America, the following typical.

\section{Tridax procúmbens L. Sp. Pl. 900. 1753.}

Hirsute, branched from the base, the branches spreading or ascending, slender, $2-5 \mathrm{dm}$. long. Leaves ovate to ovate-lanceolate, short-petioled, 2-6 em. long, incised-dentate, acute or acuminate at the apex, mostly cuneate at the base; peduncles solitary, terminal, 1-3 dm. long; involucre subcampanulate, about $6 \mathrm{~mm}$. high, its bracts hispid, the inner elliptic, the outer lanceolate; rays nearly white; achenes about $2 \mathrm{~mm}$. long.

Waste places, Lignum Vitae Cay, New Providence, Eleuthera, Cat Island and Fortune Island :-Florida; Cuba; Grenada; continental troplcal America. Recorded by Hitchcock as Amellus aspera (Jacq.) Kuntze. 'TrIDAx.

\section{FLAVìrIA Juss.; J. F. Gmel. Syst. 2: 1269. 1791.}

Glabrous or minutely puberulent, light green, annual or perennial herbs, with opposite sessile leaves, and small, 1-several-flowered, usually sessile, oblong, densely cymose-capitate heads of tubular, or both tubular and radiate, yellow or yellowish flowers. Involucre of 2-5 narrow, nearly equal, appressed bracts, sometimes with 1 or 2 additional small exterior ones. Receptacle small, naked. Ray-flower commonly one, pistillate, fertile, sometimes wanting. Disk-flowers 1-15, perfect, fertile, their corollas 5-toothed. Anthers entire at the base. Style-branches of the disk-flowers truncate. Achenes oblong or linear-oblong, 8-10-ribbed. Pappus none. [Latin, flavus, yellow, from its dyeing properties.] Type species: Flaveria chilensis J. F. Gmel.

\section{Flaveria lineàris Lag. Gen. et Sp. Nov. 33. 1816.}

Perennial, glabrous or nearly so, somewhat woody, usually branched, erect or decumbent, 3-9 dm. long. Leaves linear, entire, 3-7 cm. long, 1-6 mm. wide; heads commonly numerous, in terminal corymbose cymes, short-peduncled; involucre narrow, about $4 \mathrm{~mm}$. high, its principal bracts about 5, lanceolate or oblong, acute; ray-flower usually only one, its ligule 3-4 $\mathrm{mm}$. long.

Coastal coppices and scrub-lands, Joulter's Cays, Andros, New Providence, Water Cay on Cay Sal bank :-Florida; Cuba; Alacran Shoals; Yucatan. The Cay Sal bank plant is of a broad-leaved race. NARRow-leaved Flaveria. 
29. NEOTHYMÓPSIS Britton \& Millspaugh.

[Thymopsis Benth. in Benth. \& Hook. Gen. Pl. 2: 407.1873.

Not Jaub. \& Spach, 1843.]

Low diffuse, annual or perennial, hirsute or puberulent herbs, with opposite small broad leaves, and few-flowered, small heads of tubular flowers, the outer pistillate the inner perfect. Bracts of the involucre few, nearly equal, hirsute or ciliolate. Receptacle naked, flat. Corolla of pistillate flowers slender, 2-3-toothed, shorter than the style, minutely 2-4-toothed; corolla of perfect flowers with a campanulate, 4-toothed limb. Anthers obtuse at the base, entire. Achenes oblong, nearly terete, striate. Pappus a fringed crown of several scales. [Greek, new-Thymopsis.] Only the two following species are known. Type species: Tetranthus thymoides Griseb.

Plants hirsute-hispid throughout; flowers 10 in a head; awned. Plants slightly pubescent; flowers 5 in a head; perennial.

1. N. Wrightii.

2. N. Brittonii.

\section{Neothymopsis thymoìdes (Griseb.) Britton \& Millspaugh.}

Tetranthus thymoides Griseb. Cat. Pl. Cub. 286. 1866.

Thymopsis Wrightii Benth. loc. cit. 1873.

Thymopsis thymoides Urban, Symb. Ant. 5: 254. 1907.

Annual; stems very slender, little branched, 1-3 dm. long, short-hirsute. Leaves ovate, $10 \mathrm{~mm}$. long or less, acute or obtuse at the apex, narrowed into petioles, hirsute-hispid; heads nearly sessile in the axils, about 10-flowered; involucre of 5 or 6 oblong, obtuse, hirsute bracts about $3 \mathrm{~mm}$. long.

Molst places, Acklin's Island and Mariguana:-Cuba.

\section{Neothymopsis Brittónii (Greenm.) Britton \& Millspaugh.}

Thymopsis Brittonii Greenm. Bull. N. Y. Bot. Gard. 3: 453.1905.

Perennial; stems several, erect or ascending, slender, 4-10 $\mathrm{cm}$. long, puberulent. Leaves rhombic-ovate to somewhat spatulate, 4-8 $\mathrm{mm}$. long, onehalf as broad, obtuse, entire, revolute-margined, narrowed below to a short petiole, sparingly puberulent to glabrous, dark green above, paler and glandular-punctate beneath; heads terminating the stem and branches, sessile, about $3 \mathrm{~mm}$. high, 5-flowered; involucre of 5 (4) oblong obtuse, navicular, or somewhat obtusely carinate-concave, ciliolate green bracts.

Moist places, New Providence and Great Exuma. Endemic.

\section{POROPHÝLLUM Vaill; Adans. Fam. Pl. 2: 122.1763.}

Herbs, or some species shrubby, glanduliferous, glabrous and often glaucous. Leaves alternate, or the lower opposite, toothed or entire. Heads corymbose or solitary, long-stalked. Involucre narrowly campanulate or eylindric, its bracts 5-9. Receptacle small, not chaffy. Ray-flowers none. Diskflowers perfect and fertile; corollas with a slender tube and narrowly campanulate limb. Achenes linear, many-striate, glabrous or pubescent. Pappus of copious capillary roughish bristles in 1 or 2 series. [Greek, porose-leaved.] About 25 species, of warm-temperate and tropical America, the following typical. 
1. Porophyllum Porophýllum (L.) Kuntze, Rev. Gen. Pl. 3²: 168. 1898.

Cacalia Porophyllum L. Sp. Pl. 834. 1753.

Porophyllum ruderale Griseb. Fl. Br. W. I. 379. 1861. Not Cass., 1826.

Annual; stem erect, often much branched, pale, slightly glaucous, $1 \mathrm{~m}$. high or less. Leaves thin, slender-petioled, oblong to ovate, obtuse or acute, low-crenate or entire, 2-7 cm. long, bearing marginal glands or sometimes glandless; heads solitary at the ends of the branches, many-flowered; involucre about $2 \mathrm{~cm}$. high, its 5 bracts linear, acute, bearing narrowly linear glands; corolla about $10 \mathrm{~mm}$. long; achenes linear, about $8 \mathrm{~mm}$. long, dark brown, hispidulous.

Waste places and pot-holes in good soil, Abaco, Andros, New Providence, Harbor Island, Eleuthera, Cat Island and. Great Exuma :-West Indies and continental tropical America. POROPHYLLU.

\section{PÉCTIS L. Syst. ed. 10, 1221. 1759.}

Annual or perennial, diffuse prostrate or erect, mostly glabrous herbs, gland-dotted and strong-scented, with opposite narrow, sometimes brstly-ciliate leaves, and small, usually cymose heads of both tubular and radiate yellow flowers. Involucre eylindric, oblong or campanulate, its bracts in 1 series, narrow, keeled, distinct. Receptacle small, naked. Ray-flowers pistillate, the rays small, entire or 3-lobed. Disk-flowers perfect, their corollas with expanded, somewhat irregularly 5-cleft limbs. Anthers entire at the base. Style-branches of the disk-flowers very short, obtuse. Achenes linear, slightly angled, striate. Pappus of scales, slender bristles or awns, sometimes with a few outer smaller additional ones. [Latin, pecten, comb, referring to the pappus.] About 75 species, natives of the warmer parts of America. Type species: Pectis linifolia $\mathrm{L}$.

Pappus of scales.

Pappus of $2-4$ subulate awns.

1. P. leptocephala.

2. P. linifolia.

1. Pectis leptocéphala (Cass.) Urban, Symb. Ant. 5: 280. 1907.

Chthonia leptocephala Cass. Dict. Sci. Nat. 27: 206. 1823.

Pectis Lessingii Fernald, Proc. Am. Acad. 33: 67. 1897.

Glabrous or nearly so; stems slender, diffusely branched, 1-4 dm. high. Leaves narrowly linear, 1-3 cm. long, less than $1 \mathrm{~mm}$. wide, acute, bearing a few bristles below the middle; heads filiform-peduncled, mostly solitary; involucre narrow, 4-5 mm. high, its bracts linear; achenes narrow, about 3 $\mathrm{mm}$. long; pappus of subulate-lanceolate scales.

Limestone soll, Andros, New Providence:-Florida; Cays of northern Cuba ; Hispanilola. Recorded by Mrs. Northrop, by Dolley and by Hitchcock as P. linifolia L. Narrow-leated Pectis. Wrongly called Pennyroyal.

2. Pectis linifòlia L. Syst. ed. 10, 1221. 1759.

Pectis punctata Jacq. Enum. 28. 1760.

Annual; stems glabrous, very slender, usually much-branched, $2-9 \mathrm{dm}$. high. Leaves linear, $2-8 \mathrm{~cm}$. long, usually not more than $3 \mathrm{~mm}$. wide, narrowed at both ends, sparingly glanduliferous, commonly bearing 1-3 bristles at the base; heads on filiform peduncles 7-35 $\mathrm{mm}$. long, 5-9-flowered; in. volucre about $6 \mathrm{~mm}$. long, its 4 or 5 linear glabrous bracts obtuse with revolute margins; flowers purplish to orange: achenes linear, 4-6 mm. long, gla- 
brous or sparingly pubescent; pappus of 2-4 subulate, spreading or reflexed awns about $2 \mathrm{~mm}$. long.

Sandy and rocky solls, Acklin's, Mariguana, South Caicos, Ambergris Cay, Grand Turk, Sand Cay, Inagua and Little Inagua :- West Indies, east to Anegada, south to Grenada; Aruba ; Curaçao; continental tropical America. AwN-FruITED PECTIS.

32. NEUROLAìnA R. Br. Trans. Linn. Soc. 12: 120. 1817.

Tall shrubby perennials, with large alternate leaves, and numerous small corymbose-paniculate heads of tubular yellow flowers, all perfect and fertile. Involucre campanulate, its obtuse nerved bracts imbricated in 3 or 4 series. Receptacle nearly flat, with membranous 1-nerved scales which are early deciduous. Corolla-tube slender, the limb somewhat expanded. Anthers sagittate. Achenes narrowed at the base. Pappus of many capillary persistent, somewhat unequal bristles. [Greek, referring to the nerved bracts.] Two known species of tropical America, the following typical.

1. Neurolaena lobàta (L.) R. Br.; DC. Prodr. 6: 292.1837.

Conyza lobata L. Sp. Pl. 862. 1753.

Stems somewhat woody, erect, usually much branched, $1.5-3 \mathrm{~m}$. high, appressed-pubescent and scabrous. Leaves lanceolate to ovate-lanceolate, pubescent and scabrous, dentate, denticulate or variously lobed, acuminate at the apex, narowed at the base, the lower up to $3 \mathrm{dm}$. long and petioled, the upper much smaller, sessile or nearly so; corymbs terminal, often $8 \mathrm{~cm}$. broad or more; peduncles rather slender, bracted, pubescent; involucre 6-8 $\mathrm{mm}$. high, its bracts oblong, pubescent, 3-nerved, the outer shorter than the inner; achenes pubescent; pappus brownish-white.

Thickets at Red Bays, Andros :-Cuba to St. Thomas and to Trinidad; Jamaica ; continental tropical America.

\section{EMricIA Cass. Bull. Soc. Philom. 1817: 68. 1817.}

Herbs, with alternate and basal, often clasping leaves, and long-peduncled, solitary or loosely corymbose heads of pink, purple or orange, tubular, perfect and fertile flowers. Involucre nearly cylindric, its bracts in a single equal series. Receptacle flat, naked. Corolla-limb cylindric. Achenes nearly terete or 5-angled. Pappus of numerous soft white capillary bristles. [Name unexplained.] About 5 species, natives of the Old World tropics. Type species: Emilia flammea Cass.

1. Emilia sonchifòlia (L.) DC. Prodr. 6: 302. 1837.

Cacalia sonchifolia L. Sp. Pl. 835. 1753.

Annual, glabrous, or somewhat pubescent below, usually branched, 2-7 $\mathrm{dm}$. high. Basal and lower leaves petioled, sometimes $12 \mathrm{~cm}$. long, obovate to oblanceolate, repand-dentate to lyrate-pinnatifid, obtuse or acute at the apex; upper leaves lanceolate, sessile, sagittate-clasping, dentate, lobed or entire; heads loosely corymbose, many-flowered; peduncles very slender or filiform; involuere 10-12 mm. high, its bracts linear-lanceolate, acute, at length reflexed; flowers rose, red or purple.

Waste places in good soil, Andros, New Providence, Eleuthera, Cat Island, Long Island and North Caicos:-Florida; Bermuda; West Indies and continental tropical America. Naturalized from the East Indies. Porple Emilia. 


\section{ERECHTITES Raf. Fl. Ludov. 65. 1817.}

Erect, usually branching herbs, with alternate leaves, and (in our species) rather large, discoid, many-flowered heads of whitish flowers, corymbose-paniculate at the ends of the stem and branches. Involucre eylindric, swollen at the base, its principal bracts in 1 series, linear, with or without much smaller outer ones. Receptacle concave, naked. Marginal flowers in 2-several series, pistillate, fertile, their corollas filiform, the limb 2-4-toothed. Central flowers perfect, fertile; corolla narrowly tubular, the limb 4-5-toothed, the stylebranches elongated, truncate or obtuse at the summit. Anthers obtuse and entire at the base. Achenes linear-oblong, angled or striate. Pappus of copious eapillary soft smooth white bristles. [Ancient name of some groundsel.] About 12 species, natives of America and Australasia. Type species: Erechtites praealta Raf.

1, Erechtites hieracifòlia (L.) Raf.; DC. Prodr. 6: 294. 1837.

Senecio hieracifolius L. Sp. Pl. 866. 1753.

Annual, glabrous, or somewhat hirsute; stem striate, succulent, usually branched, 3-25 dm. high. Leaves thin, lanceolate or ovate-lanceolate, dentate and often deeply incised, 5-20 cm. long, the upper sessile or auriculate-clasping, mostly acuminate, the lower usually narrowed into petioles; heads 12-20 $\mathrm{mm}$. long, about $6 \mathrm{~mm}$. in diameter, the involucre conspicuously swollen at the base before flowering, its bracts numerous, striate, green, with narrow scarious margins; pappus bright white.

Cultivated fields and coppices, Andros:- West Indies and temperate and tropical continental America. FIRE-WEED.

\section{CÍRsIUM [Tourn.] Mill. Gard. Dict. abr. ed. 4. 1754.}

Erect, branched or simple, prickly herbs, some species acaulescent, with alternate or basal, sinuate-dentate lobed or pinnatifid, usually very spiny leaves, sometimes decurrent, and large many-flowered, solitary or clustered, discoid heads of purple, yellow or white, tubular, perfect and fertile, or rarely dioecious flowers. Involucre ovoid or globose, its bracts prickle-tipped or unarmed, imbricated in many series. Receptacle flat or convex, bristly. Corollatube slender, the limb deeply 5-cleft. Filaments pilose, or rarely glabrous. Anthers sagittate at the base. Style-branches short or elongated, obtuse. Achenes obovate or oblong, compressed or obtusely 4-angled, glabrous, smooth or ribbed. Pappus of several series of slender, plumose, bristles, connate at the base. [Greek, the thistle was used as a remedy for swollen veins.] Over 200 species, widely distributed in the northern hemisphere. Type species: Carduus heterophyllus $\mathrm{L}$.

\section{Cirsium Smállii Britton.}

Carduus pinetorum Small, F1. SE. U. S. 1308, 1341. 1903.

Cirsium pinetorum Small, Fl. Miami 199, 200. 1913. Not Greenm., 1905.

Stem simple or little-branched, sparingly floccose, rather slender, $9 \mathrm{dm}$. high or less. Leaves more or less floccose, runcinate-pinnatifid or entire, the teeth and margins armed with yellowish acicular spine-like bristles $1.5 \mathrm{~cm}$. long or less; basal and lower leaves oblanceolate or spatulate-oblong, 1-2.5 dm. 
long, the upper smaller, lanceolate, acuminate, sessile, or half-clasping the stem; heads few; involuere about $3.5 \mathrm{~cm}$. high, the outermost bracts spinulosetipped, the inner acuminate; flowers pink; pappus white, long-plumose; achenes about $5 \mathrm{~mm}$. long.

Pine-lands, Abaco and Great Bahama :-Florida. Pine-Land Thistle.

\section{ANASTRÁPHIA D. Don, in Trans. Linn. Soc. 16: 295.1830.}

Shrubs or trees, with alternate leaves, and terminal discoid heads of tubular, perfect and fertile flowers. Involucre campanulate or turbinate, its bracts imbricated in several or many series, appressed or recurved, the outer gradually shorter than the inner. Receptacle flat or nearly so, naked. Corollalimb scarcely expanded, 5-parted, the lobes narrow. Anthers sagittate at the base, the auricles elongated. Style-branches short. Achenes linear, villous or pubescent. Pappus of 1 or 2 series of filiform bristles. [Greek, turned backward.] About 20 species, natives of the West Indies. Type species: Anastraphia ilicifolia D. Don.

Bracts of the involucre recurved.

Bracts of the involucre strictly erect.

1. A. Northropiana.

2. A. bahamensis.

\section{Anastraphia Northropiàna Greenm. Trans. Acad. St. Louis 7: 435. 1897.}

An irregularly branched shrub, 1-2 m. high, or, on the coast of southern Cuba becoming a tree up to $10 \mathrm{~m}$. high, with a trunk $2 \mathrm{dm}$. in diameter, the bark rough, the slender twigs densely white-tomentose. Leaves oblong to elliptic or obovate, 1-4 cm. long, coriaceous, obtuse at the apex, narrowed or obtuse at the base, serrate with few spinulose-tipped teeth, or entire, glabrous above, densely white-tomentose beneath, short-petioled; involucre campanulate, 12-15 $\mathrm{mm}$. high, its bracts pubescent, the inner linear, acute, reflexed, the outer gradually smaller; flowers $8-10$, orange, about $3 \mathrm{~cm}$. long; achenes villous, $3 \mathrm{~mm}$. long; pappus tawny, 12-16 mm. long.

Low coppices and pine-lands, .Andros, New Providence and Cat Island :-Cuba. Northrop's ANASTRAPHIA. CANDLEWOOD.

\section{Anastraphia bahaménsis Urban, Symb. Ant. 3: 415. 1903.}

Anastraphia cuneifolia Greenm. Bull. N. Y. Bot. Gard. 4: 126. 1905.

Shrub 1-2 m. high, much-branched; stem and branches covered with a light gray bark. Leaves obovate-cuneate, $1-2 \mathrm{~cm}$. long, $0.5-1.2 \mathrm{~cm}$. broad, revolute-margined, sparingly spinulose-dentate in the terminal portion, entire and narrowed below the middle into the petiole, slightly puberulent above in the early stages but soon glabrate and rather conspicuously reticulate-veined, densely and permanently white-tomentose beneath; petioles $3-5 \mathrm{~mm}$. long, tomentose; heads few, about $2 \mathrm{~cm}$. long, sessile, mostly terminating the ultimate branchlets, 5-flowered; involucre narrowly campanulate, 8.5-10 mm. long; bracts of the involucre 5-6-seriate, triangular-ovate to lance-linear, acute, externaly arachnoid-tomentulose, brownish, slightly spreading at maturity; mature achenes 3.5-4 mm. long, pubescent; pappus about $13 \mathrm{~mm}$. in length, persistent, tawny.

Low copplces and scrub-lands, Andros, Eleuthera, Cat Island, Great Exuma. Crooked, Fortune and Acklin's Islands, Mariguana, Dellis Cay, Caicos Islands and Inagua :-Cuba. Reported by Hitchcock and by Mrs. Northrop as A. paucifloscula C. Wright, an unpublished name. BaHama ANastraphia. Carrajo-bush. 
37. CHAPtÀLIA Vent. Jard. Cels. pl. 61. 1800.

Perennial scapose herbs, with floccose-tomentose foliage. Leaves basal, persistently pubescent beneath. Heads heterogamous, radiate, solitary and terminal. Involucre many-flowered, its bracts narrow, in few series, the inner successively larger. Ray-flowers pistillate, fertile, rose-purple. Disk-flowers perfect, wholly or partially neutral, their corollas white or purplish, more or less 2-lipped, the outer with 3 lobes to the lower lip, the inner with 2 lobes. Achenes 5-nerved, columnar or fusiform. Pappus of numerous soft hair-like bristles. [In honor of J. A. C. Chaptal, 1756-1831, French chemist and statesman.] About 25 species, natives of warm-temperate and tropical America. Type species: Chaptalia tomentosa Vent.

1. Chaptalia dentàta (L.) Cass. Dict. Sci. Nat. 26: 104. 1823.

Tussilago dentata L. Sp. Pl. ed. 2, 1213. 1763.

Tussilago albicans Sw. F. Ind. Oce. 3: 1348. 1806.

Chaptalia albicans Northrop, Mem. Torr. Club 12: 73. 1902.

Leaves oblanceolate or oblong-oblanceolate, $2-20 \mathrm{~cm}$. long, repand-dentate or entire, obtuse or acute at the apex, long-attenuate at the base, loosely floccose or becoming glabrous and bright green above, densely white-felted or grayish-felted beneath, the petioles very short or sometimes as long as the blades; scape slender, more or less floccose, 1-3 dm. tall; head not nodding; involucre 13-22 $\mathrm{mm}$. high, its linear bracts floccose, acuminate, the outer much shorter than the inner; flowers white (?); achenes glabrous or pubescent, the body 5-6 mm. long, the filiform beak longer; pappus straw-color, 8-10 mm. long.

Grassy places, pine-lands and coppices, Great Bahama, Abaco, Andros, New Providence :-Flarida; Cuba; Hispaniola; Porto Rico; Jamaica. Recorded as $C$. nutans Hemsl. by Hitchcock. Low Chaptalia.

[Artemisia vulgaris L. is reported by Herrick as growing on Green Turtle Cay, Abaco; we have not succeeded in finding the specles within the archipelago; this European species would probably not long endure the Bahama climate.]

\section{Class 2. GYMNOSPÈRIMAE.}

Ovules (macrosporanges) naked, not enclosed in an ovary, this represented by a scale or apparently wanting. Pollen-grains (microspores) dividing at maturity into two or more cells, one of which gives rise to the pollen-tube (male prothallium), which directly fertilizes an archegone of the nutritive endosperm (female prothallium) in the ovule.

The Gymnosperms are an ancient group, first known in Silurian time. They became most numerous in the Triassic age. They are now represented by not more than 450 species of trees and shrubs.

There are three orders, Pinales, Cycadales and Gnetales, the two first represented in the Bahama Flora.

Leaves scale-like, linear or needle-like.

Leaves large, plnnate, in a terminal crown.

Order 1. Pinales.

Order 1. PINÀLES.

Trees, or rarely shrubs, growing from both terminal and lateral buds, thus freely branching, the trunks mostly excurrent. Leaves scale-like, linear or needle-like, sometimes fascicled. Flowers mostly monoecious. Fruit a cone, with woody or fleshy scales, or drupaceous. 
Family 1. PINÁCEAE Lindl.

\section{Pine Family. Conifers.}

Resinous trees or shrubs, mostly with evergreen narrow entire or scalelike leaves, the wood uniform in texture, without tracheae, the tracheids marked by large depressed disks, the pollen-sacs and ovules borne in separate spikes (aments). Perianth none. Stamens several together, subtended by a scale; filaments more or less united; pollen-saes (anthers) 2-several-celled, variously dehiscent; pollen-grains often provided with two lateral inflated sacs. Ovules with two integuments, orthotropous or amphitropous, borne solitary or several together on the surface of a scale, which is subtended by a bract in most genera. Fruit a cone with numerous, several or few, woody, papery or fleshy scales; sometimes berry-like. Seeds wingless or winged. Endosperm fleshy or starchy, copious. Embryo straight, slender. Cotyledons 2 or several. About 25 genera and 250 species of wide distribution, most abundant in temperate regions.

Fruit a large cone with many woody scales; leaves linear, in sheaths. 1. Pinus. Fruit a berry-like cone of few fleshy scales; leaves acicular or scale-like.

2. Juniperus.

\section{PİNUS [Tourn.] L. Sp. Pl. 1000. 1753.}

Evergreen trees with two kinds of leaves, the primary ones linear or scalelike, deciduous, the secondary ones forming the ordinary foliage, narrowly linear, arising from the axils of the former in fascicles of 2-5 (rarely solitary in some western species), subtended by the bud-scales, some of which are united to form a sheath. Staminate aments (flowers) borne at the bases of shoots of the season, the clusters of stamens spirally arranged, each in the axil of a minute scale; filaments very short; anthers 2-celled, the sacs longitudinally dehiscent. Ovule-bearing aments (flowers) solitary or clustered, borne on the twigs of the preceding season, composed of numerous imbricated minute bracts, each with an ovule-bearing scale in its axil, ripening into a large cone, which matures the following autumn, its scales elongating and becoming woody. Seeds 2 on the base of each scale, winged above, the testa crustaceous. [Name Celtic.] About 100 species, of the northern hemisphere. Type species: Pinus sylvestris L.

1. Pinus caribaèa Morelet, Rev. Hort. Cote d'Or. 1851.

Pinus bahamensis Griseb. Fl. Br. W. I. 503.1861.

A tree, with a maximum height of about $30 \mathrm{~m}$., the trunk up to $1.5 \mathrm{~m}$. in diameter, the thick bark splitting into irregular plates, the stout twigs glabrous. Leaves in fascicles of 2 or 3, dark green, shining, 17-30 $\mathrm{cm}$. long, the sheaths 1-1.5 cm. long; staminate aments 2-4 cm. long; ovule-bearing aments mainly terminal; cones narrowly conic when closed, 9-14 cm. long, their seales thin, nearly flat, rounded at the apex and thickened into a low knob which bears a small spine; seeds 5-8 mm. long, the thin wing 2-2.5 cm. long.

Great Bahama, Abaco, Andros, New Providence, North Caicos and Pine Cay, Calcos Islands :- southeastern United States; Cuba. CARIBBEAN PiNe-Tree. 


\section{JUNÍPERUS L. Sp. Pl. 1038. 1753.}

Evergreen trees or shrubs with opposite or verticillate, subulate or scalelike, sessile leaves, commonly of 2 kinds, and dioecious or sometimes monoecious, small globose axillary or terminal aments. Leaf-buds naked. Staminate aments oblong or ovoid; anthers 2-6-celled, each sac 2-valved. Ovule-bearing aments of a few opposite somewhat fleshy scales, or these rarely verticillate in 3 's, each bearing a single erect ovule or rarely 2 . Cones globose, berry-like by the coalescence of the fleshy scales, containing 1-6 wingless bony seeds. [Name Celtic.] About 40 species, natives of the northern hemisphere. Type species: Juniperus communis $\mathrm{L}$.

1. Juniperus lucayàna Britton, N. A. Trees, 121. 1908.

Juniperus australis Pilger, in Urban, Symb. Ant. 7: 479. 1913.

A tree, seldom over $12 \mathrm{~m}$. high, with a trunk up to $6 \mathrm{dm}$. in diameter, the thin bark separating in low strips, the branches ascending or the lower drooping, the twigs slender. Leaves of young plants, and of ten those of the lower parts of twigs, acicular, pungent, $5-10 \mathrm{~mm}$. long; leaves of mature plants scale-like, appressed, 4-ranked, 1-1.5 mm. long; fruit blue, oblong-globose and somewhat laterally flattened, 5-6.5 mm. long.

Great Bahama, Abaco, Cat Cay, Andros, New Providence, Eleuthera :-Cuba : Jamaica. Recorded by Grisebach, by Mrs. Northrop, by Coker and by Dolley as $J$. barbadensis L., by Schoepf as $J$. bermudiana $\mathrm{L}$., and by Dolley as $J$. virginiana $\mathrm{L}$. West Indian Red CeDar.

\section{Order 2. CYCADĀLES.}

Palm-like or fern-like, dioecious, woody plants with erect trunks, sometimes short and wholly buried in the ground, growing only from the summit and thus unbranched, although sometimes forming lateral adventitious buds, the large pinnate leaves in a terminal crown. Flowers in terminal cones, or on modified leaves. Seales of the staminate cones bearing several anther-sacs. Ovule-bearing scales or leaves with two or more naked ovules. Seeds drupe-like or nut-like. Only the following family.

\section{Family 1. CYCADÀCEAE Lindl.}

\section{Crcad Family.}

Nine genera and about 90 species, of tropical and subtropical distribution.

1. ZÀMIA L. Sp. Pl. ed. 2, 1659. 1753.

Woody, dioecious plants, the trunk or caudex wholly or partly buried in the ground, the palm-like leaves tufted at its summit, pinnately compound, coriaceous, the segments entire or toothed, parallel-veined, the petioles unarmed in the following species, prickly in some others, the inflorescence strobilar, peduncled, densely many-flowered, the cones from oblong-cylindric to subglobose, the female thicker than the male. Scales of the cones peltate, nearly flat, more or less hexagonal, elosely set together, vertically superimposed. Scales of the male cone at length deciduous, bearing several sessile pollen-sacs, those of the 
female cone persistent, bearing 2 sessile, ovoid ovules. Seeds more or less angled, the testa fleshy. [Said to be Latin for a fir-cone.] About 25 species, natives of tropical and subtropical America. Type species, Zamia pumila L.

Leaflets 3-15 mm. wide.

Leaflets $7-15 \mathrm{~mm}$. wide, close together.

Leaflets 3-7 mm. wide.

Leaflets distant, 3-6 mm. wide; scales of male cone wider than high.

Leaflets closer together, 6-7 $\mathrm{mm}$. wide; scales of male cone scarcely wider than high.

Leaflets about $2.5 \mathrm{~cm}$. wide.

1. Z. pumila.

2. Z. angustifotia.

3. Z. tenuis.

4. Z. lucayana.

1. Zamia pùmila L. Sp. Pl. ed. 2, 1659. 1763.

Caudex stout, $2 \mathrm{dm}$. long or longer, the upper part usually exposed, but sometimes completely buried. Basal scales ovate, acute or acuminate, villous, 2-3 cm. long; petiole silky-villous below, glabrous above; leaves 3-10 dm. long; leaflets 20-50, coriaceous, shining, 5-15 $\mathrm{cm}$. long, 7-15 mm. wide, entire, or fewtoothed at the obtuse apex, the pairs separated $0.5-2 \mathrm{~cm}$; peduncles stout, villous-pubescent, 5-10 cm. long; male cone oblong, 5-8 cm. long, 2-2.5 cm. thick, its scales tomentose, broader than high or the lower nearly equally broad and long; ripe female cone ellipsoid, 7-11 cm. long, 5-8 cm. thick, short-tipped, its hexagonal scales tomentose, broader than high; seeds angled, 2-2.5 cm. long.

Thickets and woodlands among rocks, Great Bahama, Andros, New Providence :Florida ; Cuba. BAY-RUSH.

\section{Zamia angustifollia Jacq. Coll. 3: 263. 1789.}

Caudex slender, $2 \mathrm{dm}$. long or longer, completely buried in sand. Basal scales broadly ovate to ovate-lanceolate, acuminate, densely villous $3-5 \mathrm{~cm}$. long; leaves 2-10 dm. long; leaflets 5-20 pairs, narrowly linear, entire or with a few callous teeth at the obtuse apex, 5-20 cm. long, 3-6 mm. wide, nearly parallel-margined or slightly tapering to both ends, shining, the pairs distant, those of larger leaves about $2 \mathrm{~cm}$. apart; peduncles villous, those of male cones $5-8 \mathrm{~cm}$. long, those of female cones stouter; male cone oblong-cylindric, 5-7 $\mathrm{cm}$. long, about $2 \mathrm{~cm}$. thick, pointed, its scales oblong, or rotund, hexagonal, tomentose, 6-7 mm. wide, 3-5 mm. high; ripe pistillate cone $8-9 \mathrm{~cm}$. long, about $5 \mathrm{~cm}$. thick, stout-tipped, its scales $2-2.5 \mathrm{~cm}$. wide, about $1.5 \mathrm{~cm}$. high; seeds $2 \mathrm{~cm}$. long, red.

In white calcareous sand, Eleuthera:-Cuba. NARROW-LEAVEd BAY-RUSH.

3. Zamia ténuis Willd. Sp. Pl. 4: 846. 1806.

Caudex unknown definitely. Leaves $6 \mathrm{dm}$. long or longer; leaflets 40 or fewer, narrowly linear, 7-17 $\mathrm{cm}$. long, 6-7 $\mathrm{mm}$. wide at or below the middle, tapering to the obtuse, callously 1-several-toothed apex, the pairs separated by $1.5 \mathrm{~cm}$. or less; peduncles pubescent; male cone cylindric, its scales described as subquadrate-hexagonal, tomentose, little broader than high.

Bahamas, according to Willdenow and subsequent authors. A leaf from a New Providence plant, communicated by Hon. H. A. Brook, is tentatively referred to this species. A specimen from near Nuevitas, Cuba (Shafer 793), is also referred to it with hesitation. A leaf of the type specimen is figured by Miquel (Linneae 19:pl. 6 ). The species may not be distinct from $Z$. angustifolia.

\section{Zamia lucayàna Britton, Bull. N. Y. Bot. Gard. 5: 311. 1907.}

Caudex stout, subfusiform, about $3 \mathrm{dm}$. long, $1 \mathrm{dm}$. thick, two thirds buried in the ground. Leaves glabrous, about $1 \mathrm{~m}$. long; petiole obtusely angled, $3-4$ $\mathrm{dm}$. long; rachis somewhat angled; leaflets about 14 on each side of the rachis, spreading nearly at right angles, 17-21 cm. long, 2-2.7 cm. wide, 4-5 cm. apart, linear-oblong, obtuse, or irregularly rounded or subtruncate, and finely sparingly 
toothed at the apex, faleately narrowed at the base, the margins thickened and slightly revolute, the $40-50$ nerves closely parallel; fruiting peduncle about 4 $\mathrm{cm}$. long, $1.2 \mathrm{~cm}$. thick below, $2 \mathrm{~cm}$. thick at the top, densely pubescent; fruiting cone oblong, puberulent, $7 \mathrm{~cm}$. long, $4 \mathrm{~cm}$. in diameter, its acute conic tip $8 \mathrm{~mm}$. high, its scales oblong, hexagonal, about $1.5 \mathrm{~cm}$. wide and $8 \mathrm{~mm}$. high.

Sandy coastal thicket, Clarence Town, Long Island. Endemic. BaHaMa BaY-RUSH.

\section{Phylum 2. PTERIDÓPHYTA.}

\section{Ferns and Fern-Allies.}

Plants containing woody and vascular tissues, producing spores asexually, which, on germination, develop small flat mostly green prothallia (gametophyte). On these are borne the reproductive organs, the female known as archegones, the male as antherids. From the fertilization of the egg in the archegone by spermatozoids produced in the antherid, the asexual phase (sporophyte) of the plant is developed; this phase is represented by an ordinary fern, lycopod, or horsetail. Comprising about 6000 living species, of which more than three fourths are confined to tropical regions.

Spores produced in sporanges borne on the leaves, or panicled or in special conceptacles.

Spores all alike; Bahama specles all terrestrial or epiphytic plants.

Spores of two slzes; small floating plants.

Spores produced in sporanges borne in the axlls of scalelike leaves.

Order 1. Filicales. Order 2. SALVINIALES.

Order 3. Lycopodiales.

\section{Order 1. FILICÀLES.}

Spores all of one kind and size, produced in sporanges, which are borne usually in clusters (sori) on the back of a leaf or on greatly modified pinnae.

Sporanges borne in sori on the back or the margln of a leaf, opening transversely.

Sporanges in spikes or panicles, opening vertically.

Fam. 1. Poly PODIACEAE. Fam. 2. SchizanaCeat.

\section{Family 1. POLYPODIÀCEAE R. Br.}

\section{Fern Family.}

Ferns of various habit, the rootstocks horizontal and often elongated, or short and erect, the leaves entire, pinnate, pinnatifid or decompound, coiled in vernation, mostly with petioles (stipes). Sporanges borne in clusters (sori) on the lower side or margins of the leaves or their segments, stalked, provided with a vertical ring, opening transversely. Sori with or without a membranous covering (indusium). Prothallium green. About 150 genera and 4,500 species of wide distribution. 
A. Sori confluent, without indusia, covering the under side of leaf-segments; large pinnate marsh ferns.

B. Sori separated, or forming marginal rows on the under side of leaves or of leaf-segments.

1. Sori marginal or submarginal.

a. Sori without indusia.

Leaves grass-like: venation regularly areolate, without included veinlets.

Leaves narrow; venation irregularly areolate, with numerous included veinlets.

b. Sord with indusia.

Indusia formed

Sorl forming a continuous marginal band.

Indusia double.

Indusia simple.

Sori borne on leaf-lobes at the ends of veins.

2. Sori dorsal.

Indusia cup-like at the truncate ends of leaf-segments.

1. Sori linear or oblong, more than twice as long as wide.

Sori parallel to the midvein of leaf-segments.

Sori oblique to the midvein.

2. Sori orbicular or nearly so.

a. Sori without indusia.

Sori nearly confluent; leaves much divided, powderv beneath.

Sori distinctly separated; leaves not powdery. Veins free.

Velns anastomosing.

Leaves pinnatifid.

Leaves entire.

Small-leaved, climbing ferns.

Large-leaved, tufted ferns.

b. Sori with indusia (indusia vestigial or wanting in species of Dryopteris).

Sori borne on the backs of veins.

Veins coplously anastomosing, the areoles irregular.

Veins free or, if anastomosing, the areoles regular.

Sori borne at the ends of veins; indusia large, reniform or orbicular.

1. Acrostichum.

2. Vittaria.

3. Paltonium.

4. Pteris.

5. Pycnodoria.

6. Adiantum.

7. Sphenomeris.

8. Blechnum.

9. Asplenium.

10. Pityrogramma.

11. Polypodium.

12. Phlebodium.

13. Phymatodes.

14. Campyloneuron.

1. ACRóSTICHUM L. Sp. Pl. 1067. 1753.

Swamp-inhabiting, large ferns, with pinnate leaves growing in crowns. Sporanges spread over the whole surface of the leaf-blades, or of the upper segments. Veins forming copious areolae without free veinlets. [Greek, signifying a summit row.] A few species, natives of warm temperate and tropical America. Type species: Acrostichum aureum L.

Petiole usually armed with spurs; venation of the pinnae very oblique to the midrib.

Petiole unarmed; venation not vepy oblique.

1. A. aureum.

2. A. excelsum.

1. Acrostichum aùreum L. Sp. Pl. 1067. 1753.

Rootstocks stout, erect, often forming large colonies. Leaves 1-3 m. high; petioles tufted, erect, channelled, often armed with horny spurs; blades leathery in texture, longer than the petioles; pinnae 10 pairs or more, the venation very oblique; sporanges usually borne only on the upper pinnae; segregate of corpuscles covering sporanges not sausage-shaped.

Wet saline soil, North Cat Cay, Great Bahama, Andros, New Providence, Acklin's Island, Caicos, Inagua :-Florida; West Indies. Giant Fern. Leather Fern.

2. Acrostichum excélsum Maxon, Proc. Biol. Soc. Wash. 18: 224. 1905.

Acrostichum lomarioides Jenman, Bull. Bot. Dept. Jamaica, 5: 154. 1898. Not Bory, 1853. 
Rootstocks erect, solitary, or in masses. Petioles tufted, unarmed, erect, woody, 1-6.5 dm. long, flattish, channeled; blades leathery, 1-3 m. long, 3-4.5 dm. wide; pinnae 10 pairs or more, close or distant, the venation somewhat oblique to the midvein; sporanges confined to the upper half or third of the leaf-blade, or all segments spore-bearing, or all without spores; segregate of corpuscles covering sporanges sausage-shaped.

About fresh-water pools and in sink-holes, Andros, New Providence :-Florida ; Bermuda; West Indies and continental tropical America. GIANT FERN.

Young plants collected by Percy Wilson on Cat Island (7186), show that one or the other of these Acrostichums grows on that island.

\section{VITTÁAIA J. E. Smith, Mem. Acad. Turin, 5: 413.1793.}

Usually epiphytic ferns with narrowly linear, grass-like, entire leaves, the linear sori continuous in a groove along each margin, without indusia. Lateral veins obscure, forming a row of areoles on each side of the midvein. [Latin, ribbon-like.] About 40 species, widely distributed in tropical and subtropical regions. Type species: Pteris lineata $\mathrm{L}$.

1. Vittaria lineàta (L.) Sw. in Journ. Bot. Schrad. $1800^{2}: 72.1801$.

Pteris lineata L. Sp. Pl. 1073. 1853.

Leaves usually numerous, drooping, smooth, shining, tufted on trees, 1-9 dm. long, 2-3 mm. wide, the rootstock short, branched, scaly.

On palmettos, Andros, New Providence:-Florida; West Indies and continental tropical America. Grass-FerN. Shoestring-Fern.

\section{PALTóNTUM Presl, Epim. 156. 1849.}

Epiphytic ferns, with short-creeping rootstocks and narrow entire leaves, the venation reticulated. Sori linear, submarginal, continuous or interrupted, without indusia. [Greek, like a javelin.] Two known species, the following typical one, the other of southern China.

1. Paltonium lanceolàtum (L.) Presl, Epim. 156. 1849.

Pteris lanceolata L. Sp. Pl. 1073. 1753.

Taenitis lanceolata Kaulf. Enum. 130. 1824.

Cheilogramma lanceolata Maxon, Proc. U. S. Nat. Mus. 23: 630. 1901.

Rootstock short. Leaves tufted, narrowly linear-oblong, glabrous, subcoriaceous, $1.5-4 \mathrm{dm}$. long, 0.8-3 cm. wide, tapering to both ends, entire, the midvein prominent, the lateral venation obscure. Sporanges in a continuous or interrupted marginal row above the middle of the leaf, often only near the apex.

On trees in coppices, Great Bahama, Andros, New Providence:-Florida; Jamaica ; Cuba to St. Thomas; St. Eustatius; Guadaloupe to Barbadoes ; Central Ameríca. NARROW-LEAVED BRAKE.

\section{PTÈris L. Sp. PI. 1073. 1753.}

Large, mostly coarse ferns, growing in open sunny places, with variously divided leaves, and marginal linear continuous sori which occupy a slender or filiform receptacle, connecting the tips of free veins. Indusium double, the outer one conspicuous, membranous, formed of the reflexed margin of the leaf, the inner one delicate and obscure. Stipes continuous with the rootstock. [Greek name for ferns, from the fancied resemblance of their leaves to the wings of birds.] A few species of wide distribution. Type species: Pteris aquilina L. 
1. Pteris caudàta L. Sp. Pl. 1075. 1753.

Pteridium caudatum Maxon, Proc. U. S. Nat. Mus. 23: 631. 1901.

Pteris aquilina caudata Hook. Sp. Fil. 2: 196. 1858.

Leaves erect, 1-2 m. tall; blades triangular in outline, 2-4-pinnate; divisions pinnatifid, the ultimate segments narrow, with recurved margins, remote from one another, scarcely decurrent on the rachis except near the apex, the larger with 1-12 similar but shorter segments.

Pine-lands, scrub-lands and coppices, Abaco, Great Bahama, Andros, New Providence, Cat Island, Crooked Island, North Caicos:-Florida; Bermuda; Jamaica; Cuba; Hispaniola; Porto Rico; Montserrat; continental tropical America. SouthERN BRACKEN.

\section{PYCNODÓRIA Presl. Epim. 101. 1849.}

Mostly large ferns, the petioles not jointed with the rootstocks, the leaves variously divided. Sori marginal, continuous or nearly so, on a filiform or narrow receptacle connecting the tips of the free veins; indusium simple, membranous, formed by the reflexed margin of the leaf. Sporanges pedicelled, provided with a vertical ring which bursts transversely. [Greek, thick-skinned.] Many species, of warm and tropical regions.' Type species: Pteris opaca J. Smith.

1. Pycnodoria longifòlia (L.) Britton, Fl. Berm. 418. 1918.

Pteris longifolia L. Sp. Pl. 1074. 1753.

Leaves somewhat spreading; petioles 1.5-3 dm. long, clothed below with pale brown scales; blades simply pinnate, oblong-lanceolate, 3-6 dm. long; pinnae linear, 4-8 $\mathrm{mm}$. wide, entire, sessile; veins close, usually once branched; indusium yellowish brown.

In sink-holes. Great Bahama, Andros, New Providence:-Florida: Bermuda ; Jamaica ; Cuba ; Hispaniola ; Porto Rico ; St. Thomas ; St. Croix ; St. Kitts ; Guadeloupe; Dominica ; Martinique.

In a monstrous form from Nicholl's Town, Andros, the pinnae are deeply cut into linear lobes $4 \mathrm{~cm}$. long or less. LONG-Leaved Brake.

\section{ADIÁNTUM [Tourn.] L. Sp. Pl. 1094. 1753.}

Graceful ferns of rocky hillsides, woods, and ravines, with much divided leaves and short marginal sori borne on the under side of the reflexed and altered portion of the pinnule, which serves as an indusium. Stipes and branches of the leaves slender or filiform, often polished and shining. [Name ancient.] A genus of over 175 species, mostly of tropical America. Type species: Adiantum Capillus-Veneris L.

Leaf-segments stalked, cuneate at base. Leaf-segments sessile, truncate at base.
1. A. tenerum.

2. A. melanoleucum.

\section{Adiantum ténerum Sw. Prodr. 135. 1788.}

Rootstock short, thick. Stipes smooth, nearly black, shining, 1-3 dm. long. Blades 2-4-pinnate, 2-4 dm. long, glabrous; pinnules many, filiform-stalked, subrhombic, membranous, cuneate at the base, dentate or incised above, delicately many-veined, jointed with the stalk, 8-25 mm. long; sori few or several, roundish or oblong.

In caves, sink-holes and on steps, Abaco, Andros, New Providence, Eleuthera :Florida; Jamaica; Cuba to St. Thomas and St. Croix; St. Kitts to Tobago : continental tropical America. The fern recorded by Coker as Adiantum. Capillus-Teneris L., is, apparently, this species. Slender MaIden-mair FerN. 
2. Adiantum melanoleùcum Willd. Sp. Pl. 5: 443. 1910.

Rootstock short. Stipes slender, smooth, nearly black, shining, 1-3 dm. long. Blades mostly 2-pinnate, sometimes only once pinnate, $1-4 \mathrm{dm}$. long, glabrous; pinnules usually many, sessile, obliquely oblong, thin, 8-25 mm. long, irregularly toothed or lacerate on the upper and outer margins, the lower margin entire or nearly so; uppermost segments commonly confluent; sori few, oblong or semilinear.

In sink-holes, New Providence, Eleuthera :-Florida ; Jamaica ; Cuba ; Hispaniola ; Porto Rico. DARK MAIDEN-HAIR FERN.

\section{SPHENÓMERIS Maxon, Journ. Wash. Acad. Sci. 3: 144. 1913.}

Slender mostly small ferns, with creeping rootstocks covered by hair-like scales, the leaves 3-4-pinnately divided into narrow cuneate segments, the veins free. Sori borne solitary on the terminal margins of the segments, the indusium cup-like, attached at the base and sides. [Greek, referring to the wedgeshaped leaf-segments.] A few species of tropical and subtropical regions, the following typical.

1. Sphenomeris clavàta (L.) Maxon, Journ. Wash. Acad. Sci. 3: 144. 1913.

Adiantum clavatum L. Sp. Pl. 1096. 1753.

Davallia clavata J. E. Smith, Mem. Acad. Turin 5: 415. 1790.

Odontosoria clavata J. Smith, Hist. Fil. 264. 1875.

Rootstock short, 2-7 cm. long. Leaves often many, glabrous, nearly erect, close together, 1.5-6 dm. long, the smooth straw-colored stipe usually shorter than the much divided blade; leaf-divisions alternate; ultimate-segments 8-15 $\mathrm{mm}$. long, 1-2.5 $\mathrm{mm}$. wide at the truncate apex.

In sink-holes, most abundant in pine-lands, rarely on cliffs, Abaco, Great Bahama, Andros, liew Providence, Rose Island, Great Guana Cay, Cat Island, Eleuthera :Florida; Jamaica; Cuba. PINE-LAND FerN.

\section{BLÉCHNUM L. Sp. Pl. 1077. 1753.}

Terrestrial ferns with stout rootstocks and clustered pinnate leaves, the veinlets of the fertile pinnae joined transversely near the base. Sori linear, contiguous, parallel with the midvein of leaf-segments and close to it, the indusium membranous. [Greek, tasteless.] Forty species or more, mostly tropical in distribution. Type species: Blechnum orientale $\mathrm{L}$.

\section{Blechnum serrulàtum L. C. Rich. Act. Soc. Nat. Paris 1: 114. 1792.}

Leaves erect, tufted, 3-9 dm. high, rather stiff, the plants often forming large colonies. Blades subcoriaceous, oblong-lanceolate, once pinnate, glabrous; petiole stout, shorter than the blade; pinnae numerous, oblong, linear or oblonglanceolate, sessile, mostly close together, obtuse or acute, 3-8 $\mathrm{cm}$. long, the upper ones fertile, all incised-serrulate; veins numerous, delicate, free beyond the sori; sori approximate to the strong midvein, conspicuous; fertile segments narrower than the sterile.

Borders of swamps and lagoons, Andros, New Providence :-Florida ; West Indies ; continental tropical America. MARSH FERN. 


\section{ASPLÈNIUM L. Sp. Pl. 1078. 1753.}

Large or small ferns with entire lobed pinnate, 2-3-pinnate, or pinnatifid leaves, and linear or oblong sori oblique to the midribs or rachises. Leaves nostly uniform. Veins free. Indusia straight or curved, opening toward the niidribs. [Ancient Greek name; some species were supposed to be remedies for diseases of the spleen.] A genus of some 400 species, of very wide geographical distribution. Type species: Asplenium Trichomanes L.

\section{Asplenium dentàtum L. Sp. Pl. 1080. 1753.}

Petioles tufted, 5-15 $\mathrm{cm}$. long, naked, weak, blackish below. Fertile leafblades 5-12 cm. long, with 6-8 pairs of stalked oblong or rhombic pinnae, the lower side truncate with a curve, the outer edge irregularly crenate; sterile leaves similar but with shorter petioles; rachis naked; sori copious.

In a cave, New Providence ; in a deep sink-hole, Cat Island:-Florida; Bermuda ; Jamaica; Cuba; Hispaniola; Guadelope; Barbados; Mexico and Central America. 'TOOTHED SPLEENWORT.

Schoepf records observing Asplenium rhizophyllum L., and A. marinum L., on New Providence in 1784; we do not know what ferns he had in mind.

\section{PITYROGRÁMIMA Link, Handb. 3: 19. 1833.}

Terrestrial ferns, with tufted, mostly bipinnate leaves, usually whitepowdery or yellow-powdery on the under side, the sori dorsal, linear along the veins, nearly confluent. Indusia wanting. [Greek, bran-fern, with reference to the powdery under leaf-surfaces.] Ten species, or more, natives of tropical and subtropical regions. Type species: Acrostichum chrysophyllum Sw.

1. Pityrogramma calomelànos (L.) Link, Handb. 3: 19.1833.

Acrostichum calomelanos L. Sp. Pl. 1072. 1753.

Gymnogramme calomelanos Kaulf. Enum. Fil. 76. 1824.

Neurogramme calomelanos Diels in E. \& P. Nat. Pfl. 14: 264. 1899.

Rootstock short, rather stout, erect or nearly so. Leaves tufted, erect or arching, ovate to ovate-lanceolate in outline, 2-pinnate, 2-8 dm. long, the dark brown shining petiole usually shorter than the blade; rachis dark brown, shining; pinnae lanceolate, acuminate, usually white-pulverulent beneath; pinnules lanceolate, acute or acuminate, dentate or entire, chartaceous, decurrent, the upper commonly confluent.

Sink-hole, Smith Hill Coppice, Andros:-West Indies; continental tropical America. STLtER-FERN.

\section{POLYPÒDIUM [Tourn.] L. Sp. Pl. 1082. 1753.}

Pinnate or simple ferns with stipes articulated to the creeping rootstocks. Sori hemispheric, dorsal, in one or more rows on either side of the midribs. Indusium none. Veins free or variously anastomosing. [Greek, in allusion to the knob-like prominences on the rootstocks of some species.] About 350 species, of wide distribution, mostly tropical. Type species: Polypodium vulgare L.

Rootstocks slender, wide-creeping, the leaves distant; sori deeply impressed.

Rootstocks thicker, short-creeping, the leaves approximate; sori superficial.

1. P. polypodioides.

2. P. squamatum. 
1. Polypodium polypodioides (L.) Watt, Can. Nat. 11: 158. 1866.

Acrostichum polypodioides L. Sp. Pl. 1068. 1753.

Polypodium incanum Sw. Fl. Ind. Oce. 3: 1645. 1806.

Rootstock widely creeping, woody, covered with small brown scales. Stipes densely appressed-scaly, 2.5-10 $\mathrm{cm}$. long; blades oblong-lanceolate in outline, acute, coriaceous, evergreen, 3-15 $\mathrm{cm}$. long, $2.5-4 \mathrm{~cm}$. wide, cut very nearly or quite to the rachis into entire, oblong or linear-oblong, obtuse segments, glabrous or nearly so on the upper surface, the lower densely covered with gray unappendaged peltate scales with darker centres, as are also the rachises; veins indistinct, usually once forked, connected or free.

On trees, especially in coppices, Abaco, Great Bahama, Andros, New Providence, Crooked Island :- southeastern United States; Jamaica; Cuba to St. Jan and Trinldad; continental tropical America. GRAY POLYPODY.

\section{Polypodium squamàtum L. Sp. Pl. 1806. 1753.}

Rootstock stout, creeping, covered with linear, ciliate scales. Stipes scaly, 5-25 cm. long; blades oblong-lanceolate in outline, $2-4 \mathrm{dm}$. long, 4-10 $\mathrm{cm}$. wide, coriaceous, evergreen, cut nearly or quite to the rachis into entire linear, acute or obtusish segments; rachis and under surface of the leafsegments densely covered with appressed scales with linear, ciliate appendages; veins hidden.

On trees, Conch Sound, Andros :-Jamaica ; Cuba ; Hispaniola ; Porto Rico. Scaly POLYYODY.

\section{PHIEBÒdIUM [R. Br.] J. Smith in Hook. Journ. Bot. 4: 58.1841.}

Large, mostly epiphytic ferns, with stout creeping chaffy rootstocks, and deeply pinnatifid, rather thick, drooping or spreading leaves, the veins anastomosing. Sori dorsal, orbicular, without indusia, mostly in 1 row or more, parallel with the midvein of the leaf-segments, usually borne at the end of a pair of free veinlets. [Greek, referring to the veins.] Perhaps 10 species, tropical and subtropical, the following typical.

\section{Phlebodium aùreum (L.) J. Smith in Hook. Journ. Bot. 4: 59. 1841.}

Polypodium aureum L. Sp. P1. 1087. 1753.

Rootstock short and stout, creeping, densely clothed with linear-lanceolate membranous acuminate scales. Stipe stout, glabrous, 1-2.5 cm. long. Blade once-pinnate, glabrous, pale and glaucescent, $1.5 \mathrm{~m}$. long or less, submembranous, the lanceolate segments more or less united near the rachis, acuminate, acute or obtusish, $0.7-2 \mathrm{dm}$. long, reticulate-reined; sori large, mostly in 1 or 2 rows on each side of the midvein.

On trees, especially palmettos, Great Bahama, Whale Cay, Andros, New Providence, Eleuthera, Cat Island, Crooked Island:-Florida; West Indies; continental tropical America. Recorded by Dolley as Pteris aurea. SERPENT-FERN.

\section{PHyMatòdes Presl, Tent. Pter. 195. 1836.}

Slender creeping or climbing ferns with elongated rootstocks or stems and simple, short-petioled leaves. Sori dorsal, circular, in 1 or 2 rows on each side of the midvein; indusium wanting. Veins delicate, usually inconspicuous, copiously anastomosing, their $\epsilon$ nds sometimes enlarged. [Greek, a swelling.] Perhaps 50 species of tropical and subtropical regions. Type species: Polypodium phymatodes $\mathrm{L}$. 
1. Phymatodes exíguum (Hew.) Underw. Torreya 3: 18. 1903.

Polypodium exiguum Hew. Mag. Nat. Hist. II. 2: 458. 1838.

Polypodium Swartzii Baker, in Hook. \& Baker, Syn. Fil. ed 2, 357. 1874.

Rootstocks ereeping on trees or shrubs, slender, elothed with brown linearlanceolate scales, simple or branched, sometimes $8 \mathrm{dm}$. long. Leaves thin, various, linear, oblong, lanceolate or oblanceolate, 5-10 cm. long, 5-15 mm. wide, acute or obtuse at the apex, narrowed at the base into petioles 4-12 $\mathrm{mm}$. long, entire or slightly undulate; sori mostly in 2 rows, one row on each side of the midvein.

On tree-trunks in coppices, Andros, New Provldence:-Florida; Jamaica ; Cuba to St. Jan; St. Crolx; Montserrat. CLimbing Polypody.

\section{CAMPYLONÉURUM Presl, Tent. Pter. 189. 1836.}

Tufted ferns, with large narrow entire leaves. Sori dorsal, mostly in 1 or 2 rows on each side of the primary veins; indusium none. Primary venation regularly pinnate, the veins connected by nearly parallel veinlets forming regular areoles. [Greek, crooked-nerved.] Twenty species or more, natives of tropical and subtropical regions, the following typical.

1. Campyloneurum Phyllitidis (L.) Presl, Tent. Pter. 190. 1836.

\section{Polypodium Phyllitidis L. Sp. PI. 1083. 1753.}

Rootstock short, stout. Leaves several or many, short-petioled, broadly linear, narrowed to both ends or rarely obtuse at the apex, 3-10 dm. long, 2-10 $\mathrm{cm}$. wide, rather firm in texture, smooth and shining; sori small, often very numerous.

On trees and in sink-holes in copplces, Abaco, Great Bahama, Andros, New Providence, Crooked Island:- Florlda; West Indies; continental troplcal America. STRAP-FERN.

15. TECTÀrIA Cav. Anales Hist. Nat. 1: 115. 1799.

Usually terrestrial ferns, with creeping or horizontal rootstocks, and thin broad lobed, coarsely toothed or pinnate leaves. Sori orbicular, dorsal, borne on the backs of veins. Indusia orbicular to reniform. Veins copiously anastomosing, forming many areolae. [Latin, referring to the indusia.] Over 40 species, natives of tropical and subtropical regions. Type species: Polypodium trifoliatum L.

Fully developed leaves not much longer than broad.

Basal lobes and usually all lobes of the fully developed leaf long-acuminate; leaves ratber firm in texture.

At least the basal lobes obtuse, merely acute or rarely acumlnate; leaves thin in texture.

Fully developed leaf 2-3 times as long as broad, the lobes all rounded.

1. T. heracleifolia.

2. T. minima.

3. $T$. Amesiana.

1. Tectaria heracleifòlia (Willd.) Underw. Bull. Torr. Club 33: 200. 1906.

Aspidium heracleifolium Willd. Sp. Pl. 5: 217. 1810.

Rootstock stout, brown-sealy. Leaves 2-10 dm. high; petioles brown, shining, as long as the blades or shorter; blades various in form, rather firm in texture, the finely developed ones broadly triangular, little longer than wide, at least the lower lobes or segments long-acuminate; less developed leaves ovate, the apex long-acuminate; sori usually many, in 2 more or less complete rows parallel with the lateral veins, $2-2.5 \mathrm{~mm}$. in diameter.

Coppices, New Providence :-Florida ; Texas; West Indies ; continental tropical America. HALBERD-FERN. 
2. Tectaria minima Underw. Bull. Torr. Club 33: 199. 1906.

Rootstock slender, short, brown-scaly. Leaves 0.8-4 dm. long; petioles green, or brownish, slender, commonly much longer than the blades, often very slender; blades various, thin, ovate or ovate-lanceolate, but the fully developed ones not much longer than broad, lobed, pinnatifid or sometimes trifoliolate, the basal lobes obtuse, acute or rarely acuminate; sori usually few, scattered, or in 1 or 2 more or less complete rows parallel with the lateral veins, 1-1.5 $\mathrm{mm}$. in diameter.

In sink-holes, wells and caves, Abaco, Andros, New Providence, Eleuthera, Cat Island :-Florida ; Cuba. SMALL HALBERD-FERN.

Recorded by Mrs. Northrop as Tectaria trifoliata (L.) Cav. and by Dolley as Aspidium trifoliatum Sw.

\section{Tectaria Amesiàna A. A. Eaton, Bull. Torr. Club 33: 479. 1906.}

Rootstock short, stout. Leaves $4 \mathrm{dm}$. long or less; petioles rather slender, about as long as the blades or shorter; blades narrowly ovate or ovate-lanceolate in outline, rather thin, pinnate-pinnatifid, the segments and lobes obtuse or rounded, the lower 1 to 3 pairs of pinnae short-stalked; sori scattered or in 1 or 2 more or less rows paralle! with the venation, $1-1.5 \mathrm{~mm}$. in diameter.

Eleuthera, at Gregory Town (Coker 372) ; referred to this species with hesitation. Known otherwise only from one station in Florida. AMres' HaLberd-FERN.

\section{DRYÓPTERIS Adans. Fam. Pl. 2: 20, 550. 1763.}

Ferns with simple to 2-3 pinnate or pinnatifid leaves and round sori usually borne on the backs of the veins, the fertile and sterile leaves usually similar. Indusium flattish, roundish-reniform, superior, fixed by its sinus, or the indusium minute and vestigial or altogether wanting. Stipe continuous, not jointed with the rootstock. Veins free or anastomosing. [Greek, signifying oak-fern, in allusion to the forest babitat of most species.] Species several hundred, of wide distribution. Type species: Polypodium Filix-mas L.

Leaves mostly erect; veins free.

Pinnae elongated, linear-lanceolate.

Pinnae lanceolate.

Leaves reclining, often rooting at the tip.

Stlpe and rachis laxly puberulent, many of the halrs simple; veins with several branches, the basal ones joined.

Stipe and rachis closely stellate-puberulous, nearly or quite devoid of long simple hairs; veins mostly forked, usually free.

1. D. augescens.

2. Dormalis.

3. D. reptans.

4. D. cordata.

1. Dryopteris augéscens (Link) IC. Chr. Danske Vidensk, Selsk. Skr. VII. $10^{2}$ : 182. 1913.

Aspidium augescens Link, Fil. Sp. 103. 1841.

Rootstock horizontal, rather stout, scaly. Leaves once pinnate, mostly erect, sometimes $1 \mathrm{~m}$. long or longer, lanceolate in outline, the petiole usually shorter than the blade, puberulent and sealy at the base, otherwise smooth; pinnae many, close together, linear-lanceolate, sessile, often $1.5 \mathrm{dm}$. long, 1-2 $\mathrm{cm}$. wide, deeply pinnatifid, slender-tipped, more or less pubescent at least beneath, the segments ovate-lanceolate, acute, entire, the lower ones somewhat larger than the others; veins free.

Pine-lands, coppices, caves and sink-holes, Great Bahama, Andros, New Providence, Eleuthera:- Florida; Cuba; Central America. Reported by Mrs. Northrop as Dryopteris patens (Sw.) Kuntze.

2. Dryopteris normàlis C. Chr. Arkiv. Bot. 9: 31. 1910.

Rootstock horizontal, slender, scaly. Leaves erect or ascending, once pinnate, $3-15 \mathrm{dm}$. long, lanceolate to ovate-lanceolate in outline, the petiole usually 
shorter than the blade, puberulent and usually bearing some scales toward the base, otherwise smooth; pinnae usually many, rather close together, sessile, mostly less than $1 \mathrm{dm}$. long, 1-2 cm. wide, lanceolate, long-tipped, deeply pinnatifid, pubescent beneath, the segments ovate, obtuse or acute, entire, the lower pair somewhat larger than the others; veins free.

Pine-lands, coppices, sink-holes and marshes, Abaco, Andros, New Providence, Lignum Vitae Cay, Rose Island. Eleuthera, Cat Island, Acklin's Island, Watling's Island, Great Guana Cay, Great Exuma, North Caicos:-Florida; West Indies. Referred to $D$. patens by Dolley, by Mrs. Northrop and by Coker.

Dolley records a fern under the name Aspidium incisum Griseb.; this name applies to a West Indian Dryopteris not known to inhabit the Bahamas. The record may apply to one of the preceding species.

3. Dryopteris réptans (Gmel.) C. Chr. Ind. Fil. 288. 1905.

Polypodium reptans Gmel. Syst. 2: 1309. 1791.

Goniopteris reptans Presl, Tent. Pter. 182. 1836.

Phegopteris reptans D. C. Eaton, Bull. Torr. Club 10: 101. 1883.

Rootstock short, ascending or erect. Leaves usually several, reclining or arching, 2.5-9 dm. long, once pinnate, often rooting at the apex and sometimes along the rachis, the slender petioles mostly shorter than the blades; pinnae several or many, oblong to lanceolate, about $4 \mathrm{~cm}$. long or less, pubescent, obtuse or acute at the apex, subtruncate at the base, crenate, sessile or very nearly so ; veins slender; sori commonly few, borne about midway between the midvein and the margin; indusia vestigial or none.

In caves, and sink-holes in coppices, Abaco, Andros. New Providence, Eleuthera, Cat Island:-Florida: West Indies. Recorded by Mrs. Northrop as Dryopteris asplenioides Baker. WALKING WOOD-FERN.

4. Dryopteris cordàta (Fée) Urban, Symb. Ant. 4: 18. 1903.

Phegopteris cordata Fée, Gen. Fil. 241. 1850-52.

Aspidium reptans cordata Mett. Asp. 99. 1858.

Similar to $D$. reptans, but usually smaller, and with entire or merely undulate pinnae, and having the veins usually free.

In sink-holes in pine-lands, Andros :-Cuba ; Porto Rico; recorded from Jamaica. Recorded by Mrs. Northrop as Goniopteris reptans cordata.

Doliey records a fern as Aspidium adiantifolium Sw., but there is no such published species. Schoepf's record of Polypodium pubescens L. was probably based on some species of Dryopteris.

\section{NEPHRóLEPIS Schott, Gen. Fil. pl. 3. 1834.}

Leaves spreading or pendent, pinnate, elongated; pinnae numerous, approximate, jointed at the base, with whitish dots on the upper surface. Sori round, arising from the apex of the upper branch of a vein, usually near the margin. Veins free. [Greek, referring to the shape of the indusium.] About 12 species, natives of tropical and warm-temperate regions. Type species: Polypodium exaltatum L.

Indusia reniform; leaves $7-20 \mathrm{~cm}$. broad.

Indusia orbicular; leaves $20-40 \mathrm{~cm}$. broad.
1. N. exaltata.

2. N. biserrata.

1. Nephrolepis exaltàta (L.) S.chott, Gen. Fil. under pl. 3. 1834.

Polypodium exaltatum L. Syst. ed. 10, 1326. 1759.

Petioles $7-15 \mathrm{~cm}$. long; leaf-blades $1 \mathrm{~m}$. long or less. Pinnae sessile, lanceolate, sometimes crenulate, $2.5-8 \mathrm{~cm}$. long, the upper side auricled at the base, the lower rounded, the rachis nearly naked; sori almost marginal, covered with firm distinctly reniform indusia.

In a cave, East Caicos:-Bermuda; Fiorida ; West Indies; continental tropical America; Old World tropics. SWORD-FerN. Boston FenN. 
2. Nephrolepis biserràta (Sw.) Schott, Gen. Fil. under pl. 3. 1834.

Polypodium biserratum Sw. in Schrad. Journ. Bot. 1800²: 32. 1801.

Similar to the preceding species, the petioles $10-20 \mathrm{~cm}$. long, the leafblades up to $1.2 \mathrm{~m}$. long. Pinnae lanceolate, sessile, acute or acuminate, serrulate, crenulate or entire, 10-20 $\mathrm{cm}$. long, 10-18 $\mathrm{mm}$. wide, the base subtruncate or auricled on the upper side, rounded on the lower; sori close to the margin, the indusia nearly orbicular.

In a cave, East Caicos, with the preceding species:-Florida; West Indies; Central America. SWord FErn.

\section{Family 2. SCHIZAEÀCEAE Reichenb.}

Ferns of various habit, with simple or pinnate leaves. Sporanges borne in spikes or panicles, on modified leaves or leaf-segments, ovoid, sessile, provided with an apical ring, opening vertically by a longitudinal slit. Several genera and about 100 species, mainly tropical.

\section{ANÈMIA Sw. Syn. Fil. 6, 15̄5. 1806.}

Small to medium-sized ferns, mostly with horizontal or creeping rootstocks, the leaves distichous or tufted, pinnatifid or decompound, often dimorphous (the sterile ones quite different from those bearing sporanges). Venation mostly free.' Sporanges borne in a single row on the margins of the ultimate segments of fertile pinnae, with or without an indusium. [Greek, wind.] Thirty species or more, of tropical and subtropical America. Type species: Anemia Phyllitidis L.

Leaves wholly fertile or wholly sterile.

Segments of sterile leaf obovate, cuneate.

Segments of sterile leaf rhombic-ovate or rhombic-oblong. only the basal segments of the leaf fertile.

1. A. Wrightii.

2. A. cicutaria.

3. A. adiantifolia.

1. Anemia Wríghtii Baker in Hook. \& Baker, Syn. Fil. 435. 1868.

\section{Ornithopteris Wrightii Millsp. Field Col. Mus. Bot. 3: 14.1903.}

Rootstock creeping, finely hairy. Leaves membraneous, dimorphous. Sterile leaves 5-12 cm. long, with slender straw-colored stipes 3-7 $\mathrm{cm}$. long, the blade ovate or rhombic-ovate in outline, $2-4 \mathrm{~cm}$. wide, sparingly pilose; pinnae 3 or 4 pairs, ascending, rather distant; ultimate leaf-segments obovate, cuneate, dentate or incised at the apex, or entire. Fertile leaves about twice as long as the sterile ones, their stipes much longer than the panicles of sporanges.

In a sink-hole, coppice near Fresh Creek, Andros:-Cuba. A little-collected plant, perhaps not specifically distinct from the following specles. WrigHT's ANEMIA.

\section{Anemia cicutària Kunze; Spreng. Syst. 4: 31. 1834.}

Anemia bipinnata Moore, Index Fil. exvi. 1857.

Ornithopteris cicutaria Underw. Mem. Torr. Club 12: 15. 1902.

Rootstock short, densely brown-hairy. Leaves membranous, dimorphous. Sterile leaves $1.5 \mathrm{dm}$. long or less, the slender, straw-colored stipes about as long as the blades or shorter; blades deltoid-ovate in outline, 2-3-pinnate, with 3-7 pairs of pinnae, the ultimate segments rhombic-ovate or rhombic-oblong, dentate or incised above. Fertile leaves much longer than the sterile ones, their stipes longer than the panicles of sporanges.

In sink-holes, Abaco, Andros, New Providence:-Cuba ; Yucatan. Parsley Axemia. 
3. Anemia adiantifolia (L.) Sw. Syn. Fil. 157. 1806.

Osmunda adiantifolia L. Sp. Pl. 1065. 1753.

Ornithopteris adiantifolia Bernh. Neues Journ. Bot. Schrad. $1^{2}$ : 50. 1806.

Rootstock creeping, densely hairy. Leaves distichous, close together, subcoriaceous, 1.5-8.5 dm. long, 2-4-pinnate, ovate to subpentagonal in outline, the straw-colored stipe usually as long as the blade or longer; pinnae several or numerous, the lower the longer, the ultimate segments commonly close together, deltoid to oblong or ovate, obtuse or acutish, entire or few-toothed, 4-15 mm. long. Fertile leaf like the sterile, but the 2 lower pinnae transformed into panicles of sporanges, which are slender-stalked and erect.

In sink-holes and in pine-lands, Abaco, Great Bahama, Andros, New Providence, Eleuthera, Cat Island :-Florida; West Indies ; Central America; northern South america. MaIden-hair ANemia.

\section{Order 2. SALVINIÀLES.}

Aquatic or uliginous herbs with entire or 2-lobed, filiform, or 4-foliolate leaves. Spores of two kinds and sizes (microspores and macrospores) contained in sporocarps.

\section{Family 1. MARSILEÀCEAE R. Br.}

Perennial herbaceous plants rooting in mud, with slender creeping rootstocks and 2- or 4-foliolate or filiform leaves. Asexual propagation consisting of sporocarps borne on peduncles which rise from the rootstock near the leaf-stalk or are consolidated with it, containing both macrospores and microspores. The macrospores germinate into prothallia which bear archegonia, while the microspores grow into prothallia bearing antheridia. Three genera and some 45 species of wide distribution.

\section{MARSÍILA Sp. Pl. 1099. 1753.}

Marsh or aquatic plants, the leaves commonly floating on the surface of shallow water, slender-petioled, 4-foliolate. Peduncles shorter than the petioles, arising from their bases or more or less adnate to them. Sporocarps ovoid or bean-shaped, composed of two vertical valves with several ${ }^{\bullet}$ transverse compartments (sori) in each valve. [Name in honor of Giovanni Marsigli, an Italian botanist, who died about 1804.] About 40 species, widely distributed. Type species: Marsilea quadrifolia L.

Leaflets obliquely linear-oblanceolate.

Leaflets broadly obovate-cuneate.

1. M. Nashii.

2. M. vestita.

1. Marsilea Náshii Underwood, Bull. N. Y. Bot. Gard. 4: 137. 1906.

Plants forming compact dense mats in sandy soil. Stems short, slender, smooth or with a few appressed slender hairs, forming nodes at intervals of 3-10 $\mathrm{mm}$; ; leaves rising in clusters from short lateral branches; petioles filiform, 5-8 cm. long; leaf-divisions narrow, cutlass-shaped, 10-12 mm. long, 2 $\mathrm{mm}$. wide, sparsely covered with white appressed hairs; sporocarps abundant, solitary on short peduncles, compressed-oval, averaging $7 \times 4 \times 2 \mathrm{~mm}$., the raphe ending in a short, straight tooth with a second similar basal tooth $1 \mathrm{~mm}$. beyond, the surfaces covered with appressed hairs, becoming smoother with age; sporangia about 12 pairs, elongate-oval, $4 \mathrm{~mm}$. long by $1 \mathrm{~mm}$. thick, the gelatinous stalk $2.4 \mathrm{~cm}$. long; macrospores about $8-10$ in each sporangium, oval; microspores numerous, globose.

Smith's Thatch Pond, Inagua. Endemic. NASH's PEPPERWORT. 
2. Marsilea vestita Hook. \& Grev. Ic. Fil. pl. 159. 1831.

Rootstock slender. Petioles slender, 5-13 cm. high; leaflets entire or toothed; sporocarps 4-8 $\mathrm{mm}$. long, 4-6 mm. wide, with a short raphe, a short and blunt lower tooth and an acute and sometimes curved upper one, densely covered with soft spreading narrow hair-like scales; sori 6-11 in each valve.

Wet sandy soll, Acklin's Island and South Calcos :-southern and western United States. The Bahama speclmens are sterile and are referred to this species with doubt. Hairy PePperwort.

\section{Order 3. LYCOPODIÀLES.}

Spores produced in sporanges, which are borne in the axils of scalelike or elongated leaves.

Spores all alike.

Spores of two kinds.
Fam. 1. Psilotaceat.

Fam. 2. Selaginellaceae.

\section{Family 1. PSILOTÀCEAE Pritzel.}

\section{Psilotum Familiy.}

Perennial slender terrestrial or epiphytic plants. Sporanges sessile in the axils of the leaves, 2-3-celled, opening by valves at the apex. Spores uniform. Only the following genus, and the monotypic Tmesipteris of Australasia.

\section{PSILOTUM Sw. in Schrad. Journ. Bot. 1800²: 109. 1801.}

Terrestrial or sometimes epiphytic, the stem dichotomously forked. Leaves alternate, reduced to scales. Sporanges 3-celled, opening by 3 valves at the apex. Spores mealy, oval or elongated-reniform. [Greek, referring to the nearly naked stems and branches.] A few species of tropical and subtropical distribution, the following typical.

1. Psilotum nùdum (L.) Griseb. Veg. Kar. 130. 1857.

Lycopodium nudum L. Sp. Pl. 1100. 1753.

Psilotum triquetrum Sw. in Schrad Journ. Bot. 1800²: 109. 1801.

Stems erect, 2-3 dm. tall, or, when in caves or on trees, often pendent, 3 -angled at the base, copiously forked. above, the ultimate divisions with 3 wing-like angles; leaves remote, awl-like, less than $2 \mathrm{~mm}$. long; sporanges in interrupted spikes.

On tree-trunks and in sink-holes, Abaco, New Providence, Andros, Cat Island, Great Exuma :-Florida ; Bermuda; West Indies ; continental tropical America and Old World tropics. Psilotum.

\section{Family 2. SELAGINELLÀCEAE Underw.}

Terrestrial, annual or perennial, moss-like plants with branching stems and scale-like leaves, which are many-ranked and uniform, or 4-ranked and of two types spreading in two planes. Sporanges 1-celled, solitary in the axils of leaves which are so arranged as to form more or less quadrangular spikes, some containing 4 macrospores (macrosporanges), others containing numerous microspores (microsporanges), which develop into small prothallia, those from the macrospores bearing archegones, those from the microspores antherids. The family consists of the following genus: 
1. SELAGINÉlidA Beauv. Prod. Aetheog. 101. 1805.

Characters of family. [Name diminutive of Selago, ancient name of a Lycopodium.] About 600 species, widely distributed, most abundant in tropical regions.

1. Selaginella Eàtoni Hieron.; Small, Ferns Trop. Florida 67. 1918.

Pale green, matted, the slender branches prostrate, $1-4 \mathrm{~cm}$. long, creeping. Leaves in two planes, those of the lower plane ovate to elliptic, spreading, 1.5 $\mathrm{mm}$. long or less, abruptly acute or obtuse, sparingly setaceous-serrulate or entire; those of the upper plane somewhat smaller, lanceolate, acuminate, those subtending sporanges near the ends of the branches lanceolate or ovatelanceolate, acuminate-aristate; macrospores tubercled, about $0.2 \mathrm{~mm}$. in diameter.

Molst shaded rocky situations, Abaco, Andros:-Florida. Eaton's SELAginelua.

\section{Phylum 3. BRYÓPHYTA.}

\section{MONSES AND LIVERWORTS.}

Small plants, producing minute usually spherical bodies, called spores, in capsules, from which arise a protonema on which are borne the plants bearing archegonia and antheridia, from which the fruit is formed, which in turn bears spores.

There are two classes which differ from each other as follows:

Stems erect or prostrate, having leaves more or less equally developed on all sides; calyptra at the apex of the capsule.

Stems usually prostrate, with the leaves, when present, unequally developed on the upper and lower surfaces; calyptra at the base of the capsule.

Class 1. Musci.

Class 2. Hepaticae.

\section{Class 1. MÚSCI.}

\section{Mosses.}

Contributed by Elizabeth G. Britton.

Terrestrial, epiphytic, or rarely aquatic plants, showing two distinctly marked but closely connected and continuous phases of growth, or alternate generations, usually having stem, leaves and rhizoids but not true roots; stems arising from a more or less ephemeral protonema, which originates from the spore, forming either a filamentous or thallose growth. Sexual organs borne either apically or laterally on the stem, usually in special buds; antheridia and archegonia on the same plant or on separate plants; antheridium containing ciliate sperms; archegonium a single egg, after the fertilization of which the embryo develops into the fruit, rupturing the walls of the archegonium in its growth; the upper part of the archegonium is carried up by the elongation of the pedicel, forming the calyptra, which in many mosses covers and protects the capsule while it is developing. Capsule usually with a central axis forming 
the columella, around which the spore-sac is developed, usually separated from the walls by air-spaces and chlorophyl-bearing tissue. Capsule splitting regularly by a lid or slits, or breaking irregularly; when regular, frequently developing teeth around the mouth, forming the peristome, which serves in the protecting and scattering of the spores.

\section{Order 1. BRYÀLES.}

Protonema usually filamentous; calyptra apical; pedicel more or less elongated, apical or lateral; capsule generally with a well-developed lid; peristome present or absent, neck usually with stomata.

A. Acrocarpous Mosses:-Main stems erect, simple or branching; capsules terminal on the stems.

1. Plants pale green, almost white, leaves often iridescent; vein wider than the blade of leaf, blade often lacking.

2. Plants bright or dark green; vein narrower than the blade of leaf.

a. Leaves two-ranked, with the blades duplicated on one side at base.

Fam, 2. FisSIDENTACEAE.

* Species only known from sterile specimens in the Bahamas. Propagating by gemmae or brood-bodies.

Brood-bodies borne in clusters at the summit of longer apical leaves. Calymperes Richardi in Fam. 3. CALYMPERACEAE.

Brood-bodies borne on filaments in the axils of the upper leaves.

Hyophila and Barbula in Fam. 4. Tortulaceae.

Not propagating by gemmae or brood-bodies.

Costa thickened and spinose above, ending below the coarsely toothed. apex. Syrrhopodon Gaudichaudii in Fam. 3. CALYMPERACEAE. Costa thick but not spinose, ending below the minutely toothed apex. Desmatodon Garberi in Fam. 4. TORTULACEAE.

Costa not thickened nor spinose, ending in the mucronate apex.

** Species usually fruiting. Trichostomum in Fam. 4. Tortulaceae.

$\dagger$ Peristome and annulus none.

- Leaves papillose above with minute papillae.

Leaves not papillose.

Hymenostomum flavescens in Fam. 4. TORTULACEAD.

Macromitrium mucronifolium in Fam. 5. ORTHOTRICHACEAE.

†† Peristome and usually the annulus present.

† Peristome single, annulus double.

Teeth erect, not twisted.

Teeth inclined, twisted 1-2 times.

Gyroweisia Barbula in Fam. 4. ToRTulaceaE.

¥ Peristome double.

Tortula agraria in Fam. 4. TORTULACEAE.

Capsule erect, the lid beaked; teeth erect, not twisted, deeply inserted; annulus none.

Schlotheimia in Fam. 5. ORThotrichachae.

Capsule nodding, lid not beaked; annulus double.

1. Teeth oblique, with apical appendages and united to a disc.

Fam. 6. FUNARIACEAE.

2. Teeth erect, without appendages and not united at apex.

Fam. 7. BRYACEAE.

B. Pleurocarpous Mosses:-Main stems procumbent; capsules terminal or lateral on the branches.

1. Fruit unknown in the Bahamas :

Propagating by brood-bodies, borne in clusters in the axils of the leaves.

Leaves minutely papillose, with small papillae terminal on each cell.

Margins revolute, entire, the vein ending below the apex.

Leucodontopsis in Fam. 8. LEUCODONTACEAE.

Margins flat, serrulate, the vein ending at apex.

Pireella in Fam. 9. Neckeraceat.

Propagating by brittle terminal buds and slender branchlets; leaves papillose, with several central papillae on each cell.

Papillaria in Fam. 10. Meteoriaceae.

2. Fruit on elongated, erect pedicels; peristome double.

a. Capsules erect and symmetric.

Stereophyllum in Fam. 11. Ev rodontaceat. 
b. Capsules horizontal or curved.

* Leaves minutely papillose, on the back.

Paplllae single and central on each cell.

Haplocladium in Fam. 12. Leskeaceae.

Papillae single and terminal at the end of each cell.

Mittenothamnium in Fam. 13. HYPNACEAE.

Papillae several in a row in the middle of each cell.

Taxithelium in Fam. 13. HrPNACEAE.

** Leaves not papillose, the cells smooth.

† Leaves uniform and regular; alar cells enlarged.

Vein lacking or short and double.

Peristome teeth without deep lamellae on the inner surface.

Isopterygium in Fum. 13. HYPNACEAE.

Peristome teeth with deep lamellae, especially at base.

Sematophyllum in Fam. 14. SeMatophyllaceae.

Vein single, ending in the middle of the leaf.

Amblystegium in Fam. 13. HYPNACEAE.

it Leaves of two kinds, the lateral shorter and broader; alar cells not enlarged.

Vesicularia in Fam. 13. HYPNACEAE.

\section{Family 1. LEUCOBRYÀCEAE C. Muell.}

\section{White Moss Family.}

Plants perennial, growing in dense pale green cushions; stems medium to large, branching; sometimes fragile and breaking off (thus propagating asexually); leaves crowded, vein broad, filling most of the leaf, the green cells of the leaf small, in a single central band between several layers of larger hyaline cells; blade very narrow, sometimes lacking. Pedicels erect, terminal; capsule erect or horizontal, regular or irregular; peristome single, teeth 8 or 16; lid beaked; calyptra cucullate. Nine genera and 229 species are known. (Named in reference to their pale green color.)

Leaves four times longer than wide, incurved, apex concave and lanceolate.

Leaves ten times longer than wide, recurved, apex flat, oblongapiculate.

1. Leucobryum.

2. Octoblepharum.

\section{LEUCOBRỸUM Hampe, Flora 20: 282. 1837.}

Characters of the family. A genus of 121 species, widely distributed in temperate and tropical regions. [Greek, in reference to the pale color of the plants.] Type species: Leucobryum glaucum (L.) Schimp.

1. Leucobryum álbidum (Brid.) Lindb. Oefv. Sv. Vet. Akad. Forh. 20: 403. 1863.

Dicranum albidum Brid. Musc. Rec. $2^{1}: 167.1798$.

Leucobryum glaucum albidum Cardot, Rev. Bryol. 38: 80. 1911.

Plants in dense, pale green cushions, seldom more than $3 \mathrm{~cm}$. high; stems crowded with branches; leaves numerous at the ends of the branches, incurved and concave when dry, spreading when moist from the base to a narrower concave point, 2-4 mm. long, ending in a sharp apex, the basal blades short, forming a narrow, colorless border of $3-5$ rows of cells; the vein composed of $2-4$ layers of large hexagonal clear cells with a central band of small green quad- randular cells. [Capsule terminal, on a slender pedicel, curved and furrowed when dry; lid beaked; teeth split to the middle; calyptra cucullate.]

Only found once, sterile, growing on rotten wood and logs in copplces, Conch Sound, Andros, New Jersey to Florida and Louisiana :-Cuba; Hispanlola; Mexico and Guatemala. Whire Moss. 


\section{OCTOBLÉPHARUM Hedw. Descr. 3: 15. 1791.}

Plants growing in loose or compact pale-green tufts, with dense branching stems. Leaves crowded at the ends of the branches, usually concave with a broader base and a narrow tapering apex, composed mostly of the broad thick costa which contains a central row of small green triangular cells, and several layers of hyaline cells above and below; the blade of the leaf is reduced to a few narrow hyaline cells on the basal margins or lacking. Pedicel short; capsule erect, symmetric, smooth; peristome single, of 8 or 16 lanceolate teeth; lid beaked; calyptra cucullate. [Greek, in reference to the 8 teeth.] Eighteen species have been described, mostly from tropical regions, the following typical.

1. Octoblepharum álbidum (L.) Hedw. Descr. 3: 15.1791.

Bryum albidum L. Sp. Pl. 1118. 1753.

Plants in loose, pale yellowish-green cushions; stems brittle; leaves iridescent, often broken and recurved when dry, up to $6 \mathrm{~mm}$. long by $0.5 \mathrm{~mm}$. wide; tip flat, longer than the base, ending abruptly in a cuspidate apex. Autoicous. Seta erect, 5-7 mm. long; capsule straight, smooth, 1-1.5 mm. long, narrowing to the mouth; teeth 8 , entire or perforate; lid beaked; spores rough.

On rotten wood and stumps or on palmetto, common in coppices of New Providence [type locality], Andros, Cat Island, Eleuthera and Crooked Island:-Florida and the West Indies. Widely distributed in tropical regions of both hemispheres. RAINBOW-MOSS.

\section{Family 2. FISSIDENTĀCEAE Bruch \& Schimp.}

\section{Fissidens Family.}

Small plants, usually growing in moist shady places, on earth or stones. Stems erect or decumbent, simple or sparingly branched; leaves few, always two-ranked and conduplicate, clasping at base, with a single vein and with an apical and dorsal prolongation of the blade especially in the upper leaves, except in Sorapilla. Pedicel terminal at apex of stems or on lateral buds; capsule ovoid or cylindric, straight or curved; calyptra cucullate; lid conic, often beaked, peristome red, single, of 16 entire or bifid teeth, often thickened at joints and either papillose or spiral at apex. A large family of 4 genera, containing some 570 species, abundant in temperate and tropical regions.

\section{FÍsSIDENS Hedw. Fund. 2: 91. 1782.}

Plants scattered or crowded into dense cushions. Stems becoming decumbent when old, with apical or rarely lateral branches; leaves with duplicate basal blades present, the apical and dorsal blades sometimes lacking or reduced in size in the lower leaves or in the bracts of the inflorescence; pedicels always exserted, often bent or curved; capsules erect, inclined or rarely curved; walls often thickened with collenchyma cells around the mouth, also the base of the lid; annulus small, often fugacious or lacking; peristome deeply inserted; teeth • bifid, usually bright red and forking, with long slender apical divisions, generally quite different from the basal segments of the teeth and often suddenly bent at a sharp angle. [Latin, in reference to the split teeth.] A large genus 
of about 125 species, widely distributed in temperate and tropical regions. Type species: Hypnum bryoides L.

Leaves entire, bordered all around, cells smooth.

Leaves serrate, bordered only at base of duplicate blade of uppermost leaves; cells papillose.

Leaves not bordered, margins serrate, cells mamillose.

1. F. monandrus.

2. F. Garberi.

3. . radicans.

1. Fissidens monándrus Mitt. Journ. Linn. Soc. 12: 598. 1869.

Plants small, pale-green, erect or decumbent; seldom more than 2-5 $\mathrm{mm}$. high; leaves 4-7 pairs, palmately spreading, and increasing in size upward to $2 \mathrm{~mm}$. long by $0.33 \mathrm{~mm}$. wide, overlapping and narrow at base; margins bordered all around; costa percurrent; cells smooth, somewhat oblique and hexagonal, those of the lower blades larger at base. Autoicous. Pedicel erect, bent at base, 3 to $4 \mathrm{~mm}$. high; capsule straight, seldom more than $1 \mathrm{~mm}$. long; peristome red, paler and spiral at apex; lid beaked; calyptra small; spores smooth.

Only known from one collection from a sink-hole, Farringdon Road, New Providence :-Florida; Cuba and the West Indies to South America. Diminutive Fissidens.

2. Fissidens Gàrberi Lesq. \& James, Proc. Am. Acad. Arts \& Sci. 14: 137. 1879.

Plants minute. Stems simple, seldom more than 2-3 mm. high, erect or decumbent; leaves 4-8 pairs, most numerous on the sterile plants, usually all unbordered, except the two uppermost leaves of the fruiting plants which are Ionger and narrower than the others; vein ending in the acute apex; margins minutely serrate, with acute or truncate teeth; cells dense, with 2-4 small papillae, basal cells larger, papillose only on the outer surface; perichaetial leaves bordered only at the base by an obscure border of 1-3 rows of cells. Dioicious. Pedicel terminal, erect, short, 1-2 mm.; capsule small, 0.6 to 1 $\mathrm{mm}$. straight; lid beaked; teeth spirally thickened at apex; spores smooth.

On rotten wood and rocks in sink-holes, copplces on Farringdon Road, New Providence :- F'lorida ; Loulsiana; West Indles and South America. GARBER's FISSIDENS.

3. Fissidens radicans Mont. Ann. Sci. Nat. (II.) 14: 345. 1840.

Plants in dense, bright-green cushions. Stems decumbent and recurved when dry, rarely erect or simple, branching repeatedly, rarely more than $1 \mathrm{~cm}$. high; leaves circinate, often brittle and broken off, 5-10 or rarely 20 pairs, up to $1.5 \mathrm{~mm}$. long by $0.33 \mathrm{~mm}$. wide; vein ending below the acute apex; cells swollen, mamillose on both surfaces above, and only on the outer below. Autoicous; antheridial buds sometimes numerous on the fruiting plants. Pedicel slender, erect, 3-4 mm. long; capsule up to $1 \mathrm{~mm}$.; lid beaked; calyptra small, apical; teeth papillose and spiral at apex; spores smooth.

On rotten wood in coppices, New Providence and Abaco:-Florida and the West Indies to continental tropical America. RADICANT Fissidens.

\section{Family 3. CALYMPERÀCEAE C. Muell.}

\section{Calymperes Family.}

Plants usually growing in dense dark green cushions on trees in shade, seldom fruiting but often propagating by brood-bodies, growing in clusters from the tips of specially modified leaves. Stems mostly erect and sparingly branched. Leaves often crowded at the ends of the branches, erect or spreading, broad and clasping at base, lanceolate or contracted into a spathulate apex; margins entire or serrate, often with a band of elongated 
submarginal cells, basal cells large, clear, smooth, rectangular; upper cells small, round, often papillose. Pedicel terminal, erect usually exserted; calyptra campanulate or cucullate; lid long-beaked; peristome single of 16 short teeth or lacking. A family of mostly tropical mosses, containing 2 genera and about 313 species.

Leaves with a sub-marginal border of long narrow cells on the hyaline base.

Leaves with a thickened or hyaline margin at base, which is often coarsely serrate or double above.

\section{Calymperes.}

2. Syrrhopodon.

\section{CALYMPÉRES Sw.; Schwaegr. Suppl. 1²: 333. 1816.}

Plants in dense mats; stems crowded, simple or branching; leaves curled and twisted when dry, base hyaline, often white and broader than the point, the upper leaves often contracted into a narrow apex, bearing brood-bodies, which serve to propagate the plants when sterile. Dioicous. Calyptra large, covering the capsule, spirally, ribbed and often rough at apex; lid beaked; peristome and annulus lacking. [Named in reference to the large calyptra.] About 200 species of tropical distribution. Type species: Calymperes lonchophyllum Schwaegr.

\section{Calymperes Richárdi C. Muell. Syn. I, 524. 1849.}

Plants erowded in dark green mats, showing the white hyaline base of the leaves when dry; leaves up to $3.5 \mathrm{~mm}$. long, ovate-lanceolate, tapering to a blunt point; vein stout, ending below the apex, papillose on both surfaces above; submarginal border of $2-3$ rows of cells, extending to apex, not distinct in the hyaline base; margins serrulate above. Dioicous. [Seta short, slightly exserted; calyptra spirally ribbed $2 \mathrm{~mm}$. long, persistent and clasping at base, split above; capsule ovoid, cylindric; peristome and annulus none; lid conicbeaked.]

Only known sterile. On stumps in coppice, New Providence, Andros, Abaco and Berry Islands, Great Harbor Cay:- Florida; West Indies to tropical South America. RICHARD'S CALYMPERES.

\section{SYRRHÓPODON Schwaegr. Suppl. $2^{2}: 110.1824$.}

Plants growing in dense mats, frequently sterile and propagating by brood-bodies. Stems crowded, simple or branching; leaves curled and twisted when dry, crowded at the tips of the branches, with the upper part of the blade dense and often papillose, the lower part lax and translucent with large rectanguar cells, the margins of thickened or of a double layer of cells, often coarsely toothed; capsule erect, on a short terminal pedicel; peristome usually present, single; teeth usually entire and papillose; lid beaked; calyptra cucullate, rough or smooth at apex. [Greek, in reference to the united teeth of the peristome.] About 215 described species, tropical and subtropical. Type species: Syrrhopodon Gardneri Hook.

1. Syrrhopodon Gaudichaùdii Mont. Ann. Sei. Nat. II. 2: 376. pl. 16. 1834.

Plants pale yellowish-green, with the white bases of the leaves very conspicuous. Stems simple or with short crowded branches; leaves curled and twisted at apex, about $2 \mathrm{~mm}$. long; base with 5-6 rows of large rectangular hyaline cells on each side of the vein and the margins bordered by narrower 
cells; upper part of leaf with small green, obscure and papillose cells, extending a short distance down each side of the hyaline base; margins above with a narrow pale border of 2-3 rows of elongated smooth clear cells, mostly entire except at the spinosely toothed apex; costa also spinose on back toward the apex. Dioicous. [Seta slender, about $5 \mathrm{~mm}$. long; eapsule narrow, about 2 mm. long with a slender beaked lid; calyptra cucullate, its tip rough; teeth narrow.]

Only a few small sterlle plants found at Nicholl's Town, Andros:-Cuba; Jamaica ; Porto Rico and Guadeloupe to Brazil. GaUdichadd's Syrrhopodon.

\section{Family 4. TORTULÀCEAE Lindb.}

\section{TORTUla Family.}

Plants scattered or crowded into tufts, sometimes minute and ephemeral, with indehiscent capsules. Stems simple or branched; leaves usually crowded, sometimes forming rosettes at the apex of the stems, generally twisted when dry, lanceolate or oblong and hyaline at base often with a broader and denser apex; vein single, stout usually percurrent or sometimes excurrent into an awn; margins frequently recurved, entire, crenulate, or rarely serrulate; cells longer and smooth at base, smaller and denser or papillose at apex. Heteroicous. Pedicel terminal, more or less exserted and erect; capsule erect or inclined; peristome rarely double or lacking, usually single, of 16 narrow, often bifid teeth, sometimes long and twisted with a more or less exserted basal membrane; lid conic or beaked; calyptra cucullate; spores small. A large family of 46 genera and about 400 species widely distributed in all parts of the world. Sometimes called Pottiaceae.

A. Fruit on elongated erect pedicels; capsules erect.

Peristome single; annulus double.

Teeth oblique, twisted once or twice.

Teeth erect, not twisted.

Peristome and annulus none.

B. Fruit unknown in the Bahamas. Propagating by broodbodies, borne in the axils of the upper leaves, or the brood-bodies unknown.

Upper cells of leaves mamillose on upper surface only. Costa stout, ending below the denticulate apex. Costa tapering to the acuminate apex.

Upper cells of leaves papillose on both surfaces. Margins flat or revolute at base, denticulate at apex. Margins inrolled, entire.
1. Tortula.
2. Gyroweisia.
3. Hymenostomum.

\section{Hyophila. \\ 5. Desmatodon. \\ 6. Barbula. \\ 7. Trichostomum.}

\section{Tórtula Hedw. Fund. Musc. 2: 92.1782.}

Plants of various sizes, sometimes large and stout; usually growing on the ground or on rocks, scattered or in cushions. Stems usually simple, rarely branched; with the leaves often crowded in a rosette at the top of the stem, usually spreading when dry, or twisted, mostly broader above the middle; margins usually entire; vein single, sometimes excurrent into an awn; basal cells long, clear and smooth, the upper small and dense, generally papillose. Pedicel erect, elongate; capsule erect, cylindric; lid usually long-beaked; calyptra cucullate; peristome single, usually twisted, arising from a basal membrane; teeth 16 or 32 , slender, papillose; spores small. [Latin, with reference to the twisted peristome.] A large genus of 186 species widely distributed in all parts of the world. Type species: Bryum murale L. 
1. Tortula agrària Sw. Fl. Ind. Oce. 3: 1763. 1806.

Barbula agraria Hedw. Musc. Frond. 3: 17. pl. 6. 1792.

Plants almost stemless, forming a rosette of basal leaves, not much curled or twisted when dry. Leaves widest above the middle; base oblong, with long, clear, smooth cells; upper cells square, mamillose on the inner surface, smooth on the outer; apex acute; vein stout, ending in a mucronate tip; margins flat, entire or denticulate. Dioicous. Pedicel erect; capsule cylindric, ribbed when dry; annulus double; lid long-beaked, red at base; peristome red, papillose, twisted; teeth 16 , long and slender, bifid or trifid with a short basal membrane; calyptra cucullate; spores smooth, small, maturing in spring.

One of the most common and widely distributed species, on limestone rocks, New Providence, Abaco, Great Exuma, Great Bahama, Cat Cav, Andros and Berry Islands, Watling's and Acklin's Islands, Crooked Island and Fortune Island :-Florida and the West Indies; Mexico and South America. Common Tortula.

\section{GYROWEİSIA Schimp. Syn. (2d ed.) 38. 1876.}

Plants small, usually growing in depressions of limestone rocks or on old walls in dark green patches, discolored and matted together by fresh-water algae, stems short or acaulescent; leaves dark green, inrolled and twisted when dry, spreading in a rosette when moist, oblong-lingulate, tip acute or obtuse, the vein ending below the apex; margins flat, crenulate or obscurely toothed at apex; lower cells very thin and longer than the rounded and swollen cells of the apical blade. Dioicous. Pedicel short, erect, terminal; capsule narrow, cylindric; peristome simple, of 16 bifid, jointed and papillose teeth; lid beaked; calyptra cucullate. [Greek, in reference to the large annulus.] A small genus of 14 species, mostly in hilly regions. Type species: Gymnostomum tenue Schrad.

1. Gyroweisia Bárbula (Schwaegr.) Paris; Index Bryol. ed. 2: 2: 299.1904.

Gymnostomum Barbula Schwaegr. Supp. 22: 77. pl. 175. 1826.

Plants small, in dark green obscure mats, often sterile and acaulescent; leaves few, recurved, forming a rosette, linear-oblong, about $2 \mathrm{~mm}$. long by $0.25 \mathrm{~mm}$. wide, usually obtuse and cucullate, sometimes acute; margins crenulate-toothed, often more coarsely and irregularly so at apex; vein ending below the apex; upper cells rounded and swollen, basal cells longer, very thin and clear on the margins; pedicel short, 4-8 mm., rarely $1 \mathrm{~cm}$.; capsule dark when old, erect, up to $2 \mathrm{~mm}$. long, narrowly cylindric, mouth small; annulus double; calyptra, lid, annulus and peristome often falling off all-together; peristome slightly twisted; teeth 16 , brittle, bifid, with 5-6 basal joints, densely papillose when mature; spores brown, small; ripe in spring; calyptra cucullate.

On rocks and old walls, New Providence and Abaco:-Florida; Bermuda; Cuba; Jamaica; Porto Rico; Brazil. BLACK-FRUITED GYROWEISIA.

\section{HYMENOSTOMUM R. Br. Trans. Linn. Soc. 12: 572. 1818.}

Plants terrestrial, gregarious. Stems short and simple. Leaves crowded, much curled and twisted when dry, linear-lanceolate; margins entire, inrolled; vein stout, ending in the mucronate apex; cells small and papillose in the upper part of blade, lower ones oblong and smooth. Pedicel erect, mostly exserted; capsule eylindric, straight or bent; lid large, beak short; ealyptra cucullate; peristome and annulus absent; mouth closed by a membrane until the spores 
are ripe. [The name refers to this character.] A small genus of 45 species widely distributed in temperate and tropical regions. Type species: Gymncstomum microstomum Hedw.

\section{Hymenostomum flavéscens E. G. Britton, sp. nov.}

Plants usually light yellowish-green. Stems short, 3-5 $\mathrm{mm}$. high; leaves 1.5-2 mm. long; apex lanceolate, incurved and cucullate, base broader and hyaline; margins inrolled, entire; vein stout, rough above, ending in the mucronate point; lower cells clear and smooth, up to $67 \mu$ long; upper cells only $8 \mu$ long, densely papillose on both surfaces, with 3-4 small papillae. Dioicous. Pedicel slender, 10-15 mm. long, erect; capsule ovoid-cylindric, 1-1.25 mm. long with the beaked lid; calyptra cucullate, twisted; peristome and annulus none, the mouth bordered by 5-6 rows of smaller, denser, quadrate cells; walls thin; spores brown, papillose, ripe in winter.

New Providence, Eleuthera, Andros, Great Bahama, Abaco and Acklin's Island. Type from Pinder's Point, Great Bahama, Britton and Millspaugh 2515. Feb., 1905. BaHada HYMenostomum.

\section{HYOPHILA Brid. Bryol. Univ. 1: 760. 1826.}

Plants dark green, frequently sterile and propagating by brood-bodies borne at the apex of the stems. Leaves linear-lanceolate or oblanceolate, not very crowded; apex obtuse or acute, entire or with a few obscure teeth; vein ending in or below the apex, rarely excurrent; basal cells clear, rectangular, upper cells smaller and papillose, rarely smooth. Dioicous. Pedicel exserted, slender; capsule erect, narrow, cylindric; mouth small; annulus usually present; peristome none; lid beaked; calyptra cucullate. [Greek, referring to their moisture-loving habit.] A genus of about 8.0 species, occurring in tropical regions, widely distributed. Type species: Hyophila gymnostomoides Brid.

\section{Hyophila Tórtula (Schwaegr.) Hampe, Bot. Zeit. 4: 267. 1846.}

Gymnostomum Tortula Schwaegr. Supp. 2 : 78. pl. 175. 1826.

Tortula Donnellii Austin, Bot. Gaz. 3: 31.1878.

Barbula Donnellii Lesq. \& James, Man. 128. 1884.

Plants often growing on rocks in scattered, low cushions, usually sterile; stems short and simple; leaves inrolled and twisted when dry, up to $2 \mathrm{~mm}$. long by $0.5 \mathrm{~mm}$. broad, lanceolate; vein stout, brown, ending in the cuspidate apex, smooth or slightly rough on the back; basal cells smooth, oblong, upper cells in transverse rows, hexagonal, mamillose on the inner surface, smooth on the back; margins sometimes denticulate at apex. Dioicous. Only known sterile, in the Bahamas, propagating by brood-bodies borne on filaments from the axils of the upper leaves. [Pedicel 8-10 $\mathrm{mm}$. long, erect; capsule $2 \mathrm{~mm}$. long, eylindric; mouth bordered by smaller, darker cells; annulus compound, falling with the beaked lid; peristome none; calyptra cucullate and slightly twisted; spores smooth, small.]

New Providence and Abaco:-Florida; West Indies; Mexico; Guatemala and South America. HYopHILA.

\section{DESMÁTOdON Brid. Mant. Muse. 86. 1819.}

Plants usually in cushions on limestone rocks or in erevices of walls. Stems erect, usually short and simple or forking. Leaves crowded, incurved and twisted when dry, spreading when moist, oblong-lanceolate; apex acute or 
obtuse; margins entire or serrulate, flat or recurved, sometimes bordered; costa ending below the apex, percurrent or excurrent into a slender awn, papillose on both surfaces; upper cells smooth or papillose; lower cells longer and smooth. Monoicous or dioicous. Pedicel erect; capsules erect or nodding, ovoid or cylindric; annulus present; peristome single, of 16 short, erect or slightly twisted, papillose, teeth united at base, with a short exserted basal membrane; lid short, conic-beaked; cells oblong; calyptra cucullate; spores rough or smooth. [Latin, in reference to the basal union of the teeth.] A small genus of about 12 species, varying in habit and distribution. Type species: Discranum latifolium Hedw.

\section{Desmatodon Gárberi Lesq. \& James, Man. 112.1884.}

Plants in dense round cushions, usually fruiting abundantly. Stems simple, up to $1 \mathrm{~cm}$. high with the leaves much twisted when dry and spreading when moist, more crowded at apex of stems, only about $1 \mathrm{~mm}$. long; margins incurved, entire. crenulate or slightly toothed at apex; vein stout, smooth, ending below the point or percurrent into the cuspidate apex; upper cells irregular, rounded, and projecting on the inner surface, smooth on the back, lower cells larger, clear, oblong and smooth. Dioicous. [Thus far only found sterile associated with Tortula agraria; but the type specimens from Key West, show an erect pedicel, about $5 \mathrm{~mm}$. long; the calyptra cucullate; the capsule, with the beaked lid, about $2 \mathrm{~mm}$. long, brick-red, cylindric, the narrow annulus falling in fragments with the lid; peristome short, deeply inserted; the teeth papillose, fragile and broken, irregularly split and jointed, with no visible basal membrane; spores smooth, pale, ripe in winter.]

On limestone rocks in coppice, New Providence:-Key West, Florida; Yucatan. GaRBER's DESMATODON.

\section{BÁRBULA Hedw. Fund. Musc. 2: 92.1782.}

Plants usually a dirty green or brown color, often growing in muddy places. Stems slender and sparingly branched. Leaves crowded, usually small and narrowly lanceolate, keeled; margins recurved, seldom flat; vein stout, percurrent, rarely excurrent; cells of the upper part of the leaf dense, papillose on both surfaces; basal cells larger, rectangular and nearly or quite smooth. Dioicous: if sterile often propagating by brood-bodies. Pedicel erect, terminal; lid conic or beaked; calyptra cucullate; capsule usually erect, cylindric; annulus sometimes present; peristome rarely lacking, usually inserted below the rim of the capsule, of 32 slender, twisted, papillose teeth, united by a short basal membrane; spores small. [Latin, diminutive of barba, beard, referring to the peristome.] A large genus of 234 species, widely distributed in temperate and subtropical regions. Type species: Bryum unguiculatum Hudson.

\section{Barbula Crùgeri Sonder; C. Muell. Syn. Musc. 1: 618. 1849.}

Plants small, in dark brown patches on damp rocks. Stems slender, seldom more than $2 \mathrm{~cm}$. high; leaves curled and twisted when dry, spreading when moist, about $1 \mathrm{~mm}$. long; base oblong, with thin rectangular cells; apex keeled; upper cells minute, dense and papillose; vein stout at base, rough on the back and ending abruptly in the cuspidate apex; margins flat or revolute, entire or rarely denticulate at apex. It has only been found sterile in the Bahamas, but propagates by club-shaped brood-bodies borne in clusters, in the axils of the 
leaves. [Dioicous. Pedicels erect, about $1 \mathrm{~cm}$. long, twisted when dry; capsules up to $1 \mathrm{~mm}$., erect, cylindric; lid beaked; calyptra cucullate, rough at apex; peristome red, twisted; teeth slender, bifid and papillose, with a short basal membrane; annulus none; spores smooth, small, ripening in summer.]

On wet rocks in quarry at Nassau :-Florida; Louisiana ; Cuba ; Jamaica ; Porto Rico to Trinidad and South America. Cruger's Barbula.

\section{TRICHóSTOMUM Hedw. Fund. 2: 90. 1782.}

Plants medium-sized, usually crowded. Stems erect, simple or branched. Leaves curled and twisted when dry, larger at base than above, with a narrow sharp apex; margins flat or inrolled, entire; vein single, usually percurrent; basal cells oblong and clear; upper cells denser, small and papillose on both surfaces. Pedicel erect, elongate; capsule erect, cylindric; peristome single; teeth 16, either entire or divided to base, usually papillose; lid conic-beaked; calyptra cucullate. [Greek, in reference to the narrow teeth.] Widely distributed in various temperate and tropical regions. Type species: Weisia cylindrica Bruch.

\section{Trichostomum rivàle (Mitt.) Jaeg. Adumb. 1: 245. 1871-72.}

Tortula rivalis Mitt. Journ. Linn. Soc. 12: 147. 1869.

Plants in dense bright green or yellowish cushions. Stems up to 5-10 mm. high, usually simple; leaves crowded, curled and twisted when dry, 2-3 mm. long, base erect, clasping, the tips narrower and spreading when moist; vein smooth, excurrent into the mucronate apex; margins entire, incurved above the middle; basal cells lax with longer cells on the margins, extending up the blade to the papillose cells of the tip; upper cells densely papillose on both surfaces. Only found sterile in the Bahamas. Dioicous. [Pedicel yellow, erect, 15-20 mm. long; capsule 2-3 mm. long, erect, cylindric; calyptra cucullate; lid conic-beaked; peristome single, of 16 slender, erect or slightly twisted, papillose, bifid teeth, often disappearing and leaving only a ragged membrane; spores rough, brown, maturing in spring.] Very closely related to Trichostomum jamaicense Mitt.

On rocks and in pine-barrens, Marsh Harbor, Abaco :-Cuba ; Jamaica and Porto Rico. ROCK TRICHOSTOMUM.

Some poor sterile specimens of a Trichostomum were collected in New Providence, by L. J. K. Brace, in June, 1918, Number 9509 . The leaves are less papillose than in $T$. rivale and the plants may represent another species, $T$. involutum Sull.

\section{Family 5. ORTHOTRICHÀCEAE Bruch \& Schimper.}

\section{ORTHOTRICHUM FAMILY.}

Plants growing in dense dark green mats. Stems erect or ereeping, often branching and interlacing; branches short, erect, densely leafy. Leaves curled and twisted when dry, crowded, lanceolate or oblong; costa single, percurrent or excurrent into a mucronate tip; cells dense, small, obscure, smooth or papillose, basal often longer and smooth. Pedicel short, terminal; calyptra large, campanulate, plicate and lacerate at base, smooth, hairy, or rough at apex; lid usually beaked; capsule smooth or ribbed; peristome single or double, seldom lacking. Twelve genera and 824 species, widely distributed. 
1. MACROMITRIUM Brid. Mant. Musc. 132. 1819.

Plants in dense dark mats, usually on trees. Stems creeping with erect branches; leaves crowded and usually twisted when dry; vein single, percurrent or excurrent, rarely ending below the apex; margins entire or rarely toothed at apex, not bordered, except occasionally at base; cells small and dense in the upper part of the leaf smooth or papillose, larger and clearer below. Pedicel exserted or rarely immersed, terminal; capsule erect, ovoid, urn-shaped or cylindric; lid beaked; calyptra campanulate and lacerate at base, smooth or hairy. [Greek, in reference to the large calyptra.] A large genus of 385 species, common in tropical regions of both hemispheres. Type species: Schlotheimia acicularis Brid.

1. Macromitrium mucronifòlium (Hook. et Grev.) Schwaegr. Supp. $2^{2}: 61$. pl. 170. 1826.

Orthotrichum mucronifolium Hook. et Grev.; Brewst. Edinb. Jour. 1: 116. pl. 4. 1824.

Plants in dense dark green mats. Stems creeping and matted together by a brown felt of rhizoids, the branches erect, short, seldom more than 2-3 $\mathrm{mm}$. high; leaves spirally twisted when dry, spreading when moist, crowded and numerous, carinate, oblong; apex blunt or sometimes notched; vein ending in a short cuspidate tip; upper cells dense, small, opaque, with thickened swollen walls; base bordered by 3-4 rows of longer and clearer cells. Pedicels erect, about $5 \mathrm{~mm}$. long; capsule about $1 \mathrm{~mm}$., ovoid and tapering at base, with a long neck, slightly ribbed when old; calyptra covering the capsule, ribbed but not hairy; lid beaked; peristome and annulus none; spores nearly smooth.

On trees in coppices, Andros and Abaco:-Florida and the West Indies to tropical South America. Mucronate Macromitrium.

\section{SCHLOTHEIMIA Brid. Sp. Muse. 2: 16. 1812.}

Plants in dense dark mats, usually on trees. Stems ereeping, with numerous crowded and usually short simple branches. Leaves crowded, erect or spreading, often spirally twisted when dry; vein single, stout, percurrent or excurrent; margins usually entire and not bordered; upper cells much thickened, usually oblique, smooth or rarely papillose, the lower rectangular, less thickened and vertical, smooth. Pedicel exserted or immersed, terminal on the branches; capsule ovoid or cylindric; peristome double, the inner shorter than the outer, often rudimentary; lid beaked; calyptra not ribbed, usually lobed at base, sometimes hairy. [Named for Ernest Schlotheim.] A genus of about 120 species, mostly tropical or subtropical. Type species: Hypnum torquatum Hedw.

1. Schlotheimia Sullivántii C. Muell. Syn. Musc. 1: 756. 1849.

Plants in dense wide dark green or brown mats. Stems creeping and densely hairy with brown radicles; branches short, erect, crowded; leaves also densely crowded, 1-1.5 mm. long, oblong-lanceolate; apex blunt; vein ending in a short abrupt tip; upper part of the leaf undulate, the cells thickened and hexagonal, those of the lower part clearer, oblong, not bordered. Pedicel erect, about $5 \mathrm{~mm}$. high; capsule $2-3 \mathrm{~mm}$. long, cylindric, smooth or ribbed when dry; peristome double, deeply inserted, rim of 7-8 rows of cells, annulus none; the outer teeth recurved and papillose, longer than the inner ones; lid 
beaked; calyptra glossy, yellow or brown, deeply lobed at base, rough at apex; spores large and rough.

On trees and decaying wood in coppice, New Providence:-Florida and Louisiana. SULLIVANT'S SCHLOTHEIMIA.

\section{Family 6. FUNARIÀCEAE C. Muell.}

\section{Funaria Family.}

Plants usually annual, seldom biennial, sometimes ephemeral and minute or rudimentary. Stems short, erect and seldom branched. Leaves small and narrow, or large and broad; margins entire or toothed; vein present or rarely absent. Pedicel short and immersed, or long and exserted; capsule ereet or inelined, symmetric or asymmetrie, ovoid or pyriform; annulus large and conspicuous, or undeveloped; calyptra eucullate, often inflated and oblique, rarely lobed or papillose; peristome absent, rudimentary or double, its teeth straight or oblique. A family of wide distribution, including about 12 genera with some 244 species.

\section{FUNÀrIA Schreb.; L. Gen. Plant. ed. 8, 2: 760. 1791.}

Plants usually scattered, rarely crowded. Stems short, simple. Leaves crowded at the summit, usually broadest above the base, entire or serrate; vein ending below the apex, percurrent or excurrent. Pedicel exserted, elongated; capsule erect or nodding, often pear-shaped; lid flat or apiculate; calyptra much inflated at base, beaked; peristome single, double or rarely lacking. [Latin, in reference to the twisted pedicels.] A large genus of about 100 widely distributed species. Type species: Mnium hygrometricum L.

Mouth of the capsule oblique; leaves serrate.

Mouth of the capsule small; leaves nearly entire.
1. F. hygrometrica.

2. F. flavicans.

1. Funaria hygrométrica (L.) Sibth. Fl. Oxon. 288. 1794.

Mnium hygrometricum L. Sp. Pl. 1110. $175 ̄ 3$.

Plants bright yellowish-green turning brown. Stems short, simple; leaves few, erect, appressed around the base of the pedicel, broad and concave, acute or acuminate; the vein ending in the apex, the margins with swollen teeth; cells clear, smooth, oblong below, shorter and hexagonal above. Pedicel pale, twisted, variable in length; capsule horizontal or nodding, ribbed when dry, its mouth oblique; lid bordered with a red rim; annulus large, double, falling with the lid; peristome double, oblique, the teeth with apical appendages attached to a central disc; calyptra large, inflated at base; spores rough, ripening early in spring.

On charred earth, Eight Mile Rock, Great Bahama. A cosmopolitán species. Cord-Moss.

2. Funaria flávicans Michx. F'l. Bor. Am. 2: 303. 1803.

A smaller plant than the preceding, differing in the fewer leaves, which are entire, the vein ending in a short subulate tip; [the pedicel shorter, the capsule more symmetric, its mouth not oblique; spores a little larger].

Oniy known from sterile specimens collected in a coppice, Soldier's Road, New Providence :-Bermuda; southern United States. PALd-Green Funaria. 


\section{Family 7. BRYÃCEAE C. Muell.}

\section{Bryum FAmily.}

Plants usually growing in cushions, rarely scattered. Stems erect, simple or branching near the apex, often slender. Leaves scattered, os crowded at the summit, variable in shape, from oval to lanceolate, often acuminate and subulate; vein single; margins entire or toothed; cells smooth, generally hexagonal, sometimes longer and narrower on the border and rectangular at the base. Pedicel terminal, erect; capsule erect or nodding, generally symmetric with a well-developed neck; calyptra cucullate; lid flat, not beaked; peristome usually double, rarely single or lacking. A widely distributed family composed of 16 genera with over 950 species most abundant in temperate, alpine and aretic regions. [Greek, meaning a moss.]

\section{BRỸUM L. Sp. Pl. 1115. 1753.}

Plants usually growing in dense compact cushions, more or less matted with radicles. Stems erect, simple or branching by apical innovations. Lueaves more or less crowded at apex, erect, elliptic. ovate or lanceolate, concave; apex acute, obtuse or with the costa pereurrent into an awn; margins often bordered, more or less recurved, entire or serrate at apex; cells mostly hexagonal or rectangular at base. Inflorescence variable, heteroicous, pedicel exserted, erect or bent at apex; capsule nodding or rarely horizontal, usually ovoid or pyriform, with a distinct neck; annulus often large and compound, falling with the blunt lid; peristome double, its teeth usually with a zigzag median line; endostome equalling the teeth, sometimes imperfect or with keeled segments and 2-3 cilia, arising from a basal membrane. A large genus of about 625 species widely distributed from the arctic regions to the tropies in both hemispheres. [Name Greek, a moss.] Type species: Bryum argenteum $\mathrm{L}$.

Capsule cylindric, neck tapering.

Capsule pyriform, neck swollen.
1. B. capillare.

2. B. coronatum.

1. Bryum capillàre L. Sp. Pl. 1586. 1753.

Plants growing in rather dense, dark green eushions. Stems short, sparingly branched; leaves crowded in a rosette at the apex, eurled and twisted when dry, ovate to lanceolate, acuminate, the margins bordered by 1 or 2 rows of narrow cells, entire or slightly toothed near apex; vein ending in the top or excurrent; upper cells hexagonal, basal oblong, smooth. Pedicel long, red, bent at base, paler and twisted above; capsule elongated, nodding; neck distinct; lid small, apiculate; annulus large; peristome brown; teeth paler and papillose above; endostome with a basal membrane and appendiculate cilia; spores ripe in spring.

On base of palms in sand, a widely distributed and variable species, Great Bahama and Lignum Vitae Cay :-Florida; West Indles; South America; also in Europe and Africa. HAIR-LIKE BRYUM.

\section{Bryum coronàtum Schwaegr. Suppl. $1^{2}$ : 103. pl. 71.1816.}

Plants gregarious in bright green patches. Stems erect, simple or branching, usually about $1 \mathrm{~cm}$. high; leaves not crowded, spreading when moist, about $2 \mathrm{~mm}$. long, lanceolate or elliptic, with the vein excurrent into a smooth, subulate tip; margins bordered by 1 or 2 rows of narrow elongated cells, some- 
times obscurely toothed near the apex; base forming a long-decurrent wing to the next lower leaf; basal cells oblong; upper cells hexagonal. Dioicous. Pedicel erect or bent, about $15 \mathrm{~mm}$. long; capsule nodding, about $2 \mathrm{~mm}$. long, dark red when mature, with a conspicuous swollen neck (like an acorn-cup or a crown, hence the specific name); lid falling with the large annulus more or less attached; peristome double; teeth brown; endostome pale, its segments split along the keel, with 2-3 slender appendiculate eilia; spores small, green, ripe in winter.

In coppice, on dead wood and stones, New Providence, Abaco and Andros:Florida; West Indies; South America; also in Asia and Africa. CoRoNATE BRYUM.

A doubtful species of Bryum was collected by L. J. K. Brace at the quarry, Nassau, New Providence, in February, 1918 (no. 9984); the specimens are sterile and do not seem to agree with anything heretofore found.

\section{Family 8. LEUCODONTÀCEAE Broth.}

\section{LEUCODON FAMILY.}

Plants in dense mats or cushions, usually on trees. Stems creeping and rooting, leafless or with rudimentary leaves at the apex of new stems; branches pendent, simple or branching, usually with unequal and irregular branchlets, seldom regularly pinnate or dendroid and circinate. Leaves crowded, often imbricate when dry, spreading when moist, usually ovate, acuminate, entire, or serrate at apex; vein single or double, sometimes lacking; cells smooth or rarely obscurely papillose or projecting at the ends; base with several rows of alar cells, generally transversely elongated or rounded and thickened. Dioicous or autoicous. Pedicels from lateral buds with elasping bracts, short or elongate; capsule ovoid, sometimes ribbed; calyptra cucullate, smooth or hairy; lid conic or beaked; annulus usually present; peristome double, the outer of 16 short pale papillose, bifid or perforate teeth; the endostome of a more or less developed membrane with or without keeled segments and cilia. A small family of 9 genera and 69 species, widely distributed in temperate and subtropical regions.

\section{LeUcodontópsis Ren. \& Card. Bull. Soc. Bot. Belg. 32: 177. 1893.}

Plants slender and ereeping on twigs or branches. Primary stems usually closely attached to the bark, with short irregular spreading branches. Leaves crowded, small, erect-appressed on the branches, spreading, longer and more sharply pointed on the tips of the stems; lanceolate, acuminate, carinate and plicate; margins revolute, entire or obscurely toothed at apex; vein single, ending above the middle; uppér cells long and narrow, with papillose projecting cells; alar cells round or quadrate and thickened, in several rows. Dioicous. [Named in reference to its resemblance to Leucodon.] A small genus of only three species, in all of which the fruit is unknown. Type species: Leucodontopsis plicata Ren. \& Card.

1. Leucodontopsis floridàna (Aust.) E. G. Britton, Bryologist 15: 26. 1916.

Neckera (Pilotrichella?) floridana Aust. Bot. Gaz. 4: 152. 1879.

Leucodontopsis plicata Ren. \& Card. Bull. Soc. Bot. Belg. 32: 177. 1893.

Pilotrichella floridana Ren. \& Card. Rev. Bryol. 19: 11. 1893.

Stems leafless except at the apical portions, there bearing small, ovatelanceolate, acuminate, ecostate, flat-bordered leaves; branches seldom more 
than $3 \mathrm{~cm}$. long, simple or branched, when young more slender and flagellate, with smaller, less crowded leaves, when older with erect-appressed, crowded plicate leaves, up to $1.5 \mathrm{~mm}$. long by $0.33 \mathrm{~mm}$. broad at base; vein usually single, seldom double with a short accessory basal branch; alar cells fewer on one side, up to 8-10 rows, seldom reaching the vein; margins entire, revolute almost to the serrulate apex; cells spindle-shaped, with minute, terminal papillae on both surfaces. Flowers and fruit unknown; propagating by small septate brood-bodies borne in axillary clusters.

On trees in coppices, New Providence and Andros :-Florida; Cuba; Porto Rico; Costa Rica and Panama. Florida Leucodontopsis.

\section{Family 9. NECKERÀCEAE Schimper.}

\section{Neckera FAMily.}

Plants usually growing on trees with creeping stems and pendent branches, either simple or pinnately decompound, sometimes quite dendroid; branches usually densely leafy, with crowded or imbricate leaves, sometimes in 2-4 ranks. Leaves symmetric or inequilateral, various, costate or ecostate, entire or serrate, smooth or papillose; the perichaetial usually quite different from the others, often surrounding and covering the capsule. Usually dioicous. Pedicel often short and straight, immersed, rarely curved or exserted; capsule ovoid or eylindric; smooth or ribbed; lid conic, beaked; calyptra smooth or hairy; peristome usually double, the inner more or less rudimentary; annulus present or absent. A large family, of 50 genera and several hundred species, of wide temperate and subtropical distribution.

\section{PIREÉLLA Cardot, Rev. Bryol. 40: 17. 1913.}

[PIREA Cardot, Bull. Soc. Bot. Belg. 32: 175. 1893. Not Durand, 1888.]

Stems creeping, slender and radiculose; branches erect, $2-4 \mathrm{~cm}$. long, simple or pinnately branched, blunt, or rarely slender and flagellate; leaves crowded, appressed, erect or spreading; stem-leaves ovate, abruptly acuminate, entire, ecostate; branch-leaves lanceolate, acuminate, entire or serrate at apex; vein thin, wider at base, ending below the apex; cells more or less thickened and porose, linear at base; alar cells quadrate, shorter and broader with thick walls. Perichaetial leaves, erect, ovate or lanceolate-acuminate, or subulate. Dioicous, often sterile and propagating by brood-bodies. Pedicel exserted, erect, somewhat rough above, seldom short or immersed; capsule mostly exserted, calyptra cucullate, hairy; lid small, beaked; mouth small; peristome double, its teeth lanceolate, more or less bifid, smooth, pale or red; endostome hyaline, membranous, adherent to the teeth; spores smooth. [Diminutive of Pirea.] A small genus of 10 species, confined to tropical and subtropical regions of North and South America. Type species: Pireella cavifolia Cardot \& Herzog.

1. Pireella cymbifollia (Sull.) Cardot, Rev. Bryol. 40: 17. 1913.

Pilotrichum cymbifolium Sull. in A. Gray, Man. ed. 2, 681. 1856.

Plants usually growing on trees. Stems slender, creeping and rooting, the terminal growths slender with small acuminate leaves only about $0.5 \mathrm{~mm}$. long, with a short vein and faintly serrate margins, the alar cells few and rectangu- 
lar; branches stouter, usually simple, about $2 \mathrm{~cm}$. long, or pinnately branched, up to $4 \mathrm{~cm}$. long, with short branchlets; leaves crowded, imbricated in 5 ranks, concave and keeled, up to $1.5 \mathrm{~mm}$. long by $0.5 \mathrm{~mm}$. wide; vein narrow, ending in the flat acuminate tip; margins minutely toothed almost to the base; alar cells smaller, dense, rectangular; upper cells linear with projecting or obscurely papillose end walls; perichaetial leaves minute, erect, appressed, ecostate and narrowly acuminate. Dioicous, the antheridial plants unknown, as well as the fruit; usually propagating by septate brood-bodies, borne in clusters at the bases of the leaves.

Small depauperate unbranched plants have been found in coppices of New Providence and Abaco:- Florida; Louistana; Cuba; Jamaica; Hispaniola; Virgin Islands to South America. Pireelila.

\section{Family 10. METEORIÀCEAE Fleischer.}

\section{Meteorium Family.}

Plants mostly of moist mountain regions, and of tropical and subtropical distribution, usually epiphytic and characterized by their creeping stems and long pendent, simple or rarely branched habit, sometimes very glossy, with distichous leaves; base usually regular and broad, often auriculate; costa single, ending below the apex; cells smooth or papillose. Usually dioicous. Pedicel immersed or exserted; calyptra small, often hairy; lid generally beaked; peristome double, the inner sometimes perfect with eilia but more often imperfect with a short basal membrane; annulus lacking. A family of mostly tropical mosses with about 10 genera and 327 species.

1. PAPILLÀria C. Muell. Angstr. Oefv. K. Sv. Vet.-Ak.

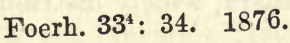

[Neckera Section Papiliaria C. Muell. Syn. Muse. 2: 134.1851.$]$

Plants growing on rocks or trees, usually in dense pale green or dark mats. Stems slender, often pendent or creeping, branching irregularly. Leaves broad and often auricled at base, tapering to an acuminate or subulate tip; vein single, rarely pereurrent or lacking; margins entire or serrulate; basal and median cells sometimes smooth, others usually papillose with several small papillae in the median line of the narrow cells; perichaetial leaves usually longer and narrower, erect. Dioicous. Pedicel exserted or immersed, straight and smooth; capsule immersed or exserted, small and ovoid; calyptra small, campanulate, hairy; lid conic-beaked; annulus absent; peristome double; teeth lanceolate and papillose; endostome hyaline and papillose from a short basal membrane, with or without eilia; spores papillose. About 70 species are known, mostly from tropical regions of both hemispheres. [Named in reference to the papillose leaves.] Type species: Neckera capillaris O. Muell.

\section{Papillaria nigréscens (Sw.) Jaeger, Adumb. 1: 169. 1875-76.}

Hypnum nigrescens Sw. Prodr. 141. 1788.

Plants in dark brown mats. Young branches green; stems often 15-20 $\mathrm{cm}$. long, branching pinnately; branches short and irregular, usually simple, and only 1-2 cm. long, but sometimes 4-5 $\mathrm{cm}$. ending in clusters of slender brittle branchlets, which propagate this species. Leaves crowded, erect- 
appressed when dry, spreading when moist, small, up to $1.5 \mathrm{~mm}$. long by $1 \mathrm{~mm}$., broad at the auricled base; vein ending in the middle of the leaf; apex acuminate; margins entire, with projecting papillae; cells spindle-shaped with thick walls and 3-4 small papillae; basal cells longer and narrower, smooth and radiating toward the margins. Dioicous. [Perichaetial leaves pale, erect, lanceolate-subulate, plicate but not papillose; seta exserted up to $1 \mathrm{~cm}$. long; capsule ovoid, about $2 \mathrm{~mm}$. long; calyptra pale and hairy; lid beaked; mouth small with a dark rim; peristome pale, papillose; teeth lanceolate with a median line, inner membrane short with pale slender segments, more or less adherent to the teeth; spores brown, mature in summer.] Only known from sterile specimens in the Bahamas.

On twigs and trunks of trees in coppice, New Providence:-Florida; Louisiana; West Indies and southern California to Panama and South America. BLACKISH Papillaria.

\section{Family 11. ENTODONTÀCEAE Brotherus.}

\section{Entodon FAMily.}

Plants growing in glossy flat mats, either on rocks or trees. Stems ereeping, usually with simple branches. Leaves spreading or flattened, usually erowded; vein single or double, rarely lacking; cells mostly longer than broad; often with the ends thickened and projecting on the back of the leaf, with the alar transversely elongated. Autoicous or dioicous. Pedicel erect, exserted; capsule eylindric, mostly erect and symmetric; lid usually short-beaked; calyptra cucullate, smooth; peristome double, often deeply inserted; teeth longer or shorter than the inner keeled segments, variously thickened; cilia usually lacking; annulus present or absent. A large family, of about 20 genera, widely distributed in temperate and tropical regions.

1. STEREOPHÝLLUM Mitt. Journ. Linn. Șoc. Suppl. 1: 117. 1859.

Plants growing in thin flat mats, on rocks or trees. Stems creeping and rooting, with simple irregular branches. Leaves crowded, somewhat flattened and glossy; apex acute or obtuse; vein stout or lacking; margins flat, entire or rarely toothed at apex; base unequal, one side composed entirely of quadrate alar cells; upper cells short or long, often with the thickened end-walls forming minute papillae. Autoicous or rarely dioicous; pedicel elongated; capsule erect to inclined, and unequally ovoid; lid conic-beaked; annulus lacking; peristome double, the outer papillose with thickened joints above, the inner narrower from a short basal membrane, without cilia. A genus of 61 species, widely distributed in tropical and subtropical regions of both hemispheres. [Greek, in reference to the thick leaves.] Type species: Pterygophyllum indicum Belang.

1. Stereophyllum radiculòsum (Hook.) Mitt. Journ. Linn. Soc. 12: 542. 1869.

Hookeria radiculosa Hook. Musci. Exot. pl. 51. 1818-1820.

Homalia Wrightii Sull. in A. Gray, Man. ed. 2, 665. 1856.

Plants in flat bright green mats. Stems matted together by numerous radicles; branches and branchlets with flattened glossy leaves, imbricate and secund when dry, spreading when moist, up to $1.75 \mathrm{~mm}$. long by $0.75 \mathrm{~mm}$. broad, concave with flat serrate margins; vein stout, tapering and ending above 
the middle of the leaf; apex acute; upper cells rhomboidal; alar cells rectangular and oblique, only reaching the vein and more numerous on one side of the base; basal radiating and longer, all minutely and distinctly papillose on the back; perichaetial leaves smaller, erect, clasping, more suddenly acuminate. Autoicous; pedicel up to $1 \mathrm{~cm}$. long; calyptra small, entire; capsule horizontal, slightly unequal, $1.5-2 \mathrm{~mm}$. long, its walls with swollen cells; lid large and pale, conic, short-beaked; annulus none, mouth with a dark rim; peristome double, the teeth yellow, paler and papillose at apex, inner with white, perforate keeled segments and shorter slender cilia; spores small and smooth, ripe in winter.

On logs and rotten wood, in coppices, New Providence, Abaco, Great Bahama and Lignum Vitae Cay:-Florida; New Mexico; Texas; Cuba; South America.

\section{Family 12. LESKEÀCEAE Reichb.}

\section{LESKea FAMily.}

Plants small or large. Stems creeping and branching, either irregularly or pinnately; branches short, usually slender and crowded with small leaves; vein single; cells papillose on one or both surfaces; branch-leaves smaller than the stem-leaves; rudimentary leaves present. Pedicel ereet or inclined; calyptra cucullate; annulus often present; capsule erect or horizontal, usually symmetric, its lid conic or beaked; peristome double, the inner sometimes shorter and imperfect. About 23 genera, containing some 333 species, widely distributed.

\section{HAPLOCLÀDIUM C. Muell. Nuov. Giorn. Bot. Ital. 3: 11. 1896.}

Branches slender, simple, not pinnately divided; leaves papillose only on the back, those at base of pedicel erect, longer and paler. [Greek, referring to the simple branches.] A genus of 43 species, natives of America and eastern Asia. Type species: Haplocladium macropilum C. Muell.

1. Haplocladium microphýllum (Sw.) Broth. in E. \& P. Nat. Pflf. 229: 1007. 1907.

Hypnum microphyllum \$w. Prodr. 142. 1788.

Plants dark green or yellow. Stems ereeping and rooting, sometimes quite slender and branching irregularly; branches short and simple, erect; leaves crowded, spreading or secund, ovate, acuminate, small, up to $0.5 \mathrm{~mm}$. long, those of the branches smaller and less acuminate than those of the stem; vein excurrent into a long tip; margins minutely toothed; cells small, square or oblong, papillose only on the back; leaves at base of pedicel longer and paler, erect. Pedicel 2-2.5 cm. long, slender, erect; capsule $1 \mathrm{~mm}$. long, horizontal and curved; annulus falling with the conic lid; peristome double, the inner with keeled segments and 3 cilia; spores smooth, maturing in summer.

On rocks in coppices, New Providence and Great Exuma:-Florida; Bermuda ; Cuba; Jamaica; Porto Rico; Mexico and South America. Small-Leaved HaploCLADIUM. 


\section{Family 13. HYPNACEAE Hampe.}

\section{HyPNUM FAMILY.}

Plants growing in loose or dense tufts, seldom floating. Stems usually decumbent and rooting, sometimes erect; branches regularly pinnate or irregular. Leaves straight or eurved, erect, spreading or secund, usually symmetric; vein either lacking, single or double; cells mostly much longer than wide, smooth or papillose, those of the basal angles often different in shape and size. Pedicel more or less elongated and exserted; capsule mostly horizontal, often curved and unsymmetric; peristome double; its segments keeled; cilia usually present; spores small. A large family, widely distributed in all parts of the globe, composed of about 37 genera with over 960 species.

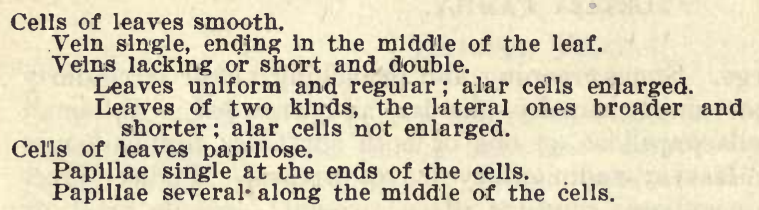

1. Amblystegium.

2. Isopterygium.

3. Vesicularia.

4. Mittenothamnium.

5. Taxithelium.

\section{AMBLYSTÉGIUM Bruch \& Schimp. Bryol. Eu. 55-56:1. 1853.}

Plants usually growing in moist situations. Stems irregularly branched; branches slender; leaves symmetric, spreading; vein single; cells smooth, not much longer than wide. Pedicel erect, smooth; capsule usually curved; calyptra cucullate; lid conic; annulus present; peristome double. [Greek, referring to the blunt lid.] A genus of 47 species, widely distributed in America and Europe. Type species: Hурпит riparium L.

\section{Amblystegium Sípho (Beauv.) E. G. Britton.}

\section{Hypnum Sipho Beauv., Prodr. Aetheog. 70. 1805.}

Amblystegium riparium floridanum Ren. \& Card. Bot. Gaz. 14: 98. 1889. Plants in thin mats on damp ground in shade. Stems creeping, very slender, more or less branched; leaves distant, shrivelfed and twisted when dry, narrowly lanceolate, acuminate, up to $1 \mathrm{~mm}$. long by $0.4 \mathrm{~mm}$. broad, the margins entire, the vein ending in the middle of the leaf; base narrow; alar cells oblong or square; upper cells 4 times longer than wide; perichaetial leaves erect, pale and faintly veined, with more slender points. Autoicous; pedicel about $1 \mathrm{~cm}$. high, red at base, paler above; capsule short, only about $1 \mathrm{~mm}$. long, horizontal and curved; lid conic; peristome double, yellow; teeth paler at apex, inner segments split along the keel; spores small, smooth, ripe in spring.

In sink-hole, Eleuthera :- southern United States. Amblystegrum.

\section{ISOPTERYGIUM Mitt. Journ. Linn. Soc. 12: 21. 1869.}

Plants usually rather small. Stems decumbent and irregularly branched; leaves somewhat flattened, small and crowded, usually symmetric; vein short and double or none; pedicel erect; capsule erect or horizontal; lid conic or 
apiculate; calyptra cucullate; peristome double. [Greek, referring to the symmetric leaves.] A genus of 168 species, mostly American, in temperate and tropical regions. Type species: Isopterygium planissimum Mitt.

1. Isopterygium mícans (Sw.) Cardot, Bull. Herb. Boiss. 4: 10. 1896.

Hypnum micans Sw. Adnot. Bot. 175. 1829.

Plants growing in dense, glossy, yellowish-green mats. Stems slender, decumbent; branches simple or divided; leaves crowded, spreading, small, 0.85 $\mathrm{mm}$. long by $0.25 \mathrm{~mm}$. wide, ovate, acuminate, faintly serrate; veins short, double, obscure; cells 10 to 15 times longer than wide, a few at basal angles distinctly shorter and broader. Pedicel erect, slender, up to $1 \mathrm{~cm}$. long; capsule horizontal, curved, contracted below the mouth when dry, about $1 \mathrm{~mm}$. long; lid conic, slightly apiculate; cilia more or less developed; spores small.

On roots of palms and rotten wood in coppices, New Providence, Great Bahama and Abaco:-United States; Bermuda; Cuba; Jamaica. GLOSSY ISOPTERYGrum.

\section{VESICULĀRIA C. Muell. Flora 82: 467. 1896.}

[Homalia Section Vesicularia C. Muell. Syn. 2: 233. 1851.]

Plants growing in moist shady places, forming thin mats on the ground. Stems ereeping; branches irregularly pinnate, usually short; leaves not crowded, shrunken and twisted when dry, usually flattened and of two kinds, the lateral ones larger and unequal, or falcate, the upper and lower ones more regular and much narrower, often longer and more acuminate; veins two, short or none; margins often bordered, entire or serrate; cells large and hexagonal, smooth, the alar not enlarged. Autoicous. Pedicels exserted and slender; capsules horizontal or nodding, ovoid and contracted below the mouth when dry; annulus present; peristome double; lid flat and beaked; calyptra cucullate; spores small. About ninety species have been described, many with very obscure and minute differences. [Named in reference to the large leaf-cells.] Type species: Hookeria Meyeniana Hampe.

1. Vesicularia vesiculàris (Schwaegr.) Broth. Pflf. 232-233: 1094.1908.

Hypnum vesiculare Schwaegr. Supp. $2^{2}: 167$, pl. 199. 1827.

Plants pale or yellowish green. Stems slender and rooting with short irregular branches; stem-leaves with long recurved tips up to $1 \mathrm{~mm}$. long, about three times longer than broad; branch-leaves of two kinds, the lateral unsymmetric, shorter and less acuminate, up to $0.85 \mathrm{~mm}$. and only about twice longer than broad with the cells about twice as long as wide; the upper and lower ones longer and narrower, with cells about five times longer than broad; leaves all ecostate or faintly bicostate, the margins bordered by one row of narrow cells, either entire or minutely toothed at apex; perichaetial leaves suddenly contracted to a slender recurved, entire or serrulate tip. Autoicous. Pedicel slender, 1.5-2 cm. long; capsule nodding, 1-1.5 mm., ovoid, with a distinct neck; walls of swollen inflated cells; lid conic-beaked; annulus large; peristome with a red base, teeth yellow, pale and papillose at apex, lamellate on the inside; endostome brown, the keeled segments split and papillose; spores small, ripe in winter.

On branches and roots of trees in coppices and in sink-holes, New Providence, Eleuthera and Andros:-Florida; West Indies and South America. Vesicunaria. 
4. MITtenothámNIUM Hennings, Hedwigia 41: 225. 1902.

[Microthamnium Mitt. Journ. Linn. Soc. 12: 21.1869.

Not Naegeli, 1849.]

Stems slender, creeping and rooting, usually branched more or less regularly, the branches erect often regularly pinnate; leaves of two kinds, the stemleaves differing from the branch-leaves in being smaller, more broadly lanceolate and sharply pointed; vein single or double; margins flat, serrate or serrulate; cells rhombic or linear, smooth or papillose at the ends; alar cells not enlarged. Monoicous, seldom dioicous. Pedicel erect, exserted; capsule erect or inclined, ovoid or cylindric; mouth wide, annulus usually present; lid beaked; calyptra cucullate, smooth or hairy; peristome double, its segments split along the keel, with 1-3 cilia; spores small. A genus of about 106 species, growing on rocks and trees, mostly in tropical regions. [Named in honor of William Mitten, 1819-1906, eminent British bryologist.] Type species: Hypnum thelistegum C. Muell.

1. Mittenothamnium diminutivum (Hpe.) E. G. Britton, Bryol. 17: 9. 1914.

Hypnum diminutivum Hampe, Linnaea 20: 86. 1847.

Plants growing in flat mats. Stems slender, branching irregularly, the branches short, seldom more than $5 \mathrm{~mm}$. long; leaves spreading when dry, minute, up to $0.75 \mathrm{~mm}$. long by $0.33 \mathrm{~mm}$. broad, ovate, acuminate, minutely serrulate; veins 2, short; alar cells not enlarged; upper cells linear, 8 times longer than wide, sharply papillose on the back; perichaetial leaves pale, longpointed with lax smooth cells. Autoicous. Pedicel up to $15 \mathrm{~mm}$. long, slender and red; capsule nodding, usually $1 \mathrm{~mm}$. long; lid blunt; annulus narrow; peristome double; teeth red at base, finely striate; keeled segments perforate and papillose, paler at apex; cilia 2 ; spores minute, ripe in summer.

On stems and rotten or charred wood in coppices, New Providence, Great Bahama and Abaco:-Fiorida; West Indies; Mexico to South America. Drminutrve MitTen's-Moss.

\section{TAXITHìuIUM Spruce, Cat. 14. 1867.}

Plants in thin pale mats. Stems flattened, with appressed leaves; simple or branching, more or less regularly and distantly pinnate, with short branches; leaves crowded, concave, with a narrow, somewhat auriculate base; veins short and double or absent; margins entire or serrulate; cells long and narrow, either with several small papillae or with conspicuous branching projecting ones; alar cells smooth, shorter and broader, the basal often elliptic. Autoicous or dioicous. Pedicel smooth, elongate; capsule horizontal, or nodding, slightly curved; lid blunt; calyptra cucullate; peristome double, the teeth paler at apex and lamellate on the inner surface; endostome narrow; cilia single. [Named in reference to the numerous papillae on the leaves.] A genus of 99 species, widely distributed in tropical regions of both hemispheres. Type species: Hypnum planum Brid.

\section{Taxithelium plànum (Brid.) Spruce, Cat. 14. 1867.}

Hypnum planum Brid. Spec. Musc. 2: 97. 1812.

Plants in yellowish-green thin mats in shade. Stems creeping and rooting, with short branches, seldom more than $1 \mathrm{~cm}$. long; leaves glossy and flattened, concave and acuminate, about $0.6 \mathrm{~mm}$. long by $0.4 \mathrm{~mm}$. wide; base narrower 
and clasping with smooth enlarged, yellow cells at angles; cells long and narrow with numerous small papillae; margins minutely and sharply toothed nearly to the base; veins short or none. Autoicous; perichaetial leaves varrower and more acuminate, with smooth lax cells; pedicel up to $15 \mathrm{~mm}$. long, slender; capsule about $1.5 \mathrm{~mm}$. long, horizontal, strongly contracted below the mouth when dry; lid blunt; neck distinct; peristome pale yellow, its teeth striate at base, pale and papillose at apex, deeply lamellate at base within; keeled segments slender, pointed; cilia 1 or 2, seldom perfect; spores small, smooth, yellow, ripe in winter.

On the ground in copplce, New Providence:-Florida; West Indies; Mexico to South America. FLAT TAXITHELIUM.

\section{Family 14. SEMATOPHYLLÀCEAE Brotherus.}

\section{Sematophyllum Family.}

Plants usually forming dense tufts. Stems creeping; branches erect, irregular and unequal, sometimes pinnate; leaves small, crowded, often secund; veins short, double or lacking; cells usually much longer than wide, smooth or papillose, those of the basal angles often larger, inflated or square. Pedicel erect; capsule usually horizontal, without an annulus; calyptra cucullate; lid usually with a long slender beak; peristome double. Twelve genera and 448 species widely distributed in tropical regions.

\section{SEMATOPHYLLUM Mitt. Journ. Linn. Soc. 8: 5.1864.}

Stems rarely pinnate with the branches usually short and crowded. Leares secund or spreading, faintly bicostate or ecostate, with the cells all smooth, the alar cells enlarged, often vesicular; margins entire or minutely serrulate; pedicels long or short; capsule with the lid long-beaked, often equaling the urn; teeth deeply lamellate inside, sometimes with minute projections on the outside, either with a zigzag median line or a deep central groove; endostome with the keeled segments more or less perforate and the cilia one or two, usually shorter, often papillose. A large genus of 314 species, mostly from tropical America. [Greek, in reference to the pointed leaves.] Type species: Hypnum substrumulosum Hampe.

Leaves recurved when dry; perichaetial leaves longer, entire or subserrulate; peristome-teeth not deeply grooved, with a zigzag median line.

Leaf-cells rhomboid, 3-5 times longer than wide.

Leaf-cells linear, 8-10 times longer than wide.

Leaves spreading when dry; perichaetial leaves shorter and serrate; peristome-teeth deeply grooved on the median line.

1. S. subpinnatum.

2. S. admistum.

3. S. sericifolium.

1. Sematophyllum subpinnàtum (Brid.) E. G. Britton, Bryol. 21: 28. 1918.

Leskea subpinnata Brid. Sp. Musc. 2: 54. 1812.

Plants growing in bright or yellowish green cushions," usually on wood. Stems creeping and rooting, irregularly pinnate, with ascending, more or less circinate, simple branches; leaves crowded, recurved or secund when dry, spreading when moist, with recurved tips and revolute margins, seldom reaching $1 \mathrm{~mm}$. in length by $0.4 \mathrm{~mm}$. wide, concave, with flat or revolute, entire margins; apex acute or short-acuminate; veins short and double, obscure or none; basal angles with 3-4 rows of square cells and a few larger inflated alar cells; upper cells rhomboid, about $3-5$ times longer than wide; perichaetial leaves 
longer, up to $1.32 \mathrm{~mm}$, erect and clasping, more acuminate, entire or finely subserrulate, ecostate with larger basal cells. Autoicous. Pedicel short, only $5 \mathrm{~mm}$; , capsule 1-1.5 mm., erect or slightly inclined; neck distinct; lid with a long beak equalling the urn; peristome short and teeth yellow, with deep basal lamellae on the inside, dark basal segments, paler and papillose points; median line not deeply grooved; endostome with narrow pale papillose keeled segments, which are not perforate, and the cilia often absent; spores smooth, ripe in winter.

On rotten wood and twigs in copplce, New Providence :-Florida; Mississippi ; Cuba; Jamaica; Hispanlola; Porto Rico to Trinidad; Mexico to Brazil. SuBPINNATE SEMATOPHYLLUM.

2. Sematophyllum admístum (Sull.) Mitt. Journ. Linn. Soc. 12: 485.1869.

Hypnum admistum Sull. Proc. Am. Acad. 5: 289. 1861.

Plants small, yellowish-green, glossy. Stems short, creeping; branches erect; leaves crowded, recurved at apex of stems and all more or less secund when dry, spreading when moist, up to $1 \mathrm{~mm}$. long by $0.3 \mathrm{~mm}$. wide, concave and acuminate with flat or slightly revolute, entire or sub-serrulate margins; veins 2, short or none; cells eight times longer than wide, those of the basal angles square with 2-3 alar cells enlarged and hyaline; perichaetial leaves longer, up to $1.33 \mathrm{~mm}$., more acuminate, entire, or subserrulate at apex. Autoicous; pedicel bent at base, up to $7 \mathrm{~mm}$. long; capsule 1-1.5 mm. long, horizontal or curved, ovoid and contracted below the mouth when dry; calyptra cucullate; lid pale, long-beaked; peristome double, its teeth with short projections on the outer surface and deep ones on the inner, paler and papillose at apex; median line zigzag, not deeply grooved; endostome pale, with 1-2 cilia; spores smooth, ripe in summer.

Common, in dense cushions on rotten wood in coppices, also on palmetto, New Providence, Ábaco, Andros, Great Bahama and Watling's Island:-Florida ; Cuba ; Jamalca; Porto Rico; Virgin Islands to Brazil. Shining Sematophyllum.

\section{Sematophyllum sericifollium Mitt. Journ. Linn. Soc. 12: 483.1869.}

Plants in thin glossy patches on rotten wood. Stems short and slender; branches erect; leaves crowded, not secund, spreading when moist, up to $1 \mathrm{~mm}$. long and only $0.2 \mathrm{~mm}$. wide at base, sharply pointed and mucronate, with inrolled entire margins, and large curved inflated alar cells; ecostate; the cells linear, about 10 times longer than wide; perichaetial leaves shorter, up to 0.85 $\mathrm{mm}$. long, clearly serrate and sometimes suddenly subulate and coarsely toothed at the shoulder. Autoicous; pedicel short, only 5-8 $\mathrm{mm}$. long, slender, curved; capsule erect or slightly inclined, ovoid; lid with a long slender beak; calyptra covering only the beak; walls of collenchyma cells; mouth bordered by red cells; peristome double, the teeth with a deep outer median groove, yellow and striate, paler and papillose at apex, within with deep lamellae extending almost to the apex; endostome papillose with 2 slender cilia; spores rough, small, ripe in spring.

A few plants were collected at Nicholl's Town, Andros, by J. I. and A. R. Northrop In 1890 :-Cuba ; Jamaica; Hispaniola; Porto Rlco; Virgin Islands to Grenada. Glossy Sematophyllum.

\section{Class 2. HEPÀTICAE.}

\section{LIVERWORTS.}

Contributed by Professor Alexander W. Evans.

Terrestrial, epiphytic, or rarely aquatic plants, showing a distinct alternation of generations, the gametophyte existing as an in- 
dependent individual, the very different sporophyte partially or wholly parasitic on the gametophyte. Gametophyte dorsiventral, consisting of a thallus or more or less differentiated into stem and leaves, attached to the substratum by means of rhizoids (true roots none), growing by means of an apical cell. Sexual organs borne on the upper surface of the gametophyte or terminal on more or less differentiated branches. Fertilized egg developing directly into the sporophyte, the wall of the venter of the archegonium usually developing into a protective cover, or calyptra, which is not ruptured until the sporophyte is nearly mature. Sporophyte consisting of a capsule only or differentiated into a capsule (spore-bearing organ), a stalk or a growing region, and a foot (absorbing organ). Capsule consisting of a wall of sterile cells and a spore-sac, the latter sometimes with a median sterile portion (columella), dehiscing irregularly or by means of a lid or of longitudinal splits; spore-sac containing spores only or spores and elaters, the latter consisting of sterile cells, often elongated and usually developing spiral bands of thickening on their walls.

Gametophyte a thallus or leafy shoot. Chloroplasts minute, many in each cell. Capsule short, spherical to oval, without a columella, borne on a translucent stalk.

Gametophyte a thick and fleshy thallus, usually pale and differentiated into distinct tissues, rarely deep green and succulent; green tissue usually with airspaces. Capsule splitting irregularly or by means of a lid.

Gametophyte a delicate thallus or a leafy shoot; tissue differentiation slight: air-spaces not present. Capsule splitting into four longitudinal valves.

Gametophyte a thick and fleshy thallus, dark green and succulent, tissue differentiation slight. Chloroplasts large, usually borne singly. Capsule long, cylindrical, with a basal growing region, splitting into two longltudinal valves.

Order 1. Marchantrales.

Order 2. JungermanNiLes.

Order 3. ANthocerotales.

\section{Order 1. MARCHANTIÀLES.}

Gametophyte a prostrate, strap-shaped, dorsiventral thallus, growing apically, branching dichotomously or from the ventral surface of the median portion, and showing a distinct differentiation into tissues, the green tissue usually with air-spaces. Ventral scales more or less distinct. Rhizoids of two kinds, the one with smooth walls, the other with interior peglike papillae. Antheridia in deep depressions on the upper surface of the thallus, sometimes seattered, sometimes grouped together in more or less definite, sessile or stalked receptacles. Archegonia similar in position but, when borne on stalked receptacles (earpocephala), becoming displaced to the lower surface through intercalary growth. Sporophyte a eapsule only or differentiated into capsule, stalk, and foot; elaters (or other sterile cells) usually present in the capsule. 


\section{Family 1. RICCIĀCEAE Dumort.*}

\section{RicCIA FAMILY.}

Gametophyte terricolous or aquatic, annual or perennial, once to several times dichotomous, often forming rosettes, half-rosettes, or flabelliform expansions. Stomata wanting or rudimentary in Riccia, well developed in Oxymitra, moderately well developed in Ricciocarpus. Ventral scales usually obvious. Antheridia and archegonia arising singly from the dorsal surface just back of the growing apex, soon becoming deeply immersed in the thallus.

Sporophyte a capsule, without foot or seta, enclosed by the calyptra, in which the spores come to lie at maturity through the disappearance of the capsule wall. Inner cells all producing spores or (Oxymitra) an inconspicuous few of them remaining sterile; spores separating at or before maturity, the separate spores large, subspheric or more commonly more or less tetrahedral, with a rounded outer face and plane inner faces, the surfaces marked with free or most frequently mesh-forming ridges, or simply with spines, the angles of the areolae often with papilliform elevations, the inner (plane) faces usually less strongly marked than the outer.

\section{RÍCCIA [Micheli] L. Sp. Pl. 1138. 1753.}

[RICCIELLA A. Br. Flora 4: 756. 1821.]

Gametophyte terricolous or rarely aquatic, usually several times dichotomously branched. Assimilatory layer consisting of vertical or subvertical columns of cells bounding very narrow air-canals, or consisting of larger polyhedral or subclavate chambers bounded by unistratose lamellae. Stomata represented by very inconspicuous pores bounded by unmodified or only very slightly modified epidermal cells. Latero-ventral scales hyaline-albescent, brownish, violet, or dark purple, rarely surpassing the margins of the thallus, sometimes apparently wanting. Antheridia and archegonia scattered, the antheridia irregularly intermingled with the archegonia in the monoecious species, with occasional tendencies to segregation, both destitute of a special involucre. Sporophyte-wall unistratose throughout, soon disintegrated. Spores separating at or before maturity. Accessory sterile cells wanting. [Commemorates P. F. Ricci, a Florentine senator and patron of science.] A genus of 130 or more species, of temperate and tropical distribution. Type species: Riccia crystallina $\mathrm{L}$.

Thallus margins and sides green or occasionally tinged with red-purple; dor'sal surface vesicular-areolate, becoming spongiose or lacunose-alveolate; spores distinctly angled and wing-margined.

Thallus margins and sides dark violet or blackish; dorsal surface rather obscurely and finely reticulate, remaining firm and intact; spores obscurely angled, destitute of wing margins.

1. $R$. crystallina.

2. R. violacea.

1. Riccia crystallìna L. Sp. Pl. 1138. 1753.

Thalli small to moderately large, 2-6 times dichotomous, forming rosettes 5-20 mm. (rarely $30 \mathrm{~mm}$.) in diameter, or soon irregularly gregarious, usually a light crystalline green, occasionally dark green or now and then tinged with

* Contributed by Dr. Marshall A. Howe. 
red-purple or brownish red, concolorous below, the dorsal surface vesicularareolate, soon becoming spongiose or lacunose-alveolate; main segments 1-2.5 $\mathrm{mm}$. wide; margins obtuse or subacute, naked; scales wanting or rudimentary; transverse sections mostly $2-4$ times as broad as high; dorsal epidermis soon indeterminate, the cells of the primary stratum subspheric, ellipsoidal or papilliform, irregularly collapsing or subpersistent, they or their successors finally 40-110 $\mu$ in maximum diameter; air-chambers elongate-polyhedral, separated by unistratose lamellae; monoecious (rarely dioecious?); antheridial ostioles elevated $75-250 \mu$; spores at first yellowish brown, soon darkening and often nearly opaque, $60-110 \mu$ in maximum diameter, distinctly angular, with a margin mostly $3-10 \mu$ wide, the outer face marked with somewhat imperfectly formed areolae usually $10-30 \mu$ wide or those in the middle sometimes larger $(30-45 \mu)$ and enclosing a free-ending spur or an isolated tubercle, the inner faces with tubercles, short, free irregular ridges, or sometimes with imperfect areolae, the older spores commonly tuberculate-papillate in profile.

On wet grounds and in sink-holes, Great Bahama and Exuma Chain :-Vermont to Alberta, Lower California and Trinldad; Europe. Crystalline Riccia.

2. Riccia violàcea M. A. Howe, Ann. Mo. Bot. Gard. 2: 51. 1915.

Thallus small, 1.5-4 mm. long, simple or 1-3 times dichotomous, irregularly gregarious, rather obscurely and-finely reticulate and dark green above, dark violet or blackish at margins and on sides; main segments $0.6-1.15 \mathrm{~mm}$. wide; margins obtuse or rounded, commonly erect-connivent or inflexed on drying, bearing especially toward the apex and often low on the sides numerous or occasional violet or sometimes hyaline conic or subcylindric acute or obtuse papillae $20-110 \mu$ long and $25-45 \mu$ broad at base; scales very short or rudimentary, dark violet, rarely overlapping, commonly divided into a series of small irregular often tooth-like laciniae, each consisting of only a few cells; transverse sections 1.5-2 times as broad as high; dioecious (?); antheridial ostioles elevated $20-150 \mu$, often violet; spores soon fuscous and very opaque, $80-105 \mu$ in maximum diameter, obscurely angled or flattened-sphaeroid, destitute of wing margins, finely, irregularly, indistinctly, and almost uniformly areolate over whole surface, the areolae $7-11 \mu$ wide, soon very obscure and the spores appearing minutely and densely verruculose.

On moist ground, Eleuthera:-Mona Island; Porto Rico; Cuba; and northern Mexico. Violet Riccia.

\section{Family 2. MARCHANTIACEAE Corda.}

\section{Marchantia Family.}

Thallus (except in Dumortiera) with a distinct dorsal layer of airchambers, communicating with the outside air by means of epidermal pores. Ventral scales in two (or more) longitudinal rows. Antheridia and archegonia borne on more or less definite receptacles; antheridial receptacles discoid, sessile or stalked; carpocephala discoid, invariably stalked, the stalk sometimes with one or two rhizoid-furrows. Sporophyte differentiated into a capsule, stalk and foot, the capsule forced through the calyptra at maturity by the elongating stalk and dehiscing irregularly or by means of a more or less distinct lid; elaters present in the capsule. Gemmae discoid, present in two genera. About 25 genera and 200 species, widely distributed, especially in warm regions.

\section{MARCHÁNTIA [Marchant f.] L. Sp. Pl. 1137. 1753.}

Thallus branching dichotomously. Air-chambers with distinct boundaries, forming a single layer; green cells in short, simple or branched filaments rising 
from the floors of the chambers, the filaments mostly three or four cells long; epidermal pores bounded by several superimposed layers, each usually composed of four cells. Ventral scales variable, some divided into a basal portion and an appendage. Inflorescence dioecious. Antheridial receptacle terminal on a thallus-branch, flat or slightly convex, more or less lobed, borne on a somewhat elongated stalk with two rhizoid-furrows. Carpocephalum arising from the extremity of a thallus-branch, composed of a flat or convex central portion from which four to ten rays spread out, often unsymmetrically, the rays terete or flat; stalk with two or four rhizoid-furrows; archegonia (and sporophytes) in radiating groups between the lobes, each group enclosed by a membranous involucre consisting of two folds with fringed margins; pseudoperianth (around each sporophyte) tubular, membranous, with an open, irregularly cleft mouth. Capsule without a lid, splitting into from four to eight irregular teeth; cells of wall with ring-like thickenings. Gemmae discoid, several cells thick in the middle and with the growing points, borne in circular, cup-like conceptacles. [In honor of Nicholas Marchant, director. of the ducal garden at Blois, died 1678.] About fifty species, mostly tropical. Type species: Marchantia polymorpha L.

1. Marchantia domingénsis Lehm. \& Lindenb. Pug. 6: 22. 1834.

Thallus pale to dark green, mostly $2-3 \mathrm{~cm}$. long and 4-6 mm. wide, flat or slightly furrowed, sinuate along the margin. Ventral scales more or less pigmented, in two longitudinal rows on each side of the middle, those of the inner row with broadly, lanceolate to ovate, toothed appendages; antheridial receptacle deeply lobed, the lobes mostly four to six, palmately spreading; carpocephalum deeply rayed, the rays mostly seven, not cylindrical; spores spherical about $28 \mu$ in diameter, with low irregular ridges; elaters bispiral; gemmaeconceptacles closely short-ciliate.

Along a drain, Fort Charlotte, New Providence :-southern United States; West Indies: Mexico; Central America and Venezuela. Previously listed from the Bahamas as $M$. chenopoda L. Santo Domingo Marchantia.

\section{Order 2. JUNGERMANNIÀLES.}

Gametophyte a prostrate, strap-shaped, dorsiventral thallus or more or less clearly differentiated into stem and leaves, showing slight tissue differentiation, destitute of air-spaces. Rhizoids all with smooth walls. Antheridia in deep depressions or superficial and usually protected by scales or leaves, sometimes scattered, sometimes grouped together in more or less definite receptacles or androecia. Archegonia superficial but usually more or less protected by scales or leaves. Sporophyte differentiated into capsule, stalk, and foot, the capsule splitting irregularly at maturity or more commonly into four equal valves; elaters always present.

\section{Family 1. JUNGERMANNIĀCEAE Dumort.}

\section{Jungermania Family.}

Plant body usually prostrate or ascending, dorsiventral, differentiated into stem and leaves; branches lateral or ventral; leaves normally in three 
longitudinal ranks, two dorsal or lateral and one ventral, those of the ventral rank (the underleaves) smaller than the others and sometimes absent altogether. Antheridia borne singly or in some groups in the axils of more or less specialized leaves, the perigonial bracts. Archegonia borne singly or in groups at the tips of branches, surrounded by specialized leaves, the perichaetial bracts and bracteoles. Perianth present in many genera, consisting of a cylindrical or prismatic tube open at the apex. Capsule spherical to eylindrical. About 150 genera and some 4,000 species, widely distributed, most abundant in tropical regions.

A. Leaves undivided but often toothed.

B. Leaves bilobed and compllcate, the ventral lobe, or lobule, smaller than the dorsal and usually specialized as an inflated water-sac.

1. Underleaves none.

Plants large, perianth with a broad truncate mouth. Plants minute, perianth abruptly contracted to a small tubular mouth.

2. Underleaves present, one for every lateral leaf.

3. Underleaves present, one for every two laterai leaves.

a. Lobule inflated but not helmet-shaped, attached to the dorsal lobe by a long keel.

* Underleaves bifid.

t Plants pale green to yellowish green.

Divisions of underleaves not subulate.

Perianth inflated, more or less distinctly five-keeled.

Lobule with a hyaline papilla at the proximal base of the apical tooth.

Plants large ; well-developed leaves $0.6 \mathrm{~mm}$. or more in length.

Plants medium-sized; well-developed leaves mostly $0.3-0.5 \mathrm{~mm}$. in length.

Plants small ; well-developed leaves 0.3 or less in length.

Lobule with a hyallne papilla at the distal base of the apical tooth.

Perlanth compressed, at least when young.

Lobule with a hyaline papilla at the proximal base of the aplcal tooth.

Lobule with a hyaline papilla at the distal base of the aplcal tooth.

Dlvisions of underleaves subulate and spreading.

† Plants more or less plgmented with brown.

* Underleaves undivided.

Plants pale green to yellowish green.

Subfloral innovations none.

Subfloral innovations present.

Plants more or less plgmented with brown.

Subfloral innovations none.

Subfloral innovations present.

Leaves densely squarrose.

Perlanth with five to ten keels.

Perianth wlth three keels.

Leaves not squarrose; perianth with five keels.

b. Lobule usually inflated and helmet-shaped, usually attached to the lobe by a very short keel.

\section{Plagiochila.}

\section{Radula.}

4. Leptocolea.

3. Diplasiolejeunea.

10. Taxilejeunea.

5. Lejeunea.

6. Microlejeunea.

9. Euosmolejeunea.

7. Rectolejeunea.

8. Cheilolejeunea.

12. Leptolejeunea.

11. Ceratolejeunea.

15. Caudalejeunea.

18. Leucolejeunea.

14. Lopholejeunea.

13. Brachiolejeunea.

16. Mastigolejeunea.

17. Archilejeunea.

19. Frullania.

1. PLAGIOCHİLA Dumort. Recueil d'Obs. 14. 1835.

Stems ascending from a prostrate rhizome, simple or with lateral branches. Leaves succubous, undivided, decurrent dorsally and ventrally, the margin varying from entire to ciliate or spinose. Underleaves usually minute and shortlived. Inflorescence dioecious. Antheridia from one to ten in the axils of 
bracts saccate at the base, the bracts imbricated and usually arranged in elongated androecia, often proliferating at the apex. Perichaetial bracts similar to the leaves but often broader and more toothed. Perianth laterally compressed, the mouth broad, truncate, and variously dentate to eiliate. [Greek, oblique lip.] Some 800 species or more, mostly tropical. Type species: $P$. asplenioides (L.) Dumort.

\section{Plagiochila ludoviciàna Sulliv. Muse. Alleg. 223. 1845.}

Loosely tufted, yellowish to brownish green. Stems sparingly and irregularly branched. Leaves obliquely spreading, imbricated, about $2.5 \mathrm{~mm}$. long and $1.2 \mathrm{~mm}$. wide, ovate, long-decurrent dorsally and reflexed at the ventral base, irregularly toothed in the apical region and along the ventral margin; underleaves minute or larger and narrowly lanceolate.

On bark, Maidenhead Coppice, New Providence:-Louisiana to Florida; Cuba ; Virgin Islands. LOUISIANA PLAgIOCHILA.

\section{RÀDULA Dumort. Comm. Bot. 112. 1822.}

Stems prostrate or growing from a prostrate rhizome, with numerous lateral branches arising just behind normal leaves; rhizoids always borne on the ventral lobes of the leaves. Leaves complicate-bilobed, the dorsal lobes larger than the ventral, incubous, usually entire and often rounded at the apex; ventral lobes attached to the dorsal by a more or less elongated keel, the free margin usually appressed to the dorsal lobe. Underleaves none. Antheridia borne singly or in groups of two or three in the axils of saccate bracts, the latter forming more or less elongated androecia. Archegonia borne on more or less elongated branches, sometimes with subfloral innovations; bracts similar to the leaves. Perianth usually dorsiventrally compressed, rarely subterete or plicate, truncate and bilabiate but otherwise entire at the broad mouth. Gemmae, when present, diseoid, multicellular. [Latin, a seraper or spatula.] About 400 species, largely tropical. Type species: $R$. complanata (L.) Dumort.

\section{Radula australis Aust. Bot. Bull. (Bot. Gaz.) 1: 32.1875.}

Plants dark green, loosely tufted to seattered. Stems irregularly pinnate. Leaves imbricated, the dorsal lobe spreading at about a right angle, obovateoblong, about $1 \mathrm{~mm}$. long and $0.6 \mathrm{~mm}$. wide; lobule rhomboid, rounded at the apex, the upper margin parallel with the keel; inflorescence dioecious; androecium mostly median, the bracts in about six pairs; perianth elongated.

On bark, Andros and New Providence:-Georgia and Florida. Southern Radula.

\section{DIPLASIOLEJEÙNEA [Spruce] Schiffn. in E. \& P. Nat.}

Pff. $1^{3}$ : 121.1894.

Stems prostrate, copiously branched, the branching as in Radula. Leaves loosely imbricated, complicate-bilobed, the dorsal lobe ovate to orbicular, attached by a very short base, convex and widely spreading, entire; lobule inflated, attached to the dorsal lobe by a long arched keel, usually with two distinct teeth in the apical region; leaf-cells with more or less thickened walls, seattered ocelli usually present. Underleaves doubled, one for every lateral leaf, deeply bifid with divarieate lobes. Antheridia borne in pairs in the axils 
of saceate bracts, the latter usually in short androecia. Female inflorescence borne on a branch variable in length, with a single subfloral innovation. Perianth sharply five-keeled, abruptly narrowed into a short beak. Gemmae discoid, borne on the surface of the leaves. [Greek, doubled Lejeunea.] About 20 species, tropical. Type species: D. pellucida (Meissn.) Schiffn.

\section{Diplasiolejeunea Rudolphiàna Steph. Hedwigia 35: 79. 1896.}

Plants yellowish green, in compact depressed tufts. Leaves imbricated, the dorsal lobe widely spreading; somewhat convex, broadly ovate, about 1.3 $\mathrm{mm}$. long, entire or nearly so; lobule about $0.7 \mathrm{~mm}$. long, more or less inflated, the apical tooth long and slender, usually subparallel with the axis; leaf-cells with small trigones; underleaves distant to subimbricated, broadly cuneate, bifid about one half with obliquely spreading, blunt divisions and a rounded sinus; inflorescence autoecious; female inflorescence borne on a branch variable in length, the innovation usually simple and sterile; bracts bifid to the middle or beyond, the dorsal lobe rounded at the apex, the ventral obtuse to acute; bracteole ovate, shortly bifid, with acute to obtuse divisions; perianth obovate in outline, rounded at the apex; gemmiparous leaves usually two, borne terminally on branches with limited growth.

On bark, New Providence :-Florida; West Indies; Dutch Guiana; Brazil. RUDOLPH'S DIPLASIOLEJEUNEA.

\section{LEPTOCÒLEA [Spruce] Evans, Bull. Torr. Club 38: 261. 1911.}

Stems prostrate, minute and delicate, irregularly branched, the branches as in Radula. Leaves more or less imbricated, complicate-bilobed, the dorsal lobes larger than the ventral, broadly to narrowly ovate, attached by a very short base, widely spreading, usually rounded at the apex; lobule inflated, attached to the dorsal lobe by a long arched keel, usually with two teeth in the apical region; leaf-cells often with trigones and surface-tubercles, ocelli and hyaline marginal cells sometimes present. Underleaves none. Antheridia borne singly or in pairs in the axils of the male bracts, the latter usually saccate and forming more or less elongated androecia. Archegonia borne singly on more or less elongated branches, with one or two subfloral innovations, the bracts usually with plane lobules. Perianth compressed, with sharp lateral keels and sometimes with a more or less distinct two-angled ventral keel, beak short. Gemmae discoid, borne on the surface of the leaves. [Greek, delicate sheath.] About 30 species, mostly tropical. Type species: L. micrandroecia (Spruce) Evans.

1. Leptocolea Jooriàna (Aust.) Evans, Bull. Torr. Club 38: 270. 1911.

Lejeunea Jooriana Aust. Bull. Torr. Club 6: 20. 1875.

Cololejeunea Jooriana Evans, Mem. Torr. Club 8: 173. 1902.

Yellowish green or whitish, loosely tufted or scattered. Leaves imbrieated, the dorsal lobe widely spreading, plane, ovate, about $0.5 \mathrm{~mm}$. long, gradually narrowed to the apex, usually from one to ten hyaline cells with free extremities; lobule about half as long as the lobe, with two teeth in the apical region; leaf-cells with slightly thickened walls and indistinct trigones; inflorescence paroecious or synoecious; perianth ovate to obovate in outline, truncate to very slightly retuse at the apex with a very short beak.

On bark, New Providence and Crooked Island:-North Carolina to Florida and Louisiana; Porto Rico. JOOR'S LEPTOCOLEA. 
5. IEJEÙNEA Libert, Ann. Gen. Sci. Phys. (Brux.) 6: 372. 1820.

Stems prostrate, small, irregularly branched, the branches as in Radula; rhizoids springing from the bases of the underleaves. Leaves complicatebilobed, the dorsal lobes larger than the ventral, incubous, attached by a long line, ovate to obovate, rounded to obtuse at the apex, entire or slightly crenulate; lobule when well developed inflated, acute, bearing a hyaline papilla at the base of the apical tooth on the side next to the stem; leaf-cells thin-walled but sometimes with small trigones. Underleaves ovate to orbicular, bifid, the division mostly entire or crenulate. Antheridia borne or in pairs in the axils of saccate bracts, the latter in more or less elongated androecia. Archegonia borne singly on branches variable in length with one or two subfloral innovations, the bracts with plane lobules, bractole bifid. Perianth inflated, fivekeeled, abruptly narrowed to a distinct tubular beak. [Commemorates A. L. S. Lejeune, Belgian botanist.] Nearly 200 species, mostly tropical. Type species: L. cavifolia (Ehrh.) Lindb.

Lobule about $0.2 \mathrm{~mm}$. long; keels of perianth smooth or nearly so. 1 . L. flava. Lobule about $0.1 \mathrm{~mm}$. long; keels of perianth distinctly crenulate. 2 . L. glaucescens.

\section{Lejeunea flàva (Sw.) Nees, Naturges. Eur. Leberm. 3: 277. 1838.}

Jugermannia flava Sw. Prodr. 144. 1788.

Plants pale to yellowish green, scattered or growing in depressed mats. Leaves imbricated, the dorsal lobe widely spreading, ovate, about $0.5 \mathrm{~mm}$. long, rounded to obtuse at the apex; lobule inflated, ovate, more or less involute, apex tipped with a single blunt cell; leaf-cells thin-walled but usually with distinct trigones, averaging about $23 \mu$ in the middle of the lobe; underleaves usually subimbricated, orbicular, plane, bifid about one half with the segments usually sharp-pointed and the sinus narrow; inflorescence autoecious; female inflorescence borne on a more or less elongated branch with one or two subfloral innovations; bracts a little larger than the leaves; bracteole free, ovate; perianth obovoid, the keels rounded in the upper part, smooth.

On bark, Waterloo and Maldenhead Coppice, New Providence :-North Carolina to Florida and Texas; Ireland; Australla; widely distributed in troplcal regions throughout the world. YELLOW LEJEUNEA.

\section{Lejeunea glaucéscens Gottsche, in G. L. \& N. Syn. Hep. 378. 1845.}

Plants pale to bright green, scattered or growing in thin, depressed mats. Leaves subimbricated, the dorsal lobe widely spreading, ovate, about $0.7 \mathrm{~mm}$. long, usually broad and rounded at the apex; lobule inflated, triangular-ovoid, involute, apex tipped with a single blunt cell; leaf-cells thin-walled and usually without trigones, averaging about $33 \times 25 \mu$ in the middle of the lobe; underleaves distant, orbicular, plane, bifid about one third with rounded or obtuse lobes and a narrow sinus; inflorescence autoecious; female inflorescence borne on a more or less elongated branch with a single subfloral innovation; bracts shorter than the leaves, the lobule pointed; bracteole slightly connate, ovate to obovate; perianth obovoid, the keels rounded above, minutely crenulate.

On bark, Great Bahama and Cat Island:-Florida; tropical America; range not definitely known. The Bahamian speclmens are not very well developed but seem to be referable to this specles. GRAYISH LEJEUNEA. 


\title{
6. MICROLEJEÙNEA [Spruce] Jack \& Steph. Bot. Centrb.
}

\author{
60: 107. 1894 .
}

A somewhat artificial genus differing from Lejeunea in its smaller size and relatively larger lobules, the latter often equaling the dorsal lobes in length. Structure of the lobes, lobules, underleaves and floral organs very similar in the two genera. [Greek, minute Lejeunea.] About 70 species, mostly tropical.

Lobule about half as long as the dorsal lobe; leaf-cells averaging about $20 \mu$.

Lobule nearly as long as the dorsal lobe; leaf-cells averaging about $12 \mu$.

1. M. laetevirens.

2. M. bullata.

1. Microlejeunea laetevìrens (Nees \& Mont.) Evans, Bryol. 11: 68. 1908.

Lejeunea laetevirens Nees \& Mont. in Sagra, Hist. Cub. 9: 281. 1845.

Plants pale green, scattered or growing in depressed mats. Leaves distant to subimbricated, the dorsal lobe obliquely spreading, ovate, about $0.25 \mathrm{~mm}$. long, rounded to obtuse at the apex; lobule inflated, about half as long as the lobe, ovate, involute, apex tipped with a single, almost straight, blunt cell; leaf cells averaging about $20 \mu$ in the middle of the lobe, thin-walled throughout or with minute trigones; underleaves distant, ovate, bifid about one half with acute or acuminate divisions and a narrow sinus, often unidentate on one or both sides; inflorescence dioecious; female inflorescence borne on a short branch, with one or two subfloral innovations; bracts a little larger than the leaves, the lobule rounded to acuminate; bracteole free, ovate; perianth pyriform, the keels smooth.

On bark, Abaco, Berry Islands, Andros, New Providence, and Cat Island:-Virginia; Florida to Louislana; widely distributed in tropical America. YELLowisH GREEN MICROLEU EUNEA.

\section{Microlejeunea bullàta (Tayl.) Evans, Mem. Torr. Club 8: 164. 1902.}

Lejeunea bullata Tayl. Lond. Journ. Bot. 5: 398. 1846.

Plants pale or bright green, scattered or forming loose depressed mats. Leaves distant, the dorsal lobe erect or slightly spreading, ovate, about 0.15 long, rounded at the apex, entire or nearly so; lobule strongly inflated, almost as long as the lobe, ovate, usually involute, the apex tipped with a single, almost straight, blunt cell; leaf cells averaging about $12 \mu$, usually thin-walled throughout; underleaves distant, ovate to orbicular, bifid more than one half with suberect, subulate lobes and a broad sinus, margin entire; inflorescence dioecious; female inflorescence borne on an elongated branch with a single subfloral innovation; bracts about twice as long as the leaves, the lobe rounded to acute, the lobule narrower, usually acute; bractole slightly connate, oblong, bifid less than one half with sharp divisions; perianth pyriform, the keels smooth.

On bark, New Providence and Crooked Island:- southern United States; tropical America. INFLATED MICROLEJ EU NEA.

\section{RECTOLEJEÙNEA Evans, Bull. Torr. Club 33: 8. 1906.}

Differs primarily from Lejeunea in its flattened perianth with sharp lateral keels. Dorsal lobes, lobules and underleaves similar, but the lobes commonly broader; ocelli sometimes present among the leaf-cells; vegetative reproduction by means of specialized caducous leaves. [Greek, fragile Lejeunea.] About 40 species, largely of tropical America. Type species: R. flagelliformis Evans. 
Leaves with basal ocelli ; caducous leaves borne on short spreading branches with crowded perslstent underleaves and limited growth.

Leaves without basal ocelli; caducous leaves borne on ordinary branches.

Dioecious; bracteoles present along the whole length of the androecia.

Autoecious; bracteoles restricted to the base of the androecia.

1. R. Berteroana.

2. R. Brittoniae. 3. R. phyllobola.

1. Rectolejeunea Berteroàna (Gottsche) Evans, Bull. Torr. Club 33: 12.1906.

Lejeunea Berteroana Gottsche; Steph. Hedwigia 27: 282. 1888.

Pale green, scattered or in depressed tufts. Leaves imbricated, the dorsal lobe widely spreading, plane or nearly so, obliquely ovate, about $0.5 \mathrm{~mm}$. long, rounded at the apex; lobule inflated, ovoid-cylindrical, involute, apex tipped with uniformly thickened walls, averaging about $10 \mu$; basal ocelli much larger, usually occurring in groups of two to six; underleaves normally contiguous, orbicular, plane, bifid about half way with acute lobes and sinus; inflorescence dioecious; female inflorescence borne on a short branch with a single subfloral innovation; bracts with plane lobules, otherwise much like the leaves; perianth unknown; caducous leaves borne on short spreading branches with crowded persistent underleaves and limited growth.

On bark, Soldier's Road and Grantstown, New Providence:-Florida; West Indies. BERTERo's RECTOLEJEUNEA.

\section{Rectolejeunea Brittòniae Evans, Bull. Torr. Club 38: 209. 1911.}

Yellowish green, growing in depressed mats. Leaves imbricated, the dorsal lobe widely spreading, plane or nearly so, broadly ovate to orbicular, about 0.5 $\mathrm{mm}$. long, rounded at the apex, margin vaguely crenulate; lobule inflated, triangular-ovoid, involute, apex tipped with a straight, slightly projecting cell; leaf cells with indistinct trigones, averaging about $25 \mu$ in the middle of the Iobe; underleaves scarcely overlapping, orbicular, bifid about one half with sharp or blunt lobes; inflorescence dioecious; male inflorescence variable in length, the bracteoles present throughout and similar to the underleaves; female inflorescence usually on an elongated branch, with one or two subfloral innovations; bracts and bracteoles a little larger than the leaves; perianth oblong to obovate; caducous leaves borne on prastrate branches.

On bark, Great Bahama and New Providence:-Florida; Cuba; Hispaniola. Mrs. BRITTON'S RECTOLEJ DUNEA.

3. Rectolejeunea phyllòbola (Nees \& Mont.) Evans, Bull. Torr. Club 33: 15.

Lejeunea phyllobola Nees \& Mont. in Sagra, Hist. Cub. 9: 281. 1845.

Pale green, growing in depressed mats. Leaves loosely imbricated, the dorsal lobe widely spreading, ovate-orbicular, about $0.5 \mathrm{~mm}$. long, rounded at the apex, entire or nearly so; lobule inflated, ovate, involute, apex usually tipped with a single rounded cell; leaf cells thin-walled but with distinct trigones, averaging about $20 \mu$; underleaves distant, broadly ovate to orbicular, bifid to about the middle with narrow and usually sharp divisions; inflorescence autoecious; male inflorescence with the bracteoles restricted to the basal portion; female inflorescence usually borne on a short branch with a single subfloral innovation; bracts, bracteoles and perianths much as in the preceding species; caducous leaves borne on prostrate branches.

On bark, Great Bahama, New Providence, Cat and Watling's Islands :-Florida ;

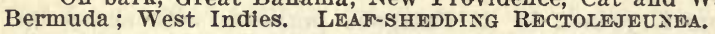

8. CHEILOLEJEÙNEA [Spruce] Schiffn. in E. \& P. Nat. Pflf. $1^{3}: 124.1894$.

Stems prostrate, small or medium-sized, irregularly branched, the branches as in Radula; rhizoids springing from the bases of the underleaves. Leaves 
complicate-bilobed, the dorsal lobes plane or slightly convex, widely spreading, ovate to orbicular, rounded at the apex, entire; lobule strongly inflated and more or less contracted in the outer part, with a single apical tooth bearing a hyaline papilla at its distal base; leaf-cells usually with distinct trigones. Underleaves suborbicular, bifid, the divisions mostly acute and the margins entire. Antheridia usually borne in pairs in the axils of saccate bracts, the latter usually in short androecia. Archegonia borne singly on branches variable in length, with or without subfloral innovations, the bracts with plane and usually acute lobules; bracteoles bifid. Perianth compressed with sharp lateral keels, often becoming two-lipped with age. Vegetative reproduction by means of caducous leaves. [Greek, lipped-Lejeunea.] About 60 species, mostly tropical. Type species: C. aneogyna (Spruce) Evans.

\section{Cheilolejeunea decìdua (Spruce) Evans, Bull. Torr. Club 33: 6. 1906.}

Lejeunea decidua Spruce, Trans. Bot. Soc. Edinb. 15: 257. 1884.

Pale or brownish green, growing in depressed mats. Leaves imbricated, the dorsal lobe ovate, about $0.7 \mathrm{~mm}$. long; lobule triangular ovate in outline, apex tipped with a long, pointed, slightly curved cell; leaf-cells usually with trigones but sometimes thin-walled throughout, averaging about $20 \mu$; underleaves distant, plane, orbicular, bifid to the middle or less with triangular, erect, sharp divisions and a broad sinus. Inflorescence dioecious. Female inflorescence borne on a short branch, with or without a subfloral innovation; perianth broadly obovate; caducous leaves borne on prostrate branches.

On logs, near Nicholl's Town, Andros :-Florida ; Cuba ; Porto Rico; Brazil. DECIDUOUS-LEAVED CHEILOLEJEUNEA.

\section{EUOSMOLEJEÙNEA [Spruce] Schiffn. in E. \& P. Nat.} Pflf. $1^{3}$ : 124.1894.

Yellowish green and firm. Stems prostrate, often elongated, irregularly branched, the branches as in Radula; rhizoids springing from the base of the underleaves. Leaves complicate-bilobed, the dorsal lobes much larger than the ventral, incubous, attached by a long line, broadly ovate, convex, rounded at the apex, entire or nearly so; lobule strongly inflated, acute, bearing a hyaline papilla in the sinus, at the base of the apical tooth; leaf-cells with conspicuous trigones; ocelli none. Underleaves varying from medium-sized to large, sometimes imbricated, orbicular and often cordate at the base, usually bifid with an acute to lunulate sinus, rarely undivided. Antheridia usually in pairs in the axils of saccate bracts, the latter in more or less elongated androecia, often proliferating. Female inflorescence borne on a more or less elongated branch, with one or two subfloral innovations; bracts similar to the leaves but with plane lobules and sometimes with pointed lobes; bracteole bifid, free. Perianth often roughened by projecting cells, sharply 5 -keeled, the keels rounded above, beak distinct. Gemmae none. [Greek, fragrant Lejeunea.] About 35 species, largely tropical. Type species: E. trifaria (Reinw. Bl. \& Nees) Schiffn.

Dioecious, perianths rarely present.

Underleaves small and distant, narrowed toward base.

Underleaves large and usually overlapping, rounded to cordate at base.

Autoecious, perianths usually present; underleaves large and usually overlapping, rounded to cordate at base.

1. E. duriuscula.

2. E. clausa.

3. E. trifaria. 
1. Euosmolejeunea duriúscula (Nees) Evans, Mem. Torr. Club 8: 135. 1902.

Lejeunea duriuscula Nees, in G. L. \& N. Syn. Hep. 364. 1845.

Yellowish green, growing in loose depressed mats. Leaves loosely imbricated, the dorsal lobe ovate, about $0.4 \mathrm{~mm}$. long; leaf-cells with distinct trigones, averaging about $20 \mu$; underleaves distinct, ovate to órbicular, narrowed toward base, bifid about one half with acute lobes and sinus; inflorescence dioecious; androecium usually intercalary on a more or less elongated branch; female inflorescence borne on a similar branch with one or two subfloral innovations.

On bark, rarely on rocks, Abaco, Andros and New Providence:-South Carolina; Florida; widely distributed in tropical America. HARSH EuOSMOLEJEUNEA.

2. Euosmolejeunea claùsa (Nees \& Mont.) Evans, Bryol. 11: 69. 1908.

Lejeunea clausa Nees \& Mont.; Mont. Ann. Sci. Nat. II. 14: 337. 1840.

In loose depressed mats. Leaves loosely imbricated, the lobe broadly ovate, about $0.5 \mathrm{~mm}$. long; leaf-cells with large trigones; underleaves contiguous or imbricated, bifid about one third with obtuse or acute divisions and an obtuse or acute sinus; inflorescence dioecious; androecium borne on a short branch, sometimes proliferating; female inflorescence borne on a short branch, with one subfloral innovation.

On logs, Soldier's Road, New Providence:-South Carolina; Florida and Alabama; Bermuda; widely distributed in tropical America. Closed EuosmoleJeunea.

3. Euosmolejeunea trifària (Reinw. Bl. \& Nees) Schiffn. in E. \& P. Nat. Pflf. $1^{8}$ : 124.1894.

Jungermannia trifaria Reinw. Bl. \& Nees, Nova Acta 12: 226.1824.

Closely related to the preceding species but characterized by its slightly larger size, more robust trigones and autoecious inflorescence.

On logs, Soldier's Road and Waterloo, New Providence. Widely distributed in tropical regions throughout the world; originally described from Javan material. THREEFOLD EUOSMOLEJEUNEA.

\section{TAXILEJEÙNEA [Spruce] Schiffn. in E. \& P. Nat.} Pflf. $1^{8}: 125.1894$.

Plants prostrate or sometimes pendulous, bright green to whitish green, medium-sized to greatly elongated, irregularly branched, the branches as in Radula. Leaves complicate-bilobed, the dorsal lobe often involute about the axis, usually acute or apiculate, with the margin more or less erenulate; leafcells large, thin-walled but with distinct and often large trigones. Underleaves medium-sized to large, often closely imbricated, bifid, usually crenulate. Antheridia usually borne in pairs in the axils of small saccate bracts, the androecia occupying short branches. Archegonia borne singly on branches of variable length, with subfloral innovations, the latter often repeatedly floriferous; bracts smaller than the leaves. Perianth sometimes terete but usually five-kelled in the upper part, the keels smooth or winged. [Greek, swift Lejeunea.] About 100 species, mostly tropical. Type species: T. chimborazensis (Spruce) Steph.

1. Taxilejeunea obtusángula (Spruce) Evans, Bull. Torr. Club 38: 215. 1911.

Lejeunea obtusangula Spruce, Trans. Bot. Soc. Edin. 15: 221. 1884.

Pale green, scattered or forming loose depressed mats. Leaves imbricated, the dorsal lobe obliquely spreading, convex, orbicular-ovate to ovate, about 0.6 
$\mathrm{mm}$. long, apex obtuse or apiculate, margin crenulate; lobule inflated, ovate, involute, the apex tipped with a single, straight, slightly projecting cell; leafcells with distinct trigones, averaging about $32 \times 18 \mu$ in the middle of the lobe; underleaves not overlapping, orbicular, plane, bifid one half or less, with erect, usually sharp divisions; inflorescence autoecious; female inflorescence borne on a short or more or less elongated branch, with one or two subfloral innovations, the latter not floriferous; perianth obovoid, bluntly five-keeled in the apical region, beak lacking.

On rocks, New Providence:-Florida; Porto Rico; Virgin Islands; Brazil. OBTUSELY ANGLED TAXILEJEUNEA.

\section{Ceratolejeùnea [Spruce] Schiffn. in E. \& P. Nat.}

Pflf. $1^{3}: 125.1894$.

Plants prostrate, medium-sized, more or less pigmented with olive-brown and glossy, irregularly branched, the branches as in Radula. Leaves complicate-bilobed, the dorsal lobe convex, often toothed, the apex blunt or acute; lobule normally as in Lejeunea with a hyaline papilla at the proximal base of the apical tooth, sometimes enlarged and bladder-like; leaf-cells with more or less thickened walls and often with apparent trigones; ocelli sometimes present. Underleaves medium-sized to large, orbicular to reniform, usually bifid. Antheridia borne singly or in pairs in the axils of saccate bracts, the latter in short androecia, often proliferating. Female inflorescence borne on a branch very variable in length, with one or two subfloral innovations; bracts often smaller and more dentate than the leaves; bracteole more or less connate. Perianth with a distinct beak and usually with four conspicuous horns. [Greek, horned Lejeunea.] About 100 species, mostly tropical. Type species: C. plumula (Spruce) Steph.

Leaves more or less dentate; autoecious.

Leaves entire or nearly so; dioecious.
1. C. cubensis.

2. C. integrifolia.

1. Ceratolejeunea cubénsis (Mont.) Schiffn. in E. \& P. Nat. Pflf. $1^{8}: 125.1894$.

Lejeunea cubensis Mont. in Sagra, Hist. Cub. 9: 481. 1845.

Olive green or brown, growing in depressed mats. Leaves imbricated, the dorsal lobe ovate, about $0.4 \mathrm{~mm}$. long, acute and usually irregularly toothed in the apical portion; lobule always small and of the normal Lejeunea type, sometimes poorly developed; leaf-cells apparently uniformly thickened, averaging about $15 \mu$; ocelli usually forming a basal pair; underleaves small, orbicular, plane, bifid about one half with acute divisions; inflorescence autoecious; perianth with short, spreading to suberect horns.

On logs, Near Nicholl's Town, Andros:-Florida; widely distributed in tropical america. Cuban Ceratolejeunea.

2. Ceratolejeunea integrifòlia Evans, Bull. Torr. Club 38: 213. 1911.

Related to the preceding species but readily distinguished by its entire leaves and dioecious inflorescence. Bracts and bracteoles of the female inflorescence sometimes very sparingly toothed.

On bark, New Providence:-Florida; Cuba; Porto Rico. Entire-Leaved CeraTOLEJEUNEA. 


\section{LEPTOLEJEÙNEA [Spruce] Schiffn. in E. \& P. Nat.}

Pflf. $1^{3}:$ 126. 1894.

Plants prostrate, small, irregularly but often copiously branched, the branches as in Radula. Leaves complicate-bilobed, the dorsal lobe usually plane, obtuse to acute; lobule as in Lejeunea, with a hyaline papilla at the proximal base of the apical tooth; leaf-cells thin-walled but sometimes with distinct trigones; ocelli usually present. Underleaves distant and minute, with widely spreading, subulate divisions. Antheridia usually in pairs, in the axils of saccate bracts, the androecia variable in length. Female inflorescence borne on a very short branch, simple or with a single subfloral innovation. Perianth sharply five-keeled in the upper part, the keels projecting upward as entire horns. Vegetative reproduction by means of caducous branches with specialized basal leaves. [Greek, delicate Lejeunea.] A genus of about 50 tropical species. Type species: L. elliptica (Lehm. \& Lindenb.) Schiffn.

1. Leptolejeunea elliptica (Lehm. \& Lindenb.) Schiffn. in E. \& P. Nat. Pflf. $1^{3}$ : 126.1894.

Jungermannia elliptica Lehm. \& Lindenb. Pug. 5: 13.1832.

Pale green, becoming blackish or brownish with age, growing in thin patches. Leaves distant, the dorsal lobe widely spreading, oblong-ovate to oblong-lanceolate, about $0.35 \mathrm{~mm}$. long, rounded to subacute, entire; lobule inflated, ovate, the apex tipped with a single, almost straight cell; leaf-cells with small but distinct trigones, averaging about $23 \mu$; ocelli two to five, in an interrupted median row; divisions of underleaves formed of two or three cells in a single row; inflorescence autoecious or dioecious; female branch without an innovation; bracts scarcely complicate, usually bilobed; bracteole connate on both sides, linear, shortly bifid; perianth obconical, terete below, the horns acute or truncate.

On bark, Soldier's Road, New Providence:-Florida; widely distributed in the tropical regions of America, Asia, and the Pacific Islands; usually growing on living leaves. ElLiptic LEPTOLEJEUNEA.

\section{BRACHIOLEJEÙNEA [Spruce] Schiffn. in E. \& P. Nat.} Pflf. $1^{3}: 128.1894$.

Plants prostrate or pendulous, medium sized to large, irregularly branched, some of the branches usually as in Frullania, the others as in Radula, color often dark brown or nearly black. Leaves imbricated, complicate-bilobed, the dorsal lobe squarrose (at least when moist), ovate, rounded to apiculate or acute, entire; lobule inflated along the keel, appressed to the dorsal lobe along the crenulate or dentate margin, hyaline papilla at the proximal base of the apical tooth, displaced from the margin; leaf-cells with distinct trigones. Underleaves undivided, orbicular to reniform, entire. Antheridia in paroecious species borne singly in the axils of scarcely modified bracts, in autoecious species borne in pairs in the axils of saccate bracts, the androecia in the latter case long and often proliferating; bracteoles everywhere present. Female inflorescence borne on a more or less elongated branch, with one or commonly two subfloral innovations; bracts scarcely complicate but often winged along the keel, unequally bilobed; bracteole rounded to shortly bilobed. Perianth 
obovoid, sometimes compressed, with from four to ten rounded keels without wings or teeth. [Greek, armed Lejeunea.] About 65 species, mostly tropical. Type species: B. laxifolia (Tayl.) Schiffn.

Autoeclous; perianth ten-keeled.

Dioecious; perianth five- to seven-keeled.

1. B. bahamensis.

2. B. corticalis.

1. Brachiolejeunea bahaménsis Evans, Bull. Torr. Club 35: 383. 1908.

Dull green, varying to brown or almost black, scattered or growing in depressed mats. Dorsal lobe of leaves convolute about the stem when dry, squarrose when moist, about $0.9 \mathrm{~mm}$. long; lobule usually with five or six teeth, each usually three or four cells long; leaf-cells averaging about $25 \times 18 \mu$; underleaves broadly orbicular, rounded at base; inflorescence autoecious; male bracts in from three to ten pairs, the androecium often proliferating; female inflorescence usually with two innovations; bracts winged, the lobule obtuse, acute, or apiculate. Perianth with ten rounded keels, scarcely compressed.

On bark, Abaco, New Providence, Watling's and Crooked Islands:-Florida; Cuba; Porto Rico. Bahamian Brachiolejeunea.

2. Brachiolejeunea corticàlis (Lehm. \& Lindenb.) Schiffn.; Evans, Mem. Torr. Club 8: 131.1902.

Jungermannia corticalis Lehm. \& Lindenb. Pug. 4: 50. 1832.

Very similar in appearance to $B$. bahamensis. Lobule usually with only four teeth, each only one or two cells long; underleaves cuneate at base; inflorescence dioecious; lobule of female bracts rounded; perianth with five to eight keels.

On bark, Great Bahama and Cat Island:-Florida; tropical America. BARK BRACHIOLEJEUNEA.

\section{LOPHOLEJEÙNEA [Spruce] Schiffn. in E. \& P. Nat.} Pflf. $1^{3}: 129.1894$.

Plants prostrate, usually dark brown or almost black, rarely olive green, often glossy, medium-sized, irregularly branched, the branches as in Radula. Leaves complicate-bilobed, the dorsal lobe not squarrose when moist, often revolute at the rounded or bluntly pointed apex, entire except in the vicinity of the female inflorescence; lobule inflated along the keel, the margin not involute, the apical tooth usually represented by a blunt, slightly projecting cell, with the hyaline papilla near its proximal base; leaf-cells with distinct trigones or apparently uniformly thickened. Underleaves plane, orbicular to reniform, undivided. Antheridia borne in pairs in the axils of saceate bracts, the androecia more or less elongated, with the bracteoles everywhere present. Female inflorescence borne on a more or less elongated branch, without subfloral innovations; bracts more or less strongly toothed, the lobule much smaller than the lobe and sometimes reduced to a minute basal tooth; bracteole usually undivided but sometimes toothed. Perianth strongly compressed with two sharp ventral keels, the keels with toothed or laciniate wings. [Greek, crested Lejeunea.] About 70 species, mostly tropical. Type species: L. Sagraeana. (Mont.) Schiffn. 
1. Lopholejeunea Sagraeàna (Mont.) Schiffn. in E. \& P. Nat. Pflf. $1^{3}: 129$. 1894.

Phragmicoma Sagraeana Mont. in Sagra Hist. Cub. 9: 464. 1845.

Brownish or blackish green, more or less glossy, growing in depressed mats. Leaves imbricated, the dorsal lobe widely spreading, oblong-ovate, about $0.75 \mathrm{~m}$. long, rounded; apical tooth of lobule often indistinct; leaf-cells apparently uniformly thickened except for minute pits, averaging about $20 \mu$; underleaves subimbricated, reniform; inflorescence normally autoecious; perichaetial bracts larger than the leaves, the dorsal one suborbicular, coarsely toothed, the lobule in the form of a minute basal tooth; bracteole entire or nearly so; perianth oval to obovate in outline, the beak short and the wings deeply and closely laciniate.

On bark, Andros and New Providence:-Florida; widely distributed in tropical America; also reported from Africa and the East Indies. SAGRA's LOPHOLEJEUNEA.

15. CAUDALEJEÙNEA [Steph.] Schiffn. in E. \& P. Nat. Pflf. $1^{3}: 129.1894$.

Plants prostrate or ascending, medium-sized to large, green, not glossy. Leaves more or less imbricated, complicate-bilobed, the dorsal lobe not squarrose, oblong-ovate, rounded to acute, usually entire; lobule inflated, the margin involute, mostly bidentate, the apical or outer tooth with the hyaline papilla near its proximal base; leaf-cells thin-walled but with distinct trigones. Underleaves orbicular, more or less retuse, entire. Antheridia in pairs in the axils of saccate bracts, the androecia more or less elongated, terminal; bracteoles everywhere present. Female inflorescence borne on a more or less elongated branch without subfloral innovations; bracts unequally bilobed, the lobe entire or toothed, the lobule narrow and scarcely projecting, entire; bracteole shortly bifid, entire or toothed. Perianth obovate, compressed and with a single sharp ventral keel, the lateral keels sometimes with entire or dentate wings. [Latin, tailed Lejeunea.] About 15 species, mostly tropical. Type species: C. Lehmanniana (Gottsche) Evans.

1. Caudalejeunea Lehmanniàna (Gottsche) Evans, Bull. Torr. Club 34: 544. 1907.

Lejeunea Lehmanniana Gottsch, in G. L. \& N. Syn. Hep. 325. 1845.

Very variable, bright or pale green, scattered or growing in loose tufts. Dorsal lobe of leaves about $1 \mathrm{~mm}$. long, the apex usually rounded and entire but sometimes acute and irregularly angular-dentate; apical tooth of lobule acute and outwardly curved, often three or four cells long; leaf-cells averaging about $28 \times 21 \mu$; perichaetial bracts about as large as the leaves, the lobe ovate-lanceolate, more or less sharp-pointed even when entire.

On twigs, Maidenhead Coppice, New Provldence:-Florida; widely distributed in the American tropics. LEHMANN'S CAUDALEJEUNEA.

\section{MASTIGOLEJEÙNEA [Spruce] Schiffn. in E. \& P. Nat.}

Pflf. $1^{8}: 129.1894$.

Plants medium-sized, with prostrate or ascending secondary stems arising from a prostrate caudex; branches as in Radula, sometimes microphyllous or flagelliform, often abundantly produced by the secondary stems; color green 
to almost black, not glossy. Leaves complicate-bilobed, the dorsal lobe squarrose when moist, ligulate to ovate, entire or nearly so, the apex rounded to subacute, not reflexed; lobule normally inflated along the keel, the margin plane or involute, the apex represented by a more or less distinct tooth with a hyaline papilla at its proximal base; lobule often poorly developed. leaf-cells with distinct trigones. Underleaves more or less convex and often revolute along the sides, orbicular to obovate, undivided but sometimes retuse, entire. Antheridia borne singly in the axils of saccate bracts, the androecia long, sometimes proliferating; bracteoles everywhere present. Female inflorescence borne on an elongated branch, usually with but one subfloral innovation; bracts unequally complicate-bilobed, without wings; bracteole similar to the underleaves. Perianth with sharp lateral keels and a single sharp ventral keel, usually wingless. [Greek, whip-bearing Lejeunea.] About 50 species, mostly tropical. Type species: $M$. auriculata (Wils. \& Hook.) Schiffn.

1. Mastigolejeunea auriculàta (Wils. \& Hook.) Schiffn. in E. \& P. Nat. Pfff. $1^{3}$ : 129.1894.

Jungermannia auriculata Wils. \& Hook.; Drummond, Musc. Amer. St. Merid. 170. 1841.

Glaucous green, varying to purplish black, growing in depressed tufts. Dorsal lobes of leaves appressed when dry, squarrose when moist, about $1 \mathrm{~mm}$. long, rounded to subacute; leaf cells averaging about $21 \times 12 \mu$; underleaves broadly orbicular, truncate to retuse, usually euneate at the base; inflorescence autoecious or dioecious; perianth oval, the keels not winged.

On bark and rocks, Andros and New Providence :-Florida to Louisiana; widely distributed in tropical America. EARED MASTIGOLEJEUNEA.

\section{ARCHILEJEÙNEA [Spruce] Schiffn. in E. \& P. Nat.}

Pflf. $1^{3}: 130.1894$.

Plants medium-sized to large, usually reddish or brownish, consisting of a prostrate caudex and secondary, often branched, stems, free from the substratum, the branches as in Radula. Leaves imbricated, complicate-bilobed, the dorsal lobes not squarrose when moist, suborbicular to ligulate, rounded and entire; lobule inflated along the keel, the margin more or less appressed to the lobe, entire except for the sharp apical tooth, with a hyaline papilla near the proximal base; lobules often imperfectly developed on the secondary stems; leaf-cells with distinct trigones. Underleaves orbicular to reniform, undivided, entire. Antheridia borne in pairs in the axils of saccate bracts, the androecia long but often proliferating; bracteoles everywhere present. Female inflorescence borne on a secondary stem or one of its branches, with one or (more rarely) two subfloral innovations, the innovations often floriferous, thus giving rise to cymose clusters; bracts unequally complicate-bilobed but not winged, the lobes entire, narrower and often more sharply pointed than the leaves; bracteole sometimes bidentate or retuse. Perianth oblong to obovate, more or less compressed, dorsal surface with one and ventral surface with two keels, the keels with narrow and interrupted wings. [Greek, chief Lejennea.] About 70 species, mostly tropical. Type species: $A$. porelloides (Spruce) Schiffn. 
1. Archilejeunea viridíssima (Lindenb.) Evans, Bull. Torr. Club 35: 169.1908.

Lejeunea viridissima Lindenb. in G L. \& Syn. Hep. 320. 1845.

Yellowish or brownish green, becoming darker with age, neither glossy nor glaucous, growing in depressed mats; secondary stems simple or sparingly branched, often with poorly developed lobules. Leaves with broadly ovate dorsal lobes, about $0.75 \mathrm{~mm}$. long; lobule (when well-developed) bearing two teeth, the outer or apical often variously eurved and longer than the inner tooth; leaf-cells averaging about $24 \times 18 \mu$; underleaves distant to loosely imbricated, broadly orbicular-ovate, cuneate, rounded to subretuse; inflorescence autoecious. Female inflorescence usually with a single subfloral innovation, the bracts very deeply bilobed; perianth oblong-obovate, the wings usually distinct but narrow, sinuate or subcrenulate.

On bark, Eight Mile Rocks, Great Bahama:-Jamaica; Porto Rico; Venezuela. GREeNest ARCHILEJEUNEA.

\section{LEUCOLEJEÙNEA Evans, Torreya 7: '225. 1908.}

Plants medium-sized to large, pale green or glaucous, neither glossy nor pigmented, prostrate, copiously branched, the branches as in Radula. Leaves imbricated, complicate-bilobed, the dorsal lobes not squarrose when moist, ovate-oblong to suborbicular, convex and often revolute along the lower margin and in the region of the rounded apex, entire or nearly so; lobule inflated throughout, the margin more or less involute, entire except for the single blunt to acuminate apical tooth with the hyaline papilla at the distal base; leafcells with small trigones. Underleaves orbicular to reniform, undivided. Antheridia borne in pairs in the axils of saccate bracts, the androecia short, not proliferating; bracteoles restricted to the base. Female inflorescence borne on a branch variable in length, innovating on one or both sides; bracts with plane lobules, otherwise similar to the leaves. Perianth five-keeled, scarcely compressed, the keels smooth or obscurely crenulate or denticulate, rarely with indistinct wings. [Greek, white Lejeunea.] A small genus, consisting of about 6 species, of tropical and temperate regions. Type species: L. clypeata (Schwein.) Evans.

Dorsal lobes slightly convex or plane, not revolute; apex of lobule easily seen.

Dorsal lobes strongly convex and revolute; apex of lobule not easily seen except by dissection.

1. L. unciloba.

2. L. xanthocarpa.

1. Leucolejeunea unciloba (Lindenb.) Evans, Torreya 7: 228. 1908.

Lejeunea unciloba Lindenb. in G. L. \& N. Syn. Hep. 331. 1845.

Pale green and glaucous, growing in depressed mats. Leaves closely imbricated, the dorsal lobe plane or slightly convex, ovate-oblong, about $1.2 \mathrm{~mm}$. long; lobule inflated toward base, the margin plane except at the base, the apical tooth acuminate and sometimes hamately eurved, usually three to six cells long, easily visible without dissection; leaf-cells averaging about $18 \mu$ in diameter; underleaves broadly orbicular to reniform; inflorescence autoecious.

On bark, Soldier's Road, New Providence :-Rhode Island south to Florida and west to Texas ; widely distributed in tropical America. HOOK-LOBED LEUCOLEJEUNEA.

2. Leucolejeunea xanthocárpa (Lehm.\& Lindenb.) Evans, Torreya $7: 229.1908$.

Jungermannia xanthocarpa Lehm. \& Lindenb. Pug. 5: 8. 1832.

Strongly resembling $L$. unciloba in size and general appearance and agreeing with it in inflorescence. Distinguished by its strongly convex leaf lobes 
with revolute apex and lower margin; lobule sometimes blunt at the apex and sometimes with a more or less elongated acuminate tooth, reaching a maximum length of four cells, not visible without dissection; leaf-cells averaging about $20 \mu$.

On bark, New Providence:-Florida; widely distributed in the American tropICs; Africa; Java. YELLOW-FRUITED LEUCOLEJEUNEA.

\section{FruLLÀnIA Raddi, Atti Soc. Ital. Sci. Modena 18: 20. 1818.}

Dark green or more or less pigmented with yellow, brown or red. Stems prostrate, ascending or pendent, more or less copiously branched, the branches all arising at the bases of leaves without lobules, rhizoids springing from the bases of the underleaves. Leaves deeply complicate-bilobed, the dorsal lobes much larger than the ventral, incubous, widely spreading, ovate to orbicular, usually entire, lobule normally inflated, helmet-shaped; leaf-cells with distinct trigones; ocelli present in certain species. Underleaves smaller than the leaves, usually bifid. Antheridia mostly in pairs, in the axils of inflated bracts with explanate lobules, the bracts imbricated and forming short or more or less elongated androecia. Female inflorescence borne on a more or less elongated branch, without innovations; bracts larger than the leaves, with explanate lobules and often more or less connate with the bifid bracteole. Perianth normally 3 -keeled, with one keel ventral, but often with supplementary folds, abruptly contracted into a short tubular beak. [Commemorates L. Frullani, a Florentine minister of state.] A very large genus, 800 or more described species, mostly tropical. Type species: $F$. dilatata (L.) Dumort.

\section{Leaves not squarrose.}

Perianth with two lateral keels and a two-angled ventral keel; lobule inflated in upper part only.

Paroecious.

Autoeclous.

Perianth distinctly three-keeled; lobule inflated throughout. Leaves more or less squarrose when moist.

Perianth with two lateral keels and a two-angled ventral keel, surface smooth.

Perianth distinctly three-keeled, the surface roughened by scattered tubercles or scales.

1. F. arietina.

2. F. riojaneirensis.

5. F. obcordata.

3. F. gibbosa.

4. F. squarrosa.

\section{Frullania ariétina Tayl. in G. L. \& N. Syn. Hep. 413.1845.}

Bright green, yellowish green or brownish green, scattered or in loose tufts. Leaves imbricated, the dorsal lobe plane or nearly so, orbicular-ovate, about 1.2 $\mathrm{mm}$. long; lobule inflated in the upper part only, the lower forming a subrhom. boidal expansion; leaf-cells with conspicuous trigones, averaging about $30 \mu$; underleaves orbicular, shortly bifid, entire or nearly so; inflorescence paroecious, the saccate male bracts in two or three pairs below the female inflorescence; the latter borne on a short branch; bracts in one to three pairs, the innermost with ovate, acute, sparingly toothed lobes and similar but narrower lobules; bracteoles highly connate, bifid with narrow, sharp divisions; perianth oblong with two distinct lateral keels and a broad two-angled ventral keel.

On twigs, Grantstown, New Providence:-Florida; widely distributed in tropical America. RAM's HEAd FrULlania. 
2. Frullania riojaneirénsis (Raddi) Spruce, Trans. Bot. Soc. Edinb. 15: 23. 1884.

Frullanoides riojaneirensis Raddi, Mem. Soc. Ital. Modena 19: 37.1823.

Closely related to $F$. arietina but distinguished by its autoecious inflorescence. Androecia occupying short branches in the vicinity of the female inflorescence, not proliferating, the bracts mostly in two or three pairs; female branch short, the leaves and bracts forming a gradual series.

On twigs, New Providence:-Florida; widely distributed in tropical America. Rio JaNeiro Frullania.

\section{Frullania gibbòsa Nees in G. L. \& N. Syn. Hep. 411.1845.}

Greenish yellow to dark brown, growing in closely appressed.tufts or mats. Leaves densely imbricated, the dorsal lobe convex when dry, concave and squarrose when moist, broadly orbicular, about $0.9 \mathrm{~mm}$. long; lobule sometimes inflated throughout but normally in the upper part only; leaf-cells with conspicuous trigones, averaging about $33 \mu$; underleaves densely crowded, orbicular to reniform, shortly and sharply bidentate at the apex with a lunulate sinus, auriculate at the base; inflorescence monoecious (autoecious or paroecious); female branch very short, the bracts in two or three pairs, the innermost with ovate, rounded or obtuse, entire lobes and subequal, strongly convolute, obtuse to acute lobules; bracteole highly connate, bifid with sharp divisions; perianth oblong, with two distinct lateral keels and a broad two-angled ventral keel.

On bark, Abaco and New Providence:-Alabama; widely distributed in the American tropics. The Bahamian specimens are not typical and may represent an undescribed species. GibBous Frullania.

4. Frullania squarròsa (Reinw. Bl. \& Nees) Dumort. Recueil d'Obs. 13.1835.

Jungermannia squarrosa Reinw. Bl. \& Nees, Nova Acta 12: 215.1824.

Dark green or pigmented with brown, scattered or growing in depressed mats. Leaves imbricated, the lobe rolled around the stem when dry, strongly squarrose when moist, ovate, rounded at the apex, and entire; lobule about as broad as long; underleaves bifid, usually with entire margins; inflorescence dioecious; female inflorescence borne on a short and simple branch, bracts in about three pairs; perianth oblong, without supplementary keels, surface more or less roughened by scattered tubercles or scales, especially along the keels.

On bark, Great Bahama, Berry Islands, New Providence, Eleuthera and Anguilla Isles:- Connecticut to Ohio and south to Florida and Louisiana; Bermuda; widely distributed in tropical regions throughout the world. SPrEiding Frullaxia.

\section{Frullania obcordàta Lehm. \& Lindenb. in G. L. \& N. Syn. Hep. 447. 1845.}

Yellowish green to reddish brown, growing scattered or in closely appressed mats. Leaves closely imbricated, the dorsal lobe convex, ovate, about $0.7 \mathrm{~mm}$. long; lobule short-clavate, inflated throughout, spreading at a wide angle; leaf-cells with more or less distinct trigones, averaging about $18 \mu$; underleaves subimbricated, orbicular, bifid about one half with obtuse or subacute divisions and sinus; inflorescence autoecious; androecia occupying short branches in the vicinity of the female inflorescence, the bracts in one or two pairs; female branch long, the bracts in three or four pairs, the innermost with ovate, obtuse or apiculate, entire lobes and smaller subacute lobules; bracteole free or slightly connate, bifid about one third; perianth obcuneate, the beak in a slight depression, lateral keels and the single ventral keel distinct.

On bark, New Providence:-Florida to Louisiana; tropical America. OBCordate Frullania. 


\section{Order 3. ANTHOCEROTÀLES.}

Gametophyte a prostrate dorsiventral thallus, varying from strapshaped to circular, with very little cell-differentiation, destitute of airspaces but sometimes developing intercellular spaces with mucilage; green cells with one or a few large flat chloroplasts, often with a single pyrenoid. Antheridia borne singly or in groups just below the upper surface of the thallus. Archegonia in irregular dorsal groups, imbedded, the tip of the neck alone projecting. Sporophyte differentiated into a broad foot and an elongated cylindrical capsule, the latter growing indefinitely by means of a basal embryonic region, splitting at maturity into two valves. Spores surrounding a central sterile structure, the columella, and interspersed with irregular, often multicellular elaters, with or without bands of thickening. Four or five genera and about 150 species, widely distributed. .

\section{Family 1. ANTHOCEROTÀCEAE Lindb.}

\section{Anthoceros Family.}

Characters of the order.

\section{ANTHócerRos [Micheli] L. Sp. Pl. 1139. 1753.}

Thallus suborbicular, variously lobed and often with plate-like outgrowths, sometimes irregularly dissected, several cells thick and destitute of a distinct midrib; green cells with a single chloroplast. Inflorescence usually (if not always) monoecious. Capsule erect, much longer than the basal sheath, with green cells in the wall and stomata in the epidermis. Spores variously roughened; elaters without spiral bands of thickening, composed of one to several cells and sometimes branched. [Greek, flowering horn.] About 50 species, largely tropical. Type species: A. punctatus L.

\section{Anthoceros laèvis L. Sp. Pl. 1139. 1753.}

Thallus nearly plane on the upper surface, dark green and somewhat lustrous, destitute of intercellular spaces. Capsule mostly 1-3 cm. long, the base surrounded by a cylindrical sheath often flaring at the mouth; spores yellow, the surface granular-papillose; elaters yellowish, very variable in size and form, often branched.

Along the Adelaide Road, New Providence, Brace. Widely distributed in North America, Europe and Asia. The Bahamian specimens are sterile and their determination is therefore doubtful. YELLOW-SPORED ANTHOCEROS.

\section{Phylum 4. THALLOPHYTA.}

This phyllum includes many thousand species of simple organization, grouped in many genera and families. The plants composing it have scarcely any woody tissue, and are propagated either by spores or by vegetative division. Most of them are small, but there are some large and conspicuous types in all the classes. 
Terrestrial, saxicolous, or corticlcolous plants, compased of filaments without chlorophyll and of cells containing chlorфphyll.

Aquatic plants, or microscopic terrestrial or corticicolous organisms with chlorophyll.

Terrestrial or corticicolous plants, or microscopic aquatics, wholly without chlorophyll.

Vegetative stage mycelial.

Vegetative stage plasmoidal.

Class 1. Lichenes.

Class 2. Algat.

Class 3. FungI.

Class 4. MYxomycetes.

\section{CLASS 1. IICHËNES.}

\section{CONTRIBUted BY LINCOLN W. RIDDLE.}

Fruit a perithecium, more or less flask-shaped, opening by a pore at maturity.

Fruit an apothecium, open at maturity.

Apothecia disk-shaped, clrcular; asci deliquescing before the spores mature.

Asci persisting until after the discharge of the spores. Apothecia typically linear, elliptical, or angular; rarely circular, and then without an exciple.

Apothecia clrcular, disk-shaped or cup-shaped.

Order 1. Pyrenulales.

Order 2. Caliciales.

Order 3. GRAPHidales.

Order 4. Lecideales.

\section{Order 1. PYRENULÄLES.}

Perithecia with an apical ostiole.

Thallus crustose.

Perithecia solitary.

Gonidia : Pleurococcus.

Gonldia : Trentepohlia.

Perithecia imbedded in a stroma.

Thallus squamulose or foliose.

Perithecla with a lateral ostiole.

Perithecia solitary.

Perithecia imbedded in a stroma.

Fam. 1. Verrocariaceae.

Fam. 2. Pyrenulaceat.

Fam. 3. TRYPeTHeliaceat.

Fam. 4. DERMATOCARPACEAD.

Fam. 5. Paratheliaceae.

Fam. 6. AstrotheliaceaE.

\section{Family 1. VERRUCARIĀCEAE.}

\section{VERRUCÀRIA Pers.}

Perithecia falling out and leaving pits in the rock.

Perithecla pruinose; ostiole papillate.

Perithecia nudate above; ostiole plane.

Perithecia not leaving pits in the rock.

Thallus nale, tinged with green or brown, perithecia superficlal.

Thallus dark olive-brown, perithecia immersed.

1. 7 . mamillaris.

2. V. rupestris.

3. . muralis.

4. . nigrescens.

1. Verrucaria mamillàris Riddle, sp. nov.

Thallus epilithicus crustaceus uniformis effusus aut subdeterminatus haud linea nigra limitatus, cretaceo-albus vel sordide albidus, crassiusculus, continuus laevigatus inaequalis. Gonidia pleurococcoidea. Perithecia nigra hemisphaerica aut deplanata aut partim subconica, apica mamilliformia aut rarius obtusa, basi deficientia, ad $0.8 \mathrm{~mm}$. lata, dispersa solitaria, primum tota immersa dein 1/2-2/3 emergentia tenuiter thallino-pruinata, demum elabentia foveolamque relinquentia. Gonidia hymenialia nulla. Paraphyses simplices deliquescentes. Asci clavati 8-spori. Sporae in ascis biseriales incolores ellipsoideae simplices membrana laevigata, 16-21 $\times 9-10 \mu$.

On limestone, vicinity of Cockburn Town, Watling's Island (Britton and Millspaugh, March 13, 1917, 6130, type); without station, New Providence (Brace, 9502, 9508).

This species, belonging to the section Euverrucaria, differs from Verrucaria rupestris in the thicker thallus and the larger, mamillate, pruinose perithecia.

2. Verrucaria rupéstris Schrad. Spicil. Fl. Germ. 109. 1794.

On limestone, New Providence, Eleuthera, Cat Island, Watling's Island :-cosmopolitan. 
3. Verrucaria muràlis Ach. Meth. Lich. 115. 1803.

On limestone, New Providence :-cosmopolitan.

4. Verrucaria nigréscens Pers. in Usteri, Ann. Bot. 14: 36. 1795.

On limestone, New Providence :-North America and Europe.

\section{Family 2. PYRENULÀCEAE.}

Spores plurilocular (two to many-celled).

Spores colorless.

Spores with cylindrical cells.

Paraphyses simple and persistent.

Paraphyses branched or deliquescent.

Spores with lens-shaped or rounded cells.

Spores brown.

Paraphyses simple and persistent.

Paraphyses branched or deliquescent.

1. Porina.

2. Arthopyrenia.

3. Pseudopyrenula.

Spores muriform-multilocular.

Spores colorless.

Paraphyses simple and persistent.

Paraphyses branched or deliquescent.

Spores brown.

4. Pyrenula.

5. Microthelia.

6. Clathroporina.

7. Polyblastiopsis.

8. Anthracothecium.

\section{PORINA Ach.}

Perithecial wall entirely black.

Thallus chalky-white; perithecla $0.6-0.8 \mathrm{~mm}$. in diameter.

Thallus greenish or purplish; perithecia $1.0-1.5 \mathrm{~mm}$. In dlameter.

Perithecial wall black at the tip only, or not at all.

Thallus subfoliose, on rocks.

Thallus with loosely adherent, convex lobes.

Thallus closely adnate, flat and merely crenate.

Thallus crustose, on bark.

Ostlole brown or reddish.

Ostlole blackening.

Spores $7-15 \mu$ wide.

Spores 4-6 $\mu$ wide.

Thallus marked with frequent black lines.

Thallus without such lines.

1. P. Wilsonii.

2. P. macrocarpa.

3. P. firmula.

4. P. subfirmula.

5. P. nucula.

6. P. mastoidea.

7. P. variegata.

8. P. Tetracerae.

\section{Porina Wilsònii Riddle, sp. nov.}

Thallus epilithicus crustaceus uniformis effusus haud limitatus, cretaceoalbus opacus tartareus, crassiusculus continuus laevigatus, spermagoniis copiose nigropunctatus. Gonidia chroolepoidea. Perithecia globosa integra nigra, $0.6-0.8 \mathrm{~mm}$. lata, primum tota immersa maculis nigrescentibus indicata dein semiemergentia, alte convexa, strato tenue thallode fere ad instar pruinae velata, demum apicibus denudatis, ostiolis minutis umbonatis, nunquam elabentia. Paraphyses persistentes tenues simplices. Asci cylindrices 8-spori. Sporae in ascis uniseriales, incolores fusiformes 4-loculares loculis cylindricis, 13-15 $\times 4-5 \mu$. Spermagonia minuta nigra apicibus emergentibus denudatis. Spermatia recta bacillaria, $3-5 \times 1 \mu$.

On limestone, Caleta Cocodrilos, Isle of Pines, Cuba (Britton, Wilson, and León, March 8, 1916, 15288, type).

Bahamas: on limestone, New Providence (Brace, 9634) ; Governor's Harbor, Eleuthera (Britton and Millspaugh, 5535). A lichen occurring near the Columbus Monument, Watling's Island, and showing spermagonia only, agrees with thls specles, but the determination can not be considered certain.

This species, which I take pleasure in naming in honor of Mr. Percy Wilson, may be distinguished from other species of the section sagedia, to which it belongs, by the chalky-white, tartareous thallus, and the delicately prulnose perithecia. It bears a strong external resemblance to Verrucaria mamillaris, but can, of course, be at once distinguished by the spores.

\section{Porina macrocárpa Riddle, sp. nov.}

Thallus epilithicus crustaceus uniformis effusus linea nigra limitatus, glaucus virescens aut purpurascens opacus, crassitudine mediocris aut tenuis, 
continuus laevigatus, olim spermagoniis nigropunctatus. Gonidia chroolepoidea. Perithecia 1.0-1.5 mm. lata, solitaria aut confluentia dimidiata, primum immersa leviter convexa dein emergentia elevata conico-hemisphaerica, basi innata, nigra sat tenue thallino suffusa aut denudata, apice obtuso aut crasso papillato, demum elabentia foveolamque relinquentia, amphithecio carbonaceo basi deficienti. Paraphyses persistentes tenues simplices. Asci cylindrices 8-spori. Sporae in ascis uniseriales, incolores ellipsoideae, 4-loculares loculis subcylindricis angulis sat rotundatis, $13-16 \times 5-7 \mu$. Spermagonia mediocria nigra apice emergente denudato. Spermatia filiformia arcuata, 18-22 $\times 1 \mu$.

On limestone, Key View Hill, Vivijagua, Isle of Pines, Cuba (Britton, Britton and Wilson, February 28-29, 1916, 15090, type).

Bahamas : on limestone, Cockburn Town, Watling's Isiand (Britton and Millspaugh, 6131).

Known also from two other stations in the Isle of Pines and from one station in Porto Rico.

The affinities of this snecies seem on the whole to be with the genus Porina, section Sagedia, although it has peculiarities which make its systematic position somewhat uncertain. While the perithecia are for the most part solitary, they occur occasionally completely confluent, except for the papillate tips. Even in these cases, however, there is never any indication of a stroma. The cells of the quadrilocular spores are somewhat more rounded than is typical for Porina. There is no other species with which this is liable to be confused.

3. Porina fírmula Muell. Arg. Bot. Jahrb. 6: 401. 1885.

On limestone, Andros, at Mastic Point, and Watling's Island, near Cockburn Town :-Cuba ; Isle of Pines.

\section{Porina subfírmula Riddle, sp. nov.}

Thallus epilithicus determinatus subfoliosus effiguratus, irregulariter rotundatus, margine integro aut crenato haud lobato, planus, arcte adnatus, crassus (crassitudine $0.15-0.2 \mathrm{~mm}$.), atro-olivaceus, continuus laevigatus vel sat inaequalis nitidulus; superne corticatus cortice tenue (erassitudine 12-14 $\mu$ ) pseudo-parenchymatica, inferne ecorticatus. Gonidia chroolepoidea. Perithecia subglobosa circ. $0.3 \mathrm{~mm}$. lata, tota immersa aut apicibus leviter emergentibus et sat denudatis, amphithecio superne nigro inferne decolore. Paraphyses persistentes simplices. Asci 8-spori. Sporae incolores fusiformes, haud bene evolutae, 6-8-loculares, loculis cylindricis, circ. $25 \times 4 \mu$.

On limestone, Sierra de las Casas, Isle of Pines, Cuba (Britton and Wilson, March 22, 1916, 15741, type).

Bahamas: on limestone, New Providence (Brace, 9487).

This species belongs to the section Segestria, and is evidently related to but quite distinct from the preceding species. Both species are decidedly Endocarponlike in appearance.

5. Porina nùcula Ach. Syn. Lich. 112. 1814.

On bark of Exothea, New Providence, at Clifton:- widely distributed in tropical regions of both hemispheres.

6. Porina mastoidea (Ach.) Mass. Ric. Lich. Crost. 191. 1852.

Pyrenula mastoidea Ach. Syn. Lich. 122. 1814.

Porina africana Muell. Arg. Linnaea 43: 41. 1880.

On bark, Great Bahama:-widely distributed in tropical regions of both hemispheres.

The material represents a form with verrucose thallus and verrucae, and the latter are somewhat constricted; but the species is so variable that it is. scarcely worth while to give this form a name.

7. Porina Tetracérae (Ach.) Muell. Arg. Bot. Jahrb. 6: 401. 1885.

Verrucaria Tetracerae Ach. Meth. Lich. 121. 1803.

On bark, New Providence, at Maidenhead Coppice:-widely distributed in tropical regions of both hemispheres.

8. Porina variegàta Fée, Suppl. Essai Crypt. 75. 1837.

On bark, Abaco, at Old Kerr's Point:-Cuba; Jamaica; Porto Rico. 


\section{ARTHOPYRÈNIA Mass.}

Spores two-celled.

Asci cyllndrical, spores uniseriate.

Spores $15-30 \times 7-13 \mu$.

Spores $12-15 \times 5-7 \mu$.

Ascl clavate, spores 2- to 3-seriate.

Perithecia spreading at the base.

Perithecla peltate, flattened, and thalline-suffused.

At least the center of the peritheclum elevated and nudate.

Spore-celis equal in size.

Spore-cells unequal.

Perithecia not spreading at the base.

1. A. gemmata.

2. A. biformis.

3. A. planorbis.

4. A. Cinchonae.

5. A. fallax.

6. A. consanguinea.

Spores four-celled.

Perithecla more or less covered by the thallus.

Thallus thin, the perithecia merely suffused.

Thallus thick, the perithecia imbedded with the tips emergent.

Perithecia superficial and nudate.

3. A. planorbis.

7. A. tumida.

8. A. contendens.

1. Arthopyrenia gemmàta (Ach.) Muell. Arg. Mem. Soc. Phys. Hist. Nat. Genève 16: 428.1862.

Lichen gemmatus Ach. Lich. Suec. Prodr. 17. 1798.

On bark, New Providence:-widely distributed in temperate regions of both hemispheres.

2. Arthopyrenia bifórmis (Borr.) Muell. Arg. Flora 66: 306. 1883.

Verrucaria biformis Borr. in Engl. Bot. Suppl. pl. 261\%. 1829.

On bark, New Providence. on the Farringdon Road:-widely distributed in the temperate regions of both hemispheres.

3. Arthopyrenia planórbis (Ach.) Muell. Arg. Flora 66: 288. 1883.

Verrucaria planorbis Ach. Syn. Lich. 92. 1814.

Arthopyrenia indusiata Muell. Arg. Flora 66: 288. 1883.

Arthopyrenia fallacior Muell. Arg. Bot. Jahrb. 6: 404.1885.

On bark, Great Bahama, and New Providence:-Cuba; Anegada; Costa Rica.

4. Arthopyrenia Cinchònae (Ach.) Muell. Arg. Flora 66: 287. 1883.

Verrucaria Cinchonae Ach. Syn. Lich. 90. 1814.

Didymella Cinchonae Wainio, Lich. Brés. 2: 233. 1890.

Arthopyrenia planior Muell. Arg. Bot. Jahrb. 6: 404.1885.

On bark, Great Bahama, New Providence, Littie San Salvador, Great Exuma, Watling's Isiand :-widely distributed in tropical America.

5. Arthopyrenia fállax (Nyl.) Arnold, Flora 68: 159. 1885.

Verrucaria epidermidis var. fallax Nyl. Bot. Notis. (1852) 178.

On bark. Great Bahama, at Barnett's Point, and New Providence, near Seven Hills :- wldely distributed in the temperate regions of both hemispheres.

6. Arthopyrenia consanguinea Muell. Arg. Bot. Jahrb. 6: 404. 1885.

On bark, Eleuthera Polnt:-Florida: Cuba.

Very closely related to forms of Arthopyrenia epidermidis (Fr.) Mudd.

7. Arthopyrenia tùmida Muell. Arg. Flora 67: 669. 1884.

On bark, New Providence, at Waterloo Coppice :-Isle of Pines, Cuba ; and Brazil.

8. Arthopyrenia conténdens (Nyl.) Muell. Arg. Flora 66: 317. 1883.

Verrucaria contendens Nyl. Act. Soc. Sci. Fenn. 7: 492. 1863.

On bark of Jacquinia keyensis, The Blght, Cat Island :-Colombia; Brazil. 


\section{PSEUDOPYRÈNULA Muell. Arg.}

1. Pseudopyrenula dirémta (Nyl.) Muell. Arg. Flora 66: 249. 1883.

Verrucaria diremta Nyl. Act. Soc. Sci. Fenn. 7: 492.1863.

On bark, New Providence :- Cuba; Venezuela; Colombia; Brazil.

\section{PYRÈnULA Ach.}

Perithecia dimidiate.

Perithecla spreading at the base and entirely nudate.

1. P. mamillana.

Perithecia not spreading, immersed when young, then emergent. 2 . P. leucoplaca.

Perithecia subglobose.

Thallus orange-brown.

Thallus more or less olfvaceous. Perithecia immersed in the thallus.

Perithecia emergent to superficial.

3. P. cerina.

4. P. punctella.

5. P. Glaziovii.

1. Pyrenula mamillàna (Ach.) Trev. Conspect. Verr. 13. 1860.

Verrucaria mamillana Ach. Meth. Lich. 120. 1803.

Vermicaria Santensis Tuck. apud Nyl. Expos. Pyren. 45. 1858.

Verrucaria Kunthii Fée, Essai Crypt. 88, pl. 34, f. 4. 1824.

Pyrenula Kunthii Fée, Suppl. Essai Crypt. 80. 1837.

Pyrenula deplanata Muell. Arg. Bot. Jahrb. 6: 411. 1885.

On bark, Great Bahama and New Providence:-widely distributed in tropical and subtropical regions of both hemispheres.

Pyrenula mamillana is an exceedingly variable species. $P$. Kunthii is the form with the larger perithecla and spores, that is the more luxurlant form; while $P$. deplanata is the less luxuriant form with the smaller perithecia and spores. But intergradations of all sizes are to be found commonly.

2. Pyrenula leucoplàca (Wallr.) Koerb. Syst. Lich. Germ. 361. 1855.

Verrucaria leucoplaca Wallr. in Bluff and Fing. Fl. Germ. 3: 299. 1831.

On bark of Casasia clusiaefolia, Little San Salvador:-widely distributed in the temperate regions of both hemispheres.

3. Pyrenula cerìna (Eschw.) Muell. Arg. Flora 67: 667. 1884.

Verrucaria cerina Eschw, in Mart. F1. Bras. 1: 133. 1833.

Pyrenula aurantiaca Fée, Suppl. Essai Crypt. 82, pl. 37, f. 1. 1837. America.

On bark, New Providence and Crooked Island:-widely distributed in tropical

4. Pyrenula punctélla (Nyl.) Muell. Arg. Flora 65: 400. 1882.

Verrucaria punctella Nyl. Expos. Pyren. 46. 1858.

On bark of Drypetes, Cay north of wide opening, Exuma Chain:- South Carolina; Colombia; Java. Probably generally distributed but confused with the wellknown Pyrenula nitida (Weig.) Ach., from which it differs in the more completely immersed perithecia and the larger spores.

5. Pyrenula Glazióvii Muell. Arg. Mem. Soc. Phys. Hist. Nat. Genève $30^{3}: 32$. 1888.

On bark, New Providence, along Soldier's Road:-Brazll.

\section{MICROTHEेLIA Koerb.}

\section{Microthelia quadriloculàta Riddle, sp. nov.}

Thallus epiphloeodes crustaceus uniformis effusus, albidus opacus, tenuis rimulosus. Gonidia chroolepoidea. Perithecia integra globosa, minuta ad 0.4 $\mathrm{mm}$. lata, superficialia basi thallino-tecta, superne nuda nitida, apice convexo aut minute umbilicato. Paraphyses persistentes distinctes ramoso-connexae. Asci oblongi 8-spori. Sporae in ascis 2-3-seriales fuscae oblongae aut fusiformes, 4-loculares loculis cylindricis, $18-20 \times 6-7 \mu$. 
On bark of Jacquinia keyensis, vicinity of The Bight, Cat Island (Britton and Millspangh, March 1-6, 1907, 5840, type).

The white epiphloeodal thallus and the shining globose perithecia will serve to distinguish this from the few species of Microthelia having four-celled spores, such as $M$. thelena var. subtriseptata Wainio.

\section{CLATHROPORINA Muell. Arg.}

1. Clathroporina nuculástrum Muell. Arg. Flora 67: 618. 1884.

On twigs, New Providence, at Maidenhead Coppice :-Florida; Madagascar.

\section{POLYBLASTIÓPSIS Zahlbr.}

1. Polyblastiopsis láctea (Mass.) Zahlbr. in Engler and Prantl, Nat. Pflanzenfam. $1^{1 *}: 65$. 1903 .

Blastodesmia lactea Mass. apud Koerb. Parerg. Lich. 336. 1865.

On bark, New Providence and The Bight, Cat Island:-North America; Europe.

\section{ANTHRACOTHÈcIUM Mass.}

Thallus from orange to yellow.

Thallus from white to ollvaceous.

Spores with two to four series of cells. Spores with two series of cells. Spores with four series of cells.

Spores with six to elght series of cells. Perithecia immersed except when old. Perithecium soon emergent and superficial.

1. A. ochraceo-flavum.

2. A. subglobosum.

3. A. corticatum.

4. A. libricolum.

5. A. americanum.

1. Anthracothecium ochràceo-flàvum (Nyl.) Muell. Arg. Linnaea 43: 44. 1880.

Verrucaria ochraceo-flavum Nyl. Expos. Pyren. 50. 1858.

Verrucaria ochraceo-flavens Nyl. Act. Soc. Sci. Fenn. 7: 491. 1863.

On bark of various species, Great Bahama, New Providence, Cave Cay, Exuma Chain, Cat Isiand:-widely distributed in tropical regions of both hemispheres.

\section{Anthracothecium subglobòsum Riddle, sp. nov.}

Thallus epiphloeodes crustaceus uniformis effusus haud limitatus, sordide aut virescenti-albidus, in crassitudine mediocris vel tenuis, rimosus rugulosus. Gonidia chroolepoidea. Perithecia dispersa solitaria, primum immersa, verrucis thallinis convexis, apice plus minusve nudato minute umbilicato, dein circa $1 / 4$ ad $1 / 3$ emergentia, globosa, 0.7-1.0 mm. diam., nigra integra. Paraphyses simplices crassiusculae. Asci cylindrices 8-spori. Sporae in ascis uniseriales, fumosae aut fusco-atrae, globosae circa $12 \mu$ diam., aut subglobosae ciréa $12 \times 10 \mu$, primum biloculares mox loculis altero ambobusve divisis rotundatis.

On bark, New Providence (Brace, February 11, 1919, 10064, type).

The specific name refers not to the perithecia but to the peculiar spores. The species is related to A. sinapispermum (F'ee) Muell. Arg., but the latter species has minute perithecia, $0.15-0.2 \mathrm{~mm}$. in diameter, and oblong spores, $7-8 \times 4-5 \mu$.

3. Anthracothecium corticàtum Muell. Arg. Bull. Soc. Roy. Bot. Belg. 301 : 96. 1891.

On bark, New Providence, at Waterloo Coppice :-Costa Rica, Venezuela.

4. Anthracothecium librícolum (Fée) Muell. Arg. Linnaea 43: 43.1880.

Pyrenula libricola Fée, Suppl. Essai Crypt. 82, pl. 41, f. 31. 1837.

On bark of various species, Great Bahama, New Providence, Great Exuma, Long Island:- widely distributed in troplcal and subtropical regions of both hemispheres.

This species is a common and variable one. All stages may be found from that in which the perithecia are completely burled in the thallus and scarceiy discernible externally, to that in which the perithecia become half emergent, when they are consplcuous and appear relatively large. Superficially the two extremes look very different. 
5. Anthracothecium americànum (Ach.) Muell. Arg. Flora 68: 339. 1885.

Verrucaria analepta var. americana Ach. Lich. Univ. 275. 1810.

On dead wood, Abaco, at Old Kerr's Point, and on bark of Drypetes diversifolia, Thatch Cay, Long Island:-Jamaica.

\section{Family 3. TRYPETHELIÀCEAE.}

Spores plurilocular (two to many-celled).

Spores colorless.

Spores with cyllndrical cells.

Spores with lens-shaped cells.

Spores brown.

Spores murlform-multilocular, brown.

1. Tomasellia.

2. Trypethelium.

3. Melanotheca.

4. Bottaria.

\section{TOMASÉLLIA Mass.}

Thallus epiphloeodal, relatively well-developed.

Thallus hypophloeodal.

Spores over $30 \times 12 \mu$.

Spores under $25 \times 10 \mu$.

Stroma with many ostioles indicated externally by whitened spots.

Stroma with few ostioles, concolorous with the black stroma.

1. T. exumana.

2. T. macrospora.

3. T. leucostoma.

4. T. cubana.

\section{Tomasellia exumàna Riddle, sp. nov.}

Thallus epiphloeodes crustaceus uniformis effusus glaucus, crassiusculus, undulatus laevigatus subnitidus rimulosus, linea nigra limitatus. Gonidia chroolepoidea. Stromata $0.6-1.0 \mathrm{~mm}$. lata, nigra nuda convexa vel hemispherica haud gibbosa, ambitu obtuse angulosa aut irregularia pauciostiolata, ostiolis superficie aequalibus aut gibbosula inconspicuis. Perithecia crassa integra globosa. Paraphyses persistentes ramoso-connexae. Sporae in ascis biseriales, incolores ovoideae biloculares, loculo superiore multo majore, 14-16 $\times 6-7 \mu$.

On bark near Georgetown, Great Exuma (Britton and Millspaugh, February 22$28,1905,3135$, type).

The well-developed thallus and the strongly convex stromata are the best characters for distinguishing this species.

\section{Tomasellia macrospòra Riddle, sp. nov.}

Thallus hypophloeodes quasi halonem albidum formans aut evanescens et cum cortice maculam testaceam constituens. Stromata $1.0-1.3 \mathrm{~mm}$. lata, solitária aut partim confluentia, deplanata vel leviter convexa peltata ambitu rotundata, nigra thallino-pruinata aut denudata, ostiolis connatis papillata. Perithecia integra globosa. Paraphyses persistentes ramoso-connexae. Sporae incolores oblongae, 4-loculares, loculis cylindricis aequalibus, $30-38 \times 12-14 \mu$.

On bark of Zanthoxylum flavum, Great Exuma (Britton and Millspaugh, February $22-28,1905,3002$, type).

Externally simllar to Tomasellia cubana, but differing in the decidedly larger spores, these measuring in the latter species only $15-25 \times 5-9 \mu$.

\section{Tomasellia leucostòma Muell. Arg. Flora 68: 257. 1885.}

On bark, Great Bahama, New Providence; Eleuthera, Exuma, Long Island:tropical America.

The material listed under this and the following specles shows considerable variation and some of the speclmens may be specifically distlnct, but it has seemed best to adopt a conservative treatment.

4. Tomasellia cubàna Muell. Arg. Bot. Jahrb. 6: 397. 1885.

On bark, New Providence, Little San Salvador, Exuma, Cat Island, Conception Island :-Cuba. 


\section{TRYPETHÈLIUM Spreng.}

Spores four-celled.

Spores over $35 \mu$ in length.

Spores under $30 \mu$ in length.

1. T. ochrothelium.

Stroma dark brown to black.

Stroma little developed, the individual perithecia evident.

Stroma well-developed, merely the tips of the perithecia showing.

Stroma some other color.

Thallus rusty-orange.

Stroma flat and covered by the thallus. Stroma elevated, conical.

Thallus some other color.

Stroma irregularly linear-elongated, perithecia often showing a serfal arrangement.

Stroma rounded, oval, or oblong.

Stroma elevated, the black tips of the perithecia conspicuous.

Stroma depressed, the tips of the peri-

Spores six to many-celled. thecia inconspicuous.

Stroma yellow within.

Thallus smooth, stroma neither yellow nor powdery externally.

Stroma varying in color from ashy to fulvous or chestnut-brown, strongly convex.

Stroma dark-brown or blackening, flattened.

Thallus smooth or powdery, stroma yellow or powdery or both.

Thallus smooth, stroma lemon-yellow and powdery.

Both thallus and stroma covered with a sulphury or aeruginous powder.

Stroma becoming brown or black within.

2. T. tropicum.

3. T. mastoideum.

4. T. aeneum.

5. T. ferrugineum.

6. T. catervarium.

7. T. ochroleucum.

8. T. pallescens.

9. T. eluteriae and varietles.

9a. forma typica.

9b. var. truncatum.

9c. var. citrinum.

9d. var. subsulphureum.

$9 e$. var. nigricans.

1. Trypethelium ochrothèlium Nyl. Act. Soc. Sci. Fenn. 7: 494. 1863.

On bark, The Bight, Cat Island :-Isle of Pines, Cuba; Colombia.

2. Trypethelium tròpicum (Ach.) Muell. Arg. Bot. Jahrb. 6: 393. 1885.

Verrucaria tropica Ach. Lich. Univ. 278. 1810.

Pyrenula tropica Tuck. Genera Lich. 273. 1872.

On bark of various species, Andros, New Providence, Cat Island, Long Island :widely distributed in tropical and subtropical regions of both hemispheres.

3. Trypethelium mastoìdeum Ach. Lich. Univ. 307. 1810.

Bathelium mastoideum Ach. Meth. Lich. 111. 1803.

Trypethelium scoria Nyl. Expos. Pyren. 74. 1858. Not Fée Essai Crypt. 69. 1824.

On bark, New Providence and Eleuthera:-widely distributed in tropical and subtropical regions of both hemispheres.

4. Trypethelium aèneum (Eschw.) Zahlbr. in Engler and Prantl, Nat. Pflanzenfam. $1^{1 *}: 70.1903$.

Verrucaria aenea Eschw. in Mart. Fl. Bras. 1: 133. 1833.

Trypethelium Kunzei Fée, Ann. Sci. Nat. I: 23: 446, pl. 15, f. 3. 1831.

Trypethelium heterochroum Tuck. Genera Lich. 260. 1872.

On bark, Andros, near Nicholl's Town; Crooked Island, at Landrall Point; Acklin's Island, at Boathouse Cove :-Florida; Cuba; Costa Rica ; Brazil.

5. Trypethelium ferruginèum Muell. Arg. Bot. Jahrb. 6: 392. 1885.

On bark, Andros, at Deep Creek:-Cuba. 
6. Trypethelium catervàrium (Fée) Tuck. Genera Lich. 260. 1872.

Verrucaria catervaria Fée, Essai Crypt. 90, pl. 22, f. 1. 1824.

On bark, New Providence, at Waterloo Coppice:-Alabama; Cuba ; Porto Rico; Costa Rica; Colombia; Australla.

7. Trypethelium ochroleùcum (Eschw.) Nyl. Flora 52: 126.1869.

Verrucaria ochroleuca Eschw. in Mart. Fl. Bras. 1: 135. 1833.

On bark, Andros, near Deep Creek:-widely distributed in tropical America, and recorded also from tropical Asia.

8. Trypethelium palléscens Fée, Ann. Sci. Nat. I: 23: 440. 1831.

Trypethelium ochroleucum var. pallescens Muell. Arg. Bot. Jahrb. 6: 392. 1885.

On bark, Eleuthera and Great Exuma:-widely distributed in tropical America.

9. Trypethelium elutèriae Spreng. Anleit. zur Kennt. Gewachse 1: 351. 1804.

Trypethelium Sprengelii Ach. Lich. Univ. 306. 1810.

9a. forma typica.

On bark of various species, Great Bahama, New Providence, Eleuthera (typelocality !), Great Exuma, Cat Island, Long Island:- widely distributed in tropical regions of both hemispheres.

9b. Trypethelium elutèriae var. truncàtum Muell. Arg. Bot. Jahrb. 6: 393. 1885.

Watling's Island :-Cuba.

9c. Trypethelium elutèriae var. citrìnum (Eschw.) Muell. Arg. 1. c. 1885.

Astrothelium varium var. citrinum Eschw. in Mart. Fl. Bras. 1: 162. 1833.

New Providence, at Waterloo Copplce:-Cuba; Brazil; Australia.

9d. Trypethelium elutèriae var. subsulphùreum (Wainio) Riddle.

Psendopyrenula eluteriae subsp. subsulphurea Wainio, Lich. Brés. 2: 205. 1890.

New Providence, at Lake Cunningham:-Cuba; Brazil.

9e. Trypethelium elutèriae var. nígricans (Fée) Muell. Arg. Mem. Soc. Phys. Hist. Nat. Genève $30^{3}: 21.1888$.

Trypethelium Sprengelii Fée, Ann. Sci.. Nat. I: 23: 430. 1831.

New Providence and Cat Island:-tropical America.

\section{MELANOTHÈcA Fée.}

1. Melanotheca cruénta (Mont.) Muell. Arg. Bot. Jahrb. 6: 397. 1885.

Trypethelium cruentum Mont. Ann. Sci. Nat. II: 8: 357. 1837.

On bark, Great Bahama and New Providence:-widely distributed in tropical regions of both hemispheres.

\section{Bottària Mass.}

1. Bottaria cruentàta Muell. Arg. Bot. Jahrb. 6: 395. 1885.

Trypethelium cruentatum Nyl. Flora 59: 365. Hyponym. 1876.

On bark, Great Bahama, Abaco, Andros, New Providence, Cat Island, Crooked Island :-Florida; Cuba.

Externally identical with the preceding species, but differing in the muriform spores, the cells of which in the specimens examined are subspherical, not cubical as given in the key in Engler and Prantl : Die Naturlichen Pflanzenfamilien $I^{1 *}: 69$. 


\section{Family 4. DERMATOCARPÀCEAE.}

Spores one-celled.

Spores muriform-multilocular.
1. Dermatocarpon.

2. Endocarpon.

\section{DERMATOCÁRPON Eschw.}

Thallus mostly over $10 \mathrm{~mm}$. in diameter, attached by a single central point.

Thallus mostly under $5 \mathrm{~mm}$. in diameter, attached by greater part of under surface.

Thallus reddish, margins free.

Thallus brown, margins adnate.

1. D. Moulinsii.

2. D. lachneum.

3. D. hepaticum.

1. Dermatocarpon Moulínsii (Mont.) Zahlbr. in Engler \& Prantl, Nat. Pflanzenfam. 1*: 60.1903.

Endocarpon Moulinsii Mont. Ann. Sci. Nat. II: 20: 358. 1843. India.

On rocks, New Providence and Cat Island, at Orange Creek:-France; Texas;

2. Dermatocarpon lachnèum (Ach.) A. L. Sm: British Lich. 2: 270. 1911.

Lichen lachneus Ach. Lich. Suec. Prodr. 140. 1798.

Endocarpon rufescens Ach. Lich. Univ. 304. 1810.

On sand, Great Sturrup Cay, Berry Islands:-widely distributed in North America and Europe.

3. Dermatocarpon hepàticum (Ach.) Th. Fr. Lich. Arct. 255. 1860.

Endocarpon hepaticum Ach. Lich. Univ. 298. 1810.

On the ground, Abaco, at Old Kerr's Point, and Acklin's Island, at Spring Point :- cosmopolitan.

\section{ENDOCÁRPON Hedw.}

1. Endocarpon pallidulum (Nyl.) Hue, Nouv. Arch. Mus. Hist. Nat. Paris III: 4: 106. 1892 .

Verrucaria pallidula Nyl. Flora 57: 73. 1874.

On limestone (mixed with Scytonema), New Providence:-Cuba; Peru; Japan.

\section{Family 5. PARATHELIÀCEAE.}

Spores brown, plurilocular.

Spores colorless, murlform-multilocular.

\section{PARATHÈLIUM Nyl.}

Spores 34-40 $311-16 \mu$.

Spores $18-22 \times 8-9 \mu$.

1. P. indutum.

2. P. microcarpum.

1. Parathelium indùtum Nyl. Bot. Zeit. 20: 279. 1862.

On bark, Conception Island, Berry Islands, Stocking Island, Great Exuma, Cat Island, Long Island :-Cuba ; St. Thomas ; Porto Rico; Colombia.

\section{Parathelium microcàrpum Riddle, sp. nov.}

Thallus crustaceus uniformis effusus haud limitatus, cum cortice maculam nitidam ochraceo-fulvam constituens, continuus laevigatus. Gonidia chroolepoidea. Perithecia pyriformia, minuta ad $0.5 \mathrm{~mm}$. longa, $0.3 \mathrm{~mm}$. lata, integra nigra semi-innata parte emersa nudata, ostiolis lateralibus collis breviusculis. Paraphyses sparse ramosae. Asci 8-spori. Sporae fuscae ellipsoideae, ad apices 
acutae, 3-septatae, ad septa modice constrictae, loculis lentiformibus, 18-22 $\times 8-9 \mu$.

On bark in coppice, West End, Great Bahama (Brace, April 16-Nay 8, 1905, 3615, type).

Parathelium microcarpum has smaller spores than any other specles of the genus, with the exception of $P$. decumbens Muell. Arg. (Hedwigia 32:134. 1893) which differs from the present species in the whitish thallus and the larger perithecia.

\section{CAMPYLOTHËLIUM Muell. Arg.}

\section{Campylothelium decòlorans Riddle, sp. nov.}

Thallus epiphloeodes crustaceus uniformis effusus stramineo-albus subnitidus, tenuis vel tenuissimus, continuus laevigatus inaequalis. Gonidia chroolepoidea. Perithecia circa $1.0 \mathrm{~mm}$. lata, tota thallino-corticata parum prominentia, quasi maculam fuscescentem formantia, superne nigra, inferne decolorata, ostiolis lateralibus collis nullis. Paraphyses persistentes satis ramosae. Asci 2-6-spori. Sporae incolores oblongae medio leviter constricto irregulariter murali-divisae, 6-8-loculares, loculi 3-4-locellati, loculis eubicis aut irregularibus, $37-43 \times 16-18 \mu$.

On bark of Drypetes, Cay North of Wide Opening, Exuma Chain (Britton and Millspaugh, February 18, 1905, 2795, type).

This species differs from other species of the genus in the pale color of the lower part of the perithecial wall.

\section{Family 6. ASTROTHELIÀCEAE.}

Spores colorless, plurilocular.

Spores brown, muriform-multilocular.

1. Lithothelium.

2. Parmentaria.

\section{IтTнотнїLIUM Muell. Arg.}

\section{Lithothelium bahaménse Riddle, sp. nov.}

Thallus epilithicus crustaceus uniformis effusus linea nigra limitatus, glaucus aut cinereus opacus, crassiusculus crebre contextus, continuus laevigatus. Gonidia chroolepoidea. Stromata minuta, 0.4-0.6 mm. lata, in foveolis saxi innata, dein semi-emergentia, demum elabentia foveolamque relinquentia, tota nigra parte emersa nudata, paucicarpica, ambitu oblonga aut satis difformia, ostiolis minutis irregulariter umbonatis. Perithecia minutissima, integra nigra. Paraphyses persistentes simplices filiformes. Asci cylindrices, 8-spori. Sporae in ascis 1-2-seriales, incolores, fusiformes, 8-loculares, loculis cylindricis, $18-22 \times 5-6 \mu$.

On limestone, vicinity of Cockburn Town, Watling's Island (Britton and Millspaugh, March 13, 1907, 6127, type; 6129).

Lithothelium bahamense differs from the only other known species of the genus. L. cubanum Muell. Arg. (Bot. Jahrb. 6:386. 1885), in the color of the thallus and the eight-celled spores.

\section{PARMENTÀRIA Fée.}

1. Parmentaria astroìdea Fée, Essai Crypt. 70, pl. 20, f. 1. 1824.

On bark, New Providence, at Clifton Coppice, and Crooked Island, at Vauxhall :widely distributed in tropical and subtropical regions.

\section{Order 2. CALICIÀLES.}

\section{Family 1. CALICIÀCEAE.}

\section{CALİCIUM Pers.}

1. Calicium hyperéllum Ach. Meth. Lich. 93. 1803.

Lichen hyperellus Ach. Lich. Suee. Prodr. 85. 1798.

On palmetto, The Bight, Cat Island:-widely distributed in North America and Europe. 


\section{Order 3. GRAPHIDÀLES.}

Apothecia without an exciple.

Fam. 1. Arthoniaceae.

Apothecia with an exciple.

Thallus without a cortex.

Apothecia solitary.

Apothecia typically imbedded in a stroma.

Thallus with an upper cortex.

Fam, 2. Graphidaceae.

Fam. 3. CHIODECTONACEAE.

Fam. 4. DirinaceAE.

\section{Family 1. ARTHONIÀCEAE.}

Spores two to many-celled.

Spores muriform-multilocular.

\section{ARTHÒNIA Ach.}

Spores four- to six-celled.

Apothecia some shade of red.

Apothecia brown or black.

A pothecia orbicular or difform.

Apothecia about $0.3 \mathrm{~mm}$. in diameter:

Spores with cells of equal size.

Spores with end-cell enlarged.

Apothecla over $0.6 \mathrm{~mm}$. In diameter.

Spores with cells of equal size.

Spores with one or both end-cells enlarged.

Apothecla linear, more or less branched.

Spores eight- to sixteen-celled.

Spores $22-32 \times 7-11 \mu$.

Apothecia fulvous, $0.1 \mathrm{~mm}$. wide.

Apothecia chestnut, $0.3-0.5$ mm. wide.

Spores 50-75 $\times 14-23 \mu$

Apothecia orbicular.

Apothecia linear and branched.
1. Arthonia

2. Arthothelium.
1. A. gregaria.

2. A. chiodectella.

3. A. cinereopruinosa.

4. A. polymorpha.

5. A. complanata.

6. A. interducta.

7. A. fissurinea.

8. A. septisepta.

9. A. platygraphidea.

10. A. atrata.

1. Arthonia gregària (Weig.) Koerb. Syst. Lich. Germ. 291. 1855.

Sphaeria gregaria Weig. Obs. Bot. 43, pl. 2, f. 10. 1772.

Arthonia cinnabarina Wallr. Crypt. Germ. 1: 320. 1831.

On bark, Stocking Island, Exuma Chain:-cosmopolitan.

2. Arthonia chiodectélla Nyl. Flora 52: 125. 1869.

On bark, New Providence :-Florida; Loulsiana; Texas.

3. Arthonia cinereopruinòsa Schaer. Enum. Lich. '243. 1850.

On bark, New Providence:-North America; Europe.

4. Arthonia polymórpha Ach. Syn. Lich. 7. 1814.

On bark, Great Bahama, New Providence, Great Exuma:-widely distributed in tropical regions of both hemispheres.

5. Arthonia complanàta Fée, Essai Crypt. 54. 1824.

On bark, Great Bahama, at Pinder's Point:-widely distributed in tropical and subtropical America and in New Zealand.

6. Arthonia interdúcta Nyl. Act. Soc. Sci. Fenn. 7: 496.1863.

On bark, Stocking Island, and Cay north of Wide Opening, Exuma Chain :Florida ; Anegada Island; Nicaragua; Brazil ; Hawallan Islands.

7. Arthonia fissurìnea Nyl. Flora 68: 447. 1885 .

On bark, Great Bahama, near Rolletown :-Florida.

8. Arthonia septisépta Nyl. Flora 69: 104. Hyponym. 1886. Nyl. apud Willey, Synops. Arth. 11. 1890.

On bark, New Providence:-Florida; Cuba.

This species is very closely related to the common Arthonia conferta (Fée) Nyl. differing only in having the apothecia spuriously margined and the spores eightcelled instead of six-celled. 
9. Arthonia platygraphidea Nyl. Act. Soc. Sci. Fenn. 7: 483. 1863.

On bark, New Providence, on Soldier's Road, and Cat Island, vicinity of The Bight:-Florida ; Cuba ; Porto Rico; Mexico ; Brazil.

10. Arthonia atràta (F'é) Muell. Arg. Mem. Soc. Phys. Hist. Nat. Genève $29^{8}$ : 59. 1887.

Graphis atrata Fée, Essai Crypt. 35. 1824.

Not Arthonia atrata Tuck. Genera Lich. 222. 1872.

On bark, New Providence:-tropical America.

\section{ARTHOTHËLIUM Mass.}

1. Arthothelium macrothècum (F'ée) Mass. Ric. Lich. Crost. 55. 1852.

Arthonia macrotheca Fée, Suppl. Essai Crypt. 42, pl. 40, f. 18. 1837.

On bark, Abaco, at Marsh Harbor, and New Providence, at Soldiers' Home :widely distributed in tropical regions of both hemispheres.

\section{Family 2. GRAPHIDÀCEAE.}

Spores four- to many-celled.

Spores colorless.

Spores with cylindrical cells.

Spores with lens-shaped cells.

Spores brown.

Spores muriform-muitilocular.

Spores colorless.

Spores brown.

1. Opegrapha.

2. Graphis.

3. Phaeographis.

4. Graphina.

5. Phaeographina.

\section{OPEGRÁPHA Humb.}

Growing on bark.

Spores four-celled.

Spores six-celled.

Spores $2-4 \mu$ wide.
Spores $7-9 \mu$ wide.

Growing on rocks.

Spores four-celled.

Thallus white.

Thallus gray, greenish or brownish.

Spores six- to eight-celled.

Thallus some shade of brown.

Thallus thin and continuous.

Thallus of medium thickness, rimulose-areolate.

Thallus slate-gray.

1. O. atra.

2. O. vulgata.

3. O. varia.

4. O. calcarea.

5. O. saxicola.

6. O. isabellina.

7. O. bahamensis.

8. O. columbina.

1. Opegrapha átra Pers. in Usteri, Ann. Bot. 7: 30. 1794.

On bark, New Providence, at Soldiers' Home :-widely distributed.

2. Opegrapha vulgàta Ach. Meth. Lich. 20. 1803.

On bark, New Providence:-widely distributed in temperate regions.

3. Opegrapha vària Pers. in Usteri, Ann. Bot. 7: 30. 1794.

On bark, New Providence:-cosmopolitan.

4. Opegrapha calcàrea Turn. in Smith, Eng. Bot. pl. 1690. 1807.

Opegrapha Chevallieri Leight. Ann. Mag. Nat. Hist. II: 13: 90.1854.

On limestone, Conception Island :-Europe; California; Cuba.

5. Opegrapha saxìcola Ach. Syn. Lich. 71. 1814.

On limestone, New Providence :-Europe; California ; Cuba. 
6. Opegrapha isabellina Riddle, sp. nov.

Thallus crustaceus uniformis effusus haud limitatus, isabellinus minute albo-maculatus, tenuis continuus laevigatus. Gonidia chroolepoidea. Apothecia dispersa aut rarius aggregata superficialia elevata, simplicia recta aut rarius flexuosa, oblonga aut linearia, 0.8-2.0 mm. longa, 0.1-0.2 $\mathrm{mm}$. lata, tota nigra, labiis haud sulcatis conniventibus disco rimaeformi; amphithecio nigricante integro basi completo. Paraphyses ramosae. Asci clavati, 8-spori. Sporae incolores, fusiformes, 6-8-loculares loculis cylindricis aequalibus, 20-24 $\times 4-5 \mu$.

On limestone, New Providence (Brace, May 20, 1918, 948\%, type). In the Tuckerman Herbarlum there is an unnamed specimen of this species from Cuba, sent to Tuckerman by Ravenel.

Scarcely anything is known of the rock-inhabiting Opegraphas of the tropics. I have been unable to find any described in the writings of Nylander, Mueller-Argau, or Wainio. The three new species here described appear to be distinct from the European species.

\section{Opegrapha bahaménsis Riddle, sp. nov.}

Thallus crustaceus uniformis effusus haud limitatus, testaceus, sat crassiusculus laevigatus aut rugulosus, rimulosus partim areolatus, sorediis nullis; hypothallo nullo. Gonidia chroolepoidea. Apothecia dispersa aut rarius aggregata, primum subinnata mox superficialia elevataque, simplicia recta, pro maxima parte brevia oblonga, 0.4-0.7 mm. longa, rarius subelongata, ad 1.5 $\mathrm{mm}$. longa, 0.1-0.2 $\mathrm{mm}$. lata, tota nigra, labiis haud sulcatis conniventibus aut rarius hiantibus, diseo rimaeformi aut rarius paullum aperto; amphithecio fusco-nigricante integro basi completo. Paraphyses sparse ramosae. Asci clavati, 8-spori. Sporae incolores fusiformes, 6-loculares loculi cylindricis aequalibus, $18-20 \times 3-4 \mu$.

On limestone, New Providence (Brace, June 5, 1918, 9454a, type).

Opegrapha bahamensis resembles $O$. Chevallieri var. incarnata Riddle (Bull. Torrey Bot. Club $43: 150$. 1916), but differs in the six-celled spores. From 0 . zonata Koerb., it differs in the absence of soredia and hypothallus. The key-characters will serve to distinguish it from $O$. isabellina.

\section{Opegrapha columbìna Riddle, sp. nov.}

Thallus crustaceus uniformis effusus haud limitatus, columbina aut plumbeus aut partim nigrescens, tenuissimus farinulentus. Gonidia chroolepoidea. Apothecia dispersa aut conglomerato-approximata, superficialia elevata, simplicia recta oblonga, $0.5-1.5 \mathrm{~mm}$. longa, circa $0.2 \mathrm{~mm}$. lata, tota nigra, labiis haud sulcatis conniventibus disco rimaeformi; amphithecio nigricante integro basi completo crasso. Paraphyses ramosae. Asci clavati, 8-spori. Sporae incolores fusiformes, 8-loculares loculis cylindricis aequalibus, 24-28 $\times 5-7 \mu$.

On limestone, vicinity of Governor's Harbor, Eleuthera Island (Britton and Millspaugh, February 19-20, 1907, 5533, type).

This species is most closely related to Opegrapha ophites Tuck. (apud Riddle in Bull. Torrey Bot. Club 43: 150, 1916), but differs in the short, straight, oblong apothecia. From $O$. lithyrga Ach. It may be distinguished by the color of the thallus and the wider spores.

\section{GRÁPHIS Adans.}

Apothecia externally black.

Apothecia $0.4-1.0 \mathrm{~mm}$. in length.

A pothecia mostly $2-5 \mathrm{~mm}$. in length.

Apothecia not externally black.

Apothecia white, contrasting with the dark thallus or bark.

Apothecia concolorous with the glaucous thallus.

Lips entire or nearly so.

Lips deeply sulcate.

1. G. Pavoniana.

2. G. scripta.

3. G. Afzelii.

4. G. vestita.

5. $G$. cinerea.

1. Graphis Pavoniàna Fée, Essai Crypt. 40. 1824.

On bark, New Providence:-Texas; Bermuda. 
2. Graphis scrípta (L.) Ach. Lich. Univ. 265. 1810.

Lichen scriptus L. Sp. Plant. 1140. 17.53.

On bark, New Providence and Stocking Island, Great Exuma:-cosmopolitan.

3. Graphis Afzèlii Ach. Syn. Lich. 85. 1814. regions.

On bark, Great Bahama and New Providence:-a common species in tropical

4. Graphis vestita Fr. Syst. Orb. Veg. 288. 1825.

On twigs, New Providence, along road between Clifton and Fort Mt. Pleasant :tropical America.

5. Graphis cinèrea Fée, Essai Crypt. 37, pl. 10, f. 3. 1824.

On bark, New Providence:-Jamaica; Colombia; Brazil.

\section{PHAEOGRÁPHIS Muell. Arg.}

Disk of apothecia dark red.

Disk of apothecia brownish-black, sometimes pruinose.

Amphithecium black at both sides and base.

Amphithecium black at the sides only.

1. P. cinnabarina.

2. P. dendritica.

3. P. inusta.

1. Phaeographis cinnabarìna (Fée) Muell. Arg. Mem. Soc. Phys. Hist. Nat. Genève 298: 27. 1887.

Graphis cinnabarina Fée, Essai Crypt. 44, pl. 13, f. 4. 1824.

On bark, New Providence:-Cuba; Colombia; Brazll ; Peru.

2. Phaeographis dendritica (Ach.) Muell. Arg. Flora 65: 382. 1882.

Opegrapha dendritica Ach. Meth. Lich. 31. 1803.

On bark, New Providence:-widely distributed in temperate regions.

3. Phaeographis inústa (Ach.) Muell. Arg. Flora 65: 383. 1882.

Graphis inusta Ach. Syn. Lich. 85. 1814.

On bark, New Providence:- widely distributed in Europe, North and South America, and New Zealand.

4. GRAPHINA Muell. Arg.

Thallus olivaceous, apothecia simple.

Thallus malachite-green, apothecia branched.

1. G. nitidescens.

2: G. virginea.

1. Graphina nitidéscens (Nyl.) Riddle, Mem. Brooklyn Bot. Gard. 1: 115. 1918.

Fissurina nitidescens Nyl. Lich. Japon. 108. 1890.

On bark, New Providence:-Florida; Cuba; Porto Rico.

2. Graphina virgìnea (Eschw.) Muell. Arg. Flora 63: 41. 1880.

Leiogramma virginea Eschw. in Mart. Fl. Bras. 1: 98.1833.

On bark, New Providence :- a common lichen in tropical America.

\section{PHAFographiNa Muell. Arg.}

1. Phaeographina caesiopruinòsa (Fée) Muell. Arg. Mem. Soc. Phys. Hist. Nat. Genève 298: 49.1887.

Arthonia caesiopruinosa Fée, Suppl. Essai Crypt. 36, pl. 40, f. 4. 1837.

Graphis scalpturata var. plurifera Nyl. Ann. Sci. Nat. V: 7: 332.1867.

On bark, New Providence and Acklin's Island, at Spring Point:-widely distributed in the tropical and subtropical regions of both hemispheres. 
$P$. caesiopruinosa dlffers from $P$. scalpturata (Ach.) Muell. Arg. in the character of the spores which in the former species are four to eight in each ascus and are $40-85 \times 14-22 \mu$ in size; while in the latter species, they are constantly solitary in the ascus, and 90-140 $\times 22-35 \mu$ in size. For a discussion of the confusion of this species with $P$. quassiaccola (Fée) Muell. Arg. and the distinctions between the two species, reference may be made to the Bulletin of the Torrey Botanical Club (44:324. 1917).

\section{Family 3. CHIODECTONÀCEAE.}

Spores with cylindrical cells: Spores coloriess. Spores brown.

Spores with lens-shaped celis. Spores colorless.

Spores brown.
1. Chiodecton.

2. Solerophyton.

3. Glyphis.

4. Surcographa.

\section{CHIODÉCTON Ach.}

Either thallus or apothecla more or less brillant red. Thallus red at least in part.

Thallus not at all red, but apothecla blood-red.

Nelther thallus nor apothecla at all red.

Apothecla linear, more or less branched.

A pothecia punctiform, difform, or oblong.

Stroma distinctly convex, apothecla seriate.

Stroma flat or absent, apothecia scattered. Growing on bark; spores 6- to 8-celled. Growing on rocks; spores 4-celled.

1. C. sanguineum.

2. C. cruentatum.

3. C. elongatum.

4. C. quassiaecolum.

5. C. crassum.

6. Bracei.

1. Chiodecton sanguìneum (Sw.) Wainio, Lich. Brés. 2: 143.1890.

Byssus sanguinea Sw. Prodr. 148. 1788.

Hypochnus rubrocinctus Ehrenb. in Nees, Hor. Phys. Berol. 84. 1820.

Chiodecton rubrocinctum Nyl. Act. Soc. Sci. Fenn. 7: 486. 1863.

On Juniperus stumps, Andros, at Nicholl's Town :-widely distributed in trop. ical regions of both hemispheres.

\section{Chiodecton cruentàtum Riddle, sp. nov.}

Thallus epiphloeodes crustaceus uniformis effusus haud limitatus, albus vel albidus opacus, crassiusculus verrucosus verrucis convexis hemisphericis aut subglobosis, 0.3-0.5 mm. diam., conglomeratis. Gonidia chroolepoidea. Stroma nulla. Apothecia dispersa, orbicularia oblonga aut pro maxima parte difformia, 0.4-0.7 mm. lata, innata, disco plano claro cruento, margine spurie thallino cincta; hymenio incolore, $60 \mu$ altit.; hypothecio incolore. Asci clavati, 8 -spori. Sporae incolores, fusiformes, 6-loculares, loculis cylindricis aequalibus, 13-16 $\times 4 \mu$.

On bark of Eugenia confusa, Barnett's Point, Great Bahama (Britton and Millspaugh, February 5-13, 1905, 2634, type).

The compact thallus and the absence of a stroma indicate that this species belongs to the section Enterographa. The absence of a stroma as well as the lack of any trace of red coloration in the thallus serve to distingulsh it from the preceding species. There does not seem to be any other species with which it could possibly be confused.

3. Chiodecton elongàtum Wainio, Lich. Brés. 2: 138. 1890.

On bark, New Providence:-Brazil.

The apothecia vary from immersed in and even with the thallus to conditions in which there is a definlte convex stroma; the spores may be ten-celied.

4. Chiodecton quassiaècolum (F'ée) Muell. Arg. Mem. Soc. Phys. Hist. Nat. Genève $29^{8}: 69.1887$.

Enterographa quassiaecola Fée, Essai Crypt. 57, pl. 33, f. 2. 1824.

On bark of Erithalis fruticosa, Stocking Island, Great Exuma:-Martinique;

New Caledonia; Oceanica. 
5. Chiodecton crássum (DC.) Zahlbr. in Engler and Prantl, Nat. Pflanzenfam. $1^{1 *}: 104.1905$.

Opegrapha crassa DC. Fl. Franc. 2: 312. 1805.

On bark, New Providence, at Maidenhead Coppice:-Europe; northern Africa ; Japan. Not previously recorded from North America.

\section{Chiodecton Bràcei Riddle, sp. nov.}

Thallus epilithicus crustaceus uniformis subdeterminatus maculas 3-15 $\mathrm{mm}$. diam. formans haud linea nigra limitatus, argillaceus aut albus, in crassitudine mediocris, crebre contextus continuus laevigatus undulatus. Gonidia chroolepoidea. Stroma nulla. Apothecia dispersa aut rarius aggregata thallo immersa punctiformes aut difformia aut partim elongata, $0.1-0.5 \mathrm{~mm}$. longa, simplicia, disco sicco nigro madefacto badio, nudo plano superficiem thallo subaequante, margine tenuissime spurie thallino aut margine evanescente; epithecio fuscescente; hymenio et hypothecio incolore. Paraphyses crassiusculae ramoso-connexae. Asci clavati 8-spori. Sporae incolores fusiformes 4-loculares loculis cylindricis aequalibus, 14-20 $\times 4 \mu$.

On limestone, New Providence (Brace, June 16, 1918, 9513, type). Also, Watling's Island, vicinity of Cockburn Town (Britton and Millspaugh. 6128a).

Chiodecton Bracei belongs to the section Enterographa. It differs from $C$. rufescens Wainio (Journ. Bot. 34:262. 1896) in having simple apothecia which are more often punctate or difform than elongated. I take pleasure in naming this species in honor of Mr. Brace, whose collections have greatly extended our knowledge of the lichens of the Bahamas.

\section{SCLEROPHỲTON Eschw.}

1. Sclerophyton élegans Eschw. in Mart. Fl. Bras. 1: 103. 1833.

Stigmatidium elegans Nyl. Bull. Soc. Linn. Norm. II: 3: 274. 1869.

On bark, New Providence, along Soldier's Road:-Florida; Bermuda; Cuba ; Guadeloupe ; Brazll.

Easily confused with species of Arthonia, as the stroma is by no means obvious.

\section{GLÝPHIS Ach.}

1. Glyphis cicatricòsa Ach. Syn. Lich. 107. 1814.

Glyphis Achariana Tuck. Amer. Journ. Sci. 25: 429. 1858.

On bark of various species, and at various localities, Great Bahama, New Providence, Watling's Island :- one of the commonest of tropical lichens.

\section{SARCOGRÁ́ HA Fée.}

1. Sarcographa tricòsa (Ach.) Muell. Arg. Mem. Soc. Phys. Hist. Nat. Genève 298: 63.1887.

Graphis tricosa Ach. Lich. Univ. 674. 1810.

On bark, New Providence, and Long Island:-widelv distributed in tropical regions of both hemispheres.

\section{Family 4. DIRINÀCEAE.}

\section{DIRINNA Fr.}

Growing on rocks.

Growing on bark (of Jacquinia keyensis).

1. D. repanda.

2. D. ceratoniae.

1. Dirina repánđa (Fr.) Nyl. Act. Soc. Linn. Bordeaux 21: 343. 1856.

Parmelia repanda Fries, Lich. Europ. 177. 1831.

On limestone, New Providence, near Queen's Staircase, Nassau ; Great Exuma, along Haynes Road; Long Cay, on Cunningham Hili :- southern Europe and northern Africa, Hawali. India. The occurrence in the Bahamas of this species, not previously known from North America, was recorded in the Bryologist (21:50. 1918). 
2. Dirina ceratòniae (Ach.) DeNot. Giorn. Bot. Ital. 2: 188.1846.

Lecanora ceratoniae Ach. Lich. Univ. 361. 1810.

On bark of Jacquinia keyensis (apparently confined to this, so far as it occurs in the Bahamas), New Providence, road south of Fox Hill, Eleuthera Island, at Miller's Point; Little San Salvador: Stocking Island, Great Exuma; Watling's Island, on island in lake:- southern Europe and northern Africa.

\section{Order 4. LECIDEÀLES.}

A. Spores with uniformly thickened wall, colorless in all Bahama genera except Leptotrema and there brown and muriform.

1. Thallus gelatinous when moist.

Gonidia : Gloeocapsa.

Gonidia: Nostoc.

2. Thallus not gelatinous when moist.

$a$. Thallus appearing as a mat of Trentepohlia

flaments, the hyphae to be seen only under the microscope.

b. Thallus not as above.

* Thallus crustose or squamulose. t Thallus crustose.

Thalline exclple absent or soon disappearing.

Margin of apothecla pllose.

Margin of apothecia naked. Gonldia : Trentepohlia.

Apothecia with a black exciple.

Exciple not black.

Gonidia: Cystococcus.

Thalline exciple present.

Apothecia immersed in the thallus or in thalline verrucae. Apothecia superficial and discoid.

t† Thallus squamulose, or developing erect fruticose podetia and the original squamules disappearing. Apothecla sessile on the souamules.

Apothecia on the tips of erect podetia.

* Thallus foliose or fruticose.

Thallus foliose.

Gonidia : Blue-green.

Gonidia : Green.

Thallus fruticose, growing on trees.

(Species of Cladonia might be sought here, but never grow on trees.) B. Spores with irregularly thickened wall (i.e., polar-
bilocular) or uniformly thickened, but then always brown; never muriform.

Spores colorless.

Spores brown.

Thallus crustose.

Thallus follose.

Fam. 1. Prrenopsidaceae. Fam. 2. Collemaceae.

Fam. 3. Coenogoniaceafa

Flam. 4. Pilocarpaceat.

Fam. 5. Lecanactinacead.

Fam. 6. GyaleCtACEAE.

Fam. 7. Lecideaceae.

Fam. 8. THelotremachae.

Fam. 9. LecanoraceaE.

Fam. 10. Phyllopsoraceat.

Fam. 11. Cladoniaceae.

Fam. 12. Pannariaceat.

Fam. 13. Parmeliaceat.

Fam. 14. USNEACEAE.

Fam. 15. Caloplacacear.

Fam. 16. Buelliaceas.

Fam. 17. Phy sciaceae.

\section{Family 1. PYRENOPSIDÀCEAE.}

\section{PSOROTÍCHIA Mass.}

1. Psorotichia Boergesènii Wainio, Ann. Acad. Sci. Fenn. A: 67: 118. 1915.

On limestone, New Providence:-St. Thomas.

\section{Family 2. COLLEMÀCEAE.}

Spores simple.

Spores plurilocular or muriform-multilocular.

Thallus without a cortex.

Thallus corticate, at least above.

1. Physma.

2. Collema

3. Leptogium. 


\section{PHÝSMA Mass.}

1. Physma umbélla (Tuck.) Riddle.

Omphalaria umbella Tuck. apud Nyl. Syn. Lich. 1: 105.1858.

On a rock, New Providence, at sink-hole, on Farringdon Road:-Alabama.

\section{COLLÈMA Hill.}

Surface of thallus granuiose.

Thallus not granulose.

Thallus radiately plicate, with rounded lobes.

Thallus merely uneven, with narrow lobes.

1. C. rupestre.

2. C. nigrescens.

3. C. laciniatum.

1. Collema rupéstre (Sw.) Rabenh. Deutsch. Krypt. Flora 2: 50. 1845.

Lichen rupestris Sw. Meth. Muscor. 37. 1781.

Lichen flaccidus Ach. Nov. Act. Acad. Sci. Stockholm 5: 14, pl. 1, f. 4. 1795.

Collema flaccidum Ach. Lich. Univ. 647. 1810.

On Annona glabra, Cat Isiand, at Port Howe:-widely distributed in temperate regions of both hemispheres.

2. Collema nigréscens (Huds.) Ach. Syn. Lich. 321. 1814.

Lichen nigrescens Huds. Fl. Angl. 450. 1762.

On trees, Great Bahama, at Barnett's Point, and New Providence, at Waterloc Coppice :-cosmopolitan.

The material is without isidia, and would represent what Wainio (Lich. Brés. 1: 235. 1890) calls Collema vespertilio (Lightf.) Wainio, but the original plants upon which these names were based are doubtful.

3. Collema laciniàtum Nyl. Syn. Lich. 1: 115. 1858.

At base of tree, Watling's Island, near Cockburn Town:-Alabama; Kansas. The type came from calcareous rocks, and as the present material is sterile, the determination must be considered uncertain, although the thalline characters agree with the material in the Tuckerman Herbarium.

\section{LEPTÒGIUM S. F. Gray.}

Thallus dark green to black.

Thallus bluish iead-color.

Thalline margin of apothecia a piaited corona.

Thalline margin of apothecia thickly lobuiate.

1. L. chloromelum.

2. L. bullatum.

3. L. phyllocarpum.

1. Leptogium chloromèlum (Sw.) Nyl. Syn. Lich. 1: 128.1858.

Lichen chloromelos Sw. Fl. Ind. Occ. 3: 1892. 1806.

On trees, New Providence, Watling's Island, and Salt Key Bank, Anguilla Isiands :- throughout North America, and recorded as cosmopolitan.

This is the most "Collema-like" of all the species of Leptogium, and is very variable. Some of the specimens cited are near the variety stellans Tuck. Syn. N. A. Lich. 1: 163.1882.

2. Leptogium bullàtum (Ach.) Nyl. Syn. Lich. 1: 129.1858.

Lichen bullatus Ach. Lich. Suec. Prodr. 137. 1798.

On trees, Great Bahama, at Golden Grove, and New Providence, along Soldier's Road:- widely distributed in tropical America, and recorded from tropical Asia and New Zealand.

3. Leptogium phyllocárpum (Pers.) Nyl. Syn. Lich. 1: 130. 1858.

Collema phyllocarpum Pers. in Gaudich. Voy. Uran. 204. 1826.

Leptogium bullatum var. phyllocarpum Tuck. Syn. N. A. Lich. 1: 165. 1882.

On trees, New Providence, at Grantstown and along Soldier's Road :-widely distributed in tropical regions of both hemispheres. 


\section{Family 3. COENOGONIÀCEAE.}

\section{COENOGÒNIUM Ehrenb.}

1. Coenogonium interplèxum Nyl. Ann. Sci. Nat. IV: 16: 92.1862.

On trees, Abaco, vicinity of Cherokee Sound, and Andros, at Louisa Copplce, near Nicholl's Town :-Costa Rica; Colombia; Venezuela.

\section{Family 4. PILOCARPÀCEAE.}

\section{PILOCÁRPON Wainio.}

1. Pilocarpon tricholòma (Mont.) Wainio, Lich. Brés. 2: 89. 1890.

Biatora tricholoma Mont. Ann. Sci. Nat. III: 16: 53.1851.

Lecidea leucoblephara Nyl. Ann. Sci. Nat. IV: 19: 337. 1863.

On leaves of Eugenia, Crooked Island, at Stopper Hill:-widely distributed in tropical America.

\section{Family 5. LECANACTIDĀCEAE.}

\section{IECANÁCTIS Eschw.}

1. Lecanactis denticulata Wainio, Ann. Acad. Sci. Fenn. A: 67: 141. 1915.

Opegrapha acicularis Riddle, Mem. Brooklyn Bot. Gard. 1: 110. 1918.

On bark of Coccolobis laurifolia, Great Harbor Cay, Berry Islands, and on Eugenia buxifolia, Watling's Island :-Florida; Cuba ; St. Thomas ; St. Croix ; Porto Rico.

It has only recently been possible for me to see a copy of Wainio's paper. His description of $L$. denticulata differs from that of $O$. acicularis only in stating that the base of the amphithecium is black, while I found it to be colorless in the material that I examined; but the denticulate margin of the apothecia is so peculiar and so characteristic that I am convinced that the plants are the same. Furthermore, the acicular spores are identical, and Wainio has proposed a new section Bacidiactis to receive this species.

\section{Family 6. GYALECTÀCEAE.}

Spores one-celled.

Spores two-celled.
1. Ionaspis.

2. Microphiale.

\section{IONÁSPIS Th. Fr.}

\section{Ionaspis tròpica Riddle, sp. nov.}

Thallus crustaceus effusus tenuissimus cum saxo conferruminatus, fuscescens, minutissime farinosus, circa apothecia rimuloso-areolatus. Gonidia pauca chroolepoidea. Apothecia caespitosa minuta, in areolis thallinis immersa, disco primum punctiforme dein aperto ad $0.3 \mathrm{~mm}$. lato, concavo aut plano, castaneo aut fuscescente, margine pallidiore integro tenue parum prominente persistente; epithecio fulvo, excipulo et hypothecio pallido. Asci clavati 8-spori. Sporae incolores simplices ellipsoideae membrano tenue, $10-12 \times 6-7 \mu$.

On limestone, New Providence (Brace, November 20, 1918, 969\%, type).

This species has the general appearance of Ionaspis suaveolens (Ach.) Arnold, but differs in the brown thallus and disk of the apothecium.

\section{MICROPHIÀLE Stizenb.}

1. Microphiale lùtea (Dicks.) Steiner, Sitzungsber. kais. Akad. Wiss. Wien 106: 227. 1897.

Lichen luteus Dicks. Pl. Crypt. Brit. 1: 11. 1785.

Gyalecta lutea Tuck. Gen. Lich. 136. 1872.

On bark, New Providence :-widely distributed. 


\section{Family 7. LECIDEÀCEAE.}

Spores simple.

Spores four- to many-celled.

1. Lecidea.

Spores thick-walled, with more or less lens-shaped cells.

Spores thin-walled, with cylindrical cells.

Spores four-celled, fusiform.

Spores many-celled, acicular.

2. Bombyliospora.

3. Bilimbia

4. Bacidia.

\section{IECIDEA Ach.}

Growing on rocks.

Growing on bark.

Hypothecium pale.

Hypothecium blackish-brown.

1. L. immersa.

2. L. vernalis $\nabla$. minor.

3. L. furfurosa.

1. Lecidea immérsa (Web.) Ach. Meth. Lich. 34. 1803.

Lichen immersus Web. Spicil. Fl. Goett. 188. 1778.

Lecidea calcivora Mass. Ric. Lich. Crost. 78. 1852.

Biatora calcivora Tuck. Syn. N. A. Lich. 2: 29.1888.

On calcareous rocks, New Provldence, along Soldier's Road:-southern United States; Europe.

2. Lecidea vernàlis (L.) Ach. var. minor Nyl. apud Norrl. in Not. Saellsk. Faun. Fl. Fenn. 13: 335. 1873.

On bark, New Providence:-North America; Europe.

3. Lecidea furfuròsa Tuck. apud Nyl. Ann. Sci. Nat. IV: 19: 341. 1863.

Biatora furfurosa Tuck. Syn. N. A. Lich. 2: 19. 1888.

On bark, New Providence, at Grantstown:-Florida; Cuba.

\section{BOMBYLIOSPÒRA DeNot.}

1. Bombyliospora domingénsis (Pers.) Zahlbr. apud Wawra and Beck; Jtinera Princip. Coburg. 2: 154. 1888.

Patellaria domingensis Pers. Annal. Wetter. 2: 12. 1810.

Heterothecium domingense Flot., Tuck. Syn. N. A. Lich. 2: 57. 1888.

On bark, New Providence, copplce near Clifton :-widely distributed in tropical regions of both hemispheres.

\section{BILÍmBIA DeNot.}

Growing on rocks; apothecia blackening.

1. B. trachona.

Growing on bark or old wood.

Thallus and apothecia golden-yellow.

Thallus gray or greenish; apothecia pallid.

2. B. aurata.

3. B. molybditis.

1. Bilimbia trachòna (Ach.) Th. Fr. Lich. Scand. 386. 1871.

Verrucaria trachona Ach. Meth. Lich. Suppl. 16. 1803.

Lecidea phaeomela Nyl. Ann. Sci. Nat. IV: 19: 34. 1863. Europe.

On limestone, New Providence:-locally distributed in North America and

The original description of this species says, "crusta pulverulenta." Mr. L. J. K. Brace has sent in a serles of collections from New Providence showing that the thallus varies from areolate-rimose, in well-developed specimens, to a dispersed and granulate condition, and in some cases disappearing. The name Lecidea phaeomela was applied by Nylander to the last named condition. The color of the thallus varies from the typical sordid-green to fuscescent. The very youngest apothecia are baybrown, but they blacken quickly. 


\section{Bilimbia auràta Riddle, sp. nov.}

Thallus crustaceus uniformis effusus haud limitatus, e flavo intense aurescens, tenuis leprosus laxe contextus. Gonidia cystococcoidea. Apothecia minutissima, $0.1-0.15 \mathrm{~mm}$. lata, sat elevata rotundata regularia ceracea, disco aurantiaco, primum plano margine tenuissime pallidiore subleproso, mox convexo margine excluso; epithecio lutescente, hymenio et hypothecio incolore. Asci clavati, 8-spori. Sporae incolores fusiformes apicibus rotundatis aut altero apice subacuto, 4-loculares, loculis cylindricis aequalibus, 10-12 $\times 3 \mu$.

On bark, Farringdon Road, New Provldence (Elizabeth G. Britton, August, 1904, 221, type). The following sterile specimens appear to belong here also:-on dead Suriana, Andros, at Barton Creek (Brace, 5297) ; on dead wood, Crooked Island, at Gun Bluff (Brace, 4693). Also, Palm Beach, Florida (R. Thaxter).

The sterile specimens are simllar to the Lepraria flava of the older authors, although brighter and more golden. But the fertile specimen has abundant apothecla, which certainly belong to the thallus in question. The species is a very distinct one.

3. Bilimbia molybditis (Tuck.) Riddle.

Biatora molybditis Tuck. Syn. N. A. Lich. 2: 34. 1888.

On bark, New Providence :-Florida.

\section{BACIDIA DeNot.}

Apothecla pallid to flesh-color.

Apothecla reddish-brown to black.

Apothecla persistently brown.

Apothecia soon becoming black.

1. B. medialis.

2. B. fuscorubella.

3. B. atrogrisea.

1. Bacidia mediàlis (Tuck.) Riddle.

Lecidea medialis Tuck. apud Nyl. Ann. Sci. Nat. IV: 19: 346. 1863.

Biatora medialis Tuck. Syn. N. A. Lich. 2: 132. 1888.

On bark, New Providence:-Florida; Texas; Cuba; Nicaragua; Brazil.

2. Bacidia fuscorubélla (Hoffm.) Arnold, Flora 54: 55. 1871.

Verrucaria fuscorubella Hoffm. Deutsch. FI. 2: 175. 1795.

Biatora fuscorubella Tuck. Syn. N. A. Lich. 2: 43.1888.

On bark, New Providence:-widely distributed in the northern hemisphere.

3. Bacidia atrogrìsea (Delise) Arnold, Flora 41: 505. 1858.

Biatora atrogrisea Delise apud Hepp, Fl. Eur. 26. 1853.

Lecidea luteola f. endoleuca Nyl. Bot. Notis. (1853) 98.

Bacidia endoleuca Kickx, F1. Crypt. Fland. 1: 261. 1867.

On bark, New Providence, at Maidenhead Copplce:-widely distributed in North America and Europe.

\section{Family 8. THELOTREMÀCEAE.}

Paraphyses branched and anastomosing.

Paraphyses simple and free.

Spores plurilocular, colorless.

Spores muriform-multilocular.

Spores colorless.

Spores brown.

1. GYRóSTOMUM Fr.

1. Gyrostomum.

2. Ocellularia.

3. Thelotrema.

4. Leptotrema.

1. Gyrostomum scyphulìferum (Ach.) Fr. Syst. Orb. Veg. 268.1825.

Lecidea scyphulifera Ach. Synops. Lich. 27. 1814. spheres.

On bark, New Providence:- widely distributed in tropical regions of both hemi- 


\section{OCELLULÀRIA Spreng.}

Spores four- to six-celled.

Spores eight- to sixteen-celled.

1. O. micropora.

2. O. subtilis.

1. Ocellularia micropòra (Mont.) Muell. Arg. Nuov. Giorn. Bot. Ital. 23: 129. 1891.

Thelotrema microporum Mont. Ann. Sci. Nat. III: 10: 130. 1848.

On bark, Andros, at Louisa Coppice near Nicholl's Town:-Florida; Cuba ; Brazil ; Tahiti ; Japan.

2. Ocellularia súbtilis (Tuck.) Riddle.

Thelotrema subtile Tuck. Am. Journ. Sci. 25: 426. 1858. •

Thelotrema bicinctulum Nyl. Ann. Sci. Nat. IV: 15: 46.1861.

On bark, New Providence:-widely distributed.

\section{THELOTRÈMA Ach.}

Apothecia in raised, convex verrucae.

Apothecia sunken in the thallus.

1. T. lepadinum.

2. T. paralbidum.

1. Thelotrema lepadìnum Ach. Meth. Lich. 132. 1803.

Lichen lepadinus Ach. Lich. Suec. Prodr. 30. 1798.

On dead wood, New Providence, near Soldiers' Home :-cosmopolitan.

2. Thelotrema parálbidum Riddle, sp. nov.

Thallus epiphloeodes crustaceus uniformis effusus haud limitatus, sordide albidus, in crassitudine mediocris, rimoso-areolatus areolis subquadrangularibus 0.6-1.0 mm. latis inaequalibus vel leviter convexis. Gonidia chroolepoidea. Apothecia approximata aut partim dispersa, areolis thallinis immersa haud verrucas formantia, suborbicularia $0.5-0.8 \mathrm{~mm}$. lata, disco aperto plano albissimo farinoso, superficiem thalli subaequante aut paullum submerso, margine duplice crenato aut sublacerato parum prominente; intus hyalino. Paraphyses simplices. Asci clavati, 8-spori. Sporae incolores ovideae murali-divisae, 8-10loculares, loculis cubicis 2-3-locellatis, 22-25 $\times 9-11 \mu$.

On bark, Maldenhead Coppice, New Providence (Elizabeth G. Britton, February, 1905,3234, type).

Thelotrema paralbidum is externally similar to Ocellularia albida (Nyl.) Riddle, (Thelotrema albidum Nyl. Act. Soc. Sci. Fenn. 7: 451. 1863), but differs in sporecharacters. It is, perhaps, most closely related to $T$. velatum Muell. Arg. (Bull. Soc. Roy. bot. Belg. 321 $: 26$. 1894), but differs in the thicker, areolate thallus, the white disk, and the shorter spores.

4. IEPTOTRÈMA Mont. \& v. d. Bosch.

Apothecia in convex verrucae.

Spores 1-2 in each ascus.

Spores 8 in each ascus.

Verrucae $0.8-1.0 \mathrm{~mm}$. diameter ; spores $20-30 \mu$ in length.

Verrucae $0.3-0.5 \mathrm{~mm}$. dlameter; spores $35-50 \mu$ in length.

Apothecia sunken in the thallus.

Spores $1-4$ in each ascus.

Spores 8 in each ascus.

Spores with $4-6$ series of cells.

Spores $10-14 \times 6-8 \mu$

Spores $17-27 \times 10-18 \mu$.

Spores with 6-10 series of cells.

1. L. monosporum.

2. L. bahianum.

3. L. simplex.

4. L. bisporum.

5. L. glaucescens.

6. L. Wightii.

7. L. compunctum.

1. Leptotrema monospòrum (Nyl.) Muell. Arg. Bull. Soc. Roy. Bot. Belg. $31^{2}$ : 35. 1892.

Thelotrema monosporum Nyl. Ann. Sci. Nat. IV : 15: 46. 1861.

On bark, New Providence:-wideiy distributed in the warmer regions. 
2. Leptotrema bahiànum (Ach.) Muell. Arg. Mem. Soc. Phys. Hist. Nat. Genève $29^{8}: 12$. 1887:

Thelotrema lepadinum var. bahianum Ach. Meth. Lich. 132. 1803. Brazil.

On bark, New Providence, along Soldier's Road:-Cuba; Costa Rica; Colombia;

3. Leptotrema símplex (Tuck.) Riddle.

Thelotrema simplex Tuck. Proc. Am. Acad. 6: '271. 1864.

On bark, Andros, along road to Conch Sound, and along road to Morgan's Bluff, and New Providence:-Cuba.

4. Leptotrema bispòrum (Nyl.) Riddle.

Thelotrema bisporum Nyl. apud Hue, Nouv. Arch. Mus. Nat. Hist. Paris III: 3: 96. 1891.

On bark, Great Bahama, near Eight Mile Rocks :-Guadeloupe.

The specimens agree exactly with the external characters of the type preserved in the Museum d'Histoire Naturelle in Paris. But Nyiander says that the spores are 1 to 2 in the ascus and $80-115 \times 34-36 \mu$ in size; while the present material shows spores 2 to 4 in the ascus and only $38-50 \times 14-18 \mu$ in size. It is to be expected, however, that with a larger number of spores in the ascus the size should be smaller. A similar condition is found in species of Pertusaria, for example, Pertusaria leioplaca (Ach.) Schaer.

5. Leptotrema glaucéscens (Nyl.) Muell. Arg. Flora 65: 499. 1882.

Thelotrema glaucescens Nyl. Ann. Sci. Nat. IV: 19: 499.1882.

On bark, Andros, along road to Conch Sound:- southern United States; Cuba; Porto Rico.

6. Leptotrema Wíghtii (Taylor) Muell. Arg. Flora 65: 499. 1882.

Endocarpon Wightii Taylor in Hook. Journ. Bot. 6: 155.1847.

Thelotrema Ravenelii Tuck. in part. (fide Muell. Arg. in herb.)

On bark, Abaco, at Old Kerr's Point:-widely distributed in the warmer regions of both hemispheres.

7. Leptotrema compúnctum (Sm.) Muell. Arg. Flora 70: 400. 1887.

Lichen compunctus J. E. Smith apud Ach. Meth. Lich. 143. 1803.

On bark, New Providence:-Cuba; Costa Rica; Colombia; Brazil. Mueller (l. c.) misspeit the name as "compacto," but corrected the error in a list of errata published in Hedwigia $34: 36.1895$.

\section{Family 9. LECANORÀCEAE.}

Spores simple.

Paraphyses simple and free.

Paraphyses branched and anastomosing. Spores piurilocuiar.

1. Lecanora.

2. Ochrolechia.

3. Haematomma.

1. IECANÒRA Ach.

Growing on rocks.

Growing on bark or old wood.

Disk of apothecia distinctiy brown.

Disk of apothecia not brown.

Disk typically vellowish-green.

Disk typically flesh-color.

1. L. badia.

2. L. subfusca.

3. L. varia.

4. L. cincreocarnea.

1. Lecanora bàdia (Pers.) Ach. Lich. Univ. 407. 1810.

Lichen badius Pers. in Usteri, Ann. Bot. 7: 27. 1794.

On limestone, Eleuthera Island, at Eleuthera Point:- widely distributed in Europe; local in North America: mountains of Brazil, Peru, and Chili. 
2. Lecanora subfùsca (L.) Ach. Lich. Univ. 393. 1810.

Lichen subfuscus L. Fl. Suee. ed. 2. 409. 1755.

On bark, New Providence :-cosmopolitan.

3. Lecanora vària (Ehrh.) Ach. Lich. Univ. 377. 1810.

Lichen varius Ehrh. apud Hoffm. Pl. Lich. 1: 102, pl. 23, f. 4. 1790.

On bark and old wood, Great Bahama and New Providence :-cosmopolitan.

4. Lecanora cinereocárnea (Eschw.) Wainio, Lich. Brés. 1: 80. 1890.

Parmelia varia var. cinereocarnea Eschw. in Mart. Fl. Bras. 1: 187. 1833.

Lecanora chlaroterodes Nyl. Flora 59: 508. 1876.

Lecanora chlaronella Nyl. apud Crombie, Journ. Linn. Soc. 16: 215.1877.

Lecanora subfusca var. cinereocarnea Tuck. in Wright Lich. Cub. no. 118.

On bark of trees and shrubs, from Berry Islands to Acklin's:-widely distributed in tropical regions of both hemispheres.

\section{OCHROLÉCHIA Mass.}

1. Ochrolechia palléscens (L.) Koerb. Syst. Lich. Germ. 149. 1855.

Lichen pallescens L. Sp. Plant. 1142. 1753.

Lecanora pallescens Schaer., Tuck. Syn. N. A. Lich. 1: 196. 1888. politan.

On bark of Maba crassinervis, Watling's Island, near Cockburn Town :-cosmo-

\section{HAEMATÓMMA Mass.}

1. Haematomma punìceum (Ach.) Wainio, Lich. Brés. 1: 72. 1890.

Lecanora punioea Ach. Syn. Lich. 174. 1814. spheres.

On bark, New Providence:-widely distributed in tropical regions of both hemi-

\section{Family 10. PHYLLOPSORÃCEAE.}

1. PHYLlopsòra Muell. Arg.

1. Phyllopsora parvifòlia (Pers.) Muell. Arg. Bull. Herb. Boiss. 2: appendix 1: 45.1894.

Lecidea parvifolia Pers. in Gaudich. Voy. Uran. 192. 1826.

Biatora parvifolia Tuck. Genera Lich. 157. 1872.

On tree-trunks, Andros, and New Providence, in Waterloo Coppice:-widely distributed in the warmer regions of both hemispheres.

\section{Family 11. CLADONIÀCEAE.}

\section{CLAdòNIA Hill.}

Apothecia some shade of red.

Apothecia some shade of brown.

Podetla with dilated axils or cup-shaped.

Axils or cups perforate.

Axils or cups closed.

Podetia entirely corticate and without soredia.

Cups proliferating from the center.

Cups proliferating from the margins, or not at all.

Podetia at least partially decorticate and more or less sorediate.

Podetia powdery-sorediate.

Podetia warty or scurfy or granular-sorediate. Cups well-developed. Cups reduced.

Podetia with closed axils, not at all cup-shaped, much branched. Podetla fine and somewhat uniform in size throughout.

Podetia with main part stout and branching progressively finer.

1. C. areolata.

2. C. Dilleniana.

3. C. verticillata.

4. C. gracilis.

5. C. fimbriata.

6. C. pyxidata.

7. C. pityrea.

8. C. pycnoclada.

9. C. rangiferina. 
1. Cladonia areolàta Nyl. Syn. Lich. 1: 226. 1858.

On decaying log, Eleuthera Island, between Harbor Island and Lower Bogue :Guadeloupe.

This is a peculiar and distinct species, with a subcrustose thallus.

2. Cladonia Dilleniàna Floerke, Clad. Comm. 138. 1828.

On ground and over rocks, Andros, vicinity of Lisbon Creek, Deep Creek, Scrub Creek :-Cuba; Jamaica ; Australasia; Madagascar.

3. Cladonia verticillàta Hoffm. Deutsch. Fl. 2: 122.1795.

Cladonia gracilis var. verticillata Fr.; Tuck. Syn. N. A. Lich. 1: 242. 1882.

On the ground, Abaco, along Callfornia Road:-cosmopolitan.

4. Cladonia gràcilis (L.) Willd. var. dilaceràta Floerke, Clad. Comm. 37. 1828.

Cladonia gracilis var. hybrida Tuck. Syn. N. A. Lich. 1: 243, in part. 1882.

Over rocks, Great Bahama, vicinity of Eight Mile Rocks:-widely distributed in Europe and North America.

5. Cladonia fimbriàta (L.) Fr. var. símplex (Weis.) Flot. Linnaea 18: 18. 1843.

Lichen fimbriatus var. simplex Weis, Pl. Crypt. Gott. 84. 1770.

Cladonia fimbriata var. tubaeformis Fr.; Tuck. Syn. N. A. Lich. 1: 241. 1882.

On the ground, Crooked Island, along road to Stopper Hill :-cosmopolitan.

6. Cladonia pyxidàta (L.) Fr. var. chlorophaèa Floerke, Clad. Comm. 70 . 1828.

Cladonia pyxidata (L.) Fr.; Tuck. Syn. N. A. Lich. 1: 240, in part. 1882.

On the ground, Great Bahama and New Providence:-cosmopolitan.

7. Cladonia pityrèa (Floerke) Fr. Nov. Sched. Crit. 21. 1826.

Capitularia pityrea Floerke, Berl. Magaz. 2: 135. 1808.

Cladonia fimbriata var. adspersa Tuck. Syn. N. A. Lich. 1: 242.1882.

On dead wood, and on the ground, Andros, near Nicholl's Town, and Crooked Island, at Vauxhall :- cosmopolitan.

8. Cladonia pycnoclàda (Pers.) Nyl. Journ. Linn. Soc. 9: 244.1866.

Cenomyce pycnoclada Pers. in Gaudich. Voy. Uran. 212. 1826.

On the ground and over rocks, Abaco, at Marsh Harbor, and Mangrove Cay, Andros, at Pineland, Lisbon Creek:- widely distributed in the southern hemisphere.

9. Cladonia rangiferìna (L.) Web. in Wiggers, Prim. Fl. Hols. 90. 1780.

Lichen rangiferinus L. Sp. Plant. 1153. 1753.

Over rocks, Great Bahama:-cosmopolitan.

\section{Family 12. PANNARIÀCEAE.}

Upper cortex composed of vertical hyphae; gonidia Nostoc. Upper cortex composed of longitudinal hyphae; gonidia Scytonema.

1. Pannaria.

2. Coccocarpia.

\section{PANNÀrIA Delise.}

1. Pannaria rubiginòsa (Thunb.) Delise, Diction. Class. 13: 20.1828.

Lichen rubiginosus Thunb. Prodr. Flor. Capens. 176. 1794.

On trees, New Providence, along Soldier's Road:-common in tropical regions and locally distributed in temperate regions of both hemispheres. 


\section{COCCOCÁRPIA Pers.}

1. Coccocarpia péllita (Ach.) Muell. Arg. Flora 65: 320. 1882.

Parmelia pellita Ach. Lich. Univ. 468. 1810.

Thallus without isidia.

Hypothallus copious and extending beyond the lobes.

Hypothallus medium or scanty.

Lobes about $0.4-1.0 \mathrm{~mm}$. wide, repeatedly pinnatifidincised.

Lobes 2-10 mm. wide, cuneate, subentire.

Rhizoids blue-black; apothecia blackening.

Rhizoids partly white; apothecia persistently pale brown.

Thallus more or less isidiose.

a. var. pannosa.

b. var. genuina.

c. var. parmelioides.

d. var. smaragdina.

e. var. tenuior.

1a. Coccocarpia pellita var. pannòsa Muell. Arg. Flora 65: 320. 1882.

On trees, New Providence, at Lake Cunningham, and Crooked Island, at Vauxhall :-Cuba ; Australia.

1b. Coccocarpia pellita var. genuìna Muell. Arg. Flora 65: 321.1882.

On trees, Watling's Island, near Cockburn Town :-Cuba; Porto Rico; Brazil. This represents the Acharian type and is well illustrated in Swartz Lich. Amer. pl.6.

1c. Coccocarpia pellita var. parmelioides (Hook.) Muell. Arg. Flora 65: 320. 1882.

Lecidea parmelioides Hook. in Kunth Syn. Plant. Orb. 162. 1822.

Coccocarpia molybdea Pers. in Gaudich. Voy. Uran. 206. 1826.

Pannaria molybdea Tuck. Syn. N. A. Lich. 1: 124. 1882.

On trees, Great Bahama, Abaco, New Providence:-widely distributed in the warmer regions of both hemispheres.

1d. Coccocarpia pellita var. smarágdina (Pers.) Muell. Arg. Flora 65: 320. 1882.

Coccocarpia smaragdina Pers. in Gaudich. Voy. Uran. 206. 1826.

On trees, New Providence, at Lake Cunningham:-widely distributed in the warmer regions of both hemispheres.

1e. Coccocarpia pellita var. tenùior (Nyl.) Muell. Arg. Flora 65: 322.1882.

Coccocarpia molybdea var. tenuior Nyl. apud Krplh. Flora 59: 76.1876.

On trees, New Providence, at Maidenhead Coppice :-Porto Rico; Mauritius.

\section{Family 13. PARMELIÀCEAE.}

1. PARMìtIA Ach.

Margins ciliate.

Margins naked.

Medulia yellow.

Medulla white.

Thallus greenish-straw-color.

Thalius gray or whitish.

Medulla turning red when tested with caustic potash.

Margins entirely without soredia.

Margins more or less sorediate. Medulla not red with caustic potash.
1. P. urceolata.

2. P. sulphurata.

3. P. flava.

4. P. latissima.

4a. P. latissima var. cristifera. 5. P. perlata.

1. Parmelia urceolàta Eschw. in Mart. Fl. Bras. 1: 207. 1833. Africa.

On trees, New Providence, along Soldier's Road:-tropical South America and 
2. Parmelia sulphuràta Nees \& Flot. Linnaea 9: 501. 1834.

On trees, New Providence, at Maidenhead Coppice :-widely distributed in trow ical regions of both hemispheres.

3. Parmelia fiàva Krempelh. in Warming, Symbol. Flor. Bras. in Villensk. Meddel. 9. 1873.

On tree, Andros, along road to Conch Sound:-Brazil.

4. Parmelia latíssimá Fée, Suppl. Essai Crypt. 119, pl. 38, f. 1. 1837.

On trees, Abaco, New Providence, Watling's Island, Crooked Island:-widely distributed in the warmer regions of both hemispheres.

4a. Parmelia latissima var. cristìfera (Taylor) Hue, Nouv. Arch. Mus. Hist. Nat. Paris IV: 1: 204. '1899.

Parmelia cristifera Taylor in Hook. Journ. Bot. 6: 165. 1847. cal form.

On trees, New Providence, at Maidenhead Coppice:-distributed as in the typi-

5. Parmelia perlàta (L.) Ach. Meth. Lich. 216. 1803.

Lichen perlatus L. Syst. Nat. ed. 12, p. 712. 1767.

On trees, Great Bahama, New Providence :-cosmopolitan.

\section{Family 14. USNEÀCEAE.}

Medulla of loosely interwoven hyphae; spores two-celled.

Medulla with a tough central strand of compacted hyphae; spores simple.

1. Ramalina.

2. Usnea.

\section{RAMALINA Ach.}

Thallus more or less sorediate.

Thallus without soredia.

Thallus elongated and pendulous.

Thallus short and erect.

Branches flattened; spores ellipsoid.

Branches more or less cylindrical; spores fusiform.

1. R. peruviana.

2. R. usneoides.

3. R. complanata.

4. R. Montagnei.

1. Ramalina peruviàna Ach. Lich. Univ. 599. 1810.

On trees, Crooked Island, road to Stopper Hill :-Jamaica ; Porto Rico ; Curaçao Island ; Peru.

2. Ramalina usneoides (Ach.) Fr. Lich. Europ. 468. 1831.

Parmelia usneoides Ach. Meth. Lich. 270. 1803.

On branches of trees, Abaco and Watling's Island:-widely distributed in tropical regions of both hemispheres.

3. Ramalina complanàta (Sw.) Ach. Lich. Univ. 599. 1810.

Lichen complanatus Sw. Fl. Ind. Occ. 3: 1911. 1806.

Ramalina denticulata (Eschw.) Nyl. Bull. Soc. Linn. Norm. II: 4: 129. 1870.

On trees, Abaco, New Providence, Eleuthera and Long Island:-widely distributed in the warmer regions of both hemispheres.

4. Ramalina Montágnei DeNot. Giorn. Bot. Ital. 2: 218. 1846.

Ramalina rigida var. Montagnei Tuck. Syn. N. A. Lich. 1: 23. 1882.

On twigs and branches, Great Bahama, New Providence, Cat, Watling's, and Acklin Islands :-southern United States; Cuba; Jamaica; Porto Rico. 


\section{2. ÚSNEA Adans.}

1. Usnea flòrida (L.) Web. var. strigòsa Ach. Meth. Lich. 310. 1803.

On trees, Crooked Island, at Stopper Island :-cosmopolitan.

\section{Family 15. CALOPLACÀCEAE.}

Thalline exciple never present.

Thalline exciple present, or sometimes disappearing in old apothecia. 2 . Baloplaca.

\section{BLASTÈNIA Mass.}

Disk of apothecia orange or rusty.

Disk of apothecla dark brown to black.

1. B. ferruginea.

2. B. floridana.

1. Blastenia ferruginea (Huds.) Koerb. Syst. Lich. Germ. 184. 1855.

Lichen ferrugineus Huds. Fl. Ang. 444. 1762.

On bark, New Providence:-cosmopolitan.

2. Blastenia floridàna (Tuck.) Zahlbr. in Engler \& Prantl, Nat. Pflanzenfam. $1^{1 *}$ : 227. 1907 .

Lecanora floridana Tuck. Proc. Am. Acad. 5: 402. 1862.

Placodium floridanum Tuck. Syn. N. A. Lich. 1: 179. 1882.

On bark, New Providence:-widely distributed in tropical America.

\section{CALOPLÀCA Th. Fr.}

Thallus conspicuously white-powdery.

Thallus not at all white-powdery.

Thallus on bark, copiously isidiose.

Thallus on rocks, without isidia.

Apothecia superficial on convex, thick, thalline areoles.

Apothecia immersed in flat, thin, thalline areoles.
1. C. galactophylla.

2a. C. aurantiaca var. isidiosella.

2b. C. aurantiaca var. erythrella. 2c. C. aurantiaca var. diffracta.

1. Caloplaca galactophýlla (Tuck.) Riddle.

Placodium galactophyllum Tuck. Proc. Amer. Acad. 12: 171. 1877.

On limestone, New Providence:-Kansas.

2. Caloplaca aurantiaca (Lightf.) Th. Fr. Lich. Aret. 116. 1860.

Lichen aurantiacus Lightf. Fl. Scot. 2: 810. 1777.

2a. Caloplaca aurantiaca var. isidiosélla (Crombie) Riddle.

Lecanora aurantiaca var. isidiosella Crombie, Journ. Linn. Soc. 15: 437. 1877.

Lepraria Bassiae Ach. Meth. Lich. 5. 1803.

Placodium aurantiacum subsp. Bassiae Wainio, Journ. Bot. 34: 67. 1896. India.

On bark, New Providence:-Jamalca; St. Thomas; St. Vincent; Guadeloupe;

2b. Caloplaca aurantiaca var. erythrélla (Ach.) Th. Fr. Lich. Scand. 178. 1871.

Lichen erythrellus Ach. Lich. Prodr. Suec. 43. 1798.

On limestone, Eleuthera Island:-probably cosmopolitan. 
2c. Caloplaca aurantiaca var. diffrácta (Mass.) Riddle.

Callopisma aurantiacum var. diffractum Mass. Monog. Lich. Blast. 73. 1853. Italy.

On limestone, New Providence, and Watling's Island, near Cockburn Town :The Bahama material agrees exactly with the specimen in Massalongo Lich. Exsic. Ital. no. 243.

\section{Family 16. BUELLIĀCEAE.}

\section{BUÉruIA DeNot.}

Thallus areolate, even, medulla white.

Thallus yellow with caustic potash.

Apothecia black and nudate.

Apothecla with an aeruginous bloom.

Thallus red with caustic potash.

Thallus verrucose, the verrucae with a dark red medulla.

1. B.parasema.

1a. B. parasema var. aeruginascens.

2. B. conspirans.

3. B.sanguinariella.

1. Buellia parasèma (Ach.) Koerb. Syst. Lich. Germ. '228. 1855.

Lecidea parasema Ach. Meth. Lich. 35. 1803.

Buellia disciformis Auct.

On bark, New Providence :- cosmopolitan.

1a. Buellia parasema var. aerugináscens (Nyl.) Muell. Arg. Flora 68: 530. 1885.

Lecidea disciformis var. aeruginascens Nyl. Bull. Soc. Linn. Norm. II: 2: 52. 1868.

On bark, Ship Channel Cay and Stocking Island, Exuma Chain:-widely distributed in tropical America.

2. Buellia conspìrans (Nyl.) Wainio, Ann. Acad. Sci. Fenn. A: 67: 88. 1915.

Lecidea conspirans Nyl. Flora 51: 345. 1868.

Lecidea subdisciformis Leight. Lich. Fl. Brit. 308. 1871.

Buellia subdisciformis Wainio, Li.ch. Brés. 1: 167. 1890.

On bark, common in many of the islands from New Providence to Long Island :widely distributed in the warmer regions.

3. Buellia sanguinariélla (Nyl.) Wainio, Lich. Brés. 1: 168. 1890.

Lecidea sanguinariella Nyl. Ann. Sci. Nat. V: 7: 328. 1867.

On bark, Crooked Island, at Vauxhall and Jingo Hill :-Cuba; Colombia.

\section{Family 17. PHYSCIÀCEAE.}

Hypothecium brownish-black.

Hypothecium colorless.
1. Pyxine.

2. Physcia.

\section{PYXINE Fr.}

Apothecia lecanorine at least when young.

Apothecia persistently lecanorine.

Apothecia soon becoming lecideine.

Apothecia lecideine from the first.

Medulla white.

Medulla sulphury.

1. P. picta.

2. P. Meissneri.

3. P. Cocoes.

3a. P. Cocoes var. endoxantha.

1. Pyxine pícta (Sw.) Tuck. Proc. Amer. Acad. 4: 398. 1860.

Lichen pictus Sw. Prodr. 146. 1788.

Physcia picta Nyl. Syn. Lich. 1: 430. 1858.

On trees and shrubs, Great Bahama, New Providence, Cat Island, Watling's Island :-widely distributed in warmer regions of both hemispheres. 
2. Pyxine Meíssneri Tuck. Proc. Amer. Acad. 4: 400. 1860.

On bark, New Providence :-tropical America and Africa, and East Indies.

3. Pyxine Còcoes (Sw.) Nyl. Mem. Soc. Sci. Cherb. 5: 108. 1857.

Lichen Cocoes Sw. Prodr. 146. 1788.

Circinaria dissecta F'ée, Essai Crypt. 127, pl. 30, f. 2. 1824.

Pyxine dissecta Wainio, Ann. Acad. Sci. Fenn. A: 67 : 70. 1915.

On bark, New Providence and Watling's Island:-widely distributed in the warmer regions of both hemispheres.

Wainio (l. c.) gives reasons for dropping the name "Cocoes" and adopts Fée's name in its place. His reasons do not seem very convlncing, and as the name "Cocoes" has been in use so long and is so well recognized, it has seemed best to retain it.

3a. Pyxine Cocoes var. endoxántha Muell. Arg. Flora 65: 318. 1882.

On bark, New Providence, Eleuthera, Cat Island:-distribution similar to that of the specles.

\section{PHÝSCIA Ach.}

Thallus gray-brown.

Thallus closely adnate; center areolate.

Thallus merely appressed; center subcontinuous.

Thallus whitish or glaucous.

Rhizoids black and hispid-branched.

Rhizoids white or brown, and simple. Lobes flat.

Lobes $0.4-0.8 \mathrm{~mm}$. broad.

Lobes $1.2-3.0 \mathrm{~mm}$. broad.

Thallus without soredia.

Lobes convex.

sorediat

Thallus without soredia.

Lobes discrete and radiate.

Lobes more or less imbricate and irregular.

Thallus sorediate.

1. P. adglutinata.

2. P. obscura.

3. P. hypoleuca.

4. P. alba.

5. P. dilatata.

6. P. crispa.

7. P. stellaris.

8. P. integrata.

8a. P. integrata var, sorediosa.

1. Physcia adglutinàta (Flke.) Nyl. Syn. Lich. 1: 428.1858.

Lecanora adglutinata Floerke, Deutsch. Lich. 4: 7.- 1815.

On bark, New Providence:-widely distributed in temperate regions.

2. Physcia obscùra (Ehrh.) Nyl. Act. Soc. Linn. Bordeaux 21: 309. 1856.

Lichen obscurus Ehrh. Crypt. no. 177.

On bark, Nẹw Providence :- cosmopolitan.

3. Physcia hypolèuca (Ach.) Tuck. Syn. N. A. Lich. 1: 68. 1882.

Parmelia speciosa var. hypoleuca Ach. Syn. Lich. 211. 1814.

On twigs, New Providence, on Soldier's Road:-widely distributed.

4. Physcia álba (Fée) Muell. Arg. Rev. Mycol. 9: 136.1887.

Parmelia alba Fée, Essai Crypt. 125, pl. 30, f. 4. 1824.

On bark, Lignum Vitae Cay, Berry Islands and New Providence:-widely distributed in tropical America.

5. Physcia dilatàta Nyl. Syn. Lich. 1: 423. 1858.

On dead wood, and on living shrubs, New Providence, at the Race Course and Cat Island, vicinity of Port Howe :-Mexico; Colombia ; Abyssinia.

This species is probably more widely distributed than the stations cited would Indicate, but does not seem to have been recognized. According to original specimens in the Museum d'Histoire Naturelle at Paris, $P$. dilatata has exactly the lobing and texture of the common Physcia crispa, but without the soredia of that species. From $P$. integrata, it differs in flatter lobes and in being membranaceous rather than cartilaginous. 
6. Physcia críspa (Pers.) Nyl. Syn. Lich. 1: 423. 1858.

Parmelia crispa Pers. in Gaudich. Voy. Uran. 196. 1826.

Common on trees, from Great Bahama to Cat Island:- widely distributed in the warmer regions of both hemispheres.

7. Physcia stellàris (L.) Nyl. Syn. Lich. 1: 424. 1858.

Lichen stellaris L. Sp. Plant. 1144. 1753. politan.

On trees, Berry Islands, New Providence, Cat, and Watling's Islands :-cosmo-

8. Physcia integràta Nyl. Syn. Lich. 1: 424. 1858.

On trees, Harbor Island, Eleuthera, Cat Island, at Port Howe, and Watling's Island, near Cockburn Town:- tropical America.

8a. Physcia integrata var. sorediòsa Wainio, Lich. Brés. 1: 142. 1890.

On Cocolobis, Lignum Vitae Cay, Berry Islands:-with the species.

\section{Class 2. ALGAE.}

Contributed by Marshall A. Howe.

\section{SUB-CLASS RHODOPHYCEAE.}

Family 1. BANGIÀCEAE.

1. BÁNGIA Lyngb.; Hornem. Fl. Dan. 927 : 8. 1818; Lyngb. Hydroph.

Dan. 82. 1819.

? Diadenus Pal. de Beauv.; Desv. Jour. de Bot. 1: 124. 1808.

1. Bangia lùtea J. Ag. Alg. Med. et Adriat. 14. 1842.

Bangia pallida Kütz. Phyc. Gen. 250. 1843.

Bangia bidentata Kütz. Phye. Germ. 195. 1845.

Bangia pallescens Kütz. Sp. Alg. 260. 1849.

In its short broad cells, the Bahamian plant resembles Kützing's fig. $c$ (Tab. Phyc. 3: pl. $28 \mathrm{IV}$ ) of his Bangia bidentata. It appears to be more rosaceous and less luteous than old specimens from the Mediterranean, but otherwise not essentially different.

On rocks between the tide-lines, Silver Cay (New Providence) :-reported from Guadeloupe; Mediterranean and Adriatic seas. Type from Italy.

2. ERYTHROTRÍCHIA Aresch.; Summ. Veg. Scand. 132. 1846.

1. Erythrotrichia cárnea (Dillw.) J. Ag. Till Alg. Syst. 3: 15. 1883.

Conferva carnea Dillw. Brit. Conferv. pl. 84. 1807.

Conferva ceramicola Lyngb. Hydroph. Dan. 144. pl. 48D. 1819.

Erythrotrichia ceramicola Aresch.; Phyc. Scand. Mar. 210. 1850.

On Sargassum, etc., probably common, Berry Islands:-widely distributed in temperate and tropical seas. Type from Wales.

\section{GONIÓTRICHUM Kütz. Linnaea 17: 89. 1843; Phyc.} Gen. 244. 1843.

1. Goniotrichum Alsidii (Zanard.) M. A. Howe, Mem. Torrey Club 15: 75. 1914. Bangia Alsidii Zanard. Bibl. Ital. 96: 136. 1839; Syn. Alg. Mar. Adriat. 115. pl. 6. f. \%. 1841.

Bangia elegans Chauv. Mém. Soc. Linn. Norm. 6: 13 (nomen nudum). 1838. Goniotrichum elegans Zanard. Not. Cell. Mar. 69. 1847.

On Spermothamnion speluncarum and Wrangelia penicillata, Mariguana :-wideiy distributed in temperate and tropical seas. Type from 'Trleste. 


\title{
4. ASTEROCỲTIS Gobi, Trud. St. Peterb. Obsht. Yest. 10:
}

\author{
85. 1879. [Not seen.]
}

\section{Asterocytis ramòsa (Thwaites) Gobi, loc. cit.}

Filaments $0.5-1 \mathrm{~mm}$. long, mostly $13-28 \mu$ in diameter, sparingly dichotomous; vegetative cells (protoplasts) 5-10 $\mu$ long, 1-2 times as long as broad, chromatophore vaguely stellate or indeterminate; eysts (akinetes \&) subglobose, ovoid, or ellipsoid, uniseriate or rarely in a double series, $13-19 \mu$ in longest diameter (including walls), their walls $2-5 \mu$ thick. The monospores or akinetes of the Bahamian specimens resemble in form those shown by Wille in his $f .10$ (Nyt. Mag. Naturvidensk. 38: pl. 1. 1900).

On the older parts of Polysiphonia hapalacantha, Great Exuma :-apparently of wide distribution; American Virgin Islands. Type from England.

\section{Family 2. NEMALIONĀCEAE.}

1. IIAGÒRA Lamour. Nouv. Bull. Sci. Soc. Phil. 3: 185. 1812.

Branching dominantly dichotomous (dichotomy sometimes obscured by prollferations, especially in Nos. 1 and 3 ) ; dioicous.

Assimilatory filaments cylindric, 13-21 $\mu$ in diameter in distal parts, projecting beyond the calcification and forming a more or less conspicuous rufous or fulvous superficial nap; antheridia in isolated compact, conicovoid, subglobose, or hemispheric tufts $40-65 \mu$ broad.

Assimilatory flaments more or less monillate, $3-13 \mu$ in diameter in distal parts, a superficial nap wanting or inconspicuous; antherldia in rather loose flabellate or funnelshaped clusters $10-20 \mu$ wide, commonly forming an apparently confluent and continuous peripheral stratum.

Surface of thallus in dried state smooth and compact or minutely pitted; cystocarp with a rather inconspicuous and poorly defined involucre.

Surface of thallus in dried state alveolate, farinaceous, or pulverulent; cystocarp with a sharply defined basal involucre of long ascending or partly encircling filaments. Branching dominantly monopodial.*

Monoicous.

Calcification axial, the distal ends of the assimilatory filaments free; antheridia in compact tufts $25-40 \mu$ broad, on penultimate or antepenultimate segments ; cystocarp with an involucre of ascending filaments.

Calclfication chiefly and primarily extra-peripheral ; antheridia in small tufts, mostly $13-20 \mu$ broad, on ultimate and penultimate segments ; involucre of cystocarp represented by a few pendent or appressed-decurrent rhizoidal filaments or wanting.

Dioicous; calcification usually light, chiefly axial ; plant very flaccld and mucous; assimilatory filaments usually beautlfully moniliform; cystocarp with an inconspicuous involucre of ascending flaments.

1. L. farinosa.

2. L. valida.

3. L. ceranoides.

4. L. pinnata.

5. L. pedicellata.

6. L. mucosa.

1. Liagora farinòsa Lamour. Hist. Polyp. 240. 1816.

Liagora elongata Zanard. Flora 34: 35. 1851.

Liagora Cheyneana Harv. Trans. Roy. Irish Acad. 22: 552.1855.

Liagora lurida Dickie, Jour. Linn. Soc. Bot. 14: 195. 1874.

Liagora crassa Dickie, loc. cit.

Liagora cayohuesonica Melvill, Jour. Bot. 13: 262. 1875.

Liagora farionicolor Melvill, loc. cit. 263.

Liagora corymbosa J. Ag. p. p. max., Anal. Alg. Cont. 3: 104. 1896.

Extremely variable in size and in habit of branching, but constant in the large compact capitate tufts of antheridia, dioicously disposed, in the protrusion

* Occasional conditions of $L$. farinosa may be sought here. $L$. decussata Mont., not yet reported from the Bahamas, has its branches commonly denudate at base and thus apparently stipitate or articulate, which is not true of the other West Indian members of the monopodial group. It differs also in being more compactly calcified, less mucous, and less adherent to paper when dried. 
of the stout eylindric assimilatory filaments beyond the axial calcification and in the characters of the cystocarp. Monosporangium-bearing discs, looking like epi-endophytes, but probably arising from gemmae of the Liagora, occur, especially on antheridial plants.

On rocks and stones from low-water mark down to a depth of at least two meters, New Providence, Great Bahama, Gun Cay, South Cat Cay, Berry Islands, Exuma Chain, Mariguana, and Little Inagua :-Bermuda; Florida; Cuba ; Jamaica; St. Croix; Barbados; of wide distribution in tropical and subtropical seas. Type from the Red Sea, near Suez.

2. Liagora válida Harv. Ner. Bor.-Am. 2: 138. pl. 31A. 1853.

Liagora annulata J. Ag. (in part, at least) Sp. Alg. 3: 518. 1876.

Liagora tenuis J. Ag. p. p. max., Anal. Alg. Cont. 3: 101. 1896.

Liagora rosacea Zeh, Notizbl. Königl. Bot. Gart. Berlin 5: 271. 1912.

Extremely variable in size and habit, in the amount of calcification, in presence or absence of annulations, in the compactness of the cortex, in the subparallel or subumbellate disposition of the distal branches of the assimilatory filaments, and in the form and size of the peripheral cells, yet specific segregations seem to the writer to be impracticable. Plants growing on surf-beaten rocks between the tide-lines form rigid brittle closely adherent cushions suggesting fruticulose Lithothamnieae or species of the lichen genus Cladonia; those growing below the low-water line or in less agitated water are longer, laxer, less heavily calcified, and more flexible. In intermediate positions, forms of intermediate habit occur. Certain conditions of the species appear to be close to Liagora fragilis (Forsk. ?) Zanard. and L. rugosa Zanard., from the Red Sea, with which they may need further comparisons.

On rocks from near the high-water mark, in exposed positions, down to a depth of at least one meter (low-tide), New Providence, Great Bahama, Berry Islands, North Cat Cay, South Cat Cay, Gun Cay, Andros, Orange Cay, Exuma Chain, Eleuthera, Watling's Island, Mariguana, and Calcos Islands:-Bermuda; Florida; Cuba ; Jamaica ; Porto Rico; St. Crolx; and Barbados. Type from Sand Key, near Key West, Florida.

3. Liagora ceranoìdes Lamour. Hist. Polyp. 239. 1816.

Liagora pulverulenta Ag. Sp. Alg. 1: 396. 1822.

Liagora leprosa J. Ag. Öfv. Kongl. Vet.-Akad. Förh. 4: 8. 1847.

Liagora opposita J. Ag. Anal. Alg. Cont. 3: 101. 1896.

Liagora Pilgeriana Zeh, Notizbl. Königl. Bot. Gart. Berlin 5: 272.1912.

This species, also, as here conceived, shows great variation in size and habit, in the amount of calcification, and in the presence or absence of lateral proliferations, yet is fairly constant in the alveolate or farinaceous-pulverulent character of the surface of the dried plant, in the small subglobose or ovoid ultimate or penultimate cells of the assimilatory filaments, in the compact, many-filamented, small-spored cystocarp, and in the highly developed cystocarpic involucre of numerous long ascending or partly encircling filaments. Monosporangium-bearing dises, apparently arising from gemmae, are of frequent occurrence on both antheridial and cystocarpic plants.

On rocks, stones, and shells and on other algae from low-water mark down to a depth of two meters or more (taken at a depth of twenty meters by Börgesen in the Amerlcan Virgin Islands), Great Bahama, North Cat Cay, Gun Cay, Berry Islands, Mariguana, Calcos Islands, Little Inagua and Castle Islands:-Bermuda; Florida; Jamaica; Porto Rico; American Virgin Islands; Barbados; Mexico; Brazil ; of wide distribution in troplcal and subtropical seas. Type from St. Thomas, American Virgin Islands.

4. Liagora pinnàta Harv. Ner. Bor.-Am. 2: 138. pl. 31B. 1853.

Liagora paniculata J. Ag. Anal. Cont. 3: 106. 1896.

On rocks, etc., from low-water mark down to a depth of at least two meters, Great Bahama, Berry Islands, and Exuma Chain :-Florida; Jamaica; and St. Croix. Type from Sand Key, near Key West, Florida. 


\section{Liagora pedicellàta M. A. Howe, sp. nov.}

Thallus usually very soft and flaceid, 4-16 $\mathrm{cm}$. long or high, irregularly monopodial, the main divisions paniculate or pyramido-paniculate, each branch surrounded in the living state by a soft mucous sheath about as thick as the whole diameter of the enclosed branch, this sheath showing a floceulent precipitate of microscopic calcareous granules arranged mostly in the walls of irregular alveolae, making surface in dried state minutely alveolate or farinaceousalveolate; branches for the most part progressively shorter, varying from rather sparse to crowded, tapering slightly to obtuse or subacute apex, $1.2-2 \mathrm{~mm}$. broad towards apex, including more or less calcified mucous sheath, $0.45-0.8 \mathrm{~mm}$. without sheath; central axis in basal parts $1.5-2.5 \mathrm{~mm}$. in diameter, more or less calcified and often denudate, in ultimate branches mostly $150-175 \mu$ in diameter, usually readily visible after decalcification, commonly reduced to about four filaments towards apex, the cells subcylindric-ellipsoid or dolioform, 104$340 \mu \times 36-104 \mu$, descending rhizoids $8-13 \mu$ in diameter few in younger parts; fascicles of assimilatory filaments mostly 300-600 $\mu$ long, 4-7 times divided, usually subtrichotomous at one or two of the proximal articulations, otherwise dichotomous, intermingled in older parts with simple or subsimple filaments 8-11 cells long, all filaments submoniliate in distal parts, the distal or subdistal cells mostly obovoid, 15-26 $\mu$ long, 12-16 (20) $\mu$ broad; apical hairs numerous, slender, long and flexuous, often cylindric-capitate, soon gelatinizing, leaving inconspicuous vestigia; monoicots; antheridia in small inconspicuous tufts mostly 13-20 $\mu$ broad, on ultimate and penultimate segments; earpogonial branch straight, 20-25 $\mu$ broad, of 4-6 cells (including the usually long pedicel cell) situated terminally or subterminally on the third or fourth segment of the fascicle; cystocarp compact, subhemispheric, 90-215 $\mu$ broad, peripheral, terminating a rather stout and rigid submonopodial axis or pedicel 300-450 $\mu$ (4-8 cells) long, involucre wanting or represented by a few short appresseddecurrent or pendent rhizoidal filaments; carpospores obovoid, ellipsoid, or pyriform, $23-39 \mu \times 15-21 \mu$.

On more or less exposed rocks, near the low-water mark (also found washed ashore), Cockburn Harbor, South Caicos (Howe 5554-type), Malcolm Road, South Caicos, Atwood Cay, Mariguana, Rose Island, Whale Cay, Great Bahama:-Florida (Boot Key).

Liagora pedicellata is allied to $L$. pinnata Harv., in general habit, but differs constantly in being more flaccid and mucous, in the more external or sheathing (usually lighter) calcification, in the smaller simpler more terminal tufts of antheridia, in the stralghter, more terminal carpogonial branches, in the more peripheral, more obviously pedicelled, more compact and homogeneous, large-spored cystocarps, which are destitute of a proper ascending involucre. In $L$. pedicellata, the calcification is mostly in the external mucous sheath, extending irregularly down among the peripheral flaments in the older parts; the distal ends of the filaments are covered by it with the possible exception of the tips of the hairs in the apical region. In $L$. pinnata the calcification is in among the flaments, the distal ends of most of the filaments, with or without hairs, remaining free or protruding beyond the calcification. The essentially terminal rather than lateral carpogonial branches might be regarded by some as sufficient ground for placing the plant in the genus Trichogloea rather than in Liagora, but in habit and other characters the plant is essentially a Liagora, bearing, in fact, so close a resemblance to $L$. mucosa that a microscopic examination is commonly necessary for their separation.

\section{Liagora mucòsa M. A. Howe, sp. nov.}

Thallus very soft and mucous, lightly and irregularly calcified, 5-20 cm. long or high, irregularly monopodial, the main divisions panieulate or pyramidopaniculate, the calcification beginning near the central axis and often extending into the extra-peripheral mucus as mostly isolated flocculent granules, the surface in dry state pulverulent, farinaceous, or sometimes minutely alveolate; branches for the most part progressively shorter, varying from rather sparse to moderately crowded, tapering slightly to obtuse or subacute apex, $0.32-0.6 \mathrm{~mm}$. broad towards apex (not including hairs); central axis in basal parts $0.7-1.25$ $\mathrm{mm}$. in diameter, lightly calcified, often denudate, in ultimate branches mostly 
45-125 $\mu$ in diameter, readily visible, commonly reduced to three or four rather easily separable filaments towards apex, the cells subcylindric or fusiform, mostly $52-300 \mu \times 11-75 \mu$, descending rhizoids $3-8 \mu$ in diameter few in younger parts; fascicles of assimilatory filaments mostly $150-300 \mu$ long, 3 or 4 times dichotomous, intermingled in older parts with simple or subsimple filaments 8-15 cells long, all beautifully moniliate or submoniliate in distal parts at least, the distal or subdistal cells subglobose or bitruncate-subglobose to ellipsoid or obovoid, 13-24 $\mu$ long, 13-19 $\mu$ broad; apical hairs very numerous, becoming 300-800 $\mu$ long, cylindric-capitate, gelatinizing and leaving inconspicuous vestigia; dioicous; antheridia forming rather compact subglobose or subhemispheric tufts $25-50 \mu$ broad, crowning ultimate and penultimate segments; carpogonial branch slightly curved, 15-28 $\mu$ broad, of four cells (often with conspicuous intercellular spaces), situated latero-terminally on the second or third (rarely first or fourth) segment of the fascicle; cystocarp compact, subhemispheric or subglobose, 100-200 $\mu$ broad, with a few rather inconspicuous ascending involucral filaments; carpospores obovoid to pyriform-clavate, 25$32 \mu \times 14-18 \mu$.

On more or less exposed rocks, at or near the low-water mark (also found washed ashore), Little Inagua (Howe 5717-type), Rose Island, Whale Cay, Great Stirrup Cay, Great Bahama :-Florida (Key West, Mrs. G. A. Hall, Mrs. F. A. Curtiss) ; Barbados (Vlckers, Alg. Barb. 106-a coarse form). Liagora mucosa resembles $L$. pedicellata so much in general habit that a microscopic examination is commonly necessary for their distinction, yet it differs constantly in being dioicous, in the larger tufts of antheridia, in the less distal and more lateral insertion of the more curved carpogonial branch, and in the presence of a proper, even though rather inconspicuous, ascending involucre for the cystocarp. It differs less constantly in the shorter, more moniliform assimilatory filaments and in the more axial, less extra-peripheral calcification.

From Liagora pinnata Harv., the species differs in belng dioicous, in belng less calcified, in its greater mucosity, in its shorter, more moniliform assimllative filaments, etc.

From Liagora megagyna Börg., recently described from St. Crolx, $L$. mucosa differs in being much more flaccid and mucous, in being less calcified, in the long and numerous apical hairs, in the fascicles of the more moniliate assimilatory filaments being about one half as long, in the absence of rhizoldal trichomes on the assimilatory filaments (except for the decurrent rhizoid springing from the basal segment), in the more curved, usually less stout, and more proximally situated carpogonial branches, etc.

\section{Family 3. CHAETANGIÀCEAE.}

1. GALAXAÙrA Lamour. Nouv. Bull. Sci. Soc. Phil. 3: 185. 1812.

Dichotomaria Lamarck, Hist. Nat. Anim. sans Vert. 2: 143. 1816.

BrachYCLAdia Sonder, Linnaea 26: 514. 1853.

ZANARDinia J. Ag. Sp. Alg. 3: 533. 1876.

Thallus terete, villous, hirtous, or pubescent throughout with numerous, crowded mostly free assimilatory filaments. Only tetrasporangia known for reproductive organs; so-called species of this group probably only non-sexual phases of other species of very different habit.

Long and short assimilatory flaments in obvious alternating transverse zones.

Long and short assimilatory filaments intermingled, not obviously zonate.

Thallus coarse, reddish, central axes mostly 1-2 mm. in dlameter; intervals between dichotomies mostly $1-3$ $\mathrm{cm}$; assimilatory filaments often branched, their basal cells commonly amyliferous.

Thallus more slender, fuscous or reddish, axes mostly 0.6-1 $\mathrm{mm}$. in diameter.

Thallus rather divaricately dichotomous, usually fuscous; intervals between dichotomies mostly less than $1 \mathrm{~cm}$.; long assimilatory flaments mostly $0.6-1.5 \mathrm{~mm}$. long.

Thallus rather fastiglately dichotomous, usually reddish; intervals between dichotomles commonly more than $1 \mathrm{~cm}$.; long assimilatory filaments mostly $0.15-0.7 \mathrm{~mm}$. long.

1. G. subverticillata.

2. G. comans.

3. G. lapidescens.

4. G. flagelliformis. 
Thallus with a compact cortex, free assimilatory flaments wholly or mostly wanting.

Thallus terete or nearly so, at least when living.

Thallus continuous or only occasionally and irregularly articulate; only sexual reproduction known.

Thallus slightly or not all annulate, the surface commonly more or less roughened in lower parts by free assimilatory filaments.

Thallus distinctly annulate or transversely rugose, glabrous or nearly so.

Thallus regularly articulate, the surface glabrous and often polished.

Main segments terete, 1-2 mm. broad; superficial cells $7-27 \mu$ broad, mostly with intercellular spaces, rather easily separating on decalcification: only sexual reproduction known.

Main segments often somewhat flattened, $1.5-4 \mathrm{~mm}$. broad; superficial cells $24-40 \mu$ broad, mostly without intercellular spaces, closely coherent after decalcification; sexual and tetrasporic plants differing in structure of cortex.

Thallus distinctly flattened when living, commonly canaliculate on drying; sexual and tetrasporic plants differing in structure of cortex.

5. G. squalida.

6. G. rugosa.

7. G. oblongata.

8. G. obtusata.

9. G. marginata.

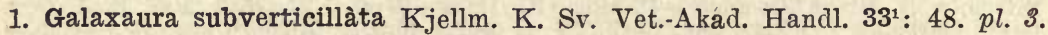
f. 12-14; pl. 20. f. 1\%. 1900.

On rocks at low-water mark or in shallow water, probably the tetrasporic phase of G. rugosa, New Providence, Berry Islands, Gun Cay, North Cat Cay, Salt Cay Bank, Mariguana, and Caicos Islands :-Bermuda ; Florida; Cuba ; Jamaica ; Porto Rico; and American Virgin Islands. Type from St. Croix.

2. Galaxaura còmans Kjellm. K. Sv. Vet.-Akad. Handl. 33²: 44. pl. 2. f. 10-18; pl. 20. f. 13. 1900.

From low-water mark down to 8 meters (fide Börgesen), perhaps the tetrasporic phase of $G$. oblongata, Great Bahama, Berry Islands, and Exuma Chain:-Cuba ; Jamaica; Porto Rico; American Virgin Islands ; and Guadeloupe. 'Type from Guadeloupe.

3. Galaxaura lapidéscens (Ell. \& Sol.) Lamour. Hist. Polyp. 264. 1816.

Corallina lapidescens Ell. \& Sol. Nat. Hist. Zooph. 112. pl. 21. f. g. 1786.

Perhaps the tetrasporic phase of G. cylindrica (not yet reported from the

Bahamas-similar to G. oblongata, but more slender).

On rocks from low-water mark down to 12 meters (fide Börgesen), Eleuthera :Cuba; Jamaica; Porto Rico; and American Virgin Islands. Type locality unknown.

4. Galaxaura flagellifórmis Kjellm. K. Sv. Vet.-Akad. Handl. $33^{1}$ : 47. pl. 3. $f$. 2-11; pl. 20. f. 16.1900.

Probably the tetrasporic phase of $G$. squalida.

On exposed rocks at low-water mark or in shallow water, New Providence, Berry Islands, Great Bahama, North Cat Cay, Caicos Islands, and Great Ragged Islands :Bermuda; Florida; Cuba; Porto Rico; and American Virgin Islands. Type from Key West, Florída.

5. Galaxaura squálida Kjellm. K. Sv. Vet.-Akad. Handl. $33^{1}$ : 55. pl. 6. f. 1-12; pl. 20. f. 9. 1900.

From low-water mark on exposed rocks down to at least $20 \mathrm{~m}$., New Providence, Rose Island, Great Bahama, Watling's Island, Mariguana, Caicos Islands, Castle Island, and Great Ragged Island:-Bermuda; Cuba ; Jamalca ; Porto Rico; American Virgin Islands; and Panama (Colon). Type from St. Crolx.

6. Galaxaura rugòsa (Ell. \& Sol.) Lamour. Hist. Polyp. 263. 1816.

Corallina rugosa Ell. \& Sol. Nat. Hist. Zooph. 115. pl. 22. f. 3. 1786.

On rocks near low-water mark, Great Bahama :-Cuba; Jamaica; Porto Rico; American Virgin Islands; and Barbados. Type from Jamaica. 
7. Galaxaura oblongàta (Ell. \& Sol.) Lamour. Hist. Polyp. 262. 1816.

Corallina oblongata Ell. \& Sol. Nat. Hist. Zooph. 114. pl. 22. f. 1. 1786.

Dichotomaria fragilis Lamarck, Hist. Nat. Anim. sans Vert. 2: 145. 1816.

Galaxaura fragilis Decaisne, Ann. Sci. Nat. Bot. II. 18: 116. 1842.

From low-water mark down to 50 meters, South Bimini and Calcos Islands :Cuba; Jamalca; Porto Rico; American Virgin Islands; Barbados; and Panama (Colon). Type from "West Indian Islands."

8. Galaxaura obtusàta (Ell. \& Sol.) Lamour. Hist. Polyp. 262. 1816.

Corallina obtusata Ell. \& Sol. Nat. Hist. Zooph. 113. pl. 22. f. 2. 1786.

Galaxaura Decaisnei J. Ag: Sp. Alg. 31: 526. 1876.

Galaxaura moniliformis Kjellm. K. Sv. Vet.-Akad. Handl, $3^{1}$ : 83. pl. 1\%. $f$. 15-30; pl. 20. f. 54. 1900.

Mostly in 7-18 meters of water, type attributed to the Bahamas:-Bermuda; Florida; Cuba; Jamaica ; Porto Rico; Barbados; and Brazil.

9. Galaxaura marginàta (Ell. \& Sol.) Lamour. Hist. Polyp. 264. 1816.

Corallina marginata Ell. \& Sol. Nat. Hist. Zooph. 115. pl. 22. f. 6. 1786.

Zanardinia marginata J. Ag. Sp. Alg. $3^{1}$ : 534. 1876.

Brachycladia marginata Schmitz, Flora 47: 438. 1889.

Galaxaura occidentalis Börg. Dansk Bot. Ark. 31: 109. f. 118-123. 1916.

Low-littoral under shelving rocks or in sh́allow water, Berry Islands and Great Bahama :-Bermuda; Florida ; Cuba ; Jamaica ; Porto Rico; American Virgin Islands ; Barbados; and Panama (Colon). Type from the Bahamas.

\section{Family 4. GELIDIĀCEAE.}

1. WRANGÈLIA Ag. Sp. Alg. 2: 136. 1828.

Principal filaments corticated.

Filaments uncorticated or with loose irregular rhizoidal cortications at nodes only.

Plants 1-3 cm. high, purple-red; the conic-acute terminal cells of the ultimate ramull mostly solitary.

Plants 4-10 cm. long or high. usualiy rose-pink; the conlcacuminate or acicular terminal cells of the ultimate ramuli mostly geminate.

1. W. penicillata.

2. W. Argus.

3. W. bicuspidata.

1. Wrangelia penicillàta (Ag.) Ag. Sp. Alg. 2: 138. 1828.

Griffitsia penicillata Ag. Syst. Alg. 143. 1824.

Variable in size, color, and habit of branching; often blackening with age or on drying. On rocks and on other algae from between the tide-lines in sprayed or surfbeaten locations down to a depth of 30 meters (fide Börgesen), New Providence, Great Bahama, North Cat Cay, Berry Islands, Exuma Chain, Watling's Island, Mariguana, and Caicos Islands:- of wide distribution in the West Indies and in the warmer seas. Type from Italy."

2. Wrangelia Árgus (Mont.) Mont. Syll. 444. 1856.

Griffithsia Argus Mont. in Webb. \& Berth. Phyt. Canar. Pl. Cell. 176. pl. 8. f. 4. 1840.

Wrangelia plebeja J. Ag. Sp. Alg. 2: 7.07. 1852.

Forming low compact cushions on rocks and algae near the low-water mark, Great Bahama, South Bimini, and the Calcos Islands;-Mexico; Florida; Porto Rico; American Virgin Islands; Barbados; and Canary Islands. Type from the Canary Islands.

3. Wrangelia bicuspidàta Börg. Dansk Bot. Ark. 31: 118. f. 127-130. 1916.

On roots of Rhizophora and on various algae and Gorgoniaceae, from low-water mark down to 30-40 meters (flde Börgesen), often abundant, Rose Island, Berry Islands, Great Bahama, Exuma Chain, Watling's Island, Atwood Cay, Caicos Islands, and Great Ragged Island:-American Virgin Islands. Type from Ámerican Virgin Islands. 


\section{GRALLATÒRIA M. A. Howe, gen. nov.}

Thallus filiform, monosiphonous, the primary filaments dorso-ventrally organized, repent, uncorticated, the ramuli ("short branches") lateral and dorsal in origin, in threes or falsely fives and semi-verticillate, or in opposite pairs; opposite lateral ramuli commonly each forking in its basal cell, the two members simple or subsimple, few-celled, one of each pair ascending, the other deflexed and terminating in stelliform or avipedate haptera, giving the primary filaments the appearance of walking on stilts; dorsal ramuli comparatively stout, erect, repeatedly ramified, the branching somewhat secundly subdichotomous or occasionally subtrichotomous. Chromatophore in the younger cells an irregular subspiral band, in the older apparently consisting of numerous minute, more or less confluent granules. Sporangia on ramelli of the dorsal ramuli, usually tetrahedrally divided (tripartite). Other parts unknown.

\section{Grallatoria réptans M. A. Howe, sp. nov.}

Repent primary filaments simple or sparingly dichotomous, sinuous, 38-66 $\mu$ in diameter, their cells 1.5-2 times as long as broad, often bulging slightly above the septum, their walls 5-13 $\mu$ thick; opposite lateral ramuli from nearly every segment of the primary filament, the ascending prong simple, $200-400 \mu$ (4-8 cells) long, tapering, about $20 \mu$ in diameter near base, about $8 \mu$ at apex, the deflexed stilt-like prong simple or once furcate, mostly $150-450 \mu$ (4-6 cells) long, slightly tapering, $20-26 \mu$ in diameter; dorsal erect ramuli $1-4 \mathrm{~mm}$. high, springing usually from every second segment of the primary filament, their main axes $34-46 \mu$ in diameter near base, the basal cell 1.5-2 times as long as broad, the succeeding cells mostly 3-6 times as long as broad, the penicillate, or dimidiosubfastigiate terminal divisions subsecund along the inner (anterior) faces of the divisions; tetrasporangia obovoid or pyriform, solitary, or in twos or rarely threes, 52-64 $\times 40-50 \mu$ (including wall, which is 6-8 $\mu$ thick), tripartite or sometimes irregularly divided, mastly on one-celled pedicels; ovoid, globose or pyriform densely granular cysts $60-150 \mu$ in diameter occasional, especially near the distal ends of the deflexed gralliform filaments; color of plants vinaceous-purple to dark vinaceous-brown (near the color of Wrangelia Argus).

Forming a soft purple or reddish-brown lubricous velutinous coating in crevices of surf-beaten rocks near the low-water mark, covering small shells, crustaceous or prostrate algae, etc. In size and habit, the plant bears some superficial resemblance to specles of Acrochaetium or to Rhodochorton Rothii, but its affinlties are apparently with Wrangelia, from which, however, it amply differs in the characters indicated.

Great Ragged Island (Howe 578\%-type-and 5766).

\section{GELIDIUM Lamour. Essai, 40. 1813.}

1. Gelidium rígidum (Vahl) Grev. Alg. Brit. lvii. 1830.

Fucus rigidus Vahl, Nat. Selsk. Skr. 5²: 46. 1802.

Ahnfeltia (?) pinnatula Harv. Ner. Bor.-Am. 2: 169. 1853.

Echinocaulon rigidum Kütz. Tab. Phyc. 18: 14. pl. 40. f. a-d. 1868.

Gelidiopsis rigida Web.-v. Bosse, Rec. Trav. Bot. Néer. 1: 104. 1904.

Not uncommon in tide-pools and in shallow water, North Cat Cay, South Cat Cay, Watling's Island, Mariguana, Caicos Islands, Great Ragged Island, and Salt Cay Bank :-Bermuda; Florida; and the West Indies in general. Type from St. Croix. 


\section{Family 5. GIGARTINÀCEAE.}

1. KALIYMÈnIA J. Ag. Alg. Med. et Adriat. 98. 1842.

1. Kallymenia Limmínghii Mont. Ann. Sci. Nat. Bot. IV. 14: 173. 1860. [As Callymenia Limminghii.]

Plants suborbicular or reniform, 5-8 mm. broad, dark red, short-stipitate, sterile. Possibly a young or dwarf condition of $K$. reniformis (Turn.) J. Ag., but probably distinct.

Low-littoral, on a rock shelf in a cavern, Malcolm Road, Caicos Islands :-Guadeloupe. Type from Guadeloupe.

\section{Family 6. RHODOPHYLLIDĀCEAE.}

\section{CAtenélla Grev. Alg. Brit. Ixiii. 1830.}

1. Catenella Opúntia (Good. \& Woodw.) Grev. loc. cit.

Fucus Opuntia Good. \& Woodw. Trans. Linn. Soc. 3: 219.1797.

Catenella pinnata Harv. Ner. Bor.-Am. 2: 201. pl. $29 B .1853$.

Catenella Opuntia pinnata J. Ag. Sp. Alg. $3^{1}$ : 588. 1876.

On roots and trunks of Rhizophora, etc., littoral, Berry Islands, Great Bahama, Bimini, Conception Isiand, Watling's Island, and Great Ragged Island:-Bermuda; Florida; Jamaica ; and the West Indies in general. Type from Wales.

\section{AGARDHIÉLLA Schmitz, Flora 72: 441. 1889.}

1. Agardhiella ténera (J. Ag.) Schmitz, loc. cit.

Gigartina tenera J. Ag. Linnaea 15: 18. 1841.

Sphaerococcus tener Kütz. Sp. Alg. 777. 1849.

Rhabdonia tenera J. Ag. Sp. Alg. 2: 354. 1852.

Solieria chordalis Harv. Ner. Bor.-Am. 2: 121. pl. 23A. 1853. Not J. Ag. 1842.

Rhabdonia Baileyi Harv.; Kütz. Tab. Phyc. 16: 26. pl. 74. f. c, d. 1866. Sphaerococcus tenuis Kütz. Tab. Phyc. 18: 27. pl. 75. f. d, e. 1868. [According to type in herb. Kütz.]

In shallow water. The type of Sphaerococcus tenuis Kütz. is said to have come from " archipelago Bahamensi." The species is otherwise unknown from the Bahamas and is apparently uncommon there, at least in winter and spring when most of the collections of algae have been made, though it doubtless occurs:-Massachusetts to Florida and the West Indies; California; Peru. Type locality indefinite (southern shores of North America and the West Indian islands).

3. MERISTOTHÈCA J. Ag. Bidr. Act. Univ. Lund. $8^{8}: 36.1872$.

1. Meristotheca Duchassaíngii J. Ag. loc. cit. 37 .

On rocks, near low-water mark, Gun Cay:-Bermuda and North Carolina to Barbados. Type from Guadeloupe.

4. EUCHEÙMA J. Ag. Ofø. K. Vet.-Akad. Förh. 4: 16.1847.

1. Eucheuma isifórme (Ag.) J. Ag. loc. cit.

Sphaerococcus isiformis Ag. Sp. Alg. 1: 271. 1822.

Gigartina isiformis Kütz. Tab. Phyc. 18: 3. pl. \%. f. c, d. 1868.

Near low-water mark, especially under shelving rocks and among Rhizophora roots, Exuma Chain:-Bermuda; Florida; and the West Indies in general. Type from the West Indies. 
5. WURDEMÁNNIA Harv. Ner. Bor.-Am. 2: 245.1853.

1. Wurdemannia setàcea Harv. loc. cit. 246.

On rocks among other algae and on sea-rods, sea-fans, etc., from low-water mark down to at least 20 meters, common, Joulter's Cay, Berry Islands, Great Bahama, South Cat Cay, Exuma Chain, Atwood Cay, and Caicos Islands:-Bermuda; Florida; and Cuba. Type from Key West, Florida.

\section{Family 7. SPHAEROCOCCÀCEAE.}

1. GRACILÀrIA Grev. p. p. Alg. Brit. liv, 121. 1830.

Ceramiantemum Donati, Auszug Natur-Geschichte Adriat. Meers 26. 1753. Ceramion Adans. Fam. Pl. 2: 13. 1763.

\& Plocaria Nees, Hor. Phys. Berol. 42. 1820.

Thallus plane or distinctly compressed, di-polychotomous or more or less pinnate.

Membranaceous when dry; main axes or segments mostly $0.3-1 \mathrm{~mm}$. thick.

Thallus dichotomo-palmatifid, marginal branches or. proliferations usually wanting or few.

Thallus with main divisions subdichotomous, these pinnately decompound or repeatedly dichotomo-pinnatisect.

Hard and corneous when dry, cartilaginous when living, mostly

2-7 $\mathrm{mm}$. thick, prostrate or repent, often concrescent or anastomosing, branches irregular, mostly distichous and deflexed, often short and verrucaeform, sometimes subterete, digitiform or hapteroid.

1. G. Iacinulata.

2. G. cervicornis.

llus terete or nearly so, corneous when dry.

Thallus rather closely and somewhat divaricately subdichotomous, the uitimate divisions short, often incurved, cervicorn.

Thallus rather distantiy and somewhat fastigiately subdichotomous, the ultimate divisions not cervicorn.

3. G. crassissima.

4. G. damaecornis.

5. G. cornea.

1. Gracilaria lacinulàta (Vahl) M. A. Howe, comb. nov.

$\checkmark$ Fucus lacinulatus Vahl, Nat. Selsk. Skr. $5^{2}: 39.1802$.

Fucus multipartitus Clem. Ensayo 311. 1807.

Chondrus agathoicus Lamour. Essai 39. pl. 9. f. 3, 4, 5. 1813.

Fucus aeruginosus Turn. Hist. Fuc. 3: 29. pl. 14\%. 1811.

Chondrus aeruginosus Lamour. Essai 40. 1813.

Sphaerococcus polycarpus Grev. Scot. Crypt. Fl. 6: pl. 352. 1828.

Gracilaria multipartita Harv. Phyc. Brit. pl. 15. 1846.

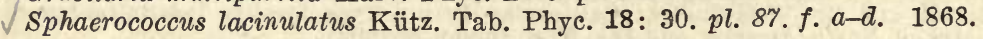

In shallow water, Berry Islands :-Massachusetts to Bermuda; Florida; Mexico; and throughout the West Indies; Europe. Type from St. Croix,

2. Gracilaria cervicórnis (Turn.) J. Ag. Sp. Alg. 2: 604. 1852.

Fucus cervicornis Turn. Hist. Fuc. 2: 132. pl. 121. 1809.

Sphaerococcus domingensis (Sond.) Kütz. Tab. Phyc. 12: 8. pl. 22. f. $a, b$. 1869.

In shallow water, New Providence and Caicos Islands :-Florida to Brazil. Type from Jamaica.

3. Gracilaria crassíssima Crouan; J. Ag. Sp. Alg. 34: 78. 1901.

? Gracilaria horizontalis Collins \& Hervey, Proc. Am. Acad. 53: 111.1918.

Forming prostrate, crust-like, intertangled masses in shallow water, Berry Islands, North Cat Cay, South Cat Cay, and Mariguana:-Bermuda (?) ; Porto Rico; and Guadeloupe. Type from Guadeloupe. 
4. Gracilaria damaecórnis J. Ag. Sp. Alg. 2: 597. 1852.

In tide-pools and in shallow water, North Cat Cay and Caicos Islands :-Bermuda; Florida; and the West Indies generally. Type probably from St. Croix.

5. Gracilaria/córnea J. Ag. Sp. Alg. 2: 598. 1852.

In shallow water, Caicos Islands:-Florida; Porto Rico. Type from Pernambuco (?).

\section{HYPNÈA Lamour. Essai, 43. 1813.}

HyPNOPHYCUS Kütz. Linnaea 17: 102. 1843.

1. Hypnea muscifórmis (Wulf.) Lamour. loc. cit.

Fucus musciformis Wulf. in Jacq. Collect. 3: 154. pl. 14. f. 3. 1789.

Hypnophycus musciformis Kütz. loc. cit.

Common in shallow water, extremely variable, Berry Islands, Great Bahama, Bimini, Gun Cay, Exuma Chain, Watling's Island, Atwood Cay, Mariguana, Caicos Islands, and Great Ragged Island:-Massachusetts to Bermuda and Florida and throughout the West Indies; widely distributed in temperate and tropical seas. Type from Trieste.

\section{Family 8. RHODYMENIÀCEAE.}

\section{CORDYIECLÁdIA J. Ag. Sp. Alg. 2: 702. 1852.}

1. Cordylecladia irregulàris Harv. Ner. Bor.-Am. 2: 156.1853.

Chylocladia rigens J. Ag. p. p. Sp. Alg. 2: 362. 1852. Not Sphaerococcus rigens Ag. Sp. Alg. 1: 332. 1822.

Cordylecladia rigens Collins \& Hervey p. p.; C., H., \& S., Phyc. Bor.-Am. 2186. 1917.

In tide-poois and on rocks in shallow water, more or less steel-blue and iridescent when living, Berry Isiands, Bimini, Eleuthera, Exuma Chain, Watling's Island, Atwood Cay, Mariguana, and Great Ragged Island:-Bermuda; Florida; Cuba; Jamaica ; and Porto Rico. Type from Key West, Florida.

2. CHRYSYMÈNIA J. Ag. Alg. Med. et Adriat. 105. 1842.

1. Chrysymenia uvària (L.) J. Ag. loc. cit. 106.

Fucus uvarius ["ovarius"] L. p. p., Syst. Nat. 2: 714. 1767 [ed. 12].

Fucus botryoides Wulf. in Jacq. Collect. 3: 146. pl. 13. f. 1. 1789.

In deep water or under sheiving rocks in shallow water, South Caicos:-Bermuda; North Carolina; Florida; Porto Rico; American Virgin Islands; Barbados ; Brazil; Canary Isiands; Mediterranean and Adriatic seas.

3. CHÁMPIA Desv. Jour. de Bot. Desv. 1: 245. 1808.

Mertensia Thunb.; Roth, Neues Jour. Bot. Schrad. 21: 11. 1806. Not Mertensia Roth, Cat. Bot. 1: 34. 17.97.

Mature segments mostiy $0.3-0.9 \mathrm{~mm}$. broad. Mature segments mostly $1-2 \mathrm{~mm}$. broad.

C. parvula.

C. salicornioides.

1. Champia párvula (Ag.) Harv. Ner. Bor.-Am. 2: 76.1853.

Chondria parvula Ag. Syst. 207. 1824.

On other algae, Thalassia, etc., from low-water mark down to 20 fathoms ( $f$ de Börgesen), Great Bahama, Exuma Chain, Great Ragged Isiand, and Caicos Islands : -Massachusetts to Bermuda ; Florida ; and the West Indies generally ; Europe. Type
from Cadiz, Spain. 
2. Champia salicornioìdes Harv. Ner. Bor.-Am. 2: 76. pl. 19B. 1853.

On other algae, stones, etc., from low-water mark down to 15 fathoms (fide Börgesen), Great Bahama and Caicos Islands :-Florida; American Virgin Islands, etc. Type from Key West, Florida.

\section{Family 9. DELESSERIÀCEAE.}

\section{HYPOGLósSUM Kütz. Linnaea 17: 106. 1843.}

1. Hypoglossum tenuifỏlium (Harv.) J. Ag. Sp. Alg. $3^{3}: 186.1898$.

Delesseria tenuifolia Harv. Ner. Bor.-Am. 2: 97. pl. 22B. 1853.

Under shelving rocks near low-water mark and in deep water, North Cat Cay, Exuma Chain, Caicos Isiands, and Great Ragged Island:- Florida and American Virgin Islands. Type from Key West, Florida.

\section{CALOGLóssA (Harv.) J. Ag. Sp. Alg. $3^{1}: 498.1876$.}

Delesseria, sect. Caloglossa Harv. Ner. Bor.-Am. 2: 98.1853.

1. Caloglossa Leprieùrii (Mont.) J. Ag. loc. cit. 499.

Delesseria Leprieurii Mont. Ann. Sci. Nat. Bot. II. 13: 196. pl. 5. f. 1. 1840. Hypoglossum Leprieurii Kütz. Sp. Alg. 875. 1849.

On roots of Rhizophora, littoral, probably common, Bimini and Berry Islands :West Point, N. Y., and Connectlcut to northern South America. Type from French Guiana.

\section{TAENIÒMA J. Ag. Sp. Alg. 2: 1256. 1863.}

1. Taenioma perpusíllum (J. Ag.) J. Ag. loc. cit. 1257.

Polysiphonia perpusilla J. Ag. Öfv. K. Vet.-Akad. Förh. 4: 16. 1847.

On or with other algae, in shallow water, West Calcos:-Bermuda; Porto Rico; and Mexico. Type from St. Augustin on the Pacific Coast of Mexico.

\section{Family 10. BONNEMAISONIÀCEAE.}

1. ASPARAGóPSIS Mont. in Webb \& Berth. Phytog. Canar. 4: xiv, xv. 1841.

Lictoria J. Ag. Linnaea 15: 23. 1841.

1. Asparagopsis taxifórmis (Del.) Collins \& Hervey, Proc. Am. Acad. 53: 117. 1917.

Fucus taxiformis Del. Descr. Egypte. Hist. Nat. 2: 295. pl. 5\%. f. 2. 1812. Chondria taxiformis Ag. Sp. Alg. 1: 368. 1822.

Dasya Delilei Mont. in Webb \& Berth. Phytog. Canar. 4: 166. pl. 8. f. 6. 1841.

Asparagopsis Delilei Mont. loc. cit. xiv.

Lictoria taxiformis J. Ag. Linnaea 15: 23. 1841.

In shallow water on reefs down to at least 12 fathoms (fide Börgesen), Green Turtle Cay:-Bermuda; Jamalca; American Virgin Islands; Barbados; Canary Isiands; and Mediterranean Sea. Type from near Alexandria, Egypt. 


\section{Family 11. RHODOMELÀCEAE.}

\section{IAURÉNCIA Lamour. Essai 42. 1813.}

Osmundea Stackh. Mém. Soc. Imp. Nat. Moscou 2: 56, 79. 1809.

Not Osmunda L. Sp. Pl. 1063. 1753.

Branchlng chiefly monopodial.

Walls of medullary cells of main axes with numerous refringent often lenticular or reniform thickenings, ${ }^{*}$ visible through the cortex; fronds or perlpheral branches mostly narrowly virgate, with numerous small ultimate ramuli $0.2-0.45 \mathrm{~mm}$. in maximum width.

Walls of medullary cells of main axes without thickenings; ultimate ramuli mostly more than $0.45 \mathrm{~mm}$. broad.

Surface cells of main axes mostly $40-130 \mu$ long in surface view.

Surface smooth or nearly so.

Plants rather soft and flaccid, usually pink, yellowish pink, or green with pink tips; ultimate ramull obovoid to subclavate-cylindric.

Plants erect, panlculate-decompound, with welldefined leading axes.

Plants decumbent or intertangled, without welldefined leading axes, firmer than No. 2 and with more cylindric ultimate ramuli.

Plants rather rigid, purple or greenish purple; ult1mate ramuli mostly peg-shaped or verrucaeform.

Surface cells, in aplcal parts at least, with mammilliform, conlc-mammillate or aculeate papillae.

Surface cells of main axes mostly $20-40 \mu$ long in surface view; plants rigid, green or dark greenish purple, corneous when dry.

Branching chiefly dichotomous, subdichotomous, or corymbose.

Main segments of thallus $0.75-1.2 \mathrm{~mm}$. In diameter; plants mostly 4-12 cm. high; branches free.

Main segments of thallus $0.22-0.45 \mathrm{~mm}$. In diameter; plants mostly $1-2 \mathrm{~cm}$. high ; branches more or less concrescent or coherent.

1. L. microcladia.

2. L. obtusa.

3. L. intricata.

4. L. Poitei.

5. L. gemmifera.

6. L. papillosa.

7. L. Corallopsis.

8. L.nana.

1. Laurencia microclàdia Kütz. Tab. Phyc. 15: 22. pl. 60. f. b, c. 1865.

Laurencia glomerata Suhr; J. Ag. Sp. Alg. 2: 753. 1852. Not L. glomerata Kütz. Sp. Alg. 857. 1849.

Laurencia obtusa gelatinosa Collins \& Hervey, Proc. Am. Acad. 53: 119. 1917. Not L. obtusa gelatinosa J. Ag.

Distinguished from all conditions of $L$. obtusa by its virgate habit, its small ultimate ramuli, and its numerous refringent thickenings of the walls of the medullary cells.

On rocks and on other algae, low littoral down to $1 \mathrm{~m}$. or more, New Providence, Berry Islands, Great Bahama, Wa,tling's Island, Mariguana, and Great Ragged Island: -Bermuda; and northern South America. Type from the West Indies.

2. Laurencia obtùsa (Huds.) Lamour. Essai 42. 1813:

Fucus obtusus Huds. Fl. Angl. 586. 1778.

Laurencia multiflora Kütz. Tab. Phyc. 15: 21. pl. 58. f. a, b. 1865.

Very common on rocks and on other algae, at low-water mark and in shallow water, New Providence, Rose Island, Berry Islands, Great Bahama, North Cat Cay, Exuma Chain, Cat Island, Watling's Island, Atwood Cay, Mariguana, CaIcos Islands, Great Ragged Island, and Orange Cay:-Bermuda; Florida; and the West Indies generally; widely distributed in the warmer seas. Type from southern England. Specimens from Nassau have been reported under name of Laurencia paniculata by F. S., Collins, Mem. Torrey Club 12:14. 1902.

* The thickenings often lose their refringent character in fluid-preserved material. 
3. Laurencia intricàta Lamour. Essai 43. pl. 3. f. 8, 9. 1813. Not L. intricata Kütz. Tab. Phyc. 15: 22. pl. 61. f. $a, b, c .1865$.

Laurencia Chauvini Bory, p. p. max. Dict. Class. Hist. Nat. 9: 239. 1826.

Laurencia implicata J. Ag. Sp. Alg. 2: 745. 1852.

Perhaps only a variety of L. obtusa.

In shallow water, Rose Island, Great Bahama, Bimini, Abaco, Exuma Chain, Cat Island, Mariguana, and Great Ragged Island :-Bermuda ; Florida ; Cuba ; and American Virgin Islands. Type from Antilles.

4. Laurencia Poitei (Lamour.) M. A. Howe; Collins \& Hervey, Proc. Am. Acad. 53: 118. 1917.

Fucus Poitei Lamour. Diss. 63. pl. 31. f. 2, 3. 1805.

Laurencia tuberculosa J. Ag. Sp. Alg. 2: 760. 1852.

Laurencia mexicana Kütz. Tab. Phyc. 15: 25. pl. \%0. f. c, d. 1865.

On rocks, etc., in shallow water, New Providence, Berry Islands, Great Bahama, Abaco, Cat Island, Watling's Island, Caicos Islands, and Great Ragged Island :-Bermuda; North Carolina; Florida; the West Indies generally; Vera Cruz; and northern South America. Type from Santo Domingo.

5. Laurencia gemmífera Harv. Ner. Bor.-Am. 2: 73. pl. 18B. 1853.

Laurencia Chauvini Bory, p. p. min. Dict. Class. Hist. Nat. 9: 239.1826.

Sometimes simulating $L$. Poitei and $L$. papillosa, but apparently quite distinct, differing from both in the papillate epidermal cells (at least in apical parts) and differing from L. papillosa, and, in a less degree, from L. Poitei in the larger epidermal cells.

In shallow water, Berry Islands, Great Bahama, Bimini, Exuma Chain, Cat Island, Watling's Island, Mariguana, and Great Ragged Island :-Bermuda ; Florida ; Cuba; American irgin Islands. Type from Key West, Florida.

6. Laurencia papillòsa (Forsk.) Grev. Alg. Brit. lii. 1830.

Fucus papillosus F'orsk. FI. Aegypt.-Arab. 190. 1775.

Chondria papillosa Ag. Sp. Alg. 1: 344. 1822.

On rocks between the tide-lines and in shallow water, New Providence, Berry Islands, Great Bahama, Gun Cay, Exuma Chain, Watling's Island, Mariguana, Caicos Islands, Great Ragged Island, and Orange Cay :-Bermuda; Florida; Cuba ; Santo Domingo; Porto Rico; American Virgin Islands; Barbados; and northern South America; widely distributed in the warmer seas. Type from the Red Sea.

7. Laurencia Corallópsis (Mont.) M. A. Howe, in Britton, Fl. Bermuda 519. 1918.

Sphaerococcus Corallopsis Mont. in Sagra, Hist. Cuba, Bot. Pl. Cell. 49. 1842 ; in Sagra, Ic. Pl. Fl. Cuba, pl. 3. f. 1. 1863.

Laurencia cervicornis Harv. Ner. Bor.-Am. 2: 73. pl. 18C. 1853.

On rocks in shallow water; reduced abortive forms of what is apparently this species occur also between the tide-lines, New Providence, Berry Islands, Great Bahama, and Mariguana:-Bermuda; Florida; Cuba; American Virgin Islands; and Barbados. Type form near Havana, Cuba.

8. Laurencia nàna M. A. Howe, sp. nov.

Densely cespitose and intricate, rose-red to garnet-brown, mostly 1 to 2 $\mathrm{cm}$. high, fragile, often innovating from broken ends, dichotomous or subdichotomous, the branches more or less concrescent or coherent; main segments $0.15-$ $0.45 \mathrm{~mm}$. in diameter; ultimate branches eylindric or subcylindric, mostly 0.1 $0.35 \mathrm{~mm}$. broad at truncate apex; surface of cortex smooth or lightly crenulatemammillate, showing numerous or occasional rhizoidal haptera, epidermal cells orbicular-hexagonal and mostly $25-45 \mu$ broad in surface view, firm-walled; tetrasporic branches similar to the sterile or slightly enlarged.

On corals, corallines, and sea-fans, near low-water mark, Mariguana (Howe 5393 -type), Shroud's Cay (Exuma Chain), and Great Ragged Island. 
2. CHÓNDRIA Ag. p. p. Syn. Scand. xviii. 1817.

Uarpocaulon Kütz. Phyc. Gen. 436. 1843.

CHONDRIopsis J. Ag. Sp. Alg. 2: 794. 1863.

Aplces of ultimate ramuli acute, with growing points readily visible.

Plants erect, mostly $5-40 \mathrm{~cm}$. high, without rhizolds except at base.

Primary branches more slender than the stout well-defined main axes ; plants large, mostly $15-40 \mathrm{~cm}$. high, yellowish brown when drled.

Primary branches rather similar to the often poorly defined main axes.

Plants blackish purple on drying, rather coarse, branching irregular.

Plants yellowish red or dusky red on drying, more delicate, branching sparsely virgate.

Plants low-cespitose, $2-3 \mathrm{~cm}$. high or subrepent, with numerous multicellular rhizoldal haptera.

Apices of ultimate ramuli obtuse or truncate, with growing point immersed and hidden in an apical pit.

The five perlcentral siphons with conspicuous saucer-shaped, dome-shaped, or cup-shaped thickenings of their anterlor end-walls, forming regular transverse crenate lines bounding the even-ended bundles of siphons and visible through the cortex.

Plants cespitose, the cushions $1-3 \mathrm{~cm}$. high; main axes mostly $0.22-0.35 \mathrm{~mm}$. In diameter; apical tufts of filaments inconspicuous.

Plants solitary or merely gregarious, mostly $3-8 \mathrm{~cm}$. hlgh ; main axes $0.4-0.75 \mathrm{~mm}$. In diameter; apical tufts of trichoblasts conspicuous, often $0.75 \mathrm{~mm}$. or more in length, becoming yellowish brown or fuscous on drying.

Pericentral siphons without conspicuous thickenings of the anterior end-walls (or such thickenings of only irregular and occasional occurrence).

Plants pink, purple, or yellowish red; main axes mostly $0.5-1.5 \mathrm{~mm}$. In diameter; ultimate ramuli mostly $0.35-$ $0.75 \mathrm{~mm}$. in greatest diameter.

Plants usually yellowish brown; main axes mostly 0.22$0.32 \mathrm{~mm}$. in diameter; ultimate ramull mostly $0.1-0.2$ $\mathrm{mm}$. in greatest diameter.

1. C. littoralis.

2. C.atropurpurea.

3. C. tenuissima.

4. C. polyrhiza.

5. C. curvilineata.

6. C. Collinsiana.

7. C. dasyphylla.

8. C. leptacremon.

1. Chondria littoràlis Harv. Ner. Bor.-Am. 2: 23. 1853.

Chondriopsis littoralis J. Ag. Sp. Alg. 2: 795. 1863.

Carpocaulon littorale Kuntze, Rev. Gen. Pl. $3^{2}$ : 399. 1898.

Rather common on moderately exposed shores, near the low-water mark, New Provldence, Berry Islands, Great Bahama, Exuma Chain, Watling's Island, Mariguana, and Caicos Islands :- Florida and the West Indies generally. Type from Key West, Florida.

2. Chondria atropurpùrea Harv. Ner. Bor.-Am. 2: 22. pl. 18E. 1853.

Chondriopsis atropurpurea J. Ag. Sp. Alg. 2: 801. 1863.

Carpocaulon atropurpureum Kuntze, loc. cit.

In shallow water, especially in creeks and lagoons, commonly straw-colored when living, Great Bahama, Great Exuma, Watling's Island, and Great Ragged Island:Bermuda; South Carolina; Florida; and the West Indles generally. Type from Charleston, South Carolina.

3. ? Chondria tenuíssmia (Good. \& Woodw.) Ag. Syn. Alg. Scand. xviii. 1817.

Fucus tenuissimus Good. \& Woodw. Trans. Linn. Soc. 3: 215. pl. 19. 1797.

Carpocaulon tenuissimum Kuntze, loc. cit.

Laurencia Baileyana Mont. Ann. Sci. Nat. Bot. III. 11: 63. 1849.

Two specimens that we refer provisionally to $C$. tenuissima differ considerably from each other and from the English type of the species, in habit, texture, form and size of the cortical cells, etc.

In shallow water, Bimini and Great Bahama:-Massachusetts to Florida and Cuba; Europe. Type from southern England. 
4. Chondria polyrhiza Collins \& Hervey, Proc. Am. Acad. 53: 121. pl. 2. f. 12. 1917.

In shallow water down to 18 meters (fide Collins), Atwood Cay (with C. curvilineata) :-Bermuda and American Virgin Islands. Type from Bermuda.

5. Chondria curvilineàta Collins \& Hervey, Proc. Am. Acad. 53: 120. pl. 2. $f$. 10, 11.1917.

On corals and among other algae, near low-water mark, more or less iridescent when llving, Atwood Cay, Mariguana, and Great Ragged Island:-Bermuda. Type from Bermuda.

\section{Chondria Collinsiàna M. A. Howe, sp. nov.}

Fronds erect, solitary or gregarious, mostly $3-8 \mathrm{~cm}$. high, texture rather soft, color (dried) stramineous to yellowish rose; branching rather sparsely virgate or paniculate-virgate, with well-defined main axes mostly $0.4-0.75 \mathrm{~mm}$. in diameter; pericentral siphons in all parts with conspicuous saucer-shaped, dome-shaped, or cup-shaped thickenings of their anterior end-walls, forming crescentric or crenate lines in regular transverse series, visible through cortex, the longitudinal walls also occasionally showing somewhat similar or more lenticular thickenings; surface cells mostly $65-160 \mu \times 26-40 \mu$ in surface view, 2-5 times as long as wide; ultimate ramuli fusiform-obovoid to cylindric-clavate or cylindric, mostly $0.75-4.5 \mathrm{~mm}$. long, and $0.28-0.45 \mathrm{~mm}$. in greatest diameter, patent or subdivaricate, straight or slightly recurved, solitary and rather widely spaced (0.5-2.5 mm. apart), moderately attenuate or constricted at base, the apex obtuse or subtruncate, crowned with conspicuous tufts of trichoblasts ("leaves") often $0.75 \mathrm{~mm}$. or more in length and becoming yellowish brown or fuscous on drying; the growing point immersed and concealed in an apical pit (sect. Coelochondria); tetrasporangia confined to apical part of ramulus or sometimes occupying the whole of it.

Chondria Collinsiana differs from $C$. curvilineata as indicated in above key and aiso in its yellowlsh or rose rather than purple-red or brownish red color.

On Penicillus, Rhipocephalus, Halimeda, Thalassia, etc., in shallow water, Mariguana (Howe 5386-type), New Providence, Berry Islands, Watling's Island, and Great Bahama.

7. Chondria dasyphýlla (Woodw.) Ag. Syn. Alg. Scand. xviii. 1817.

Fucus dasyphyllus Woodw. Trans. Linn. Soc. 2: 239. pl. 23. f. 1. 1794.

Chondria sedifolia Harv. Ner. Bor.-Am. 2: 19. pl. 18G. 1853.

Chondriopsis dasyphylla J. Ag. Sp. Alg. 2: 809. 1863.

Carpocaulon dasyphyllum Kuntze, loc. cit.

In shallow water, New Providence, Berry Islands, and Great Bahama:-Massachusetts to Bermuda; Florida; and Barbados; southern Europe and the Mediterranean. Type from eastern England.

\section{Chondria leptacrèmon (Melv.) De-Toni, Syll. Alg. 4: 848. 1903.}

Chondriopsis leptacremon Melv. Jour. Bot. 26: 333. pl. 284. f. 2a, 2b. 1888.

In shallow water in Rhizophora associations, Exuma Chain and Watling's Island :-Florida. Type from Key West, Florida.

\section{ACANTHÓPHORA Lamour. Essai 44. 1813.}

Spines not occurring on the main axes; main branches narrowly virgate.

Spines of occasional occurrence on the main axes; branching very irreguiar.

1. A. spicifera.

2. A. muscoides. 
1. Acanthophora spicífera (Vahl) Börg. Bot. Tidsskr. 30: 201. f. 18, 19. 1910.

Fucus spiciferus Vahl, Nat. Selsk. Skr. 5²: 44. 1802.

Fucus acanthophorus Lamour. Diss. 61. pl. 30; pl. 31. f. 1. 1805.

Acanthophora Thierii Lamour. Essai 44. 1813.

Chondria acanthophora Ag. Spec. Alg. 1: 363. 1822.

Acanthophora Antillarum Mont. Kütz. Tab. Phye. 15: 27. pl. 75. f. d-g. 1865.

In shallow water, especially in sheltered bays, New Providence, Rose Island, Bimini, Exuma Chaln, Watling's Island, Mariguana, and Great Ragged Island:Bermuda ; Florida ; to Barbados and Brazil. Type from St. Crolx.

2. Acanthophora muscoìdes (L.) Bory, Voy. Coquille, Bot. Crypt. 156. 1828.

Fucus muscoides L. Sp. P1. 1161. 1753.

Acanthophora militaris Lamour. Essai, 44. pl. 4. f. 4, 5. 1813.

Chondria muscoides Ag. Sp. Alg. 1: 361. 1822.

Acanthophora Delilei Harv. Ner. Bor.-Am. 2: 18. 1853. Not A. Delilei Lamour. Essai, 44. 1813.

In shallow water, Great Bahama:-Florida to Brazil and Ascension Island. Type from Ascension Island.

\section{DIGÈNEA Ag. Sp. Alg. 1: 388. 1822.}

1. Digenea símplex (Wulf.) Ag. loc. cit. 389 .

Conferva simplex Wulf. Crypt. Aquat. 17. 1803.

Fucus Lycopodium Turn. Hist. Fuc. 4: 6. pl. 199. 1819.

Digenea Wulfeni Kütz. Phyc. Gen. 433. 1843.

In tide-pools and in shallow water, New Providence, Great Bahama, Bimini, Exuma Chain, Mariguana, and Great Ragged Island:-Bermuda and Florida to South America; widely distributed in the warmer seas. Type from Trieste.

\section{POLYSIPHÒNIA Grev. Fl. Edinb. 308. 1824.}

? Polyostea Donati, Auszug Natur-Ges. Adriat. Meers 22. 1753.

Hutchinsia Ag. Syn. Alg. Scand. xxvi. 1817. Not Hutchinsia R. Br. 1812. Verteibrata S. F. Gray, Nat. Arr. Brit. Pl. 1: 338. 1821.

Grammita Bonnem. Jour. Phys. 94: 186. 1822. [Not seen.]

Grateloupella Bory, Dict. Class. Hist. Nat. 3: 340. 1823; 7: 480. 1825.

DicarPella Bory, loc. cit. 3: 340. 1823; 5: 464. 1824.

CARRadoria Mart. Fl. Bras. Acot. 15. 1833.

Grammitella Crouan, Ann. Sci. Nat. Bot. III. 10: 372. 1848.

Pericentral cells four.

Uncorticated or with few and Inconspicuous cortical cells in older parts.

Trichoblasts ("halrs," "leaves ") apparently wanting; plants blackish purple, usually not adhering well to paper on drying.

Trichoblasts manifest, few or numerous.

Branching obviously monopodial.

Lateral branchlets arising in the axils of trichoblasts.

Main axes mostly 50-90 $u$ in diameter ; plants soft and mucous, reddish purple, branches fastigiate.

Main axes mostly $100-300 \mu$ in diameter; plants firmer, brownish purple; branches not fastigiate, very irregular, or the ultimate ramuli sometimes short and alternatedistichous or pseudo-distichous.

Lateral branchlets arising without apparent references to the trichoblasts; segments often shorter than broad, outer cell walls in adult parts commonly $12-40 \mu$ thick.

1. P. subtilissima.

3. P. Binneyi.

4. P. ferulacea. 
Main branching subdichotomous, commonly fastigiate.

Plants $0.5-2.5 \mathrm{~cm}$. high, growing chiefly on leaves of Cymodocea, Thalassia, etc.

Plants 4-12 cm. high, Jellowish or straw-colored when living, vinaceous-tawny to chocolate-colored when dry, commonly bearing frequent short subspinescent patent ramuli, clothed with numerous trichoblasts.

Main axes or branches strongly corticated, the main branches virgately clothed with numerous much more slender taper-pointed or subspinescent ramuli.

Pericentral cells 8-10, trichoblast few and inconspicuous.

Pericentral cells 12-24, trichoblasts usually numerous and very conspicuous.

5. P. Gorgoniae.

6. P. hapalacantha.

7. P. ramentacea.

8. P. exilis.

9. P. opaca.

1. Polysiphonia subtilíssima Mont. Ann. Sci. Nat. Bot. II. 13: 199.1840.

Under shelving rocks, low-littoral, Exuma Chain, and Great Ragged Island :Massachusetts to northern South America. Type from Cayenne, French Guiana.

2. Polysiphonia havanénsis Mont. Ann. Sci. Nat. Bot. II. 8: 352.1837.

From between the tide-lines to a depth of 5 meters, found especially on the roots of Rhizophora and in mangrove associations, New Providence, Rose Island, Great Bahama, Cat Island, Watling's Island, Mariguana, Caicos Islands, and Great Ragged Island:-Bermuda; Florida; and the West Indles generally. Type from Havana.

3. Polysiphonia Bínneyi Harv. Ner. Bor.-Am. 2: 37. 1853.

Polysiphonia havanensis Binneyi J. Ag. Sp. Alg. 2: 960. 1863.

In shallow water, possibly intergrading with $P$. havanensis, but usually very distinct, New Providence, Berry Islands, Joulter's Cay, Great Bahama, Exuma Chain, Watling's Island, Mariguana, Caicos Islands, and Great Ragged Island:-Florida. Type from Key West, Florida.

4. Polysiphonia ferulàcea Suhr; J. Ag. Sp. Alg. 2: 980.1863.

Polysiphonia breviarticulata Harv. Ner. Bor.-Am. 2: 36. pl.16B. 1853. Not Hutchinsia breviarticulata Ag. Syst. Alg. 153. 1824.

Usualiy low-littoral on surf-beaten rocks, New Providence, Berry Islands, Joulter's Cay, Great Bahama, Gun Cay, Watling's Island, Atwood Cay, Mariguana, Caicos Islands, and Little Inagua:-Bermuda; Florida; Mexico; and the West Indies generally. Type locality unknown, probably West Indian.

\section{Polysiphonia Gorgòniae Harv. Ner. Bor.-Am, 2: 39. 1853.}

On Cymodocea, Thalassia, corals, sea-fans, and occasionally on the larger algae, in shallow water, New Providence, Berry Islands, Great Bahama, North Cat Cay, Watling's Island, Mariguana, and Great Ragged Island:-Florida. Type from Key West, Florida.

6. Polysiphonia hapalacántha Harv. Ner. Bor.-Am. 2: 39. 1853.

In shallow water, Great Bahama and Exuma Chain:-Florida. Type from Key West, Florida.

7. Polysiphonia ramentàcea Harv. Ner. Bor.-Am. 2: 42. pl. 16A. 1853.

Related to $P$. foeniculacea (Drap.) J. Ag. and $P$. hirta J. Ag. of the Mediterranean Sea, but differing considerably in its virgate habit due to the closely set ramuli of nearly uniform length, becoming gradually shorter at apex. On rocks and other algae from low-water mark down to a depth of at least two meters, New Providence, Berry Islands, Great Bahama, Exuma Chain, and Little Inagua:-Florida. Type from Key West, Florida.

8. Polysiphonia éxilis Harv. Ner. Bor.-Am. 2: 47. 1853.

Lophosiphonia? exilis De-Toni, Syll. Alg. 4: 1070. 1903.

Near low-water mark and on sea-fans in shallow water, New Providence, Rose Island, and Great Ragged Island:-Florida. Type from Key West, Florida. 
9. Polysiphonia opàca (Ag.) Moris \& De Not. Fl. Capr. 208. pl. 5 II. 1839.

Hutchinsia opaca Ag. Syst. Alg. 148. 1824.

Low-littoral on surf-beaten rocks and in tide-pools, New Providence, Berry Islands, Great Bahama, and Watling's Island :-Bermuda; Florida; and the Mediterranean and Adriatic seas. Type from the Adriatic Sea.

\section{BRYOTHÁMNION Kütz. Linnaea 17: 105. 1843;}

Phyc. Gen. 433. 1843.

Physcophora Kütz. loc. cit.; Phyc. Gen. 434.

1. Bryothamnion triquètrum (S. G. Gmel.) M. A. Howe, Jour. N. Y. Bot. Gard. 16: 222 . 1915.

Fucus triqueter S. G. Gmel. Hist. Fuc. 122. pl. 8. f. 4. 1768.

Fucus trifarius Swartz, Prod. 148. 1788.

Fucus triangularis J. F. Gmel. Syst. Nat. 1383. 1791.

Plocamium triangulare Lamour. Essai, 50. 1813.

Thamnophora triangularis Ag. Sp. Alg. 1: 226. 1822.

Alsidium triangulare J. Ag. Linnaea 15: 28. 1841.

Physcophora triangularis Kütz. Linnaea 17: 105. 1843.

Bryothamnion triangulare Kütz. Sp. Alg. 842. 1849.

From low-water mark down to a depth of 30 meters or more, Bimini and Caicos Islands :- Florida to Brazil. Type locality unknown.

\section{IOPHOCLÀdIA Schmitz, Ber. Deuts. Bot. Ges. 11: 222. 1893.}

1. Lophocladia trichóclados (Mert.) Schmitz, loc. cit.

Conferva trichocladia Mert. fide Ag. Syst. Alg. 137. 1824.

Ceramium Trichocladis Ag. loc. cit.

Griffitsia? trichoclados Ag. Sp. Alg. 2: 132. 1828.

Dasya trichoclados J. Ag. Linnaea 15: 32. 1841.

Dasya lophoclados Mont. Ann. Sci. Nat. Bot. II. 18: 254. 1842.

Eupogonium? trichoclados Kütz. Sp. Alg. 799. 1849.

Polysiphonia trichoclada Kütz. loc. cit. 819.

Polysiphonia lophoclados Kütz. loc. eit. 834 .

Lophothalia trichoclados J. Ag. Till Alg. Syst. 6: 64. 1890.

Apparently in deep water, usually found washed ashore, Great Bahama :-Bermuda; Florida; Santo Domingo; American Virgin Islands; and Barbados. Type from the West Indles.

8. WRIGHTIÉLA Schmitz, Ber. Deuts. Bot. Ges. 11: 221. 1893.

Main branches persistent, beset with numerous 4-ranked subulate ramuli $1-4 \mathrm{~mm}$. long.

Main branches commonly deliquescent, bearing filiform ramuli or a few subulate ramuli.

1. W. Blodgettii.

2. W. Tumanoviczi.

1. Wrightiella Blodgéttii (Harv.) Schmitz, loc. cit.

Alsidium Blodgettii Harv. Ner. Bor.-Am. 2: 16. pl. 15B. 1853.

Usually found washed ashore, presumably from deep water, Great Bahama:Bermuda and Florida. Type from Key West, Florida.

2. Wrightiella Tumanowíczi (Gatty) Schmitz, loc. cit. 222.

Dasya Tumanowiczi Gatty; Harv. Ner. Bor.-Am. 2: 64. 1853.

The Bahama plants show five pericentral cells except in ramuli, but appear to be otherwise ldentical with the Key West type.

Found washed ashore, Berry Islands and Abaco:-Florida. Type from Key West, Florida. 
9. MURRAYÉLLA Schmitz, Ber. Deuts. Bot. Ges. 11: 227. 1893.

1. Murrayella períclados (Ag.) Schmitz, loc. cit.

Hutchinsia periclados Ag. Sp. Alg. 2: 101. 1828.

Polysiphonia periclados Kütz. Sp. Alg. 822. 1849.

Bostrychia Tuomeyi Harv. Ner. Bor.-Am. 2: 58. pl. 14E. 1853.

Bostrychia periclados J. Ag. Sp. Alg. 2: 860. 1863.

Polysiphonia Binderi Sond.; Kütz. Tab. Phyc. 14: 16. pl. 45. f. a, b. 1864.

In rock caverns, on the roots of Rhizophora, etc., between the tide-lines and in shallow water, New Providence and Biminl:-Bermuda and Florida to northern South America. Type from St. Crolx.

\section{AMPHíbIA Stackh. Mém. Soc. Imp. Nat. Moscou 2: 58, 89. 1809.}

Scorpiura Stackh. Ner. Brit. ix, xi. 1816 [ed. 2-not seen].

Bostrychia Mont. in Sagra, Hist. Cuba, Pl. Cell. 39. 1838. Not Bostrychia

Fr. Sv. Vet. Akad. Handl. 1818: 119. 1818.

Helicothamnion Kütz. Linnaea 17: 105. 1843 ; Phyc. Gen. 433. 1843.

STICTOSIPHonia Harv. in Hook. f. F'. Antaret. 483. 1847.

Fronds stout and rigid, having commonly a spread of 2.5-5 $\mathrm{cm}$.; sections of main axes showing $3-7$ series of perlcentral cells; monosiphonous apices usually short or more commonly wanting.

Fronds smaller; sections of main axes showing 1-3 series of pericentral cells.

Branchlets bearing numerous long deflexed and incurved often branched monosiphonous ramelli $20-50$ cells long, these cells 26-55 $\mu$ long, longer than broad; plants repent or prostrate, forming thin mats; sections of main axes showing 2 or 3 serles of pericentral cells.

1. A. Montagnet.

Branchlets without monosiphonous ramelli or occasionally terminating in monosiphonous prolongations 2-10 (rarely -20) cells long, these cells 15-26 $\mu$ long, shorter than broad at least in proximal parts; maln axes showing 1 or 2 serles of pericentral cells; plants forming dense mats.

Regularly bi-tri-pinnate; ultimate branchlets, 75-200 $\mu$ (6-12 cells) long; main branches prostrate or ascending.

Bi-tri-pinnate or often more or less quadrifarious through the development of two rows of ventral branches near the bases of the lateral branches; ultimate branchlets $200-750 \mu(12-40$ segments or cells) long; main branches deflexed or drooping.

2. A. tenella.

3. A. Sertularia.

4. A. pectinata.

1. Amphibia Montàgnei (Harv.) Kuntze, Rev. Gen. Pl. 2: 881. 1891.

Bostrychia Montagnei Harv. Ner. Bor.-Am. 2: 55. pl. 14B. 1853.

On roots of Rhizophora and rarely on other objects, usually just above the lowwater mark, Biminl, Great Bahama, Exuma Chain, and Watling's Island:-Bermuda ; Forida; Cuba ; and Jamaica. Type from Key West, Florida.

2. Amphibia tenélla (Vahl) Kuntze, Rev. Gen. Pl. 2: 882. 1891.

Fucus tenellus Vahl, Nat. Selsk. Skr. $5^{2}: 45.18 .02$.

Rhodomela calamistrata Mont. Ann. Sci. Nat. Bot. II. 8: 354. 1837.

Bostrychia calamistrata Mont.; Harv. Ner. Bor.-Am. 2: 56. pl. 14C. 1853.

Bostrychia tenella J. Ag. Sp. Alg. 2: 869. 1863.

Bostrychia Vieillardi Kütz. Tab. Phyc. 15: 10. pl. 26. f. a-e. 1865.

Creeping on rocks, roots of Rhizophora, pneumatophores of Avicennia, etc., near the hlgh-water mark, New Provldence, Rose Island, Great Bahama, Gun Cay, Watling's Island, and Caicos Islands:-Bermuda ; Florida ; and the West Indies generally ; wldely distributed in the warmer seas. Type from St. Crolx. 
3. Amphibia Sertulària (Mont.) M. A. Howe, comb. nov.

Bostrychia Sertularia Mont. Ann. Sci. Nat. Bot. IV. 12: 176.1859.

Bostrychia sertularina Kütz. Tab. Phyc. 15: 9. pl. 25. f. a-c. 1865.

-Bostrychia Mazei Crouan; J. Ag. Anal. Alg. Cont. 4: 83. 1897.

Forming dense mats on rocks near the high-water mark, Rose Island, Great Bahama, Gun Cay, Exuma Chain, and Watling's Island :-Bermuda to northern South America. Type from Gulana.

4. Amphibia pectinàta (Kütz.) M. A. Howe, sp. nov.

Bostrychia Vieillardi pectinata Kütz. Tab. Phyc. 15: 10.pl. 26.f.f-h. 1865.

Somewhat intermediate between $A$. tenella and $A$. Sertularia, being found occasionally in herbaria sometimes under the one specific name and sometimes under the other, but usually, in the West Indies, quite distinct from either species, differing from both in its greater rigidity, in its habit of growth, and in the frequent presence of two rows of "adventitious" ventral branches, showing in extreme cases, four ranks of branches of almost equal size and similar development.

Between the tide-lines on roots of Rhizophora and pneumatophores of Avicennia, rarely pendent from the roofs of caverns, Rose Island, Berry Islands, Great Bahama, Bimini, Exuma Chain, Watling's Island, and Mariguana :-Florida and the West Indies generally; New Caledonia. Type from New Caledonia.

11. HERPOSIPHÒNIA Näg. in Schleid. \& Näg. Zeits. Wiss. Bot. 3-4: 238, (without mention of species). 1846. Ambronn, Bot. Zeit. 38: 197. 1880.

Maln axes or long branches with a branch (or branch rudiment) from each node.

Maln axes or long branches strongly curved, with convexity dorsal, giving short branches a somewhat squarrose appearance; short branches mostly 8-10 segments long; plants mostly 4-10 cm. long.

Main axes or long branches nearly straight or slightly curved with concavity dorsal; short branches mostly $12-30$ segments long : plants mostly $1-3 \mathrm{~cm}$. long.

Main axes or long branches with some of their nodes regularly and wholly destitute of branches.

Plants of straggling, intricate, or repent habit, elongate and subsimple, $0.5-3 \mathrm{~cm}$. long. with apex consplcuously rolled towards dorsal surface; maln axes $75-150 \mu$ in diameter, even.

Plants somewhat bi-tri-pinnate, filiculoid, $2.5-5 \mathrm{~cm}$. long, with apex inconspicuously curved towards dorsal surface; main axes 150-250 $\mu$ in dlameter, swollen at nodes in older parts.

1. H. Pecten-Veneris.

2. H. tenella.

4. H. bipinnata.

1. Herposiphonia Pécten-Véneris (Harv.) Falkenb. Rhodomel. 315. 1901.

Polysiphonia Pecten-Veneris var. a, Harv. Ner. Bor.-Am. 2: 46. pl. $16 C$. 1853.

On Penicillus, Halimeda, Thálassia, and various other objects in shallow water, New Providence, Rose Island, Berry Islands, Great Bahama, Bimini, Andros, Exuma Chain, Mariguana, Caicos Islands, and Great Ragged Island:-Florida. Type from Key West, Florida.

2. Herposiphonia tenélla (Ag.) Ambronn, Bot. Zeit. 38: 197. pl.4. f. 9, 11, 1316. 1880.

Hutchinsia tenella Ag. Sp. Alg. 2: 105. 1828.

Polysiphonia tenella J. Ag. Alg. Med. et Adriat. 123. 1842.

Polysiphonia Pecten-Veneris var. $\beta$, Harv. Ner. Bor.-Am. 2: 46. pl. $16 D$. 1853.

On sponges, various algae, roots of Rhizophora, etc., from low-water mark down to a depth of at least 20 meters, Berry Islands, Great Bahama, Biminl, Exuma Chaln, Watling's Island, Mariguana, and Calcos Islands :-Bermuda and North Carolina to

Florida and Barbados; Mediterranean and Adriatic seas. Type from Sicily. 
3. Herposiphonia secúnda (Ag.) Ambronn, Bot. Zeit. 38: 197. pl. 4. f. 8, 12. 1880 ,

Hutchinsia secunda Ag. Syst. Alg. 149. 1824.

Polysiphonia secunda Zanard. Syn. Alg. Adriat. 64. 1841.

On Sargassum, Chondria, Laurencia, etc., In shallow water, Berry Islands, Great Bahama, Gun Cay, Exuma Chain, Watling's Island, Marlguana, Caicos Islands, and Castle Island :-Bermuda and Florida to Barbados; Mediterranean and Adriatic seas. Type from the Mediterranean.

\section{Herposiphonia bipinnàta M. A. Howe, sp. nov.}

Frond rose-purple, filiculold or flocculose, free, or subrepent at base only, somewhat bi-tri-pinnate, or paniculate, 2-5 $\mathrm{cm}$. long, the branchlets here and there obviously pectinate-secund; main axes stramineous or decolorate except in youngest parts, $150-250 \mu$ in diameter, somewhat swollen at the nodes, the segments $1 \frac{1}{2}-2$ times as long as broad, becoming subequal towards apices; pericentral cells usually 10 , the central cell large, $50-90 \mu$ in diameter; branches obscurely quadrifarious, or subsecund through the abortion of the usually frequent lateral long branches, commonly arising from two immediately consecutive nodes, one from each, followed by one or two naked nodes, and then by two branches from immediately consecutive nodes, and so on, the branches being sometimes represented by rudiments; long branches abruptly diminishing in size at apex and rather inconspicuously dorsiflexed; short branches 8-12 segments long, slightly flexed or subfalcate, crowned with rather coarse trichoblasts, often as long as the branch, the segments $1 / 2-11 / 4$ as long as broad; sporangia somewhat protuberant, mostly in a single linear series, the sporangiiferous branch 105-135 $\mu$ in greatest width; cystocarps ovoid, short-stalked, subtruncate, $380-540 \mu \times 300-450 \mu$.

In technical microscopic characters, the present species seems to be related to $H$. secunda, from which, however, it is amply distinct, as indicated in the above key.

On Cymodocea, washed ashore, Whale Cay, Berry Islands (Howe 3497 -type).

12. LOPHOSIPHONIA Falkenb. in Eng. \& Prantl, Nat.

Pflanzenfam. $1^{2}: 459.1897$.

Trichoblasts spirally arranged.

Pericentral cells usually 11-18.

Pericentral cells usually 6-10.

Trichoblasts in a single secund series on the convex (dorsal) surface of the strongly hamate tips of the erect branches.

1. L. obscura.

2. L. subadunca.

3. L. cristata.

1. Lophosiphonia obscùra Auct. Not Hutchinsia obscura Ag. Sp. Alg. 2: 108. 1828.

? Conferva intertexta Roth, Cat. Bot. 1: 188. pl. 3. f. 6. 1797.

Polysiphonia reptabunda Suhr; Kütz. Sp. Alg. 806. 1849.

Polysiphonia adunca Kütz. Sp. Alg. 808. 1849.

Forming mats or a turf on rocks and on roots of Rhizophora between the tidelines, common, New Providence, Rose Island, Berry Islands, Bimini, Gun Cay, Exuma Chain, Watling's Island, Caicos Islands, and Great Ragged Island :-Bermuda and Florida to the American Virgin Islands; Adriatic and Mediterranean seas and England.

2. Lophosiphonia subadúnca Kütz. Phyc. Gen. 418. 1843.

Hutchinsia obscura Ag. Sp. Alg. 2: 108 (according to apparent original in herb. Ag.). 1828.

Polysiphonia barbatula Kütz. loc. eit. 417.

Polysiphonia pygmaea Kütz. Phyc. Germ. 313. 1845.

Making a close nap or turf on surf-beaten rocks, between the tide-lines, Exuma Chaln:- southern Europe. Type from. Corsica. 
3. Lophosiphonia cristàta Falkenb. Rhodomel. 499. pl. 9. f. 7-10. 1901.

Making a velvety coating on surf-beatén rocks, low-littoral, Berry Islands, Mariguana, and Great Ragged Island:-St. Thomas and Mediterranean Sea. Type from Naples.

13. DIPTEROSIPHŌNIA Schmitz \& Falkenb. in Eng. \& Prantl, Nat. Pflanzenfam. $1^{2}: 463.1897$.

1. Dipterosiphonia dendrítica (Ag.) Schmitz, loc. cit. 464 . Hutchinsia dendritica Ag. Syst. Alg. 146. 1824.

Creeping on Chamaedoris and on Laurencia papillosa, Eleuthera:-American Virgin Islands; Brazil. Type from Brazil.

\section{AMÁNSIA Lamour. Nouv. Bull. Sci. Soc, Philom. 1: 332. 1809.}

1. Amansia multífida Lamour. loc. cit. pl. 6. f. $2 C, D, E$. Domingo.

Usually found washed ashore, Eleuthera:-Florida to Brazll. Type from Santo

15. Heterosiphònta Mont. Prod. Phyc. Pol. Antarct. 4. 1842.

Trichothamnion Kütz. Phyc. Gen. 415. 1843.

Main axes uncorticated, mostly $65-130 \mu$ in diameter ; fronds $1-6 \mathrm{~cm}$. long or high.

Main axes strongly corticated, mostly 0.4 oٌ-1.1 $\mathrm{mm}$. in diameter; the brownish diaphragms of the central siphon visible through cortex; fronds 4-18 cm. high.

1. H. Wurdemanni.

2. H. Gibbesii.

1. Heterosiphonia Wurdemánni (Bail.) Falkenb. Rhodomel. 638. pl. 16. f. 11. 1901.

? Callithamnion crispellum Ag. Sp. Alg. 2: 183. 1828.

Dasya Wurdemanni Bail.; Harv. Ner. Bor.-Am. 2: 64. pl. 15C. 1853.

Resembling a species of Dasya, as pointed out on a later page.

On corallines and various other algae, under shelving rocks, on roots of Rhizophora, etc., low-littoral or in shallow water, Berry Islands, Great Bahama, Bimini, Gun Cay, Exuma Chain, Watling's Island, Mariguana, Caicos Islands, and Little Inagua :-Bermuda and Florida to Barbados; Adrlatic and Mediterranean seas. Type from Key West, Florida.

2. Heterosiphonia Gibbèsii (Harv.) Falkenb. Rhodomel. 653.' 1901.

Dasya Gibbesii Harv. Ner. Bor.-Am. 2: 59. pl. 15 A. 1853.

In tide-pools and in shallow water down to 2 meters or more, New Providence, Berry Islands, Great Bahama, Andros, Eleuthera, Cat Island, Exuma Chain, and Watling's Island:-Florida. Type from Key West, Florida.

16. DASYA Ag. Syst. Alg. xxxiv, 211 (as Dasia). 1824.

RHodonema Martens, Reise nach Venedig 2: 641. 1824.

Dichotomous monosiphonous ramelli $(2-4 \mathrm{~mm}$. long) springing without order from the firm cortex, densely clothing the main axes or deficient in older parts.

Stichidia on 1 - or 2 -celled monsiphonous pedicels, translucent after dehiscence of sporangia, showing central axis clearly.

Plants mostly $8-80 \mathrm{~cm}$. high, main axes vaguely quasipinnate or virgate; cystocarps pedicellate.

plants mostly 3-6.5 cm. high, subdichotomous ; ramell1 very soft and mucous, more or less coherent or confluent on drying; cystocarps sessile or subsessile.

Stichidia sessile or on 1 -celled pedicels, rather opaque after dehiscence of sporangia and consplcuously zonate-annulate.

1. D. pedicellata.

2. D. Crouaniana.

3. D. ramosissima. 
Dichotomous monosiphonous ramelli subverticiliate and often subsquarrose, sometimes lightly corticated at base; main axes well corticated.

Monosiphonous ramelli spirally disposed, patent, divaricate, or subsquarrose, divaricately dichotomous.

Main axes $0.25-0.75 \mathrm{~mm}$. in diameter, corticated except in youngest parts; cystocarp subspheric-rostrate, 0.67-0.92 mm, broad.

Main axes $0.1-0.3 \mathrm{~mm}$. In diameter, uncorticated or slightly corticated near base; cystocarp conic-ovoid, about 0.2 $\mathrm{mm}$. broad (immature).

4. D. mollis.

5. D. Collinsiana.

6. D. rigidula.

1. Dasya pedicellàta (Ag.) Ag. Syst. Alg. 211. 1824.

Sphaerococcus pedicellatus Ag. Sp. Alg. 1: 321. 1822.

Rhodonema elegans Martens, Reise nach Venedig 2: 641. pl. 8. 1824.

Dasya elegans Ag. Sp. Alg. 2: 117. 1828.

Mostly in shallow water, New Providence, Berry Islands, and Great Bahama :Massachusetts to Bermuda; Florida; and the northern West Indies; Adriatic and Mediterranean seas; Canary Islands. Type from New York.

The southern specimens are sometimes yellowish when living instead of the customary lake-red.

2. Dasya Crouaniàna J. Ag. Till Alg. Syst. 6: 95. 1890.

On surf-beaten rocks at low-water mark, Exuma Chain:-Florida and Guadeloupe. Type from Guadeloupe.

3. Dasya ramosíssima Harv. Ner. Bor.-Am. 2: 61.1853.

The verticils of sterile cells of the stichidia are inclined to be protuberant and they occasionally develop into few-celled simple or one-branched trichophylls. In two observed cases the stichidium was forked near the apex.

On roots of Rhizophora near low-water mark, Great Bahama:-Florida. Type from Key West, Florida.

4. Dasya móllis Harv. Ner. Bor.-Am. 2: 62. 1853.

On roots of Rhizophora, under shelving rocks, etc., near low-water mark, Exuma Chain and Little Inagua :-Florida and Cuba. Type from Key West, Florida.

5. Dasya Collinsiàna M. A. Howe, in Britton, Fl. Bermuda 524. 1918.

The only specimen seen differs from the Bermudian type in being more laxly branched, in being less manifestly dichotomo-corymbose, in the more "ocellate" congestion of the ramuli at the apices, and in the lighter cortication. It also bears cystocarps, hitherto undescribed for this species. These are sessile, subspheric-rostrate, $670-920 \mu$ broad, 600-750 $\mu$ high (without beak) the beak being $350-500 \mu$ long. In its cystocarps it seems to resemble $D$. ramosissima, but the ramuli of $D$. Collinsiana are coarser and more divaricately dichotomous and have a regularly spiral arrangement while those of $D$. ramosissima are irregular or inclined to be subverticillate.

In 2 meters of water, Great Bahama:-Bermuda. Type from Bermuda.

6. Dasya rigídula (Kütz.) Ardiss. Florid. Ital. 2: 140. 1878.

Eupogonium rigidulum Kütz. Phyc. Gen. 415. 1843; Tab. Phyc. 14: pl. 85. f. c, d. 1864.

Eupogonium squarrosum Kütz. Phyc. Gen. 415. 1843; Tab. Phyc. 14: pl. 85. f. $a, b .1864$.

Dasya squarrosa Zanard. Mem. Ist. Veneto 13: 163. pl. 53B. 1866. Not Dasya squarrosa Harv. in Hooker, J. D., F'l. New Zealand 2: 232. 1855.

Much resembling Heterosiphonia Wurdemanni in size, habit, and microscopic characters and easily confused with that species, but differing in its radial instead of dorsiventral organization, in having its ramuli spirally dis- 
posed and one springing from each segment, while $H$. Wurdemanni has tworanked ramuli, one from every second segment; the main axes of $D$. rigidula are also sometimes corticated towards base.

On rocks and various algae in shallow water, Berry Islands, Great Bahama and Exuma Chain :-Bermuda; Adriatic and Mediterranean seas. Type from Spalato, Adriatic Sea.

\section{DASYÓPSIS Zanard. Saggio Class. Fic. 52. 1843.}

Eupogodon Kütz. Phyc. Germ. 312. 1845.

\section{Dasyopsis Antillàrum M. A. Howe, sp. nov.}

Plants dark vinaceous-purple, claret-brown, or orange-rufous, 4-10 cm. high, rather copiously, irregularly and radially branched, or quasi-pinnate, occasionally subdichotomous below; main axes subterete or slightly flattened, 1-2.5 $\mathrm{mm}$. in diameter; principal branches showing more or less numerous subspinescent branchlets 1-3 $\mathrm{mm}$. long, the surface clothed at and near the apices, or sometimes to bases of the branches and branchlets, with more or less tufted dichotomous, monosiphonous, often early deciduous ramelli, these springing chiefly from slightly elevated cushions or sorus-like spots, the segments mostly $15-26 \mu$ in diameter, usually 3-6 times as long as broad; cortical cells mostly rather short, 12-70 $\mu$ long, 1-5 times as long as broad; stichidia fusiform, 300$450 \mu$ long, $75-150 \mu$ in maximum width, borne close to the rhachides, on onecelled pedicels or sometimes apparently sessile on the rhachides, occasionally proliferous at apex and bearing short trichophylls.

On corals in shallow water and washed ashore, Fort George Cay, Calcos Islands (Howe 5625-type), and Atwood Cay.

Dasyopsis Antillarum in color and in the character and arrangement of the monosiphonous ranelli bears some resemblance to small conditions of Dasya pedicellata, but differs in the more copious and more irregular branching, in having short subspinescent branchlets, in the shorter cortical cells, in the absence of visible pericentral siphons at the apices, in the more proximal location of the stichidia, etc.

From the Bermudian Dasyopsis spinuligera (Collins \& Hervey) M. A. Howe (Dasya spinuligera Collins \& Herv. Proc. Am. Acad. 53:130, pl. 4. f. 24, 25. 1917), D. Antillarum differs in being much larger and coarser, in the more vinaceous-purple color, in the softer longer-celled monosiphonous ramelli, and in the shorter, more fusiform stichidia (the stichidia of $D$. spinuligera are eventually cylindric, with conlc apex, and $600-800 \mu$ long by $75-80 \mu$ in diameter, and they are often geminate).

From the Adriatic and Mediterranean Dasyopsis penicillata and $D$. spinella, the specles differs much in habit and in not having the monosiphonous ramelli confined to the apices but springing irregularly from the cortex or from slightly elevated cushions or sorus-like areas.

\section{FAIKENBÉrgiA Schmitz, in Eng. \& Prantl, Nat. Pflanzenfam. $1^{2}: 479.1897$.}

1. Falkenbergia Hillebrándii (Born.) Falkenb. Rhodomel. 689. 1901.

Polysiphonia Hillebrandii Born.; Ardiss. Phye. Med. 1: 376. 1883.

On roots of Rhizophora, etc., in shallow water, Gun Cay and Exuma Chain :Bermuda to Barbados; Canary Islands ; Mediterranean Sea. Type from the Canary Islands.

19. HALOdÍCTYON Zanard. Saggio Class. Fic. 52

(as Halydictyon). 1843.

Hanowia Sond. Bot. Zeit. 3: 52. 1845.

Coelodictyon Kütz. Phyc. Germ. 287. 1845.

1. Halodictyon mirábile Zan. loc. cit.

On and with other algae (Heterosiphonia Wurdemanni, Jania, Polysiphonia, etc.), Exuma Chain and Little Inagua :-Florida and Barbados; Mediterranean and Adriatic seas. Type from the Adriatic Sea. 


\section{Family 12. CERAMIÀCEAE.}

1. SPERMOTHÁMNION Aresch.; Fries, Summa Veg. Scand.-127. 1845.

Cells of erect filaments mostly $10-20 \mu$ in diameter, 3-6 times as long as broad; tetrasporangla on 1-4-celled pedicels; plants usually growing on Galaxaura.

Cells of erect filaments mostly $20-40 \mu$ in diameter, $2-5$ times as long as broad.

Vinaceous-purple or Indian lake, on Codium, manifestly repent.

Usually dark vinaceous-brown, under shelving rocks and on Jania, Galaxaura, etc., Intricate, less manifestly repent.

Cells of erect filaments $40-65 \mu$ in diameter, 5-15 times as long as broad; terminal cells clavate, $26-40 \mu$ in diameter, walls of all cells 6-14u thick ; tetrasporangia terminal, often more or less corymbose; plants growing on rocks.

Cells of erect filaments $50-115 \mu$ in diameter, 3-7 times as long as broad, their walls $5-40 u$ thick; terminal cells commonly cylindric, often only $12-15 \mu$ in diameter. thelr walls $1-2 \mu$ thick; tetrasporangla at nodes, solitary or more commonly several and unilaterally glomerate or subverticillate; plants on or with other algae.

1. S. investiens.

2. S. gorgoneum.

3. S. speluncarum.

4. S. macromeres.

5. S. gymnocarpum.

1. Spermothamnion invéstiens (Crouan) Vickers, Ann. Sci. Nat. Bot. IX. 1: 64. 1905.

Callithamnion investiens Crouan; Schramm \& Mazé, Alg. Guad. 7. 1865 [not seen].

On Galaxaura flagelliformis, G. subverticillata, and G. comans, and on and with Jania (growing on Sargassum), Great Bahama, Watling's Island, Marlguana, and Caicos Islands :-Bermuda to Barbados. Type from Guadeloupe.

2. Spermothamnion gorgòneum (Mont.) Bornet; Vickers, Ann. Sci. Nat. Bot. VIII. 4: 305. 1897.

Callithamnion gorgoneum Mont. Ann. Sci. Nat. Bot. IV. 8: 289. 1857.

On Codium isthmocladum, Berry Islands :-Bermuda to Barbados ; Canary Islands and Cape Verde Islands. Type from island of St. Nicholas, Cape Verde Islands.

3. Spermothamnion speluncàrum (Collins \& Hervey) M. A. Howe, comb. nov.

Rhodochorton speluncarum Collins \& Hervey, Proc. Am. Acad. 53: 148. 1917.

Variable in length of cells and thickness of the cell-walls; cells mostly 2-4 times as long as broad, but occasionally as much as 8 times; cell-walls usually 3-6 $\mu$ thick, but ranging up to $12 \mu$ thick; tetrasporangia occurring mostly on the lower part of the main erect filaments, solitary or rarely two (opposite) on a segment, ellipsoid or subglobose, $52-65 \mu$ in maximum diameter, subsecund, sessile or on 1- or 2-celled pedicels; antheridial stands terminal, short-cylindric or ovoid-ellipsoid, about $40 \mu \times 20-28 \mu$. Erect filaments sometimes tortuous and intricate, forming intertangled cushions. Related to the North-European S. roseolum (Ag.) Pringsh., especially to the form occasional in herbaria under the name Callithamnion repens Lyngb., but filaments more intricate and flexuous, more slender (commonly $22-39 \mu$ vs. 35-55 $\mu$ ), cells shorter (usually 2-4 times vs. 3-8 times as long as broad), more often dolioform, and more often collabent.

Under shelving rocks and on various algae (Chamaedoris, Galaxaura, Jania, etc.) and on sponges, in shaded situations, near low-water mark, Rose Island, Great Bahama, North Cat Cay, Mariguana, and Great Ragged Island:-Bermuda. Type (sterile) from Bermuda.

4. Spermothamnion macromères Collins \& Hervey, Proc. Am. Acad. 53: 132. 1907.

On surf-beaten, sand-covered rocks at low-water mark, Berry Islands :-Bermuda. Type from Bermuda. 


\section{Spermothamnion gymnocárpum M. A. Howe, sp. nov.}

Indian lake or purplish-vinaceous, fading to brownish-vinaceous, grayishvinaceous, or vinaceous-fawn, forming rather dense cushions $1-3 \mathrm{~cm}$. deep or somewhat straggling in habit; primary creeping filaments $50-130 \mu$ in diameter, their cells 130-400 $\mu$ long, mostly 3-5 times as long as broad, their walls $13-50 \mu$ thick, the erect branches arising mostly from near the end of the cell; erect filaments $50-115 \mu$ in diameter, rather freely subdichotomously, alternately, or subsecundly branched, rarely with 3 or 4 branches at a node, the branches patent or erecto-patent, arising subterminally or laterally just below the septum, the cells $300-750 \mu$ long, mostly 3-7 times as long as broad, cylindric or slightly enlarged at upper end, the walls $5-40 \mu$ thick, the terminal cells $40-65 \mu$ in diameter, obtuse, or in the more branched conditions often' only $12-15 \mu$ in diameter with walls only 1-2 $\mu$ thick; chromatophores suborbicular, elliptic, fusiform, substellate, or difform, more or less confluent dises $2-13 \mu$ in maximum diameter; monoicous (polyoicous \&); procarps and cystocarps solitary or several closely approximate; procarps subglobose or hemispheric, $40-50 \mu$ broad, the trichogyne $10-13 \mu$ in diameter; eystocarps moriform or irregularly hemispheric, $80-150 \mu$ broad, wholly destitute of an involucre; antheridial stands ovoid to subcylindric, $40-80 \mu \times 26-40 \mu$; tetrasporangia borne on one-celled pedicels at nodes in distal parts of the main erect filaments and their branches, solitary or more often $2-5$ at a node and aggregated on the inner side, or subverticillate, subglobose, $60-80 \mu$ in diameter, their walls 5-12 $\mu$ thick.

On and with various other algae (Jania, Laurencia, Chamaedoris, etc.), in shallow water and washed ashore, Great Bahama (Howe 3879-type) and Exuma Chain.

The species is perhaps related to the European S. irregulare (J. Ag.) Ardiss., but manifestly differs in its longer, less ventricose celis, naked cystocarps, etc. Most of the few antheridial stands seen have been very close to the procarps, but the procarps preponderate so much in number that it may be suspected that dioicous conditions also occur.

\section{MESOTHÁMNION Börg. Dansk Bot. Ark. $3^{1}: 208.1917$.}

\section{Mesothamnion caribaèum Börg. loc. cit.}

The single Bahamian specimen seen is sterile and the determination is open to possible doubt. It is $0.5-1 \mathrm{~cm}$. high and is remarkable for its penicillately tufted apices, the lower parts of the main axes being more or less denudate.

On Gelidium rigidum, near low-water mark, Gun Cay :-American Virgin Islands. Type from St. Jan (dredged in 30 meters of water).

\section{GRIFF'́THSIA Ag. Syn. Alg. Scand. xxviii. (as Griffitsia). 1817.}

Branching mostly subdichotomous, the branches issuing from the upper end of the parent cell.

Branching distinctly lateral, the branches issuing from near the middle or below the middle of the parent cell.

1. G. globulifera.

2. G. tenuis.

1. Griffthsia globulifera Harv.; Kütz. Tab. Phyc. 12: 10. pl. 30. f. a-d. 1862.

Griffithsia corallina globifera Harv. Ner. Bor.-Am. 2: 228. pl. 35 A. 1853.

Griffithsia corallina tenuis Harv. loc. cit.

Griffithsia globifera Harv.; J. Ag. Sp. Alg. $3^{1}$ : 67. 1876.

Griffithsia Bornetiana Farl. Proc. Am. Acad. 12: 243.1877.

The Bahamian plants referred here seem to agree essentially with the northern type in the character of the antheridia, cystocarps, and tetrasporangia, but they are smaller plants and the filaments are often more moniliform, these differences being especially manifest in sterile and more doubtful specimens that have been identified tentatively with this species. The plants occur on surf- 
beaten rocks between the tide-lines and as epiphytes on other algae, habitats that are not characteristic of the northern G. globulifera.

Joulter's Cay, Exuma Chain, Atwood Cay, Caicos Islands, and Great Ragged Island:-Massachusetts to the American Virgin Islands and Barbados (?). Type from New York.

2. Griffithsia ténuis Ag. Sp. Alg. 2: 131. 1828.

Callithamnion tenue Harv. Ner. Bor.-Am. 3: 130. 1858.

Griffithsia thyrsigera (Thwait.) Grun. Alg. Fidschi 8. 1877.

An antheridial fragment, washed ashore, Berry Islands:-Massachusetts and Bermuda to Barbados; Adriatic Sea; Ceyion; Australia; etc. Type from Venice.

4. CALIITHÁMNION Lyngb. Hydroph. Dan. 123. 1819.

1. Callithamnion Hálliae Collins, in C., H., \& S., Phyc. Bor.-Am. 698. 1900.

Related to $C$. corymbosum and $C$. byssoides, but differs from both in having the main axes uncorticated throughout.

On other algae at low-water mark, under shelving rocks (and washed ashore), Great Bahama and Exuma Chain :-Florida. Type from Key West, Florida.

5. SErRóSPORA Harv. Phyc. Brit. pl. 21. 1846.

1. ? Seirospora occidentàlis Börg. Bot. Tidsskr. 30: 14. f. 8, 9. 1909.

The scanty fertile material has the triangularly divided tetrasporangia sessile or on one-celled pediceis; paraspores $30-40 \mu$ broad, in branching, subterminal tufts; main axes uncorticated throughout. Exuma Chain :-American Virgin Islands. Type from sound between St. Thomas and St. Jan.

6. HALOPLÉGMA Mont. Ann. Sci. Nat. Bot. II. 18: 258. 1842.

RHODOPLExIA Harv. in Hook. Ic. Pl. 7: pl. 613. 1844.

1. Haloplegma Dupérreyi spinulòsum M. A. Howe, subsp. nov.

Differs from typical $H$. Duperreyi Mont. in having a thallus that is beset with numerous rigid subspinescent ramelli usually in twos or threes and 25-140 $\mu$ (2-11 cells) long, the cells of these ramelli mostly 1.5-3 times as long as broad.

Between the tide-lines on a rock shelf, under an overhang, Cave Cays, Exuma Chain (Howe 3998).

\section{GYMNOTHÁMINION J. Ag. Anal. Alg. 27. 1892.}

1. Gymnothamnion élegans (Schousb.) J. Ag. loc. cit. 178.

Callithamnion elegans Schousb.; Ag. Sp. Alg. 2: 162. 1828; Born. \& Thur. Not. Alg. 32. pl. 10. 1876.

Ptilota Schousboei Born. in Born. \& Thur. loc. cit. 34.

Plumaria Schousboei Schmitz; Born. Mém. Soc. Sci. Cherbourg 28: 330. 1892.

? Gymnothamnion bipinnatum Collins \& Hervey, Proc. Am. Acad. 53: 139. pl. 4. f. 26. 1917.

? Ptilothamnion bipinnatum M. A. Howe, in Britton, Fl. Bermuda 525. 1918.

The main branches are simply pinnate and the opposite ramuli are usually longer than in Bermudian specimens deseribed as G. bipinnatum but not altogether dissimilar conditions occur in the Bermudian type and the species is probably the same. The Bahamian specimens, like the Bermudian, appear to bear only tetrasporangia (tripartite), and pending the discovery of antheridia 
and eystocarps, the generic position of the plants must remain in some doubt. There are discrepancies between Bornet's and J. Agardh's figures of the cystocarp of Gymnothamnion elegans and the relation of Gymnothamnion to Ptilothamnion would seem to be in need of further study.

Forming a thin coating on rocks a little above the low-water mark, Gun Cay :northern Africa and Mediterranean shores of Europe; Bermuda (?). Type from Tangier, Morocco.

\section{ANTITHÁMNION Näg. Neu. Algensyst. 200. 1847.}

Main axes $24-30 \mu$ in diameter, for the most part regularly bipinnate.

Main axes $75-150 \mu$ in diameter, their branches tetrastichous, the uitimate branchlets often alternate or subdistichous.

1. A. Butleriae.

2. A. cruciatum.

1. Antithamnion Butlèriae Collins, Proc. Am. Acad. 37: 258. 1901.

The fronds in Bahamian specimens are broader and the cells are usually longer, both actually and relatively, than in the type form.

On a rock shelf under an overhang, between the tide-lines, and washed ashore, Rose Island, Exuma Chain, and Caicos Islands :-Jamaica and Barbados. Type from Kingston, Jamaica.

2. Antithamnion cruciàtum (Ag.) Näg. Neu. Algensyst. 200. 1847.

With Jania, washed ashore, Great Bahama:-Massachusetts and Bermuda to Barbados; Europe. Type from Trieste.

9. CROUÀNIA J. Ag. Alg. Med. et Adriat. 83. 1842.

1. Crouania attenuàta (Bonnem.) J. Ag. loc. cit.

Batrachospermum attenuatum Bonnem. fide Ag.

Mesogloia attenuata Ag. Syst. Alg. 51. 1824.

On various algae, Thalassia, etc., from near low-water mark down to 20 meters (fide Börgesen), New Providence, Berry Isiands, Joulter's Cay, Great Bahama, Watling's Island, and Mariguana:-Bermuda and Florida to Barbados; southern Europe. Type (in herb. Ag.) from northwestern France ("Armorica").

\section{SPYRIDIA Harv. in Sm. Eng. F1. 5 $: 336.1833$.}

Ramuli without lateral uncinate spines.

Ramuli normally with one or more uncinate spines on the distal nodes.

1. S. filamentosa.

2. S. aculeata.

1. Spyridia filamentòsa (Wulf.) Harv. loc. cit. 337.

Fucus filamentosus Wulf. Crypt. Aquat. 64. 1803.

Spyridia occidentalis Kütz. Sp. Alg. 666. 1849.

Spyridia apiculata Kütz. Tab. Phyc. 12: 15. pl. 49. f. c, d. 1862.

Common in shallow warm water, Rose Island, Berry Islands, Great Bahama, Bimini, North Cat Cay, Exuma Chain, Cat Island, and Caicos Isiands :-Massachusetts and Bermuda to South America; widely distributed in the warmer seas. Type from the Adriatic Sea.

2. Spyridia aculeàta (Schimp.) Kütz. Phye. Gen. 377. 1843.

Ceramium aculeatum Schimp. in Unio Itin. no. 966 (not seen).

On rocks and on other algae in shallow water or down to 30 meters (fide Börgesen), Berry Islands, Great Bahama, Gun Cay, and Mariguana :-Bermuda and Fiorida to American Virgin Islands; southern Europe and northern Africa; Red Sea. Type from the Red Sea. 
11. CERÀMIUM Ag. Syn. Alg. Seand xxvi. 1817.

? APONA Adans. Fam. Pl. 2: 2, 519. 1763.

? EPISPERMA Raf. Prec. Somiol. 48. 1814.

Boryna Grateloup. Bory, Dict. Class. Hist. Nat. 2: 412. 1822.

Filaments continuously corticated.

Filaments manifestly zonate, corticated at nodes only.

1. C. nitens.

Filaments regularly and equally dichotomous, more or less fastiglate, apices forcipate.

Segments mostly longer than broad, becoming 3-7 times longer than broad below; tetrasporangia triangularly divided.

Segments mostly shorter than broad or subequal, becoming 2-3 times longer than broad below; tetrasporangia often cruciate or decussately palred.

Filaments unequally dichotomous or showing various intermediate conditions between dichotomy and lateral branching.

Upper margins of cortex-zones commonly showing in younger parts verticils of delicate caducous mostly 1- or 2-celled hairs; branching dichotomo-alternate and slightly zig-zag.

Hairs wanting or very rare.

Main filaments mostly $45-75 \mu$ in diameter; nodai bands protuberant, bitruncate, most of the corticating cells, or at least the lower with thelr longer axes running transversely to the filament; tetrasporangia on main filaments.

Main filaments mostly $90-200 \mu$ in diameter; nodal bands not protuberant, the corticating cells with their longer axes lengthwise of the filament; tetrasporangia on clavate or fusiform lateral branches.

2. C. tenuissimum.

3. C. cruciatum.

4. C. subtile.

5. C. byssoideum.

6. C. corniculatum.

1. Ceramium nitens (Ag.) J. Ag. Sp. Alg. 2: 130. 1851.

Ceramium rubrum nitens Ag. Syst. Alg. 136. 1824.

? Ceramium leptophloeum Kütz. Linnaea 15: 740. 1841.

Ceramium divaricatum Kütz. Tab. Phyc. 13: 5. pl. 12. f. c-e. 1863.

Rather common in shallow water, New Providence, Berry Islands, Joulter's Cay, Great Bahama, Bimini, Exuma Chain, and Watling's Island :-Bermuda and Florida to the American Virgin Islands. Type from the "Antilles."

2. Ceramium tenuíssimum J. Ag. Sp. Alg. 2: 120. 1851.

? Ceramium diaphanum tenuissimum Roth, Cat. Bot. 3: 156. 1806.

The usually sterile Bahamian plants referred tentatively to $C$. tenuissimum seem to agree essentially with other West Indian specimens currently thus referred, but their identity with the European type is doubtful. They are more regularly dichotomous, more fastigiate, firmer and more rose-colored than the plants here referred to $C$. subtile.

On various other algae, roots of Rhizophora, etc., in shallow water, Great $\mathrm{Ba}$ hama, Exuma Chaln, Mariguana, and Great Ragged Island :-Europe; Massachusetts ; Bermuda; and the West Indies generally. Type locallty unknown.

3. Ceramium cruciàtum Collins \& Hervey, Proc. Am. Acad. 53: 144. pl. 4. f. 27, 28. 1917.

Similar in structure to the Bermudian plant, but less obviously repent and taller, reaching a height of $1-3 \mathrm{~cm}$.

On Digenea, Thalassia, etc., and on rocks, near the low-water mark, Mariguana, Caicos Islands, and Great Ragged Island:-Bermuda. Type from Bermuda.

4. Ceramium subtile J. Ag. Sp. Alg. 2: 120. 1851.

On Chondria and various other algae, roots of Rhizophora, etc., in shallow water, New Providence, Berry Islands, Great Bahama, Bimini, Joulter's Cay, Exuma Chain, and Watling's Island :-Mexico. Type from Vera Cruz. 
5. Ceramium byssoìdeum Harv. Ner. Bor.-Am. 2: 218. 1853.

Ceramium transversale Collins \& Hervey, Proc. Am. Acad. 53: 145. pl. 5. f. 29-31. 1917.

On various algae, leaves of Cymodocea, roots of Rhizophora, etc., near the lowwater mark, Berry Islands, North Cat Cay, Exuma Chain, and Mariguana :-Bermuda and Florida to the American Virgin Islands. Type from Key West, Florida.

6. Ceramium corniculàtum Mont. Ann. Sci. Nat. Bot. IV. 14: 172.1860.

Gongroceras corniculatum Kütz. Tab. Phyc. 12: 25. pl. 81. f. e-g. 1862.

Under shelving rocks, on roots of Rhizophora, etc., near low-water mark, Rose Island, Bimini, Mariguana, and Calcos Islands:-Florida to Guadeloupe and Martinique. Type from Guadeloupe.

12. CERAMOTHÁMNION Richards, Bull. Torrey Club 28:

257, 264. 1901.

1. Ceramothamnion Còdii Richards, loc. cit. pl. 21, 22. muda.

On Codium intertextum, Atwood Cay:-Bermuda to Barbados. Type from Ber-

\section{CENTRóCERAS Kütz. Linnaea 15: 731, 741. 1842.}

1. Centroceras clavulàtum (Ag.) Mont. in Durieu, F'l. Algérie 1: 140. 1846.

Ceramium clavulatum Ag. in Kunth, Syn. Pl. Aeq. 1: 2. 1822.

Centroceras cryptacanthum Kütz. loc. cit. 741 ; Tab. Phyc. 13: pl. 1\%. $f$. $a-d .1863$.

Centroceras micranthemum Kütz. loc. eit. 741 ; Tab. Phyc. 13: pl. 18. f. $a-d$.

Centroceras hyalacanthum Kütz. loc. cit. 742; Tab. Phyc. 13: pl. 19. f. $d-f$.

Centroceras oxyacanthum Kütz. loc. cit. 742; Tab. Phyc. 13: pl. 20. f. a-c.

Centroceras brachyacanthum Kütz. Tab. Phyc. 13: 8, pl. 20. f. $d-f$.

On rocks and on various algae, low-littoral and in shallow water; very common and variable. Most of the Bahamian specimens accord with Kuitzing's $\boldsymbol{C}$. hyalacanthum and $C$. oxyacanthum; a few agree with his $C$. cryptacanthum (type form of $C$. clavulatum), C. micracanthum, and $C$. brachyacanthum. New Providence, Rose Island, Berry Islands, Great Bahama, Bimini, North Cat Cay, Abaco, Eleuthera, Cat Island, Exuma Chain, Watling's Island, Mariguana, Calcos Islands, Great Ragged Island, and Orange Cay:- Bermuda and Florida to South America; widely distributed in the warmer seas. Type from Callao, Peru.

\section{Family 13. DUMONTIÀCEAE.}

1. DUDRESNAYA Bonnem. Jour. Phys. 94: 180. 1822 (not seen).

1. Dudresnaya bermudénsis Setchell, Univ. California Publ. Bot. 4: 244. pl. 2\%. 1912.

Washed ashore, Great Bahama:-Bermuda. Type from Bermuda.

\section{Family 14. RHIZOPHYLLIDĀCEAE.}

1. OCHTÒdes J. Ag. Act. Univ. Lund. 8 : 5. 1872.

1. Ochtodes secundiràmea (Mont.) M. A. Howe, comb. nov.

Hypnea ? secundiramea Mont. Ann. Sci. Nat. Bot. II. 18: 255. 1842.

Chondrococcus filiformis Kütz. Sp. Alg. 752. 1849; Tab. Phyc. 17: 28. pl. 95. f. c, d, e. 1867.

Sphaerococcus filiformis J. Ag. Sp. Alg. 2: 644. 1852.

Ochtodes filiformis J. Ag. Act. Univ. Lund. $8^{8}: 5.1872$.

Acanthococcus adelphinus Mont.; Crouan in Mazé \& Schramm, Alg. Guad. 189. 1870-1877.

Near low-water mark, commonly iridescent, Cave Cays, Exuma Chain :-Cuba ; Jamaica; Porto Rico; Martinique; and Barbados. Type from Martinique (in herb. Mus. Paris.). 


\section{Family 15. SQUAMARIÀCEAE.}

1. PEYSSONNÈLIA Decaisne, Arch. Mus. 2: 168 (as

Peyssonelitia). 1841.

SquAMaria Zanard. Syn. Alg. Adriat. 133. 1841. Not Squamaria

(Rivin.) Hall. 1768.

1. Peyssonnelia rùbra (Grev.) J. Ag. Sp. Alg. 2: 502.1852.

Zonaria rubra Grev. Trans. Linn. Soc. 15: 340. pl. 3. f. 3. 1827.

On Valonia ventricosa under shelving rocks at low-water mark, Cave Cays, Exuma Chaln :-Bermuda; Cuba; and American Virgin Islands; Mediterranean Sea. Type from Greece.

The genus Peysonnelia is represented by other species in the Bahamas and the family Squamariaceae doubtless has other generic representatives besides Peyssonnelia, but the available material has not yet been studied with sufficient care to warrant the publication of further determinations.

\section{Family 16. CORALLINÀCEAE.}

\section{ARCHAEOLITHOTHÁMNIUM Rothpl. Zeits. Deuts. Geol.}

Ges. 43 : 295.1891.

Sporolithon Heyd. Ber. Deuts. Bot. Ges. 15: 66. 1897.

1. Archaeolithothamnium dimòtum Fosl. \& Howe, Bull. N. Y. Bot. Gard. 4: 128. pl. 80. f. $1 ; p l .8 \% .1906$.

Forming rather smooth crusts on the older parts of living corals, near low-water mark, Mariguana :- Jamaica and Porto Rico. Type from Porto Rico.

2. LITHOTHÁMNIUM Philippi, Wiegm. Archiv Naturgesch. $3^{1}$ : 387. 1837.

Thallus forming smooth, thin, fragile, often ascending, nverlapping, scarcely adherent crusts $0.15-0.2 \mathrm{~mm}$. thick.

Thallus forming an irregularly nodulose crust 10-15 $\mathrm{mm}$. thick.

1. L. mesomorphum ornatum.

2. L. aemulans.

1. Lithothamnium mesomórphum ornàtum Fosl. \& Howe, Bull. N. Y. Bot. Gard. 4: 129. pl. 80. f. 2; pl. 90. f. 2. 1906.

Low-littoral on a deeply shaded rock shelf, yellowish-rose or salmon-colored when living, Cave Cays, Exuma Chain. Type of variety from Cave Cays; type of specles from Bermuda.

2. Lithothamnium aémulans (Fosl. \& Howe) Fosl.\& Howe, K. Norske Vidensk. Selsk. Skr. 1908 : 9. 1908 .

Lithothamnium fruticulosum aemulans Fosl. \& Howe, Bull. N. Y. Bot. Gard. 4: 130. pl. 81. f. 1, 2. 1906.

Encrusting an old conch shell, Andros:-Porto Rico. Type from San Juan, Porto Rico.

3. GONIOLITHON Fosl. K. Norske Vidensk. Selsk. Skr. 19005: 15.1900.

[Apparently not Goniolithon Fosl. loc. cit. 1898²: 5. 1898.]

Thallus wholly and permanently crustaceous.

Thallus commonly rather loosely attached, the margins often free and ascending; conceptacles large, mostly $0.6-1.2 \mathrm{~mm}$. broad, usually with long-rostrate ostioles.

Thallus very firmly and persistently adherent.

Thallus essentially smooth and plane or roughened only by inequalities of substratum or by conceptacles, which are $200-400 \mu$ in diameter.

1. G. solubile.

2. G. accretum. 
Thallus plane or becoming verrucose or mammillate, the surface minutely and irregulariy tessellated; conceptacles $300-400 \mu$ in dlameter.

Thallus with rounded-obtuse or subtruncate warts or bosses 4-10 $\mathrm{mm}$. broad and high; superficial layers exfollating along concentric or zonate lines; conceptacles 1-1.2 $\mathrm{mm}$. in diameter.

Thallus fruticulose, the primary crust usually disappearing or concealed by the erect branches.

Branches much anastomosed, compressed or subterete and 1.25-3.1 $\mathrm{mm}$. In diameter, or becoming flabellate or somewhat follar and $10-25 \mathrm{~mm}$. broad by $1-2 \mathrm{~mm}$. thick.

Branches terete or subterete.

Plants attached, the intertangled frequently anastomosing branches forming rather compact cushions.

Plants commonly free, the branches mostly erect and strict or, in free-lying conditions, few, elongate, and very irregular or somewhat cervicorn.

3. G. Boergesenii.

4. G. dispalatum.

5. G. acropetum.

6. G. decutescens.

7. G. strictum.

1. Goniolithon solùbile Fosl. \& Howe, K. Norske Vidensk. Selsk. Skr. 1907 21. 1907.

Goniolithon Notarisii propinquum Fosl. loc. cit. 18995 : 21. 1900.

Goniolithon propinquum Fosl. loc. cit. $1908^{12}$ : 4. 1908.

Lithophyllum (?) propinquum Lemoine, in Börg. Dansk Bot. Ark. $3^{1}$ : 166. f. 161, 162. 1917.

The name solubile appears to be the first name given to this plant in the specific category, propinquum antedating it as a form name only.

On old corals, coral pebbles, and old shells in shallow water, sometimes covering and smothering living corals of fruticose habit, Rose Island, Great Bahama, Cat Island, Atwood Cay, Mariguana, and Castle Island:-Florida to Barbados. Type from Culebra Island, Porto Rico.

2. Goniolithon accrètum Fosl. \& Howe, Bull. N. Y. Bot. Gard. 4: 131. pl. 85. f. 2; pl. 91.1906.

Lithophyllum accretum Lemoine, in Börg. Dansk Bot. Ark. 3¹: 159. 1917.

On surf-beaten limestone rocks near low-water mark or in tide-pools or on old corals or pebbles. Berry Islands. South Cat Cay, Watling's Island, Mariguana, and Castle Island :-Florlda to American Virgin Islands. Type from Sand's Key, Florida.

3. Goniolithon Boergesénii Fosl. K. Norske Vidensk. Selsk. Skr. $1900^{\circ}$ : 19.1901.

Porolithon Boergesenii Lemoine, in Börg. Dansk Bot. Ark. $3^{1}$ : 178. $f$. 168, 169.1917.

On old shells, corals, and calcareous pebbles in shallow water, Berry Isiands, Mariguana, and Catcos Islands :-Florida to Barbados. Type from St. Croix.

4. Goniolithon dispalàtum Fosl. \& Howe, K. Norske Vidensk. Selsk. Skr. $1908^{12}$ : 6.1908.

On calcareous rocks at low-water mark, Atwood Cay. Type from Atwood Cay.

5. Goniolithon acrópetum Fosl. \& Howe, Bull. Torrey Club 33: 577. 1906.

Lithophyllum acropetum Lemoine, in Börg. Dansk Bot. Ark. $3^{1}$ : 151. 1917.

Sometimes approaching $G$. decutescens and $G$. strictum, which appear to intergrade and forms of which are close to the earlier-published $G$. frutescens of the South Pacific.

On old corals and calcareous rock in shallow water, Cat Island and Salt Cay :Porto Rico. Type from Culebra Island, Porto Rico.

6. Goniolithon decutéscens (Heyd.) Fosl.; M. A. Howe, in Britton, Fl. Bermuda 538. 1918.

Lithothamnium (?) decutescens Heyd. Bot. Jahrb. 28: 541. pl. 11. f. \%. $11 \mathrm{Ja} 1901$.

Goniolithon (?) spectabile Fosl. K. Norske Vidensk. Selsk. Skr. 1900: 16. F 1901. 
? Goniolithon Rhizophorae Fosl. \& Howe, Bull. N. Y. Bot. Gard. 4: 130. pl. 82. f. 2. 1906.

? Goniolithon strictum nanum Flosl. \& Howe, loc. cit. 131. pl. 82. f. 1.

? Lithophyllum strictum nanum Lemoine, in Börg. Dansk Bot. Ark. $3^{1}$ : 164. f. 159, 160. 1917.

On rocks, old corals, shells of (sometimes living) molluscs, etc., in shallow water, common, Rose Island, Berry Islands, Great Bahama, North Cat Cay, South Cat Cay, Eleuthera, Exuma Chain, Watling's Island, Caicos Islands, and Great Ragged Island : - Bermuda and Florida to American Virgin Islands. Type from Bermuda.

7. Goniolithon stríctum Fosl. K. Norske Vidensk. Selsk. Skr. 1900 : 14. 1901.

Goniolithon intermedium Fosl. loc. cit. 15.

Lithophyllum strictum Lemoine, in Börg. Dansk Bot. Ark. 3 ${ }^{1}$ : 164. 1917.

Mostly unattached or forming mats, in shallow water, common, New Providence, Rose Island, Andros, Berry Islands, Biminl, North Cat Cay, Cat Island, Watling's Island, and Mariguana :-Bermuda; Florlda; and Jamaica. Type from Florida.

\section{IITHOPHÝLLUM Philippi, Wiegm. Arehiv Naturgesch.}

$$
3^{1} \text { : } 387.1837 .
$$

Conceptacles $80-160 \mu$ broad, usually abundant; thallus thin $(100-300 \mu$ thick), Its surface nearly smooth or roughened by substratum.

Conceptacles $200-600 \mu$ in diameter.

Thallus thin (mostly 50-600 $\mu$ thick), smooth, forming suborbicular crusts $2-10 \mathrm{~mm}$. broad, epiphytic; vertical section showing small cells in superficial layer only.

Thallus usually thin $(200-500 \mu$; very rarely $5-10 \mathrm{~mm}$. thick); the surface showing imbricate, reniform-auriculate or semiorbicular lamellae; vertical section showing a regular alternation of vertlcally elongate cells and very short flattened or discoid cells; usually on shells, old corals, etc.

Thallus $0.5 \mathrm{~mm} .-6 \mathrm{~cm}$. thick; the surface with densely crowded knobs, verrucae, or short branches; vertical sections showing irregular, often subcrescentlc or sublunate zonations; conceptacles $200-300 \mu$ in diameter, becoming overgrown and included.

1. L. caribaeum.

2. L. pustulatum.

3. L. prototypum.

4. L. munitum.

1. Iithophyllum caribaèum (Fosl.) Fosl. K. Norske Vidensk. Selsk. Skr. 1906: 22. 1907.

Lithophyllum decipiens caribaeum Fosl. loc. cit. 1906²: 18. 1906.

Forming thin white or light pink crusts, on rocks, pebbles, and shells from just above low-water mark down to 15 fathoms (fide Börgesen), Watling's Island and Great Ragged Island:-Jamaica and American Virgin Islands. Type from the West Indies.

2. Lithophyllum pustulàtum (Lamour.) Fosl. K. Norske Vidensk. Selsk. Skr. $1904^{2}$ : 3. 1904.

Melobesia pustulata Lamour. Hist. Polyp. 315. pl. 12. f. 2. 1816.

Dermatolithon pustulatum Fosl. K. Norske Vidensk. Selsk. Skr. 1900: 21. 1900.

On Dilophus, Dictyota, Sargassum, Halimeda and Thalassia, in shallow water, Berry Islands, North Cat Cay, Watling's Island, Atwood Cay, and Little Inagua :New England to Jamalca; Europe. Type from France.

3. Lithophyllum prototỳpum Fosl. K. Norske Vidensk. Selsk. Skr. 1897² 18. 1897.

Dermatolithon (?) prototypus F'osl. loc. cit. $1900^{5}: 22.1900$.

On old corals, shells, etc., near low-water mark or in shallow water, Exuma Chain and Atwood Cay:-Florida; Jamalca; Porto Rico; and American Virgin Islands. Type from St. Croix. 
4. Lithophyllum munitum Fosl. \& Howe, Bull. N. Y. Bot. Gard. 4: 132. pl. 86, 88, 89. 1906.

Covering an old coral near low-water mark under shelving rocks, Cave Cays, Exuma Chain :-Jamaica and Porto Rico. Type from Cave Cays.

\section{POROLITHON Fosl. K. Norske Vidensk. Selsk. Skr.} $1909^{2}$ : 57. 1909.

Vertical sections (of decalcifled material) showing vertical rows of small oval, subglobose, or ellipsoldal perithallic cells, mostly $4-12 \mu \mathrm{hlgh}$, with the firmly coherent horizontal lamellations usually obscure or unrecognizable; grouped heterocysts mostly $13-15 \mu$ broad.

Vertical sections (of decalcified material) showing distinct horizontal lamellations, easily separable in pairs, each pair consisting of one moderately long-celled layer (cells 12-25 $\mu$ high) and one inconsplcuous short-celled layer (cells $3-6 \mu$ high) ; grouped heterocysts mostly $20-26 \mu$ broad.

1. P. pachydermum.

Porolithon pachydérmum (Fosl.) Fosl. loc. cit.

Lithophyllum oncodes pachydermum Fosl. loc. cit. 1904²: 5. 1904.

Lithophyllum pachydermum Fosl. K. Norske Vidensk. Selsk. Aarsber. 1905: 22(6). 1906.

On rocks, corais, corallines, etc., near low-water mark, New Providence, Berry Islands, Great Bahama, South Cat Cay, Atwood Cay, Mariguana, and Great Ragged Island:- Jamaica; Porto Rico; American Virgin Islands; and Barbados. Type from West Indies.

2. Porolithon improcèrum (Fosl. \& Howe) Lemoine; in Börg. Dansk Bot. Ark. $3^{1}: 151 . \quad 1917$.

Goniolithon improcerum Fosl. \& Howe, K. Norske Vidensk. Selsk. Skr. $1907^{6}: 24.1907$.

Hydrolithon improcerum Fosl. loc. cit. 1909² : 55. 1909.

On old corals or calcareous rocks, near low-water mark.

The basis for recording this species from the Bahamas is a note from M. Foslie (in litt.) to the effect that a specimen of Goniolithon propinquum $(=G$. solubile $)$ from Mariguana (Howe 5336) was "partly covering Goniolithon (Hydrolithon) improcerum." In the type (from Jamaica), the species accompanied Porolithon pachydermum, which it resembles in habit. In structure the plant is suggestive of Lithophyllum prototypum, from which, however, it differs in the presence of heterocysts (in groups) as well as in general habit and in the mostly smaller conceptacles.

\section{FOSLIÉrLA M. A. Howe, nom. nov.}

Type: Melobesia farinosa Lamour. Hist. Polyp. 315. pl. 12. f. 3. 1816. MELOBESIA, subgen. Eu MELOBESIA Fosl.K. Norske Vidensk. Selsk. Skr. 1905³ : 1905. Melobesia Lamour. p. p. min. Hist. Polyp. 313. 1816. Not Melobesia Lamour.

Nouv. Bull. Sei. Soc. Philom. 3: 186. 1812 (type, Corallina membranacea Esper).

Thallus 1-3 cells thick.

Heterocysts present; growing on other algae.

Heterocysts wanting; growing on Thalassia.

Thallus mostly 8-10 cells thick except at or near the unistratose margin; growing on Chamaedoris.

1. F. farinosa.

2. F. Lejolisii.

3. F. Chamaedoris.

1. Fosliella farinòsa (Lamour.) M. A. Howe, comb. nov.

Melobesia farinosa Lamour. Hist. Polyp. 315. pl. 12. f. 3. 1816.

On various algae (Dictyota, Dilophus, Padina, Sargassum, and Polysiphonia), in shallow water, very common, Rose Island, Berry Islands, Watling's Island, Mariguana, and Little Inagua :-Massachusetts to Barbados; widely distributed. Type European. 
2. Fosliella Lejolisii (Rosan.) M. A. Howe, comb. nov.

Melobesia Lejolisii Rosan. Mém. Soc. Imp. Sci. Nat. Cherbourg 12: 62. pl. 1. f. 1-13. 1866.

On Thalassia in shallow water, Berry Islands and Watling's Island :-Nova Scotia to Florida; Europe. Type from Cherbourg, France.

3. Fosliella Chamaedòris (Fosl. \& Howe) M. A. Howe, comb. nov.

Lithophyllum Chamaedoris Fosl. \& Howe, Bull. N. Y. Bot. Gard. 4: 134. pl. 90. f. 1.1906.

Melobesia (Pliostroma) Chamaedoris Fosl. \& Howe, K. Norske Vidensk. Selsk. Skr. 1908 ${ }^{11}$ : 6. 1908.

Encrusting and often completely encircling the stalks of Chamaedoris Peniculum, from low-water mark (under shelving locks) down to a depth of 40 meters (fide Börgesen), Cave Cays, Exuma Chain:-American Virgin Islands. Type from Cave Cays.

7. AMPHIRòA Lamour. Nouv. Bull. Sci. Soc. Philom. 3: 186. 1812.

Thallus usually distinctly flattened, 1-3 $\mathrm{mm}$. broad, the branches $2-5$ at a node, often patent or arcuate-deflexed. Thallus terete or subterete, $0.15-1.4 \mathrm{~mm}$. in diameter.

Thallus $0.15-0.6 \mathrm{~mm}$. in diameter, usually yellowish or pale rose when living, commonly dichotomous (rarely 3-5 branches at a node); nodes at the dichotomies, the nodal cushions conspicuous, often protuberant or their diameter equaling that of the segment, which is often enlarged at the nodes.

Thallus $0.45-1.4 \mathrm{~mm}$. in diameter, bluish-violet when living; nodes mostly above the dichotomles, often obscure or more or less deficient, the nodal cushions short and their diameter $1 / 2-4 / 5$ that of the segments.

1. A. Tribulus.

2. A. fragilissima.

3. A. rigida antillana.

1. Amphiroa Tríbulus (Ell. \& Soland.) Lamour. loc. eit.

Corallina Tribulus Ell. \& Soland. Nat. Hist. Zooph. 124. pl. 21. f. e. 1786.

In shallow water, South Cat Cay and Watling's Island:-Cuba and Porto Rico. Type from the West Indies.

\section{Amphiroa fragilíssima (L.) Lamour. Hist. Polyp. 298. 1816.}

Corallina fragilissima L. Syst. Nat. 1: 806. 1758 [ed. 10].

Amphiroa debilis Kütz. Sp. Alg. 700. 1849.

Variable as to diameter of the segments and in the presence or absence of nodal enlargements of the segments, and possibly including two spcies. Whether Linnaeus originally described the species from an actual specimen or relied wholly upon Sloane's description and figure of a Jamaican plant is not altogether clear.

Forming mats, especially in association with Thalassia and Cymodocea in shallow bays, common, New Providence, Berry Islands, Bimini, South Cat Cay, North Cat Cay, Watling's Island. Atwood Cay, and Mariguana:-Bermuda and Florida to Barbados ; East Indies. Type "in Indiis" (Jamalca ?).

3. Amphiroa rígida antillàna Börg. Dansk Bot. Ark. $3^{1}$ : 182. f. 171-173. 1917.

In shallow water, often with A. fragilissima, but always distinct, South Cat Cay, North Cat Cay, and Mariguana :-Florida to Barbados. Type (of var.) from St. Croix.

\section{CORALIiNA L. Syst. Nat. 1: 805. 1758 [ed. 10].}

Rather vaguely and irregularly pinnate or subverticllate, the branches often few; segments of maln axes terete or subterete, 1.5-6 times as long as broad.

Pinnate or bipinnate, the rapidly tapering branchlets somewhat peniclilate or fasciculate; segments of main axes distinctly flattened, cuneate-obovate, or inversely deltoid, about as broad as long.

1. C. cubensis.

2. C. subulata. 
1. Corallina cubénsis (Mont.) Kütz. Tab. Phyc. 8: 37. pl. 7\%. f. c, e, f. 1858.

Jania cubensis Mont.; Kütz. Sp. Alg. 709. 1849.

Forming dense cushions on various aigae (Sargassum, Galaxaura, Digenea, etc.) and on rocks with other algae, in shallow water, often associated with species of Jania, New Providence, Berry Islands, Great Bahama, Gun Cay, Caicos Islands, and Great Ragged Island:-Florida to the American Virgin Islands. Type from Cuba.

2. Corallina subulàta Ell. \& Soland. Nat. Hist. Zooph. 119. pl. 21. f. B, b. 1786. On or with Amansia multifida, Eleuthera:-Brazil. Type from the West Indies.

9. JÀNIA Lamour. Nouv. Bull. Sci. Soc. Philom. 3: 186. 1812.

The characters relied upon to distinguish the currently recognized European and West Indian species of Jania appear to be unstable and unsatisfactory and the determinations often arbitrary.

Branches mostiy strict and fastigiate, mostly $100-160 \mu$ in diameter, the terminal segments usually acute or taper-pointed.

Dichotomies mostiy wide-angled, the branches often subdivaricate, recurved, and interwoven, the terminal segments usually obtuse.

Segments mostly 90-150 $\mu$ in diameter and 2-4 times as long as broad.

Segments mostly 50-100 $\mu$ in diameter and 4-10 times as long as broad.

1. J. rubens.

2. J. adhaerens.

3. J. capillacea.

1. Jania rùbens (L.) Lamour. loc. cit.

Corallina rubens L. Syst. Nat. 1: 806. 1758 [ed. 10].

On Sargassum, Chondria, and other algae, from low-water mark down to a depth of 10-20 meters, Rose Island, Great Bahama, Exuma Chain, Watling's Island, Caicos Isiands, and Great Ragged Island:-Bermuda ; Florida ; Cuba ; and probably throughout the West Indies. Type European.

2. Jania adhaèrens Lamour. Hist. Polyp. 270. 1816.

Corallina adhaerens Kütz. Tab. Phyc. 8: 40. pl. 83. f. $d, f, g, h .1858$.

On Sargassum, Bryothamnion, Gelidium, etc., in shallow water :-American Virgin Isiands; Red Sea; Japan. Type from the Mediterranean Sea (?).

3. Jania capillacea Harv. Ner. Bor.-Am. 2: 84. 1853.

On Sargassum, pneumatophores of Avicennia, etc., in shallow water, and more or less free in lagoons, New Providence, Rose Island, Berry Islands, and Great Ragged Island :- North Carolina and Florida. Type from Bahia Honda, Florida.

\section{SUb-Class PHAEOPHYCEAE.}

\section{Family 1. ECTOCARPÀCEAE.}

1. PYLAIÉluA Bory, Dict. Class. Hist. Nat. 4: 393 (as Pilayella). 1823.

1. Pylaiella Antillàrum (Grun.) De-Toni, Syll. Alg. 3: 535. 1895.

Ectocarpus (Pilayella) Antillarum Grun. Reise Novara Bot. 1: 46. pl. 4. f. 2. 1867.

Pylaiella sp. Bornet, Rev. Gen. Bot. 1: 9. 1889.

Pylaiella Hooperi De-Toni, Syll. Alg. 3: 537. 1895. Probably not Ectocarpus Hooperi Harv. Ner. Bor.-Am. 1: 143. pl. 12E. 1852.

Forming yellowish brown, subcylindric, wick-like tufts, $1.5-3.5 \mathrm{~cm}$. high in tidepoois and low-littoral on surf-beaten rocks. Great Stirrup Cay, Berry Isiands :Bermuda to northern South America. Type from Guadeloupe. 
The flaments are mostly $25-40 \mu$ in diam., whlle Grunow's description of the type makes the diameter only $11-25 \mu$, but as the base of one of the filaments figured by Grunow is nearly $35 \mu$ broad it seems difficult to distinguish the Bahamlan plant. The later-described $P$. fulvescens (Schousb.) Bornet may be a synonym, but perhaps differs in the more protuberant, sometimes laterally geminate sporangla.

\section{ECTOCÁRPUS Lyngb. Hydroph. Dan. 130. 1819.}

1. Ectocarpus Mitchéllae Harv. Ner. Bor.-Am. 1: 142. pl. 12G. 1852.

On Thalassia, etc., in shallow water. Berry Islands, Great Bahama, and Exuma Chain :-Massachusetts to American Virgin Islands; apparently widely distributed in temperate and tropical seas. Type from Nantucket, Mass.

\section{Family 2. SPHACELARIÀCEAE.}

1. SPHACELÀRIA Lyngb. Hydroph. Dan. 103 p.p. 1819.

1. Sphacelaria tribuloìdes Menegh. Lett. al Corinaldi 2. 1840. [Not seen.]

Low-littoral. Berry Islands :-Bermuda to Mexico and Barbados; widely distributed in the warmer seas. Type from Italy.

\section{Family 3. ENCOELIĀCEAAE.}

1. PHAEOSTRÒMA Kuckuck, in Reinbold, Schrift. Naturwiss. Ver. Schleswig-Holst. 10: 43. 1893.

1. Phaeostroma pusillum Howe \& Hoyt, Mem. N. Y. Bot. Gard. 6: 109. pl. 11. f. $1-9.1916$.

Making minute discs, $0.15-0.35 \mathrm{~mm}$. in diameter, on Polysiphonia ferulacea; the unilocular sporangia mostly in sori. Berry Islands :- North Carolina (type).

2. COLPOMÈnIA (Endi.) Derb. \& Sol. Mém. Phys. Alg. 11.1856.

1. Colpomenia sinuòsa (Roth) Derb. \& Sol. loc. cit. [C. sinuata by misprint.]

Ulva sinuosa Roth, Cat. Bot. 3: 327. pl. 12. 1806.

Encoelium sinuosum Ag. Sp. Alg. 1: 146. 1820.

Asperococcus sinuosus Bory, Expéd. Sci. Morée 32: 326. 1832.

Hydroclathrus sinuosus Zanard.; Mitchell, in Murray, Phyc. Mem. 53-56. pl. 14. pl. 15. f. 1. 1893.

On rocks near low-water mark or in shallow water. Gun Cay :-Bermuda and Florida to Brazil; Peru; widely distributed in warm-temperate and tropical seas. Type from near Cadiz, Spain.

3. HYDROCLÁTHRUS Boø, Dict. Class. Hist. Nat. 8: 419.1825.

1. Hydroclathrus clathràtus (Bory) M. A. Howe, comb. nov.

Encoelium clathratum (Bory) Ag. Sp. Alg. 1: 412. 1822.

Hydroclathrus cancellatus Bory, Dict. Class. Hist. Nat. 8: 419. 1825.

Stilophora clathrata Ag. Flora 10: 642. 1827.

Asperococcus clathratus J. Ag. Sp. Alg. 1: 75. 1848.

On rocks near low-water mark or in shallow water. Gun Cay and North Cat Cay :-Bermuda and Florida to Brazil; widely distributed in warm-temperate and tropical seas. Type from Belle Isle, France. 


\section{Family 4. MESOGLOIÀCEAE.}

1. CAstàgneA Derb. \& Sol. Mém. Phys. Alg. 56. 1856.

1. ? Castagnea Zósterae (Mohr) Thuret; Le Jol. Liste Mar. Alg. Cherbourg 85. 1864.

Rivularia Zosterae Mohr, in Weber, Beitr. Naturkunde 2: 367. 1810.

Mesogloia Zosterae Aresch. Linnaea 16: 228. pl. 8. f. 1a, b. 1842.

On Thalassia, etc., Berry Islands and North Cat Cay:-Bermuda to American Virgin Islands; Europe. Type from near Kiel, Germany.

\section{Family 5. CUTLERIÀCEAE.}

1. AGLAOZÒnIA Zanard. Saggio Class. Fic. 15, 38. [Mr] 1843.

PAdinella Aresch. Linnaea 17: 259. [My-Je] 1843.

1. Aglaozonia canariénsis Sauv. Soc. Sci. d'Arcachon Trav. Lab. 8: 79.1905. Börg. Dansk Bot. Ark. 2: 37. 1914.

Forming dark brown closely adherent crusts on calcareous rocks or old corals at low-water mark or a little above. New Providence, Rose Island, Atwood Cay, Mariguana, and Caicos Islands:-American Virgin Islands; Canary Islands. Type from the Canary Islands.

This plant (sterile) bears much resemblance to young prostrate conditions of Zonaria variegata in habit and color, in the apical margin of large cells, and in general structure, but seems to differ in the usually thinner and more closely adherent thallus, the absence of frequent or occasional mats or tufts of brown rhizolds, and, under the compound microscope, in the more translucent thallus with a more obviously tessellated dorsal surface, 4-16 cells of the dorsal epidermis corresponding to one of the large medullary cells, while in $Z$. variegata $1-4$ (more elongate) epidermal cells correspond to and overlie a single large medullary cell; and, in section, the dorso-ventrality is seen to be more pronounced, the dorsal epidermis always consisting of more numerous and smaller cells than the ventral epldermis, while in $Z$. variegata the two epidermal layers are essentially the same.

\section{Family 6. FUCÀCEAE.}

1. CYSTOSEIRA Ag. Sp. Alg. 1: 50. 1820.

1. Cystoseira Myrica (S. G. Gmel.) Ag. loc. cit. 53.

Fucus Myrica S. G. Gmel. Hist. Fuc. 88. pl. 3. f. 1. 1768.

On rocks and in tide-pools, near low-water mark. New Providence, Rose Island, Berry Islands, Great Bahama, and Gun Cay:-Florida and the Red Sea. Type locality unknown.

\section{TURBINÀrIA Lamour.; Bory, Voy. Coquille 116. 1828.}

Petiole wings entire, the lamina usually with vesicle. Petiole wings dentate, the lamina without vesicle.
1. T. turbinata.

2. T. tricostata.

1. Turbinaria turbinàta (L.) Kuntze, Rev. Gen. Pl. 3: 434. 1898.

Fucus turbinatus L. Sp. Pl. 1160. 1753. (Excluding presumably spurious

"type" from Sumatra in herb. Linn.).

Sargassum turbinatum Ag. Sp. Alg. 1: 41. 1820.

Turbinaria vulgaris trialata J. Ag. Sp. Alg. 1: 268. 1848.

Turbinaria trialata Kütz. Tab. Phyc., 10: 24. pl. 67. 1860.

On surge-swept rocks, near low-water mark. New Providence, Joulter's Cay, Berry Islands, Great Bahama, Abaco, George Island, Watling's Island, Atwood Cay, Caicos Islands, Great Ragged Island, and Anguilla Isles :-Florida to northern South America; Indian Ocean. Type from Jamaica. 
2. Turbinaria tricostàta Barton, Trans. Linn. Soc. Bot. II. 3: 218. pl. 54. f. 3. 1891.

On surge-swept rocks, low-1ittoral. New Providence, South Cat Cay, and Gun Cay :-Bermuda to Guadeloupe. Type from Guadeloupe (?). Apparently intergrading with $T$. turbinata.

\section{SARGÁSSUM Ag. Sp. Alg. 1: 1. 1820.}

Floating and sterile.

Leaves very narrowly linear or linear-fillform, mostly 1-2 mm. broad, the teeth aculeate-acuminate; vesicles commonly aristate-aplculate.

Leaves linear or linear-lanceolate, mostly 2-4 mm. broad, the teeth triangular-acuminate; vesicles muticous.

Normally attached (nos. 3 and 10 sometlmes more or less pelagic).

Leaves mostly narrowiy linear, usually $7-50$ times as long as maximum width.

Leaves rather rigid, cryptostomata usually somewhat obscure, pedicels of the muticous vesicles commonly shorter than the vesicles themselves; receptacles in rather short axillary clusters.

Leaves serrate-dentate, the costa prominent and often dentate; vesicles commonly large and crowded; stems often 1-2 m. long and subsimple.

Leaves subentire, the costa not dentate; vesicles usually scattered; stems mostly 2-10 dm. long.

Leaves thinly membranous, cryptostomata obvious, pedicels of the often appendaged usually scattered vesicles commonly of about the same length as the vesicles themselves; receptacles finally elongate and often forming a kind of loose terminal panicle through reduction of the leaves.

Leaves ovate, ovate-elliptic, oblong, lanceolate, or rather broadly linear.

Cryptostomata elevated, very large and conspicuous (0.6-0.9 $\mathrm{mm}$. In maximum diam.) often elliptic, in a single series on elther slde of the costa; leaves linear or lanceolate.

Cryptostomata smaller, sometimes obscure or wanting. Cryptostomata obvious.

Receptacles mostly in a rather dense terminal panicle; leaves lanceolate or linear-oblong, rather obscurely and obtusely dentate or margins merely sinuate, cryptostomata in almost a single series on either side of the costa; vesicles sometimes few.

Receptacles obviously lateral and axillary, elongate or contracted; cryptostomata in more than a single series.

Leaves llnear or linear-oblong, mostly 4-8 times as long as broad, sharply serratedentate; vesicles mostly ellipsoid or obovold, often subaplculate: receptacles contracted, often ( $($ ?) spinose-dentate.

Leaves ovate, elliptlc, oblong, or lanceolate, mostly 2-4 times as long as broad, commonly crisped, variously aculeate-dentate or Ilex-toothed; vesicles globose or subglobose, mutlcous ; receptacles sometimes elongate, occasionally with a few subsplnescent processes.

Cryptostomata obscure or wanting; leaves coriaceous, oblong-elliptic, spinescent-dentate or entire or sub-entire; receptacles more or less spinescent-dentate.

1. S. natans.

2. S. fluitans.

3. S. pteropleuron.

4. S. сутовит.

5. S. Filipendula.

6. S. platycarpum.

7. S. lendigerum.

8. S. vulgare?

9. $\$$ polyceratium.

10. S. Hystrix.

1. Sargassum nàtans (L.) Meyen, Wiegm. Arch. Naturgesch. $4^{2}: 185.1838$.

Fucus natans L. Sp. Pl. 1160. 1753.

Fucus Sargasso S. G. Gmel. Hist. Fuc. 92. 1768.

Fucus bacciferus Turn. Hist. Fuc. 1: 105. pl. 4\%. 1808.

Sargassum bacciferum Ag. Sp. Alg. 1: 6. 1820.

The chief ingredlent of the "Sargasso Sea "-found floating or washed ashore throughout the archipelago. 
2. Sargassum flùitans (Börg.) Börg. Dansk Bot. Ark. 2²: 66. 1914.

Sargassum Hystrix fluitans Börg. Mindeskr. for Japetus Steenstrup 32: 11. 1914.

Often associated with S. natans. New Providence, Rose Island, Great Bahama, Cat Island, and Watling's Island.

3. Sargassum pteropleùron Grun. Reise Novara Bot. 1: 55. pl. 5. f. 1. 1867.

In 1-3 meters of water, often detached and floating. New Providence, Rose Island, Berry Islands, Andros, Joulter's Cay, Great Bahama, Green Cay, Exuma Chain, Watling's Island, Caicos Islands, and Orange Cay:-Bermuda and Florida. Type from New Providence.

4. Sargassum cymòsum Ag. Sp. Alg. 1: 20. 1820.

Sargassum stenophyllum (Mert.) Mart. Ic. Pl. Crypt. 8. pl. 5. 1828.

Sargassum ramifolium Kütz. Phyc. Gen. 362. 1843.

Sargassum rigidulum Kütz. Sp. Alg. 615. 1849.

In shallow water and floating. Great Bahama, Exuma Chain, and Cat Island:Bermuda to Brazil. Type from Brazil.

5. Sargassum Filipéndula Ag. Syst. Alg. 300. 1824.

Sargassum Montagnei Bail.; Harv. Ner. Bor.-Am. 1: 58. pl. 1A. 1852.

Sargassum Filipendula Montagnei Collins \& Hervey, Proc. Am. Acad. 53: 83. 1917.

Apparently rare in the Bahamas, its place being taken by $S_{\text {. pteropleuron. }}$ New Providence and Orange Cay:-Massachusetts and Bermuda to South America. Type from the Gulf of Mexico (?).

6. Sargassum platycárpum Mont. Sci. Nat: Bot. II. 18: 248. 1842.

Carpacanthus platycarpus Kütz. Sp. Alg. 623. 1849.

In shallow water. New Providence, Berry Islands, Great Bahama, South Cat Cay, and Exuma Chain :-Cuba, Jamaica, Porto Rico, and Martinique. Type from Martinique.

The most sharpiy defined species of Sargassum of the West Indian region, rather constant in the form of its leaves and easily Identified by its very large elevated cryptostomata in a single series on each side of the costa.

7. Sargassum lendígerum (L.) Ag. Sp. Alg. 1: 9. 1820.

Fucus lendigerus L. Sp. Pl. 1160. 1753.

Near low-water mark. Berry Islands:-Bermuda to St. Thomas. Type from Ascension Island.

\section{8. ? Sargassum vulgàre Ag. Sp. Alg. 1: 3. 1820.}

Fucus natans Turn. Hist. Fuc. 1: 99. pl. 46. 1808. Not F. natans L.

Near low-water mark. Andros, Great Bahama, Abaco, Watling's Island, Atwood Cay, Mariguana, Caicos Islands, Little Inagua, and Castle Island:-Supposed to be widely distributed in warm-temperate and tropical seas. Type locality unknown.

The plants that are now placed provisionally and doubtfully under $S$. vulgare form a rather homogeneous group and are apparently different in species from the more diversified assemblage here grouped under $S$. polyceratium. They differ from Turner's figure $a$, which seems to have furnished the type idea for $s$. vulgare, in their more virgate habit, their somewhat smaller (both shorter and narrower), more sharply serrate and less sinuate-dentate leaves, and their shorter, probably more spinose-dentate receptacles.

9. Sargassum polyceràtium Mont. Ann. Sci. Nat. Bot. II. 8: 356. 1837; Pl. Cell. Cuba 72. pl. 1. 1842.

Fucus foliosissimus Lamour. Essai 16. pl. 1. f. 1. 1813. (Nomen nudum aut seminudum.)

Sargassum leptocarpum Kütz. Phyc. Gen. 362. 1843. 
Sargassum pteropus Kütz. Sp. Alg. 608. 1849.

Sargassum bahiense Kütz. loc. cit.

Sargassum trachyphyllum Kütz. loc. cit. 609.

Sargassum polyphyllum Kütz. loc. cit. Not S. polyphyllum J. Ag. Sp. Alg. 1: 308. 1848.

Carpacanthus polyceratius Kütz. loc. cit. 624 .

Carpacanthus spinulosus Kütz. Tab. Phyc. 11: 15. pl. 46 f. II. 1861.

At low-water mark and in shallow water. New Providence, Rose Island, Great Bahama, North Cat Cay, Watling's Island, Caicos Islands, and Castle Island :-West Indies in general. Type from Cuba.

The species, as here conceived, shows great variability in form, size, and texture of the leaves, in the size and number of the cryptostomata, in smoothness or roughness of the stem, and in the presence or absence of spines on the receptacles, but specific segregations seem impossible.

10. Sargassum Hýstrix J. Ag. Öfv. K. Vet.-Akad. Förh. 4: 7. 1847.

Sargassum Hystrix buxifolium (Chauv.) J. Ag. Sp. Alg. 1: 322. 1848.

Usually found floating or washed ashore, but also attached, in about $3 \mathrm{~m}$. of water. New Providence, Joulter's Cay, Abaco, Berry Islands, and Exuma Chain :off North Carolina, Isle of Pines, and Mexico. Type from the Campeche Banks.

A form with large oblong entire or subentire leaves is var. buxifolium.

\section{Family 7. DICTYOTÀCEAE.}

1. ZONĀrIA Drap.; Ag. Syn. Alg. Scand. xx. .1817.

STYPopodiUm Kütz. Linnaea 17: 97. 1843.

PHYCOPTERIS Kütz. loc. cit.

Gymnosonus J. Ag. Anal. Alg. Cont. 1: 9. 1894. Not Gymnosorus Trevis.

Alg. Coce. 108. 1848.

Thallus obscurely zonate, brownish both when living and on drying, $2-7 \mathrm{~cm}$. long, at first more or less prostrate or subrepent and semiorbicular or flabelliform, later free except at the broad or occasionally substipitate base and showing few entire or sparingly laciniate flabelliform lobes.

Thallus distinctly zonate, more or less brownish blue-green and iridescent when living, commoniy blackening on drying, mostly 7-30 cm. Iong, erect, stipitate or substipitate, repeatedly cleft or lobed, the lobes cuneate, cuneate-oblong, cuneate-flabelliform, or linear, occasionally lacerate or fimbriate-laciniate.

1. Z.variegata.

1. Zonaria variegàta (Lamour.) Ag. loc. cit.

Dictyota variegata Lamour. Nouv. Bull. Sci. Soc. Philom. 1: 331. 1809.

Zonaria collaris Ag. Sp. Alg. 127. 1820.

Padina variegata Gaill. in Dict. Sci. Nat. 53: 371. 1828.

Spatoglossum variegatum Kütz. Sp. Alg. 560. 1849.

Gymnosorus variegatus J. Ag. Anal. Alg. Cont. 1: 11.1894.

Gymnosorus collaris J. Ag. loc. cit.

On calcareous algae, rocks, old corals, Gorgonildae, roots of Rhizophora, shells of conchs, etc., common from low-water mark down to a depth of several meters: often found washed ashore. New Providence, Rose Island, Andros, Berry Islands, Great Bahama, Gun Cay, Abaco, Green Cay, Exuma Chain, Watling's Island, Atwood Cay, Mariguana, Caicos Islands, and Great Ragged Island:-Bermuda and Florida to Brazil; Canary Islands; Philippines; widely distributed in the warmer seas. Type from the "Antilles." Prostrate or subrepent forms are to be distinguished carefully from Aglaozonia canariensis.

2. Zonaria zonàlis (Lamour.) M. A. Howe, in Britton, Fl. Bermuda 507. 1918. Fucus zonalis Lamour. Diss. 38. pl. 25. $f$. 1. 1805.

Dictyota zonata Lamour. Nouv. Bull. Sci. Soc. Philom. 1: 331. 1809.

Zonaria lobata Ag. Syst. Alg. 265. 1824.

Stypopodium lobatum Kütz. Tab. Phyc. 9: 25. pl. 63. f. I. 1859.

On rocks, etc., in shallow water, in moderately exposed positions. New Providence, Berry Islands, South Bimini, Gun Cay, Exuma Chain, and Atwood Cay; Bermuda to Brazil ; Canary Islands. Type from Santo Domingo. 
2. PADINA Adans. Fam. P1. 2: 13. 1763.

Thallus consisting of only two layers of cells except near base; tetrasporic sori just above every second piliferous line and provided with evanescent induslum.

Thallus consisting of 3-6 layers of cells except at sometimes blstratose apical margin; tetrasporic sori scattered irregularly or forming an irregular confluent line near middle of each interpllar zone, indusium subpersistent.

1. P. Sanctae-Crucis.

2. P. Vickersiae.

1. Padina Sánctae-Crùcis Börg. Dansk Bot. Ark. 2²: 45. f. 2\%, 28. 1914.

Common on rocks near the low-water mark. New Providence, Berry Islands, Gun Cay, Exuma Chain, Crooked Island, Watling's Island, Mariguana, Calcos Islands, Great Ragged Island, Orange Cay, and Anguilla Isles:-Bermuda and Florida to northern South America. Type from St. Croix.

\section{Padina Vickérsiae Hoyt, sp. nov.*}

Spatoglossum variegatum Kütz. Sp. Alg. 560 p.p. 1849.

Zonaria variegata Kütz. Tab. Phyc. 9: 30 p.p. pl. 73. f. II. 1859. Not Zonaria variegata Lamour. Nouv. Bull. Sci. Soc. Philom. 1: 331. 1809.

Padina variegata Hauck, Hedwigia 26: 42. 1887; Vickers, Phyc. Barb. 2: 37. pl. 8. 1908. Not Padina variegata Gaill. in Dict. Sci. Nat. 53: 371. 1828.

Thallus stipitate, 4-22 cm. tall, 5-37 cm. broad, entire when young, becoming repeatedly more or less deeply laciniate, the segments varying from cuneatespatulate to fan-shaped, sometimes encrusted with lime, the interpilar zones 1.5-8 $\mathrm{mm}$. wide, often ineonspicuous in older parts, the subterete, rhizoidcovered stipe commonly 3-12 mm. long; lamina of 2 or 3 layers of cells at revolute apical margin, of 4 layers throughout most of thallus, becoming 6-8 layers toward base; epidermal cells about one half as long as the central cells; dioicous; antheridia and oogonia in often broken lines near the middle of each interpilar zone, occurring on both surfaces but chiefly on the ventral, the oogonia with a thin evanescent indusium, the antheridia naked; tetrasporangia borne in a similar manner, often in scattered irregular sori near middle of interpilar zone, the thin indusium commonly subpersistent.

Type a tétrasporic plant collected from Fort Macon jetty, Beaufort, North Carolina, by W. D. Hoyt, August 23, 1907, and deposited in the U. S. National Herbarium. Representatives of this species have often been erroneously identified with Padina pavonia (L.) Gaill. and P. Durvillaei Bory. Padina dubia Hauck, from East Africa, is a much closer relative and may prove to be identical.

In shallow water. New Providence, Berry Islands, and Eleuthera:-Bermuda and North Carolina to Brazil. Type from North Carolina.

3. NEUROCÁRPUS Web. \& Mohr, Beitr. Naturk. 1: 300 (242-246). 1805.

Dictropteris Lamour. Nouv. Bull. Sci. Soc. Philom. 1: 332. My 1809.

Polypodoidea Stackh. Mém. Soc. Imp. Nat. Moscou 2: 96, 97. 1809.

HALISERIS (Mich.) Ag. Sp. Alg. 1: 141. 1820.

1. Neurocarpus Jústii (Lamour.) Kuntze, Rev. Gen. P1. 2: 907. 1891.

Dictyopteris Justii Lamour. Nouv. Bull. Sci. Soc. Philom. 1: 332. pl. 6. f. 2A. 1809 .

Haliseris Justii Ag. Sp. Alg. 1: 142. 1820.

On rocks in 1-20 meters of water. Gun Cay, Abaco, and Green Turtle Cay :Bermuda and Florida to Barbados. Type from Santo Domingo.

Neurocarpus delicatulus (Lamour.) Kuntze is of general occurrence in the West Indian region and is to be expected in the Bahamas. It is a much smaller and more delicate plant than $N$. Justii, the thallus segments being mostly only 1-4 mm. broad, while in $N$. Justii they are $1-3 \mathrm{~cm}$. broad; when living it commonly shows beautifully iridescent blue-green hues. It grows in sheltered and well-shaded places.

* This preliminary diagnosis is published with the permission of the U. S. Com. missioner of Fisherles. 
4. DICTYÒtA Lamour. Nouv. Bull. Sei. Soc. Philom. 1: 331. My 1809. Jour. de Bot. 2: 38. 1809.

Branching more or less regularly dichotomous.

Segments mostly 1-5 $\mathrm{mm}$. broad, the apical obtuse, patent or suberect.

Segments linear, the dichotomies usually $1-2 \mathrm{~cm}$. apart.

Segments oblong, the dichotomies usually $0.5-1 \mathrm{~cm}$. apart.

Segments mostly $0.3-1 \mathrm{~mm}$. broad, the apical acute, acuminate or subobtuse, divaricate or subdivaricate.

Branching dichotomo-pinnatifid or cervicorn.

Branching cervicorn, or dichotomo-subpinnate below and dichotomous above; segments narrowly ribbon-shaped, mostly $0.5-1 \mathrm{~mm}$. broad, often proliferous along the middle, the apical segments acute or subobtuse, sometimes subterete or subconic, mostly patent.

Branching dichotomo-pinnatifid, main segments or axes mostly $2-5 \mathrm{~mm}$. broad, the apices usually acuminate, sometimes obtuse.

1. D. dichotoma.

2. D. Bartayresii.

3. D. divaricata.

4. D. cervicornis.

5. D. dentata.

1. Dictyota dichótoma (Huds.) Lamour. Nouv. Bull. Sci. Soc. Philom. 1: 331. My 1809.

Ulva dichotoma Huds. Fl. Angl. 476. 1762.

From near low-water mark down to a depth of several meters. Rose Isiand, Berry Islands, Bimini, Exuma Chain, Watling's Island, Atwood Cay, Mariguana, Caicos Islands, and Great Ragged Island :-Bermuda, North Carolina, Florida and West Indies; widely distributed in temperate and tropical seas. Type from Isle of Wainey, England.

2. Dictyota Bartayrèsii Lamour. loc. cit.

Dictyota Bartayresiana Lamour. Jour. de Bot. 2: 43.1809.

Dictyota patens J. Ag. Till Alg. Syst. 2: 93.1882.

Common, mostly in shallow water, often slightiy iridescent when living. New Providence, Rose Island, Berry Islands, South Cat Cay, North Cat Cay, Eleuthera, Watling's Island, Atwood Cay, Mariguana, Caicos Islands, and Great Ragged Island :West Indies. Type from Santo Domingo (?).

The type specimen (in "Zonaria dichotoma" cover in herb. Lamour. at Caen) has segments $2-5 \mathrm{~mm}$. broad and obtuse apices. Specimens with acute and acuminate apices referred to this species by later writers are to be looked upon as probably representing the more dichotomous or less pinnate conditions of D. dentata.

3. Dictyota divaricàta Lamour. loc. cit.

In shallow water. New Providence, Berry Islands, Great Bahama, North Cat Cay, Exuma Chain, and Caicos Islands:-West Indies and warmer seas generally. Type from the Mediterranean.

Apparently intergrades with $D$. cervicornis, $D$. indica, and $D$. Bartayresii.

4. Dictyota cervicórnis Kütz. Tab. Phyc. 9: 11. pl. 24. f. II. 1859.

Dictyota Fasciola Harv. Ner. Bor.-Am. 1: 108. pl. 8 B. 1852. Not Fucus Fasciola Roth (= Dilophus repens J. Ag.).

On rocks near low-water mark in rather exposed situations. New Providence, Rose Island, Berry Islands, Great Bahama, Gun Cay, Exuma Chain, Mariguana, Caicos Islands, and Little Inagua:-Bermuda, Florida, and probably West Indies in general. Type from Key West, Florida.

Often proliferous near the middle line of thallus and easily confused with Dilophus guineensis which is rather similar both in general habit and in tendency to proliferate.

5. Dictyota dentàta Lamour. Nouv. Bull. Sci. Soc. Philom. 1: 331. My 1809.

Fucus atomarius S. G. Gmel. Hist. Fuc. 125. pl. 10. f. 1. 1768. Not D. Atomaria Grev. Not Dictyota Atomaria Hauck.

Ulva Mertensii Mart. Fl. Bras. Acot. 21. 1833.

Dictyota Brongiartii J. Ag. Linnaea 15: 5.1841.

Dictyota Mertensii Kütz. Tab. Phyc. 9: 15. pl. 36. f. 1. 1859.

Dictyota subdentata Kütz. loc. cit. 14. pl. 33. f. II.

On rocks in shallow water. New Providence, Berry Islands, Great Bahama, North Cat Cay, Gun Cay, Atwood Cay, Mariguana, Caicos Islands, and Great Ragged Island:-Bermuda and Florida to Brazil. Type from the Antilles. 


\section{DILòPHUS J. Ag. Till Alg. Syst. 2: 106. 1882.}

Segments mostly $0.3-1 \mathrm{~mm}$. broad, the apices acute, acuminate or subobtuse; medulla 2-4 cells thick or here and there only 1 cell thick.

Segments mostly 1-2 mm. broad, the apices obtuse; medulla 2-5

cells thick at or near the margins, 1 or 2 cells thick in the middle.

1. D. guineensis.

2. D. alternans.

1. Dilophus guineénsis (Kütz.) J. Ag. loc. cit. 108.

Spatoglossum guineense Kütz. Phyc. Gen. 339. 1843.

? Dictyota Antiguae Kütz. Tab. Phyc. 9: 16. pl. 3\%: f. II. 1859.

Dictyota guineensis Crouan; Mazé \& Schramm, Alg. Guad. 126. 1870-1877.

On rocks in shallow water in rather exposed situations. Rose Island, Berry Islands, Great Bahama, Gun Cay, Watling's Island, Mariguana, Caicos Islands, Little Inagua, and Great Ragged Island:-Bermuda and Florida to Jamaica and Barbados. Type from St. Thomas.

Often proliferous along the middle line and often closely resembling Dictyota cervicornis but usually darker on drying.

2. Dilophus álternans J. Ag. loc. cit. 108.

On rocks near low-water mark. Gun Cay, North Cat Cay, South Cat Cay, and Caicos Islands :-Florida to Barbados. Type from Key West, Florida.

6. DICTYÉRPA Collins, Proc. Am. Acad. Arts and Sci. 37: 251.1901.

1. Dictyerpa jamaicénsis Collins, loc. cit.

On rocks in shallow water. South Cat Cay and Watling's Island:-Jamaica. Type from Jamaica.

Resembles narrow conditions of Dilophus guineensis, but is more irregular in its branching and is terete or subterete, with a medulla more than four cells wide. Phyc. Bor.-Am. 780 in herb. N. Y. Bot. Gard. shows tetrasporangia (?) similar to those of Dilophus guineensis.

\section{SUB-CLASS CHLOROPHYCEAE.}

\section{Family 1. PLEUROCOCCÀCEAE.}

1. PSEUDOTETRÁSPORA Wille, K. Norske Vidensk. Selsk. Skr. 1906⿱ : 20. 1906.

\section{Pseudotetraspora Antillàrum M. A. Howe, sp. nov.}

Thallus subglobose, obovoid, pyriform, saccate, or allantoid, variously wrinkled, constricted, or bullate, mostly $2-20 \mathrm{~mm}$. in length or height, often more or less explanate and lacunose with age, yellowish brown when living, brownish or dark brown on drying; cells subglobose or ellipsoid, mostly $3-7 \mu$ in maximum diameter.

Enveloping leaves of Halodule and Thalassia and older parts of the thallus of Chondria littoralis and other marine algae, in shallow water. Sometimes washed ashore in great quantities. New Providence, Rose Island, Exuma Chain and Cat Island. Type Howe 3443, Rose Island, Jan. 28, 1905.

The specles apparently differs from the Norwegian $P$. marina Wille in its yellowish brown color, its larger more saccate or allantold thallus, and the somewhat smaller cells.

\section{Family 2. PROTOCOCCÀCEAE.}

\section{PROTоcóccus Ag. Syst. Alg. 13. 1824.}

1. Protococcus viridis Ag. loc. cit.

Pleurococcus vulgaris Naeg. Gatt. einzel. Alg. 65. pl. 4E. f. 2. 1849.

On trunks of trees, etc. (det. F. S. Collins), probably common. New Providence :- cosmopolitan. Type from Sweden. 


\section{Family 3. ULVÀCEAE.}

1. ÚLVA L. Sp. Pl. 1163. 1753.

1. Ulva Lactùca L. loc. cit.

Near low-water mark, apparently not common. Berry Islands, Great Bahama, and Atwood Cay :-widely distributed. Type locality presumably European.

2. *ENTERomórpha Link, Hor. Phys. Berol. 5. 1820.

Thallus simple.

Thallus branched, the branches often monostphonous at

1. E. flexuosa. apices.

Chromatophores much smaller than the cells.

Chromatophores nearly filling the cell.

2. E. plumosa.

3. E. salina polyclados.

1. Enteromorpha flexuòsa (Wulf.) J. Ag. Till Alg. Syst. 3: 126.1883.

Conferva flexuosa Wulf.; Roth, Cat. Bot. 2: 188. 1797.

On stones, low-littoral. Great Bahama, Mariguana, and Caicos Islands :-Bermuda to American Virgin Islands; widely distributed in the warmer seas. Type from shores of the Adriatic Sea.

2. Enteromorpha plumòsa Kütz. Phyc. Gen. 300. pl. 20. f. I. 1843.

Enteromorpha Hopkirkii MeCalla; Harv. Phyc. Brit. pl. 263. 1849-'51.

On stones, etc., near low-water mark. Berry Islands, Joulter's Cay, Exuma Chaln, and Mariguana:-Maine to American Virgin Islands; Europe. Type from Trieste.

3. Enteromorpha salìna polyclàdos Kütz. Phyc. Germ. 248. 1845.

Enteromorpha polyclados Kütz. Tab. Phyc. 6: 13. pl. 36. f. $d-f .1856$.

On stones at low-water mark. South Calcos:-Florida; Europe. Type from Spiekeroog, East Friesian Islands, North Sea.

\section{Family 4. CHAETOPHORÀCEAE.}

1. GOMóNTIA Born. \& Flah. Jour. de Bot. 2: 163, 164. 1888.

1. Gomontia polyrhiza (Lagerh.) Born. \& Flah. loc. cit.

Codiolum polyrhizum Lagerh. Öfvers. K. Vet.-Akad. Förh. 428: 21. pl. 28. 1886.

Boring into old crusts of various Lithothamnieae (Goniolithon Börgesenii, $G$. a.ocretum, and Porolithon pachydermum) and probably common in shells. Berry Islands and Marlguana :- widely distributed in temperate and tropical seas. Type from near Kristineberg, Sweden.

2. ENDODÉRMA Lagerh. Öfvers. K. Vet.-Akad. Förh. 40²: 75.1883.

Entocladia Reinke, Bot. Zeit. 37: 476. 1879. Not Endocladia J. Ag. Linnaea 15: 449.1841.

1. Endoderma víride (Reinke) Lagerh. loc. cit.

Entocladia viridis Reinke, Bot. Zeit. 37: 476. pl. 6. f. 6-9. 1879.

In the cell walls of Hypnea musciformis. Cave Cays:-Bermuda to American Virgin Islands; Europe; Peru. Type from the Bay of Naples.

* The treatment of the known Bahamian species is based upon determinatlons by Mr. F. S. Collins. 


\section{Family 5. CHROOLEPIDĀCEAE.}

1. TRENTEPÒHIIA Mart. Fl. Crypt. Erlang. 351. 1817.

Amphiconium Nees, Syst. Pilz. 69. 1817.

Chroolepus Ag. Syst. Alg. xxi, 34. 1824.

Filaments cylindric or subcylindric.

Filaments torulose, diameter of cells at middle about twice the diameter at septa; occurring on or with crustaceous lichens.

1. T. aurea.

2. T. rigidula.

1. Trentepohlia aùrea (L.) Mart. loc. cit.

Byssus aurea L. Sp. Pl. 1168. 1753.

Chroolepus aureus Kütz. Phyc. Gen. 284. 1843.

On rocks, fences, trunks of trees, etc., probably common. New Providence, Andros, Abaco, and Great Bahama :-cosmopolltan. Type European.

2. Trentepohlia rigídula (Müll. Arg.) Hariot, Jour. de Bot. 3: 403. f. 17. 1889.

Coenogonium rigidulum Müll. Arg. Flora 65: 490. 1882.

Trentepohlia torulosa De Wild. Bull. Soc. Roy. Bot. Belg. 27²: 181.1888.

On and with small crustaceous lichens, especially on bark of Annona sp. New Providence:- widely distributed in the warmer parts of the earth. Type from Australia.

The cell walls of the Bahamian specimens are smooth or slightly roughened, differing in that respect considerably from those of the Australian type, which are strongly roughened.

\section{Family 6. CLADOPHORÀCEAE.}

1. Chaftomórpha Kütz. Phyc. Germ. 203. My 1845.

Aplonema Hass. Brit. Freshw. Alg. 213. J1 1845.

Filaments attached, $400-800 \mu$ in diameter except at extreme base, commonly monillform in upper part, with cells about as broad as long or broader. 1. C. clavata.

Fllaments free, less than $400 \mu$ in diameter.

Filaments mostly 200-250 $\mu$ in diameter. $\quad$ 2. O. Linum.

Filaments mostly $80-180 \mu$ in diameter.

1. Chaetomorpha clavàta (Ag.) Kütz. Bot. Zeit. 5: 166. 1847.

Conferva clavata Ag. Syst. Alg. 99.1824.

? Conferva intestinalis Ag. loc. cit.

In a tide-pool, Hog Island (near Nassau) :-Jamaica, American Virgin Islands, and Barbados. Type from West Indies.

2. Chaetomorpha Iìnum (O. F. Müll.) Kütz. Phyc. G'erm. 204. 1845.

Conferva Linum O. F. Müll. Fl. Dan. 513: 7. pl. 7771. f. 2. 1778.

In a Rhizophora swamp, Rose Island:-widely distributed, especially in the North Temperate Zone. Type from Denmark.

3. Chaetomorpha brachýgona Harv. Ner. Bor.-Am. 3: 87, pl. 46 A. 1858.

In shallow water, especially in tidal ponds. New Providence, Exuma Chain, Atwood Cay, and Caicos Islands :-Bermuda, Florida, Porto Rico, American Virgin Islands, and northern South America. Type from Key West, Florida.

2. RHIZOCLÒNIUM Kütz. Linnaea 17: 90. 1843.

Filaments $39-110 \mu$ in diameter; cell-walls mostly 10-26 $\mu$ thick, usually laminated.

Cells 2-4 times as long as broad.

Cells 1-2 times as long as broad.

1. R. Hookeri.

2. R. crassipellitum robustum. 
Filaments $10-28 \mu$ in diameter; cell walls mostly 1-4 $\mu$ thick.

In or near salt water; cells mostly 1-2 times as long as broad; chromatophore usually rather solld and uniform.

In fresh water; cells mostly $1-5$ times as long as broad; chromatophore usually lacunose or resolved into discs, plates, or bands of protean forms.

3. $R$. riparium implexum.

4. R. hieroglyphicum.

1. Rhizoclonium Hoókeri Kütz. Sp. Alg. 383. 1849.

High-littoral to low-water mark, often in Rhizophora association :-Bermuda and Florida to South America. Type from Kerguelen Island.

The West Indian plants currently referred to this species appear to be coarser, longer-celled, and thicker-walled than the Kerguelen Island type.

2. Rhizoclonium crassipéllitum robústum G. S. West, Jour. Bot. 42: 283.1904.

In fresh or brackish water, often in association with Rhizophora. New Providence, South Bimini, Exuma Chain, Cat Island, and Mariguana:-Barbados. Type of varlety from Barbados.

The flaments of the Bahamian specimens have a diameter of $39-90 \mu$. Apparently distinct from the plants here referred to $R$. Hookeri.

3. Rhizoclonium ripàrium impléxum (Dillw.) Rosenv. Medd. om Grönland 3: 915. f. 34. 1893.

Conferva implexa Dillw. Brit. Conf. 46. pl. B. 1809.

In association with Rhizophora, often clothing its roots. Berry Islands and Bimini (det. F. S. Collins) :- widely distributed. Type from Ireland.

4. Rhizoclonium hieroglýphicum (Ag.) Kütz. Phyc. Germ. 206. 1845.

Conferva hieroglyphica Ag. Flora 10:636. 1827.

In fresh-water pools. New Providence (Brace):-widely distributed. Type from Carlsbad, Austria.

\section{3. *CLADóPHoRA Kütz. Linnaea 17: 91. 1843.}

Plants of fresh or brackish water, unattached, usually floating; filaments much bent and curved; main filaments $60-120 \mu$ in diameter, the ramuli

$20-40 \mu$; cells $3-6$ times as long as broad.

1. C. fracta.

Marine.

Ultimate ramull nearly as stout as the main filaments.

Filaments $35-95 \mu$ in diameter; plants sponglose-cespitose or spongiose-funicular; cells mostly 8-10 times as long as broad.

Filaments $150-320 \mu$ in diameter, plants cespitose, rather rigid, dark green or blackish green, blackening after collection, known only in association with a filamentous fungus endophytic in its cell walls.

Ultimate ramull much more slender than the main filaments.

Plants bright green or light green.

Ultimate ramuli more or less fascicled, $50-120 \mu$ in diameter, constricted at septa.

Ultimate ramuli not fascicled, $16-40 \mu$ in diameter. Virgate in habit.

Dichotomous or trichotomous, not virgate.

Plants yellowish; cells 4-10 times as long as broad, often somewhat enlarged at distal end; diameter of main filaments $60-80 \mu$, the often secund ultimate ramull 18-50

2. C. crispula.

3. C. fuliginosa.

4. C. fascicularis.

5. C. nitida.

6. C. crystallina.

7. C. luteola.

1. Cladophora frácta (Vahl) Kütz. Linnaea 17: 91.1843.

Conferva fracta Vahl, Fl. Dan. 6 ${ }^{16}:$ 7. pl. 946. 1787.

? Conferva vagabunda L. Sp. Pl. 1167. 1753.

Floating on brackish ponds, New Providence and Berry Islands :-widely distributed. Type from Denmark.

* The treatment of the recognized Bahamian species is based chiefly upon determinations by Mr. F. S. Collins. 
2. Cladophora críspula Vickers, Ann. Sci. Nat. Bot. IX. 1: 56. 1905.

On Digenea, near low-water mark. Mariguana:-Bermuda, American Virgin Islands, and Barbados. Type from Barbados.

3. Cladophora fuliginòsa Kütz. Sp. Alg. 415. 1849.

Blodgettia confervoides Harv. Ner. Bor.-Am. 3: 48. pl. 45 C. 1858.

Common in shallow water, mostly in rather exposed places. New Providence, Rose Island, Great Bahama, North Cat Cay, Eleuthera, Cat Island, Mariguana, Caicos Islands, and Great Ragged Island :-Bermuda to the American Virgin Islands. Type from Havana, Cuba.

4. Cladophora fasciculàris (Mert.) Kütz. Linnaea 17: 91. 1843.

Conferva fascicularis Mert.; Ag. Syst. Alg. 114. 1824.

In shallow water. Berry Islands and Great Bahama :-Florida to Brazll; Peru. Type from the West Indies.

5. Cladophora nítida Kütz. Phyc. Gen, 269. 1843.

In shallow water. Great Bahama and Exuma Chain:-Jamaica; Europe. Type from Trieste.

6. Cladophora crystallìna (Roth) Kütz. Linnaea 17: 91. 1843.

Conferva crystallina Roth, Cat. Bot. 1: 196. 1797.

In shallow water. Berry Islands, Great Bahama, Exuma Chain, Atwood Cay, and Caicos Islands :-Massachusetts to West Indies; Europe. Type from the Baltic Sea. forms.

The Bahamian specimens provisionally referred to this species are not typical

7. ? Cladophora lutèola Harv. Ner. Bor.-Am. 3: 81. 1858.

In tide-pools. Atwood Cay and Caicos Islands :-Florida and Cuba. Type from Key West, Florida.

The Bahamian specimens somewhat doubtfully referred to this species have a more cespitose, less diffuse habit than the type, with rather stouter filaments, and less secund ultimate ramuli.

4. PITHóPHoRA Wittr. Syst. Arr. Pithoph. 48. 1877.

1. Pithophora oedogònia (Mont.) Wittr. loc. cit. 55. pl. 6.

Conferva (Cladophora) oedogonia Mont. Ann. Sci. Nat. Bot. III. 14: 301. 1850.

In fresh-water holes, New Provldence (Brace) :-Pennsylvania and Nebraska to South America, Type from Cayenne.

\section{Family 7. VALONIÀCEAE.}

1. CLAdOPHORÓPsis Börg. Overs. K. Danske Vidensk. Selsk. Forh. $1905^{3}$ : 288. 1905.

1. Cladophoropsis membranàcea (Ag.) Börg. loc. cit. 276. f. 8-13.

Conferva membranacea Ag. Syst. 120. 1824.

Cladophora aegagropila membranacea Kütz. Sp. Alg. 415. 1849.

Siphonocladus membranaceus Born.; De-Toni, Syll. Alg. 1: 358. 1889.

Common in shallow water and washed ashore. New Providence, Rose Island, North Cat Cay, Gun Cay, Andros, Exuma Chain, Watling's Island, Atwood Cay, Mariguana, and Caicos Islands:-Bermuda and Florida to Barbados. Type from St. Croix.

The plant is normally rather compactly or somewhat diffusely cespitose, but when attacked by a dark flamentous endophytic fungus it becomes depressed or prostrate and the filaments become thicker-walled. 
2. SIPHONÓCLADUS Schmitz, Ber. Sitz. Naturf. Ges. Halle 1878: 18.1878 ( 8$)$

1. Siphonocladus rígidus M. A. Howe, Bull. Torrey Club 32: 244. pl. 13. f. 1.; pl. 14. 1905.

In shallow water in rather protected places, sometimes forming pulvinate crusts on corals, occasionally in tide-pools. New Providence, Great Bahama, Exuma Chain, Cat Island, Atwood Cay, Mariguana, Caicos Islands, and Great Ragged Island:Bermuda, Florida, and Jamaica. Type from Key West, Florida.

3. PetrosíphoN M. A. Howe, Bull. Torrey Club 32: 247. 1905.

1. Petrosiphon adhaèrens M. A. Howe, loc. cit. 248. pl. 15.

Forming crusts and patches on calcareous rocks and corals near low-water mark and in tide-pools, not uncommon. New Providence, Rose Island, Great Bahama, Exuma Chain, Watling's Island, Mariguana, and Castle Island :-Bermuda, Cuba, and Jamaica. Type from Silver Cay, in Nassau Harbor, N. $\mathbf{P}$.

4. CHAMAEDòrIS Mont. Compt. Rend. Acad. Sci. 15: 171. 1842.

1. Chamaedoris Penículum (Ell. \& Soland.) Kuntze, Rev. Gen. Pl. 3: 400. 1898.

Corallina Peniculum Ell. \& Soland. Nat. Hist. Zooph. 127. pl. \%. f. 5-8; pl. 25. f. 1. 1786.

Penicillus annulatus Lamarek, Ann. Mus. Hist. Nat. 20: 299. 1813.

Nesea annulata Lamour. Hist. Polyp. 256. 1816.

Chamaedoris annulata Mont. loc. cit.

Under shelving rocks near low-water mark, but more commonly found washed ashore from deeper water. New Providence, Great Bahama, Abaco, Eleuthera, and Exuma Chain :-Florida to Barbados and South America; Mauritius; Ceylon. Type from the Bahama Islands.

5. MICRODÍCTYON Decaisne, Arch. Mus. Hist. Nat. 2: 115. 1841.

1. Microdictyon crássum J. Ag. Anal. Alg. Cont. 1: 107. 1894.

Common from low-water mark down to a depth of at least 8 meters; especially abundant on the "Long Bank" in 3-8 meters of water, growing particularly about sponges. New Providence, Rose Island, Great Bahama, North Cat Cay, Long Bank. Green Turtle Cay, Green Cay, Exuma Chain, Cat Island, Watling's Isiand, Atwood Cay, Mariguana, and Caicos Islands:-Cuba. Type from the Bahama Islands.

6. ANADYOMiène Lamour. Nouv. Bull. Sci. Soc. Philom. 3: 187. 1812. [As Anadyomena. ]

1. Anadyomene stellàta (Wulf.) Ag. Sp. Alg. 1: 400. 1822. [As Anadynomene stellata.]

Ulva stellata Wulf. in Jacq. Collect. 1:351. 1786.

Anadyomena flabellata Lamour. loc. cit.

Anadyomene flabellata Lamour. Hist. Polyp. 366. pl. 14. f. 3. 1816.

Not uncommon in shallow water and ranging down to a depth of at least 50 meters (flde Börgesen). New Providence, Andros, Great Bahama, Exuma Chain, Watling's Island, Mariguana, Caicos Islands, and Great Ragged Island :-Bermuda and Florida to Brazll : Mediterranean and Adriatic seas. Type from the Adriatic Sea.

Just above the low-water line under shelving rocks and on roots of Rhizophora, there occurs a form of Anadyomene consisting chiefly of free or solute flaments, with the pseudoparenchyma reduced to a small few-celled palmate-flabellate apical expansion or wholly deficient. Possibly this represents a species bearing to $A$. stellata about the same relation that Struvea anastomosans bears to the more elaborate species of Struvea, but as conditions intermediate appear to occur, the writer prefers to consider it a form, which may be designated as forma prototypa (trpe Howe 5842, on roots of Rhizophora in a lagoon, Great Ragged Island, Dec. 26, 1907). 
7. DICTYOSPHAÈRIA Decaisne, Ann. Sci. Nat. Bot. II. 17: 328. 1842.

1. Dictyosphaeria favulòsa (Ag.) Decaisne, loc. cit.

Valonia favulosa Ag. Sp. Alg. 1: 432. 1822.

Common, especially on old corals in shallow warm water. New Providence, Andros, Great Bahama, South Cat Cay, North Cat Cay, Bimini, Green Cay, Watling's Island, and Marlguana:-Bermuda and Florida to Barbados; widely distributed in the warmer seas. Type from the Island of Rawak, Dutch East Indies.

\section{VALÒNIA Ginn.; Ag. Sp. Alg. 1: 428. 1822.}

Thallus simple or subsimple, ovoid, obovoid, pyriform, or subglobose, mostly $1.5-5 \mathrm{~cm}$. in maximum diameter.

1. V. ventricosa.

Thallus branched.

Cells mostly 5-10 mm. broad, obovoid or pyriform, occasionally subglobose; thallus sparingly or rather copiously branched.

Cells mostly $0.45-2 \mathrm{~mm}$. broad.

Cells all subcylindric or subclavate ; thailus, under favorable conditions, forming subglobose, solid or finally hollow, free or attached masses 4-20 cm. in diameter.

Cells in supertor or dorsal parts irregularly polyhedral or angulate-subglobose; those of descending inferior or ventral parts subcylindric; thallus cespitose or crustaceous.

2. V. macrophysa.

3. V. Aegagropila.

4. T. ocellata.

1. Valonia ventricòsa J. Ag. Till Alg. Syst. 5: 96.1887.

Under sheiving rocks at low-water mark and among corallines and " mossy" aigae in shallow water. Rose Island, Berry Islands, Great Bahama, North Cat Cay, South Cat Cay, Abaco, Eleuthera, Exuma Chain, Cat Isiand, Mariguana, and Caicos Islands :-Bermuda to Barbados. Type from St. Croix.

2. Valonia macrophỳsa Kütz. Phyc. Gen, 307. 1843.

Under shelving rocks at low-water mark and on and among other algae and corals in shallow water. Berry Islands, Great Bahama, Eleuthera, Atwood Cay, Mariguana, and Caicos Islands:-Bermuda, Cuba, Jamaica, and American Virgin Islands; Mediterranean and Adriatic seas. Type from the isiand of Lessina, in the Ađriatic Sea.

3. Valonia Aegagrópila Ag. Sp. Alg. 1: 429. 1822.

Valonia utricularis Aegagropila Hauck, in Rabenh. Krypt.-Fl. 2: 469. 1885.

In shailow water and at its best in lagoons. New Providence, Rose Island, Great Bahama, North Cat Cay, Watling's Island, Atwood Cay, Mariguana, and Calcos Islands:-Cuba, Jamaica, Porto Rico, and American Virgin Islands; widely distributed in the warmer seas. Type from the lagoons of Venice.

4. Valonia ocellàta M. A. Howe, sp. nov.

Plants for the most part filamentous, densely cespitose or crustaceous, the cushions, under favorable conditions becoming 10-20 cm. broad and 4-6 cm. thick; the superior or dorsal parts consisting of small few-celled dises, or more often, oblong or linear, irregular, multicellular filaments mostly 1-4 cells broad, the cells polyhedral or angulate-subglobose, $0.45-0.9 \mathrm{~mm}$. in maximum diameter, with numerous small flattened ellipsoidal or lentiform cells 50-90 $\mu$ in long diameter along their separating walls; few or many of the ventral and lateral cells of the superior or dorsal facetted parts growing out into rather rigid descending stilt-like or root-like non-septate processes, mostly $5-30 \mathrm{~mm}$. long and $0.5-0.8 \mathrm{~mm}$. in diameter; occasional cells in dorsal parts enclosing few or numerous aplanospores $200-320 \mu$ in diameter.

In shallow water in lagoons, on pneumatophores of Avicennia between the tidelines, and low-littoral on rocks, both in exposed and sheltered locations, common. New Providence, Bimini, Watling's Island, Atwood Cay, Mariguana, and Caicos Islands :-Bermuda, Porto Rico, and American Virgin Íslands. Type, Howe 5090 from the great lake or lagoon of Watling's Island, Nov. 25, 1907. 
Valonia ocellata is perhaps related to Dictyosphaeria valonioides Zanard., which Hauck believed to be a condition of Valonia macrophysa, but manifestly differs in its smaller cells, in never belng hollow, and rarely, if ever, globose, and in the absence of large vesicular marginal cells. Specimens from Bermuda and the West Indies have sometimes been referred to Valonia utricularis forma crustacea Kuck., from which it differs in having its superior parts divided by cross-walls into more or less polyhedral or angulate-subglobose cells instead of consisting of interwoven and compacted clavate or obovoid cells. The plant bears some resemblance to young stages of species of Dictyosphaeria but the small-celled or facetted parts are usually elongate, vittate, or irregularly discoid, very rarely subglobose. It occurs in great abundance in lagoons, often associated with Valonia Aegagropila and remaining perfectly distinct. It is found in a great variety of habitats and it evidently deserves a distinctive specific name, at least until such time as cultures may prove it to be capable of assuming the characters of some previously described species.

\section{Family 8. DASYCLADÀCEAE.}

1. DASÝCLAdUS Ag. Flora 10: 640. 1827.

1. Dasycladus vermiculàris (Scop.) Krasser, Ann. K. K. Naturhist. Hofmus. 13: 459.1899.

Spongia vermicularis Scop. Fl. Carn. 2: 412. pl. 64.1772.

Conferva clavaeformis Roth, Cat. Bot. 3: 315. 1806.

Fucus vermicularis Bertol. Amoen. Ital. 308. 1819.

Dasycladus clavaeformis Ag. Sp. Alg. 2: 16. 1828.

On stones, shelis, etc., in shallow water, mostly in protected bays. New Providence, Rose Island, Berry Islands, North Cat Cay, Exuma Chain, Caicos Islands, Castle Island, and Great Ragged Island :-Bermuda, Florida, Cuba, and Jamaica : Canary and Madeira Islands; Medtterranean and Adriatlc seas. Type from Adriatlc Sea.

2. BAtóphora J. Ag. Öfv. K. Vet.-Akad. Förh. 11: 107. 1854.

Botryophora J. Ag. Till Alg. Syst. 5: 139. 1887. Not BOtryophora Bompard, Hedwigia 6: 129. 1867.

Coccocladus Cramer, Neue Denkschr. Schweiz. Naturf. Ges. 30:-(37). 1887.

1. Batophora Oérstedi J. Ag. Öfv. K. Vet.-Akad. Förh. 11: 108. 1854.

Botryophora Conquerantii Crouan; Cramer, Neue Denkschr. Schweiz. Naturf. Ges, 32:-(6). pl. 4. f. 1. 1890.

Coccocladus occidentalis Conquerantii M. A. Howe, Bull. Torrey Club 31: 96. 1904.

Coccocladus occidentalis laxus M. A. Howe, loc. cit. 95. pl. 6. f. 1, 2.

Common in lagoons, creeks, ponds, and sink-holes of salt or brackish water, the laxer conditions in water that is almost fresh. New Providence, Rose Island, Berry Isiands, Great Bahama, Andros, Exuma Chaln, Watling's Island, Calcos Islands, Acklin's Island, and Great Ragged Isiand:-Florida to Guadeloupe. Type from Krause's Lagoon, St. Croix.

1a. Batophora Oerstedi occidentàlis (Harv.) M. A. Howe, Bull. Torrey Club 32: 579.1905.

Dasycladus occidentalis Harv. Ner. Bor.-Am. 3: 38. 1858.

Botryophora occidentalis J. Ag. Till Alg. Syst. 5: 141. 1887.

Coccocladus occidentalis Cramer, Neue Denkschr. Schweiz. Naturf. Ges. $30:-(37) .1887$.

On stones, shells, etc., in shallow salt water, mostly in protected bays, common. New Providence, Andros, Berry Islands, Great Bahama, Exuma Chain, Cat Island, Watling's Island, Mariguana, and Great Ragged Island:-Bermuda, Florida, and Cuba. Type of varlety from Key West, Florida. 


\section{NEÓMERIS Lamour. Hist. Polyp. 241. 1816.}

Hairs monomorphous; ends of branches of second order forming a cortex with distinct facets.

Sporangla coherent laterally by their calcareous capsules, the plant thereby appearing transversely annulate in the lower fertile parts. $1 . N$. annulata.

Sporangia strongly calcified but mutually free.

Hairs dimorphous, the two forms in alternating zones; branches of the second order subfusiform, scarcely forming a cortex, surface of the plant after the fall of the halrs somewhat shaggy or minutely and irregularly punctate; sporangia free or coherent in short rows of $2-8$.

2. N. mucosa.

1. Neomeris annulàta Dickie, Jour. Linn. Soc. Bot. 14: 198. 1874.

Neomeris Kelleri Cramer, Neue Denkschr. Schweiz. Naturf. Ges. 30:-(310, 39).pl. 1; pl. 2. f. 1-12; pl. 3. f. 1,2. 1887.

On stones, shells, ete., from near low-water mark down to a depth of 50 meters (fide Börgesen). New Providence, Rose Island, Berry Islands, Great Bahama, . North Cat Cay, Mariguana, Caicos Islands, Castle Island, and Great Ragged Island:Bermuda and Florida to Barbados; Mauritius, Madagascar, and the Dutch East Indies. Type from Mauritius.

2. Neomeris mucòsa M. A. Howe, Bull. Torrey Club 36: 84. pl. 1. f. 5 ; pl. 5. f. 1-14. 1909.

On moderately exposed rocks, at and near low-water mark, often with other specles of the genus. Atwood Cay, Caicos Islands, and Great Ragged Island. Apparently endemic. Type from Atwood Cay.

3. Neomeris Còkeri M. A. Howe, Bull. Torrey Club 31: 97. pl. 6. f. 3-12. 1904.

Common, usually under shelving rocks, near low-water line, occasionally on shells and pebbles in deeper water. New Providence, Berry Islands, Great Bahama, Gun Cay, Eleuthera, Exuma Chain, Atwood Cay, Castle Island, and Great Ragged Island. Apparently endemic. Type from opposite Current Town, Eleuthera.

4. CYMOPÒLIA Lamour. Hist. Polyp. 292. 1816.

1. Cymopolia barbàta (L.) Lamour. loc. cit. 293.

Corallina barbata L. Syst. Nat. 1: 806. 1758.

Corallina Rosarium Ell. \& Soland. Nat. Hist. Zooph. 111. pl. 21. f. $h, H$. $H_{1-8 .} 1786$.

Cymopolia Rosarium Lamour. loc. cit. 294.

Cymopolia bibarbata Kütz. Phyc. Gen. 312. 1843.

Cymopolia unibarbata Kütz. loc. cit. 313.

Cymopolia mexicana J. Ag. Till Alg. Syst. 5: 147. 1887.

On rocks and stones in shallow, moderately agitated water. New Providence, Andros, Berry Islands, and Mariguana :-Florida, Cuba, Jamalca, Halti, Porto Rico, and Mexico; reported also from Canary Islands and Spain. Type from Jamaica.

5. ACETÁBULUM (Tourn.) Ludwig. Def. Gen. PI. 504. 1760.

Olivia Bertol. Rar. Pl. Ital. Dec. 3: 117. 1810.

Acetabularia Lamour. Nouv. Bull. Sci. Soc. Philom. 3: 185. 1812.

Polyphysa Lamarek; Lamour. Hist. Polyp. 250. 1816.

Plants large or medium-sized (dises $5-18 \mathrm{~mm}$. broad) ; hypopeltal processes present.

Plants small or minute (discs $1-5 \mathrm{~mm}$. broad) ; hypopeltal processes wanting.

Discs $2-5 \mathrm{~mm}$. broad; coronal processes $75-150 \mu$ in radial diameter, with 5-13 halrs or hair-rudiments : aplanospores $88-190 \mu$ in diameter.

Discs 1-2.5 mm. broad; coronal processes $22-35 \mu$ in radial diameter, with 2 (rarely 3) hairs or hairrudlments; aplanospores $68-82 \mu$ in diameter.

1. A. crenulatum.

2. A. polyphysoides.

3. A. pusillum. 
1. Acetabulum crenulàtum (Lamour.) Kuntze, Rev. Gen. Pl. 2: 881. 1891.

Acetabularia crenulata Lamour. Hist. Polyp. 249. 1816.

Acetabulum caribaeum Lamarck, Hist. Nat. Anim. sans Vertèb. 2: 150. 1816.

Acetabularia caraibica Kütz. Tab. Phyc. 6: 33. 1856.

On sandy bottom and on stones, shells, sticks, etc., in shallow rather quiet water (down to 10 meters or more), common. New Providence, Rose Island, Andros, Great Bahama, Green Cay, Exuma Chain, Cat Island, Watling's Island, Mariguana, Caicos Islands, and Great Ragged Island:-Bermuda and southern Florida to Barbados. Type from "mer des Antilles" [Santo Domingo].

2. Acetabulum polyphysoìdes (Crouan) Kuntze, Rev. Gen. P1. 2: 881. 1891. Acetabularia polyphysoides Crouan; Solms, Trans. Linn. Soc. Bot. II. 5: 29. $p l$. 4. f. 2, 6. 1895.

Low-littoral down to a depth of at least 4 or 5 meters. Atwood Cay, Caicos Islands, and Castle Island:-Jamalca and Guadeloupe. Type from Guadeloupe.

2a. Acetabulum polyphysoides deltoìdeum M. A. Howe, Bull. Torrey Club 36: 92. pl. 6. f. 21; pl. \%. f. 10. 1909.

Just above low-water mark, with the typical form and with Neomeris Cokeri. Atwood Cay (type station of form deltoideum).

3. Acetabulum pusillum M. A. Howe, Bull. Torrey Club 36: 89. pl. 6. f. 13$15 ; p l$. \%. f. 1-4. 1909.

Acetabularia pusilla Collins, Tufts College Stud. 2: 379. 1909.

On stones, shells, and film-covered rocks in shallow water, sometimes with $A$. polyphysoides and $A$. crenulatum. Mariguana and Castle Island:-Jamalca. Type from Montego Bay, Jamaica. diameter.

A minute plant, only 1-3 $\mathrm{mm}$. high, and the disc averaging about $1.6 \mathrm{~mm}$. in

6. ACICULÀria d'Archiac, Mém. Soc. Géol. France 5²: 386. 1843.

Solms, Trans. Linn. Soc. Bot. II. 5: 32.1895.

1. Acicularia Schénckii (Möb.) Solms, loc. cit. 33. pl. 3. f. 9, 11, 12, 14, 15. 1895. M. A. Howe, Bull. Torrey Club 28: 323-331. pl. 24. f. 1-16, 18-22; pl. 25. 1901.

Acetabularia Schenckii Möb. Hedwigia 28: 318-320. pl. 10. f. 8-12. 1889.

On stones, etc., from near low-water mark down to a depth of at least 30 meters (fde Börgesen), usually in assoclation with Rhizophora. Rose Island:Bermuda, Jamaica, Porto Rico, American Virgin Islands, Barbados, and Brazil. Type from Cabo Frio, Brazil.

\section{Family 9. BRYOPSIDÀCEAE.}

1. BRYÓPsis Lamour. Nouv. Bull. Sei. Soc. Philom. 1: 333. My 1809.

Ultimate ramuli 2-ranked, the main axes for the most part simply pinnate, commonly naked in lower half.

Uitimate ramuli irregularly disposed.

Main axes usually deliquescent, the ultimate ramuli rarely less than $20 \mu$ in diameter at apex.

Main axes persistent, strongly contrasting in size with the various orders of branches and branchlets, the ultimate ramuli often only $5-15 \mu$ in diameter at apex; plant very gelatinous.

1. B. pennata.

2. B. hypnoides.

3. B. Duchassaingil.

1. Bryopsis pennàta Lamour. loc. cit.; Jour. de Bot. 2: 134. pl. \%. f. 1 a, b. 1809.

On stones at low-water mark. Atwood Cay and Caicos Islands:-Bermuda to Barbados. Type from "Antilles." 
2. Bryopsis hypnoìdes Lamour. loc. cit.; Jour. de Bot. 2: 135. pl. 5. f. \& a, b. 1809.

Found washed ashore-probably from a little deeper water than the last. Great Bahama:- southern Massachusetts to Bermuda; widely distributed in the warm temperate seas. Type from near Cette, southern France.

3. Bryopsis Duchassaíngii J. Ag. Öfv. Vet.-Akad. Förh. 11: 107. 1854.

Trichosolen Antillarum Mont. Ann. Sci. Nat. Bot. IV. 14: 171. 1860.

Found washed ashore. Great Bahama:-Bermuda to Guadeloupe (Barbados?). Type from Guadeloupe.

\section{Family 10. CAULERPĀCEAE.}

1. CAUlérra Lamour. Nouv. Bull. Sei. Soc. Philom. 1: 332 . My 1809. Chauvinia Bory, Voy. Coquille, Bot. Crypt. 204. 1829.

Tricladia Decaisne, Ann. Sei. Nat. Bot. II. 17: 337. 1842.

Herpochaeta Mont. Ann. Sei. Nat. Bot. II. 20: 305.1843.

Stephanocoelium Kütz. Bot. Zeit. 5: 54. 1847.

Chemnitzia (Decaisne) Mont. Orb. Dict. 10: 53. 1849.

PhyllerPa Kütz. Sp. Alg. 494. 1849.

Stolons and upright fronds similar, filiform, in habit somewhat suggestive of Vaucheria, Derbesia, or the irregularly branched species of Bryopsis.

Stolons and upright fronds more or less different in form. Fronds filiform, the ramull verticillate (at least the upper), fastigiate or subfastigiate, di- or trichotomous. Fronds stouter, ramuli not in distinct whorls.

Fronds foliaceous, entire, linear or elliptic-oblong, often proliferous.

Fronds terete, subterete, or angled, or, if flattened, pinnately dentate, lobed, or plumose-pinnate.

Fronds distinctly flattened.

Fronds plumose-pinnate, the pinnules terete, mucronate.

Pinnules or teeth flattened.

Fronds linear-lanceolate in outline, 6-15 $\mathrm{mm}$. broad, the pinnules often contracted at base.

Fronds narrowly linear, 2-3 mm. broad, often twisted and constricted here and there, the margins occasionally entire.

Fronds terete, subterete, or angled, in general outline.

Stolons densely clothed with short simple or sparingly branched root-hairs; fronds with crowded, imbricate, bristle-like, mucronate ramuli. Stolons naked.

Frond with a naked stlpe bearing usually a dichotomo-palmate or dichotomo-umbellate cluster of secondary ramuliferous branches ; ramuli (2) 3-10(16)-ranked, with acicular 2-ranked ramelli pectinately secund or pinnately disposed, the longer often sparingly dichotomous or again pinnate.

Stipe usually not well differentiated.

1. C. fastigiata.

2. C. verticillata.

3. C. prolìfera.

Frond usually angled, the ramull mostly in 2-6 ranks, somewhat boat-shaped or prow-shaped (at least the basal), ovoid, mamilliform, or less commoniy terete, always mucronate.

Frond not angled, the ramuli subglobose, pyriform, pestle-shaped, or occasionally subclavate.

Ramuli in more or less elongate raceme-like clusters, several-ranked,

4. C. sertularioides.

5. C. crassifolia.

6. C. Freycinetii.

7. C. lanuginosa.

8. C. puspaloides:

9. C. cupressoides. 
mostly pestle-shaped, the pedicel usually as long as the subglobose or flattened-subglobose summit or often longer.

Ramull mostly irregulariy 2- or 3ranked, subglobose or obliquely pyriform, the pedicel usually shorter than the enlarged summit or obsolete; clusters short and somewhat botryoid or more elongate with rather distant ramuli.

10. C. racemosa.

11. C. clavifera.

1. Caulerpa fastigiàta Mont. Ann. Sci. Nat. Bot. II. 8: 353. 1837.

Herpochaeta fastigiata Mont. Ann. Sci. Nat. Bot. II. 20: 305. 1843.

On stones, etc., near low-water mark. New Providence, Mariguana, and Great Bahama (profusely abundant in a "bolling hole" in Golden Grove Creek) :-Bermuda and Fiorida to Brazil; Friendly Islands. Type from Cuba.

The plant has quite a different habit from the other West Indian species of the genus, bearing a superficial resembiance to filamentous siphonaceous algae of other genera and families, from which, however, it is usualiy distinguishable at sight (in the dried condition) by its greater rigidity and dull dark green color; under a moderately high magnification, the delicate cellulose threads running from the inner surface of the wall into the lumen serve at once to determine its affinities.

2. Caulerpa verticillàta J. Ag. Öfv. K. Vet.-Akad. Förh. 4: 6. 1847.

Herpochaeta verticillata Kütz. Tab. Phyc. 7: 1. pl. 1. f. II. 1857.

Stephanocoelium verticillatum Kütz. loc. cit. 7: 1.

In shallow water in sheltered places, usually in association with Rhizophora. New Providence, Great Bahama, and Bimini:-Bermuda to Brazil ; Indian and Pacific Oceans. Type locality indefinite (American Virgin Islands or Guadeloupe?).

This species in habit and size is suggestive of some of the more delicate species of Nitella.

3. Caulerpa prolífera (Forsk.) Lamour. Nouv. Bull. Sci. Soc. Philom. 1: 332. My 1809.

Fucus prolifer Forsk. Fl. Aegypt.-Arab. 193. 1775.

From near low-water mark to rather deep water. Joulter's Cays, Watling's Island, Castle Island, and Great Ragged Island:-Bermuda and Florida to Guadeloupe; Canary Islands and Mediterranean Sea. Type from Alexandría, Egypt.

Most of the Bahamian specimens have short, elliptic-oblong, or obovate fronds and represent f. obovata J. Ag.

4. Caulerpa sertularioides (S. G. Gmel.) M. A. Howe, Bull. Torrey Club 32: 576.1905.

Fucus sertularioides S. G. Gmel. Hist. Fuc. 151 pl. 15. f. 4. 1768.

Fucus plumaris Forsk. Fl. Aegypt.-Arab. 190. 1775.

Caulerpa plumaris Ag. Sp. Alg. 1: 436. 1822.

From near low-water mark to a depth of several meters. New Providence, Great Bahama, Bimini, North Cat Cay, Exuma Chain, Cat Island, Watling's Island, Mariguana, Caicos Isiands, and Great Ragged Island:-Bermuda and Florida to Barbados ; widely distributed in tropical and subtropical seas. Type "American."

5. Caulerpa crassifòlia (Ag.) J. Ag. Till Alg. Syst. 1: 13. 1873.

Caulerpa taxifolia crassifolia Ag. Sp. Alg. 1: 436. 1822. (Excl. syn.)

Caulerpa pinnata Web.-v. Bosse, Ann. Jard. Bot. Buitenzorg 15: 289. 1898. (Excl. syn. Fucus pinnatus L. fil. Suppl. 452. 1781.)

Caulerpa mexicana Sond.; Kütz. Sp. Alg. 496. 1849.

In sheltered localities from near low-water mark down to a depth of 30 meters (fide Börgesen). Exuma Chain, Mariguana, and Great Ragged Island:-Bermuda and Fiorida to Mexico and Brazil; widely distributed in tropical and subtropical seas. Type from the West Indies. 
6. Caulerpa Freycinètii Ag. Sp. Alg. 1: 446. 1822.

On corais in shallow water. Atwood Cay :-Guadeloupe; Red Sea ; Pacific Ocean. Type from the Mariana Islands.

The Atwood Cay specimens apparently belong with var pectinata Web.-v. Bosse, differing from the type in being only slightly twisted and in the more regular and better developed marginal teeth; it seems to approach closely certain conditions of c. cupressoides.

7. Caulerpa lanuginòsa J. Ag. Till Alg. Syst. 1: 28. 1873.

Caulerpa Lycopodium Harv. Ner. Bor.-Am. 3: 19. pl. 37B. 1858. Not $C$. Lycopodium J. Ag. Öv. K. Vet.-Akad. Förh. 4: 6. 1847.

On a sandy bottom in shallow water. New Providence (south shore) :-Florida. Type from Key West, Florida.

\section{Caulerpa paspaloìdes (Bory) Grev. Alg. Brit. lxiv. 1830.}

Chauvinia paspaloides Bory, Voy. Coquille, Bot. Crypt. 205. pl. 23. f. 1. 1829.

On a sandy bottom, mostly in 1-40 dm. of water. New Providence (south shore), Long Bank, Abaco, Green Cay, and Great Bahama :- Florida and Cuba. Type from the Bahama Islands.

The type is characterized by having its ramuli in (2) 3 or 4 ranks, the spikes distinctly alate or strongly angled when living and shaggy when dry, the ramelli pectinately secund, and always much shorter than the axis from which they spring. In addition to the type form, there are in the Bahamas two other strongly marked forms, varieties, or subspecies, which appear to be locally distinct, that is, they seem to occur with little if any local intergrading or intermingling, though growing in similar habitats; however, when plants from various localities are compared, it seems difficult to maintain these three groups as distinct species.

8a. Caulerpa paspaloides phleoìdes (Bory) J. Ag. Till Alg. Syst. 1: 32. 1873.

Chauvinia phleoides Bory, Voy. Coquille, Bot. Crypt. 206. pl. 23. f. 2. 1829.

On a sandy bottom in shallow water. Exuma Chain. Type from the Bahama Islands. Apparentiy endemic.

Differs from the typical $C$. paspaloides in having its ramuli in 6-10 ranks, the spikes slightly angular or strongly ribbed when living, more or less shaggy when dry, the ramelli mostly pinnately distichous or occasionally subsecund.

8b. Caulerpa paspaloides compréssa (Web.-v. Bosse) M. A. Howe, comb. nov.

Caulerpa paspaloides var. typica f. compressa Web.-v. Bosse, Ann. Jard. Bot. Buitenzorg 15: 353. pl. 30. f. 3, 4. 1898.

Caulerpa compressa M. A. Howe, Bull. Torrey Club 31: 93. 1904.

On a sandy bottom in shallow water. Rose Island, Long Island, Exuma Chain, and Ragged Island. Type from the Bahama Isiands. Apparently endemic.

Differs from the typical $C$. paspaloides and $C$. paspaloides phleoides in having its ramuli in 8-16 ranks, the spikes dense and wholly terete or very lightly ribbed, the ramelli pinnately distichous and corymbose, the lower ramelli as long or neariy as long as the axls from which they spring.

9. Caulerpa cupressoìdes (West) Ag. Sp. Alg. 1: 441. 1822.

Fucus cupressoides West; Vahl, Nat. Selsk. Skr. 5²: 38. 1802.

Caulerpa hypnoides Lamour. Jour. de Bot. 2: 145. pl. \%. f. 3. 1809.

Fucus ericifolius Turn. Hist. Fuc. 1: 124. pl. 56. 1808.

Caulerpa ericifolia Ag. Sp. Alg. 1: 442. 1822.

Caulerpa mamillosa Mont. Prod. Phye. Antarct. 13. 1842.

Caulerpa Lycopodium J. Ag. Öfv. K. Vet.-Akad. Förh. 4: 6. 1847.

Caulerpa juniperoides J. Ag. Till Alg. Syst. 1: 26.1873.

On sand-covered rocks and sandy bottoms in shallow water and in tide-pools, common. Andros, Great Bahama, Bimini, Exuma Chain, Watling's Island, Atwood 
Cay, Mariguana, Caicos Islands, and Great Ragged Island:-Bermuda and Florida to South America; Indian and Pacific Oceans. Type from St. Croix, American Virgin Islands.

Variable in the number of ranks of the ramuli and in the length of the ramuli. The forms or varieties chlefly represented are the typlcal form, the var. ericifolia (Turn.) Web.-v. Bosse, and the var. Lycopodium (J. Ag.) Web.-v. Bosse.

10. Caulerpa racemòsa (Forsk.) J. Ag. Till Alg. Syst. 1: 35. 1873.

Fucus racemosus Florsk. F1. Aegypt.-Arab. 191. 1775.

Fucus uvifer Turn. Hist. Fuc. 4: 81. pl. 230. 1819. Not Fucus uvifer Forsk. Fl. Aegypt.-Arab. 192. 1775.

Caulerpa clavifera uvifera Ag. Sp. Alg. 1: 438. 1822.

On reefs in shallow water and in more sheltered places, as on roots of Rhizophora. New Providence, Rose Island, Bimini, Exuma Chain, Watling's Island, Atwood Cay, and Castle Island :-Bermuda and Florida to Barbados; widely distributed in tropical and subtropical seas. Type probably from the Red Sea.

\section{Caulerpa clavífera (Turn.) Ag. Sp. Alg. 1: 438.1822.}

Fucus clavifer Turn. Hist. Fuc. 1: 126. pl. 5\%. 1808.

Caulerpa racemosa clavifera Web.-v. Bosse, Ann. Jard. Bot. Buitenzorg 15: 360. pl. 33. $f .1-5.1898$.

Caulerpa racemosa uvifera Web.-v. Bosse, loc. cit. 362 p.p.

Habitat same as $C$. racemosa. Exuma Chain, South Cat Cay, Mariguana, Caicos Islands, and Great Ragged Island:-Florida to Barbados; widely distributed in troplcal and subtropical seas. Type from the Red Sea.

Caulerpa racemosa and $\boldsymbol{C}$. clavifera sometimes approach each other in form and habit and rarely occurring specimens are difflcult to determine, but the writer has often seen the two growing close together, in apparently identical surroundings (especially in Porto Rico and Jamaica) and maintaining their distinctions so perfectly and strikingly that it seems more satisfactory to treat them as independent species than to follow the prevailing modern fashion of regarding them as forms of a single polymorphous species.

\section{Family 11. DERBESIÀCEAE.}

1. DERBÈsIÁ Solier, Ann. Sei. Nat. Bot. III. 7: 158. 1847.

1. Derbesia vaucheriaefórmis (Harv.) J. Ag. Till Alg. Syst. 5: 34. 1887.

Chlorodesmis (\&) vaucheriaeformis Harv. Ner. Bor.-Am. 3: 30. pl. 40 D. 1858.

Derbesia tenuissima Farl. Mar. Alg. N. E. 60 p.p. pl. 4. f. 4. 1881. Not D. tenuissima (De Not.) Crouan.

On rocks in a salt spring, high littoral, Cave Cays, Exuma Chain :-southern Massachusetts, Bermuda, and Florida. Type from Key West, Florida.

The only Bahamian collection seems to be sterile, like Harvey's original ; its filaments are somewhat coarser, being $35-93 \mu$ in diameter, while those of the type are $30-52 \mu$; the plants are also much darker green than Harvey's specimens at the present day, but the latter have doubtless suffered some loss of color in neariy seventy years of preservation.

\section{BRYOBESIA Web.-v. Bosse, Ann. Jard. Bot. Buitenzorg 24: 26.1910.}

\section{Bryobesia cylindrocárpa sp. nov.}

Filaments sparingly subdichotomous, 5-15 mm. long, $75-156 \mu$ in diameter, very rarely septate, their walls mostly $3-10 \mu$ thick, the branches occasionally with a septum at the base; sporangia short-cylindric, obovoid, or cylindric-clavate, $150-450 \mu \times 90-180 \mu$, sessile, erect or erecto-patent, constituting one arm of a 
dichotomy or pseudo-dichotomy, or sometimes apparently terminal, the filament continued by a lateral innovation; zoospores numerous (about 200-500 to a sporangium), ellipsoid or ovoid, $20-40 \mu \times 20-25 \mu$.

Green Cay, W. C. Coker, June 30, 1903, dredged in 4 fathoms, - a smail amount of material preserved in formalin. There is a possibility that the plant belongs in Cladophoropsis, but the terminal rather than intercalary sporangia and the large zoospores, on some of which indications of a circle of cilia have been noted, have suggested its reference to Bryobesia, the Javan type-species of which it resembles closely, though the Bahamian plant is evidently longer and coarser, with filaments twice as broad.

\section{Family 12. CODIÀCEAE.}

1. AVRatnvíllea Decaisne, Ann. Sci. Nat. Bot. II. 18: 108.1842.

Fradelia Chauv. Recherches 124. 1842.

Chloroplegma Zanard. Mem. R. Ist. Ven. 7: 290. 1858.

Thallus eventually developing a flabellum (usually stipitate).

Fusco-nigrescent, yellowish brown, or tawny green; surface subvelutinous, spongiose, or strigose; filaments of flabellum 28-70 $\mu$ in diameter.

Filaments of flabellum moniliform.

Filaments of flabellum cylindric, with a strong constriction at base of each branch, rarely subtorulose.

Olivaceous or cinereous; surface smooth and compact; filaments of surface of flabellum $6-24 \mu$ in diameter.

Thallus not developing a flabellum, forming more or less digitate, sometimes capitate lobes, these commoniy very irregular in form, and often branching, diffluent, or anastomosing.

1. A. nigricans.

2. A. longicaulis.

3. A. levis.

4. A. Rawsoni.

1. Avrainvillea nìgricans Decaisne, loc. cit.

Fradelia fuliginosa Chauv. Recherehes 124. 1842.

Avrainvillea longicaulis Murr. \& Boodle, Jour. Bot. 27: 70 p.p. pl. 228. f. 1-5. 1889. [Excluding syn. Rhipilia longicaulis Kütz.]

Common in shallow water, mostly on reefs or in places protected by reefs. New Providence, Andros, Berry Islands, Great Bahama, Gun Cay, Eleuthera, Exuma Chain, Mariguana, Caicos Islands, Castle Island, and Great Ragged Island:-Bermuda and Florida to South America. Type from Iles des Saintes, near Guadeloupe.

Forma fuilva M. A. Howe (in C. H. \& S. Phyc. Bor.-Am. 1480) differs from the typical form in its thicker, more snongiose. and usually more cuneate flabellum, in its flatter, broader, less differentiated stipe, and in the firmer-walled, usually coarser, though often more tapering filaments, which are less regularly moniliform, often more tortuous or zig-zag, more frequently and more divaricately dichotomous, and nearly always yellow or yellowish brown rather than fuscous at maturity.

2. Avrainvillea longicaùlis (Kütz.) Murr. \& Boodle, Jour. Bot. 27: 70 p.p. 1889. [Excluding all but syn. Rhipilia longicaulis Kütz.]

Rhipilia longicaulis Kütz. Tab. Phyc. 8: 13. pl. 28. f. II. 1858.

Avrainvillea Mazei Murr. \& Boodle, loc. cit.

Common in shallow or moderateiy deep water, often with A. nigricans. New Providence, Exuma Chain, Watling's Island, Mariguana, Caicos Islands, Castle Island, Great Ragged Island, and Salt Cay:-Bermuda to Barbados. Type from Antigua.

3. Avrainvillea lèvis M. A. Howe, Bull. Torrey Club 32: 565. pl. 23. f. 1; pl. 26. f. 8-10. 1905.

Avrainvillea sordida Murr. \& Boodle, Jour. Bot. 27: 70. 1889. Not $A$. sordida (Mont.) Crouan; Mazé \& Schramm, Alg. Guad. 89. 1870-'77. [Based upon Udotea sordida Mont. in technicalities of publication.]

Near low-water mark. Exuma Chain, Mariguana, and Caicos Islands :-Florida, Cuba, and Jamaica. Type from Cave Cays, Exuma Chain. 
4. Avrainvillea Ráwsoni (Dickie) M. A. Howe, Bull. Torrey Club 34: 510. 1907.

Rhipilia Rawsoni Dickie, Jour. Linn. Soc. Bot. 14: 151. pl. 11. f. 1, 2. 1874.

In shallow water, often at low-water line on exposed rocks. Abaco, Gun Cay, North Cat Cay, Berry Islands, Exuma Chain, Watling's Island, Mariguana, Caicos Islands, and Great Ragged Island :-Jamaica, Porto Rico, Guadeloupe, and Barbados. Type from Barbados.

\section{RHIPÍIIA Kütz. Tab. Phyc. 8: 12.1858.}

1. Rhipilia tomentòsa Kütz. loc. cit. pl. 28. $f$. 1.

Udotea tomentosa Murr. Jour. Bot. 27: 239. 1889.

In shallow water (down to 30 meters, fde Börgesen). North Cat Cay :-Cuba, Porto Rico, American Virgin Islands, Antigua, and Guadeloupe. Type from Antigua.

3. CLAdocíphatus M. A. Howe, Bull. Torrey Club 32: 569. 1905.

1. Cladocephalus scopàrius M. A. Howe, loc. cit. pl. 25; pl. 26. f. 11-20.

In shallow water. New Providence, Exuma Chain, and Watling's Island. Apparently endemic. Type from a tidal pond, Georgetown, Great Exuma.

4. PENICÍLIUS Lamarek, Ann. Mus. Hist. Nat. 20: 297. 1813.

Nesaea Lamour. Nouv. Bull. Sei. Soc. Philom. 3: 185. 1812. Not Nesaea Commers.; Juss. Gen. Pl. 332. 1789.

Coraliodendron Kütz. Polyp. Calcif. 11. 1841.

CoRallocephalus Kütz. Linnaea 17: 95. 1843.

Surface of stipe compact, indurated, smooth or minutely granulose under a handlens; ultimate branchlets of corticating filaments short-oblong, obtuse, truncate, or capitate.

Filaments of capitulum $135-250 \mu$ in diameter.

Filaments of capltulum $300-550 \mu$ in diameter.

1. P. capitatus.

2. P. Lamourouxii.

Surface of stipe spongiose or velutinous-tomentulose under a hand-lens; ultimate branchlets of corticating filaments elongate, taper-pointed.

Filaments of capitulum $500-900 \mu$ in diameter.

Filaments of capitulum $150-320 \mu$ in diameter.

3. P. dumetosus.

4. P. pyriformis.

1. Penicillus capitàtus Lamarck, loc. cit. 299.

? Corallina Penicillus L. Syst. Nat. 1: 807. 1758.

Corallina Penicillus Ell. \& Soland. Nat. Hist. Zooph. 126 p.p. pl. 25. f. 4. 1786.

Nesea Penicillus Lamour. Hist. Polyp. 258. 1816.

Penicillus elongatus Decaisne, Ann. Sei. Nat. Bot. II. 18: 109. 1842.

Corallocephalus Penicillus Kütz. Linnaea 17: 95. p.p. 1843.

Corallocephalus barbatus Kütz. Tab. Phyc. 7: 8. pl. 20. f. II. 1857.

"The Merman's Shaving-brush"; very common, usually on a sandy or muddy bottom in shallow water (mostly in 0.5-10 meters). New Providence, Rose Island, Berry Islands, Andros, Great Bahama, Garden Cay, Exuma Chain, Cat Island, Watling's Island, Atwood Cay, Mariguana, Calcos Islands, and Great Ragged Isiand: -Bermuda and Florida to Guadeloupe. Type from American seas.

2. Penicillus Lamouroùxii Decaisne, Ann. Sci. Nat. Bot. II. 18: 109.1842. ? Corallina Penicillus Ell. \& Soland. Nat. Hist. Zooph. 126 p.p. pl. 25. f. 5. 1786.

? Nesea pyramidalis Lamour. Hist. Polyp. 258. 1816.

Penicillus Lamourouxii gracilis A. \& E. S. Gepp, Jour. Bot. 43: 2. 1905.

On a sandy bottom in shallow water. New Providence, Rose Island, Great Bahama, Garden Cay, Bimini, Green Turtle Cay, Exuma Chain, Watling's Island, 
Mariguana, Caicos Islands, Castle Island, and Great Ragged Island:-Florida, Cuba, Jamalca, Porto Rico, and American Virgln Islands. Type from Bahama Islands.

3. Penicillus dumetòsus (Lamour.) Blainville, Man. Actin. 553. 1834. [As P. dumetosa.]

Neзе a dumetosa Lamour. Hist. Polyp. 259. 1816.

Corallocephalus dumetosus Kütz. Sp. Alg. 506. 1849.

Corallocephalus affinis Kütz. Tab. Phye. 8: 13. pl. 30. 1858.

On sandy or muddy bottom, mostly in shallow water. Long Bank, Great Bahama, and Bimini :-Florida to Guadeloupe. Type from "Antilles."

4. Penicillus pyrifórmis A. \& E. S. Gepp, Jour. Bot. 43: 1. pl. 468. f. 1a, $1 b$. 1905.

On a sand bottom in shallow water, common. New Provldence, Rose Island, Berry Islands, Andros, Great Bahama, Bimlni, Exuma Chain, Cat Island, Watling's Island, Marlguana, Calcos Islands, and Angullla Isles:-Bermuda and Florida to Jamaica and Guadeloupe. Type from Bimlni Harbor, Bahamas.

5. RHIPOCÉPHALUS Kütz. Linnaea 17: 95. 1843; Phye. Gen. 311. 1843.

Filaments of capitulum 55-90 $\mu$ in dlameter toward apices, rather firmiy and persistently coherent, in always easily recognizable flabella.

Filaments of capitulum $100-230 \mu$ in dlameter toward aplces, lightly and transiently coherent, the flabella scarcely recognizable at maturity.

2. P. oblongus.

1. Rhipocephalus Phoènix (Ell. \& Soland.) Kütz. loc. cit.

Corallina Phoenix Ell. \& Soland. Nat. Hist. Zooph. 126. pl. 25. f. 2, \&. 1786.

On sandy or graveliy bottom or on rocks, mostly in shallow water. New Provldence, Rose Island, Berry Islands, Andros, Bimlni, Exuma Chain, Cat Island, Atwood Cay, and Mariguana :-Florida, Cuba, Jamaica, Porto Rico, and Guadeloupe. Type from the Bahama Islands.

2. Rhipocephalus oblóngus (Decaisne) Kütz. Sp. Alg. 506. 1849.

Penicillus oblongus Decaisne, Ann. Sci. Nat. Bot. II. 18: 109. 1842.

On sandy bottom in shallow water, not common. New Providence, Berry Islands, Bimini, and North Cat Cay:-Florida and Cuba. Type from the Bahama Islands.

Often resembling certain conditions of Penicillus capitatus, but usually recognizable, at least in living or fluld-preserved states, by the more flabelliform arrangement of the fllaments of the capitulum and by the presence of a cup-shaped apical depression.

6. UdòtreA Lamour. Nouv. Bull. Sci. Soc. Philom. 3: 186. 1812.

Flabellum with a compact, firm, highly speclalized cortex, distinctly zonate.

Flabellum with an imperfect rudimentary cortex or none at all.

Filaments of flabellum without lateral appendages, each filament enclosed in a porose calcareous sheath.

Flabellum plane; transition from stipe to flabellum gradual; filaments of flabellum $28-60 \mu$ in diameter, interwoven and tortuous, usually forming' a superficial tomentulose nap; branches of the corticating filaments of the stipe somewhat loosely and Irregularly fastiglate, the ultimate divisions mostly finger-shaped, subacute, or taper-pointed.

Flabellum more or less cyathiform, or open on one side and almost plane (then usually a little concavoconvex, at least at base); transition from stipe to flabellum abrupt; flaments of flabellum nearly

1. U. Flabellum.

2. U. conglutinata. 
straight and parallel, mostly 60-100 $\mu$ in diameter : branches of corticating filaments of stipe compactly cymose-fastigiate, the ultimate divisions scarcely longer than broad, truncate, truncate-obtuse, or commonly with expanded truncate-capitate aplces.

Filaments of flabellum appendaged; calcareous sheaths, if differentlated, non-porose.

Filaments strongly constricted above dichotomies; appendages crowned with 2-8 acuminate prongs or spines.

Filaments not constricted above dichotomies; appendages simple or sparingly furcate, obtuse, truncate, or capitate.

3. U. cyathiformis.

4. U. spinulosa.

5. U. Wilsoni.

1. Udotea Flabéllum (Ell. \& Solanł.) M. A. Howe, Bull. Torrey Club 31: 94. 1904.

Corallina Flabellum Ell. \& Soland. Nat. Hist. Zooph. 124. pl. 24. f. A, B, C. 1786 .

Flabellaria pavonia Lamarck, Ann. Mus. Hist. Nat. 20: 301. 1813.

Udotea flabellata Lamour. Hist. Polyp. 311. 1816.

Flabellaria incrustata Chauvin, Recherches 123. 1842.

Udotea Halimeda Kütz. ISp. Alg. 503. 1849.

Common on a sandy or muddy bottom, from near low-water mark down to 30-40 meters. New Providence, Berry Islands, Great Bahama, Garden Cay, Bimini, Exuma Chain, Watling's Island, Marlguana, Caicos Islands, Great Ragged Island, and Salt Cay:-Bermuda and Florida to Guadeloupe and Panama (Colon). Type from "West Indies."

2. Udotea conglutinàta (Ell. \& Soland.) Lamour. Hist. Polyp. 312. 1816.

Corallina conglutinata Ell. \& Soland. Nat. Hist. Zooph. 125. pl. 25. f. \%. 1786.

Flabellaria conglutinata Lamarck, Ann. Mus. Hist. Nat. 20: 301. 1813.

On a sandy bottom from near low-water mark down to 14 meters or more. New Providence, Andros, Joulter's Cays, North Cat Cay, Bimini, Green Cay, Watling's Island, Mariguana, Caicos, and Castle Island :-Bermuda and Florida to the American Virgin Islands. Type from the Bahama Islands.

3. Udotea cyathifórmis Decaisne, Ann. Sci. Nat. Bot. II. 18: 106.1842.

Udotea conglutinata Vickers, Phyc. Barbad. 1: pl. 32. 1908.

on a sandy bottom from near low-water mark down to 30 meters or more. Berry Islands, Blmini, North Cat Cay, Exuma Chain, Calcos Islands, and Castle Island:- North Carolina to Barbados and Panama (Colon). Type from Isles des Saintes, Guadeloupe.

4. Udotea spinulòsa M. A. Howe, Bull. Torrey Club 36: 97. pl. 4. f. 2; pl. 8. f. $1-\% .1909$.

On a sandy bottom near low-water mark. Bimini (type):-American Virgin Islands (in 30-40 meters, fide Börgesen).

5. Udotea Wílsoni Gepp \& Howe, Siboga Exped. Monog. 62: 130. pl. \%. f. 66; pl. 8. f. $6 \%, 68.1911$.

On a sandy bottom in shallow water. Angullla Isles (type):-Florida and Cuba.

7. HALIMEDA Lamour. Nouv. Bull. Sci. Soc. Philom. 3: 186 (as Halimedea* ${ }^{*}$. 1812.

Opuntia Nace. FI. Ven. 6: 104. 1828. Not Opuntia L.

Sertolara (Imp.) Nardo, Isis 1834: 673. 1834.

BotryopHorA Bompard, Hedwigia 6: 129. 1867.

Segments reniform, semiorbicular, or deltoid-obovate, margins entire or (in $H$. opuntia) crenate or sometimes lobed. Nodal filaments of central strand fusing more or less completely in pairs or in threes.

* Afterwards (1816) changed by Lamouroux himself to Halimeda. 
Peripheral utricles galeate-cuspidate.

1. H. scaura.

Peripheral utricles truncate or rounded-obtuse.

Fusion of nodal fllaments complete (or sometimes incomplete in $H$. discoidea); segments not ribbed or nerved.

Peripheral utricles in contact for one-eighth of their length or less; utricles of subcortical layer subturbinate, obconic, cornucoplaeform, or clavate, $35-110 \mu$ in max. width; segments moderately calcified, 5-15 mm. broad.

Peripheral utricles in contact for one-fifth to twothirds of their length; utricles of the subcortical layer bullate, mostly ventricose-obovold, 110-215 $\mu$ in max. width; segments very lightly calcified, 6-35 $\mathrm{mm}$. broad.

Fusion of nodal flaments incomplete (i.e., flaments retaining their identity) in pairs; segments more or less ribbed or nerved.

Segments discoid or subterete, often 3-lobed or 3-dentate. Nodal filaments of the central strand coherent, communicating by pits, pores, or very short tubular processes, very rarely (especially in $H$. Monile) merely thick-walled and separable.

Peripheral utricles less than $80 \mu$ in average maximum diameter, surface view.

Peripheral utricles $49-77 \mu$ in average maximum diameter, surface vlew: gegments usually flattened.

Peripheral utricles $30-44 \mu$ in average maximum diameter.

Segments mostly subterete.

Segments discold (suggesting $H$. Tuna).

Peripheral utricles $175-190 \mu$ in average maximum diameter, surface view.

Segments obovoid, pyriform, or subglobose. Nodal filaments of the central strand fusing in twos or threes or rarely fours, the resulting filaments sometimes again incompletely fused.

2. H. Tuna.

3. H. discoidea.

4. H. Opuntia.

5. H. tridens.

6. H. Monile.

7. H. simulans.

8. H. favulosa.

9. H. lacrimosa.

1. Halimeda scàbra M. A. Howe, Bull. Torrey Club 32: 241. pl. 11, 12. 1905.

Common on rocks, old corals, the bases of sponges, etc., from low-water mark down to a depth of 3 meters or more. New Providence, Rose Island, Berry Islands, Great Bahama, Bimini, North Cat Cay, South Cat Cay. Gun Cay, Eleuthera, Exuma Chain, Watling's Island. Atwood Cay, Mariguana, Caicos Islands, Castle Island, Great Ragged Island. Angullla Isles, and Salt Cay:-Florida. Type from Sands Key, Florida.

2. Halimeda Tùna (Ell. \& Soland.) Lamour. Hist. Polyp. 309. pl. 11. f. 8a. 1816.

Corallina Tuna Ell. \& Soland. Nat. Hist. Zooph. 111. pl. 20. f. e. 1786.

Flabellaria Tuna Lamarck, Ann. Mus. Hist. Nat. 20: 302. 1813.

Halimeda platydisca Decaisne, Ann. Sci. Nat. Bot. II. 18: 102.1842.

On rocks, etc., from low-water mark down to 60 meters. Atwood Cay, Mariguana, Caicos Islands, Great Ragged Island, and Anguilla Isles :-Bermuda and Florida to Jamaica and Barbados; apparently of wide distribution in the warmer seas. Type from the Mediterranean Sea.

\section{Halimeda discoìdea Decaisne, Ann. Sei. Nat. Bot. II. 18: 102.1842.}

Mostly in shallow, somewhat agitated water (down to 20-40 meters, fide Börgesen) Great Bahama :-Florida, Cuba, Porto Rico, Lower California, Hawail, and the Phllippines. Type locallty unknown ("Kamtschatka").

4. Halimeda Opùntia (L.) Lamour. Hist. Polyp. 308. 1816.

Corallina Opuntia L. Syst. Nat. 1: 805 p.p. 1758. Ell. \& Sol. Nat. Hist. Zooph. 110. pl. 20. f. b. 1786.

Common from near low-water mark down to a depth of 20 meters or more, often forming extensive beds. New Providence, Rose Island, Berry Islands, South Cat Cay, Gun Cay, Exuma Chain, Watling's Island, Mariguana, and Anguilla Isles :

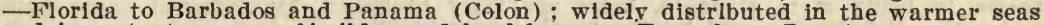
and important as a reef-builder and land-former. Type from Jamaica. 
5. Halimeda trìdens (Ell. \& Soland.) Lamour. Hist. Polyp. 308. 1816.

Corallina tridens Ell. \& Soland. Nat. Hist. Zooph. 109. 1786.

Corallina incrassata Ell. \& Soland. loc. cit. 111.

Halimeda incrassata Lamour. Hist. Polyp. 307. 1816.

Halimeda brevicaulis Kütz. Tab. Phyc. 8: 11. pl. 25. f. II. 1858.

Very common on a sandy or muddy bottom from near the low-water mark down to 40 meters or more. New Providence, Rose Island, Andros, Great Bahama, North Cat Cay, Green Cav, Exuma Chain. Cat Island, Watling's Island, Atwood Cay. Mariguana, Caicos Islands, Castle Island, Great Ragged Island, Salt Cay, and Anguilla Isles:-Bermuda and Florida to Guadeloupe; also in the tropical seas of the Eastern Hemisphere. Type from the Bahama Islands.

6. Halimeda Monile (Ell. \& Soland.) Lamour. Hist. Polyp. 306.1816.

Corallina Monile Ell. \& Soland. Nat. Hist. Zooph. 110. 1786.

Halimeda incrassata monilis Harv. Ner. Bor.-Am. 3: 24.1858.

Halimeda tridens Monile M. A. Howe, Bull. Torrey Club 32: 564. 1905.

Common on a sandy bottom. often with $H$. tridens and $H$. simulans, but distinct. Rose Island, Cat Island, Watling's Island, Mariguana, Calcos Islands, Great Ragged Island, Salt Cay, and Anguilla Isles:-Bermuda and Florida to Guadeloupe and Panama (Colon). Type from Jamaica.

7. Halimeda símulans M. A. Howe, Bull. Torrey Club 34: 503. pl. 29. 1907.

On a sandy bottom, rocks, old corals, etc., from near low-water mark down to a depth of several meters. Berry Islands, Atwood Cay, Mariguana, Caicos Islands, and Great Ragged Island:-Bermuda. Florida, Cuba, Jamalca, Porto Rico, American Virgin Islands, and Panama (Colon). Type from Culebra Island, Porto Rico.

8. Halimeda favulòsa M. A. Howe, Bull. Torrey Club 32: 563. pl. 23 ; pl. 24; pl. 26. $f .1-6.1905$.

On a sandy bottom in shailow water. Rose Island and Exuma Chain. Type from Cave Cays, Exuma Chain. Apparentiy endemic.

9. Halimeda lacrimòsa M. A. Howe, Bull. Torrey Club 36: 93. pl. 4. f. 1 ; pl. 6. f. 3-11. 1909.

On a sandy bottom from near low-water mark down to a depth of 10-20 meters or more. Exuma Chain, Mariguana, and Great Ragged Island:-Cuba. Type from Mariguana.

\section{CÒDIUM Stackh. Ner. Brit. xvi, xxii, xxiv. 1797.}

Lamarckia Olivi, Zool. Adriat. 258. 1792. Not Lamarckia Medic. 1789. Spongodium Lamour. Essai 71, 72. 1813.

Agardhia Cabrera; Ag. Syn. Alg. Seand. xxiv. 1817.

Thallus mostly erect and fruticose.

Peripheral utricles cylindric-clavate, mostly $75-200 \mu$ in max. diam.; thallus dull and rather rigid when dry, the branches not constricted at base.

Perinheral utricles ohovoid. ohconic, or goblet-shaped. mostly $150-300 \mu$ in max. diam.; thallus commonly nitent and rather flaccid when dry, the branches constricted at base.

Thallus adherent, prostrate, or repent.

1. C. tomentosum.

2. C. isthmocladum.

3. $C$. intertextum.

1. Codium tomentòsum (Huds.) Stackh. Ner. Brit. xxiv. 1797.

Fucus tomentosus Huds. Fl. Angl. 584. 1778.

On rocks. etc.. in shallow water. North Cat Cay. Eleuthera. Atwood Cay. and Caicos Islands:-Bermuda and North Carolina to Panama (Colon) and South America; widely distributed in the warmer seas. Type from Great Britain.

Codium decorticatum (Woodw.) M. A. Howe (C. elongatum Ag.) has not yet been reported from the Bahamas, but is likely to occur. It differs from $C$. tomentosum in being more elongate, more sparingly branched, by flattened expansions under the dichotomies, and by the much larger utricies. 
2. Codium isthmócladum Vickers, Ann. Sci. Nat. Bot. IX. 1: 57. 1905.

In shallow water. Berry Islands :-Bermuda and Florida to Barbados. Type from Barbados.

The only Bahamian specimen seen that seems referable to this species is coarser, more rigid, and less nitent than the typical form, but conforms in the characters of the peripheral utricles and sporangia.

3. Codium intertéxtum Collins \& Hervey, Proc. Am. Acad. 53: 54.1917.

Under shelving rocks and in crevices, closely adherent. Gun Cay and Atwood Cay :-Bermuda and Florida to Barbados. Type from Bermuda.

3a. Codium intertextum cribròsum M. A. Howe, var. nov.

Codium adhaerens M. A. Howe; Gardner, Univ. California Publ. Bot. 6: 492, 496. pl. 42. f. 9. 1919. Not C. adhaerens (Cabr.) Ag.

Wall of the peripheral utricles (of the more exposed at least) slightly thickened at the apex, the incrassate area mostly $5-13 \mu$ thick and internally cribrose-pitted, the walls elsewhere mostly 1-2 $\mu$ thick.

On rocks and other algae, from above lcw-water mark down to a depth of at least 12 meters. Little Harbor Cay, Berry Islands (Howe 3583-type) :-Jamaica and Porto Rico.

It was at first thought that the peculiar pitting of the apical walls of the utricles might be sufficient to warrant ranging this plant in the specific category, but the occasional occurrence of similarly marked utricles in plants otherwise predominantly agreeing with $C$. intertextum (e. g., no. 3139 from Gun Cay) would seem to make this impractical.

\section{Family 13. VAUCHERIÀCEAE.}

1. DIснотомоsiphoN Ernst, Beih. Bot. Centralbl. 13: 115.1902.

1. Dichotomosiphon pusíllus Collins, Tufts College Stud. 2: 431.1909.

On and with Amphibia on roots of Rhizophora, in tlde-pools and lagoons, and often forming a compact dark-green velvety turf on rocks between the tide-lines and on the mud in Rhizophora associations. New Providence, Exuma Chaln, Watling's Island, and Great Ragged Island:-Bermuda to Jamaica. Type from West Indies (Jamaica).

The filaments show a wlde range in size, even in a single tuft, varying from $15 \mu$ to $60 \mu$ in diameter.

\section{Family 14. CHARÀCEAE.}

1. *CHÀra L. Sp. Pl. 1156. 1753.

Stems triply cortlcated, but, by imperfect development of some of the secondary cells usually appearing doubly cortlcated; stipulodes forming a single whorl; at least the basal leaf-internode uncorticated; dioicous ; spinecells conspicuous on all stem-internodes.

Stems usually very regularly triplý coricated; stlpules form-

ing a double whorl; monoicous.

Some or all leaflets well developed.

All leaflets at sterlle nodes greatly reduced.

1. C. Hornemannii.

2. . foliolosa.

3. C. haitensis.

1. Chara Hornemánnii Wallm. K. Vet.-Akad. Handl. 1852: 288.1854.

Chara ceratophylla Halsted, Proc. Boston Soc. Nat. Hist. 20: 182. 1879.

Not $C$. ceratophylla Wallr.

In salt or brackish ponds. New Providence, Exuma Chain, and Watling's Island:- Southern Florida and New Mexico through the West Indies and Mexico to southern Brazll. Type from Crab Island (Vieques), Porto Rico.

- Determinations chlefly by the late Dr. Charles Budd Robinson and the key and synonymy adapted from the paper published by him in Bull. N. Y. Bot. Gernee 4: 244-308. 1906. 
2. Chara foliolòsa Muhl.; Willd. Mem. Acad. Roy. Berlin 1803: 86. pl. 1. f. 2. 1805.

Chara polyphylla Muhlenbergii A. Br. Boston Jour. Nat. Hist. 5: 264. 1845.

Chara Wikströmii Wallm. K. Vet.-Akad. Handl. 1852: 297. 1854.

Chara gymnopus Humboldtii A. Br.; Allen, Char. Am. 2. 1880.

Chara depauperata Allen, Bull. Torrey Club 21: 167. pl. 192. 1894.

Chara zeylanica H. \& J. Groves, in Urban, Symb. Antill. 7: 40. 1911.

In fresh-water and brackish ponds. New Providence, Great Bahama, Abaco, Cat Island, and Great Exuma:-Pennsylvanla to South America. Type from South America. The type of $C$. depauperata, here considered a synonym, was from New Providence.

3. Chara haiténsis Turpin, Dict. Sci. Nat. Veg. Acot. pl. 101. (Livr. $40: p l .1$ ). 1826.

Chara polyphylla A. Br. Flora 18: 70. 1835.

Chara Michauxii A. Br. Am. Jour. Sci. 46: 93. 1844.

Chara gymnopus Michauxii A. Br.; Allen, Char. 2. 1880.

Chara zeylanica Michauxii H. \& J. Groves, in Urban, Symb. Antill. 7: 42. 1911.

In fresh-water and brackish ponds. Inagua:-Illinois and Virginia to Haiti, Jamaica, and South America. Type from Haiti.

\title{
Sub-class MYXOPHỲCEAE.
}

\author{
Contributed by Frank S. Collins.
}

\section{Family 1. CHROOCOCCÀCEAE}

1. CHROOcóccuss Näg. Gatt. 45. 1849.

Cells $3-8 \mu$ in diameter.

Cells $13-25 \mu$ in diameter.
1. C. membraninus.

2. C. turgidus.

1. Chroococcus membranìnus (Menegh.) Näg. Gatt. 46. 1849.

Pleurococcus membraninus Menegh. Monogr. 34. pl. 4. f. 1. 1843.

Among other small algae, in company with Chroococcus turgidus, Caicos Islands : -Europe; Bermuda. Type from Italy.

2. Chroococcus túrgidus (Kütz.) Näg. Gatt. 46. 1849.

Protococcus turgidus Kütz. Tab. Phyc. 1: 5. pl. 6. f. 1. 1846.

Among other blue-green algae, Caicos Islands:- of world-wide distribution, marine and fresh water. Type from Europe.

\section{APHANOCÁPSA Näg. Gatt. 52. 1849.}

\section{Aphanocapsa Hówei Collins, sp. nov.}

Marina. Celulis 9-15 $\mu$ diam., sphaericis, raro subfusiformibus, membrana pertenui, plasmate homogeneo; cellulis in gelatina communi hyalina mollissima inordinatis; strato obscuro- vel atro-aerugineo.

Cells $9-15 \mu$ in diameter, spherical or rarely slightly fusiform, wall very thin, substance homogeneous, color pale aeruginous; forming a dull or dark aeruginous stratum, united by thin, homogeneous common gelatine, closely set in no definite order. 
In $3 \mathrm{dm}$. water in a salt lake, Watling's Island, November 25, 1907, $M$. A. Howe 5091 (type), 5092, 5100.

The general gelatine is very thin, hardly perceptible except by use of stains; at first glance the plant would be taken for a species of Synechocystis. Some of the cells, usually those near the surface of the colony, show a thicker tegument outside the very thin cell wall. Its nearest relative appears to be A. Zanardinii (Hauck) Hansg.* of Southern Europe and 3orneo, which has cells of much the same dimen-

* The record in Forti, Syll. Myx. 68. of the occurrence of A. Zanardinii in North America "Massachusetts (Collins)" is wrong. The writer has never found it, and has never seen American material.

sions, but of deeper color "viridi-smaragdino," and arranged by 2 or 4 in a firmer, more sharply defined common gelatine.

\section{GLOEOCÁPSA Kütz. Phyc. Gen. 173. 1843.}

Marine ; teguments brownish.

Terrestrial.

Teguments red; cells $4.5-7 \mu$ in diameter.

Teguments violet or steel-blue; cells $2.5-3.5 \mu$ in diameter.
1. G. bahamensis.

2. G. Magma.

3. G. lignicola.

\section{Gloeocapsa bahaménsis Collins, sp. nov.}

Marina. Cellulis indivisis $4-8 \mu$ diam., sine membrana $3-5 \mu$, pallide aerugineis, in familias 4-24 cellularum unitis; tegumentis amplis, distinctis, lamellosis, sub-vel perfuscis; familiis sparsis vel inter myxophyceas varias in crustam fuscam compactis.

Undivided cells $4-8 \mu$ in diameter, without wall $3-5 \mu$ in diameter, pale aeruginous; teguments wide, lamellose, distinct, lighter or darker brown; families scattered or loosely compacted with other Myxophyceae into a brownish crust.

On the border of a salt pond, east end of Mariguana, December 12, 1907, M. A. Howe 5538 (type).

The cells in this material are dividing so rapidly that single free cells are seldom seen; the wide teguments may persist through many generations of cell division. G. crepidinum 'Thuret, the best known and most generally distributed species, has thin and rather inconspicuous teguments, the cells, not including the walls, larger, the color brownish. G. deusta (Menegh.) Kütz. also has larger cells and thinner teguments, with cells and teguments dark green to blackish.

2. Gloeocapsa Mágma (Bréb.) Kütz. Tab. Phyc. 1: 17. pl. 22. f. 1. 1847.

Protococcus Magma, Bréb. Alg. de Falaise, 40. pl. 4. 1836.

Among other blue-green algae, New Providence:- of wide distribution inland in warm and temperate regions. Type from France.

3. Gloeocapsa lignícola Rab. Fl. Eur. Alg. 2: 41. 1865.

On bark, New Providence, first American record:-Europe. Type from France.

\section{ENTOPHÝSALIS Kütz. Phyc. Gen. 177. 1843.}

\section{Entophysalis violàcea Collins, sp. nov.}

Marina. Cellulis sphaericis, 4-5 $\mu$ diam., sine membrana 2-3 $\mu$ diam., elongatis ante divisionem, atroviolaceis, membrana hyalina, incolori vel plusminus coerulescente; cellulis 2 , interdum 4 , in membrana matricali persistente, series longitudinales indefinitas formantibus; seriebus dense compactis in stratum tenue firmum nigrum.

Cells with wall spherical, $4-5 \mu$ in diameter, becoming elongate when dividing, without wall ' $2-3 \mu$ in diameter, color dark violet, wall translucent, colorless or more or less bluish; cells usually 2, occasionally 4 in the mothercell wall, in indefinite longitudinal series, closely packed to form a thin smooth black crust. (type).

On rocks at low water mark, Atwood Cay, December 3, 1907, M. A. Howe 5282

E. granulosa Kütz., the type of the genus, forms a thicker, warty and granular 
crust of a brown color; the cells are somewhat larger than in the present species, and brownish or yellowish. $E$. violacea approaches the genus Placoma in the tendency of the cells to arrange in radiate filaments, but the tendency is less marked than in Placoma, and the frond is closely adherent to the substratum, not bullate and hollow as in Placoma.

5. GLOEOTHÈCE Näg. Gatt. 57. 1849.

1. Gloeothece rupéstris (Lyngb.) Bornet; Wittr. \& Nordst. Alg. Exsice. 399. 1880.

Palmella rupestris Lyngb. Tent. 207. pl. 69. f. D. 1819.

On rocks, nearly pure, Caicos Islands:-common everywhere in small quantity among other algae, especially in shallow pools, both alongshore and inland; of general distribution. Type from Denmark.

Very variable; teguments often diffluent, giving the appearance of Aphanothece.

6. ONCOBÝRSA Ag. Flora 10: 629. 1827.

1. Oncobyrsa marìna (Grun.) Rab. Flor. Eur. Alg. 2: 68. 1865.

Hydrococcus marinus Grun. Verh. Zool.-Bot. Ges. Wien. 11: 420. 1861.

On Chondria, Mariguana:-Europe; Africa; Bermuda. Type from the Mediterranean.

\section{Family 2. CHAMAESIPHONÀCEAE.}

1. HYÉLIA Born. \& Flah. Jour. de Bot. 2: 162. 1888.

1. Hyella caespitòsa Born. \& Flah. loc. cit.

In dead shells, common:-generally distributed. Type from France.

2. DERMOCÁRPA Crouan, Ann. Sci. Nat. Bot. IV. 9: 70. 1858.

1. Dermocarpa prasina (Reinsch) Bornet \& Thuret, Notes Alg. 75. pl. 26. f. 6-9. 1880.

Sphaenosiphon prasinus Reinsch, C'ontrib. 17. pl. 26. f. 1. 1875.

On Catenella opuntia pinnata, Berry Islands; probably to be found wherever the host occurs:-Europe. Type from Europe.

The common species of the New England coast, whlch has passed under this name, has much larger cells, and was segregated by Börgesen as D. Farlowii.

3. XENocóccus Thuret, Ann. Sci. Bot. VI. 1: 373. 1875.

1. Xenococcus Schoùsboei Thuret in Born. \& Thur. Notes Alg. 76. pl. 26. f.1-2. 1880.

Attached to wall of Lyngbya sp., Atwood Cay :-of general distribution. Type from northern Africa.

\section{Family 3. OSCILLATORIÀCEAE.}

1. OsCirluatòria Vaucher, ex Gomont, Monogr. 218. 1893.

Trichomes not torulose, $4-10 \mu$ in diameter.

Trichomes distinctly torulose.

Stratum and trichomes red or red-brown.

Stratum and trichomes aeruginous or chalybeous.

Trichomes $10-20 \mu$ in diameter, apex straight.

Trichomes $6-10 \mu$ in diameter, apex usually curved.
4. O. tenuis.

2. O. miniata.

1. O. sancta.

3. O. Corallinae.

1. Oscillatoria sáncta Kütz. ex Gomont, Monogr. 229. pl. 6. f. 12. 1893 Atwood Cay:-generally distributed, normally in fresh water. Type from Italy.

2. Oscillatoria miniàta Hauck ex Gomont, Monogr. 236. 1893.

Floating, with Trichodesmium Thiebautii, in Gulf Stream between Gun Cay and Florida:-Bermuda; Guadeloupe; and Adrlatic Sea. Type from Adriatic Sea. 
3. Oscillatoria Corallìnae Gomont, Monogr. 238. pl. 6. f. 21. 1893.

On Halimeda, etc., Mariguana :-Europe; North America. Type from France.

4. Oscillatoria ténuis Ag. ex Gomont, Monogr. 241. 1893.

Watling's Island :- of world-wide distribution, fresh water, occasionally submarine. Type from Sweden.

2. TRICHODÉSMIUM Ehrenb. Ann. Phys. u. Chem. 18: 506. 1830.

1. Trichodesmium Thiebaùtii Gomont, Jour. de Bot. 4: 356. 1890.

Pelagic in Guif Stream, between Gun Cay and Florida:-Bermuda; Guadeloupe; and Canary Islands. Type from Guadeloupe.

\section{PHORḾ́dIUM Kütz. ex Gomont, Monogr. 176. 1893.}

Trichomes distinctly torulose, $1.2-2.3 \mu$ in diameter. Trichomes not torulose.

Trichomes less than $2 u$ in diameter; forming definite cartilaginous discs or cushions.

Trichomes $2 \mu$ in diameter or more.

Trichomes $2-2.5 \mu$ in diameter, cells 1.5-3 diameters long. Trichomes over $3 \mu$ in diameter.

Apical cell obtusely conical, trichomes $3-4.5 \mu$ in diameter.

Apical cell truncate, cells $5 u$ in diameter or more.

Cells usually shorter than their diameter, dissepiments often constricted, sheaths loose and diffluent.

Cells usually longer than their diameter, trichomes always cylindrical, sheath close, persistent.

1. P. fragile.

2. P. Hendersonii.

3. $P$. valderianum.

4. P. Corium.

5. P. Retzii.

6. P.pulvinatum.

1. Phormidium frágile Gomont, Monogr. 183. pl. 4. f. 13-15. 1893.

On walls of fresh-water tanks, New Providence:-Europe; Africa; North America. Type from Italy.

2. Phormidium Hendersònii M. A. Howe, Smiths. Misc. Coll. 68 ${ }^{11}$ : 3. 1918.

Forming definite discs or cushions on rocks, Watling's Island:-Cuba, Porto Rico. Type from Cuba.

3. Phormidium valderiànum Gomont, Monogr. 197. pl. 4. f. 20. 1893.

Among other algae, New Providence, North Cat Cay, Watling's Island :-Europe ; North America; fresh water and marine. Type from Italy.

4. Phormidium Còrium Gomont, Monogr. 192. pl. 5. f. 1-2. 1893.

Great Ragged Island:-generally distributed. Type from Sweden.

5. Phormidium Rétzii Gomont, Monogr. 195. pl. 5. f. 6-9. 1893.

Caicos Islands:-generally distributed. Type from Sweden.

6. Phormidium pulvinàtum Collins, sp. nov.

Marinum. Strato pallide aerugineo, crasso, compacto, pulvinato; filamentis rectis vel leviter curvatis, vaginis tenuibus, membranaceis, persistentibus, adhaerentibus nec diffluentibus; trichomatibus pallide aerugineis, cylindricis, apice rectis, non capitatis nec attenuatis; cellulis $7-9 \mu$ diam., $\frac{3}{4}-1 \frac{1}{2}$ diam. longis; dissepimentis non granulatis; cellula apicali rotundata.

Stratum pale aeruginous, thick, compact, pulvinate; filaments straight or slightly curved; sheaths thin, membranaceous, persistent, adherent but not diffluent; trichomes pale aeruginous, cylindrical, apex not attenuate nor capitate, $7-9 \mu$ in diameter, cells $\frac{3}{4}-1 \frac{1}{2}$ diameters long, dissepiments not granulate; apical cell rounded. 
Abundant in 4-5 m. Water, forming pulvinate masses among Thalassia, Penicillus, etc., Cockburn Harbor, South Caicos Island, December 16, 1907, M. A. Hove 559S (type).

Nearest allied to $\boldsymbol{P}$. Retzii; but differing by the firmer and more persistent sheaths, the uniformly cylindrical trichomes and the generally longer cells, as well as by the distinctly marine habitat. There is more or less lime scattred through the mass, but incidentally ; it does not form a stony mass as in the encrusting species.

4. IÝNGBYA Ag. ex Gomont, Monogr. 138. 1893.

Fllaments attached at the middle, both ends free.

Filaments attached at one end or without definite point of attachment.

Fllaments spirally wound about some other filamentous alga.

Filaments not epiphytic and spiral.

Trichomes $4 \mu$ in diameter or less, seldom over $3 \mu$.

Trichomes over $5 \mu$ in diameter.

Trichomes usually $20-40 \mu$ in diameter; length of cells 1/6-1/15 of the diameter; dissepiments not granulate.

Trichomes usually $16 \mu$ in diameter or less; length of cells $1 / 3-1 / 8$ of the diameter; dissepiments usually granulate.

Trichomes usually $9-16 \mu$ in diameter; apex not attenuate nor capitate; stratum usually yellow.

Trichomes usually more or less attenuate and capitate.

Sheath becoming yellowish or brownish with age ; stratum mostly aeruginous or rusty ; trichomes usually 10-16 $\mu$.

Sheath always hyaline; stratum dull or yellow green; trichomes $7-10 \mu$ in dlameter.

1. L. gracilis.

7. L. epiphytica.

6. L. Lagerheimii.

3. L. majuscula.

4. L. confervoides:

2. L. aestuarii.

5. L. semiplena.

1. Lyngbya grácilis Rab. ex Gomont, Monogr. 145. pl. 2. f. 20. 1893.

Among other algae, Exuma Chain:-Europe; North America. Type from Italy.

2. Lyngbya aestuàrii (Mert.) Liebmann ex Gomont, Monogr. 147. pl. 3. f. 1-2. 1893.

Exuma Chain :-common on all shores. Type from Denmark.

2a. Lyngbya aestuarii forma limícola Gomont, Monogr. 149. 1893. known.

Exuma Chain, with the typical form; of same distribution. Type station un-

3. Lyngbya majúscula Harv. ex Gomont, Monogr. 151. pl. 3. f. 3-4. 1893.

New Providence, Berry Islands, Exuma Chain, Watling's Island, Atwood Cay, Mariguana, Caicos Isiands, Great Ragged Island:-everywhere in tropical and warm temperate waters. Type from England.

4. Lyngbya confervoìdes Ag. ex Gomont, Monogr. 156. pl. 3. f. 5-6. 1893.

New Providence, Joulter's Cay, Bimini, Berry Islands, Exuma Chain, Watling's Island, Cat Island, Mariguana, Caicos Islands, Great Ragged Isiand:-generally distributed in tropical and warm temperate waters. Type from Spain.

5. Lyngbya semiplèna J. Ag. ex Gomont, Monogr. 158. pl. 3. f. 7-11. 1893.

New Providence, Berry Islands, Great Bahama, Exuma Chain, Watling's Island, Atwood Cay, Mariguana, Great Ragged Island:-generally distributed. Type from the Mediterranean.

6. Lyngbya Lagerheìmii Gomont, Monogr. 167. pl. 4. f. 6-\%. 1893.

Caicos Islands:-Europe; North and South America. Type from Brazil.

7. Lyngbya epiphýtica Hieronymus; Kirchner in Engl. \& Prantl, Nat. Pflanzenfam. $1^{1 \mathrm{a}}: 67.1898$.

Winding about the filaments of Lyngbya sp.; Watling's Island, Atwood Cay :Europe; North America. Type from Germany. 
5. PLECTONÈMA Thuret ex Gomont, Monogr. 116. 1893.

Trichomes torulose; flaments inhabiting colonies of gelatinous algae.

Trichomes not torulose; filaments matted into a rose-colored membrane.

1. P. nostocorum.

2. P. roseolum.

1. Plectonema nostocòrum Born. ex Gomont, Monogr. 122. pl. 1. f. 11. 1893.

New Providence, in colonies of Gloeothece, etc.:-common everywhere in similar habitats. Type from France.

2. Plectonema rosèolum Gomont, Monogr. 122. pl. 1. f. 9-10. 1893.

On sand and mud, New Providence:-Europe; North America. Type from Germany.

6. SÝMPLOCA Kütz. ex Gomont, Monogr. 124. 1893.

1. Symploca hydnoìdes forma fruticulòsa Gomont, Monogr. 127. 1893.

North Cat Cay and Great Bahama :-the typical form is widely distributed, the type from Great Britain; no type locality for the forma fruticulosa which occurs generally with the typical form.

\section{HYDROCÒLEUM Kütz. ex Gomont, Monogr. 71. 1893.}

Sheath cylindrical, distinct.

Sheath irreguiar, often becoming shapeless and diffluent.

Trichomes usually $9-11 \mu$ in diameter.

Trichomes seldom under $17 \mu$ in diameter.

Filaments forming tufts attached to algae or to sand and rocks; sheaths broad, with irregular and erose margins, but fairly persistent.

Filaments not attached, forming an indefinite geiatinous stratum; sheaths very irregular or shapeless, soon diffluent.
1. H. comoides.

2. H. lyngbyaceum.

3. $H$. cantharidosmum.

4. H. glutinosum.

1. Hydrocoleum comoìdes Gomont, Monogr. 73. pl. 12. f. 3-5. 1893.

Great Bahama and Exuma Chain :-Bermuda; Guadeloupe; Australia. Type from Australia.

2. Hydrocoleum lyngbyàceum Kütz. ex Gomont, 75. pl. 12. f. 8-10. 1893. France.

Caicos Islands and Great Ragged Islands:- of general distribution. Type from

3. Hydrocoleum cantharidósmum Gomont, Monogr. 74. pl. 12. f. 6-7. 1893. Islands.

Mariguana:-widely distributed in warmer waters. Type from the Canary

4. Hydrocoleum glutinòsum Gomont, Monogr. 77. 1893.

Caicos Islands :-Europe and America. Type from Sweden.

The genus Hydrocoleum is fairly distinct from neighboring genera, but the species have much similarity. Absolute certainty of determination can be obtained only by observing the development of the living plant.

8. SCHIZÒTHRIX Kütz. ex Gomont, Monogr. 30. 1893.

Sheaths hyaline, trichomes $2-3 \mu$ in diameter.

Sheaths with inner layer violet or slate color; outer layer hyaline, trichomes $7-9 \mu$ in diameter.

1. S. vaginata.

2. S. chalybea.

1. Schizothrix vaginàta Gomont, Monogr. 40. pl. \%. f. 1-4. 1893. land.

New Providence and Caicos Islands:-generally distributed. Type from Switzer- 
2. Schizothrix chalybèa Gomont, Monogr. 57. pl. 9. f. 3-5. 1893.

On mud, in company with Scytonema velutinum, New Providence. Type locality Mexico; no other records. The determination is from the description, as type material is at present inaccessible.

\section{Family 4. NOSTOCÀCEAE.}

1. NósToc Vaucher, ex Born. \& Flah. Ann. Sci. Nat. Bot. VII. 7: 181. 1888.

1. Nostoc commùne Vaucher, ex Born. \& Flah. Ann. Sci. Nat. Bot. VII. 7: 203. 1888.

New Providence, Castle Island, and Crooked Island :- universally distributed in warm and temperate regions, on ground and rocks. Type from Switzerland.

2. HORMOTHÁMINION Grunow, ex Born. \& Flah. Ann. Sci. Nat. Bot. VII. 7: 259.1888.

1. Hormothamnion enteromorphoìdes Grunow, ex Born. \& Flah. loc. eit. 260. 1888.

North Cat Cay, Calcos Islands, and Watling's Island:-generally distributed in troplcal and subtroplcal waters. Type from Guadeloupe.

\section{Family 5. SCYTONEMATÀCEAE.}

1. scytonìmA Ag. ex Born. \& Flah. Ann. Sci. Nat. Bot. VII. 5:

85. 1887.

1. Sheaths homogeneous or with uniform parallel strata.

1. Sheaths with plainiy divergent strata.

2. Aquatic; sheaths firmly membranaceous.

2. Terrestrial.

3. Heterocysts compressed, shorter than the diameter of the trichome.

3. Heterocysts quadrate or longer.

4. Filaments mostly prostrate, $10-18 \mu$ in diameter.

4. Filaments in erect fascicles, usually $7-12 \mu$ in diameter.

5. Strata of sheath moderately divergent, rather firm.

5. Strata of sheath strongly divergent, gelatinous and diffluent.

6. Cells and heterocysts shorter than the diameter of filament.

6. Cells quadrate or longer; heterocysts quadrate or globose.

1. S. cincinnatum.

5.

2. S. Millei.

3. S. ocellatum.

4. S. Hofmanni.

5. S. myochrous.

6. S. velutinum.

7. S. crassum.

1. Scytonema cincinnàtum Thuret, ex Born. \& Flah. Ann. Sci. Bot. VII. 5: 89. 1887.

New Providence and Bimini:-widely distributed. Type from Germany.

2. Scytonema Míllei Born. \& Flah. Ann. Sci. Nat. Bot. VII. 5: 93.1887.

New Providence, Berry Islands, South Cat Cay, and Watling's Island :-North and South America. Type from Guiana.

3. Scytonema ocellàtum Lyngb. ex Born. \& Flah. Ann. Sci. Nat. Bot. VII. 5: 95. 1887.

New Providence:-widely distributed. Type from Denmark.

4. Scytonema Hófmanni Ag. ex Born. \& Flah. Ann. Sci. Nat. Bot. VII. 5: 97. 1887. Sweden.

New Providence, Abaco, and Acklin Island:-widely distributed. Type from 
5. Scytonema myochròus Ag. ex Born. \& Flah. Ann. Sci. Nat. Bot. VII. 5: 104. 1887.

Cat Island, Watling's Island, and Great Ragged Island:-widely distributed. Type from Sweden.

6. Scytonema velùtinum Rab. ex Born. \& Flah. Ann. Sci. Nat. Bot. VII. 5: 108. 1887.

New Providence, Exuma Chain, and Abaco:-Europe. Type from Germany.

7. Scytonema crássum Näg. ex Born. \& Flah. Ann. Sci. Nat. Bot. VII. 5: 109. 1887.

New Providence:-Europe; Ceylon. Type from Italy.

\section{Family 6. STIGONEMATÀCEAE.}

1. MAStigocòteus Lagerheim, ex Born \& Flah. Ann. Sci. Nat. Bot. VII. 5: 54. 1887.

1. Mastigocoleus testàrum Lagerheim, ex Born. \& Flah. loc. cit.

2. STIGONÈMA Ag. ex Born. \& Flah. Ann. Sci. Nat. Bot. VII. 5: 62. 1887.

Fragments of a Stigonema have been found mixed with other algae, but not in condition for specific determination.

\section{Family 7. RIVULARIÀCEAE.}

1. CALÒTHRIX Ag. ex Born \& Flah. Ann. Sci. Nat. Bot. VII. 3 : 345. 1886.

Trichome violet.

Trichome olivaceous or aeruginous.

More or less endophytic.

Not endophytic.

Filaments attached at the middle.

Filaments attached at one end.

Usually epiphytic, forming a bright aeruginous continuous coating; filaments usually $9-10 \mu$ in diameter; intercalary heterocysts often present.

Usually saxicolous, rarely epiphytic, forming a blackish green or ollvaceous stratum; filaments $10-18 \mu$ in diameter; heterocysts basal.
1. C. fusco-violacea.

3. C. parasitica.

5. C. pilosa.

4. C. aeruginea.

2. C. scopulorum.

1. Calothrix fúsco-violàcea Crouan, ex Born. \& Flah. Ann. Sci. Nat. Bot. VII. 3: 352. 1886.

New Providence:-Europe; North America. Type from France.

2. Calothrix scopulòrum Ag. ex Born. \& Flah. Ann. Sci. Nat. Bot. VII. 3: 353.1886. Britain.

In small quantities, with other algae:-widely distributed. Type from Great

3. Calothrix parasítica Thuret, ex Born. \& Flah. Ann. Sci. Nat. Bot. VII. 3: 357. 1886.

In small quantitles, with other algae:-widely distributed. Type from France.

4. Calothrix aeruginea Thuret, ex Born. \& Flah. Ann. Sci. Nat. Bot. VII. 3: 358. 1886.

Berry Islands and Great Bahama :-Widely distributed. Type from Germany. 
5. Calothrix pilòsa Harv. ex Born. \& Flah. Ann. Sci. Nat. Bot. VII. 3: 363. 1886.

New Providence:-warm waters generally. Type from Florida.

2. DICHÒTHRIX Zan. ex Born. \& Flah. Ann. Sci. Nat. Bot. VII. 3: 373. 1886.

Filaments $17-22 \mu$ in diameter; branches long. erect.

Filaments about $15 \mu$ in diameter; branches short, flexuous.
1. D. fucicola.

2. D. penicillata.

1. Dichothrix fucícola Born. \& Flah. Ann. Sci. Nat. Bot. VII. 3: 379. 1886.

Watling's Island, Castle Island, and Mariguana :-Bermuda; West Indies; Central America. Type from Central America.

2. Dichothrix penicillàta Zan. ex Born. \& Flah. Ann. Sci. Nat. Bot. VII. 3: 379. 1886.

Bimini, Great Bahama, Berry Islands, Castle Island, and Watling's Island:Red Sea; Florida; West Indies. Type from Red Sea.

3. POLÝTHRIX Zan. ex Born. \& Flah. Ann. Sci. Nat. Bot. VII. 3: 380.1886.

1. Polythrix corymbòsa Grunow, ex Born. \& Flah. loc. cit. 380. 1886.

New Providence and Exuma Chain :-widely distributed in warm waters. Type from Florida.

4. RIVULÀrIA Ag. ex Born. \& Flah. Ann. Sci. Nat. Bot. VII. 3: 345. 1886.

Trichomes tapering from middle to each end.

Trichomes tapering towards apex only.

Trichomes 5-9 $\mu$ in diameter, sheaths wide, loose.

Trichomes $2-5 \mu$ in diameter, sheaths close, compacted.

3. R. polyotis.

1. R. Biasolettiana.

2. R. nitida.

1. Rivularia Biasolettiàna Menegh. ex Born. \& Flah. Ann. Sci. Nat. Bot. VII. 3: 352 . 1886.

Mariguana and Atwood Cay :-Europe; North America. Type from the Adriatic.

2. Rivularia nítida Ag. ex Born. \& Flah. Ann. Sci. Nat. Bot. VII. 3: 357. 1886.

New Providence and Exuma Chain:-generally distributed. Type from Sweden.

3. Rivularia polyòtis Born. \& Flah. Ann. Sci. Nat. Bot. VII. 3: 360. 1886.

Watling's Island:-Europe; North America. Type from the Mediterranean.

\section{Sub-class DIATOMEAE}

\section{Contributed by Charles S. Boyer.}

The diatomaceous flora of the Bahamas includes twenty-five or more genera most of which are common to the North American coast. Of this number, however, two genera, Plagiogramma and Mastogloia, are especially prominent. The former is represented by species first described by Greville as occurring on conch shells at Nassau and New Providence. The latter is quite prolific in species on algae collected by Dr. Marshall A. Howe. The forms which, perhaps, are characteristic of the Bahamas are Mastogloia bahamensis Cleve, not very 
rare. and Mastogloia rimosa Cleve, which is common in one locality. Mastogloia erythraea Grun. is common but quite variable in size, outline and the inequality of the loculi. Mastogloia splendida (Greg.) Cleve occurs in all localities. Podocystis adriatica Kütz. is abundant on Antithamnion. Climacosphenia moniligera Ehrenb. is also noticeable, while Grammatophora flexuosa Grun is found in all gatherings, occurring pure on Centroceras. The minute form, Striatella delicatula (Kütz.) Grun., not heretofore recorded from this locality, is abundant on Polysiphonia. One specimen of Plagiogramma labuense Cleve, a form peculiar to Borneo, although somewhat similar to Plagiogramma caribaeum Cleve, has been found.

The following list includes the greater number of the forms noticed but there are probably many more as various algae appear to differ much in the variety of diatoms found upon them.

BIDDULPHIA S. F. Gray, em. Van Heurck.

Biddulphia Pentácrinus (Ehrenb.) Boyer. Rare.

ANAÙLUS Ehrenb., em. Van Heurck.

Anaulus minùtus Grun. Rare.

GRAMMATÓPHORA Ehrenb.

Grammatophora flexuòsa Grun. Common.

STRIATÉLLA Ag., em. Heiberg.

Striatella delicátula (Kütz.) Grun. Local.

LICMÓPHORA Ag. em. Roper.

Licmophora dalmática (Kütz.) Grun. Local.

CLIMACOSPHÈNIA Ehrenb.

Climacosphenia monilígera Ehrenb. Common.

PLAGIOGRÁMMA Grev.

Plagiogramma inaequàle Grev. Rare.

Plagiogramma labuénse Cleve. Rare.

Plagiogramma lyràtum Grev. Not common.

Plagiogramma obèsum Grev. Not common.

Plagiogramma pulchéllum Grev. Not common.

Plagiogramma pygmàeum Grèv. Not common.

TRACHYSPHÈNIA P. Petit.

Trachysphenia austràlis P. Petit. Rare.

\section{CYMATOSIRA Grun.}

Cymatosira Lorenziàna Grun. Occasional.

\section{GLYPHODÉSMIS Grev.}

Glyphodesmis exímia Grev. Rare. 
SYNÈDRA Ehrenb.

Synedra Gaillònii mìnor Kütz. Local.

Synedra supérba mìnor Kütz. Rare.

Synedra undulàta Bailey. Rare.

\section{COCCONÈIS Ehrenb.}

Cocconeis Scutéllum Ehrenb. Common.

\section{ÁMPHORA Ehrenb.}

Amphora obtùsa Greg. Occasional.

Amphora bigíbba Grun. Rare.

\section{MASTOGLÒIA Thw.}

Mastogloia angulàta Lewis. Common.

Mastogloia apiculàta W. Smith. Common.

Mastogloia aspérula Grun. Not common.

Mastogloia bahaménsis Cleve. Not common.

Mastogloia binotàta (Grun.) Cleve. Rare.

Mastogloia Citrus Cleve. Common.

Mastogloia cocconeifórmis (Grun.) Cleve. Common.

Mastogloia cuspidàta Cleve. Common.

Mastogloia delicátula Cleve. Not common.

Mastogloia erythraèa Grun. Common and variable.

Mastogloia lanceolàta Thw. Common.

Mastogloia lemniscàta Leud. Rare.

Mastogloia minùta Grev. Common.

Mastogloia rimòsa Cleve. Rare or local.

Mastogloia Smithii Thw. Common.

Mastogloia spléndida (Greg.) Cleve. Common and variable.

\section{DICTYONÈIS Cleve.}

Dictyoneis jamaicénsis Cleve: Rare.

DIPIONÈIS Ehrenb., em. Cleve.

Diploneis vacillans (A. Schmidt) Cleve. Rare.

Diploneis Weissflògii (A. Schmidt) Cleve. Rare.

\section{NAVícula Bory.}

Navicula brasiliénsis Grun. Rare.

Navicula Lỳra dilatàta A. Schmidt. Rare.

Navicula ramosíssima (Ag.) Cleve. Local.

Navicula suborbiculàris (Greg.) Donkin. Rare.

Navicula Zosterèti Grun. Rare.

\section{TRACHYNÈIS Cleve.}

Trachyneis áspera (Ehrenb.) Cleve. Rare.

\section{PINNULÀría Ehrenb.}

Pinnularia rectangulàta Greg. Rare.

PIEURosígMA W. Smith.

Pleurosigma formòsum W. Smith. Rare. 


\section{TROPIDONÈIS Cleve.}

Tropidoneis lepidóptera (Greg.) Cleve. Not common.

\section{EPITHÈMாA Bréb.}

Epithemia Músculus Kütz. Rare.

\section{NITZSCHIA Hassall.}

Nitzschia apiculàta (Greg.) Grun. Common.

Nitzschia Sígma (Kütz.) W. Smith. Rare.

Nitzschia válida Cleve \& Grun. Rare.

\section{SURIRELLA Turpin.}

Surirella fastuòsa Ehrenb. Rare.

Surirella recèdens A. Schmidt. Rare.

\section{PODOCÝsTIS Kütz.}

Podocystis adriática Kütz. Local.

\section{CAMPYLODÍSCUS Ehrenb.}

Campylodiscus símulans Greg. Rare.

Campylodiscus imperiàlis Grev.

The following list contains additional names of species occurring in the harbor mud of Nassau, as reported by Tempère (Diatomées du Monde entier, 144, 375. 1915). To avoid inconsistency, the nomenclature, in some instances, is revised to agree with the classification of Cleve, Van Heurck, Deby, Grunow and others. Nearly all of the forms are more or less common along the Atlantic coast.

Meloseìra arenària Moore.

Meloseira sulcàta Kütz.

Coscinodíscus concínnus Jonesianus (Grev.) Rattray.

Coscinodíscus excéntricus Ehrenb.

Coscinodíscus léptopus Grun.

Coscinodíscus marginàtus Ehrenb.

Coscinodíscus nitidulus Grun.

Coscinodíscus nítidus Greg.

Coscinodíscus nodùlifer Janisch.

Coscinodíscus obscùrus A. Schmidt.

Coscinodíscus radiàtus Ehrenb.

Coscinodíscus Róthii Grun.

Actinoptỳchus spléndens (Shadb.) Ralfs.

Actinoptỳchus undulàtus (Bailey) Ralfs.

Actinoptỳchus vulgàris Schumann.

Actinocỳclus fasciculàtus C'astr.

Actinocỳclus monilifórmis Ralfs.

Actinocỳclus Ròtula Brun, var.

Euòdia Gíbba Bailey.

Ropèria tessellàta (Roper) Grun.

Aulíscus caelàtus Bailey.

Aulíscus reticulàtus Grev.

Biddúlphia Antillàrum (Cleve) Boyer.

Biddúlphia árctica (Brightw.) Boyer. 
Biddúlphia Fàvus (Ehrenb.) Van Heurck.

Biddúlphia mobiliénsis (Bailey) Grun.

Biddúlphia peruviàna Grun.

Biddúlphia reticulàta Roper.

Biddúlphia Retículum (Ehrenb.) Boyer.

Biddúlphia Robertsiàna (Grev.) Boyer.

Biddúlphia Smíthii (Ralfs) Van Heurck.

Biddúlphia spinòsa (Bailey) Boyer.

Biddúlphia Tabellàrium (Brightw.) Boyer.

Rhabdonèma adriáticum Kütz.

Grammatóphora marìna (Lyngb.) Kütz.

Entopỳla austràlis (Arnott) Grun.

Petítia* Tempèrei Perag.

Plagiográmma decussàtum Grev.

Plagiográmma tessellàtum Grev.

Dimerográmma lanceolàtum Perag.

Dimerográmma mìnus (Greg.) Ralfs.

Synèdra formòsa Hantzsch.

Synèdra fúlgens (Grev.) W. Smith.

Synèdra supérba Kütz.

Synedrosphaènia baculifórmis Perag.

Cocconèis heteroìdea Hantzsch.

Cocconèis pseudomarginàta Greg.

Á mphora acùta arcuàta (A. Schmidt) Cleve.

Á mphora coffaeifórmis (Ag.) Cleve.

Ámphora crássa Greg.

Ámphora cymbelloìdes Grun.

Ámphora gigantèa fúsca (A. Schmidt) Cleve.

Â mphora Graèffei Grun.

Ámphora Gruèndleri Greg.

Ámphora Janíschii A. Schmidt.

Ámphora ostreària Bréb.

Ámphora ostreària vitraèa Cleve.

Ámphora rhómbica Kitton.

Calonèis formòsa (Greg.) Cleve.

Calonèis Liber (W. Smith) Cleve.

Calonèis Lìber Bleìschii (Janisch) Cleve.

Calonèis Powéllii (Lewis) Cleve.

Mastoglòia affinis Cleve.

Mastoglòia affirmàta Leud.

Mastoglòia amoèna túrgida Brun.

Mastoglòia bisulcàta Grun.

Mastoglòia bisulcàta corsicàna (Grun.) Cleve.

Mastoglòia Cràveni Leud.

Mastoglòia euxina Cleve var.

Mastoglòia lineàta Cleve \& Grove.

Mastoglòia Macdonáldii Grev. var.

Mastoglòia ovàta Grun.

Mastoglòia Peragálli Brun.

Mastoglòia Pisículus Cleve.

Mastoglòia Rhómbus P. Petit.

Mastoglòia rostellàta Grun.

Dictyonèis marginàta (Lewis) Cleve.

Diploneis advèna sansegàna (Grun.) Cleve.

Diploneis Bómbus (Ehrenb.) Cleve.

* Petitia for a modern diatom genus is invalid. See Petitia Jacq. 1760, a genus of Verbenaceae, p. 373 of this book. N. L. B. 
Diploneis Campylodíscus (Grun.) Cleve.

Diploneis coffaeifórmis (A. Schmidt) Cleve.

Diploneis Cràbro Ehrenb.

Diploneis démta (A. Schmidt) Cleve.

Diploneis gemmátula (Grun.) Cleve.

Trachynèis Antillàrum Cleve.

Trachynèis Débyi (Leud.) Cleve.

Navícula approximàta Grev.

Navícula complanàta Grun.

Navícula cuspidàta ambigua (Ehrenb.) (Teve

Navícula dirécta W. Smith.

Navícula irroràta Grev.

Navícula Scopulòrum Bréb.

Navicula transfùga Grun.

Gyrosígma réctum (Donkin) Cleve.

Pleurosígma compáctum Grev.

Pleurosígma Weissflògii (Grun.) Cleve.

Aurícula intermèdia Cleve.

Aurícula minùta Cleve.

Epithèmia gibbérula (Ehrenb.) Kütz.

Nítzschia angulàris W. Smith.

Nítzschia compréssa (Bailey) Boyer.

Nítzschia granulàta Grun.

Nitzschia Jelinéckii Grun.

Nítzschia pandurifórmis Greg.

Nitzschia vermiculàris (Kütz.) Hantzsch.

Surirélla fusifórmis Leud.

Surirélla incurvàta A. Schmidt.

Surirélla mánca Janisch.

Surirélla mexicàna A. Schmidt.

Campylodíscus angulàris Greg.

Campylodíscus biangulàtus Grev.

Campylodíscus crebrecostàtus Grev.

Campylodíscus Daemeliànus Grun.

Campylodíscus Ecclesiànus Grev.

Campylodíscus làtus Shadb.

Campylodíscus limbàtus Bréb.

Campylodíscus samoénsis Grun.

Campylodíscus undulàtus Grev.

Campylodíscus Wallichiànus Grev.

CLASS 3. FUNGI.

Contributed by Fred J. Seaver.

\section{Sub-class 1. PHYCOMYCÈTES.}

\section{Order 1. PERONOSPORÀLES.}

1. Albùgo cándida (Pers.) Kuntze, Rev. Gen. Pl. 2: 658. 1891.

Aecidium candidum Pers. in Gmelin, Syst. Nat. 2: 1473.1791.

On Lepidium virginicum L., New Providence, Watling's Island:-widely distributed, probably occurring wherever the host plants are found.

2. Albugo Ipomoèae-pandurànae (Schw.) Swing. Jour. Myc. 7: 112. 1892. Aecidium Ipomoeae-panduranae Schw. Schr. Nat. Ges. Leipzig 1:69. 1822. ceding.

On Jacquemontia cayensis Britton, Inagua:-distribution similar to the pre- 


\section{Sub-class 2. ASCOMYCÈTES.}

Spores borne in perithecia which are closed or open to the exterior by an ostiolum. Ostiolum wanting or obscure; vegetative mycelium superficial.

Ostiolum present and often conspicuous; vegetative mycelium not as above.

Perithecia consisting of cavities in the stroma without well developed wall.

Perithecla provided with well developed wall, with or without stroma.

Perithecia and stroma bright colored, fleshy.

Perithecia and stromata black, usually carbonaceous.

Spores borne in apothecia with the hymenium freely exposed at maturity.

Hymenium circular or subcircular in form.

Hymenium elongated, often opening with a slit-like aperture.

Order 1. Perisporiales.

Order 2. Dothideales.

Order 3. HY POCREALES.

Order 4. Sphaeriales.

Order 5. Pezizales.

Order 7. Phacidiales.

\section{Order 1. PERISPORIÀLES.}

1. Dimerospòrium guarapiénse Speg. Anal. Soc. Cient, Arg. 17: 130. 1884.

On Cestrum bahamense Britton, Great Bahama :-South America.

\section{Dimerosporium zonàtum Seaver sp. nov.}

Superficial mycelium rather scant but giving the surface of the leaf a blackish appearance; perithecia black and arranged so as to give rise to a series of rings, the outer one usually reaching a diameter of $5 \mathrm{~mm}$., the individual perithecia small, pyriform, reaching a diameter of $100 \mu$, surrounded with brownish appendages; asci broad-clavate, with a short stem-like base, reaching a diameter of $16-20 \mu$ and a length of $40 \mu$; spores eliipsoid-fusoid, 1-septate and slightly constricted at the septum, about 5-6 $616-20 \mu$.

On Corchorus hirsutus L. Type collected by N. L. Britton and C. F. Millspaugh at Barrett's Point, Great Bahama, February 5-13, 1905.

3. Meliòla ambígua Pat. \& Gaill. Bull. Soc. Myc. Fr. 4: 104. 1888.

On Lantana involucrata L., New Providence:-Porto Rico; South America.

4. Meliola longípoda Gaill. Bull. Soc. Myc. Fr. 8: 178. 1892.

On Tournefortia volubilis L., New Providence:-Porto Rico; South America.

Meliola simillima Ellis \& Ev. Rep. Missouri Bot. Garden 9: 118. 1898.

This species, recorded by Ellis as from Nassau, was really from Bog Walk, Jamaica, as shown by the specimen.

5. Perispòrium Wríghtii Berk. \& Curt. Grevillea 4: 157. 1875.

On Opuntia Dillenii (Ker.) Haw., Inagua :-Cuba; Texas.

\section{Order 2. DOTHIDEÀLES.}

1. Phyllachòra Atelèiae Seaver, sp. nov.

Stromata rather numerous, appearing on either side of the leaf but more conspicuous on the upper side, black, shining, scarcely exceeding a diameter of $1 \mathrm{~mm}$. perithecia few to each stroma, conspicuous; asci clavate, reaching a diameter of 14-16 $\mu$; spores fusoid, hyaline, 4-5 $\times 18-20 \mu$.

On Ateleia cubensis Griseb., Andros, New Providence, Great Exhuma. Type collected by J. K. Small and J. J. Carter, on Andros, January 25-27, 1910, 8715. 


\section{Phyllachora fusicárpa Seaver, sp. nov.}

Stromata rather numerous, often thickly scattered over the leaf, visible on both sides but more conspicuous on the under side, small, ranging from 1-2 $\mathrm{mm}$. in diameter, several often confluent; perithecial cavities few to each stroma, opening on the under side of the leaf; asci clavate, 8-spored; spores fusiform, slightly unsymmetrical, about $6 \times 25-30 \mu$.

On Duranta repens L. Type collected by F. S. Earle at Nassau. No date given. Specimens collected also at Rio Piedras, Porto Rico, by H. H. Whetzel and Edgar W. Olive.

In external appearance the species resembles Phyllachora Durantae Rehm, but differs from that species in its nuch longer and narrower spores.

\section{Phyllachora Galáctiae Earle, sp. nov.}

Epiphyllous on slightly discolored areas; stromata $1 \mathrm{~mm}$. broad, confluent in long anastomosing lines which often follow the principal veins, black, shining, prominently elevated; loculi crowded, not prominent, about $150 \mu$, ostiole none; asci stipitate, cylindrical, about $65 \times 7 \mu$; paraphyses abundant, threadlike; ascospores obliquely monostichous, colorless, narrowly ellipsoid, about $20 \times 5 \mu$.

On leaves of Galactia rudolphtoides, Soldiers' Road, New Providence, June 25, 1905, Millspaugh 2502.

A conspicuous species well characterized by the long branched and anastomosing black lines formed by the confluent stromata.

4. Phyllachora oxalìna Ellis \& Ev. Jour. Myc. 3: 41.1887.

On Xanthoxalis corniculata L., New Providence:-North America.

\section{Ophiodóthis bahaménsis Seaver, sp. nov.}

Stromata occurring only on the under side of the leaf, as many as twelve to twenty on a single leaf, reaching a diameter of 1-2 mm., occasionally confluent, lenticular in form, smooth, shining-black, the surface slightly roughened by the protruding necks of the perithecia; perithecia consisting of globose or ovoid cavities; asci reaching a length of $200-400 \mu$ and a diameter of $20-25 \mu$; spores filiform, nearly as long as the ascus, reaching a diameter of $2 \mu$.

On Tricera bahamensis (Baker) Britton. Type collected by Nash \& Taylor, October 22, 1904, on Inagua near Camfield Bay. The species has also been collected by L. J. K. Brace on Andros.

\section{Order 3. HYPOCREÀLES.}

1. Córdyceps sobolífera (Hill.) Sacc. Michelia 1: 321. 1878.

Clavaria sobolifera Hill.; W. Wats. Phil. Trans. Royal Soc. London 53: 271. 1763. Ceylon.

On some insect. Reported by C. G. Lloyd the exact locality not being given :-

2. Hypócrea sulphùrea (Schw.) Sacc. Syll. Fung. 2: 535. 1883.

Sphaeria sulphurea Schw. Trans. Am. Phil. Soc. II. 4: 193. 1832. America.

On the remains of some fungus, New Providence :-Cuba; eastern part of North

3. Sphaerostílbe gracílipes Tul., Fung. Carp. 1: 130. 1861.

On dead wood, New Providence :-southeastern North America. 


\section{Order 4. SPHAERIÀLES.}

1. Daldinia concéntrica (Bolt.) Ces. \& DeNot. Comm. Soc. Critt. Ital. 1: 198. 1863.

Sphaeria concentrica Bolt. Fungi Halifax 3: 180. 1789.

On old wood, New Providence:-Europe; Siberia; North and South America: India; Ceylon; Borneo; Tasmania ; New Zealand ; and Java.

2. ? Diatrype Stígma (Hoffm.) Fries, Summa Veg. Scand. 385.1849.

Sphaeria Stigma Hoffm. Veg. Crypt. 7. 1787.

On old wood, New Providence:-Europe; Siberia; and North America.

3. Hypóxylon annulàtum (Schw.) Mont. Hist. Chil. 445. 1850.

Sphaeria annulata Schw. Jour. Acad. Sci. Phila. 5: 11.1825. Zealand.

On old wood and bark, New Providence:-North and South America; and New

4. Hypoxylon Bómba Mont. Pl. Cell. Cuba 338. 1842.

On old wood, New Providence, Cat Island :-Cuba and South America.

5. Hypoxylon fuscopurpùreum (Schw.) Berk. \& Curt. Jour. Linn. Soc. 10: 385. 1869.

Sphaeria fuscopurpurea Schw. Jour. Acad. Nat. Sci. Phila. 5: 16.1825. On old wood, New Providence:-Cuba and temperate North America.

6. Hypoxylon jecorìnum Berk. \& Rav. Grevillea 4: 50. 1875.

On old wood, New Providence:-southeastern North America.

7. Nummulària Bulliárdii Tul. Fung. Carp. 2: 43.1863.

On old wood, New Providence:-North America and Europe.

8. Porònia Oèdipus Mont. Pl. C'ell. Cuba 346. 1842.

On dung, New Providence:-Cuba; northern Italy; North America; Australia ; Java and Borneo.

9. Sphaerélla Rajàniae Ellis \& Ev. Rep. Missouri Bot. Garden 9: 118. 1898. On Rajania microphylla Kunth., New Providence. Endemic.

10. Ustulìna vulgàris Tul. Fung. Carp. 2: 23. 1863.

On old wood, New Providence; widely distributed.

11. Válsa sp.

On old wood, New Providence.

12. Xylària Arbúscula Sace. Michelia 1: 249. 1878.

On dead wood, New Providence:-West Indies; Europe.

13. ?Xylaria aristàta Mont. Ann. Sci. Nat. Bot. IV. 3: 106.1855.

On dead wood, New Providence:-Cuba.

14. Xylaria polymórpha (Pers.) Grev. Fl. Edin. 355. 1824.

Sphaeria polymorpha Pers. Syn. Fung. 7. 1801.

On dead wood, New Providence:-Europe; Asla; Australla: Tasmanla; North and South America. 


\section{Order 5. PEZIZÀLES.}

1. Pyronèma omphalòdes (Bull.) Fuckel, Symb. Myc. 319. 1869.

Peziza omphalodes Bull. Hist. Champ. 264. 1791.

On burned places, New Providence:-probably world-wide in distribution,

2. Láchnea cubénsis (Berk. \& Curt.) Sace. Syll. Fung. 8: 176.1889.

Peziza cubensis Berk. \& Curt. Journ. Linn. Soc. 10: 366. 1869.

On rotten wood or on soll, New Providence:-West Indies and Texas.

\section{Order 6. PHACIDIALES.}

1. Triblìdium rúfulum (Spreng.) Ellis \& Ev. N. Am. Pyrenom. 690. 1892.

Hysterium rufulum Spreng. Vet. Akad. Handl. 1820: 50. 1820.

On dead wood, New Providence :-Cuba; North and South America.

\section{Sub-class 3. IMPERFECTI.}

Spores borne in perithecia-like bodies known as pycnidia. Order 1. SpHAEropsidales. Spores not borne in pycnidia.

\section{Order 1. SPHAEROPSIDÀLES.}

1. Phyllostícta Coccolòbae Ellis \& Ev. Rep. Missouri Bot. Garden 9: 118. 1898. On Coccolobis Uvifera (L.) Jacq., New Providence:-Apparently endemic.

2. Phyllosticta Robérti Boy. \& Jacz. Bull. Soc. Bot. Fr. 40: CCXC. 1893. On Ficus aurea Nutt., Great Bahama :-Florida ; Europe.

3. Phyllosticta Sapòtae Sace. Ann. Myc. 10: 312. 1912.

On Sapota Achras Mill., New Providence:-Endemic.

4. Septòria sp.

On Plumeria obtusa L., New Providence.

\section{Order 2. HYPHOMYCETÀLES.}

1. Cercóspora Calotròpidis Ellis \& Ev., Rep. Missouri Bot. Garden 9: 120. 1898.

On Calotropis procera (Ait.) R. Br., Fortune Island :-Apparently endemic.

2. Cercospora Melóchiae P. Henn. Hedwigia 43: 395.1904.

On Moluchia tomentosa (L.) Britton, Eleuthera:-South America.

3. Cercospora Stachytárphetae Ellis \& Ev., Rep. Missouri Bot. Garden 9: 120. 1898.

On Valerianodes jamaicensis (L.) Medic., New Providence:-Apparentiy endemic.

4. Cercospora Túrnerae Ellis \& Ev., Rep. Missouri Bot. Garden 9: 119. 1898.

On Turnera ulmifolia L., New Providence:-Apparently endemic.

5. Helminthospòrium Ravenèlii Curt.; Berk. \& Curt. Grevillea 3: 102.1874. On Sporobolus sp., New Providence, Great Bahama:-Bermuda; Cuba; South Carolina ; and Florida. 
6. Rhinotríchum Curtìsii Berk. Grevillea 3: 108. 1874.

On old bark, New Providence:-North America, south to Texas and Florida.

STERILE MYCELIUM.

1. Ozonium aurìcomum Link, Mag. Ges. Nat. Freunde Berlin 3: 21. 1809.

On wood, New Providence:-Europe and North America.

\section{Sub-class 4. HEMIBASIDIOMYCETES.}

Plants usually having different spore cycles.

Plants having only one spore cycle.
Order 1. UREDiNales.

Order 2. UstrlaginaLes.

\section{Order 1. UREDINÀLES.}

1. Nigrèdo proèminens (DiC.) Arth. N. Am. Fl. 7: 259. 1912.

Uredo proeminens DC. Fl. Fr. 2: 235. 1805.

On Chamaesyce hypericifolia (L.) Small, Inagua:-Bermuda; West Indies; North and South America; Europe; Asia; and Africa.

2. Prospòdium bahaménse Arth. Bull. Torrey Club 34: 587. 1907.

On Tabebuia bahamensis (Northrop), Britton, New Providence:-Endemic.

3. Puccìnia heteróspora Berk. \& Curt. Jour. Linn. Soc. 10: 356. 1869.

On Gayoides crispum (L.) Small, Fortune Island:-Porto Rico; St. Thomas; St. Croix; and probably in other West Indian islands.

4. Puccinia Lantànae Farlow, Proc. Am. Acad. 18: 83. 1883. Thomas.

On Lantana involucrata L., Nassau:-Bermuda; Jamaica; Porto Rico; St.

5. Puccinia Leonòtidis (P. Henn.) Arth. Mycologia 7: 245.1915.

Uredo Leonotidis P. Henn. in Eng. Pflanz. Ost-Afr. C: 52. 1895. Rico.

On Leonotis nepetaefolia (L.) R. Br., New Providence:-Jamaica; and Porto

6. Puccinia mirifica Diet. \& Holw. Erythea 3: 79. 1895.

On Borrichia arborescens (L.) DC., Great Bahama :-Texas.

7. Puccinia obliqua Berk. \& Curt. Jour. Linn. Soc. 10: 356. 1869.

Puccinia Cynanchi Lagerh. Bol. Soc. Brot. 7: 129. 1889.

On Metastelma palustre (Pursh) Schlecht., New Providence, on Metastelma sp., Whale Cay, and on Philibertella clausa (Jacq.) Vail, New Providence :-Cuba ; Porto Rico; Virgin Islands ; Martinique.

8. Urómyces Bidéntis Lagerh. Bull. Soc. Myc. Fr. 11: 213. 1895.

Uredo bidenticola P. Henn. Hedwigia 37: 279. 1898.

On Bidens pilosa L., reported from the Bahamas by Dr. Arthur:-Jamaica; Cuba; Porto Rico; and Martinique.

9. Urèdo Sapòtae Arth. \& Johnston, Mem. Torrey Club 17: 169. 1918.

On Sapota Achras Mill., Nąssau :-Cuba.

10. Uredo Wílsòni Arth. Bull. Torrey Club 37: 577. 1910.

On Anastraphia bahamensis Urban, Fortune Island :-Endemic. 


\section{Order 2. USTILAGINÀLES.}

1. Cintráctia Montágnei (Tul.) Magn. Abh. Bot. Ver. Prov. Brand. 37: 79. 1896.

Ustilago Montagnei Tul. Ann. Sei. Nat. III. 7: 88. 1847. Africa.

On Rynchospora sp., New Providence :-North and South America; Europe; and

2. Mykosỳrinx Císsi (D.C.) G. Beck. Ann. Nat. Hofmus. Wien. 9: 123. 1894.

Uredo Cissi DC. in Poir. Encycl. Meth. Bot. 8: 228. 1808.

On Cissus sicyoides L., Long Island:-West Indles; North and South America; and Africa.

3. Sphacelothèca pampàrum (Speg.) Clint. Jour. Myc. 8: 141.1902.

Ustilago pamparum Speg. Anal. Soc. Cient. Arg. 17: 89. 1884.

On Chaetochloa geniculata (Lam.) Millsp. \& Chase, Anguilla Isles; Salt Key Bank:-Cuba; Mexico; South America; and Europe.

\section{Sub-class 5. AUTOBASIDIOMYCETES.}

Contributed by William A. Murrill.

Sporophore gelatinous.

Basidia septate.

Basidia not septate; clavate and blfurcate.

Sporophore not gelatinous ; fleshy, membranous, or woody.

Hymenlum naked at maturity, covering the surface of gills, pores, spines, etc.

Hymenium enclosed in a definite peridium.

Spores borne in a gleba, which is elevated and exposed at maturity.

Spores remaining enclosed in the peridium at maturity.

Puffballs.

Bird's-nest fungi.

Order 1. Auriculariales.

Order 2. DACRYOMYCETALES.

Order 3. AgARICALES.

Order 4. Phallales.

Order 5. LYCOPERDAIES. Order 6. NIDULaRIALES.

\section{Order 1. AURICULARIÀLES.}

1. Auriculària Aurícula (L.) Underw. in Northrop, Mem. Torrey Club 12: 15. 1902.

Tremella Auricula L. Sp. Pl. 1157. 1753.

Dead wood, New Providence, Andros:-tropical regions.

zิ. Auriculària nigréscens (Sw.) Farlow, Bib. Index N. Am. Fungi 1: 308. 1905.

Peziza nigrescens Sw. Prod. 150. 1788.

Dead wood, New Providence :-troplcal regions.

\section{Order 2. DACRYOMYCETÀLES.}

1. Guepínia pálmiceps Berk. (\%)

Doubtfully recorded by Coker.

2. Guepínia Spathulària (Schw.) Fries, Elench. Fung. 2: 32.1828.

Merulius Spathularia Schw. Schr. Nat. Ges. Leipzig 1: 66. 1822.

Dead logs, New Providence:-cosmopolitan. 


\section{Order 3. AGARICÀLES.}

\section{a. THELEPHORÀCEAE.}

A number of species in this family have not been determined, especially those that belong to the genera Corticium and Stereum.

\section{Cortícium.} dence.

One or more undetermined species jave been found on dead wood in New Provi-

2. Hypóchnus spongiòsus (Schw.) Burt, Ann. Mo. Bot. Gard. 3: 216.1916.

Thelephora spongiosa Schw. Schr. Nat. Ges. Leipzig 1: 109. 1822.

Dead wood. Recorded by Burt from the Bahamas, collected for Dr. Farlow by A. E. Wight :- temperate North America and Europe.

3. Sebacina spongiòsa C. G. Lloyd, Myc. Notes 5: 779. 1918.

Encircling the base of small shrubs, New Providence. Endemic.

4. Septobasídium cirràtum Burt, Ann. Mo. Bot. Gard. 3: 334. 1916.

Branches of living trees, New Providence:-Cuba.

5. Stèreum albobàdium (Schw.) Fries, Epicr. Myc. 551. 1838.

Thelephora albobadia Schw. Schr. Nat. Ges. Leipzig 1: 82. 1822.

Dead wood, New Providence:- -eastern United States.

6. Stèreum cándidum (Schw.) Fries, Epicr. Myc. 552. 1838.

Thelephora candida Schw. Schr. Nat. Ges. Leipzig 1: 84. 1822.

Dead wood, New Providence:-eastern United States.

7. Stèreum Leveilleànum (Berk. \& Curt.) Sacc. Syll. Fung. 6: 581. 1888.

Corticium Leveilleanum Berk. \& Curt. Jour. Bot. \& Kew Misc. 1: 238. 1849.

Dead wood, New Providence:- southern United States and tropical America.

8. Theléphora spiculòsa Fries, Epicr. Myc. 539. 1838.

Ground in moist woods, New Providence:- - eastern United States.

\section{b. Cluavariàceae.}

\section{Clavària.}

One or more undetermined species were collected in New Providence, Andros, and Crooked Island.

\section{c. Hydnàceae.}

Several resupinate species of this family have been found in the islands, but they have not been determined.

\section{d. Xylophagàceae.}

10. Merùlius Còrium Fries, Elench. Fung. 1: 58. 1828.

Dead wood, New Providence :-cosmopolitan. 
e. PolTPORÀceae.

11. Coltrícia cinnamòmea (Jacq.) Murrill, Bull. Torrey Club 31: 343. 1904. Boletus cinnamomeus Jacq. Coll. 1: 116. 1786.

Polystictus cinnamomeus Sace. Michelia 1: 362. 1878.

Ground on humus, Andros:-cosmopolitan.

12. Coltrícia spathulàta (Hook.) Murrill, N. Am. Flora 9: 93. 1908.

Boletus spathulatus Hook. in Kunth, Syn. Pl. 1: (9). 1822.

Dead or buried wood, Crooked Island:-tropical America.

13. Coriolópsis occidentàlis (Klotsch) Murrill, Bull. Torrey Club 32: 358. 1905.

Polyporus occidentalis Klotsch, Linnaea 8: 486. 1833.

Dead wood, New Providence, Andros, Eleuthera :-tropical regions.

14. Corìolus abiétinus (Dicks.) Quél. Ench. Fung. 175.1886.

Boletus abietinus Dicks. Pl. Crypt. Brit. 3: 21. 1793.

Dead plne trunks, New Providence:-temperate regions.

15. Corìolus máximus (Mont.) Murrill, Bull. Torrey Club 34: 467. 1907.

Irpex maximus Mont. Ann. Sci. Nat. II. 8: 364. .1837.-Syll. Crypt. 174. 1856.

Dead logs, New Providence :-tropical regions.

16. Corìolus membranàceus (Sw.) Pat. Tax. Hymén. 94. 1900.

Boletus membranaceus Sw. Prodr. 148. 1788.-Sw. Fl. Ind. Occ. 1922. 1806.

Dead wood, New Providence:-tropical America.

17. Coriolus nigromarginàtus (Schw.) Murrill, Bull. Torrey Club 32: 649. 1906.

Boletus nigromarginatus Schw. Schr. Nat. Ges. Leipzig 1: 98.1822.

Dead wood, New Providence, Andros :-cosmopolltan.

18. Corìolus pinsìtus (Fries) Pat. Tax. Hymén. 94. 1900.

Polyporus pinsitus Fries, Elench. Fung. 95. 1828.

Dead wood, New Providence, Great Bahama, Abaco, Eleuthera, Cat Island, Watling's Island :- troplcal America.

19. Coriolus sericeohirsùtus (Klotsch) Murrill, Bull. Torrey Club 32: 651. 1906.

Polyporus sericeohirsutus Klotsch, Linnaea 8: 483. 1833.

Dead trunks of red cedar, New Providence:- southern United States.

20. Daedalea amanitoìdes Beauv. Fl. Oware 1: 44. 1805.

Lenzites applanata Fries, Epicr. Myc. 404. 1838.

Dead wood, New Providence :-tropicai regions. 
21. Elfvíngia tornàta (Pers.) Murrill, Bull. Torrey Club 30: 301. 1903. Polyporus tornatus Pers.; Gaud. Voy. Freye. Bot. 173. 1826.

Dead wood, Abaco:-tropical regions.

22. Fávolus alutàceus Berk. \& Mont.; Mont. Ann. Sci. Nat. III. 11: 240. 1849.

Recorded by Coker from Andros, but the species is probably confined to South America.

23. Fávolus ténuis (Hook.) Murrill, Bull. Torrey Club 32: 100.1905.

Boletus tenuis Hook. in Kunth, Syn. Pl. 1: (10). 1822.

Dead hardwood trunks and branches, New Providence:-troplcal regions.

24. Fòmes Auberiànus (Mont.) Murrill, Bull. Torrey Club 32: 491. 1905.

Polyporus Auberianus Mont. Pl. Cell. Cuba 397. 1842.

Dead or wounded hardwood trunks, New Providence :-tropical America.

25. Fulvifòmes depéndens Murrill, Tropical Polypores 87. 1915.

Pyropolyporus dependens Murrill, N. Am. Flora 9: 106. 1908.

Trunks of living hardwood trees, New Providence, Little San Salvador, Atwood Cay, Calcos Islands, Great Harbor Cay, Long Cay, Andros :-West Indies.

26. Fulvifòmes Swieténiae Murrill, Tropical Polypores 87. 1915.

Mahogany stumps, Acklin's Island :-Cuba.

27. Funàlia versátilis (Berk) Murrill, Bull. Torrey Club 34: 469. 1907.

Trametes versatilis Berk. Lond. Journ. Bot. 1: 150. 1842.

Dead wood, New Providence:-tropical regions and Gulf States.

28. Fuscoporélla corúscans Murrill, N. Am. Flora 9: 7. 1907.

Dead wood, New Providence :-Cuba.

29. Ganodérma pulveruléntum Murrill, N. Am. Flora 9: 121. 1908.

Dead wood, New Providence:-Cuba, St. Thomas, Grenada.

30. Ganodérma subincrustàtum Murrill, N. Am. Flora 9: 122. 1908.

Dead wood, New Providence:-tropical America.

31. Gloeophýllum Bérkeleyi (Sace.) Murrill, Bull. Torrey Club 32: 370. 1905.

Daedalea Berkeleyi Sacc. Syll. Fung. 6: 381. 1888.

Pine rallway ties and other forms of dead coniferous wood, New Providence, Great Bahama, Andros:-tropical America and Gulf States.

32. Gloeophýllum hirsùtum (Schaeff.) Murrill, Journ. Myc. 9: 94.1903.

Agaricus hirsutus Schaeff. Fung. Bavar. pl. 76. 1762.

Dead conlferous wood, New Providence:-temperate regions.

33. Gloeophýllum striàtum (Sw.) Murrill, Bull. Torrey Club 32: 370. 1905. Agaricus striatus Sw. Prodr. 148. 1788.-Sw. Fl. Ind. Occid. 3: 1920. 1806.

Dead wood, New Providence, Rose Island, Fortune Island, Crooked Island, Cat Island:- troplcal America. 
34. Hapalópilus licnoìdes (Mont.) Murrill, Bull. Torrey Club 31: 417. 1904. Polyporus licnoides Mont. PI. Cell. Cuba 401. 1842.

Dead wood, New Providence:-tropical and subtropical America and Asia.

35. Inonòtus corròsus Murrill, Bull. Torrey Club 31: 598. 1904.

Decayed vines and trunks, New Providence, Great Bahama, Abaco, Andros, Mariguana, Crooked Island, Anguilla Isles:-Florida; West Indies.

36. Inonòtus frùticum (Berk. \& Curt.) Murrill, Bull. Torrey Club 31: 601. 1904.

Polyporus fruticum Berk. \& Curt. Journ. Linn. Soc. 10: 310. 1868.

Living twigs of orange, etc., New Providence :-Cuba.

37. Inonòtus porréctus Murrill, Tropical Polypores 68. 1915.

Dead wood, Caicos Islands :-Louisiana.

38. Pogonómyces hydnoìdes (Sw.) Murrill, Bull. Torrey Club 31: 609. 1904.

Boletus hydnoides Sw. Pradr. 149. 1788.-Fl. Ind. Occid. 3: 1924.1806. Trametes hydnoides Fries, Epicr. Myc. 490. 1838.

Dead wood, New Providence, Abaco, Andros, Crooked Island:-tropical America and Gulf States.

39. Polýporus Bràcei Murrill, Mycologia 11: 222.1919.

Buried wood, New Providence. Endemic.

40. Polýporus guyanénsis Mont. Ann. Sci. Nat. II. 13: 201. 1840. America.

Recorded by Coker for Andros, but the species is probably confined to South

41. Polýporus Tricholòma Mont. Ann. Sci. Nat. II. 8: 365. 1837.

Dead sticks and logs, New Providence:-tropical America.

42. Pòria.

One or more undetermined species have been collected. They occur in resupinate forms on dead wood.

43. Pycnóporus sanguíneus (L.) Murrill, Bull. Torrey Club 31: 421. 1904.

Boletus sanguineus L. Sp. Pl. ed. 2. 1646. 1762.

Polystictus sanguineus Fries, Nova Acta Soc. Sci. Upsal. III. 1: 75. 1851.

Dead wood, New Providence, Great Bahama, Abaco, Andros, Hog Island, North Bimini, Fortune Island, Crooked Island, Cat Island, Anguilla Isles, Cay Sal :tropical regions.

44. Rigidóporus surinaménsis (Miq.) Murrill, Bull. Torrey Club 34: 473.1907.

Polyporus surinamensis Miq. Bull. Sci. Phys. Nat. Neérl. 1839: 454. 1839. States.

Water-soaked hardwood trunks, New Providence:-tropical America and Gulf

45. Tramètes submurìna Murrill, N. Am. Flora 8: 43. 1907.

Old logs, New Providence:-West Indies and western Mexico.

46. Tyrómyces palústris (Berk. \& Curt.) Murrill, N. Am. Flora 9: 31. 1907.

Polyporus palustris Berk. \& Curt. Grevillea 1: 51. 1872.

Pine trunks, New Providence:-Florida; Cuba. 
f. Boletàceae.

47. Ceriómyces commùnis (Bull.) Murrill, Mycologia 1: 155. 1909.

Boletus communis Bull. Herb. Fr. pl. 393. A, C. 1788.

Shaded soll, New Providence:-temperate regions.

\section{g. Agaricàceae.}

48. Chánterel cinnabarìnus Schw. Trans. Am. Phil. Soc. II. 4: 153.1832. Agaricus cinnabarinus Schw. Schr. Nat. Ges. Leipzig 1: 73. 1822. Ground, New Providence, Andros :-eastern United States, Jamaica, Mexico.

49. Chánterel infundibulifórmis (Scop.) Fries, Spier. Myc. 366. 1838. Merulius infundibuliformis Scop. Fl. Carn. ed. 2. 2: 462.1772. Shaded soll, New Providence:-temperate North America and Europe.

50. Chlorophýllum molybdites (G. Meyer) Massee, Kew Bull. 1898: 136. 1898. Agaricus molybdites G. Meyer, Fl. Esseq. 300. 1818.

Rich soll, New Providence, Cat Island:-New Jersey to Iowa and Brazil.

51. Collỳbia sp. (?)

Recorded doubtfully by Coker as occurring on decaying wood in New Providence.

52. Coprìnus micáceus (Bull.) Fries, Epicr. Myc. 246. 1838. Agaricus micaceus Bull. Herb. Fr. pl. 246. 1785.

Rich soll or humus, New Providence:-temperate regions.

53. Crinipéllis sp.

Dead wood, New Providence.

54. Gymnópilus ténuis Murrill, Mycologia 5: 22.1913.

Dead wood, New Providence :-Cuba; Jamaica.

55. Gỷmnopus sp.

Ground, New Providence.

56. Hydrócybe cónica (Scop.) P. Karst. Bidr. Finl. Nat. Folk 32: 236. 1879. Agaricus conicus Scop. Fl. Carn. ed. 2. 2: 443. 1772.

Moist soil, New Providence:-temperate North America and Europe.

57. Lentinus crinitus (L.) Fries, Syst. Orbis Veg. 77. 1825.

Agaricus crinitus L. Sp. Pl. ed. 2. 1644. 1763.

Exposed logs or stumps, New Providence, Great Bahama:-tropical and subtropical regions.

58. Lentìus hírtus (Fries) Murrill, Mycologia 3: 29. 1911.

Agaricus hirtus Fries, Linnaea 5: 508. 1830.

Dead wood, New Providence:-tropical regions.

59. Lentìnus strigéllus Berk. \& Curt. Journ. Linn. Soc. 10: 302. 1868.

Dead wood, New Providence:-tropical America. 
60. Lentinus strigòsus (Schw.) Fries, Syst. Orbís Veg. 77. 1825.

Agaricus strigosus Schw. Schr. Nat. Ges. Leipzig 1: 89. 1822. mopolitan.

Old logs and stumps, New Providence, Great Bahama, Watling's Island :-cos-

61. Lentìnus velùtinus Fries, Linnaea 5: 510. 1830.

Dead wood, New Providence, Great Bahama :-tropical regions.

62. Lentòdium squamòsum (Schaeff.) Murrill, Mycologia 3: 27.1911.

Agaricus squamosus Schaeff. Fung. Bavar. 4: Ind. 15.1774.

Lentinus lepideus Fries, Syst. Orbis Veg. 78. 1825.

Structural timbers and logs, especially of coniferous trees, New Providence:cosmopolitan.

63. Lepiòta cretàcea (Bull.) Morgan, Journ. Myc. 13: 3. 1907.

Agaricus cretaceus Bull. Herb. Fr. pl. 374. 1787.

Rich soil in cultivated grounds or woods, New Providence :-cosmopolitan.

64. Marásmius atropurpùreus Murrill, N. Am. Flora 9: 262. 1915.

Dead leaves and sticks, New Providence. Endemic.

65. Marásmius bahaménsis Murrill, N. Am. Flora 9: 265. 1915.

Dead leaves and twigs, New Providence. Endemic.

66. Marásmius bermudénsis Berk. Journ. Linn. Soc. 15: 49. 1876.

Doubtfully recorded by Coker for New Providence:-Bermuda.

67. Marásmius hemileùcus (Berk. \& Curt.) Murrill, N. Am. Flora 9: 266. 1915. Agaricus hemileucus Berk. \& Curt. Journ. Linn. Soc. 10: 285. 1868.

Dead leaves and sticks, New Providence:-Cuba.

68. Marásmius opàcus Berk. \& Curt. Journ. Bot. \& Kew Mise. 1: 99.1849.

Doubtfully recorded by Coker as occurring on leaves in New Providence :-South Carolina and Ohio.

69. Marásmius rameàlis (Bull.) Fries, Epicr. Myc. 381. 1838.

Agaricus ramealis Bull. Herb. Fr. pl. 366. 1786.

Dead branches, New Providence :-eastern United States and Europe.

70. Marásmius Rótula (Scop.) Fries, Epier. Myc. 385. 1838.

Agaricus Rotula Scop. Fl. Carn. ed. 2. 2: 456. 1772.

Dead wood or leaves, New Providence:-temperate North America and Europe.

71. Maràsmius setulósipes Murrill, N. Am. Flora 9: 257. 1915.

Dead leaves and sticks, New Providence. Endemic.

72. Marásmius Vaillántii Fries, Epicr. Myc. 380. 1838 ,

Doubtfully recorded by Coker as occurring on banana leaves in Andros:- a European specles reported by Curtis from the Carolinas.

73. Naucòria semiorbiculàris (Bull.) Quél. Champ. Jura Vosg. 100. 1872.

Agaricus semiorbicularis Bull. Herb. Fr. pl. 422, f. 1. 1788.

Open manured ground, New Providence:-cosmopolitan. 
74. Panéllus eugrámmus (Mont.) Murrill, N. Am. Flora 9: 245. 1915. Agaricus eugrammus Mont. Ann. Sci. Nat. II. 8: 366. 1837. Dead wood, New Providence :-tropical America.

75. Pleurotópsis liliputiàna (Mont.) Murrill, N. Am. Flora 9: 239. 1915. Agaricus liliputianus Mont. Ann. Sci. Nat. IV. 1: 99.1854. Marasmius nidulus Berk. \& Curt. Journ. Linn. Soc. 10: 299. 1868. Doubtfully recorded by Coker for New Providence :-tropical America.

76. Plicatùra oblìqua (Berk. \& Curt.) Murrill, Mycologia 3: 25.1911. Marasmius obliquus Berk. \& Curt. Journ. Linn. Soc. 10: 299. 1868. Dead wood, New Providence:-tropical America.

77. Resupinàtus subbarbátulus 'Murrill, N. Am. Flora 9: 241. 1915. Dead logs, New Providence :-Cuba; Jamaica; Mexico.

78. Schizophýllus álneus (L.) Schroet. Krypt.-Fl. Schles. $3^{1}: 553.1889$. Agaricus alneus L. Sp. Pl. 1176. 1753.

Dead wood, New Providence, Abaco, Great Bahama, Eleuthera, Crooked Island, Rose Island:-cosmopolitan.

79. Strophària floccòsa Earle, Inf. An. Estac. Centr. Agron. Cuba 1: 241. 1906. Ground in the open, New Providence :- Cuba.

80. Vaginàta farinòsa (Schw.) Murrill, Mycologia 4: 3. 1912. Amanitopsis farinosa Atk. Stud. Am. Fungi 76. 1900.

Soil, New Providence, Watling's Island:-New York to Alabama.

81. Vaginàta plúmbea (Schaeff.) Murrill, Mycologia 5: 82. 1913. Amanitopsis vaginata P. Karst. Bidr. Finl. Nat. Folk 32: 6. 1879. Shaded soll, New Providence:-temperate reglons.

\section{Order 4. PHALLÀLES.}

1. Cláthrus cancellàtus L. Sp. Pl. 1179. 1753.

Ground, Fortune Island, Acklin's Island:-tropical and warm-temperate regions.

2. Cláthrus críspus Turp.; Fries, Syst. Myc. 2: „288. 1823.

Dead wood, New Providence, Andros:-tropical regions.

3. Latérnea triscàpa Turp. Dict. Sci. Nat. 25: 248. 1822.

Sandy soll, New Providence:-tropical America; Texas; Chill.

4. Símblum sphaerocéphalum Schlecht. Linnaea 31: 154. 1861.

Ground, New Providence :-tropical America.

\section{Order 5. LYCOPERDÀLES.}

1. Diplocýstis Wríghtii Berk. \& Curt.; Berk. Journ. Linn. Soc. 10: 344. 1868.

Ground, in soll or humus, New Providence, Great Bahama, Great Sturrup Cay, Fortune Island, Acklin's Island, Crooked Island, Conception Island, Watling's Island, Eleuthera, Inagua, Andros:-Cuba. 
2. Geáster saccàtus Fries, Syst. Myc. 3: 16. 1829.

Ground, New Providence :-cosmopolitan.

3. Lycopérdon sp.

Ground and humus, New Providence, Abaco.

\section{Order 6. NIDULARIÀLES.}

1. Cỳathus intermédius (Mont.) Tul. Ann. Sci. Nat. III. 1: 72. 1844.

Nidularia intermedia Mont. Pl. Cell. Cuba 321. 1842.

Dead sticks, New Providence:-tropical regions.

2. Cỳathus pállidus Berk. \& Curt.; Berk. Journ. Linn. Soc. 10: 346.1868.

Dead wood, New Providence:-tropical regions.

\section{Class 4. MYXOMYCETES.}

The following slime-moulds have been reported on determinations made by W. G. Farlow. All were collected at Mangrove Cay, Andros. All are widely distributed.

1. ?Arcỳria Oerstédtii Rost. Mycet. Monog. 278. 187 J.

2. Arcyria cinérea (Bull.) Pers. Syn. Fung. 184. 1801.

Trichia cinerea Bull. Champ. Fr. 120. 1791.

3. Arcyria punícea Pers. N. Bot. Mag. 1: 90. 1794.

4. Dictỳdium cancellàtum (Batsch) Macbr. N. Am. Slime-moulds 172. 1899. Mucor cancellatus Batsch, Elench. Fung. 2: 135. 1789.

5. Dictydium squamulòsum (Alb. \& Schw.) Fries, Syst. Myc. 3: 118. 1829. Diderma squamulosum Alb. \& Schw. Consp. Fung. 88. 1805.

6. Hemitríchia clavàta (Pers.) Rost. Versuch. Mycet. 14. 1873. Trichia clavata Pers. N. Bot. Mag. 1: 90. 1794.

7. Lycógala epidéndrum (L.) Fries. Syst. Myc. 3: 80. 1829. Lycoperdon epidendrum L. Sp. Pl. 1184. 1753.

8. Physàrum compréssum Alb. \& Schw. Consp. Fung. 97. 180 5.

9. Physarum globuliferum' (Bull.) Pers. Syn. Fung. 175. 1801. Sphaerocarpus globuliferus Bull. Herb. Fr. pl. 484, f. 3. 1790.

10. Physarum víride Pers.; Usteri, Ann. Bot. 15: 6. 1795.

11. Stemonitis herbàtica Peck, Ann. Rep. N. Y. State Mus. 26: 75. 1875. 


\section{EXPLORATION AND COLLECTIONS.}

1703. Thomas Walker, Chief Justice for the Bahama Plantation, sent plants from New Providence to James Petiver in London, as recorded on the last page of Petiver's "Musei Petiveriani"' in the following paragraph:

30. Mr. Thomas Walker. This Generous Gentleman, at the desire of my kind Friend Mr. RoBerT ElLIS, hath lately sent me Specimens of the Brasiletto Wood, and some other Trees and Plants from New Providence, one of the Bahama Islands: for which I am extreamly obliged to him, and for his kind Promises of greater Performances, by the next and all Opportunities.

From information given us by Mr. L. J. K. Brace, it would appear that Walker lived at Nassau until 1722.

1725-6. Mark Catesby sailed from Florida to New Providence in 1725 and there began his studies of the plant life of the island in connection with his pursuit of general Natural History. He later embodied the results of his work, with that along the Atlantic Coast, in his excellently illustrated folios on the "Natural History of the Carolinas," the fine plates of which formed one of the bases of Linnaeus' Species. In the course of his work he is known to have also visited Abaco, Andros and Eleuthera. His plates illustrating Bahama species are cited in our text with the exception of plate 86 of the first volume, which we are unable to understand. The balance of his plates are either not botanical or are plants of the Atlantic Coast from Virginia southward to North Florida.

He preserved but few specimens of dried plants: one set of these he gave to his patron, Sir Hans Sloane, this set is now in herb. British Museum; another to Sherard, now in herb. Oxford; and a third series is said to have come into the possession of the Physick Garden of Chelsea.

1730-32. Francis Dale, Jr., probably of Hoxton, England, appears to have collected in both the East and West Indies. In 1730 he sent to Samuel Dale (a relative) a large number of specimens from New Providence, and in 1732 another lot from "Bahama, with seeds, some of which were raised in the Braintree Garden"' (Journ. Bot. 21: 227, 1883). His library and "'Hort. Sicc." were bequeathed to the Society of Apothecaries of London with the proviso that they be deposited in the Physick Garden of Chelsea.

1784. F. Boos, in company with F. J. Märter and Dr. J. D. Schöpf, visited New Providence and other islands from March to September 1784. Their collections consisted principally of living plants which were transferred to the Botanic Gardens of Schönbrunn, near Vienna, where many of them were depicted and described by Jacquin. Märter's plants are in herb. Munich.

1789. André Michaux collected in the Bahamas from Feb. 25 to March 29, 1789. His collection, which consisted largely of living material, was principally confined to New Providence though he also explored the nearby 
cays. His collections were sent to the Botanical Garden, Paris. (See C. S. Sargent, "Journal of André Michaux"' in Proc. Am. Phil. Soc. 26. 1888.)

1790? Dr. J. W. Crudy collected in the Bahamas "before 1810," and his collections are in the herbarium of the Botanical Museum at Münich, according to Urban (Symb. Ant, 3: 33). A more recent and extended account of Crudy and his West Indian collections, by Solereder (Symb. Ant. 7: 145-150), makes no mention of the Bahamas; from this account it seems clear that Crudy had not collected in the Bahamas prior to 1789 , and that he died in or before 1793 .

1802. J. Fraser, of Chelsea, London, after collecting in the southern United States and Cuba, spent some time in the field at Nassau, New Providence. The extent of his collections there is not known to us. The plants are deposited, with his personal herbarium, in the Linnean Society, London.

181:0? Jean Baptiste Ricord-Madiana, a noted author and naturalist, went to the West Indies, from New York, in $1810(q)$ and there traveled and practised medicine extensively among the Windward Islands. How large a series of plants he collected, the exact years (1810-25\%), and where his material was deposited are, at this writing, unknown to us. A very few sheets have been seen in the herbaria of Harvard University and of the New York Botanical Garden; these are labeled simply "TTurks IslandMadiana.',

1830-42. Swainson (whose identity is not certain: not William Swainson the Zoologist) collected in the Bahamas between 1830 and 1842. The exact locality of his field work and the extent of his collections, are not known, though Mr. Brace judges, from frequent local inquiries, that his plants were collected, in a large part at least, on Long Island. Grisebach, who chronicles the material in his Flora of the British West Indies, mentions specifically less than 200 species. His plants were turned over to Hooker and are now in herb. Kew, London.

1857-8. Dr. Wm. F. Daniell collected in the Bahamas in 1857-8. The extent of his collections is not definitely known. The specimens are in the herbarium of the British Museum.

1858. J. A. Hjalmarson, of Stockholm, on his return voyage from conchological collecting in Hayti, stopped off at Grand Turk Island in 1858. Here he spent a fortnight in field work. The extent of his botanical collection is not definitely known. His specimens are to be found in the herbaria at Kew, Göttingen and Berlin.

1859. William Cooper visited New Providence in 1859 for the purpose of making dredgings for zoological material. While there he collected, in the neighborhood of Nassau, about 100 plants for his friend, Dr. John Torrey. The prime set of these plants is now in the herbarium of the New York Botanical Garden. (See Bull. Torrey Club 17: 187.)

1865. Dr. Anna H. Searing, of Rochester, N. Y., collected to some extent on New Providence in 1865. The number of specimens, and present location of her collection we have not been able to positively determine, though the 
specimens were probably deposited in the herbarium of the University of Pennsylvania, Philadelphia.

1866. Henrik J. Krebs, who spent most of his life on St. Thomas, made a short trip to New Providence in 1866. The plant collections made by him on the island are deposited in the herbarium of the Botanical Museum at Copenhagen.

1867-8. Sir Rawson Wm. Rawson collected to some extent on New Providence, and probably other islands, during his two years incumbency as Governor of the Bahamas. His collections were sent to the British Museum. Duplicates are to be found in herb. Kew and in Berlin.

1874. Dr. Edward Palmer. well known as a collector upon the North American mainland, visited Nassau in May, 1874. The algae collected by him were studied and enumerated by Prof. D. C. Eaton [see Bibliography].

1875-1919. Lewis J. K. Brace began his collections in the Bahamas in 1875. He worked principally on New Providence until 1880, but also secured material on Fortune Island or Long Cay, and Andros. His work resulted in about 525 numbers, of which his personal series is now in the herbarium of the New York Botanical Garden and duplicate sets in the herbarium at Kew and that of the Field Museum. He began field work for the survey resulting in this Flora in September, 1904 (see Britton \& Brace), and later in the same year was commissioned by the New York Botanical Garden to make an exploration of the Abaco Islands, where he collected as follows: Green Turtle Cay (1475-1515), Allen's Cay (1526-54), Spanish Cay (1555-62), Man-o'-War Cay (1563-89), Pigeon Cay (166273), Elbow Cay (1688-1712), and on the island of Abaco at Butler Cay (1516-25), Marsh Harbor (1590-1661, 1713-53, 1787-1846), Great Cistern (1674-87, 1754-86), Cherokee Sound (1847-9, 1898-1980, 1999, 2080-84, 2086), Eight Mile Bay (1850-97), opposite Cherokee Settlement (1981-98, 2064-79), Old Kerr's Point (2000-2036), and California road (2037-63), a total of 611 numbers. Following this expedition he continued work on New Providence in localities from which, from time to time, it became necessary to have more material of previously secured species.

In June, 1905, a commission was given him by both the New York Botanical Garden and the Field Museum to continue on Great Bahama, the work already undertaken there. (See Britton \& Millspaugh.) On this exploration he collected at Eight Mile Rocks (3633-5, 3671-3738), Deadman's Reef (3631-2), and the western extremity of the island (3484-3630, $3636-37$ ). He also collected on Garden Cay (3658-70), and visited (during his sailings to and from Great Bahama) North Bimini (3461-75, 3479-83), South Bimini (3476-8), North Cat Cay (3739-54), and Andros Island (3755-6), and after returning to New Providence collected Nos. 3893-3918. He was later commissioned by the New York Botanical Garden and the Field Museum to make three further explorations. From these he has returned over 1,800 numbers as follows: Rum Cay (3919-3993); Fortune Island (3994-4179); Acklin's Island (4260-4471) ; Crooked Island (4533$4776)$; and Andros (4876-5377 and 6657-7139). In the Andros work he 
not only traversed the East side but also made his way around to the diffcult swash region of the West coast, and penetrated the dividing channel across the southern third of the Island. Mr. Brace also continued his search for interesting plants on New Providence (7141-7161 and 79057910) and during 1918 and 1919 obtained large collections of Cryptogams (9395-10138).

1877. H. E. Wm. Robinson, while Governor of the Bahamas, took considerable interest in the plant life of the islands even to the establishment of an Experimental Botanic Station for the Study of Economic Plants suitable for the Islands. His collections of Bahamian plants (192 specimens) are in the herbarium at Kew:

1885-6. John Gardiner spent two years in the Bahamas going there in 1885 as scientific advisor to the Board of Agriculture. Under the direction of Governor H. A. Blake he spent a considerable time in botanically exploring New Providence and the Out Islands, notably Andros, Berry Islands, Atwood Cay, Inagua and the Biminis; at the latter place he lost his notes and books of reference through the wreck of his vessel. Unfortunately he made no collections during his Bahama explorations, contenting himself with analyzing the plants in the field and recording his results in the lost note books.

1886. F. H. Herrick worked on Abaco, Pawpaw Cay, Joe's Cay and Little Abaco in June 1886, devoting most of his time to zoölogy. He made a small collection of plants which is now in the herbarium of Yale University. A large number of the species in the list of 66 plants published by Eaton \& Setchell, were, however, reported from his field observations only.

1887. Charles S. Dolley visited New Providence in 1887 and has recently resided at Nassau. His private herbarium, principally of plants collected in the United States, is deposited in the herbarium of the University of Pennsylvania, Philadelphia. [See Bibliography.]

1887-88. H. F. A. von Eggers, plant collector for many years in various parts of the West Indies and South America, was on Grand Turk in July, 1887. From January to March, 1888, he collected on Acklin's, Fortune, Long, and Hog Islands, and on New Providence under the auspices of the committee of the British Association for the Advancement of Science.

1889-91. Alexander Keith, of Edinburgh, owner of a sisal plantation on Andros, collected a few plants on that island especially for Mrs. Northrop (whom see). Those preserved are in the Herbarium of the New York Botanical Garden.

1890. Mrs. Alice (Rich) Northrop, accompanied by her husband, Prof. John I. Northrop, made, in 1890, a large collection of the plants of New Providence (nos. 1-239, 280-331), Rose Island (251), Salt Cay (240-244, 271279), Hog Island (245-8, 252-70), and Andros (332-758). These plants formed the basis of Mrs. Northrop's "Flora of New Providence and Andros." They are now deposited in equal sets in the herbaria of the Field Museum and the New York Botanical Garden. Very full sets are also to be found in the herbarium at Kew and at Berlin. 
1890. Prof. J .T. Rothrock made, in the interests of the University of Pennsylvania, an expedition to the British West Indies in his 41-ton yawl "White Cap" during the winter of 1890-91. On this expedition he collected 4 days on New Providence; 2 on Cat Island; a part of one day on Watling's; 2 days on Crooked Island; 2 on Fortune Island, and a day on Great Inagua. His collecting was done independently from that of Prof. Hitchcock, who accompanied him. The first set was deposited in the herbarium of the University of Pennsylvania; the second, comprising 162 sheets, he has kindly placed in the herbarium of the Field Museum and the third in the herbarium of the New York Botanical Garden.

1890. Prof. Albert S. Hitchcock collected in the Bahamas in November and December, 1890. The collections were largely made on New Providence, Eleuthera, Cat, Watling's, Crooked, Fortune, and Inagua and form the basis of his "Plants collected in the Bahamas," etc. The material collected was deposited in the herbarium of the Missouri Botanical Garden, from which, through the kindness of the director, Dr. William Trelease, the authors have been allowed to reassemble the sheets. The collection, embracing about 600 sheets, is at this writing a loan to the Field Museum. Through a later purchase of his "Florida Herbarium" the Field Museum secured 133 duplicate sheets of the Bahama plants.

1893. Miss Bertha Wilson accompanied the Bahamian Expedition from the State University of Iowa in May and June, 1893, collecting-principally algae - on Egg Island, Harbor Island, Eleuthera, New Providence, Cat Cay and Water Cay. (Narrative of the Bahamian Expedition, Nutting.) On leaving the university she took her collections with her in the anticipation of determining the species. All trace of them has since been lost to the botanists of the institution. Her land plants are said to have been but scraps and to have been thrown away.

1893-4. G. F. Curtiss, of Schenectady, New York, an amateur collector of ferns, spent the winter of 1893-4 on the islands. The extent of his collecting (which was doubtless of ferns only) is unknown. Although his private herbarium has lately come into the possession of the Field Museum of Natural History it contains but one sheet from the Bahamas and that from Andros.

1900-2. Mrs. Emilia Royce (Crane) Anthony, of Gouverneur, N. Y., collected the ferns of the neighborhood of Nassau, New Providence, in 1900 to 1902. Her personal collections were destroyed in the great fire at Jacksonville, Florida. Duplicates of her series were deposited in the private herbaria of B. D. Gilbert, Clayville, N. Y.; and W. N. Clute, Joliet, Ill.

1901. Dr. John W. Harshberger, while on his passage to Hayti, spent a portion of July 1, 1901, in the vicinity of Matthewtown, Inagua, during the eall of his steamer at that port. He made a small collection which was sent to Prof. Urban, for determination, and is now in the herbarium of the Botanical Garden of Berlin.

1903. Prof. F. S. Earle collected during one day only, on New Providence (Nos. 1-79), while on his way to Cuba, in March, 1903. His plants, 
largely from the vicinity of Nassau, are in the herbarium of the New York Botanical Garden.

1903. Prof. Lucien M. Underwood and E. W. D. Holway accompanied Prof. Earle on the trip (mentioned above). Prof. Holway informs us that his collections consisted solely of Rusts. These are at present in his private herbarium.

1903. A. H. Curtiss collected his first series of "West Indian Plants" in April, 1903, in the neighborhood of Nassau, New Providence. This series comprises numbers 1-211, of which the prime set, with the unnumbered unicates, is deposited in the herbarium of the New York Botanical Garden, the first distributed set in the Herbarium of the Field Museum and several others in various American and European herbaria.

1903. Dr. William C. Coker, botanist of the Bahamian expedition of the Geographical Society of Baltimore, assisted by Messrs. C. A. Shore and F. M. Hanes, collected in the summer of 1903 on the following islands: New Providence (I-193, 247-305, 551), Andros Island and Little and Great Mangrove Cays (194-234), Green Cay (235-246), George's Island (306$317)$, Eleuthera (318-421), Cat Island (422-437), Rum Cay (438-457), Watling's Island (458-491, 521, 528), Long Island (492-520, 524), Water Cay (523, 525), Abaco (558-568, 575-6), and Elbow Cay (569-574). This collection was deposited in the herbarium of the New York Botanical Garden, and forms the basis of his "Vegetation of the Bahama Islands" in Shattuck's "The Bahama Islands." Owing to the insufficiency of the material secured many phanerogams therein published are based upon provisional determinations only. The eryptogams exist under a separate series of numbers.

1904. Dr. N. L. Britton collected on New Providence in April, 1904, in the neighborhood of Nassau, South Side Beach, Blue Hills, Farrindon Road, West Bay Street Road, Cunningham Road, Lake Cunningham, and Old Fort. In this preliminary investigation, in company with Millspaugh, he collected 158 numbers (1-158). An account of the field work is published in the Journal of the New York Botanical Garden 5: 129-136. See also Britton \& Brace, and Britton \& Millspaugh.

1904. Dr. C. F. Millspaugh began his collections among the islands on New Providence, in April, 1904, in company with Dr. N. L. Britton (see Britton), visiting substantially the same stations, where, as his collecting was to extend to other islands, he kept his individual series of numerals. $\mathrm{He}$ collected at the following localities: Blue Hills (2048-2100), South Shore (2101-2151 and 2262-2277), West Bay Street road (2152-2178), pine barrens and hammock lands along Lake Cunningham road (2179-2217), region of Lake Cunningham (2218-2244), Farringdon Road (2245-7), Swingate (2248-51), Old Fort (2252-4), and Waterloo (2255-61). Then hiring and commissioning a sloop, he sailed in company with Dr. M. A. Howe for an investigation of the Bimini Islands, collecting at the following stations: West End Bight, New Providence (2278-2293), Joulter's Cays (2294-2304), Gun Cay (2305-2328), North Cat Cay (2329-2347, 
2415), South Bimini (2348-2368, 2379-85, 2387-98, 2406-2414), North Bimini (2369-78, 2386, 2399-2405), South Cay (2416-2441). Again in January, 1905, he collected in the following localities while awaiting the arrival of Dr. Britton (see Britton \& Millspaugh) ; Blue Hills road (244244, 2461-81), Silver Cay (2445-2460), and South Side, Soldiers Road, Fort Montague and Fort Fincastle (2482-2502). (See also Britton and Millspaugh, and Millspaugh and Millspaugh.)

1904. Britton and Brace-Dr. N. L. Britton, Mrs. E. G. Britton, and Mr. Lewis J. K. Brace collected together on New Providence (nos. 159-328, 361-872), and Hog Island (329-360), in September and October, 1904. They ranged New Providence with great thoroughness, penetrating to the coast region north, east, south and west, and to the coppices, pine barrens, and openings in the neighborhood of Nassau, Fort Montague, Farringdon Road, Swingate, Maidenhead, Tea House, Race Course, Delaport, Fox Hills, Village Road, Mt. Vernon, Rifle Range, Harold Road, Carmichael, Adelaide, Southwest Landing, Miller's, Blue Hills, Soldiers Road, Lake Cunningham, Winton, Old Fort, Waterloo, Clifton, Mt. Pleasant, Fort Charlotte, Gambier, Killarney, Bonefish Pond, and Seven Hills. The commoner things were not taken, the attempt being made to secure only such species as were previously unfamiliar or those which had only been gathered when out of character. This survey resulted in 714 particularly interesting plants, embracing the series of numbers indicated above. The prime set of these collections is deposited in the herbarium of the New York Botanical Garden, the duplicates in the herbarium of the Field Museum.

An account of this expedition is published in the Journal of the New York Botanical Garden 5: 201-209.

1904, 1905, 1907. Dr. Marshall A. Howe, phycologist of the New York Botanical Garden, has collected extensively the sea vegetation of the Bahamas, accompanying C. F. Millspaugh on his first trip, and later the first expedition of Britton and Millspaugh. (See Jour. N. Y. Bot. Gar. 5: 129-136 and 6: 77-85.) In 1907 he accompanied Mr. Percy Wilson on the expedition to the southern islands (see Wilson) whence he returned a large amount of interesting and critical additional material. His large collection of algae is deposited in the herbarium of the New York Botanical Garden.

1904. Alex. E. Wight, under the patronage of the Gray Herbarium, Cambridge, Mass., made a Bahamian collection of 281 numbers from December, 1904, to May, 1905. He collected on New Providence and Hog Island (1-226 and 271-274), and on Andros at Mangrove Cay, Fresh Creek, Calabash Bay, and Small Hope (227-270). The resulting plants were determined at the Field Museum and the initial set retained (with the exception of about six numbers in the Orchidaceae which are in the herbarium of Prof. Oakes Ames). Duplicate sets have been deposited in the Gray Herbarium and the herbarium of the New. York Botanical Garden.

1904. Geo. V. Nash and Norman Taylor, of the New York Botanical Garden, were commissioned by the Garden, in October, 1904, to investigate the Inaguas. They made an exhaustive survey of the islands, 
collecting on Inagua 482 numbers (874-1138 and 1258-1474), on Sheep Cay 23 numbers (1139-1161), and on Little Inagua 96 numbers (11621257). In September, 1905, on their return from an exploration in Haiti, they spent a week on Grand Turk Island, collecting all such plants as were noted by them at that season, 136 numbers (3757-3892). Accounts of these expeditions may be found in the Journal of the New York Botanical Garden 6: 1-19 and 189-191.

1904. Glover M. Allen and Thomas Barbour, while collecting zoölogical material on the Bahamas in July, 1904, gave considerable attention to the plant life of Abaco, Elbow Cay, Great Guana Cay, Little Abaco, Pensacola Cays, Stranger Cay and Great Bahama. Their collections amounting to about 100 sheets are deposited in the Gray Herbarium, Cambridge, Mass.

1904. Owen Bryant collected a number of plants on Mangrove Cay and Andros in 1904 while engaged in zoölogical investigations there. His plants are in Herb. Gray, Cambridge, Mass.

1905 and 1907. Britton and Millspaugh-the authors of this Flora, accompanied by Dr. M. A. Howe, began an exploration of the Berry Islands, Great Bahama, and the Exuma Chain, in January, 1905. A schooner was chartered and equipped at Nassau, where, after a day's delay on account of heavy weather (during which collecting was done in the scrublands and coppices south of Nassau (2085-2110), the expedition began at Rose Island (2111-2166) and Hog Island (2167-2176). The first island of the Berry Group visited was Whale Cay (2177-2201), followed by Frozen Cay (2202-2224), Little Harbor Cay (2225-2254), Great Sturrup Cay (2255285), Goat Cay (2286-2301), Lignum Vitae Cay (2302-2332), and Great Harbor Cay (2333-2354). The exploration began on Great Bahama Island at Eight Mile Rocks (2355-2596), and was continued at Barnett's Point (2597-2716), and Golden Grove (2717-2741). Returning to Nassau, a fresh start was made to the Exuma Chain, of which the following islands were diligently searched: Ship Channel Cay (2742-2767), Cay north of Wide Opening (2768-2804), Cave Cay (2805-2836), Little Galiot (28372850), Great Galiot (2851-2860), Great Guana (2861-2922), Great Exuma (2923-3051, 3073-3141), and Stocking Island (3052-3072).

On Great Exuma the regions studied were the scrub lands and coppices lying west of Georgetown: Hayne's Road from the east to the west shores across the island; and the Rolletown scrub lands and coppices. The total series of this exploration is 1,057 sheets. An account of this expedition may be found in Journal of the New York Botanical Garden 6: 78-85.

They further undertook, in 1907, a very exhaustive exploration of the Out Islands, embracing the following localities: Eleuthera, from the Glass Window to Harbor Island (5376-5404) ; Glass Window to Gregorytown (54055440); Governor's Harbor and vicinity (5441-5542); Rock Sound and vicinity (5543-5590); Miller's and Bannermantown and vicinities (55915613 ) and in the vicinity of the extreme southern point of the island (56145656). Little San Salvador (5657-5701). Cat Island, from Orange Creek around the extreme north end of the island, down the northeast shore of 
Cotton Point and across (5702-5791); the vicinity of The Bight and across the island and back (5792-5945); and Port Howe and vicinity (5946-5986). Conception Island (5987-6043). Watling's Island, Cockburntown vicinity (6044-6144); from Cockburntown across Little and Great Lakes to the Light on the east coast (6145-6169) ; Graham's Harbor south along the east coast to Columbus' Monument (6170-6188) ; Graham's Harbor around the north end of the island to Cockburntown (61896224). Long Island, vicinity of Clarencetown and across the island to the west shore, and on Thatch and Strachan's Cays (6225-6359); and the extreme north end of the island at Cape St. Maria (6360-6370). New Providence in the vicinity of Nassau.

1905, 1907. Mrs. N. L. Britton, often accompanied by her cousin, Mr. Brace, visited, in April and May, 1905, all those stations on New Providence previously collected by Britton \& Brace, at which it had become desirable to secure additional material of interesting plants or characters missing on previous notable species. In addition to achieving marked success in this undertaking, she secured many other plants of particular interest. Her survey resulted in 310 sheets (nos. 3141-3460), and is mentioned in the Journal of the New York Botanical Garden 5: 129-136. In 1907 she accompanied her husband and the co-author as far as Harbor Island and remained there, as a base, while working that island and the extreme north end of Eleuthera (6370-6527). Returning to New Providence she did further discriminating field work on that island (6529-6656) while awaiting the return of the authors' second expedition.

1907 and 1909. Percy Wilson, of the New York Botanical Garden, on a commission from that institution and the Field Museum, accompanied by Dr. Howe, made an exploration of the southeastern islands from November 22 to December 29, 1907. His field was as follows: Cat Island, at The Bight (7163-7197) and the southwest end of the island (7198-7202). Watling's Island, at Cockburntown (7203-7225); Graham's Harbor (7226-7258); and the extreme southeast and southwest ends (7259-7336 and 7337-7359). Atwood's Cay (Samana) (7360-7424 and 7903-7904). Mariguana, at a point ten miles west of Abraham Bay (7425-7451); Abraham Bay and vicinity (7452-7540) ; five miles west of Southeast Point (7541-7557) and at Southeast Point (7558-7589). The Caicos Islands: on South Caicos (7590-7693); Pine Cay (7694-7697); North Caicos at Kew and vicinity (7698-7748); Providenciales (7749-7752) and West Caicos (7753-7763); Little Inagua, at the western end (7764-7782). Castle Island (7783-7802). The Ragged Cays, at Great Ragged Island (7803-7869) and Hog Cay (7870-7882). The Exuma Chain, at Harvest Cay (7883-7898); and Rose Island (7899-7902). From May 13 to June 7, 1909, he explored the Cay Sal Bank, spending four days on Anguilla Islands (7932-8078, 8438) and one day each on Salt Cay (8079-8124), Water Cay (8132-8159), and Elbow Cay (8125-8131). On the trip out he spent one day at Riding Rocks (7912-7924), and one on Orange Cay (7925-7931), of the Bimini Group; and on his return to Nassau: six days collecting on New Provi- 
dence $(8168-8247,8323-8343,8370-8413,8434-8437)$ and four on Hog Island (8248-8322, 8344-8469, 8414-8433). The collections are deposited in duplicate in the herbaria of the New York Botanical Garden and the Field Museum.

1910. Small and Carter. Feeling that the central portion of Andros, fifteen miles from the sea, might yield species not to be found on any other of the islands, Dr. John K. Small and Mr. Joel J. Carter were commissioned by the New York Botanical Garden and the Field Museum of Natural History to make a thorough survey of the interior, especially in the Fresh Creek region, the broadest part of the island. This they thoroughly did and added two other central areas to their field of exploration (see Jour. N. Y. Bot. Gard. 11: 88-101). Beginning January 15, 1910, they collected on Mangrove Cay at Lisbon Creek (8439-8540), passed southward to Deep Creek (8541-8637), and worked northward to Smith Hill (8638-8689), Crow Hill (8690-8746), Fresh Creek (8747-8841), Staniard Creek (88428919) and concluded their work at the north end of the island: Nichol's Town (8920-8976).

From the fact that these two indefatigable and acute Florida Everglade workers failed to bring to light more than 8 species not before aceredited to the Bahamas in our lists it would appear: first, that the great breadth of Andros does not mitigate the salinity; second, that previous collecting had pretty thoroughly covered the flora of the group.

1911. Millspaugh and Millspaugh. C. F. Millspaugh and his wife (Clara Mitchell Millspaugh) undertook, in February and March; 1911, a survey of the Turk's and Caicos Islands in order to ascertain the most southerly extension of the species of this Flora. They collected on Grand Turk Island (8981-9059; 9324-9347; 9378-9390); then, chartering a sloop, investigated the following islands: East Caicos (9060-9114); Grand Caicos (91159122) ; North Caicos (9123-9191) ; Bay Cay (9192); Parrot Cay (91939204); Stubb's Cay (9205-9210); Pine Cay (9211-9215); Dellis' Cay (9216-9225) ; South Caicos (9226-9233; 9240-9247) ; Long Cay (92349239; 9274) ; Salt Cay (9248-9262; 9392) ; Sand Cay (9263-9270; 9391); Ambergris Cay (9275-9316); Little Ambergris Cay (9317-9323); Long Cay (Turk's) (9348-9350) ; Gibbs' Cay (9351-9356) ; Cotton Cay (93579363); Penniston Cay (9364); and East ("Eastern')) Cay (9365-9377). 


\section{BIBLIOGRAPHY}

\section{Prepared With the co-operation OF JoHN H. BarnharT}

Only documents dealing wholly or chiefly with Bahamian plants, and the more important treatises on West Indian botany including references to Bahama species are here cited.

Allen, Glover M., and Barbour, Thomas. Narrative of a Trip to the Bahamas. Cambridge, Mass. Privately printed. 1904.

Ames, Oakes. A new Ponthieva from the Bahamas. Torreya 10: 90, 91. 1910. Description of Ponthieva Brittonae.

Anonymous. Agave seen by Columbus found. Discovery 1: 30-32. 1907.

Popular account of the Agave indagatorum of Watling's Island.

Anthony, Emilia C. Fern Hunting in Nassau. Fern Bull. 10: 65-68. 1902. Popular account of ferns found on New Providence.

Bennett, John J. Note on the Species of Croton described by Linnaeus under the Names of Clutia Eluteria and Croton Cascarilla. Journ. and Proc. Linn. Soc. Bot. 4: 26-30. 1859. Copied in Pharm. Journ, and Trans. II. 1: 132-134. 1860. German translation under the title "Ueber die Croton-Art, welch die Cortex Cascarillae liefert.", Bonplandia 9: 213215. 1861.

Discussion of three species inhabiting the Bahamas.

Britton, N. L. Review of the Provisional List of the Plants of the Bahama Islands. Bull. Torr. Club 17: 187, 188. 1890.

Britton, N. L. A new Waltheria from the Bahamas. Torreya 3: 105, 106. 1903.

Description of Waltheria bahamensis.

Britton, N. L. Explorations in Florida and the Bahamas. Journ. N. Y. Bot. Gard. 5: 129-136. 1904.

Record of the first visit of Dr. Britton, Dr. Millspaugh and Dr. Howe to New Providence.

Britton, N. I. Report on Exploration of the Bahamas. Journ. N. Y. Bot. Gard. 5: 201-209. 1904.

Record of collecting on New Providence with Mrs. Britton and Mr. L. J. K. Brace.

Britton, N. I. Savia bahamensis. Torreya 4: 104, 105. 1904.

Description of a species new to science.

Britton, N. L. Notes on the Flora of the Bahamas. Torreya 4: 190. 1904.

Remarks before the Torrey Botanical Club upon the flora of New Providence.

Britton, N. I. Contributions to the Flora of the Bahama Islands. Bull. N. Y. Bot. Gard. 3 : 441-453; 4: 115-127; 137-143; 5: 311-318. 1905-1907. 
Descriptions of new species and records of distribution of species. Each of the four Contributions was distributed separately in advance.

Britton, N. L. Explorations in the Bahamas. Journ. N. Y. Bot. Gard. 6: 7885. 1905.

Narrative of exploration of Rose Island, the Berry Islands, Great Bahama and the Exuma Cays with Dr. Millspaugh and Dr. Howe.

Britton, N. I. Report on the Continuation of the Botanical Exploration of the Bahama Islands. Journ. N. Y. Bot. Gard. 8: 71-81. 1907.

Narrative of exploration, with Dr. Millspaugh, of Eleuthera, Little San Salvador, Cat Island, C'onception Island, Watling's Island, and Long Island. Mrs. Britton and Mrs. Millspaugh collected on Harbor Island.

Britton, N. L. The Genus Ernodea Swartz: A Study of Species and Races. Bull. Torr. Club 35: 203-208. 1908.

Discussion of the six species of the Bahamas, three described as new.

Britton, N. L. The Botanical Name of the Wild Sapodilla. Torreya 11: 128, 129. 1911.

Synonymy of Mimusops emarginata (L.) Britton.

Britton, N. L. Four Undescribed West Indian Sedges. Torreya 13: 215-217. 1913.

Stenophyllus Wilsoni, Fimbristylis inaguensis, Rynchospora bahamensis from the Bahamas.

Catesby, Mark. The natural history of Carolina, Florida, and the Bahama Islands. 2 vols., folio, London, " 1731 ", and " 1734. ."

Issued in ten parts, of twenty plates each, 1730-43; and an appendix of twenty plates, 1748. The plates are numbered 1-100 in each volume, and 1-20 in the appendix. Each plate, as a rule, illustrated one animal and one plant, and descriptive text accompanied each object figured; these include about sixty-five Bahama plants.

A second issue in 1754, "revised" by George Edwards, librarian to the Royal College of Physicians, is a mere reprint, with the addition of a sheet at the end of each volume giving the Linnaean names of the animals and plants in the work.

A third issue, in 1771, differs from the preceding only in the resetting of the title-page and preface, and the numbering of the pages and plates of the appendix consecutively with those of the second volume.

The London issues all had the text in both English and French, in parallel columns. There was another edition (Nürnberg, 1750), with text in Latin and German, in parallel columns; this contained a few additional plates, not in Catesby's work.

The Bradley Bibliography mentions also a German translation by Huth (Nürnberg, 1755), and a Dutch translation by Houttuyn in nine volumes (Amsterdam, 1772-81), but both are indicated as not seen by the compiler.

Coker, William C. Vegetation of the Bahama Islands. In Shattuck "The

Bahama Islands,', 185-270. Baltimore, 1905. Also issued as a separate.

Contains an account of previous botanical exploration, a discussion of the composition and relationships of the flora and of its distribution, notes on useful plants indigenous and introduced, a description of the botanical for- 
mations, and a list of the plants collected by the author in 1903 ; several species are described as new.

Committee. Report of the Committee, consisting of Messrs. W. Carruthers, W. F. R. Weldon, J. G. Baker, G. M. Murray, and W. T. Thiselton-Dyer (Secretary), appointed for the Purpose of Exploring the Flora of the Bahamas. Rep. Brit. Assoc. Adv. Sci. 58: 361-363. 1889. Also reprinted. Baron Eggers made collections for this Committee in 1887 and 1888.

Daniell, William F. On the C'ascarilla and other species of Croton of the Bahamas and other West Indian Islands. Pharm. Journ. and Trans. II. 4: 144-150; 226-231. 1863.

Botanical and pharmaceutical deseriptions of the Bahama Crotons, with illustrations.

Dolley, C. S. The Botany of the Bahamas. Proc. Acad. Nat. Sci. Phila. 1889: 130-134. 1889.

Remarks upon the flora, with reference to the list of plants presented by him for publication. (See Gardiner, John, and Brace, L. J. K.)

Dyer, W. T. Thiselton. Flora of the Bahamas. Nature 37: 565, 566. 1888. Account of exploration, with a letter from Baron Eggers.

Eaton, D. C. A List of the Marine Algae collected by Dr. Edward Palmer on the Coast of Florida and at Nassau, Bahama Islands, March-August, 1874. 8vo, pp. 6. New Haven, 1875.

Record of about 30 species found at Nassau, New Providence.

Eaton, D. C., and Setchell, W. A. List of Plants from Abaco Island, Bahamas. Johns Hopkins Univ. Circ. 6: 46, 47. 1886.

A list of 66 species collected by F. H. Herrick or observed by him.

Eggers, H. F. A. Die Bahama Inseln. Globus 62: 209-214. Braunschweig, 1892.

A brief general account of the islands and of their vegetation.

Flkman, E. L. West Indian Vernoniae. Arkiv. Bot. 13' $: 1-106, p l .6 .1914$. Includes the Bahama species.

Evans, Alexander W. The Hepaticae of the Bahama Islands. Bull. Torr. Club 38: 205-222. 1911.

Enumeration with distribution of 34 species, three of them illustrated, with descriptions, as new to science.

Gardiner, John, and Brace, L. J. K. Provisional List of the Plants of the Bahama Islands, arranged with notes and additions by Charles S. Dolley. Proc. Acad. Nat. Sci. Phila. 1889: 349-426. 1889. Also issued as a separate.

An annotated catalogue of over 600 Bahama plants based upon a manuscript list prepared by Mr. Brace, with a glossary and index of popular names. This document is eited in the present volume as of Dolley.

Gleason, Henry A. The Genus Vernonia in the Bahamas. Bull. Torr. Club 33: 183-188. 1906. [Separately as Contr. Bot. Dept. Col. Univ. no. 224.]

Records and descriptions of the five species, three of them described as new. Grisebach, A. H. R. Flora of the British West Indian Islands. 8vo, pp. 789. London, 1859-1864. 
Published in seven parts. Includes records and descriptions of about 200 Bahamian species mostly from specimens collected by Swainson and by Hjalmarson.

Grisebach, A. H. R. Die geographische Verbreitung der Pflanzen Westindiens. Abhand. Koenigl: Gesell. Wiss. Goettingen 12: 3-80. 1865. Also issued as a separate.

A treatise on geographic distribution of West Indian species, with references to those of the Bahamas.

Guppy, H. B. The Flora of the Turks' Islands. In his 'Plants, Seeds and Currents in the West Indies and Azores"' 277-293. 8vo. London, 1917.

Harshberger, John W. Notes on the Strand Flora of Great Inagua, Haiti and Jamaica. Torreya 3: 67-70. 1903.

Herrick, F. H. Notes on the Flora of Abaco and adjoining Islands. Johns Hopkins Univ. Circ. 6: 46. 1886.

General account of the vegetation.

Hitchcock, A. S. A visit to the West Indies. Bot. Gaz. 16: 130-141. 1891. Narrative of a trip with J. T. Rothrock, including exploration on New Providence, Eleuthera, Cat Island, Watling's Island, Crooked Island, Fortune Islands and Inagua.

Hitchcock, A. S. List of Plants collected in the Bahamas, Jamaica and Grand Cayman. Rep. Mo. Bot. Gard. 4: 47-179. 1893. Also distributed separately in advance.

Record of the trip above mentioned, with a catalogue of the plants collected, a discussion of the relations of the Bahama Flora, descriptions and illustrations of new species and tables of distribution.

Hitchcock, A. S. List of Cryptogams collected in the Bahamas, Jamaica and Grand Cayman. Rep. Mo. Bot. Gard. 9: 111-120. 1898. Also distributed separately in advance.

Bahama species are listed of Lichens determined by T. A. Williams, of Basidiomycetes by W. G. Farlow, of Uredineae by M. A. Carleton, of Ustilagineae by P. Magnus and of Pyrenomycetes and Peronosporaceae by J. B. Ellis. Nine new species of Pyrenomycetes are described.

Hitchcock, A. S., and Chase, Agnes. Grasses of the West Indies. Contr. U. S. Nat. Herb. 18: 261-471. 1917.

Contains many records of Bahama species.

Hooker, J. D. Bahama Flora. Rep. Progr. and C'ond. Royal Gardens Kew for $1880,30.1881$.

Note on the receipt at Kew of a collection made by L. J. K. Brace.

House, Homer D. Two Bahamian Species of Evolvulus. Bull. Torr. Club 35 : 89, 90. 1908. Evolvulus bahamensis and E. Bracei, new species.

Howe, Marshall A. Notes on Bahaman Algae. Bull. Torr. Club 31: 93-100, pl. 6. 1904. [Separately as Contr. N. Y. Bot. Gard. no. 51.] Records of the algae collected by Dr. W. C. Coker in 1903.

Howe, Marshall A. Collections of Marine Algae from Florida and the Bahamas. Journ. N. Y. Bot. Gard. 5: 164-166. 1904. 
Narrative of collections made on the shores of New Providence, at Joulter's Cays, Gun Cay, the Biminis, North and South Cat Cays, in company of Dr. Millspaugh on the sloop "Cynosure."

Howe, Marshall A. Phycological Studies-I. New Chlorophyceae from Florida and the Bahamas. Bull. Torr. Club 32: 241-252, pl. 11-15. 1905. [Separately as Contr. N. Y. Bot. Gard. no. 67.]

Descriptions and illustrations of one genus and three species new to science.

Howe, Marshall A. Phycological Studies-II. New Chlorophyceae, new Rhodophyceae, and miscellaneous Notes. Bull. Torr. Club 32: 563-571, pl. 2329. 1905. [Separately as Contr. N. Y. Bot. Gard. no. 72.]

Includes descriptions and illustrations of one genus and three species, new to science, from the Bahamas.

Howe, Marshall A. Phycological Studies-IV. The Genus Neomeris and Notes on other Siphonales. Bull. Torr. Club 36: 75-104, pl. 1-8. 1909. [Separately as Contr. N. Y. Bot. Gard. no. 120.]

Includes deseriptions and illustrations of four Bahamian species new to science.

Howe, Marshall A., and Wilson, Percy. Report on the Botanical Exploration of the Bahama and Caicos Islands. Journ. N. Y. Bot. Gard. 9: 41-50. 1908 .

Narrative of collecting on Watling's Island, Atwood Cay, Mariguana, the Caicos Islands, Little Inagua, Providenciales, Castle Island, Great Ragged Island and Harvey's Cay.

Jackson, J. R. Princewood Bark, a Febrifuge from the Bahamas. Pharm. Journ. and Trans. III. 6: 681. 1876.

Note on the bark of Exostema caribaeum.

Millspaugh, C. F. A new Bahaman Euphorbia. Torreya 4: 172.1904.

Euphorbia cayensis, from Joulter's Cays.

Millspaugh, C. F. Praenunciae bahamenses. Field Mus. Bot. 2: 137-184; 289321. $1906,1909$.

Contains accounts of collectors and collections, largely republished in the present volume (pp. 646-655), bibliography, a list of the islands on which collections have been made, lists of species of several families with descriptions of numerous novelties and a list of native plant names.

Murray, G. Catalogue of the Marine Algae of the West Indian Region. Journ. Bot. 26: 193-196, 237-243, 303-307, 331-338, 358-363. 1888; 27: 237242, 257-262, 298-305. 1889.

Includes numerous records of the occurrence of marine algae in the Bahamas.

Nash, George V. Botanical Exploration of the Inagua Islands, Bahamas. Journ. N. Y. Bot. Gard. 6: 1-19. 1905.

Narrative of exploration of Inagua and Little Inagua in 1904, with Norman Taylor.

Nash, George V. A Trip to the Inaguas. Plant World 8: 63-71; 91-98. 1905. Also issued as a separate.

Popular account of the exploration of Inagua and Little Inagua. 
Northrop, Alice R. Flora of New Providence and Andros. Mem. Torr. Club 12: 1-98, pl. 1-19. 1902.

A general account of the location and conformation of these two islands, their botanical regions, an annotated list of plants collected by Mrs. Northrop and her husband, John I. Northrop, in 1890, with descriptions and illustrations of new species and discussions of the distribution of species.

Nutting, C. C. Narrative and Preliminary Report of Bahama Expedition. Bull. Lab. Nat. Hist. Univ. Iowa 3: 1-252. 1895.

Contains occasional references to the vegetation observed during a voyage in 1893.

Rothrock, J. T. Some Observations on the Bahamas and Jamaica. Proc. Am. Phil. Soc. 29: 145-148. 1892. Also issued as a separate.

Rydberg, P. A. The Flowers and Fruit of the Turtle Grass. Journ. N. Y. Bot. Gard. 10: 261-264. 1909.

Study of Thalassia testudinum, from 'Bahama specimens collected by Percy Wilson.

Schoepf, J. D. Materia Medica Americana potissimum regni vegetabilis. 8vo, pp. xviii, 170. Erlangen, 1787. Reprinted as Bull. Lloyd Library no. 6 (Reprod. Ser. 3). 1903.

Includes references to some 30 wild and cultivated species found in the Bahamas.

Schoepf, J. D. Reise durch einige der mittlern und südlichen Vereinigten Staaten nach Ost-Florida und den Bahama Inseln unternommen in den Jahren 1783 und 1784. 2 volumes. Erlangen, 1788. [Translated and edited by Alfred J. Morrison, under the title "Travels in the Confederation."' 2 volumes, small 8vo, Philadelphia, 1911.]

A chapter in the second volume (pp. 396-502), "Reise von St. Augustin nach den Bahama-Inseln" [Translation, pp. 252-319, "Voyage from St. Augustine to the Bahama Islands''] describes the Gulf Stream, Abaco, Egg Island and New Providence, with records of plants both cultivated and indigenous.

Small, J. K. Report on Botanical Exploration in Andros, Bahamas. Journ. N. Y. Bot. Gard. 11: 88-101. 1910.

Narrative of exploration, with J. J. Carter, in 1910.

Small, J. K. Exploration in Andros. Torreya 10: 131-133. 1910.

Account of the work above-mentioned before the Torrey Botanical Club.

Urban, Ignatz. Additamenta ad Cognitionem Florae Indiae Occidentalis.

Bot. Jahrb. 15: 286-361；19: 562-681；21: 514-638; 24: 10-152. 18921897 .

These articles contain numerous records and descriptions of Bahama plants. Urban, Ignatz. Symbolae Antillanae seu Fundamenta Florae Indiae Occidentalis. 8vo, vols. 1-7. Berlin, 1898-1913.

Each volume was published in four parts; the work contains many records and descriptions of Bahama species and lists and monographs of many families and genera of West Indian plants written by Professor Urban and by other students. 
Wilson, Henry W. A Winter Visit to the Bahama Islands. Trans. Mass. Hort. Soc. 1891: 210-229. 1891.

General description of several of the islands with accounts of the vegetation, especially of cultivated or conspicuous plants, illustrated.

Wilson, Percy. Report on the Botanical Exploration of the Islands of the Salt

Key Bank, Bahamas. Journ. N. Y. Bot. Gard. 10: 173-176. 1909.

Record of collections made in 1909 on Riding Rocks, Orange Key, Anguilla Isles, Salt Key (Cay Sal), Elbow Key, and Water Key; also on New Providence. 


\section{INDEX}

Abelmoschus, 272

esculentus, 272

Abena jamaicensis, 366

Abildgardia, 52 monostachya, 52

Above-all, 396

Abraham-bush, 220

Abrus, 187

Abrus, 187 precatorius, 187

Abutilon, 264.

abutiloides, 265

Bushy, 265

crispum, 266

Eggersii, 264

fliforme, 266

Hairy, 265

hirtum, 265

indicum, 265

indicum hirtum, 265

lignosum, 265

Low, 266

pauciflorum, 266

permolle, 265

triquetrum, 265

trisulcatum, 265

Velvety, 265

Woolly, 266

Acacia, 159

acuifera, 160

Bahama, 160

bahamensis, 158

choriophylla, 160

Farnesian $a, 161$

formosa, 158, 159

haematomma, 159

latisiliqua paucifoliola 158

Lebbeck, 157

Long-spined, 160

macracantha, 160

tortuosa, 161

Acalypha, 228

alopecuroidea, 228

caroliniana, 229

chamaedrifolia, 228

Hornbeam, 229

ostryaefolia, 229

persimilis, 229

polystachya, 228

Prostrate, 228

reptans, 228

setosa, 229

Setose, 229

Spicate, 228

ACANTHACEAE, 400

Acanthococcus adelphinus, 583

Acanthophora, 568

Antillarum, 569

Delilei, 569

militaris, 569

muscoides, 569

spicifera, 569

Thierii, 569

Acanthospermum, 447

humile, 447

ACANTHUS FAMILY, 400
Acetabularia, 605

caraibica, 606

crenulata, 606

polyphysoides, 606

pusilla, 606

Schen ckii, 606

Acetabulum, 605

caribaeum, 606

crenulatum, 606

polyphysoides, 606

polyphysoides deltoideum, 606

pusillum, 606

Achras bahamensis, 324

salicifolia, 322

Zapota, 324

Zapotilla parvifolia, 324

Achyranthes, 126

aspera indica, 126

aspera obtusifolia, 126

Beach, 126

Creeping, 127

indica, 126

Knotweed, 127

linearifolia, 127

maritima, 126

obtusifolia, 126

polygonoides, 126

repens, 127

Acicularia, 606

Schenckii, 606

Acoelorraphe, 60

Acrochaetium, 560

Acrostichum, 465

aureum, 465

calomellanos, 469

excelsum, 465

lomarioide 8,465

polypodioides, 470

Actinocyclus fasciculatus, 629

moniliformis, 629

Rotula, 629

Actinoptychus splendens, 629

undulatus, 629

vulgaris, 629

Acuan, 162

depressum, 163

virgatum, 163

Adelia, 227

Adelia, 226

Acidoton, 219

Bernardia, 227

porulosa, 327

segregata, 327

Adenorima, 234

Bahama, 234

gymnonota, 234

Adenoropium, 225 gossypifolium, 225

Adiantum, 467

Capillus-Veneris, 467

clavatum, 468

melanoleucum, 468

tenerum, 467

Aecidium candidum. 631
Aecidium

Ipomoeae-panduranae, 631

Aeschynomene grandiflora, 182

Afzella, 392

Afzelia, 391

cassioides, 392

Agalinis, 392

Harperi, 392

Marsh, 392

spiciflora, 392

Agardhia, 616

Agardhiella, 561

tenera, 561

AGARICACEAE, 642

AGARICALES, 638

Agaricus alneus, 644

cinnabarin 48,642

conicus, 642

cretaceus, 643

crinitus, 642

eugram $m u s, 644$

hemileucus, 643

hirsutus, 640

hirtus, 642

liliputianus, 644

micaceus, 642

molybdites, 642

ramealis 643

Rotula, 643

semiorbicularis, 643

squamosus, 643

striatus, 640

strigosus, 643

Agati, 182

grandiflora, 182

sericea, 182

Agave, 73

a ckilinicola, 75

americana, 75

bahamana, 74

bahamana, 75

Braceana, 74

cacozela, 75

inaguensis, 76

indagatorum, 76

Millspaughii, 75

Nashì, 76

rigida, 75

rigida sisalana, 76

sisalana, 76

sisalana armata, 76

sobolifera, 75

Ageratum, 436

conyzoides, 437

conyzoides inaequipale aceum, 437

latifolium, 436

latifolium, 437

muticum, 436

Wild, 437

Aglaozonia, 591

canariensis, 591

canariensis, 594

Agrostis indica, 32

radiata, 35

tenacissima, 32

virginica, 33 
Ahnfeltia pinnatula, 560

AIZOACEAE, 136

Aklema, 236 petiolare, 236

Albizzia, 157

Lebbeck, 157

Albugo candida, 631

Ipomoeae-panduranae, 631

Alectoroctonum petiolare, 236

Aletris, 70

bracteata, 70

guineensis, 69

hyacinthoides guianensis, 69

ALGAE, 553

Alisma cordifolia, 7

ALismaCeae, 7

ALISMALES, 6

Allophylus, 253

Allophylus, 253 Cominia, 253

Allspice, 305

Almond-tree, 302

Aloe, 69

barbadensis. 69

perfoliata, 69

vera, 69

vulgaris, 69

Aloes, 69

Alsidium Blodgettii, $\mathbf{5 7 1}$ triangulare, 571

ALSINACEAE, 137

Alternanthera Achyrantha, 127

flavescens, 128

maritima, 126

paronychioides, 126

repens, 127

Alvaradoa, 211

Alvaradoa, 211

amorphoides, 211

Alysicarpus, 185

nummularifolius, 185 vaginalis, 185

A manitopsis farinosa, 644 vaginata, 644

Amansia, 575

multifida, 575

multiflda, 589

Amaranth, Knotweed, 124

Notch-leaved, 124

Slendier, 124

Spiny, 125

Thick-stalked, 124

AMARANTH FAMILY, 122

AMARANTHACEAE, 122

Amaranthus, 123

crassipes, 124

dubius, 125

emarginatu8, 124

gracilis, 124

hybridus, 125

paniculatus, 125

polygonoides, 124

spinosus, 125

tristis, 125

viridis, 124

AMARYLLIDACEAE, 73

AMARYLLIS FAMILY, 73

A mblogyna polygonoides. 124

Amblystegium, 496

Amblystegium, 496

riparium floridanum, 496
AmblystegiumSipho, 496

Ambrosia, 431 artemisiaefolia, 432 crithmifolia, 432

hispida, 432

paniculata, 432

AMBrosiaceAn, 430

Amellus aspera, 449, 454

Ames' Halberd-fern, 472

Ammannia, 299

Ammannia, 298

latifolia, 299

AMMIACEAE, 311

AMMIALES, 311

Ammocallis rosea, 336

Ampelopsis quinquefolia, 261

Amphibia, 572

Amphibia, 617

Montagnel, 572

pectinata, 573

Sertularia, 573

Sertularia, 573

tenella, 572

tenella, 573

Amphiconium, 599

Amphiroa, 588

debilis, 588

fragillssima, 588

fragilissima, 588

rigida antillana, 588 Tribulus, 588

Amphora, 628

acuta arcuata, 630

bigibba, 628

coffaeiformis, 630

crassa, 630

cymbelloides, 630

gigantea fusca, 630

Graeffei, 630

Gruen dleri, 630

Janischil, 630

obtusa, 628

ostrearia, 630

ostrearia vitraea, 630

rhombica, 630

Amygdala Ceate, 153

Amyris, 208

bijuga, 209

elemifera, 208

maritima, 208

sylvatioa, 209

toxifera, 244

ANACARDIACEAE, 243

Anacardium occidentale, 245

Anacheilium, 93 cochleatum, 93

Anaconda, 358

Anadyomena, 602 fiabellata, 602

Anadyomene, 602 flabellata, 602 stellata, 602 stellata, 602

Anamomis, 305 bahamensis, 306 longipes, 306 lucavana, 306

Anastraphia 459

Bahama, 459

bahamensis, 459

bahamensis, 636

cuneifolia, 459

Northropiana, 459

Northrop's, 459
Anastraphia-

paucifloscula, 459

Anastrophus compressu8, 17

Anatherum macrurum, 14

Anaulus, $62 \pi$

minutus, 627

Andrographis, 403

Andrographis, 403 paniculata, 403

Andropogon, 13

barbatum, 36

giomeratus, 14

gracilis, 13

insulare, 16

polydactylon, 36

repens, 37

semiberbis, 13

tener, 13

tenuispatheus, 14

virginicus, 14

Anemia, 474

adiantifolia, 475

bipinnata, 474

cicutaria, 474

Maiden-hair, 475

Parsley, 474

Wrightii, 474

Wright's, 474

Anethum, 313

Foeniculum, 313

graveolens, 313

ANGIOSPERMAE, 2

Anguria, 426

Keithil, 426 pedata, 426

Anneslia, 158

formosa, 159

haematostoma, 159

Red, 159

White, 159

Annona, 141

Annona, 599

glabra, 141

glabra, 540

laurifolia, 141

palustris, 141

reticulata, 142

squamosa, 141

ANNONACEAE, 141

Anonymos cassioides, 392

Anthacanthus, 402

acicularis, 403

spinosus, 403

Anthephora, 15

Anthephora, 15

hermaphrodita, 15

Anthoceros, 521

laevis, 521

Yellow-spored, 521

A NTHOCEROS FA MILY, 521

ANthocerotaceae, 521

ANTHOCEROTALES, 521

Anthracothecium, 527 americanum, 528 corticatum, 527

libricolum, 527

ochro-flavum, 527

sinapispermum. 527

subglobosum, 527

Antigonon, 116

leptopus, 116

Antirrhinum antirrhiniflora, 388

Antirrhoea lucida, 414

myrtifolia, 415

Antithamnion, 581 
Antithamnion, 627 Butleriae, 581 cruciatum, 581

Aphanocapsa, 618 Howel, 618 Zanardinii, 619 Aphanothece, 620 Apium Ammi, 314 Aplonema, 599

A POCY NACEAE, 333

Apona, 582

Arabian Jasmine, 327

Arales, 62

Archaeolithothamnium, 584 dimotum, 584

Archilejeunea, 517 Greenest, 518 viridissima, 518

Arcyria cinerea, 645 Oerstedtii, 645 punicea, 645

Ardisia guadalupensis, 316 Pickeringia, 315

ARECACEAE, 58

ARECALES, 58

Argemone, 145 mexicana, 145

Argithamnia lanceolata, 226

Argythamnia, 225 argentea, 226

Bahama, 226

candicans, 226

lucayana, 226

sericea, 225

Silky, 226

Silverv, 226

Aristida, 30

adscensionis, 31

americana, 37

cognata, 31

gyrans, 31

purpurascens, 31

scabra, 31

stricta, 31

Aristolochia, 113

Coastal, 113

passifloraefolla, 113

pentandra, 113

Slender, 113

ARISTOLOCHIACEAB, 112

ARISTOLOCHIALES, 112

Aroma, 161

Artemisia capillifolia, 437 vulgaris. 460

Arthonia, 53.

Arthonia, 538

atrata, 534

atrata, 534

caesiopruinosa. 536

chiodectella, 533

cinereopruinosa. 533

cinnabarina, 533

complanata. 533

conferta, 533

fissurinea, 533

gregaria, 533

interducta, 533

macrotheca $\mathbf{5 3 4}$

platygraphidea. 534

polymorpha. 533

septisepta. 533

ARthoniaceae. 533

Arthopyrenia, 525

b1formis, 525

Cinchonae, 525

43
Arthopyrenia -

consanguinea, 525

contendens, 525

epidermidis, 525

fallacior. 525

fallax, 525

geminata, 525

indusiata, 525

planior, 525

planorbis, 525

tumida, 525

Arthothelium, 534 macrothecum, 534

Arthrostylidium, 43 capillifollum, 43

Arthrothamnus, 235 cassythoides, 235

Arum sagittifolium, 62

Arundo Phragmites, 39

ASCLEPIADACEAE, 340

Asclepias, 341

clausa, 344

curassavica, 341

curassavica concolor, 341

paupercula, 341

procera, 341

ASCOMYCETES, 632

Ascyrum, 280

linifolium, 280

Asparagopsis, 564

Delilei, 564

taxiformis, 564

Asperococcus clathratus, 590

sinuosus, 590

Aspidium adiantifolium, 473

augescens, 472

heracleifolium, 471

incisum, 473

reptans cordata, 473

trifoliat um, 472

Asplenium, 469

dentatum, 469

marinum, 469

rhizophyllum, 469

Astephanus, 344

Aster, 440

adnatus, 441

Bahama, 441

bahamensis, 441

Bracei, 441

Brace's, 441

exilis, 441

lucayanus, 441

Pine-land, 441

Scale-leaved, 441

Slim, 441

ten uifolius, 441

Asterocytis, 554

ramosa, 554

AstroTh ELIACEAE, 532

Astrothelium varium citrinum, 530

Atamasco-111y, 78

Atamosco, 77 cardinalis, 78 rosea, 78

Ateleia, 177 cubensis, 177 cubensis, 632 multijuga, 177

Athanasia hastata, 449

Atriplex, 119 arenaria, 120
Atriplex-

Crested, 120

cristata, 120

cristata arenaria, 120

Domingan, 120

domingensis, 120

pentandra, 120

Sea-beach, 120

Auliscus caelatus, 629 ret1culatus, 629

Auliza, 90 nocturna, 90 Slender, 90

A uricula intermedia, 631 minuta, 631

Auricularia Auricula, 637 nigrescens, 637

AURICULARIALES, 637

AUTOBASIDIOMYCETES, 637

Avicennia, 375

Avicennia, 572, 573, 603 nitida, 375

Avrainvillea, 611

levis, 611

longlcaulis, 611

longicaulis, 611

Mazei, 611

nigricans, 611

nigricans, 611

nigricans fulva, 611

Rawsoni, 612

sordida, 611

Axonopus, 17

compressus, 17

Axyris pentandra, 120

Ayenia, 278

Common, 279

pusilla, 278

Baccharis, 444

angustlfolia, 444

dioica, 445

foetida, 445

halimlfolia, 444

Vahlii, 445

Bacidia, 543

atrogrisea, 543

endoleuca, 543

fuscorubella, 543

medialis, 543

Bacopa Monniera, 389

Badiera, 216

domingensis, 217

Oblong-leaved, 217 oblongata, 216

Bahama Bay-rush, 464

Hymenostomum, 485

Phymosia, 264

Solanum, 383

Bahamian Brachlolejeunea, 515

Balloon-vine, 252

Ballota suaveolens, 380

Bamboo, 74

Banara, 283 reticulata, 284

Bangia, 553

Alsidii, 553

bidentata, 553

elegans 553

lutea, 553

pallescens, 553

pallida, 553

BANGIACEAE, 553

Banisteria angulos $a, 204$ 


\section{Banisteria -}

lupuloides, 258 microphylla, 204

Banyan, 105

Barbadoes Pride, 175

Barbula, 486

agraria, 484

Crugeri, 486

Cruger's, 487

Donnellii, 485

Bark Brachiolejeunea, 515

Barnyard-grass, 26

Bastard Buttonwood, 301 Stopper, 373

Torch, 143

Bastardia, 269

Viscid, 270

viscosa, 270

Bathelium mastoideum, 529

BATIDACEAE, 133

Batis, 133 maritima, 133

Batophora, 604 Oerstedi, 604

Oerstedi occidentalis, 604

Batrachospermum attenuatum, 581

Bay-bean, 191

Cedar, 209

Bay CEDar Family, 209

Bay Geranium, 432

Hops, 352

Lavender, 361

Marigold, 450

Bay-rush, 463

Bahama, 464

Narrow-leaved, 463

Bay Tansy, 432

-top, 59

Winders, 352

Wormwood, 223

Bayberry, 102

BAYBERRY FAMILY, 101

Beaked-rush, 54

Beard-grass, 13, 14

Bed-grass, 14

Beef-bush, 396 -wood, 100, 132

BEEF-WOOD FAMILY, 100

Beggar-ticks, 453

Bellflower, 387

Benny-seed, 399

Bermuda-grass, 35

Bernardia, 226

Bernardia, 227

carninifolia, 227

dichotoma, 227

mexicana, 227

Bertero's Rectolejeunea, 510

Biatora atrogrisea, 543 calcivora, 542

furfurosa, 542

fuscorubella. 543

medialis, 543

molybditis, 543

parvifolia, $\mathbf{5 4 6}$

tricholoma, 541

Biddulphia, 627

Antillarum, 629

arctica, 629

Favus, 630

mobillensis, 630

Pentacrinus. 627

peruviana, 630
Biddulphia -

reticulata, 630

Reticulum, 630

Robertsiana, 630

Smithil, 630

splnosa, 630

Tabellarium, 630

Bidens, 453

bipinnata, 453

cynapiifolla, 453

leucantha, 453

nivea, 449

pilosa, 453

pilosa, 636

Big Man, 110

Sage, 370

Bignonia coerulea, 398

lepidota, 396

pentaphylla, 396

stans, 397

BIGNONIACEAE, 395

Bilimbia, 542

aurata, 543

molybditis, 543

trachona, 542

Bird Pepper, 385

BIRTH W ORT FA MILY, 112

Bitter Bush, 210, 438

Bitters, 227, 258

Black-bead, 156

Bean, 195

Ebony, 196, 229, 328

-eyed Susan, 187

-fruited Gyroweisia, 484

Mangrove, 375

Nightshade, 383

Olive, 301

Soap, 429

Torch, 143, 416

Wattle, 304

Willow, 150

Wood, 103

Blackish Papillaria, 494

Bladderwort, 394

BLADDERWORT FAMILY, 393

Blastenia, 550

ferruginea, 550

floridana, 550

Blastodesmia lactea, 527

Blechnum, 468 serrulatum, 468

Blechum, 401

Blechum, 401

Brownei, 401

Bletia, 96

alta, 96

Purple, 96

purpurea, 96

verecunda, 96

Blind-eye Bush, 276

Blodgettia confervoides, 601

Blolly, 131, 132

Blue-eyed Grass, 81

-flower, 366

-pea, 187

Boa-wood, 326

Boar-hog Bush, 373

Boat Lily, 68

Boerhaavea, 130

coccinea, 130

erecta, 130

hirsuta, 130

paniculata, 130

scanden 8,131
Boerhaavea

splendens, 131

BOLETACEAE, 642

Boletus abietin us, 639

cinnamomeus, 639

communis, 642

hydnoides, 641

membranaceus, 639

nigromarginatus, 639

sanguineus, 641

spathulatus, 639

tenuis, 640

BOMBACACEAE, 274

Bombax pentandrum, 274

BOMBAX FAMILY, 274

Bombyliospora, 542 domingensis, 542

Bonaney-bean, 193

Bonania, 231

Bonania, 230 cubana, 231

BONNEMAISONIACEAE, 564

Bontia, 406

Bontia, 405

daphnoides, 405

BORAGE FA MILY, 360

BORAGINACEAE, 360

Borreria, 421

bahamensis, 423

inaguensis, 422

laevis, 422

ocimoides, 422

parviflora, 422

savannarum, 423

saxicola, 422

Slender, 422

thymifolia, 422

thymocephala, 423

Wilsonil, 423

Borrichia, 450

arborescens, 450

arborescens, 636

argentea, 450 glabrata, 450

Boryna, 582

Boston Catnep, 450

Fern, 473

Bostrychia. 572

calamistrata, $\mathbf{5 7 2}$

Mazei, 573

Montagnei, 572

periclados, 572

Sertularia, 573

sertularina, 573

tenella, 572

Tuomeyi, 572

Vieillardi, 572

Vieillardi peotinata, 573

Botryophora, 604, 614 Conquerantii, 604 occidentalis, 604

Bottaria, 530 cruentata, 530

Bouchea, 366 Ehrenbergii, 366 prismatica, 366

Bourreria, 359

havanensis, 359

ovata, 359

succulenta, 359

thymifolia, 423

tomentosa, 359

Bouteloua, 37

americana, 37 
Bouteloua -

litigiosa, 37

Bow Pigeon, 118

Bowstring Hemp, 70

Box Briar, 410

Box FAMILY, 242

Boxwood, 398

Bracea, 335 bahamensis, 335

Brachiolejeunea, 514 bahamensis, 515

Bahamian, 515

Bark, 515 corticalis, 515

Brachycladia, 557 marginata, 559

Bracken, Southern, 467

Bradburya, 188 floridana, 188 virginiana, 188

Brake, Long-leaved, 467 Narrow-leaved, 466

Bramia, 389 Monnleri, 389

Brasiletto, 173

Brassica, 146 integrifolia, 147 orientalis, 148 Sinapistrum, 147

BRASSICACEAE, 145

Brazilian Kalanchoe, 153

Brier, 172 -tree, 301

Britton's Rectolejeunea, Mrs., 510

Bromelia Pinguin, 66

BROMELIACEAE, 63

Broom-bush, 346, 442, 445

Broughtonia domingensis, 95

lilacina, 95

Brya Ebenus, 196

BRYACEAE, 490

BRYALES, 478

Bryobesia, 610

Bryobesia, 611 cylindrocarpa, 610

Bryonia americana, 427 guadalupensis, 426 racemosa, 427

Bryophyllum, 152 calycinum, 152 pinnatum, 152

BRYOPHYTA, 477

BRYOPSIDACEAE, 606

Bryopsis, 606

Bryopsis, 607 Duchassaing 11,607 hypnoides, 607 pennata, 606

Bryothamnion, 571

Bryothamnion, 589 triangulare, 571 triquetrum, 571

Bryum, 490 albidum, 480 capillare, 490 Coronate, 491 coronatum, 490 Hair-like, 490

BRyUM FAMILY, 490

Buceras angustifolia, 301 Catappa, 302

Buchnera, 393 elongata, 393
Bucida, 300

Buceras, 300 spinosa, 301

BUCKBEAN FAMILY, 332

BUCKTHORN FAMILY, 255

Buckwheat, 115

BUCK WHEAT FAMILY, 114

Buellia, 551

conspirans, 551

disciformis, 551

parasema, 551

parasema aeruginascens, 551

sanguinariella, 551 subdisciformis, 551

BUELLIACEAE, 551

Buffalo-top, 59

Bull-grass, 33 -vine, 261

Bulrush, 42 American Great, 53 Salt Marsh, 52

Bumelia, 323 angustifolia, 323

Bahama, 324

bahamensis, 323

cubensis, 323

Eggersii, 323

loranthifolia, 323

microphylla, 323

Narrow-leaved, 323

retusa, 323

retusa loranthifolia, 323

Bunchosia, 206

Bunchosia, 205

glandulosa, 206

Buphthalmum arborescens, 450

Bur-bush, 263

-grass, 29,30

-head, 7

Vervain, 367

Bursera anigustata, 212

gummifera, 212

gummifera glabrata, 212

gummifera pubescens, 212

inaguensis, 212

Simaruba, 212

BURSERACEAE, 211

Bush Iva, 433

Bustic, 322

Butter-bough, 254

Buttercup, 202, 283

Butterfly-pea, 188

Butterwort, 395

Button-weed, 422

Button wood, 302

BUXACEAE, 242

Buxus bahamensis, 243

Byrsonima, 205

cuneata, 205

lucida, 205

Byssus aurea, 599 sanguinea, 537

Cacalia Porophyllum, 456 sonchifolia, 457

Cactaceae, 291

Cactus, 294

Dillenii, 296

grandiflorus, 294

intortus, 294

Tuna, 297
CaCtUs Family, 291

Caesalpinia, 173

Bahama, 173

bahamensis, 173

bahamensis, 208

bijuga, 173

Bonduc, 172

bonducella, 172

brasiliensis, 173

coriaria, 174

Crista, 172, 173

lucida, 172

Net-veined, 174

ovalifolia, 172

pulcherrima, 174

reticulata, 174

Rugeliana, 173

vesicaria, 173

CAESALPINIACEAE, 164

Cajan, 192

Cajan, 192

Cajanus indicus, 192

Cakile, 149

aequalis, 149

lanceolata, 149

Calabash, 399

Calalue, 125

Calea oppositifolia, 450

Caliciaceae, 532

Caliciales, 532

Calicium, 532 hyperellum, 532

Calliandra formosa, 159 formosa cubensis, 159 gracilis, 159 haematomma, 159 portoricensis, 159

Callicarpa, 373 fulva, 373 Hitch cockii, 373

Callithamnion, 580 byssoides, 580 corymbosum, 580 crispellum, 575 elegans, 580 gorgoneum, 578

Halliae, 580

investiens, 578

repens, 578 tenue, 580

Callopisma aurantiacum diffractum, 551

Callymenia Limminghii, 561

Caloglossa, 564

Caloglossa, 564

Leprieuril, 564

Caloneis formosa, 630 Liber, 630

Liber Bleischil, 630

Powelli1, 630

Calonyction, 349

aculeatum, 349

album, 350

grandiflorum, 350

Tuba, 350

Caloplaca, 550

a urantiaca, 550

aurantiaca diffracta, 551

aurantlaca erythrella, 550

aurantiaca isidiosella, 550

galactophylla. 550

CALOPLACACEAE, 550 
Calopogon pulchellus Simp80 ni, 95

Calothrix, 625 aeruginea, 625 fusco-violacea, 625 parasitica, 625 pilosa, 626 scopulorum, 625

Calotropis, 341 procera, 341 procera, 635

Caltrop, 202, 203

CALTROP FAMILY, 201

CALY MPERACEAE, 481

Calymperes, 482 Richardi, 482 Richard's, 482

CALYMPERES FAMILY, 481

Calyptranthes, 307 pallens, 307 Zuzygium, 307

CAMPaNulaLes, 424

Campylodiscus, 629 angularis, 63 biangulatus, 631 crebrecostatus, 631 Daemelianus, 631 Ecclesianus, 631 imperialis, 629

latus, 631

limbatus, 631 samoensis, 631 simulans, 629 undulatus, 631 Wallichianus, 631

Campyloneurum, 471 Phyllitidis, 471

Campylothelium, 532 decolorans, 532

Canavali, 191 bahamensis, 192 gladiata, 191 lineata, 191

Canavalia obtusifolia, 191

Cancer-tree, 398

Candle-berry, 205

Candlewood, 416, 459

Cane-grass, 25

Canella, 282

Canella, 281 alba, 282 Winterana, 282

Canella Family, 281

CANTLlLACEAE, 281

Canker-berry, 383

Cape-weed, 368

CAPER FAMILY, 149

Caper-tree, 151

Capitularia pityrea, $\mathbf{5 4 7}$

Capparidaceae, 149

Capparis, 150 cynophallophora, 150 cynophallophora, 150 flexuosa, 150 jamaicensis, 150

Capraria, 390 biflora, 391 biflora pilosa, 391

Capriola, 34 Dactylon, 34

Capsicum, 384 baccatum, 385 frutescens, 385

Carara, 148 didyma, 148
Cardiospermum, 252

Halicacabum, 252

microcarpum, 252

CARDUACEAE, 433

Carduus pinetorum, 458

Caribbean Pine-tree, 461

Carica, 289 Papaya, 289

Caricaceae, 289

Carpacanthus platyaarpus, 593

polyceratius, 594

spinulosus, 594

CARPET-WEed FAMILY, 136

Carpocaulon, 567 atropurpureum, 567 dasyphyllum, 568

littorale, 567 tenuissimum, 567

Carradoria, 569

Carrajo-bush, 459

CARROT F"A MILY, 311

Carteria, 82 corallicola, 83

Casasia, 409 clusiaefolia, 410 clusiaefolia, 526

Cascarilla Bark, 223

Casearia, 285

$a l b a, 286$

bahamensis, 285

laetioides, 285

serrulata, 285

Smooth, 285

spinescens, 286

Spiny, 286

Cashia, 161

Cassada-wood, 322

Cassava, 230

Cassia, 165 angustisiliqua, 167 aspera, 169

bahamensis, 167 bahamensis latifolia, 167

bicapsularis, 166

biflora, 167

biflora angustisiliqua, 167

caribaea, 169

Chamaecrista, 168, 170

emarginata, 168

glandulosa, 169

inaguensis, 170

ligustrina, 167

lineata, 170

Iucayana, 169

mimosoides, 169

nictitans, 169

obtusifotia, 166

occidentalis, 166

polyadena, 170

riparia, 169

sericea, 168

Sophera, 166

Tora, 166

uniflora, 168

villosa, 168

Cassine attenuata, 249

Cassip. 160

Cassytha, 144

americana, 144

filiformis, 144

CASSYTHACEAE, 144

Castagnea, 591
Castagnea-

Zosterae, 591

Castalia, 139 ampla, 140 pulchella, 139

Castor-oil Plant, 230

Casuarina, 100 equisetifolia, 100

CASUARINACEAE, 100

Casuarinales, 100

Catalpa, 397

Cuban, 397

longissima, 398

punctata, 397

Catenella, 561

Opuntia, 561

Opuntia pinnata, 561. 620 pinnata, 561

Catesbaea, 410

campanulata, 411

fasciculata, 411

foliosa, 411

Large-flowered, 411

Leafy, 411

parviflora, 411

parviflora septentriona lis, 411

Small-flowered, 411

spinosa, 411

Catesby's Vine, 338

Catharanthus, 336

roseus, 336

Cathartic-bark, 338

Cathartolinum, 199

bahamense, 200

Bracel, 201

corallicola, 200

Curtissii, 200

lignosum, 201

Catopsis, 66

Berteroniana, 66

nutans, 66

vitellina, 66

Cat-tail, 4

CAT-TAIL FAMILY, 3

Cat's-claw, 155, 156, 157 -paw, 384

tongue, 367,438

Cattleya domingensis, 95

Cattleyopsis Northropiana, 95

Caudalejeunea, 516

Lehmanniana, 516

Lehmann's, 516

Caulerpa, 607

clavifera, 610

clavifera, 610

clavifera uvifera, 610

compressa, 609

crassifolla, 608

cupressoides, 609

cupressoides, 609

cupressoides ericifolia, 610

cupressoides Lycopodium, 610

ericifolia, 609

fastigiata, 608

Freycinet11, 609

Freycinetii pectinata, 609

hypnoides, 609

juniperoides, 609

lanuginosa, 609 
Caulerpa-

Lycopodium, 609

mamillosa, 609

mexicana, 608

paspaloides, 609

paspaloides, 609

paspaloides compressa, 609

paspaloides phleoides, 609

paspaloides phleoides, 609

paspaloides typica compres8a, 609

pinnata, 608

plumaris, 608

prolifera, 608

prolifera obovata, 608

racemosa, 610

racemosa, 610

racemosa clavtera, 610

racemosa uvifera, 610

sertularioides, 608

sertularioides, 608

taxifolia crassifolia, 608

verticillata, 608

Caulerpa CeaE, 607

Cayaponia, 426

americana, 427

Panicled, 427

racemosa, 427

Racemose, 427

Ceanothus cubensis, 258

ferreus, 256

reclinatus, 257

Cedrela odorata, 214

Celba, 274 pentandra, 274

Celastraceae, 246

Celastrus myrtifolius, 153 ovata, 258

Celosia, 123

nitida, 123

paniculata, 128

Slender, 123

Celtis Lamarckiana, 104

Cenchorus hirsutus, 30

Cenchropsis, 28 myosuroldes, 28

Cenchrus, 28

carolinianus, 29

echinatus, 30 echinatus viridis, 29

hirsutus, 30, 263

microcephalus, 29

myosuroides, 28

racemosus, 14

tribuloides, 29

tribuloides, 29

viridis, 29

Cenomyce pycnoclada, 547

Centaurium, 330 Brittonii, 330

Centa ury, 330

Centella, 312

asiatica, 313

asiatica, 312

repanda. 313

Centroceras, 583

Centroceras, 627

brachyacanthum, 583

clavulatum, 583

clav'ulatum 583

cryptacanthum, 583
Centroceras-

hyalacanthum, 583

micranthemum, 583

oxyacanthum, 583

Centrosema virginianum, 188

virginianum angustifolium, 188

Centrostachys, 125

indica, 126

Century-plant, Acklin's Island, 76

Bahama, 75

Brace's, 74

Inagua, 76

Millspaugh's, 75

Nash's, 76

New Providence, 75

Watling's Island, 76

Cephalocereus, 291

bahamensis, 292

Millspaughil, 292

Ceramiaceae, 578

Ceramiantemum, 562

Ceramion, 562

Ceramium, 582

aculeatum, 581

byssoideum, 583

clavulatum, 583

corniculatum, 583

cruciatum, 582

diaphanum tenuissimum, 582

divaricatum, 582

leptophloeum, 582

nitens, 582

rubrum nitens, 582

subtile, 582

subtile, 582

tenuissimum, 582

transversale, 583

Trichocladis, 571

Ceramothamnion, 583

Codii, 583

Ceratolejeunea, 513

Cuban, 513

cubensis. 513

Entire-leaved, 513

integrifolia, 513

Ceratoschoenus capitatus, 54

Cerbera, 338

Thevetia, 338

Cercospora Calotropidis, 635

Melochiae, 635

Stachytarphetae, 635

Turnerae, 635

Cereus Boeckmanni. 293 grandiflorus. 294

pellucidus, 292

repandus, 292

Swartzii, 292

triangularis, 293

tricostatus. 293

undatus, 293

Ceriom vces communis, 642

Ceropegia palustris, 343

Cerothamnus ceriferus, 102

Cestrum, 385

Bahama, 386

bahamense, 385

bahamense 632

diurnum, 386

pallidum, 386

vespertinum, 386
Chamtangiacear, 557

Chaetochloa, 27

geniculata, 27

geniculata, 637

glauca, 27

imberbis, 27

macrosperma, 28

setosa, 28

Chaetomorpha, 599

brachygona, 599

clavata, 599

Linum, 599

Chamtophoraceati, 598

Chamaecrista, 168

caribaea, 169

Chamaecrista, 168

inaguensis, 170

lineata, 170

lucayana, 169

riparia, 169

Chamaedoris, 602

Chamaedoris, 575, 578, 579

annulata, 602

Peniculum, 602

Peniculum, 588

Chamaesiphonaceae, 620

Chamaesyce, 237

articulata, 239

Berteriana, 241

Blodgettii. 240

Bracei, 239

brasiliensis, 240

Brittonil, 242

buxifolia, 237

cayensis, 23 ?

exumensis, 238

hirta, 241

hypericifolia, 240

hypericifolia, 636

insulae-salis, 238

lecheoides, 238

prostrata, 241

vaginulata, 240

Wilsonil, 238

Champia, 563

parvula, 563

salicornioides, 564

Chaney-vine, 71

Chanterel cinnabarinus, 642

infundibuliformis, 642

Chaptalia, 460

albicans, 460

dentata, 460

Low, 460

nutans, 460

Chara, 617

ceratophylla, 617

depauperata, 618

foliolosa, 618

gymnopus Humboldtii. 618

gymnopus Michauxii, 618

haitensis, 618

Hornemannii. 617

Michauxii, 618

polyphylla, 618

polyphylla Muhlen. bergii, 618

Wikströmii. 618

zeylanica, 618

zevlanica Michauxii. 618

Characeiat, 617

Charlock, 147 
Chauvinia, 607 paspaloides, 609 phleoides, 609

Cheilogramma lanccolata, 466

Cheilolejeunea, 510 decidua, 511 Deciduous-leaved, 511 Chemnitzia, 607

CHENOPODIACEAE, 118

Chenopodiales, 118

Chenopodium, 119 ambrosioides, 119 fruticosum, 121 murale, 119 spathulatum, 119

Chew-stick, 259

ChicK Weed FAMrLy, 137

CHICORY FAMILY, 429

China-brier, 71

Chiococca, 416 alba, 416 parvifolia, 416 pinetorum, 417 racemosa, 416

Chiodecton, 537

Bracei, 538

Bracei, 538

crassum, 538

cruentatum, 537

elongatum, 537

quassiaecolum, 537

rubrocinctum, 537

rufescens, 538

sanguineum, 537

Chiodectona Ceae, 537

Chironia campanulata, 331

Chloris, 35

barbata, 36

ciliata, 36

cruciata, 35

eleusinoides, 35

Fringed, 36

Many-spiked, 36

paraguaiensis, 36

Paraguay, 36

petraea, 36

polydactyla, 36

radiata, 35

Radiate, 35

Sagraeana, 35

Sagra's, 35

Swartziana, 36

Chlorodesmis vaucheriaeformis, 610

Chlorophy ceae, 597

Chlorophyllum molybdites, 642

Chloroplegma, 611

CHOCOLATE FAMILY, 275

Chondria, 567

Chondria 574, 582, 589, 620

acanthophora, 569

atropurpurea, 567

Collinsiana, 568

curvilineata, 568

dasyphylla, 568

leptacremon. 568

littoralis, 567

littoralis, $5 \cap 7$

muscoides, 569

papillosa. 566

parvula, 563

polvrhiza. 568

sedifolia, 568
Chondria-

taxiformis, 564

tenuissima, 567

Chondriopsis, 567 atropurpurea, 567

dasyphylla, 568

leptacremon, 568

littoralis, 567

Chondrococcus filiformis, 583

Chondrus aeruginosus, 562 agathoicus, 562

Choripetalan, 99

Christmas-bush, 166 -flower, 354 Vine, 354

Chroococcaceae, 618

Chroococcus, 618 membraninus, 618 turgidus, 618 turgidus, 618

CHROOLEPIDACEAE, 599

Chroolepus, 599 aureus, 599

Chrysobalanus, 154 Icaco, 154 Ioaco pellocarpus, 154 pellocarpus, 154

Chrysolite-lily, 79

Chrysophyllum, 320 Cainito, 321 monopyrenum, 321 oliviforme, 321

Chrysopsis, 440 graminifolia, 440

Chrysymenia, 563 uvaria, 563

Chthonia leptocephala, 456

Chylocladia rigens, 563

Chytraculia, 307 Suzygium, 307

Cicca, 219 disticha, 219

CICHORIACEAE, 429

Cinchona caribaea, 409

Cinna glomerata, 14

Cinnamon, 305 -bark, 282

Cinnecord, 160

Cintractia Montagnei, 637

Circinaria dissecta, 552

Cirsium, 458 pinetorum, 458 Smallil, 458

Cissampelos, 142 tomentosa, 142 Velvety, 142

Cissus, 260

Cissus, 261 acida, 260

Common, 260

intermedia, 260

microcarpa, 260

sicyoides, 260

sicyoides, 637

Thick-leaved. 260

trifoliata, 260

tuberculata, 260 Wartv. 260

Citharexylum, 371

bahamense. 371

Berterii, 37

caudatum, 372

cinereum, 371

fruticosum, 371
Citharexylum-

lucidum, 372

quadrangulare, 372

subserratum, 371

villosum, 371

Cladium jamaicense, 56 mariscus, 56

occidentale, 56

Cladocephalus, 612 scoparius, 612

Cladonia, 546

Cladonia, 555

areolata, 547

Dilleniana, 547

fimbriata adspersa, 547

fimbriata simplex, 547

fimbriata tubaeformis, 547

gracilis dilacerata, 547 gracilis hybrida, 547 gracilis verticillata, 547

pityrea, 547

pycnociada, 547

pyxidata, 547

pyxidata chlorophaea, 547

rangiferina, 547

verticillata, 547

Cladoniaceae, 546

Cladophora, 600 aegagropila membranacea, 601 crispula, 601 crystallina, 601

fascicularis, 601 fracta, 600

fuliginosa, 601 luteola, 601 nitida, 601

CladophoraCEAF, 599

Cladophoropsis, 601

Cladophoropsis, 611 membranacea, 601

Clathroporina, 527 nuculastrum, 527

Clathrus cancellatus, 644 crispus, 644

Clavaria, 638 sobolifera, 633

Clavariaceae, 638

Clematis, 140

bahamica, 140

dioica, 140

dioica bahamica, 140

flammulastrum, 140

Vitalba, 140

Cleome, 149

gynandra, 149

pentaphylla, 149

clerodendron aculeatum, 374

Odorous, 375

Clerodendrum, 374

fragrans, 375

Climacosphenia, 627 moniligera, 627 moniligera, 627

Climbing Hempweed, 440 Polypody, 471

Clitoria, 187 Ternatea, 187 virainiana, 188

Closed Fuosmolejeunea, 512

Clusia, 281 
Clusia-

flava, 281

rosea, 281

Clusia Family, 280

CLUSIACEA , 280

Clutia Cascarilla, 223 Eluteria, 223

Coca Family, 198

Coccocarpia, 548 molybdea, 548 molybdea tenuior, 548 pellita, 548 pellita genuina, 548 pellita pannosa, 548 pellita parmelioides, 548 pellita smaragdina, $\mathbf{5 4 8}$ pellita tenulor, 548 smaragdina, 548

Coccocladus, 604 occidentalis, 604 occidentalis Conquerantii, 604 occidentalis laxus, 604

Coccolobis, 116

Coccolobis, 553

bahamensis, 117

diversifolia, 117

Krugii, 118

laurifolla, 117

laurifolia, 541

leoganensis, 116

Northroplae, 117

obtusifolia, 117

punctata, 117

retusa, 117

tenuifolia, 117

Uvifera, 116

Uvifera, 635

Wrightii, 117

Cocconeis, 628 heteroldea, 630 pseudomarginata, 630 Scutellum, 628

Coccothrinax, 59 argentea, 59 jucunda, 59

Cock-spur, 132

Cocklebur, 431

Cockroach Berry, 383

Coco-nut, 61 Plum, 154

Cocobey, 358

Cocos, 61 nuclfera, 61

CODIACEAE, 611

Codiolum polyrhizum, 598

Codium, 616

adhaerens, 617

decorticatum, 616

elongatum, 616

intertextum, 617

intertextum, 583, 617

intertextum cribrosum, 617

isthmocladum, 617

isthmocladum, 578

tomentosum, 616

Coelodictyon, 577

Connogoniaceae, 541

Coenogonium, 541

interplexum. 541

rigidulum , 599

Coffee Senna, 167

Colic-root, 70
Collema, 540

flacoidum, 540

laciniatum, 540

nigrescens, 540

phyllocarpum, 540

rupestre, 540

vespertilio, 540

Collemaceae, 539

Collybia, 642

Cololejeunea Joorian a, 507

Colpomenia, 590 sinuosa, 590

Coltricia cinnamomea, 639 spathulata, 639

Colubrina, 257

colubrina, 258

cubensis, 258

ferruginos $a, 258$

reclinata, 257

Commelina, 67

communis, 67

elegans, 67

longicaulis, 67

nudiflora, 67

COMMELINACEAE, 66

Commicarpus, 131

Commicarpus, 130 scandens, 131

Common Tortula, 484

Comocladia integrifolia, 245

Condalia ferrea, 256

Conferva carnea, 553

ceramicola, 553

clavaeformis, 604

clavata, 599

crystallina, 601

fascicularis, 601

flexuosa, 598

fracta, 600

hieroglyphica, 600

implexa, 600

intertexta, 574

intestinalis, 599

Linum, 599

membranacea, 601

oedogonia, 601

simplex, 569

trichocladia, 571

vagabunda, 600

Conifers, 461

Conocarpus, 302 erecta, 302

erecta, 109 racemosa, 301

Conringia, 148 orientalis, 148

Convolvd LACEAE, 345

Cońvolvulus aculeatus, 349 Batatas, 354

brasiliensis, 352

corymbosus, 354

dissectus, 353

domingensis, 354

fastigiatus, 354

jamaicensis, 348

littoralis, 352

micranthus, 348

pentanthos, 349

Pes-caprae, 352

sidaefolius, 354

tiliaceus, 354

Tuba, 350

Conyza cinerea. 436

lobata, 457

lyrata, 444
Conyza-

odorata, 445

purpurascens, 446

Coperniclia Wrightii, 60

Coprinus micaceus, 642

Corallina, 116

Corallina, 588

adharens, 589

barbata, 605

conglutinata, 614

cubensis, 589

Flabellum, 614

fragilissima, 588

incrassata, 616

lapidescens, 558

marginata, 559

Monile, 616

oblongata, 559

obtusata, 559

Opuntia, 615

Penicillus, 612

Peniculum, 602

Phoenix, 613

Rosarium, 605

rubens, 589

rugosa, 558

subulata, 589

Tribulus, 588

tridens, 616

Tuna, 615

CónallinaCeae, 584

Coralliodendron, 612

Corallocephalus, 612

affinis, 613

barbatus, 612

dumetosus, 613

Penicillus, 612

Corchorus, 262

hirsutus, 262

hirsutus, 632

Indian, 262

olltorius, 262

siliquosus, 262

Smooth, 262

Wooliy, 263

Cord-moss, 489

Cordia alba, 360

angustifolia, 359

bahamensis, 358

Brittonii, 359

cylindrostachya, 350

gerascanthoides, 360

globosa, 358

Lima, 358

Sebestena, 357

Spanish, 358

Cordyceps sobollfera. 633

Cordylecladia, 563

irregularis, 563

rigens, 563

Cordyline, 69 guineensis, 69

Coreopsis leucantha, 453

Coriolopsis occidentalis, 639

Coriolus abietinus, 639

maximus, 639

membranaceus, 639

nigromarginatus, 639

pinsitus, 639

sericeohirsutus, 639

Cork-tree, 273

Coronate Bryum, 491

Coronilla occidentalis, 182 sericea, 182

Coronopus, 148 
Coronopusdidymus, 148

Corticium, 638

Corticium, 638

Leveilleanum, 638

Corypha Palmetto, 60

Coryphantha, 294

nivosa, 295

Coscinodiscus concinnus Jonesianus, 629 excentricus, 629 leptopus, 629 marginatus, 629 nitiduius, 629 nitidus, 629 nodullfer, 629 obscurus, 629 radiatus, 629 Rothii, 629

Cotton, 274

Cotyledon pinnata, 152

Cough-bush, 445

Country Belie, 379

Cow-bush, 162, 276

Cowitch, 106, 189

Crab-grass, 16, 30 -wood, 118, 232

Crab's Eyes, 187

Cracca, 181 cathartica, 181 cinerea, 181 Schottii, 181

Cranichis, 84 luteola, 89 oligantha, 86

Crassina, 448 muitiflora, 448

Crassullacead, 152

Crataeva Tapia, 151

Creeping-Cucumber, 426

Crescentia, 398 Cujete, 398

Crinipellis, 642

Crocus, 78

Crossopetalum aquifolium. 248

coriaceum, 247

floridanum, 248

ilicifolium, 248

pallens, 248

Rhacoma, 248

Crotalaria, 178

incana, 179

lotifolia, 179

pumila, 179

retusa, 178

stipularis, 179

verrucosa, 178

Croton, 222

argenteum, 224
Bahama, 224
bahamensis, 224
Cascarilla, 223
Cascarilla linearis, 223
chamaedrifolius, 228
discolor, 223
Eluteria, 223
Fergusonii, 223
favens, 223
focculosus, 223
glabellum, 224
Hjalmarsonit, 224
humilis, 224
humilis origanifolius,
224

argenteum, 224

Bahama, 224

Cascarilla, 223

Cascarilla linearis, 223

chamaedrifolius, 228

discolor, 223

Fergusonii, 22

flavens, 223

flocculosus, 223

humilis, 224 224
Croton, Linear-leaved, 223

linearis, 223

lobatus, 224

Lobed, 224

lucidus, 224

lucidus pubigerus, 224

Rosemary, 223

rosmarinifolius, 222

rosmarinoides, 222

Crouania, 581 attenuata, 581

Crowfoot FAMILY, 140

Cruger's Barbula, 487

Cryptostegia, 340 grandiflora, 340

Crystalline Riccia, 503

Cuban Ceratolejeunea, 513 Yellow-wood, 207

Cucumis Anguria, 426

CUCURBITACEAE, 425

Cuphea, 299 Parsonsia, 300

Curcas, 224

Curcas, 225

indica, 225

Cuscuta, 355

americana, 356

americana, 356

arvensis, 356

obtusiflora, 356

pentagona, 356

Cuscutaceat, 355

Custard-apple, 142

Custard-APPLE FAMILY, 141

CUTLeriacean, 591

Cuttle-fish, 64

Cyathus intermedius, 645 pallidus, 645

CyCad FaMrLy, 462

CYCADACEAE, 462

CyCADALES, 462

Cyclospathe Northropi, 61

Cymatosira, 627

Lorenziana, 627

Cymbidium utriculatum, 96

Cymodocea, 6

Cymodocea, 570, 574, 583, 588

manatorum, 6

Cy modoceaceae, 6

Cymopolia, 605

barbata, 605

bibarbata, 605

mexicana, 605

Rosarium, 605

unibarbata, 605

Cynoctonum, 329

Mitreola, 329

sessilifolia, 329

Cynodon, 34

Dactylon, 34

Cynosurus aegyptius, 38

domingensis, 39

indicus, 37

virgatus, 38

C'T Peraceae, 43

Cyperus, 44

aristatu8, 45

brunneus, 46

brunneus, 46

Capitate, 47

Coarse, 47

Coast, 47

compressus, 45
Cyperus-

confertus, 47

Cuspidate, 45

cuspidatus, 45

elegans, 45

ferax, 47

filiformis, 47

Flat, 45

Florida, 46

floridanus, 46

fuligineus; 46

Gatesii, 44

hirtus, 51

Large, 46

ligularis, 46

Luzulae, 45

Marsh, 45

monostachyos, 52

ochraceus, 45

Panicled, 44

panicuiatus, 44

polystachyus, 44

pseudovegetus, 45

rotundus, 46

Sand, 47

Slender, 47

Vahlii, 46, 47

Viscid, 45

viscosus, 45

Yeilow, 45

Cypress Vine, 350

Cyrilla paniculata, 315

Cystoseira, 591

Myrica, 591

Cytisus Cajan, 192

DACRYOMYCETALES, 637

Dactylis patens, 34

Dactyloctenium, 38

aegyptium, 38

Daedalea amanitoides, 639

Berkeleyi, 640

Dahoon Holly, 245

Dalbergia Brownei, 186

Ecastophyllum, 186

Daldinia concentrica, 634

Danish, 336

Dark Maiden-hair Fern, 468

Dasia, 575

Dasya, 575

Dasya, 575

Collinsiana, 576

Crouaniana, 576

Delilei, 564

elegans, 576

Gibbesii, 575

lophoclados, 571

mollis, 576

pedicellata, 576

pedicellata, 577

ramosissima, 576

rigidula, 576

rigidula, 577

spinuligera, 577

squarrosa, 576

trichoclados, 571

Tumanowiczi, 571

Wurdemanni, 575

DASYCLADACEAE, 604

Dasycladus, 604

clavaeformis, 604

occidentalis, 604

vermicularis, 604

Dasyopsis, 577

Antillarum, 577 
Dasyopsis-

Antillarum, 577

penicillata, 577

spinella, 577

spinuligera, 577

Datura, 386

fastuosa, 386

Garden, 387

Metel, 386

Stramonium, 386

Tatula, 386

Davallia clavata, 468

Day-flower, 67 -lily, 79

Delesseria, 564

Leprieurii, 564

tenuifolla, 564

DELESSERIACEAE, 564

Delonix, 175 regia, 175

Dendrobium polystachyum, 89

Dendropemon, 108

bahamensis, 109

brevipes, 108

emarginatus, 109

emarginatus lepidotus, 109

purpureus, 108

Dendropogon, 63 usneoides, 63

Derbesia, 610

Derbesia, 607 tenuissima, 610 vaucheriaeformis, 610

DERBDSIACEAE, 610

DERMATOCARPACEAE, 531

Dermatocarpon, $\mathbf{5 3 1}$ hepaticum, 531

la chneum, 531

Moulinsii, 531

Dermatolithon prototypus, 586 pustulatum 586

Dermocarpa, $620^{\circ}$ Farlowii. 620 prasina, 620

Desmanthus denressus, 163 strictus, 163 virgatus, 163

Desmatodon, 485 Garberi, 486 Garber's, 486

Desmodium incanum, 184 molle, 184 tortuosum, 184

Devil-grass, 29

Devil's Potato-ront, 336 Pumpkin, 289

Diadenus, 553

Diaperium, 404

Diapedium, 404 assurgens, 404

DIATOMEAF, 626

Diatrype Stigma, 634

Dicarpella, 569

Dichondra, 355

Carolina, 355 carolinensis, 355 repens, 355

DICHONDRA FAMILY 355

DICHONDRACEAE, 355

Dichothrix, 626 fuclcola, 626 penicillata, 626
Dichotomaria, 557 fragilis, 559

Dichotomosiphon, 617 pusillus, 617

Dichromena, 53 colorata, 53 Inagua, 53 inaguensis, 53 leucocephala, 53 Narrow-leaved,53

Dicliptera, 404 assurgens, 404

DICOTYLEDONES, 98

Dicranum albidum, 479

Dictydium cancellatum, 645 squamulosum, 645

Dictyerpa, 597 jamaicensis, 597

Dictyoneis, 628 jamaicensis, 628 marginata, 630

Dictyopteris, 595 Justii, 595

Dictyosphaeria, 603

Dictyosphaeria, 604 favulosa, 603 valonioides, 604

Dictyota, 596

Dictyota, 586, 587

Antiguae, 597

Atomaria, 596

Bartayresiana, 596

Bartayresii, 596

Bartayresii, 596

Brongiartii, 596

cervicornis, 596

cervicornis, 596, 597

dentata, 596

dentata, 596

dichotoma, 596

divaricata, 596

Fasciola, 596

guineensis, 597

indica, 596

Mertensii, 596

patens, 596

subdentata, 596

variegata, 594 zonata, 594

DICTYOTACEAE, 594

Diderma squamulosum, 645

Didymella Cinchonae, 525

Digenea, 569

Digenea, 582, 589, 601

simplex, 569

Wulfeni, 569

Digitaria fimbriata, 16

horizontalis, 16

marginata, 16

sanguinalis, 16

Dildo, 292

Dillweed, 313

Dilophus, 597

Dilophus, 586, 587 alternans, 597 guineensis, 597 repens, 596

Dimerogramma lanceolatum, 630 minus, 630

Dimerosporium guarapiense, 632 zonatum, 632

Diminutive Fissidens, 481 Mitten's-moss, 498
Dioclea rudolphioide8, 189 Dioscorea, 79 alata, 79

Dioscoreacear, 79

Diospyros halesioides, 326

Dipholis, 322 salicifolia, 322

Diplachne, 39 fascicularis, 39

Diplanthera Wrightii, 6

Diplasiolejeunea, 506 Rudolphiana, 507 Rudolph's 507

Diplocalyx chrysophylloides, 111

Diplocystis Wrightil, 644 Diploneis, 628

advena sansegana, 630 Bombus, 630

Campylodiscus, 631

coffaeiformis, 631

Crabro, 631

demta, 631

gemmatula, 631

vacillans, 628

Weissflogii, 628

Dipterosiphonia, 575 dendritica, 575

Dirina, 538 ceratoniae, 539 repanda, 538

DIRINACEAE, 538

Distichlis, 42 spicatal 42

Ditch-grass, 5

Divi-divi, 174

Doctor-bush, 319

Doctor's Club, 207

Dodder, 356

DODDER FAMILY, 355

Dodonaea, 250

Ehrenbergii, 250

viscosa obovata, 250

Dodonaea Fa miLy, 250

DODONAEACEAE, 250

Dog-berry, 316 -drink-water, 65 -fennel, 437, 438

DOGBANE FAMILY, 333

Dogwood, 186, 250

Dolicholus, 192 minimus, 193

Net-veined, 193

reticulatus, 193

Small, 193

Swartzii, 193

Swartz's', 193

Dolichos, 194

insularis, 195

Lablab, 195

Lablab, 191

lineatus, 191

luteolus, 195

minimus, 193

obtusifolius, 191

pruriens, 189

repens, 195

Dondia, 120

carinata, 121

fruticosa, 121

fruticosa, 121

insularis, 121

intermedia, 121

linearis, 121

Wilsonii, 121 
Donkey Thistle, 145

DOTHIDEALES, 632

DRACAENA FAMILY, 72

Dracaenaceas, 72

Dropseed-grass, 33

Drymaria, 137

Drymaria, 137 cordata. 137

Dryopteris, 472 asplenioides, 473 augescens, 472 cordata, 473 normalis, 472 patens, 472,473 reptans, 473 reptans, 473

Drypetes, 221

Drypetes, 526, 532 diversifolla, 222 diversifolia, 528 keyensis, 222

lateriflora, 221

mucronata, 222

Sharp-leaved, 222

Duck-weed, 62

DUCK-WEED FAMILY, 62

Dudresnaya, 583 bermudensis, 583

DUMONTIACEAE, 583

Duranta, 372 Ellisia, 372 Plumieri, 372 repens, 372 repens, 633

Eared Mastigolejeunea, 517

Eaton's Selaginella, 477

EBENACEAE, 325

EbenAIES, 320

Ebony, 255

EBONY FAMILY, 325

Ecastaphyllum, 185 Brownei, 186 Ecastaphyllum, 186

Echinocactus, 295

Echinocaulon rigidum, 560

Echinochloa, 26 colonum, 26 Crus-galli, 26

Echinodorus, 7 cordifolius, 7 rostratus, 7

Echites, 336 Andrewsii, 338 biflora, 337 Catesbaei, 338

Echites, 336 jamaicensis, 337 macrocarpa, 397 neriandra, 338 paludosa, 337 Sagraei, 337 suberecta, 338 umbellata, 336

Eclipta alba, 449 erecta, 449

ECTOCARPACEAE, 589

Ectocarpus, 590 Antillarum, 589 Hooperi, 589 Mitchellae, 590

Egg-fruit, 322.

Egyptian Grass, 38

Ehretia Beureria, 359 tinifolia, 359
EHRETIA FAMILY, 357

EH RETIACEAE, 357

Elaeodendron, 249 attenuatum, 249 xylocarpum, 111, 250

xylocarpum bahamense, 249

Elaphrium, 211

Bahama, 212

inaguense, 212

Simaruba, 212

Simaruba, 109

Eleocharis, 47

atropurpurea, 49

atropurpurea, 49

camptotricha Schweinitzii, 49

capitata, 49

cellulosa, 48

flaccida, 48

interstincta, 48

ochreata, 48

prolifera, 49

Eleusine, 37

indica, 37

Eleuthera Bark, 223

Eleutheranthera ruderalis, 449

Elfvingla tornata, 640

Elliptic Leptolejeunea, 514

ELM FAMILY, 103

FLODEA CEAE, 8

Emilia, 457

Purple, 457

sonchifolia, 457

ENCOELIACEAE, 590

Encoelium clathratum, 590 sinuosum, 590

Encyclia, 90

acicularis, 92

Bahama, 91

bahamensis, 91

diurna, 92

fucata, 91

Inagua, 92

inaguensis, 92

Narrow-leaved, 93

plicata, 92

Plicate, 92

rufa, 91

Rufous, 91

Simall-flowered, 91

Tampa, 91

tampensis, 91

Endocarpon, 531

hepaticum, 531

Moulinsii, 531

pallidulum, 531

rufescens, 531

Wightii, 545

Endoderma, 598 viride, 598

Enterographa quassiaecola, 537

Enteromorpha, 598

flexuosa, 5.98

Hopkirkii, 598

plumosa, 538

potyclados, 598

salina polvclarios, 598

Entire-leaved Ceratole. jeunea. 513

Entocladia, 5.98 viridis, 598

ENTODON FAMILY, 494

ENTODONTACEAE, 494
Entophysalis, 619 granulosa, 619 violacea, 619 violacea, 620

Entopyla australis, 630

Epicion bahamense, 342

Epicladium, 93 Boothianum, 93

Epidendrum aciculare, 92 altissimum, 92

bahamense, 91

Boothianum, 93

cochleatum, 93

diurnum, 92

erythronioides, 93

fucatum, 91

gracile, 92

minutum, 89

nocturnum, 90

odoratissimum, 91

Ottonis, 94

papilionaceum, 93

phoeniceum, 92

plicatum, 92

primulinum, 91

rigidum, 89

rufum, 91

tampense, 91

virens, 92

Episperma, 582

Epithemia, 629

gibberula, 631

Musculus, 629

Eragrostis, 40

amabilis, 41

bahamensis, 41

clllaris, 41

Elliottii, 40

gigantea, 41

macropoda, 40

major, 41

minor, 41

pectinacea, 40

plumosa, 41

prolifera, 41

tephrosanthos, 40

Erechtites, 458 hieracifolia, 458

Erigeron, 442

annadensis, 443

linifolius, 443

pusillus. 443

quercifolium, 442

tenuis, 442

Erinus procumbens, 390

Eriodendron anfractuosum, 274

Erithalis, 415

fruticosa, 415, 416

fruticosa, 537

odorifera, 415, 416

rotundata, 416

Ernodea, 420

angusta, 420

Cokeri, 420

Coker's, 420

Common, 420

littoralis, 420

Millspaugh11, 421

Millspau'gh's 421

Niashil, 421

Nash's. 421

Taylori, 421

Taylor's, 421

Erythrina corallodendron, 196 
Erythrina-

Piscipula, 186 velutina, 196

Erythrodes, 87

Erythrotrichia, 553 carnea, 553 ceramicola, 553

ERYTHROXYLACEAE, 198

Erythroxylon, 108 affine, 199 a reolatum, 198

Bahama, 199 brevipes, 198 confusum, 199 obovatum, 198, 199 Ovate-leaved, 199 reticulatum, 199 rotundifolium, 198

Round-leaved, 198 spinescens, 198 suave, 198 suave aneurum, 198

Eschenbachia, 443 lyrata, 444

Eucheuma, 561 isiforme, 561

Eugenia, 303

Eugenia, 541

androslana, 304

axtllaris, 303

axillaris microcarpa. 303

bahamensis, 306

buxlfolia, 303

confusa, 304

confusa, 537

fliformis, 304

foetida rhombea, 304

fragrans, 306

lateriflora, 304

ligustrina, 305

longipes, 306

monticola, 303

pallens, 307

pseudopsidium, 304

punctata, 306

rhombea, 304

uniflora, 304

Eumelobesia, 587

Euodia Gibba, 629

Euosmolejeunea, 511

clausa, 512

Closed, 512

duriuscula, 512

Harsh, 512

Threefold, 512

trifaria, 512

Eupatorium, 437

ageratifolium, 438

atriplicifolium, 439

bahamense, 438

capillifollum, 437

conyzoides, 438

corymbosum, 439

foeniculaceum 437

havanense, 438

integrifolium, 438

leptophyllum, 437

lucayanum, 439

odoratum, 438

repandum, 439

scandens, 439

villosum, 438

Euphorbia, 234

antiquorum, 235
Euphorbia-

articulata, 239

Balbisii, 239

Berteriana, 241

Blodgettii, 240

Bracei, 239

brasiliensis, 240

Brittonii, 242

buxifolia, 237

cass ythoides, 235

cayensis, 239

flexuosa, 239

graminifolia, 236

gymnonota, 234

havanensis, 236

heterophylla, 236

hirta, 241

hypericifolia, 240

lactea, 234

lecheoides, 238

linearis, 239

maculata, 241

nutans, 240

petiolaris, 236

pilulifera, 241

prostrata, 241

punicea, 234

serpens, 241

tithymaloides, 233

trichotoma, 235

vaginulata, 240

EUPHORBIACEAE, 217

Euphorbiodendron gymnonotum, 234

Eupogodon, 577

Eupogonium rigidulum, 576 squarrosum, 576 trichoclados, 571

Eustachys, 36 petraea, 36

Eustoma, 331 exaltatum, 331

Euterpe oleracea, 61 vinifera, 61

Evening-Primrose Family, 309

Evolvulus, 345

alsinoldes, 347

arbuscula. 346

Bahama, 346

bahamensis, 346

Bracei, 346

Brace's, 347

Chickweed, 347

glaber. 347

linlfolius, 347

Moneywort, 348

mucronatus, 347

Narrow-leaved, 347

nummularius, 347

sericeus, 347

Silky, 347

Smooth, 347

squamosus, 346

Excaecaria eglandulosa, 232 Sagraci, 232

Excoecaria oubana, 231 lucida, 232

Exogonium, 351 microdactylum, 351 microdactylum integrifolium, 351

Exostema, 409 caribaeum, 409

Exothea, 254
Exothea, 524

oblongifolia, 254

panlculata, 254

FABACEAa, 176

Fagara coriacea, 207

Fagara, 206

flava, 207

lentiscifolia, 206

Pterota, 206

Fagopyrum, 115

esculentum, 115

Fagopyrum, 115

Falkenbergia, 577 Hillebrandii, 577

False Boxwood, 249 Mallow, 267, 268 Moneywort, 185

Favolus alutaceus, 640 tenuis, 640

Feather-bed, 326

Fennel, 314

Fern, Boston, 473

Giant, 465

Leather, 465

Marsh, 468

Plne-land, 468

Serpent, 470

Slender Maiden-hair, 467

Fern Allies, 464

FERN FAMILY, 464

FWRNS, 464

F'estuca fascicularis, 39

Ficus, 104

aurea, 105

aurea, 635

brevifolia, 105

dimidiata, 105

jacquinifolia, 105

laevigata, 105

pedunculata, 105

pertusa, 105

populnea bahamensis, 105

sapotaefolia, 105

Fiddle-flower, 233

-wood, 372

FigWORT FAMILY, 387

Filicalies 464

Fimbristylis, 50

castanea, 50

diphylla, 50

exilis, 51

ferruginea, 50

glomerata, 51

Hairy, 51

hirta, 51

inaguensis, 51

Marsh, 51

monostachya. 52

Salt Marsh, 50

Slender, 50

spadicea, 51

spathacea, 51

West Indian, 51

Finger-grass. 15, 37

Fire-bush, 224

-weed, 458

Fish-polson, 186

Fissidens, 480

Diminutive, 481

Garber1, 481

Garber's, 481

monandrus, 481 
Fissidens-

radicans, 481

Radicant, 481

Fissidens FAMILY, 480

FissidentaceAe, 480

Fissurina nitidescen 8,536

Flabellaria conglutinata, 614

incrustata, 614

pavonia, 614

Tuna, 615

FLACOURTIA FAMILT, 283

FuA COURTIACEAE, 283

Flamboyant, 175

Flamingo-bill, 183

Flat Taxithelium, 499

Flaveria, 454

linearis, 454

Narrow-leaved, 454

Flax, Bahama, 200

Brace's, 201

Curtiss', 200

Rock, 200

Wood, 201

Flax Family, 199

Fleabane, 442

Fleurya, 106 aestuans, 106

Floating Heart, 333

Florida Leucodontopsis, 492 Privet, 327

Flueggia Acidothamnus, 219

Foeniculum, 313

Foeniculum, 313

vulgare, 313

Fomes Auberianus, 640

Forestiera, 326

cassinoides, 327

segregata, 327

segregata stenocarpa, 327

Fosliella, 587

Chamaedoris, 588

farinosa, 587

Lejolisii, 588

Fountain-plant, 389

Four-o'clock, 130

Four-o'CLOCK FAMILY, 129

Fowl-foot, 251

Fox-tail Grass, 27, 28

Fradelia, 611

fuliginosa, 611

Frangipanni, 334, 335

French Trumpet-flower, 338

Frog-wood, 413

Frog's-bit, 9

Frog's-BIT FAMILY, 9

Frullania, 519

arietina, 519

gibbosa, 520

Gibbous 520

obcordata, 520

Obcordate, 520

Ram's Head, 519

riojaneirensis. 520

Rio Janeiro, 520

Spreading, 520

squarrosa, 520

Frullanoides riojaneirensis, 520

FUCACEAE, 591

Fucus acanthophorus, 569

aeruginosus.562

atomarius, 596

bacciferu 8,592

\begin{tabular}{|c|}
\hline 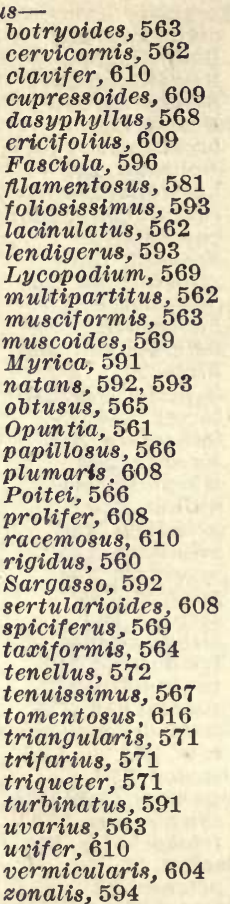 \\
\hline
\end{tabular}

Fulvifomes dependens, 640 Swieteniae, 640

Funalia versatilis, 640

Funaria, 489

flavicans, 489

hygrometrica, 489

Pale-green, 489

FUNARIA FAMILY, 489

FUNARIACEAE, 489

Fungr, 631

Furcraea, 77

cubensis, 77

macrophylla, 77

undulata, 77

Fuscoporella coruscans, 640

Galactia, 189

angustifolia, 191

bahamensis, 190

cubensis, 190

fliformis, 190

galactioides, 190

monophylla, 190

pendula, 190

rudolphioides, 189

rudolphioides, 633

spiciformis, 190

tenuiflora, 191

uniflora, 190

Galaxaura, 557

Galaxaura, 578, 589

comans, 558

comans, 578

cylindrica, 558
Galaxaura-

Decaisnei, 559

flagelliformis, $\mathbf{5 5 8}$

flagelliformis, $\mathbf{5 7 8}$

fragilis, 559

lapidescens, 558

marginata, 559

moniliformis, 559

oblongata, 559

oblongata, 558

obtusata, 559

occidentalis, 559

rugosa, 558

rugosa. 558

squalida, 558

squalida, 558

subverticillata, $\mathbf{5 5 8}$

subverticillata, 578

Gale-of-wind, 221

Galega cathartica, 181 cinerea, 181

Galium, 424

bermudense, 424

hispidulum, 424

hypocarpum, 424

Gama-grass, 12

GamoptyatuaE, 314

Ganoderma pulverulentum, 640

subincrustatum, 640

Garber's Fissidens, 481

Gardena, 149

Gardenia clusiaefolia, 410

Garlic-weed, 135

Gaudichaud's Syrrhopodon, 483

Gayoides, 266

crispum, 266

crispum, 636

Geaster saccatus, 645

Geiger Tree, 358

GELIDIACEAE, 559

Gelidiopsis rigida, 560

Gelidium, 560

Gelidium, 589

rigidum, 560

rigidum, 579

Genip, 254

Genipa clusiaefolia, 410

GENTIAN FAMILY, 330

Gentiana exaltata, 331

GENTIANACEAE, 330

Gentianales, 326

Geraniales, 196

Gerardia, 402

Bracted, 402

bracteosa, 402

domingensis, 392

droseroides, 402

maritima, 392

purpurea, 392

spiciflora, 392

Sundew, 402

tuberosa, 402

Ghinia, 367

curassavica, 367

Giant Fern, 465 Milk-weed, 341

Gibbous Frullania, 520

Gigartina isiformis, 561 tenera, 561

GIGARTINACEAE, 561

Glasswort, 122

Gloeocapsa, 619

bahamensis, 619 
Gloeocapsa-

crepidinum, 619 deusta, 619

lignicola, 619

Magma, 619

Gloeophyllum Berkeleyi. 640

hirsutum, 640

striatum, 640

Gloeothece, 620

Gloeothece, 623 rupestris, 620

Glory-morning, 352

Glossy Isopteryglum, 497 Sematophyllum, 500

Glycine Abrus, 187 reticulata, 193

Glycosmis pentaphylla, 209

Glyphis, 538 Achariana, 538 cicatricosa, 538

Glyphodesmis, 627 eximia, 627

Goat-bush, 437 -weed, 391

Goat's-rue, 181

Golden Aster, 440 Crownbeard, 452

Goldenrod, 370

Gomontia, 598 polyrhiza, 598

Gomphrena, 126 polygonoides, 126 vermicularis, 128

Gongroceras corniculatum. 583

Goniolithon, 584

accretum, 585

accretum, 598

acropetum, $\mathbf{5 8 5}$

Boergesen 11, 585

Börgesenii, 598

decutescens, 585

decutescens, 585

dispalatum, $\mathbf{5 8 5}$

frutescens, $\mathbf{5 8 5}$

improcerum, 587

intermedium, 586

Notarisii propinquum, 585

propinquum, 585, 587

Rhizophorae.586

solubile, 585

solubile, 587

spectabile, 585

strictum, 586

strictum, 585

strictum nanum, 586

Goniopteris reptans, 473 reptanis cordata, 473

Goniotrichum, 553

Alsidil, 553

elegans, 553

GOODENIA FAMrLY, 428

GOODENIACEAE, 428

Gooma-bush, 383

Gooseberry-tree, 219

Goosefoot FA MILY, 118

Gossypium, 273

barbadense, 274 punctatum, 274

Gouania, 258

domingensis, 258

glabra, 258

lupuloides, 258
GOURD FAMILY, 425

Govenia, 96

Swollen, 96

utriculata, 96

Governor Grant's Livery, 236

Gracilaria, 562

cervicornis, 562

cornea, 563

crassissima, 562

damaecornis, 563

horizontalis, 562

lacinulata, 562

multipartita, 562

Grallatoria, 560 reptans, 560

Gramma tophora, 627

flexuosa, 627

tlexuosa, 627 marina, 630

Grammita, 569

Grammitella, 569

Granigrain, 262

Granny-bush, 223

GRAPE FAMILY, 259

GRAPHIDACEAE, 534

GRAPHIDALES, 533

Graphina, $536^{\circ}$

nitidescens, 536

virginea, 536

Graphis, 535

Afzelii, 536

atrata, 534

cinerea, 536

cinnabarina, 536

inusta, 536

Pavoniana, 535

scalpturata plurifera, 536

scripta, 536

tricosa, 538

vestita, 536

Grass FAMILY, 10

Grass-fern, $466^{\circ}$

-pink, 95

Grateloupella, 569

Gratiola Monnieri, 389

Gray Nickers, 172

Polypody, 470

Grayish Lejeunea, 508

Green Turtle Bough, 301, 375

Greenbrier, 71, 72

Greenest Archilejeunea, 518

Greens, 119

Griffithsia, 579

Argus, 559

Bornetiana, 579

corallina globifera, 579

corallina tenuis, 579 globifera, 579

globulifera, 579

globulifera, 580

tenuis, 580

thyrsigera, 580

Griffitsia, 579

penicillata, 559

trichoclados, 571

Grimmeodendron, 231 eglandulosum, 232

Ground Cherry, 381, 382

Groundsel-bush, 444,445

Guaiacum, 201

officinale, 202

sanctum, 202

Guana-berry, 205

Guava, 307
Guepinia palmiceps, 637

Spathularia, 637

Guettarda, 412

calyptrata, 413

densiflora, 415

elliptica, 414

inaguensis, 413

Krugii. 413

Nashil, 413

scabra, 412

specios $a, 412$

Taylori, 413

Guiana Plum, 221

Guilandina, 171

Bonduc, 172

bonducella, 172

Crista, 172

major, 172

Moringa, 151

ovalifolia, 172

Guinea-bead, 122

Grass, 22

Gum-elemi, 212

Gumbio-limbo, 212

GUMBO-LIMBO FAMILY, 211

Gundlachia, 442

corymbosa, 442

domingensis corymbosa, 442

Gunwood, 396

Guzmania lingulata, 66

Gyalecta lutea, 541

GYALECTACEAE, 541

Gyminda, 248

Grisebachii, 249

latifolia, 249

Gymnanthes, 232

lucida, 232

Gymnogramme calomelanos, 469

Gymnopilư's tenuis, 642

Gymnopus, 642

Gymnosorus, 594 collaris, 594 variegatus, 594

GyMNOSPERMAE, 460

Gymnostomum Barbula, 484 Tortula, 485

Gymnothamnion, 580

bipinnatum, 580 elegans, 580

Gymnothamnium, 581

Gynandropsis pentaphylla, 149

Gyrosigma rectum, 631

Gyrostachys peruviana, 85

Gyrostomum, 543 scyphullferum, 543

Gyroweisia, 484

Barbula, 484

Black-fruited, 484

Haema tomma, 546 puniceum, 546

Haema toxylum, 171 campechianum, 171

Hair-like Bryum, 490

Hairy Pepperwort, 476

Halberd-fern, 471 Ames', 472

Small, 472

Halimeda, 614

Halimeda, 568, 573, 586, 614,621

brevicaulis, 616

discoidea, 615

favulosa, 616

incrassata, 616 
Halimeda-

incrassata monilis, 616

lacrimosa, 616

Monile, 616

Opuntia, 615

Opuntia, 614

platydisca, 615

scabra, 615

simulans, 616

tridens, 616

tridens Monile, 616

Tuna, 615

Haliseris, 595

Justii, 595

Halodictyon, 577

mirabile, 577

Halodule, 6

Halodule, 597 Wrightii, 6

Halophila, 8 Engelmanni, 9

Haloplegma, 580

Duperreyi, 580

Duperreyi spinulosa, 580

Haloragidaceae, 310

Halydictyon, 577

Hamelia, 411

erecta, 412

patens, 412

Scarlet, 412

Hanowia, 577

Hapalopilus licnoides, 641

Haplocladium, 495

microphyllum, 495

Small-leaved, 495

Hard-bark, 253

Hardhead, 220

Hare's-ear, 148

Harrisia, 292

Brookil, 292.

Harsh Euosmolejeunea, 512

Hat Palmetto, 60

Haulback, 162

Heather, 320

Hecastophyllum Brownei, 186

Hedera quinquefolia, 261

Hedge-hyssop, 390

Hedwigia balsamifera, 212

Hedyotis americana, 409 rupestris, 409

Hedysarum canescens, 184 Ecastaphyllum, 186

hamatum, 183

incanum, 184

molle, 184

nummularifolium, 185

supinum, 184

tortuosum, 184

Heleocharis bahamensis, 48, 49

Sintenisii, 49

Helicothamnion, 572

Helicteres, 275

Isora, 276

famaícensis, 276

semitriloba, 275

spiralis, 276

Heliotrope', Bushy, 363

Diffuse I ow, 364

Eggers', 363

Inagua, 364

Indian, 362

I,ow Ashv, 364

Nash's, 364

Serside, 363

Slender, 363
Heliotropium, 362

brevicaule, 364

curassavicum, 363

diffusum, 364

Eggersii, 363

gnaphalodes, 361

inaguense, 364

indicum, 362

inundatum, 363

microphyllum, 364

nanum, 364

Nashi1, 364

parviflorum, 362

ternatum, 363

Helminthosporium Ravenelii, 635

Helosciadium, 314

Ammi, 314

Hemianthus, 390 caliitrichoides, 390 multiflorus, 390

IEMIBA SIDIOMYCETES, 636

Hemitrichia clavata; 645

Henna Plant, 299

HePATICAE, 500

Herb Mercury, 228

Hercules' Ciub, 207

Herpestis Monnieria, 389

Herpochaeta, 607

fastigiata, 608 verticillata, 608

Herposiphonia, 573

bipinnata, 574

Pecten-Veneris, 573

secunda, 574

tenella, 573

Heterosiphonia, 575

Wurdemanni, 575

Wurdemanni, 576, 577

Heterothecium domingense, 542

Hibiscus, 272

Bahama 272

bahamensis, 272

cryptocarpus, 272

esculentus, 272

populneus, 273

spinifex, 270

tiliaceus, 273

Hippo, 341

Hippomane, 231

Mancinella, 231

Hog-bush, 409

Cabbage-palm, 61

Palmetto, 61

-weed, 130

Hold-back, 132

Holly, 245

HoLLY FAMILY, 245

Holosteum cordatum, 137

Homalia, 497

Wrightii, 494

Honeysuckle, 404

Hook-lobed Leucolejeunea, 518

Hookeria radiculosa, 494

Hormothamnion, 624 enteromorphoides, 624

Horse-bean, 171, 191

-bush, 176, 363, 442

Horseflesh, 158

Horseradish-tree, 151

HoRSERADISH-TREE FAMILY, 151

Horseweed, 443

Hura, 232

crepitans, 233
Hurricane-grass, 51

Hutchinsia, 569

breviarticulata, 570

dendritica, 575

obscura, 574

opaca, 571

periclados, 572

secunda, 574

tenella, 573

HYDNACEAE, 638

HYDROCHARITACEAE,

HYDROCHARITALES, 8

Hydroclathrus, 590

cancellatus, 590

clathratus, 590 sinuosu8, 590

Hydrococcus marinus, 620

Hydrocoleum, 623

Hydrocoleum, 623

cantharidosmum, 623

comoides, 623

glutinosum, 623

lyngbyaceum, 623

Hydrocotyle, 312

asiatica, 313

hirsuta, 312

pygmaea, 312

repanda, 313

spicata, 312

umbellata, 312, 313

verticiliata, 312

Hydrocybe conica, 642

Hydrolith on improcerum, 587

HYDROPHYLLA CEAE, 356

Hyella, 620 caespitosa, 620

Hylocereus, 293 undatus, 293

Hymenocallis, 78 arenicola, 78 caribaea, 79 caymanensis, 79 crassifolia, 79 declinata, 78 declinata, 79

Hymenos tomum, 484

Bahama, 485 flavescens, 485

Hyophila, 485

Hyophila, 485

Tortulq, 485

Hypelate, 254

paniculata. 254

trifoliata, 254

HY PERI CACEAE, 280

HYPERICAIES, 279

HYPHOMY CETALES, 635

HYPNACEAE, 496

Hypnea, 563

musciformis, 563 musciformis, 598 secundiramea, 583

Нурпорһусив, 563 musciformis, 563

Hypnum admistum. 500 diminutivum, 498 micans, 497

microphyllum, 495 nigrescens, 493

planum, 498

Sipho, 496 vesiculare, 497

HYPNOM FAMILY, 496

Hypochnus rubrocinctus, 537

spongiosus, 638

Hypocrea sulphurea, 633 
Hypocreales, 633

Hypoglossum, 564

Leprieurii, 564

tenuifolium, 564

Hypoxis, 73 juncea, 73

Hypoxylon annulatum, 634 Bomba, 634 fuscopurpureum, 634 jecorinum, 634

Hyptis, 379 pectinata, 380 Pectinate, 380 Pilose, 380 suaveolens, 380

Hysterium rufulum, 635

Ibidium, 85 lucayanum, 85 tortile, 85

Icacorea, 315 guadalupensis, 316 paniculata, 315

Ichthyomethia, 186 Piscipula, 186

Ilex, 245 Cassine, 245 cuneata, 246 Krugiana, 246 Macoucoua, 246 montana, 246 repanda, 246

ILICACEAE, 245

Imperata, 12 brasiliensis, 12

IMPERFECTI, 635

Indian Almond, 302

Indigo fera, 180 Anil, 180 argentea, 180 suffruticosa, 180

Inflated Microlejeunea, 509 Inga hystrix, 156

Ink-berry, 383, 429 -bush, 327

Inodes Palmetto, 60

Inonotus corrosus, 641 fruticum, 641 porrectus, 641

Inula graminifolia, 440

Ionaspis, 541 suaveolens, 541 tropica, 541

Ionoxalis, 197 intermedia, 197

Ipomoea, 351 antillana, 354 arenaria, 351

Batatas, 354 bona-nox, 349 carolina, 353 cathartica, 352 coccinea, 350 commutata, 352 cymosa, $\mathbf{3 5 4}$ dissecta, 353 fastigiata 354 gracilis, 354 grandifiora, 350 hederacea, 351 heptaphylla, 353 jamaicensis, 352 littoralis, 352 microdactyla, 351 Pes-caprae. 352 purpurea, 352

Ouamoclit 350 sagittata, 353
Ipomoea

sidaefolia, 354

sinuata, 353

stolonifera, 352

tiliacea, $3 \overline{5} 4$

triloba, 353

tuba, 350

verticillata, 348 villosa, 352

Iresine, 128

Bahama, 129

Celosia, 128

celosioides, 128, 129

Coastal, 129

flavescens, 128

inaguensis, 129

keyensis, 128

paniculata, 128, 129

IRIDACEAE, 80

IIIS FAMILY, 80

I ronwood, 304, 317

Irpex maximus, 639

Ischaemum secundatum, 30

Island Bean, 195

Isnardia, 309 natans, 309 repens, 309

Isocarpha, 449 angustata, 450 oppositifolia, 450

Isopterygium, 496 Glossy, 497 micans, 497

Iva, 432

Beach, 432

Bushy, 433

cheiranthifolia, 433

imbricata, 432

Jacaranda, 398 bahamensis, 398 caroliniana, 398 coerulea, 398

Jack-switch, 263

Jackmada, 438

Jacob's Ladder, 236

Jacquemontia, 348

Blue, 349

cayensis, 349

cayensis, 631

Common, 348

Fleshy, 349

jamaicensis, 348

micrantha, 348

pentantha, 349

reclinata, 349

Small-flowered, 348

verticillata, 348

violacea, 349

Jacquinia, 317

armillaris, 317

Berterii, 317

Berterii retusa, 317

keyensis, 317 539

keyensis, 525, 527, 538,

Jamaica Weed, 357

Jania, 589

Jania, 577, 578, 579, 581

adhaerens, 589

capillacea, 589

cubensis, 589

rubens, 589

Jasminum, 327 Sambac, 327

Jatropha Curcas, 225 gossypifolia, 225 Manihot, 230
Jerusalem Parsley, 119

Jessamine, 335

Jimbay, 162

Joe-bush, 317 -wood, 317

Joint-grass, 17, 20

Joor's Leptocolea, 507

JUGLA NDALES, 102

Jumbie Bean, 162

Jungermannia auriculata 517

corticalis, 515

elliptica, 514

flava, 508

squarrosa, 520

trifaria, 512

xanthocarpa, 518

JUNGERMAN NIA FAMILY, 504

JUNGERMAN NIACEAE, 504

JUNGERMAN N IALES, 504

Jungle Rice, 26

Juniper-berry, 288

Juniperus, 462

australis, 462

barbadensis, 462

bermudiana, 462

lucayana, 462

virginiana, 462

Jussiaea, 310

angustifolia, 310

Bushy, 310

palustris, 310

suffruticosa, 310

Justicia, 403

assurgens, 404

carthaginensis, 403

paniculata, 403

spinosa, 403

Kalanchoe, 152

brasiliensis, 153

Brazilian, 153

Kallstroemia, 203

maxima, 203

Kallymenia, 561

Limminghii, 561

reniformis, 561

Kasondi Senna, 166

Krugiodendron, 256 ferreum, 256

Kyllinga monocephala, 47

Lace-plant, 106

Lachnea cubensis, 635

Lactuca, 430

intybacea, 430

Ladies-tresses, 85,86

Lady's Slipper, 188

Laeliopsis, 95 domingensis, 95

Laetia Guidonia, 285

Lagenocarpus guianensis, 56

Laguncularia, 301

racemosa, 301

Lamarckia, 616

IAAMIACEAE, 375

Lantana, 369

Bahama, 370

bahamensis, 370

balsamifera, 370

Camara, 369

Camara 370

crocea, 369,370

demutata, 370

involucrata, 370

involucrata, 371, 632 , 636

odorata, 370 
Lantana-

Ovate-leaved, 369 ovatifolla, 369

Lappago aliena, 14

Lasiacis, 25 divaricata, 25

Lasiocroton, 227

bahamensis, 227

macrophyllus, 227

micranthus, 227

Laternea triscapa, 644

Laugeria densiflora, 415 lucida, 414

LAURACEAE, 143

Laurel-cherry, 153

LAUREL FAMILY, 143

Laurencia, 565

Laurencia, 574, 579

Baileyana, 567

cervicornis, 566

Chauvini 566

Corallopsis, 566

gemmifera, 566

glomerata, 565

implicata, 566

intricata, 566

mexicuna 566

microcladia, 565

multiflora, 565

nana, 566

obtusa, 565

obtusa, 565, 566

obtusa gelatinosa, 565

paniculata, $\mathbf{5 6 5}$

papillosa, 566

papillosa, 575

Poitei, 566

tuberculosa, 566

Laurocerasus, 153 myrtifolla, 153

Laurus carolinensis pubes. cens, 144

Catesbyana, 143

coriacea, 143

Winterana, 282

Lawsonia, 299

alba, 299

inermis, 299

Leaf-shedding Rectolejeunea, 510

Leafless Beaked-orchid, 86

Leather Fern 465

Lebidibia coriaria, 174

LECANACTIDACEAE, 541

Iecanactis, 541

denticulata, 541

denticulata, 541

Lecanora, 545

adglutinata, 552

aurantiaca isidiosella, 550

badia, 545

ceratoniae, 539

chlaronella, 546

chlaroterodes, 546

cinereocarnea, 546

floridana, 550

pallescens, 546

punicea, 546

subfusca, 546

subfusca cinereocarnea, 546

varia, 546

IECANORACEAE, 545

Lecidea, 542

calcivora, 542

conspirans, 551
Lecidea-

disciformis aeruginascens, 551

furfurosa, 542

immersa, 542

leucoblephara, 541

luteola endoleuca, 543

medialis, 543

parasema, 551

parmelioides, 548

parvifolia, 546

phaeomela, 542

sanguinariella, 551

scyphulifera, 543

subdisciformis, 551

vernalis, 542

LECIDEACEAE, 542

LECIDELLES, 539

Lehmann's Caudalejeunea, 516

Leiogramma virginea, 536

Leiphaimos, 332 parasitica, 332

Lejeunea, 508

Berteroana, 510

bullata, 509

clausa, 512

cubensis, 513

decidua, 511

duriuscula, 512

flava, 508

glaucescens, 508

Grayish, 508

Jooriana, 507

laetevirens, 509

Lehmanniana, 516

obtusangula, 512

phyllobola, 510

unciloba, 518

viridissima, 518

Yellow, 508

Lemna, 62

minor, 62

LEMNACEAE, 62

LENTIBULARIACEAF, 393

Lentinus crinitus, 642

hirtus, 642

lepideus, 643

strigellus, 642

strigosus, 643

velutinus, 643

Lentodium squamosum, 643

Lenzites applanata, 639

Leonotis, 377

nepetaefolla, 378

nepetaefolia, 636

Leonurus, 377

sibiricus, 377

Lepidium, 146

didymum, 148

virginleum, 146

virginicum, 631

Lepiota cretacea, 643

Lepraria Bassiae, 550 flava, 543

Ieptilon, 443

linifolium, 443

pusillum, 443

Leptochloa, 38

domingensis, 39

fascicularis, 39

Slender, 39

virgata, 38

virgata gracilis, 39

Virgate, 38

Leptocolea, 507

Joorlana, 507

Joor's, 507
Leptogium, 540

bullatum, 540

bullatum phyllocarpum, 540

chloromelum, 540

phyllocarpum 540

Leptolejeunea, 514

Elliptic, 514

elliptica, 514

Leptotrema, 544

bahianum, 545

bisporum, $\mathbf{5 4 5}$

compunctum, 545

glaucescens, 545

monosporum, 544

simplex, 545

Wightii, 545

Leskea subpinnata, 499

LESKEA FA MILY, 495

IESKEACEAD, 495

Leucaena, 162 glauca, 162

LEU COBRY ACEAE, 479

Leucobryum, 479 albidum, 479 glaucum albidum, 479

LEUCODON FAMILY, 491

LEUCODONTACEAE 491

Leucodon topsis, 491 Florida, 492

floridana, 491 plicata, 491

Leucolejeunea, 518 Hook-lobed, 518 unclloba, 518 unciloba, 518 xanthocarpa, 518

Yellow-fruited, 519

Liagora, 554

Liagora, 556

annulata, 555

cayohuesonica, 554

ceranoides, 555

Cheyneana, 554

corymbosa, 554

crassa, 554

decussata, 554

elangata, 554

farinosa, 554

farinosa, 554

farionicolor, 554

fragilis, 555

leprosa, 555

lurida, 554

megagyna, 557

mucosa, 556

mucosa, 556, 557

opposita, 555

paniculata, 555

pedicellata, 556

pedicellata, 556, 557

Pilgeriana 555

pinnata, $\mathbf{5 5 5}$

pinnata, 556, 557

pulverulenta, 555

rosacea, 555

rugosa, 555

tenuis, 555

valida, 555

Libidibia coriaria, 174

Lice-root, 337

Lichen aurantiacus, 550

badius, 545

bullatus, 540

chloromelos, 540

Cocoes, 552

complanatus, 549

compunctus, 545 
Lichen-

ferrugineus, 550

flmbriatus simplex; 547

flaccidus, 540

gemmatus, 525

hyperellus, 532

immersus, 542

lachneus, 531

lepadinus, 544

luteus, 541

nigrescens, 540

obscurus, 552

pallescens, 546

perlatus, 549

pictus, 551

rangiferinus, 547

rubiginosus, 547

rupestris, 540

scriptus, 536

stellaris, 553

subfuscus, 546

varius, 546

LICHENES, 522

Licmophora, 627 dalmatica, 627

Lictoria, 564 taxiformis, 564

Life-plant, 152

Lightwood, 227

Lignum Vitae, 202

LILIACEAE, 68

LILIALES, 68

LILY FAMILY, 68

Lima Bean, 194

Limnanthemum, 332 aureum, 333

Limodorum, 95 altum, 96

diurnum, 92

lanceolatum, 86

purpureum, 96

Simpsoni, 95

tuberosum, 95

Limonium, 319

bahamense, 320

LINACEAE, 199

Linaria vulgaris, 393

LINDEN FAMILY, 261

Link-vine, 84

Linociera bumelioides, 328

Linum bahamense, 200 Curtissii, 200

Lewisii, 201 virginicum, 200

Lion's Ear, 378 Tail, 377

Lippia, 367

Bushy, 368

canescens, 368

Creeplng, 368

geminata, 368

geminata microphylla, 368

inaguensis, 371

Large Creeping, 369

Marsh, 368

nodiflora, 368

nodiflora, 369

reptans, 369 stoechadifolia; 368

Iithophila, 127

Moss-like, 127

muscoides, 127

vermiculata, 128

Lithophyllum, 586 accretum, 585
Lithophyllum-

acropetum, 585

caribaeum, 586

Chamaedoris, 588

decipiens caribaeum, 586

munitum, 587

oncodes pachydermum, 587

pachydermum, 587

propinquum, 585

prototypum, 586

prototypum, 587

pustulatum, 586

strictum, 586

strictum nanum, 586

Lithothamnium, 584

aemulans, 584

decutescens, 585

fruticulosum aemulans, 584

mesomorphum ornatum, 584

Lithothelium, 532

bahamense, 532

bahamense, 532

cubanum, 532

LIVERWORTS, 477, 500

LOASA FAMILY, 290

LOASACEAE, 290

I OASALES, 290

Lobelia, 428

Bahama, 428

Feayana, 428

lucayana, 428

Plumierii, 429

LoBELIA FAMILY, 427

LOBELIACEAE, 427

Locust-berry, 205

LOGANIA FAMILY, 328

LOGANIACEAE, 328

Logwood, 171

I.ong-leaved Brake, 467 Tom, 372

Lonicera alba, 416

LOOSES TRIFE FAMILY, 298

Lophocladia, 571 trichoclados, 571

Lopholejeunea, 515

Sagraeana, 516

Sagra's, 516

Iophosiphonia, 574

cristata, 575

exilis, 570

obscura, 574

subadunca, 574

Lophothalia trichoclados, 571

LORANTHACEAE, 108

Loranthus emarginatus, 109 parviflorus, 109 uniflorus, 108

Louisiana Plagiochila, 506

Love-grass, 40,41 -vine, 356

LOVE-VINE FAMILY, 144

Luck-seed, 338

Lucky-nut, 338

Lucuma, 321 multiflora, 322

pauciflora, 322

Serpentaria, 322

Ludwigia, 309

microcarpa, 310

natans, 309

repens, 309

Small-fruited, 310

Lycium, 385
Iycium-

Inagua, 385

spathulifolium, 385

Lycogala epidendrum, 645

LYCOPERDALES, 644

Lycoperdon, 645 epidendrum, 645

LYCOPODIALES, 476

Lycopodium nudum, 476

Iyngbya, 622

Lyngbya, 620, 622

aestuarii, 622

aestuarii limicola, 622

confervoldes, 622

epiphytica, 622

gracilis, 622

Lagerheimii, 622

majuscula, 622

semiplena, 622

Lyonia maritima, 343 palustris, 343

Lysiloma, 157

bahamensis, 158

formos $a, 158$

latisiliqua, 158

paucifoliola, 158

Sabicu, 158

Sabicu, 109

Lysimachia Monnieri, 389

ITTHRACEAE, 298

Lythrum Parsonsia, 300

Maba, 325

caribaea crassinervis, 325

crassinervis, 325

crassinervis, 546

Macreightia caribaea, 326

Macrocatalpa, 397 longissima, 398 punctata, 397

Macromitrium, 488 Mucronate, 488 mucronifolium, 488

MADDER FAMILY, 407

Madeira, 214

Mahoe, 273

Mahogany, 214

MAHOGANY FA MILY, 212

Maiden-bush, 218

Maiden-hair Anemia, 475 Fern, Dark, 468 Slender, 467

Malache, 270 bahamensis, 271 scabra, 271

Malaxis, 88 Slender 88 spicata, 88

Mallet, 263

Mallotonia, 361 gnaphalodes, 361

MALIOW FAMILY, 263

Malocchia gladiata, 191

Malpighia, 204

Bahama, 205

cuneata, 205

glandulosa, 206

lucida. 205

polytricha, 205

punicifolia, 205

setosa, 205

MaLPighia FAMILY 203

MALPIGH IACEAE, 203

Malva abutiloides, 264 corchorifolia, 267

coromandeliana, 267

Malvaceae, 263 
Malvales, 261

Malvastrum, 266

american um, 267

corchorifolium, 267

coromandelianum, 267

Rugelii, 267

tricuspidatum, 267

Malvaviscus, 271

arboreus Sagraeanus. 271

Cokeri, 271

Sagraeanus, 271

Sagra's, 271

Mammillaria, 294 nivosa, 295

Manatee-grass, 6

MANATEE-GRASS FAMILY, 6

Manchioneel, 231

Mangifera, 244

indica, 245

Mango, 245

Mangrove, 308 Swamp Vine, 337

MANGROVE FAMILY, 308

Manihot, 230

Manihot, 230

Manilkara parvifolia, 324

Marasmius atropurpureus, 643

bahamensis, 643

bermudensis, 643

hemileucus, 643

nidulus, 644

obliquus, 644

opacus, 643

ramealis, 643

Rotula, 643

setulosipes, 643

Vallantii, 643

Marchantia, 503

chenopoda, 504

domingensis, 504

Santo Domingo, 504

MARCHANTIA FAMILY, 503

MaRCHANTIACEAE, 503

MarChantiales, 501

Margaritaria, 219

Bahama, 220

bahamensis, 220

Marigold, 451

Marilaunidium, 356 jamaicense, 357

Mariscus, 56

brizaeus, 46

filiformis, 47

fuligine $u s, 46$

jamaicensis, 56

Marlberry, 316

Marrubium vulgare, 380

Marsdenia floribunda, 344

Marsh Fern, 468

Fleabane, 446

Gentian, 331

Parsley, 314

Pennywort, 312

Pennywort, Ovateleaved, 313

Pink, 331, 332

Purslane, 309

Marsilea, 475

Nashil, 475

vestita, 476

MARSILEACEAE, 475

Martynia, 400

annua, 400

diandra, 400

Small-fruited, 400
MARTYNIACEAE, 399

Mastic-bully, 321

Mastigocoleus, 625

testarum, 625

Mastigolejeunea, 516

auriculata, 517

Eared, 517

Mastogloia, 628

Mastogloia, 626

affinis, 630

affirmata, 630

amoena turgida, 630

angulata, 628

apiculata, 628

asperula, 628

bahamensis, 628

bahamensis, 626

binotata, 628

bisulicata, 630

bisulcata corsicana, 630

Citrus, 628

cocconeiformis, 628

Craven1, 630

cuspidata, 628 .

delicatula, 628

erythraea, 628

erythraea, 627

euxina, 630

lanceolata, 628

lemniscata, 628

lineata, 630

Macdonaldil, 630

minuta, 628

ovata, 630

Peragalli, 630

Pisiculus, 630

Rhombus, 630

rimosa, 628

rimosa, 627

rostellata, 630

Smithii, 628

splendida, 628

splendida, 627

Matthiola scabra, 412

Maurandya, 388

antirrhinaeflora, 388

Mayepea, 327

bumelioides, 328

Maytenus, 246

Bahama, 247

Box-leaved, 247

buxifolia, 247

lucayana, 247

Meadow-Beadty Family, 297

Mecardonia, 390 procumbens, 390

Metbomia, 183

mollis, 184

supina, 184

tortuosa, 184

Melampodium humile, 447

Melanotheca, 530

cruenta, 530

Melanthera, 449

brevifolia, 449

crenata, 449

deltoldea, 449

hastata, 449

Hastate, 449

Melastoma bicolor, 298 discolor, 298

MelastomaCEAE, 297

Melia, 213

Ázedarach, 213

sempervirens, 213

MELIACEAE, 212

Melicocca, 253

bijuga, 253
Melicocca

paniculata, 254

Mellola ambigua, 632

longipoda, 632

simillima, 632

Melobesia, 587

Chamaedoris, 588

farinosa, 587

Lejolisii, 588

pustulata, 586

Melocactus communis, 294

Melochia, 277

crenata, 277

nodiflora, 277

pyramidata, 277

tomentosa, 276

Meloseira arenaria, 629 sulcata, 629

Melosmon, 376 cubense, 376

Melothria, 425 guadalupensis, 426 pervaga, 426

MENISPERMACEAE, 142

Mentzelia, 290 Florida, 290 floridana, 290

MENYANTHACEAE, 332

Mercurialis, 227

annua, 228

Meristotheca, 561 Duchassaingli, 561

Mermaid-weed, 311

Mertensia, 563

Merulius Corium, 638 infundibuliformis, 642 Spathularia, 637

Mesogloia atten uata, 581 Zosterae, 591

MESOGLOIACEAE, 591

Mesosphaerum, 379

Mesothamnion, 579 caribaeum, 579

Mesquite, 164 -grass, 37

Metastelma, 342

Metastelma, 636

Bahama, 342

bahamense, 342

bahamense, 342

barbatum, 343

brachystephanum, 342

cubense, 342

Eggers, $\mathbf{3 4 3}$

Eggersii, 343

hamatum, 342

Inagua, 343

inaguense, 343

linearifolium, 343

Marsh, 344

Narrowed-leaved, 343

Northropiae, 342

Northrop's, 342

palustre, 343

palustre, 636

Schlechtendahlii, 342

MeteoriacEAe, 493

METEORIU M FA,MILY, 493

Metopium, 244

Metopium, 244

toxiferum, 244

Mexican Poppy, 145

Senna, 168

Mickle-berry, 102

Microdictyon, 602 crassum, 602

Microlejeunea, 509 bullata, 509 
Microlejeunea, inflated, 509 la etevirens, 509 Yellowish-green, 509

Micromeria, 379 Brownei, 379

Microphiale, 541 lutea, 541

Microstylis spicata, 88

Microthamnium, 498

Microthelia, 526

Microthelia, 527 quadriloculata, 526 thelena subtriseptata, 527

Mikania, 439 batatifolia, 439 orinocensis, 439 scandens, 439

Milium compressum, 17 digitatum, 16 paniceum, 15

Milk-berry, 323 -pea, 190 -vine, 344

MILKWEED FAMILY, 340

MILKWORT FAMILY, 214

Mimosa, 161 arborea, 162 Bahama, 162 bahamensis, 162 Farnesiana, 161 glauca, 162 juliflora, 164 Lebbeck. 157

Low, 163 pernambucana, 163 plena, 164 pudica, 161 Unguis-cati, 155 virgata, 163 Virgate, 173

Mimosa FAMILY, .154

MimosaceAe, 154

Mimusops, 324

Mimusops, 110 bahamensis, 324 dissecta, 324 emarginata, 324 floridana, 324 parvifolia, 324 Sieberi, 324

MINT FAMILY, 375

Mirabilis, 129 Jalapa, 129

Mistletoe, 108-110

Mistletoe FAMiLY, 108

Mitreola petiolata, 329

Mitrewort, 329

Mittenothamnium, 498 diminutivum, 498

Mitten's-moss, Diminutive, 498

Mnium hygrometricum, 489

Moluchia, 276 pyramidata, 277

Smooth, 277

tomentosa, 276

tomentosa, 635

Velvety, 277

Momordica, 425 Balsamina, 425 Charantia, 425

Monkey-fiddle, 234

Monniera Brownei, 389 Monniera, 389

MoNocotyledones, 3

Monteverdia buxifolia, 247

Moon-vine, 349
MOONSEED FAMILY, 142 Coast, 350

MORACEAD, 104

Morinda, 419

Royoc, 419

Moringa, 151

Moringa, 151

pterygosperma, 15.1

MORINGACEAE, 151

Morning-glory, Arrowleaved, 353

Beach, 353

Creeping, 353

Dark-eyed, 354

Ivy-leaved, 352

Pedate-leaved, 353

Purple, 352

Salverform, 351

Small Red, 350

Villous, 352

MORNING-GLORY FAMILY, 345

Mosquito-bush, 167

Moss, White, 479

Mosses, 477

Mottled Spurge, 235

Mougeotia nodiflora, 277

Moujean Tea, 371

Mucor cancellatus, 645

Mucronate Macromitrium, 488

Mucuna, 188

pruriens, 189

pruriens, 189 urens, 189

Muhlenbergia, 31 caplliaris, 32

MulberRy FAMILY, 104

Murrayella, 572 periclados, 572

Muscadinia Munsoniana, 259

MUSCI, 477

MUSTARD FAMILY, 145

Myginda aquifolia, 248

ilicifolia, 248

latifolia, 249

pallens, 248

Rhacoma 248

Mykosyrinx Císsi, 637

MYOPORACEAE, 405

MYOPORUM FAMILY, 405

Myrica, 102

cerifera, 102 segregata, 327

MYRICACEAE, 101

MYRICALES, 101

Myroxylon, 284

bahamense, 284

buxifolium pauciflorum 284

ilicifolium, 284

MYRSINACEAE, 315

Myrsine laeta, 316

Mrrsine FAMILY, 315

Myrstiphyllum ligustrifolium, 419 pubescens, 418 undatum, 419

My RTACEAE, 302

MYRTALES, 297

Myrtle-of-the-River, 307

MYRTLE FAMILY, 302

Myrtus axillaris. 303

buxifolia, 303

Pimenta, 305

punctata, 306

Zuzygium, 307
MrXoMYCETES, 645

MYXOPHYCEAE, 618

Natadales, 4

Naked-wood, 253, 306

Nama jamaicen 8 e, 357

Narrow-leaved Bay-rush, 463

Brake, 466

Nashia, 371

inaguensis, 371

Nash's Pepperwort, 475

Nasturtium brevipes, 148 palustre brevipes, 148

Naucoria semiorbicularis, 643

Navicula, 628

approximata, 631

brasilliensis, 628

complanata, 631

cuspidata ambigua, 631

directa, 631

irrorata, 631

Lyra dilatata, 628

ramosissima, 628

Scopulorum, 631

suborbicularis, 628

transfuga, 631

Zostereti, 628

Nazia, aliena, 14

Neckera, 493

floridana, 491

NeCKERA FAMILY, 492

NECK ERACEAE, 492

Nectandra, 143 coriacea, 143 sanguinea, 143

NEMALIONACEAE, 554

Neobracea, 335 bahamensis; 335

Neomeris, 605 annulata, 605

Cokeri, 605

Cokeri, 606

Kelleri, 605

mucosa 6:)

Neothymopsis, 455

Brittunii. 455

thrucides, 455

Neotitia adnata, 84 tortilis, 85

Nepeta Cataria, 379 coerulea, 379 pectinata, 380

Nephrolepis, 473 biserrata, 474 exaltata, 473

Neptunia, 164

Neptunia, 163 plena, 164

Nesaea, 612

Nesea annulata, 602 dumetosa, 613

Penicillus, 612 pyramidalis, 612

Netrta Family, 105

Neurocarpus, 595 delicatulus, 595 Justii, 595

Neurogramme calomelanos, 469

Neurolaena, 457

lobata, 457

New-burn Weed, 128

Nickers, 172

Nicotiana, 387 Tabacum, 387

Nidema, 94 
Nidema-

Otton is, 94

Nidularia intermedia, 645

NIDULA RIALES, 645

Night-blooming Cereus, 293

Nigredo proeminens, 636

Nitella, 608

Nitzschia, 629

angularis, 631

apiculata, 629

compressa, 631

granulata, 631

Jelineckii, 631

panduriformis, 631

Sigma, 629

valida, 629

vermicularis, 631

Nodeweed, 452

Nostoc, 624 commune, 624

NostocaceAe, 624

Noyau Vine, 353

Nummuiaria Bulliardil, 634

Nut-grass, 46 rush, 57

Nrctaginaceae, 129

Nyctanthes Sambac, 327

Nymphaea ampla pulchella. 139 pulchella, 139

NrMPHAFACEAE, 139

Nymphoides, 332 aureum, 333

Oak, 301

Obcordate Frullania, 520

Obeah-bush, 135

Obtusely angled Taxilejeunea, 513

Ocellularia, 544 albida, 544 micropora, 544 subtilis, 544

Ochrolechia, 546 pallescens, 546

Ochtodes, 583

filiformis, 583 secundiramea, 583

Ocimum, 380 micranthum, 380

Ocotea, 143

Ocotea, 110 Catesbyana, 143 coriacea, 143

Octoblepharum, 480 albidum, 480

Odontosoria clavata, 468

Okra, 272

OLACACDAE. 111

OLAX FAMILY, 111

Old Maid, 336

Man Cactus, 292

Man's Beard, 43, 63

Oldenlandia, 408 callitrichioldes, 408

Oleaceae, 32:

Olive, 103. 406 -wood, 250

OLIVE FAMILY, 326

Olivia, 605

Omphalaria umbella, 540

ONAGRACEAF, 309

Oncidium, 97

bahamense, 97

bahamense. 98

Leiboldi, 98

lucayanum, 98
Oncidium -

sphacelatum, 97

sylvestre, 98

variegatum, 98

Oncobyrsa, 620

marina, 620

Opegrapha, 534

acicularis, 541

ảtra, 534

bahamensis, 535

bahamensis, 535

calcarea, 534

Chevallieri, 534

Chevallieri incarnata. 535

columbina, 535

crassa, 538

dendritica, 536

isabellina, 535

isabellina, 535

lithyrga, 535

ophites, 535

saxicola, 534

varia, 534

vulgata, 534

zonata, 535

Operculina dissecta, 353

Ophiodothis bahamensis, 633

Ophiorrhiza Mitreola, 329

Oplismenus, 26

hirtellus, 27

setarius, 27

Opoponax, 161

Opuntia, 295

opuntia, 614

bahamana, 296

Darrahiana, 297

Dillenii, 296

Dillenii, 632

lanceolata. 296

lucayana, 296

lucayana, 296

Millspaughii, 296

Nashii, 295

spinosissima, 295

triacantha, 295

Tuna, 296, 297

OPUNTIALES, 291

Orchid, Carter's, 83

ORCHID FAMILY, 81

ORCHIDACEAE, 81

ORCH IDALES, 81

Ornithopteris adiantifolia, 475

cicutaria, 474

Wrightii, 474

Orontium aquaticum, 62

ORPINE FAMILY, 152

Ortachne fioridana, 31

ORTHOTRICHACEAE, 487

Orthotrichum mucronifolium, 488

ORTH OTRICH UM FAMILY, 487

Oscillatoria, 620 Corallinae, 621

minlata, 620

sancta, 620

tenuis, 621

OSCILLATORIACEAE, 620

Osmunda, 565 adiantifnlia, 475

Osmundea, 565

Otaheite Gooseherry, 219

Ovate-leaved Marsh Pennywort, 313

ovieda aculeata, 374
Ovieda-

fragrans, 375

OXALIDACEAE, 196

Oxalis corniculata, 197

corniculata repens, 197

intermedia, 197

Oxypetalum, 343

Oyster Plant, 68

Ozonium auricomum, 636

Padina, 595

Padina, 587

dubia, 595

Durvillaei, 595

pavonia, 595

Sanctae-Crucis, $\mathbf{5 9 5}$

variegata. 594,595

Vickersiae, $\mathbf{5 9 5}$

Padinella, 591

Pain-in-back, 104

Pale-green Funaria, 489

PALM FAMILY, 58

Palmella rupestris, 620

Paltonium, 466

lanceolatum, 466

Pancratium declinatum, 78

PANDANALES, 3

Panellus eugrammus. 644

Panic-grass, Bluish, 24

Brown, 22

Chapman's, 23

Dense, 23

Diffuse, 23

Hair-like, 24

Loose, 22

Narrow, 22

Nerved, 25

Red-top, 23

Shining, 25

Slender, 23

Panicum, 20

adspersum, 21

agrostidiforme, 23

amarulum, 24

barbinode, 22

bartowense, 24

brevifolium, 24

capillaceum, 24

Chapmani, 22

coerulescens, 24

colonum, 26

condensum, 23

Crus-galli, 26

Dactylon 34

dichotomiflorum, 24

dichotomum, 24

diffusum, 23

distantiflorum, 22

divaricatum, 25

elephantipes, 22,24

exiguiflorum, 25

fasciculatum, 22

filiforme, 15

fimbriatum, 16

flavescens. 22

fuscum, 22

geminatum, 21

geniculatum, 27

Ghiesbreghtil, 23

hirtellum, 27

hirtivaginum, 23

horizontale, 16

imberbe, 27

insulare. 16

laxum. 23

leucophaeum, 16

Linkianum, 16 


\section{Panicum-}

lucidum, 25

maximum, 22

molle, 22

neuranthum, 24

nitidum, 25

paniculatum, 22

paractaenoides, 28

paspaloides, 21

proliferum, 24

sanguinale, 16

setosum, 28

tenerum, 23

tenuiculmum, 23

trichoides, 24

tricolor 25

Pannaria, 547

molybdea, 548

rubiginosa, 547

PANNARIACEAE, 547

Papaveraceae, 145

Papaverales, 145

Papaw, 290

Papaw Family, 289

Papillaria, 493

Blackish, 494

nigrescens, 493

Para Grass, 22

Paradise-tree, 211

Paratheliaceae, 531

Parathelium, 531

decumbens. 532

indutum, 531

microcarpum, 531

microcarp um, 532

Parietaria microphylla, 106

Pariti, 272

tiliaceum, 273

Paritium tiliaceum, 273

Parkinsonia, 170 aculeata, 170

Parmelia, 548

alba, 552

crispa, 553

cristifera, 549

flava, 549

latissima, 549

latissima cristifera, 549

molybdea, 548

pellita, 548

perlata, 549

repanda, 538

speciosa hypoleuca, 552

sulphurata, 549

urceolata, 548

usneoides, 549

varia cinereocarnea, 546

Parmeliachae, 548

Parmentaria, 532 astroidea, 532

Parsley Anemia, 474

Parsonsia, 299 Parsonsia, 300

Purple, 300

radicans, 300

Parthenium, 447

Hysterophorus, 448

Parthenocissus, 261

quinquefolia, 261

quinquefolia latifolia, 261

Paspalum, 17

Blodgettii, 18

caespitosum, 18

caespitos um, 18

conjugatum, 19
Paspalum -

distichum, 20

fimbriatum, 19

Fringed, 19

glabrum, 19

gracillimum, 18

Helleri, 19

millegrana, 19

nanum, 19

Poiretil, 18

Poiret's, 18

portoricense, 18

Schreberianum, 19

secans, 19

Sheathed, 20

Simpsoni, 18

Simpson's, 18

Slender, 18

Tall, 19

tristachyon, 17

Two-spiked, 19

Underwoodii, 19

Underwood's, 19

vaginatum, 20

vaginatum, 20

Passiflora, $286^{\circ}$

angustifolia, 288

bàhamensis, 287

biflora, 289

ciliata, 287

ciliata riparia, 288

cupraea, 289

foetida, 287

lunata, 289

minima, 288

multiflora, 288

pallida, 288

pectinata, 287

pectinata, 287

rubra, 288

suberosa, 288

Vespertilio, 289

villos $a, 288$

Passifloraceae, 286

PASSiflorales, 286

Passion-flower, 287, 288

PASSION-FLOWER FAMILY, 286

Patellaria domingensis, 542

Paullinia diversifolia, 251 Seriana, 251

Paurotis, 60

androsana, 60

Wrightil, 60

Pavonia, 270

Pavonia, 270

bahamensis, 271

racemosa, 271

spicata, 271

spinifex, 270

Pea FAMily, 176

Pectis, 456

Awn-fruited, 457

leptocephala, 456

Lessingii, 456

linifolla, 456

Narrow-leaved, 456

punctata, 456

Pedaliaceae, 399

PEDAlium FAMILY, 399

Pedicellaria pentaphylla, 149

Pedilanthus, 233

bahamensis, 233

tithymaloides, 233

Pelexia, 84

adnata, 84

Long-spurred, 85
Pelexia-

setacea, 84

Short-spurred, 84

spiranthoides, 84

Peltophorum, 175

adnatum, 175

Pencil-flower, 183

Penicillus, 612

Penicillus, 568, 573, 622

annulatus, 602

capitatus, 612

dumetosa, 613

dumetosus, 613

elongatus, 612

Lamourouxii, 612

Lamourouxiigracilis, 612

oblongus, 613

pyriformis, 613

Pennyroyal, 456

Peperomia, 101 spathulifolia, 101

Pepper bush, 224, 383

Pepper FAMILY, 101

Pepperwort, Hairy, 476

Nash's, 475

Pera, 229

Pera, 229

bumeliaefolia, 229

bumeliaefolia, 196

Perisporialles, 632

Perisporium Wrightii, 632

Peronosporales, 631

Persea, 144

pubescens, 144

Persicaria, 114

Dense-flowered, 115

hydropiperoides, 114

portoricensis, 115

punctata, 114

Pertusaria leioplaca, 545

Petitia, 373, 630

Petitia, 630

domingensis, 373

Poeppigii, 373

Temperei, 630

Petiveria, 135 alliacea, 135

Petrosiphon, 602 adhaerens, 602

Peyssonellia, 584

Peyssonnelia, 584

Peyssonnelia, 584 rubra, 584

Peziza cubensis, 635 nigrescens, 637 omphalodes, 635

Pezizales, 635

Phacidiales, 635

Phaeographina, 536 caesiopruinosa, 536 caesiopruinosa, 537 quassiaecola, 587 scalpturata, 537

Phaeographis, 536 cinnabarina, 536 dendritica, 536 inusta, 536

Phaeophy ceae, 589

Phaeostroma, 590 pusilium, 590

Phalluales, 644

Pharbitis cathartica, 352

Pharnaceum maritimum, 136

Phaseolus, 193

lathyroides, 194

lunatus, 194 
Phaseolus-

semierectus, 194

Phegopteris cordata, 473 reptans, 473

Phialanthus, 416 myrtilloides, 416 Myrtle, 416

Philibertella, 344 clausa, 344 clausa, 636

Philibertia clausa, 344

Philoxerus, 127 vermicularis, 128

Phlebodium, 470 aureum, 470

Phlomis nepetaefolia, 378

Phoradendron, 109 Northroplae, 110 racemosum, 110 rubrum, 110 spathulifolium, 110 tetrastichum, 110 trinervium, 110

Phormidium, 621 Corlum, 621

fragile, 621

Hendersonii, 621 pulvinatum, 621

Retzii, 621

Retzii, 622

valderianum, 621

Phragmicoma Sagraeana, 516

Phragmites, 39

communis, 39

Phragmites, 39

PHYCOMYCETES, 631

Phycopteris, 594

Phyla nodiflora, 368 stoechadifolia, 368

Phyllachora Ateleiae, 632 Durantae, 633 fusicarpa, 633 Galactlae, 633 oxalina; 633

Phyllanthus, 220 angustifolius, 220 bahamensis, 220 distichus, 219 falcatus, 220 Niruri, 220 pentaphyllus, 221 pruinosus, 221 radicans, 221

Rock, 221

saxicola, 221

Tufted, 221

viren 8,220

Phyllerpa, 607

Phyllopsora, 546 parvifolia, 546

Phyllopsoraceae, 546

Phyllosticta Coccolobae, 635 Roberti, 635 Sapotae, 635

Phymatodes, 470 exlguum, 471

Phymosia, 264 abutiloides, 264

Physalis, 381 angulata, 381 barbadensis, 382 curassavica. 382 Linkiana, 381 pubescens, 382 turbinata, 382

Physarum compressum, 645 globultferum, $\mathbf{6 4 5}$
Physarum -

virlde, 645

Physcia, 552 adglutinata, 552

alba, 552

crispa, 553

crispa, 552

dilatata, 552

dilatata, 552

hypoleuca, 552

integrata, 553

integrata, 552

integrata sorediosa, 553

obscura, 552

picta, 551

stellaris, 553

Physciaceas, 551

Physcophora, 571

triangularis, 571

Physma, 540

umbella, 540

Physurus, 87

querceticola, 87

Sagraeanus, 87

Phytolacca, 135

icosandra, 135

octandra, 135

Phytolaccaceae, 133

Picramnia, 210

pentandra, 210

Picrodendraceae, 102

Picrodendron, 103

baccatum bahamense, 103

juglans, 103

macrocarpum, 103

Plgeon-berry, 372 -pea, 192

-plum, 117

Plgweed, 125

Pilea, 106

herniarioides, 107

microphylla, 106

muscosa, 106

tenerrima, 107

Pilocarpaceae, 541

Pilocarpon, 541

tricholoma, 541

Pilocereus, 291

lanuginosus, 292

Pilotrichella floridana, 491

Pilotrichum cymbifolium, 492

Pimenta, 305

officinalis, 305

Plmenta, 305

vulgaris, 305

Pinachae, 461

Pinales, 460

PINE-APPLE FAMILY, 63

Pine Family, 461

Pine-land Fern, 468

Thistle, 459

-tree, Caribbean, 461

Pinguicula, 395

pumila, 395

Pink, 329

Pinnularia, 628 rectangulata, 628

Pinus, 461

bahamensis, 461

caribaea, 461

Plpe-shank, 377

Piperaceat, 101

Piperales, 101

Pirea, 492

Plreella, 493
Pireella, 492

cymbifolla, 492

Piscidia Erythrina, 186

Pisonia, 132

aculeata, 132

calophylla, 131

discolor longifolia, 132

obtusata, 131

rotundata, 133

Round-leaved, 133

subcordata rotundata, 133

Pistacia Simaruba, 212

Pitch-apple, 281

Pitcher-plant, 113

Pithecolobium, 155

asplenifolium 160

bahamense, 15

calliandriflorum, 156

circinale, 156

discolor, 157

flavovirens, 155

guadalupense, 156

Hystrix, 156

keyense, 156

mucronatum, 156

Unguis-cati, 155

Unguis-cati, 155

Pithophora, 601

oedogonia, 601

Pityrogramma, 469

calomellanos, 469

Placodium aurantiacum Bassiae, 550

floridanum, 550

galactophyllum, 550

Placoma, 620

Plagiochila, 505

Loulsiana, 506

ludoviciana, 506

Plagiogramma, 627

Plagiogramma, 626

caribaeum, 627

decussatum, 630

inaequale, 627

labuense, 627

labuense, 627

lyratum, 627

obesum, 627

pulchelium, 627

pygma eum, 627

tessellatum, 630

Plantaginaceae, 406

Plantaginales, 406

Plantago, 406

lanceolata, 407

major, 406

Plantaln, 406

Pluantain Family, 406

Plectonema, 623

nostocorum, 623

roseolum, 623

Pleurococcaceae, 597

Pleurococcus membraninus 618

vulgaris, 597

Pleurosigma, 628

compactum, 631

formosum, 628

Weissflogil, 631

Pleurotopsis liliputlana,

644

Pllcatura obliqua, 644

Plocamium triangulare, $\mathbf{5 7 1}$

Plocaria, 562

Pluchea, 445

bifron 8,445

camphorata, 446 
Pluchea-

foetida, 445

odorata, 445

purpurascens, 446

PLUM FAMILY, 153

Plumaria Schousboei, 580

Plumbagina Ceae, 319

Plumbago, 319 scandens, 319

Plumbago FAMILY, 319

Plumiera, 334

alba, 334

Bahama, 334

bahamensis, 334

Blunt-leaved, 334

emarginata, 334

Hairy, 335

Inagua, 334

inaguensis, 334

obtusa, 334

obtusa, 635

Red, 335

rubra, 335

sericifolia, 335

Poa amabilis, 41

ciliaris, 41

domingensis, 41 .

nitida, 40

plumosa, 41

prolifera, 41

virgata, 42

Poaceae, 10

Poales, 10

Podocystis, 629 adriatica, 629

adriatica, 627

Pogonomyces hydnoides, 641

Poinciana, 174 coriaria, 174

pulcherrima, 174

regia, 175

Poinsettia, 236 heterophylla, 236

Poison Bush, 232 Cherry, 248

Ivy, 244

-tree, 244

Poke-bush, 136

-weed, 136

Poke-Wend Family, 133

Polemoniales, 344

Polyblastiopsis, 527 lactea, 527

Polygala, 214

bahamensis, 215

brizoides, 215

corallicola, 215

Krugii, 215

Krug's, 215

oblongata, 216

spathulata, 215

Spatulate-leaved, 215

Wightiana, 215

Wight's, 216

Wilsoni, 216

Wilson's, 216

POLYGathacea, 214

Polygonaceae, 114

Polygonales, 113

Polygonum acre, 114 Fagopyrum, 115

glabrum, 115

hydropiperoides, 114

portoricense, 115

punctatum, 114

Uvifera. 116

Polyostea, 569

Polyphysa, 605
Polypodiaceae, 464

Polypodium, 469

aureum, 470

biserratum, 474

exaltatum, 473

exiguum, 471

incanum, 470

Phyllitidis, 471

polypodioides, 470

pubescens, 473

reptans, 473

squamatum, 470

Swartzii, 471

Polypodoidea, 595

Polypody, Climbing, 471 Gray, 470

Scaly, 470

POLYPORACEAE, 639

Polyporus Auberianus, 640

Bracei, 641

fruticum, 641

guyanensis, 641

licnoides, 641

occidentalis, 639

palustris, 641

pinsitus, 639

sericeohirsutus, 639

surinamensis, 641

tornatus, 640

Tricholoma, 641

Polypremum, 329

procumbens, 329

Polysiphonia, 569

Polysiphonia, 577, 587, 627

adunca, 574

barbatula, 574

Binderi, 572

Binneyi, 570

breviarticulata, 570

exilis, 570

ferulacea, 570

ferulacea, 590

foeniculacea, 570

Gorgoniae, 570

hapalacantha, 570

hapalacantha, 554

havanensis, 570

havanensis, 570

havanensis Binneyi. 570

Hillebrandii, 577

hirta, 570

lophoclados, 571

opaca, 571

Pecten-Veneris, 573

periclados, 572

perpusilla, 564

pygmaea, 574

ramentacea, 570

reptabunda, 574

secunda, 574

subtilissima, 570

tenella, 573

trichoclada, 571

Polystachya, 88

follosa, 89

Large, 89

luteola, 89

minuta, 89

Small, 89

Polystictus cinnamomeus, 639

sanguineus, 641

Polythrix, 626

corymbosa, 626

Pond-apple, 141

-thatch, 60

-top, 60
Pondweed, 5, 363

PONDWEED FAMILY, 4

Ponthieva, 87

Brittonae, 87

Mrs. Britton's, 87

Poppers, 381

POPPy FAMILY, 145

Poria, 641

Porina, 523

Porina, 524

africana, 524

firmula, 524

macrocarpa, 523

mastoidea, 524

nucula, 524

subfirmula, 524

Tetracerae, 524

variegata, 524

Wilsonii, 523

Pork-and-Doughboy, 160

-bush, 136, 149

-fat Apple, 154

Porolithon, 587

Boergesenii, 585

improcerum, 587

pachydermum, 587

pachydermum, 587, 598

Poronia Oedipus, 634

Porophyllum, 455 Porophyllum, 456 ruderale, 456

Portulaca, 138

Bahama, 138

Brown-seeded, 138

ga'gatosperma, 138

halimoides, 138

oleracea, 138

phaeosperma, 138 pilosa, 138

Portulacacean, 137

Potamogeton, 4 heterophyllus, 5

Potato FaMrLy, 381

Potmargin, 380

Prescottia, 86

oligantha, 86

Small, 87

Prickle-grass, 14

Prickly-apple, 411 -bur, 386

-bush, 403

Myrtle, 374

- pear, 295-297

-tree, 301

Pride-of-india, 213

Primrose Family, 318

Primulaceae, 318

Primulales, 315

Princew ood, 409

Priva, 366

echinata, 367 lappulacea, 367

Privet Senna, 167

Proserpinaca, 310 palustris, 311 platycarpa, 311

Prosopis, 164 juliflora, 164

Prospodium bahamense, 636

PROTOCOCCACEAE, 597

Protococcus, 597

Magma, 619

turgidus, 618

viridis, 597

Prunus myrtifolia, 153 sphaerocarpa, 153

Pseudocarpidium, 373 Wrightil, 374 
PseudocarpidiumWright's, 374

Pseudophoenix, 60 Sargentii, 61 vinifera, 61

Pseudopyrenula, 526 diremta, 526 eluteriae subsulphurea 530

Pseudotetraspora, 597 Antiliarum,597 marina, 597

Psidium, 306 Guajava, 307 Guava, 307

Psilotacear, 476

Psilotum, 476 rudum, 476 triquetrum, 476

Psirotu M FAMILY, 476

Psorotichia, 539 Boergesenii, 539

Psychotria, 418 asiatica, 419 bahamensis, 419 lanceolata, 419 ligustrifolia, 419 pubescens, 418 undata, 419

Pteridium caudatum, 467

PTERIDOPhyta, 464

Pteris, 466

aquilina caudata, 467

aurea, 470

caudata, 467

lanceolata, 466

lineata, 466 longifolia, 467

Ptilota Schousboei, 580

Ptilothamnion, 581 bipinnatum, 580

Puccinia Cynanchi, 636 heterospora, 636 Lantanae, 636 Leonotidis, 636 mirifica, 636 obliqua, 636

Puli-back, 132

Purple-grass, 32

Purslane, 138

Purslane Family, 137

Pycnodoria, 467 longifolia, 467

Pycnoporus sanguineus, 641 Pycraeus ferrugineus, 44

Pylaiella, 589 Antillarum, 589 Hooperi, 589

Py renopsidaceae, 539

Pyrenula, 526

aurantiaca, 526

cerina, 526

deplanata, 526

Giaziovil, 526

Kunthii, 526

leucoplaca, 526

libricola, 527

mamillana, 526

mamillana, 526

mastoidea. 524

nitida, 526

punctella, 526

tropica, 529

Pxrenulaciae, 523

Pyrenulates, 522

Pyronema omphalodes, 635

Pyropolyporus dependens, 640
Pyxine, 551

Cocoes, 552

Cocoes endoxantha, 552

dissecta, 552

Meissneri, 552

picta, 551

Quamoclit, 350

coccinea, 350

Quamoclit, 350

vulgaris, 350

QUASSIA FAMILY, 209

Quassia Simarouba, 210

Queen-of-the-Night, 294

Quicksilver-bush, 253

Rabbit-grass, 42

Rachicallis, 408 americana, 409 rupestris, 409

Radicant Fissidens, 481

Radicula, 147 brevipes, 148

Radula, 506 australis, 506 Southern, 506

Ragweed, Southern, 432

RAGWEED FAMILY, 430

Rainbow-moss, 480

Rajania, 80

hastata, 80

microphyila, 80

microphylla, 634

Small, 80

Ramalina, 549

complanata, 549

denticulata 549

Montá gnei, 549

peruviana, 549

rigida Montagnei, 549 usneoides, 549

Ram's Head Frullania, 519 -horn, 156

RANALES, 139

Randia, 410 aculeata, 410 mitis, 410

RANUNCULACEAE, 140

Rapanea, 316 guianensis, 316

Raphanus lanceolatus, 149

Rat-root, 417 -wood, 198

Rattlebox, 178

Rauwolfia, 339

glabra, 339

nitida, 339

Smooth, 339

tetraphylla, 339

Rectolejeunea, 509

Berteroana, 510

Bertero's, 510

Brittoniae 510

Leaf-shedding, 510

Mrs. Britton's, 510

phyilobola, 510

Red Bay, 144

Cedar, 462

Clover, 180

Morning-glor. 350

Periwinkle, 336

Sage-bush, 370

Stopper, 304

-top, 23

Reed-grass, 39

Relbunium bermudense, 424

Renealmia usneoides, 63
Resupinatus subbarbatulus, 644

Reynosia, 255

Bahama, 256

Common, 256

latifolia, 256

Northropiana, 256

septentrionalis, 256

Rhabdadenia, 337

biflora, 337

paludosa, 337

Sagraei, 337

Rhabdonema adriaticum, 630

Rhabdonia Baileyi, 561 tenera, 561

Rhacoma, 247

aquifolia, 248

Bahama, 247

coriacea, 247

Crossopetalum, 248

Holly-leaved, 248

ilicifolia, 248

pallens, 248

Spiny-leaved, 248

RHAMNACEAE, 25

RHAMNALES, 255

Rhamnidium ferreum, 256 revolutum, 256

Rhamnus colubrinus, 258 cubensis, 258 ferreus, 256

Rhinotrichum Curtisii, 636

Rhipilia, 612

longicaulis, 611

Rawsoni, 612

tomentosa, 612

Rhipocephalus, 613

Rhipocephalus, 568 oblongus, 613

Phoenix, 613

Rhizoclonium. 599

crassipeliitum robustum, 600

hierogìphicum, 600

Hookeri, 600

riparium implexum, 600

Rhizophora, 308

Rhizophora, 559, 561, 564, $570,572,573,574,575$ $576,577,582,583,594$, $599,600,602,606,608$, 610,617

Mangle, 308

RHIZOPHORACEAE, 308

RHIZOPHYLLIDACEAE, 583

Rhodochorton Rothii, 560 speluncarum, 578

Rhodomela calamistrata, 572

RHODOMELACEAE, 565

Rhodonema, 575 elegans, 576

RHODOPHY CEAE, 553

RHODOPH YLLIDACEAE, 561

Rhodoplexia, 580

RHODYMENIACEAE, 563

Rhoeo, 68 discolor. 68

Rhubarb, 419

Rhus Blodgettii. 244 Cominia, 253 Metopium 244 radicans, 244 Toxicodendron, 244

Rhynchosia, 192

caribaea. 193

Gundlachii, 193 
Rhynchosia minima, 193 reticulata, 193

Ribwort, 407

Riccia, 502 crystallina, 502 Crystalline, 503 violacea, 503 Violet, 503

RICCIA FAMILY. 502

RICCIACEAE, 502

Ricciella, 502

Richard's Calymperes, 482

Ricinus, 230 communis, 230

Rigidoporus surinamensis, 641

Rio Janeiro Frullania, 520

Rivina, 134 humilis, 134

laevis, 134 octandra, 134

Rivularia, 626

Blasolettiana, 626

nitida, 626

polyotis, 626

Zosterae, 591

RIVULARIACEAE, 625

Robinia grandiflora, 182

Rochefortia, 360 bahamensis, 360

Rock Balsam, 223 Trichostomum, 487

Rong-bush, 451

Roperia tessellata, 629

RosALES, 151

Rosewood, 160

Rousselia, 107 humilis, 107 lappulacea, 107

Roving Sallor, 388

Royal Palm, 61 Poinciana, 175

Roystonca regia, 61

Rubber-vine, 336, 340

RUBIACEAE, 407

RUBIALES, 407

Rudolph's Diplasiolejeunea, $507^{\circ}$

RUE FAMILY, 206

Ruellia, 401

tuberosa, 401

Tuberous, 401

Ruppia, 5 maritima, 5

Rush, Flat-splked, 52 -grass, 32-34 White-headed, 53

Russellia, 388 equisetiformis, 388 juncea, 388

RUTACEAE, 206

Rynchospora, 53

Rynchospora, 637 bahamensis, 55 capitata, 54 cyperoides, 54 divergens, 55 jubata, 56 marisculus, 56 microcarpa, 55 perplexa, 55 tenuis, 55 Tracyi, 54

Sabal, 59 Palmetto, 60
Sabal-

Palmetto bahamensis, 60

umbraculifera, 60

Sabbatia, 331

campanulata, 331

campanulata, 332

gracilis, 331,332

simulata, 332

Sabicu, 158

Sachsia, 446

bahamensis, 446

Saffron-tree, 321

Sage, Big, 370

Scarlet, 379

Small White, 379

West Indian, 378

Wild, 370

Sage-bush, Bahama, 370

Inagua, 371

Red, 370

Sagittaria, 7

Lance-leaved, 8 lancifolla, 8

Sagra's Lopholejeunea, 516

St. Andrew's Cross, 280

ST. JOHN'S-WORT FAMILY, 280

St. Thomas Bush, 341

Salicornia, 121 ambigua, 122

Bigelovii, 122

fruticosa, 122

mucronata, 122 perennis, 122

Salmea, 452

Bushy, 453 petrobioides, 453

Salsola linearis, 121

Salt Grass, 34 -weed, 128 -wort, 133

SALTWORT FAMILY, 133

Saltwater-bush, 409

Salve-bush, 383

Salvia, 378 coccinea, 379 micrantha, 378 occidentalis, 378 serotina, 378 tenella, 379

Salviniales, 475

Salz-bush, 276

Samodia ebracteata, 318

Samolus, 318 ebracteatus, 318 floribundus, 318

Valerandi americanus, 318

Sampire, 128

Samyda spinescens, 286

Sandbox-tree, 233

Sandfly-bush, 409

Sanseviera, 69 guineensis, 69

Santa Maria, 448

SANTALALES, 107

Santo Domingo Marchantla, 504

SAPINDACEAE, 250

SAPI NDALES, 242

Sapium laurifolium, 242

Sapodilla, 325

SAPODILLA FAMILY, 320

Sapota, 324

Achras, 324

Achras, 635, 636

SAPOTACEAE, 320
Sarcographa, 538

tricosa, 538

Sarcomphalus, 257

Taylori, 257

Taylor's', 257

Sarcostemma Brownei, 344

Sargassum, 592

Sargassum, 553, 574, 578, $586,587,589$

bacciferum, 592

bahiense, 594

cymosum, 593

Filipendula, 593

Filipendula Montagnei, 593

fluitans, 593

Hystrix, 594

Hystrix buxifolium, 594

Hystrix fuitans, 593

lendigerum, 593

leptocarpum, 593

Montagnei, 593

natans, 592

natans, 593

platycarpum, 593

polyceratium, 593

polyphyllum, 594

pteropleuron, 593

pteropus, 594

ramifolium, 593

rigidulum, 593

stenophylium, 593

trachyphyllum, 594

turbinatum, 591

vulgare, 593

Satin-wood, 207, 208

Satinleaf, 321

Satureia Brownei, 379

Satyrium orchioides, 86

Savia, 218

bahamensis, 218 erythroxyloides, 218

Saw-brier, 71 -grass, 46, 56 Palmetto, 60

Scaevola, 428

Lobelia, 429

Plumierli, 429

Scaly Polypody, 470

Scarlet Sage, 379

Schaefferia, 249 Common, 249

frutescens, 249

lateriflora, 221

Schinus F'agara, 206

Schizachyrium, 13 gracile, 13 semiberbe, 13

SCHIZAEACEAE, 474

Schizophyllus alneus, 644

Schizothrix, 623 chalybea, 624 vaginata, 623

Schlotheimia, 488 Sullivantii, 488 Sullivant's, 489

Schmidelia macrocarpa, 103 Schoenus, 56

coloratus, 53

cyperoides, 54

nigricans, 57

nigrican 8,47

Schoepfla, 111 chrysophylloides, 111 obovata, 111

Sciplo-bush, 220

Scirpus, 52

atropurpureus, 49 
Scirpus-

capitatus, 49

castaneus, 50

diphyllus, 50

exilis, 51

ferrugineus, 50

flaccidus, 48

glomeratus, 51

interstinctus, 48

lithospermus, 57

ochreatus, 48

robustus, 52

validus, 53

Scleria, 57

fliformis, 28, 57

lithosperma, 57

verticillata, 57

Sclerophyton, 538 elegans, 538

Scleropus amaranthoides, 124

Scolosanthus, 417 bahamensis, 417

Scoparia, 391

Scoparia, 391

dulcis, 391

Scorpion-tail, 363

Scorpiura, 572

SCrophulariaceat, 387

Scutellaria, 376

cubensis, 377

havanensis, 377

longiflora, 377

purpurascens, 377

Scutia ferrea, 256

Scytonema, 624

Scytonema, 531

cincinnatum, 624

crassum, 625

Hofmanni, 624

Millei, 624

myochrous, 625

ocellatum, 624

velutinum, 625

velutinum, 624

SCyTONEMATACEAE, 624

Sear-beach grass, 24

Blite, 121

-bush, 450

Grape, 117

Lavender, 320

Oats, 42

Ox-eye, 450

Purslane, 136, 137

-rocket, 149

-weed, 409

Sebacina spongiosa, 638

Sebesten, 357

Sebestena, 357

Securinega, 219

Securinega, 218

Acidothamnus, 219

Acidoton, 219

Sedge, Black-headed, 57

Sedge Famrit, 43

Seirospora, 580 occirentalis, $\mathbf{5 8 0}$

Selaginella, 477

Eatoni, 477

Eaton's 477

Selaginellaceae, 476

Selenicereus, 293

Boeckmanni, 293

grandiflorus, 294

SeMatophyllaceae, 499

Sematophyllum, 499

admistum, 500

Glossy, 500
Sematophyllum-

sericifolium, 500

Shining, 500

Subpinnate, 500

subpinnatum, 499

SEMATOPHYLLUAI FAMILY, 499

Senecio hieracifolius, 458

Senna, 166, 167

SENNA FAMILY, 164

Sensitive Plant, 161

Septobasidium cirratum, 638

Septoria, 635

Serenoa arborescens, 60

Serjania, 251

diversifolia, 251

lucida, 251

paniculata, 251

subdentata, 251

Serpent-fern, 470

Sertolara, 614

Sesame, 399

Sesamum, 399

indicum, 399

orientale, 399

Sesban, 181 grandiflorus, 182 occidentalis, 182

sericea, 182

Silky, 182

Smooth, 182

Sesuvium, 136 maritimum, 136

pentandrum, 136 portulacastrum, 136

Setaria caudata, 28

fliformis 28

glauca, 27

macrostachya, 28

setosa, 28

Setiscapella, 394 subulata, 394

Seutera maritima, 343

Seven-year Apple, 410

Shanks, 453

Sheep-grass, 355

Shell Orchid, 94

Shepherd's'-needle, 454

Shining S'ematophyllum, 500

Shoestring-fern, 466

Sicyos trifoliata, 260

Sida, 267

abutiloides, 265

acuminata, 269

acuminata, Bracei, 269

acuta carpinifolia, 268

angustifolia, 268

antillensis, 268

carpinifolia, 268

ciliaris, 267

Creeping, 269

crispa, 266

Fringed, 268

glomerata, 268

glutinosa, 269

glutinosa, 270

hederaefolia, 268

hirta, 265

Ivy-leaved, 268

nervosa, 269

permollis, 265

procumbens, 269

spinosa, 268

spinosa angustifolia. 268

Sticky, 269
Sida-

supina, 269

trisulcata, 265

urens, 268

Velvety, 269

viscosa, 270

Sideroxylon, 321

foetidissimum, 321

mastichodendron, 321

Silk-cotton Tree, 275

Silky-grass, 17

Senna, 168

Silphium trilobatum, 451

Silver-fern, 469

-plume- grass, 13

-thatch, 59

-top, 59

Simarouba, 210

glauca, 210

medicinalis, 210

SimarodBACEAE, 209

Simaruba amara, 210

officinalis, 210

officinalis glabra, 210

Simblum sphaerocephalum. 644

Sinapis, 147

arvensis, 147

brassicata, 147

integrifolia, 147

Singer-tree, 157

Siphonocladus, 602

membranaceus, 601 rigidus, 602

Sisal, 77

Sison A mmi, 314

Sisyrinchium, 80

miamiense, 81

Skullcap, 377

Slag, 4

Slender Maiden-hair Fern, 467

Sea Purslane, 136

Slipper-plant, 233

Sloanea emarginata, 324

Small Halberd-fern, 472

-leaved Haplocladium, 495

SMillacaceae, 70

Smilax, 70

auriculata, 71

Beyrichii, 71

domingensis. 71

havanensis, 71

havanensis dentata, 71

havanensis ovata laevis, 71

laurifolia, 72

oblongata, 71

oblongata viscifolia, 71

populnea, 71

Walteri, 72

SMILAX FAMILY, 70

Snake-bark, 258

-root, 210,417

Snowberry, 417

Snowdrop, 78

SOAPBERRY FAMILY, 250

SolanaCEAE, 381

Solanum, 382

aculeatissimum, 382

americanum, 383

bahamense, 383

bahamense lancieolatum, 383

Blodgettii, 384 
Solanum -

Blodgett's, 384

Bushy White, 384

didymacanthum, 384

gracile, 383

havanense, 386

ignaeum, 383

Mullein-leaved, 383

nigrum, 383

nigrum oleraceum, 383

nodiflorum, 383

purpuratum, 383

subarmatum, 383

torvum, 384

verbascifolium, 383

Soldier-bush, 361, 442

Solieria chordalis, 561

Sonchus, 429 oleraceus, 430

Sophora, 177

Coast, 178

tomentosa, 178

Sore-bush, 363

Sour-bush, 445

Southern Bracken, 467 Radula, 506

Sow-thistle, 430

Sowbane, 119

Spanish Bayonet, 72

Cedar, 100

Cordia, 358

Cork, 273

Guava, 411

Jasmine, 335

Moss, 63

Plum, 112

Stopper, 304

-top, 60

Spertina, 34

juncea, 34

patens, 34

Spathelia, 208

Low, 208

vernicosa, 208

Spathiger, 89

rigidus, 89

Spatoglossum guineense, 597

variegatum, 594595

Spermacoce, 423

laevis, 422

ocimoides, 422

tenuior, 423

tetraquetra, 424

SPERMATOPHYTA, 2

Spermothamnion, 578

gorgoneum, 578

gymnocarpum, 579

investiens, 578

irregulare, 579

macromeres, 578

roseolum, 578

speluncarum, 578

speluncarum, 553

Sphacelaria, 590

tribuloides, 590

Sphacelariaceae, 590

Sphacelotheca pamparum, 637

Sphaenosiphon prasinus, 620

Sphaeralcea abutiloides, 264

Sphaerella Rajaniae, 634

Sphaeria annulata, 634

concentrica, 634

fuscopurpurea, 634

gregaria, 533

polymorpha, 634
Sphaeria-

Stigma, 634

sulphurea, 633

SPHADRIALES, 634

Sphaerocarpus globuliferus, 645

SpHaERococcacean, 562

Sphaerococcus Corallopsis, 566

domingensis, 562

filiformis, 583

isiformis, 561

lacinulatus, 562

pedicellatus, 576

polycarpus, 562

rigens, 563

tener, 561

tenuis, 561

Sphatropsidales, 635

Sphaerostilbe gracilipes, 633

Sphenomeris, 468

clavata, 468

Spice-wood, 308

Spider-flower, 150 -lily, 79

SPIDERWORT FAMILY, 66

Spigelia, 328 Anthelmia, 329

Spike-grass, 40,42 -rush, 48, 49

Spiny-bur, 447

Spiranthes elata, 86 lucayana, 85 tortilis, 85

Spleenwort, Toothed, 469

Spondias lutea, 245

Spongia vermicularis, 604

Spongodium, 616

Sponia Lamarckiana, 104

Sporobolus, 32

Sporobolus, 635

angustus, 33

argutus, 33

atrovirens, 33

bahamens is, 33

Berteroanus, 33

domingensis, 33

indicus, 32

Jacquemontii, 32

tenacissimus, 32

virginicus, 33

Sporolithon, 584

Spreading Frullania, 520

Spurge, Bahama, 239

Bertero's, 242

Blodgett's, 241

Brace's, 239

Brazilian, 240

Britton's, 242

Broad-leaved, 237

Bushy, 238

Cay Sal, 238

Coast, 237

Exuma, 239

Forking, 235

Hairy, 241

Hypericum-leaved, 240

Leafless Cuban, 23

Mottled, 235

Pin-weed, 238

Prostrate, 241

Sheathed, 240

Wilson's, 238

Spurge FAMILY, 217

Spyridia, 581

aculeata, 581

apiculata, 581

filamentosa, 581
Spyridia occidentalis, 581

Squamaria, 584

SQUAMARIACEAE, 584

Stachytarpheta fruticosa, 365

jamaicensis, 366

STAFI-TREE FA MILY, 246

Star-of-the-Earth, 148

Statice bahamen sis, 320

Stelis foliosa, 89

Stemmodontia bahamensis, 451 trilobata, 451

Stemodia, 389

Coast, 389

durantifolia, 389

maritima, 389

Stemonitis herbatica, 645

Stenandrium, 402

droseroides, 402

rupestre, 402

Stenolobium stans, 397

Stenophyllus, 49

Wilsoni, 49

Wilson's, 50

Stenorrhynchus, 86 lanceolatus, 86 orchioides, 86

Stenostomum, 414 densiflorum, 415

lucidum, 414 myrtifolium, 415

Mytie,415

Shining, 414

Viscid, 415

Stenotaphrum, 30

americanum, 30

secundatum, 30

Stephanocoelium, 607 verticillatum, 608

Stephanotis floribunda, 344

STERCULIACEAE, 275

Stereophyllum, 494 radiculosum, 494

Stereum, 638

Stereum albobadium, 638 candidum, 638 Levelleanum, 638

Sticky-weed, 444

Stictosiphonia, 572

Stigmaphyllon, 204

Faustinum, 204

reticulatum, 204

Sagraeanum, 204

Sagra's, 204

Stigmatidum elegans, 538

Stigonema, 625

Stigonema, 625

StigonemataCeAE, 625

Stillingia eglandulosa, 232

Stilophora clathrata, $\mathbf{5 9 0}$

Stinking Pea, 167 -pea, Root, 177

Stipa, 31 capillaris, 32

Stomoisia, 395 cornuta, 395

Stopper,Bahama, 306

Long-stalked, 306

Pale, 306

Red, 304

Spanish, 304

White, 303, 308

Stow-weed, 391

Strap-fern, 471

Streptachne cubensis, 31 scabra. 31

Striatella, 627 
Striatella delicatula, 627 delicatula, 627

Strong-back, 359

Stropharia floccosa, $\mathbf{7 4 4}$

Strumpfia, 418

Strumpfia, 417 maritima, 418

struvea, 602 anastomosans, 602

Stylosanthes, 183 hamata, 183 procumbens, 183 viscosa, 183

Stypopodium, 594 lobatum, 594

Suaeda intermedia, 121

Subpinnate Sematophyllum, 500

Sugar-apple, 141

Sullivant's 'Schlotheimia, 489

Sumac Family, 243

Suriana, 209

Suriana, 543 maritima, 209

SURIANACEAE, 209

Surinam Cherry, 304

Surirella, 629

fastuosa, 629

fusiformis, 631

incurvata, 631

manca, 631

mexicana, 631

recedens, 629

Swamp-bush, 271

Swartzia multijuga, 177

Sweet-bay, 432 Potato, 354

Torch, 143

William, 336

Sweetwood Bark, 223

Swietenia, 213

Mahagoni, 213

Mahagoni, 109

Sword-bush, 220

-fern, 473

Symploca, 623

hydnoides fruticulosa, 623

Synechocystis, 619

Synedra, 628

formosa, 630

fulgens, 630

Gaillonii minor, 628

superba, 630

superba minor, 628 undulata, 628

Synedrella, 452 nodiflora, 452

Synedrosphaenia baculi-

formis, 630

Syntherisma, 15

digitata, 16

filiformis, 15

marginatum, 16

paniceum, 15

sanguinalis, 16

setosa, 16

Syrrhopodon, 482

Gaudichaudii, 482

Gaudichaud's, 483

Tabebuia, 396

bahamensis, 396

bahamensis. 636

lepidota, $396^{\circ}$
Tabernaemontana Echites, 336

Taenioma, 564 perpusillum, 564

Taenitis lanceolata, 466

Tallow Wood, 112

Tamala pubescens, 144

TAMARICACEAE, 279

Tamarind, 165

Tamarindus, 165 ndica 165

Tamarisk, 279

TAMARISK FAMILY, 279

Tamarix, 279 gallica, 279

Tamonea, 367 curassavica, 367 scabra, 367

Tape-grass, 8

TAPE-GRASS FAMILY, 8

Tassel Plant, 209

Taxilejeunea, 512 obtusangula, 512 Obtusely-angled, 513

Taxithelium, 498

Flat, 499 planum, 498

Tecoma, 397

bahamensis, 396

lepidota, 396

Leucoxylon, 396 stans, 397

Tectaria, 471

Amesiana, 472

heracleifolia, 471

minima, 472 trifoliata, 472

Tephrosia, 181 cathartica, 181 cinerea, 181

Teramnus uncinatus, 190

Terebinthus, 211

inaguensis, 212

Simaruba, 212

Terminalia, 301

Catappa, 302

spinosa, 301

TERMINALIACEAE, 300

Tetramicra, 94

Bahama, 94

Urbaniana, 94

Tetranthus, 446

Bahama, 447

bahamensis, 447

thymoides, 455

Tetrazygia, 298

Tetrazygia, 298

angustiflora, 298

bicolor, 298

Teucrium, cubense, 376 inflatum, 367

Thalassia, 9

Thalassia, 563, 568, 570 573, 581, 582, 586, 588, 590, 591, 597, 622

testudinum, 9

THALLOPHYTA, 521

Thamnophora triangularis, 571

Thatch-palm, 59

Thelephora albobadia, 638 candida, 638 spiculosa, 638 spongiosa, 638

THFLEPHORACEAE, 638

Thelotrema, 544

albidum, 544
Thelotrema

bicinctulum, 544

bisporum, 545

glaucescens, 545

lepadinum, 544

lepadinum bahianum. 545

microporum, 544

monosporum, 544

paralbidum, 544

paralbidum, 544

Ravenelii, 545

simplex, 545

subtile, 544

velatum, 544

THELOTREMACEAE, 543

Theophrasta FAMILY, 316

THEOPHRASTACEAE, 316

Thespesia, 273

populnea, 273

Thevetia nereifolia, 338

Thevetia, 338

Thistle FAMILY, 433

Thorn-apple, 386

Thoroughwort, 438

Thouinia, 252 discolor, 252

Threefold Euosmolejeunea, 512

Thrinax, 58

argentea, 59

bahamensis, 58

floridana, 59

keyensis, 58

microcarpa, 58

parviflora, 59

parviflora, 59

Thunbergia, 404

alata, 405

fragrans, 405

volubilis, 405

White, 405

Winged, 405

Thyana, 252

discolor, 252

Thymopsis 455

Brittonii, 455

thymoides, 455

Wrightii, 455

Thymus Brownei, 379

Tick-trefoil, 184

Tie-tongue, 118

Tiliaceae, 261

Tillandsia, 64

alolfolia, 65

Balbisiana, 64

Berteroniana, 66

bulbosa, 65

canescens, 66

circinata, 65

fasciculata, 65

flexuosa, 65

lingulata, 66

polystachy, 64

recurvata, 64

usneoides, 63

utriculata, 65

Valenzuelana, 64

Tithymalus, 235

trichotomus, 235

Ti-Ti, 186

Tobacco, 387

Tomasellia, 528

cubana, 528

cubana, 528

exumana, 528

leucostoma, 528

macrospora, 528 
Tonka Bean, 438

Toothed Spleenwort, 469 Torch-wood,209

Torrubia, 131

Bracei, 132

Cokeri, 131

longifolia, 132

obtusata, 131

Tortula, 483

a graria, 484

Common, 484

Donnelli, 485

rivalis, 487

TORTULA FAMILY, 483

TORTULACEAE, 483

Touch-me-not, 205

Tournefortia, 361 gnaphalodes, 361

humilis, 363

poliochros, 362

Slender Green-leaved, 361

tomentosa, 362

volubilis, 361

volubilis, 632

White-leaved, 362

Toxicodendron, 243

Blodgettii, 244

radicans, 244

Trachyneis, 628

Antillarum, 631

aspera, 628

Debyi, 631

Trachysphenia, 627 a ustralis, 627

Tradescantia discolor, 68 virginica, 68

Trametes hydnoides, 641 submurina, 641 versatilis, 640

Trema, 104

Lamarckiana, 104 Lima, 104

Tremella A uricula, 637

Trentepohlia, 599

aurea, 599

rigidula, 599

torulosa, 599

Triacis microphylla, 283

Trianospermum racemosum. 427

Triblidium rufulum, 635

Tribulus, 202

cistoides, 202

maximus, 203

terrestris cistoides, 202

Tricera, 243

Bahama, 243

bahamensis, 243

bahamensis, 633

Trichachne insularis, 16

Trichia cinerea, 645 clavata, 645

Trichodesmium, 621

Thiebautil, 621

Thiebautii, 620

Trichogloea, 556

Tricholaena leucophaea, 17

Trichosolen Antillarum, 607

Trichostigma, 135

Trichostigma, 134 octandrum, 134 rivinoides, 134

Trichostomum, 487

Trichostomum, 487 involutum, 487 jamaicense, 487 rivale, 487
Trichostomum -

rivale, 487

Rock, 487

Trichothamnion, 575

Tricladia, 607

Tridax, 454

procumbens, 454

Trifolium, 179

pratense, 180

repens, 180

Triopteris, 204

Triopteris, 203

havanensis, 204

jamaicensis, 204

lucida, 204

parvifolia, 204

rigida, 204

Triple-awned Grass, 31

Tripsacum, 12

dactyloides, 12 hermaphroditum. 15

Triumfetta, 263

althaeoides, 263

semitriloba, 263

Tropidoneis, 629

lepidoptera, 629

TRUMPET-CREEPER FAMILY, 395

Trumpet-fiower, 397

TRYPETHELIACEAE, 528

Trypethelium, 529

aeneum, 529

catervarium, $\mathbf{5 3 0}$

cruentatum, 530

cruentum, 530

eluteriae, 530

eluteriae citrinum, 530

eluteriae nigricans, 530

eluteriae subsulphureum, 530

eluteriae truncatum, 530

ferrugineum, 529

heterochroum, 529

Kunzci, 529

mastoldeum, 529

ochroleucum, 530

ochroleucum pallescens, 530

ochrothelium, 529

pallescens, $\mathbf{5 3 0}$

scoria, 529

Sprengelii, 530

tropicum, 529

Tulip, 336

Turbina, 354

corymbosa, 354

Turbinaria, 591

trialata, 591

tricostata, 592

turbinata, 591

turbinata, 592

vulgaris trialata, 591

Turk's-cap, 294

Turnera, 282

diffusa, 283

Small-leaved, 283

ulmifolia, 282

ulmifolia, 635

TURNERACEAE, 282

Turtle-grass, 9

-weed, 133

Tussilago albicans, 460 dentata, 460

Typha, 4

angustifolia, 4

angustifolia domingensis, 4
Typha-

domingensis, 4

latifolia, 4

TYPHACEAE, 3

Tyromyces palustris, 641

Ucacou nodiflorum, 452

Udotea, 613

conglutinata, 614

cyathiformis, 614

flabellata, 614

Flabellum, 614

Halimeda, 614

sordida, 611

spinulosa, 614

tomentosa 612

Wilsoni, 614

UlmaCEaE, 103

Ulva, 598

dichotoma, 596

Lactuca, 598

Mertensii, 596

sinuosa, 590

stellata, 602

ULVACEAE, 598

UNICORN-PLANT FAMILT, 399

Uniola, 41

paniculata, 42

racemiflora, 42

spicata, 42

virgata, 42

Urechites, 337

Andrewsii, 338

lutea, 338

UREDINALES, 636

Uredo bidenticola, 636

Cissi, 637

Leonotidis, 636

proeminens, 636

Sapotae, 636

Wilsoni, 636

Uromyces Bidentis, 636

Urtica aestuans, 106 humilis, 107

lappulacea, 107

Trticaceat, 105

URTICALES, 103

Usnea, 550

florida strigosa, $\mathbf{5 5 0}$

USNEACEAE, 549

USTILAGINALES, 637

Ustilago Montagnei. 637 pamparum, 637

Ustulina vulgaris, 634

Utricularia, 394

cornuta, 395

foliosa; 394

foliosa, 394

gibba, 394

pumila, 394 subulata, 394

Vachellia, 160

Farmesiana, 161

Vaginata farinosa, 644 plumber, 644

Valerianodes, 365

fruticosa, 365

jamaicensis, 366

jamaicensis, 635

Vallesia, 339

Vallesia, 339

dichotoma, 339

glabra. 339

Valonia, 603

Aegagropila, 603

Aegagropila. 604

favulosa, 603 
Valonia -

macrophysa, 603

macrophysa, 604

ocellata, 603

ocellata, 604

utricularis A egagropila. 603

utricularis crustacea, 604

ventricosa, 603 ventricosa, 584

VALONIACEAE, 601

Valota, 16 insularis, 16

Vaisa, 634

Vanilia, 83, 84, 438

Vanilla, 83

articulata, 84

claviculata, 83

Egrgersí i 83 phaeantha, 83

Varronia, 358

Bahama, 359

bahamensis, 358

Brittonli, 359

Britton's, 359

globosa, 358

Capitate, 358

iucayana, 359

Rough, 358

Vaucheria, 607

VAUCHERIACEAE, 617

Velvet-berry, 412 -seed, 412-414

Verbascum pulverentum. 393

Verbena curassavica, 367 jamaicensis, 366 lappulacea, 367 nodiflora, 368 prismatica, 366 stoechadifolia, 368

Verben A CEAE, 364

Verbesina, 448

alba, 449

encelioides, 452

nodiflora 452

Vernonia, 435

arbuscula, 435

arctata, 435

Bahama, 436

bahamensis, 436

bahamensis, 435

cinerea, 436

Herbaceous, 436

Inagua, 435

insularis, 436

Long-leaved, 436

Low Bushy, 435

obcordata, 435

Verrucaria, 522

aenea, 529

analepta americana 528

biformis, 525

catervaria, 530

cerina, 526

Cinchonae, 525

contendens, 525

diremta, 526

epidermidis fallax, 525

fuscorubella, 543

Kunthii, 526

leucoplaca, 526

mamillana, 526

mamillaris, 522

mamillaris, 523

muralis, 523
Verrucaria-

nigrescens, 523

ochraceo-flavens, 527

ochraceo-flavum, 527

ochroleuca, 530

pallidula, 531

planorbis, 525

punctella, 526

rupestris, 522

rupestris, 522

Santensis, 526

Tetracerae, 524

trachona, 542

tropica, 529

VERRUCARIACEAE, 522

Vertebrata, 569

Vesicularia, 497

Vesicularia, 497 veslcularis, 497

Vigna, 195

luteola, 195

repens, 195

Yellow, 195

Vilfa arguta, 33 atroviren 8,33

Berteroana, 33

domingensis, 33

Villamilla, 134 octandra, 134

Vinca lutea, 338 rosea, $\mathbf{3 3 6}$

Vincetoxicum palustre, 343

Virginia-Creeper, 261

Virgin's-bower, 140

Viscum purpureum, 108 racemosum, 110 rubrum, 110

trinervium, 110

VitACEAE, 259

Vitex ilicifolia, 374

Vitis, 259

caribaea, 259

Munsoniana, 259

rotundifolia, 259

Vittaria, 466

lineata, 466

Volkameria, 374

aculeata, 374

Voyria mexicana, 332

Walking Wood-fern, 473

Walla-berry, 249

Waltheria, 277

americana, 278

Bahama, 278

bahamensis, 278

Common, 278

Washerwoman, 127

Washerwoman's Bush, 386

Water-grass, 21

WATER-IJEAF FAMILY, 357

Water-lily, 140

WATHR LILY FAMILY, 139 MILLFOIL FAMILY, 310

Water Pepper, 114 Pimpernel, 318

Water Plantain Family, 7

Water Smartweed, 115

Wattle, 303

Wax-berry, 102

Wedelia, 450

Bahama, 451

bahamensis, 451

buphthalmoides, 451

carnosa, 451

Trailing, 451

trilobata, 45

West Indian Birch, 212
West Indian Germander, 376

Grass, 37

Sage, 378

Thyme, 379

What o'clock, 398

Whistling-bean, 157

White Beefwood, 11 I

Beggar-ticks, 454

Cedar, 396

Clover, 180

-headed Rush, 53

Ironwood, 255

Mangrove, 301

White Mangrove Family, 300

White Moss, 479

WHITE MOSS FAMILY 479

White Pussley, 364

Stopper, 303, 308

Torch, 209

Whitewood, 112, 222 bark, 282

Wild Apricot, 288

Balsam-apple, 425

Basil, 380

Bush-bean, 194

Cane, 25

Cassada, 322

Cherry, 205, 248

Cinnamon, 262

Coffee, 418, 419

Coral, 122

Cotton, 274, 341

Dilly, 324

Down, 341

Fig, 105, 292

Flax, 200

Grape, 259

Guava, 306

Indian, 90

Indigo, 180

Ipecac, 341

Jessamine, 375

Lettuce, 430

Lime, 207

Mulberry, 419

Mustard, 147

Oak, 227

Onion, 65

Pepper, 101

Peppergrass, 146

Pine, 64, 65

Potato, 336

Raisin, 166

Saffron, 323

Sage, 370

Salve, 276

Sisal, 77

Tamarind, 158

Tea, 102

Thyme, 363, 409

Tobacco, 383, 445

Tomato, 134

Torch, 209

Unction, 338

Watermelon, 289

Yam, 80

Willoughbya scandens, 439

Willugbaeya heterophyila. 439

Winterana Canella, 282

Wire-grass, 37

-weed, 268

Witch-grass, 24

Woetvine, 144

Woman's-tongue Tree, 157

Wood-fern, Walking, 473 -grass, 27 
Wood-

Sorrel, 197

WOOD-SORREL FAMILY, 196

Worm-vine, 84

Wormseed, 119

Wrangelia, 559

Argus, 559

Argus, 560

bicuspidata, 559

penicillata, 559

penicillata, 553 plebeja, 559

Wrightiella, 571 Blodgettii, 571

Tumanowiczi, 571

Wright's Anemia, 474

Wurdemannia, 562 setacea, 562

Xanthium, 431

chinense, 431

longirostre, 431

strumarium, 431

Xanthoxalis, 197

corniculata, 197

corniculata, 633

Xanthoxylon cribrosum, 207

Xenococcus, 620 Schousboei, 620

Ximenesia, 451 encelioides, 452

Ximenia, 112

americana, 112

inermis, 112

Xylaria Arbuscula, 634

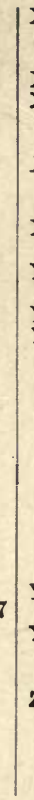

Xylaria-
aristata, 634
poiymorpha, 634
XYLOPHAGACEAE, 638
Xylophylla, 220

Xylophylla, 20 Epiphyilanthus, 220

latifolia, 220

Xylosma buxifolium, 284

ilicifolia, 284

nitidum, 284

Xrridales, 63

Yam, 80

Wild, 80

YAM FAMILY, 79

Yeliow Cress, 148

Elder, 397

-eyed Grass, 73

-fruited Leucolejeunea, 519

Lejeunea, 508

Procumbent Wood-Sorrel, 197

-spored Anthoceros', 521

Vigna, 195

-wood, 208

-wood, Cuban, 207

Yellowish Green Microle. jeunea, 509

Yucca, 72 aloifolia, 72

Zamia, 462 angustifolla, 463 angustifolia, 463 lucayana, 463 pumila, 463
Zamia

tenuis, 463

Zanardinia, 557 marginata, 559

ZAN NICHELLIACEAE, 4

Zanthoxylum, 206 Clava-Herculis, 208

corlaceum, 207 coriaceum, 208

cribrosum, 207

cubense, 207

emarginatum, 207

Fagara, 206

flavum, 207

flavum, 528

fraxineum, 208

juglandifolium, 207

Pterota, 206

Zephyranthes cardinalis, 78 rosea, 78

Zinnia, 448

Zinnia, 448 multiflora, 448

Zonaria, 594

collaris, 594

dichotoma, 596

lobata, 594

rubra, 584

variegata, 594

variegata, 591, 595

zonalis, 594

Zuelania, 285

Zuelania, 285

Guidonia, 285

- laetioide8,285

ZYGOPHYLLACEAE, 201 


RETURN BIOLOGY LIBRARY

TO $\longrightarrow 3503$ Life Sciences Bldg. 642-2531

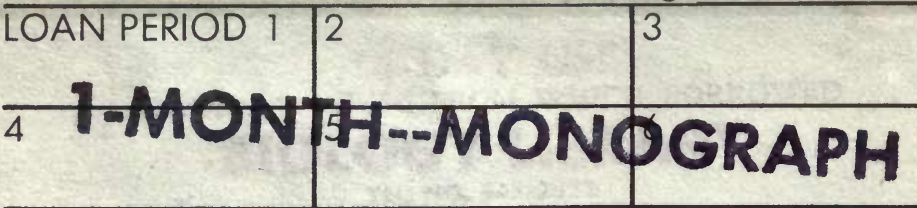

ALL BOOKS MAY BE RECALLED AFTER 7 DAYS

Renewed books are subject to immediate recall

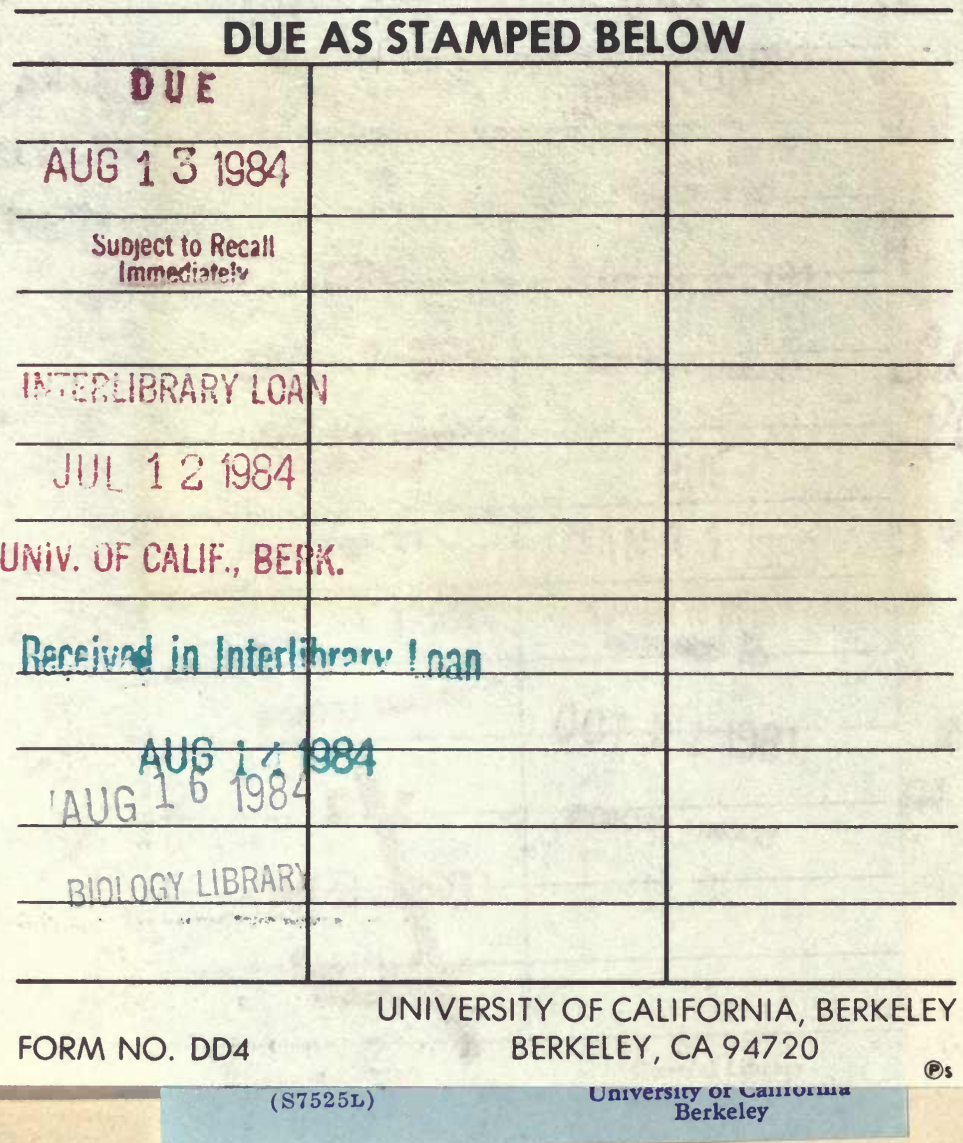



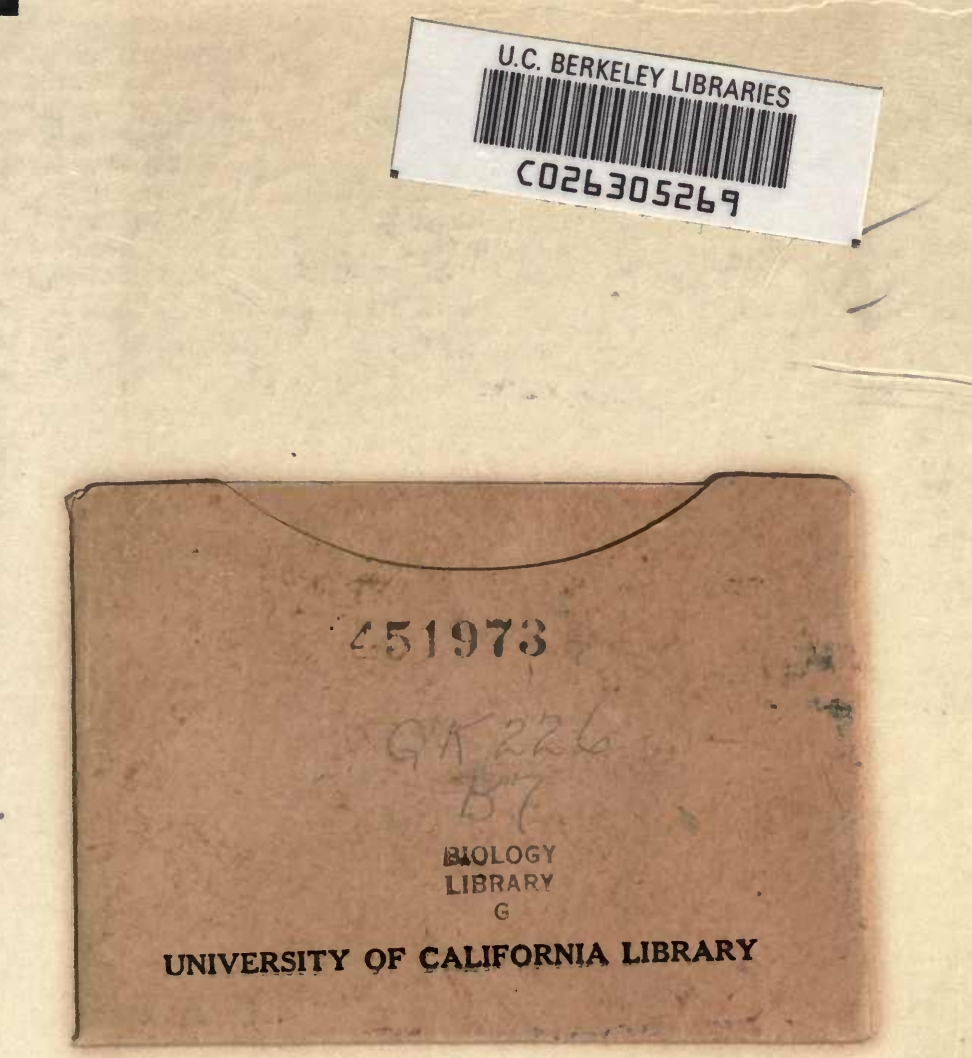
